\title{
MONTANA AMPHIBIAN AND REPTILE STATUS ASSESSMENT, LITERATURE REVIEW, AND CONSERVATION PLAN
}

\author{
Last updated: 11 June 2009 \\ Submitted To The Following Cooperators: \\ Native Species Coordinator (Kristi DuBois) \\ Montana Fish, Wildlife, and Parks \\ 3201 Spurgin Road \\ Missoula, Montana 59804 \\ Aquatic Ecologist (Ann Carlson) \\ Region 1 Office of the U.S. Forest Service \\ 200 E. Broadway \\ Missoula, Montana 59807 \\ Wetland Coordinator (Lynda Saul) \\ Montana Department of Environmental Quality \\ 1520 East 6th Avenue \\ Helena, Montana 59620 \\ Wildlife, Fisheries, and Threatened and Endangered Species Program Lead (Gayle Sitter) \\ Montana State Office of Bureau of Land Management \\ 5001 Southgate Drive, P.O. Box 36800 \\ Billings, Montana 59107 \\ Research Zoologist (Stephen Corn) \\ USGS Northern Rocky Mountain Science Center \\ Aldo Leopold Wilderness Research Institute \\ 790 East Beckwith \\ Missoula, Montana 59801 \\ Submitted by: \\ Bryce A. Maxell, Paul Hendricks, M.T. Gates, and S. Lenard \\ Montana Natural Heritage Program \\ 1515 East $6^{\text {th }}$ Avenue \\ Helena, Montana 59620 \\ Contact: Bryce Maxell \\ Senior Zoologist, Montana Natural Heritage Program \\ (406) 444-3655 (phone) \\ (406) 444-0581 (fax) \\ bmaxell@mt.gov
}




\section{Suggested Citation:}

Maxell, B.A., P. Hendricks, M.T. Gates, and S. Lenard. 2009. Montana amphibian and reptile status assessment, literature review, and conservation plan. Montana Natural Heritage Program, Helena, MT and Montana Cooperative Wildlife Research Unit and Wildlife Biology Program, University of Montana, Missoula, MT. 642 p. 


\section{ACKNOWLEDGEMENTS}

The statewide amphibian inventory program, pilot reptile surveys, this and other reports, and website developments resulting from this work could not have been completed without collaborative funding from a number of cooperators. Ann Carlson, Linda Ulmer, Jim Claar, and Tom Wittinger at the Region 1 Office of the U.S. Forest Service, Kristi DuBois and Heidi Youmans at the Montana Department of Fish, Wildlife, and Parks, Lynda Saul and Randy Apfelbeck at the Montana Department of Environmental Quality, Marc Whisler and Roxanne Falise at the Montana State Office of the Bureau of Land Management, Steve Corn at the Biological Resources Division of the U.S. Geological Survey, Don Sasse and Barb Pitman at the Custer National Forest, Scott Barndt and Marion Cherry at the Gallatin National Forest, Jim Brammer at the Beaverhead-Deerlodge National Forest, Rob Brassfield at the Bitterroot National Forest, Sandy Kratville at the Lolo National Forest, Jo Christenson and Jim Sparks at the Missoula Field Office of the Bureau of Land Management, and Henning Stabins at Plum Creek Timber Company all helped attain funding for the surveys included in this report. Many of these same individuals provided access to aerial photos and/or helped coordinate accessing sites scheduled for survey. Others providing this assistance include Jim Brammer, Buddy Drake, Glen Gill, Daniel Gomez, Chris Riley, and Jim Roscoe. Scott Spaulding and Brian Riggers at the Lolo National Forest provided use of electrofishing gear for Idaho Giant Salamander surveys. Special thanks to all of the individuals who put in long field days under sometimes difficult conditions on the Montana Amphibian Inventory Project. Through the 2006 field season they include: Steve Amish, Matthew Bell, Danielle Blanc, Mickey Bland, Anna Breuninger, Andy Brown, Peter Brown, Mark Byall, Jessica Easley, Eric Dallalio, Ashton Fink, Matt Gates, Alex Gunderson, Renee Hoadley, Grant Hokit and a number of his students from Carroll College, Phil Jellen, Ryan Killackey, Todd Leifer, Robert Lishman, Patrick Lizon, Gary Maag, Lorraine McInnes, Andrew Munson, Rachelle Owen, Stacy Polkowske, Thomas Schemm, Keif Storrar, Tomi Sugahara, Anatole Suttschenko, John Thayer, Allan Thompson, Brian Tomson, Ryan Zajac, and Franz Zikesch. A number of people helped review and manage data, including: Steve Amish, Danielle Blanc, Andy Brown, Beth Clarke, Teri Hamm, Ryan Killackey, Amy Puett, Allan Thompson, Lisa Wilson, Chris Welch, and Alison Zmud. Ryan Killackey and Tom Schemm mapped the vast majority of the lentic sites that were surveyed so that these sites could be easily located in the field and relocated on future surveys. Ryan Killackey and Steve Amish reviewed aerial photos across the watershed surveyed in order to identify lentic sites not mapped on 1:24,0000 scale topographic maps. Randy Gazda at the U.S. Fish and Wildlife Service provided helpful information for accessing private lands in the Dillon area and he, Teri Nall, and Jeff Marks were instrumental in tracking down breeding populations of the Plains Spadefoot (Spea bombifrons) near Dillon. Kirwin Werner, Jim Reichel, and Paul Hendricks conducted numerous baseline surveys across Montana in the 1990s and provided this information to the Point Observation Database at the Montana Natural Heritage Program for everyone's benefit. A number of agency personnel have been especially vigilant about gathering observation records for amphibians and reptiles in their area, especially Don Sasse on the Custer National Forest, Mike Enk, Stan VanSickle, and Wendy Maples on the Lewis and Clark National Forest, Rob Brassfield and Mike Jakober on the Bitterroot National Forest, Dave Wrobleski on the Lolo National Forest, Glen Gill and David Dorman on the Kootenai National Forest, and Barb Garcia, Steve Kujala, and Chris Riley on the Beaverhead-Deerlodge National Forest. Randy Apfelbeck, Lynda Saul, and Courtney Frost at the Montana Department of Environmental Quality and Marc Jones, formerly at the Montana Natural Heritage Program, helped develop rapidly impacts on wetlands. This project benefited greatly from discussions on sampling design, survey methods, and data analysis with Steve Corn, Blake Hossack, Mark Lindberg, and Chuck Peterson. Steve Carson and Bob McFarland, at the Montana Department of Fish, Wildlife, and Parks, provided a statewide database of fish stocking records used in each of the watershed reports. Many GIS layers were provided by the Montana Natural Resources Information System and I would like to specifically thank Gerry Daumiller and Duane Lund for their assistance with these. Vanetta Burton, Joe Ball, and Mike Mitchell at the Montana Wildlife Cooperative Research Unit, Darlene Patzer and Sue Crispin at the Montana Natural Heritage Program, and Cecelia Egley, Pat Bristol, and Bob Pfister at the University of Montana were instrumental in managing the contracts and accounts associated with this project. 


\section{TABLE OF CONTENTS \\ (Report sections are hyperlinked)}

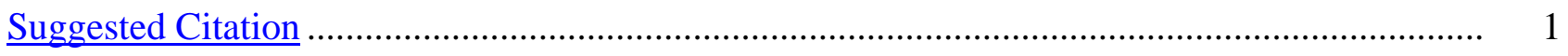

Acknowledgements ............................................................................................................... 2

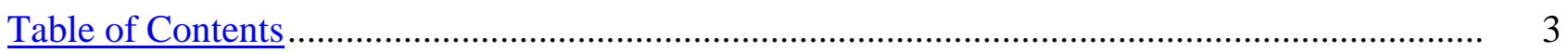

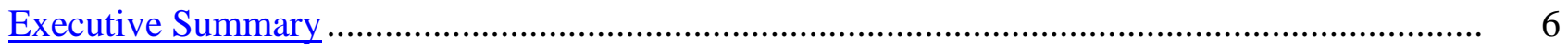

Accessing Information in this Conservation Plan...................................................................... 6

Background .............................................................................................................. 7

Highest Priority Issues for the Conservation of Amphibians and Reptiles .............................. 9

Checklist of Montana's Amphibian and Reptile Species .............................................................. 11

Taxonomy and Common and Scientific Names …………..................................................... 11

Documented Native Amphibian Species ............................................................................. 11

Documented Native Reptile Species....................................................................................... 12

Potential Native Species Currently Unconfirmed in Montana ................................................ 13

Exotic Species Successfully Breeding in Montana.................................................................. 13

Species Successfully Breeding in Montana for Which There is Uncertainty About Their

Status as Natives or Exotics............................................................................................... 13

Exotic Species Documented in Montana for Which There is No Evidence of Successful

Breeding

Presence and Status Ranks for Amphibians and Reptiles in Various Land Management Regions

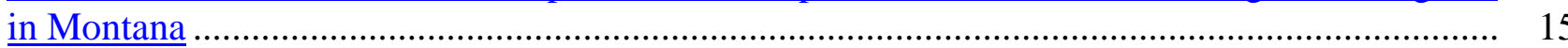

NatureServe and Heritage Program Ranks .......................................................................... 15

State Rank Criteria for Montana Animal Species of Concern................................................ 16

Presence and Status Ranks for Amphibians and Reptiles on National Forests in Montana ..... 29

Presence and Status Ranks for Amphibians and Reptiles on BLM Lands in Montana............ 32

Presence and Status Ranks for Amphibians and Reptiles on Tribal Lands in Montana........... 35

Presence and Status Ranks for Amphibians and Reptiles Within Montana Fish, Wildlife, and Parks Wildlife Regions in Montana .................................................................................. 38

Presence and Status Ranks for Amphibians and Reptiles on USFWS Refuges in Montana.... 41

General Habitat Associations for Amphibians in Montana ............................................................. 44

General Habitat Associations for Reptiles in Montana................................................................... 45

Laws and Regulations Applicable to Amphibians and Reptiles in Montana................................. 46

Federal Laws and Regulations ............................................................................................ 46

Tribal Regulations............................................................................................................ 46

Portions of Montana Code Annotated Relevant to Nongame and Endangered Species........... 47

Portions of Montana Code Annotated Relevant to Importation, Introduction, and

Translocation of Wildlife................................................................................................ 52 
Review of Literature Relevant to the Conservation of Amphibians and Reptiles in General ........ 60

Ecological Function and Importance of Amphibians and Reptiles .................................... 60

Amphibian and Reptile Biology and Disturbance Regimes Relevant to Management........... 61

Global Amphibian Declines........................................................................................ 62

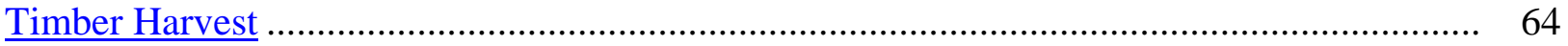

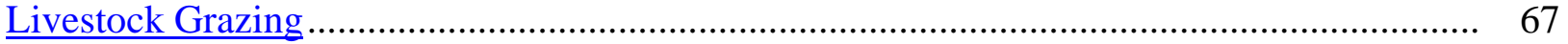

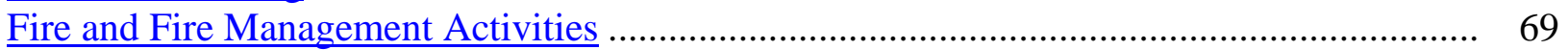

Nonindigenous Species and Their Management................................................................ 71

Road and Trail Development and On- and Off-Road Vehicle Use ...................................... 76

Development and Management of Water Impoundments and Recreational Facilities............ 79

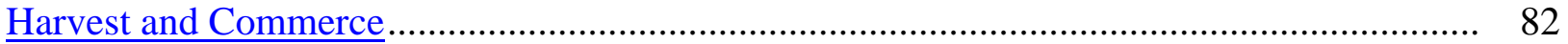

Habitat Fragmentation and Metapopulation Impacts..................................................... 83

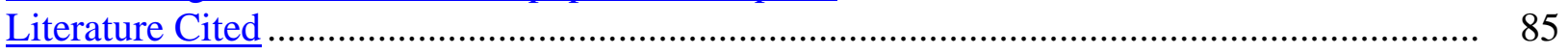

Introduction to Species Accounts …............................................................................. 101

Species Accounts for Species Documented in Montana.......................................................... 102

Amphibians

Long-toed Salamander (Ambystoma macrodactylum) ..................................................... 102

Tiger Salamander (Ambystoma tigrinum) ......................................................................... 118

Idaho Giant Salamander (Dicamptodon atterimus) .......................................................... 139

Coeur d'Alene Salamander (Plethodon idahoensis) ......................................................... 145

Rocky Mountain Tailed Frog (Ascaphus montanus) ......................................................... 155

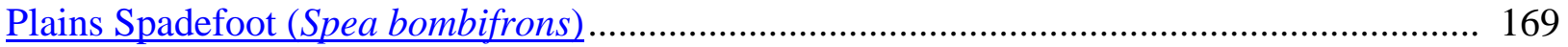

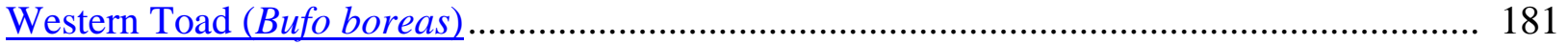

Great Plains Toad (Bufo cognatus) ................................................................................. 208

Woodhouse's Toad (Bufo woodhousii)......................................................................... 217

Boreal Chorus Frog (Pseudacris maculata) ................................................................... 231

Pacific Treefrog (Pseudacris regilla) ............................................................................ 247

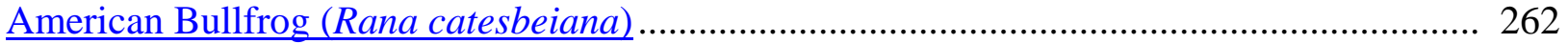

Columbia Spotted Frog (Rana luteiventris) …............................................................... 281

Northern Leopard Frog (Rana pipiens) ......................................................................... 303

Reptiles

Snapping Turtle (Chelydra serpentina) .......................................................................... 330

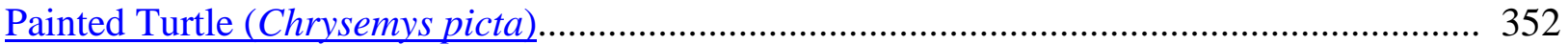

Spiny Softshell (Apalone spinifera) ............................................................................... 385

Northern Alligator Lizard (Elgaria coerulea) ................................................................... 396

Greater Short-horned Lizard (Phrynosoma hernandesi) ................................................. 404

Common Sagebrush Lizard (Sceloporus graciosus).......................................................... 417

Western Fence Lizard (Sceloporus occidentalis) .......................................................... 428

Western Skink (Eumeces skiltonianus) ........................................................................ 434

Rubber Boa (Charina bottae) ....................................................................................... 441

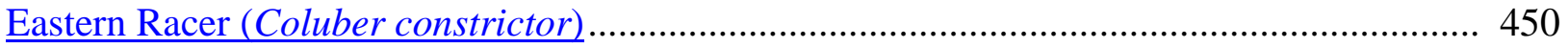

Western Hog-nosed Snake (Heterodon nasicus) .............................................................. 465

Smooth Greensnake (Opheodrys vernalis) ......................................................................... 476 
Milksnake (Lampropeltis triangulum) ................................................................................... 484

Gophersnake (Pituophis catenifer) ................................................................................... 496

Terrestrial Gartersnake (Thamnophis elegans) ............................................................... 516

Plains Gartersnake (Thamnophis radix).............................................................................. 540

Common Gartersnake (Thamnophis sirtalis)........................................................................ 553

Prairie Rattlesnake (Crotalus viridis) ..................................................................................... 587

Species Accounts for Amphibian and Reptile Species Potentially Present In Montana ................ 618

Great Basin Spadefoot (Spea intermontana) .................................................................... 618

Canadian Toad (Bufo hemiophrys) ....................................................................................... 621

Wood Frog (Rana sylvatica) ............................................................................................ 625

Pigmy Short-horned Lizard (Phrynosoma douglasii).............................................................. 628

Contact Information for Montana’s Amphibian and Reptile Working Group ............................... 630

Field Data Forms

Site Data Form for Lentic Breeding Amphibian and Aquatic Reptile Surveys......................... 632

Roadside Amphibian Calling Survey Datasheet...................................................................... 636

Data Form for Reptile Site Surveys ....................................................................................... 638

Incidental Observation Datasheet ............................................................................................. 641 


\section{EXECUTIVE SUMMARY}

\section{Accessing Information in this Conservation Plan}

This document summarizes a great deal of information on the distribution, status, and biology of amphibians and reptiles known or thought to potentially inhabit Montana and is intended to become a dynamic living document that can be updated on a regular basis from research conducted in Montana or elsewhere. The document will be posted on the Montana Natural Heritage Program's website at http://nhp.nris.state.mt.us/reports.asp as well as Montana Fish, Wildlife, and Parks' Comprehensive Fish and Wildlife Conservation Strategy website at http://fwp.mt.gov/wildthings/cfwcs/swg/planning.html

The document begins with taxonomic checklists for amphibians and reptiles that: (1) have been documented as native species; (2) are potentially present as native species; (3) have been documented as exotic species successfully reproducing in the state; (4) have been documented as successfully reproducing in the state but for which there is uncertainty about their status as native or exotic species; and (5) have been documented in the state but for which there is no evidence of successful reproduction.

Presence and status ranks for amphibians and reptiles are then summarized for various land management regions in Montana and background information is provided as to why species were assigned these ranks and what the associated management implications are for each state, federal, or tribal agency. Status ranks are described for Global Ranks (G ranks) assigned to species by NatureServe and State Ranks (S ranks) assigned to species by the Montana Natural Heritage Program because they are often used by federal and state agencies when they are developing their own special status ranks for species they will give special protections or considerations in land use planning. Status ranks and summaries of distribution and/or site occupancy rates from recent amphibian inventory surveys are provided for: (1) Region 1 National Forests; (2) Bureau of Land Management Field Offices; (3) tribal reservations; (4) Fish, Wildlife, and Parks Regions; and (5) National Wildlife Refuges or refuge complexes.

General habitat associations are then summarized in tables listing major habitat types and all of the amphibian and reptile species that are typically found in these habitats.

Laws and regulations applicable to Montana's amphibians and reptiles are then summarized, including federal laws and regulations, tribal regulations, portions of Montana Code Annotated relevant to nongame and endangered species, and portions of Montana Code Annotated relevant to importation, introduction, and translocation of wildlife.

A review of literature relevant to conservation of amphibians and reptiles includes sections on (1) ecological function and importance of amphibians and reptiles, (2) amphibian and reptile biology and disturbance regimes relevant to management, (3) risk factors relevant to the viability of amphibian and reptile populations including: (a) global amphibian declines; (b) timber harvest; (c) grazing; (d) fire and fire management activities; (e) nonindigenous species and their management; (f) road and trail development and on- and off-road vehicle use; (g) development and management of recreational facilities and water impoundments; (h) harvest and commerce; 
and (i) habitat fragmentation and metapopulation impacts. This review is currently somewhat biased toward amphibians, both because of the much higher recent concern over the status of amphibians and because this literature review drew from previous efforts focused on amphibians.

Accounts for individual species then summarize what is known about the species' distributition, taxonomy, maximum documented elevation, habitat use and natural history, and conservation status. Sections on identification of various life history stages and priority research and management issues are also included. Finally, an attempt was made to compile a complete bibliography of published and gray literature for each species in order to provide everyone easy access to this information. These accounts are intended to be updated on a regular basis in order to provide everyone access to the latest information.

A contact list for members of the Montana Amphibian and Reptile Working Group is included in order to promote communication between agency biologists, resource managers, students, researchers, and anyone interested in the conservation of amphibians and reptiles in Montana.

An overview of the statewide inventory and monitoring program for amphibians and reptiles provides background information on the sampling schemes used, methods used for surveys, and the survey forms used for a variety of amphibian inventory work.

Watershed summaries for the lentic breeding amphibian and aquatic reptile surveys complete the current version of this report in order to provide resource managers easy access to this information. Georeferenced site photos associated with this inventory work have been posted on the Montana Natural Heritage Program's TRACKER website which can be accessed at: http://mtnhp.org

It is recommended that users of this document first use the tables at the beginning of the document to identify management status, likelihood of a species presence in the area of interest, and the complement of species that are typically found in each general habitat type. Users should then examine individual species accounts in order gain a more thorough understanding of a species distribution, status, resource needs, factors that may pose a threat to population viability, and management actions that may mitigate these threats. Finally, users can review results of field surveys contained in individual watershed reports or see up-to-date distribution information for each species on the Montana Natural Heritage TRACKER website at: http://mtnhp.org

\section{Background}

There are only 13 amphibian species and 17 reptile species currently documented as native to Montana. Yet these species play important ecological roles in transferrring energy up the food chain and shaping terrestrial and aquatic communities and they may serve as valuable bioindicators of the health of certain environments. This relatively low species diversity, relative to other portions of the United States and the world, highlights the need for a thorough understanding of the conservation status of these species because Montana has relatively few species to carry out these important ecological functions. 
Until recently, there has been very little information available on the distribution, status, and biology of the majority of the amphibian and reptile species in Montana. As recently as the year 2000 there were only approximately 6,000 observation records for these species in the statewide Point Observation Database housed at the Montana Natural Heritage Program and a number of species were documented in the state fewer than 40 times. Much of the state lacked baseline surveys for amphibians and reptiles until the mid 1990s and some of the best information available for some regions still dates back to the Lewis and Clark expedition in 1805 and 1806 or information gathered by naturalists associated with various military, road, or railroad surveys in the 1850s through 1870s. Understanding of the status of amphibians and reptiles in Montana was greatly advanced in the 1960s and 1970s through the work of students and faculty at the University of Montana and Montana State University. Among other things, their work documented healthy populations of Western Toads (Bufo boreas) and Northern Leopard Frogs (Rana pipiens) in western Montana. Baseline surveys for amphibians and reptiles were undertaken on a number of federal and tribal lands in the mid 1990s by Kirwin Werner, Jim Reichel, and Paul Hendricks in response to evidence that these and other amphibian species had undergone declines in Montana and around the world. These surveys filled in large gaps in our understanding of the distribution and status of a number of amphibian and reptile species and compiled evidence that populations of Western Toads had undergone declines and populations of Northern Leopard Frogs had been virtually extirpated from their former range in western Montana since the late 1970s.

These findings, as well as documented declines in amphibian populations around the world, spurred the development of several documents that compiled information on the status, distribution, and biology of amphibians and reptiles in Montana. These documents include: (1) Management of Montana's Amphibians (Maxell 2000) which developed species accounts for Montana amphibians that included information on identification, distribution, taxonomy, natural history, status, and conservation; (2) Herpetology in Montana (Maxell et al. 2003) which summarized the history of herpetology in Montana and provided checklists, dichotomous keys, dot distribution maps, maximum elevation records, a summary of museum voucher records, and indexed bibliographies for all amphibian and reptile species; and (3) the first field guide to Amphibians and Reptiles of Montana (Werner et al. 2004) which provided user friendly keys, numerous photos, contact information for federal, state, and tribal agencies associated with the management of amphibians and reptiles, information on actions to be taken in case of being bitten by a Prairie Rattlesnake (Crotalus viridis), and detailed species accounts that summarize identification, taxonomy, distribution, habitat use, behavior, and development for each of Montana's amphibians and reptiles.

In addition to concerns about the status of Western Toads and Northern Leopard Frogs, the compilation of information in these summary documents also indicated reasons for concern about the status of populations of Coeur d'Alene Salamander (Plethodon idahoensis), Plains Spadefoot (Spea bombifrons), Great Plains Toad (Bufo cognatus), Snapping Turtle (Chelydra serpentina), Spiny Softshell (Apalone spinifera), Greater Short-horned Lizards (Phrynosoma hernandesi), Common Sagebrush Lizard (Sceloporus graciosus), Northern Alligator Lizard (Elgaria coerulea), Western Skink (Eumeces skiltonianus), Western Hog-nosed Snake (Heterodon nasicus), Smooth Greensnake (Opheodrys vernalis), and Milksnake (Lampropeltis triangulum). For each of these species, a lack of recent records and/or a lack of adequate 
baseline inventory data raises numerous questions about their status and distribution. It was clearly beyond the power of the available information to identify whether populations of most of these species were stable or had undergone declines. However, for at least one species, Greater Short-horned Lizard, lack of records in recent decades indicate that declines have taken place in at least a portion of their range due, at least in part, to wholesale conversion of native habitats to agricultural lands.

Coupled with growing evidence for declines in numerous amphibian, and some reptile, populations around the world, the concerns raised by these documents spurred the development of a statewide inventory and monitoring program for lentic breeding amphibians collaboratively funded by the Region 1 Office of the U.S. Forest Service, the Montana Department of Fish, Wildlife, and Parks through the U.S. Fish and Wildlife Service's State Wildlife Grants Program, the Montana Department of Environmental Quality's EPA wetland grants program, the Montana State Office of the Bureau of Land Management, and the U.S. Geological Surveys' Amphibian Research and Monitoring Initiative. This collaborative effort was facilitated by a common statewide sampling scheme that allowed each agency to contribute to portions of the overall effort. This common statewide lentic breeding amphibian sampling scheme has also prompted inventory efforts on private lands to be performed using the same survey methodology and the same data forms so that all information is compatible. Furthermore, these efforts have lead to a number of 3-day workshops in which agency biologists have received training on: (1) the identification, status, and basic natural history of all of Montana's amphibians and reptiles; (2) methodologies used to survey for Montana's amphibians and reptiles; (3) how to record data on incidental observations or formal surveys for amphibians and reptiles; (4) transferring survey and incidental observation data to central databases at the Montana Natural Heritage Program; and (5) how to access and use incidental information or information gathered under the common sampling effort in regional and local project level planning decisions.

\section{Highest Priorities for the Conservation of Amphibians and Reptiles in Montana}

Huge holes still exist in our understanding of the status, distribution, and biology of the amphibian and reptile species that have been definitively documented in the state. There is probably no better testimony to this than the recent confirmation that populations of the Idaho Giant Salamander (Dicamptodon aterrimums) do inhabit portions of western Montana or the possibility that 3 additional amphibian species (Great Basin Spadefoot (Spea intermontana), Canadian Toad (Bufo hemiophrys), and Wood Frog (Rana sylvatica)) and 1 additional reptile species (Pigmy Short-horned Lizard (Phrynosoma douglassi) may still be identified as native to the state.

The following priority actions for the conservation of amphibians and reptiles in Montana were deemed to be among the highest priority issues identified under the research and management sections of individual species accounts.

1. A statewide systematic survey for terrestrial reptiles using a common sampling scheme. designed to identify proportions of habitat patches occupied as a measure of status and that allows individual agencies to contribute to portions of the overall effort.

2. Conduct systematic lentic breeding amphibian surveys on Tribal and private lands in the near future when the public land baseline surveys have been completed. 
3. Complete baseline surveys for Coeur d'Alene Salamanders at springs, seeps, and waterfall spray zones in western Montana.

4. Implement control measures for introduced American Bullfrog populations, especially isolated populations, in order to reduce the risk of their spread and impacts on a variety of native wildlife.

5. Reintroductions of Northern Leopard Frogs throughout their historic range in western Montana (identify source populations and the best sites for reintroduction).

6. Focal surveys for Greater Short-horned Lizards, Pigmy Short-horned Lizards, and other reptile species in southwest Montana.

7. Focal surveys for Woodfrogs in the Bighorn Mountains on the Crow Indian Reservation.

8. Focal surveys for Plains Spadefoots and Northern Leopard Frogs in the mountain valleys of the upper Missouri River tributaries immediately east of the Continental Divide.

9. Evaluation of the frequency and intensity of disturbance associated with beaver created sites across Montana with the long-term goal of managing for a beaver population that will maintain lentic sites across Montana landscapes in order to provide habitat for amphibians, reptiles, and a variety of other wildlife.

10. Plan for fortuitous/adaptive amphibian call surveys across Montana in order to take advantage of proper weather conditions in order to better understand the status of species like the Great Plains Toad and Plains Spadefoot.

11. Focal studies on the basic natural history and population demography of a number of amphibian and reptile species in Montana.

12. Educate biologists, resource managers, and the general public about the biology and conservation of amphibians and reptiles in the state. 


\section{CHECKLISTS OF MONTANA'S AMPHIBIAN AND REPTILE SPECIES}

\section{Taxonomy and Common and Scientific Names}

Throughout this document common and scientific names used are consistent with those in the $5^{\text {th }}$ edition of Scientific and Standard English Names of the Amphibians and Reptiles of North America North of Mexico (Crother 2000, Crother et al. 2001, 2003). These have been used in preference to those in the $6^{\text {th }}$ edition (Crother 2008) because they currently have more of a consensus among herpetologists and because changes in the $6^{\text {th }}$ edition have been questioned by several authors as not adequately reflecting a consensus among herpetologists and unnecessary to reflect evolutionary history (e.g., Smith and Chiszar 2006, Hillis 2007, Wiens 2007).

\section{DOCUMENTED NATIVE AMPHIBIAN SPECIES}

\section{Amphibians (Class Amphibia)}

\section{Salamanders (Order Caudata)}

Mole Salamanders (Family Ambystomatidae) Long-toed Salamander (Ambystoma macrodactlyum) Tiger Salamander (Ambystoma tigrinum)

Giant Salamanders (Family Dicamptodontidae) Idaho Giant Salamanders (Dicamptodon atterimus)

Lungless Salamanders (Family Plethodontidae) Coeur d'Alene Salamander (Plethodon idahoensis)

\section{Frogs and Toads (Order Anura)}

Tailed Frogs (Family Ascaphidae) Rocky Mountain Tailed Frog (Ascaphus montanus)

Spadefoot Toads (Family Pelobatidae) Plains Spadefoot (Spea bombifrons)

True Toads (Family Bufonidae)

Western Toad (Bufo boreas)

Great Plains Toad (Bufo cognatus)

Woodhouse's Toad (Bufo woodhousii)

Treefrogs (Family Hylidae)

Boreal Chorus Frog (Pseudacris maculata)

Pacific Treefrog (Pseudacris regilla)

True Frogs (Family Ranidae)

Columbia Spotted Frog (Rana luteiventris)

Northern Leopard Frog (Rana pipiens) 


\section{DOCUMENTED NATIVE REPTILE SPECIES}

\section{Reptiles (Class Reptilia)}

\section{Turtles (Order Testudines)}

Snapping Turtles (Family Chelydridae)

Snapping Turtle (Chelydra serpentina)

Pond Turtles (Family Emydidae)

Painted Turtle (Chrysemys picta)

Softshell Turtles (Family Trionychidae)

Spiny Softshell (Apalone spinifera)

\section{Lizards (Order Squamata, Suborder Lacertilia)}

Alligator Lizards (Family Anguidae)

Northern Alligator Lizard (Elgaria coerulea)

Spiny Lizards (Family Phrynosomatidae)

Greater Short-horned Lizard (Phrynosoma hernandesi)

Common Sagebrush Lizard (Sceloporus graciosus)

Skinks (Family Scincidae)

Western Skink (Eumeces skiltonianus)

\section{Snakes (Order Squamata, Suborder Serpentes)}

Boas (Family Boidae)

Rubber Boa (Charina bottae)

Colubrids (Family Colubridae)

Eastern Racer (Coluber constrictor)

Western Hog-nosed Snake (Heterodon nasicus)

Smooth Greensnake (Opheodrys vernalis)

Milksnake (Lampropeltis triangulum)

Gophersnake (Pituophis catenifer)

Terrestrial Gartersnake (Thamnophis elegans)

Plains Gartersnake (Thamnophis radix)

Common Gartersnake (Thamnophis sirtalis)

Vipers (Family Viperidae)

Prairie Rattlesnake (Crotalus viridis) 
POTENTIAL NATIVE SPECIES CURRENTLY UNCONFIRMED IN MONTANA

Amphibians (Class Amphibia)

Frogs and Toads (Order Anura)

$\underline{\text { Spadefoot Toads (Family Pelobatidae) }}$

Great Basin Spadefoot (Spea intermontana)

True Toads (Family Bufonidae)

Canadian Toad (Bufo hemiophrys)

True Frogs (Family Ranidae)

Wood Frog (Rana sylvatica)

\section{Reptiles (Class Reptilia)}

Lizards (Order Squamata, Suborder Lacertilia)

Spiny Lizards (Family Phrynosomatidae)

Pigmy Short-horned Lizard (Phrynosoma douglasii)

EXOTIC SPECIES SUCCESSFULLY BREEDING IN MONTANA

Amphibians (Class Amphibia)

Frogs and Toads (Order Anura)

True Frogs (Family Ranidae)

American Bullfrog (Rana catesbeiana)

\section{SPECIES SUCCESSFULLY BREEDING IN MONTANA FOR WHICH THERE IS UNCERTAINTY ABOUT THEIR STATUS AS NATIVES OR EXOTICS}

\section{Reptiles (Class Reptilia)}

Lizards (Order Squamata, Suborder Lacertilia)

Spiny Lizards (Family Phrynosomatidae)

Western Fence Lizard (Sceloporus occidentalis) 


\section{EXOTIC SPECIES DOCUMENTED IN MONTANA FOR WHICH THERE IS NO EVIDENCE OF SUCCESSFUL BREEDING}

\section{Salamanders (Order Caudata)}

Newts (Family Salamandridae)

Rough-skinned Newt (Taricha granulosa)

\section{Turtles (Order Testudines)}

Pond Turtles (Family Emydidae)

Mississippi Map Turtle (Graptemys pseudogeographica kohnii)

Red-eared Slider (Trachemys scripta elegans)

Spiny Lizards (Family Phrynosomatidae)

Coast Horned Lizard (Phrynosoma coronatum) 


\section{Presence and Status Ranks for Amphibians and Reptiles in Various Land Management Regions in Montana}

Current distribution and status information can be found on the Montana Natural Heritage Program's website at www.mtnhp.org

\section{Natureserve and Heritage Program Ranks}

NatureServe and the international network of Natural Heritage Programs employ a standardized ranking system to denote global and state status. These ranks are often used by federal and state agencies in assigning their own special status ranks for species they will give special protections or considerations in land use planning. Under the NatureServe and Natural Heritage Program conservation data network, each species is given a global (G) rank, denoting range-wide status, and a state (S) rank for its status in Montana. Status ranks range from 1 (greatest concern) to 5 (least concern).

Global ranks are assigned by scientists at NatureServe (the international affiliate organization for the heritage network) in consultation with biologists in the natural heritage programs and other taxonomic experts. State ranks are determined jointly by Montana Natural Heritage Program and Montana Fish, Wildlife, and Parks biologists in consultation with the Montana Chapter of the Wildlife Society, the Montana Chapter of the American Fisheries Society, and other experts (see ranking criteria below). Among other things, the combination of global and state ranks often helps describe the proportion of a species' range and/or total population occurring in Montana. For instance, a rank of G3 S3 often indicates that Montana comprises most or a very significant portion of an animal's total population. In contrast, an animal ranked G5 S1 often occurs in Montana at the periphery of its much larger range; thus, the state supports a relatively small portion of its total population.

In Montana, vertebrate species assigned a state rank of S1, S2, or S3 and invertebrate species assigned a state rank of S1 or S2 are included in the Montana Species of Concern report. The latest version of this report can be found at: http://nhp.nris.state.mt.us/reports.asp Designation of a species as a Montana Animal Species of Concern is not a statutory or regulatory classification. Instead, these designations provide a basis for resource managers and decision-makers to direct limited resources to priority data collection needs and address conservation needs proactively.

\section{Definitions of NatureServe and Heritage Program Ranks}

G1 / S1 At high risk because of extremely limited and/or rapidly declining numbers, range, and/or habitat, making it highly vulnerable to global extinction or extirpation in the state.

G2 / S2 At risk because of very limited and/or declining numbers, range, and/or habitat, making it vulnerable to global extinction or extirpation in the state.

G3 / S3 Potentially at risk because of limited and/or declining numbers, range, and/or habitat, even though it may be abundant in some areas.

G4 / S4 Uncommon but not rare (although it may be rare in parts of its range), and usually widespread. Apparently not vulnerable in most of its range, but possibly cause for long-term concern.

G5 / S5 Common, widespread, and abundant (although it may be rare in parts of its range). Not vulnerable in most of its range.

SNA Currently unranked at the state level. 


\section{State Rank Criteria for Montana Animal Species of Concern}

The ranking criteria described below were used in developing state ranks for vertebrate animal species in Montana. Detailed definitions and guidance for use are provided individually for each criterion. Information from multiple reviewers was combined by MTNHP and MFWP staff to generate "compiled" responses to each criterion. The final state rank was then derived using the process described in Appendix A, with input and review from staff and other experts.

This methodology has been adapted for Montana from a process developed and proposed by scientists at NatureServe (the international affiliate for natural heritage programs), as documented in:

Master, L. L., L. E. Morse, A. S. Weakley, G. A. Hammerson, and D. Faber-Langendoen. 2003. NatureServe Conservation Status Assessment Criteria. NatureServe, Arlington, Virginia, U.S.A.

\section{Conservation Criteria}

\section{Population Size}

Enter the code for the estimated current naturally occurring wild total population of the species within Montana. Count or estimate the number of individuals of reproductive age or stage (at an appropriate time of the year), including mature but currently non-reproducing individuals.

Guidance, consider the following points (from IUCN 2000) when estimating population numbers:

- Mature individuals that will never produce new recruits should not be counted (e.g., densities are too low for fertilization) [But see note below regarding long-persisting nonreproductive clones.]

- In the case of populations with biased adult or breeding sex ratios it is appropriate to use lower estimates for the number of mature individuals, which take this into account (e.g., the estimated effective population size).

- Where the population size fluctuates use a lower estimate. In most cases this will be much less than the mean.

- Reproducing units within a clone should be counted as individuals, except where such units are unable to survive alone (e.g., corals).

- In the case of taxa that naturally lose all or a subset of mature individuals at some point in their life cycle, the estimate should be made at the appropriate time, when mature individuals are available for breeding.

- $\quad$ Re-introduced individuals must have produced viable offspring before they are counted as mature individuals

Also consider:

- For species that produce more than one generation per year, use the size of the smallest annual reproducing generation in estimations.

- For seed-banking plants or other intermittently obvious organisms, consider population size to be the number of mature individuals in a typical "good" year, but not a "poor" year or an 
extraordinarily productive year. Although data will rarely be available, population size for such species should be conceptually considered the median of the population over a 10-year or 3-generation (whichever is longer) time span.

- For clone-forming organisms that persist or spread locally but rarely if ever reproduce, consider the population size to be the number of distinct, self-maintaining clonal patches (approximating the number of genets), rather than the number of physiologically separate individuals (ramets).

Select from the following values:

$$
\begin{aligned}
& Z=\text { Zero, no individuals known extant } \\
& A=1-50 \text { individuals } \\
& B=50-250 \text { individuals } \\
& C=250-1,000 \text { individuals } \\
& D=1,000-2,500 \text { individuals } \\
& E=2,500-10,000 \text { individuals } \\
& F=10,000-100,000 \text { individuals } \\
& G=100,000-1,000,000 \text { individuals } \\
& H=>1,000,000 \text { individuals } \\
& U=\text { Unknown } \\
& \text { Null = Rank factor not assessed }
\end{aligned}
$$

\section{Range Extent / Area of Occupancy}

Range extent is described by IUCN (2001) for taxa:

Extent of occurrence is defined as the area contained within the shortest continuous imaginary boundary that can be drawn to encompass all the known, inferred or projected sites of present occurrence of a taxon, excluding cases of vagrancy. This measure may exclude discontinuities or disjunctions within the overall distribution of a taxon (e.g. large areas of obviously unsuitable habitat) (but see 'area of occupancy').

Area of occupancy is described by IUCN (2001) for taxa as:

Area of occupancy is defined as the area within its 'extent of occurrence' (see definition), which is occupied by a taxon, excluding cases of vagrancy. The measure reflects the fact that a taxon will not usually occur throughout the area of its extent of occurrence, which may contain unsuitable or unoccupied habitats. In some cases (e.g. colonial nesting sites, feeding sites for migratory taxa) the area of occupancy is the smallest area essential at any stage to the survival of existing populations of a taxon. The size of the area of occupancy will be a function of the scale at which it is measured, and should be at a scale appropriate to relevant biological aspects of the taxon, the nature of threats and the available data. 
Figure 1 illustrates the differences between range extent and area of occupancy.
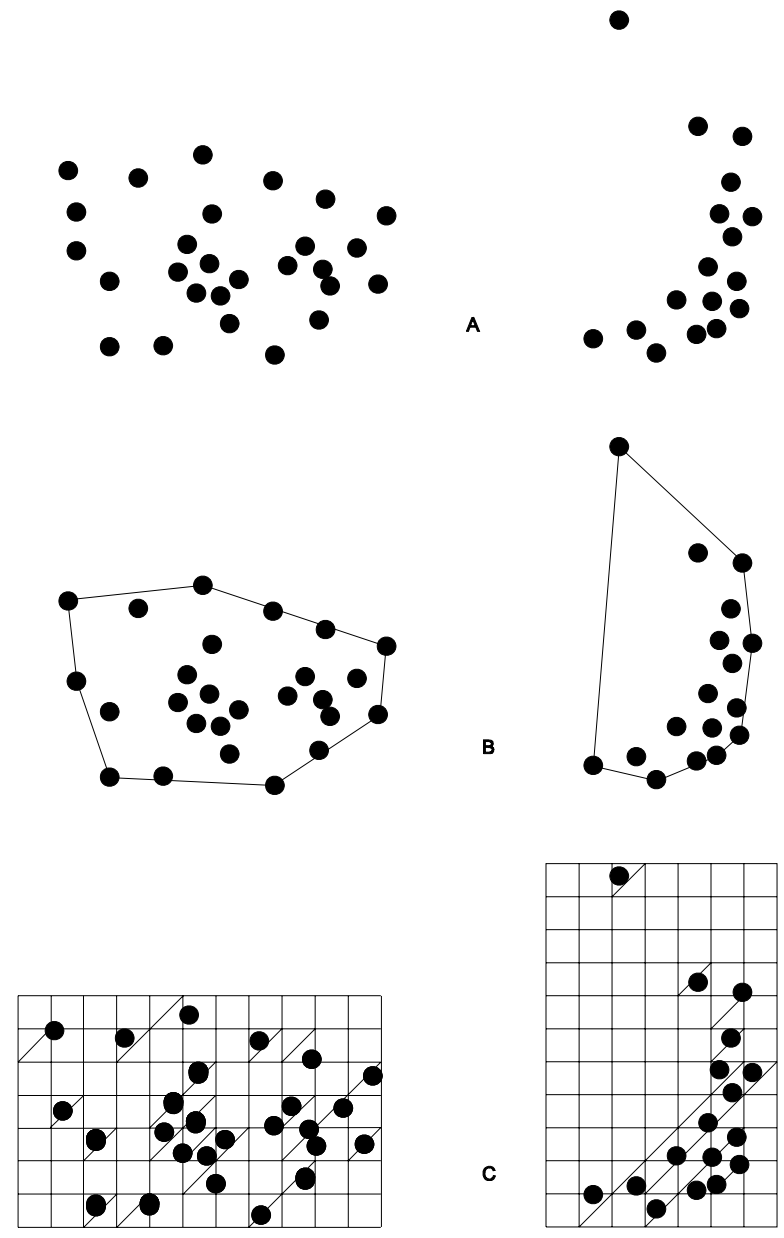

Figure 1. Two examples of the distinction between range extent and area of occupancy. (A) Is the spatial distribution of known, inferred or projected sites of present occurrence. (B) Shows one possible boundary to the range extent, which is the measured area within this boundary using a minimum convex polygon. [Note that Burgman and Fox (2001) strongly recommend the use of $\alpha$ hulls rather than minimum convex polygons to estimate range extent as otherwise significant overestimates (e.g., right side of example B) may result.] (C) Shows one measure of area of occupancy, which can be achieved by the sum of the occupied grid squares.

(From IUCN 2001)

\section{Range Extent}

Enter the code that best describes the estimated current range of the species in Montana. See below for definitions of range extent (extent of occurrence) and for contrast of this with area of occupancy.

Select from the following values:

$\mathrm{Z}=$ Zero (no occurrences believed extant)

$\mathrm{A}=<100 \mathrm{~km}^{2}$ (less than about 40 square miles)

$\mathrm{B}=100-250 \mathrm{~km}^{2}$ (about $40-100$ square miles)

$\mathrm{C}=250-1,000 \mathrm{~km}^{2}$ (about $100-400$ square miles)

$\mathrm{D}=1,000-5,000 \mathrm{~km}^{2}$ (about $400-2,000$ square miles)

$\mathrm{E}=5,000-20,000 \mathrm{~km}^{2}$ (about 2,000-8,000 square miles)

$\mathrm{F}=20,000-200,000 \mathrm{~km}^{2}$ (about $8,000-80,000$ square miles)

$\mathrm{G}=200,000-2,500,000 \mathrm{~km}^{2}$ (about $80,000-1,000,000$ square miles)

$\mathrm{U}=$ Unknown

Null $=$ Rank factor not assessed 


\section{Area of Occupancy}

Determine the code for the estimated current area of occupancy of the species in Montana. See above for differences between area of occupancy and range extent.

For species in linear habitats (e.g., riverine shoreline, or cliff-edge species), enter the code for the total length of all currently occupied habitat segments. Where better information is lacking, area can be estimated from a linear dimension by assuming an appropriate average width (e.g., 100 meters) for a linear habitat. If information on both occupied area and occupied length is available, use the one that results in the more restrictive value, but provide information on both in the comments field.

For migratory species, enter the code (area or length) that reflects the current area of occupancy (or length of occupied area) at the time of the year when occupancy is most restricted.

Select from the following values:

Area:

$$
\begin{aligned}
& \mathrm{Z}=\text { Zero (no occurrences believed extant) } \\
& \mathrm{A}=<0.4 \mathrm{~km}^{2} \text { (less than about } 100 \text { acres) } \\
& \mathrm{B}=0.4-4 \mathrm{~km}^{2} \text { (about } 100-1,000 \text { acres) } \\
& \mathrm{C}=4-20 \mathrm{~km}^{2} \text { (about } 1,000-5,000 \text { acres) } \\
& \mathrm{D}=20-100 \mathrm{~km}^{2} \text { (about } 5,000-25,000 \text { acres) } \\
& \mathrm{E}=100-500 \mathrm{~km}^{2} \text { (about } 25,000-125,000 \text { acres) } \\
& \mathrm{F}=500-2,000 \mathrm{~km}^{2} \text { (about } 125,000-500,000 \text { acres) } \\
& \mathrm{G}=2,000-20,000 \mathrm{~km}^{2}(500,000-5,000,000 \text { acres) } \\
& \mathrm{H}=>20,000 \mathrm{~km}^{2} \text { (greater than } 5,000,000 \text { acres) } \\
& \mathrm{U}=\text { Unknown } \\
& \text { Null = Rank factor not assessed }
\end{aligned}
$$

Length:

$$
\begin{aligned}
& \mathrm{LZ}=\text { Zero (no occurrences believed extant) } \\
& \mathrm{LA}=<4 \mathrm{~km} \text { (less than about } 2.5 \text { miles) } \\
& \mathrm{LB}=4-40 \mathrm{~km} \text { (about } 2.5-25 \text { miles) } \\
& \mathrm{LC}=40-200 \mathrm{~km} \text { (about } 25-125 \text { miles) } \\
& \mathrm{LD}=200-1,000 \mathrm{~km} \text { (about } 125-620 \text { miles) } \\
& \mathrm{LE}=1,000-5,000 \mathrm{~km} \text { (about } 620-3,000 \text { miles) } \\
& \mathrm{LF}=5,000-20,000 \mathrm{~km} \text { (about } 3,000-12,500 \text { miles) } \\
& \mathrm{LG}=20,000-200,000 \mathrm{~km} \text { (about } 12,500-125,000 \text { miles) } \\
& \mathrm{LH}=>200,000 \mathrm{~km} \text { (greater than } 125,000 \text { miles) } \\
& \mathrm{LU}=\text { Unknown } \\
& \text { Null }=\text { Rank factor not assessed }
\end{aligned}
$$

\section{Long-term Trend}

Enter the code that best describes the observed, estimated, inferred, or suspected degree of change in population size, extent of occurrence, area of occupancy, and/or number or condition of occurrences over the long term (ca. 200 years) in Montana. Specify in the comment field the time period for the change noted, as well as a longer-term view (e.g., back to European 
exploration) if information is available. If there are data on more than one aspect, specify which aspect is most influential.

Select from the following values:

$\mathrm{A}=$ Very Large Decline (decline of $>90 \%$, with $<10 \%$ of population size, range extent, area occupied, and/or number or condition of occurrences remaining)

$\mathrm{B}=$ Large Decline (decline of 75-90\%)

$\mathrm{C}=$ Substantial Decline (decline of $50-75 \%$ )

$\mathrm{D}=$ Moderate Decline (decline of $25-50 \%$ )

$\mathrm{E}=$ Relatively Stable $( \pm 25 \%$ change $)$

$\mathrm{F}=$ Increase (increase of $>25 \%$ )

$\mathrm{U}=$ Unknown. Long-term trend in population, range, area occupied, or number or condition of occurrences unknown

Null $=$ Rank factor not assessed

\section{Short-term Trend}

Enter the code that best describes the observed, estimated, inferred, suspected, or projected shortterm trend in population size, extent of occurrence, area of occupancy, whichever most

significantly affects the rank in Montana. Consider short-term historical trend within 10 years or 3 generations (for long-lived species), whichever is the longer (up to a maximum of 100 years.

The trend may be recent, current, or projected (based on recent past), and the trend may or may not be known to be continuing. Trends may be smooth, irregular or sporadic. Fluctuations will not normally count as trends, but an observed change should not be considered as merely a fluctuation rather than a trend unless there is evidence for this.

Specify what is known about various pertinent trends in the comment field, including trend information for particular factors, more precise information, regional trends, etc. Also comment, if known, on whether the causes of decline, if any, are understood, reversible, and/or ceased. If the trend is known not to be continuing, specify that in comments.

Select from the following values:

$\mathrm{A}=$ Severely Declining. Decline of $>70 \%$ in population, range, area occupied, and/or number or condition of occurrences

$\mathrm{B}=$ Very Rapidly Declining. Decline of $50-70 \%$ in population, range, area occupied, and/or number or condition of occurrences

$\mathrm{C}=$ Rapidly Declining. Decline of $30-50 \%$ in population, range, area occupied, and/or number or condition of occurrences

$\mathrm{D}=$ Declining. Decline of $10-30 \%$ in population, range, area occupied, and/or number or condition of occurrences

$\mathrm{E}=$ Stable. Population, range, area occupied, and/or number or condition of occurrences unchanged or remaining within $\pm 10 \%$ fluctuation

$\mathrm{F}=$ Increasing. Increase of $>10 \%$ in population, range, area occupied, and/or number or condition of occurrences

$\mathrm{U}=$ Unknown. Short-term trend in population, range, area occupied, and number and condition of occurrences unknown.

Null $=$ Rank factor not assessed 


\section{Threats (Severity, Scope, and Immediacy)}

Indicate the degree to which the species is observed, inferred, or suspected to be directly or indirectly threatened in Montana (or throughout its range if it affects persistence in Montana). Use this field to evaluate the impact of extrinsic threats, which typically are anthropogenic but may be natural. The impact of human activity may be direct (e.g., destruction of habitat) or indirect (e.g., invasive species introduction). Effects of natural phenomena (e.g., fire, hurricane, flooding) may be especially important when the species is concentrated in few locations. Characteristics of the species that make it inherently susceptible to threats should be considered under the rank factor Intrinsic Vulnerability.

Threats considerations apply to the present and the future. Effects of past threats (whether or not continuing) should be addressed instead under the short-term trend and/or long-term trend factors. For species known only historically in the area of interest, but with significant likelihood of rediscovery in identifiable areas, current or foreseeable threats in those areas may be addressed here where appropriate if they would affect any extant (but unrecorded) occurrences of the species.

Threats may be observed, inferred, or projected to occur in the near term. They should be characterized in terms of severity (how badly and irreversibly the species population is affected), scope (what proportion of it is affected), and degree of imminence (how likely the threat is and how soon is it expected). "Magnitude" is sometimes used to refer to scope and severity collectively.

Consider threats collectively, and for the foreseeable threat with the greatest magnitude (severity and scope combined), rate the severity, scope, and immediacy each as High, Moderate, Low, Insignificant, or Unknown, as briefly defined below. Identify in the comment field the threat to which severity, scope, and immediacy pertains, and discuss additional threats identified, or interactions among threats, including any high-magnitude threats considered insignificant in immediacy.

Severity

High: Loss of species population (all individuals) or destruction of species habitat in area affected, with effects essentially irreversible or requiring long-term recovery ( $>100$ years). Moderate: Major reduction of species population or long-term degradation or reduction of habitat in Montana, requiring 50-100 years for recovery.

Low: Low but nontrivial reduction of species population or reversible degradation or reduction of habitat in area affected, with recovery expected in 10-50 years.

Insignificant: Essentially no reduction of population or degradation of habitat or ecological community due to threats, or populations, habitats, able to recover quickly (within 10 years) from minor temporary loss. Note that effects of locally sustainable levels of hunting, fishing, logging, collecting, or other harvest from wild populations are generally considered Insignificant as defined here. 
$\underline{\text { Scope }}$

High: $>60 \%$ of total population or area affected

Moderate: $20-60 \%$ of total population or area affected

Low: $5-20 \%$ of total population or area affected

Insignificant: $<5 \%$ of total population or area affected

$\underline{\text { Immediacy }}$

High: Threat is operational (happening now) or imminent (within a year).

Moderate: Threat is likely to be operational within 2-5 years.

Low: Threat is likely to be operational within 5-20 years.

Insignificant: Threat not likely to be operational within 20 years.

The system will calculate a rank factor value of A, B, C, D, E, F, or G, as shown in Table 2 below. If two of the three parameters are known, the rank factor value will be calculated by treating the unknown (or not assessed [null]) parameter as "Low." If only one of the rank factors is rated (as High, Moderate, or Low), the resulting rank factor value will be "U" (unknown). If any of the three factors are considered "Insignificant," the resulting rank factor will be "H" (unthreatened)."

Threat values, calculated from scope, severity, and immediacy, or unknown, may be considered as follows.

$\mathrm{A}=$ Substantial, imminent threat. Threat is moderate to severe and imminent for most $(>60 \%)$ of the population or area.

$\mathrm{B}=$ Moderate and imminent threat. Threat is moderate to severe and imminent for a significant proportion $(20-60 \%)$ of the population or area.

$\mathrm{C}=$ Substantial, non-imminent threat. Threat is moderate to severe but not imminent $(>10$ years) for most of the population or area.

$\mathrm{D}=$ Moderate, non-imminent threat. Threat is moderate to severe but not imminent for a significant portion of the population or area.

$\mathrm{E}=$ Localized substantial threat. Threat is moderate to severe for a small but significant proportion of the population or area.

$\mathrm{F}=$ Widespread, low-severity threat. Threat is of low severity but affects (or would affect) most or a significant portion of the population or area.

$\mathrm{G}=$ Slightly threatened. Threats, while recognizable, are of low severity, or affecting only a small portion of the population or area.

$\mathrm{H}=$ Unthreatened. Threats if any, when considered in comparison with natural fluctuation and change, are minimal or very localized, not leading to significant loss or degradation of populations or area even over a few decades' time. (Severity, scope, and/or immediacy of threat considered Insignificant.)

$\mathrm{U}=$ Unknown. The available information is not sufficient to assign degree of threat as above. (Severity, scope, and immediacy are all unknown, or mostly [two of three] unknown or not assessed [null].)

Null $=$ Rank factor not assessed, including instances in which the species is extinct (or extirpated from the area of interest). 
Table 2. Calculation of Threats factor values from values for Severity, Scope, and Immediacy subfactors.

\begin{tabular}{|c|c|c|c|c|}
\hline SEVERITY & SCOPE & IMMEDIACY & VALUE & DESCRIPTION \\
\hline $\begin{array}{c}\text { High } \\
\text { High } \\
\text { Moderate } \\
\text { Moderate }\end{array}$ & $\begin{array}{l}\text { High } \\
\text { High } \\
\text { High }\end{array}$ & $\begin{array}{c}\text { High } \\
\text { Moderate } \\
\text { High } \\
\text { Moderate }\end{array}$ & $=\mathrm{A}$ & $\begin{array}{l}\text { Moderate to severe, } \\
\text { imminent threat for } \\
\text { most }(>60 \%) \text { of } \\
\text { population, } \\
\text { occurrences, or area }\end{array}$ \\
\hline $\begin{array}{c}\text { High } \\
\text { High } \\
\text { Moderate } \\
\text { Moderate }\end{array}$ & $\begin{array}{l}\text { Moderate } \\
\text { Moderate } \\
\text { Moderate } \\
\text { Moderate }\end{array}$ & $\begin{array}{c}\text { High } \\
\text { Moderate } \\
\text { High } \\
\text { Moderate }\end{array}$ & $=\mathrm{B}$ & $\begin{array}{l}\text { Moderate to severe, } \\
\text { imminent threat for a } \\
\text { significant proportion } \\
\text { (20-60\%) of population, } \\
\text { occurrences, or area }\end{array}$ \\
\hline $\begin{array}{c}\text { High } \\
\text { Moderate }\end{array}$ & $\begin{array}{l}\text { High } \\
\text { High }\end{array}$ & $\begin{array}{l}\text { Low } \\
\text { Low }\end{array}$ & $=\mathrm{C}$ & $\begin{array}{l}\text { Moderate to severe, } \\
\text { non-imminent threat for } \\
\text { most of population, } \\
\text { occurrences, or area }\end{array}$ \\
\hline $\begin{array}{c}\text { High } \\
\text { Moderate }\end{array}$ & $\begin{array}{l}\text { Moderate } \\
\text { Moderate }\end{array}$ & $\begin{array}{l}\text { Low } \\
\text { Low }\end{array}$ & $=\mathrm{D}$ & $\begin{array}{l}\text { Moderate to severe, } \\
\text { non-imminent threat for } \\
\text { a significant proportion } \\
\text { of population, } \\
\text { occurrences, or area }\end{array}$ \\
\hline High & Low & High & & \\
\hline High & Low & $\begin{array}{c}\text { Moderate } \\
\text { Low }\end{array}$ & & $\begin{array}{l}\text { Moderate to severe } \\
\text { threat for small }\end{array}$ \\
\hline Moderate & Low & High & $=\mathrm{E}$ & $\begin{array}{l}\text { proportion or } \\
\text { population, } \\
\text { occurrences, or area }\end{array}$ \\
\hline Moderate & Low & Moderate & & \\
\hline Moderate & Low & Low & & \\
\hline
\end{tabular}




\begin{tabular}{|c|c|c|c|c|}
\hline Low & High & High & \multirow{6}{*}{$=\mathrm{F}$} & \multirow{6}{*}{$\begin{array}{l}\text { Low severity threat for } \\
\text { most or significant } \\
\text { proportion of } \\
\text { population, } \\
\text { occurrences, or area }\end{array}$} \\
\hline Low & High & Moderate & & \\
\hline Low & High & Low & & \\
\hline Low & Moderate & High & & \\
\hline Low & Moderate & Moderate & & \\
\hline Low & Moderate & Low & & \\
\hline Low & Low & High & \multirow{3}{*}{$=\mathrm{G}$} & \multirow{3}{*}{$\begin{array}{c}\text { Low severity threat for } \\
\text { a small proportion of } \\
\text { population, } \\
\text { occurrences, or area }\end{array}$} \\
\hline Low & Low & Moderate & & \\
\hline Low & Low & Low & & \\
\hline
\end{tabular}

\section{Intrinsic Vulnerability}

Enter the appropriate letter code for the observed, inferred, or suspected degree to which intrinsic or inherent factors of the species (such as life history or behavior characteristics of species) make it vulnerable or resilient to natural or anthropogenic stresses or catastrophes. Examples of such factors include reproductive rates and requirements, time to maturity, dormancy requirements, and dispersal patterns.

Since geographically or ecologically disjunct or peripheral populations may show additional vulnerabilities not generally characteristic of the species, these factors are to be assessed for the species throughout the area of interest, or at least for its better populations. Do not consider here such topics as population size, number of occurrences, area of occupancy, extent of occurrence, or environmental specificity; these are addressed as other ranking factors.

Note that the intrinsic vulnerability factors exist independent of human influence, but may make the species more susceptible to disturbance by human activities. The extent and effects of current or projected extrinsic influences themselves should be addressed in the Threat comments field.

Describe the reasons for your selection in the Intrinsic Vulnerability Comments field.

Select from the following values:

A = Highly Vulnerable. Species is slow to mature, reproduces infrequently, and/or has low fecundity such that populations are very slow ( $>20$ years or 5 generations) to recover from decreases in abundance; or species has low dispersal capability such that extirpated 
populations are unlikely to become reestablished through natural recolonization (unaided by humans).

$\mathrm{B}=$ Moderately Vulnerable. Species exhibits moderate age of maturity, frequency of reproduction, and/or fecundity such that populations generally tend to recover from decreases in abundance over a period of several years (on the order of 5-20 years or 2-5 generations); or species has moderate dispersal capability such that extirpated populations generally become reestablished through natural recolonization (unaided by humans).

$\mathrm{C}=$ Not Intrinsically Vulnerable. Species matures quickly, reproduces frequently, and/or has high fecundity such that populations recover quickly ( $<5$ years or 2 generations) from decreases in abundance; or species has high dispersal capability such that extirpated populations soon become reestablished through natural recolonization (unaided by humans).

$\mathrm{U}=$ Unknown

Null $=$ Rank factor not assessed

\section{Environmental Specificity}

Enter the appropriate letter code for the observed, inferred, or suspected vulnerability or resilience of the species due to habitat preferences or restrictions or other environmental specificity or generality. Describe the reasons for your selection in the Environmental Specificity field. Indicate in the comment field why environmental specificity affects vulnerability. This factor is most important when the number of populations and the range extent or area of occupancy are largely unknown.

Select from the following values:

$\mathrm{A}=$ Very Narrow. Specialist. Specific habitat(s), substrate(s), food type(s), hosts, breeding/nonbreeding microhabitats, or other abiotic and/or biotic factor(s) are used or required by the Element in the area of interest, with these habitat(s) and/or other requirements furthermore being scarce within the generalized range of the species within the area of interest, and, the population (or the number of breeding attempts) expected to decline significantly if any of these key requirements become unavailable.

B = Narrow. Specialist. Specific habitat(s) or other abiotic and/or biotic factors (see above) are used or required by the Element, but these key requirements are common and within the generalized range of the species within the area of interest.

$\mathrm{C}=$ Moderate. Generalist. Broad-scale or diverse (general) habitat(s) or other abiotic and/or biotic factors are used or required by the species but some key requirements are scarce in the generalized range of the species within the area of interest.

$\mathrm{D}=$ Broad. Generalist. Broad-scale or diverse (general) habitat(s) or abiotic and/or biotic factors are used or required by the species, with all key requirements common in the generalized range of the species in the area of interest. If the preferred food(s) or breeding/nonbreeding microhabitat(s) become unavailable, the species switches to an alternative with no resulting decline in numbers of individuals or number of breeding attempts.

$\mathrm{U}=$ Unknown

Null $=$ Rank factor not assessed 


\section{Other Considerations}

Provide and comment on any other information that should be considered in the assignment of a conservation status rank, especially when the status rank resulting from the overall assessment is different from the rank that the values for the formal status factors, taken alone, would suggest. This (text only) field may also be used for other general notes pertinent to multiple factors.

The following are some examples of Other Considerations:

- Preliminary rank assessment does not necessarily reflect current status, since the rank was done by inspection from review of published distribution and habitat information, or museum collection information.

- A population viability analysis may indicate that the species has x percent probability of surviving for y years (or an equivalent number of generations) in the same area of interest (globe, nation, or subnation). 


\section{Conservation Status For Species: A Rule- And Point-Based Process For Rank Assignment}

Adopted for Montana from a draft by- L. Master \& T. Regan- 17 November 2001

A Quantitative approximation to assigning Heritage Ranks

The method for determining an SRank is a hybrid of rule based approaches and point scoring techniques. The method incorporates unknown data. To determine an Srank, first determine what information is available for the species. Use the following rationale along with the Status Assessment Factors presented in this document and the method for point allocation for each of the factors presented below to determine the classification.

- Population size. If the number of mature individuals is small, it may be appropriate to raise the priority by one-half rank or more. If there are many mature individuals, the priority may be lowered. $[\mathrm{A}=-1, \mathrm{~B}=-0.75, \mathrm{C}=-0.5, \mathrm{D}-\mathrm{E}=-0.25, \mathrm{~F}=0, \mathrm{G}=+0.25, \mathrm{H}=+0.5$, $\mathrm{U}=0]$

- Geographic distribution. If a species' area of occupancy or extent of occurrence (= range extent) is relatively small, it is more vulnerable to negative effects from localized events. It may be appropriate to raise priority by one-quarter rank or more for a species with a narrow distribution and lower it by one-quarter to one-half rank for a widespread species. [Area of occupancy: $\mathrm{A}=-1, \mathrm{~B}=-0.75, \mathrm{C}=-0.5, \mathrm{D}=-.25, \mathrm{E}=0, \mathrm{~F}=0, \mathrm{G}=0, \mathrm{H}=+0.25, \mathrm{U}=0$; $\underline{\text { or }}$ (whichever is greatest) Extent of occurrence: $A-B=-0.5, C-D=-0.25 ; E-F-G-H=0, U=0]$

- Environmental specificity. If a species requires highly specific habitat(s) or other abiotic or biotic factor(s), and if the number of populations and distribution is unknown, the rank may be raised or lowered. $[A=-0.5, B \& C=0, D=+0.5, U=0]$.

- Short-term trends in population size, area of occupancy, extent of occurrence, or number or condition of occurrences. A significant short term and non-cyclic negative trend may be reason to raise priority by one-quarter rank or more, or a significant positive trend may indicate that priority should be lowered by one-half rank. $[A=-1, B=-0.75, C=-0.5, D=-$ $0.25, \mathrm{E}=0, \mathrm{~F}=+0.25, \mathrm{U}=0$ ] In the absence of short-term trend data, the rank may be raised or lowered for long-term trends. $[\mathrm{A}=-0.5, \mathrm{~B}=-0.25, \mathrm{C} \& \mathrm{D} \& \mathrm{E}=0, \mathrm{~F}=+0.25, \mathrm{U}=0]$

- Threats. Threats include habitat destruction or degradation, introduction of exotic species, overexploitation and direct human-caused mortality, and elimination of natural disturbance regimes, such as fire or flooding. Depending on the severity, scope, and immediacy of threats, the priority may be raised or lowered by one-half to one rank. $[A=-$ $1, \mathrm{~B}=-0.75, \mathrm{C}=-0.5, \mathrm{D}=-0.25, \mathrm{E} \& \mathrm{~F}=0, \mathrm{G}=+0.75, \mathrm{H}=+1.0, \mathrm{U}=0]$

- Intrinsic vulnerability. If a species is intrinsically vulnerable because it is slow to mature, reproduces infrequently, and/or has low fecundity such that populations are very slow to recover from decreases in abundance, or is a species has low dispersal capability such that extirpated populations are unlikely to become reestablished through natural colonization, it may be appropriate to raise its priority. $[A=-0.5, B=-0.25, C \& U=0]$ 
Step 1: Determine the available data for the species. The following subheadings are indicative of the types of data useful for classification (Refer to Heritage Conservation Status Assessment Factors for definitions of the following factors as noted in this document.

Population size

Geographic Distribution (Extent of Occurrence [EOO] or Area of Occupancy [AOO])

Environmental Specificity

Trends (short-term and long-term trends)

Threats (scope, severity, immediacy)

Management / Protection

Intrinsic Vulnerability

Step2: Determine which of the following combinations of the first five data requirements suits the available data (only choose one combination and the first to apply).

Pop size + Geographic Distribution (greatest value from EOO or AOO)

Pop size + Environmental Specificity

Population size

Geographic Distribution (EOO only; AOO unknown) and Environmental Specificity

Geographic Distribution (greatest value from EOO or AOO)

Environmental Specificity

Step 3: Start point allocation at 3.5. Using the point allocation document below, determine a value for the combination you choose and add or subtract if appropriate. If all six factors are unknown: points $=3.5$

Step 4: Once a value has been determined for the first five data requirements, incorporate remaining data.

$\mathrm{P}=$ points (total from step 3$)+$ trends (short term trend otherwise use Long term trend) + threats

$\underline{\mathrm{OR}}$

$\mathrm{P}=$ points (total from step 3) + trends (short term trend if known, otherwise use Long term trend) + intrinsic vulnerability

Explanation: Only include intrinsic vulnerability if you have no information on threats.

The following Heritage Ranks correspond to the final point total.

\begin{tabular}{|c|c|}
\hline Points (P) & SRANK \\
\hline $\mathrm{P} \leq 1.5$ & $\mathrm{~S} 1$ \\
\hline $1.5<\mathrm{P} \leq 2.5$ & $\mathrm{~S} 2$ \\
\hline $2.5<\mathrm{P} \leq 3.5$ & $\mathrm{~S} 3$ \\
\hline $3.5<\mathrm{P} \leq 4.5$ & $\mathrm{~S} 4$ \\
\hline $\mathrm{P}>4.5$ & $\mathrm{~S} 5$ \\
\hline
\end{tabular}




\section{Presence and Status Ranks for Amphibians and Reptiles on National Forests in Montana}

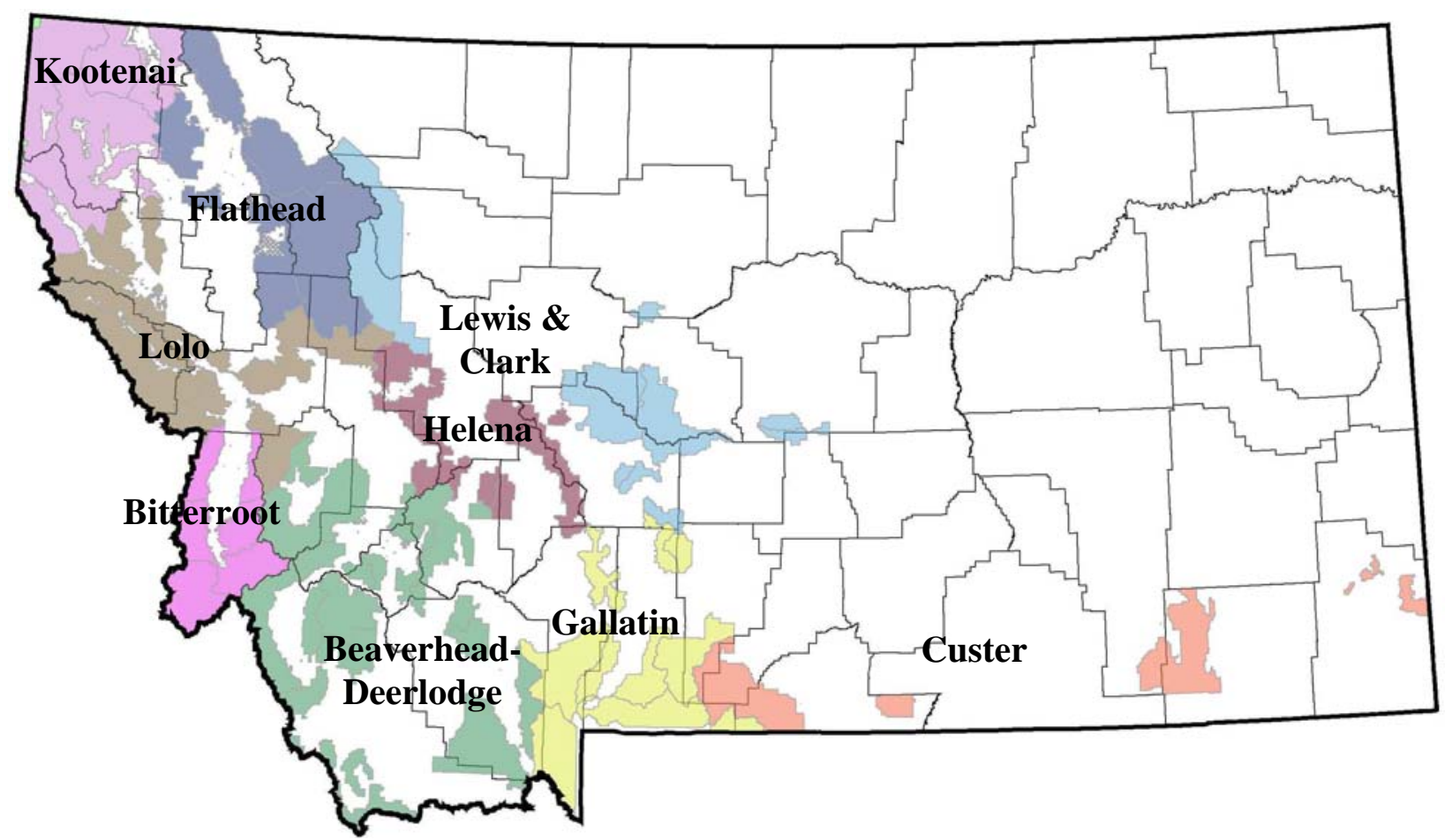

U.S. Forest Service and Montana Natural Heritage Program status ranks and notations on species presence are listed in the table below for each of the National Forests in Montana. Until recently, U.S. Forest Service Manual (2670.22) defined Sensitive species on U.S. Forest Service lands as those for which population viability is a concern as evidenced by a significant downward trend in population or a significant downward trend in habitat capacity. Sensitive species receive special considerations in various planning and project level decisions. The Regional Forester for the Northern Region designates Sensitive species on National Forests in Montana. These designations were last updated in 2007 and they apply only on USFSadministered lands. However, the U.S. Forest Service is implementing new planning regulations which will lead to changes in the identification of "special status" species on National Forest lands. For the time being, species will continue to be recognized as Sensitive for Region 1 under existing agency policy, but in addition many of the newly revised Forest Plans may also identify USFS Species of Concern and USFS Species of Interest as outlined below (FSH 1909.12, 43.22b). The new USFS Species of Concern will be species for which management actions may be necessary to prevent listing under the Endangered Species Act (ESA) based on proposed or candidate status under the ESA, recent delisting of species from the federal Endangered Species List, or NatureServe/Heritage Ranks of G1-G3 or T1-T3. The new USFS Species of Interest will be species for which management actions may be necessary or desirable to achieve ecological or other multiple-use objectives based on criteria as diverse as NatureServe ranks of S1-S2, species identified as of conservation concern in State Comprehensive Wildlife Strategies, species that are hunted, fished, or are otherwise of public interest, or other species for which there is evidence for significant threats to populations or habitat, declining trends in populations or habitat, rarity, or restricted ranges. 
Presence and Status Ranks for Amphibians on National Forests in Montana

Current distribution and status information can be found on the Montana Natural Heritage Program's website at www.mtnhp.org

\begin{tabular}{|c|c|c|c|c|c|c|c|c|c|c|c|}
\hline $\begin{array}{c}\text { Common and } \\
\text { Scientific Name }\end{array}$ & $\begin{array}{l}\text { R1 USFS } \\
\text { Status }\end{array}$ & $\begin{array}{l}\text { Heritage } \\
\text { Ranks }\end{array}$ & $\begin{array}{l}\text { Beaverhead- } \\
\text { Deerlodge }\end{array}$ & Bitterroot & Custer & Flathead & Gallatin & Helena & Kootenai & $\begin{array}{l}\text { Lewis \& } \\
\text { Clark }\end{array}$ & Lolo \\
\hline $\begin{array}{l}\text { Long-toed Salamander } \\
\text { (Ambystoma macrodactylum) }\end{array}$ & $\begin{array}{l}\text { No Special } \\
\text { Status }\end{array}$ & G5/S4 & $\begin{array}{l}\text { Present } \\
\text { Part }\end{array}$ & $\begin{array}{l}\text { Present } \\
\text { Entire }\end{array}$ & $\begin{array}{l}\text { Outside } \\
\text { Range }\end{array}$ & $\begin{array}{l}\text { Present } \\
\text { Entire }\end{array}$ & $\begin{array}{l}\text { Outside } \\
\text { Range }\end{array}$ & $\begin{array}{l}\text { Present } \\
\text { Part }\end{array}$ & $\begin{array}{l}\text { Present } \\
\text { Entire }\end{array}$ & $\begin{array}{l}\text { Present } \\
\text { Part }\end{array}$ & $\begin{array}{l}\text { Present } \\
\text { Entire }\end{array}$ \\
\hline $\begin{array}{l}\text { Tiger Salamander } \\
\text { (Ambystoma tigrinum) }\end{array}$ & $\begin{array}{l}\text { No Special } \\
\text { Status }\end{array}$ & G5/S4 & $\begin{array}{l}\text { Present } \\
\text { Part }\end{array}$ & $\begin{array}{l}\text { Outside } \\
\text { Range }\end{array}$ & $\begin{array}{l}\text { Present } \\
\text { Entire }\end{array}$ & $\begin{array}{l}\text { Outside } \\
\text { Range }\end{array}$ & $\begin{array}{l}\text { Present } \\
\text { Entire }\end{array}$ & $\begin{array}{l}\text { Presence } \\
\text { Possible }\end{array}$ & $\begin{array}{l}\text { Present } \\
\text { Part }\end{array}$ & $\begin{array}{l}\text { Present } \\
\text { Entire }\end{array}$ & $\begin{array}{l}\text { Outside } \\
\text { Range }\end{array}$ \\
\hline $\begin{array}{l}{ }_{\text {Adaho Giant Salamander }} \\
\text { (Dicamptodon aterrimus) }\end{array}$ & $\begin{array}{l}\text { No Special } \\
\text { Status }\end{array}$ & G3/S1S3 & $\begin{array}{l}\text { Outside } \\
\text { Range }\end{array}$ & $\begin{array}{l}\text { Outside } \\
\text { Range }\end{array}$ & $\begin{array}{l}\text { Outside } \\
\text { Range }\end{array}$ & $\begin{array}{l}\text { Outside } \\
\text { Range }\end{array}$ & $\begin{array}{l}\text { Outside } \\
\text { Range }\end{array}$ & $\begin{array}{l}\text { Outside } \\
\text { Range }\end{array}$ & $\begin{array}{l}\text { Outside } \\
\text { Range }\end{array}$ & $\begin{array}{l}\text { Outside } \\
\text { Range }\end{array}$ & $\begin{array}{l}\text { Present } \\
\text { Part }\end{array}$ \\
\hline $\begin{array}{l}\text { Coeur d' Alene Salamander } \\
\text { (Plethodon idahoensis) }\end{array}$ & $\begin{array}{l}\text { Sensitive } \\
\text { Species }\end{array}$ & G4/S2 & $\begin{array}{l}\text { Outside } \\
\text { Range }\end{array}$ & $\begin{array}{l}\text { Present } \\
\text { Part }\end{array}$ & $\begin{array}{l}\text { Outside } \\
\text { Range }\end{array}$ & $\begin{array}{l}\text { Outside } \\
\text { Range }\end{array}$ & $\begin{array}{l}\text { Outside } \\
\text { Range }\end{array}$ & $\begin{array}{l}\text { Outside } \\
\text { Range }\end{array}$ & $\begin{array}{l}\text { Present } \\
\text { Part }\end{array}$ & $\begin{array}{l}\text { Outside } \\
\text { Range }\end{array}$ & $\begin{array}{l}\text { Present } \\
\text { Part }\end{array}$ \\
\hline $\begin{array}{l}\text { Rocky Mountain Tailed Frog } \\
\text { (Ascaphus montanus) }\end{array}$ & $\begin{array}{l}\text { No Special } \\
\text { Status }\end{array}$ & G4/S4 & $\begin{array}{l}\text { Present } \\
\text { Part }\end{array}$ & $\begin{array}{l}\text { Present } \\
\text { Entire }\end{array}$ & $\begin{array}{l}\text { Outside } \\
\text { Range }\end{array}$ & $\begin{array}{l}\text { Present } \\
\text { Entire }\end{array}$ & $\begin{array}{l}\text { Outside } \\
\text { Range }\end{array}$ & $\begin{array}{l}\text { Present } \\
\text { Part }\end{array}$ & $\begin{array}{l}\text { Present } \\
\text { Entire }\end{array}$ & $\begin{array}{l}\text { Present } \\
\text { Part }\end{array}$ & $\begin{array}{l}\text { Present } \\
\text { Entire }\end{array}$ \\
\hline $\begin{array}{l}\text { APlains Spadefoot } \\
\text { (Spea bombifrons) }\end{array}$ & $\begin{array}{l}\text { Sensitive } \\
\text { Species }\end{array}$ & G5/S3 & $\begin{array}{l}\text { Presence } \\
\text { Possible }\end{array}$ & $\begin{array}{l}\text { Outside } \\
\text { Range }\end{array}$ & $\begin{array}{l}\text { Present } \\
\text { Part }\end{array}$ & $\begin{array}{l}\text { Outside } \\
\text { Range }\end{array}$ & $\begin{array}{l}\text { Presence } \\
\text { Possible }\end{array}$ & $\begin{array}{l}\text { Presence } \\
\text { Possible }\end{array}$ & $\begin{array}{l}\text { Outside } \\
\text { Range }\end{array}$ & $\begin{array}{l}\text { Presence } \\
\text { Possible }\end{array}$ & $\begin{array}{l}\text { Outside } \\
\text { Range }\end{array}$ \\
\hline $\begin{array}{l}\text { Great Basin Spadefoot } \\
\text { (Spea intermontana) }\end{array}$ & $\begin{array}{c}\text { No Special } \\
\text { Status }\end{array}$ & G5/SNA & $\begin{array}{l}\text { Presence } \\
\text { Possible }\end{array}$ & $\begin{array}{l}\text { Outside } \\
\text { Range }\end{array}$ & $\begin{array}{l}\text { Outside } \\
\text { Range }\end{array}$ & $\begin{array}{l}\text { Outside } \\
\text { Range }\end{array}$ & $\begin{array}{l}\text { Outside } \\
\text { Range }\end{array}$ & $\begin{array}{l}\text { Outside } \\
\text { Range }\end{array}$ & $\begin{array}{l}\text { Outside } \\
\text { Range }\end{array}$ & $\begin{array}{l}\text { Outside } \\
\text { Range }\end{array}$ & $\begin{array}{l}\text { Outside } \\
\text { Range }\end{array}$ \\
\hline $\begin{array}{l}\text { B'Western Toad } \\
\text { (Bufo boreas) }\end{array}$ & $\begin{array}{l}\text { Sensitive } \\
\text { Species }\end{array}$ & G4/S2 & $\begin{array}{l}\text { Present } \\
\text { Entire }\end{array}$ & $\begin{array}{l}\text { Present } \\
\text { Entire }\end{array}$ & $\begin{array}{l}\text { Present } \\
\text { Part }\end{array}$ & $\begin{array}{l}\text { Present } \\
\text { Entire }\end{array}$ & $\begin{array}{l}\text { Present } \\
\text { Entire }\end{array}$ & $\begin{array}{l}\text { Present } \\
\text { Entire }\end{array}$ & $\begin{array}{l}\text { Present } \\
\text { Entire }\end{array}$ & $\begin{array}{c}\text { Present } \\
\text { Part }\end{array}$ & $\begin{array}{l}\text { Present } \\
\text { Entire }\end{array}$ \\
\hline $\begin{array}{l}{ }^{\mathrm{A}} \text { Great Plains Toad } \\
\text { (Bufo cognatus) }\end{array}$ & $\begin{array}{l}\text { Sensitive } \\
\text { Species }\end{array}$ & G5/S2 & $\begin{array}{l}\text { Outside } \\
\text { Range }\end{array}$ & $\begin{array}{l}\text { Outside } \\
\text { Range }\end{array}$ & $\begin{array}{l}\text { Present } \\
\text { Part }\end{array}$ & $\begin{array}{l}\text { Outside } \\
\text { Range }\end{array}$ & $\begin{array}{l}\text { Outside } \\
\text { Range }\end{array}$ & $\begin{array}{l}\text { Presence } \\
\text { Possible }\end{array}$ & $\begin{array}{l}\text { Outside } \\
\text { Range }\end{array}$ & $\begin{array}{l}\text { Presence } \\
\text { Possible }\end{array}$ & $\begin{array}{l}\text { Outside } \\
\text { Range }\end{array}$ \\
\hline $\begin{array}{l}\text { Woodhouse's Toad } \\
\text { (Bufo woodhousei) }\end{array}$ & $\begin{array}{c}\text { No Special } \\
\text { Status }\end{array}$ & G5/S4 & $\begin{array}{l}\text { Outside } \\
\text { Range }\end{array}$ & $\begin{array}{l}\text { Outside } \\
\text { Range }\end{array}$ & $\begin{array}{l}\text { Present } \\
\text { Part }\end{array}$ & $\begin{array}{l}\text { Outside } \\
\text { Range }\end{array}$ & $\begin{array}{l}\text { Presence } \\
\text { Possible }\end{array}$ & $\begin{array}{l}\text { Outside } \\
\text { Range }\end{array}$ & $\begin{array}{l}\text { Outside } \\
\text { Range }\end{array}$ & $\begin{array}{l}\text { Presence } \\
\text { Possible }\end{array}$ & $\begin{array}{l}\text { Outside } \\
\text { Range }\end{array}$ \\
\hline $\begin{array}{l}\text { Pacific Treefrog } \\
\text { (Pseudacris regilla) }\end{array}$ & $\begin{array}{c}\text { No Special } \\
\text { Status }\end{array}$ & G5/S4 & $\begin{array}{l}\text { Outside } \\
\text { Range }\end{array}$ & $\begin{array}{l}\text { Present } \\
\text { Part }\end{array}$ & $\begin{array}{l}\text { Outside } \\
\text { Range }\end{array}$ & $\begin{array}{l}\text { Present } \\
\text { Part }\end{array}$ & $\begin{array}{l}\text { Outside } \\
\text { Range }\end{array}$ & $\begin{array}{l}\text { Outside } \\
\text { Range }\end{array}$ & $\begin{array}{l}\text { Present } \\
\text { Entire }\end{array}$ & $\begin{array}{l}\text { Outside } \\
\text { Range }\end{array}$ & $\begin{array}{l}\text { Present } \\
\text { Part }\end{array}$ \\
\hline $\begin{array}{l}\text { Boreal Chorus Frog } \\
\text { (Pseudacris maculata) }\end{array}$ & $\begin{array}{l}\text { No Special } \\
\text { Status }\end{array}$ & G5/S4 & $\begin{array}{l}\text { Present } \\
\text { Part }\end{array}$ & $\begin{array}{l}\text { Outside } \\
\text { Range }\end{array}$ & $\begin{array}{l}\text { Present } \\
\text { Part }\end{array}$ & $\begin{array}{l}\text { Outside } \\
\text { Range }\end{array}$ & $\begin{array}{l}\text { Present } \\
\text { Part }\end{array}$ & $\begin{array}{l}\text { Presence } \\
\text { Possible }\end{array}$ & $\begin{array}{l}\text { Outside } \\
\text { Range }\end{array}$ & $\begin{array}{l}\text { Present } \\
\text { Entire }\end{array}$ & $\begin{array}{l}\text { Outside } \\
\text { Range }\end{array}$ \\
\hline $\begin{array}{l}\text { American Bullfrog } \\
\text { (Rana catesbeiana) }\end{array}$ & $\begin{array}{c}\text { No Special } \\
\text { Status }\end{array}$ & $\begin{array}{l}\text { G5/SNA } \\
\text { Exotic }\end{array}$ & $\begin{array}{l}\text { Presence } \\
\text { Possible }\end{array}$ & $\begin{array}{l}\text { Continue to } \\
\text { Spread }\end{array}$ & $\begin{array}{l}\text { Limited } \\
\text { Presence }\end{array}$ & $\begin{array}{l}\text { Limited } \\
\text { Presence }\end{array}$ & $\begin{array}{l}\text { Presence } \\
\text { Possible }\end{array}$ & $\begin{array}{l}\text { Presence } \\
\text { Possible }\end{array}$ & $\begin{array}{l}\text { Continue to } \\
\text { Spread }\end{array}$ & $\begin{array}{l}\text { Presence } \\
\text { Possible }\end{array}$ & $\begin{array}{l}\text { Continue to } \\
\text { Spread }\end{array}$ \\
\hline $\begin{array}{l}\text { Columbia Spotted Frog } \\
\text { (Rana luteiventris) }\end{array}$ & $\begin{array}{l}\text { No Special } \\
\text { Status }\end{array}$ & G4/S4 & $\begin{array}{l}\text { Present } \\
\text { Entire }\end{array}$ & $\begin{array}{l}\text { Present } \\
\text { Entire }\end{array}$ & $\begin{array}{l}\text { Present } \\
\text { Part }\end{array}$ & $\begin{array}{l}\text { Present } \\
\text { Entire }\end{array}$ & $\begin{array}{l}\text { Present } \\
\text { Entire }\end{array}$ & $\begin{array}{l}\text { Present } \\
\text { Entire }\end{array}$ & $\begin{array}{l}\text { Present } \\
\text { Entire }\end{array}$ & $\begin{array}{l}\text { Present } \\
\text { Part }\end{array}$ & $\begin{array}{l}\text { Present } \\
\text { Entire }\end{array}$ \\
\hline $\begin{array}{l}{ }^{{ }^{B}} \text { Northern Leopard Frog } \\
\text { (Rana pipiens) }\end{array}$ & $\begin{array}{l}\text { Sensitive } \\
\text { Species }\end{array}$ & G5/S1S3 & $\begin{array}{l}\text { Present } \\
\text { Part }\end{array}$ & $\begin{array}{l}\text { Historic } \\
\text { Presence }\end{array}$ & $\begin{array}{l}\text { Present } \\
\text { Part }\end{array}$ & $\begin{array}{l}\text { Historic } \\
\text { Presence }\end{array}$ & $\begin{array}{l}\text { Presence } \\
\text { Possible }\end{array}$ & $\begin{array}{l}\text { Presence } \\
\text { Possible }\end{array}$ & $\begin{array}{c}\text { Nearly } \\
\text { Extirpated }\end{array}$ & $\begin{array}{l}\text { Present } \\
\text { Part }\end{array}$ & $\begin{array}{l}\text { Historic } \\
\text { Presence }\end{array}$ \\
\hline $\begin{array}{l}\text { Wood Frog } \\
\text { (Rana sylvatica) }\end{array}$ & $\begin{array}{l}\text { No Special } \\
\text { Status }\end{array}$ & G5/SNA & $\begin{array}{l}\text { Outside } \\
\text { Range }\end{array}$ & $\begin{array}{l}\text { Outside } \\
\text { Range }\end{array}$ & $\begin{array}{c}\text { Outside } \\
\text { Range }\end{array}$ & $\begin{array}{c}\text { Outside } \\
\text { Range }\end{array}$ & $\begin{array}{l}\text { Outside } \\
\text { Range }\end{array}$ & $\begin{array}{l}\text { Outside } \\
\text { Range }\end{array}$ & $\begin{array}{l}\text { Presence } \\
\text { Possible }\end{array}$ & $\begin{array}{l}\text { Outside } \\
\text { Range }\end{array}$ & $\begin{array}{l}\text { Outside } \\
\text { Range }\end{array}$ \\
\hline
\end{tabular}

${ }^{\mathrm{A}}$ relatively few records for species. $\quad{ }^{\mathrm{B}}$ evidence that species has declined 
Presence and Status Ranks for Reptiles on National Forests in Montana

Current distribution and status information can be found on the Montana Natural Heritage Program's website at www.mtnhp.org

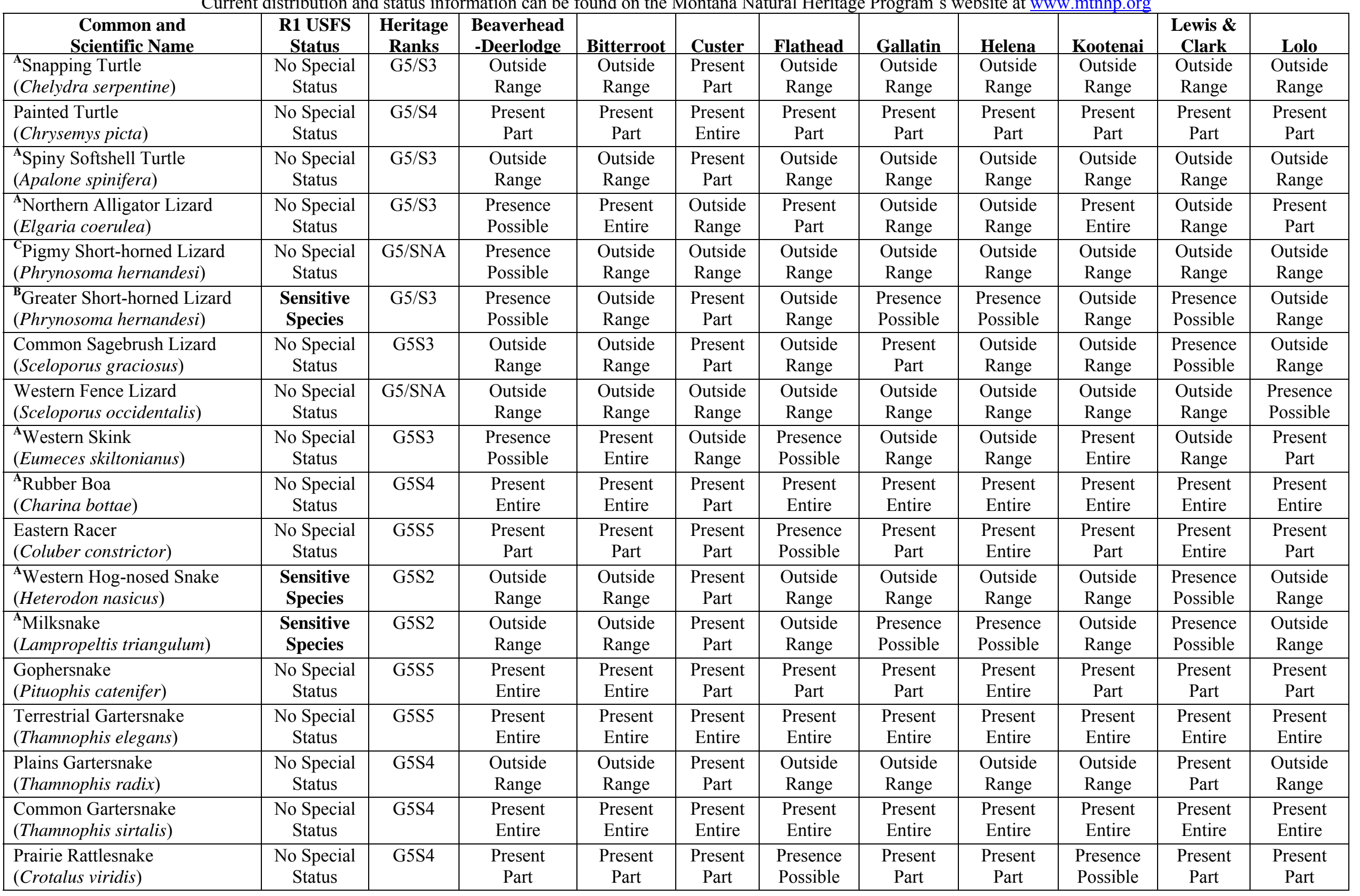

${ }^{A}$ relatively few records for species. $\quad{ }^{B}$ evidence that species has declined. $\quad{ }^{\mathrm{C}}$ single historic museum record and current presence is possible. 


\section{Presence and Status Ranks for Amphibians and Reptiles on BLM Lands in Montana}

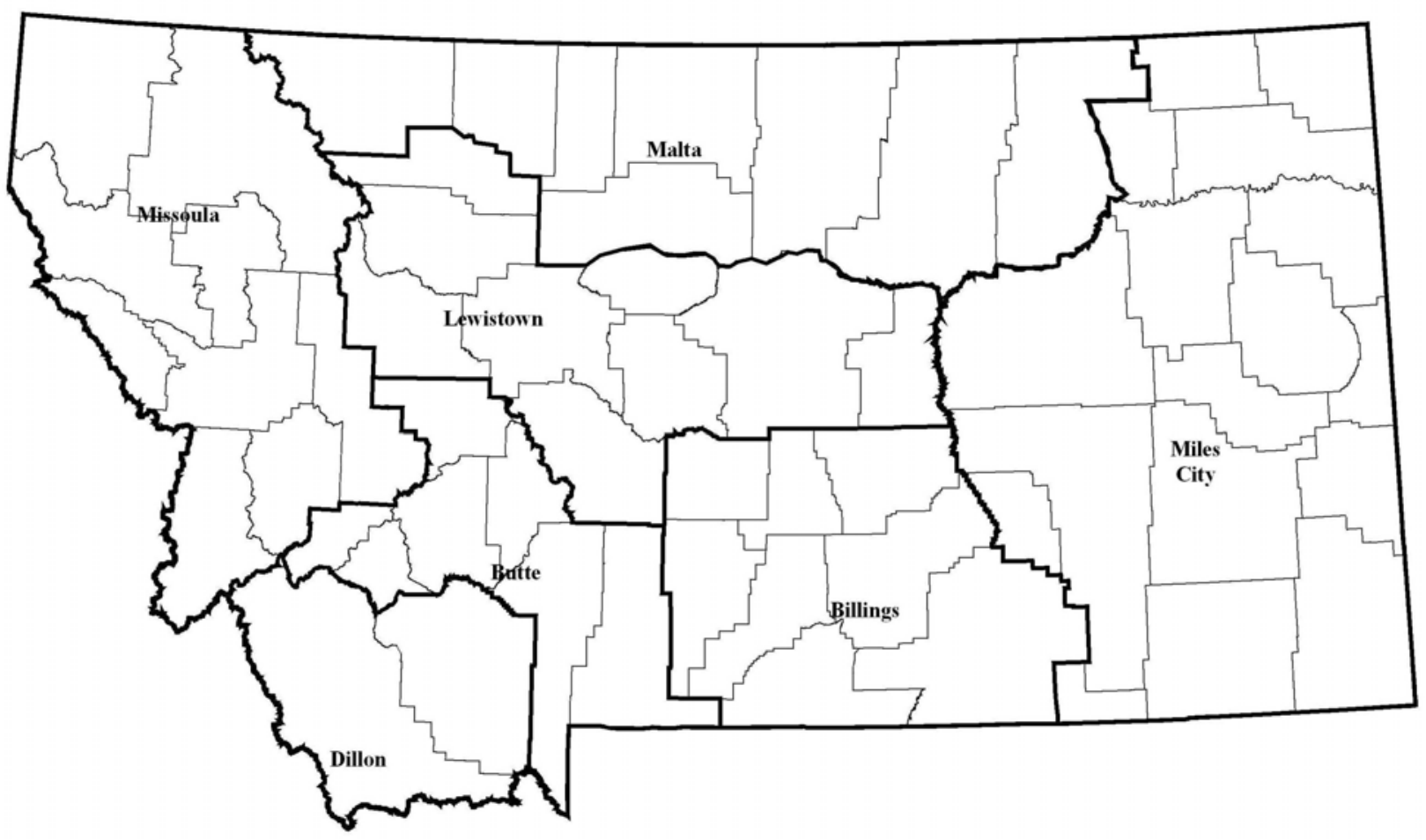

Bureau of Land Management and Heritage Program status ranks and notations on species presence are listed in the table below for each of the BLM Field Offices in Montana. BLM Manual 6840 requires the State BLM Director, usually in cooperation with State agencies and Natural Heritage programs, to designate species as Sensitive if they: (1) are federally listed, proposed, or candidate species; (2) could become endangered in or extirpated from a State, or within a significant portion of their distribution; (3) are under status review by the U.S. Fish and Wildlife Service or National Marine Fisheries Service; (4) are undergoing significant current or predicted downward trends in habitat capability that would reduce a species' existing distribution; (5) are undergoing significant current or predicted downward trends in population or density such that federal listed, proposed, candidate, or State listed status may become necessary; (6) typically have small and widely dispersed populations; (7) inhabit ecological refugia or other specialized or unique habitats; or (8) are State listed but which may be better conserved through application of BLM sensitive species status.

As specified in the 6840 policy, BLM Sensitive species are specially considered in budget planning, project planning, and analysis and land use planning and are given the same level of protection given to Federal candidate species in order to improve the condition of the species and their habitats so that special status recognition is no longer warranted. The Montana BLM Sensitive Species list was last updated in 2004. 
Presence and Status Ranks for Amphibians on BLM Lands in Montana

Current distribution and status information can be found on the Montana Natural Heritage Program's website at www.mtnhp.org

\begin{tabular}{|c|c|c|c|c|c|c|c|c|c|}
\hline $\begin{array}{l}\text { Common and } \\
\text { Scientific Name }\end{array}$ & $\begin{array}{c}\text { BLM } \\
\text { Status }\end{array}$ & $\begin{array}{l}\text { Heritage } \\
\text { Ranks }\end{array}$ & Billings & Butte & Dillon & Lewistown & Malta & Miles City & Missoula \\
\hline $\begin{array}{l}\text { Long-toed Salamander } \\
\text { (Ambystoma macrodactylum) }\end{array}$ & $\begin{array}{l}\text { No Special } \\
\text { Status }\end{array}$ & G5/S4 & $\begin{array}{l}\text { Outside } \\
\text { Range }\end{array}$ & $\begin{array}{l}\text { Present } \\
\text { Part }\end{array}$ & $\begin{array}{l}\text { Present } \\
\text { Part }\end{array}$ & $\begin{array}{l}\text { Present } \\
\text { Part }\end{array}$ & $\begin{array}{l}\text { Present } \\
\text { Part }\end{array}$ & $\begin{array}{l}\text { Outside } \\
\text { Range }\end{array}$ & $\begin{array}{l}\text { Present } \\
\text { Entire }\end{array}$ \\
\hline $\begin{array}{l}\text { Tiger Salamander } \\
\text { (Ambystoma tigrinum) }\end{array}$ & $\begin{array}{l}\text { No Special } \\
\text { Status }\end{array}$ & G5/S4 & $\begin{array}{l}\text { Present } \\
\text { Entire }\end{array}$ & $\begin{array}{l}\text { Present } \\
\text { Part }\end{array}$ & $\begin{array}{l}\text { Present } \\
\text { Part }\end{array}$ & $\begin{array}{l}\text { Present } \\
\text { Entire }\end{array}$ & $\begin{array}{l}\text { Present } \\
\text { Entire }\end{array}$ & $\begin{array}{l}\text { Present } \\
\text { Entire }\end{array}$ & $\begin{array}{l}\text { Present } \\
\text { Part }\end{array}$ \\
\hline $\begin{array}{l}{ }^{\mathrm{A}} \text { Idaho Giant Salamander } \\
\text { (Dicamptodon aterrimus) }\end{array}$ & $\begin{array}{l}\text { No Special } \\
\text { Status }\end{array}$ & G3/S1S3 & $\begin{array}{l}\text { Outside } \\
\text { Range }\end{array}$ & $\begin{array}{l}\text { Outside } \\
\text { Range }\end{array}$ & $\begin{array}{l}\text { Outside } \\
\text { Range }\end{array}$ & $\begin{array}{l}\text { Outside } \\
\text { Range }\end{array}$ & $\begin{array}{l}\text { Outside } \\
\text { Range }\end{array}$ & $\begin{array}{l}\text { Outside } \\
\text { Range }\end{array}$ & $\begin{array}{c}\text { Not present } \\
\text { on BLM }\end{array}$ \\
\hline $\begin{array}{l}\text { Coeur d' Alene Salamander } \\
\text { (Plethodon idahoensis) }\end{array}$ & $\begin{array}{l}\text { Sensitive } \\
\text { Species }\end{array}$ & G4/S2 & $\begin{array}{l}\text { Outside } \\
\text { Range }\end{array}$ & $\begin{array}{l}\text { Outside } \\
\text { Range }\end{array}$ & $\begin{array}{l}\text { Outside } \\
\text { Range }\end{array}$ & $\begin{array}{l}\text { Outside } \\
\text { Range }\end{array}$ & $\begin{array}{l}\text { Outside } \\
\text { Range }\end{array}$ & $\begin{array}{l}\text { Outside } \\
\text { Range }\end{array}$ & $\begin{array}{l}\text { Present } \\
\text { Part }\end{array}$ \\
\hline $\begin{array}{l}\text { Rocky Mountain Tailed Frog } \\
\text { (Ascaphus montanus) }\end{array}$ & $\begin{array}{l}\text { No Special } \\
\text { Status }\end{array}$ & G4/S4 & $\begin{array}{l}\text { Outside } \\
\text { Range }\end{array}$ & $\begin{array}{l}\text { Present } \\
\text { Part }\end{array}$ & $\begin{array}{l}\text { Present } \\
\text { Part }\end{array}$ & $\begin{array}{l}\text { Present } \\
\text { Part }\end{array}$ & $\begin{array}{l}\text { Present } \\
\text { Part }\end{array}$ & $\begin{array}{l}\text { Outside } \\
\text { Range }\end{array}$ & $\begin{array}{l}\text { Present } \\
\text { Entire }\end{array}$ \\
\hline $\begin{array}{l}\text { A Plains Spadefoot } \\
\text { (Spea bombifrons) }\end{array}$ & $\begin{array}{l}\text { Sensitive } \\
\text { Species }\end{array}$ & G5/S3 & $\begin{array}{l}\text { Present } \\
\text { Entire }\end{array}$ & $\begin{array}{l}\text { Present } \\
\text { Part }\end{array}$ & $\begin{array}{l}\text { Present } \\
\text { Part }\end{array}$ & $\begin{array}{l}\text { Present } \\
\text { Part }\end{array}$ & $\begin{array}{l}\text { Present } \\
\text { Entire }\end{array}$ & $\begin{array}{l}\text { Present } \\
\text { Entire }\end{array}$ & $\begin{array}{l}\text { Outside } \\
\text { Range }\end{array}$ \\
\hline $\begin{array}{l}\text { Great Basin Spadefoot } \\
\text { (Spea intermontana) }\end{array}$ & $\begin{array}{l}\text { No Special } \\
\text { Status }\end{array}$ & G5/SNA & $\begin{array}{l}\text { Outside } \\
\text { Range }\end{array}$ & $\begin{array}{l}\text { Outside } \\
\text { Range }\end{array}$ & $\begin{array}{l}\text { Presence } \\
\text { Possible }\end{array}$ & $\begin{array}{l}\text { Outside } \\
\text { Range }\end{array}$ & $\begin{array}{l}\text { Outside } \\
\text { Range }\end{array}$ & $\begin{array}{l}\text { Outside } \\
\text { Range }\end{array}$ & $\begin{array}{l}\text { Outside } \\
\text { Range }\end{array}$ \\
\hline $\begin{array}{l}{ }^{\mathrm{B}} \text { Western Toad } \\
\text { (Bufo boreas) }\end{array}$ & $\begin{array}{l}\text { Sensitive } \\
\text { Species }\end{array}$ & G4/S2 & $\begin{array}{l}\text { Present } \\
\text { Part }\end{array}$ & $\begin{array}{l}\text { Present } \\
\text { Entire }\end{array}$ & $\begin{array}{l}\text { Present } \\
\text { Entire }\end{array}$ & $\begin{array}{l}\text { Present } \\
\text { Part }\end{array}$ & $\begin{array}{l}\text { Present } \\
\text { Part }\end{array}$ & $\begin{array}{l}\text { Outside } \\
\text { Range }\end{array}$ & $\begin{array}{l}\text { Present } \\
\text { Entire }\end{array}$ \\
\hline $\begin{array}{l}\text { A Great Plains Toad } \\
\text { (Bufo cognatus) }\end{array}$ & $\begin{array}{l}\text { Sensitive } \\
\text { Species }\end{array}$ & G5/S2 & $\begin{array}{c}\text { Present } \\
\text { Part }\end{array}$ & $\begin{array}{l}\text { Outside } \\
\text { Range }\end{array}$ & $\begin{array}{l}\text { Outside } \\
\text { Range }\end{array}$ & $\begin{array}{c}\text { Present } \\
\text { Part }\end{array}$ & $\begin{array}{c}\text { Present } \\
\text { Part }\end{array}$ & $\begin{array}{l}\text { Present } \\
\text { Entire }\end{array}$ & $\begin{array}{l}\text { Outside } \\
\text { Range }\end{array}$ \\
\hline $\begin{array}{l}{ }^{{ }^{C} \text { Canadian Toad }} \\
\text { (Bufo hemiophrys) }\end{array}$ & $\begin{array}{l}\text { No Special } \\
\text { Status }\end{array}$ & G4/SNA & $\begin{array}{l}\text { Outside } \\
\text { Range }\end{array}$ & $\begin{array}{l}\text { Outside } \\
\text { Range }\end{array}$ & $\begin{array}{l}\text { Outside } \\
\text { Range }\end{array}$ & $\begin{array}{l}\text { Outside } \\
\text { Range }\end{array}$ & $\begin{array}{l}\text { Presence } \\
\text { Possible }\end{array}$ & $\begin{array}{l}\text { Presence } \\
\text { Possible }\end{array}$ & $\begin{array}{l}\text { Outside } \\
\text { Range }\end{array}$ \\
\hline $\begin{array}{l}\text { Woodhouse's Toad } \\
\text { (Bufo woodhousii) }\end{array}$ & $\begin{array}{l}\text { No Special } \\
\text { Status }\end{array}$ & G5/S4 & $\begin{array}{l}\text { Present } \\
\text { Part }\end{array}$ & $\begin{array}{l}\text { Outside } \\
\text { Range }\end{array}$ & $\begin{array}{l}\text { Outside } \\
\text { Range }\end{array}$ & $\begin{array}{l}\text { Present } \\
\text { Part }\end{array}$ & $\begin{array}{l}\text { Present } \\
\text { Part }\end{array}$ & $\begin{array}{l}\text { Present } \\
\text { Entire }\end{array}$ & $\begin{array}{l}\text { Outside } \\
\text { Range }\end{array}$ \\
\hline $\begin{array}{l}\text { Pacific Treefrog } \\
\text { (Pseudacris regilla) }\end{array}$ & $\begin{array}{l}\text { No Special } \\
\text { Status }\end{array}$ & G5/S4 & $\begin{array}{l}\text { Outside } \\
\text { Range }\end{array}$ & $\begin{array}{l}\text { Outside } \\
\text { Range }\end{array}$ & $\begin{array}{l}\text { Outside } \\
\text { Range }\end{array}$ & $\begin{array}{l}\text { Outside } \\
\text { Range }\end{array}$ & $\begin{array}{l}\text { Outside } \\
\text { Range }\end{array}$ & $\begin{array}{l}\text { Outside } \\
\text { Range }\end{array}$ & $\begin{array}{l}\text { Present } \\
\text { Part }\end{array}$ \\
\hline $\begin{array}{l}\text { Boreal Chorus Frog } \\
\text { (Pseudacris maculata) }\end{array}$ & $\begin{array}{l}\text { No Special } \\
\text { Status }\end{array}$ & G5/S4 & $\begin{array}{l}\text { Present } \\
\text { Entire }\end{array}$ & $\begin{array}{l}\text { Present } \\
\text { Part }\end{array}$ & $\begin{array}{l}\text { Present } \\
\text { Part }\end{array}$ & $\begin{array}{l}\text { Present } \\
\text { Entire }\end{array}$ & $\begin{array}{l}\text { Present } \\
\text { Entire }\end{array}$ & $\begin{array}{l}\text { Present } \\
\text { Entire }\end{array}$ & $\begin{array}{l}\text { Outside } \\
\text { Range }\end{array}$ \\
\hline $\begin{array}{l}\text { American Bullfrog } \\
\text { (Rana catesbeiana) }\end{array}$ & $\begin{array}{l}\text { No Special } \\
\text { Status }\end{array}$ & $\begin{array}{l}\text { G5/SNA } \\
\text { Exotic }\end{array}$ & $\begin{array}{l}\text { Continue } \\
\text { to Spread }\end{array}$ & $\begin{array}{l}\text { Limited } \\
\text { Presence }\end{array}$ & $\begin{array}{l}\text { Limited } \\
\text { Presence }\end{array}$ & $\begin{array}{l}\text { Limited } \\
\text { Presence }\end{array}$ & $\begin{array}{c}\text { No } \\
\text { Records }\end{array}$ & $\begin{array}{l}\text { Limited } \\
\text { Presence }\end{array}$ & $\begin{array}{l}\text { Continue } \\
\text { to Spread }\end{array}$ \\
\hline $\begin{array}{l}\text { Columbia Spotted Frog } \\
\text { (Rana luteiventris) }\end{array}$ & $\begin{array}{l}\text { No Special } \\
\text { Status }\end{array}$ & G4/S4 & $\begin{array}{l}\text { Present } \\
\text { Part }\end{array}$ & $\begin{array}{l}\text { Present } \\
\text { Entire }\end{array}$ & $\begin{array}{l}\text { Present } \\
\text { Entire }\end{array}$ & $\begin{array}{l}\text { Present } \\
\text { Part }\end{array}$ & $\begin{array}{l}\text { Present } \\
\text { Part }\end{array}$ & $\begin{array}{l}\text { Outside } \\
\text { Range }\end{array}$ & $\begin{array}{l}\text { Present } \\
\text { Entire }\end{array}$ \\
\hline $\begin{array}{l}{ }^{\mathbf{B}} \text { Northern Leopard Frog } \\
\text { (Rana pipiens) }\end{array}$ & $\begin{array}{l}\text { Sensitive } \\
\text { Species }\end{array}$ & G5/S1S3 & $\begin{array}{l}\text { Present } \\
\text { Entire }\end{array}$ & $\begin{array}{l}\text { Present } \\
\text { Part }\end{array}$ & $\begin{array}{l}\text { Apparently } \\
\text { Extirpated }\end{array}$ & $\begin{array}{l}\text { Present } \\
\text { Entire }\end{array}$ & $\begin{array}{l}\text { Present } \\
\text { Entire }\end{array}$ & $\begin{array}{l}\text { Present } \\
\text { Entire }\end{array}$ & $\begin{array}{c}\text { Nearly } \\
\text { Extirpated }\end{array}$ \\
\hline
\end{tabular}

\footnotetext{
${ }^{A}$ relatively few records for species. $\quad{ }^{B}$ evidence that species has declined. $33{ }^{C}$ questionable historic observation record, but presence is possible.
} 
Presence and Status Ranks for Reptiles on BLM Lands in Montana

Current distribution and status information can be found on the Montana Natural Heritage Program's website at www.mtnhp.org

\begin{tabular}{|c|c|c|c|c|c|c|c|c|c|}
\hline $\begin{array}{l}\text { Common and } \\
\text { Scientific Name }\end{array}$ & $\begin{array}{c}\text { BLM } \\
\text { Status }\end{array}$ & $\begin{array}{l}\text { Heritage } \\
\text { Ranks }\end{array}$ & Billings & Butte & Dillon & Lewistown & Malta & $\begin{array}{l}\text { Miles } \\
\text { City }\end{array}$ & Missoula \\
\hline $\begin{array}{l}{ }^{{ }^{\mathbf{A}} \text { Snapping Turtle }} \\
\text { (Chelydra serpentine) }\end{array}$ & $\begin{array}{l}\text { Sensitive } \\
\text { Species }\end{array}$ & G5/S3 & $\begin{array}{l}\text { Present } \\
\text { Part }\end{array}$ & $\begin{array}{c}\text { Limited } \\
\text { Introduction }\end{array}$ & $\begin{array}{l}\text { Outside } \\
\text { Range }\end{array}$ & $\begin{array}{l}\text { Outside } \\
\text { Range }\end{array}$ & $\begin{array}{l}\text { Presence } \\
\text { Possible }\end{array}$ & $\begin{array}{l}\text { Present } \\
\text { Part }\end{array}$ & $\begin{array}{c}\text { Limited } \\
\text { Introduction }\end{array}$ \\
\hline $\begin{array}{l}\text { Painted Turtle } \\
\text { (Chrysemys picta) }\end{array}$ & $\begin{array}{l}\text { No Special } \\
\text { Status }\end{array}$ & G5/S4 & $\begin{array}{l}\text { Present } \\
\text { Entire }\end{array}$ & $\begin{array}{l}\text { Present } \\
\text { Entire }\end{array}$ & $\begin{array}{l}\text { Present } \\
\text { Entire }\end{array}$ & $\begin{array}{l}\text { Present } \\
\text { Entire }\end{array}$ & $\begin{array}{l}\text { Present } \\
\text { Entire }\end{array}$ & $\begin{array}{l}\text { Present } \\
\text { Entire }\end{array}$ & $\begin{array}{l}\text { Present } \\
\text { Entire }\end{array}$ \\
\hline $\begin{array}{l}{ }_{\text {A }}^{\mathrm{A}} \text { Spiny Softshell Turtle } \\
\text { (Apalone spinifera) }\end{array}$ & $\begin{array}{l}\text { Sensitive } \\
\text { Species }\end{array}$ & G5/S3 & $\begin{array}{l}\text { Present } \\
\text { Part }\end{array}$ & $\begin{array}{l}\text { Outside } \\
\text { Range }\end{array}$ & $\begin{array}{l}\text { Outside } \\
\text { Range }\end{array}$ & $\begin{array}{l}\text { Present } \\
\text { Part }\end{array}$ & $\begin{array}{l}\text { Present } \\
\text { Part }\end{array}$ & $\begin{array}{l}\text { Present } \\
\text { Part }\end{array}$ & $\begin{array}{l}\text { Outside } \\
\text { Range }\end{array}$ \\
\hline $\begin{array}{l}\text { A Northern Alligator Lizard } \\
\text { (Elgaria coerulea) }\end{array}$ & $\begin{array}{l}\text { No Special } \\
\text { Status }\end{array}$ & G5/S3 & $\begin{array}{l}\text { Outside } \\
\text { Range }\end{array}$ & $\begin{array}{l}\text { Outside } \\
\text { Range }\end{array}$ & $\begin{array}{l}\text { Outside } \\
\text { Range }\end{array}$ & $\begin{array}{l}\text { Outside } \\
\text { Range }\end{array}$ & $\begin{array}{l}\text { Outside } \\
\text { Range }\end{array}$ & $\begin{array}{l}\text { Outside } \\
\text { Range }\end{array}$ & $\begin{array}{l}\text { Present } \\
\text { Entire }\end{array}$ \\
\hline $\begin{array}{l}{ }^{{ }^{C}} \text { Pigmy Short-horned Lizard } \\
\text { (Phrynosoma hernandesi) }\end{array}$ & $\begin{array}{l}\text { No Special } \\
\text { Status }\end{array}$ & G5/SNA & $\begin{array}{l}\text { Outside } \\
\text { Range }\end{array}$ & $\begin{array}{l}\text { Outside } \\
\text { Range }\end{array}$ & $\begin{array}{l}\text { Presence } \\
\text { Possible }\end{array}$ & $\begin{array}{l}\text { Outside } \\
\text { Range }\end{array}$ & $\begin{array}{l}\text { Outside } \\
\text { Range }\end{array}$ & $\begin{array}{l}\text { Outside } \\
\text { Range }\end{array}$ & $\begin{array}{l}\text { Outside } \\
\text { Range }\end{array}$ \\
\hline $\begin{array}{l}{ }^{\mathbf{B}} \text { Greater Short-horned Lizard } \\
\text { (Phrynosoma hernandesi) }\end{array}$ & $\begin{array}{l}\text { Sensitive } \\
\text { Species }\end{array}$ & G5/S3 & $\begin{array}{l}\text { Present } \\
\text { Entire }\end{array}$ & $\begin{array}{l}\text { Present } \\
\text { Part }\end{array}$ & $\begin{array}{l}\text { Presence } \\
\text { Possible }\end{array}$ & $\begin{array}{l}\text { Present } \\
\text { Entire }\end{array}$ & $\begin{array}{l}\text { Present } \\
\text { Entire }\end{array}$ & $\begin{array}{l}\text { Present } \\
\text { Entire }\end{array}$ & $\begin{array}{l}\text { Outside } \\
\text { Range }\end{array}$ \\
\hline $\begin{array}{l}\text { Common Sagebrush Lizard } \\
\text { (Sceloporus graciosus) }\end{array}$ & $\begin{array}{l}\text { No Special } \\
\text { Status }\end{array}$ & G5S3 & $\begin{array}{l}\text { Present } \\
\text { Entire }\end{array}$ & $\begin{array}{l}\text { Present } \\
\text { Part }\end{array}$ & $\begin{array}{l}\text { Outside } \\
\text { Range }\end{array}$ & $\begin{array}{l}\text { Present } \\
\text { Part }\end{array}$ & $\begin{array}{l}\text { Present } \\
\text { Part }\end{array}$ & $\begin{array}{l}\text { Present } \\
\text { Entire }\end{array}$ & $\begin{array}{l}\text { Outside } \\
\text { Range }\end{array}$ \\
\hline $\begin{array}{l}{ }^{\mathrm{A}} \text { Western Skink } \\
\text { (Eumeces skiltonianus) }\end{array}$ & $\begin{array}{l}\text { No Special } \\
\text { Status }\end{array}$ & G5S3 & $\begin{array}{l}\text { Outside } \\
\text { Range }\end{array}$ & $\begin{array}{l}\text { Outside } \\
\text { Range }\end{array}$ & $\begin{array}{l}\text { Outside } \\
\text { Range }\end{array}$ & $\begin{array}{l}\text { Outside } \\
\text { Range }\end{array}$ & $\begin{array}{l}\text { Outside } \\
\text { Range }\end{array}$ & $\begin{array}{l}\text { Outside } \\
\text { Range }\end{array}$ & $\begin{array}{l}\text { Present } \\
\text { Part }\end{array}$ \\
\hline $\begin{array}{l}\text { A Rubber Boa } \\
\text { (Charina bottae) }\end{array}$ & $\begin{array}{l}\text { No Special } \\
\text { Status }\end{array}$ & G5S4 & $\begin{array}{l}\text { Present } \\
\text { Part }\end{array}$ & $\begin{array}{l}\text { Present } \\
\text { Entire }\end{array}$ & $\begin{array}{l}\text { Present } \\
\text { Entire }\end{array}$ & $\begin{array}{l}\text { Present } \\
\text { Part }\end{array}$ & $\begin{array}{l}\text { Presence } \\
\text { Possible }\end{array}$ & $\begin{array}{l}\text { Present } \\
\text { Part }\end{array}$ & $\begin{array}{l}\text { Present } \\
\text { Entire }\end{array}$ \\
\hline $\begin{array}{l}\text { Eastern Racer } \\
\text { (Coluber constrictor) }\end{array}$ & $\begin{array}{l}\text { No Special } \\
\text { Status }\end{array}$ & G5S5 & $\begin{array}{l}\text { Present } \\
\text { Entire }\end{array}$ & $\begin{array}{l}\text { Present } \\
\text { Entire }\end{array}$ & $\begin{array}{l}\text { Present } \\
\text { Entire }\end{array}$ & $\begin{array}{l}\text { Present } \\
\text { Entire }\end{array}$ & $\begin{array}{l}\text { Present } \\
\text { Entire }\end{array}$ & $\begin{array}{l}\text { Present } \\
\text { Entire }\end{array}$ & $\begin{array}{l}\text { Present } \\
\text { Entire }\end{array}$ \\
\hline $\begin{array}{l}{ }^{\mathrm{A}} \text { Western Hog-nosed Snake } \\
\text { (Heterodon nasicus) }\end{array}$ & $\begin{array}{l}\text { Sensitive } \\
\text { Species }\end{array}$ & G5S2 & $\begin{array}{l}\text { Present } \\
\text { Part }\end{array}$ & $\begin{array}{l}\text { Outside } \\
\text { Range }\end{array}$ & $\begin{array}{l}\text { Outside } \\
\text { Range }\end{array}$ & $\begin{array}{l}\text { Present } \\
\text { Part }\end{array}$ & $\begin{array}{l}\text { Present } \\
\text { Entire }\end{array}$ & $\begin{array}{l}\text { Present } \\
\text { Entire }\end{array}$ & $\begin{array}{l}\text { Outside } \\
\text { Range }\end{array}$ \\
\hline $\begin{array}{l}{ }^{\mathrm{A}} \text { Smooth Greensnake } \\
\text { (Opheodrys vernalis) }\end{array}$ & $\begin{array}{l}\text { No Special } \\
\text { Status }\end{array}$ & G5S2 & $\begin{array}{l}\text { Outside } \\
\text { Range }\end{array}$ & $\begin{array}{l}\text { Outside } \\
\text { Range }\end{array}$ & $\begin{array}{l}\text { Outside } \\
\text { Range }\end{array}$ & $\begin{array}{l}\text { Outside } \\
\text { Range }\end{array}$ & $\begin{array}{l}\text { Present } \\
\text { Part }\end{array}$ & $\begin{array}{l}\text { Present } \\
\text { Part }\end{array}$ & $\begin{array}{l}\text { Outside } \\
\text { Range }\end{array}$ \\
\hline $\begin{array}{l}\mathrm{A}^{\mathrm{A}} \text { Milksnake } \\
\text { (Lampropeltis triangulum) }\end{array}$ & $\begin{array}{l}\text { Sensitive } \\
\text { Species }\end{array}$ & G5S2 & $\begin{array}{l}\text { Present } \\
\text { Part }\end{array}$ & $\begin{array}{l}\text { Possible } \\
\text { Presence }\end{array}$ & $\begin{array}{l}\text { Outside } \\
\text { Range }\end{array}$ & $\begin{array}{l}\text { Present } \\
\text { Part }\end{array}$ & $\begin{array}{l}\text { Present } \\
\text { Part }\end{array}$ & $\begin{array}{l}\text { Present } \\
\text { Part }\end{array}$ & $\begin{array}{l}\text { Outside } \\
\text { Range }\end{array}$ \\
\hline $\begin{array}{l}\text { Gophersnake } \\
\text { (Pituophis catenifer) }\end{array}$ & $\begin{array}{l}\text { No Special } \\
\text { Status }\end{array}$ & G5S5 & $\begin{array}{l}\text { Present } \\
\text { Entire }\end{array}$ & $\begin{array}{l}\text { Present } \\
\text { Entire }\end{array}$ & $\begin{array}{l}\text { Present } \\
\text { Entire }\end{array}$ & $\begin{array}{l}\text { Present } \\
\text { Entire }\end{array}$ & $\begin{array}{l}\text { Present } \\
\text { Entire }\end{array}$ & $\begin{array}{l}\text { Present } \\
\text { Entire }\end{array}$ & $\begin{array}{l}\text { Present } \\
\text { Entire }\end{array}$ \\
\hline $\begin{array}{l}\text { Terrestrial Gartersnake } \\
\text { (Thamnophis elegans) }\end{array}$ & $\begin{array}{l}\text { No Special } \\
\text { Status }\end{array}$ & G5S5 & $\begin{array}{l}\text { Present } \\
\text { Entire }\end{array}$ & $\begin{array}{l}\text { Present } \\
\text { Entire }\end{array}$ & $\begin{array}{l}\text { Present } \\
\text { Entire }\end{array}$ & $\begin{array}{l}\text { Present } \\
\text { Entire }\end{array}$ & $\begin{array}{l}\text { Present } \\
\text { Part }\end{array}$ & $\begin{array}{l}\text { Present } \\
\text { Part }\end{array}$ & $\begin{array}{l}\text { Present } \\
\text { Entire }\end{array}$ \\
\hline $\begin{array}{l}\text { Plains Gartersnake } \\
\text { (Thamnophis radix) }\end{array}$ & $\begin{array}{l}\text { No Special } \\
\text { Status }\end{array}$ & G5S4 & $\begin{array}{l}\text { Present } \\
\text { Part }\end{array}$ & $\begin{array}{l}\text { Outside } \\
\text { Range }\end{array}$ & $\begin{array}{l}\text { Outside } \\
\text { Range }\end{array}$ & $\begin{array}{l}\text { Present } \\
\text { Part }\end{array}$ & $\begin{array}{l}\text { Present } \\
\text { Entire }\end{array}$ & $\begin{array}{l}\text { Present } \\
\text { Entire }\end{array}$ & $\begin{array}{l}\text { Outside } \\
\text { Range }\end{array}$ \\
\hline $\begin{array}{l}\text { Common Gartersnake } \\
\text { (Thamnophis sirtalis) }\end{array}$ & $\begin{array}{l}\text { No Special } \\
\text { Status }\end{array}$ & G5S3 & $\begin{array}{l}\text { Present } \\
\text { Entire }\end{array}$ & $\begin{array}{l}\text { Present } \\
\text { Entire }\end{array}$ & $\begin{array}{l}\text { Present } \\
\text { Entire }\end{array}$ & $\begin{array}{l}\text { Present } \\
\text { Entire }\end{array}$ & $\begin{array}{l}\text { Present } \\
\text { Part }\end{array}$ & $\begin{array}{l}\text { Present } \\
\text { Part }\end{array}$ & $\begin{array}{l}\text { Present } \\
\text { Entire }\end{array}$ \\
\hline $\begin{array}{l}\text { Prairie Rattlesnake } \\
\text { (Crotalus viridis) }\end{array}$ & $\begin{array}{l}\text { No Special } \\
\text { Status }\end{array}$ & G5S4 & $\begin{array}{l}\text { Present } \\
\text { Entire }\end{array}$ & $\begin{array}{l}\text { Present } \\
\text { Entire }\end{array}$ & $\begin{array}{l}\text { Present } \\
\text { Entire }\end{array}$ & $\begin{array}{l}\text { Present } \\
\text { Entire }\end{array}$ & $\begin{array}{l}\text { Present } \\
\text { Entire }\end{array}$ & $\begin{array}{l}\text { Present } \\
\text { Entire }\end{array}$ & $\begin{array}{l}\text { Present } \\
\text { Part }\end{array}$ \\
\hline
\end{tabular}

${ }^{A}$ relatively few records for species. $\quad{ }^{B}$ evidence that species has declined. $\quad{ }^{C}$ single historic museum record and current presence is possible. 
Presence and Status Ranks for Amphibians and Reptiles on Tribal Lands in Montana

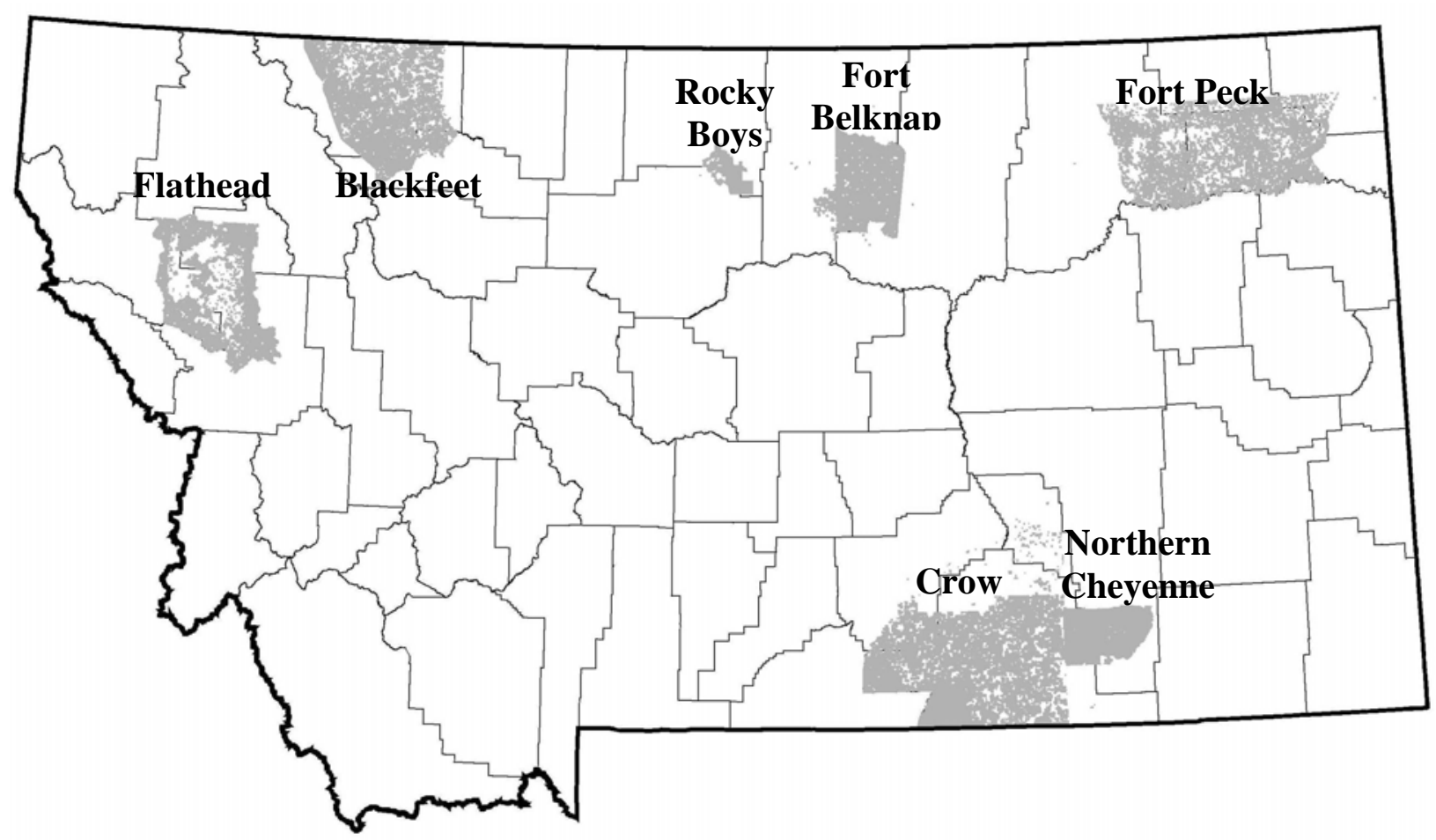

Heritage Program status ranks and notations on species presence are listed in the table below for each of the Indian Reservations in Montana. Tribal fish and wildlife departments have responsibility for management of amphibians and reptiles on each reservation and as independent nations, each tribe independently decides the status designations of species on their lands.

Species status designations on reservations in Montana were not identified for the current draft of this report. 
Presence and Status Ranks for Amphibians on Tribal Lands in Montana

Current distribution and status information can be found on the Montana Natural Heritage Program's website at www.mtnhp.org

\begin{tabular}{|c|c|c|c|c|c|c|c|c|c|}
\hline $\begin{array}{l}\text { Common and } \\
\text { Scientific Name }\end{array}$ & $\begin{array}{l}\text { Tribal } \\
\text { Status }\end{array}$ & $\begin{array}{l}\text { Heritage } \\
\text { Ranks }\end{array}$ & Blackfeet & Crow & Flathead & $\begin{array}{c}\text { Fort } \\
\text { Belknap }\end{array}$ & Fort Peck & $\begin{array}{l}\text { Northern } \\
\text { Cheyenne }\end{array}$ & $\begin{array}{l}\text { Rocky } \\
\text { Boy's }\end{array}$ \\
\hline $\begin{array}{l}\text { Long-toed Salamander } \\
\text { (Ambystoma macrodactylum) }\end{array}$ & $?$ & G5/S4 & $\begin{array}{l}\text { Present } \\
\text { Part }\end{array}$ & $\begin{array}{l}\text { Outside } \\
\text { Range }\end{array}$ & $\begin{array}{l}\text { Present } \\
\text { Entire }\end{array}$ & $\begin{array}{l}\text { Outside } \\
\text { Range }\end{array}$ & $\begin{array}{l}\text { Outside } \\
\text { Range }\end{array}$ & $\begin{array}{l}\text { Outside } \\
\text { Range }\end{array}$ & $\begin{array}{l}\text { Outside } \\
\text { Range }\end{array}$ \\
\hline $\begin{array}{l}\text { Tiger Salamander } \\
\text { (Ambystoma tigrinum) }\end{array}$ & $?$ & G5/S4 & $\begin{array}{l}\text { Present } \\
\text { Entire }\end{array}$ & $\begin{array}{l}\text { Present } \\
\text { Entire }\end{array}$ & $\begin{array}{l}\text { Outside } \\
\text { Range }\end{array}$ & $\begin{array}{l}\text { Present } \\
\text { Entire }\end{array}$ & $\begin{array}{l}\text { Present } \\
\text { Entire }\end{array}$ & $\begin{array}{l}\text { Present } \\
\text { Entire }\end{array}$ & $\begin{array}{l}\text { Present } \\
\text { Entire }\end{array}$ \\
\hline $\begin{array}{l}{ }^{\mathrm{A}} \text { Idaho Giant Salamander } \\
\text { (Dicamptodon aterrimus) }\end{array}$ & $?$ & G3/S1S3 & $\begin{array}{l}\text { Outside } \\
\text { Range }\end{array}$ & $\begin{array}{l}\text { Outside } \\
\text { Range }\end{array}$ & $\begin{array}{l}\text { Outside } \\
\text { Range }\end{array}$ & $\begin{array}{l}\text { Outside } \\
\text { Range }\end{array}$ & $\begin{array}{l}\text { Outside } \\
\text { Range }\end{array}$ & $\begin{array}{l}\text { Outside } \\
\text { Range }\end{array}$ & $\begin{array}{l}\text { Outside } \\
\text { Range }\end{array}$ \\
\hline $\begin{array}{l}\text { Coeur d' Alene Salamander } \\
\text { (Plethodon idahoensis) }\end{array}$ & $?$ & G4/S2 & $\begin{array}{l}\text { Outside } \\
\text { Range }\end{array}$ & $\begin{array}{l}\text { Outside } \\
\text { Range }\end{array}$ & $\begin{array}{l}\text { Presence } \\
\text { Possible }\end{array}$ & $\begin{array}{l}\text { Outside } \\
\text { Range }\end{array}$ & $\begin{array}{l}\text { Outside } \\
\text { Range }\end{array}$ & $\begin{array}{l}\text { Outside } \\
\text { Range }\end{array}$ & $\begin{array}{l}\text { Outside } \\
\text { Range }\end{array}$ \\
\hline $\begin{array}{l}\text { Rocky Mountain Tailed Frog } \\
\text { (Ascaphus montanus) }\end{array}$ & $?$ & G4/S4 & $\begin{array}{l}\text { Present } \\
\text { Part }\end{array}$ & $\begin{array}{l}\text { Outside } \\
\text { Range }\end{array}$ & $\begin{array}{l}\text { Present } \\
\text { Part }\end{array}$ & $\begin{array}{l}\text { Outside } \\
\text { Range }\end{array}$ & $\begin{array}{l}\text { Outside } \\
\text { Range }\end{array}$ & $\begin{array}{l}\text { Outside } \\
\text { Range }\end{array}$ & $\begin{array}{l}\text { Outside } \\
\text { Range }\end{array}$ \\
\hline $\begin{array}{l}\text { APlains Spadefoot } \\
\text { (Spea bombifrons) }\end{array}$ & $?$ & G5/S3 & $\begin{array}{l}\text { Present } \\
\text { Part }\end{array}$ & $\begin{array}{l}\text { Present } \\
\text { Entire }\end{array}$ & $\begin{array}{l}\text { Outside } \\
\text { Range }\end{array}$ & $\begin{array}{l}\text { Present } \\
\text { Entire }\end{array}$ & $\begin{array}{l}\text { Present } \\
\text { Entire }\end{array}$ & $\begin{array}{l}\text { Present } \\
\text { Entire }\end{array}$ & $\begin{array}{l}\text { Present } \\
\text { Entire }\end{array}$ \\
\hline $\begin{array}{l}{ }^{\mathbf{B}} \text { Western Toad } \\
\text { (Bufo boreas) }\end{array}$ & $?$ & G4/S2 & $\begin{array}{c}\text { Present } \\
\text { Part }\end{array}$ & $\begin{array}{l}\text { Outside } \\
\text { Range }\end{array}$ & $\begin{array}{l}\text { Present } \\
\text { Entire }\end{array}$ & $\begin{array}{l}\text { Outside } \\
\text { Range }\end{array}$ & $\begin{array}{l}\text { Outside } \\
\text { Range }\end{array}$ & $\begin{array}{l}\text { Outside } \\
\text { Range }\end{array}$ & $\begin{array}{l}\text { Outside } \\
\text { Range }\end{array}$ \\
\hline $\begin{array}{l}{ }^{\mathbf{A}} \text { Great Plains Toad } \\
\text { (Bufo cognatus) }\end{array}$ & $?$ & G5/S2 & $\begin{array}{l}\text { Presence } \\
\text { Possible }\end{array}$ & $\begin{array}{l}\text { Present } \\
\text { Entire }\end{array}$ & $\begin{array}{l}\text { Outside } \\
\text { Range }\end{array}$ & $\begin{array}{l}\text { Present } \\
\text { Entire }\end{array}$ & $\begin{array}{l}\text { Present } \\
\text { Entire }\end{array}$ & $\begin{array}{l}\text { Present } \\
\text { Entire }\end{array}$ & $\begin{array}{l}\text { Present } \\
\text { Entire }\end{array}$ \\
\hline $\begin{array}{l}{ }^{{ }^{C} \text { Canadian Toad }} \\
\text { (Bufo hemiophrys) }\end{array}$ & $?$ & G4/SNA & $\begin{array}{l}\text { Outside } \\
\text { Range }\end{array}$ & $\begin{array}{l}\text { Outside } \\
\text { Range }\end{array}$ & $\begin{array}{l}\text { Outside } \\
\text { Range }\end{array}$ & $\begin{array}{l}\text { Outside } \\
\text { Range }\end{array}$ & $\begin{array}{l}\text { Presence } \\
\text { Possible }\end{array}$ & $\begin{array}{l}\text { Outside } \\
\text { Range }\end{array}$ & $\begin{array}{l}\text { Outside } \\
\text { Range }\end{array}$ \\
\hline $\begin{array}{l}\text { Woodhouse's Toad } \\
\text { (Bufo woodhousii) }\end{array}$ & $?$ & G5/S4 & $\begin{array}{l}\text { Outside } \\
\text { Range }\end{array}$ & $\begin{array}{l}\text { Present } \\
\text { Entire }\end{array}$ & $\begin{array}{l}\text { Outside } \\
\text { Range }\end{array}$ & $\begin{array}{l}\text { Presence } \\
\text { Possible }\end{array}$ & $\begin{array}{l}\text { Present } \\
\text { Entire }\end{array}$ & $\begin{array}{l}\text { Present } \\
\text { Entire }\end{array}$ & $\begin{array}{l}\text { Presence } \\
\text { Possible }\end{array}$ \\
\hline $\begin{array}{l}\text { Pacific Treefrog } \\
\text { (Pseudacris regilla) }\end{array}$ & $?$ & G5/S4 & $\begin{array}{l}\text { Outside } \\
\text { Range }\end{array}$ & $\begin{array}{l}\text { Outside } \\
\text { Range }\end{array}$ & $\begin{array}{l}\text { Present } \\
\text { Entire }\end{array}$ & $\begin{array}{l}\text { Outside } \\
\text { Range }\end{array}$ & $\begin{array}{l}\text { Outside } \\
\text { Range }\end{array}$ & $\begin{array}{l}\text { Outside } \\
\text { Range }\end{array}$ & $\begin{array}{l}\text { Outside } \\
\text { Range }\end{array}$ \\
\hline $\begin{array}{l}\text { Boreal Chorus Frog } \\
\text { (Pseudacris maculata) }\end{array}$ & $?$ & G5/S4 & $\begin{array}{l}\text { Present } \\
\text { Entire }\end{array}$ & $\begin{array}{l}\text { Present } \\
\text { Entire }\end{array}$ & $\begin{array}{l}\text { Outside } \\
\text { Range }\end{array}$ & $\begin{array}{l}\text { Present } \\
\text { Entire }\end{array}$ & $\begin{array}{l}\text { Present } \\
\text { Entire }\end{array}$ & $\begin{array}{l}\text { Present } \\
\text { Entire }\end{array}$ & $\begin{array}{l}\text { Present } \\
\text { Entire }\end{array}$ \\
\hline $\begin{array}{l}\text { American Bullfrog } \\
\text { (Rana catesbeiana) }\end{array}$ & $?$ & $\begin{array}{l}\text { G5/SNA } \\
\text { Exotic }\end{array}$ & $\begin{array}{c}\text { No } \\
\text { Records }\end{array}$ & $\begin{array}{c}\text { No } \\
\text { Records }\end{array}$ & $\begin{array}{l}\text { Continuing to } \\
\text { Spread }\end{array}$ & $\begin{array}{c}\text { No } \\
\text { Records }\end{array}$ & $\begin{array}{c}\text { No } \\
\text { Records }\end{array}$ & $\begin{array}{c}\text { No } \\
\text { Records }\end{array}$ & $\begin{array}{c}\text { No } \\
\text { Records }\end{array}$ \\
\hline $\begin{array}{l}\text { Columbia Spotted Frog } \\
\text { (Rana luteiventris) }\end{array}$ & $?$ & G4/S4 & $\begin{array}{l}\text { Present } \\
\text { Part }\end{array}$ & $\begin{array}{l}\text { Outside } \\
\text { Range }\end{array}$ & $\begin{array}{l}\text { Present } \\
\text { Entire }\end{array}$ & $\begin{array}{l}\text { Outside } \\
\text { Range }\end{array}$ & $\begin{array}{l}\text { Outside } \\
\text { Range }\end{array}$ & $\begin{array}{l}\text { Outside } \\
\text { Range }\end{array}$ & $\begin{array}{l}\text { Outside } \\
\text { Range }\end{array}$ \\
\hline $\begin{array}{l}{ }^{\mathrm{B}} \text { Northern Leopard Frog } \\
\text { (Rana pipiens) }\end{array}$ & $?$ & G5/S1S3 & $\begin{array}{l}\text { Present } \\
\text { Entire }\end{array}$ & $\begin{array}{l}\text { Present } \\
\text { Entire }\end{array}$ & $\begin{array}{c}\text { Ongoing } \\
\text { Reintroduction }\end{array}$ & $\begin{array}{l}\text { Present } \\
\text { Entire }\end{array}$ & $\begin{array}{l}\text { Present } \\
\text { Entire }\end{array}$ & $\begin{array}{l}\text { Present } \\
\text { Entire }\end{array}$ & $\begin{array}{l}\text { Present } \\
\text { Entire }\end{array}$ \\
\hline $\begin{array}{l}\text { Wood Frog } \\
\text { (Rana sylvatica) }\end{array}$ & $?$ & G5/SNA & $\begin{array}{l}\text { Outside } \\
\text { Range }\end{array}$ & $\begin{array}{l}\text { Presence } \\
\text { Possible }\end{array}$ & $\begin{array}{l}\text { Outside } \\
\text { Range }\end{array}$ & $\begin{array}{l}\text { Outside } \\
\text { Range }\end{array}$ & $\begin{array}{l}\text { Outside } \\
\text { Range }\end{array}$ & $\begin{array}{l}\text { Outside } \\
\text { Range }\end{array}$ & $\begin{array}{l}\text { Outside } \\
\text { Range }\end{array}$ \\
\hline
\end{tabular}

\footnotetext{
${ }^{A}$ relatively few records for species. $\quad{ }^{B}$ evidence that species has declined.
}

${ }^{\mathrm{C}}$ questionable historic observation record, but presence is possible. 
Presence and Status Ranks for Reptiles on Tribal Lands in Montana

Current distribution and status information can be found on the Montana Natural Heritage Program's website at www.mtnhp.org

\begin{tabular}{|c|c|c|c|c|c|c|c|c|c|}
\hline $\begin{array}{c}\text { Common and } \\
\text { Scientific Name }\end{array}$ & $\begin{array}{l}\text { Tribal } \\
\text { Status } \\
\end{array}$ & $\begin{array}{c}\text { Heritage } \\
\text { Ranks }\end{array}$ & Blackfeet & Crow & Flathead & $\begin{array}{c}\text { Fort } \\
\text { Belknap }\end{array}$ & Fort Peck & $\begin{array}{l}\text { Northern } \\
\text { Cheyenne }\end{array}$ & $\begin{array}{l}\text { Rocky } \\
\text { Boy's }\end{array}$ \\
\hline $\begin{array}{l}{ }^{{ }^{\mathbf{A}} \text { Snapping Turtle }} \\
\text { (Chelydra serpentina) }\end{array}$ & $?$ & G5/S3 & $\begin{array}{l}\text { Outside } \\
\text { Range }\end{array}$ & $\begin{array}{l}\text { Present } \\
\text { Entire }\end{array}$ & $\begin{array}{c}\text { Limited } \\
\text { Introduction }\end{array}$ & $\begin{array}{l}\text { Presence } \\
\text { Possible }\end{array}$ & $\begin{array}{l}\text { Presence } \\
\text { Possible }\end{array}$ & $\begin{array}{l}\text { Present } \\
\text { Entire }\end{array}$ & $\begin{array}{l}\text { Outside } \\
\text { Range }\end{array}$ \\
\hline $\begin{array}{l}\text { Painted Turtle } \\
\text { (Chrysemys picta) }\end{array}$ & $?$ & G5/S4 & $\begin{array}{l}\text { Present } \\
\text { Entire }\end{array}$ & $\begin{array}{l}\text { Present } \\
\text { Entire }\end{array}$ & $\begin{array}{l}\text { Present } \\
\text { Entire }\end{array}$ & $\begin{array}{l}\text { Present } \\
\text { Entire }\end{array}$ & $\begin{array}{l}\text { Present } \\
\text { Entire }\end{array}$ & $\begin{array}{l}\text { Present } \\
\text { Entire }\end{array}$ & $\begin{array}{l}\text { Present } \\
\text { Entire }\end{array}$ \\
\hline $\begin{array}{l}{ }^{\mathrm{A}} \text { Spiny Softshell Turtle } \\
\text { (Apalone spinifera) }\end{array}$ & $?$ & G5/S3 & $\begin{array}{l}\text { Outside } \\
\text { Range }\end{array}$ & $\begin{array}{l}\text { Present } \\
\text { Part }\end{array}$ & $\begin{array}{l}\text { Outside } \\
\text { Range }\end{array}$ & $\begin{array}{l}\text { Outside } \\
\text { Range }\end{array}$ & $\begin{array}{l}\text { Outside } \\
\text { Range }\end{array}$ & $\begin{array}{l}\text { Present } \\
\text { Part }\end{array}$ & $\begin{array}{l}\text { Outside } \\
\text { Range }\end{array}$ \\
\hline $\begin{array}{l}{ }^{\mathrm{A}} \text { Northern Alligator Lizard } \\
\text { (Elgaria coerulea) }\end{array}$ & $?$ & G5/S3 & $\begin{array}{l}\text { Outside } \\
\text { Range }\end{array}$ & $\begin{array}{l}\text { Outside } \\
\text { Range }\end{array}$ & $\begin{array}{l}\text { Present } \\
\text { Entire }\end{array}$ & $\begin{array}{l}\text { Outside } \\
\text { Range }\end{array}$ & $\begin{array}{l}\text { Outside } \\
\text { Range }\end{array}$ & $\begin{array}{l}\text { Outside } \\
\text { Range }\end{array}$ & $\begin{array}{l}\text { Outside } \\
\text { Range }\end{array}$ \\
\hline $\begin{array}{l}{ }^{\mathbf{B}} \text { Greater Short-horned Lizard } \\
\text { (Phrynosoma hernandesi) }\end{array}$ & $?$ & G5/S3 & $\begin{array}{l}\text { Present } \\
\text { Part }\end{array}$ & $\begin{array}{l}\text { Present } \\
\text { Entire }\end{array}$ & $\begin{array}{l}\text { Outside } \\
\text { Range }\end{array}$ & $\begin{array}{l}\text { Present } \\
\text { Entire }\end{array}$ & $\begin{array}{l}\text { Possible } \\
\text { Presence }\end{array}$ & $\begin{array}{l}\text { Present } \\
\text { Entire }\end{array}$ & $\begin{array}{l}\text { Present } \\
\text { Entire }\end{array}$ \\
\hline $\begin{array}{l}\text { Common Sagebrush Lizard } \\
\text { (Sceloporus graciosus) }\end{array}$ & $?$ & G5S3 & $\begin{array}{l}\text { Outside } \\
\text { Range }\end{array}$ & $\begin{array}{l}\text { Present } \\
\text { Entire }\end{array}$ & $\begin{array}{l}\text { Outside } \\
\text { Range }\end{array}$ & $\begin{array}{l}\text { Presence } \\
\text { Possible }\end{array}$ & $\begin{array}{l}\text { Presence } \\
\text { Possible }\end{array}$ & $\begin{array}{l}\text { Present } \\
\text { Entire }\end{array}$ & $\begin{array}{l}\text { Presence } \\
\text { Possible }\end{array}$ \\
\hline $\begin{array}{l}\text { Western Fence Lizard } \\
\text { (Sceloporus occidentalis) }\end{array}$ & $?$ & G5/SNA & $\begin{array}{l}\text { Outside } \\
\text { Range }\end{array}$ & $\begin{array}{l}\text { Outside } \\
\text { Range }\end{array}$ & $\begin{array}{l}\text { Introduced } \\
\text { in Part }\end{array}$ & $\begin{array}{l}\text { Outside } \\
\text { Range }\end{array}$ & $\begin{array}{l}\text { Outside } \\
\text { Range }\end{array}$ & $\begin{array}{l}\text { Outside } \\
\text { Range }\end{array}$ & $\begin{array}{l}\text { Outside } \\
\text { Range }\end{array}$ \\
\hline $\begin{array}{l}{ }^{\mathrm{A}} \text { Western Skink } \\
\text { (Eumeces skiltonianus) }\end{array}$ & $?$ & G5S3 & $\begin{array}{l}\text { Outside } \\
\text { Range }\end{array}$ & $\begin{array}{l}\text { Outside } \\
\text { Range }\end{array}$ & $\begin{array}{l}\text { Present } \\
\text { Entire }\end{array}$ & $\begin{array}{l}\text { Outside } \\
\text { Range }\end{array}$ & $\begin{array}{l}\text { Outside } \\
\text { Range }\end{array}$ & $\begin{array}{l}\text { Outside } \\
\text { Range }\end{array}$ & $\begin{array}{l}\text { Outside } \\
\text { Range }\end{array}$ \\
\hline $\begin{array}{l}{ }^{\mathrm{A}} \text { Rubber Boa } \\
\text { (Charina bottae) }\end{array}$ & $?$ & G5S4 & $\begin{array}{l}\text { Presence } \\
\text { Possible }\end{array}$ & $\begin{array}{l}\text { Outside } \\
\text { Range }\end{array}$ & $\begin{array}{l}\text { Present } \\
\text { Entire }\end{array}$ & $\begin{array}{l}\text { Outside } \\
\text { Range }\end{array}$ & $\begin{array}{l}\text { Outside } \\
\text { Range }\end{array}$ & $\begin{array}{l}\text { Outside } \\
\text { Range }\end{array}$ & $\begin{array}{l}\text { Outside } \\
\text { Range }\end{array}$ \\
\hline $\begin{array}{l}\text { Eastern Racer } \\
\text { (Coluber constrictor) }\end{array}$ & $?$ & G5S5 & $\begin{array}{l}\text { Present } \\
\text { Entire }\end{array}$ & $\begin{array}{l}\text { Present } \\
\text { Entire }\end{array}$ & $\begin{array}{l}\text { Present } \\
\text { Entire }\end{array}$ & $\begin{array}{l}\text { Present } \\
\text { Entire }\end{array}$ & $\begin{array}{l}\text { Present } \\
\text { Entire }\end{array}$ & $\begin{array}{l}\text { Present } \\
\text { Entire }\end{array}$ & $\begin{array}{l}\text { Present } \\
\text { Entire }\end{array}$ \\
\hline $\begin{array}{l}{ }^{\mathrm{A}} \text { Western Hog-nosed Snake } \\
\text { (Heterodon nasicus) }\end{array}$ & $?$ & G5S2 & $\begin{array}{l}\text { Presence } \\
\text { Possible }\end{array}$ & $\begin{array}{l}\text { Present } \\
\text { Entire }\end{array}$ & $\begin{array}{l}\text { Outside } \\
\text { Range }\end{array}$ & $\begin{array}{l}\text { Present } \\
\text { Entire }\end{array}$ & $\begin{array}{l}\text { Present } \\
\text { Entire }\end{array}$ & $\begin{array}{l}\text { Present } \\
\text { Entire }\end{array}$ & $\begin{array}{l}\text { Presence } \\
\text { Possible }\end{array}$ \\
\hline $\begin{array}{l}{ }^{\mathrm{A}} \text { Smooth Greensnake } \\
\text { (Opheodrys vernalis) }\end{array}$ & $?$ & G5S2 & $\begin{array}{l}\text { Outside } \\
\text { Range }\end{array}$ & $\begin{array}{c}\text { Outside } \\
\text { Range }\end{array}$ & $\begin{array}{l}\text { Outside } \\
\text { Range }\end{array}$ & $\begin{array}{l}\text { Outside } \\
\text { Range }\end{array}$ & $\begin{array}{l}\text { Present } \\
\text { Part }\end{array}$ & $\begin{array}{l}\text { Outside } \\
\text { Range }\end{array}$ & $\begin{array}{l}\text { Outside } \\
\text { Range }\end{array}$ \\
\hline $\begin{array}{l}{ }^{\mathrm{A}} \text { Milksnake } \\
\text { (Lampropeltis triangulum) }\end{array}$ & $?$ & G5S2 & $\begin{array}{l}\text { Outside } \\
\text { Range }\end{array}$ & $\begin{array}{l}\text { Present } \\
\text { Entire }\end{array}$ & $\begin{array}{l}\text { Outside } \\
\text { Range }\end{array}$ & $\begin{array}{l}\text { Presence } \\
\text { Possible }\end{array}$ & $\begin{array}{l}\text { Presence } \\
\text { Possible }\end{array}$ & $\begin{array}{l}\text { Present } \\
\text { Entire }\end{array}$ & $\begin{array}{l}\text { Presence } \\
\text { Possible }\end{array}$ \\
\hline $\begin{array}{l}\text { Gophersnake } \\
\text { (Pituophis catenifer) }\end{array}$ & $?$ & G5S5 & $\begin{array}{l}\text { Present } \\
\text { Entire }\end{array}$ & $\begin{array}{l}\text { Present } \\
\text { Entire }\end{array}$ & $\begin{array}{l}\text { Present } \\
\text { Entire }\end{array}$ & $\begin{array}{l}\text { Present } \\
\text { Entire }\end{array}$ & $\begin{array}{l}\text { Present } \\
\text { Entire }\end{array}$ & $\begin{array}{l}\text { Present } \\
\text { Entire }\end{array}$ & $\begin{array}{l}\text { Present } \\
\text { Entire }\end{array}$ \\
\hline $\begin{array}{l}\text { Terrestrial Gartersnake } \\
\text { (Thamnophis elegans) }\end{array}$ & $?$ & G5S5 & $\begin{array}{l}\text { Present } \\
\text { Entire }\end{array}$ & $\begin{array}{l}\text { Present } \\
\text { Entire }\end{array}$ & $\begin{array}{l}\text { Present } \\
\text { Entire }\end{array}$ & $\begin{array}{l}\text { Present } \\
\text { Part }\end{array}$ & $\begin{array}{l}\text { Outside } \\
\text { Range }\end{array}$ & $\begin{array}{l}\text { Present } \\
\text { Entire }\end{array}$ & $\begin{array}{l}\text { Present } \\
\text { Entire }\end{array}$ \\
\hline $\begin{array}{l}\text { Plains Gartersnake } \\
\text { (Thamnophis radix) }\end{array}$ & $?$ & G5S4 & $\begin{array}{l}\text { Present } \\
\text { Entire }\end{array}$ & $\begin{array}{l}\text { Present } \\
\text { Part }\end{array}$ & $\begin{array}{l}\text { Outside } \\
\text { Range }\end{array}$ & $\begin{array}{l}\text { Present } \\
\text { Entire }\end{array}$ & $\begin{array}{l}\text { Present } \\
\text { Entire }\end{array}$ & $\begin{array}{l}\text { Present } \\
\text { Entire }\end{array}$ & $\begin{array}{c}\text { Present } \\
\text { Entire }\end{array}$ \\
\hline $\begin{array}{l}\text { Common Gartersnake } \\
\text { (Thamnophis sirtalis) }\end{array}$ & $?$ & G5S3 & $\begin{array}{l}\text { Present } \\
\text { Entire }\end{array}$ & $\begin{array}{l}\text { Present } \\
\text { Entire }\end{array}$ & $\begin{array}{l}\text { Present } \\
\text { Entire }\end{array}$ & $\begin{array}{l}\text { Presence } \\
\text { Possible }\end{array}$ & $\begin{array}{l}\text { Presence } \\
\text { Possible }\end{array}$ & $\begin{array}{l}\text { Present } \\
\text { Entire }\end{array}$ & $\begin{array}{l}\text { Presence } \\
\text { Possible }\end{array}$ \\
\hline $\begin{array}{l}\text { Prairie Rattlesnake } \\
\text { (Crotalus viridis) }\end{array}$ & $?$ & G5S4 & $\begin{array}{l}\text { Present } \\
\text { Entire }\end{array}$ & $\begin{array}{l}\text { Present } \\
\text { Entire }\end{array}$ & $\begin{array}{l}\text { Present } \\
\text { Entire }\end{array}$ & $\begin{array}{l}\text { Present } \\
\text { Entire }\end{array}$ & $\begin{array}{l}\text { Present } \\
\text { Entire }\end{array}$ & $\begin{array}{l}\text { Present } \\
\text { Entire }\end{array}$ & $\begin{array}{l}\text { Present } \\
\text { Entire }\end{array}$ \\
\hline
\end{tabular}

\footnotetext{
${ }^{A}$ relatively few records for species. $\quad{ }^{B}$ evidence that species has declined.
} 


\section{Presence and Status Ranks for Amphibians and Reptiles Within Montana Fish, Wildlife, and Parks Wildlife Regions in Montana}

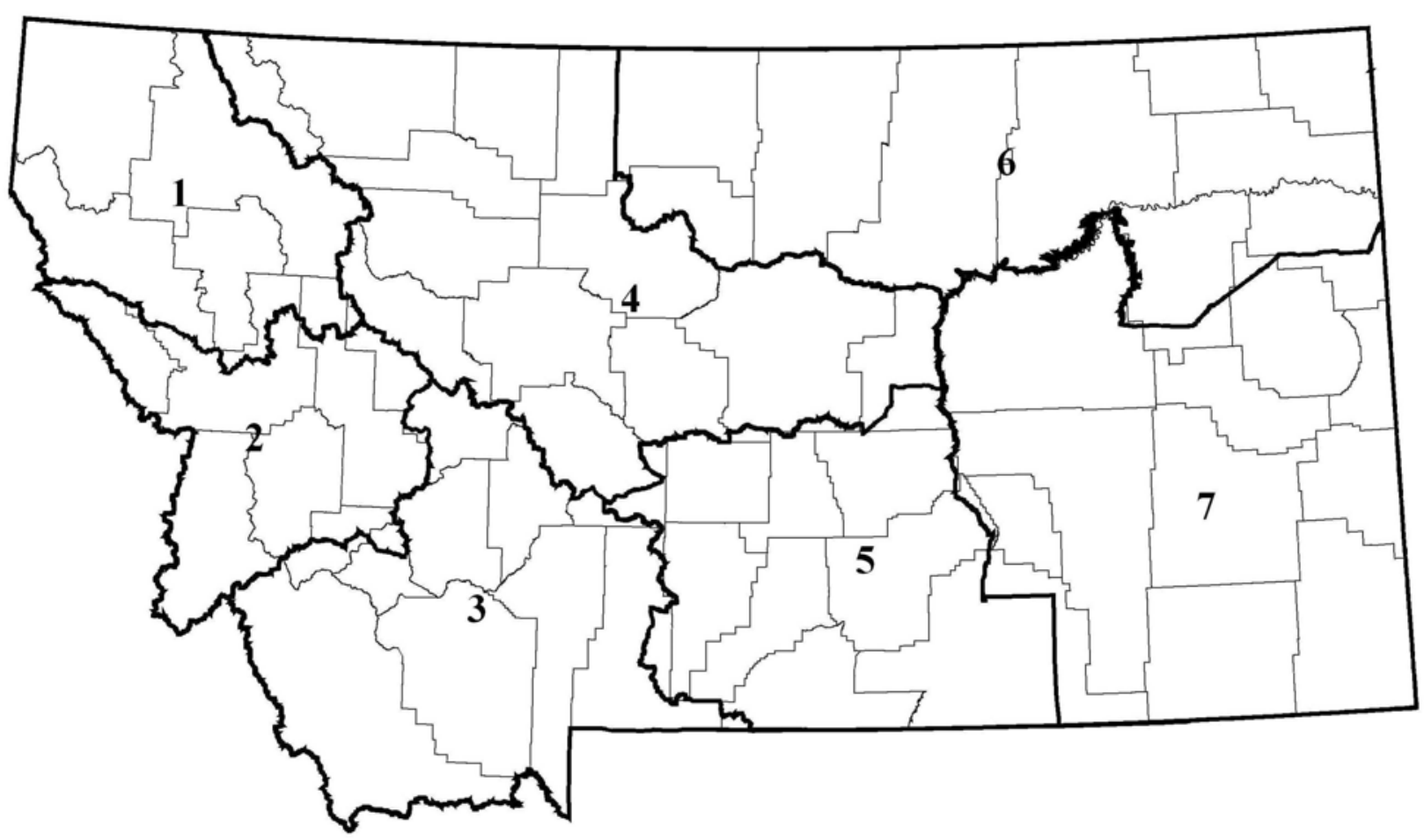

Montana Fish, Wildlife, and Parks' conservation and inventory tiering status, Heritage Program status ranks, and notations on species presence are listed in the table below for each of the Montana Fish, Wildlife, and Parks Regions in Montana. Montana's Comprehensive Fish and Wildlife Conservation Strategy (CFWCS) identifies fish and wildlife species that are in greatest need of conservation using a combination of criteria used in the joint Montana Fish, Wildlife, and Parks, and Montana Natural Heritage Program Species of Concern List (see above) as well as the input of a variety of biologists around the state. The significance of each conservation tier is defined as follows:

Tier I: Greatest conservation need. Montana Fish, Wildlife \& Parks has a clear obligation to use its resources to implement conservation actions that provide direct benefit to these species, communities, and focus areas.

Tier II: Moderate conservation need. Montana Fish, Wildlife \& Parks could use its resources to implement conservation actions that provide direct benefit to these species, communities, and focus areas.

Tier III: Lower conservation need. Although important to Montana's wildlife diversity, these species, communities, and focus areas are either abundant and widespread or are believed to have adequate conservation already in place.

Tier IV: Species that are non-native, incidental, or on the periphery of their range and are either expanding or very common in adjacent states.

Montana's CFWCS also identifies 3 tiers of individual species and taxonomic groups that are in need of inventory work. Each species' conservation and inventory tiering status is indicated before and after a dash, respectively in the table below. 
Presence and Status Ranks for Amphibians Within Montana Fish, Wildlife, and Parks Wildlife Regions in Montana

Current distribution and status information can be found on the Montana Natural Heritage Program's website at www.mtnhp.org

\begin{tabular}{|c|c|c|c|c|c|c|c|c|c|}
\hline $\begin{array}{c}\text { Common and } \\
\text { Scientific Name }\end{array}$ & $\begin{array}{l}\text { CFWCS } \\
\text { Tiers* }\end{array}$ & $\begin{array}{c}\text { Heritage } \\
\text { Ranks }\end{array}$ & $\begin{array}{c}\text { Region } \\
1\end{array}$ & $\begin{array}{l}\text { Region } \\
2\end{array}$ & $\begin{array}{l}\text { Region } \\
3\end{array}$ & $\begin{array}{c}\text { Region } \\
4\end{array}$ & $\begin{array}{l}\text { Region } \\
5\end{array}$ & $\begin{array}{l}\text { Region } \\
6\end{array}$ & $\begin{array}{l}\text { Region } \\
7\end{array}$ \\
\hline $\begin{array}{l}\text { Long-toed Salamander } \\
\text { (Ambystoma macrodactylum) }\end{array}$ & $2-3$ & G5/S4 & $\begin{array}{l}\text { Present } \\
\text { Entire }\end{array}$ & $\begin{array}{l}\text { Present } \\
\text { Entire }\end{array}$ & $\begin{array}{c}\text { Present } \\
\text { Part }\end{array}$ & $\begin{array}{l}\text { Present } \\
\text { Part }\end{array}$ & $\begin{array}{l}\text { Outside } \\
\text { Range }\end{array}$ & $\begin{array}{l}\text { Outside } \\
\text { Range }\end{array}$ & $\begin{array}{l}\text { Outside } \\
\text { Range }\end{array}$ \\
\hline $\begin{array}{l}\text { Tiger Salamander } \\
\text { (Ambystoma tigrinum) }\end{array}$ & $2-3$ & G5/S4 & $\begin{array}{l}\text { Present } \\
\text { Part }\end{array}$ & $\begin{array}{l}\text { Outside } \\
\text { Range }\end{array}$ & $\begin{array}{l}\text { Present } \\
\text { Part }\end{array}$ & $\begin{array}{l}\text { Present } \\
\text { Entire }\end{array}$ & $\begin{array}{l}\text { Present } \\
\text { Entire }\end{array}$ & $\begin{array}{l}\text { Present } \\
\text { Entire }\end{array}$ & $\begin{array}{l}\text { Present } \\
\text { Entire }\end{array}$ \\
\hline $\begin{array}{l}{ }^{\mathrm{A}} \text { Idaho Giant Salamander } \\
\text { (Dicamptodon aterrimus) }\end{array}$ & $4-3$ & G3/S1S3 & $\begin{array}{l}\text { Presence } \\
\text { Possible }\end{array}$ & $\begin{array}{l}\text { Present } \\
\text { Part }\end{array}$ & $\begin{array}{l}\text { Outside } \\
\text { Range }\end{array}$ & $\begin{array}{l}\text { Outside } \\
\text { Range }\end{array}$ & $\begin{array}{l}\text { Outside } \\
\text { Range }\end{array}$ & $\begin{array}{l}\text { Outside } \\
\text { Range }\end{array}$ & $\begin{array}{l}\text { Outside } \\
\text { Range }\end{array}$ \\
\hline $\begin{array}{l}\text { Coeur d' Alene Salamander } \\
\text { (Plethodon idahoensis) }\end{array}$ & $1-1$ & G4/S2 & $\begin{array}{l}\text { Present } \\
\text { Part }\end{array}$ & $\begin{array}{l}\text { Present } \\
\text { Part }\end{array}$ & $\begin{array}{l}\text { Outside } \\
\text { Range }\end{array}$ & $\begin{array}{l}\text { Outside } \\
\text { Range }\end{array}$ & $\begin{array}{l}\text { Outside } \\
\text { Range }\end{array}$ & $\begin{array}{l}\text { Outside } \\
\text { Range }\end{array}$ & $\begin{array}{l}\text { Outside } \\
\text { Range }\end{array}$ \\
\hline $\begin{array}{l}\text { Rocky Mountain Tailed Frog } \\
\text { (Ascaphus montanus) }\end{array}$ & $2-3$ & G4/S4 & $\begin{array}{l}\text { Present } \\
\text { Part }\end{array}$ & $\begin{array}{l}\text { Present } \\
\text { Part }\end{array}$ & $\begin{array}{l}\text { Present } \\
\text { Part }\end{array}$ & $\begin{array}{l}\text { Present } \\
\text { Part }\end{array}$ & $\begin{array}{l}\text { Outside } \\
\text { Range }\end{array}$ & $\begin{array}{l}\text { Outside } \\
\text { Range }\end{array}$ & $\begin{array}{l}\text { Outside } \\
\text { Range }\end{array}$ \\
\hline $\begin{array}{l}{ }^{\mathrm{A}} \text { Plains Spadefoot } \\
\text { (Spea bombifrons) }\end{array}$ & $2-1$ & G5/S3 & $\begin{array}{l}\text { Outside } \\
\text { Range }\end{array}$ & $\begin{array}{l}\text { Outside } \\
\text { Range }\end{array}$ & $\begin{array}{l}\text { Present } \\
\text { Part }\end{array}$ & $\begin{array}{l}\text { Present } \\
\text { Part }\end{array}$ & $\begin{array}{l}\text { Present } \\
\text { Part }\end{array}$ & $\begin{array}{l}\text { Present } \\
\text { Entire }\end{array}$ & $\begin{array}{l}\text { Present } \\
\text { Entire }\end{array}$ \\
\hline $\begin{array}{l}\text { Great Basin Spadefoot } \\
\text { (Spea intermontana) }\end{array}$ & $3-2$ & G5/SNA & $\begin{array}{l}\text { Outside } \\
\text { Range }\end{array}$ & $\begin{array}{l}\text { Outside } \\
\text { Range }\end{array}$ & $\begin{array}{l}\text { Presence } \\
\text { Possible }\end{array}$ & $\begin{array}{l}\text { Outside } \\
\text { Range }\end{array}$ & $\begin{array}{l}\text { Outside } \\
\text { Range }\end{array}$ & $\begin{array}{l}\text { Outside } \\
\text { Range }\end{array}$ & $\begin{array}{l}\text { Outside } \\
\text { Range }\end{array}$ \\
\hline $\begin{array}{l}{ }^{\mathrm{B}} \text { Westerm Toad } \\
\text { (Bufo boreas) }\end{array}$ & $1-1$ & G4/S2 & $\begin{array}{l}\text { Present } \\
\text { Entire }\end{array}$ & $\begin{array}{l}\text { Present } \\
\text { Entire }\end{array}$ & $\begin{array}{l}\text { Present } \\
\text { Entire }\end{array}$ & $\begin{array}{l}\text { Present } \\
\text { Part }\end{array}$ & $\begin{array}{l}\text { Present } \\
\text { Part }\end{array}$ & $\begin{array}{l}\text { Outside } \\
\text { Range }\end{array}$ & $\begin{array}{l}\text { Outside } \\
\text { Range }\end{array}$ \\
\hline $\begin{array}{l}{ }_{\text {A Great Plains Toad }} \\
\text { (Bufo cognatus) }\end{array}$ & $2-1$ & G5/S2 & $\begin{array}{l}\text { Outside } \\
\text { Range }\end{array}$ & $\begin{array}{l}\text { Outside } \\
\text { Range }\end{array}$ & $\begin{array}{l}\text { Present } \\
\text { Part }\end{array}$ & $\begin{array}{l}\text { Present } \\
\text { Part }\end{array}$ & $\begin{array}{l}\text { Present } \\
\text { Part }\end{array}$ & $\begin{array}{l}\text { Present } \\
\text { Entire }\end{array}$ & $\begin{array}{l}\text { Present } \\
\text { Entire }\end{array}$ \\
\hline $\begin{array}{l}{ }^{\mathrm{C}} \text { Canadian Toad } \\
\text { (Bufo hemiophrys) }\end{array}$ & $4-3$ & G4/SNA & $\begin{array}{l}\text { Outside } \\
\text { Range }\end{array}$ & $\begin{array}{l}\text { Outside } \\
\text { Range }\end{array}$ & $\begin{array}{l}\text { Outside } \\
\text { Range }\end{array}$ & $\begin{array}{l}\text { Outside } \\
\text { Range }\end{array}$ & $\begin{array}{l}\text { Outside } \\
\text { Range }\end{array}$ & $\begin{array}{l}\text { Possible } \\
\text { Presence }\end{array}$ & $\begin{array}{l}\text { Outside } \\
\text { Range }\end{array}$ \\
\hline $\begin{array}{l}\text { Woodhouse's Toad } \\
\text { (Bufo woodhousii) }\end{array}$ & $2-3$ & G5/S4 & $\begin{array}{l}\text { Outside } \\
\text { Range }\end{array}$ & $\begin{array}{c}\text { Outside } \\
\text { Range }\end{array}$ & $\begin{array}{l}\text { Outside } \\
\text { Range }\end{array}$ & $\begin{array}{c}\text { Present } \\
\text { Part }\end{array}$ & $\begin{array}{c}\text { Present } \\
\text { Part }\end{array}$ & $\begin{array}{c}\text { Present } \\
\text { Part }\end{array}$ & $\begin{array}{l}\text { Present } \\
\text { Entire }\end{array}$ \\
\hline $\begin{array}{l}\text { Pacific Treefrog } \\
\text { (Pseudacris regilla) }\end{array}$ & $2-2$ & G5/S4 & $\begin{array}{l}\text { Present } \\
\text { Part }\end{array}$ & $\begin{array}{l}\text { Present } \\
\text { Part }\end{array}$ & $\begin{array}{l}\text { Outside } \\
\text { Range }\end{array}$ & $\begin{array}{l}\text { Present } \\
\text { Part }\end{array}$ & $\begin{array}{l}\text { Outside } \\
\text { Range }\end{array}$ & $\begin{array}{l}\text { Outside } \\
\text { Range }\end{array}$ & $\begin{array}{l}\text { Outside } \\
\text { Range }\end{array}$ \\
\hline $\begin{array}{l}\text { Boreal Chorus Frog } \\
\text { (Pseudacris maculata) }\end{array}$ & $3-3$ & G5/S4 & $\begin{array}{c}\text { Outside } \\
\text { Range }\end{array}$ & $\begin{array}{l}\text { Outside } \\
\text { Range }\end{array}$ & $\begin{array}{c}\text { Present } \\
\text { Part }\end{array}$ & $\begin{array}{c}\text { Present } \\
\text { Entire }\end{array}$ & $\begin{array}{c}\text { Present } \\
\text { Entire }\end{array}$ & $\begin{array}{l}\text { Present } \\
\text { Entire }\end{array}$ & $\begin{array}{l}\text { Present } \\
\text { Entire }\end{array}$ \\
\hline $\begin{array}{l}\text { American Bullfrog } \\
\text { (Rana catesbeiana) }\end{array}$ & $4-3$ & $\begin{array}{l}\text { G5/SNA } \\
\text { Exotic }\end{array}$ & $\begin{array}{l}\text { Continue to } \\
\text { Spread }\end{array}$ & $\begin{array}{c}\text { Continue to } \\
\text { Spread }\end{array}$ & $\begin{array}{c}\text { Limited } \\
\text { Presence }\end{array}$ & $\begin{array}{c}\text { Limited } \\
\text { Presence }\end{array}$ & $\begin{array}{c}\text { Continue to } \\
\text { Spread }\end{array}$ & $\begin{array}{c}\text { No } \\
\text { Records }\end{array}$ & $\begin{array}{c}\text { Limited } \\
\text { Presence }\end{array}$ \\
\hline $\begin{array}{l}\text { Columbia Spotted Frog } \\
\text { (Rana luteiventris) }\end{array}$ & $2-3$ & G4/S4 & $\begin{array}{l}\text { Present } \\
\text { Entire }\end{array}$ & $\begin{array}{l}\text { Present } \\
\text { Entire }\end{array}$ & $\begin{array}{l}\text { Present } \\
\text { Entire }\end{array}$ & $\begin{array}{l}\text { Present } \\
\text { Part }\end{array}$ & $\begin{array}{l}\text { Present } \\
\text { Part }\end{array}$ & $\begin{array}{l}\text { Outside } \\
\text { Range }\end{array}$ & $\begin{array}{l}\text { Outside } \\
\text { Range }\end{array}$ \\
\hline $\begin{array}{l}{ }^{\mathbf{B}} \text { Northern Leopard Frog } \\
\text { (Rana pipiens) }\end{array}$ & $1-1$ & G5/S1S3 & $\begin{array}{c}\text { Nearly } \\
\text { Extirpated }\end{array}$ & Extirpated & $\begin{array}{l}\text { Present } \\
\text { Part }\end{array}$ & $\begin{array}{c}\text { Present } \\
\text { Entire }\end{array}$ & $\begin{array}{c}\text { Present } \\
\text { Entire }\end{array}$ & $\begin{array}{c}\text { Present } \\
\text { Entire }\end{array}$ & $\begin{array}{c}\text { Present } \\
\text { Entire }\end{array}$ \\
\hline $\begin{array}{l}\text { Wood Frog } \\
\text { (Rana sylvatica) }\end{array}$ & $?-3$ & G5/SNA & $\begin{array}{l}\text { Presence } \\
\text { Possible }\end{array}$ & $\begin{array}{l}\text { Outside } \\
\text { Range }\end{array}$ & $\begin{array}{l}\text { Outside } \\
\text { Range }\end{array}$ & $\begin{array}{l}\text { Outside } \\
\text { Range }\end{array}$ & $\begin{array}{l}\text { Presence } \\
\text { Possible }\end{array}$ & $\begin{array}{l}\text { Outside } \\
\text { Range }\end{array}$ & $\begin{array}{l}\text { Outside } \\
\text { Range }\end{array}$ \\
\hline
\end{tabular}

${ }^{A}$ relatively few records for species. $\quad{ }^{B}$ evidence that species has declined.

${ }^{\mathrm{C}}$ questionable historic observation record, but presence is possible. 
Presence and Status Ranks for Reptiles Within Montana Fish, Wildlife, and Parks Wildlife Regions in Montana

Current distribution and status information can be found on the Montana Natural Heritage Program's website at www.mtnhp.org

\begin{tabular}{|c|c|c|c|c|c|c|c|c|c|}
\hline $\begin{array}{c}\text { Common and } \\
\text { Scientific Name }\end{array}$ & $\begin{array}{c}\text { CFWCS } \\
\text { Tiers* }\end{array}$ & $\begin{array}{c}\text { Heritage } \\
\text { Ranks }\end{array}$ & $\begin{array}{c}\text { Region } \\
1\end{array}$ & $\begin{array}{l}\text { Region } \\
2\end{array}$ & $\begin{array}{c}\text { Region } \\
\mathbf{3}\end{array}$ & $\underset{4}{\text { Region }}$ & Region & $\begin{array}{l}\text { Region } \\
6\end{array}$ & $\begin{array}{c}\text { Region } \\
7\end{array}$ \\
\hline $\begin{array}{l}{ }^{\mathbf{A}} \text { Snapping Turtle } \\
\text { (Chelydra serpentina) }\end{array}$ & $1-1$ & G5/S3 & $\begin{array}{c}\text { Limited } \\
\text { Introduction }\end{array}$ & $\begin{array}{l}\text { Outside } \\
\text { Range }\end{array}$ & $\begin{array}{c}\text { Limited } \\
\text { Introduction }\end{array}$ & $\begin{array}{l}\text { Outside } \\
\text { Range }\end{array}$ & $\begin{array}{l}\text { Present } \\
\text { Part }\end{array}$ & $\begin{array}{l}\text { Present } \\
\text { Part }\end{array}$ & $\begin{array}{l}\text { Present } \\
\text { Entire }\end{array}$ \\
\hline $\begin{array}{l}\text { Painted Turtle } \\
\text { (Chrysemys picta) }\end{array}$ & $3-3$ & G5/S4 & $\begin{array}{l}\text { Present } \\
\text { Entire }\end{array}$ & $\begin{array}{l}\text { Present } \\
\text { Entire }\end{array}$ & $\begin{array}{l}\text { Present } \\
\text { Entire }\end{array}$ & $\begin{array}{l}\text { Present } \\
\text { Entire }\end{array}$ & $\begin{array}{l}\text { Present } \\
\text { Entire }\end{array}$ & $\begin{array}{l}\text { Present } \\
\text { Entire }\end{array}$ & $\begin{array}{c}\text { Present } \\
\text { Entire }\end{array}$ \\
\hline $\begin{array}{l}{ }^{\mathrm{A}} \text { Spiny Softshell Turtle } \\
\text { (Apalone spinifera) }\end{array}$ & $1-1$ & G5/S3 & $\begin{array}{l}\text { Outside } \\
\text { Range }\end{array}$ & $\begin{array}{l}\text { Outside } \\
\text { Range }\end{array}$ & $\begin{array}{l}\text { Outside } \\
\text { Range }\end{array}$ & $\begin{array}{l}\text { Present } \\
\text { Part }\end{array}$ & $\begin{array}{l}\text { Present } \\
\text { Entire }\end{array}$ & $\begin{array}{l}\text { Present } \\
\text { Part }\end{array}$ & $\begin{array}{c}\text { Present } \\
\text { Entire }\end{array}$ \\
\hline $\begin{array}{l}\text { (Elgaria coerulea) } \\
\text { Northern Alligator Lizard }\end{array}$ & $2-1$ & G5/S3 & $\begin{array}{l}\text { Present } \\
\text { Part }\end{array}$ & $\begin{array}{l}\text { Present } \\
\text { Part }\end{array}$ & $\begin{array}{l}\text { Outside } \\
\text { Range }\end{array}$ & $\begin{array}{l}\text { Outside } \\
\text { Range }\end{array}$ & $\begin{array}{l}\text { Outside } \\
\text { Range }\end{array}$ & $\begin{array}{l}\text { Outside } \\
\text { Range }\end{array}$ & $\begin{array}{l}\text { Outside } \\
\text { Range }\end{array}$ \\
\hline $\begin{array}{l}{ }^{\mathrm{C}} \text { Pigmy Short-horned Lizard } \\
\text { (Phrynosoma douglasii) }\end{array}$ & $\begin{array}{l}\text { No Tier } \\
\text { Assigned }\end{array}$ & G5/SNA & $\begin{array}{l}\text { Outside } \\
\text { Range }\end{array}$ & $\begin{array}{l}\text { Outside } \\
\text { Range }\end{array}$ & $\begin{array}{l}\text { Presence } \\
\text { Possible }\end{array}$ & $\begin{array}{l}\text { Outside } \\
\text { Range }\end{array}$ & $\begin{array}{l}\text { Outside } \\
\text { Range }\end{array}$ & $\begin{array}{l}\text { Outside } \\
\text { Range }\end{array}$ & $\begin{array}{l}\text { Outside } \\
\text { Range }\end{array}$ \\
\hline $\begin{array}{l}\text { Bareater Short-horned Lizard } \\
\text { (Phrynosoma hernandesi) }\end{array}$ & $2-2$ & G5/S3 & $\begin{array}{l}\text { Outside } \\
\text { Range }\end{array}$ & $\begin{array}{l}\text { Outside } \\
\text { Range }\end{array}$ & $\begin{array}{c}\text { Possibly } \\
\text { Extirpated }\end{array}$ & $\begin{array}{l}\text { Present } \\
\text { Entire }\end{array}$ & $\begin{array}{l}\text { Present } \\
\text { Entire }\end{array}$ & $\begin{array}{l}\text { Present } \\
\text { Entire }\end{array}$ & $\begin{array}{l}\text { Present } \\
\text { Entire }\end{array}$ \\
\hline $\begin{array}{l}\text { Common Sagebrush Lizard } \\
\text { (Sceloporus graciosus) }\end{array}$ & $2-2$ & G5S3 & $\begin{array}{l}\text { Outside } \\
\text { Range }\end{array}$ & $\begin{array}{l}\text { Outside } \\
\text { Range }\end{array}$ & $\begin{array}{l}\text { Present } \\
\text { Part }\end{array}$ & $\begin{array}{l}\text { Present } \\
\text { Part }\end{array}$ & $\begin{array}{l}\text { Present } \\
\text { Entire }\end{array}$ & $\begin{array}{l}\text { Present } \\
\text { Part }\end{array}$ & $\begin{array}{c}\text { Present } \\
\text { Entire }\end{array}$ \\
\hline $\begin{array}{l}\text { Western Fence Lizard } \\
\text { (Sceloporus occidentalis) }\end{array}$ & $\begin{array}{l}\text { No Tier } \\
\text { Assigned }\end{array}$ & G5/SNA & $\begin{array}{l}\text { Introduced } \\
\text { in Part }\end{array}$ & $\begin{array}{l}\text { Outside } \\
\text { Range }\end{array}$ & $\begin{array}{l}\text { Outside } \\
\text { Range }\end{array}$ & $\begin{array}{l}\text { Outside } \\
\text { Range }\end{array}$ & $\begin{array}{l}\text { Outside } \\
\text { Range }\end{array}$ & $\begin{array}{l}\text { Outside } \\
\text { Range }\end{array}$ & $\begin{array}{l}\text { Outside } \\
\text { Range }\end{array}$ \\
\hline $\begin{array}{l}{ }^{\mathrm{A}} \text { Western Skink } \\
\text { (Eumeces skiltonianus) }\end{array}$ & $2-1$ & G5S3 & $\begin{array}{l}\text { Present } \\
\text { Part }\end{array}$ & $\begin{array}{l}\text { Present } \\
\text { Part }\end{array}$ & $\begin{array}{l}\text { Outside } \\
\text { Range }\end{array}$ & $\begin{array}{l}\text { Outside } \\
\text { Range }\end{array}$ & $\begin{array}{l}\text { Outside } \\
\text { Range }\end{array}$ & $\begin{array}{l}\text { Outside } \\
\text { Range }\end{array}$ & $\begin{array}{l}\text { Outside } \\
\text { Range }\end{array}$ \\
\hline $\begin{array}{l}{ }^{\mathrm{A}} \text { Rubber Boa } \\
\text { (Charina bottae) }\end{array}$ & $2-1$ & G5S4 & $\begin{array}{l}\text { Present } \\
\text { Entire }\end{array}$ & $\begin{array}{l}\text { Present } \\
\text { Entire }\end{array}$ & $\begin{array}{l}\text { Present } \\
\text { Entire }\end{array}$ & $\begin{array}{l}\text { Present } \\
\text { Part }\end{array}$ & $\begin{array}{l}\text { Present } \\
\text { Part }\end{array}$ & $\begin{array}{l}\text { Outside } \\
\text { Range }\end{array}$ & $\begin{array}{l}\text { Outside } \\
\text { Range }\end{array}$ \\
\hline $\begin{array}{l}\text { Eastern Racer } \\
(\text { Coluber constrictor })\end{array}$ & $3-2$ & G5S5 & $\begin{array}{l}\text { Present } \\
\text { Entire }\end{array}$ & $\begin{array}{l}\text { Present } \\
\text { Entire }\end{array}$ & $\begin{array}{l}\text { Present } \\
\text { Entire }\end{array}$ & $\begin{array}{l}\text { Present } \\
\text { Entire }\end{array}$ & $\begin{array}{l}\text { Present } \\
\text { Entire }\end{array}$ & $\begin{array}{l}\text { Present } \\
\text { Entire }\end{array}$ & $\begin{array}{c}\text { Present } \\
\text { Entire }\end{array}$ \\
\hline $\begin{array}{l}{ }^{\mathrm{A}} \text { Western Hog-nosed Snake } \\
\text { (Heterodon nasicus) }\end{array}$ & $1-1$ & G5S2 & $\begin{array}{l}\text { Outside } \\
\text { Range }\end{array}$ & $\begin{array}{l}\text { Outside } \\
\text { Range }\end{array}$ & $\begin{array}{l}\text { Outside } \\
\text { Range }\end{array}$ & $\begin{array}{l}\text { Present } \\
\text { Part }\end{array}$ & $\begin{array}{l}\text { Present } \\
\text { Part }\end{array}$ & $\begin{array}{l}\text { Present } \\
\text { Entire }\end{array}$ & $\begin{array}{c}\text { Present } \\
\text { Entire }\end{array}$ \\
\hline 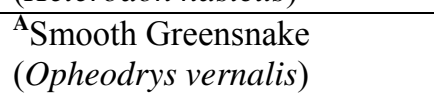 & $1-1$ & G5S2 & $\begin{array}{l}\text { Outside } \\
\text { Range }\end{array}$ & $\begin{array}{l}\text { Outside } \\
\text { Range }\end{array}$ & $\begin{array}{l}\text { Outside } \\
\text { Range }\end{array}$ & $\begin{array}{l}\text { Outside } \\
\text { Range }\end{array}$ & $\begin{array}{l}\text { Outside } \\
\text { Range }\end{array}$ & $\begin{array}{l}\text { Present } \\
\text { Part }\end{array}$ & $\begin{array}{l}\text { Outside } \\
\text { Range }\end{array}$ \\
\hline $\begin{array}{l}\text { (Lampropeltis triangulum) } \\
\text { (Lalksnake }\end{array}$ & $1-1$ & G5S2 & $\begin{array}{l}\text { Outside } \\
\text { Range }\end{array}$ & $\begin{array}{l}\text { Outside } \\
\text { Range }\end{array}$ & $\begin{array}{l}\text { Presence } \\
\text { Possible }\end{array}$ & $\begin{array}{l}\text { Present } \\
\text { Part }\end{array}$ & $\begin{array}{l}\text { Present } \\
\text { Entire }\end{array}$ & $\begin{array}{l}\text { Present } \\
\text { Part }\end{array}$ & $\begin{array}{l}\text { Present } \\
\text { Entire }\end{array}$ \\
\hline $\begin{array}{l}\text { Gophersnake } \\
\text { (Pituophis catenifer) }\end{array}$ & $3-2$ & G5S5 & $\begin{array}{l}\text { Present } \\
\text { Entire }\end{array}$ & $\begin{array}{l}\text { Present } \\
\text { Entire }\end{array}$ & $\begin{array}{l}\text { Present } \\
\text { Entire }\end{array}$ & $\begin{array}{l}\text { Present } \\
\text { Entire }\end{array}$ & $\begin{array}{l}\text { Present } \\
\text { Entire }\end{array}$ & $\begin{array}{l}\text { Present } \\
\text { Entire }\end{array}$ & $\begin{array}{l}\text { Present } \\
\text { Entire }\end{array}$ \\
\hline $\begin{array}{l}\text { Terrestrial Gartersnake } \\
\text { (Thamnophis elegans) }\end{array}$ & $3-3$ & G5S5 & $\begin{array}{l}\text { Present } \\
\text { Entire }\end{array}$ & $\begin{array}{l}\text { Present } \\
\text { Entire }\end{array}$ & $\begin{array}{l}\text { Present } \\
\text { Entire }\end{array}$ & $\begin{array}{l}\text { Present } \\
\text { Entire }\end{array}$ & $\begin{array}{l}\text { Present } \\
\text { Entire }\end{array}$ & $\begin{array}{c}\text { Present } \\
\text { Part }\end{array}$ & $\begin{array}{c}\text { Present } \\
\text { Part }\end{array}$ \\
\hline $\begin{array}{l}\text { Plains Gartersnake } \\
\text { (Thamnophis radix) }\end{array}$ & $3-2$ & G5S4 & $\begin{array}{l}\text { Outside } \\
\text { Range }\end{array}$ & $\begin{array}{l}\text { Outside } \\
\text { Range }\end{array}$ & $\begin{array}{l}\text { Outside } \\
\text { Range }\end{array}$ & $\begin{array}{l}\text { Present } \\
\text { Entire }\end{array}$ & $\begin{array}{l}\text { Present } \\
\text { Part }\end{array}$ & $\begin{array}{l}\text { Present } \\
\text { Entire }\end{array}$ & $\begin{array}{c}\text { Present } \\
\text { Entire }\end{array}$ \\
\hline $\begin{array}{l}\text { Common Gartersnake } \\
\text { (Thamnophis sirtalis) }\end{array}$ & $2-3$ & G5S3 & $\begin{array}{l}\text { Present } \\
\text { Entire }\end{array}$ & $\begin{array}{l}\text { Present } \\
\text { Entire }\end{array}$ & $\begin{array}{l}\text { Present } \\
\text { Entire }\end{array}$ & $\begin{array}{l}\text { Present } \\
\text { Entire }\end{array}$ & $\begin{array}{l}\text { Present } \\
\text { Entire }\end{array}$ & $\begin{array}{l}\text { Presence } \\
\text { Possible }\end{array}$ & $\begin{array}{c}\text { Present } \\
\text { Entire }\end{array}$ \\
\hline $\begin{array}{l}\text { Prairie Rattlesnake } \\
\text { (Crotalus viridis) }\end{array}$ & $2-2$ & G5S4 & $\begin{array}{l}\text { Present } \\
\text { Part }\end{array}$ & $\begin{array}{l}\text { Present } \\
\text { Entire }\end{array}$ & $\begin{array}{c}\text { Present } \\
\text { Entire }\end{array}$ & $\begin{array}{c}\text { Present } \\
\text { Entire }\end{array}$ & $\begin{array}{l}\text { Present } \\
\text { Entire }\end{array}$ & $\begin{array}{c}\text { Present } \\
\text { Entire }\end{array}$ & $\begin{array}{c}\text { Present } \\
\text { Entire }\end{array}$ \\
\hline
\end{tabular}

\footnotetext{
${ }^{A}$ relatively few records for species. $\quad{ }^{B}$ evidence that species has declined. $\quad{ }^{C}$ single historic museum record and current presence is possible.
} 


\section{Presence and Status Ranks for Amphibians and Reptiles on USFWS Wildlife Refuges in Montana}

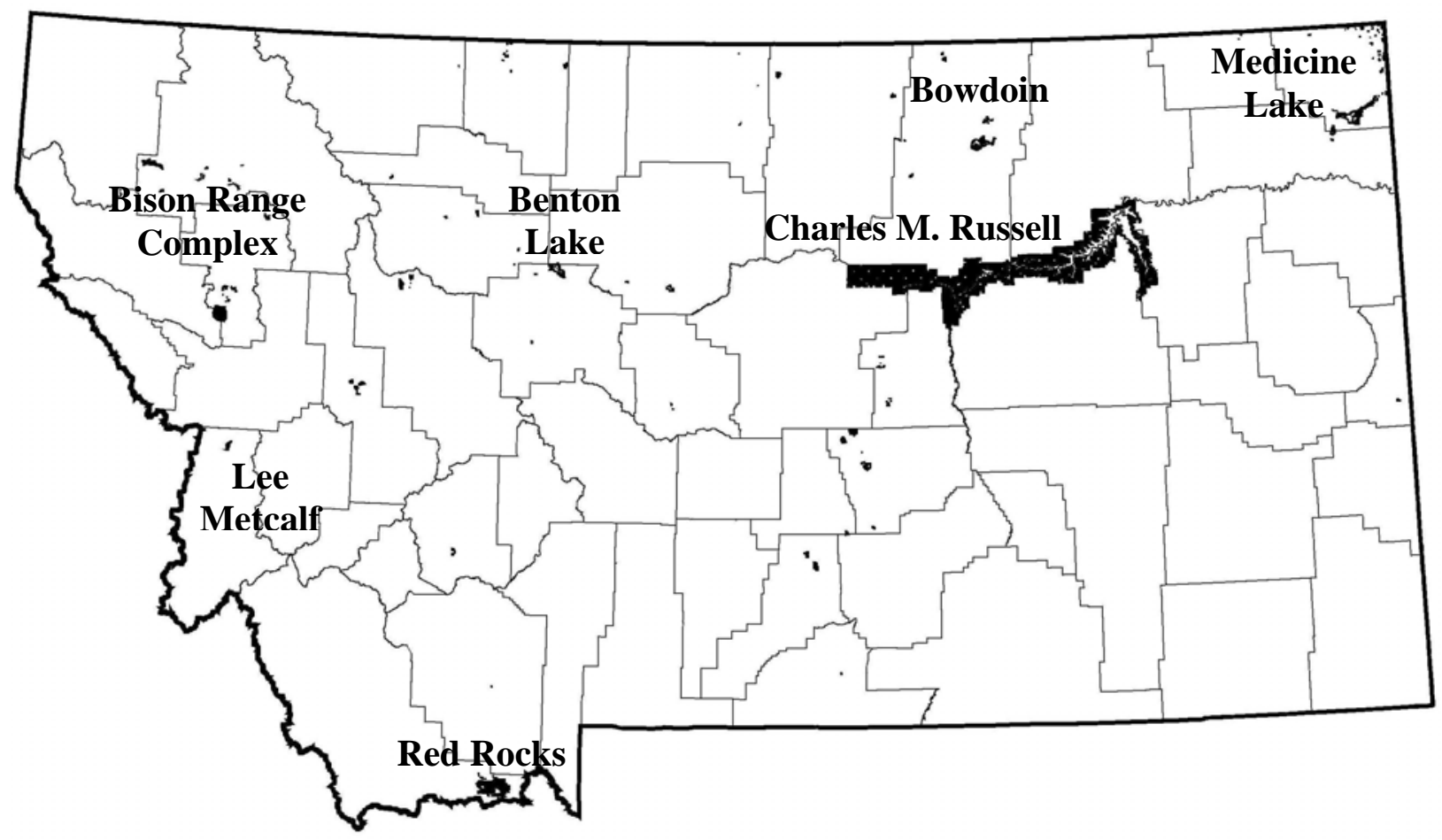

Heritage Program status ranks and notations on species presence are listed in the table below for each of the U.S. Fish and Wildlife Refuge or refuge complexes in Montana. While some amphibian and reptile species in Montana have undergone declines and/or regional extirpations in recent decades (e.g., Northern Leopard Frog, Western Toad, Greater Short-horned Lizard), none of these species is currently listed or is a candidate for listing under the federal Endangered Species Act of 1973 (ESA) by the U.S. Fish and Wildlife Service (16 U.S.C.A. §1531-1543 (Supp. 1996)). If an amphibian or reptile species in Montana were to be proposed for listing as threatened or endangered under the ESA the decision as to whether the species is threatened or endangered must be made solely on the basis of the best scientific and commercial data and must be judged according to the species status due to the five following factors (1) the present or threatened destruction, modification, or curtailment of its habitat or range, (2) overutilization for commercial, recreational, scientific, or educational purposes, (3) disease or predation, (4) the inadequacy of existing regulatory mechanisms, and (5) other natural or manmade factors affecting its continued existence (U.S.C. $§ 1533$ (a) (1), (b)(1)). Clearly, it is in the best interest of the species, various state, federal, and tribal agencies, and the general public to take measures to avoid having these factors justify a listing under the ESA. 
Presence and Status Ranks for Amphibians on USFWS Wildlife Refuges in Montana

Current distribution and status information can be found on the Montana Natural Heritage Program's website at www.mtnhp.org

\begin{tabular}{|c|c|c|c|c|c|c|c|c|c|}
\hline $\begin{array}{l}\text { Common and } \\
\text { Scientific Name }\end{array}$ & $\begin{array}{l}\text { USFWS } \\
\text { Status }\end{array}$ & $\begin{array}{c}\text { Heritage } \\
\text { Ranks }\end{array}$ & $\begin{array}{c}\text { Benton } \\
\text { Lake }\end{array}$ & Bowdoin & CMR & $\begin{array}{c}\text { Lee } \\
\text { Metcalf }\end{array}$ & $\begin{array}{l}\text { Medicine } \\
\text { Lake }\end{array}$ & $\begin{array}{c}\text { Bison Range } \\
\text { Complex }\end{array}$ & $\begin{array}{l}\text { Red Rock } \\
\text { Lakes }\end{array}$ \\
\hline $\begin{array}{l}\text { Long-toed Salamander } \\
\text { (Ambystoma macrodactylum) }\end{array}$ & $\begin{array}{l}\text { No Special } \\
\text { Status }\end{array}$ & G5/S4 & $\begin{array}{l}\text { Outside } \\
\text { Range }\end{array}$ & $\begin{array}{l}\text { Outside } \\
\text { Range }\end{array}$ & $\begin{array}{l}\text { Outside } \\
\text { Range }\end{array}$ & $\begin{array}{l}\text { Present } \\
\text { Entire }\end{array}$ & $\begin{array}{l}\text { Outside } \\
\text { Range }\end{array}$ & $\begin{array}{l}\text { Present } \\
\text { Entire }\end{array}$ & $\begin{array}{l}\text { Outside } \\
\text { Range }\end{array}$ \\
\hline $\begin{array}{l}\text { Tiger Salamander } \\
\text { (Ambystoma tigrinum) }\end{array}$ & $\begin{array}{l}\text { No Special } \\
\text { Status }\end{array}$ & G5/S4 & $\begin{array}{c}\text { Present } \\
\text { Entire }\end{array}$ & $\begin{array}{c}\text { Present } \\
\text { Entire }\end{array}$ & $\begin{array}{c}\text { Present } \\
\text { Entire }\end{array}$ & $\begin{array}{l}\text { Outside } \\
\text { Range }\end{array}$ & $\begin{array}{c}\text { Present } \\
\text { Entire }\end{array}$ & $\begin{array}{l}\text { Outside } \\
\text { Range }\end{array}$ & $\begin{array}{c}\text { Present } \\
\text { Entire }\end{array}$ \\
\hline $\begin{array}{l}{ }^{\mathrm{A}} \text { Idaho Giant Salamander } \\
\text { (Dicamptodon aterrimus) }\end{array}$ & $\begin{array}{l}\text { No Special } \\
\text { Status }\end{array}$ & $\mathrm{G} 3 / \mathrm{S} 1 \mathrm{~S} 3$ & $\begin{array}{l}\text { Outside } \\
\text { Range }\end{array}$ & $\begin{array}{l}\text { Outside } \\
\text { Range }\end{array}$ & $\begin{array}{c}\text { Outside } \\
\text { Range }\end{array}$ & $\begin{array}{c}\text { Outside } \\
\text { Range }\end{array}$ & $\begin{array}{l}\text { Outside } \\
\text { Range }\end{array}$ & $\begin{array}{l}\text { Outside } \\
\text { Range }\end{array}$ & $\begin{array}{l}\text { Outside } \\
\text { Range }\end{array}$ \\
\hline $\begin{array}{l}\text { Coeur d' Alene Salamander } \\
\text { (Plethodon idahoensis) }\end{array}$ & $\begin{array}{l}\text { No Special } \\
\text { Status }\end{array}$ & G4/S2 & $\begin{array}{l}\text { Outside } \\
\text { Range }\end{array}$ & $\begin{array}{l}\text { Outside } \\
\text { Range }\end{array}$ & $\begin{array}{l}\text { Outside } \\
\text { Range }\end{array}$ & $\begin{array}{l}\text { Outside } \\
\text { Range }\end{array}$ & $\begin{array}{l}\text { Outside } \\
\text { Range }\end{array}$ & $\begin{array}{c}\text { Outside } \\
\text { Range }\end{array}$ & $\begin{array}{l}\text { Outside } \\
\text { Range }\end{array}$ \\
\hline $\begin{array}{l}\text { Rocky Mountain Tailed Frog } \\
\text { (Ascaphus montanus) }\end{array}$ & $\begin{array}{l}\text { No Special } \\
\text { Status }\end{array}$ & G4/S4 & $\begin{array}{l}\text { Outside } \\
\text { Range }\end{array}$ & $\begin{array}{l}\text { Outside } \\
\text { Range }\end{array}$ & $\begin{array}{l}\text { Outside } \\
\text { Range }\end{array}$ & $\begin{array}{l}\text { Presence } \\
\text { Possible }\end{array}$ & $\begin{array}{l}\text { Outside } \\
\text { Range }\end{array}$ & $\begin{array}{l}\text { Presence } \\
\text { Possible }\end{array}$ & $\begin{array}{l}\text { Outside } \\
\text { Range }\end{array}$ \\
\hline $\begin{array}{l}{ }^{\text {A }} \text { Plains Spadefoot } \\
\text { (Spea bombifrons) }\end{array}$ & $\begin{array}{l}\text { No Special } \\
\text { Status }\end{array}$ & G5/S3 & $\begin{array}{c}\text { Present } \\
\text { Entire }\end{array}$ & $\begin{array}{c}\text { Present } \\
\text { Entire }\end{array}$ & $\begin{array}{c}\text { Present } \\
\text { Entire }\end{array}$ & $\begin{array}{l}\text { Outside } \\
\text { Range }\end{array}$ & $\begin{array}{c}\text { Present } \\
\text { Entire }\end{array}$ & $\begin{array}{l}\text { Outside } \\
\text { Range }\end{array}$ & $\begin{array}{l}\text { Presence } \\
\text { Possible }\end{array}$ \\
\hline $\begin{array}{l}\text { Great Basin Spadefoot } \\
\text { (Spea intermontana) }\end{array}$ & $\begin{array}{l}\text { No Special } \\
\text { Status }\end{array}$ & G5/SNA & $\begin{array}{l}\text { Outside } \\
\text { Range }\end{array}$ & $\begin{array}{l}\text { Outside } \\
\text { Range }\end{array}$ & $\begin{array}{l}\text { Outside } \\
\text { Range }\end{array}$ & $\begin{array}{l}\text { Outside } \\
\text { Range }\end{array}$ & $\begin{array}{l}\text { Outside } \\
\text { Range }\end{array}$ & $\begin{array}{l}\text { Outside } \\
\text { Range }\end{array}$ & $\begin{array}{l}\text { Presence } \\
\text { Possible }\end{array}$ \\
\hline $\begin{array}{l}{ }^{\text {B }} \text { Western Toad } \\
\text { (Bufo boreas) }\end{array}$ & $\begin{array}{l}\text { No Special } \\
\text { Status }\end{array}$ & $\mathrm{G} 4 / \mathrm{S} 2$ & $\begin{array}{l}\text { Outside } \\
\text { Range }\end{array}$ & $\begin{array}{l}\text { Outside } \\
\text { Range }\end{array}$ & $\begin{array}{l}\text { Outside } \\
\text { Range }\end{array}$ & $\begin{array}{c}\text { Present } \\
\text { Entire }\end{array}$ & $\begin{array}{l}\text { Outside } \\
\text { Range }\end{array}$ & $\begin{array}{l}\text { Present } \\
\text { Entire }\end{array}$ & $\begin{array}{c}\text { Present } \\
\text { Entire }\end{array}$ \\
\hline $\begin{array}{l}\text { A Great Plains Toad } \\
\text { (Bufo cognatus) }\end{array}$ & $\begin{array}{l}\text { No Special } \\
\text { Status }\end{array}$ & G5/S2 & $\begin{array}{l}\text { Present } \\
\text { Entire }\end{array}$ & $\begin{array}{c}\text { Present } \\
\text { Entire }\end{array}$ & $\begin{array}{c}\text { Present } \\
\text { Entire }\end{array}$ & $\begin{array}{l}\text { Outside } \\
\text { Range }\end{array}$ & $\begin{array}{c}\text { Present } \\
\text { Entire }\end{array}$ & $\begin{array}{l}\text { Outside } \\
\text { Range }\end{array}$ & $\begin{array}{l}\text { Outside } \\
\text { Range }\end{array}$ \\
\hline $\begin{array}{l}{ }^{\mathrm{C}} \text { Canadian Toad } \\
\text { (Bufo hemiophrys) }\end{array}$ & $\begin{array}{c}\text { No Special } \\
\text { Status }\end{array}$ & G4/SNA & $\begin{array}{c}\text { Outside } \\
\text { Range }\end{array}$ & $\begin{array}{c}\text { Outside } \\
\text { Range }\end{array}$ & $\begin{array}{l}\text { Outside } \\
\text { Range }\end{array}$ & $\begin{array}{c}\text { Outside } \\
\text { Range }\end{array}$ & $\begin{array}{l}\text { Presence } \\
\text { Possible }\end{array}$ & $\begin{array}{c}\text { Outside } \\
\text { Range }\end{array}$ & $\begin{array}{c}\text { Outside } \\
\text { Range }\end{array}$ \\
\hline $\begin{array}{l}\text { Woodhouse's Toad } \\
\text { (Bufo woodhousii) }\end{array}$ & $\begin{array}{l}\text { No Special } \\
\text { Status }\end{array}$ & G5/S4 & $\begin{array}{l}\text { Presence } \\
\text { Possible }\end{array}$ & $\begin{array}{l}\text { Presence } \\
\text { Possible }\end{array}$ & $\begin{array}{c}\text { Present } \\
\text { Entire }\end{array}$ & $\begin{array}{l}\text { Outside } \\
\text { Range }\end{array}$ & $\begin{array}{c}\text { Present } \\
\text { Entire }\end{array}$ & $\begin{array}{c}\text { Outside } \\
\text { Range }\end{array}$ & $\begin{array}{l}\text { Outside } \\
\text { Range }\end{array}$ \\
\hline $\begin{array}{l}\text { Pacific Treefrog } \\
\text { (Pseudacris regilla) }\end{array}$ & $\begin{array}{l}\text { No Special } \\
\text { Status }\end{array}$ & G5/S4 & $\begin{array}{l}\text { Outside } \\
\text { Range }\end{array}$ & $\begin{array}{l}\text { Outside } \\
\text { Range }\end{array}$ & $\begin{array}{l}\text { Outside } \\
\text { Range }\end{array}$ & $\begin{array}{l}\text { Outside } \\
\text { Range }\end{array}$ & $\begin{array}{l}\text { Outside } \\
\text { Range }\end{array}$ & $\begin{array}{c}\text { Present } \\
\text { Part }\end{array}$ & $\begin{array}{l}\text { Outside } \\
\text { Range }\end{array}$ \\
\hline $\begin{array}{l}\text { Boreal Chorus Frog } \\
\text { (Pseudacris maculata) }\end{array}$ & $\begin{array}{l}\text { No Special } \\
\text { Status }\end{array}$ & G5/S4 & $\begin{array}{c}\text { Present } \\
\text { Entire }\end{array}$ & $\begin{array}{c}\text { Present } \\
\text { Entire }\end{array}$ & $\begin{array}{c}\text { Present } \\
\text { Entire }\end{array}$ & $\begin{array}{l}\text { Outside } \\
\text { Range }\end{array}$ & $\begin{array}{c}\text { Present } \\
\text { Entire }\end{array}$ & $\begin{array}{l}\text { Outside } \\
\text { Range }\end{array}$ & $\begin{array}{c}\text { Present } \\
\text { Entire }\end{array}$ \\
\hline $\begin{array}{l}\text { American Bullfrog } \\
\text { (Rana catesbeiana) }\end{array}$ & $\begin{array}{l}\text { No Special } \\
\text { Status }\end{array}$ & $\begin{array}{l}\text { G5/SNA } \\
\text { Exotic }\end{array}$ & $\begin{array}{c}\text { No } \\
\text { Records }\end{array}$ & $\begin{array}{l}\text { No } \\
\text { Records }\end{array}$ & $\begin{array}{c}\text { No } \\
\text { Records }\end{array}$ & $\begin{array}{l}\text { Present } \\
\text { Entire }\end{array}$ & $\begin{array}{l}\text { Outside } \\
\text { Range }\end{array}$ & $\begin{array}{l}\text { Presence } \\
\text { Possible }\end{array}$ & $\begin{array}{l}\text { Outside } \\
\text { Range }\end{array}$ \\
\hline $\begin{array}{l}\text { Columbia Spotted Frog } \\
\text { (Rana luteiventris) }\end{array}$ & $\begin{array}{l}\text { No Special } \\
\text { Status }\end{array}$ & G4/S4 & $\begin{array}{l}\text { Outside } \\
\text { Range }\end{array}$ & $\begin{array}{l}\text { Outside } \\
\text { Range }\end{array}$ & $\begin{array}{l}\text { Outside } \\
\text { Range }\end{array}$ & $\begin{array}{c}\text { Present } \\
\text { Entire }\end{array}$ & $\begin{array}{l}\text { Outside } \\
\text { Range }\end{array}$ & $\begin{array}{c}\text { Present } \\
\text { Entire }\end{array}$ & $\begin{array}{c}\text { Present } \\
\text { Entire }\end{array}$ \\
\hline $\begin{array}{l}{ }^{\mathrm{B}} \text { Northern Leopard Frog } \\
\text { (Rana pipiens) }\end{array}$ & $\begin{array}{l}\text { No Special } \\
\text { Status }\end{array}$ & G5/S1S3 & $\begin{array}{l}\text { Present } \\
\text { Entire }\end{array}$ & $\begin{array}{l}\text { Present } \\
\text { Entire }\end{array}$ & $\begin{array}{l}\text { Present } \\
\text { Entire }\end{array}$ & Extirpated & $\begin{array}{l}\text { Present } \\
\text { Entire }\end{array}$ & Extirpated & $\begin{array}{l}\text { Outside } \\
\text { Range }\end{array}$ \\
\hline
\end{tabular}

${ }^{A}$ relatively few records for species. $\quad{ }^{B}$ evidence that species has declined.

$42{ }^{\mathrm{C}}$ single historic museum record in area and current presence is possible. 
Presence and Status Ranks for Reptiles on USFWS Wildlife Refuges in Montana

Current distribution and status information can be found on the Montana Natural Heritage Program's website at www.mtnhp.org

\begin{tabular}{|c|c|c|c|c|c|c|c|c|c|}
\hline $\begin{array}{c}\text { Common and } \\
\text { Scientific Name }\end{array}$ & $\begin{array}{l}\text { USFWS } \\
\text { Status }\end{array}$ & $\begin{array}{l}\text { Heritage } \\
\text { Ranks }\end{array}$ & $\begin{array}{l}\text { Benton } \\
\text { Lake }\end{array}$ & Bowdoin & CMR & $\begin{array}{c}\text { Lee } \\
\text { Metcalf }\end{array}$ & $\begin{array}{l}\text { Medicine } \\
\text { Lake }\end{array}$ & $\begin{array}{c}\text { Bison Range } \\
\text { Complex } \\
\end{array}$ & $\begin{array}{c}\text { Red Rock } \\
\text { Lakes }\end{array}$ \\
\hline $\begin{array}{l}{ }^{\mathbf{A}_{\text {Snapping Turtle }}} \\
\text { (Chelydra serpentina) }\end{array}$ & $\begin{array}{l}\text { No Special } \\
\text { Status }\end{array}$ & G5/S3 & $\begin{array}{l}\text { Outside } \\
\text { Range }\end{array}$ & $\begin{array}{l}\text { Outside } \\
\text { Range }\end{array}$ & $\begin{array}{l}\text { Presence } \\
\text { Possible }\end{array}$ & $\begin{array}{l}\text { Outside } \\
\text { Range }\end{array}$ & $\begin{array}{l}\text { Outside } \\
\text { Range }\end{array}$ & $\begin{array}{l}\text { Introduction } \\
\text { Possible }\end{array}$ & $\begin{array}{l}\text { Outside } \\
\text { Range }\end{array}$ \\
\hline $\begin{array}{l}\text { Painted Turtle } \\
\text { (Chrysemys picta) }\end{array}$ & $\begin{array}{l}\text { No Special } \\
\text { Status }\end{array}$ & G5/S4 & $\begin{array}{l}\text { Present } \\
\text { Entire }\end{array}$ & $\begin{array}{l}\text { Present } \\
\text { Entire }\end{array}$ & $\begin{array}{l}\text { Present } \\
\text { Entire }\end{array}$ & $\begin{array}{l}\text { Present } \\
\text { Entire }\end{array}$ & $\begin{array}{l}\text { Present } \\
\text { Entire }\end{array}$ & $\begin{array}{l}\text { Present } \\
\text { Entire }\end{array}$ & $\begin{array}{l}\text { Outside } \\
\text { Range }\end{array}$ \\
\hline $\begin{array}{l}{ }_{\text {A }}^{\mathrm{A}} \text { Spiny Softshell Turtle } \\
\text { (Apalone spinifera) }\end{array}$ & $\begin{array}{l}\text { No Special } \\
\text { Status }\end{array}$ & G5/S3 & $\begin{array}{l}\text { Outside } \\
\text { Range }\end{array}$ & $\begin{array}{l}\text { Outside } \\
\text { Range }\end{array}$ & $\begin{array}{l}\text { Present } \\
\text { Part }\end{array}$ & $\begin{array}{l}\text { Outside } \\
\text { Range }\end{array}$ & $\begin{array}{l}\text { Outside } \\
\text { Range }\end{array}$ & $\begin{array}{l}\text { Outside } \\
\text { Range }\end{array}$ & $\begin{array}{l}\text { Outside } \\
\text { Range }\end{array}$ \\
\hline $\begin{array}{l}\text { A Northern Alligator Lizard } \\
\text { (Elgaria coerulea) }\end{array}$ & $\begin{array}{l}\text { No Special } \\
\text { Status }\end{array}$ & G5/S3 & $\begin{array}{l}\text { Outside } \\
\text { Range }\end{array}$ & $\begin{array}{l}\text { Outside } \\
\text { Range }\end{array}$ & $\begin{array}{l}\text { Outside } \\
\text { Range }\end{array}$ & $\begin{array}{l}\text { Presence } \\
\text { Possible }\end{array}$ & $\begin{array}{l}\text { Outside } \\
\text { Range }\end{array}$ & $\begin{array}{l}\text { Presence } \\
\text { Possible }\end{array}$ & $\begin{array}{l}\text { Outside } \\
\text { Range }\end{array}$ \\
\hline 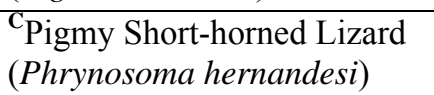 & $\begin{array}{l}\text { No Special } \\
\text { Status }\end{array}$ & G5/SNA & $\begin{array}{l}\text { Outside } \\
\text { Range }\end{array}$ & $\begin{array}{l}\text { Outside } \\
\text { Range }\end{array}$ & $\begin{array}{l}\text { Outside } \\
\text { Range }\end{array}$ & $\begin{array}{l}\text { Outside } \\
\text { Range }\end{array}$ & $\begin{array}{l}\text { Outside } \\
\text { Range }\end{array}$ & $\begin{array}{l}\text { Outside } \\
\text { Range }\end{array}$ & $\begin{array}{l}\text { Presence } \\
\text { Possible }\end{array}$ \\
\hline $\begin{array}{l}{ }^{\mathbf{B}} \text { Greater Short-horned Lizard } \\
\text { (Phrynosoma hernandesi) }\end{array}$ & $\begin{array}{l}\text { No Special } \\
\text { Status }\end{array}$ & G5/S3 & $\begin{array}{l}\text { Presence } \\
\text { Possible }\end{array}$ & $\begin{array}{l}\text { Presence } \\
\text { Possible }\end{array}$ & $\begin{array}{l}\text { Present } \\
\text { Entire }\end{array}$ & $\begin{array}{l}\text { Outside } \\
\text { Range }\end{array}$ & $\begin{array}{l}\text { Presence } \\
\text { Possible }\end{array}$ & $\begin{array}{l}\text { Outside } \\
\text { Range }\end{array}$ & $\begin{array}{l}\text { Outside } \\
\text { Range }\end{array}$ \\
\hline $\begin{array}{l}\text { Common Sagebrush Lizard } \\
\text { (Sceloporus graciosus) }\end{array}$ & $\begin{array}{l}\text { No Special } \\
\text { Status }\end{array}$ & G5S3 & $\begin{array}{l}\text { Presence } \\
\text { Possible }\end{array}$ & $\begin{array}{l}\text { Presence } \\
\text { Possible }\end{array}$ & $\begin{array}{l}\text { Present } \\
\text { Entire }\end{array}$ & $\begin{array}{l}\text { Outside } \\
\text { Range }\end{array}$ & $\begin{array}{l}\text { Presence } \\
\text { Possible }\end{array}$ & $\begin{array}{l}\text { Outside } \\
\text { Range }\end{array}$ & $\begin{array}{l}\text { Outside } \\
\text { Range }\end{array}$ \\
\hline $\begin{array}{l}{ }^{\mathrm{A}} \text { Western Skink } \\
\text { (Eumeces skiltonianus) }\end{array}$ & $\begin{array}{l}\text { No Special } \\
\text { Status }\end{array}$ & G5S3 & $\begin{array}{l}\text { Outside } \\
\text { Range }\end{array}$ & $\begin{array}{l}\text { Outside } \\
\text { Range }\end{array}$ & $\begin{array}{l}\text { Outside } \\
\text { Range }\end{array}$ & $\begin{array}{l}\text { Presence } \\
\text { possible }\end{array}$ & $\begin{array}{l}\text { Outside } \\
\text { Range }\end{array}$ & $\begin{array}{l}\text { Presence } \\
\text { Possible }\end{array}$ & $\begin{array}{l}\text { Outside } \\
\text { Range }\end{array}$ \\
\hline $\begin{array}{l}{ }_{\mathrm{A}}^{\mathrm{R} u b b e r} \text { Boa } \\
\text { (Charina bottae) }\end{array}$ & $\begin{array}{l}\text { No Special } \\
\text { Status }\end{array}$ & G5S4 & $\begin{array}{l}\text { Outside } \\
\text { Range }\end{array}$ & $\begin{array}{l}\text { Outside } \\
\text { Range }\end{array}$ & $\begin{array}{l}\text { Outside } \\
\text { Range }\end{array}$ & $\begin{array}{l}\text { Present } \\
\text { Entire }\end{array}$ & $\begin{array}{l}\text { Outside } \\
\text { Range }\end{array}$ & $\begin{array}{l}\text { Present } \\
\text { Entire }\end{array}$ & $\begin{array}{l}\text { Present } \\
\text { Entire }\end{array}$ \\
\hline $\begin{array}{l}\text { Eastern Racer } \\
\text { (Coluber constrictor) }\end{array}$ & $\begin{array}{l}\text { No Special } \\
\text { Status }\end{array}$ & G5S5 & $\begin{array}{l}\text { Present } \\
\text { Entire }\end{array}$ & $\begin{array}{l}\text { Present } \\
\text { Entire }\end{array}$ & $\begin{array}{l}\text { Present } \\
\text { Entire }\end{array}$ & $\begin{array}{l}\text { Present } \\
\text { Entire }\end{array}$ & $\begin{array}{l}\text { Present } \\
\text { Entire }\end{array}$ & $\begin{array}{l}\text { Present } \\
\text { Part }\end{array}$ & $\begin{array}{l}\text { Present } \\
\text { Entire }\end{array}$ \\
\hline $\begin{array}{l}{ }^{\mathrm{A}} \text { Western Hog-nosed Snake } \\
\text { (Heterodon nasicus) }\end{array}$ & $\begin{array}{l}\text { No Special } \\
\text { Status }\end{array}$ & G5S2 & $\begin{array}{l}\text { Present } \\
\text { Entire }\end{array}$ & $\begin{array}{l}\text { Present } \\
\text { Entire }\end{array}$ & $\begin{array}{l}\text { Present } \\
\text { Entire }\end{array}$ & $\begin{array}{l}\text { Outside } \\
\text { Range }\end{array}$ & $\begin{array}{l}\text { Present } \\
\text { Entire }\end{array}$ & $\begin{array}{l}\text { Outside } \\
\text { Range }\end{array}$ & $\begin{array}{l}\text { Outside } \\
\text { Range }\end{array}$ \\
\hline $\begin{array}{l}{ }^{\mathrm{A}} \text { Smooth Greensnake } \\
\text { (Opheodrys vernalis) }\end{array}$ & $\begin{array}{l}\text { No Special } \\
\text { Status }\end{array}$ & G5S2 & $\begin{array}{l}\text { Outside } \\
\text { Range }\end{array}$ & $\begin{array}{l}\text { Outside } \\
\text { Range }\end{array}$ & $\begin{array}{l}\text { Outside } \\
\text { Range }\end{array}$ & $\begin{array}{l}\text { Outside } \\
\text { Range }\end{array}$ & $\begin{array}{l}\text { Present } \\
\text { Entire }\end{array}$ & $\begin{array}{l}\text { Outside } \\
\text { Range }\end{array}$ & $\begin{array}{l}\text { Outside } \\
\text { Range }\end{array}$ \\
\hline $\begin{array}{l}{ }^{\mathrm{A}} \text { Milksnake } \\
\text { (Lampropeltis triangulum) }\end{array}$ & $\begin{array}{l}\text { No Special } \\
\text { Status }\end{array}$ & G5S2 & $\begin{array}{l}\text { Presence } \\
\text { Possible }\end{array}$ & $\begin{array}{l}\text { Presence } \\
\text { Possible }\end{array}$ & $\begin{array}{l}\text { Present } \\
\text { Entire }\end{array}$ & $\begin{array}{l}\text { Outside } \\
\text { Range }\end{array}$ & $\begin{array}{l}\text { Outside } \\
\text { Range }\end{array}$ & $\begin{array}{l}\text { Outside } \\
\text { Range }\end{array}$ & $\begin{array}{l}\text { Outside } \\
\text { Range }\end{array}$ \\
\hline $\begin{array}{l}\text { Gophersnake } \\
\text { (Pituophis catenifer) }\end{array}$ & $\begin{array}{l}\text { No Special } \\
\text { Status }\end{array}$ & G5S5 & $\begin{array}{l}\text { Present } \\
\text { Entire }\end{array}$ & $\begin{array}{l}\text { Present } \\
\text { Entire }\end{array}$ & $\begin{array}{l}\text { Present } \\
\text { Entire }\end{array}$ & $\begin{array}{l}\text { Present } \\
\text { Entire }\end{array}$ & $\begin{array}{l}\text { Present } \\
\text { Entire }\end{array}$ & $\begin{array}{l}\text { Present } \\
\text { Entire }\end{array}$ & $\begin{array}{l}\text { Present } \\
\text { Entire }\end{array}$ \\
\hline $\begin{array}{l}\text { Terrestrial Gartersnake } \\
\text { (Thamnophis elegans) }\end{array}$ & $\begin{array}{l}\text { No Special } \\
\text { Status }\end{array}$ & G5S5 & $\begin{array}{l}\text { Present } \\
\text { Entire }\end{array}$ & $\begin{array}{l}\text { Outside } \\
\text { Range }\end{array}$ & $\begin{array}{l}\text { Present } \\
\text { Part }\end{array}$ & $\begin{array}{l}\text { Present } \\
\text { Entire }\end{array}$ & $\begin{array}{l}\text { Outside } \\
\text { Range }\end{array}$ & $\begin{array}{l}\text { Present } \\
\text { Entire }\end{array}$ & $\begin{array}{l}\text { Present } \\
\text { Entire }\end{array}$ \\
\hline $\begin{array}{l}\text { Plains Gartersnake } \\
\text { (Thamnophis radix) }\end{array}$ & $\begin{array}{l}\text { No Special } \\
\text { Status }\end{array}$ & G5S4 & $\begin{array}{l}\text { Present } \\
\text { Entire }\end{array}$ & $\begin{array}{l}\text { Present } \\
\text { Entire }\end{array}$ & $\begin{array}{l}\text { Present } \\
\text { Part }\end{array}$ & $\begin{array}{l}\text { Outside } \\
\text { Range }\end{array}$ & $\begin{array}{l}\text { Present } \\
\text { Entire }\end{array}$ & $\begin{array}{l}\text { Outside } \\
\text { Range }\end{array}$ & $\begin{array}{l}\text { Outside } \\
\text { Range }\end{array}$ \\
\hline $\begin{array}{l}\text { Common Gartersnake } \\
\text { (Thamnophis sirtalis) }\end{array}$ & $\begin{array}{l}\text { No Special } \\
\text { Status }\end{array}$ & G5S3 & $\begin{array}{l}\text { Present } \\
\text { Entire }\end{array}$ & $\begin{array}{l}\text { Presence } \\
\text { Possible }\end{array}$ & $\begin{array}{l}\text { Present } \\
\text { Part }\end{array}$ & $\begin{array}{l}\text { Present } \\
\text { Entire }\end{array}$ & $\begin{array}{l}\text { Presence } \\
\text { Possible }\end{array}$ & $\begin{array}{l}\text { Present } \\
\text { Entire }\end{array}$ & $\begin{array}{l}\text { Present } \\
\text { Entire }\end{array}$ \\
\hline $\begin{array}{l}\text { Prairie Rattlesnake } \\
\text { (Crotalus viridis) }\end{array}$ & $\begin{array}{l}\text { No Special } \\
\text { Status }\end{array}$ & G5S4 & $\begin{array}{l}\text { Present } \\
\text { Entire }\end{array}$ & $\begin{array}{l}\text { Present } \\
\text { Entire }\end{array}$ & $\begin{array}{l}\text { Present } \\
\text { Entire }\end{array}$ & $\begin{array}{l}\text { Present } \\
\text { Entire }\end{array}$ & $\begin{array}{l}\text { Present } \\
\text { Entire }\end{array}$ & $\begin{array}{l}\text { Present } \\
\text { Part }\end{array}$ & $\begin{array}{l}\text { Presence } \\
\text { Possible }\end{array}$ \\
\hline
\end{tabular}

\footnotetext{
${ }^{A}$ relatively few records for species. $\quad{ }^{B}$ evidence that species has declined. $\quad{ }^{C}$ single historic museum record and current presence is possible.
} 


\section{General Habitat Associations for Amphibians in Montana}

\begin{tabular}{|c|c|c|}
\hline & Habitat Type & Species Typically Present \\
\hline \multirow{7}{*}{ 尝 } & $\begin{array}{l}\text { Temporary ponds and wetlands in the } \\
\text { mountainous region of the state }\end{array}$ & $\begin{array}{l}\text { Long-toed Salamander (Ambystoma macrodactylum) } \\
\text { Western Toad (Bufo boreas) } \\
\text { * Pacific Treefrog (Pseudacris regilla) } \\
\text { Columbia Spotted Frog (Rana luteiventris) }\end{array}$ \\
\hline & $\begin{array}{l}\text { Temporary ponds and wetlands in the } \\
\text { plains region of the state }\end{array}$ & $\begin{array}{l}\text { Tiger Salamander (Ambystoma tigrinum) } \\
\text { Plains Spadefoot (Spea bombifrons) } \\
\text { Great Plains Toad (Bufo cognatus) } \\
\text { Woodhouse's Toad (Bufo woodhousii) } \\
\text { Boreal Chorus Frog (Pseudacris maculata) } \\
\text { Northern Leopard Frog (Rana pipiens) } \\
\end{array}$ \\
\hline & $\begin{array}{l}\text { Permanent lakes and ponds in the } \\
\text { mountainous region of the state }\end{array}$ & $\begin{array}{l}\text { Long-toed Salamander (Ambystoma macrodactylum) } \\
\text { + Tiger Salamander (Ambystoma tigrinum) } \\
\text { Western Toad (Bufo boreas) } \\
\text { * Pacific Treefrog (Pseudacris regilla) } \\
\text { * \# American Bullfrog (Rana catesbeiana) } \\
\text { Columbia Spotted Frog (Rana luteiventris) } \\
\text { * @ Northern Leopard Frog (Rana pipiens) }\end{array}$ \\
\hline & $\begin{array}{l}\text { Permanent lakes and ponds in the plains } \\
\text { region of the state }\end{array}$ & $\begin{array}{l}\text { Tiger Salamander (Ambystoma tigrinum) } \\
\text { Great Plains Toad (Bufo cognatus) } \\
\text { Woodhouse's Toad (Bufo woodhousii) } \\
\text { Boreal Chorus Frog (Pseudacris maculata) } \\
\text { *\# American Bullfrog (Rana catesbeiana) } \\
\text { Northern Leopard Frog (Rana pipiens) }\end{array}$ \\
\hline & $\begin{array}{l}\text { Riverine and riparian habitats in the } \\
\text { mountainous region of the state }\end{array}$ & $\begin{array}{l}\text { Idaho Giant Salamander (Dicamptodon aterrimus) } \\
\text { Rocky Mountain Tailed Frog (Ascaphus montanus) } \\
\text { Western Toad (Bufo boreas) } \\
\text { * \# American Bullfrog (Rana catesbeiana) } \\
\text { Columbia Spotted Frog (Rana luteiventris) } \\
\text { * @ Northern Leopard Frog (Rana pipiens) }\end{array}$ \\
\hline & $\begin{array}{l}\text { Riverine and riparian habitats in the } \\
\text { plains region of the state }\end{array}$ & $\begin{array}{l}\text { Plains Spadefoot (Spea bombifrons) } \\
\text { Woodhouse's Toad (Bufo woodhousii) } \\
\text { Boreal Chorus Frog (Pseudacris maculata) } \\
\text { * \# American Bullfrog (Rana catesbeiana) } \\
\text { Northern Leopard Frog (Rana pipiens) }\end{array}$ \\
\hline & $\begin{array}{l}\text { Fractured rock sites with subterranean } \\
\text { water near streams, springs, and spray } \\
\text { zones on the northwestern margin of the } \\
\text { state }\end{array}$ & $\begin{array}{l}\text { Long-toed Salamander (Ambystoma macrodactylum) } \\
\text { Coeur d'Alene Salamander (Plethodon idahoensis) } \\
\text { Rocky Mountain Tailed Frog (Ascaphus montanus) }\end{array}$ \\
\hline \multirow{3}{*}{ 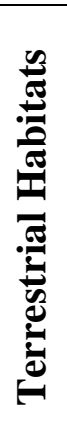 } & $\begin{array}{l}\text { Closed forest habitats in the mountainous } \\
\text { region of the state }\end{array}$ & $\begin{array}{l}\text { Long-toed Salamander (Ambystoma macrodactylum) } \\
\text { Idaho Giant Salamander (Dicamptodon aterrimus) } \\
\text { * Pacific Treefrog (Pseudacris regilla) }\end{array}$ \\
\hline & $\begin{array}{l}\text { Open forest, shrubland, and grassland } \\
\text { habitats in the mountainous region of the } \\
\text { state }\end{array}$ & $\begin{array}{l}\text { + Tiger Salamander (Ambystoma tigrinum) } \\
\text { Western Toad (Bufo boreas) }\end{array}$ \\
\hline & $\begin{array}{l}\text { Prairies, badlands, and open forest } \\
\text { habitats in the plains region of the state }\end{array}$ & $\begin{array}{l}\text { Tiger Salamander (Ambystoma tigrinum) } \\
\text { Plains Spadefoot (Spea bombifrons) } \\
\text { Great Plains Toad (Bufo cognatus) } \\
\text { Woodhouse's Toad (Bufo woodhousii) } \\
\text { Boreal Chorus Frog (Pseudacris maculata) }\end{array}$ \\
\hline $\begin{array}{l}* \\
+ \\
\# \\
\text { @ }\end{array}$ & $\begin{array}{l}\text { pically restricted to lower elevations } \\
\text { ly found in the Tobacco Valley near Eurek } \\
\text { otic invasive species introduced and spread } \\
\text { pical historical habitat prior to declines }\end{array}$ & g in some areas \\
\hline
\end{tabular}




\section{General Habitat Associations for Reptiles in Montana}

\begin{tabular}{|c|c|c|}
\hline & Habitat Type & Species Typically Present \\
\hline \multirow{6}{*}{. } & $\begin{array}{l}\text { Temporary ponds and wetlands in the } \\
\text { mountainous region of the state }\end{array}$ & $\begin{array}{l}\text { Terrestrial Gartersnake (Thamnophis elegans) } \\
\text { Common Gartersnake (Thamnophis sirtalis) }\end{array}$ \\
\hline & $\begin{array}{l}\text { Temporary ponds and wetlands in the } \\
\text { plains region of the state }\end{array}$ & $\begin{array}{l}\text { * Smooth Greensnake (Opheodrys vernalis) } \\
\text { Terrestrial Gartersnake (Thamnophis elegans) } \\
\text { Plains Gartersnake (Thamnophis radix) } \\
\text { Common Gartersnake (Thamnophis sirtalis) }\end{array}$ \\
\hline & $\begin{array}{l}\text { Permanent lakes and ponds in the } \\
\text { mountainous region of the state }\end{array}$ & $\begin{array}{l}\text { Painted Turtle (Chrysemys picta) } \\
\text { Terrestrial Gartersnake (Thamnophis elegans) } \\
\text { Common Gartersnake (Thamnophis sirtalis) }\end{array}$ \\
\hline & $\begin{array}{l}\text { Permanent lakes and ponds in the } \\
\text { plains region of the state }\end{array}$ & $\begin{array}{l}\text { Snapping Turtle (Chelydra serpentina) } \\
\text { Painted Turtle (Chrysemys picta) } \\
\text { * Smooth Greensnake (Opheodrys vernalis) } \\
\text { Terrestrial Gartersnake (Thamnophis elegans) } \\
\text { Plains Gartersnake (Thamnophis radix) } \\
\text { Common Gartersnake (Thamnophis sirtalis) }\end{array}$ \\
\hline & $\begin{array}{l}\text { Riverine and riparian habitats in the } \\
\text { mountainous region of the state }\end{array}$ & $\begin{array}{l}\text { Painted Turtle (Chrysemys picta) } \\
\text { Rubber Boa (Charina bottae) } \\
\text { Terrestrial Gartersnake (Thamnophis elegans) } \\
\text { Common Gartersnake (Thamnophis sirtalis) }\end{array}$ \\
\hline & $\begin{array}{l}\text { Riverine and riparian habitats in the } \\
\text { plains region of the state }\end{array}$ & $\begin{array}{l}\text { Snapping Turtle (Chelydra serpentina) } \\
\text { Painted Turtle (Chrysemys picta) } \\
\text { Spiny Softshell (Apalone spinifera) } \\
\text { Western Hog-nosed Snake (Heterodon nasicus) } \\
\text { * Smooth Greensnake (Opheodrys vernalis) } \\
\text { Gophersnake (Pituophis catenifer) } \\
\text { Terrestrial Gartersnake (Thamnophis elegans) } \\
\text { Plains Gartersnake (Thamnophis radix) } \\
\text { Common Gartersnake (Thamnophis sirtalis) } \\
\text { Prairie Rattlesnake (Crotalus viridis) }\end{array}$ \\
\hline \multirow{5}{*}{ 窇 } & $\begin{array}{l}\text { Closed forest habitats in the } \\
\text { mountainous portion of the state }\end{array}$ & $\begin{array}{l}\text { Western Skink (Eumeces skiltonianus) } \\
\text { Rubber Boa (Charina bottae) }\end{array}$ \\
\hline & $\begin{array}{l}\text { Open forest, shrubland, and grassland } \\
\text { habitats in the mountainous region of } \\
\text { the state }\end{array}$ & $\begin{array}{l}\text { Northern Alligator Lizard (Elgaria coerulea) } \\
\text { + Greater Short-horned Lizard (Phrynosoma hernandesi) } \\
\text { Western Skink (Eumeces skiltonianus) } \\
\text { \# Common Sagebrush Lizard (Sceloporus graciosus) } \\
\text { Rubber Boa (Charina bottae) } \\
\text { Eastern Racer (Coluber constrictor) } \\
\text { Gophersnake (Pituophis catenifer) } \\
\text { Prairie Rattlesnake (Crotalus viridis) }\end{array}$ \\
\hline & $\begin{array}{l}\text { Prairies, badlands, shrublands, and } \\
\text { open forest habitats in the plains region } \\
\text { of the state }\end{array}$ & $\begin{array}{l}\text { Greater Short-horned Lizard (Phrynosoma hernandesi) } \\
\text { Common Sagebrush Lizard (Sceloporus graciosus) } \\
\text { Eastern Racer (Coluber constrictor) } \\
\text { Milksnake (Lampropeltis triangulum) } \\
\text { Gophersnake (Pituophis catenifer) } \\
\text { Prairie Rattlesnake (Crotalus viridis) } \\
\end{array}$ \\
\hline & $\begin{array}{l}\text { Rock outcrops in the mountainous } \\
\text { region of the state }\end{array}$ & $\begin{array}{l}\text { Northern Alligator Lizard (Elgaria coerulea) } \\
\text { Western Skink (Eumeces skiltonianus) } \\
\text { Rubber Boa (Charina bottae) } \\
\text { Gophersnake (Pituophis catenifer) } \\
\text { Prairie Rattlesnake (Crotalus viridis) }\end{array}$ \\
\hline & $\begin{array}{l}\text { Rock outcrops in the plains region of } \\
\text { the state }\end{array}$ & $\begin{array}{l}\text { Greater Short-horned Lizard (Phrynosoma hernandesi) } \\
\text { Common Sagebrush Lizard (Sceloporus graciosus) } \\
\text { Eastern Racer (Coluber constrictor) } \\
\text { Milksnake (Lampropeltis triangulum) } \\
\text { Gophersnake (Pituophis catenifer) } \\
\text { Prairie Rattlesnake (Crotalus viridis) }\end{array}$ \\
\hline
\end{tabular}




\section{LAWS AND REGULATIONS APPLICABLE TO AMPHIBIANS AND REPTILES IN MONTANA}

Federal Laws and Regulations, Tribal regulations, and Montana state laws and regulations, all govern the management of amphibians and reptiles in Montana.

\section{Federal Laws and Regulations}

Federal laws applicable to amphibians and reptiles include those governing the management of agencies responsible for the management of federal lands and the Endangered Species Act of 1973 (16 U.S.C.A. $\$ 1531-1543$ (Supp. 1996). Federal regulations for agencies managing federal lands that are applicable to amphibians and reptiles are mostly associated with special status designations as described in the Presence and Status sections above. While some amphibian and reptile species in Montana have undergone declines and/or regional extirpations in recent decades (e.g., Northern Leopard Frog, Western Toad, Greater Short-horned Lizard), none of these species is currently listed or is a candidate for listing under the federal Endangered Species Act of 1973 by the U.S. Fish and Wildlife Service (16 U.S.C.A. §1531-1543 (Supp. 1996)). If an amphibian or reptile species in Montana were to be proposed for listing as threatened or endangered under the ESA the decision as to whether the species is threatened or endangered must be made solely on the basis of the best scientific and commercial data and must be judged according to the species status due to the five following factors (1) the present or threatened destruction, modification, or curtailment of its habitat or range, (2) overutilization for commercial, recreational, scientific, or educational purposes, (3) disease or predation, (4) the inadequacy of existing regulatory mechanisms, and (5) other natural or manmade factors affecting its continued existence (U.S.C. $§ 1533$ (a) (1), (b)(1)). If a species was listed, a recovery plan for the species must be developed unless a plan would not promote the conservation of the species (U.S.C. $\S 1533$ (f)). The development of recovery programs for listed species is undertaken according to the threats faced by the species and the degree to which it conflicts with economic activity (48 FR 43104). Each recovery plan must include, "to the maximum extent practicable" (1) a description of site specific management actions, (2) objective, measurable criteria which, if met, would allow the agency to find the species has recovered and therefore may be removed from the list, and (3) estimates of the time and costs required to carry out the measures detailed in the recovery plan (48 FR 16756).

\section{Tribal Regulations}

Tribal fish and wildlife departments have responsibility for management of amphibians and reptiles on each reservation and as independent nations, each tribe independently decides the status designations of species on their lands. Species status designations on reservations in Montana were not identified for the current draft of this report. 


\section{Portions of Montana Code Annotated Relevant to Nongame and Endangered Species}

\section{7-5-101. Short title.}

This part shall be known and may be cited as "The Nongame and Endangered Species Conservation Act".

87-5-102. (Effective October 1, 2007). Definitions.

As used in this part, the following definitions apply:

(1) "Account" means the nongame wildlife account established in 87-5-121.

(2) "Commercial purposes" means the collection, harvest, possession, or transportation of a species or subspecies of nongame wildlife from the wild with the intent to barter, offer for sale, ship or transport for eventual sale, or sell the animal or any part of the animal.

(3) "Ecosystem" means a system of living organisms and their environment, each influencing the existence of the other and both necessary for the maintenance of life.

(4) "Endangered species" means a species or subspecies of wildlife that is actively threatened with extinction due to any of the following factors:

(a) the destruction, drastic modification, or severe curtailment of its habitat;

(b) its overutilization for scientific, commercial, or sporting purposes;

(c) the effect on it of disease, pollution, or predation;

(d) other natural or artificial factors affecting its prospects of survival or recruitment within the state; or

(e) any combination of the foregoing factors.

(5) "Management" means the collection and application of biological information for the purposes of increasing the number of individuals within species and populations of wildlife up to the optimum carrying capacity of their habitat and maintaining those levels. The term includes the entire range of activities that constitute a modern scientific resource program, including but not limited to research, census, law enforcement, habitat improvement, and education. The term also includes the periodic or total protection of species or populations as well as regulated taking.

(6) "Nongame wildlife" means a wild mammal, bird, amphibian, reptile, fish, mollusk, crustacean, or other wild animal not otherwise legally classified by statute or regulation of this state. Animals designated by statute or regulation of this state as predatory in nature are not classified as nongame wildlife for purposes of this part.

(7) "Optimum carrying capacity" means that point at which a given habitat can support healthy populations of wildlife species, having regard to the total ecosystem, without diminishing the ability of the habitat to continue that function.

(8) "Person" means an individual, firm, corporation, association, or partnership.

(9) "Take" means to harass, hunt, capture, or kill or attempt to harass, hunt, capture, or kill wildlife.

(10) "Wildlife" means a wild mammal, bird, reptile, amphibian, fish, mollusk, crustacean, or other wild animal or any part, product, egg, or offspring or the dead body or parts of the animal.

87-5-103. Legislative intent, findings, and policy.

(1) The legislature, mindful of its constitutional obligations under Article II, section 3, and Article IX of the Montana constitution, has enacted The Nongame and Endangered Species Conservation Act. It is the legislature's intent that the requirements of this part provide adequate remedies for the protection of the environmental life support system from degradation and provide adequate remedies to prevent unreasonable depletion and degradation of natural 
resources.

(2) The legislature finds and declares all of the following:

(a) that it is the policy of this state to manage certain nongame wildlife for human enjoyment, for scientific purposes, and to ensure their perpetuation as members of ecosystems;

(b) that species or subspecies of wildlife indigenous to this state that may be found to be endangered within the state should be protected in order to maintain and, to the extent possible, enhance their numbers;

(c) that the state should assist in the protection of species or subspecies of wildlife that are considered to be endangered elsewhere by prohibiting the taking, possession, transportation, exportation, processing, sale or offer for sale, or shipment within this state of species or subspecies of wildlife unless those actions will assist in preserving or propagating the species or subspecies.

\section{7-5-104. Investigations by department.}

The department shall conduct investigations on nongame wildlife in order to develop information relating to population, distribution, habitat needs, limiting factors, and other biological and ecological data to determine management measures necessary for their continued ability to sustain themselves successfully. The department shall conduct ongoing investigations of nongame wildlife.

\section{7-5-105. Regulations to manage nongame wildlife.}

(1) On the basis of the determinations made pursuant to $\underline{87-5-104}$, the department shall issue management regulations. The regulations must set forth species or subspecies of nongame wildlife that the department considers to be in need of management pursuant to $\underline{87-5-104}$ through 87-5-106, giving their common and scientific names by species and subspecies.

(2) The department shall by regulation establish limitations relating to taking, possession, transportation, exportation, processing, sale or offer for sale, or shipment considered necessary to manage nongame wildlife that is designated in need of management.

\section{7-5-106. Unlawful acts.}

Except as provided in regulations issued by the department, it shall be unlawful for any person to take, possess, transport, export, sell, or offer for sale nongame wildlife deemed by the department to be in need of management. Subject to the same exception, it shall further be unlawful for any common or contract carrier knowingly to transport or receive for shipment nongame wildlife deemed by the department to be in need of management.

\section{7-5-107. List of endangered species.}

(1) (a) On the basis of investigations on nongame wildlife provided for in 87-5-104 and other available scientific and commercial data and after consultation with other state wildlife agencies, appropriate federal agencies, and other interested persons and organizations, the department shall recommend to the legislature a list of those species and subspecies of wildlife indigenous to the state that are determined to be endangered within this state, giving their common and scientific names by species and subspecies.

(b) The department may propose legislation to specifically include any species or subspecies of fish and wildlife appearing on the United States' list of endangered native fish and wildlife (part 17 of Title 50 of the Code of Federal Regulations, appendix D) as it appears on July 1, 1973, as well as any species or subspecies of fish and wildlife appearing on the United States' list 
of endangered foreign fish and wildlife (part 17 of Title 50 of the Code of Federal Regulations, appendix A), as that list may be modified.

(2) (a) The department shall conduct a review of the state list of endangered species every 2 years. The department may propose specific legislation to amend the list by additions that are considered appropriate and at times that are considered appropriate.

(b) Whenever a species or subspecies is removed from the United States' list of endangered native fish and wildlife (part 17 of Title 50 of the Code of Federal Regulations, appendix D) and that species or subspecies is also on the state list of endangered species in ARM 12.5.201, the department shall amend the state list to remove that species or subspecies. The removal of a species or subspecies from the state list pursuant to this subsection (2)(b) does not require approval by the legislature.

(3) Except as otherwise provided in this part, it is unlawful for any person to take, possess, transport, export, sell, or offer for sale and for any common or contract carrier knowingly to transport or receive for shipment any species or subspecies of wildlife appearing on any of the following lists:

(a) the list of wildlife indigenous to the state determined to be endangered within the state pursuant to subsection (1);

(b) any species or subspecies of fish and wildlife included by the department and appearing on the United States' list of endangered native fish and wildlife (part 17 of Title 50, Code of Federal Regulations, appendix D) as it appears on July 1, 1973; and the United States' list of endangered foreign fish and wildlife (part 17 of Title 50, Code of Federal Regulations, appendix A), as that list may be modified.

(4) Any species or subspecies of fish and wildlife appearing on any of the enumerated lists that is brought into the state from another state or from a point outside the territorial limits of the United States and that is transported across the state destined for a point beyond the state may be brought into the state and transported without restriction in accordance with the terms of any federal permit or permit issued under the laws or regulations of another state.

(5) If the United States' list of endangered native fish and wildlife is modified by additions, the modifications, whether or not involving species or subspecies indigenous to the state, may be accepted as binding under subsections (3) and (4) if, after the type of scientific determination described in subsection (1), the department proposes and the legislature accepts the modification for the state.

\section{7-5-108. Establishment of programs.}

(1) The director shall establish such programs, including acquisition of land or aquatic habitat, as are deemed necessary for management of nongame and endangered wildlife. The department shall establish such policies as are necessary to carry out the purpose of this section and $\underline{87-5-}$ 109.

(2) In carrying out programs authorized by this section, the department may enter into agreements with federal agencies, political subdivisions of the state, or with private persons for administration and management of any area established under this section and $\underline{87-5-109}$ or utilized for management of nongame or endangered wildlife.

(3) The governor shall review other programs administered by him and, to the extent practicable, utilize such programs in furtherance of the purposes of this section and 87-5-109. The governor shall also encourage other state and federal agencies to utilize their authorities in furtherance of the purposes of this section and 87-5-109. 


\section{7-5-109. Taking of species for educational, scientific, or other purposes.}

(1) The director may permit the taking, possession, transportation, exportation, or shipment of species or subspecies of wildlife which appear on the state list of endangered species, on the United States' list of endangered native fish and wildlife, as amended and accepted in accordance

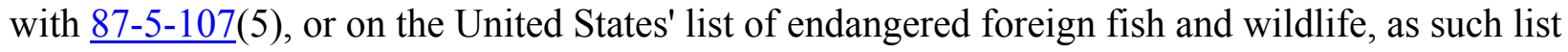
may be modified hereafter, for scientific, zoological, or educational purposes, for propagation in captivity of such wildlife, or for other special purposes.

(2) Upon good cause shown and where necessary to alleviate damage to property or to protect human health, endangered species may be removed, captured, or destroyed but only pursuant to permit issued by the director and, where possible, by or under the supervision of an agent of the department. Endangered species may be removed, captured, or destroyed without permit by any person in emergency situations involving an immediate threat to human life. Provisions for removal, capture, or destruction of nongame wildlife for the purposes set forth above shall be set forth in regulations issued by the department pursuant to $\underline{87-5-105}$.

\section{7-5-110. Department to issue regulations.}

The department shall issue such regulations as are necessary to carry out the purposes of this part.

\section{7-5-111. Enforcement and penalty.}

(1) Any person who violates the provisions of this part or whoever fails to procure or violates the terms of any permit issued thereunder shall be guilty of a misdemeanor.

(2) Upon a first conviction for a violation under this part, the court may fine the defendant not to exceed $\$ 250$. Upon a second such conviction, the defendant may be fined not to exceed $\$ 500$ or be imprisoned in the county jail for any term not to exceed 30 days, or both. Upon subsequent such convictions, the defendant shall be fined not less than $\$ 500$ or more than $\$ 1,000$ and in addition may be imprisoned in the county jail for any term not to exceed 6 months.

(3) Any officer employed and authorized by the director or any peace officer of the state or of any municipality or county within the state shall have authority to enforce the provisions of this part.

(4) Wildlife seized under the provisions of this part shall be held by an officer or agent of the department pending disposition of court proceedings and thereafter be forfeited to the state for disposition as the director may deem appropriate. Prior to forfeiture, the director may direct the transfer of wildlife so seized to a qualified zoological, educational, or scientific institution for safekeeping. The department is authorized to issue regulations to implement this subsection.

\section{7-5-112. Construction.}

This part may not be construed to apply retroactively or to prohibit importation into the state of wildlife that are lawfully imported into the United States or lawfully taken or removed from another state or to prohibit entry into the state or possession, transportation, exportation, processing, sale or offer for sale, or shipment of any wildlife whose species or subspecies is determined to be threatened with statewide extinction in this state but not in the state where originally taken, if the person engaging therein demonstrates by substantial evidence that the wildlife was lawfully taken or removed from the state. However, this section may not be construed to permit the possession, transportation, exportation, processing, sale or offer for sale, or shipment within this state of wildlife on the United States' list of endangered native fish and 


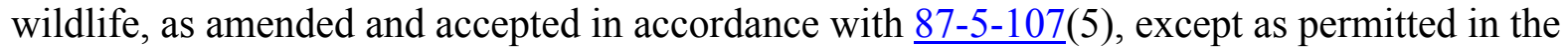
provision by $\underline{87-5-107(3)}$ and (4) and $\underline{87-5-109(1) . ~}$

\section{7-5-116. Limited taking of certain nongame wildlife for commercial purposes -- exceptions.}

(1) The following nongame wildlife may not be taken for commercial purposes, except as provided in subsections (3) and (4), without prior authorization of the department, subject to regulations adopted by the department:

(a) northern flying squirrel (Glaucomys sabrinus);

(b) pika (Ochotona princeps);

(c) pygmy rabbit (Brachylagus idahoensis);

(d) amphibians native to the state of Montana; and

(e) reptiles native to the state of Montana.

(2) The department may regulate the taking of nongame wildlife for commercial purposes. Regulations may establish limitations related to the taking, possession, transportation, exportation, processing, sale or offer for sale, and shipment of nongame wildlife that are considered necessary to manage nongame wildlife.

(3) The harvest of the prairie rattlesnake (Crotalus viridis) for commercial purposes may not be regulated under this section.

(4) This section does not prohibit:

(a) outfitting for the shooting of nongame wildlife;

(b) payment by a landowner to an individual for shooting or removing nongame wildlife; or

(c) the use of byproducts of nongame wildlife in fishing flies, jewelry, or other handicrafts.

\section{7-5-121. Nongame wildlife account.}

(1) There is a nongame wildlife account in the state special revenue fund provided for in 17-2102.

(2) All money collected under 15-30-150 and all interest earned by the fund before being expended under this section must be deposited in the account.

(3) Money in the account must be used by the department, upon the approval of the commission as determined under 87-5-122, to provide adequate funding for:

(a) research and education programs on nongame wildlife in Montana, as provided for in $87-$ 5-104; and

(b) any management programs for nongame wildlife approved by the legislature under $\underline{87-5-}$ 105 as species or subspecies in need of management.

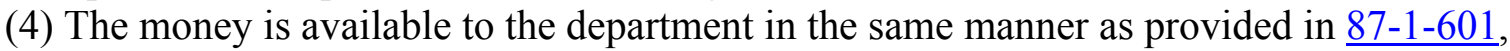
except that money collected under 15-30-150 may not be used:

(a) for the purchase of any real property; or

(b) in such a way as to interfere with the production on or management of private property.

87-5-122. Duties of commission. (1) The commission shall review and approve annually the nongame wildlife programs projects recommended by the department for funding from the nongame wildlife account. The commission shall provide for public comment during the review and approval process.

(2) The commission may adopt rules governing:

(a) the use of the nongame wildlife account set forth in $\underline{87-5-121}$; and

(b) the review and approval process set forth in subsection (1). 


\section{Portions of Montana Code Annotated Relevant to Importation, Introduction, and Translocation of Wildlife}

\section{7-5-701. Purpose}

The legislature finds that in order to protect Montana's native wildlife and plant species, livestock, horticultural, forestry, and agricultural production, and human health and safety, it is necessary to regulate the importation for introduction and the transplantation or introduction of wildlife in the state and to regulate the importation, transplantation, possession, and sale of exotic wildlife. Serious threats, known and unknown, from the introduction of wildlife and exotic wildlife into Montana necessitate the regulation of the importation for introduction and the transplantation or introduction of wildlife and regulation of the importation, transplantation, possession, and sale of exotic wildlife unless it can be shown that no harm will result from the importation, transplantation, possession, sale, or introduction. Any importation, transplantation, possession, sale, or introduction permitted must be conducted in a manner to ensure that wildlife or exotic wildlife can be controlled if harm arises from unforeseen effects.

\section{7-5-702. Definitions.I}

For purposes of this part, the following definitions apply:

(1) "Controlled exotic wildlife" means species placed on the controlled exotic wildlife list under 87-5-707 that may be imported, possessed, or sold only pursuant to commission and

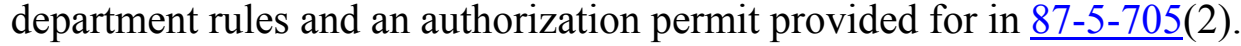

(2) "Domestic animal" means an animal that, through long association with humans, has been bred to a degree that has resulted in genetic changes affecting color, temperament, conformation, or other attributes of the species to an extent that makes the animal unique and distinguishable from wild individuals of the species and that is readily controllable if accidentally released into the wild. The term includes livestock, as defined in $\underline{81-2-702}$, dogs, cats, rodents, Eurasian ferrets, and poultry.

(3) "Exotic wildlife" means a wildlife species that is not native to Montana.

(4) "Feral" means the appearance of an animal and any offspring that have escaped captivity and become wild.

(5) "Importation" means the act of receiving, bringing or having brought, or shipping into the state for a person's temporary or permanent residence or domicile any wildlife from a location outside the state.

(6) "Introduction" means the release from captivity or attempt to release from captivity, intentional or otherwise, wildlife from outside the state into the wild within the state.

(7) "Native wildlife" means a species or subspecies of wildlife that historically occurred in Montana and that has not been introduced by humans or has not migrated into Montana as a result of human activity.

(8) "Noncontrolled exotic wildlife" means animal species traditionally sold or kept as pets and includes animals listed in $\underline{87-5-706}$ or animals that are added to the list in $\underline{87-5-706}$ by commission rule.

(9) "Possession" means to own or have control over an animal for personal use or resale.

(10) "Prohibited exotic wildlife" means animal species placed on the list provided in $\underline{87-5-}$ 704(3)(a) that may not be imported, possessed, or sold.

(11) "Transplantation" means the release of or attempt to release, intentional or otherwise, wildlife from one place within the state into another part of the state. 
(12) (a) "Wildlife" means any wild mammal, bird, reptile, amphibian, fish, mollusk, crustacean, or other wild animal or the egg, sperm, embryo, or offspring of the wild animal.

(b) The term does not include domestic animals.

\section{7-5-704. Rulemaking}

(1) The commission may adopt rules to implement $\underline{87-5-701}, \underline{87-5-702}$, and $\underline{87-5-711}$ through $\underline{87-5-715}$. In implementing $\underline{87-5-713}$, the commission may adopt rules approving species of wildlife that may be introduced by the department. In implementing 87-5-715, the commission may adopt rules to authorize the control or extermination by the department of introduced wildlife species.

(2) The department may adopt rules to implement $\underline{87-5-713}$ and $\underline{87-5-715}$. In implementing $\underline{87-5-713}$ and 87-5-715, the department may not adopt rules in the subject areas reserved to the commission in subsection (1).

(3) (a) The commission may adopt rules to implement $\underline{87-5-705}$ through $\underline{87-5-709}$ and $\underline{87-5-}$ $\underline{712}$ regarding the importation, possession, and sale of exotic wildlife, including adoption of a list of controlled exotic wildlife and a list of prohibited exotic wildlife. The commission may by rule add to the list of noncontrolled exotic wildlife provided in 87-5-706. The department of livestock may not issue import permits for exotic wildlife on a list of controlled exotic wildlife or prohibited exotic wildlife without authorization from the department.

(b) The commission may adopt rules regarding the operation of the classification review committee established in 87-5-708.

(4) (a) The department may adopt rules regarding issuance of the authorization permit provided for in 87-5-705(2), including the establishment of a reasonable fee for the permit.

(b) The department may adopt rules regarding the amnesty program provided for in $\underline{87-5-}$ $\underline{709}(2)$.

\section{7-5-705. Regulation of exotic wildlife}

(1) A person may not import into the state, possess, or sell any exotic wildlife unless:

(a) the importation, possession, or sale of the exotic wildlife is allowed by law or commission rule; and

(b) the person has obtained authorization for importation from the department of livestock pursuant to Title 81 , chapter 2, part 7.

(2) The department may issue a permit for authorizing the possession or sale of controlled exotic wildlife and make the permit available to persons who wish to import, possess, or sell controlled exotic wildlife, subject to rules of the commission and the department. The department may charge a reasonable fee, as determined by department rule, for the issuance of the authorization permit.

\section{7-5-706. Noncontrolled exotic wildlife authorized for possession or sale}

(1) The following noncontrolled exotic wildlife may not be released or transplanted in the state but may be possessed or sold as pets in Montana without a permit:

(a) tropical and subtropical birds in the order Passeriformes, including but not limited to birds in the families:

(i) Sturnidae (mynahs);

(ii) Ramphastidae (toucans, toucanettes);

(iii) Fringillidae (siskins); 
(iv) Estrildidae (finches);

(v) Emberizidae (cardinals);

(vi) Ploceidae (weavers);

(vii) Timaliidae (mesias);

(viii) Viduinae (wydahs);

(ix) Thraupidae (tanagers);

(x) Zosteropidae (zosterops);

(xi) Psittacidae (parrots);

(xii) Loriidae (lories); and

(xiii) Cacatuidae (cockatoos);

(b) nonnative species in the subfamily Phaisianae, except:

(i) chukar partridge (Alectoris chukar);

(ii) gray (Hungarian) partridge (Perdix perdix);

(iii) ring-necked pheasant (Phasianus colchicus); and

(iv) turkey (Meleagris gallopavo);

(c) all tropical fish, subtropical fish, marine fish, common goldfish (Carassius auratus), and koi (Cyprinus carpio) for use in residential and office aquariums;

(d) unless otherwise regulated pursuant to $\underline{87-5-116}$, all nonnative tropical and subtropical species of nonvenomous snakes not on the controlled or prohibited lists in the families:

(i) Boidae (boas);

(ii) Bolyeriidae (Round Island Boas);

(iii) Tropidophiidae (dwarf boas);

(iv) Pythonidae (pythons);

(v) Colubridae (modern snakes);

(vi) Acrochordidae (file and elephant trunk snakes);

(vii) Xenopeltidae (sunbeam snakes);

(viii) Aniliidae (pipe snakes);

(ix) Uropeltidae (shield-tailed snakes);

(x) Anomalepididae (blind snakes);

(xi) Leptotyphlopidae (blind snakes); and

(xii) Typhlopidae (blind snakes);

(e) unless otherwise regulated pursuant to $\underline{87-5-116}$, all nonnative tropical and subtropical species of nonvenomous lizards not on the controlled or prohibited lists, including but not limited to the following families or subfamilies:

(i) Agamidae (chisel-teeth lizards);

(ii) Amphisbaenidae (worm lizards);

(iii) Anelytropsidae (limbless lizards);

(iv) Anguidae (glass and alligator lizards);

(v) Anniellidae (legless lizards);

(vi) Chamaeleonidae (chameleons);

(vii) Cordylidae (girdle-tailed lizards);

(viii) Corytophanidae (casquehead lizards);

(ix) Crotaphytidae (collared and leopard lizards);

(x) Dibamidae (blind lizards);

(xi) Eublepharidae (eyelid geckos);

(xii) Feyliniidae (African snake skinks); 
(xiii) Gekkonidae (geckos);

(xiv) Helodermatidae (beaded lizards and gila monsters);

(xv) Iguanidae (iguanas);

(xvi) Lacertidae (wall lizards);

(xvii) Lanthanotidae (earless monitor);

(xviii) Phrynosomatidae (earless, spiny, and horned lizards);

(xix) Polychrotidae (anoles);

(xx) Pygopodidae (snake lizards);

(xxi) Scincidae (skinks);

(xxii) Teiidae (whiptail);

(xxiii) Tropiduridae (neotropical ground lizards);

(xxiv) Varanidae (monitor lizard);

(xxv) Xantusiidae (night lizards); and

(xxvi) Xenosauridae (knob-scaled lizards);

(f) unless otherwise regulated pursuant to $\underline{87-5-116}$, all nonnative tropical and subtropical species of turtles with a carapace or shell length of more than 4 inches and not on the controlled or prohibited lists in the families:

(i) Carettochelyidae (New Guinea softshell turtles);

(ii) Chelidae (snake-necked turtles);

(iii) Chelydridae (snapping turtles);

(iv) Dermatemydidae (Central American river turtle);

(v) Emydidae (pond turtles);

(vi) Kinosternidae (mud turtles and musk turtles);

(vii) Pelomedusidae (hidden-necked turtles);

(viii) Platysternidae (big-headed turtle);

(ix) Testudinidae (tortoises); and

(x) Trionychidae (soft-shelled turtles);

(g) unless otherwise regulated pursuant to $\underline{87-5-116}$, all nonnative tropical and subtropical species of frogs and toads not on the controlled or prohibited lists in the families:

(i) Atelopodidae (harlequin frogs);

(ii) Bufonidae (true toads);

(iii) Centrolenidae (glass frogs);

(iv) Dendrobatidae (poison dart frogs);

(v) Hylidae (tree frogs);

(vi) Leptodactylidae (rain frogs);

(vii) Microhylidae (narrow-mouthed toads);

(viii) Pelobatidae (spadefoot toads);

(ix) Pelodytidae (old world spadefoot toads);

(x) Ranidae (true frogs, except bullfrogs, Rana catesbeiana);

(xi) Rhacophoridae (old world tree frogs); and

(xii) Rhinophrynidae (Mexican burrowing frog);

(h) unless otherwise regulated pursuant to $\underline{87-5-116}$, all nonnative tropical and subtropical species of limbless amphibians not on the controlled or prohibited lists in the families:

(i) Caeciliidae (caecilians);

(ii) Ichthyophiidae (fish caecilians);

(iii) Rhinatrematidae (beaked caecilians); 
(iv) Scolecomorphidae (tropical caecilians); and

(v) Uraeotyphlidae (Indian caecilians); and

(i) unless otherwise regulated pursuant to $\underline{87-5-116}$, all nonnative tropical and subtropical species of salamanders not on the controlled or prohibited lists in the families:

(i) Ambystomatidae (mole salamanders);

(ii) Amphiumidae (amphiumas);

(iii) Cryptobranchidae (hellbenders);

(iv) Dicamptodontidae (giant salamanders);

(v) Hynobiidae (Asian salamanders);

(vi) Plethodontidae (woodland salamanders);

(vii) Proteidae (waterdogs);

(viii) Salamandridae (newts, except for rough-skinned newt, Taricha granulosa); and

(ix) Sirenidae (sirens).

(2) The commission may by rule authorize the possession or sale of other species of noncontrolled exotic wildlife that are not listed in subsection (1) if it is determined that the other species present minimal disease, ecological, environmental, safety, or health risks.

87-5-708. Classification review committee -- composition, appointment, and duties. (1) The director shall appoint a classification review committee whose duty is to advise the commission regarding the importation, possession, and sale of exotic wildlife, including recommendations on animals to be placed on the noncontrolled, controlled, or prohibited exotic wildlife list.

(2) The classification review committee is composed of at least one representative from:

(a) the department;

(b) the department of public health and human services;

(c) the department of livestock;

(d) the department of agriculture;

(e) a business that breeds or exhibits exotic wildlife; and

(f) the general public who has an interest in fish or wildlife.

(3) Members of the classification review committee are not entitled to compensation or travel expenses as provided in $\underline{2-15-122}$.

87-5-709. Exceptions and exemptions to possession and sale of exotic wildlife.

(1) Sections $\underline{87-5-705}$ through $\underline{87-5-708}$ and this section do not apply to:

(a) institutions that have established that their proposed facilities are adequate to provide secure confinement of wildlife, including:

(i) an accredited zoological garden chartered by the state as a nonprofit corporation;

(ii) a roadside menagerie permitted under $\underline{87-4-803}$ that was established for the purpose of exhibition or attracting trade;

(iii) a research facility for testing and science that employs individuals licensed under 37-34$\underline{301}$ or that submits evidence to the department that it meets animal testing standards as provided by the national institutes of health, the national science foundation, the centers for disease control and prevention, the United States department of agriculture, or another similar nationally recognized and approved testing standard; or

(b) domestic animals.

(2) Authorization for possession must be provided by the department for exotic wildlife 
possessed as of January 1, 2004, and the authorization may include any conditions and restrictions necessary to minimize risks.

\section{7-5-711. Control of importation for introduction and transplantation or introduction of wildlife.}

(1) Except as otherwise provided, the importation for introduction or the transplantation or introduction of any wildlife is prohibited unless the commission determines, based upon scientific investigation and after public hearing, that a species of wildlife poses no threat of harm to native wildlife and plants or to agricultural production and that the transplantation or introduction of a species has significant public benefits.

(2) With regard to the transplantation or introduction of a fish species not previously legally transplanted to a specific water body within the state or not previously legally introduced to the state, the requirement for scientific investigation in subsection (1) may be satisfied only by completion of an environmental review conforming to the provisions of Title 75 , chapter 1 , part 2 .

\section{7-5-712. Authority for commission to control importation, possession, or sale of certain wildlife species and exotic wildlife.}

(1) The commission may, after public hearing and recommendation by the classification review committee in $\underline{87-5-708}$, list by administrative rule wildlife species or exotic wildlife that may not be imported, possessed, or sold as pets for captive breeding for research or commercial purposes, for the commercial pet trade, or for any other reason. A wildlife species or exotic wildlife may be placed on the list only after the commission finds that:

(a) the exotic wildlife would not be readily subject to control by humans while in captivity;

(b) if released from captivity, the exotic wildlife would pose a substantial threat to native wildlife and plants or agricultural production; or

(c) the exotic wildlife would pose a risk to human health or safety, livestock, or native wildlife through disease transmission, hybridization, or ecological or environmental damage.

(2) The commission may make exceptions for wildlife species or exotic wildlife otherwise prohibited under this section if the wildlife species or exotic wildlife is controlled in an

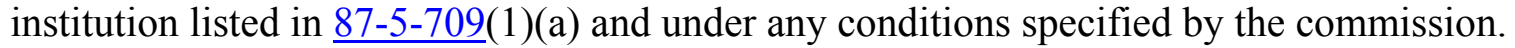

\section{7-5-713. Control of wildlife species permitted to be transplanted or introduced.}

Any wildlife species listed in $\underline{87-5-714}$ or approved by the commission for introduction or transplantation may be introduced or transplanted only subject to a plan developed by the department to assure that the population can be controlled if any unforeseen harm should occur.

\section{7-5-714. Wildlife species authorized for introduction or transplantation.}

(1) The following wildlife species may be introduced or transplanted by the department based upon scientific investigation and upon approval of the commission:

(a) gray (Hungarian) partridge (Perdix perdix);

(b) chukar partridge (Alectoris chukar);

(c) ring-necked pheasant (Phasianus colchicus);

(d) turkey (Meleagris gallopavo);

(e) rainbow trout (Salmo gairdneri);

(f) golden trout (Salmo aquabonita); 
(g) brown trout (Salmo trutta);

(h) brook trout (Salvelinus fontinalis);

(i) lake trout (Salvelinus namaycush);

(j) northern pike (Esox lucius);

(k) black bullhead (Ictalurus melas);

(l) yellow bullhead (Ictalurus natalis);

(m) largemouth bass (Micropterus salmoides);

(n) smallmouth bass (Micropterus dolomieui);

(o) pumpkinseed sunfish (Lepomis gibbosus);

(p) bluegill (Lepomis macrochirus);

(q) green sunfish (Lepomis cyanellus);

(r) rock bass (Ambloplites rupestris);

(s) black crappie (Pomoxis nigromaculatus);

(t) white crappie (Pomoxis annularis);

(u) yellow perch (Perca flavescens);

(v) walleye (Stizostedion vitreum);

(w) cisco (tulibee) (Coregonus artedii);

(x) spottail shiner (Notropis hudsonius);

(y) kokanee salmon (Oncorhynchus nerka);

(z) chinook salmon (Oncorhynchus tshawytscha);

(aa) lake whitefish (Coregonus clupeaformis);

(bb) golden shiner (Notemigonus crysoleucas).

(2) The commission may by rule and subject to the provisions of $87-5-711$ authorize the department to transplant or introduce species of wildlife not listed in subsection (1).

\section{7-5-715. Extermination or control of transplanted or introduced wildlife or feral species posing threat.}

Any wildlife or feral species transplanted or introduced in the state may be exterminated or controlled by the department if the commission determines that the species poses harm to native wildlife or plants or to agricultural production.

\section{7-5-716. Consultation with departments of agriculture, public health and human services, and livestock.}

The commission and the department shall consult with the departments of agriculture, public health and human services, and livestock in all matters relating to the control of wildlife species and exotic wildlife that may have a harmful effect on agricultural production or livestock operations in the state or that may pose a risk to human health or safety.

\section{7-5-721. Penalty -- license and permit revocation and denial.}

(1) Except as provided in subsection (2), a person who violates a provision of this part is guilty of a misdemeanor punishable as provided in 87-1-102, and the department, upon conviction of the person, shall revoke any license or permit issued by it under this title to the person and deny any application by the person for a license or permit under this title for a period not to exceed 2 years from the date of the conviction.

(2) A person who intentionally imports, introduces, or transplants fish in violation of this part:

(a) is guilty of an offense punishable by a fine of not less than $\$ 500$ or more than $\$ 5,000$ and 
imprisonment for up to 1 year. A sentencing court may consider an appropriate amount of community service in lieu of imprisonment. A sentencing court may not defer or suspend $\$ 500$ of the fine amount.

(b) is civilly liable for the amount necessary to eliminate or mitigate the effects of the violation. The damages may be recovered on behalf of the public by the department or by the county attorney of the county in which the violation occurred, in a civil action in a court of competent jurisdiction. Money recovered by the department or a county attorney must be

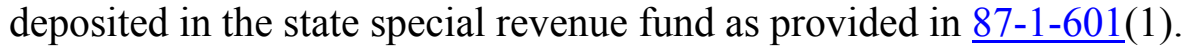

(c) upon conviction or forfeiture of bond or bail, shall forfeit from the date of conviction or forfeiture any current hunting, fishing, or trapping license issued under this title and the privilege to hunt, fish, or trap in this state for not less than 24 months. If the time necessary to eliminate or mitigate the effects of the violation exceeds 24 months, a person may be required to forfeit the privilege to hunt, fish, or trap in this state for more than 24 months. If the effects of the violation cannot be eliminated or mitigated, a person may be required to forfeit the privilege to hunt, fish, or trap in this state for the lifetime of that person.

(3) Any exotic wildlife held in violation of this part must be shipped out of state, returned to the point of origin, or destroyed within 6 months of a conviction or sooner if ordered by the court. The person in possession of the exotic wildlife may choose the method of disposition. If the person in possession of the exotic wildlife does not comply with this requirement, the department may confiscate and then house, transport, or destroy the unlawfully held exotic wildlife. The department may charge any person convicted of a violation of this part for the costs associated with the handling, housing, transporting, or destroying of the exotic wildlife. 


\section{REVIEW OF LITERATURE RELEVANT TO THE CONSERVATION OF AMPHIBIANS AND REPTILES IN GENERAL}

\section{Ecological Function and Importance of Amphibians and Reptiles}

Montana's 13 native amphibians represent a valuable biological and cultural resource whose conservation is essential not only to their own survival, but to the survival of other vertebrate and invertebrate taxa as well. As larvae, amphibians structure aquatic communities by being important herbivores (e.g., Dickman 1968; Seale 1980), competitors (e.g., Werner 1992), predators (e.g., Morin 1983; Wilbur et al. 1983), and prey (e.g., Wilbur 1997). Many metamorphosing amphibians act as key links between aquatic and terrestrial food webs as they transfer energy from aquatic prey to terrestrial predators (Wilbur 1997). The importance of adult amphibians in terrestrial food webs is highlighted by their efficiency at converting the prey they consume to new animal tissue; as ectotherms they are up to 50 times more efficient than mammals or birds (Pough 1980, 1983). Their importance to terrestrial food webs is further highlighted by studies conducted in eastern deciduous forests which demonstrate that amphibians rival or exceed mammals and birds with respect to numbers, biomass, and energetics (Burton and Likens 1975a; Burton and Likens 1975b; Hairston 1987).

Amphibians also contribute a great deal to human welfare. In many impoverished societies they are among the most important sources of animal protein and many affluent societies import large quantities of frog legs for culinary purposes; the U.S. imports 1,000-2,000 tons of frog legs annually, while France imports 3.4 million tons annually (Stebbins and Cohen 1995). Amphibians have been extremely important to studies of vertebrate anatomy, neurology, physiology, embryology, developmental biology, genetics, evolutionary biology, animal behavior, and community ecology (Stebbins and Cohen 1995; Petranka 1998; Pough et al. 1998). Eggs and larvae have been extensively used in toxicological studies on the effects of chemical contaminants that may impact human health (Harfenist et al. 1989). Skin secretions of some species show promise as antibiotics and as nonaddictive pain killers that are 200 times more powerful than morphine (Stebbins and Cohen 1995). They are important in the control of insect pests such as mosquitoes (Pough et al. 1998). Amphibians are also important reminders of one of the most significant events in the evolution of vertebrate life, the movement into the terrestrial environment some 360 million years ago (Pough et al. 1998). Finally, some species are valuable bioindicators of environmental health because they have highly permeable skin and egg membranes and because they have complex life cycles with both aquatic and terrestrial life history stages that are philopatric to specific breeding, foraging, and overwintering sites connected by habitats suitable for migration (Turner 1957; Duellman and Trueb 1986; Weygoldt 1989; Wake 1991; Olson 1992; Blaustein 1993, 1994; Welsh and Ollivier 1998). 


\section{Amphibian and Reptile Biology and Disturbance Regimes Relevant to Management}

Possibly the most important feature of the biology of amphibians that management plans need to address is that their complex life histories require a complex set of habitats connected by suitable migratory corridors. At higher latitudes all amphibians require suitable breeding/rearing, foraging and overwintering habitats in order to survive (e.g., Turner 1957, Dole 1965; Ewert 1969). Many amphibians require warmer lentic waters with emergent vegetation for breeding/rearing habitat, riparian areas that support large insect populations for foraging habitat, and terrestrial burrows, forest litter, or deep waters that are unlikely to freeze for overwintering habitats (Nussbaum et al. 1983; Stebbins and Cohen 1995). Loss or exclusion from any one of these habitats, or loss of the resources they contain, may cause the species to decline or be extirpated from a local area unless individuals dispersing from nearby areas recolonize (e.g., Hecnar and M'Closkey 1996; Patla 1997). In cases where all 3 of these habitats are present in a relatively small geographic area herpetofauna often do not undergo extensive migrations between overwintering, breeding, and foraging habitats (Sinsch 1990). In these instances, isolated populations may successfully perpetuate themselves unless the specific area is altered by natural succession or anthropogenic activity (e.g., Gulve 1994). In cases where the 3 required habitat types are isolated spatially, herpetofauna are capable of undertaking quite extensive seasonal migrations (e.g., Sinsch 1990; Dodd 1996). In these instances, they are not only dependent on suitable breeding, foraging and overwintering habitats, but are also dependent on habitats suitable for migration (Dodd and Cade 1998). Coupled with the importance of considering all habitat requirements is the importance of considering the extreme philopatry shown by many herpetofauna species to the same breeding, foraging and overwintering sites year after year (Daugherty and Sheldon 1982; Sinsch 1990; Stebbins and Cohen 1995; Pough et al. 1998).

In order to ensure the presence of habitats critical to the survival of amphibians management plans need to consider the disturbance regimes that create and maintain them. Disturbance regimes that create and drive the succession of breeding, foraging, and overwintering habitats used by amphibian species include glaciation, flooding, fire, and the dam building, wallowing, and foraging activities of beaver and other large mammals. The majority of standing water bodies in western Montana and on the plains north of the Missouri River in eastern Montana are the result of Pleistocene glaciation (Alt and Hyndman 1986, 1995). Flooding carves out depressions and eliminates vegetation so that important breeding, foraging, and basking habitats are maintained (Lind et al. 1996; Cavallo 1997). Standing water bodies that are used as breeding and overwintering sites are created and maintained as the result of the dam building and foraging activities of beaver (Donkor and Fryxell 1999; Russell et al. 1999a) and the foraging and wallowing activities of large mammals such as moose, elk, and bear (Bryce Maxell, pers. obs.). Beaver seem to be particularly important in the maintenance of standing waterbodies in western Montana. For example where historic fur trapping has eliminated beaver from some mountain ranges in the central portion of the state many water bodies are approaching their final successional stages as they fill in with sediments (Bryce Maxell, pers. obs.; Grant Hokit, Carroll College, pers. comm.). Finally, periodic fires may act to maintain open waters by eliminating vegetation that catches sediment, and may contribute to the amount of downed woody debris that provides habitat for terrestrial amphibians (Russell et al 1999b). 


\section{Global Amphibian Declines}

In the past few hundred years, increases in human population and our ability to impact natural ecosystems have led to a dramatic increase in the global rate of species extinction (Wilson and Peter 1988). Within this overall biodiversity crisis, evidence has accumulated during the past few decades that amphibians around the globe may be declining at a higher rate than other taxonomic groups (Blaustein and Wake 1990; Phillips 1990; Wyman 1990; Wake and Morowitz 1991; Drost and Fellers 1996; Alford and Richards 2000; Houlahan et al. 2000; but see Pechmann and Wilbur 1994). In North America, amphibian declines have been most numerous in the West and have occurred among species that occupy a variety of elevations, habitat types, and disturbance regimes (Corn 1994).

Seven major factors, and their interaction, have been implicated as causative agents of amphibian declines. These include: (1) loss, deterioration, and fragmentation of aquatic and terrestrial habitats (e.g., Bury et al. 1980; Schwalbe 1993; Van Rooy and Stumpel 1995; Lind et al. 1996; Beebee 1997); (2) introduction of nonindigenous species (e.g., Bradford 1989; Fisher and Schaffer 1996; Gamradt and Kats 1996; Kupferberg 1996; Adams 1997; Hecnar and M Closkey 1997; Kiesecker and Blaustein 1997a); (3) environmental pollutants (e.g., Lewis et al. 1985; Kirk 1988; Beebee et al. 1990; Dunson et al. 1992); (4) increased ambient UV-B radiation (e.g., Blaustein et al. 1994a; Blaustein et al. 1995; Kiesecker and Blaustein 1995; Nagl and Hofer 1997); (5) climate change (e.g., Pounds and Crump 1994; Stewart 1995; Pounds et al. 1999); (6) pathogens (e.g., Carey 1993; Kiesecker and Blaustein 1997b; Berger et al. 1998; Carey et al. 1999; Daszak et al. 1999; Lips 1999) and (7) human commerce (e.g. Nace and Rosen 1979; Jennings and Hayes 1985; Buck 1997; Pough et al. 1998). Not suprisingly, a majority of these factors have also been implicated as causative agents of the overall decline in biodiversity (Wilson and Peters 1988). Thus, the conspicuous decline of amphibian populations may indeed be a good indication of the declining health of our environment.

In recent years concerns over environmental health have also been raised by the issue of amphibian deformities, an issue that seems to be completely distinct from that of amphibian declines because declines have not been reported in the species and areas where deformities have been found. Most amphibian deformities that have been reported involve missing, deformed, or multiple hind limbs (Bishop and Hamilton 1947; Sessions and Ruth 1990; Ouellet et al 1997; Sessions et al. 1999; Johnson et al. 1999). In Montana missing, malformed, and multiple hind limb deformities have been found in western toads (Bufo boreas), Pacific treefrogs (Pseudacris regilla), and Columbia spotted frogs (Rana luteiventris) at a few sites in the western portion of the state and have been reported as early as 1958 (Hebard and Brunson 1963; Bryce Maxell, pers. obs.). Suggested causes of deformities include UVB radiation (e.g., Blaustein et al. 1997), contaminants including pesticides containing retinoic acid (Scadding and Madden 1986; Bryant and Gardiner 1992; Sessions 1999) and infection by a nematode parasite in the genus Ribeiroia (Johnson 1999; Kaiser 1999). Currently evidence favors two of these mechanisms, contaminants in the midwestern United States and nematode parasites in the western United States (Souder 2000). The Ribeiroia parasite has been documented in populations of the Pacific treefrog and the Columbia spotted frog in western Montana and may be the cause of limb deformities in western toads (Pieter Johnson, Claremont Mckenna College, pers. comm.). Deformities apparently result from the amphibian larvae's response to the mechanical perturbation of the cysts the parasites 
form after they burrow through the larvae's body wall because mechanical implants of resin beads result in almost identical deformities (Sessions and Ruth 1990; Johnson et al. 1999) While it is uncertain how long or to what extent this phenomena has occurred, accelerated eutrophication of waters due to organic pollution may cause planorbid snail (the first host of Ribeiroia) numbers to rise, thereby increasing the rate of parasite infection and deformities (Johnson 1999).

Montana's 13 native amphibians occupy a diverse array of habitats and vary greatly in their life history patterns (Reichel and Flath 1995; Hart et al. 1998). Furthermore, relatively few studies have investigated the impacts of human activities on amphibians. Thus, identification of all possible impacts on Montana's amphibians, and development of a comprehensive set of guidelines that would mitigate these impacts, are not possible at this time. However, because 60$70 \%$ of the predicted ranges of these species are in private lands without any formal protection from conversion of natural habitat types to anthropogenic habitat types (Hart et al. 1998; Redmond et al. 1998) a review of likely impacts is appropriate in order to ensure the viability of these populations on public lands. A review of the scientific literature identified nine major risk factors that may affect the viability of amphibian populations. In no particular order they are:

1. Timber harvest

2. Grazing

3. Fire and fire management activities

4. Nonindigenous species and their management

5. Road and trail development and on- and off-road vehicle use

6. Development and management of recreational facilities and water impoundments

7. Harvest and commerce

8. Habitat fragmentation and metapopulation impacts

9. Lack of information / research needs

Specific areas of concern associated with each of these themes and a general set of management guidelines that would allow impacts to be minimized are addressed individually below. 


\section{Timber Harvest}

The timing and extent of the impacts of timber harvest on Montana's amphibians likely depend on the preferred habitat, physiological adaptations, and dispersal abilities of individual species as well as the spatial, extent, location, and configuration of the harvest, the timing and method of harvest, and the speed of forest regeneration. deMaynadier and Hunter (1995) conducted a thorough review of literature on forest management and amphibian ecology in North America. In 18 studies that examined the effects of clear-cutting on amphibians they found that most amphibians (toads were sometimes an exception) were always present at lower median abundances on 6 month to 40 year old clear-cuts as compared to control plots. However, clear taxonomic differences existed: amphibians in general were 3.5 times greater on control plots; anurans (frogs and toads) were 1.7 times greater; salamanders in general were 4.3 times greater; and plethodontid salamanders were 5.0 times greater. While these reductions in species' abundances may result in some impacts on the food chain, by themselves reductions in abundance may be an acceptable consequence of timber harvest as long as species are able to persist and abundances are not reduced in the long run. Species richness may, therefore, be a more important measure of the impacts of timber harvest because it may indicate the addition or extirpation of species as a result of harvest. deMaynadier and Hunter (1995) found that patterns of species richness between clearcut and control plots across the 18 studies were less conclusive. In most studies species richness values were not changed. However, clear decreases in species richness have been reported by several studies in the Pacific Northwest and most of these indicate the loss of species that are dependent on healthy stream, streamside, or other moist microhabitats. For example, in a study of four streamside amphibians in Oregon and Washington, Corn and Bury (1989) reported that only 1 of 20 streams in logged stands contained all four species as compared to 11 of 23 streams in uncut stands. Furthermore, only 2 of the streams in the uncut stands had fewer than three species, whereas 11 streams in the logged stands had only 1 or no species present. Similarly, a number of other studies in the Pacific Northwest have reported that stream dwelling amphibians such as the tailed frog (Ascaphus truei) were absent or found in greatly reduced numbers in clear cuts versus mature or old growth forests, apparently as a result of decreased canopy cover and increased sedimentation (Bury 1983; Bury and Corn 1988; Corn and Bury 1990; Welsh 1990; Welsh and Lind 1988). Finally, it should be noted that many of the negative impacts associated with timber harvest may be associated with the building and maintenance of roads and road traffic (see section on road impacts below). For instance sedimentation of streams has major impacts on stream dwelling amphibians (e.g., Welsh and Lind 1998) and 90\% of the sediment runoff from some harvest operations comes from roads (Anderson et al. 1976).

Although positive impacts of timber harvest have rarely been reported there may be some instances in which some amphibian species benefit. For example, in higher gradient streams, Pacific giant salamanders (Dicamptodon ensatus) have been documented to increase in the abundance in cut stands, apparently as a result of warmer water temperatures, increased light, and increased insect or salmonid prey ( Murphy and Hall 1981; Murphy et al. 1981; Hawkins et al. 1983; Bury and Corn 1988). However, it should be noted that these apparent benefits do not hold for all streams because in lower gradient streams increased sedimentation associated with harvested stands eliminates microhabitats used by Pacific giant salamanders and other stream dwelling amphibians (Connor et al. 1988; Corn and Bury 1989). Depending on the scale of 
timber harvest positive impacts on individual species may include forest openings that benefit more terrestrial species by creating basking or foraging sites (e.g., Raphael 1988; Kirkland et al. 1996) and the creation of habitat by debris left over from harvest activities. For example, Bury and Martin (1973) and Bury (1983) both found that the clouded salamander (Aneides ferreus) was more abundant in second-growth stands, apparently because the species uses crevices and bark under downed timber. In addition, limited removal of forest trees immediately adjacent to standing waters that are used for breeding may enhance the length of time ephemeral wetlands are present by reducing evapotranspiration and may reduce the length of the larval period of many amphibians by increasing solar radiation, thereby ensuring that metamorphosis takes place prior to pond drying (deMayandier and Hunter 1999; Russell et al. 1999b). For example, McGraw (1997) found that larval long-toed salamanders (Ambystoma macrodactylum) were more abundant in ponds where a fraction of the pond margin was harvested than either ponds whose margins were completely harvested or ponds whose forest margins were completely intact.

Both the taxonomic differences in abundance and species diversity resulting from timber harvest highlight the importance of considering the individual needs of species and indicate that amphibians that rely almost exclusively on moist microhabitats or streams are likely to be the most heavily impacted by timber harvest activities. In Montana forest species that utilize these habitats include the long-toed salamander, the Coeur d'Alene salamander (Plethodon idahoensis), the tailed frog, and the Pacific treefrog. Unfortunately, the impacts of timber harvest has only been studied for one of these species in Montana and many of the findings for coastal sites in the Pacific Northwest may not be directly applicable here because of differences in precipitation and forest types. In a study of the long-toed salamander in Douglas-fir forests in the Swan River Valley McGraw (1997) found that areas where overstory removal (250-300 trees harvested per hectare) and new forestry (leave 13-25 dominant tree species per hectare and retain all snags and hardwoods) harvest techniques were applied had less ground cover, higher soil temperatures, and $75 \%$ fewer terrestrial salamanders than control plots. He suggested that retention of greater amounts of all types of forest debris and understory vegetation may mitigate these impacts. In their review of the management of the Coeur d'Alene salamander Groves et al. (1996) suggest that the impacts of timber harvest at sites known or likely to support populations be mitigated by: (1) avoiding concentration of harvest activities in headwater subdrainages; (2) using partial cutting that maintains at least $60 \%$ canopy cover; (3) ensuring that forest harvest activities provide for recruitment of woody debris; (4) reducing ground disturbance by winter harvesting and using low ground pressure tracked vehicles; (5) carrying out harvest activities during periods of salamander are not active on the ground surface (dry periods in the summer or during the winter); and (6) maintaining 30 meter forest buffers along both sides of all streams. Maintenance of buffer zones around streams has also been suggested by Corn and Bury (1989) (7.6-15.0 meters) and deMaynadier and Hunter (1995) (30-100 meters). A study in the Blue Mountains of Oregon provides evidence that stream buffers do provide protection for tailed frogs in drier forests similar to those found across much of Montana. Bull and Carter (1996) found that the number of tailed frogs was best predicted by a combination of stream substrates and the presence of stream buffers. deMaynadier and Hunter (1995) note that adjusting buffers proportionally to (1) stream width, (2) the intensity of the adjacent harvest, and (3) the slope of the area is likely to result in the most appropriate and efficient application of buffers. Finally, if buffers are applied it is important to ensure that they represent the habitat needs and home range 
of the animals they are designed to protect (Burke and Gibbons 1995). Unfortunately, information on the home range size of Montana's amphibians is virtually non existent.

\section{Research and Management Suggestions}

1. The impacts (both positive and negative) of timber harvest and subsequent forest succession on all amphibians that inhabit Montana's forests should be formally studied using sound experimental designs that gather pre-harvest data as well as a time series of post-harvest data. This should be done for stream and seep dwelling amphibians as well as those that use permanent and ephemeral standing waters.

2. When planning a timber harvest the area impacted by the harvest should be thoroughly surveyed for all amphibian species in order to identify the likely impacts of the harvest activities. Special emphasis should be placed on detecting the presence of Coeur d'Alene salamanders and tailed frogs because of their dependence on moist microhabitats and known sensitivities to timber harvest.

3. Harvested areas should leave 30 meter forest buffers along both sides of all streams (especially headwater streams) in order to prevent sedimentation of streams and desication of moist microhabitats adjacent to streams.

4. Timber harvest should not be allowed in areas that serve as refugia for the Coeur d'Alene salamander because of the species' dependence on moist microhabitats and the fact that populations of this species are usually isolated from one another by long distances, thereby eliminating the opportunity for recolonization.

5. Timber management practices that make use of intensive site preparation, such as plantations, and practices that modify levels of coarse woody debris and other microhabitats should not be used extensively. Harvest practices which minimize the immediate and longterm differences in abundance and distribution of moist microhabitats (e.g., woody debris or undergrowth) between harvested and nonharvested areas are preferred.

6. In areas that prove to be critical breeding, foraging, or overwintering habitat, timber harvest should be limited to periods of inactivity by amphibians (drier periods in the summer or during the winter) and during harvest ground disturbance should be minimized with low ground pressure tracked vehicles. 


\section{Livestock Grazing}

Livestock grazing is one of the most widespread land management practices in western North America ( $70 \%$ of the western United States is grazed) and has been associated with negative impacts on a variety of plant, invertebrate, and vertebrate taxa (Fleischner 1994). However, studies reporting the impacts of livestock grazing on amphibians are virtually nonexistent. Livestock have been documented to cause the direct mortality of amphibians as a result of trampling. Individual northern leopard frogs (Rana pipiens) and woodhouse's toads (Bufo woodhousii) have been found crushed at the bottoms of cattle hoove prints at the margins of several wetlands in eastern Montana (Bryce Maxell, pers. obs.). In some instances trampling can result in severe population-level impacts. For example, after what may have been the first successful reproductive event at a site in southeastern Idaho in 10 years Bartelt (1998) documented the deaths of thousands of western toad metamorphs when 500-1,000 sheep were herded through the drying pond the toadlets were concentrated around. He found that hundreds of animals had been directly killed underfoot and hundreds more died soon afterward as a result of dessication because the vegetation they had been hiding in had been trampled to the point that it no longer provided a moist microhabitat.

Riparian areas often provide critical breeding, foraging, and overwintering habitats and frequently serve as migratory or dispersal corridors for amphibians. These areas are also usually the preferred habitat of livestock (Kauffman and Krueger 1984; Fleischner 1994) so grazing likely has a number of indirect impacts on amphibian populations. In certain areas one possible positive impact may be that mechanical clearing of vegetation opens up basking areas that amphibians require (Bill Leonard, Washington State D.O.T., pers. comm.; Dick Tracy, University of Nevada at Reno, pers. comm.). In addition, in some areas livestock defecation and subsequent eutrophication of waters may benefit some amphibian larvae via a bottom-up control of the food web (Reaser 1996). Another possible positive impact of livestock grazing is the increased number of water bodies available to amphibians because of tanks and dams used for watering; assuming the hydroperiod is not long enough to allow exotic or native predators to become established (Scott 1996).

Unfortunately, it is likely that the majority of indirect impacts on amphibians are negative (Jones 1988). For example, contamination of waters through livestock defecation may increase fecal coliform counts and lead to mass mortality events and life history changes such as those documented and suspected, respectively, for the tiger salamander (Ambystoma tigrinum) (Worthylake and Hovingh 1989; Pfenning et al. 1991). Furthermore, eutrophication of waters through fecal contamination may cause planorbid snail numbers to rise, thereby increasing the number of nematode parasites and the rate of parasite infection that subsequently lead to limb deformities in amphibians (Johnson 1999). Livestock also cause major changes in the bank structure, substrate composition and vegetation in riparian habitats (Kauffman and Krueger 1984; Fleischner 1994). Elimination of bankside vegetation and collapse of overhanging banks reduces the number of moist non freezing microhabitats that are required by many amphibian species during summer foraging and overwinter periods, respectively. Compaction of soils in the riparian area may eliminate the ability of many species to burrow underground in order to prevent dessication or freezing (Duellman and Trueb 1986; Swanson et al. 1996). The collapse of banks leads to increased sedimentation which has negative impacts on stream dwelling 
amphibians such as the tailed frog (Kauffman and Krueger 1984; Corn and Bury 1989; Bull and Carter 1996). Loss of bankside willows may result in reduced beaver activity or possibly even the extirpation of beaver; a species whose activities are responsible for the creation of a large portion of amphibian breeding habitats (Donkor and Fryxell 1999; Russell et al. 1999a). Grazing may also reduce the number of insect prey that amphibians are dependent on (Fleischner 1994). Finally, a number of amphibian species may be highly dependent on the burrows created by prairie dogs and other small mammals (Reading et al. 1989; Sharps and Uresk 1990; Scott 1996). Loss of prairie dogs as a result of control programs associated with the protection of livestock from injury is, therefore, likely to have major impacts on grassland amphibians.

\section{$\underline{\text { Research and Management Suggestions }}$}

1. The impact of different livestock grazing regimes on amphibian populations should be formally investigated using sound experimental designs.

2. Livestock should be fenced from all or portions of water bodies that are critical breeding habitat in order to prevent mass mortality as a result of disease or trampling at or prior to the time of metamorphosis.

3. Livestock should be fenced from all or portions of riparian areas that provide critical breeding, foraging, or overwintering habitats or that serve as important migratory or dispersal corridors in order to protect these critical areas from damage.

4. Hydroperiods of waterbodies should not be altered in order to provide water for livestock.

5. Prairie dog control efforts undertaken to prevent harm to livestock should be eliminated in order to conserve critical summer refugia and overwintering habitats. 


\section{Fire and Fire Management Activities}

Although the impacts of fire and fire management activities have been investigated for a number of vertebrates (e.g., Lyon et al. 1978; DeBano et al. 1998), impacts on amphibians have received virtually no attention at all (Russell et al. 1999b). Furthermore, the little attention that has been given has been focused on scrub forests in the southeastern United States (Vogl 1973) hardwood and pine forests in the northeastern United States (Kirkland et al. 1996; McLeod and Gates 1998), and chapparal communities in California and Australia (Friend 1993; Gamradt and Kats 1997; Hannah and Smith 1997). The sparse amount of research may in part be due to the belief that the wet areas occupied by many amphibian species act as refugia from fire or that many amphibians are inactive in burrows during the dry season when fires are more frequent. Vogl's (1973) observations of a large breeding chorus of Hyla crucifer in a Florida wetland surrounded by still-smoking ashes and Friend's (1993) finding that most Australian anurans (frogs and toads) were inactive in burrows during the dry season support this contention. However, wildfire, prescribed fire, and fire control actions are all likely to have both direct and indirect impacts on amphibians.

Direct mortality of amphibians as a result of fire has been documented in wetlands (Vogl 1973) and the relatively low vagility of many amphibian species (Sinsch 1990) indicates that species that inhabit forest vegetation may face high rates of fire induced mortality (Friend 1993; Russell et al. 1999b; Papp and Papp 2000). However, the population-level impacts of direct fire induced mortality have not been examined. Indirect effects of fire may be either positive or negative. For instance, increased sedimentation following a chaparral wildfire in California reduced the number of stream pools and was apparently related to reduced numbers of California newt (Taricha granulosa) egg masses (Gamradt and Kats 1997) Furthermore, fire may remove the forest canopy, downed logs, leaf litter, and other structures that create moist microhabitats suitable for amphibians. This may be why both Mushinsky (1985) and McLeod and Gates (1998) found amphibian species present in greater numbers in unburned scrub and pineforest, respectively, relative to adjacent burned areas. However, fire may also have positive indirect effects by creating openings that allow more terrestrial amphibians to bask and forage (Kirkland et al. 1996). Fire may also positively impact amphibian populations by removing vegetation and opening wetlands to an earlier succession stage, thereby enhancing the life of the wetland (Russell et al. 1999b). In addition removal of forest trees immediately adjacent to wetlands may enhance the length of time ephemeral wetlands are present by reducing evapotranspiration (Russell et al. 1999b) and may reduce the length of the larval period of many amphibians by increasing solar radiation, thereby ensuring that metamorphosis takes place prior to pond drying.

The impacts of prescribed fire and fire management activities have not been investigated, but may present some serious risks to amphibian populations. For instance many of Montana's amphibians are most active on the ground surface during moist periods in the spring and fall (e.g., Turner 1957; Beneski et al. 1986; Hill 1995) when most prescribed burns take place. As these animals migrate between terrestrial and aquatic habitats they may be particularly susceptible to fire because many migrate in mass (e.g., DeLacey 1876) and most remain closer to the ground surface where they may be more easily reached by flames. Fire control activities may also present a risk to amphibians. The large volumes of water required for control efforts may decrease wetland hydroperiods and thereby desicate larvae before they are capable of 
metamorphoses (Rowe and Dunson 1995; Skelly 1996). Finally, no published studies of the impacts of aerially dropped fire retardant slurries on amphibian larvae were found, but it is reasonable to assume that these retardants may be toxic to amphibian larvae or adults.

\section{Research and Management Suggestions}

1. The impacts of wildfire, prescribed burns on terrestrial and aquatic amphibians should be formally investigated so that the impacts of both the timing and magnitude of fire and the subsequent succession of vegetation can be understood.

2. The toxicity of commonly used fire retardants to amphibians should be investigated for both terrestrial and aquatic species and/or life history stages at different periods of time after application.

3. Radio telemetry studies should be conducted for all amphibian species in order to gain a better understanding of how far they migrate to and from aqautic breeding habitats so that the spatial context of the impacts of wildfire, prescribed burns, and fire control efforts can be better understood.

4. Prescribed burns should not be conducted outside of the normal fire season in areas where amphibian species are present as disjunct populations unless research indicates the population is not widely present in habitat that will be impacted by the burn (i.e. on the ground surface or in vegetation that will burn). 


\section{Nonindigenous Species and Their Management}

\section{Impacts of Nonindigenous Fish}

At least 52 species of fish belonging to 14 families have been introduced in Montana (Nico and Fuller 1999; Fuller et al. 1999). Of these species, 9 belonging to 3 families have been widely introduced for recreational fishing and have been implicated in the decline of native amphibians across the globe (Sexton and Phillips 1986; Bahls 1992; Bradford et al. 1993; Bronmark and Endenhamn 1994; Brana et al. 1996; Hecnar and M Closkey 1997a; Fuller et al. 1999). These species include pumpkinseed (Lepomis gibbosus), blue gill (Lepomis macrochirus), largemouth bass (Micropterus salmoides), and smallmouth bass (Micropterus dolomieu) in the family Centrarchidae, yellow perch (Perca flavescens) in the family Percidae, and rainbow trout (Oncorhynchus mykiss), cutthroat trout (Oncorhynchus clarki), brook trout (Salvelinus fontinalis) and brown trout (Salmo trutta) in the family Salmonidae. Introductions of warm water centrarchids and percids and cold water salmonids have undoubtedly been made into a number of low-elevation water bodies that support or formerly supported amphibian communities. However, introductions of salmonids at higher elevations, which began as early as the $1880 \mathrm{~s}$ (Jordan 1891), are likely to have had a particularly important impact on native amphibian communities inhabiting high ( $>800$ meters) mountain lakes because $95 \%$ of these lakes in the western United States were naturally fishless prior to stocking (Bahls 1992). Thus, historically, as many as 15,000 lakes at elevations greater than 800 meters in the western United States may have supported native amphibian communities without the threat of predation or competition from fish. Presently, about 9,500 of the West's high-elevation lakes and virtually all of the deeper lakes contain introduced salmonids (Bahls 1992). In Montana, approximately 47\% of the state's 1,650 high-elevation lakes now contain nonindigenous salmonids (Bahls 1992).

Egg, larval, and adult amphibians may be subject to direct predation by introduced warm and cold water fishes (e.g.s, Korschgen and Baskett 1963; Licht 1969; Semlitsch and Gibbons 1988; Liss and Larson 1991). Similarly, all 3 amphibian life history stages are likely to be indirectly effected by the threat of predation due to (1) adult avoidance of oviposition sites where predators are present (e.g. Resetarits and Wilbur 1989; Hopey and Petranka 1994), (2) decreased larval foraging and, therefore, growth rates as a result of staying in refuges to avoid predators (e.g., Figiel and Semlitsch 1990; Skelly 1992; Kiesecker and Blaustein 1998; Tyler et al. 1998), and (3) decreased adult foraging, growth rates, and overwinter survival as a result of avoiding areas with fishes (e.g., Bradford 1983).

\section{Impacts of Chemical Management of Sport Fisheries}

Rotenone and commercial piscicides containing rotenone have often been used to remove unwanted fish stocks from a variety of aquatic habitats (Schnick 1974). The impacts of rotenone-containing piscicides on amphibians and turtles were recently reviewed by Fontenot et al. (1994) and McCoid and Bettoli (1996). They found the range of lethal doses of rotenonecontaining piscicides for amphibian larvae $(0.1-0.580 \mathrm{mg} / \mathrm{L})$ to overlap to a large extent with lethal doses for fish $(0.0165-0.665 \mathrm{mg} / \mathrm{L})$, and to be much lower than the concentrations commonly used in fisheries management $(0.5-3.0 \mathrm{mg} / \mathrm{L})$. Furthermore, they reviewed, a number of studies that noted substantial mortality of nontarget amphibian larvae. However, the effects of rotenone on newly metamorphosed and adult amphibians was found to vary with the degree of each species' aquatic respiration and their likelihood of exiting treated water bodies (Fontenot et 
al. 1994; McCoid and Bettoli 1996). Hockin et al. (1985) reduced nontarget mortality of amphibian larvae by providing several untreated refuge areas that could be accessed through Netlon fence divisions and by protecting one refuge area containing high densities of amphibian larvae by placing a sheet of hessian sacking soaked in a saturated potassium permanganate solution that neutralized the rotenone. The nontarget effects of another piscicide, antimycin, have apparently not been formally studied, but preliminary observations seem to indicate that antimycin is also toxic to amphibian larvae (Patla 1998). In Montana all amphibian larvae as well as tailed frog adults use some sort of aquatic respiration or may be unlikely to exit treated water bodies depending on the time of day (Daugherty and Sheldon 1982). Thus, all amphibian species are likely to suffer mortality if piscides are applied to waters they inhabit.

Impacts of Nonindigenous Bullfrogs

Bullfrogs (Rana catesbeiana) are native to the United States east of a line extending from northwest Wisconsin to south central Texas (Bury and Whelan 1984). However, they have now been widely introduced into permanent waters in all lower forty-eight states, with the possible exception of North Dakota, and have been implicated in the declines of a number of amphibian and reptile species throughout this area (Moyle 1973; Hammerson 1982; Bury and Whelan 1984; Kupferberg 1994; Rosen et al. 1995; Kupferberg 1997; Lawler et al. 1999). The impetus for bullfrog introduction seems largely to be due to their use as a recreational hunting and food item, apparently, in some cases, as a result of native frogs having already declined because of human hunting and consumption (Bury and Whelan 1984; Jennings and Hayes 1985). In Montana, bullfrogs were introduced for unknown reasons into the Bitterroot Valley sometime prior to 1968 and they are now continuously distributed along much of the lower Bitterroot, Flathead, and Clark Fork Rivers as well as a few other isolated localities around the state (Black 1969a; 1969b; Werner and Reichel 1994; Reichel 1995; Hendricks and Reichel 1996; Werner et al. 1998). Unfortunately, bullfrogs continue to be introduced into new sites from source populations both inside and outside of Montana despite the fact that unauthorized introduction or transplantation of wildlife into the natural environment is prohibited by Montana law (Bryce Maxell, pers. obs.; Levell 1995; MCA 87-5-711).

All 3 life history stages of amphibians may be subject to direct predation by adult bullfrogs (e.g., Korschgen and Baskett 1963; Carpenter and Morrison 1973; Bury and Whelan 1984; Clarkson and DeVos 1986). Additionally, both the eggs and larvae of native amphibians may be preyed upon by larval bullfrogs (e.g., Ehrlich 1979; Kiesecker and Blaustein 1997a). Furthermore, egg, larval and adult amphibians are also likely to be indirectly effected by the threat of predation due to (1) adult avoidance of oviposition sites where predators are present (e.g., Resetarits and Wilbur 1989), (2) decreased larval foraging and, therefore, growth rates as a result of staying in refuges to avoid predators (e.g., Kiesecker 1997; Kiesecker and Blaustein 1998), and (3) decreased adult foraging and growth rates as a result of avoiding areas with bullfrogs. Native amphibian larvae or adults may also be subject to chemically mediated interference competition (e.g., Petranka 1989; Griffiths et al. 1993) or exploitative competition for resources (e.g., Kupferberg 1997). Finally, predators that are dependent on larval or adult amphibians as a food source may also be impacted as a result of the loss of native amphibian larvae and the presence of larger bullfrog tadpoles and adults that they are unable to efficiently forage on (e.g., Kupferberg 1994). 
$\underline{\text { Impacts of Nonindigenous Species as Vectors for Pathogens }}$

Reports of mass mortality of amphibians due to pathogens are increasingly common (e.g., Nyman 1986; Worthylake and Hovingh 1989; Carey 1993; Blaustein et al. 1994b; Berger et al. 1998, Carey et al. 1999; Daszak 1999; Lips 1999). Nonindigenous species, such as bullfrogs and other amphibians that are sold in pet stores, and introduced centrarchid, percid, and salmonid fishes, may act as vectors for amphibian pathogens. For example, the chytrid fungus

Batrachochytrium dendrobatidis is now the primary suspect for amphibian declines in Australia, Central America, and the Western United States, and many amphibians exported to pet stores in the United States come from these areas (Daszak et al. 1999, 2000). Similarly, the water fungus Saprolegnia, a common pathogen of fish species reared and released from fish hatcheries, has recently been associated with declines of amphibian populations (Blaustein et al. 1994b). Releasing hatchery-raised fish may, therefore, increase the inoculation rate and lead to declines in native amphibian populations. Laurance et al. (1996) suggest that declines in stream-dwelling amphibian populations in Australia are caused by an unknown pathogen and hypothesize that nonindigenous species, such as the cane toad (Bufo marinus) and aquarium fish, are responsible for the introduction of the pathogen. Similarly, nonindigenous organisms may change environmental conditions leading to enhanced survival and number of pathogens. For example, Worthylake and Hovingh (1989) found that elevated nitrogen levels, caused by high numbers of sheep, increased bacterial concentrations and lead to periodic mass mortality of salamanders. Finally, pathogens may act synergistically with other natural and anthropogenically caused environmental stressors. For example, Kiesecker and Blaustein (1995) found that an interaction between UV-B radiation and Saprolegnia fungus enhanced the mortality of amphibian embryos.

\section{Impacts of Weeds and Weed and Pest Management Activities}

Noxious weeds may be spread by the use of off-road vehicles, watercraft, recreational livestock use, and camping activities. There is little knowledge of the impacts that weeds have on amphibian communities. However, nonindigenous aquatic and terrestrial weeds often form dense stands that are likely to exclude native amphibians and enhance the probability of successful introduction of other exotic species. For example, there is some evidence that the survival of exotic bullfrogs is enhanced by the presence of exotic aquatic vegetation, which provides habitat more suitable to the bullfrogs (Kupferberg 1996).

Management of weeds and insect pests with chemical herbicides and pesticides can have major impacts on amphibian communities. In particular, several features of amphibian biology may enhance their susceptibility to chemical contamination (Stebbins and Cohen 1995). The life history of most amphibians involves both aquatic larvae and terrestrial adults, allowing exposure to toxicants in both habitats. Many amphibians have skin with vascularization in the epidermis and little keritinization, allowing easy absorption of many toxicants. In fact, many studies have demonstrated the effects of chemical contamination on amphibians (reviewed in Cooke 1981; Hall and Henry 1992; Boyer and Grue 1995; Carey and Bryant 1995). The effects range from direct mortality to sublethal effects such as depressed disease resistance, inhibition of growth and development, decreased reproductive ability, inhibition of predator avoidance behaviors, and morphological abnormalities. 
Currently, there are no requirements for testing the toxicity of herbicides and pesticides on amphibians (Hall and Henry 1992). Furthermore, there are no water quality criteria established for amphibians (Boyer and Grue 1995). It is often assumed that criteria for mammals, birds, and fish will incorporate the protection needed for amphibians. The few chemicals that have been tested with fish and larval amphibians suggest that tadpoles may be more vulnerable to some toxicants than others (Hall and Henry 1992; Boyer and Grue 1995). Several studies have examined the acute (lethal) toxicity of herbicides and pesticides on amphibians. Saunders (1970) and Harfenist et al. (1989) reviewed the effects of 25 and 211 different pollutants, respectively. However, it is important to recognize sublethal effects as well. Johnson and Prine (1976) found that organophosphates affect the thermal tolerance of western toad tadpoles. Polychlorinated biphenyls (PCBs) and organochlorines can disrupt corticosterone production and inhibit glucogenesis (Gendron et al. 1997). Many pesticides result in decreased growth rate and inhibition of a predator response in amphibians (e.g., Berrill et al. 1993; Berrill et al. 1994).

Many of the newer pesticides and herbicides are designed to decompose soon after application. Although still toxic, presumably this reduces the impact area and, thus, the number of exposed individuals. However, many of the older chemicals may still be present in sediments. For example, Russell et al. (1995) found potentially toxic levels of DDT in tissues of spring peepers (Pseudacris crucifer) at Point Pelee National Park, Ontario, even though DDT had not been used in the area for 26 years. Levels as high as $1,188 \mu \mathrm{g} / \mathrm{kg}$ were found in spring peepers and implicate DDT as a possible causative agent in the local extinction of several amphibian populations.

$\underline{\text { Research and Management Suggestions }}$

1. The impacts of introduced fish, bullfrogs, weeds, and pathogens on Montana's native amphibians should be formally investigated.

2. Introduction of nonindigenous fish species should be limited to areas where they have already been introduced and nonindigenous fish should be removed from waters that act as key overwintering or breeding sites for amphibians.

3. Streams and lakes should be thoroughly surveyed for amphibians prior to and after the application of piscicides in order to identify impacts of piscicide application.

4. If lakes are to be treated with piscicides, they should be treated in late summer after most amphibian larvae have metamorphosed and before adults enter deeper water bodies for overwintering. When amphibians are present an effort should be made to remove them before treatments begin.

5. Piscicides should not be used in streams containing tailed frogs because of the possibility of removing multiple larval and adult cohorts. Other methods of removal should be explored in these instances. If piscicide use is the only option available then pretreatment gathering and posttreatment restocking of tailed frog tadpoles and adults should be undertaken and treatment should occur in the late evening hours so that adults are more likely to exit waters.

6. The public should be educated on the possible impacts of bullfrogs on native communities and be made aware of the fact that it is illegal to introduce them into the wild in Montana.

7. Where possible, bullfrog populations should be removed. Removal may be accomplished by altering habitats from permanent waters that support exotic bullfrogs, fish, and aquatic weeds to ephemeral habitats that support native species. Removal may also be accomplished by surrounding waterbodies with a drift fence and subsequently draining the water body in the 
late fall after bullfrogs have moved into overwintering sites. Individuals can then either be captured by hand or left to dessicate and/or freeze.

8. The Montana state legislature could further prohibit the introduction of bullfrogs by designating them a species that is detrimental to Montana's native flora and fauna (Levell 1995; MCA 87-5-712).

9. Because animals sold in pet stores can act as vectors for pathogens they should be examined and formally certified as free of pathogens such as the chytrid fungus which seems to be responsible for amphibian population declines around the world and in the western United States.

10. The impacts of commonly used herbicides and pesticides on all life history stages of all of Montana's amphibians should be formally investigated. In the meantime herbicide and pesticide use should be limited to brands that rapidly decompose after application, and herbicides and pesticides should not be sprayed within 100 meters of water bodies or wetlands. Alternative methods of weed and pest removal should be used in these areas. 


\section{Road and Trail Development and On- and Off-Road Vehicle Use}

\section{$\underline{\text { Road Kill }}$}

Many studies have reported large numbers of amphibians killed on roadways. Ehmann and Cogger (1985) estimated that five million reptiles and frogs are killed annually on Australian roads. Thousands of amphibians may be killed in a single population if they undertake a mass migration to or from breeding habitats across a road (e.g., Koch and Peterson 1995; Langton 1989). Wyman (1991, as cited in deMaynadier and Hunter 1995) reported mortality rates ranging from 50.3 to $100 \%$ for individuals of three salamander species that tried to cross a paved rural road in New York. Although the number of mortalities reported in road-kill studies is alarming, only a few studies have taken the extra step to demonstrate an impact of such mortality at the population level (e.g., Lehtinen et al. 1999). Vos and Chardon (1998) found that the density of roads within 250 meters of a pond site was negatively associated with the size of moor frog (Rana arvalis) populations. Furthermore, the density of roads within 750 meters of a pond site was negatively associated with the probability that the pond would be occupied at all. van Gelder (1973) estimated that $30 \%$ of the females from a local breeding population of the common toad (Bufo bufo) succumbed to road kill and reported that an equivalent percentage for males was likely. Kuhn (1987, as cited in deMaynadier and Hunter 1995) correlated road use with mortality of common toads, demonstrating that 24-40 cars per hour is sufficient to kill 50\% of migrating individuals. Similarly, in a study of frogs and toads, Fahrig et al. (1995) found the proportion of dead-to-live animals increased and the total density of animals decreased with increasing traffic intensity.

Several management options are available to reduce traffic mortality on established roads including culverts or underpasses, temporary road closures during major migrations, reduced speed zones, or relocating roads (Langton 1989; Yanes et al. 1995; Boarman and Sazaki 1996). For example, spotted salamanders (Ambystoma maculatum) appear to successfully use culverts (Jackson and Tyning 1989). However, Auiderwijk (1989) reported that less than 4\% of a local toad population used culverts installed for their migration. Yanes et al. (1995) suggest that culvert dimensions, road width, height of drift fence, and vegetation along roadways may all influence the effectiveness of culverts. Funnels leading into culverts, lighted culverts, vegetation around culvert openings, and pitfall-trap entrances may all enhance the effectiveness of culverts. Many other suggestions for constructing effective culverts can be found in the studies reported by Langton (1989).

\section{Off-Road Vehicle Impacts}

The impacts of motorized vehicles on amphibian populations do not end at the roadside. Although far less studied, impacts from ORVs have been documented. In addition to direct mortality resulting from collisions, ORVs may disrupt habitat to the point that it becomes unusable by herpetofauna (see below). Furthermore, noise from on- and off-road vehicles is also likely to have negative indirect impacts on herpetofauna. For example, Nash et al. (1970) found that leopard frogs exposed to loud noises (120 decibels) remained immobilized for much longer periods of time than a similarly handled control group. Thus, an immobility reaction resulting from noise-induced fear could increase mortality of herpetofauna that inhabit areas used by ORVs or for herpetofauna undertaking road crossings by inhibiting their ability to find shelter or move across a roadway. Although I found no studies documenting the impacts of noise on 
breeding choruses of amphibians, it is also possible that vehicle noise may not allow amphibians to properly hear and move toward breeding aggregations. This may be especially true for species such as our native Columbia spotted frog and western toad, which do not have loud calls and may not be heard from long distances or in the presence of other noises.

\section{Chemical Contamination and Sedimentation from Roads}

Soil disturbance has been directly implicated in both lethal and sublethal effects on amphibians. If not contained, road construction may cause increased sedimentation in adjoining aquatic habitats. Road construction in Redwood National Park introduced large amounts of sediments into neighboring streams and densities of tailed frogs, Pacific giant salamanders (Dicamptodon tenebrosus), and southern torrent salamanders (Rhyacotriton variegatus) were lower in these streams compared to nearby control streams (Welsh and Ollivier 1998). Similarly, Corn and Bury (1989) reported species richness and abundance to be negatively correlated with the amount of fine sediments for four species of stream amphibians in the Pacific Northwest. The impacts of sedimentation may be further heightened if the sediments contain toxic materials. Road construction in Great Smoky Mountains National Park involved using fill from the Anakeestra rock formation that when oxidized, formed a leachate with sulfuric acid, iron, zinc, manganese, and aluminum (Huckabee et al. 1975, Kucken et al. 1994). Runoff from roadsides and culverts resulted in contamination of streams within the park and 2 stream breeding salamander species were eliminated and 2 other species exhibited a $50 \%$ reduction in population size. Declines in macroinvertebrates and fish were also noted. Similarly, disturbance of, and runoff from, mine tailings increased the acidity and heavy metal concentrations in a drainage system in Colorado (Porter and Hakanson 1976). Laboratory bioassays indicated that water in the drainage was lethal for western toad larvae and required a 1000 fold dilution before tadpoles were able to survive. Sublethal effects may also result from heavy metal poisoning (e.g., Lefcort et al. 1998). Deformities in the oral cavity were observed in bullfrog tadpoles exposed to sediments high in arsenic, barium, cadmium, chromium, and selenium (Rowe et al. 1998), and southern toads (Bufo terrestris) exposed to coal combustion wastes had elevated levels of stress hormones (Hopkins et al. 1997).

Contaminant runoff from roads or campground surfaces may also affect amphibians. Maintenance of gravel road surfaces with calcium or magnesium chloride or oils in order to control airborne dust and prolong the life of the road surface may present a serious biohazard. Calcium chloride has been associated with mass mortalities of migrating salamanders apparently as a result of dessication caused by the chemical (deMaynadier and Hunter 1995). Petroleum products may also contaminate aquatic habitats next to roadways or may be directly introduced from motorized watercraft. Mahaney (1994) examined the effects of crankcase oil on tadpoles of the green treefrog (Hyla cinerea). Concentrations of $100 \mathrm{mg} / \mathrm{L}$ inhibited tadpole growth and prevented metamorphosis. Finally, although leaded fuels are no longer a concern Birdsall et al.'s (1986) finding that lead concentrations in frog tadpoles living in roadside ponds and ditches were correlated with daily traffic volumes in Maryland and Virginia demonstrates how contaminant levels are likely to be correlated with traffic volume.

\section{$\underline{\text { Research and Management Suggestions }}$}

1. The impacts of road and trail development, on- and off-road vehicle use, and watercraft use on Montana's amphibians should be formally studied, especially in areas of high human use. 
2. Potential road and trail routes should be thoroughly surveyed for amphibians in order to identify impacts of road or trail construction and vehicle use.

3. When possible roads and trails should avoid water bodies, wetlands, and denning sites that are key habitats.

4. When new roads and trails must be constructed near water bodies or wetlands care should be taken to avoid increased sedimentation, maintain the essential hydrographic period, and allow natural processes, such as changes in river courses to continue.

5. Areas identified as key migration routes should either be closed to vehicle use during peak migration periods or culverts and underpasses should be constructed in conjunction with drift fences in order to minimize road mortality.

6. ORV use should be restricted to designated roads, trails, or pit areas.

7. Road and trail development and off-road vehicle use in areas with soils that contain mine tailings or other toxic substances should be prevented. If road and trail construction is absolutely necessary in these areas then reclamation activities should be undertaken prior to road or trail construction. 


\section{Development and Management of Water Impoundments and Recreational Facilities}

\section{Water Impoundments}

The suitability of many water bodies for amphibians depends on their hydroperiod: if ponds dry up to soon, larvae desicate, and if they are too permanent they often attract native and introduced predators that may negatively impact amphibian populations (Scott 1996; Skelly 1996). In some cases water impoundments may create breeding, foraging, and overwintering habitat for amphibians or lengthen the hydroperiod of water bodies in areas that were previously inhospitable (e.g., Cooper et al. 1998). However, in a number of instances, their development can result in the loss of these key habitats. Replacement of ephemeral wetlands or water bodies with small water impoundments often attracts native predators and provides habitat suitable for introduced fish or bullfrogs that may predate and subsequently extirpate amphibians (Scott 1996). Construction of larger impoundments can have a variety of negative impacts. For example, construction of the Jordanelle Reservoir on the Provo River in Utah flooded a large amount of habitat used by Columbia spotted frogs, a species that is threatened in the region (Wilkinson 1996a). Water impoundments can also cause downstream riverine habitats to deteriorate as a result of changes in flow regimes. Lind et al. (1996) found that reduced water flows below dams on the Trinity River in California resulted in the loss of flood plain breeding pools and vegetational overgrowth of riparian areas used for basking and foraging by amphibians. Furthermore, manipulation of water levels in water impoundments can result in direct and indirect mortality of amphibian larvae and eggs. For example, during the summer of 1998, fluctuating water levels in Cabinet Gorge Reservoir in northwest Montana led to the dessication of Columbia spotted frog eggs and larvae when water levels dropped for power generation (Bryce Maxell, pers. obs.). Fluctuations in water levels may also cause a decline in water temperatures as a result of increased water movement. Colder water temperatures may increase mortality by decreasing larval growth rates and increasing the length of the larval life history stage (Wilbur 1980). Colder water temperatures can also result in a decreased immune response, leaving amphibian larvae more susceptible to pathogens (Nyman 1986; Carey 1993; Maniero and Carey 1997). Some factors associated with water level fluctuations may interact in a complex manner resulting in amphibian mortality. For example, Worthylake and Hovingh (1989) describe periodic mass mortality of tiger salamanders caused by interactions between fluctuating water levels, high numbers of sheep, and high levels of a pathogenic bacteria (Acinetobacter spp.). High numbers of sheep increased the nitrogen input into the lake and, combined with low water levels, resulted in high nitrogen concentrations that were conducive to the pathogen. Kiesecker and Blaustein (1997b) describe another complex interaction. Western toads apparently lay their eggs in one particular portion of an Oregon lake, regardless of the water levels. Low water levels resulted in mass mortality of toad eggs due to the synergistic effect of UV-B radiation and the pathogenic fungus Saprolegnia. Moving eggs to deeper waters significantly reduced egg mortality.

Some water impoundments are managed exclusively for waterfowl production. Because many waterfowl and wading birds feed on amphibians and reptiles (Duellman and Trueb 1986), concentrated numbers of waterfowl may lead to increased depredation. Furthermore, high concentrations of migratory waterfowl have been associated with decreased water quality (Manny et al. 1994; Post et al. 1998) and habitat degradation (Kerbes et al. 1990; Ankney 1996). For example, Post et al. (1998) estimated that waterfowl increased nitrogen and phosphorus 
levels by $40 \%$ and $75 \%$, respectively, on Bosque del Apache National Wildlife Refuge in the winter of 1995-1996 and Kerbes et al. (1990) reported that high concentrations of snow geese (Chen caerulescens) have lead to destruction of wetland vegetation.

Finally, declines in amphibian populations resulting from water impoundments would also be expected to lead to declines in predators that depend on amphibians as prey (Kupferberg 1994; Koch et al. 1996).

\section{Recreational Facilities}

Several aspects of recreational facilities and associated activities may negatively impact amphibians. Amphibian populations in or near recreational facilities are at risk of increased mortality as a result of handling and killing by humans (Bryce Maxell, pers. obs.). Furthermore, amphibians may become stressed by human handling (e.g., Reinking et al. 1980) and, if translocated to unfamiliar microhabitats, may not be able to find local refugia from predators, or water to rehydrate themselves. Amphibian populations in or near recreational facilities may also face increased mortality as a result of handling and killing by human pets (e.g., Coman and Brunner 1972). In the United States there may be more than 120 million dogs and cats, with as many as 50 million of these being homeless (Denney 1974). In addition, wild predators, including ravens (Corvus corax), striped skunks (Mephitis mephitis), raccoons (Procyon lotor), coyotes (Canis latrans), and foxes (Vulpes vulpes) may be supported at artificially high numbers around areas of human activity due to the availability of human refuse and a lack of larger predators. Olson (1989) found that ravens at a recreational facility depredated more than $20 \%$ of a breeding aggregation of western toads in the Oregon Cascades. Schaaf and Garton (1970) found that raccoons ate at least 50 individuals of a breeding chorus of American toads (Bufo americanus). Similarly, Parker et al. (2000) concluded that predator control programs may be necessary to ensure the survival of the federally endangered Wyoming toad (Bufo baxteri) after at least $20 \%$ of the adult population was depredated in a single event by an unidentified mustelid.

Finally, a number of amphibians breed and forage nocturnally and it is possible that artificial lighting at recreational facilities may negatively impact these activities. For example, large choruses of breeding Pacific treefrogs in western Montana can be rapidly and completely quieted by shining a flashlight across a breeding pond, and calling may not be reinitiated for up to 5 minutes (Bryce Maxell, pers. obs.). If breeding ponds are subject to constant illumination by a fixed light or repeated exposure to car lights near a recreational facility it is possible that breeding success may be negatively impacted. Similarly, nocturnal foraging behavior of amphibians and reptiles may be impacted by the presence of artificial lights, especially when species depend on extremely dark conditions (e.g., Hailman 1982). Buchanan (1993) found that the ability of nocturnally foraging grey treefrogs (Hyla versicolor) to detect and subsequently consume prey was significantly reduced when artificial light sources were present as compared to ambient-light conditions.

\section{$\underline{\text { Research and Management Suggestions }}$}

1. The impact of recreational facilities, water impoundments, and associated human activities on amphibian populations should be formally investigated.

2. Current and potential sites for recreational facilities and water impoundments should be thoroughly surveyed for amphibians to identify potential impacts of these facilities. 
3. New recreational facilities should not be located within 300 meters of key breeding, foraging, or overwintering habitats.

4. When past or future water impoundments have eliminated key breeding, foraging, and overwintering habitats, impacts on amphibians should be mitigated by the creation of adjacent water bodies that have deeper areas for overwintering and areas with shallow waters for larval rearing. Furthermore, fish should not be introduced to these water bodies and fluctuations in water levels at these sites should not be correlated with fluctuations in water levels in the adjacent water impoundment.

5. Downstream flows from water impoundments should mimic natural flow regimes in order to maintain flood plain breeding and foraging habitats.

6. Management of habitats exclusively for waterfowl production should be avoided. A multispecies or community approach is preferable.

7. Recreational facilities located near documented amphibian populations should contain educational signs or pamphlets pertaining to the amphibians in the area and how they may be impacted by humans and their pets.

8. If domestic or wild predators are found in high densities in areas with key breeding habitat, predator control programs may be required in order to ensure that native amphibian populations persist.

9. The subsidization of native predators should be minimized by maintaining fully enclosed waste facilities. 


\section{Harvest and Commerce}

The worldwide collection and harvest of amphibians for food, sport, and commerce as pets, skins, art, souvenirs, and medicinal products is extensive. Hundreds of millions of amphibians are removed from the wild and/or killed each year for these activities and annual worldwide commerce in amphibians may be valued in the hundreds of millions, possibly even billions, of dollars annually (Scott and Siegel 1992; Wilkinson 1996b; Buck 1997; Pough et al. 1998). For example, each year the United States imports 1,000 to 2,000 tons of frog legs for human consumption; France imports around 3.4 million tons (Stebbins and Cohen 1995). As another example, the fishing bait industry's use of salamander larvae may be quite extensive with 2.5 million salamander larvae being sold as bait on the lower Colorado River area in 1968 alone (Collins 1981). Finally, pet shops across Montana sell a large number of amphibians annually, including bullfrogs (Bryce Maxell, pers. obs.).

Unfortunately, we currently do not know the degree to which Montana's amphibians are collected or harvested for biological or commercial purposes. Furthermore, we do not know the extent of the impacts of selling exotic and native amphibians in pet stores. In addition to the possible introduction of exotic predators such as bullfrogs, sales of exotic species from overseas may act as a vector for diseases such as the chytrid fungus which has populations of amphibians to decline or go extinct around the world (Burger et al. 1998; Daszak et al. 1999). Sales of nonindigenous native species can also result in hybridization and genetic introgression with native populations, possibly leading to the elimination of distinct life histories and genetic makeups (Collins 1981). Unfortunately, the state of Montana currently does not have any permit requirements or regulations for the collection, harvest, or possession of wild native amphibians (Levell 1995; MCA 87-5). Thus, biologists and commercial collectors from across the country can collect unlimited numbers of Montana's native amphibians without a collecting permit.

\section{$\underline{\text { Research and Management Suggestions }}$}

1. The degree to which amphibians are harvested and sold in Montana and the impacts of harvesting and selling amphibians should be formally studied.

2. Collecting or harvesting of all amphibians should be regulated and/or monitored by requiring permits to undertake these activities.

3. Because animals sold in pet stores can act as vectors for pathogens they should be examined and formally certified as free of pathogens such as the chytrid fungus which seems to be responsible for amphibian population declines around the world and in the western United States.

4. Collecting or harvesting rare species, such as the Coeur d' Alene salamander, plains spadefoot, western toad, Great Plains toad, and Canadian toad should be regulated by requiring permits in order to prevent declines in these species.

5. A public education program should be undertaken in order to encourage people to enjoy and value native amphibians in the wild. 


\section{Habitat Fragmentation and Metapopulation Impacts}

Many of the factors described above may result in the loss of amphibian habitat and the subsequent loss of local populations (e.g., Bury et al. 1980; Rosen et al. 1995; Knapp 1996; Lind et al. 1996; Beebee 1997). However, loss of individual local populations may also influence the persistence of regional populations or metapopulations, even when the total amount of habitat remains constant (e.g., Hanski and Gilpin 1991; Robinson et al. 1992; Simberloff 1993; Fahrig and Merriam 1994). For example, Rosen et al. (1995) found that extirpation of native amphibians in Arizona resulting from the introduction of nonindigenous bullfrogs and fishes into permanent water bodies led to the extirpation of native amphibians from nearby regions when smaller water bodies the natives had been exiled to dried up during a drought. Thus, loss of core habitats that support local source populations can lead to more widespread extirpations. Core habitats for Montana's amphibians are described in the table at the end of the document.

Habitat patch size, shape, isolation, and quality all influence the persistence of regional metapopulations. The size of habitat patches is often associated with the probability that a patch is occupied by amphibian species (e.g., Laan and Verboom 1990; Marsh and Pearman 1997; Fahrig 1998). Patch distribution across a landscape may also greatly influence whether a patch is occupied or not. The degree of patch isolation is often negatively associated with patch occupancy (Sjögren 1991; Vos and Stumpel 1995; Sjögren-Gulve and Ray 1996). Even manipulating the matrix habitat in between habitat patches can influence patch occupancy. For example, Sjögren-Gulve and Ray (1996) found that ditches meant to drain forest areas between frog ponds effectively isolated them even though the distance between ponds had not been altered.

Another complication is that different species respond to patchy landscapes in different ways. For example, Semlitsch (1998) found that six species of Ambystoma salamanders varied in their dispersal and use of habitat surrounding ponds. Some species dispersed and used terrestrial habitat up to 250 meters from the pond edge, suggesting that managers need to seriously consider providing extensive buffer zones surrounding water bodies and wetlands. Although knowledge of maximum dispersal and migration distances represents one of the most important pieces of information required to ensure the viability of amphibian metapopulations this information is currently lacking for the majority of Montana's amphibian species. Finally, species may also differ with respect to their response to habitat edges. For instance, demaynadier and Hunter (1998) found that while salamanders, frogs, and toads were all negatively effected by forest edges, salamanders were much more sensitive to abrupt forest edges than frogs and toads.

$\underline{\text { Research and Management Suggestions }}$

1. The effects of habitat fragmentation should be formally investigated for all amphibian species in Montana. Specifically, the degree to which each species tolerates habitat fragmentation should be identified.

2. Loss or deterioration of overwintering, breeding, foraging, or migration habitats used by various amphibian species should be avoided. 
3. When loss or deterioration of overwintering, breeding, foraging, or migration habitat is unavoidable, mitigation measures should be addressed in order to ensure that regional populations are maintained.

4. Radio telemetry studies should be conducted in order to identify common and maximum dispersal and migration distances for all of Montana's amphibian species.

5. Studies should document the demographic vital rates and/or population dynamics of individual populations and metapopulations in order to understand how the dynamics of individual populations and metapopulations are linked to landscape attributes, including elevation, distance between habitat patches, number of habitat patches in a given area, and the physical qualities of individual habitat patches and the matrix habitat between habitat patches. 


\section{Literature Cited}

Adams, M.J. 1997. Experimental analysis of tadpole mortality factors: effects of bullfrogs and exotic fish in the Puget Sound Lowlands, Washington. Dissertation, University of Washington, Seattle, Washington.

Alford, R.A., and S.J. Richards. 2000. Global amphibian declines: a problem in applied ecology. Annual Review of Ecology and Systematics 31: 133-165.

Alt, D.D. and D.W. Hyndman. 1986. Roadside geology of Montana. Mountain Press Publishing Company, Missoula, Montana. 427 p.

Alt, D.D. and D.W. Hyndman. 1995. Northwest exposures : a geologic story of the Northwest. Mountain Press Publishing Company, Missoula, Montana. 443 p.

Anderson, H.W., M.D. Hoover, and K.G. Reinhart. 1976. Forests and water: effects of forest management on floods, sedimentation and water supply. USDA Forest Service General Technical Report. PSW 18.

Ankney, C.D. 1996. An embarrassment of riches: too many geese. Journal of Wildlife Management 60:217-223.

Auiderwijk, A. 1989. Amphibians and reptile tunnels in the Netherlands. In T.E.S. Langton editor. Amphibians and roads: proceedings of the toad tunnel conference, Rendsburg, Federal Repbulic of Germany. Published by ACO Polymer Products Ltd, Hitching Road, Shefford, Bedfordshire, SG17 5JS, England. 202pp.

Bahls, P. 1992. The status of fish populations and management of high mountain lakes in the western United States. Northwest Science 66(3): 183-193.

Bartelt, P.E. 1998. Bufo boreas mortality. Herpetological Review 29(2): 96.

Beebee, T.J.C. 1997. Changes in dewpond numbers and amphibian diversity over 20 years on chalk downland in Sussex, England. Biological Conservation 81: 215-219.

Beebee, T.J.C., R.J. Flower, A.C. Stevenson, S.T. Patrick, P.G. Appleby, C. Fletcher, C. Marsh, J. Natkanski, B. Rippey, and R.W. Battarbee. 1990. Decline of the natterjack toad Bufo calamita in Britain: palaeoecological, documentary and experimental evidence for breeding site acidification. Biological Conservation 53: 1-20.

Beneski, J.T. Jr., E.J. Zalisko and J.H. Larsen, Jr. 1986. Demography and migratory patterns of the eastern long-toed salamander, Ambystoma macrodactylum columbianum. Copeia 1986(2): 398-408.

Berger, L., R. Speare, P. Daszak, D.E. Green, A.A. Cunningham, C.L. Goggin, R. Slocombe, M.A. Ragan, A.D. Hyatt, K.R. McDonald, H.B. Hines, K.R. Lips, G. Marantelli, and H. Parkes. 1998. Chytridiomycosis causes amphibian mortality associated with population declines in the rain forests of Australia and Central America. Proceedings of the National Academy of Sciences 95: 9031-9036.

Berrill, M., S. Bertram, A. Wilson, S. Louis, D. Brigham, and C. Stromberg. 1993. Lethal and sublethal impacts of pyrethroid insecticides on amphibian embryos and tadpoles. Environmental Toxicology and Chemistry 12(3): 525-539.

Berrill, M., S. Bertram, L. McGillivray, M. Kolohon, and B. Paul. 1994. Effects of low concentrations of forest-use pesticides on frog embryos and tadpoles. Environmental Toxicology and Chemistry 13(4): 657-664.

Birdsall, C.W., C.E. Grye, and A. Anderson. 1986. Lead concentrations in bullfrog Rana catesbeiana and green frog $R$. clamitans tadpoles inhabiting highway drainages. Environmental Pollution A. 40: 233-247. 
Bishop, D.W. and R. Hamilton. 1947. Polydactyly and limb duplication occurring naturally in the tiger salamander, Ambystoma tigrinum. Science 106: 641-642.

Black, J.H. 1969a. Yes--there are bullfrogs in Montana. Montana Outdoors 1969: 4.

Black, J.H. 1969b. The frog genus Rana in Montana. Northwest Science 43(4): 191-195.

Black, J.H. 1981. Oklahoma rattlesnake hunts --1981. Bulletin of the Oklahoma Herpetological Society 6: 39-43.

Blaustein, A.R. 1993. Declining amphibian populations in perspective. Park Science 1993(Fall): 8-9.

Blaustein, A.R. 1994. Chicken little or Nero's fiddle: a perspective on declining amphibian populations. Herpetologica 50: 85-87.

Blaustein, A.R., and D.B. Wake. 1990. Declining amphibian populations a global phenomenon? Trends in Ecology and Evolution 5: 203-204.

Blaustein, A.R., J.M. Kiesecker, D.P. Chivers and R.G. Anthony. 1997. Ambient UV-B radiation causes deformities in amphibian embryos. Proceedings of the National Academy of Sciences 94: 13735-13737.

Blaustein, A.R., P.D. Hoffman, D.G. Hokit, J.M. Kiesecker, S.C. Walls, and J.B. Hays. 1994a. UV repair and resistance to solar UV-B in amphibian eggs: a link to population declines? Proceedings of the National Academy of Sciences 91: 1791-1795.

Blaustein, A.R., D.G. Hokit, and R.K. O’Hara. 1994b. Pathogenic fungus contributes to amphibian losses in the pacific northwest. Biological Conservation 67:251-254.

Blaustein, A.R., B. Edmond, J.M. Kiesecker, J.J. Beatty, and D.G. Hokit. 1995. Ambient ultraviolet radiation causes mortality in salamander eggs. Ecological Applications 5: 740743.

Boarman W., and M. Sazaki. 1996. Highway mortality in desert tortoises and small vertebrates: Success of barrier fences and culverts. Pages 169-173 in Evink G., D. Ziegler, P. Garrett, and J. Berry, editors. Highways and movement of wildlife: Improving habitat connections and wildlife passageways across highway corridors. Proceedings of the Florida Department of Transportation/Federal Highway Administration Transportation-Related Wildlife Mortality Seminar [April 30-May 2, 1996, Orlando, Florida].

Boyer, R., and C.E. Grue. 1995. The need for water quality criteria for frogs. Environmental Health Perspectives 103: 352-357.

Bradford, D.F. 1983. Winterkill, oxygen relations, and energy metabolism of a submerged dormant amphibian, Rana muscosa. Ecology 64: 1171-1183.

Bradford, D.F. 1989. Allotopic distribution of native frogs and introduced fishes in high Sierra Nevada lakes of California: Implication of the negative effect of fish introductions. Copeia 1989: 775-778.

Bradford, D.F., F. Tabatabai, and D.M. Graber. 1993. Isolation of remaining populations of the native frog, Rana muscosa, by introduced fishes in Sequoia and Kings Canyon National Parks, California. Conservation Biology 7: 882-888.

Brana, F., L. Frechilla, and G. Orizaola. 1996. Effect of introduced fish on amphibian assemblages in mountain lakes of northern Spain. Herpetological Journal 6: 145-148.

Brattstrom, B.H. and M.C. Bondello. 1979. The effects of dune buggy sounds on the telencephalic auditory evoked response in the Mojave fringe-toed lizard, Uma scoparia Report to U.S. Bureau of Land Management, California Desert Program, Riverside, California. 31 p. Contract CA-060-CT7-2737. 
Bronmark, C., and P. Edenhamn. 1994. Does the presence of fish affect the distribution of tree frogs (Hyla arborea)? Conservation Biology 8(3): 841-845.

Bryant, S.V. and D.M. Gardiner. 1992. Retinoic acid, local cell-cell interactions, and pattern formation in vertebrate limbs. Developmental Biology 152: 1-25.

Buchanan, B.W. 1993. Effects of enhanced lighting on the behavior of noctural frogs. Animal Behaviour 45: 893-899.

Buck, S.V. 1997. Florida's Herp trade: a collector's paradise and a land exploited. Reptile and Amphibian Magazine. Jan/Feb. 1997: 72-81.

Bull, E.L., and B.E. Carter. 1996. Tailed frogs: distribution, ecology, and association with timber harvest in northeastern Oregon. USDA Forest Service, Research Paper PNW-RP-497, Portland, Oregon.

Burke, V.J. and J.W. Gibbons. 1995. Terrestrial buffer zones and wetland conservation: a case study of freshwater turtles in a Carolina Bay. Conservation Biology 9: 1365-1369.

Burton, T.M., and G.E. Likens. 1975a. Salamander populations and biomass in the Hubbard Brook Experimental Forest, New Hampshire. Copeia 1975: 541-546.

Burton, T.M., and G.E. Likens. 1975b. Energy flow and nutrient cycling in salamander populations in the Hubbard Brook Experimental Forest, New Hampshire. Ecology 56: 10681080.

Bury, R.B. 1983. Differences in amphibian populations in logged and old growth redwood forest. Northwest Science. 57(3): 167-178.

Bury, R.B. and P.S. Corn. 1988. Responses of aquatic and streamside amphibians to timber harvest: a review. Pages 165-181 in K.J. Raedeke, editor. Streamside management: riparian wildlife and forestry interactions. Institute of Forest Resources, University of Washington, Contribution No. 59.

Bury,R.B. and P.S. Corn. 1988. Douglas-fir forests in the Oregon and Washington Cascades: relation of the herpetofauna to stand age and moisture. Pages 11-22 in R.C. Szaro, K.E. Severson, and D.R. Patton, technical coordinators. Management of amphibians, reptiles, and small mammals in North America. General Technical Report RM-166. U.S. Forest Service, Rocky Mountain Forest and Range Experiment Station, Fort Collins, Colorado.

Bury, R.B., and J.A. Whelan. 1984. Ecology and management of the bullfrog. USFWS Resource Publication 155: 1-23.

Bury, R.B., C.K. Dodd, Jr., and G.M. Fellers. 1980. Conservation of the amphibia of the United States: a review. Department of the Interior, Fish and Wildlife Service Publication Number 134: 1-34, Washington, D.C., USA.

Carey, C. 1993. Hypothesis concerning the causes of the disappearance of Boreal toads from the mountains of Colorado. Conservation Biology 7(2): 355-362.

Carey, C., and C.J. Bryant. 1995. Possible interrelations among environmental toxicants, amphibian development, and decline of amphibian populations. Environmental Health Perspectives 103 (Suppl. 4): 13-17.

Carey, C., N. Cohen, and L. Rollins-Smith. 1999. Amphibian declines: an immunological perspective. Developmental and Comparative Immunology 23: 459-472.

Carpenter, H.L., and E.O. Morrison. 1973. Feeding behavior of the bullfrog, Rana catesbeiana, in north central Texas. Bios 44: 188-193.

Cavallo, B.J. 1997. Floodplain habitat heterogeneity and the distribution, abundance, and behavior of fishes and amphibians in the Middle Fork Flathead River Basin, Montana. Master of Science Thesis, University of Montana. Missoula, MT. 133 pp. 
Christiansen, J.L., and B.J. Gallaway. 1984. Raccoon removal, nesting success, and hatchling emergence in Iowa turtles with special reference to Kinosternon flavescens (Kinosternidae). Southwestern Naturalist 29: 343-348.

Clarkson, R.W., and J.C. DeVos, Jr. 1986. The bullfrog, Rana catesbeiana Shaw, in the lower Colorado River, Arizona, California. Journal of Herpetology 20: 42-49.

Collins, J.P. 1981. Distribution, habitats and life history variation in the tiger salamander, Ambystoma tigrinum, in east-central and southeast Arizona. Copeia 1981: 666-675.

Coman, B.J., and H. Brunner. 1972. Food habits of the feral house cat in Victoria. Journal of Wildlife Management 36: 848-853.

Congdon, J.D., A.E. Dunham, and R.C. van Loben Sels. 1993. Delayed sexual maturity and demographics of Blanding's turtles (Emydoidea blandingii): implications for conservation and management of long-lived organisms. Conservation Biology 7(4): 826-833.

Connor, E.J., W.J. Trush, and A.W. Knight. 1988. Effects of logging on Pacific giant salamanders: influence of age-class composition and habitat complexity. Bulletin of the Ecological Society of America 69 (Suppl.): 104-105.

Cooke, A.K. 1981. Tadpoles as indicators of harmful levels of pollution in the field. Environmental Pollution (Series A) 25: 123-133.

Cooper, C.M., P.C. Smiley, Jr., J.D. Wigginton, S.S. Knight, and K.W. Kallies. 1998. Vertebrate use of habitats created by installation of field-scale erosion control structures. Journal of Freshwater Ecology 12(2): 199-207.

Corn, J., and P. Hendricks. 1998. Lee Metcalf National Wildlife Refuge bullfrog and painted turtle investigations: 1997. Montana Natural Heritage Program. Helena, MT. 20pp.

Corn, P.S. 1994. What we know and don't know about amphibian declines in the west. Pages 59-67 in W. Covington and L. DeBano (technical coordinators.), Sustainable ecological systems: implementing an ecological approach to land management. U.S.D.A. Forest Service, Rocky Mountain Forest and Range Experimental Station, Ft. Collins, Colorado. General Technical Report RM-247.

Corn, P.S. and R.B. Bury. 1989. Logging in Western Oregon: responses of headwater habitats and stream amphibians. Forest Ecology and Management. 29: 39-57.

Corn, P.S. and R.B. Bury. 1990. Sampling methods for terrestrial amphibians and reptiles. pp. 1-34. In: A.B. Carey and L.F. Ruggiero (eds). Wildlife-habitat relationships: sampling procedures for Pacific Northwest vertebrates. USDA Forest Service General Technical Report PNW-GTR-256.

Corn, P.S., W. Stolzenburg, and R.B. Bury. 1989. Acid precipitation studies in Colorado and Wyoming: interim report of surveys of montane amphibians and water chemistry. Biological Report 80(40.26). Air Pollution and Acid Rain Report No. 26. 57 pp.

Crother, B.I. (ed.) 2000. Scientific and standard English names of amphibians and reptiles of North America north of Mexico, with comments regarding confidence in our understanding. SSAR Herpetological Circular No. 29:1-82.

Crother, B.I. (ed.) 2008. Scientific and standard English names of amphibians and reptiles of North America north of Mexico. SSAR Herpetological Circular No. 37:1-84.

Crother, B.I., J. Boundy, J.A. Campbell, K. De Quieroz, D. Frost, D.M. Green, R. Highton, J.B. Iverson, R.W. McDiarmid, P.A. Meylan, T.W. Reeder, M.E. Seidel, J.W. Sites, Jr., S.G. Tilley, and D.B. Wake. 2003. Scientific and standard English names of amphibians and reptiles of North America North of Mexico: update. Herpetological Review 34:196-203. 
Crother, B.I., J. Boundy, K. De Quieroz, and D. Frost. 2001. Scientific and standard English names of amphibians and reptiles of North America North of Mexico: errata. Herpetological Review 32:152-153.

Daszak, P., A.A. Cunningham and A.D. Hyatt. 2000. Emerging infectious diseases of wildlife threats to biodiversity and human health. Science 287: 443-449.

Daszak, P., L. Berger, A.A. Cunningham, A.D. Hyatt, D.E. Green, and R. Speare. 1999. Emerging infectious diseases and amphibian population declines. Emerging Infectious Diseases 5(6): 735-748.

Daugherty, C.H. and A.L. Sheldon. 1982. Age specific movement patterns of the frog Ascaphus truei. Herpetologica 38(4): 468-474.

DeBano, L.F., D.G. Neary and P.F. Ffolliott. 1998. Fire's effects on ecosytems. John Wiley and Sons, New York.

DeLacey, W.W. 1876. A trip up the South Snake River in 1863. Contributions to the Historical Society of Montana 1: 130-132.

demaynadier, P.G. and M.L. Hunter. 1998. Effects of silvicultural edges on the distribution and abundance of amphibians in Maine. Conservation Biology 12:340-352.

deMayandier, P.G., and M.L. Hunter, Jr. 1995. Forest canopy closure and juvenile emigration by pool-breeding amphibians in Maine. Journal of Wildlife Management 63(2): 441-450.

Denney, R.N. 1974. The impact of uncontrolled dogs on wildlife and livestock. Transactions of the 39th North American Wildlife and Natural Resources Conference. Pp. 257-291.

Dickman, M. 1968. The effect of grazing by tadpoles on the structure of a periphyton community. Ecology 49: 1188-1190.

Dodd, C.K., Jr. 1996. Use of terrestrial habitats by amphibians in the sandhill uplands of northcentral Florida. Alytes 14: 42-52.

Dodd, C.K., Jr. and B.S. Cade. 1998. Movement patterns and the conservation of amphibians breeding in small, temporary wetlands. Conservation Biology 12(2): 331-339.

Dole, J.W. 1965. Summer movement of adult leopard frogs, Rana pipiens Schreber, in northern Michigan. Ecology 46: 236-255.

Donkor, N.T. and J.M. Fryxell. 1999. Impact of beaver foraging on structure of lowland boreal forests of Algonquin Provincial Park, Ontario. Forest Ecology and Management 118 (1-3): 83-92.

Drost, C.A., and G.M. Fellers. 1996. Collapse of a regional frog fauna in the Yosemite area of the California Sierra Nevada, USA. Conservation Biology 10: 414-425.

Duellman, W.E., and L. Trueb. 1986. Biology of amphibians. Johns Hopkins University Press, Baltimore, Maryland, USA.

Dunson, W.A., R.L. Wyman, and E.S. Corbett. 1992. A symposium on amphibian declines and habitat acidification. Journal of Herpetology 26(4): 349-442.

Ehmann, H. and H.G. Cogger. 1985. Australia's endangered herpetofauna: a review of criteria and policies. Pages 435-447. In: G. Grigg, R. Shine, and H. Ehmann (eds.) The biology of Australasian frogs and reptiles. Surrey Beatty and Sons, Sydney.

Ehrlich, D. 1979. Predation by bullfrog tadpoles (Rana catesbeiana) on eggs and newly hatched larvae of the plains leopard frog (Rana blairi). Bulletin of the Maryland Herpetological Society 15: 25-26.

Elton, C.S. 1958. The ecology of invasions by animals and plants. Methuen, London, England. 
Ewert, M.A. 1969. Seasonal movements of the toads Bufo americanus and Bufo cognatus in northwestern Minnesota. Ph.D. dissertation. University of Minnesota, St. Paul, Minnesota. $193 \mathrm{pp}$.

Fahrig, L. 1998. Relative effects of habitat loss and fragmentation on population extinction. Journal of Wildlife Management 61(3): 603-610.

Fahrig, L., and G. Merriam. 1994. Conservation of fragmented populations. Conservation Biology 8:50-59.

Fahrig, L., J. H. Pedlar, S. E. Pope, P. D. Taylor, and J. F. Wegner. 1995. Effect of road traffic on amphibian density. Biological Conservation 73(3): 177-182.

Figiel, C.R., Jr. and R.D. Semlitsch. 1990. Population variation in survival and metamorphosis of larval salamanders (Ambystoma maculatum) in the presence and absence of fish predation. Copeia 1990: 818-826.

Fisher, R.N. and H.B. Shaffer. 1996. The decline of amphibians in California's Great Central Valley. Conservation Biology 10(5): 1387-1397.

Fleischner, T.L. 1994. Ecological costs of livestock grazing in western North America. Conservation Biology 8(3): 629-644.

Fontenot, L.W., G.P. Noblet, and S.G. Platt. 1994. Rotenone hazards to amphibians and reptiles. Herpetological Review 25(4): 150-156.

Friend, G.R. 1993. Impact of fire on small vertebrates in mallee woodlands and heathlands of temperate Australia: a review. Biological Conservation 65: 99-114.

Fuller, P.L., L.G. Nico, and J.D. Williams. 1999. Nonindigenous fishes introduced into inland waters of the United States. American Fisheries Society Special Publication 27.

Gamradt, S.C., and L.B. Kats. 1996. Effect of introduced crayfish and mosquitofish on California newts. Conservation Biology 10: 1155-1162.

Gamradt, S.C. and L.B. Kats. 1997. Impact of chaparral wildfire-induced sedimentation on oviposition of stream-breeding California newts (Taricha torosa). Oecologia 110: 546-549.

Gendron, A.D., C.A. Bishop, R. Fortin, and A. Hontela. 1997. In vivo testing of the functional integrity of the corticosterone-producing axis in mudpuppy (Amphibia) exposed to chlorinated hydrocarbons in the wild. Environmental Toxicology and Chemistry 16(8): 16941706.

Griffiths, R.A., J. Denton, and A.L.C. Wong. 1993. The effect of food level on competition in tadpoles: interference mediated protothecan algae? Journal of Animal Ecology 62: 274-279.

Groves, C.R., E.F. Cassirer, D.L. Genter, and J.D. Reichel. Element Stewardship. Abstract for the Coeur d' Alene Salamander Plethodon idahoensis. Natural Areas Journal 16: 238-247.

Gulve, P.S. 1994. Distribution and extinction patterns within a northern metapopulation of the pool frog, Rana lessonae. Ecology 75(5): 1357-1367.

Hailman, J.P. 1982. Extremely low ambient light levels of Ascaphus truei. Journal of Herpetology 16: 83-84.

Hairston, N.G., Sr. 1987. Community ecology and salamander guilds. Cambridge University Press, Cambridge.

Hall, R.J., and P.F.P. Henry. 1992. Assessing effects of pesticides on amphibians and reptiles: status and needs. Herpetological Journal 2: 65-71.

Hammerson, G.A. 1982. Bullfrog eliminating leopard frogs in Colorado? Herpetological Review 13: 115-116.

Hannah and Smith. 1995. Effects of prescribed burning on herptiles in southeastern Queensland. Memoirs of the Queensland Museum 38: 529-531. 
Hanski, I., and M. Gilpin. 1991. Metapopulation dynamics: brief history and conceptual domain. Biological Journal of the Linaean Society 42: 3-16.

Harfenist, A., T. Power, K.L. Clark, and D.B. Peakall. 1989. A review and evaluation of the amphibian toxicological literature. Canadian Wildlife Service Technical Report Series 61. Canadian Wildlife Service, Ottawa, Canada. 222 pp.

Hart, M.M., W.A. Williams, P.C. Thornton, K.P. McLaughlin, C.M. Tobalske, B.A. Maxell, D.P. Hendricks, C.R. Peterson, and R.L. Redmond. 1998. Montana atlas of terrestrial vertebrates. Montana Cooperative Wildlife Research Unit, The University of Montana. Missoula, Montana vii +1302 p.

Hawkins, C.P., M.L. Murphy, N.H. Anderson, and M.A. Wilzbach. 1983. Density of fish and salamanders in relation to riparian canopy and physical habitat in streams of the northwestern United States. Canadian Journal of Fisheries and Aquatic Sciences 40: 1173-1185.

Hebard, W.B. and R.B. Brunson. 1963. Hind limb anomalies of a western Montana population of the pacific tree frog, Hyla regilla. Copeia 1963: 570-572.

Hecnar, S.J. and R.T. M'Closkey. 1996. Regional dynamics and the status of amphibians. Ecology 77: 2091-2097.

Hecnar, S.J. and R.T. M'Closkey. 1997. The effects of predatory fish on amphibian species richness and distribution. Biological Conservation 79: 123-131.

Henderson, R.W. 1992. Consequences of predator introductions and habitat destruction on amphibians and reptiles in the post-Columbus West Indies. Caribbean Journal of Science 28(1-2): 1-10.

Hendricks, P., and J.D. Reichel. 1996. Preliminary amphibian and reptile survey of the Ashland District, Custer National Forest: 1995. Montana Natural Heritage Program. Helena, Montana. 79pp.

Hill, S.R. Jr. 1995. Migratory chronology of adult tiger salamanders (Ambystoma tigrinum) and survey of larvae of the tiger salamander in the northern range of Yellowstone National Park. Masters thesis, Montana State University. Bozeman, MT. 72 pp.

Hockin, D.C., K. O'Hara, D. Cragg-Hine, and J.W. Eaton. 1985. Fish population estimation: the use of rotenone to evaluate the reliability of a removal technique. Aquaculture and Fisheries Management 16: 349-357.

Hopey, M.E., and J.W. Petranka. 1994. Restriction of wood frogs to fish-free habitats: how important is adult choice? Copeia 1994: 1023-1025.

Hopkins, W.A., M.T. Mendona, and J.D. Congdon. 1997. Increased circulating levels of testosterone and corticosterone in southern toads, Bufo terrestris, exposed to coal combustion waste. General Comparative Endrocrinology 108: 237-246.

Houlahan, J.E., C.S. Findlay, B.R. Schmidt, A.H. Meyer, and S.L. Kuzmin. 2000. Quantitative evidence for global amphibian population declines. Nature 404(13): 752-755.

Huckabee, J.W., C.P. Goodyear, and R.D. Jones. 1975. Acid rock in the Great Smokies: unanticipated impact on aquatic biota of road construction in regions of sulfide mineralization. Transactions of the American Fisheries Society 4:677-684.

Jackson, S.D., and T.F. Tyning. 1989. Effectiveness of drift fences and tunnels for moving spotted salamanders Ambystoma maculatum under roads. In T.E.S. Langton editor. Amphibians and roads: proceedings of the toad tunnel conference, Rendsburg, Federal Repbulic of Germany. Published by ACO Polymer Products Ltd, Hitchin Road, Shefford, Bedfordshire, SG17 5JS, England. 202 pp. 
Jennings, M.R., and M.P. Hayes. 1985. Pre-1900 overharvest of California red-legged frogs (Rana aurora draytoni): the inducement for bullfrog (Rana catesbeiana) introduction. Herpetologica 41: 94-103.

Jennings, M.R., D.F. Bradford, and D.F. Johnson. 1992. Dependence of the garter snake Thamnophis elegans on amphibians in the Sierra Nevada of California. Journal of Herpetology 26: 503-505.

Johnson, C.R., and J.E. Prine. 1976. The effects of sublethal concentrations of organophosphorus insecticides and an insect growth regulator on temperature tolerance in hydrated and dehydrated juvenile western toads, Bufo boreas. Comparative Biochemistry and Physiology 53A:147-149.

Johnson, P.T.J., K.B. Lunde, E.G. Ritchie, and A.E. Launer. 1999. The effect of trematode infection on amphibian limb development and survivorship. Science 284: 802-804.

Jones, K.B. 1988. Comparison of herpetofaunas of a natural and altered riparian ecosystem. Pages 222-227 in R.C. Szaro, K.E. Severson, and D.R. Patton, technical coordinators. Management of amphibians, reptiles, and small mammals in North America. General Technical Report RM-166. U.S. Forest Service, Rocky Mountain Forest and Range Experiment Station, Fort Collins, Colorado.

Jordan, D.S. 1891. A reconnoissance of the streams and lakes of Yellowstone National Park, Wyoming. The American Angler 21(2), November 1891.

Kauffman, J.B. and W.C. Krueger. 1984. Lifestock impacts on riparian ecosystems and streamside management implications: a review. Journal of Range Management 37(5): 430436.

Kerbes, R.H., P.M. Kotanen, and R.J. Jefferies. 1990. Destruction of wetland habitats by lesser snow geese: a keystone species on the west coast of Hudson Bay. Journal of Applied Ecology 27:242-258.

Kiesecker, J.M. 1997. The effects of pathogens, UV-B radiation, and introduced species on amphibians in the Pacific Northwest. Ph.D. dissertation, Oregon State University. Corvallis, OR. 194 pp.

Kiesecker, J.M., and A.R. Blaustein. 1995. Synergism between UV-B radiation and a pathogen magnifies amphibian embryo mortality in nature. Proceedings of the National Academy of Sciences 92: 11049-11052.

Kiesecker, J.M., and A.R. Blaustein. 1997a. Population differences in responses of red-legged frogs (Rana aurora) to introduced bullfrogs. Ecology 78: 1752-1760.

Kiesecker, J.M., and A.R. Blaustein. 1997b. Influences of egg laying behavior on pathogenic infection of amphibian eggs. Conservation Biology 11: 214-220.

Kiesecker, J.M., and A.R. Blaustein. 1998. Effects of introduced bullfrogs and smallmouth bass on microhabitat use, growth, and survival of native red-legged frogs (Rana aurora). Conservation Biology 12: 776-787.

Kirk, J.J. 1988. Western spotted frog (Rana pretiosa) mortality following forest spraying of DDT. Herpetological Review 19(3): 51-53.

Kirkland, G.L., Jr., H.W. Snoddy, and T. Lamsler. 1996. Impact of fire on small mammals and amphibians in a Central Appalachian deciduous forest. American Midland Naturalist 135: 253-260.

Knapp, R.A. 1996. Non-native trout in natural lakes of the Sierra Nevada: an analysis of their distribution and impacts on native aquatic biota. Pages 363-406 in Sierra Nevada ecosystem project: final report to Congress, volume III, assessments, commissioned reports, and 
background information. University of California Centers for Water and Wildland Resources, Wildland Resources Center Report 38, Davis, California.

Koch, E.D., and C.R. Peterson. 1995. The amphibians and reptiles of Yellowstone and Grand Teton National Parks. University of Utah Press. Salt Lake City, Utah. 188 pp.

Koch, E.D., G. Williams, C.R. Peterson, and P.S. Corn. 1996. Conference on declining and sensitive amphibians in the Northern Rockies and the Pacific Northwest: a summary paper. Idaho Herpetological Society Technical Bulletin and U.S. Fish and Wildlife Service Report, Boise, Idaho.

Korschgen, L.J., and T.S. Baskett. 1963. Foods of impoundment and stream dwelling bullfrogs in Missouri. Herpetologica 19: 88-99.

Kucken, D.J., J.S. Davis, J.W. Petranka, and C.K. Smith. 1994. Anakeesta Stream acidification and metal contamination - effects on a salamander community. Journal of Environmental Quality 23(6): 1311-1317.

Kupferberg, S.J. 1994. Exotic larval bullfrogs (Rana catesbeiana) as prey for native garter snakes: functional and conservation implications. Herpetological Review 25(3): 95-97.

Kupferberg, S.J. 1996. The ecology of native tadpoles (Rana boylii and Hyla regilla) and the impact of invading bullfrogs (Rana catesbeiana) in a northern California river. Ph.D. dissertation, University of California at Berkeley, Berkeley, California. $289 \mathrm{pp}$.

Kupferberg, S.J. 1997. Bullfrog (Rana catesbeiana) invasion of a California river: the role of larval competition. Ecology 78: 1736-1751.

Laan, R., and B. Verboom. 1990. Effects of pool size and isolation on amphibian communities. Biological Conservation 54:251-262.

Langton, T.E.S. (ed.). 1989. Amphibians and Roads. Proceedings of the toad tunnel conference. Rendsburg, Federal Republic of Germany, 7-8 January 1989. ACO Polymer Products, Shefford Bedfordshire, United Kingdom pp. 202.

Laurance, W.F., K.R. McDonald, and R. Speare. 1996. Epidemic disease and the catastrophic decline of Australian rain forest frogs. Conservation Biology 10:406-413.

Lawler, S.P., D. Dritz, T. Strange, and M. Holyoak. 1999. Effects of introduced mosquitofish and bullfrogs on the threatened California red-legged frog. Conservation Biology 13(3): 613-622.

Lehtinen, R.M., S.M. Galatowitsch, and J.R. Tester. 1999. Consequences of habitat loss and fragmentation for wetland amphibian assemblages. Wetlands 19(1): 1-12.

Lefcort, H., R.A. Meguire, L.H. Wilson, and W.F. Ettinger. 1998. Heavy metals alter the survival, growth, metamorphosis, and antipredatory behavior of Columbia spotted frog (Rana luteiventris) tadpoles. Archives of Environmental Contaminants and Toxicology 35: 447-456.

Levell, J. 1995. A field guide to reptiles and the law. Serpent's Tale Natural History Book Distribution. Excelsior, Minnisota. 240 pp.

Lewis, D.L., G.T. Baxter, K.M. Johnson, and M.D. Stone. 1985. Possible extinction of the Wyoming toad, Bufo hemiophrys baxteri. Journal of Herpetology 19: 166-168.

Licht, L.E. 1969. Palatability of Rana and Hyla eggs. American Midland Naturalist 82: 296298.

Lind, A.J., H.H. Welsh, Jr., and R.A. Wilson. 1996. The effects of a dam on breeding habitat and egg survival of the Foothill Yellow-legged frog (Rana boylii) in Northwestern California. Herpetological Review 27(2): 62-67. 
Liss, W.J., and G.L. Larson. 1991. Ecological effects of stocked trout on North Cascades naturally fishless lakes. Park Science 11:22-23.

Lips, K.R. 1999. Mass mortality and population declines of anurans at an upland site in Western Panama. Conservation Biology 13: 117-125.

Lodge, D.M. 1993. Biological invasions: lessons for ecology. Trends in Ecology and Evolution 8: 133-137.

Loeffler, C. (ed.). 1998. Conservation plan and agreement for the management and recovery of the Southern Rocky Mountain population of the boreal toad (Bufo boreas boreas). Boreal Toad Recovery Team. 80 pp.

Lyon, L.J., H.S. Crawford, E Czuhai, R.L. Fredriksen, R.F. Harlow, L.J. Metz, and H.A. Pearson. 1978. Effects of fire on fauna: a state-of-knowledge review. United States Department of Agriculture Forest Service GTR WO-6.

MacArthur, R.H., and E.O. Wilson. 1967. The theory of island biogeography. Princeton University Press, Princeton, New Jersey. 203 pp.

Mahaney, P.A. 1994. Effects of freshwater petroleum contamination on amphibian hatching and metamorphosis. Environmental Toxicology and Chemistry 13(2):259-265.

Maniero, G.D., and C. Carey. 1997. Changes in selected aspects of immune function in the leopard frog, Rana pipiens, associated with exposure to cold. Journal of Comparative Physiology 167:256-263.

Manny, B.A., W.C. Johnson, and R.G. Wetzel. 1994. Nutrient additions by waterfowl to lakes and reservoirs: predicting their effects on productivity and water quality. Hydrobiologia 279/280:121-132.

Marsh, D.M., and P.B. Pearman. 1997. Effects of habitat fragmentation on the abundance of two species of leptodactylid frogs in an Andean montane forest. Conservation Biology 11:13231328.

Maxell, B.A., P.S. Corn, P. Hendricks, T. Koch, C. Peterson, and K. Werner. 1998. Brief overview of boreal toad status in USFS Region 1. Unpublished report. 8 pp.

Maxell, B.A., and D.G. Hokit. 1999. Amphibians and reptiles. Pages 2.1-2.30 In G. Joslin and H. Youmans, committee chairs. Effects of recreation on Rocky Mountain wildlife: a compendium of the current state of understanding in Montana. Committee on Effects of Recreation on Wildlife, Montana Chapter of the Wildlife Society.

Maxell, B.A., J.K. Werner, P. Hendricks, and D. Flath. 2003. Herpetology in Montana: a history, status summary, checklists, dichotomous keys, accounts for native, potentially native, and exotic species, and indexed bibliography. Olympia, WA: Society for Northwestern Vertebrate Biology. Northwest Fauna 5: 1-138.

McCoid, M.J., and P.W. Bettoli. 1996. Additional evidence for rotenone hazards to turtles and amphibians. Herpetological Review 27(2): 70-71.

McGraw, R.L., II. 1997. Timber harvest effects on metamorphosed and larval long-toed salamanders (Ambystoma macrodactylum). Masters thesis, University of Montana, Missoula Montana. $74 \mathrm{pp}$.

McLaughlin, G.S. 1999. Draft revised recovery plan for the Santa Cruz long-toed salamander. U.S. Fish and Wildlife Service Region 1. Portland, Oregon.

McLeod, R.F. and J.E. Gates. 1998. Response of herpetofaunal communities to forest cutting and burning at Chesapeake Farms, Maryland. American Midand Naturalist 139: 164-177.

Montana Code Annotated 87-2-101(10), 87-2-603, 87-3-118, and 87-2-103(1)(d). 
Morin P.J. 1983. Predation, competition, and the composition of larval anuran guilds. Ecological Monographs 53: 119-138.

Moyle, P.B. 1973. Effects of introduced bullfrogs, Rana catesbeiana on the native frogs of the San Joaquin Valley, California. Copeia 1973(1): 18-22.

Murphy, M.L. and J.D. Hall. 1981. Vareid effects of clear-cut logging on predators and their habitat in small streams of the Cascade Mountains, Oregon. Canadian Journal of Fisheries and Aquatic Sciences 38: 137-145.

Murphy, M.L., C.P. Hawkins, and N.H. Anderson. 1981. Effects of canopy modification and accumulated sediment on stream communities. Transactions of the American Fisheries Society 110: 469-478.

Mushinsky, H.R. 1985. Fire and the Florida sandhill herpetofaunal community: with special attention to responses of Cnemidophorus sexlineatus. Herpetologica 41: 333-342.

Nace, G.W., and J.K. Rosen. 1979. Source of amphibians for research II. Herpetological Review 10: 8-15.

Nagl, A.M., and R. Hofer. 1997. Effects of ultraviolet radiation on early larval stages of the Alpine newt, Triturus alpestris, under natural and laboratory conditions. Oecologia 110: 514-519.

Nash, R.F., G.G. Gallup, Jr., and M.K. McClure. 1970. The immobility reaction in leopard frogs (Rana pipiens) as a function of noise-induced fear. Psychonometric. Science 21(3): 155-156.

Nico, L.G., and P.L. Fuller. 1999. Spatial and temporal patterns of nonindigenous fish introductions in the United States. Fisheries 24(1): 16-27.

Nussbaum, R.A., E.D. Brodie, Jr., and R.M. Storm. 1983. Amphibians and reptiles of the Pacific Northwest. University of Idaho Press. Moscow, Idaho. 332 pp.

Nyman, S. 1986. Mass mortality in larval Rana sylvatica attributable to the bacterium, Aeromonas hydrophila. Journal of Herpetology 20:196-201.

Olson, D.H. 1989. Predation on breeding western toads (Bufo boreas). Copeia 1989(2):391397.

Olson, D.H. 1992. Ecological susceptibility of amphibians to population declines. Pages 55-62 in R.R. Harris, D.E. Erman (technical Coordinators) and H.M. Kerner (editors). Proceedings of symposium on biodiversity of northwestern California. University of California Wildland Resources Center, Report 29, Davis, California.

Olson, D.H., W.P. Leonard and R.B. Bury. 1997. Sampling amphibians in lentic habitats. Northwest Fauna Number 4. Society for Northwest Vertebrate Biology. pp. 134.

Ouellet, M., J. Bonin, J. Rodrigue, J.L. Desgranges and S. Lair. 1997. Hindlimb deformities (Ectromelia, Ectrodactyly) in free-living anurans from agricultural habitats. Journal of Wildlife Diseases 33(1): 95-104.

Papp, M.G., and C.O.G. Papp. 2000. Decline in a population of the treefrog Phyllodytes luteolus after fire. Herpetological Review 31(2): 93-95.

Patla, D.A. 1997. Changes in a population of spotted frogs in Yellowstone National Park between 1953 and 1995: the effects of habitat modification. M.S. thesis, Idaho State University, Pocatello, Idaho. 215 pp.

Patla, D.A. 1998. Potential effects of native fish restoration projects on amphibians in Yellowstone National Park Part I. Report to National Park Service, Yellowstone National Park. 20 November 1998. 26 pp. 
Pechmann, J.k., and H.M. Wilbur. 1994. Putting declining amphibian populations in perspective: natural fluctuations and human impacts. Herpetologica 50(1): 65-84.

Petranka, J.W. 1989. Chemical interference competition in tadpoles: does it occur outside laboratory aquaria? Copeia 1989: 921-930.

Petranka, J.W. 1998. Salamanders of the United States and Canada. Smithsonian Institution Press, Washington D.C. 587 pp.

Pfenning, D.W., M.L.G. Loeb, and J.P. Collins. 1991. Pathogens as a factor limiting the spread of acannibalism in tiger salamanders. Oecologia 88: 161-166.

Phillips, K. 1990. Where have all the frogs and toads gone? Bioscience 40: 422-424.

Pimental, D. 1971. Ecological effects of pesticides on non-target organisms. U.S. Government Printing Office, Washington D.C. 220 pp.

Porter, K.R., and D.E. Hakanson. 1976. Toxicity of mine drainage to embryonic and larval boreal toads (Bufonidae: Bufo boreas). Copeia 1976: 327-331.

Post, D.M., J.P. Taylor, J.F. Kitchell, M.H. Olson, D.E. Schindler, and B.R. Herwig. 1998. The role of migratory waterfowl as nutrient vectors in a managed wetland. Conservation Biology 12:910-920.

Pough, F.H. 1980. The advantages of ectothermy for tetrapods. American Naturalist 115: 92112.

Pough, F.H. 1983. Amphibians and reptiles as low-energy systems. Pages 141-188 in Behavioral Energetics: the cost of survival in vertebrates. Ohio State University Press. Columbus, Ohio.

Pough, F.H., R.M. Andrews, J.E. Cadle, M.L. Crump, A.H. Savitzky, and K.D. Wells. 1998. Herpetology. Prentice-Hall Inc., Upper Saddle River, New Jersey. 577 pp.

Pounds, J.A., and M.L. Crump. 1994. Amphibian declines and climate disturbance: the case of the golden toad and harlequin frog. Conservation Biology 8(1): 72-85.

Pounds, J.A., M.P.L. Fogden, and J.H. Campbell. 1999. Biological response to climate change on a tropical mountain. Nature 398: 611-615.

Prior, K.A., and P. Weatherhead. 1994. Response of free-ranging eastern Massasauga rattlesnakes to human disturbance. Journal of Herpetology 28(2): 255-257.

Raphael, M.G. 1988. Long-term trends in abundance of amphibians, reptiles, and mammals in douglas-fir forests of northwestern California. Pages 23-31 in R.C. Szaro, K.E. Severson, and D.R. Patton, technical coordinators. Management of amphibians, reptiles, and small mammals in North America. General Technical Report RM-166. U.S. Forest Service, Rocky Mountain Forest and Range Experiment Station, Fort Collins, Colorado.

Rauscher, R.L. 1998. Amphibian and reptile survey on selected Montana Bureau of Reclamation impoundments. Montana Department of Fish, Wildlife and Parks, Nongame Program. Bozeman, Montana. 24 pp.

Reading, R.P., S.R. Beissinger, J.J. Grenston, and T.W. Clark. 1989. Attributes of black-tailed prairie dog colonies in northcentral Montana, with management recommendations for the conservation of biodiversity. Pages 13-28 in T.W. Clark, D. Hinckley, and T. Rich (editors). The prairie dog ecosystem: managing for biodiversity. Montana Bureau of Land Management, Wildlife Technical Bulletin no. 2.

Reaser, J.K. 1996. Spotted frog: catalyst for sharing common ground in the riparian ecosystems of Nevada's range landscape. U.S. Forest Service General Technical Report INT 343: 32-39. 1996. 
Redmond, R.L., M.M. Hart, J.C. Winne, W.A. Williams, P.C. Thornton, Z. Ma, C.M. Tobalske, M.M. Thornton, K.P. McLaughlin, T.P. Tady, F.B. Fisher, and S.W. Running. 1998. The Montana gap analysis project: final report. Montana Cooperative Wildlife Research Unit, University of Montana, Missoula, Montana. xiii +136 pp. + appendices.

Reichel, J.D. 1995. Preliminary amphibian and reptile survey of the Sioux District of the Custer National Forest: 1994. Montana Natural Heritage Program. Helena, Montana. 75 pp.

Reichel, J.D., and D.L. Flath. 1995. Identification guide to the amphibians and reptiles of Montana. Montana Outdoors 26(3): 15-34.

Reinking, L.N., C.H. Daugherty, and L.B. Daugherty. 1980. Plasma aldosterone concentrations in wild and captive western spotted frogs (Rana pretiosa). Comparative Biochemistry and Physiology 65A(4): 517-518.

Resetarits, W.J., Jr., and H.M. Wilbur. 1989. Choice of oviposition site by Hyla chrysoscelis: role of predators and competitors. Ecology 70: 220-228.

Robinson, G.R., R.D. Holt, M.S. Gaines, S.P. Hamburg, M.J. Johnson, H.S. Fitch, and E.A. Martinko. 1992. Diverse and contrasting effects of habitat fragmentation. Science 257: 524526.

Roedel, M.D., and D.P. Hendricks. 1998. Amphibian and reptile survey on the Bureau of Land Management Lewistown District: 1995 - 1998. Montana Natural Heritage Program. Helena, Montana. $53 \mathrm{pp}$.

Rosen, P.C., C.R. Schwalbe, D.A. Parizek Jr., P.A. Holm, and C.H. Lowe. 1995. Introduced aquatic vertebrates in Chiricahua region: effects on declining native ranid frogs. U.S. Forest Service General Technical Report RM 264: 251-261.

Rowe, C.L., O.M. Kinney, and J.D. Congdon. 1998. Oral deformities in tadpoles of the bullfrog (Rana catesbeiana) caused by conditions in a polluted habitat. Copeia 1998(1): 244-246.

Rowe, C.L., and W.A. Dunson. 1995. Impacts of hydroperiod on growth and survival of larval amphibians in temporary ponds of central Pennsylvania. Oecologia 102: 397-403.

Russell, R.W., S.J. Hecnar, and G.D. Haffner. 1995. Organochlorine pesticide residues in southern Ontario spring peepers. Environmental Toxicology and Chemistry 14: 815-817.

Russell, K.R., C.E. Moorman, J.K. Edwards, B.S. Metts, D.C. Guynn, Jr. 1999a. Amphibian and reptile communities associated with beaver (Castor canadensis) ponds and unimpounded streams in the Piedmont of South Carolina. Journal of Freshwater Ecology 14(2): 149-158.

Russell, K.P., Van Lear DH, Guyunn DC Jr. 1999b. Prescribed fire effects on herpetofauna: review and management implications. Wildlife Society Bulletin 27(2):374-384.

Saunders, H.O. 1970. Pesticide toxicities to tadpoles of the western chorus frog, Pseudacris triseriata, and Fowler's toad, Bufo woodhousei fowleri. Copeia 1970(2): 246-251.

Scadding, S.R. and M. Madden. 1986. Comparison of the effects of vitamin A on limb development and regeneration in the axolotl, Ambystoma mexicanum. Journal of Embryolgy and Experimental Morphology 91: 19-34.

Schaaf, R.T., and J.S. Garton. 1970. Raccoon predation on the American toad, Bufo americanus. Herpetologica 26: 334-335.

Schnick, R.A. 1974. A review of the literature on use of rotenone in fisheries. U.S. Fish and Wildlife Service, Literature Review 74-15. No. PB-235 454/AS. 130pp.

Schwalbe, C.R. 1993. Status of amphibians in Arizona. Park Science 1993(Fall): 10.

Scott, N.J., Jr. 1996. Evolution and management of the North American grassland herpetofauna. Pages 40-53 in D.M. Finch editor. Ecosystem disturbance and wildlife conservation in western grasslands: a symposium proceedings. General Technical Report RM-GTR-285. 
U.S. Forest Service, Rocky Mountain Forest and Range Experiment Station, Fort Collins, Colorado.

Scott, N.J., Jr., and R.A. Siegel. 1992. The management of amphibian and reptile populations: specific priorities and methodological and theoretical constraints. In D.R. McCullough and R.H. Barrett (eds.) Wildlife 2001: populations. Elsevier Applied Science Publications Limited. Essex, England.

Seale, D.B. 1980. Influence of amphibian larvae on primary production, nutrient flux, and competition in a pond ecosystem. Ecology 61: 1531-1550.

Semlitsch, R.D. 1998. Biological delineation of terrestrial buffer zones for pond-breeding salamanders. Conservation Biology 12:1113-1119.

Semlitsch, R.D., and J.W. Gibbons. 1988. Fish predation in size-structured populations of treefrog tadpoles. Oecologia 75: 321-326.

Sessions, S.K., R.A. Franssen, and V.L. Horner. 1999. Morphological clues from multilegged frogs: are retinoids to blame. Science 284: 800-802.

Sessions, S.K., and S.B. Ruth. 1990. Explanation for naturally occurring supernumerary limbs in amphibians. Journal of Experimental Zoology 254(1): 38-47.

Sexton, O.J., and C. Phillips. 1986. A qualitative study of fish-amphibian interactions in 3 Missouri ponds. Transactions of the Missouri Academy of Science 20: 25-35.

Sharps, J.C. and D.W. Uresk. 1990. Ecological review of black-tailed prairie dogs and associated species in western South Dakota. Great Basin Naturalist 50: 339-345.

Simberloff, S.S. 1993. Effects of fragmentation on some Florida ecosystems, and how to redress them. In D.A. Saunders, R.J. Hobbs, and P.R. Erlich, editors. Nature Conservation 3. Reconstruction of fragmented ecosystems, global and regional perspectives. Surrey Beatty and Sons, Chipping Norton, New South Wales, Australia.

Sinsch, U. 1990. Migration and orientation in anuran amphibians. Ethology Ecology and Evolution 2: 65-79.

Sjögren, P. 1991. Extinction and isolation gradients in metapopulations: the case of the pool frog (Rana lessonae). Biological Journal of the Linnean society 42:135-147.

Sjögren-Gulve, P., and C. Ray. 1996. Using logistic regression to model metapopulation dynamics: large-scale forestry extirpates the pool frog. Pages 111-137 in D.R. McCullough editor. Metapopulations and wildlife conservation. Island Press, Washington D.C., USA.

Skelly, D.K. 1992. Field evidence for a cost of behavioral antipredator response in a larval amphibian. Ecology 73: 704-708.

Skelly, D.K. 1996. Pond drying, predators, and the distribution of Pseudacris tadpoles. Copeia 1996: 599-605.

Souder, W. 2000. A plague of frogs: the horrifying true story. Hyperion, New York. 299 pp.

Soulé, M.E. 1990. The onslaught of alien species, and other challenges in the coming decades. Conservation Biology 4: 233-239.

Stebbins, R.C., and N.W. Cohen. 1995. A natural history of amphibians. Princeton University Press, Princeton, New Jersey. 316 pp.

Stewart, M.M. 1995. Climate driven population fluctuations in rain forest frogs. Journal of Herpetology 29(3): 437-446.

Swanson, D. L., B.M. Graves and K.L. Koster. 1996. Freezing tolerance/intolerance and cryoprotectant synthesis in terrestrially overwintering anurans in the Great Plains, USA. Journal of Comparative Physiology B Biochemistry, Systematics and Environmental Physiology 166(2): 110-119. 
Turner, F.B. 1957. The ecology and morphology of Rana pretiosa pretiosa in Yellowstone Park, Wyoming. Ph.D. dissertation, University of California, Berkeley, California. 252 pp.

Tyler, T.J., W.J. Liss, R.L. Hoffman, and L.M. Ganio. 1998. Experimental analysis of trout effects on survival, growth, and habitat use of two species of ambystomatid salamanders. Journal of Herpetology 32(3): 345-349.

Van Gelder, J.J. 1973. A quantitative approach to the mortality resulting from traffic in a population of Bufo bufo L. Oecologia 13: 93-95.

Van Rooy, P.T.J.C. and A.H.P. Stumpel. 1995. Ecological impacts of economic development on Sardinian Herpetofauna. Conservation Biology 9(2):263-269.

Vogl, R.J. 1973. Effects of fire on the plants and animals of a Florida wetland. American Midland Naturalist 89: 334-347.

Vos, C.C., and J.P. Chardon. 1998. Effects of habitat fragmentation and road density on the distribution pattern of the moor frog Rana arvalis. Journal of Applied Ecology 35: 44-56.

Vos, C.C., and A.H.P. Stumpel. 1995. Comparison of habitat-isolation parameters in relation to fragmented distribution patterns in the tree frog (Hyla arborea). Landscape Ecology 11:203214.

Wake, D.B. 1991. Declining amphibian populations. Science 253: 860.

Wake, D.B., and H. Morowitz. 1990. Declining amphibian populations - a global phenomena? Workshop sponsored by Board on Biology, National Research Council. Irvine, California.

Welsh, H.H. Jr. 1990. Relictual amphibians and old-growth forests. Conservation Biology 4(3): 309-319.

Welsh, H.H. Jr., and A.J. Lind. 1988. Old growth forests and the distribution of the terrestrial herpetofauna. Pages 439-458 in in R.C. Szaro, K.E. Severson, and D.R. Patton, technical coordinators. Management of amphibians, reptiles, and small mammals in North America. General Technical Report RM-166. U.S. Forest Service, Rocky Mountain Forest and Range Experiment Station, Fort Collins, Colorado.

Welsh, H.H., Jr., and L.M. Ollivier. 1998. Stream amphibians as indicators of ecosystem stress: a case study from California's redwoods. Ecological Applications 8(4): 1118-1132.

Werner, E.E. 1992. Competitive interactions between wood frog and northern leopard frog larvae: the influence of size and activity. Copeia 1992: 26-35.

Werner, J.K., B.A. Maxell, P. Hendricks, and D. Flath. 2004. Amphibians and reptiles of Montana. Missoula, MT: Mountain Press Publishing Company. 262p.

Werner, J.K., and J.D. Reichel. 1994. Amphibian and reptile survey of the Kootenai National Forest: 1994. Montana Natural Heritage Program, Helena, Montana. 104 pp.

Werner, J.K., T. Plummer, and J. Weaslehead. 1998. Amphibians and reptiles of the Flathead Indian Reservation. Intermountain Journal of Sciences 4(1-2): 33-49.

Weygoldt, P. 1989. Changes in the composition of mountain stream frog communities in the Atlantic Mountains of Brazil: frogs as indicators of environmental deteriorations? Studies on Neotropical Fauna and Environment 243: 249-255.

Wilbur, H.M. 1980. Complex life cycles. Annual Review of Ecology and Systematics 11: 6793.

Wilbur, H.M. 1997. Experimental ecology of food webs: complex systems in temporary ponds. Ecology 78(8): 2279-2302.

Wilbur, H.M., P.J. Morin, and R.N. Harris. 1983. Salamander predation and the structure of experimental communities and anuran responses. Ecology 64: 1423-1429. 
Wilkinson, T. 1996a. Utah ushers its frogs toward oblivion. High Country News, No. 19: 1, 1013. May 27, 1996.

Wilkinson, T. 1996b. Reptile rustlers. National Parks 1996 (November/December): 36-39.

Wilson, E.O., and F.M. Peter (editors) 1988. Biodiversity. National Academy Press, Washington, DC. $521 \mathrm{p}$.

Worthylake, K.M., and P. Hovingh. 1989. Mass mortality of salamanders (Ambystoma tigrinum) by bacteria (Acinetobacter) in an oligotrophic seepage mountain lake. Great Basin Naturalist 49:364-372.

Wyman, R.L. 1990. What's happening to the amphibians? Conservation Biology 4(4): 350-352.

Yanes, M., J.M. Velasco and F. Suarez. 1995. Permeability of roads and railways to vertebrates: the importance of culverts. Biological Conservation 71(3): 217-222. 


\section{INTRODUCTION TO SPECIES ACCOUNTS}

The following species accounts compile information on each species' distribution, conservation status, and biology across the species' range with a focus on Montana. These accounts are intended to be updated on a regular basis in order to provide everyone access to the latest information. Each species account contains the following sections:

Dot Distribution and Range Maps

Each map contains all point observation records that are currently in the Point Observation Database (POD) at the Montana Natural Heritage Program represented as black dots. Each map also shows shading which estimates the potential maximum limits of the species' range in the state based on general habitat types, major topographic features, and climate regimes. Dots and shading are overlayed on maps showing county boundaries, shaded relief, and major hydrographic features. The latest up-to-date distribution information can be found on the Montana Natural Heritage Program's TRACKER website at http://mtnhp.org

\section{Distribution/Taxonomy}

This section briefly describes what is known about the latitudinal, longitudinal, and elevational limits of the species overall range as well as those limits in Montana. The section also summarizes information on the number of subspecies that are currently recognized, which subspecies are present in Montana, and ongoing debates regarding taxonomy.

Maximum Elevation

This section identifies the maximum documented elevation for the species in Montana in both meters and feet, identifies the county in which the record was documented, and lists the source of this information.

\section{Identification}

This section discusses the key identifying morphological features of eggs, larvae, neonates, juveniles, and adults of the species as well identifying other species which might have similar morphological features.

\section{Habitat Use/Natural History}

This section reviews literature on the general natural history and habitat use of the species for breeding, foraging, and overwintering. In general this section tries to identify habitats the species depends on during each part of its life history as well the size of the species' seasonal or overall home range and maximum documented migration or dispersal distance. Other note worthy natural history information is also included.

\section{$\underline{\text { Status and Conservation }}$}

This section summarizes what is known about the species' general conservation status throughout its range and in Montana. It also reviews scientific literature on specific anthropogenic impacts that have been studied for the species.

\section{$\underline{\text { Research and Management Suggestions }}$}

This section provides a list of priority research and management issues for each species in Montana in order to provide for the conservation of the species in the state.

\section{Bibliography}

An attempt was made to compile a complete bibliography of published and gray literature for each species in order to provide everyone easy access to this information. All article citations are in alphabetical order, but articles that contain information specific to Montana are prefaced by an asterisk, *. 


\section{SPECIES ACCOUNTS FOR SPECIES DOCUMENTED IN MONTANA}

\section{Long-toed Salamander (Ambystoma macrodactylum)}

Up-to-date distribution and status information can be found on the Montana Natural Heritage Program's TRACKER website at http://mtnhp.org

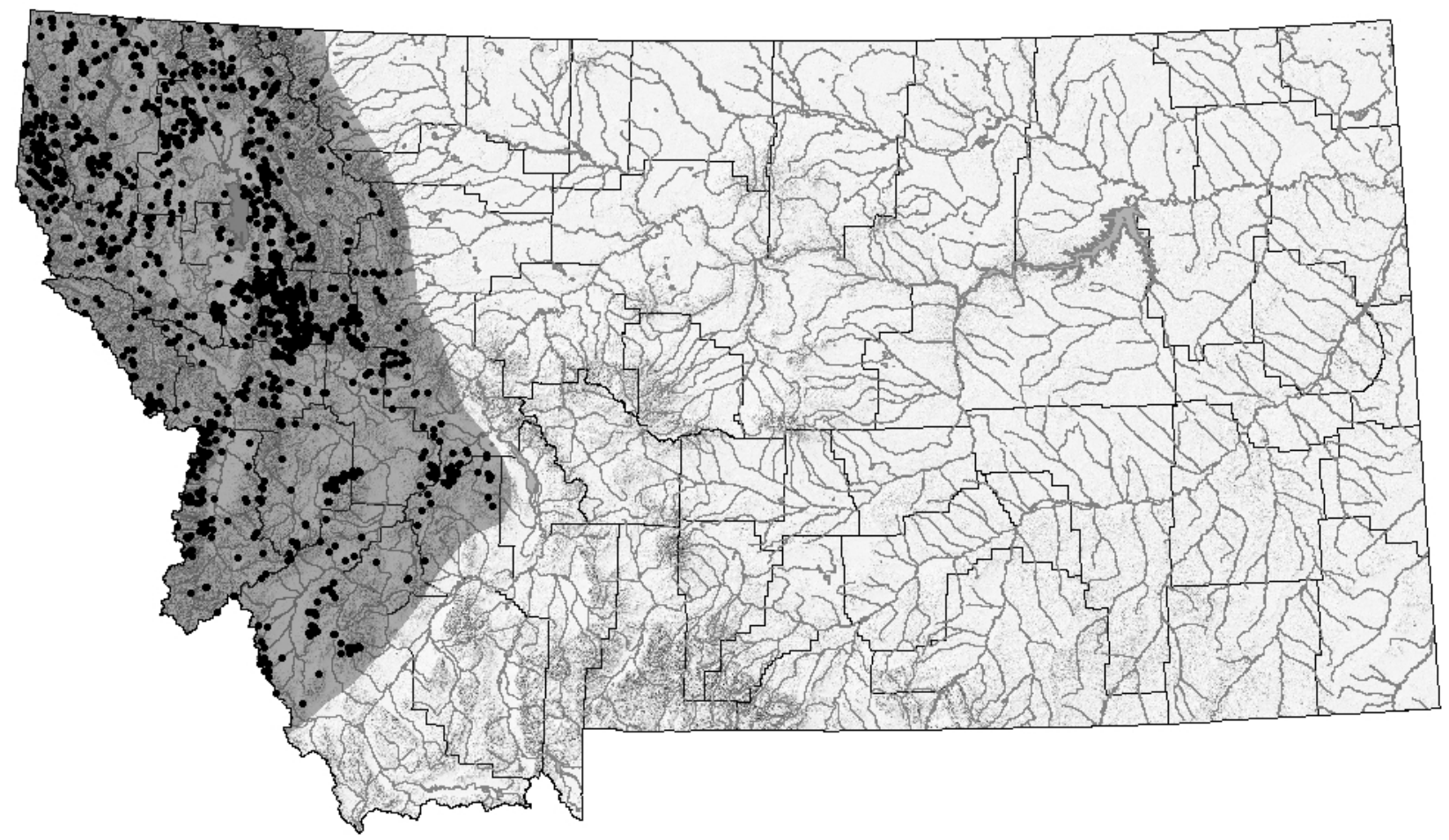

Distribution/Taxonomy

Five subspecies are recognized and range from central California through the Pacific Northwest to southeast Alaska at elevations up to or above 2,700 M (8,859 ft) (Ferguson 1961; Petranka 1998). Only a single subspecies, the northern long-toed salamander (A. m. krausei), occurs in Montana. Their known range in Montana extends west of the Rocky Mountain Front and the Missouri, Jefferson, and Beaverhead Rivers.

Maximum Elevation

2,774 m (9,100 ft) Keif Storrar - Lake, 1.5 miles W of Homer Youngs Peak, Beaverhead County (Zone 12, 287796E, 5020869N). 18 August 2003. (Werner et al. 2004).

\section{Identification}

Eggs:

Laid in clusters of 9-81 $(\mathrm{X}=23, \mathrm{SD}=14.5, \mathrm{~N}=36$ across 5 sites in northwest Montana). Each ovum is black or brown above, white to gray below, and surrounded by two jelly layers. Ovum diameters are approximately $2.5 \mathrm{~mm}$, but total egg diameters, including the two jelly layers, are usually 12-17 mm (Slater 1936).

\section{Larvae:}

Translucent, light tan, or black dorsally and laterally with black and gold flecks. White to pinkish ventrally. Three pairs of external feathery gills eminate from the sides of the head with 
9-13 gill rakers on their anterior surface (Russell and Bauer 2000). Snout to vent length (SVL) of $10-60 \mathrm{~mm}$.

Juveniles and Adults:

Fourth toe on the hind foot is elongate and longer than the sole of the foot. Incomplete or fully formed yellow, orangish, or reddish dorsal stripe may extend from the tip of the snout to the tip of the tail. Eyelids are the same color as the dorsal stripe. White flecking present on the lateral and ventral surfaces over a black lateral and pink ventral base color. 12-13 costal grooves are present. SVL of 25-80 mm (Russell et al. 1996).

Similar Species:

Adult Coeur d'Alene salamanders have nasolabial grooves and their toes are webbed and shorter than the soles of their feet. See sections on habitat use for differences in habitat used by longtoed and Coeur d'Alene salamanders. Tiger salamander eggs have 3 jelly layers and have total diameters less than $10 \mathrm{~mm}$, including the jelly layers. Larval tiger salamanders have larger heads are usually olive green to silvery white in base color and have 15-25 gill rakers on the anterior surface of their gills (Russell and Bauer 2000). See sections on distribution for geographic areas of possible overlap for long-toed and tiger salamanders.

\section{Habitat Use/Natural History}

Adults are found in a wide variety of habitats including semiarid sagebrush, alpine meadows, dry woodlands, humid forests, rocky shores of mountain lakes and disturbed agricultural areas (Nussbaum et al. 1983). Outside of the breeding season adults are primarily subterranean and have been documented to commonly move at least 600 meters from the nearest breeding site on the University of Montana's Lubrecht Experimental Forest (Jennifer Pierson, Wildlife Biology Program, University of Montana, pers. comm.). Breeding takes place in temporary or permanent ponds or in quiet water at the edge of lakes and streams. During the breeding season adults may be found in shallow waters or under logs, rocks, and other debris near water. Although individual animals tend to use the same migration routes, no preference in habitat, relative soil moisture or vegetation is evident for the species' movements to and from breeding pools (Beneski et al. 1986). Eggs are attached to vegetation or loose on the bottom at depths up to 0.8 meters. Larvae usually transform at the end of their first summer at low elevations or at the end of their second, third or fourth summer at high elevations and in cold waters at lower elevations (Howard and Wallace 1985, Bryce Maxell, pers. obs.). Larvae and adults feed on a variety of aquatic and terrestrial invertebrates and larvae feed on other amphibian larvae including conspecifics (Farner 1947; Anderson 1968; Walls et al. 1993, Bryce Maxell, pers. obs.).

\section{Status and Conservation}

Long-toed salamanders are the most widely distributed and common amphibian species west of the Continental Divide with larvae being found in most fishless standing waterbodies with adjacent soils that provide suitable terrestrial habitat (i.e., sites that are not surrounded by extensive areas of bare rock). Their status in the front ranges east of the Continental Divide is uncertain. Risk factors relevant to the viability of populations of this species are likely to include all the general risk factors described above with the exception of harvest and commerce. Individual studies that specifically identify risk factors or other issues relevant to the conservation of long-toed salamanders include the following. (1) A number of studies have found adverse impacts of introduced fish on long-toed salamanders. Funk and Dunlap (1999) 
found that trout effectively excluded salamander populations from lakes in the Bitterroot Mountains. However, when fish went extinct in lakes that did not have spawning habitat salamanders were able to recolonize some of them over a twenty year time period. In the Palouse region of northern Idaho Monello and Wright (1999) found the presence of long-toed salamanders to be highly negatively correlated with the presence of a variety of fish species, including largemouth bass, bluegill, channel catfish, and goldfish. Tyler et al. (1998a) found a similar pattern in North Cascades National Park and found that nitrogen levels were positively correlated with salamander densities in fishless lakes, apparently an indication of bottom up limitations on the food web. Similarly, long-toed salamanders in the central and northern portion of the Sierra Nevada Mountains are largely restricted to fishless lakes (Bradford and Gordon 1992 as cited in Knapp 1996). Tyler et al. (1998b) found that when rainbow trout were stocked in experimental ponds with long-toed salamanders, larval survivorship was lower and larval body lengths were smaller than in control ponds without fish, supporting the theory that introduced trout not only impact salamanders through direct predation, but also indirectly by increasing refuge use and, thereby, reducing foraging time. (2) In a study of the long-toed salamander in Douglas-fir forests in the Swan River Valley McGraw (1997) found that areas where overstory removal (250-300 trees harvested per hectare) and new forestry (leave 13-25 dominant tree species per hectare and retain all snags and hardwoods) harvest techniques were applied had less ground cover, higher soil temperatures, and $75 \%$ fewer terrestrial salamanders than control plots. Interestingly, he also found that larvae were more abundant in ponds where a fraction of the pond margin was harvested than either ponds whose margins were completely harvested or ponds whose forest margins were completely intact. (3) Tallmon et al. (2000) found that gene flow among populations in the Bitterroot Mountains is greater between populations on the same mountain ridge than between populations on adjacent mountain ridges, indicating that drainages between ridges act as more of a barrier to dispersal than the steep terrain on the ridge itself. The dominance of terrestrial dispersal is also supported by the genetic analyses of Howard and Wallace (1981). (4) Fukumoto and Herrero (1998) documented mortality of a minimum of $1-2 \%$ of the adult breeding population as they crossed a roadway to the breeding site in Waterton Lakes National Park in Alberta. However, the authors suggest that actual mortality may have been considerably higher, contributing to the unusual 3:1 female biased sex ratio observed at the breeding site. (5) Blaustein et al. (1994) found that the species has low levels of photolyase, an enzyme that repairs UV-B radiation damage to DNA. Blaustein et al. (1997) subsequently found that only $14.5 \%$ of embryos exposed to $94 \%$ of ambient UV-B radiation survived to hatching as compared to $95 \%$ survival for larvae exposed to only $10 \%$ of ambient UV-B radiation. Together these findings suggest that enhanced UV-B radiation from thinning of the ozone layer may be impacting salamander populations now or will impact them at some time in the future. (6) Sessions and Ruth (1990) found that cysts of a trematode parasite apparently caused limb deformities at the site of the cyst. This parasite has now been found in larvae collected in Montana (Pieter Johnson, Claremont Mckenna College, pers. comm.). (7) The extent of the use of larval long-toed salamanders as fishing bait is unknown in Montana, however the species is known to be used in large numbers in other states (Collins 1981) so this practice does have the potential to impact populations in Montana. Accidental introduction of larvae being used for bait may result in hybridization and genetic introgression, possibly leading to the elimination of distinct genetic makeups (Collins 1981). (8) Bradford et al. (1994) found that the $\mathrm{LC}_{50} \mathrm{pH}$ for Pacific treefrog embryos and hatchlings exposed for 7 days averaged 4.3 and that $\mathrm{pH}$ levels greater than or equal to 5.0 had no significant lethal or sublethal effects. 
$\underline{\text { Research and Management Suggestions }}$

1. See research and management suggestions under all of the general risk factors described above with the exception of harvest and commerce.

2. Additional information is needed on their distribution east of the Continental Divide, especially in southwest Montana. Documentation of their presence along the upper Clark Fork River and in the Pioneer and Beaverhead Mountain Ranges is poor and their presence in the southern Boulder Mountains and the Highland and Tendoy Mountains is uncertain.

3. Local and landscape wide impacts of fish introductions should be examined in order to develop fish stocking guidelines that will allow for the persistence of individual populations and connectivity between sets of local populations or metapopulations.

4. Fish stocking at both high and low elevation sites should only be carried out where fish have previously been stocked and in areas where they are contained in a limited number of water bodies (i.e., introduction in one lake in a basin will not result in the colonization of other lakes in the basin).

5. Fish removal should be considered in areas that appear to be key habitats that ensure the survival of local sets of populations.

6. The practice of using salamander larvae as fishing bait should be banned in order to protect the genetic makeup of native populations.

Bibliography *indicates an article with information specific to Montana

*Adams, M.J., B.R. Hossack, R.A. Knapp, P.S. Corn, S.A. Diamond, P.C. Trenham, and D.B. Fagre. 2005. Distribution patterns of lentic-breeding amphibians in relation to ultraviolet radiation exposure in western North America. Ecosystems 8:488-500.

Alvarado, R.H. 1967. The significance of grouping on water conservation in Ambystoma. Copeia 1967(3): 667-668.

Anderson, A.R. and J.W. Petranka. 2003. Odonate predator does not affect hatching time or morphology of embryos of two amphibians. Journal of Herpetology 37(1):65-71.

Anderson, J.D. 1961. The courtship behavior of Ambystoma macrodactylum croceum. Copeia 1961(2): 132-139.

Anderson, J.D. 1963. Reactions of the western mole to skin secretions of Ambystoma macrodactylum croceum. Herpetologica 19(4): 282-284.

Anderson, J.D. 1967. A comparison of life histories of coastal and montane populations of Ambystoma macrodactylum in California. American Midland Naturalist 77(2): 323-355.

Anderson, J.D. 1968a. Thermal histories of two populations of Ambystoma macrodactylum. Herpetologica 24(1): 29-35.

Anderson, J.D. 1968b. A comparison of the food habits of Ambystoma macrodactylum sigillatum, Ambystoma macrodactylum croceum and Ambystoma tigrinum californiense. Herpetologica 24(4): 273-284.

*Anderson, J.D. 1972a. Behavior of three subspecies of Ambystoma macrodactylum in a soil moisture gradient. Journal of Herpetology 6(3-4): 191-194.

Anderson, J.D. 1972b. Phototactic behavior of larvae and adults of two subspecies of Ambystoma macrodactylum. Herpetologica 28(3):222-226.

Anderson, J.D., and R.E. Graham. 1967. Vertical migration and stratification of larval Ambystoma. Copeia 1967: 371-374. 
*Anderson, M.E. 1977. Aspects of the ecology of two sympatric species of Thamnophis and heavy metal accumulation with the species. M.S. Thesis, University of Montana. Missoula, MT. 147 pp.

*Atkinson, E.C. and M.L. Atkinson. 2004. Amphibian and reptile survey of the Ashland and Sioux of the Custer National Forest with special emphasis on the Three-Mile Stewardship Area:2002. Marmot's Edge Conservation. 22 p.

Bailey, J.L. 1948. Supplementary observations on the geographic variation of Ambystoma macrodactylum. Herpetologica 4: 171-174.

Belden, L.K., E.L.Wildy, and A.R. Balustein. 2000. Growth, survival and behaviour of larval long-toed salamanders (Ambystoma macrodactylum) exposed to ambient levels of UV-B radiation. Journal of Zoology : Proceedings of the Zoological 251(4): 473.

Beneski, J.T., Jr., E.J. Zalisko, and J.H. Larsen Jr. 1986. Demography and migratory patterns of the eastern long-toed salamander, Ambystoma macrodactylum columbianum. Copeia 1986(2): 398-408.

Beneski, J.T., Jr., J.H. Larsen Jr., and B.T. Miller. 1995. Variation in the feeding kinematics of mole salamanders (Ambystomatidae: Ambystoma). Canadian Journal of Zoology 73(2): 353-366.

Berner, N.J. and R.L. Ingermann. 1988. Interaction of exogenous proteins with the jelly coat of eggs from the salamander, Ambystoma macrodactylum. Comparative Biochemistry and Physiology 90A(2): 265-268.

Berner, N.J. and R.L. Ingermann. 1990. Role of sialic acid in exogenous protein accumulation and water retention by the egg jelly of the salamander Ambystoma macrodactylum. Journal of Experimental Zoology 256(1): 38-43.

Blackwell, E.A., R.A. Angus, G.R. Cline, and K.R. Marion. 2003. Natural growth rates of Ambystoma maculatum in Alabama. Journal of Herpetology 37(3):608-612.

Blaustein, A.R., E.L. Wildy, L.K. Beldan, and A. Hatch. 2001. Influence of abiotic and biotic factors on amphibians in ephemeral ponds with special reference to long-toed salamanders (Ambystoma macrodactylum). Israel Journal of Zoology 47(4):333-345.

*Blaustein, A.R., J.J. Beatty, H. Deanna, and R.M. Storm. 1995. The biology of amphibians and reptiles in old-growth forests in the Pacific Northwest. General Technical Report PNWGTR-337. Portland, OR: U.S. Department of Agriculture, Forest Service, Pacific Northwest Research Station. 98 p.

Blaustein, A.R., J.M. Keisecker, D.P. Chivers, and R.G. Anthony. 1997. Ambient UV-B radiation causes deformities in amphibian embryos. Proceedings of the National Academy of Science USA 94: 13735-13737.

Blaustein, A.R., P.D. Hoffman, D.G. Hokit, J.M. Kiesecker, S.C. Walls, and J.B. Hays. 1994. UV repair and resistance to solar UV-B in amphibian eggs: a link ti population declines? Proceedings of the National Academy of Sciences 91:1791-1795.

*Boundy, J. 2001. Herpetofaunal surveys in the Clark Fork Valley region, Montana. Herpetological Natural History 8: 15-26.

Bradford, D.F., and M.S. Gordon. 1992. Aquatic amphibians in the Sierra Nevada: current status and potential effects of acidic deposition on populations. Final Report, Contract No. A932-139. California Air Resources Board. Sacramento, CA.

Bradford, D.F., C. Swanson, and M.S. Gordon. 1994. Effects of low $\mathrm{pH}$ and aluminum on amphibians at high elevation in Sierra Nevada, California. Canadian Journal of Zoology 72: 1272-1279. 
Branch, L.C. and R. Altig. 1981. Nocturnal stratification of three species of Ambystoma larvae. Copeia 1981(4): 870-873.

Brodie, E.D., Jr. 1977. Salamander antipredator postures. Copeia 1977(3): 523-535.

Brodman, R. 1993. The effect of acidity on interactions of Ambystoma salamander larvae. Journal of Freshwater Ecology 8(3): 209-214.

Brodman, R. 2004. Intraguild predation on congeners affects size, aggression, and survival among Ambystoma salamander larvae. Journal of Herpetology 38(1):21-26.

Brodman, R., J. Ogger, M. Kolaczyk, R.A. Pulver, A.J. Long, T. Bogard. 2003. Mosquito control by pond-breeding salamander larvae. Herpetologocal Review 34(2):116-119.

*Brunson, R.B. 1955. Check list of the amphibians and reptiles of Montana. Proceedings of the Montana Academy of Sciences 15: 27-29.

*Brunson, R.B. and H.A. Demaree. 1951. The herpetology of the Mission Mountains, Montana. Copeia 1951: 306-308.

Carl, G.C. 1942. The long-toed salamander on Vancouver Island. Copeia 1942(1): 56.

Carl, G.C. and I.M. Cowan. 1945. Notes on the salamanders of British Columbia. Copeia 1945(1): 43-44.

Chivers, D.P., J.M. Kiesecker, M.T. Anderson, E.L. Wildy, and A.R. Blaustein. 1996. Avoidance response of a terrestrial salamander (Ambystoma macrodactylum) to chemical alarm cues. Journal of Chemical Ecology 22(9): 1709-1716.

Chivers, D.P., E.L. Wildy, and A.R. Blaustein. 1997. Eastern long-toed salamander (Ambystoma macrodactylum columbianum) larvae recognize cannabilistic conspecifics. Ethology 103: 187-197.

Clark, K.L. 1985. Responses of spotted salamander (Ambystoma maculatum) populations in central Ontario (Candada) to habitat acidity. Canadian Field Naturalist 100(4): 463-469.

Collins, J.P. 1981. Distribution, habitats and life history variation in the tiger salamander, Ambystoma tigrinum, in east-central and southeast Arizona. Copeia 3:666-675.

Cook, R. and K. Boland. 2005. A comparison of approaches to counting spotted salamander (Ambystoma maculatum) egg masses in vernal ponds. Herpetological Review 36(3):272-274.

*Cope, E.D. 1867. A review of the species of the Amblystomidae. Proceedings of the Academy of Natural Sciences of Philadelphia 19: 166-211.

*Cope, E.D. 1875. Check-list of North American Batrachia and Reptilia; with a systematic list of the higher groups, and an essay on geographical distribution. U.S. National Museum Bulletin 1(1): 1-104.

*Cope, E.D. 1889. The Batrachia of North America. Bulletin of the U.S. National Museum 34: 1-525, figs. 1-119, pls. 1-86.

Corkran, C.C. and C. Thoms. 2006. Amphibians of Oregon, Washington, and British Columbia. $2^{\text {nd }}$ Edition. Vancouver, B.C.: Lone Pine Publishing. 176 p.

*Corn, P.S., B.R. Hossack, E. Muths, D.A. Palta, C.R. Peterson, and A.L. Gallant. 2005. Status of amphibians on the Continental Divide: surveys on a transect from Montana to Colorado, USA. Alytes 22:85-94.

*Corn, P.S., E. Muths, and C.R. Peterson. 2008. U.S. Geological Survey Amphibian Research and Monitoring Initiative Rocky Mountain Region, 2007 Progress Report. Missoula, MT: Report to U.S. Geological Survey. 6 p.

Cunnington, D.C. and R.J. Brooks. 2000. Optimal egg size theory: Does predation by fish affect egg size in Ambystoma maculatum? Journal of Herpetology 34(1):46-53. 
Dempster, W.T. 1930. The growth of larvae of Ambystoma maculatum under natural conditions. Biology Bulletin 58: 182-192.

Dougherty, C.K., D.A. Vaala, and G.R. Smith. 2005. Within-pond oviposition site selection in two spring-breeding amphibians (Ambystoma maculatum and Rana sylvatica). Journal of Freshwater Ecology 20(4):781-782.

Ducey, P.K. 1989. Agonistic behavior and biting during intraspecific encounters in Ambystoma salamanders. Herpetologica 45(2): 155-160.

Duncan, R.B. 2005. Ambystoma maculatum (Spotted Salamander). Predation. Herpetological Review 36:294.

*Dunlap, W.W. and F.W. Allendorf. No Date. Population structure of the long-toed salamander. Unpublished report. University of Montana. Missoula, MT. 24 p. +8 figs.

Efford, I.E. and J.A. Mathias. 1969. A comparison of two salamander populations in Marion Lake, British Columbia. Copeia 1969: 723-735.

Faccio, S.D. 2003. Postbreeding emigration and habitat use bu Jefferson and Spotted Salamanders in Vermont. Journal of Herpetology 37(3):479-489.

*Farmer, P. and S.B. Heath. 1987. Wildlife baseline inventory, Rock Creek study area, Sanders County, Montana. Western Technology and Engineering, Inc. Helena, MT.

Farner, D.S. 1947. Notes on the food habits of the salamanders of Crater Lake, Oregon. Copeia 1947(4): 259-261.

*Ferguson, D.E. 1961. The geographic variation of Ambystoma macrodactylum Baird, with the description of two new subspecies. American Midland Naturalist 65: 311-338.

*Ferguson, D.E. 1963. Ambystoma macrodactylum. Catalogue of American Amphibians and Reptiles 4.1-4.2.

Figiel, C.R. Jr. and R.D. Semlitsch. 1990. Population variation in survival and metamorphosis of larval salamanders (Ambystoma maculatum) in the presence and absence of fish predation. Copeia 1990(3): 818-826.

*Franz, R. 1971. Notes on the distribution and ecology of the herpetofauna of northwestern Montana. Bulletin of the Maryland Herpetological Society 7: 1-10.

Fukumoto, J.M. 1995. Long-toed salamander (Ambystoma macrodactylum) ecology and management in Waterton Lakes National Park. M.S.. Thesis. Faculty of Environmental Design, University of Calgary, Calgary, Alberta.

Fukumoto, J.M. and S. Herrero. 1998. Observations of the long-toed salamander, Ambystoma macrodactylum, in Waterton Lakes National Park, Alberta. The Canadian Field Naturalist 112(4): 579-585.

*Funk, W.C. and W.W. Dunlap. 1999. Colonization of high-elevation lakes by long-toed salamanders (Ambystoma macrodactylum) after the extinction of introduced trout populations. Canadian Journal of Zoology 77: 1759-1767.

*Funk, W.C., D.A. Tallmon, and F.W. Allendorf. 1999. Small effective population size in the long-toed salamander. Molecular Ecology 8: 1633-1640.

Gibson, J.D. and D.A. Merkle. 2005. Ambystoma maculatum (Spotted Salamander). Reproduction. Herpetological Review 36:294.

Graham, K.L. and G.L. Powell. 1999. Status of the Long-toed salamander (Ambystoma macrodactylum) in Alberta. Alberta Wildlife Status Report No. 22, Edmonton, AB. 19p.

Graham, K.L. 1997. Habitat use of long-toed salamanders (Ambystoma macrodactylum) at three different scales. M.S. Thesis, University of Guelph, Guelph, ON. 71pp. 
Grant, E.H.C. and P. Nanjappa. 2006. Adressing errors in identification of Ambystoma maculatum (spotted salamanders) using spot patterns. Herpetological Review 37(1):57-60.

*Greer, K.R. 1955. Yearly food habits of the river otter in the Thompson Lakes Region, Northwestern Montana, as indicated by scat analysis. American Midland Naturalist 54: 299313.

Gunzburger, M.S. and J. Travis. 2005. Critical literature review of the evidence for unpalatability of amphibian eggs and larvae. Journal of Herpetology 39(4):547-571.

Hamilton, I.M., K.L. Graham, L. Powell, and A. Russell. 1996. The range of long-toed salamanders in northwestern Alberta. Alberta Environmental Protection, Fish and Wildlife Service, Edmonton, AB. 186 pp.

*Hendricks, P. 1997. Lee Metcalf National Wildlife Refuge preliminary amphibian and reptile investigations: 1996. Montana Natural Heritage Program, Helena, MT. 21 p.

*Hendricks, P. 2000. Amphibian and reptile survey of the Thompson Chain of Lakes. A report to the Montana Department of Fish, Wildlife, and Parks. Montana Natural Heritage Program, Helena, MT. 15 p.

*Hendricks, P. and J.D. Reichel. 1996. Amphibian and reptile survey of the Bitterroot National Forest: 1995. Montana Natural Heritage Program, Helena, MT. 95 p.

*Hilliard, J., H. Minkus, and M. Weber. 1997. Amphibian survey of the Birch Creek drainage, Beaverhead County. Wildland Studies Project, San Francisco State University, San Francisco, CA. 12 p.

Hoffman, R.L., G.L. Larson, and B.J. Brokes. 2003. Habitat segregation of Ambystoma gracile and Ambystoma macrodactylum in mountain ponds and lakes, Mt. Rainier National Park, Washington, USA. Journal of Herpetology 37(1): 24-34.

Homan, R.N., J.M. Reed, and B.S. Windmiller. 2005. Analysis of spotted salamander (Ambystroma maculatum) growth rates based on long-bone growth rings. Journal of Herpetology 37(3):617-621.

*Hossack, B.R. 2002. Ambystoma macrodactylum krausei (northern long-toed salamander) vocalization. Herpetological Review 33(2): 121.

*Hossack, B.R. and P.S. Corn. 2007. Responses of pond-breeding amphibians to wildfire: short-term patterns in occupancy and colonization. Ecological Applications 17:1403-1410.

*Hossack, B.R., D. Pilliod, and S. Corn. 2001. Preliminary amphibian surveys of the National Bison Range, Lost Trail National Wildlife Refuge, and Swan River National Wildlife Refuge: 2001. USGS Northern Rocky Mountain Science Center, Aldo Leopold Wilderness Research Institute, Missoula, MT. 15 p.

Howard, J.H. 1979. Ecological, genetic and physiological variation in populations of the longtoed salamander (Ambystoma macrodactylum columbianum) from different altitudes. Ph.D. dissertation, University of Idaho. Moscow, Idaho. 82pp.

Howard, J.H. and J.R. Stauffer. 1983. Critical thermal maxima in populations of Ambystoma macrodactylum from different elevations. Journal of Herpetology 17(4): 402-404.

Howard, J.H. and R.L. Wallace. 1980. Effects of altitude on selected blood parameters in populations of the salamander Ambystoma macrodactylum. Comparative Biochemistry and Physiology 65A(2): 243-245.

Howard, J.H. and R.L. Wallace. 1981. Microgeographic variation of electrophoretic loci in populations of Ambystoma macrodactylum columbianum (Caudata: Ambystomatidae). Copeia 1981(2): 466-471. 
Howard, J.H. and R.L. Wallace. 1985. Life history characteristics of populations of the longtoed salamander (Ambystoma macrodactylum) from different altitudes. American Midland Naturalist 113(2): 361-373.

Husting, E.L. 1965. Survival and breeding structure in a population of Ambystoma maculatum. Copeia 1965: 352-362.

*Johnson, P.T.J., K.B. Lunde, E.M. Thurman, E.G. Ritchie, S.N. Wray, D.R. Sutherland, J.M. Kapfer, T.J. Frest, J. Bowerman, and A.R. Blaustein. 2002. Parasite (Ribeiroia ondatrae) infection linked to amphibian malformations in the western United States. Ecological Monographs 72(2): 151-168.

*Jones, L.L.C., W.P. Leonard, and D.H. Olson (eds). 2005. Amphibians of the Pacific Northwest. Seattle, WA: Seattle Audubon Society. 227 p.

Jones, T.R., A.G. Kluge, and A.J. Wolf. 1993. When theories and methodologies clash: a phylogenetic reanalysis of the North American ambystomatid salamanders (Caudata: Ambystomatidae). Systematic Biology 42: 92-102.

Kezer, J. and D.S. Farner. 1955. Life history patterns of the salamander Ambystoma macrodactylum in the high Cascade Mountains of southern Oregon. Copeia 1955(2): 127131.

Knapp, R.A. 1996. Non-native trout in natural lakes of the Sierra Nevada: an analysis of their distribution and impacts on native aquatic biota. In: Sierra Nevada ecosystem project: final report to Congress, volume III, assessments, commissioned reports, and background information. Davis, CA: University of California Centers for Water and Wildland Resources. Wildland Resources Center Report 38. p 363-407.

Knudsen, J.W. 1960. The courtship and egg mass of Ambystoma gracile and Ambystoma macrodactylum. Copeia 1960(1): 44-46.

Kraus, F. 1988. An empirical evaluation of the use of the ontogeny polarization criterion in phylogenetic inference. Systematic Zoology 37(2): 106-141.

Kutka, F.J. 1994. Low pH effects of swimming activity of Ambystoma salamander larvae. Environment, Toxicology and Chemistry 13(11): 1821-1824.

*Laselle, B.T. 2000. Association of wetland area with breeding activity for multiple amphibian species. Undergraduate Honors Thesis. Carroll College, Helena, MT. 18 p.

Leonard, W.P. and K.O. Richter. 1994. Western long-toed salamander demographics and oviposition in a small vernal wetland of the Puget Sound lowlands. Northwest Science 68(2): 135 .

Liss, W.J. and G.L. Larson. 1991. Ecological effects of stocked trout on North Cascades naturally fishless lakes. Park Science 11: 22-23.

*Manville, R.H. 1957. Amphibians and reptiles of Glacier National Park, Montana. Copeia 1957: 308-309.

*Marnell, L.F. 1996. Amphibian survey of Glacier National Park, Montana. Abstract. Intermountain Journal of Sciences 2(2): 52.

*Marnell, L.F. 1997. Herpetofauna of Glacier National Park. Northwestern Naturalist 78: 1733.

Matsuda, B.M., D.M. Green, and P.T. Gregory. 2006. Amphibians and reptiles of British Columbia. Victoria, B.C.: Royal British Columbia Museum. 266 p.

* Maxell, B.A. 2002. Amphibian and aquatic reptile inventories in watersheds in the South and Middle Forks of the Flathead River drainage that contain lakes being considered for application of piscicides and subsequent stocking of west slope cutthroat trout. Report to the 
Region 1 Office of the U.S. Forest Service and the Montana Department of Fish, Wildlife, and Parks. Montana Cooperative Wildlife Research Unit and Wildlife Biology Program, University of Montana, Missoula, MT. 62 p.

*Maxell, B.A. 2004a. Amphibian and aquatic reptile inventories conducted on and around the Bitterroot National Forest 2000-2003. Report to Region 1 Office of the U.S. Forest Service, Bitterroot National Forest, Montana Department of Fish, Wildlife, and Parks, and Biological Resources Division of the U.S. Geological Survey. Missoula, MT: Montana Cooperative Wildlife Research Unit and Wildlife Biology Program, University of Montana. $128 \mathrm{p}$.

*Maxell, B.A. 2004b. Amphibian and aquatic reptile inventories conducted on and around the Thompson River 2003-2004. Report to Region 1 Office of the U.S. Forest Service and Plum Creek Timber Company. Missoula, MT: Montana Cooperative Wildlife Research Unit and Wildlife Biology Program. 83 p.

*Maxell, B.A. 2004c. Report on amphibian and aquatic reptile inventories conducted on and around the Beaverhead-Deerlodge National Forest 2001-2003. Report to Region 1 Office of the U.S. Forest Service, Beaverhead-Deerlodge National Forest, Montana Department of Fish, Wildlife, and Parks, Montana State Office of the Bureau of Land Management, and Montana Department of Environmental Quality. Missoula, MT: Montana Cooperative Wildlife Research Unit and Wildlife Biology Program, University of Montana. 260 p.

*Maxell, B.A. 2005a. Amphibian and aquatic reptile inventories conducted on and around lands administered by the Missoula Field Office of the Bureau of Land Management. Report to Missoula Field Office of the Bureau of Land Management. Montana Natural Heritage Program, Helena, MT and Montana Cooperative Wildlife Research Unit and Wildlife Biology Program, University of Montana, Missoula, MT. 53 p.

*Maxell, B.A. 2005b. A review of monitoring methods and a multi-tiered scheme for assessing and monitoring the status of amphibians in Montana. Report to Montana Department of Environmental Quality, Region 1 Office of the U.S. Forest Service, Montana Department of Fish, Wildlife, and Parks, and Montana State Office of the Bureau of Land Management. Montana Natural Heritage Program, Helena, MT and Montana Cooperative Wildlife Research Unit and Wildlife Biology Program, University of Montana, Missoula, MT. 29 p. + Appendices.

*Maxell, B.A. 2006. Evaluation of Montana's lentic breeding amphibian survey methodology and variables correlated with species occupancy. Report to Montana Department of Environmental Quality. Montana Natural Heritage Program, Helena, MT and Montana Cooperative Wildlife Research Unit and Wildlife Biology Program, University of Montana, Missoula, MT. 49 p.

*Maxell, B.A. 2009. State-wide assessment of status, predicted distribution, and landscapelevel habitat suitability of amphibians and reptiles in Montana. Ph.D. Dissertation. Missoula, MT: Wildlife Biology Program, University of Montana. 294 p.

*Maxell, B.A. and D.G. Hokit. 1999. Amphibians and reptiles. pp. 2.1-2.30. In G. Joslin and H. Youmans, coordinators. Effects of recreation on Rocky Mountain wildlife: a review for Montana. Committee on Effects of Recreation on Wildlife, Montana Chapter of the Wildlife Society. 307 p.

*Maxell, B.A., J.K. Werner, P. Hendricks, and D. Flath. 2003. Herpetology in Montana: a history, status summary, checklists, dichotomous keys, accounts for native, potentially native, and exotic species, and indexed bibliography. Olympia, WA: Society for Northwestern Vertebrate Biology. Northwest Fauna 5: 1-138. 
McAvoy, S.A. 2003. Wetland characteristics associated with amphibian presence in the Rocky Mountain Region. Undergraduate Honors Thesis. Carroll College, Helena, MT. 23 p.

McCoy, K.A., R.N. Harris. 2003. Integrating development stability analysis and current amphibian monitoring techniques: an experimental evaluation with the salamander Ambystoma maculatum. Herpetologica 59(1): 22-36.

*McGraw, R.L., II. 1997. Timber harvest effects on metamorphosed and larval long-toed salamanders (Ambystoma macrodactylum). M.S. Thesis. University of Montana, Missoula, MT. 74 p.

McKnight, M.L. and H.B. Shaffer. 1997. Large, rapidly evolving intergenic spacers in the mitochondrial DNA of the salamander family Ambystomatidae (Amphibia: Caudata). Molecular Biology and Evolution 14(11): 1167-1176.

McLaughlin, G.S. 1999. Draft revised recovery plan for the Santa Cruz long-toed salamander. U.S. Fish and Wildlife Service Region 1. Portland, Oregon.

Menninger, K.L. 2004. The effects of hydroperiod on the head morphology of long-toed salamanders (Ambystoma macrodactylum). Undergraduate Honors Thesis. Carroll College, Helena, MT. 20 p.

*Miller, J.D. 1975. Interspecific food relationships of anurans in northwestern Montana and fluoride accumulation in amphibians and reptiles in northwestern Montana. M.S. Thesis, University of Montana, Missoula, MT. 105 p.

*Miller, M. 1995. Amphibian survey Birch Creek July 1995. Wildland Studies Project, San Francisco State University, San Francisco, CA. 9 p.

*Mittleman, M.B. 1948, American Caudata II. Geographic variation in Ambystoma macrodactylum. Herpetologica 4: 81-95.

Monello, R.J. and R.G. Wright. 1999. Amphibian habitat preferences among artificial ponds in the Palouse Region of Northern Idaho. Journal of Herpetology 33(2): 298-303.

Monello, R.J. and R.G. Wright. 2001. Predation by goldfish (Carassius auratus) on eggs and larvae of the eastern long-toed salamander (Ambystoma macrodactylum columbianum). Journal of Herpetology. 35(2): 350-353.

*[MTNHP] Montana Natural Heritage Program. 2006. Point Observation Database. Montana Natural Heritage Program, Helena, MT. Accessed May 1, 2006.

*Muths, E., R.E. Jung, L.L. Bailey, M.J. Adams, P.S. Corn, C.K. Dodd, Jr., G.M. Fellers, W.J. Sadinski, C.R. Schwalbe, S.C. Walls, R.N. Fisher, A.L. Gallant, W.A. Battaglin, and D.E. Green. 2005. Amphibian Research and Monitoring Initiative (ARMI): a successful start to a national program in the United States. Applied Herpetology 2:355-371.

*Naughton, G.P., C.B. Henderson, K.R. Foresman, and R.L. McGraw, II. 2000. Long-toed salamanders in harvested and intact Douglas-fir forests of western Montana. Ecological Applications 10(6): 1681-1689.

*[NDTI] Northrop, Devine, and Tarbell Incorporated. 1994. Cabinet Gorge and Noxon Rapids hydroelectric developments 1993 wildlife study. Northrop, Devine, and Tarbell Incorporated, Portland, ME. 197 p.

Nelson, S.J., G.L. Powell, and A.P. Russell. 1995. Population survey of the long-toed salamander (Ambystoma macrodactylum) in southwestern Alberta. Alberta Environmental Protection, Fish and Wildlife Service, Edmonton, AB. 161pp.

Oseen, K.L., G.L. Powell, and A.P. Russell. 1995a. The distribution of the long-toed salamander (Ambystoma macrodactylum) in southwestern Alberta. Report submitted to Alberta Fish and Wildlife, Environmental Protection, Edmonton, Alberta. pp. 45. 
Oseen, K.L., G.L. Powell, and A.P. Russell. 1995b. The distribution of the long-toed salamander (Ambystoma macrodactylum) in northwestern Alberta. Report submitted to Alberta Fish and Wildlife, Environmental Protection, Edmonton, Alberta. pp. 56.

Pearson, K.J. 2004. Long-toed salamander (Ambystoma macrodactylum) Alberta Species at Risk Report 90:136-147.

Pearman, P.B. 2002. Interactions between Ambystoma salamander larvae: evidence for competitive asymmetry. Herpetologica 58(2):156-165.

*Peters, W. 1882. Legte drei neue Batrachier (Amblystoma krausei, Nyctibatrachus sinensis, Bufo buchneri) vor. Sitzungs - bericht der Gesellschaft Naturforschender Freunde zu Berlin 10: $145-148$.

*Petranka, J.W. 1998. Salamanders of the United States and Canada. Smithsonian Institution Press, Washington, DC. 587 p.

*Powell, R., J.T. Collins, and E.D. Hooper, Jr. 1998. A key to amphibians and reptiles of the Continental United States and Canada. University Press of Kansas, Lawrence, KS. 131 p.

Powell, G.L., A.P. Russell, J.D. James, S.J. Nelson, and S.M. Watson. 1997. Population biology of the long-toed salamander (Ambystoma macrodactylum) in the front range of Alberta. In: D.M. Green (Ed.). Amphibians in decline: Canadian studies of a global problem. Herpetological Conservation 1: 37-44.

Powell, G.L., A.P. Russell, S.J. Nelson, I.M. Hamilton, and K.L. Graham 1997. The status of the Long-toed salamander (Ambystoma macrodactylum) in Alberta. Alberta Environmental Protection, Fish and Wildlife Division, Edmonton, AB.

Powell, G.L., S.J. Nelson, and A.P. Russell. 1993. The Bow Valley long-toed salamander population study: a preliminary report on the 1992 field season. Alberta Environmental Protection, Fish and Wildlife Service, Edmonton, AB. 124 pp.

Reed, R.J. 1978. Population study of the Santa-Cruz long-toed salamander (Ambystoma marcrodactylum croceum) at Valencia Lagoon 1977-1978 with notes on habitat and occurrence in Santa Cruz and Monterey counties. California Department of Fish and Game Report. Contract S-1180, Sacramanto. 90pp.

Reed, R.J. 1980. The population dynamics of Ambystoma macrodactylum croceum as a response to climatological variables. American Zoologist 20(4): 879.

*Reichel, J.D. 1995. Preliminary amphibian and reptile survey of the Lewis and Clark National Forest: 1994. Montana Natural Heritage Program, Helena, MT. 92 p.

*Reichel, J.D. 1996. Preliminary amphibian and reptile survey of the Helena National Forest: 1995. Montana Natural Heritage Program, Helena, MT. 87 p.

*Reichel, J.D. 1997. Amphibian, reptile and northern bog lemming survey on the Rocky Mountain Front: 1996. Montana Natural Heritage Program, Helena, MT. 81 p.

*Rodgers, T.L., and W.L. Jellison. 1942. A collection of amphibians and reptiles from western Montana. Copeia 1942(1): 10-13.

*Roedel, M.D. and P. Hendricks. 1998a. Amphibian and reptile survey on the Bureau of Land Management Lewistown District: 1995-1998. Montana Natural Heritage Program, Helena, MT. $53 \mathrm{p}$.

*Roedel, M.D. and P. Hendricks. 1998b. Amphibian and reptile inventory on the Headwaters and Dillon Resource Areas in conjunction with Red Rocks Lakes National Wildlife Refuge: 1996-1998. Montana Natural Heritage Program, Helena, MT. 46 p.

Russell, A.P., and A.M. Bauer. 2000. The amphibians and reptiles of Alberta. Second Edition. Calgary, AB: University of Calgary Press. 279 p. 
Russell, A.P., G.L. Powell, and D.R. Hall. 1996. Growth and age of Alberta long-toed salamanders (Ambystoma macrodactylum krausei): a comparison of two methods of estimation. Canadian Journal of Zoology 74: 397-412.

Russell, R.W. and J.D. Anderson. 1956. A disjunct population of the long-toed salamander from the coast of California. Herpetologica 12: 137-140.

Ruth, S.B. 1988. The life history and current status of the Santa Cruz long-toed salamander (Ambystoma macrodactylum croceum). Pages 89-110 In: H.F. Lisle, P.R. Brown, B.Kaufman, and B.M. McGurty, editors. Proceedings of the Conference on California Herpetology. Southwestern Herpetologists Society.

Ruth, S.B. and K. Tollestrup. 1973. Aspects of the life history and current status of the Santa Cruz long-toed salamander (Ambystoma macrodactylum croceum) at Valencia Lagoon, Santa Cruz County, California. Report for California Division of Highways. 54pp.

*Schmidt, K.P. 1953. A checklist of North American Amphibians and Reptiles. Sixth edition. American Society of Icthyologists and Herpetologists. 280 p.

Semlitsch, R.D. 1983. Burrowing ability and behavior of salamanders of the genus Ambystoma. Canadian Journal of Zoology 61: 616-620.

Sessions, S.K. and S.B. Ruth. 1990. Explanation for naturally occurring supernumerary limbs in amphibians. Journal of Experimental Zoology 254(1): 38-47.

Shaffer, H. B., J. M. Clark and F. Kraus. 1991. When molecules and morphology clash: a phylogenetic analysis of the North American ambystomatid salamanders (Caudata: Ambystomatidae). Systematic Zoology 40: 284-303.

Sheppard R.F. 1977. The ecology and home range movements of Ambystoma macrodactylum krausei (Amphibia : Urodela). Masters Thesis, University of Calgary. 138pp.

Sherratt, J. 2003. The effects of hydroperiod on the morphology of the long-toed salamanser Ambystoma macrodatylum. Undergraduate Honors Thesis. Carroll College, Helena, MT. $26 \mathrm{p}$.

Shoop, C.R. 1968. Migratory orientation of Ambystoma maculatum: movements near breeding ponds and displacements of migrating individuals. Biology Bulletin 135: 230-238.

*Slater, J.R. 1936. Notes on Ambystoma gracile Baird and Ambystoma macrodactylum Baird. Copeia 1936(4): 234-236.

Spohr, S.M. 2005. Ambystoma maculatum (Spotted Salamander). Predation. Herpetological Review 36:294-295.

Sprules, W.G. 1974. The adaptive significance of paedogenesis in North American species of Ambystoma (Amphibia: Caudata): an hypothesis. Canadian Journal of Zoology 52: 393-400.

*Stebbins, R.C. 2003. A field guide to western reptiles and amphibians. 3rd edition. New York, NY: Houghton Mifflin Co. 533 p.

Talent, L.G. and C.L. Talent. 1980. A population of the endangered Santa Cruz long-toed salamander, Ambystoma macrodactylum croceum, from Monterey County, California. California Fish and Game 66(3):184-186.

*Tallmon, D.T., W.C. Funk, W.W. Dunlap, and F.W. Allendorf. 2000. Genetic differentiation of long-toed salamanders (Ambystoma macrodactylum) populations. Copeia 2000(1): 27-35.

*Test, F.C. 1893. Annotated list of reptiles and batrachians collected. In B.W. Evermann. A reconnaisance of the streams and lakes of western Montana and northwestern Wyoming. Bulletin of United States Fish Commission 11(1891): 57-59.

Thompson, M.D. 2000. Long-toed phylogeography a 'neo-perspective' on declines. The Boreal Dip Net 5(1): 14-16. 
Thompson, M.D. 2001. An unusually adept ambystomatid, the long toed salamander, coping at northern extremes. The Boreal Dip Net. 5(2):8-10.

Thompson, M.D. and A.P. Russell. 2000. Phylogeography of Ambystoma macrodactylum: post glacial range expansion and resultant genetic diversity. Field Summary Report No. 1. University of Calgary. Calgary, Canada. 39 p.

Thompson, M.D. and A.P. Russell. 2001. Phylogeography of Ambystoma macrodactylum: post glacial range expansion and resultant genetic diversity. Field Summary Report No. 2. University of Calgary, Calgary, Canada. 65 p.

Thoms, C., and C.C. Corkran. 1994. Identifying Oregon amphibians in the field: distinctions between long-toed and northwestern salamanders. Northwest Science 68(2): 154.

*Tihen, J.A. 1969. Ambystoma. Catalogue of American Amphibians and Reptiles 75.1-75.4.

*Timken, R. No Date. Amphibians and reptiles of the Beaverhead National Forest. Western Montana College, Dillon, MT. 16 p.

Turtle, S.L. 2000. Embyonic survivorship of the spotted salamander (Ambystoma maculatum) in roadside wand woodland vernal pools in southeastern New Hampshire. Journal of Herpetology 34: 60-67.

Tyler, T., W.J. Liss, L.M. Ganio, G.L. Larson, R. Hoffman, E. Deimling, and G. Lomnicky. 1998a. Interaction between introduced trout and larval salamanders (Ambystoma macrodactylum) in high elevation lakes. Conservation Biology 12: 94-105.

Tyler, T.J. 1996. Interactions between stocked trout larval salamanders (Ambystoma macrodactylum) in high-elevation lakes. Masters Thesis, Oregon State University. 55p.

Tyler, T.J., W.J. Liss, R.L. Hoffman, and L.M. Ganio. 1998b. Experimental analysis of trout effects on survival, growth, and habitat use of two species of Ambystomid salamanders. Journal of Herpetology 32(3): 345-349.

Vasconcelos, D. and A.J.K. Calhoun. 2004. Movement patterns of adult and juvenile Rana sylvatica (LeConte) and Ambystoma maculatum (Shaw) in three restored seasonal pools in Maine. Journal of Herpetology 38(4):551-561.

Verrell, P.A. 2004. The male reproductive cycle of the North American salamander Ambystoma macrodactylum columbianum. Amphibia-Reptilia 25(3):349-356.

Verrell, P. and J. Pelton. 1996. The sexual strategy of the central long-toed salamander, Ambystoma macrodactylum columbianum, in south-eastern Washington. Journal of the Zoological Society of London 240: 37-50.

Verrell, P., K. Davis. 2003. Do non-breeding, adult long-toed salamanders respond to conspecifics as friends or as foes? Herpetologica 59(1): 1-7.

Verrell, P., N. Strand, and E.Hanson. Sexual dimorphism of mate location in the long-toed salamander Ambystoma macrodactylum columbianum. Ethology 107(8): 677-684.

*Walker, R.S. 1984. Distribution of the northern long-toed salamander (Ambystoma macrodactylum) east of the continental divide in Montana. Undergraduate Honors Thesis. Carroll College, Helena, Montana. 37 p.

Walls, S.C., J.J. Beatty, B.N. Tissot, D.G. Hokit, and A.R. Blaustein. 1993. Morphological variation and cannibalism in a larval salamander (Ambystoma macrodactylum columbianum). Canadian Journal of Zoology 71: 1543-1551.

Walls, S.C., S.S. Belanger, and A.R. Blaustein. 1993. Morphological variation in a larval salamander: dietary induction of plasticity in head shape. Oecologica 96:162-168.

Walsh, R. 1998. An extension of the known range of the long-toed salamander, Ambystoma macrodactylum, in Alberta. The Canadian Field Naturalist 112: 331-333. 
Watson S. 1997. Food level effects on metamorphic timing in the long-toed salamander, Ambystoma macrodactylum krausei. Masters thesis, The Univesisty of Calgary. pp. 206.

*Weisel, G.F. 1952. Animal names, anatomical terms, and some ethnozoology of the Flathead Indians. Journal of the Washington Academy of Sciences 42(11): 345-355.

*Werner, J.K., B.A. Maxell, P. Hendricks, and D. Flath. 2004. Amphibians and reptiles of Montana. Missoula, MT: Mountain Press Publishing Company. 262p.

*Werner, J.K. and J.D. Reichel. 1994. Amphibian and reptile survey of the Kootenai National Forest: 1994. Montana Natural Heritage Program, Helena, MT. 104 p.

*Werner, J.K. and J.D. Reichel. 1996. Amphibian and reptile monitoring/survey of the Kootenai National Forest: 1995. Montana Natural Heritage Program, Helena, MT. 115 p.

*Werner, J.K. and T. Plummer. 1994. Amphibian and reptile survey of the Flathead Indian Reservation 1993-1994. Salish Kootenai College, Pablo, MT. 55 p.

*Werner, J.K. and T. Plummer. 1995. Amphibian monitoring program on the Flathead Indian Reservation 1995. Salish Kootenai College, Pablo, MT. 46 p.

*Werner, J.K., T. Plummer, and J. Weaselhead. 1998a. Amphibians and reptiles of the Flathead Indian Reservation. Intermountain Journal of Sciences 4(1-2): 33-49.

*Werner, J.K., T. Plummer, and J. Weaselhead. 1998b. The status of amphibians on the Flathead Reservation, Montana. Intermountain Journal of Sciences 4(3-4): 88.

Wildy, E.L. and A.R. Blaustein. 2001. Learned recognition of intraspecific predators in larval long-toed salamanders Ambystoma macrodactylum. Ethology 107(6): 479-494.

Wildy, E., D.P. Chivers, J.M. Kiesecker, and A.R. Blaustein. 1998. Cannibalism enhances growth in larval long-toed salamanders, (Ambystoma macrodactylum). Journal of Herpetology 32(2) 286-289.

Wildy, E.L., D.P. Chivers, and A.R. Blaustein. 1999. Shifts in life history trairs as a response to cannibalism in larval long-toed salamanders (Ambystoma macrodactylum). Journal of Chemical Ecology 25: 2337-2346.

Wildy, E.L., D.P. Chivers, J.M. Kiesecker, and A.R. Blaustein. 2001. The effects of food level and conspecific density on biting and cannibalism in larval long-toed salamanders, Ambystoma macrodactylum. Oecologial 128(2): 202-209.

Williams, T.A., and C.D. Anthony. 1994. Technique to isolate salamander granular gland products with a comment on the evolution of adhesiveness. Copeia 1994(2): 540-541.

Williams, T.A., and J.H. Larsen, Jr. 1986. New function for the granular skin glands of the eastern long-toed salamander, Ambystoma macrodactylum columbianum. Journal of Experimental Zoology 239(3): 329-334.

Wright, A.N. and K.R. Zamudio. 2002. Color pattern asymmetry as a correlate of habitat disturbance in spotted salamanders (Ambystoma maculatum). Journal of Herpetology 36(1):129-133.

*[WWPC] Washington Water Power Company. 1995. 1994 wildlife report Noxon Rapids and Cabinet Gorge Reservoirs. Washington Water Power Company. Spokane, WA.

Zalisko, E.J. 1987. Morphology, histochemistry, and seasonal changes in the vasa deferentia of Rhyacotriton olympicus olympicus (Dicamptodontidae) and Ambystoma macrodactylum columbianum (Ambystomatidae), (Amphibia, Urodela). Ph.D. Dissertation. Washington State University. $95 \mathrm{pp}$.

Zalisko, E.J. and J.H. Larsen, Jr. 1989. Fate of unused sperm in post-breeding male Ambystoma macrodactylum columbianum. Journal of Herpetology 23(4): 463-464. 
Zalisko, E.J., and J.H. Larsen Jr. 1990. Breeding and post-breeding structure of the vas deferens of the long-toed salamander Ambystoma macrodactylum. Journal of Morphology 203(3): 321-330.

*Zisook, R., K. Almond, and B. Sharpe. 1996. Amphibian survey of the Birch Creek drainage, Beaverhead County. Wildland Studies Project. San Francisco State University, San Francisco, CA. 9 p. 


\section{Tiger Salamander (Ambystoma tigrinum)}

Up-to-date distribution and status information can be found on the Montana Natural Heritage Program's TRACKER website at http://mtnhp.org

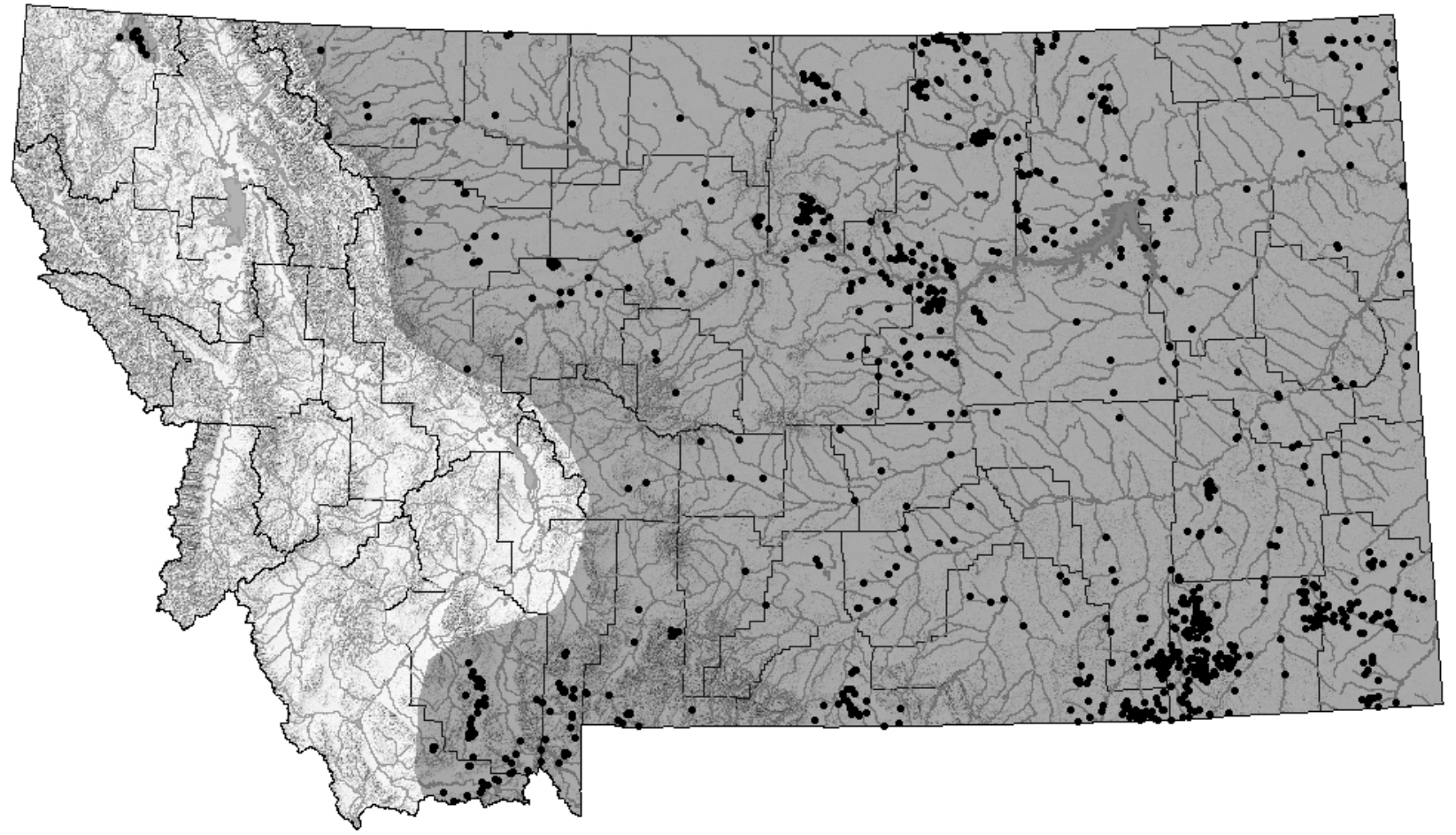

Distribution/Taxonomy

The systematics of the tiger salamander species complex are under debate, but most authorities recognize 7 varieties which range from the Atlantic Ocean to the Great Basin and Columbia Plateau and from central Mexico to central Canada at elevations up to 3,350 M (11,000 ft) (Gehlbach 1967; Shaffer and McKnight 1996; Irschick and Shaffer 1997; Petranka 1998). Although the edge of the range of the gray tiger salamander, Ambystoma t. diaboli, approaches the northeastern corner of Montana, only a single subspecies, the blotched tiger salamander, Ambystoma t. melanostictum, is currently known to occur in the state. In Montana they are known to range across the prairies and, in some places, into the mountains to the east of the Continental Divide. In addition, A. tigrinum have recently been documented at a number of sites in the Tobacco Valley of northwestern Montana (Werner and Reichel 1996). It is not known whether this is a naturally occurring disjunct population, or whether their presence is the result of human introduction.

Maximum Elevation

2,769 m (9,085 ft) just north of Coffin Mountain in southern Gallatin County (Dave Deavours; MTNHP 2007).

\section{Identification}

\section{Eggs:}

Laid singly or in small linear clusters. Each ovum is black or brown above, light gray below, and surrounded by three jelly layers (Micken 1968). Ovum diameters are 2-3 mm, but total egg diameters, including the three jelly layers, are 7-9 mm (Micken 1968; Tanner 1971; Kaplan 
1980).

Larvae:

Color is variable, but usually olive green dorsally and silvery white ventrally. Three pairs of external feathery gills eminate from the sides of the head with 15-25 gill rakers on their anterior surface (Russell and Bauer 2000). SVL of 5-98 mm. (Kaplan 1980; Hill 1995).

Juveniles and Adults:

Color is variable. Commonly mottled dorsally with green, yellow, or tan patches on a brown or black background, but some may be uniformally dark in color (Koch and Peterson 1995). Venter gray. 12-13 costal grooves are present. SVL of 70-90 mm (Russell and Bauer 2000).

Similar Species:

Long-toed salamander eggs have 2 jelly layers and have diameters greater than $10 \mathrm{~mm}$, including the jelly layers. Larval long-toed salamanders have smaller heads and are translucent, light tan, or black dorsally and laterally with black and gold flecks. In addition, larval long-toed salamanders are white to pinkish ventrally and have 9-13 gill rakers on the anterior surface of their gills. See sections on distribution for geographic areas of possible overlap for tiger and long-toed salamanders.

\section{Habitat Use/Natural History}

Adults are found in virtually any habitat, providing there is a terrestrial substrate suitable for burrowing and a body of water nearby suitable for breeding. Terrestrial adults usually remain underground, in self-made burrows or in those made by rodents or other animals (Koch and Peterson 1995; Madison and Farrand 1998). Breeding takes place soon after snow melt at sites ranging from clear mountain ponds to temporary, manure-polluted pools in the lowlands. Breeding sites almost always lack predatory fishes (Micken 1971; USFWS 1964-1982; Baxter and Stone 1985; Hill 1995). Adults may migrate several hundred meters between terrestrial burrows and breeding habitats (Koch and Peterson 1995). Migrations usually occur nocturnally around the time of precipitation events when minimum daily temperatures are greater than zero degrees celsius (Hill 1995). Eggs are attached to submerged objects at shallower depths. Larvae may transform at the end of their first summer if the growing season is long enough, but may remain larvae for a second or third summer at high elevations in cold waters (Micken 1968; Hill 1995). Metamorphosed adults may spend extensive periods of time feeding in ponds after breeding. Stays of up to 159 days have been documented in Montana (Hill 1995). In some instances larvae may become sexually mature (paedogenesis) and reproduce without transforming (Micken 1968; Hill 1995). In the water larvae and adults feed on a variety of aquatic and terrestrial invertebrates and some larvae and paedomorphic adults feed on other amphibian larvae including conspecifics (Dodson and Dodson 1971; Pfenning et al. 1991). On land terrestrial adults may feed on a variety of invertebrates or even small mammals (Moore and Strickland 1955; Petranka 1998).

\section{$\underline{\text { Status and Conservation }}$}

Tiger salamanders are widely distributed and common on the prairies east of the main Rocky Mountain chain with larvae being found in the majority of fishless ponds with adjacent soils that have not been plowed or otherwise heavily modified. However, their status in the mountains and 
mountain valleys east of the Continental Divide is largely uncertain. Risk factors relevant to the viability of populations of this species are likely to include grazing, nonindigenous species and their management, road and trail development and on- and off-road vehicle use, development of water impoundments, and habitat fragmentation, all as described above. Individual studies that specifically identify risk factors or other issues relevant to the conservation of tiger salamanders include the following. (1) A number of studies in the western United States over the past five decades have documented the almost complete exclusion of tiger salamanders from waters were predatory fish have been introduced (Blair 1951; Carpenter 1953; Levi and Levi 1955; USFWS 1964-1982; Collins et al. 1988; Geraghty 1992; Corn et al. 1997). Furthermore, at least two studies have documented multiple extinction and recolonization events by tiger salamanders as a result of the introduction, subsequent natural and human caused extinction, and subsequent reintroduction of trout in lakes in Yellowstone and Rocky Mountain National Parks (USFWS 1964-1982; Corn et al. 1997). Even larger larvae, or reproductively mature adults that fish are unable to prey on because of gape limitations are likely to be negatively impacted as a result of fish stocking because the diets of fish and salamanders largely overlap one another (Olenick and Gee 1981). (2) Hamilton (1941) reports that the piscicide rotenone has an $\mathrm{LC}_{50}$ value (i.e., causes 50\% mortality) for metamorphosing tiger salamander larvae when 5\% rotenone is applied at $0.1 \mathrm{mg} / \mathrm{L}$ for 24 hours. (3) The use of larval tiger salamanders as bait for sport fishing may have major impacts on tiger salamander populations and the entire aquatic community at both the site of collection and introduction because of there status as a top level predator in many aquatic communities (Holomuzki and Collins 1987; Holomuzki et al. 1994). Furthermore, introduction can result in hybridization and genetic introgression with native populations, possibly leading to the elimination of distinct life histories and genetic makeups (Collins 1981; Collins et al. 1988). The bait industry's use of salamander larvae may be quite extensive. For example, the average number and wholesale value of tiger salamander larvae in South Dakota wetlands was estimated at 35,625 and \$1,614 per hectare, respectively, in 1989 (Carlson and Berry 1990) and Collins (1981) notes that in 19682.5 million salamander larvae were sold as bait on the lower Colorado River area alone. (4) Mass mortalities of tiger salamanders have been observed in agricultural landscapes in eastern Montana (Bryce Maxell, pers. obs.). Worthylake and Hovingh (1989) documented the recurring mass mortality of tiger salamanders in lakes contaminated with nitrogen from atmospheric pollution and the feces of sheep. The lakes were previously nitrogen limited and increased nitrogen levels allowed bacterial counts to increase in the summer leading to the mass mortality events. Pfenning et al. (1991) propose that contamination of waters through livestock defecation may alter life histories of tiger salamanders by limiting the number of cannibal morphs. Cannibal morphs may be more likely to spread pathogens as a result of eating infected conspecifics. Eutrophication of waters through fecal contamination may also cause planorbid snail numbers to rise, thereby increasing the number of nematode parasites and the rate of parasite infection that can subsequently lead to limb deformities (Bishop and Hamilton 1947; Johnson 1999). Finally, although they have not been linked to water quality, a number of recent mass mortality events have been caused by an iridovirus in the genus, Ranavirus (e.g., Bollinger et al. 1999). (5) Disturbance of terrestrial habitats by plowing and deep raking has been identified as a serious threat to a closely related species, the California tiger salamander (Ambystoma californiense) which as recently been emergency listed as a federally endangered species (Herpetological Review 31(2):68). (6) Lefcort et al. (1997) found that waters contaminated with motor oil and silt resulted in decreased growth and survival rates of tiger salamander larvae as well as decreasing their ability to detect predators. (7) Kiesecker 
(1996) and Whiteman et al. (1995) documented reduced growth rates, survival rates, predatory success rates, in waters with lower $\mathrm{pH}(<\mathrm{pH}$ 5.0). Harte and Hoffman (1989) hypothesized that acid precipitation, in the form of an acidic pulse during snow melt, had killed salamander embryos and caused a decline of a population of tiger salamanders in central Colorado from 1982 to 1987 . However, this population has now apparently recovered (Wissinger and Whiteman 1992), and there is little evidence that either chronic or episodic acidification occurs in this area at levels sufficient to directly kill embryos (Corn and Vertucci 1992; Vertucci and Corn 1994; Vertucci and Corn 1996). However, lower $\mathrm{pH}$ levels resulting from acidification could act synergistically with pathogens or other contaminants to cause population declines as a result of reduced function of their immune systems (Carey et al. 1999).

\section{Research and Management Suggestions}

1. See research and management suggestions under all of the general risk factors described above with the exception of timber harvest, fire and fire management activities, and harvest and commerce.

2. The causes of mass mortality events in eastern Montana should be investigated to ensure that appropriate conservation measures are taken.

3. At the present time it is unknown whether or not they inhabit much of the region between Great Falls and the Idaho border south of Dillon.

4. Systematists should be contacted regarding the genetic makeup of the isolated population in the Tobacoo Valley near Eureka. If their presence in this region is the result of human introduction, control efforts may be required in order to protect local long-toed salamander populations from this superior predator/competitor. If they are a truely disjunct population, some conservation efforts may be justified in order to ensure their persistence.

5. Local and landscape wide impacts of fish introductions should be examined in order to develop fish stocking guidelines that will allow for the persistence of individual populations and connectivity between sets of local populations or metapopulations.

6. Fish stocking at both high and low elevation sites should only be carried out where fish have previously been stocked and in areas where they are contained in a limited number of water bodies (i.e., introduction in one lake will not result in the colonization of other nearby lakes).

7. Fish removal should be considered in areas that appear to be key habitats that ensure the survival of local sets of populations.

8. Piscicide use in waters known to contain tiger salamanders should be limited to the late fall after most of the year's metamorphosis has taken place and adults have migrated to terrestrial overwintering sites.

9. The practice of using tiger salamander larvae as fishing bait should be banned in order to protect the genetic makeup of native tiger salamander populations they may interbreed with or other native communities they may alter as a top aquatic predator.

10. The extent and impact of agricultural runoff and contaminants from roads should be investigated in order to identify the effects on larvae or aquatic adults, especially in areas where mass mortality events have been observed.

11. Until the lethal and sublethal impacts of commonly used fertilizers, herbicides, and pesticides on all amphibian life history stages present in an area are examined they should not be applied within 100 meters of waterbodies or wetlands. 
Bibliography *indicates an article with information specific to Montana

*Allen, J.A. 1874. Notes on the natural history of portions of Dakota and Montana Territories, being the substance of a report to the Secretary of War on the collections made by the North Pacific Railroad Expedition of 1873, General D.S. Stanley, Commander. Proceedings of the Boston Society of Natural History 17: 33-85. pp. 68-70.

Allison, L.J., P.E. Brunkow, and J.P. Collins. 1994. Opportunistic breeding after summer rains by Arizona tiger salamanders. Great Basin Naturalist 54(4): 376-379.

Amdt, R.G. 1989. Notes on the natural history and status of the tiger salamander, Ambystoma tigrinum, in Delaware. Bulletin of the Maryland Herpetological Society 25(1): 1-21. Anderson, F.B., D.D. Hassinger, and G.H. Dalrymple. 1971. Natural mortality of eggs and larvae of Ambystoma t. tigrinum. Ecology 52: 741-758.

Anderson, J.D. 1970. Description of the spermatophore of Ambystoma tigrinum. Herpetologica 26(3): 304-308.

Anderson, J.D., D.D. Hassinger, and G.H. Dalrymple. 1971. Natural mortality of eggs and larvae of Ambystoma t. tigrinum. Ecology 52(6): 1107-1112.

Arndt, R.G. 1989. Notes on the natural history and status of the tiger salamander (Ambystoma tigrinum) in Delaware. Bull. MD. Herpetological Society 25: 1-21.

Arnold, S.J. 1976. Sexual behavior, sexual interference, and sexual defense in the salamanders Ambystoma maculatum, Ambystoma tigrinum, and Plethodon jordani. Zeitschrift fur Tierpsychologie 42:247-300.

Artz, A.H., W.L. Silver, J.R. Mason and L. Clark. 1986. Olfactory responses of aquatic and terrestrial tiger salamanders (Ambystoma tigrinum) to airborne and waterborne stimuli. Journal of Comparative Physiology A Sensory Neural and Behavioral Physiology 158(4): 479-488.

*Baird S.F 1860. Siredon lichenoides? Baird. In: Cooper JG. Report upon the reptiles collected on the survey. Volume 12, Book 2, Part 3, No. 4. 36th Congress, 1st session, House Executive Document No. 56. Serial 1055. p 306.

*Bauman, J.S. 1950. Migration of salamanders. Yellowstone Nature Notes 24(1): 4-5.

*Baxter, G.T. and M.D. Stone. 1985. Amphibians and reptiles of Wyoming. Second Edition. Wyoming Game and Fish Department. 137 p.

*Beal, M.D. 1951. The occurrence and seasonal activity of vertebrates in the Norris and Gibbon Geyser Basins of Yellowstone National Park. M.S. Thesis. Utah State Agricultural College. Logan, Utah. $61 \mathrm{pp}$.

Benoy, G.A., T.D. Nudds, and E. Dunlop. 2002. Patterns of habitat and invertebrate diet overlap between tiger salamanders and ducks in prairie potholes. Hydrobiologia 481:47-59.

*Bergeron, D.J. 1979. Terrestrial wildlife survey, Coal Creek Mine area, Montana 1977-1978. Western Technology and Engineering, Inc. Helena, MT.

Berna, H.J. 1990. Ecology and life history of the tiger salamander (Ambystoma tigrinum nebulosum Hallowell) on the Kaibab Plateau. M.S. Thesis. Tempe, AZ: Arizonia State University. $121 \mathrm{p}$.

Biedermann, B.P. 1988. Life history notes. Ambystoma tigrinum (tiger salamander). Migration. Herpetological Review 19(2): 33-34.

Bishop, D.W. and R. Hamilton. 1947. Polydactyly and limb duplication occurring naturally in the tiger salamander (Ambystoma tigrinum). Science 106: 641-642.

*Bishop, S.C. 1942. An older name for a recently described salamander. Copeia 1942(4): 256. 
Bizer, J.R. 1977. Life history phenomena of Ambystoma tigrinum in montane Colorado. Ph.D. dissertation, Washington University. $211 \mathrm{pp}$.

Bizer, J.R. 1978. Growth rates and size at metamorphosis of high elevation populations of Ambystoma tigrinum. Oecologia 34: 175-184.

*Black, J.H. 1970. Amphibians of Montana. Montana Wildlife, Montana Fish and Game Commission. Animals of Montana Series 1970(1): 1-32.

*Black, J.H. and A.N. Bragg. 1968. New additions to the herpetofauna of Montana. Herpetologica 24: 247.

Blair, A.P. 1951. Note on the herpetology of the Elk Mountains, Colorado. Copeia 1951: 239240.

Bolek, M.G. 2000. Ambystoma tigrinum (Tiger Salamander) Coccidia. Herpetological Review 31(2): 97.

Bollinger, T.K., J. Mao, D. Schock, R.M. Brigham, and V.G. Chinchar. 1999. Pathology, isolation, and preliminary molecular characterization of a novel iridovirus from tiger salamanders in Saskatchewan. Journal of Wildlife Diseases 35(3): 413-429.

Botts, D.A. 1978. Life history and movement of Ambystoma tigrinium and associated vertebrates around a semi-permanent pond. M.S. Thesis, Auburn University, Auburn, Alabama. 105p.

Brandon, R.A., and D.J. Bremer. 1967. Overwintering of larval tiger salamanders in southern Illinois. Herpetologica 23: 67-68.

Brodman, R. 1995. Annual variation in breeding success of two syntopic species of Ambystoma salamanders. Journal of Herpetology 29(1): 111-113.

Brodman, R. 2004. Intraguild predation on congeners affects size, aggression, and survival among Ambystoma salamander larvae. Journal of Herpetology 38(1):21-26.

Brophy, T.E. 1980. Food habits of sympatric larval Ambystoma tigrinum and Notophthalmus viridescens. Journal of Herpetology 14: 1-6.

Brukow, P.E. and J.P. Collins. 1996. Effects of individual variation in size on growth and development of larval salamanders. Ecology 77(5): 1483-1492.

*Brunson, R.B. 1955. Check list of the amphibians and reptiles of Montana. Proceedings of the Montana Academy of Sciences 15: 27-29.

Buhlmann, K.A. and R.L. Hoffman. 1990. Ambystoma tigrinum tigrinum. Herpetological Review 21: 36.

*Burton, S.R., D.A. Patla, and C.R. Peterson. 2002. Amphibians of Red Rock Lakes National Wildlife Refuge: occurrence, distribution, relative abundance, and habitat associations. Herpetology Laboratory, Department of Biological Sciences, Idaho State University, Pocatello, ID. 66 p.

*Butts, T.W. 1997. Mountain Inc. wildlife monitoring Bull Mountains Mine No. 1, 1996. Western Technology and Engineering. Helena, MT.

Calef, R.T. 1954. The salamander Ambystoma tigrinum nebulosum in southern Arizonia. Ibid. 1954: 223.

Carey, C., N. Cohen, and L. Rollins-Smith. 1999. Amphibian declines: an immunological perspective. Developmental and Comparative Immunology 23: 459-472.

Carlson, B.N. and C.R. Berry, Jr. 1990. Population size and economic value of aquatic bait species in palustrine wetlands of eastern South Dakota (USA). Prairie Naturalist 22(2): 119128. 
Carpenter, C.C. 1953. An ecological survey of the herpetofauna of the Grand Teton-Jackson Hole area of Wyoming. Copeia 1973: 170-174.

Carpenter, C.C. 1955. Aposematic behavior in the salamander Ambystoma tigrinum melanostictum. Copeia 1955: 311.

Church, S.A., J.M. Kraus, J.C. Mitchell, D.R. Church, and D.R. Taylor. 2003. Evidence for multiple Pleistocene refugia in the postglacial expansion of the eastern tiger salamander (Ambystoma tigrinum tigrinum). Evolution 57(2): 372-383.

Clevenger, A.P., M. Mclvor, D. McIvor, B. Chruszcz, and K. Gunson. 2001. Tiger salamander, Ambystoma tigrinum, movements and mortality on the Trans-Canada Highway in southwestern Alberta. The Canadian Field-Naturalist 115: 199-204.

Collins, J.P. 1981. Distribution, habitats and life history variation in the tiger salamander (Ambystoma tigrinum) in east-central and southeast Arizona. Copeia 1981(3): 666-675.

Collins, J.P. 1988. Evolutionary relationships of Ambystoma tigrinum stebbinsi to other southwestern A. tigrinum based on mitochondrial DNA. Final Report, Nongame Branch, Arizona Game and Fish Department: 28p.

Collins, J.P. and J.E. Cheek. 1983. Effect of food and density on development of typical and cannibalistic salamander larvae in Ambystoma tigrinum nebulosum. American Zoologist 23: 77-84.

Collins, J.P. and J.R. Holomuzki. 1984. Intraspecific variation in diet within and between trophic morphs in larval tiger salamanders (Ambystoma tigrinum nebulosum). Canadian Journal of Zoology 62: 168-174.

Collins, J.P., T.R. Jones, and H.J. Berna. 1988. Conserving genetically distinctive populations: the case of the Huachuca tiger salamander (Ambystoma tigrinum stebbinsi Lowe). Pp. 45-53 In: Management of amphibians, reptiles, and small mammals in North America, R. C. Szaro, K. E. Severson, and D. R. Patton, technical coordinators. USDA Forest Service, Rocky Mountain Forest and Range Experiment Station, Fort Collins, Colorado, Technical Report RM-166.

Collins, J.P., J.B. Mitton, and B.A. Pierce. 1980. Ambystoma tigrinum: a multispecies conglomerate? Copeia 1980(4): 938-941.

Collins, J.P., K.E. Zerba, and M.J. Sredl. 1993. Shaping intraspecific variation: development, ecology and the evolution of morphology and life history variation in tiger salamanders. Genetica 89: 167-183.

*Conant, R. and J.T. Collins. 1998. A field guide to reptiles and amphibians of eastern and central North America. $3^{\text {rd }}$ edition, expanded. New York, NY: Houghton Mifflin Co. 616 p.

*Cooper, J.G. 1860. Report upon the reptiles collected on the survey. In: Reports of explorations and surveys to ascertain the most practicable and economical route for a railroad from the Mississippi River to the Pacific Ocean. Volume 12, Book 2, Part 3, Number 4. pp. 292-306, +14 pls. 36th Congress, 1st session, House Executive Document Number 56. Serial 1055.

*Cooper, S.V., C. Jean, and P. Hendricks. 2001. Biological survey of a prairie landscape in Montana's glaciated plains. Report to the Bureau of Land Management. Montana Natural Heritage Program, Helena, MT. 24 pp. plus appendices.

*Cope, E.D. 1867. A review of the species of the Amblystomidae. Proceedings of the Academy of Natural Sciences of Philadelphia 19: 166-211. 
*Cope, E.D. 1875. Check-list of North American Batrachia and Reptilia; with a systematic list of the higher groups, and an essay on geographical distribution. U.S. National Museum Bulletin 1(1):1-104.

*Cope, E.D. 1879. A contribution to the zoology of Montana. American Naturalist 13(7):432441.

*Cope, E.D. 1889. The Batrachia of North America. Bulletin of the U.S. National Museum 34: 1-525, figs. 1-119, pls. 1-86.

Corkran, C.C. and C. Thoms. 2006. Amphibians of Oregon, Washington, and British Columbia. $2^{\text {nd }}$ Edition. Vancouver, B.C.: Lone Pine Publishing. 176 p.

*Corn, P.S., B.R. Hossack, E. Muths, D.A. Palta, C.R. Peterson, and A.L. Gallant. 2005. Status of amphibians on the Continental Divide: surveys on a transect from Montana to Colorado, USA. Alytes 22(3-4):85-94.

Corn, P.S., M.L. Jennings and E. Muths. 1997. Survey and assessment of amphibian populations in Rocky Mountain National Park. Northwestern Naturalist 78: 34-55.

*Corn, P.S., E. Muths, and C.R. Peterson. 2008. U.S. Geological Survey Amphibian Research and Monitoring Initiative Rocky Mountain Region, 2007 Progress Report. Missoula, MT: Report to U.S. Geological Survey. 6 p.

Corn, P.S. and F.A. Vertucci. 1992. Descriptive risk assessment of the effects of acid deposition on Rocky Mountain Amphibians. Journal of Herpetology 26(4): 361-369.

*Coues, E. and H.C. Yarrow. 1878. Notes on the herpetology of Dakota and Montana. Bulletin of the U.S. Geologic and Geographic Survey 4(1): 259-291.

*Craig, V. 1963. The axolotl "walking fish". Montana Wildlife 1963(Autumn): 3-4. Montana Fish and Game Department, Helena, MT.

Dalrymple, G.H. 1970. Caddis fly larvae feeding upon eggs of Ambystoma t. tigrinum. Herpetologica 26: 128-129.

Darda, D. 1982. Osteology and ontogeny of cannibalistic larvae in Ambystoma tigrinum. Abstract. 25th Annual ASIH Meeting. August 1-6. Raleigh, North Carolina. 117p.

Davidson, E. W., M. Parris, J.P. Collins, J.E. Longcore, A.P. Pessier, and J. Brunner. 2003. Pathogenicity and Transmission of Chytridiomycosis in Tiger Salamanders (Ambystoma tigrinum). Copeia 3: 601-607.

Davidson, E.W., M. Parris, J.P. Collins, J.E. Longcore, A.P. Pessier, and J. Brunner. 2003. Pathogenicity and transmission of chytridiomycosis in Tiger Salamanders (Ambystoma tigrinum). Copeia 3: 601-607.

*Day, D., P.J. Farmer, and C.E. Farmer. 1989. Montco terrestrial wildlife monitoring report December, 1987 - July, 1989. Montco, Billings, MT, and Western Technology and Engineering, Inc. Helena, MT.

*[DCC] Decker Coal Company. 1998. 1997 Consolidated annual progress report. Decker Coal Company West, North and East Pits. Decker, MT.

Degenhardt, W.G., C.W. Painter, and A.H. Price. 1996. Amphibians and reptiles of New Mexico. Albuquerque, NM: University of New Mexico Press. 431 p.

*DeLacey, W.W. 1876. A trip up the South Snake River in 1863. Contributions to the Historical Society of Montana 1: 130-132.

Deutschman, M.R. and J.J. Peterka. 1988. Secondary production of tiger salamanders (Ambystoma tigrinum) in three North Dakota (USA) prairie lakes. 45(4): 691-697.

Dineen, C.F. 1955. Food habits of the larval tiger salamander (Ambystoma tigrinum). Proceedings of the Indiana Acacdemy of Sciences 65: 231-233. 
Dodson, S.I. and V.E. Dodson. 1971. The diet of Ambystoma tigrinum larvae from western Colorado. Copeia 1971(4): 614-624.

*Dood, A.R. 1980. Terry Badlands nongame survey and inventory final report. Montana Department of Fish, Wildlife, and Parks and Bureau of Land Management, Helena, MT. 70 p.

Duellman, W.E. 1954. Observations on autumn movements of the salamander Ambystoma tigrinum tigrinum in southeastern Michigan. Copeia 1954(2): 156-157.

*Dunn, E.R. 1940. The races of Ambystoma tigrinum. Copeia 1940(3): 154-162.

Dupre, R.K. and S.C. Wood. 1988. Behavioral temperature regulation by aquatic ectotherms during hypoxia. Canadian Journal of Zoology 66(12): 2649-2652.

Duvall, D. and D.O. Norris. 1978. Stimulation of land-drive behavior in adult salamanders (Ambystoma tigrinum) by thyroxine (T4). American Zoologist 18: 589.

Duvall, D. and D.O. Norris. 1980. Stimulation of terrestrial-substrate preferences and locomotor activity in newly transformed tiger salamanders (Ambystoma tigrinum) by exogenous and endogenous thyroxine. Animal Behavior 28: 116-123.

*[EI] Econ Incorporated. 1984. Terrestrial wildlife inventory for the Lame Jones and Ismay coal lease tracts. Econ Incorporated. Helena, MT.

*Farmer, P. 1980. Terrestrial wildlife monitoring study, Pearl area, Montana June, 1978 - May, 1980. Western Technology and Engineering, Inc. Helena, MT.

Fernandez, P.J., Jr., and J.P. Collins. 1988. Effect of environment and ontogeny on color pattern variation in Arizona tiger salamanders (Ambystoma tigrinum nebulosom Hallowell). Copeia 1988(4): 928-938.

Fontenot, L.W., G.P. Noblet and S.G. Platt. 1994. Rotenone hazards to amphibians and reptiles. Herpetological Review 25(4):150-156.

Fronzuto, J. and P. Verrell. 2000. Sampling aquatic salamanders: tests of the efficiency of two funnel traps. Journal of Herpetology 34(1): 146-147.

*Gates, M.T. 2005. Amphibian and reptile baseline survey: CX field study area. Report to Billings and Miles City Field Offices of Bureau of Land Management. Maxim Technologies, Billings, MT. 28pp + Appendices.

*Gehlbach, F.R. 1966. Types and type-localities of some taxa in the synonymy of Ambystoma tigrinum (Green). Copeia 1966(4): 881-882.

*Gehlbach, F.R. 1967a. Ambystoma tigrinum. Catalogue of American Amphibians and Reptiles. 52.1-52.4.

Gehlbach, F.R. 1967b. Evolution of tiger salamanders (Ambystoma tigrinum) on the Grand Canyon rims, Arizonia. Year Book of American Phil. Society: 266-269.

Gehlbach, F.R. 1969. Determination of tiger salamander larval populations to different stages of pond succession at the Grand Canyon, Arizonia. Year Book of the American Philosophical Society. 1969: 299-302.

Geraghty, C. 1992. Current habitat status and anthropogenic impacts on the tiger salamander, Ambystoma tigrinum nebulosum . M.S. Thesis, University of Illinois at Chicago. 68 pp.

Glass, B.P. 1951. Age at maturity of neotenic Ambystoma tigrinum mavortium Baird. American Midland Naturalist 46: 391-394.

Gruberg, E.R. and R.V. Stirling. 1972. Observations on the burrowing habits of the tiger salamander (Ambystoma tigrinum). Herpetological Review 4: 85-87.

Gunzburger, M.S. and J. Travis. 2005. Critical literature review of the evidence for unpalatability of amphibian eggs and larvae. Journal of Herpetology 39(4):547-571. 
Hamilton, H.L. 1941. The biological action of rotenone on freshwater animals. Proceedings of the Iowa Academy of Science 48:467-479.

Hamilton, R. 1948. The egg-laying process in the tiger salamander. Copeia 1948(3): 212-213.

Hamilton, W.J., Jr. 1946. Summer habitat of the yellow-barred tiger salamander. Copeia 1946: 51.

Hammerson, G.A. 1999. Amphibians and reptiles in Colorado. Second Edition. University Press of Colorado and Colorado Division of Wildlife. 484 p.

Hampton, P.M. 2006. Ambystoma t. tigrinum (eastern tiger salamander) paedomorphic population. Herptological Review 37(1):68-69.

*Hart, M.M., W.A. Williams, P.C. Thornton, K.P. McLaughlin, C.M. Tobalske, B.A. Maxell, D.P. Hendricks, C.R. Peterson, and R.L. Redmond. 1998. Montana atlas of terrestrial vertebrates. Montana Cooperative Wildlife Research Unit, University of Montana, Missoula, MT. $1302 \mathrm{p}$.

Harte, J. and E. Hoffman. 1989. Possible effects of acidic deposition on a Rocky Mountain population of the tiger salamander (Ambystoma tigrinum). Conservation Biology 3(2): 149158.

Harte, J. and E. Hoffman. 1994. Acidification and salamander recruitment. BioScience 44(3): $125-126$.

Hassinger, D.D., J.D. Anderson, and G.H. Dalrymple. 1970. The early life history and ecology of Ambystoma tigrinum and Ambystoma opacum in New Jersey. American Midland Naturalist 84: 474-495.

Heath, A.G. 1975. Behavioral thermoregulation in high altitude tiger salamanders, Ambystoma tigrinum. Herpetologica 31(1): 84-93.

Heath, A.G. 1976. Respiratory responses to hypoxia by Ambystoma tigrinum larvae, paedomorphs, and metamorphosed adults. Comp. Biochem Physiol 55: 45-49.

*Hendricks, P. 1999. Amphibian and reptile survey of the Bureau of Land Management Miles City District, Montana. Montana Natural Heritage Program, Helena, MT. 80 p.

*Hendricks, P. and J.D. Reichel. 1996. Preliminary amphibian and reptile survey of the Ashland District, Custer National Forest: 1995. Montana Natural Heritage Program, Helena, MT. $79 \mathrm{p}$.

*Hendricks, P. and J.D. Reichel. 1998. Amphibian and reptile survey on Montana refuges: 1996. Montana Natural Heritage Program, Helena, MT. 19 p.

*Hendricks, P. and M. Roedel. 2001. A faunal survey of the Centennial Valley Sandhills, Beaverhead County, Montana. Report to the U.S. Bureau of Land Management and U.S. Fish and Wildlife Service. Montana Natural Heritage Program, Helena, MT. 44 p.

Hensley, M. 1964. The tiger salamander in northern Michigan. Herpetologica 20: 203-204.

*Hill, S.R. 1995. Migratory chronology of adult tiger salamanders (Ambystoma tigrinum) and survey of larvae of the tiger salamander in the northern range of Yellowstone National Park. MS Thesis. Montana State University. 72pp.

*Hill, S.R. and R.E. Moore. 1994a. Herpetological survey in the northern range of Yellowstone National Park. Investigator's Annual Reports Yellowstone National Park 1993. Yellowstone Center for Resources. pp. 96-97.

*Hill, S.R. and R.E. Moore. 1994b. Herpetological survey in the northern range of Yellowstone National Park. Annual Report to Yellowstone National Park. February 1, 1994. 21 p.

Holomuzki, J. 1986. Effect of microhabitat use on fitness components of larvae of tiger salamanders, Ambystoma tigrinum tigrinum. Oecologia 71: 142-148. 
Holomuzki, J.R. 1986. Intraspecific predation and habitat use by tiger salamanders (Ambystoma tigrinum nebulosum). Journal of Herpetology 20(3): 439-441.

Holomuzki, J.R. 1986. Predator avoidance and diel patterns of microhabitat use by larval tiger salamanders. Ecology 67(3): 737-748.

Holomuzki, J.R. 1989. Salamander predation and vertical distributions of zooplankton. Freshwater Biology 21(3) 461-472.

Holomuzki, J.R. and J.P. Collins. 1987. Trophic dynamics of a top predator, Ambystoma tigrinum nebulosum (Caudata: Ambystomatidae), in a lentic community. Copeia 1987(4): 949-957.

Holomuzki, J.R., J.P. Collins and P.E. Brunkow. 1994. Trophic control of fishless ponds by tiger salamander larvae. Oikos 71(1): 55-64.

*Hossack, B.R. and P.S. Corn. 2001. Amphibian survey of Medicine Lake National Wildlife Refuge Complex: 2001. USGS Northern Rocky Mountain Science Center, Aldo Leopold Wilderness Research Institute, Missoula, MT. 13 p.

Hossack, B.R., P.S. Corn, and D.S. Pilliod. 2005. Lack of significant changes in the herpetofauna of Theodore Roosevelt National Park, North Dakota, since the 1920s. American Midland Naturalist 154:423-432.

*Irschick, D.J. and H.B. Shaffer. 1997. The polytypic species revisited: morphological differentiation among tiger salamanders (Ambystoma tigrinum) (Amphibia: Caudata). Herpetologica 53(1): 30-49.

Jancovich, J.K., Davidson, E.W., Morado, J.F., Jacobs, B.L. and Collins, J.P. 1997. Isolation of a lethal virus from the endangered tiger salamander Ambystoma tigrinum stebbinsi. Diseases of Aquatic Organisms 31: 161-167.

Jancovich, J.K., J. Mao, V. G. Chinchar, C. Wyatt, S.T. Case, S. Kumar, G. Valente, S. Subramanian, E.W. Davidson, J.P. Collins, and B.L. Jacobs. 2003. Genomic sequence of a ranavirus (family Iridoviridae) associated with salamander mortalities in North America. Virology 316: 90-103.

Jensen, J.B. 2003. Ambystoma tigrinum (Tiger Salamander). Predation. Herpetological Review 34(2):132-33.

*Jones, L.L.C., W.P. Leonard, and D.H. Olson (eds). 2005. Amphibians of the Pacific Northwest. Seattle, WA: Seattle Audubon Society. 227 p.

Jones, T.R. 1988. Macrogeographic and microgeographic patterns of evolutionary differentiation in tiger salamanders (Ambystoma tigrinum) in the southwestern U.S.A., Ph.D. Dissertation, Arizonia State University, Tempe, AZ.

Jones, T.R. and J.P. Collins. 1992. Analysis of a hybrid zone between subspecies of the tiger salamander (Ambystoma tigrinum) in central New Mexico, USA. Journal of Evolutionary Biology 5: 375-402.

Jones, T.R., J.P. Collins, T.D. Kocher, and J.B. Mitton. 1988. Systematic status and distribution of Ambystoma tigrinum stebbinsi Lowe (Amphibia: Caudata). Copeia 1988: 621-635.

Jones, T.R., E.J. Routman, D.J. Begun, and J.P. Collins. 1995. Ancestry of an isolated subspecies of salamander, Ambystoma tigrinum stebbensi Lowe: The evolutionary significance of hybridization. Molecular Physiological Evolution 4: 194-202.

Kaplan, R.H. 1980. The implications of ovum size variability for offspring fitness and clutch size within several populations of salamanders (Ambystoma). Evolution 34(1): 51-64.

Kenney, J.W., and F.L. Rose. 1974. Oxygen requirements and activity rhythms of the tiger salamander, Ambystoma tigrinum (Amphibia: Caudata). Herpetologica 30: 333-337. 
Kiesecker, J. 1996. pH mediated predator-prey interactions between Ambystoma tigrinum and Pseudacris triseriata. Ecological Applications 6(4): 1325-1331.

Knopf, G.N. 1962. Paedogenesis and metamorphic variation in Ambystoma tigrinum mavortium. Southwest Naturalist 7: 75.

*Koch, E.D. and C.R. Peterson. 1989. A preliminary survey of the distribution of amphibians and reptiles in Yellowstone National Park. pp. 47-49. In: T.W. Clark, A.H. Harvey, R.D. Dorn, D.C. Genter, and C. Groves (eds). Rare, sensitive and threatened species of the Greater Yellowstone Ecosystem. Northern Rockies Conservation Cooperative , Montana Natural Heritage Program, The Nature Conservancy, and Mountain West Environmental Services. 153 p.

*Koch, E.D. and C.R. Peterson. 1995. The amphibians and reptiles of Yellowstone and Grand Teton National Parks. University of Utah Press, Salt Lake City, UT. 188 p.

Kocher, T.D. 1986. Genetic differentiation during speciation in the Rana pipiens and Ambystoma tigrinum species complexes. Ph.D. Dissertation, University of Colorado, Boulder, Colorado.

Kolbe, J.J., B.E. Smith, and D.M. Browning. 2002. Burrow use by Tiger Salamanders (Ambystoma tigrinum) at a Black-tailed Prairie Dog (Cynomys ludovicianus) town in southwestern South Dakota. Herpetological Review 33(2):95-99.

Kumpf, K.F. 1934. The courtship of Ambystoma tigrinium. Copeia 1934(1): 7-10.

Lannoo, M.J. 1982. Food habits and feeding behavior of tiger salamander larvae (Ambystoma tigrinum) in northwestern Iowa. M.S. Thesis, Iowa State University, Ames, Iowa. 87p.

Lannoo, M.J. and M.D. Bachmann. 1984. Aspects of cannibalistic morphs in a population of Ambystoma tigrinum tigrinum larvae. American Midland Naturalist 112(1): 103-109.

Lannoo, M.J. and M.D. Bachmann. 1984. On flotation and air breathing in Ambystoma tigrinum larvae: stimuli for and the relationship between these behaviors. Canadian Journal of Zoology 62: 15-18.

Lannoo, M.J., L. Lowcock, and J.P. Bogart. 1989. Sibling cannibalism in noncannibal morph Ambystoma tigrinum larvae and its correlation with high growth rates and early metamorphosis. Canadian Journal of Zoology 67(8) 1989: 1911-1914.

Lannoo, M.J., M.P. Sweet, N.M. Ladehoff, E.S. Fangman, and W.B. Collins. 1990. Time to metamorphosis as a function of larval size in a population of Ambystoma tigrinum salamanders consisting of cannibal and typical morph phenotypes. Journal of the Iowa Academy of Science 97(4): 121-126.

Larson, D.W. 1968. The occurrence of neotenic salamanders, Amystoma tigrinum diaboli Dunn in Devil's Lake, North Dakota. Copeia, 1968: 620-621.

Lefcort, H., K. Hancock, K. Maur, and D. Rostal. 1997. The effects of used motor oil and silt on the growth, survival, and the ability to detect predators by tiger salamanders, Ambystoma tigrinum. Archives of Environmental Contaminants and Toxicology 32: 383-388.

Leff, L.G. and M.D. Bachmann. 1986. Ontogenetic changes in predatory behavior of larval tiger salamanders (Ambystoma tigrinum). Canadian Journal of Zoology 64: 1337-1344.

Leff, L.G. and M.D. Bachmann. 1988. Basis of selective predation by the aquatic larvae of the salamander, Ambystoma tigrinum. Freshwater Biology 19(1): 87-94.

Leonard, W.P. and D.M. Darda. 1995. Ambystoma tigrinum (tiger salamander). Reproduction. Herpological Review 26(1): 29-30.

Levi, H.W. and L.R. Levi. 1955. Neotenic salamanders, Ambystoma tigrinum, in the Elk Mountains of Colorado. Copeia 1955(4): 309. 
Lindberg, A.J. 1995. Ambystoma tigrinum tigrinum. (Eastern tiger salamander). Reproduction and twinning. Herpetological Review 26(3): 142.

Lindquist, S.B. and M.D. Bachmann. 1982. The role of visual and olfactory cues in the prey catching behavior of the tiger salamander, Ambystoma tigrinum. Copeia 1982(1): 81-90.

Loeb, M.L.G., J.P. Collins and T.J. Maret. 1994. The role of prey in controlling expression of a trophic polymorphism in Ambystoma tigrinum nebulosum. Functional Ecology 8(2): 151158.

Long, C.A. 1964. The badger as a natural enemy of Ambystoma tigrinum and Bufo boreas. Herpetologica 20(2): 144.

Loredo, I., D.V. Vuren, and M.L. Morrison. 1996. Habitat use and migration behavior of the California tiger salamander. Ibid. 30: 282-285.

Madison, D.M., and L. Farrand, III. 1998. Habitat use during breeding and emigration in radioimplanted tiger salamanders (Ambystoma tigrinum). Copeia 1998: 402-410.

*Manville, R.H. 1957. Amphibians and reptiles of Glacier National Park, Montana. Copeia 1957: 308-309.

*Marnell, L.F. 1997. Herpetofauna of Glacier National Park. Northwestern Naturalist 78: 1733.

*Martin, P.R. 1980. Terrestrial wildlife habitat inventory in southeastern Montana. Montana Department of Fish, Wildlife and Parks and Bureau of Land Management, Helena MT. 114 p.

Matsuda, B.M., D.M. Green, and P.T. Gregory. 2006. Amphibians and reptiles of British Columbia. Victoria, B.C.: Royal British Columbia Museum. 266 p.

*Matthews, W.L. 1979. Wibaux-Beach wildlife baseline study - nongame species. Bureau of Land Management, Miles City, MT. 93 p.

*Matthews, W.L. 1981. Broadus-Pumpkin Creek baseline inventory - wildlife. Bureau of Land Management, Miles City, MT. 83 p.

*Maxell, B.A. 2004a. Preliminary report on amphibian and aquatic reptile inventories conducted in the West Boulder River area during summer 2003. Report to Region 1 Office of the U.S. Forest Service, and the Montana Department of Fish, Wildlife, and Parks. Missoula, MT: Montana Cooperative Wildlife Research Unit and Wildlife Biology Program, University of Montana. $27 \mathrm{p}$.

*Maxell, B.A. 2004b. Preliminary report on amphibian and aquatic reptile inventories conducted on and around the Ashland District of the Custer National Forest in 2002 and 2004. Report to Ashland District of Custer Forest, Region 1 Office of the U.S. Forest Service, and Montana Department of Fish, Wildlife, and Parks. Missoula, MT: Montana Cooperative Wildlife Research Unit and Wildlife Biology Program, University of Montana. $93 \mathrm{p}$.

*Maxell, B.A. 2004c. Report on amphibian and aquatic reptile inventories conducted on and around the Beaverhead-Deerlodge National Forest 2001-2003. Report to Region 1 Office of the U.S. Forest Service, Beaverhead-Deerlodge National Forest, Montana Department of Fish, Wildlife, and Parks, Montana State Office of the Bureau of Land Management, and Montana Department of Environmental Quality. Missoula, MT: Montana Cooperative Wildlife Research Unit and Wildlife Biology Program, University of Montana. 260 p.

*Maxell, B.A. 2005a. Amphibian and aquatic reptile inventories conducted on and around lands administered by the Missoula Field Office of the Bureau of Land Management. Report to Missoula Field Office of the Bureau of Land Management. Montana Natural Heritage 
Program, Helena, MT and Montana Cooperative Wildlife Research Unit and Wildlife Biology Program, University of Montana, Missoula, MT. $53 \mathrm{p}$.

*Maxell, B.A. 2005b. A review of monitoring methods and a multi-tiered scheme for assessing and monitoring the status of amphibians in Montana. Report to Montana Department of Environmental Quality, Region 1 Office of the U.S. Forest Service, Montana Department of Fish, Wildlife, and Parks, and Montana State Office of the Bureau of Land Management. Montana Natural Heritage Program, Helena, MT and Montana Cooperative Wildlife Research Unit and Wildlife Biology Program, University of Montana, Missoula, MT. 29 p. + Appendices.

*Maxell, B.A. 2006. Evaluation of Montana's lentic breeding amphibian survey methodology and variables correlated with species occupancy. Report to Montana Department of Environmental Quality. Montana Natural Heritage Program, Helena, MT and Montana Cooperative Wildlife Research Unit and Wildlife Biology Program, University of Montana, Missoula, MT. 49 p.

*Maxell, B.A. 2009. State-wide assessment of status, predicted distribution, and landscapelevel habitat suitability of amphibians and reptiles in Montana. Ph.D. Dissertation. Missoula, MT: Wildlife Biology Program, University of Montana. 294 p.

*Maxell, B.A. and D.G. Hokit. 1999. Amphibians and reptiles. pp. 2.1-2.30. In G. Joslin and H. Youmans, coordinators. Effects of recreation on Rocky Mountain wildlife: a review for Montana. Committee on Effects of Recreation on Wildlife, Montana Chapter of the Wildlife Society. 307 p.

*Maxell, B.A., J.K. Werner, P. Hendricks, and D. Flath. 2003. Herpetology in Montana: a history, status summary, checklists, dichotomous keys, accounts for native, potentially native, and exotic species, and indexed bibliography. Olympia, WA: Society for Northwestern Vertebrate Biology. Northwest Fauna 5: 1-138.

*McEneaney, T. and J. Jensen. 1974. The reptiles and amphibians of the Charles M. Russell National Wildlife Range - 1974. Charles M. Russell National Wildlife Refuge. Lewistown, MT. 3 p.

McKnight, M.L. and H.B. Shaffer. 1997. Large, rapidly evolving intergenic spacers in the mitochondrial DNA of the salamander family Ambystomatidae (Amphibia: Caudata). Molecular Biology and Evolution 14(11): 1167-1176.

*Micken, L. 1968. Some summer observations on the tiger salamander, Ambystoma tigrinum, in Blue Lake, Madison County, Montana. Proceedings of the Montana Academy of Sciences 28: 77-80.

*Micken, L. 1971. Additional notes on neotenic Ambystoma tigrinum melanostictum in Blue Lake, Madison County, Montana. Proceedings of the Montana Academy of Sciences 31: 6264.

Miller, B.T. and J.H. Larson. 1986. Feeding habits of metamorphosed Ambystoma tigrinum melanostictum in ponds of high pH (>9). Great Basin Naturalist 46(2): 299-301.

Moore, J.E. and E.H. Strickland. 1955. Further notes on the food of Alberta amphibians. American Midland Naturalist 52: 221-224.

*[MTNHP] Montana Natural Heritage Program. 2006. Point Observation Database. Montana Natural Heritage Program, Helena, MT. Accessed May 1, 2006.

Nicholas, J.S. 1922. The reactions of Ambystoma tigrinum to olfactory stimuli. Journal of Experimental Zoology 35: 257-281. 
Nicholas, J.S. 1925. A balancer in larvae of Ambystoma tigrinum. American Naturalist 59: 191192.

Norris, D.O. 1973. Some aspects of reproduction in a population of neotenic tiger salamander, Ambystoma tigrinum. Journal of the Colorado-Wyoming Academy Science 7:39.

Norris, D.O. 1989. Seasonal changes in diet of paedogenetic tiger salamanders (Ambystoma tigrinum mavortium). Journal of Herpetology 23: 87-89.

Norris, D.O., R.E. Jones, and B.B. Criley. 1973. Pituitary prolactin levels in larval, neotenic and metamorphosed salamanders (Ambystoma tigrinum). Gen. Comp. Endocrinol., 20: 437-442.

*[OEAR] Olson Elliot and Associates Research. 1985. 1983-1984 Wildlife monitoring report for the CX Ranch project. Olson Elliot and Associates Research. Helena, MT.

Olenick, R.J. and J.H. Gee. 1981. Tiger salamanders (Ambystoma tigrinum) and stocked rainbow trout (Salmo gairderi): potential competitors for food in Manitoba prairie pothole lakes. Canadian Field Naturalist 95: 129-132.

Pague, C.A. and K.A. Buhlmann. 1991. Eastern tiger salamander. Pp. 431-433 In K. Terwilliger, coor. Virginia's endangered species. McDonald and Woodward, Blacksburg, VA.

*Patla, D.A. 1998a. Amphibians and reptiles in the Old Faithful sewage treatment area. Report to Yellowstone Center for Resources, Yellowstone National Park. 10 September, 1998. Greater Yellowstone Ecosystem Amphibian Survey and Monitoring Program, Herpetology Laboratory, Department of Biological Sciences, Idaho State University, Pocatello, ID. 7 p.

*Patla, D.A. 1998b. Potential effects of native fish restoration projects on amphibians in Yellowstone National Park Part I. 20 November, 1998. Greater Yellowstone Ecosystem Amphibian Survey and Monitoring Program, Herpetology Laboratory, Department of Biological Sciences, Idaho State University, Pocatello, ID. 26 p.

*Patla, D.A. 1999a. Amphibians and reptiles of the Madison to Norris road improvement project area, Yellowstone National Park. 11 November, 1999. Greater Yellowstone Ecosystem Amphibian Survey and Monitoring Program, Herpetology Laboratory, Department of Biological Sciences, Idaho State University, Pocatello, ID. 17 p.

*Patla, D.A. 1999b. Amphibians and reptiles, Tower Junction to Canyon Village, Yellowstone National Park; addendum to previous report. 24 November, 1999. Greater Yellowstone Ecosystem Amphibian Survey and Monitoring Program, Herpetology Laboratory, Department of Biological Sciences, Idaho State University, Pocatello, ID. 10 p.

*Patla, D.A. 1999c. Amphibians and reptiles along the grand loop road in Yellowstone National Park: Canyon Junction to Fishing Bridge Junction. December 11, 1999. Greater Yellowstone Ecosystem Amphibian Survey and Monitoring Program, Herpetology Laboratory, Department of Biological Sciences, Idaho State University, Pocatello, ID. 24 p.

*Patla, D.A. 2000. Amphibians in potential native fish restoration areas, Yellowstone National Park Part II. 7 March, 2000. Greater Yellowstone Ecosystem Amphibian Survey and Monitoring Program, Herpetology Laboratory, Department of Biological Sciences, Idaho State University, Pocatello, ID. 22 p.

*Patla, D.A. and C.R. Peterson. 1996. Amphibians and reptiles along the Grand Loop Highway in Yellowstone National Park: Tower Junction to Canyon Village. 24 February, 1996. Greater Yellowstone Ecosystem Amphibian Survey and Monitoring Program, Herpetology Laboratory, Department of Biological Sciences, Idaho State University, Pocatello, ID. 49 p.

*Patla, D.A. and C.R. Peterson. 1997. Amphibians and reptiles along the Grand Loop Highway in Yellowstone National Park: Mammoth Hot Springs to Norris Junction. 1 February, 1997. 
Greater Yellowstone Ecosystem Amphibian Survey and Monitoring Program, Herpetology Laboratory, Department of Biological Sciences, Idaho State University, Pocatello, ID. 60 p. *Patla, D.A. and C.R. Peterson. 1998. Amphibians of the Greater Yellowstone Ecosystem. Natural Resource Conservation Cooperative News 11(Autumn 1998): 10-11.

*Patla, D.A., and C.R. Peterson. 1999. Are amphibians declining in Yellowstone National Park? Yellowstone Science 7(1): 2-11.

*Patla, D.A. and C.R. Peterson. 2001. Status and trends of amphibian populations in the Greater Yellowstone Ecosystem, progress report, February 2001. Greater Yellowstone Ecosystem Amphibian Survey and Monitoring Program, Herpetology Laboratory, Department of Biological Sciences, Idaho State University, Pocatello, ID. 8 p.

Pedersen, S.C. 1991. Dental morphology of the cannibal morph in the tiger salamander (Ambystoma tigrinum). Amphibia-Reptilia 12: 1-14.

Pedersen, S.C. 1993. Skull growth in cannibalistic tiger salamanders, Ambystoma tigrinum. Southwestern Naturalist 38:316-324.

*Peterson, C.R., C.J. Askey, and D.A. Patla. 1993. Amphibians and reptiles along the Grand Loop and Fountain Freight Roads between Madison Junction and Biscuit Basin in Yellowstone National Park. 26 July, 1993. Greater Yellowstone Ecosystem Amphibian Survey and Monitoring Program, Herpetology Laboratory, Department of Biological Sciences, Idaho State University, Pocatello, ID. 45 p.

*Peterson, C.R., E.D. Koch and P.S. Corn. 1992. Monitoring amphibian populations in Yellowstone and Grand Teton National Parks final report to University of Wyoming. National Park Service Research Center, Laramie, WY. 37 p.

*Peterson, C.R., D.A. Patla, and S.R. Sullivan. 1995. Amphibians and reptiles along the Grand Loop Highway in Yellowstone National Park: Madison Junction to Norris Campground. 7 July, 1995. Greater Yellowstone Ecosystem Amphibian Survey and Monitoring Program, Herpetology Laboratory, Department of Biological Sciences, Idaho State University, Pocatello, ID. 64 p.

*Petranka, J.W. 1998. Salamanders of the United States and Canada. Smithsonian Institution Press, Washington, DC. 587 p.

Petranka, J.W., A. Sih, L.B. Kats, and J.R. Holomuzki. 1987. Stream drift, size-specific predation, and the evolution of ovum size in an amphibian. Oecologia 71(4): 624-630.

Pfenning, D.W. and J.P. Collins. 1993. Kinship affects morphogenesis in cannibalistic salamanders. Nature 362: 836-838.

Pfenning, D.W., J.P. Collins, and R.E. Ziemba. 1999. A test of alternative hypotheses for kin recognition in canninbalistic tiger salamanders. Behavior Ecology 10: 436-443.

Pfenning, D.W., M.L.G. Loeb, and J.P. Collins. 1991. Pathogens as a factor limiting the spread of cannibalism in tiger salamanders. Oecologia 88: 161-166.

Pfennig, D.W., P.W. Sherman and J.P. Collins. 1994. Kin recognition and cannibalism in polyphenic salamanders. Behavioral Ecology 5(2): 225-232.

Pierce, B.A., J.B. Mitton, L. Jackson, and F.L. Rose. 1983. Head shape and size in cannibal and noncannibal larvae of the tiger salamander from west Texas. Copeia 1983: 1006-1012.

Pierce, B.A., J.B. Mitton, and F.L. Rose. 1981. Allozyme variation among large, small and cannibal morphs of the tiger salamander inhabiting the Llano Estacado of west Texas. Copeia 1981: 590-595.

*Pierson, M.A. 1950. Mysterious Mr. Salamander. Yellowstone Nature Notes 24(2): 23-24. 
*Powell, R., J.T. Collins, and E.D. Hooper, Jr. 1998. A key to amphibians and reptiles of the Continental United States and Canada. University Press of Kansas, Lawrence, KS. 131 p.

Powers, J.H. 1903. The causes of acceleration and retardation in the metamorphis of Amblystoma tigrinium: a preliminary report. American Naturalist 34: 551-562.

Powers, J.H. 1907. Morphological variation and is causes in Amblystoma tigrinum. Studies in Zoology Laboratory University of Nebraska, 7: 197-273, pls. 1-9.

*[PRESI] Powder River Eagle Studies Incorporated. 1998a. Big Sky Mine 1997 wildlife monitoring studies. Powder River Eagle Studies Incorporated. Gillete, WY.

*[PRESI] Powder River Eagle Studies Incorporated. 1998b. Spring Creek Mine 1997 wildlife monitoring studies. Powder River Eagle Studies Incorporated. Gillete, WY.

Prosser, D.T. 1911. Habits of Amblystoma tigrinum at Tolland, Colorado. University of Colorado Studies 8: 257-263.

*Rauscher, R.L. 2000. Tiger salamander axolotls in southwest Montana, final report. Bozeman, MT: Montana Department of Fish, Wildlife and Parks. 28p.

Reese, R.W. 1969. The taxonomy and ecology of the tiger salamander (Ambystoma tigrinum) of Colorado. Ph.D. dissertation, University of Colorado, Boulder. 154 pp.

*Reichel, J.D. 1995a. Preliminary amphibian and reptile survey of the Lewis and Clark National Forest: 1994. Helena, MT: Montana Natural Heritage Program. 92 p.

*Reichel, J.D. 1995b. Preliminary amphibian and reptile survey of the Sioux District of the Custer National Forest: 1994. Montana Natural Heritage Program, Helena, MT. 75 p.

*Reichel, J.D. 1997. Amphibian, reptile and northern bog lemming survey on the Rocky Mountain Front: 1996. Montana Natural Heritage Program, Helena, MT. 81 p.

Reilly, S.M., G.V. Lauder, and J.P. Collins. 1992. Performance consequences of a trophic polymorphism: feeding behavior in typical and cannibal phenotypes of Ambystoma tigrinium. Copeia 1992: 672-679.

Rodgers, L.T. and P.L. Risley. 1938. Sexual difference of urogenital ducts of Ambystoma tigrinum. Journal of Morphology 63: 119-141.

*Roedel, M.D. and P. Hendricks. 1998a. Amphibian and reptile survey on the Bureau of Land Management Lewistown District: 1995-1998. Montana Natural Heritage Program, Helena, MT. $53 \mathrm{p}$.

*Roedel, M.D. and P. Hendricks. 1998b. Amphibian and reptile inventory on the Headwaters and Dillon Resource Areas in conjunction with Red Rocks Lakes National Wildlife Refuge: 1996-1998. Montana Natural Heritage Program, Helena, MT. 46 p.

Rogers, K.L. 1985. Facultative metamorphosis in a series of high altitude fossil populations of Ambystoma tigrinum (Irvington: Alamosa County, Colorado). Copeia 1985: 926-932.

Rojas, S., K. Richards, J.K. Jancovich, and E.W. Davidson. 2005. Influence of temperature on Ranavirus infection in larval salamanders Ambystoma tigrinum. Diseases of Aquatic Organisms 63(2-3):95-100.

Rose, F.L. 1976. Sex ratios of larval and transformed Ambystoma tigrinum Green inhabiting the Llano Estacado of west Texas. Copeia 1976: 455-461.

Rose, F.L., and D. Armentrout. 1976. Adaptive strategies of Ambystoma tigrinum Green inhabiting the Llano Estacado of west Texas. Journal of Animal Ecology 45:713-729.

Rose, F.L. and J.C. Harshbarger. 1977. Neoplastic and possibly related skin lesions in neotenic tiger salamanders from a sewage lagoon. Science 196: 315-317.

Rossman, D.A. 1965. Rediscovery of the tiger salamander (Ambystoma tigrinium) in Louisana. Proceedings of Louisiana Academy of Science 27: 17-20. 
Routman, E.J. 1984. Paedomorphosis and population structure in the salamanders Cryptobranchus alleganiensis and Ambystoma tigrinum. Ph.D. Diss. Washington University. St. Louis, MO.

Routman, E.J. 1993. Population structure and genetic diversity of metamorphic and paedomorphic populations of the tiger salamander, Ambystoma tigrinum. Journal of Evolutionary Biology 6: 329-357.

Russell, A.P., and A.M. Bauer. 2000. The amphibians and reptiles of Alberta. Second Edition. Calgary, AB: University of Calgary Press. 279 p.

Salthe, S.N. and J.S. Mecham. 1974. Reproductive and courtship patterns. pp. 310-473 in B. Lafts, ed., Physiology of the Amphibia, vol.II. Academic Press, New York.

Semlitsch, R.D. 1983. Structure and dynamics of two breeding populations of the eastern tiger salamander (Ambystoma tigrinum). Copeia 1983(3): 608-616.

Semlitsch, R.D. 1983. Terrestrial movements of an eastern tiger salamander, Ambystoma tigrinum. Herpetological Review 14: 112-113.

Semlitsch, R.D. 1987. Density dependant growth and fecundity in the paedomorphic salamander Ambystoma tigrinum. Ecology 68: 1003-1008.

*Sestrich, C. 2007. 2006 Hebgen Reservoir amphibian survey. USDA Forest Service Annual Report to PPL Montana. West Yellowstone, MT: Gallatin National Forest, Hebgen Lake Ranger District. 75 p.

Sever, D.M. 1995. Spermathecae of Ambystoma tigrinum (Amphibia: Caudata): development and a role for the secretions. Journal of Herpetology 29(2): 243-255.

Sever, D.M. and C.F. Dineen. 1978. Reproductive ecology of the tiger salamander (Ambystoma tigrinum) in northern Indiana. Proceedings of the Indiana Academy of Science 87:189-203.

Sexton, O.J. and J.R. Bizer. 1978. Life history patterns of Ambystoma tigrinum in montane Colorado. American Midland Naturalist 99(1): 101-118.

*Shaffer, H.B. and M.L. McKnight. 1996. The polytypic species revisited: genetic differentiation and molecular phylogenetics of the tiger salamander, Ambystoma tigrinum (Amphibia: Caudata) complex. Evolution 50(1): 417-433.

Sheen, J.P. and H.H. Whiteman. 1998. Head and body size relationships in polymorphic tiger salamander larvae from Colorado. Copeia 1998: 1089-1093.

Shoop, R.C. 1974. Yearly variation in larval survival of Ambystoma tigrinum. Ecology 55: 440-444.

*Skinner, M.P. 1924. The Yellowstone Nature Book. A.C. McClurg Company, Chicago, IL. $221 \mathrm{p}$.

Slater, J.R. 1934. Ambystoma tigrinium in the state of Washington. Copeia 1934: 189-190.

Slater, J.R. 1937. Notes on the tiger salamander (Ambystoma tigrinum) in Washington and Idaho. Herpetologica 1: 81-83.

Sprules, W.G. 1974. The adaptive significance of paedogenesis in North American species of Ambystoma (Amphibia: Caudata): an hypothesis. Canadian Journal of Zoology 52: 393-400.

Sredl, M.J. and J.P. Collins. 1992. The interaction of predation, competition, and habitat complexity in structuring an amphibian community. Copeia 1992(3): 607-614.

Stark, M.A. 1986. Overwintering of an ambystomid salamander in a prairie rattlesnake hibernaculum. Herpetological Review 17(1): 7.

*Stebbins, R.C. 2003. A field guide to western reptiles and amphibians. 3rd edition. New York, NY: Houghton Mifflin Co. 533 p. 
Stine, C. Jr. 1984. The life history and status of the eastern tigher salamander (Ambystoma tigrinum tigrinum Green) in Maryland. Bulletin of Maryland Herpetology Society 20: 65108.

Stine, C. Jr., J.A. Fowler, and R.S. Simmons. 1954. Occurrence of the eastern tiger salamander (Ambystoma tigrinium tigrinum) (Green) in Maryland, with notes on its life history. Ann. Carnegie Museum 33: 145-148 pls. 17-20.

Storfer, A. and C. White. 2004. Phenotypically plastic responses of larval Tiger Salamanders, Ambystoma tigrinum, to different predators. Journal of Herpetology 38(4):612-615.

*Sullivan, S.R. and C.R. Peterson. 1996. Amphibians and reptiles along the highway in Yellowstone National Park: Tower Junction to the Northeast Entrance. 25 February, 1996. Greater Yellowstone Ecosystem Amphibian Survey and Monitoring Program, Herpetology Laboratory, Department of Biological Sciences, Idaho State University, Pocatello, ID. 60p.

*Tanner, W.W., D.L. Fisher, and T.J. Willis. 1971. Notes on the life history of Ambystoma tigrinum nebulosum Hallowell in Utah. Great Basin Naturalist 31(4): 213-222.

Taylor, D.H. 1972. Extra-optic photoreception and compass orientation in the larval and adult salamanders (Ambystoma tigrinum). Animal Behavior 20(2):233-236.

Taylor, D.H. and K. Adler. 1978. The pineal body: site of extraocular perception of celestial cues for orientation in the tiger salamander (Ambystoma tigrinum). Journal of Comparative Physiology 124:357-361.

Templeton, A.R., E. Routman, and C.A. Phillips. 1995. Separating population structure from history: a cladistic analysis of the geographical distribution of mitochondrial DNA haplotypes in the tiger salamander, Ambystoma tigrinum. Genetics 140: 767-782.

*Test, F.C. 1893. Annotated list of reptiles and batrachians collected. In: B.W. Evermann. A reconnaisance of the streams and lakes of western Montana and northwestern Wyoming. Bulletin of United States Fish Commission 11(1891): 57-59.

*Thompson, L.S. and P.S. Nichols. 1982. Circle West wildlife monitoring study; fourth annual report for period March 1, 1981 - May 31, 1982. Circle West Technical Report No. 10. Montana Department of Natural Resources and Conservation, Helena, MT.

Tihen, J.A. 1958. Comments on the osteology and phylogeny of ambystomatid salamanders. Bulletin of the Florida State Museum 3: 1-50.

*Tihen, J.A. 1969. Ambystoma. Catalogue of American Amphibians and Reptiles 75.1-75.4.

*Timken, R. No Date. Amphibians and reptiles of the Beaverhead National Forest. Western Montana College, Dillon, MT. $16 \mathrm{p}$.

Trenham, P.C. 2001. Terrestrial habitat use by adult California tiger salamanders. Journal of Herpetology 35(2): 343-346.

Trenham, P.C., W.D. Koenig, and H.B. Shaffer. 2001. Spatially autocorrelated demography and interpond dispersal in the salamander Ambystoma californiense. Ecology 82: 3519-3530.

Trenham, P.C., H.B. Shaffer and M.R. Stromberg. 2000. Life history and demographic variation in the California tiger salamander (Ambystoma californiense). Copeia 2000: 365377.

*Turner, F.B. 1951. A checklist of the reptiles and amphibians of Yellowstone National Park with incidental notes. Yellowstone Nature Notes 25(3): 25-29.

*Turner, F.B. 1952. Duel in the sun. Yellowstone Nature Notes 26(5): 59-60.

*Turner, F.B. 1953. New localities for the northwestern tiger salamander (Ambystoma tigrinum melanostictum) in Yellowstone Park. Yellowstone Nature Notes 27(5): 58-59. 
*Turner, F.B. 1955. Reptiles and amphibians of Yellowstone National Park. Yellowstone Interpretive Series No. 5. Yellowstone Library and Museum Association. Yellowstone National Park, WY. 40 p.

*Turner, F.B. 1957. The ecology and morphology of Rana pretiosa pretiosa in Yellowstone Park, Wyoming. Ph.D. Dissertation, University of California, Berkeley, CA. 252 p. Twitty, V.C. 1941. Data on the life history of Ambystoma tigrinum californiense. Copeia 1941(1): 1-4.

*[USFWS] US Fish and Wildlife Service. 1964-1982. Fishery and aquatic management program in Yellowstone National Park annual project technical reports for calendar years 1964-1982. USDI Fish and Wildlife Service. Mammoth, WY.

*Van Kirk, R., L. Benjamin, and D. Patla. 2000. Riparian area assessment and amphibian status in the watersheds of the Greater Yellowstone Ecosystem. Greater Yellowstone Coalition, Bozeman, MT. $102 \mathrm{p}$.

Vertucci, F.A. and P.S. Corn. 1994. A reply to Harte and Hoffman, acidification and salamander recruitment. BioScience 44: 126.

Vertucci, F.A. and P.S. Corn. 1996. Evaluation of episodic acidification and amphibian declines in the Rocky Mountains. Ecological Applications 6(2): 449-457.

*Vitt, L.J., J.P. Caldwell, and D.B. Shepard. 2005. Inventory of amphibians and reptiles in the Billings Field Office Region, Montana. Sam Noble Oklahoma Museum of Natural History and Department of Zoology, University of Oklahoma, Norman, OK. 33 pp.

*[VTNWI] VTN Wyoming Incorporated. No Date. Second year's analysis of terrestrial wildlife on proposed mine access and railroad routes in southern Montana and northern Wyoming, March 1979 - February 1980. VTN Wyoming Incorporated. Sheridan, WY. 62 p.

*Waage, B.C. 1998. Western Energy Company Rosebud Mine 1997 annual wildlife monitoring report December 1, 1996 to November 30, 1997 survey period. Western Energy Company, Colstrip, MT.

Webb, R.G. 1969. Survival adaptations of tiger salamanders (Ambystoma tigrinum) in the Chihuahuan Desert. In: Physiological systems in semiard environments. C. Clayton Hoff and Marvin L. Riedull (eds.). University of New Mexico Pr., Albuquerque.

Webb, R.G. and W.L. Roueche. 1971. Life history aspects of the tiger salamander (Ambystoma tigrinum mavortium) in the Chihuahuan desert. Great Basin Naturalist 31(4): 193-212.

*Werner, J.K., B.A. Maxell, P. Hendricks, and D. Flath. 2004. Amphibians and reptiles of Montana. Missoula, MT: Mountain Press Publishing Company. 262p.

*Werner, J.K. and J.D. Reichel. 1996. Amphibian and reptile monitoring/survey of the Kootenai Naitonal Forest: 1995. Helena, MT: Montana Natural Heritage Program. 115 p.

*Werner, J.K., T. Plummer, and J. Weaselhead. 1998. Amphibians and reptiles of the Flathead Indian Reservation. Intermountain Journal of Sciences 4(1-2): 33-49.

*[WESCO] Western Ecological Services Company. 1983a. Wildlife inventory of the Knowlton known recoverable coal resource area, Montana. Western Ecological Services Company, Novato, CA. 107 p.

*[WESCO] Western Ecological Services Company. 1983b. Wildlife inventory of the Southwest Circle known recoverable coal resource area, Montana. Western Ecological Services Company, Novato, CA. 131 p.

*[WESTECH] Western Technology and Engineering Incorporated. 1998. Wildlife monitoring Absaloka Mine area 1997. Western Technology and Engineering, Inc., Helena, MT. 
*Wheeler, G.C. and J. Wheeler. 1966. The amphibians and reptiles of North Dakota. University of North Dakota, Grand Forks, ND. 104 p.

Whiteman, Howard H., J.P. Sheen, E.B. Johnson, A. VanDeusen, R. Cargille, and T.W. Sacco. 2003. Heterospecific prey and trophic polyphenism in larval tiger salamanders. Copeia. 2003(1):56-67.

Whiteman, H.H., R.D. Howard and K.A. Whitten. 1995. Effects of $\mathrm{pH}$ on embryo tolerance and adult behavior in the tiger salamander, Ambystoma tigrinum tigrinum. Canadian Journal of Zoology 73(8): 1529-1537.

Whiteman, H.H. and S.A. Wissinger. 1990. Ecological correlates of paedomorphosis in high elevation populations of Ambystoma tigrinum nebulosum. American Zoologist 30: A86.

Whiteman, H.H., S.A. Wissinger and A.J. Bohonak. 1994. Seasonal movement patterns in a subalpine population of the tiger salamander, Ambystoma tigrinum nebulosum. Canadian Journal of Zoology 72(10): 1780-1787.

Whiteman, H. H., S.A. Wissinger, and W.S. Brown. 1996. Growth and foraging consequences of facultative paedomorphosis in the tiger salamander, Ambystoma tigrinum nebulosum. Evolutionary Ecology 10(4): 433-446.

Whitford, W.G. and M. Massey. 1970. Responses of a population of Ambystoma tigrinum to thermal and oxygen greadients. Herpetologica 26: 372-376.

Willey, R.L., B. Inouye, and S. Horn. 1989. Survey of reproducing populations containing neotenic morphs of the salamander Ambystoma tigrinum nebulosm, in the Gunnison Basin of Colorado. Colorado Division of Wildlife, Biological Report.

Wissinger, S.A. and H.H. Whiteman. 1992. Fluctuation in a Rocky Mountain population of salamanders: anthropogenic acidification or natural variation? Journal of Herpetology 26: 377-391.

Woodward, B. 1985. Ambystoma tigrinum (Ambystomidae) predation on Scaphiopus couchi (Pelobatidae) tadpoles of different sizes. Southwestern Naturalist 30(3): 460-461.

Worthylake, K.M. and P. Hovingh. 1989. Mass mortality of salamanders (Ambystoma tigrinum) by bacteria (Acinetobacter) in an oligotrophic seepage mountain lake. Great Basin Naturalist 49(3):364-372.

*Yarrow, H.C. 1882. Check list of North American reptilia and batrachia, with catalogue of specimens in the U.S. National Museum. United States National Museum Bulletin 24. 249 p.

Zerba, K.E. 1989. Individual variation in diet of larval tiger salamanders (Ambystoma tigrinium nebulosum) in Arizona. Ph.D. Thesis, Arizona State University.

Zerba, K.E. and J.P. Collins. 1992. Spatial heterogeneity and individual variation in diet of an aquatic top predator. Ecology 73(1): 268-279. 
Idaho Giant Salamander (Dicamptodon aterrimus)

Up-to-date distribution and status information can be found on the Montana Natural Heritage Program's TRACKER website at http://mtnhp.org

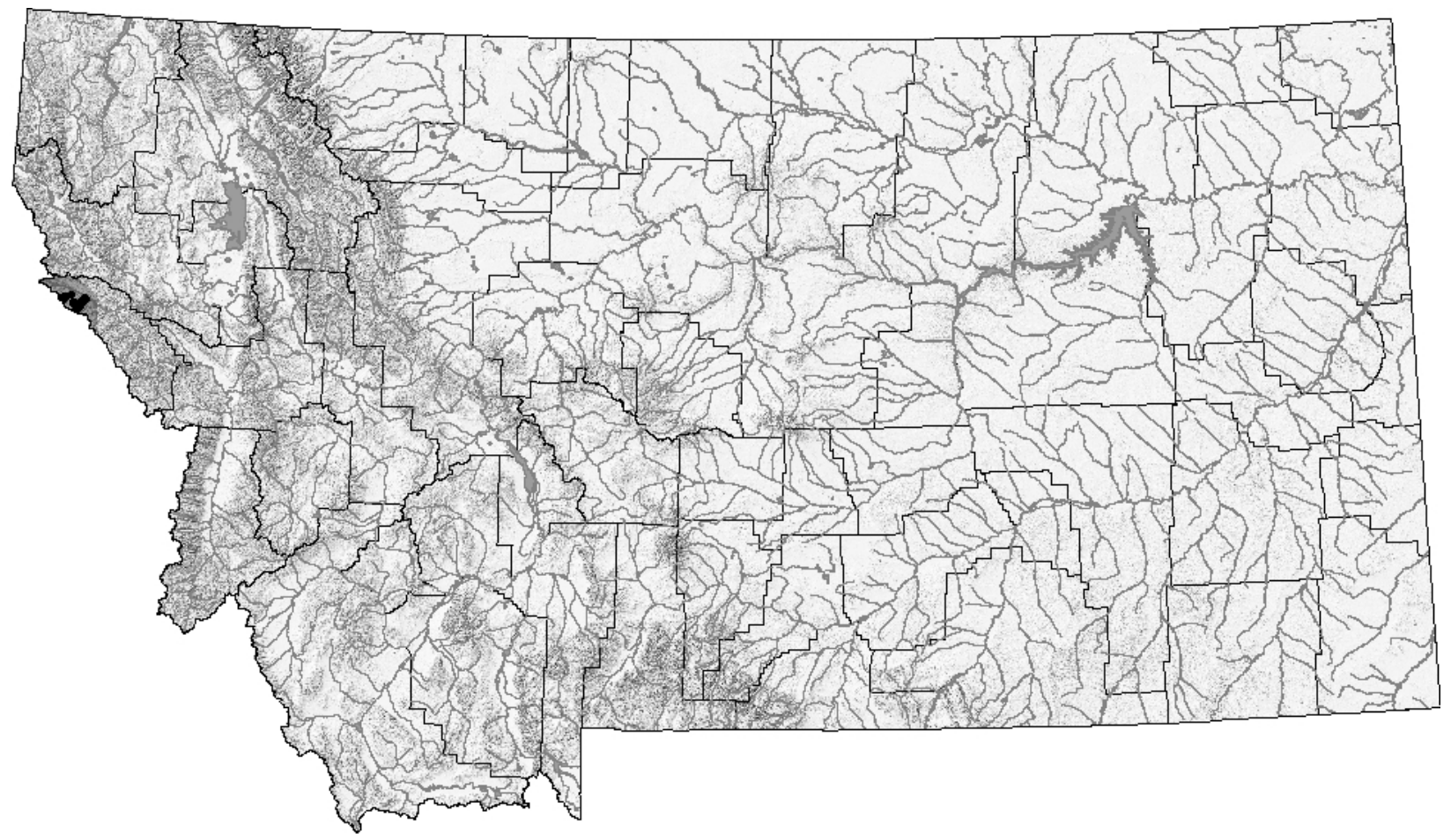

Distribution/Taxonomy

In 2005, Idaho Giant Salamander (Dicamptodon aterrimus) were confirmed to be present in Mineral County south of Haugan by Jennifer Copenhaver of the Lolo National Forest. Electrofishing surveys in the same region in 2006 and 2007 detected more than 100 individuals in 51 different portions of 11 different tributaries of 3 major watersheds. Prior to these observations, the species had been reported or illustrated as occuring in Mineral and Ravalli counties by a number of authors (Anderson 1969; Black 1970a; Daugherty et al. 1983; Stebbins 2003; Good 1989; Reichel and Flath 1995; Petranka 1998). However, as noted by Nussbaum (1976) and Savage (1952) all these distributional claims were apparently based on the assumption that the holotype specimen (USNM 5242) described by Cope (1867) and later by Cope (1889) as being collected by Lieutenant Mullan from the "North Rocky Mountains" was actually collected in western Montana. Thus, prior to the detection in 2005 there was no valid documentation of their presence in the state (Franz 1971; Nussbaum 1976; Maxell et al. 2003; Werner et al. 2004).

Maximum Elevation

$1,737 \mathrm{~m}(5,700 \mathrm{ft})$ in Mineral County (Eric Dallalio and Phil Jellen, pers. comm.; MTNHP 2007).

\section{Identification}

\section{Eggs:}

Eggs are laid singly, but placed together in a mass approximately $15 \mathrm{~cm}$ wide by $20 \mathrm{~cm}$ long containing 129 to 200 eggs (Nussbaum et al. 1983; Jones et al. 1990). Each ovum is pure white and is surrounded by six clear jelly layers (Nussbaum et al. 1983). Ovum diameters are 
approximately $6.5 \mathrm{~mm}$ (Nussbaum et al. 1983). The eggs are oblong with the long access attached to the substrate. Total egg widths are $16-21 \mathrm{~mm}$ and total egg heights are $22-33 \mathrm{~mm}$, including the jelly layers (Jones et al. 1990).

\section{Larvae:}

Short external feathery gills are present at the base of the head. Body color varies to match the local substrate, but they usually have a dark dorsal color with lighter stripes behind the eyes (Nussbaum et al. 1983). The dorsal tail fin is mottled. Hatchlings have a TL of 34 to $40 \mathrm{~mm}$ and reproductively mature larvae (neotenic) larvae may reach a TL of $351 \mathrm{~mm}$ (Nussbaum et al. 1983; Jones et al. 1990).

Juveniles and Adults:

Dorsal color is dark brown or almost black in base color and light tan or coppery marbling is usually present and is often brightest on the head (Nussbaum et al. 1983). The size of new metamorphs is highly variable but adults may reach a TL of up to $340 \mathrm{~mm}$ (Nussbaum et al. 1983).

Similar Species:

No other salamander would be found as an aquatic inhabitant of streams in Montana and terrestrial adults of long-toed and tiger salamanders are much smaller (see descriptions).

\section{Habitat Use/Natural History}

Although seldom seen, adults are found terrestrially in moist coniferous forests under rocks, bark and logs and aquatically under stones in mountain streams or lakes up to $2,165 \mathrm{M}(7,100 \mathrm{ft})$ (Nussbaum et al. 1983). Adults are active terrestrially on warm, rainy nights and may feed on a variety of invertebrates and small vertebrates (Nussbaum et al. 1983). Adults breed in the spring or fall in hidden water-filled nest chambers beneath logs and stones or in crevices in mountain streams or lakes. Females subsequently deposit eggs in these chambers and guard the eggs throughout the incubation period (Nussbaum et al. 1983). Larvae and aquatic adults are the most likely life history stage to be observed as they may reach high densities in the pools of swift, cold mountain streams and they may also be found in lakes or ponds (Nussbaum et al. 1983). Larvae feed on fish and invertebrates and usually metamorphose in 18-24 months, but may become sexually mature (paedogenesis) and reproduce as larvae (Nussbaum et al. 1983; Parker 1993).

\section{Status and Conservation}

Because Idaho Giant Salamanders were only recently detected in Montana the extent of their distribution and conservation status is still largely uncertain. However, because their distribution appears to be limited to a handful of headwater streams adjacent to the Idaho border, they face a variety of risks associated with limited distribution. Risk factors relevant to the viability of populations of this species are likely to include, timber harvest, fire and fire management activities, use of piscicides, road and trail development, on- and off-road vehicle use, and habitat fragmentation, all as described above. Individual studies that specifically identify risk factors or other issues relevant to the conservation of Idaho Giant Salamanders have not been reviewed at this time. 
$\underline{\text { Research and Management Suggestions }}$

1. Because the species' known range in Montana appears to be extremely limited, special management attention should be given to watersheds where the species has been detected and surveys should be conducted prior to the initiation of projects close to headwater streams in the area along the Idaho border between Thompson Falls and Lolo Pass.

2. The impacts of tree canopy removal on egg, larval, and adult survival should be examined in order to understand the implications of timber harvest and fire management activities.

3. The impacts of road and trail development on egg, larval, and adult survival should be examined, specifically with regards to impacts resulting from increased sedimentation.

4. The phylogeography of Montana populations should be studied relative to populations in Idaho in order to identify potential genetic differences between populations in different watersheds in Montana as a result of multiple colonization events.

5. Piscicide use in waters known to contain Idaho Giant Salamanders should be eliminated or restricted.

Bibliography *indicates an article with information specific to Montana

*Anderson, J.D. 1969. Dicamptodon and D. ensatus. Catalogue of American Amphibians and Reptiles. 76.1-76.2.

Antonelli, A.L., R.A. Nussbaum and S.D. Smith. 1972. Comparative food habits of four species of stream-dwelling vertebrates (Dicamptodon ensatus, D. copei, Cottus tenius, Salmo gairdnei) Northwest Science 46: 277-289.

*Black, J.H. 1970. Amphibians of Montana. Montana Wildlife, Montana Fish and Game Commission. Animals of Montana Series 1970(1): 1-32.

*Blaustein, A.R., J.J. Beatty, H. Deanna, and R.M. Storm. 1995. The biology of amphibians and reptiles in old-growth forests in the Pacific Northwest. General Technical Report PNWGTR-337. Portland, OR: U.S. Department of Agriculture, Forest Service, Pacific Northwest Research Station. 98 p.

*Boundy, J. 2001. Herpetofaunal surveys in the Clark Fork Valley region, Montana. Herpetological Natural History 8: 15-26.

*Brunson, R.B. 1955. Check list of the amphibians and reptiles of Montana. Proceedings of the Montana Academy of Sciences 15: 27-29.

Bury, R.B. 1972. Small mammals and other prey in the diet of the Pacific Giant salamander (Dicamptodon ensatus). American Midland Naturalist 87(2): 524-526.

Bury, R.B. and M. Martin. 1967. The food of the salamander, Rhyacotriton olympicus. Copeia 1967:487.

*Cochran, D.M. 1961. Type specimens of reptiles and amphibians in the United States National Museum. United States National Museum Bulletin 220: 1-291.

Connor, E.J., W.J. Trush, and A.W. Knight. 1988. Effects of logging on Pacific giant salamanders: influence of age-class composition and habitat complexity. Bulletin of the Ecological Society of America 69 (Suppl.): 104-105.

*Cope, E.D. 1867. A review of the species of the Amblystomidae. Proceedings of the Academy of Natural Sciences of Philadelphia 19: 166-211.

*Cope, E.D. 1875. Check-list of North American Batrachia and Reptilia; with a systematic list of the higher groups, and an essay on geographical distribution. U.S. National Museum Bulletin 1(1): 1-104. 
*Cope, E.D. 1889. The Batrachia of North America. Bulletin of the U.S. National Museum 34: 1-525, figs. 1-119, pls. 1-86.

Corkran, C.C. and C. Thoms. 2006. Amphibians of Oregon, Washington, and British Columbia. $2^{\text {nd }}$ Edition. Vancouver, B.C.: Lone Pine Publishing. 176 p.

*Coues, E. and H.C. Yarrow. 1878. Notes on the herpetology of Dakota and Montana. Bulletin of the U.S. Geologic and Geographic Survey 4(1): 259-291.

Daugherty, C.H. and F.W. Allendorf. 1977. The taxonomic value of genetic distance: data from two amphibians. Abstract. American Zoologist 17(4): 973.

*Daugherty, C.H., F.W. Allendorf, W.W. Dunlap and K.L. Knudsen. 1983. Systematic implications of geographic patterns of genetic variation in the genus Dicamptodon. Copeia 1983: 679-691.

Dethlefson, E.S. 1948. A subterranean nest of the Pacific giant salamander, Dicamptodon ensatus (Eschscholtz). Wasmann Collector 7: 81-84.

Ferguson, H.M. 2000. Larval colonisation and recruitment in the Pacific giant salamander (Dicamptodon tenebrosus) in British Columbia. Canadian Journal of Zoology 78: 1238-??

*Flath, D.L. 1998. Species of special interest or concern. Montana Department of Fish, Widlife and Parks, Helena, MT. March, 1998. 7p.

*Franz, R. 1970. Additional notes on the feeding of larval giant salamanders, Dicamptodon ensatus. Bulletin of the Maryland Herpetological Society 6(3): 51-52.

*Franz, R. 1971. Notes on the distribution and ecology of the herpetofauna of northwestern Montana. Bulletin of the Maryland Herpetological Society 7: 1-10.

*Good, D.A. 1989. Hybridization and cryptic species in Dicamptodon (Caudata: Dicamptodontidae). Evolution 43(4): 728-744.

Hawkins, C.P., M.L. Murphy, N.H. Anderson, and M.A. Wilzbach. 1983. Density of fish and salamanders in relation to riparian canopy and physical habitat in streams of the northwestern United States. Canadian Journal of Fisheries and Aquatic Sciences 40: 1173-1185.

*Hendricks, P. and J.D. Reichel. 1996. Amphibian and reptile survey of the Bitterroot National Forest: 1995. Montana Natural Heritage Program, Helena, MT. 95 p.

Johnston, B. and L. Frid. 2002. Clearcut logging restricts the movements of terrestrial pacific giant salamanders (Dicamptodon tenebrosus Good). Canadian Journal of Zoology 80: 21702177.

*Jones, L.L.C., R.B. Bury and P.S. Corn. 1990. Field observation of the development of a clutch of pacific giant salamander (Dicamptodon tenebrosus) eggs. Northwestern Naturalist 71: 93-94.

*Jones, L.L.C., W.P. Leonard, and D.H. Olson (eds). 2005. Amphibians of the Pacific Northwest. Seattle, WA: Seattle Audubon Society. 227 p.

Kessel, E.L. and B.B. Kessel. 1943. The rate of growth of older larvae of the Pacific Giant Salamander, Dicamptodon ensatus (Eschscholtz). Wasmann Collector 5: 141-142.

Kessel, E.L. and B.B. Kessel. 1943. The rate of growth of the young larvae of the Pacific Giant Salamander, Dicamptodon ensatus (Eschscholtz). Wasmann Collector 5: 108-111.

Kessel, E.L. and B.B. Kessel. 1944. Metamorphosis of the Pacific giant salamander, Dicamptodon ensatus (Eschscholtz). Wasmann Collector 6: 38-48.

Lind, A.J. and H.H. Welsh, Jr. 1990. Predation by Thamnophis couchii on Dicamptodon ensatus. Journal of Herpetology 24(1): 104-106.

Loafman, P. and L. Jones. 1996. Caudata: Dicamptodon copei (Cope's giant salamander): Metamorphosis and predation. Herpetological Review 27(3): 136. 
Maughan, O.E. and M.G. Wickham. 1976. Records of the Pacific Giant Salamander, Dicamptodon ensatus, (Amphibia, Urodela, Ambystomatidae) from the Rocky Mountains in Idaho. Journal of Herpetology 10(3): 249-251.

*Maxell, B.A. 2005. Amphibian and aquatic reptile inventories conducted on and around lands administered by the Missoula Field Office of the Bureau of Land Management. Report to Missoula Field Office of the Bureau of Land Management. Montana Natural Heritage Program, Helena, MT and Montana Cooperative Wildlife Research Unit and Wildlife Biology Program, University of Montana, Missoula, MT. 53 p.

*Maxell, B.A. 2009. State-wide assessment of status, predicted distribution, and landscapelevel habitat suitability of amphibians and reptiles in Montana. Ph.D. Dissertation. Missoula, MT: Wildlife Biology Program, University of Montana. 294 p.

*Maxell, B.A., J.K. Werner, P. Hendricks, and D. Flath. 2003. Herpetology in Montana: a history, status summary, checklists, dichotomous keys, accounts for native, potentially native, and exotic species, and indexed bibliography. Olympia, WA: Society for Northwestern Vertebrate Biology. Northwest Fauna 5: 1-138.

Metter, D.E. 1963. Stomach contents of Idaho larval Dicamptodon. Copeia 1963(2): 435-436.

Murphy, M.L. and J.D. Hall. 1981. Varied effects of clear-cut logging on predators and their habitat in small streams of the Cascade Mountains, Oregon. Canadian Journal of Fisheries and Aquatic Sciences 38: 137-145.

Murphy, M.L., C.P. Hawkins, and N.H. Anderson. 1981. Effects of canopy modification and accumulated sediment on stream communities. Transactions of the American Fisheries Society 110: 469-478.

Nussbaum, R.A. 1969. Nests and eggs of the Pacific Giant Salamander Dicamptodon ensatus (Eschscholtz). Herpetologica 25: 257-262.

Nussbaum, R.A. 1970. Dicamptodon copei, n. sp., from the Pacific Northwest, USA (Amphibia: Caudata: Ambystomatidae). Copeia 1970: 506-514.

*Nussbaum, R.A. 1972. Systematics of the salamander genus Dicamptodon Strauch (Amphibia: Caudata: Ambystomatidae). Ph.D. Dissertation. Corvallis, OR: Oregon State University. $226 \mathrm{p}$.

*Nussbaum, R.A. 1976. Geographic variation and systematics of salamanders of the genus Dicamptodon Strauch (Ambystomatidae). Miscellaneous Publications of the Museum of Zoology, University of Michigan 149: 1-94.

*Nussbaun, R., E. Brodie, Jr., and R. Storm. 1983. Amphibians and reptiles of the Pacific Northwest. University of Idaho Press, Moscow, Idaho. 322 p.

Nussbaum, R.A. and G.W. Clothier. 1973. Population structure, growth, and size of larval Dicamptodon ensatus (Eschscholtz). Northwest Science 47(4): 218-227.

Parker, M.S. 1991. Relationship between cover availability and larval Pacific giant salamander density. Journal of Herpetology 25(3): 355-357.

Parker, M.S. 1993a. Predation by pacific giant salamander larvae on juvenile steelhead trout. Northwestern Naturalist 74: 77-81.

Parker, M.S. 1993b. Size-selective predation on benthic macroinvertebrates by stream-dwelling salamander larvae. Archiv fuer Hydrobiologie 128(4): 385-400.

Parker, M. 1994. Feeding ecology of stream dwelling Pacific giant salamander larvae (Dicamptodon tenebrosus). Copeia 1994(3): 705-718.

*Petranka, J.W. 1998. Salamanders of the United States and Canada. Smithsonian Institution Press, Washington, DC. 587 p. 
*Powell, R., J.T. Collins, and E.D. Hooper, Jr. 1998. A key to amphibians and reptiles of the Continental United States and Canada. University Press of Kansas, Lawrence, KS. 131 p. Reed, C.A. 1949. The problem of metamorphosis in the western marbled salamander Dicamptodon ensatus. Copeia 1949: 81.

*Reichel, J.D. and D.L. Flath. 1995. Identification guide to the amphibians and reptiles of Montana. Montana Outdoors 26(3): 15-34.

Routman, E., R. Wu, and A.R. Templeton. 1994/1995. Parsimony, molecular evolution and biogeography: The case of the North American giant salamander. Evolution 48(6): 17991809.

*Savage, J.M. 1952. The distribution of the Pacific giant salamander, Dicamptodon ensatus, east of the Cascade Mountains. Copeia 1952: 183.

*Stebbins, R.C. 2003. A field guide to western reptiles and amphibians. 3rd edition. New York, NY: Houghton Mifflin Co. 533 p.

Steele, C.A., E.D. Brodie Jr., J.G. MacCracken. 2002. Influence of forest age on densities of Cope's and Pacific giant salamander. Northwest Science 76(4): 347-352.

*Thompson, L.S. 1982. Distribution of Montana amphibians, reptiles, and mammals. Montana Audobon Council, Helena, MT. 25 p.

Welsh, H.H., Jr. 1986. Dicamptodon ensatus (Pacific Giant Salamander). Behavior. Herpetological Review 17(1): 19.

Welsh, H.H., Jr. 1986. Life history notes. Caudata. Dicamptodon ensatus (Pacific giant salamander). Herpetological Review 17(1): 19.

*Werner, J.K., B.A. Maxell, P. Hendricks, and D. Flath. 2004. Amphibians and reptiles of Montana. Missoula, MT: Mountain Press Publishing Company. 262p.

*Werner, J.K. and J.D. Reichel. 1994. Amphibian and reptile survey of the Kootenai National Forest: 1994. Montana Natural Heritage Program, Helena, MT. 104 p.

*Yarrow, H.C. 1882. Check list of North American reptilia and batrachia, with catalogue of specimens in the U.S. National Museum. United States National Museum Bulletin 24. 249 p. 


\section{Coeur d'Alene Salamander (Plethodon idahoensis)}

Up-to-date distribution and status information can be found on the Montana Natural Heritage Program's TRACKER website at http://mtnhp.org

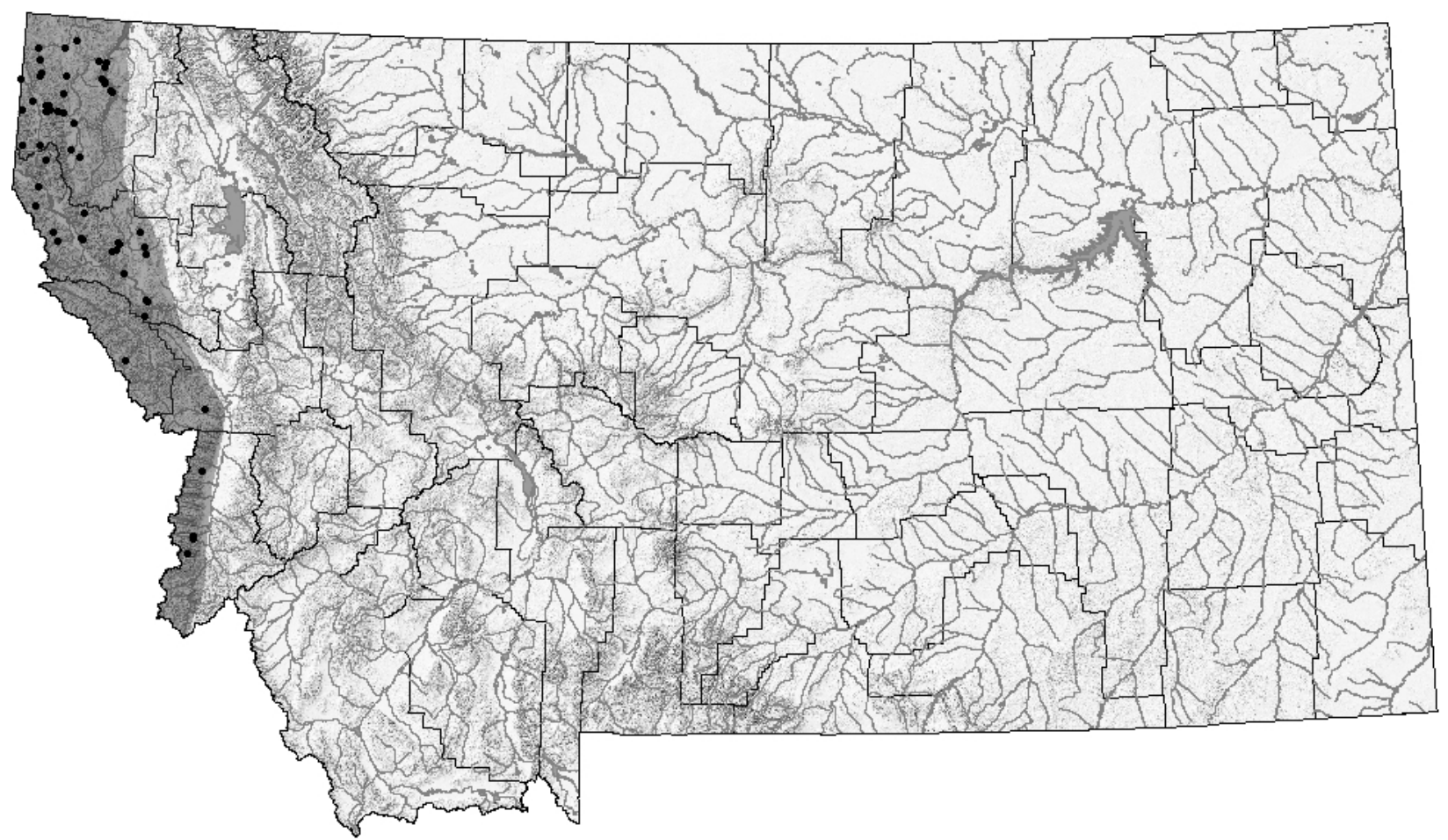

Distribution/Taxonomy

The Coeur d'Alene salamander is a distinct species inhabiting the northern Rocky Mountains in northern Idaho, northwest Montana, and southeastern British Columbia at elevations up to 1,550 M (5,086 ft) (Howard et al. 1993; Petranka 1998; Wilson et al. 1997; Wilson and Larsen 1998). In Montana they have been documented at isolated localities in a narrow band west of the Bitterroot River, Salish Mountains, and Lake Koocanusa from Sweathouse Creek in the Bitterroot Valley to just north of the town of Yaak near the Canadian border. However, given the paucity of surveys that have been conducted, it is likely that their range extends further south on the west side of the Bitterroot Valley and all the way to the Canadian border.

\section{Maximum Elevation}

$1585 \mathrm{~m}(5,200 \mathrm{ft})$ in Ravalli County (Werner et al. 2004). A biogeographic analysis indicates that they may be found up to $1,800 \mathrm{M}(5,906 \mathrm{ft})$ at the southern end of their range in Montana (Wilson and Larsen 1998). A voucher specimen was collected well above this theoretical maximum elevation at $2,438 \mathrm{~m}(8,000 \mathrm{ft})$ in Ravalli County, but because the animal was found dead on the surface it is possible that it was carried to the location (Maxell et al. 2003).

\section{Identification}

\section{Eggs:}

Eggs are unlikely to be encountered because they are apparently laid in moist subterranean fractured rock sites (Lynch 1984). Laid in clusters of up to 13 eggs (Lynch 1984). Eggs are cream colored, around $5 \mathrm{~mm}$ in diameter, and surrounded by two jelly capsules (Larson et al. 1998). 
Larvae:

There is no larval stage. Instead juveniles hatch directly from eggs.

Juveniles and Adults:

Toes are slightly webbed and shorter than the soles of the feet. A greenish-yellow, orange, or red dorsal stripe may extend from the tip of the snout to the tip of the tail and a yellowish throat patch is present. Eyelids are the same color as the dorsal stripe. White flecking is present on the lateral and ventral surfaces over a black base color. 14-15 costal grooves are present. SVL of 18 to $64 \mathrm{~mm}$ (Lynch 1984).

Similar Species:

Adult long-toed salamanders do not have nasolabial grooves, their toes are not webbed, and the fourth toe on their hind feet is longer than the soles of their hind feet. See sections on habitat use for differences in habitat used by long-toed and Coeur d'Alene salamanders.

Habitat Use/Natural History

Coeur d'Alene salamanders respire through their skin and lose water to the environment through evaporation. They are therefore restricted to cool, damp environments (Spotila 1972; Feder 1983). Habitats are limited to springs or seeps, waterfall spray zones and damp streambanks in talus or fractured rock sites, usually with a forest canopy cover (Wilson et al. 1997). The species is found in conjunction with both persistent and intermittent surface waters, but depends on the presence of stable subterranean water flows which can be accessed through rock fractures or talus (Groves et al. 1996; Wilson et al. 1997). Adults are usually above ground only at night during moist weather when temperatures are greater than 7 degrees Celsius (Wilson and Larsen 1988). Surface activity is negatively correlated with high daytime temperatures and days since last rain (Wilson and Larsen 1988). Adults breed terrestrially in late summer, fall, and, to a lesser extent, in the spring (Lynch 1984; Lynch and Wallace 1987). Females deposit eggs in April or May, presumably in underground rock crevices, although no nest sites have been found in the wild (Lynch 1984). Juveniles emerge directly from the eggs in mid-September (Lynch 1984). Juveniles and adults prey on a variety of small aquatic or semi-aquatic invertebrates found in the habitats used by Coeur d'Alene salamanders (Wilson and Larsen 1988; Lindeman 1993).

\section{$\underline{\text { Status and Conservation }}$}

Coeur d'Alene salamanders have only been documented at approximately 50 localities in Montana, with virtually all populations isolated by miles of unsuitable habitat that cannot be crossed. Populations that have been documented appear to remain healthy as long as their microhabitats are not disturbed. Risk factors relevant to the viability of populations of this species are likely to include timber harvest, fire and fire management activities, road and trail development and maintenance, on-road vehicle use, development of water impoundments, and the isolation of individual populations as described above. Individual studies that specifically identify risk factors or other issues relevant to the conservation of Coeur d'Alene salamanders include the following. (1) (Wallace 1986) found that populations separated by 60 miles had little if any gene flow and concluded that current gene flow was not sufficient to maintain interpopulation similarity. In other words individual populations that are separated from others by several miles may be on separate evolutionary trajectories because there is no gene flow given 
the dry intervening habitats which do not allow individuals to disperse. (2) Cassirer et al. (1994) and Groves et al. (1996) both thoroughly review potential risk factors relevant to the viability of Coeur d'Alene salamander populations and give details on how these potential risk factors can be mitigated through management actions. Both of these manuscripts should be consulted closely, but their recommendations are briefly summarized below. (3) In a conservation assessment completed for and partially sponsored by the Region 1 USFS office Cassirer et al. (1994) give details for inventorying for and monitoring Coeur d'Alene salamander populations in all Region 1 National Forests in which they have been documented. However, their inventory and monitoring suggestions were never initiated.

\section{$\underline{\text { Research and Management Suggestions }}$}

1. Additional surveys are needed in order to document the extent of the species northern, eastern, and southern range limits in the state and identify additional sites the species occupies within its known range so that these sites can be adequately protected.

2. The extent of recent and past levels of gene flow between what now seem to be highly isolated populations should be investigated at the local and regional scale in order to identify the conservation implications of the loss of individual populations or groups of populations.

3. Areas considered for timber harvest, prescribed burning, road or trail development and management, development of water impoundments, or application of chemicals should be thoroughly surveyed as outlined in Cassirer et al. (1994) and Groves et al. (1996) in order to identify any suitable habitat and/or the presence of a population.

4. The research and management suggestions outlined in Cassirer et al. (1994) and Groves et al. (1996) should be followed in order to understand and mitigate the impacts of the risk factors listed above. Briefly, they encourage leaving a 30 meter forest buffer around known sites, leaving a 100 meter buffer for roads that are to be placed upstream of known sites, conducting control burns in July and August when salamanders are inactive above ground, conducting logging activities in July, August, or November through March when salamanders are inactive above ground, avoiding applications of herbicides, pesticides, or chemicals used on roads near known sites, and monitoring sites annually at least one year prior to and three years after a management activity.

5. Previously documented sites, especially those near areas of human activity, should be monitored annually, possibly as part of an experiment designed to identify the cause and effect relationship between various human activities and the status of salamander populations (Cassirer et al. 1994).

Bibliography *indicates an article with information specific to Montana

Aubry, K.B., L.L.C. Jones, and P.A. Hall. 1988. Use of woody debris by plethodontid salamanders in Douglas-fir forests in Washington. Pp. 32-37. In: R.C. Szaro, K.E. Severson, and D.R. Patton (technical coordinators). Management of amphibians, reptiles, and small mammals in North America. General Technical Report RM-166. U.S. Forest Service, Rocky Mountain Forest and Range Experiment Station, Fort Collins, Colorado.

*Black, J.H. and R. Timken. 1976. Endangered and threatened amphibians and reptiles in Montana. p 36-37. In: R.E. Ashton, Jr. (chair). Endangered and threatened amphibians and reptiles in the United States. Society for the Study of Amphibians and Reptiles Herpetological Circular 5: 1-65. 
*Blaustein, A.R., J.J. Beatty, H. Deanna, and R.M. Storm. 1995. The biology of amphibians and reptiles in old-growth forests in the Pacific Northwest. General Technical Report PNWGTR-337. Portland, OR: U.S. Department of Agriculture, Forest Service, Pacific Northwest Research Station. 98 p.

*Boundy, J. 2001. Herpetofaunal surveys in the Clark Fork Valley region, Montana. Herpetological Natural History 8: 15-26.

Brodie, E.D., Jr. 1968. Observations on the mental hedonic gland-clusters of western salamanders of the genus Plethodon. Herpetologica 24: 248-250.

*Brodie, E.D., Jr. 1970. Western salamanders of the genus Plethodon: systematics and geographic variation. Herpetologica 26: 468-516.

*Brodie, E.D. and R.M. Storm. 1970. Plethodon vandykei. Catologue of American Amphibians and Reptiles: 91.1-91.2.

Bruce, R.C., R.G. Jaeger, and L.D. Houck (eds.). 2000. The biology of the Plethodontid salamanders. Kluwer Academic/Plenum Press. New York. 485 pp.

*Brunson, R.B. 1955. Check list of the amphibians and reptiles of Montana. Proceedings of the Montana Academy of Sciences 15: 27-29.

Bury, R.B. and M. Martin. 1967. The food of the salamander, Rhyacotrton olympicus. Copeia 1967:487.

Bury, R.B., and M. Martin. 1973. Comparative studies on the distribution and foods of plethodontid salamanders in the redwood region of northern California. Journal of Herpetology 7: 331-335.

*Cassirer, E.F., C.R. Groves, and D. Genter. 1993. Sensitive species management guide for the Coeur d'Alene salamander. Idaho Department of Fish and Game, Boise, and Montana Natural Heritage Program, Helena. 38 pp.

*Cassirer, E.F., C.R. Groves, and D. Genter. 1994. Coeur d' Alene salamander conservation assessment; report to U.S.D.A. Forest Service Region 1. Idaho Department of Fish and Game, Boise, and Montana Natural Heritage Program, Helena. 55 p.

Castanet, J., H. Francillon-Viellot, and R.C. Bruce. 1996. Age estimation in desmognathine salamanders assessed by skeletochronology. Herpetologica 52: 160-171.

Charland, M.B. 1992. A survey of the distribution and biology of the Coeur d'Alene salamander (Plethodon vandykei idahoensis) in British Columbia. Wildlife Branch, Ministry of the Environment, Lands, and Parks, Victoria, B.C. 32 pp.

Corkran, C.C. and C. Thoms. 2006. Amphibians of Oregon, Washington, and British Columbia. $2^{\text {nd }}$ Edition. Vancouver, B.C.: Lone Pine Publishing. 176 p.

Davis, T.M. 1996. Distribution, abundance, microhabitat use and interspecific relationships among terrestrial salamanders on Vancouver Island, British Columbia. Ph.D. Dissertation, University of Victoria. British Columbia, Canada.

Davis, T.M. 1997. Non-disruptive monitoring of terrestrial salamanders with artificial coverobjects on southern Vancouver Island, British Columbia. Herpetological Conservation 1: 161-174.

Davis, T.M. 1998. Terrestrial salamander abundance in successional forests of coastal British Columbia. Northwestern Science 72: 89-90.

Davis, T.M. and K. Ovaska. 2001. Individual recognition of amphibians: effects of toe clipping and fluorescent tagging on the salamander Plethodon vehiculum. Journal of Herpetology 35(2): 217-225. 
Diller, L. and R. Wallace. 1985. Report on the survey of the Selway-Bitterroot wilderness for the Coeur d'Alene salamander, Plethodon vandykei. USDA Forest Service, Moose Creek District. 5 pp.

Diller, L.V. and R.L. Wallace. 1994. Distribution and habitat of Plethodon elongatus on managed, young growth forests in north coastal California. Journal of Herpetology 28(3): 310-318.

Dumas, P.C. 1957. Range extension of the salamander Plethodon vandykei idahoensis. Copeia 1957(2): 147-148.

Dupuis, L.A. and F.L. Bunnell. 1999. Effects of stand age, size, and juxtaposition on abundance of western redback salamanders (Plethodon vehiculum) in coastal British Columbia. Northwest Science 73(1): 27-33.

Feder, J.H., G.Z. Wurst and D.B. Wake. 1978. Genetic variation in western salamanders of the genus Plethodon, and the status of Plethodon gordoni. Herpetologica 34: 64-69.

Feder, M.E. 1983. Integrating the ecology and physiology of plethodontid salamanders. Herpetologica 39(3): 291-310.

*Flath, D.L. 1998. Species of special interest or concern. Montana Department of Fish, Widlife and Parks, Helena, MT. March, 1998. 7 p.

*Franz, R. 1970. Additional notes on the Coeur d' Alene salamander, Plethodon vandykei idahoensis, in Montana. Bulletin of the Maryland Herpetological Society 6: 53-55.

*Franz, R. 1971. Notes on the distribution and ecology of the herpetofauna of northwestern Montana. Bulletin of the Maryland Herpetological Society 7: 1-10.

Frisbie, M.P. and R.L. Wyman. 1992. The effects of soil $\mathrm{pH}$ on sodium balance in the red backed salamander, Plethodon cinereus, and three other terrestrial salamanders. Physiological Zoology 64(4): 1050-1068.

*Genter, D.L. 1990. The Coeur d' Alene salamander, Montana's cliff-hanger. Montana Outdoors 21(5): 15-17.

*Genter, D.L., R. Summerfield, and M. Hunnicutt. 1991. Results of population monitoring for the Coeur d'Alene salamander (Plethodon idahoensis) in northwestern Montana. Montana Natural Heritage Program, Helena, MT.

Gillette, J.R. and M.G. Peterson. 2001. The benefits of transparency: candling as a simple method for determining sex in red-backed salamanders (Plethodon cinereus). Herpetological Review 32(4): 233-235.

Groves, C.R. 1988. Status and distribution of the Coeur d' Alene salamander (Plethodon vandykei idahoensis) in Idaho. Idaho Department of Fish and Game, Boise, Idaho. 39 pp.

Groves, C.R. 1989. Status and distribution of the Coeur d' Alene salamander (Plethodon vandykei idahoensis) in Idaho. Part II. Idaho Department of Fish and Game, Boise, Idaho. $18 \mathrm{pp}$.

*Groves, C.R. 1994. Candidate and sensitive species programs. Lessons for cost-effective conservation. In: Clark, T.W., R.P. Reading, and A.L. Clarke, (Eds.) Endangered species recovery: finding the lessons, improving the process. Island Press, Washington, D.C. pp. 227-250.

Groves, C. and F. Cassirer. 1989. A survey of the Katka-Boulder and Horizon Analysis areas, Idaho Panhandle National Forest, for the Coeur d'Alene salamander (Plethodon Vandykei idahoensis). Idaho Department of Fish and Game. 15p. 
*Groves, C.R., E.F. Cassirer, D.L. Genter and J.D. Reichel. 1996. Element stewardship abstract for the Coeur d' Alene Salamander (Plethodon idahoensis). Natural Areas Journal 16: 238247.

*Hammer, K. and S. Paulsen. 1989. Coeur d' Alene salamander update. Wild Rockies Review Earth First 2(2): 17-18.

*Hart, M.M., W.A. Williams, P.C. Thornton, K.P. McLaughlin, C.M. Tobalske, B.A. Maxell, D.P. Hendricks, C.R. Peterson, and R.L. Redmond. 1998. Montana atlas of terrestrial vertebrates. Montana Cooperative Wildlife Research Unit, University of Montana, Missoula, MT. $1302 \mathrm{p}$.

*Hendricks, P. and J.D. Reichel. 1996. Amphibian and reptile survey of the Bitterroot National Forest: 1995. Montana Natural Heritage Program, Helena, MT. 95 p.

Henry, J.L. and A.G. Wilson, Jr. 2003. Plethodon idahoensis (Coeur d'Alene Salamander). Coloration. Herpetological Review 34(2):134.

Herbeck, L.A. and D.R. Larsen. 1999. Plethodontid salamander response to silvicultural practices in Missouri Ozark forests. Conservation Biology 13(3): 623-632.

Herrington, R.E. 1985. The ecology, reproductive biology, and management of the Larch Mountain Salamander (Plethodon larselli Burns) with comparisons to two other sympatric plethodons. Ph.D. Dissertation. Washington State University, Pullman, WA. 102 pp.

Highton, R. 1962. Revision of the North American salamanders of the genus Plethodon. Bulletin of the Florida State Museum 6(3): 235-367.

Highton, R. 1991. Molecular phylogeny of Plethodine salamanders and Hylid frogs: statistical analysis of protein comparisons. Molecular Biology and Evolution 8(6): 796-818.

Highton, R. and A. Larson. 1979. The genetic relationships of the salamanders of the genus Plethodon. Systematic Zoology 28: 579-599.

*Howard, J.H., L.W. Seeb, and R. Wallace. 1993. Genetic variation and population divergence in the Plethodon vandykei species group (Caudata: Plethodontidae). Herpetologica 49(2): 238-247.

Hunnicutt, M. 1990. 1990 monitoring report for Plethodon idahoensis sites on the Kootenai National Forest. 6 pp.

Jaeger, R., M.G. Peterson, G. Gollmann, B. Gollmann, and V.R. Townsend, Jr. 2001. Salamander social strategies: living together in female-male pairs. Journal of Herpetology 35(2): 335-338.

Jones, L.L.C. 1989. Plethodon vandykei (Van Dyke's Salamander). Reproduction. Herpetological Review 20(2): 48.

*Jones, L.L.C., W.P. Leonard, and D.H. Olson (eds). 2005. Amphibians of the Pacific Northwest. Seattle, WA: Seattle Audubon Society. 227 p.

*Kerr, R. 1989. Summary of 1989 monitoring of the Coeur d' Alene salamander (Plethodon idahoensis) in western Montana. Report to the Montana Natural Heritage Program, Helena, MT. $8 \mathrm{p}$.

Lang, C. and R.G. Jaeger. 2000. Defense of territories by male-female pairs in the red-backed salamander (Plethodon cinereus). Copeia 2000: 169-177.

Larson, A. 1984. Neontological inferences of evolutionary pattern and process in the salamander family Plethodontidae. In: M.K. Hecth, B. Wallace, and C.T. France, eds. Evolutionary Biology, Vol. 17.), Plenum Publishing Corp., Chicago. p. 119-217

*Larson, M.D., A.G. Wilson, Jr., and J.H. Larson, Jr. 1998. Plethodon idahoensis. Egg mass. Herpetological Review 29(3): 163. 
Lindeman, P.V. 1993. Food of the Coeur d'Alene salamander (Plethodon idahoensis) at Elk Creek Falls, Idaho. Northwestern Naturalist 74: 58-59.

*Lynch, J.E., Jr. 1984. Reproductive ecology of Plethodon idahoensis. M.S. Thesis. University of Idaho, Moscow, ID. 59 p.

*Lynch, J.E., Jr., and R.L. Wallace. 1987. Field observations of courtship behavior in Rocky Mountain populations of Van Dyke's salamander, Plethodon vandykei, with a description of its spermatophore. Journal of Herpetology 21: 337-340.

Matsuda, B.M., D.M. Green, and P.T. Gregory. 2006. Amphibians and reptiles of British Columbia. Victoria, B.C.: Royal British Columbia Museum. 266 p.

*Maxell, B.A. 2002. Geographic Distribution. Plethodon idahoensis. Herpetological Review 33(2): 144.

*Maxell, B.A. 2004a. Amphibian and aquatic reptile inventories conducted on and around the Bitterroot National Forest 2000-2003. Report to Region 1 Office of the U.S. Forest Service, Bitterroot National Forest, Montana Department of Fish, Wildlife, and Parks, and Biological Resources Division of the U.S. Geological Survey. Missoula, MT: Montana Cooperative Wildlife Research Unit and Wildlife Biology Program, University of Montana. 128 p.

*Maxell, B.A. 2004b. Amphibian and aquatic reptile inventories conducted on and around the Thompson River 2003-2004. Report to Region 1 Office of the U.S. Forest Service and Plum Creek Timber Company. Missoula, MT: Montana Cooperative Wildlife Research Unit and Wildlife Biology Program. 83 p.

*Maxell, B.A. 2005a. Amphibian and aquatic reptile inventories conducted on and around lands administered by the Missoula Field Office of the Bureau of Land Management. Report to Missoula Field Office of the Bureau of Land Management. Montana Natural Heritage Program, Helena, MT and Montana Cooperative Wildlife Research Unit and Wildlife Biology Program, University of Montana, Missoula, MT. 53 p.

* Maxell, B.A. 2005b. A review of monitoring methods and a multi-tiered scheme for assessing and monitoring the status of amphibians in Montana. Report to Montana Department of Environmental Quality, Region 1 Office of the U.S. Forest Service, Montana Department of Fish, Wildlife, and Parks, and Montana State Office of the Bureau of Land Management. Montana Natural Heritage Program, Helena, MT and Montana Cooperative Wildlife Research Unit and Wildlife Biology Program, University of Montana, Missoula, MT. 29 p. + Appendices.

*Maxell, B.A. 2009. State-wide assessment of status, predicted distribution, and landscapelevel habitat suitability of amphibians and reptiles in Montana. Ph.D. Dissertation. Missoula, MT: Wildlife Biology Program, University of Montana. 294 p.

*Maxell, B.A. and D.G. Hokit. 1999. Amphibians and reptiles. pp. 2.1-2.30. In G. Joslin and H. Youmans, coordinators. Effects of recreation on Rocky Mountain wildlife: a review for Montana. Committee on Effects of Recreation on Wildlife, Montana Chapter of the Wildlife Society. 307 p.

*Maxell, B.A., J.K. Werner, P. Hendricks, and D. Flath. 2003. Herpetology in Montana: a history, status summary, checklists, dichotomous keys, accounts for native, potentially native, and exotic species, and indexed bibliography. Olympia, WA: Society for Northwestern Vertebrate Biology. Northwest Fauna 5: 1-138.

Maxson, L.R., C.H. Daugherty, and R.D. Maxson. 1979. Comparative albumin and biochemical evolution in plethodontid salamanders. Evolution 33: 1057-1062. 
Maxson, L.R., R. Highton, and D.B. Wake. 1979. Albumin evolution and its phylogenetic implications in the plethodontid salamander genera Plethodon and Ensatina. Copeia 1979(3): 502-508.

Mizuno, S., C. Andrews and H.C. Macgregor. 1976. Interspecific "common" repetitive DNA sequences in salamanders of the genus Plethodon. Chromosoma 58: 1-31.

Mizuno, S. and H.C. Macgregor. 1974. Chromosomes, DNA sequences, and evolution in salamanders of the genus Plethodon. Chromosoma 48: 239-296.

Monti, L., M. Hunter, Jr., and J. Witham. 2000. An evaluation of the artificial cover object (ACO) method for monitoring populations of the redback salamander Plethodon cinereus. Journal of Herpetology 34(4): 624-629.

Moritz, C., C.J. Schneider, and D.B. Wake. 1992. Evolutionary relationships within the Ensatina eschscholtzii complex confirm the ring species interpretation. Systematic Biology 41:273291.

*Nussbaun, R., E. Brodie, Jr., and R. Storm. 1983. Amphibians and reptiles of the Pacific Northwest. University of Idaho Press, Moscow, Idaho. 322 p.

Orchard, S.A. 1990. Provincial status report for the Coeur d' Alene salamander (Plethodon idahoensis). Wildlife Branch, Ministry of Environment, Lands, and Parks, Victoria, B.C., Canada. $12 \mathrm{p}$.

Parker, I. 1973. Observations on centromeric heterochromatin and satellite DNA in salamanders of the genus Plethodon. Chromosoma 43: 329-348.

*Peterson, S.M., A.G. Wilson, Jr., and E.M. Wilson. 1999. Plethodon idahoensis. Skeletal abnormality. Herpetological Review 30(4): 222.

*Petranka, J.W. 1998. Salamanders of the United States and Canada. Smithsonian Institution Press, Washington, DC. 587 p.

*Powell, R., J.T. Collins, and E.D. Hooper, Jr. 1998. A key to amphibians and reptiles of the Continental United States and Canada. University Press of Kansas, Lawrence, KS. 131 p.

*Reel, S. 1989. Vest-pocket preserves. Montana Outdoors 20(2): 27-29.

*Reel, S., L.A. Schassberger and W. Ruediger. 1989. Caring for our natural communities: Region 1 - threatened, endangered and sensitive species program. USDA, USFS, Northern Region. Missoula, Montana.

*Reichel, J.D. 1997. Animal species of special concern in Montana. Montana Natural Heritage Program. Helena, MT. 9 p.

*Reichel, J.D. and D.L. Flath. 1995. Identification guide to the amphibians and reptiles of Montana. Montana Outdoors 26(3): 15-34.

Resetarits, W.J. 1997. Differences in an ensemble of streamside salamanders (Plethodontidae) above and below a barrier to brook trout. Amphibia-Reptilia 18: 15-25.

Rollman, S.M., L.D. Houck, and R.C. Feldhoff. 2000. Population variation in salamander courtship pheremones. Journal of Chemical Ecology 26: 2713-2724.

Salvidio, S. 2001. Estimating terrestrial salamander abundance in different habitats: efficiency of temporary removal methods. Herpetological Review 32(1): 21-24.

Slater, J.R., and J.W. Slipp. 1940. A new species of Plethodon from northern Idaho. Occassional Papers Department of Biology College of Puget Sound 1940(8): 38-43.

Slater, J.R., and J.W. Slipp. 1941. The distributions of amphibians and reptiles in Idaho. Occassional Papers, Department of Biology, College of Puget Sound. No. 14, pp. 78-109.

Smith, C.K. and J.W. Petranka. 2000. Monitoring terrestrial salamanders: repeatability and validity of area-constrained cover object searches. Journal of Herpetology 34(4): 547-557. 
Spotila, J.R. 1972. Role of temperature and water in the ecology of lungless salamanders. Ecological Monographs 42: 95-125.

Staub, N.L. 1995. Caudata: Plethodon idahoensis (Coeur d' Alene salamander). Predation. Herpetological Review 26(4):199.

Staub, N.L. and R. Anderson. 2001. A novel behavior for Urodeles: micturition in the Plethodontid salamander Aneides lugubris. Herpetological Review 32(3): 158-159.

*Stebbins, R.C. 2003. A field guide to western reptiles and amphibians. 3rd edition. New York, NY: Houghton Mifflin Co. 533 p.

*Teberg, E.K. 1963. An extension into Montana of the known range of the salamander Plethodon vandykei idahoensis. Herpetologica 19: 287.

*Teberg, E.K. 1965. Range extensions of the salamander Plethodon vandykei idahoensis. Copeia 1965: 244.

*Thompson, L.S. 1984. Biogeography of Montana: preliminary observations on major faunal and floristic distribution patterns. Abstract. Proceedings of the Montana Academy of Sciences 43: 40-41.

Thurow, G.R. 1998. Ecological lessons from two-lined salamander translocations. Transactions of the Illinois State Academy of Science 90(1-2): 79-88.

*[USDAFS] USDA Forest Service. 1999. Update of U.S. Forest Service Northern Region Sensitive Species list. 12 March, 1999. Region 1 U.S. Forest Service Supervisors Office, Missoula, MT. 20 p.

Wake, D.B. 1966. Comparative osteology and evolution of the lungless salamanders, family Plethodontidae. Southern California Academy of Sciences, Memoirs 4: 1-111.

*Wallace, R.L. 1986. A biochemical genetic study of the Plethodon vandykei complex. Final report. Idaho fish and Game Non-Game Program, Boise, ID. 30 p.

*Werner, J.K., B.A. Maxell, P. Hendricks, and D. Flath. 2004. Amphibians and reptiles of Montana. Missoula, MT: Mountain Press Publishing Company. 262p.

*Werner, J.K. and J.D. Reichel. 1994. Amphibian and reptile survey of the Kootenai National Forest: 1994. Montana Natural Heritage Program, Helena, MT. 104 p.

*Werner, J.K. and J.D. Reichel. 1996. Amphibian and reptile monitoring/survey of the Kootenai National Forest: 1995. Montana Natural Heritage Program, Helena, MT. 115 p.

*Werner, J.K. and T. Plummer. 1994. Amphibian and reptile survey of the Flathead Indian Reservation 1993-1994. Salish Kootenai College, Pablo, MT. 55 p.

*Werner, J.K. and T. Plummer. 1995. Amphibian monitoring program on the Flathead Indian Reservation 1995. Salish Kootenai College, Pablo, MT. 46 p.

*Werner, J.K., T. Plummer, and J. Weaselhead. 1998. The status of amphibians on the Flathead Reservation, Montana. Intermountain Journal of Sciences 4(3-4): 88.

Wilson, A.G., Jr. 1990. A survey of the Nez Perce National Forest for the Coeur d'alene salamander (Plethodon idahoensis). Idaho Department of Fish and Game. 33p.

Wilson, A.G., Jr. 1991. A survey of the Avery Ranger District, Idaho Panhandle National Forests, for the Coeur d' Alene salamander (Plethodon idahoensis). Idaho Department of Fish and Game, Nongame and Endangered Wildlife Program, Boise. 44 p.

Wilson, A.G., Jr. 1992. A survey of the St. Maries and Sandpoint Ranger Districts for the Coeur d' Alene salamander (Plethodon idahoensis). Idaho Department of Fish and Game, Nongame and Endangered Wildlife Program, Boise. 28 p.

*Wilson, A.G., Jr. 1993. Biogeographic and morphometric analyses of the Plethodon vandykei species group. Ph.D. Dissertation. Washington State University, Pullman, WA. 127 p. 
*Wilson, A.G., Jr. and E.M. Simon. 1985. Plethodon vandykei idahoensis (Coeur d' Alene salamander). Predation. Herpetological Review 16: 111.

*Wilson, A.G., Jr. and E.M. Simon. 1987. Status of the Coeur d'Alene salamander (Plethodon vandykei idahoensis) in Montana. Report to the Montana Natural Heritage Program, Helena, MT. $134 \mathrm{p}$.

*Wilson, A.G., Jr. and E.M. Simon. 1988. Supplementary report on the status of the Coeur d'Alene salamander (Plethodon vandykei idahoensis) in Montana. Report to the Montana Natural Heritage Program, Helena, MT. 64 p.

*Wilson, A.G., Jr. and E.M. Wilson. 1996. Plethodon idahoensis. Snake predation. Herpetological Review 27(3): 138.

*Wilson, A.G., Jr. and J.H. Larsen, Jr. 1988. Activity and diet in seepage-dwelling Coeur d'Alene salamanders (Plethodon vandykei idahoensis). Northwest Science 62(5): 211-217.

*Wilson, A.G., Jr. and J.H. Larsen, Jr. 1998. Biogeographic analysis of the Coeur d'Alene salamander (Plethodon idahoensis). Northwest Science 72(2): 111-115.

*Wilson, A.G., Jr., and P. Ohanjanian. 2002. Plethodon idahoensis. Catalogue of American Amphibians and Reptiles 741.1-741.4.

Wilson, A. G. Jr., E. M. Simon, and J. H. Larsen, Jr. 1989. Range extension for the Coeur d'Alene salamander, Plethodon vandykei idahoensis, to the Canada-United States border. Canadian Field Naturalist 103:93-94.

*Wilson, A.G., Jr., J.H. Larsen, Jr. and E.M. Simon. 1988. Diet and activity patterns of seepage-dwelling Coeur d'Alene salamanders in Northwestern Montana. Abstract. Northwest Science 62(2): 75.

Wilson, A.G., Jr., K.R. McAllister, and J.H. Larsen, Jr. 1992. Geographic distribution: Plethodon vandykei. Herpetological Review 23: 85.

*Wilson, A.G., Jr., E.M. Wilson, C.R. Groves and R.L. Wallace. 1997. U.S. Distribution of the Coeur d'Alene salamander (Plethodon idahoensis Slater and Slipp). Great Basin Naturalist 57(4): 359-362.

Wyman, R.L. and D.S. Hawksley-Lescault. 1987. Soil acidity affects distribution, behavior, and physiology of the salamander Plethodon cinereus. Ecology 68(6): 1819-1827. 


\section{Rocky Mountain Tailed Frog (Ascaphus montanus)}

Up-to-date distribution and status information can be found on the Montana Natural Heritage Program's TRACKER website at http://mtnhp.org

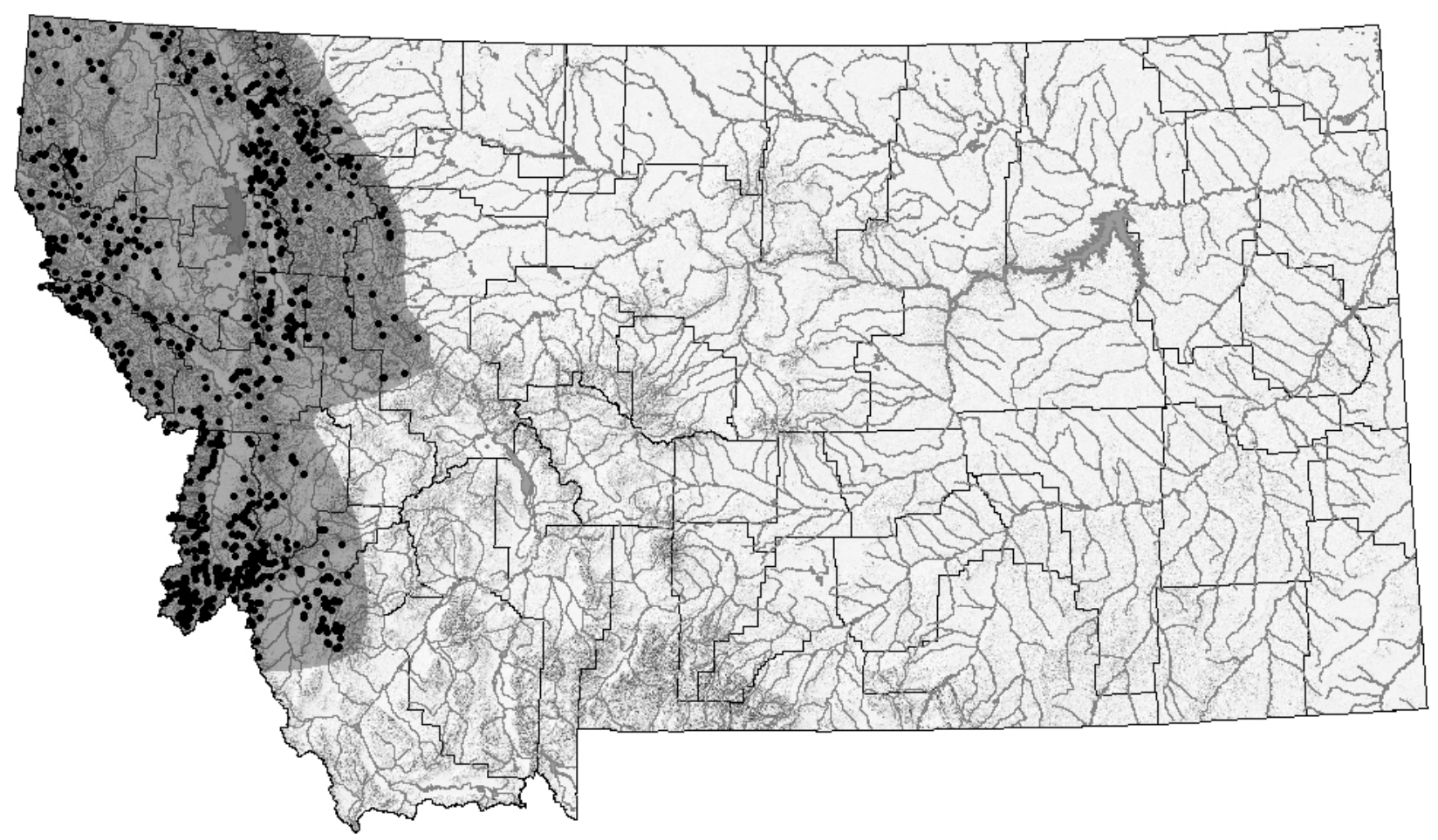

Distribution/Taxonomy

Until recently tailed frogs were recognized as a single species with a disjunct distribution that includes a coastal population ranging from northwestern California to southwestern British Columbia separated by hundreds of miles from a Rocky Mountain population that includes isolated populations in the Blue, Wallowa and Seven Devils Mountains and a more continuous population that ranges from central Idaho to the southeast corner of British Columbia (Metter 1968). However, allozyme and mitochondrial DNA analyses indicate that the Rocky Mountain and coastal populations differ to the extent that designation of separate species is warranted (Daugherty 1979; Nielson and Lohman 2000; Marilyn Nielson, University of Idaho, pers. comm.). Populations in the Rocky Mountains and those in the Blue, Wallowa and Seven Devils Mountain Ranges are now recognized as the Rocky Mountain tailed frog (Ascaphus montanus) and coastal populations are now recognized as the Coastal Tailed Frog (Ascaphus truei) (Mittleman and Myers 1949; Marilyn Nielson, University of Idaho, pers. comm.). Across their entire range Rocky Mountain tailed frogs are known to occur at elevations up to 2,590 M (8,500 $\mathrm{ft}$ ), or approximately treeline (Nussbaum et al. 1983; David Pilliod, Idaho State University, pers. comm.).

Maximum Elevation

2,649 $\mathrm{m}(8,691 \mathrm{ft})$ on unnamed tributary to Halfway Creek in the Pioneer Mountains in Beaverhead County (B. Murdock; MTNHP 2007). 


\section{$\underline{\text { Identification }}$}

\section{Eggs:}

Laid in a jelly string as a globular mass containing 28 to 86 eggs (Noble and Putnam 1931; Franz $1970 a$ ). Each ovum is creamy white and surrounded by two jelly layers which themselves lie within the outer jelly string (Franz 1970a). Ovum diameters are approximately 4-5 mm in diameter, but total egg diameters, including the three jelly layers, are approximately 6-7 mm (Metter 1967; Adams 1993). Clutches from multiple animals may be laid together in the same nest site (Adams 1993).

\section{Larvae:}

Base color is variable from solid black, to gray, to solid brown. White flecks may be present and most larvae have a white tail spot (Metter 1967). A large sucking disk is present around the mouth. The spiracle is mid-ventral and opens under a flap (Metter 1968). Total length (TL) of 10-64 mm (Metter 1967; Franz 1971).

Juveniles and Adults:

Pupil of the eye is vertical. Lacks external ear drums (tympanums). The cloaca of males opens into a tear-shaped copulatory organ (the "tail"). Skin is a granulated texture. Base color is brown, reddish brown, or olive gray with yellow and gray mottling dorsally and a dark eye stripe. Ventrally cream to pinkish. SVL of 20 to $57 \mathrm{~mm}$ (Daugherty 1979; Daugherty and Sheldon 1982a).

Similar Species:

None. No other adult anuran species lack external ear drums (tympanums). No other larval anuran species have a large sucking disk around the mouth or are found in small swift streams.

Habitat Use/Natural History

Found in small ( $\leq 4.5$ meters width), fast permanent forest streams with clear, cold water, cobble or boulder substrates, and little silt (Franz and Lee 1970; Franz 1971; Welsh 1990). In Montana, adults usually remain underwater hidden by rocks or debris and emerge at night or during humid weather from May to September to feed terrestrially along stream edges (Daugherty and Sheldon 1982a). Adults are highly philopatric, but are known to forage up to 75 meters away from water in Montana (Daugherty and Sheldon 1982b; Bryce Maxell, pers. obs.). However, they may range farther from water in wetter areas because Gomez and Anthony (1996) found them in pitfall traps 200 meters from streams in the Oregon Cascades and Corn and Bury (1990) found juveniles and adults ranging more than 300 meters from the nearest stream west of the Cascade Mountains in Oregon and Washington. At high elevations in Montana adults and juveniles have been found to be active diurnally in warmer standing water bodies 50-75 meters away from streams during warm dry weather (Bryce Maxell, pers. obs.). In Montana adults breed via internal fertilization in streams in August or September and females deposit eggs under large stones in areas with slight current the following June or July (Franz 1970a; Daugherty and Sheldon 1982a). Eggs hatch in August or September and tadpoles cling to the undersides or tops of smooth rocks which lack periphyton or silt (Nussbaum et al. 1983). Tadpoles usually metamorphose in the third summer after hatching and adults reproduce for the first time four or five years after metamorphosis; females reproduce in alternate years thereafter (Daugherty and Sheldon 1982a). Larvae feed mostly on diatoms, but also algae and small aquatic insects (Franz 
1970b). Adults feed on a variety of aquatic and terrestrial invertebrates (Metter 1964).

\section{Status and Conservation}

Tailed frogs are widely distributed and common west of the Continental Divide in smaller streams that have adequate amounts of cobble substrates. Their status in the front ranges east of the Continental Divide is uncertain. Risk factors relevant to the viability of populations of this species are likely to include all the general risk factors described above (especially those which change stream morphology, and increase sedimentation and water temperature), with the exception of harvest and commerce. Individual studies that specifically identify risk factors or other issues relevant to the conservation of tailed frogs include the following. (1) Although the impacts of timber harvest have not been studied in Montana, numerous studies have documented the extirpation of tailed frogs at a number of locations in the Pacific Northwest as a result of increased sedimentation and water temperature resulting from timber harvest and associated road building activities (Metter 1964; Bury 1983; Bury and Corn 1988; Welsh and Lind 1988; Corn and Bury 1989; Corn and Bury 1990; Welsh 1990; Bull and Carter 1996). Because tailed frogs are highly philopatric, have limited dispersal capabilities, and are apparently somewhat reliant on old growth, streams they have been extirpated from may not be recolonized for extensive periods of time after timber harvest activities (Metter 1967; Daugherty and Sheldon 1982; Corn and Bury 1989; Welsh 1990). Furthermore, some of these same studies found that even if tailed frogs were still present after timber harvest their density and biomass was negatively affected and density and biomass were lower in younger stands than older stands (e.g., Corn and Bury 1990; Welsh 1990; Gomez and Anthony 1996). A study in the Blue Mountains of Oregon provides evidence that stream buffers do provide protection for tailed frogs in drier forests similar to those found across much of Montana. Bull and Carter (1996) found that the number of tailed frogs was best predicted by a combination of stream substrates and the presence of stream buffers. (2) Although the impacts of piscicides have not been formally investigated anecdotal evidence from treated areas in Montana suggests they may have major population-level impacts on tailed frogs (Andrew Sheldon, University of Montana, pers. comm.). Fontenot et al. (1994) and McCoid and Bettoli (1996) recently reviewed the impacts of rotenone-containing piscicides on amphibians and found that the effects of rotenone on newly metamorphosed and adult amphibians varied with the degree of each species' aquatic respiration and their likelihood of exiting treated water bodies. They found the range of lethal doses of rotenone-containing piscicides for amphibian larvae $(0.1-0.580 \mathrm{mg} / \mathrm{L})$ to overlap to a large extent with lethal doses for fish $(0.0165-0.665$ $\mathrm{mg} / \mathrm{L}$ ), and to be much lower than the concentrations commonly used in fisheries management $(0.5-3.0 \mathrm{mg} / \mathrm{L})$. The nontarget effects of another piscicide, antimycin, have apparently not been formally studied, but preliminary observations seem to indicate that antimycin is also toxic to amphibian larvae (Patla 1998). Tailed frog larvae and adults both use aquatic respiration and adults are unlikely to exit treated water bodies depending on the time of day (Daugherty and Sheldon 1982b).

\section{$\underline{\text { Research and Management Suggestions }}$}

1. Additional information is needed on their distribution east of the Continental Divide, especially in central and southwest Montana. Documentation of their presence along the upper Clark Fork River and in the Beaverhead Mountain Range is poor and their presence in the Garnet, Elkhorn, Boulder, and Highland Mountains is uncertain. Surveys in these areas could be easily done by combining them with existing fisheries surveys. 
2. The most efficient method of monitoring tailed frogs is to have fisheries crews that regularly conduct surveys in headwater streams record observations of adults and larvae in areas they have used a shocker and/or kick net. These crews should be formally trained in the identification of the species and should report observations on standard forms to the database at the Montana Natural Heritage Program.

3. Studies of the impacts of timber harvest and buffer strips designed to protect headwater streams from impacts should be conducted in Montana in order to ensure that current mitigation measures are allowing isolated headwater populations to persist. Concurrent studies of the distance individuals commonly move from streams are also needed.

4. Leaving 30 to 200 meter ( 15 to 100 meters on either side) wide forest buffer strips has been proposed by various authors in order to protect headwater stream habitats for the persistence of tailed frogs (Corn and Bury 1989; Gomez and Anthony 1996). However, there has been no research in drier forests in Montana to support the value of a particular buffer width. Streams and lakes being considered for treatment with piscicides should be thoroughly surveyed for tailed frogs and the impacts of the proposed piscicides should be investigated in order to identify likely impact.

5. Without formal investigation of the impacts, piscicides should not be used in streams containing tailed frogs because of the possibility of removing multiple larval and adult cohorts. Other methods of removal should be explored in these instances. If piscicide use is the only option available then pretreatment gathering and posttreatment restocking of tailed frog tadpoles and adults should be undertaken and treatment should occur in the late evening hours so that adults are more likely to exit waters.

Bibliography $*$ indicates an article with information specific to Montana

Abourachid, A. and D.M. Green. 1999. Origins of the frog-kick? Alternate-leg swimming in primitive frogs, Families Leiopelmatidae and Ascaphidae. Journal of Herpetology 33(4): 657-663.

Adams, M.J. 1993. Summer nests of the tailed frog (Ascaphus truei) from the Oregon coast range. Northwestern Naturalist 74: 15-18.

Adams, M.J. and A.G. Wilson, Jr. 1993. Ascaphus truei (tailed frog). Herpetological Review 24(2): 64.

*Adams, S. 1998. Tailed frog migration: a local response to seasonally unsuitable habitat? Abstract. Montana Chapter of the American Fisheries Society Meeting. Helena, MT. February 2-5, 1998.

*Adams, S. and C.A. Frissell. 2001. Thermal habitat use and evidence of seasonal migration by Rocky Mountain tailed frogs, Ascaphus montanus, in Montana. Canadian Field Naturalist 115(2): 251-256.

Altig, R. 1969. Notes on the ontogeny of the osseous cranium of Ascaphus truei. Herpetelogica 25:59-62.

Altig, R., and E.E. Brodie. 1972. Laboratory behavior of Ascaphus truei tadpoles. Journal of Herpetology 6: 21-24.

*Black, J.H. and J.N. Black. 1968. Frog with a tail. Montana Outdoors 3(3): 3 p.

*Black, J.H. and R. Timken. 1976. Endangered and threatened amphibians and reptiles in Montana. p 36-37. In R.E. Ashton, Jr. (chair). Endangered and threatened amphibians and reptiles in the United States. Society for the Study of Amphibians and Reptiles Herpetological Circular 5: 1-65. 
*Blaustein, A.R., J.J. Beatty, H. Deanna, and R.M. Storm. 1995. The biology of amphibians and reptiles in old-growth forests in the Pacific Northwest. General Technical Report PNWGTR-337. Portland, OR: U.S. Department of Agriculture, Forest Service, Pacific Northwest Research Station. 98 p.

Bogart, J.P., E.K. Balon, and M.N. Bruton. 1994. The chromosomes of the living coelacanth and their remarkable similarity to those of one of the most ancient frogs. Journal of Heredity 85(4): 322-325.

*Boundy, J. 2001. Herpetofaunal surveys in the Clark Fork Valley region, Montana. Herpetological Natural History 8: 15-26.

Brown, H.A. 1975. Temperature and development of the tailed frog, Ascaphus truei. Comparative Biochemistry and Physiology 50A: 397-405.

Brown, H.A. 1989. Developmental anatomy of the tailed frog (Ascaphus truei): a primitive frog with large eggs and slow development. Journal of Zoology London 217: 525-537.

Brown, H.A. 1990a. Morphological variation and age-class determination in overwintering tadpoles of the tailed frog, Ascaphus truei. Journal of Zoology 220: 171-184.

Brown, H.A. 1990b. Temperature, thyroxine, and induced metamorphosis in tadpoles of a primitive frog, Ascaphus truei. General and Comparative Endocrinology 79(1): 136-146.

*Brunson, R.B. 1955. Check list of the amphibians and reptiles of Montana. Proceedings of the Montana Academy of Sciences 15: 27-29.

*Brunson, R.B. and H.A. Demaree. 1951. The herpetology of the Mission Mountains, Montana. Copeia 1951: 306-308.

Bull, E.L. and B.E. Carter. 1996. Tailed frogs: distribution, ecology, and association with timber harvest in northeastern Oregon. USDA Forest Service, Research Paper PNW-RP-497, Portland, Oregon. $17 \mathrm{p}$.

Bull, E.L. and B.E. Carter. 1996. Winter observations of tailed frogs in northeastern Oregon. Northwestern Naturalist 77: 45-47.

Burkholder, L.L. 2003. Seasonal activity patterns and life history characteristics of postmetamorphic tailed frogs in north coastal California. Abstract. Northwestern Naturalist 84:96.

Bury, R.B. 1968. The distribution of Ascaphus truei in California. Herpetologica 24(1): 39-46.

Bury, R.B. 1970. Food similarities in the tailed frog, Ascaphus truei, and the Olympic salamander, Rhyacotriton olympicus. Copeia 1970: 170-171.

Bury, R.B. 1983. Differences in amphibian populations in logged and old growth redwood forest. Northwest Science. 57(3): 167-178.

Bury, R.B. and M.J. Adams. 1999. Variation in age at metamorphosis across a latitudinal gradient for the tailed frog (Ascaphus truei). Herpetologica 55(2): 283-291.

Bury, R.B., G.M. Fellers, and S.B. Ruth. 1969. First records of Plethodon dunni in California, and new distributional data on Ascaphus truei, Rhyacotriton olympicus, and Hydromantes shastae. Journal of Herpetology 3: 157-161.

Bury, R.B., P. Loafman, D. Rofkar, and K.I. Mike. 2001. Clutch sizes and nests of tailed frogs from the Olympic Peninsula, Washington. Northwest Science 75(4): 419-422.

Bury, R.B. and P.S. Corn. 1988. Douglas-fir forests in the Oregon and Washington Cascades: relation of the herpetofauna to stand age and moisture. Pp. 11-22. In: R.C. Szaro, K.E. Severson, and D.R. Patton, technical coordinators. Management of amphibians, reptiles, and small mammals in North America. General Technical Report RM-166. U.S. Forest Service, Rocky Mountain Forest and Range Experiment Station, Fort Collins, Colorado. 
*Cavallo, B.J. 1997. Floodplain habitat heterogeneity and the distribution, abundance, and behavior of fishes and amphibians in the Middle Fork Flathead River Basin, Montana. M.S. Thesis. University of Montana, Missoula, MT. $133 \mathrm{p}$.

*Clancy, C.G. 1996. Statewide fisheries investigations, Bitterroot Forest inventory July 1, 1995 to June 30, 1996. Job completion report. Montana Department of Fish, Wildlife and Parks, Fisheries Division. $97 \mathrm{p}$.

*Claussen, D.L. 1971. A comparative study of the thermal and water relations of the tailed frog, Ascaphus truei and the Pacific treefrog, Hyla regilla. Ph.D. Dissertation. University of Montana, Missoula, MT. 103 p.

*Claussen, D.L. 1973a. The thermal relations of the tailed frog (Ascaphus truei) and the Pacific treefrog (Hyla regilla). Comparative Biochemistry and Physiology 44a: 137-153.

*Claussen, D.L. 1973b. The water relations of the tailed frog (Ascaphus truei) and the Pacific treefrog (Hyla regilla). Comparative Biochemistry and Physiology 44a: 155-171.

*Cochran, D.M. 1961. Type specimens of reptiles and amphibians in the United States National Museum. United States National Museum Bulletin 220: 1-291.

Corbit, C.D. 1960. Range extensions of Ascaphus truei in Idaho. Copeia 1960: 240.

Corkran, C.C. and C. Thoms. 2006. Amphibians of Oregon, Washington, and British Columbia. $2^{\text {nd }}$ Edition. Vancouver, B.C.: Lone Pine Publishing. 176 p.

Corn, P.S. and R.B. Bury. 1989. Logging in western Oregon: responses of headwater habitats and stream amphibians. Forest Ecology and Management 29: 39-57.

Corn, P.S. and R.B. Bury. 1990. Sampling methods for terrestrial amphibians and reptiles. pp. 1-34. In: A.B. Carey and L.F. Ruggiero (eds). Wildlife-habitat relationships: sampling procedures for Pacific Northwest vertebrates. USDA Forest Service General Technical Report PNW-GTR-256.

*Daugherty, C.H. 1976. Freeze-branding as a technique for marking anurans. Copeia 1976: 836-838.

*Daugherty, C.H. 1979. Population ecology and genetics of Ascaphus truei: an examination of gene flow and natural selection. Ph.D. Dissertation. University of Montana, Missoula, MT. $143 \mathrm{p}$.

*Daugherty, C.H. and F.W. Allendorf. 1977a. Divergence of populations: preliminary evidence relating to the Ehrlich-Raven hypothesis from Ascaphus truei. Abstract. Annual Report Issue of the Genetics Society of America 86(2): S14.

*Daugherty, C.H. and F.W. Allendorf. 1977b. The taxonomic value of genetic distance: data from two amphibians. Abstract. American Zoologist 17(4): 973.

*Daugherty, C.H. and F.W. Allendorf. 1979. Temporal genetic stability in a population of the tailed frog, Ascaphus truei. Abstract. American Zoologist 19(3): 962.I

*Daugherty, C.H. and A.L. Sheldon. 1982a. Age-determination, growth, and life history of a Montana population of the tailed frog (Ascaphus truei). Herpetologica 38(4): 461-468.

*Daugherty, C.H. and A.L. Sheldon. 1982b. Age specific movement patterns of the frog Ascaphus truei. Herpetologica 38(4): 468-474.

*Daugherty, C.H., L.N. Wishard, and L.B. Daugherty. 1978. Sexual dimorphism in an anuran response to severe thermal stress. Journal of Herpetology 12(3): 431-432.

De Vlaming, V.L. and R.B. Bury. 1970. Thermal selection in tadpoles of the tailed frog, Ascaphus truei. Journal of Herpetology 4: 179-189.

Diller, L.V. and R.L. Wallace. 1998. Length of the larval cycle of Ascaphus truei in coastal streams of the redwood regions, northern California. Journal of Herpetology 32(3): 404-409. 
Diller, L.V. and R.L. Wallace. 1999. Distribution and habitat of Ascaphus truei in streams on managed, young growth forests in north coastal California. Journal of Herpetology 33(1): 71-79.

*Donaldson, L.R. 1934. The occurrence of Ascaphus truei east of the Continental Divide. Copeia 1934(4): 184.

Dupuis, L.A. and F.L.Bunnell. 1999. Status and distribution of the tailed frog in British Columbia. A report for Forest Renewal British Columbia, Victoria, British Columbia.

Dupuis, L.A., F.L.Bunnell, and P.A. Friele. 2000. Determinants of the tailed frog's range in British Columbia, Canada. Northwest Science 74(2): 109-115.

Dupuis, L.A. and P. Friele. 2004. River continuum concept and management efforts - the case of the tailed frog. Abstract. Northwestern Naturalist 85:73.

Dupuis, L.A. and D. Steventon. 1999. Riparian management and the tailed frog in northern coastal forests. Forest Ecology and Management 124: 35-43.

*Enk, M. 1999. Preliminary results of amphibian monitoring on the Lewis and Clark National Forest. Intermountain Journal of Sciences 5(1-4): 48.

*Farmer, P. and S.B. Heath. 1987. Wildlife baseline inventory, Rock Creek study area, Sanders County, Montana. Western Technology and Engineering, Inc. Helena, MT.

Feminella, J.W. and C.P. Hawkins. 1994. Tailed frog tadpoles differentially alter their feeding behavior in response to non-visual cues from four predators. Journal of the North American Benthological Society 13: 310-320.

*Flath, D.L. 1998. Species of special interest or concern. Montana Department of Fish, Widlife and Parks, Helena, MT. March, 1998. 7 p.

Fontenot, L.W., G.P. Noblet and S.G. Platt. 1994. Rotenone hazards to amphibians and reptiles. Herpetological Review 25(4):150-156.

*Fraley, J. 2001. Frog with a tail. Montana Outdoors 32(2): 21-22.

*Franz, R. 1970a. Egg development of the tailed frog under natural conditions. Bulletin of the Maryland Herpetological Society 6: 27-30.

*Franz, R. 1970b. Food of larval tailed frogs. Bulletin of the Maryland Herpetological Society 6: 49-51.

*Franz, R. 1971. Notes on the distribution and ecology of the herpetofauna of northwestern Montana. Bulletin of the Maryland Herpetological Society 7: 1-10.

*Franz, R. and D.S. Lee. 1970. The ecological and biogeographical distribution of the tailed frog (Ascaphus truei) in the Flathead River drainage of northwesten Montana. Bulletin of the Maryland Herpetological Society 6: 62-73.

Fritzsch, B., R.C. Drewes, and R. Ruibal. The retention of the lateral-line nucleus in adult anurans. Copeia 1987: 127-135.

Gaige, H.T. 1920. Observations upon the habitats of Ascaphus truei Stejneger. Occassional Papers of the University of Michigan Museum of Zoology 84: 1-9, pl. 1.

Gomez, D.M. and R.G. Anthony. 1996. Amphibian and reptile abundance in riparian and upslope areas of five forest types in Western Oregon. Northwest Science 70(2):109-119.

Gradwell, N. 1971. Ascaphus tadpole: experiments on the suction and gill irrigation mechanisms. Canadian Journal of Zoology 49: 307-332.

Gradwell, N. 1973. On the functional morphology of suction and gill irrigation in the tadpole of Ascaphus, and notes on hibernation. Herpetologica 29: 84-93.

Gray, L.A. 1992a. Age determination and age at metamorphosis of the tailed frog, Ascaphus truei. Northwest Science 66(2): 115. 
Gray, L.A. 1992b. Larval growth and age at completion of metamorphosis of the tailed frog, (Ascaphus truei). Ellensburg, WA: Central Washington University. 62p. M.S. Thesis.

*Green, D.M., C.H. Daugherty, and J.P. Bogart. 1980. Karyology and systematic relationships of the tailed frog Ascaphus truei. Herpetologica 36(4): 346-352.

*Green, D.M., T.F. Sharbel, R.A. Hitchmough, and C.H. Daugherty. 1989. Genetic variation in the genus Leiopelma and relationships to other primitive frogs. Zeitschrift Fuer Zoologische Systematik und Evolutionforschung 27(1): 65-79.

*Hailman, J.P. 1982. Extremely low ambient light levels of Ascaphus truei. Journal of Herpetology 16: 83-84.

*Hailman, J.P. and R.G. Jaeger. 1974. Phototactic responses to spectrally dominant stimuli and use of colour vision by adult anuran amphibians: a comparative survey. Animal Behavior 22: 757-795.

*Hailman, J.P. and R.G. Jaeger. 1978. Phototactic responses of anuran amphibians to monochromatic stimuli of equal quantum intensity. Animal Behavior 26: 274-281.

Hansen, B.P., D.H. Olson, and C.D. Moyer. 2000. Demographics and age at metamorphosis of larval tailed frogs, Ascaphus truei, in a coastal Oregon stream. Northwestern Naturalist 81(2):75.

*Hart, M.M., W.A. Williams, P.C. Thornton, K.P. McLaughlin, C.M. Tobalske, B.A. Maxell, D.P. Hendricks, C.R. Peterson, and R.L. Redmond. 1998. Montana atlas of terrestrial vertebrates. Montana Cooperative Wildlife Research Unit, University of Montana, Missoula, MT. 1302 p.

Hawkins, C.P., J. Feminella and C.M. Crissafulli. 1994. Patterns of abundance and growth of tailed frog populations near the Mt. St. Helens blast Zone. Northwest Science 68(2): 129.

Hawkins, C.P., L.J. Gottschalk, and S.S. Brown. 1988. Densities and habitat of tailed frog tadpoles in small streams near Mt. St. Helens following the 1980 eruption. Journal of the North American Benthological Society 7: 246-252.

Hawkins, C.P. and J.R. Sedell. 1990. The role of refugia in the recolonization of streams devastated by the 1980 eruption of Mount St. Helens. Northwest Science 64(5): 271-274.

Hayes, M.P., D.J. Dugger, T.L. Hicks, and T. Quinn. 2003. Headwater habitat variation: Its relationship to stream amphibian distribution. Abstract. Northwestern Naturalist 84:100.

Hayes, M.P., T. Quinn, D.E. Runde, L.L.C. Jones, M.G. Raphael, and T. Hicks. 2002. Is the Olympic tailed frog (Ascaphus truei) a biodiversity indicator? Northwestern Naturalist 83(2):71.

Hazelwood, W.G. 1993. Extending the known range of tailed frog populations in British Columbia. Unpublished report. Alpenglow Resources, Terrace, British Columbia.

Held, S.P. 1984. Captive maintenance of the tailed frog (Ascaphus truei) at the Washington Park Zoo, Portland Oregon. Animal Keepers' Forum 11(12): 402-410.

Held, S.P. 1985. Maintenance, exhibition, and breeding of the tailed frog, Ascaphus truei, in a zoological park. Herpetological Review 16(2): 48-51.

*Hendricks, P. 1997. Lee Metcalf National Wildlife Refuge preliminary amphibian and reptile investigations: 1996. Montana Natural Heritage Program, Helena, MT. 21 p.

*Hendricks, P. and J.D. Reichel. 1996. Amphibian and reptile survey of the Bitterroot National Forest: 1995. Montana Natural Heritage Program, Helena, MT. 95 p.

*Hossack, B. and P.S. Corn. 2005. Changes in counts of Rocky Mountain tailed frog tadpoles after wildfires in Glacier National Park, Montana. Abstract. Northwestern Naturalist 86:99. 
*Jaeger, R.G. and J.P. Hailman. 1973. Effects of intensity on the phototactic responses of adult anuran amphibians: a comparative survey. Zeitschrift für Tierpsychologie 33: 352-407.

Jamieson, B.G.M., M.S.Y. Lee and K. Long. 1993. Ultrastructure of the spermatozoon of the internally fertilizing frog Ascaphus truei (Ascaphidae: Anura: Amphibia) with phylogenetic considerations. Herpetologica 49(1): 52-65.

*Jones, L.L.C., W.P. Leonard, and D.H. Olson (eds). 2005. Amphibians of the Pacific Northwest. Seattle, WA: Seattle Audubon Society. 227 p.

Jones L.C. and M.G. Raphael. 1998. Ascaphus truei (Tailed frog). Predation. Herpetological Review 29: 39.

Karraker, N.E. 2001. Ascaphus truei (tailed frog) predation. Herpetological Review 32(2): 100.

Karraker, N.E. and G.S. Beyersdorf. 1997. A tailed frog (Ascaphus truei) nest site in northwestern California. Northwestern Naturalist 78(3): 110-111.

Karraker, N.E., D.S. Pilliod, E.L. Bull, S.P. Corn, L.V. Diller. 2004. Taxonomic and geographic variation in the oviposition of tailed frogs (Ascaphus spp.). Abstract. Northwestern Naturalist 85:79.

Kelsey, K.A. 1994. Responses of headwater stream amphibians to forest practices in western Washington. Northwest Science 68(2): 133.

Lamberti, G.A., S.V. Gregory, and C.P. Hawkins. 1988. Of frogs and phyton: the importance of herbivory in devastated streams of Mount St. Helens. Bulletin of the Ecological Society of America 69(2): 201.

Landreth, H.F. and D.E. Ferguson. 1967. Movements and orientation of the tailed frog (Ascaphus truei). Herpetologica 23(2): 81-93.

Lapsansky, J.M. and H.A. Brown. 1992. Oviduct histology and sperm storage in the tailed frog (Ascaphus truei). American Zoologist 32(5):147A.

Lohman, K. 2000. Temporal and spatial variability in the abundance of tailed frog tadpoles (Ascaphus truei) in streams of the Mica Creek Experimental Watershed. Northwest Sectional Meeting of the Wildlife Society, University of Idaho, Moscow, Idaho. p. 21.

Manlow, S.W. 1994. Ascaphus truei (tailed frog). Herpetological Review 25(1): 31.

*Manville, R.H. 1957. Amphibians and reptiles of Glacier National Park, Montana. Copeia 1957: 308-309.

*Marnell, L.F. 1996. Amphibian survey of Glacier National Park, Montana. Abstract. Intermountain Journal of Sciences 2(2): 52.

*Marnell, L.F. 1997. Herpetofauna of Glacier National Park. Northwestern Naturalist 78: 1733.

Matsuda, B.M., D.M. Green, and P.T. Gregory. 2006. Amphibians and reptiles of British Columbia. Victoria, B.C.: Royal British Columbia Museum. 266 p.

Maughan, O.E, P. Laumeyer, R.L. Wallace, and M.G. Wickham. 1980. Distribution of the tailed frog, Ascaphus truei Stejneger, in several drainages in northcentral Idaho. Herpetological Review 11(1): 15-16.

*Maxell, B.A. 2002. Amphibian and aquatic reptile inventories in watersheds in the South and Middle Forks of the Flathead River drainage that contain lakes being considered for application of piscicides and subsequent stocking of west slope cutthroat trout. Report to the Region 1 Office of the U.S. Forest Service and the Montana Department of Fish, Wildlife, and Parks. Montana Cooperative Wildlife Research Unit and Wildlife Biology Program, University of Montana, Missoula, MT. 62 pp. 
*Maxell, B.A. 2004a. Amphibian and aquatic reptile inventories conducted on and around the Bitterroot National Forest 2000-2003. Report to Region 1 Office of the U.S. Forest Service, Bitterroot National Forest, Montana Department of Fish, Wildlife, and Parks, and Biological Resources Division of the U.S. Geological Survey. Missoula, MT: Montana Cooperative Wildlife Research Unit and Wildlife Biology Program, University of Montana. 128 p.

* Maxell, B.A. 2004b. Amphibian and aquatic reptile inventories conducted on and around the Thompson River 2003-2004. Report to Region 1 Office of the U.S. Forest Service and Plum Creek Timber Company. Missoula, MT: Montana Cooperative Wildlife Research Unit and Wildlife Biology Program. 83 p.

*Maxell, B.A. 2004c. Report on amphibian and aquatic reptile inventories conducted on and around the Beaverhead-Deerlodge National Forest 2001-2003. Report to Region 1 Office of the U.S. Forest Service, Beaverhead-Deerlodge National Forest, Montana Department of Fish, Wildlife, and Parks, Montana State Office of the Bureau of Land Management, and Montana Department of Environmental Quality. Missoula, MT: Montana Cooperative Wildlife Research Unit and Wildlife Biology Program, University of Montana. 260 p.

*Maxell, B.A. 2005a. Amphibian and aquatic reptile inventories conducted on and around lands administered by the Missoula Field Office of the Bureau of Land Management. Report to Missoula Field Office of the Bureau of Land Management. Montana Natural Heritage Program, Helena, MT and Montana Cooperative Wildlife Research Unit and Wildlife Biology Program, University of Montana, Missoula, MT. $53 \mathrm{p}$.

*Maxell, B.A. 2005b. A review of monitoring methods and a multi-tiered scheme for assessing and monitoring the status of amphibians in Montana. Report to Montana Department of Environmental Quality, Region 1 Office of the U.S. Forest Service, Montana Department of Fish, Wildlife, and Parks, and Montana State Office of the Bureau of Land Management. Montana Natural Heritage Program, Helena, MT and Montana Cooperative Wildlife Research Unit and Wildlife Biology Program, University of Montana, Missoula, MT. 29 p. + Appendices.

*Maxell, B.A. 2009. State-wide assessment of status, predicted distribution, and landscapelevel habitat suitability of amphibians and reptiles in Montana. Ph.D. Dissertation. Missoula, MT: Wildlife Biology Program, University of Montana. 294 p.

*Maxell, B.A. and D.G. Hokit. 1999. Amphibians and reptiles. pp. 2.1-2.30. In G. Joslin and H. Youmans, coordinators. Effects of recreation on Rocky Mountain wildlife: a review for Montana. Committee on Effects of Recreation on Wildlife, Montana Chapter of the Wildlife Society. 307 p.

*Maxell, B.A., J.K. Werner, P. Hendricks, and D. Flath. 2003. Herpetology in Montana: a history, status summary, checklists, dichotomous keys, accounts for native, potentially native, and exotic species, and indexed bibliography. Olympia, WA: Society for Northwestern Vertebrate Biology. Northwest Fauna 5: 1-138.

McCoid, M.J. and P.W. Bettoli. 1996. Additional evidence for rotenone hazards to turtles and amphibians. Herpetological Review 27(2): 70-71.

Metter, D.E. 1963. A morphological and ecological comparison of two populations of Ascaphus truei Stejneger. Ph.D. Dissertation, University of Idaho. 73 pp.

Metter, D.E. 1964a. A morphological and ecological comparison of two populations of the tailed frog (Ascaphus truei Stejneger). Copeia 1964: 181-195.

Metter, D.E. 1964b. On breeding and sperm retention in Ascaphus. Copeia 1964(4): 710-711. 
Metter, D.E. 1966. Some temperature and salinity tolerances of Ascaphus truei Stejneger. Journal of Idaho Academy of Sciences 4: 44-47.

*Metter, D.E. 1967. Variation in the ribbed frog Ascaphus truei Stejneger. Copeia 1967(3): *634-649.

*Metter, D.E. 1968a. Ascaphus and Ascaphus truei. Catalogue of American Amphibians and Reptiles 69.1-69.2.

Metter, D.E. 1968b. The influence of floods in the population structure of Ascaphus truei Stejneger. Journal of Herpetology 1: 105-106.

*Metter, D.E. and R.J. Pauken. 1969. An analysis of the reduction of gene flow in Ascaphus truei in the Northwest U.S. since the Pleistocene. Copeia 1969: 301-307.

*Mittleman, M.B. and G.S. Meyers. 1949. Geographical variation in the ribbed frog Ascaphus truei. Proceedings of the Biological Society of Washington 62: 57-68.

Morgan, G.T. and K.M. Middleton. 1988. Organization and sequence of the compact ribosomal DNA spacer of the tailed frog, Ascaphus truei. Nucleic Acids Research 16(22): 10917.

Morgan, G.T. and K.M. Middleton. 1992. Conservation of intergenic spacer length in ribosomal DNA of the tailed frog, Ascaphus truei. Gene (Amsterdam) 110(2): 219-223.

Myers, G.S. 1931. Ascaphus truei in Humboldt County, California, with a note on the habits of the tadpole. Copeia 1931: 56-67.

Myers, G.S. 1943. Notes on Rhyacotriton olympicus and Ascaphus truei in Humboldt County, California. Copeia 1943: 125-126.

*[NDTI] Northrop, Devine, and Tarbell Incorporated. 1994. Cabinet Gorge and Noxon Rapids hydroelectric developments 1993 wildlife study. Northrop, Devine, and Tarbell Incorporated, Portland, ME. 197 p.

*Nielson, M.K. 2000. Phylogeography of the tailed frog (Ascaphus truei): implications for the biogeography of the Pacific Northwest and a taxonomic revision within Ascaphus. M.S.

Thesis. Department of Fish and Wildlife Resources, University of Idaho, Moscow, ID. 82 p.

*Nielson, M.K. and K. Lohman. 2000. Genetic structure within an ancient lineage: the phylogeography of tailed frogs (Ascaphus truei). Northwest Sectional Meeting of The Wildlife Society, University of Idaho, Moscow, Idaho. p. 22.

*Nielson, M.K., K. Lohman, and J. Sullivan. 2001. Phylogeography of the tailed frog (Ascaphus truei): implications for the biogeography of the Pacific Northwest. Evolution 55: 147-160.

Nishikawa, K.C. 1991. Kinematics of prey capture in the tailed frog Ascaphus truei (Anura: Ascaphidae). Zoological Journal of the Linnean Society 103(3): 289-307.

Noble, G.K. 1922. Editorial note on Ascaphus truei. Copeia 102: 6.

Noble, G.K., and P.G. Putnam. 1931. Observations on the life history of Ascaphus truei Stejneger. Copeia 1931(3): 97-101.

*Nussbaun, R., E. Brodie, Jr., and R. Storm. 1983. Amphibians and reptiles of the Pacific Northwest. University of Idaho Press, Moscow, Idaho. 322 p.

*Patla, D.A. 1998. Potential effects of native fish restoration projects on amphibians in Yellowstone National Park Part I. Report to National Park Service, Yellowstone National Park. 20 November 1998. 26 pp.

*Pauken, R.J. and D.E. Metter. 1971. Geographic representation of morphologic variation among populations of Ascaphus truei Stejneger. Systematic Zoology 20: 434-441.

Pilliod, D.S. and P.S. Corn. 2003. Changes in stream amphibian populations following large fires in Idaho. Abstract. Northwestern Naturalist 84:110. 
Pilliod, D.S. and P.S. Corn. 2004. Effects of wildfires on stream amphibian populations in the greater Northwest. Abstract. Northwestern Naturalist 85:85.

*Powell, R., J.T. Collins, and E.D. Hooper, Jr. 1998. A key to amphibians and reptiles of the Continental United States and Canada. University Press of Kansas, Lawrence, KS. 131 p.

Pusey, H.K. 1943. On the head of the liopelmid frog Ascaphus truei. Quarterly Journal of Microscopical Science 84: 105-185.

Putman, P.J. 1931. Life history and habits of Ascaphus truei. M.S. Thesis. Washington State University Library.

*Reichel, J.D. 1995. Preliminary amphibian and reptile survey of the Lewis and Clark National Forest: 1994. Montana Natural Heritage Program, Helena, MT. 92 p.

*Reichel, J.D. 1996. Preliminary amphibian and reptile survey of the Helena National Forest: 1995. Montana Natural Heritage Program, Helena, MT. 87 p.

*Reichel, J.D. 1997a. Amphibian, reptile and northern bog lemming survey on the Rocky Mountain Front: 1996. Montana Natural Heritage Program, Helena, MT. 81 p.

Reichel, J.D. 1997b. Animal species of special concern in Montana. Montana Natural Heritage Program. Helena, MT. 9 p.

*Reichel, J.D. and D.L. Flath. 1995. Identification guide to the amphibians and reptiles of Montana. Montana Outdoors 26(3): 15-34.

Ritland, K., L.A. Dupuis, F.L. Bunnell, W.L.Y. Hung, and J.E. Carlson. 2000. Phylogeography of the tailed frog (Ascaphus truei). Canadian Journal of Zoology 78: 1749-1758.

*Ritland, R.M. 1955. Studies on the post-cranial morphology of Ascaphus truei. (I) Skeleton and spinal nerves. Journal of Morphology 97: 119-177.

*Rodgers, T.L., and W.L. Jellison. 1942. A collection of amphibians and reptiles from western Montana. Copeia 1942(1): 10-13.

*Roedel, M.D. and P. Hendricks. 1998a. Amphibian and reptile survey on the Bureau of Land Management Lewistown District: 1995-1998. Montana Natural Heritage Program, Helena, MT. $53 \mathrm{p}$.

*Roedel, M.D. and P. Hendricks. 1998b. Amphibian and reptile inventory on the Headwaters and Dillon Resource Areas in conjunction with Red Rocks Lakes National Wildlife Refuge: 1996-1998. Montana Natural Heritage Program, Helena, MT. 46 p.

Roper, B.B. and D.L. Scarnecchia. 2001. Patterns of diversity, density, and biomass of ectothermic vertebrates in ten small streams along a North American river continuum. Northwest Science 75(2): 168-175.

Rundio, D.E. and C.P. Hawkins. 2000. Effects of tailed frog tadpole density on tadpole growth, invertebrate abundance, and algal abundance. Northwestern Naturalist 81(2):87.

Russell, A.P., and A.M. Bauer. 2000. The amphibians and reptiles of Alberta. Second Edition. Calgary, AB: University of Calgary Press. 279 p.

Schell, S.C. 1964. Bunoderella metteri gen. and sp. N. (Trematoda: Allocreadiidae) and other trematode parasites of Ascaphus truei Stejneger. Journal of Parasitology 50(5): 652-655.

Schell, S.C., G. Anderson and I. Pratt. 1965. The life cycle of Bunoderella metteri (Allocreadiidae: Bunoderinae), a trematode parasite of Ascaphus truei. Journal of Parasitology 51(4): 579-582.

*Schmidt, K.P. 1953. A checklist of North American Amphibians and Reptiles. Sixth edition. American Society of Icthyologists and Herpetologists. $280 \mathrm{p}$.

Schmidt, P.S. 1970. Auditory receptors of two mating call-less anurans. Copeia 1970: 169-170. 
Simons, L.H. and M. Simons. 1998. Ascaphus truei (tailed frog). Herpetological Review 29(2): 106.

Slater, J.R. 1931. The mating behavior of Ascaphus truei Stejneger. Copeia 1931(2): 62-63.

*Slipp, J.W. and G.C. Carl. 1943. Northward extensions of the range of Ascaphus. Copeia 1943(2): 127.

*Smith, H.M. 1932. Ascaphus truei Stejneger in Montana. Copeia 1932(2): 100.

Smith, S.N. 1997. Ascaphus truei (tailed frog). Herpetological Review 28(1): 47.

*Stebbins, R.C. 2003. A field guide to western reptiles and amphibians. 3rd edition. New York, NY: Houghton Mifflin Co. 533 p.

Stejneger, L.H. 1899. Description of a new genus and species of discoglossoid toad from North America. Proceedings of the U.S. National Museum. Volume 21, p.899-901, pl. 89, figs. 14.

Stephenson, N.G. 1951. Observations on the development of the amphicoelous frogs, Leiopelma and Ascaphus. Journal of the Linnaean Society 14: 18-28.

Storm, G.L., G.J. Fosmire, and E.D. Bellis. 1994. Persistence of metals in soil and selected vertebrates in the vicinity of the Palmerton Zinc Smelters. Journal of Environmental Quality 23(3): 508-514.

*Timken, R. No Date. Amphibians and reptiles of the Beaverhead National Forest. Western Montana College, Dillon, MT. 16 p.

*[USFWS] US Fish and Wildlife Service. 1994. Endangered and threatened wildlife and plants; animal candidate review for listing as endangered or threatened species. Federal Register 59(219): 58982-59028.

*Van Denburgh, J. 1912. Notes on Ascaphus, the discoglossoid toad of North America. Proceedings of the California Academy of Sciences (4) 3: 259-264.

Van Dijk, D.E. 1955. The "tail" of Ascaphus. Ann. University Stellenbosch 31: 1-71.

Van Eeden, J.A. 1951. The development of the condo-cranium of Ascaphus truei Stejnegar. Acta Zoologica 32: 41-176.

Villiers, 1934a. On the morphology of the epipubis, the Nobelian bones and the phallic organ of Ascaphus truei Stejneger. Anatomischer Anzeiger 98: 23-47.

Villiers, 1934b. Studies on the cranial anatomy of Ascaphus truei Stejneger the American "liopelmid". Bulletin Museum of Comparative Zoology Harvard 77: 1-38.

Visalli, D. and W.P. Leonard. 1994. Ascaphus truei (tailed frog). Herpetological Review 25(1): 31.

Wahbe, T.R. 1996. Tailed frogs (Ascaphus truei, Stejneger) in natural and managed coastal temperate rainforests of southwestern British Columbia, Canada. M.S. Thesis, University of British Columbia, Vancouver, British Columbia.

Wahbe, T.R. and F.L. Bunnell. 2001. Preliminary observations on movements of tailed frog tadpoles (Ascaphus truei) in streams through harvested and natural forests. Northwest Science 75(1): 77-83.

Wahbe, T.R., C. Ritland, F.L. Bunnell, and K. Ritland. 2005. Population genetic structure of tailed frogs (Ascaphus truei) in clearcut and old-growth stream habitat in south coastal British Columbia. Canadian Journal of Zoology 83:1460-1468.

Wahbe, T.R., F.L. Bunnell, and B. Bury. 2001. Philopatry and movements of tailed frogs in coastal British Columbia. Northwestern Naturalist 82(2):83. 
Wahbe, T.R., F.L. Bunnell, and R.B. Bury. 2004. Terrestrial movements of juvenile and adult tailed frogs in relation to timber harvest in coastal British Columbia. Canadian Journal of Forest Research 34:2455-2466.

Wallace, R.L., and L.V. Diller. 1998. Length of the larval cycle of Ascaphus truei in coastal streams of the redwood region, northern California. Journal of Herpetology 32: 404-409.

Welsh, H.H., Jr. 1985. Geographic distribution. Ascaphus truei (tailed frog). Herpetological Review 16(2): 59.

Welsh, H.H. Jr. 1990. Relictual amphibians and old-growth forests. Conservation Biology 4(3): 309-319.

Welsh, H.H. Jr. and A.J. Lind. 1988. Old growth forests and the distribution of the terrestrial herpetofauna. U.S. Forest Service, Rocky Mountain Forest and Range Experiment Station, Fort Collins, Colorado. General Technical Report RM-166: 439-458.

Welsh, H.H., Jr. and L.M. Ollivier. 1998. Stream amphibians as indicators of ecosystem stress: a case study from California's redwoods. Ecological Applications 8(4): 1118-1132.

Welsh, H.H., Jr. and R.J. Reynolds. 1986a. Ascaphus truei (Tailed Frog). Behavior. Herpetological Review 17(1):19.

Welsh, H.H., Jr. and R.J. Reynolds. 1986b. Life history notes. Anura. Ascaphus truei (tailed frog). Herpetological Review 17(1): 19.

*Werner, J.K., B.A. Maxell, P. Hendricks, and D. Flath. 2004. Amphibians and reptiles of Montana. Missoula, MT: Mountain Press Publishing Company. 262p.

*Werner, J.K. and J.D. Reichel. 1994. Amphibian and reptile survey of the Kootenai National Forest: 1994. Montana Natural Heritage Program, Helena, MT. 104 p.

*Werner, J.K. and J.D. Reichel. 1996. Amphibian and reptile monitoring/survey of the Kootenai National Forest: 1995. Montana Natural Heritage Program, Helena, MT. 115 p.

*Werner, J.K. and T. Plummer. 1994. Amphibian and reptile survey of the Flathead Indian Reservation 1993-1994. Salish Kootenai College, Pablo, MT. 55 p.

*Werner, J.K. and T. Plummer. 1995. Amphibian monitoring program on the Flathead Indian Reservation 1995. Salish Kootenai College, Pablo, MT. 46 p.

*Werner, J.K., T. Plummer, and J. Weaselhead. 1998a. Amphibians and reptiles of the Flathead Indian Reservation. Intermountain Journal of Sciences 4(1-2): 33-49.

*Werner, J.K., T. Plummer, and J. Weaselhead. 1998b. The status of amphibians on the Flathead Reservation, Montana. Intermountain Journal of Sciences 4(3-4): 88.

Wernz, J.G. 1969. Spring mating of Ascaphus. Journal of Herpetology 3: 167-169.

Wernz, J.G. and R.M. Storm. 1969. Pre-hatching stages of the tailed frog (Ascaphus truei Stejneger). Herpetologica 25: 86-93.

Wickbom, T. 1950. The chromosomes of Ascaphus truei and the evolution of the annuran karyotypes. Hereditas 36: 406-418.

*Wilson, A.G., Jr. and E.M. Simon. 1987. Status of the Coeur d'Alene salamander (Plethodon vandykei idahoensis) in Montana. Report to the Montana Natural Heritage Program, Helena, MT. 134 p. 


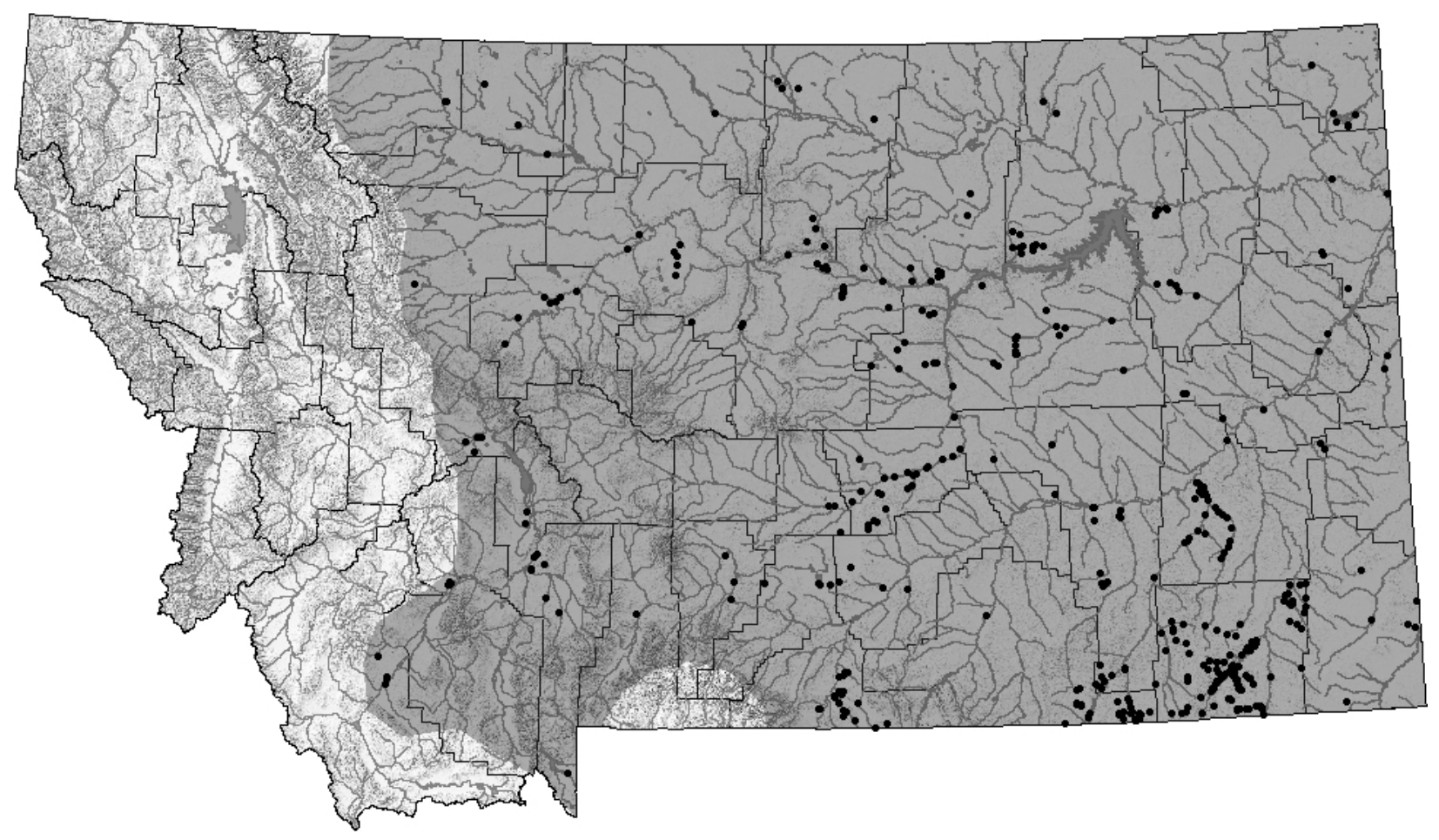

Distribution/Taxonomy

There is currently some debate as to whether the plains spadefoot and other western spadefoots should be placed in the genus or Spea or Scaphiopus (Hall 1998). However, regardless of the generic name, a single distinct species is recognized as ranging across the Great Plains from northern Mexico to southern Canada at elevations up to 2,440 M (8,000 ft) (Stebbins 2003; Wiens and Titus 1991). In Montana they have been sparsely documented across the eastern plains and at a handful of locations in the mountain valleys of the upper Missouri watershed at elevations up to $1,524 \mathrm{M}(5,000 \mathrm{ft})$.

Maximum Elevation

2,014 m (6,608 ft) near the Madison Arm of Hebgen Reservoir in Gallatin County (Ryan DeKnikker and Nichole Walker; MTNHP 2008).

\section{Identification}

\section{Eggs:}

Laid in smaller clusters 10-250 totaling up to 3,844 eggs per female (Mabry and Christiansen 1991). Each ovum is dark brown above, pale yellow below, and is surrounded by three jelly layers (two thin layers immediately adjacent to the ovum and a thicker outer layer) (Hoyt 1960). Ovum diameters are approximately $1.5 \mathrm{~mm}$, but total egg diameters, including the three jelly layers, are approximately $3 \mathrm{~mm}$ (Hoyt 1960).

Larvae:

Light gray or brown dorsally and lighter irridescent golden ventrally (Hammerson 1999). Tail 
fin is clear with sparse yellow flecks. Eyes are located dorsally. TL of 9-68 mm (Russell and Bauer 2000; Klassen 1998).

Juveniles and Adults:

Pupil of the eye is vertical. A large and usually bony bump or boss is present between the eyes (Hall 1998). A single black digging "spade" is present on the soles of the hind feet. Base color is white ventrally and ranges from light brown to dull green dorsally. Four lighter stripes and a few darker splotches are usually present laterally and dorsally and few warts are present (Hammerson 1999). SVL of 10-60 mm (Hammerson 1999; Klassen 1998).

\section{Similar Species:}

No other adult frogs or toads that are known to inhabit Montana have a rounded bony boss directly between the eyes or a vertical eye pupil. Larvae of the western toad, Great Plains toad, and Woodhouse's toad are all dark dorsally. Larvae of Columbia spotted frogs and northern leopard frogs are much more mottled in color with gold and black flecking. See account for the Great Basin spadefoot. Adult Great Basin spadefoots have a soft and pliable boss directly between their eyes.

\section{Habitat Use/Natural History}

Found on or adjacent to sandy soils in native grasslands and shrublands as well as pastures and haylands with non-native vegetation (Lauzon and Balagus 1998). Adults retreat to burrows excavated to depths of one meter in loose soils during periods when terrestrial conditions are not favorable (Russell and Bauer 2000). Adults are present on the surface on warm nights during damp and dry weather where they feed on a variety of insects, but seem to rely on lepidopterans, coleopterans, and homopterans to a greater extent (Kellog 1932; Whitaker et al. 1977). Breeding takes place in warm, often muddy, temporary water bodies formed by extensive rains when minimum temperatures are 7-12 degrees Celsius or warmer (Klassen 1998). Eggs are deposited on rocks, submerged vegetation, or loose on the bottom of the pool, and hatch in 2-3 days (Hammerson 1999). Tadpoles commonly have two morphologies, omnivores which feed on phytoplankton and detritus, and carnivores which feed on fairy shrimp, other invertebrates and frequently their own or other amphibian larvae (Bragg 1964; Pfenning 1990). Depending on conditions, time to metamorphosis can vary from 21 to more than 75 days, with carnivorous morphs reaching metamorphosis much sooner than omnivorous morphs (Gilmore 1934; Bragg 1964). Tadpoles are capable of surviving extended periods ( $\geq 20$ hours) out of water (Moore 1937; Black 1974). Juveniles and adults are known to disperse at least 2.25 kilometers from breeding ponds (Klassen 1998).

\section{Status and Conservation}

In the past 125 years plains spadefoots have only been documented at about 40 localities across the plains and in the mountain valleys east of the Continental Divide and at the present time their status across this region is almost completely unknown. Risk factors relevant to the viability of populations of this species are likely to include grazing, road and trail development, on- and offroad vehicle use, use of pesticides and herbicides, development of water impoundments, habitat loss/fragmentation, and metapopulation impacts, all as described above. However, the lack of information on the distribution, status, habitat use, and basic biology of the species may currently represent the greatest risk to the viability of the species (i.e., the species could have undergone, 
or currently be undergoing, drastic declines but we lack any kind of baseline information that would allow us to make such a determination). Individual studies that specifically identify risk factors or other issues relevant to the conservation of plains spadefoots include the following. (1) At least two reports indicate that non-intensive agriculture may be compatible with the survival of plains spadefoot populations. Lauzon and Balagus (1998) found them breeding in wetlands adjacent to improved pasture and haylands comprised almost completely of non-native vegetation. Klassen (1998) found spadefoots breeding in temporary pools that formed in native grasslands used as cattle pastures and some of these pools were fouled with cattle manure. However, Bragg (1937) reports that all the spadefoot eggs in pools that were heavily contaminated with fecal material from cattle died while other eggs in nearby uncontaminated pools survived. Klassen (1998) also reports that males called from a number of regularly irrigated cultivated fields and found them successfully breeding in one. Klassen (1998) indicated that irrigation may positively benefit populations by allowing regular reproduction in some areas. However, it is also conceivable that some irrigated areas may act as population sinks by drawing animals into areas where they may be impacted by agricultural chemicals or plowing which could disturb individuals in their burrows. (2) Both Bragg (1944) and Hammerson (1999) note that large numbers of plains spadefoots are killed on roads adjacent to breeding sites. (3) Hammerson (1999) notes that several populations have been extirpated due to residential and commercial development near Fort Collins, Colorado. (4) In a study of a congeneric species, Couch's spadefoot Scaphiopus couchii, Judd (1977) found that the herbicide monosodium methanearsonate killed 86 percent of juvenile toads when they were exposed to only one eighth of the concentration recommended for agricultural spraying. The relationship of this herbicide to commonly applied herbicides in Montana is not known, but it is likely that both herbicides and pesticides may represent a threat to plains spadefoot populations. (5) Sounds from offroad vehicles have apparently been found to impact the emergence of congeneric Couch's spadefoots from their underground burrows (Bondello and Brattstrom 1979).

\section{$\underline{\text { Research and Management Suggestions }}$}

1. See research and management suggestions under all of the general risk factors described above with the exception of timber harvest, fire and fire management activities, and harvest and commerce.

2. More thorough documentation of their presence is needed across their entire range in the state, especially on the highline north of the Missouri River, in the mountain valleys upstream of Canyon Ferry Reservoir, and along the Musselshell and Judith Rivers.

3. Studies of their habitat use and population dynamics relative to grazing and dry and irrigated agricultural activities would identify both positive and negative impacts of these activities. The knowledge gained by such studies may be essential to their long term viability.

4. Until the lethal and sublethal impacts of commonly used fertilizers, herbicides, and pesticides on all amphibian life history stages present in an area are examined they should not be applied within 100 meters of waterbodies or wetlands.

5. Where populations are found to be in close proximity to areas of high human use the population impacts of vehicle use near known breeding or burrowing sites should be examined. If impacts are heavy or poorly understood then vehicle use should be curtailed or limited during major periods of activity (e.g., during breeding migrations/choruses or metamorphosis and dispersal). 
Bibliography *indicates an article with information specific to Montana

*Allen, J.A. 1874. Notes on the natural history of portions of Dakota and Montana Territories, being the substance of a report to the Secretary of War on the collections made by the North Pacific Railroad Expedition of 1873, General D.S. Stanley, Commander. Proceedings of the Boston Society of Natural History 17: 33-85. Pages 68-70.

*Atkinson, E.C. and M.L. Atkinson. 2004. Amphibian and reptile survey of the Ashland and Sioux of the Custer National Forest with special emphasis on the Three-Mile Stewardship Area:2002. Marmot's Edge Conservation. 22 p.

*Baxter, G.T. and M.D. Stone. 1985. Amphibians and reptiles of Wyoming. Second Edition. Wyoming Game and Fish Department. 137 p.

Black, J.H. 1973. Ethoecology of Scaphiopus (Pelobatidae) larvae in temporary pools in central and southwestern Oklahoma. Ph.D. Dissertation, University of Oklahoma. Norman, Oklahoma. $221 \mathrm{pp}$.

Black, J.H. 1974. Larval spadefoot survival. Journal of Herpetology 8(4): 371-373.

Blair, W.F. 1949. Development of the solitary spadefoot toad in Texas. Copeia 1949(1): 72.

Blair, W.F. 1955. Differentiation of mating call in spadefoots, genus Scaphiopus. Texas Journal of Science 7: 183-188.

Blair, W.F. 1956. The mating call of hybrid toads. Texas Journal of Science 8: 350-355.

Blair, W.F. 1958. Mating call in the speciation of anuran amphibians. American Naturalist 92: 27-51.

Bondello, M.C. and B.H. Brattstrom. 1979. The effect of motorcycle sounds on the emergence of Couch's spadefoot toad, Scaphiopus couchi. U.S. Bureau of Land Management, California Desert Program. Riverside, California. 27 p. Contract CA-060-CT7-2737.

Boundy, J. 1992b. Spea bombifrons (Plains spadefoot). Herpetological Review 23(1): 25.

*Bragg, A.N. 1937. Observations on Bufo cognatus with special references to breeding habits and eggs. American Midland Naturalist 18: 273-284.

Bragg, A.N. 1941. Tadpoles of Scaphiopus bombifrons and Scaphiopus hammondii. Waserman Collector 4: 92-94.

Bragg, A.N. 1944. The spadefoot toads in Oklahoma with a summary of our knowledge of the group. American Naturalist 78: 517-533.

Bragg, A.N. 1945. The spadefoot toads in Oklahoma with a summary of our knowledge of the group. II. American Naturalist 79. 52-72.

Bragg, A.N. 1946. Aggregation with cannibalism in tadpoles of Scaphiopus bombifrons with some general remarks on the probably evolutionary significance of such phenomena. Herpetologica 3: 89-96.

Bragg, A.N. 1948. Additional instances of social aggregations in tadpoles. Wassmann Collector 7: 65-79.

Bragg, A.N. 1956. Dimorphism and cannabalism in tadpoles of Scaphiopus bombifrons (Amphibia, Salientia). Southwestern Naturalist 1: 105-108.

Bragg, A.N. 1962a. Predation on arthropods by spadefoot tadpoles. Herpetologica 18: 144.

Bragg, A.N. 1962b. Predator-prey relationship in two species of spadefoot tadpoles with notes on some features of their behavior. Wasmann Journal of Biology 20: 81-97.

Bragg, A.N. 1964. Further study of predation and cannibalism in spadefoot tadpoles. Herpetologica 20(1): 17-24.

Bragg, A.N. 1965. Gnomes of the Night: The Spadefoot toads. University of Pennsylvania Press, Philadelphia. 
Bragg, A.N. 1966. Longevity of the tadpole stage in the plains spadefoot (Amphibia: Salientia). Wasmann Journal of Biology 24: 71-73.

Bragg, A.N. and W.N. Bragg. 1958. Parasitism of Spadefoot tadpoles by Saprolegnia. Herpetologica 14: 34 .

Bragg, A.N. and W.N. Bragg. 1958b. Variations in the mouth parts in tadpoles of Scaphiopus (Spea) bombifrons Cope (Amphibia: Salientia). Southwestern Naturalist 3: 55-69.

Bragg, A.N. and O. King. 1960. Aggregational and associated behavior in tadpoles of the Plains spadefoot. Wasmann Journal of Biology 18:273-289.

Brown, H.A. 1976. The status of California and Arizona populations of the western spadefoot toads (Genus Scaphiopus). Contributions of Science of the Natural History Museum of Los Angeles Co. 286 pp.

*Brunson, R.B. 1955. Check list of the amphibians and reptiles of Montana. Proceedings of the Montana Academy of Sciences 15: 27-29.

*Burton, S.R., D.A. Patla, and C.R. Peterson. 2002. Amphibians of Red Rock Lakes National Wildlife Refuge: occurrence, distribution, relative abundance, and habitat associations. Herpetology Laboratory, Department of Biological Sciences, Idaho State University, Pocatello, ID. 66 p.

Cannatella, D.C. 1985. A phylogeny of primitive frogs (Archaeobatrachians). Ph.D. Thesis, University of Kansas, Lawrence, Kansas.

Chrapliwy, P.S. and J.S. Findley. 1956. Records of the central plains spadefoot toad, Scaphiopus bombifrons Cope, in South Dakota and Wyoming. Herpetologica 12: 124.

*Conant, R. and J.T. Collins. 1998. A field guide to reptiles and amphibians of eastern and central North America. $3^{\text {rd }}$ edition, expanded. New York, NY: Houghton Mifflin Co. 616 p.

Cook, F.R. 1960. New localities for the plains spadefoot toad, tiger salamander, and the great plains toad in the Canadian prairies. Copeia 1960 (4): 363-364.

*Cope, E.D. 1863b. On Trachycephalus, Scaphiopus and other American Batrachia. Proceedings of the Academy of Natural Sciences of Philadelphia 15: 43-54.

*Cope, E.D. 1875. Check-list of North American Batrachia and Reptilia; with a systematic list of the higher groups, and an essay on geographical distribution. U.S. National Museum Bulletin 1(1): 1-104.

*Cope, E.D. 1879. A contribution to the zoology of Montana. American Naturalist 13(7): 432441.

*Cope, E.D. 1889. The Batrachia of North America. Bulletin of the U.S. National Museum 34: 1-525, figs. 1-119, pls. 1-86.

Corkran, C.C. and C. Thoms. 2006. Amphibians of Oregon, Washington, and British Columbia. $2^{\text {nd }}$ Edition. Vancouver, B.C.: Lone Pine Publishing. 176 p.

Corn, P.S., E. Muths, and W.M. Iko. 2000. A comparison in Colorado of three methods to monitor breeding amphibians. Northwestern Naturalist 81:22-30.

Creusere, F.M. and W.G. Whitford. 1976. Ecological relationships in a desert anuran community. Herpetologica 32: 7-18.

Dimmitt, M.A. and R. Ruibal. 1980. Exploitation of food resources by spadefoot toads (Scaphiopus). Copeia 1980(4): 854-862.

*Dood, A.R. 1980. Terry Badlands nongame survey and inventory final report. Montana Department of Fish, Wildlife, and Parks and Bureau of Land Management, Helena, MT. 70 p. 
Farrar, E.S. and J.D. Hey. 1997. Carnivorous spadefoot (Spea bombifrons Cope) tadpoles and fairy shrimp in Western Iowa. Journal of the Iowa Academy of Science 104(1): 4-7.

Firschen, I.L. 1950. A new record of Spea bombifrons from northern Mexico and remarks on the status of the hammondii group of spadefoot group of spadefoot anurans. Herpetologica 6(3): 75-77.

Forester, D.C. 1969. Reproductive isolation and hybridization between the spadefoot toads (Scaphiopus bombifrons) and (Scaphiopus hammondii) in west Texas. M.S. Thesis. Texas Tech University, Lubbock, Texas.

Forester, D.C. 1973. Mating call as a reproductive isolating mechanism between Scaphiopus bombifrons and Scaphiopus hammondii. Copeia 1973(1): 60-67.

Forester, D.C. 1975. Laboratory evidence for potential gene flow between two species of spadefoot toads Scaphiopus bombifrons and Scaphiopus hammondii. Herpetologica 31(3): 282-286.

Gilmore, R.J. 1924. Notes on the life history and feeding habits of the spadefoot toad of the western plains. Colorado College Publications in Science 13(1): 1-12.

Gilmore, R.J. 1929. Life history and feeding habits of the spadefoot toad. Journal of the Colorado-Wyoming Academy of Science 1(1): 41.

Gilmore, R.J. 1934. The tadpole of the spadefoot toad. Journal of the Colorado-Wyoming Academy of Science 1(6): 76

Hall, J.A. 1998. Scaphiopus intermontanus. Catalogue of American Amphibians and Reptiles 650.1-650.17.

Hammerson, G.A. 1999. Amphibians and reptiles in Colorado. Second Edition. University Press of Colorado and Colorado Division of Wildlife. $484 \mathrm{p}$.

*Hart, M.M., W.A. Williams, P.C. Thornton, K.P. McLaughlin, C.M. Tobalske, B.A. Maxell, D.P. Hendricks, C.R. Peterson, and R.L. Redmond. 1998. Montana atlas of terrestrial vertebrates. Montana Cooperative Wildlife Research Unit, University of Montana, Missoula, MT. 1302 p.

*Hendricks, P. 1999. Amphibian and reptile survey of the Bureau of Land Management Miles City District, Montana. Montana Natural Heritage Program, Helena, MT. 80 p.

*Hendricks, P. and J.D. Reichel. 1996. Preliminary amphibian and reptile survey of the Ashland District, Custer National Forest: 1995. Montana Natural Heritage Program, Helena, MT. $79 \mathrm{p}$.

*Hendricks, P. and J.D. Reichel. 1998. Amphibian and reptile survey on Montana refuges: 1996. Montana Natural Heritage Program, Helena, MT. 19 p.

Holycross, A.T. and K.B. Malmos. 1992b. Spea bombifrons (Plains spadefoot). Herpetological Review 23(1): 25.

*Hossack, B.R. and P.S. Corn. 2001. Amphibian survey of Medicine Lake National Wildlife Refuge Complex: 2001. USGS Northern Rocky Mountain Science Center, Aldo Leopold Wilderness Research Institute, Missoula, MT. 13 p.

Hossack, B.R., P.S. Corn, and D.S. Pilliod. 2005. Lack of significant changes in the herpetofauna of Theodore Roosevelt National Park, North Dakota, since the 1920s. American Midland Naturalist 154:423-432.

*Hoyt, D.L. 1960. Mating behavior and eggs of the Plains spadefoot. Herpetologica 16: 199201. 
Hughes, N. 1965. Comparison of frontoparietal bones of Scaphiopus bombifrons and Scaphiopus hammondii as evidence for interspecific hybridization. Herpetologica 21: 196201.

Johnson, K.H., G.L. Kurtz, R.A. Olson and T.D. Whitson. 1994. Spea bombifrons (Plains Spadefoot) Herpetological Review 25(2): 75.

Judd, F.W. 1977. Toxicity of monosodium methanearsonate herbicide to Couch's spadefoot toad, Scaphiopus couchi. Herpetologica 33: 44-46.

Justus, J.T., M. Sandomir, T. Urquhart and B.O. Ewan. 1977. Developmental rates of two species of toads from the desert southwest. Copeia 1977(3): 592-594.

*Kellog, R. 1932. Notes on the spadefoot of the western plains (Scaphiopus hammondii). Copeia 1932(1): 36.

Klassen, M.A. 1990. Spadefoot spring. Nature Canada 19: 8-9.

Klassen, M.A. 1998. Observations on the breeding and development of the plains spadefoot (Spea bombifrons) in southern Alberta. Canadian Field Naturalist 112(3): 387-392.

Kluge, A. G. 1966. A new pelobatine frog from the lower Miocene of South Dakota with a discussion of the evolution of the Scaphiopus-Spea complex. Contributions of Science to the Natural History Museum of Los Angeles County 113: 1-26.

Landreth, H.F. and M.T. Christensen. 1971. Orientation of the Plains spadefoot toad, Scaphiopus bombifrons, to solar cues. Herpetologica: 27(4): 454-461.

Lauzon, R.D. and P. Balagus. 1998. New records from the northern range of the plains spadefoot toad (Spea bombifrons) in Alberta. Canadian Field Naturalist 112: 506-509.

*Lynch, C. 2001. North American Amphibian Monitoring Program's Montana frog-call survey: report on year two of a program in south-central Montana started April 2001 and completed in June 2001. Zoo Montana Conservation Through Education Program, Billings MT. 12 p.

Mabry, C.M. and J.L. Christiansen. 1991. The activity and breeding cycle of Scaphiopus bombifrons in Iowa. Journal of Herpetology 25(1): 116-119.

*Manville, R.H. 1957. Amphibians and reptiles of Glacier National Park, Montana. Copeia 1957: 308-309.

*Marnell, L.F. 1997. Herpetofauna of Glacier National Park. Northwestern Naturalist 78: 1733.

*Matthews, W.L. 1979. Wibaux-Beach wildlife baseline study - nongame species. Bureau of Land Management, Miles City, MT. 93 p.

*Maxell, B.A. 2004a. Preliminary report on amphibian and aquatic reptile inventories conducted on and around the Ashland District of the Custer National Forest in 2002 and 2004. Report to Ashland District of Custer Forest, Region 1 Office of the U.S. Forest Service, and Montana Department of Fish, Wildlife, and Parks. Missoula, MT: Montana Cooperative Wildlife Research Unit and Wildlife Biology Program, University of Montana. $93 \mathrm{p}$.

*Maxell, B.A. 2004b. Report on amphibian and aquatic reptile inventories conducted on and around the Beaverhead-Deerlodge National Forest 2001-2003. Report to Region 1 Office of the U.S. Forest Service, Beaverhead-Deerlodge National Forest, Montana Department of Fish, Wildlife, and Parks, Montana State Office of the Bureau of Land Management, and Montana Department of Environmental Quality. Missoula, MT: Montana Cooperative Wildlife Research Unit and Wildlife Biology Program, University of Montana. 260 p.

* Maxell, B.A. 2005a. Amphibian and aquatic reptile inventories conducted on and around lands administered by the Missoula Field Office of the Bureau of Land Management. Report to 
Missoula Field Office of the Bureau of Land Management. Montana Natural Heritage Program, Helena, MT and Montana Cooperative Wildlife Research Unit and Wildlife Biology Program, University of Montana, Missoula, MT. $53 \mathrm{p}$.

*Maxell, B.A. 2005b. A review of monitoring methods and a multi-tiered scheme for assessing and monitoring the status of amphibians in Montana. Report to Montana Department of Environmental Quality, Region 1 Office of the U.S. Forest Service, Montana Department of Fish, Wildlife, and Parks, and Montana State Office of the Bureau of Land Management. Montana Natural Heritage Program, Helena, MT and Montana Cooperative Wildlife Research Unit and Wildlife Biology Program, University of Montana, Missoula, MT. 29 p. + Appendices.

*Maxell, B.A. 2009. State-wide assessment of status, predicted distribution, and landscapelevel habitat suitability of amphibians and reptiles in Montana. Ph.D. Dissertation. Missoula, MT: Wildlife Biology Program, University of Montana. 294 p.

*Maxell, B.A. and D.G. Hokit. 1999. Amphibians and reptiles. pp. 2.1-2.30. In: G. Joslin and H. Youmans (coordinators). Effects of recreation on Rocky Mountain wildlife: a review for Montana. Committee on Effects of Recreation on Wildlife, Montana Chapter of the Wildlife Society. 307 p.

*Maxell, B.A., J.K. Werner, P. Hendricks, and D. Flath. 2003. Herpetology in Montana: a history, status summary, checklists, dichotomous keys, accounts for native, potentially native, and exotic species, and indexed bibliography. Olympia, WA: Society for Northwestern Vertebrate Biology. Northwest Fauna 5: 1-138.

*McEneaney, T. and J. Jensen. 1974. The reptiles and amphibians of the Charles M. Russell National Wildlife Range - 1974. Charles M. Russell National Wildlife Refuge. Lewistown, MT. $3 \mathrm{p}$.

Moore, G.A. 1937. The spadefoot toad under drought conditions. Copeia 1937(4): 225-226.

Moore, J.E. 1952. The spadefoot toad, Scaphiopus, in Alberta. Copeia 1952: 278.

Morlan, R.E. and J.V. Matthews, Jr. 1992. Range extension for the plains spadefoot, Scaphiopus bombifrons, inferred from owl pellets found near outlook, Saskatchewan. Canadian Field Naturalist 106(3): 311-315.

*Mosimann, J.E. and G.B. Rabb. 1952. The herpetology of Tiber Reservoir area, Montana. Copeia 1952: 23-27.

Nero, R.W. 1959. The Spadefoot toad in Saskatchewan. Blue Jay 17(1): 41-42.

Northern, P.T. 1970. The geographic and taxonomic relationships of the Great Basin spadefoot toad, Scaphiopus intermontanus, to other members of the subgenus. Ph.D. Dissertation, University of Wisconsin, Madison.

Ott, J.A. and D.E. Scott. 1999. Effects of toe-clipping and PIT-tagging on growth and survival in metamorphic Ambystoma opacum. Journal of Herpetology 33(2): 344-348.

*Peterson, C.R., C.J. Askey, and D.A. Patla. 1993. Amphibians and reptiles along the Grand Loop and Fountain Freight Roads between Madison Junction and Biscuit Basin in Yellowstone National Park. 26 July, 1993. Greater Yellowstone Ecosystem Amphibian Survey and Monitoring Program, Herpetology Laboratory, Department of Biological Sciences, Idaho State University, Pocatello, ID. 45 p.

Pfennig, K.S. and M.A. Simovich. 2002. Differential selection to avoid hybridization in two toad species. Evolution 56(9): 1840-1848.

Pfenning, D.W. 1990. The adaptive significance of an environmentally-cued development switch in an anuran tadpole. Oecologia 85:101-107. 
Pfenning, D.W. 1992. Proximate and functional causes of polyphenism in an anuran tadpole. Functional Ecology 6:167-174.

Pfenning, D.W., H.K. Reeve and P.W. Sherman. 1993. Kin recognition and cannibalism in spadefoot toad tadpoles. Animal Behaviour 46(1): 87-94.

Pierce, J.R. 1976. Distribution of two mating call types of the plains spadefoot (Scaphiopus bombifrons) in southwestern United States. Southwest Naturalist: 20(4): 578-582.

Plummer, M.V. and G. Turnipseed. 1982. Scaphiopus bombifrons (Plains spadefoot). Herpetological Review 13(3): 80.

Plumpton, D.L. and R.S. Lutz. 1993. Prey selection and food habits of burrowing owls in Colorado. Great Basin Naturalist 53: 299-304.

Potthoff, T.L. and J.D. Lynch. 1986. Interpopulation variability in mouthparts in Scaphiopus bombifrons in Nebraska (USA) (Amphibia: Pelobatidae). Prairie Naturalist 18(1): 15-22.

*Powell, R., J.T. Collins, and E.D. Hooper, Jr. 1998. A key to amphibians and reptiles of the Continental United States and Canada. University Press of Kansas, Lawrence, KS. 131 p.

*[PRESI] Powder River Eagle Studies Incorporated. 1998a. Big Sky Mine 1997 wildlife monitoring studies. Powder River Eagle Studies Incorporated. Gillete, WY.

*[PRESI] Powder River Eagle Studies Incorporated. 1998b. Spring Creek Mine 1997 wildlife monitoring studies. Powder River Eagle Studies Incorporated. Gillete, WY.

Preston, W.B. and D.R.M. Hatch. 1986. The Plains spadefoot (Scaphiopus bombifrons) in Manitoba (Canada). Canadian Field Naturalist 100(1): 123-125.

*Rauscher, R.L. 1998. Amphibian and reptile survey on selected Montana Bureau of Reclamation impoundments. Montana Department of Fish, Wildlife and Parks, Nongame Program, Bozeman, MT. 24 p.

*Reichel, J.D. 1995a. Preliminary amphibian and reptile survey of the Lewis and Clark National Forest: 1994. Montana Natural Heritage Program, Helena, MT. 92 p.

*Reichel, J.D. 1995b. Preliminary amphibian and reptile survey of the Sioux District of the Custer National Forest: 1994. Montana Natural Heritage Program, Helena, MT. 75 p.

*Reichel, J.D. 1996. Preliminary amphibian and reptile survey of the Helena National Forest: 1995. Montana Natural Heritage Program, Helena, MT. 87 p.

*Reichel, J.D. 1997. Amphibian, reptile and northern bog lemming survey on the Rocky Mountain Front: 1996. Montana Natural Heritage Program, Helena, MT. 81 p.

*Roedel, M.D. and P. Hendricks. 1998a. Amphibian and reptile survey on the Bureau of Land Management Lewistown District: 1995-1998. Montana Natural Heritage Program, Helena, MT. $53 \mathrm{p}$.

*Roedel, M.D. and P. Hendricks. 1998b. Amphibian and reptile inventory on the Headwaters and Dillon Resource Areas in conjunction with Red Rocks Lakes National Wildlife Refuge: 1996-1998. Montana Natural Heritage Program, Helena, MT. 46 p.

Ruibal, R., L. Tevis, Jr., and V. Roig. 1969. The terrestrial ecology of the spadefoot toad Scaphipus hammondii. Copeia 1969(3): 571-584.

Russell, A.P., and A.M. Bauer. 2000. The amphibians and reptiles of Alberta. Second Edition. Calgary, AB: University of Calgary Press. 279 p.

Sadler, L.M. and M.A. Elgar. 1994. Cannibalism among amphibian larvae: A case of good taste. Trends in Ecology and Evolution 9(1): 5-6.

Sattler, P.W. 1978. Biochemical genetic investigations of introgressive hybridization and systematic relationships in the spadefoot toads, genus Scaphiopus. Ph.D. Dissertation, Texas Technical University. 
Sattler, P.W. 1980. Genetic relationships among selected species of North American Scaphiopus. Copeia 1980(4): 605-610.

Sattler, P.W. 1985. Introgressive hybridization between the spadefoot toads Scaphiopus bombifrons and Scaphiopus multiplicatus (Salientia: Pelobatidae). Copeia 1985(2): 324-332.

Sattler, P.W. and J.S. Mecham. 1979. Gene duplication at an isocitrate dehydrogenase locus in Scaphiopus. Journal of Heredity 70: 352-353.

Sexton, O.J. and K.R. Marion. 1974. Probable predation by Swainson's hawks on swimming spadefoot toads. Wilson Bulletin 86(2): 167-168.

Seymour, R.S. 1973a. Energy metabolism of dormant Spadefoot toads (Scaphiopus). Copeia 1973(3): 435-445.

Seymour, R.S. 1973b. Gas exchanage in spadefoot toads beneath the ground. Copeia 1973(3): 452-460.

Shannon, F.A. 1953. Scaphiopus bombifrons, a state record for Arizonia. Herpetologica 9: 127128.

Shoemaker, V.H., L. McClanahan, Jr., and R. Ruibal. 1969. Seasonal changes in body fluids in a field population of spadefoot toads. Copeia 1969(3): 585-591.

Simovich, M.A. 1985. Analysis of a hybrid zone between the spadefoot toads (Scaphiopus multiplicatus) and (Scaphiopus bombifrons). Ph.D. diss., University of California, Riverside, CA.

Simovich, M.A. 1994. The dynamics of a spadefoot toad (Spea multiplicata and S. bombifrons) hybridization system. Pp. 167-182 in P.R. Brown and J.W. Wright, eds. Herpetology of North American deserts, special publication no. 5. Southwestern Herpetologists Sociery, Los Angeles, CA.

Simovich, M.A. and C.A. Sassaman. 1986. Four independent electrophoretic markers in spadefoot toads. Journal of Heredity 77(6): 410-414.

Simovich, M.A., C.A. Sassamam, and A. Chovnick. 1991. Post-mating selection of hybrid toads (Scaphiopus multiplicatus and Scaphiopus bombifrons). Proceedings of the San Diego Society of Natural History 1991: 1-6.

Smith, H.M., C.E. Bock, and J.H. Bock. 1993. Spea bombifrons (Plains spadefoot). Herpetological Review 24(4): 154.

Stabler, R.M. 1948. Prairie rattlesnake eats spadefoot toad. Herpetologica 4: 168.

*Stebbins, R.C. 2003. A field guide to western reptiles and amphibians. 3rd edition. New York, NY: Houghton Mifflin Co. 533 p.

*Stejneger, L. and T. Barbour. 1943. A check list of North American amphibians and reptiles. 5th edition. Bulletin of the Museum of Comparative Zoology 93(1): 1-260.

Sullivan, B.K. 1985. Sexual selection and mating system variation in anuran amphibians of the Arizona-Sonoran desert. Great Basin Naturalist 45(4): 688-696.

Sullivan, B.K. and E.A. Sullivan. 1985. Variation in advertisement calls and male mating success of Scaphiopus bombifrons, Scaphiopus couchi and Scaphiopus multiplicatus (Pelobatidae). Southwestern Naturalist 30(3): 349-356.

Swanson, D.L. and B.M. Graves. 1995. Supercooling and freeze intolerance in overwintering juvenile spadefoot toads (Scaphiopus bombifrons). Journal of Herpetology 29(2): 280-285.

Swanson, D.L., B.M. Graves and K.L. Koster. 1996. Freezing tolerance/intolerance and cryoprotectant synthesis in terrestrially overwintering anurans in the Great Plains, USA. Journal of Comparative Physiology B Biochemistry, Systematics and Environmental Physiology 166(2): 110-119. 
*Tanner, V.M. 1939. A study of the genus Scaphiopus. The spade-foot toads. Great Basin Naturalist 1: 3-23.

Tanner, W.W. 1989. Status of Spea stagnalis Cope (1875), Spea intermontanus Cope (1889), and a systematic review of Spea hammondii Baird (1839) (Amphibia: Anura). Great Basin Naturalist 49(4): 503-510.

*Thompson, L.S. 1982. Distribution of Montana amphibians, reptiles, and mammals. Montana Audobon Council, Helena, MT. 25 p.

*Timken, R. No Date. Amphibians and reptiles of the Beaverhead National Forest. Western Montana College, Dillon, MT. 16 p.

Trauth, S.E., B.P. Butterfield, and W.E. Meshaka, Jr. 1989. Scaphiopus bombifrons (plains spadefoot). Herpetological Review 20(1): 12.

Trowbridge, A.H. and M.S. Trowbridge. 1937. Notes on the clevage rate of Scaphiopus bombifrons Cope, with additional remarks on certain aspects of its life history. American Naturalist 71(736): 460-480.

Trowbridge, M. 1941. Studies on the normal development of Scaphiopus bombifrons Cope. I. The clevage period. Transactions of the American Microscopical Society 60: 508-526.

Trowbridge, M. 1942. Studies on the normal development of Scaphiopus bombifrons Cope. II. The later embryonic and larval periods. Transactions of the American Microsopical Society 61: 66-83.

*Turner, F.B. 1951. A checklist of the reptiles and amphibians of Yellowstone National Park with incidental notes. Yellowstone Nature Notes 25(3): 25-29.

*Turner, F.B. 1955. Reptiles and amphibians of Yellowstone National Park. Yellowstone Interpretive Series No. 5. Yellowstone Library and Museum Association. Yellowstone National Park, WY. 40 p.

*Van Kirk, R., L. Benjamin, and D. Patla. 2000. Riparian area assessment and amphibian status in the watersheds of the Greater Yellowstone Ecosystem. Greater Yellowstone Coalition, Bozeman, MT. $102 \mathrm{p}$.

*Vitt, L.J., J.P. Caldwell, and D.B. Shepard. 2005. Inventory of amphibians and reptiles in the Billings Field Office Region, Montana. Sam Noble Oklahoma Museum of Natural History and Department of Zoology, University of Oklahoma, Norman, OK. 33 p.

Voss, W.J. 1961. Rate of larval development and metamorphosis of the spadefoot toad, Scaphiopus bombifrons. Southwestern Naturalist 6: 168-174.

*[VTNWI] VTN Wyoming Incorporated. No Date. Second year's analysis of terrestrial wildlife on proposed mine access and railroad routes in southern Montana and northern Wyoming, March 1979 - February 1980. VTN Wyoming Incorporated. Sheridan, WY. 62 p.

*Werner, J.K., B.A. Maxell, P. Hendricks, and D. Flath. 2004. Amphibians and reptiles of Montana. Missoula, MT: Mountain Press Publishing Company. 262p.

*[WESTECH] Western Technology and Engineering Incorporated. 1998. Wildlife monitoring Absaloka Mine area 1997. Western Technology and Engineering, Inc., Helena, MT.

*Wheeler, G.C. and J. Wheeler. 1966. The amphibians and reptiles of North Dakota. University of North Dakota, Grand Forks, ND. 104 p.

Whitaker, J.A., Jr., D. Rubin, and J.R. Munsee. 1977. Observations on food habits of four species of spadefoot toads, genus Scaphiopus. Herpetologica 33(4): 468-475.

*Wied, M.P. 1865. Verzeichniss der reptilien, welche auf einer reise in nordlichen America beobachtet wurden, von Maximilian, Prinzen zu Wied. Eigengangen bei der Akademie am 1, Juni 1865. Druck von E. Blochmann und Sohn, Dresden, Germany. 141 p. 
Wiens, J.J. 1989. Ontogeny of the skeleton of Spea bombifrons (Anura: Pelobatidae). Journal of Morphology 202(1): 29-52.

Wiens, J.J. and T.A. Titus. 1991. A phylogenetic analysis of Spea (Anura: Pelobatidae). Herpetologica 47(1): 21-28.

Woodward, B.D. 1982. Sexual selection and nonrandom mating patterns in desert anurans (Bufo woodhousii, Scaphiopus couchi, S. multiplicatus, and S. bombifrons). Copeia 1982(2): 351-355. 28.

Woodward, B.D. 1984. Operational sex ratios and sex biased mortality in Scaphiopus (Pelobatidae). Southwestern Naturalist 29: 232-233.

Woodward, B.D. 1987. Intra- and interspecific variation in spadefoot toad (Scaphiopus) clutch parameters. Southwestern Naturalist 32(1):127-131.

Woody, J.R. 1967. Study of certain meteorological influences on the emergence and breeding with notes on the embryology of the plains spadefoot toad, Scaphiopus bombifrons. M.A. Thesis, University of Northern Colorado, Greely, $72 \mathrm{pp}$.

Woody, J.R. and B.O. Thomas. 1966. Preliminary studies of the Scaphiopus bombifrons in northeastern Colorado. Journal of the Colorado-Wyoming Academy of Science 5(7): 11-12.

Woody, J.R. and B.O. Thomas. 1968. Study of certain meterological influences on the emergence and breeding of the plains spadefoot toad, Scaphiopus bombifrons. Journal of the Colorado-Wyoming Academy of Science 6(1): 11.

*Yarrow, H.C. 1882. Check list of North American reptilia and batrachia, with catalogue of specimens in the U.S. National Museum. United States National Museum Bulletin 24. 249 p.

Zweifel, R.G. 1968. Reproductive biology of anurans of the arid southwest, with emphasis on adaptation of embryos to temperature. Bulletin of the American Museum of Natural History 140(1): 1-64. 
Western Toad (Bufo boreas)

Up-to-date distribution and status information can be found on the Montana Natural Heritage Program's TRACKER website at http://mtnhp.org

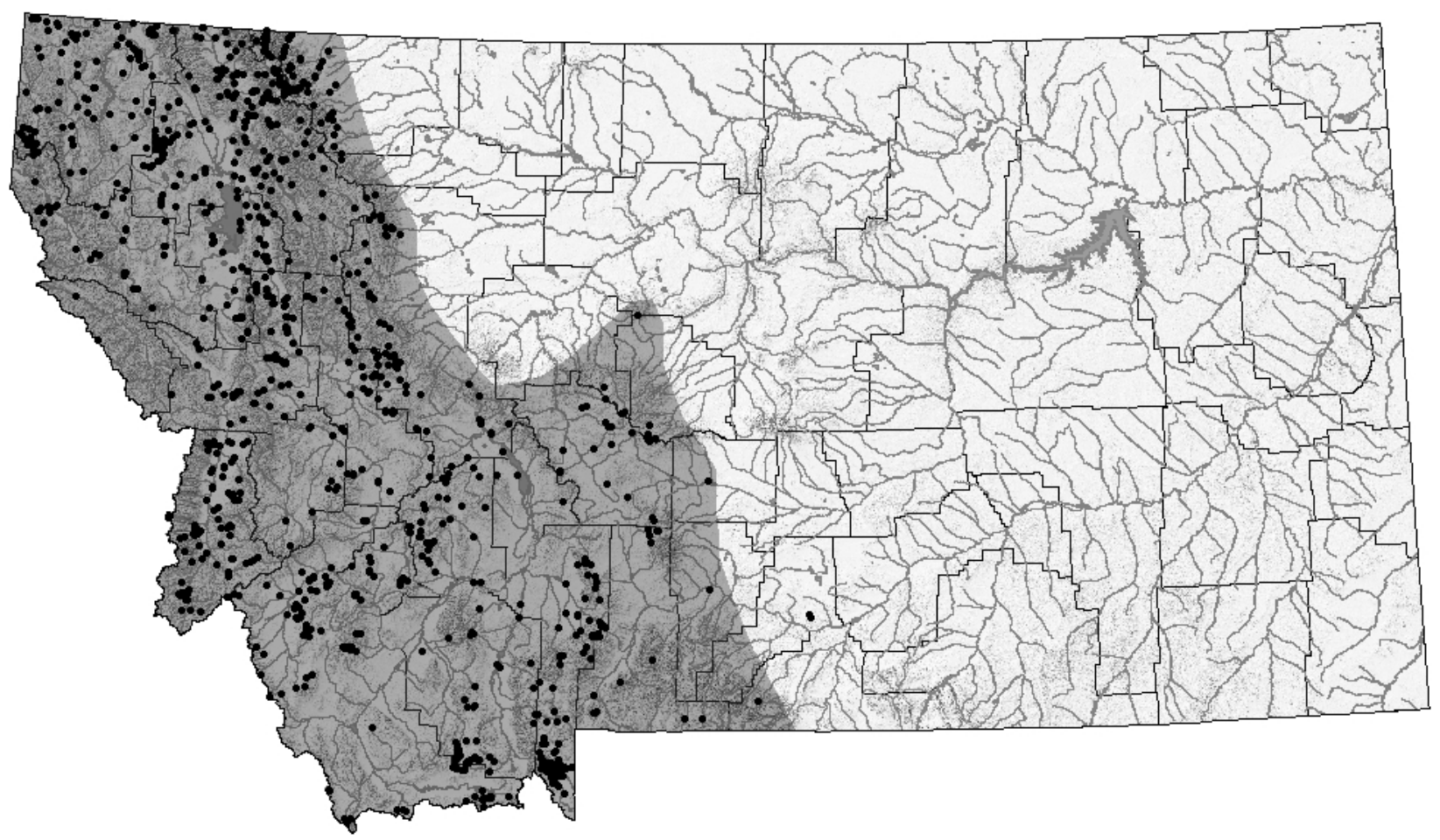

Distribution/Taxonomy

The western toad is currently recognized as two subspecies that range from the Rocky Mountains to the Pacific Coast and from Baja Mexico to southeast Alaska and the Yukon Territory at elevations up to 3,640 M (11,940 ft) (Stebbins 2003; Hammerson 1999). One subspecies, the boreal toad, Bufo boreas boreas is currently recognized as occuring in Montana. However, mitochondrial DNA analysis indicates that four main phylogenetic groups exist and each may warrant recognition as separate species: (1) a southern Rocky Mountain group in Colorado and southern Wyoming; (2) a southern Utah group; (3) a northwest group including all specimens in Montana, northern Idaho, and northern Wyoming; and (4) a southwest group composed of individuals currently recognized as the California toad, Bufo boreas halophilus, the black toad, Bufo exsul, and the Amargosa toad, Bufo nelsoni (Goebel 1996). If these phylogenetic groups are eventually recognized as full species it is likely that populations across Montana and the Pacific Northwest will be recognized as the boreal toad, Bufo boreas. In Montana the species has been documented across the mountainous portion of the state west of the Beartooth Plateau, and the eastern edge of the Castle, Little Belt, and Highwood Mountains (Black 1970a; Black 1971).

Maximum Elevation

2,810 m (9,220 ft) in Gallatin County (Maxell et al. 2003).

Identification

Eggs:

Laid in long strings that are one to three (usually two) eggs wide in a zigzag pattern and contain 
1,000 to more than 18,000 eggs (usually 6,000 to 12,000) (Livezey and Wright 1947; Samallow 1980; Olson 1988; Carey et al. 2000). Each ovum is black above, white below, and is surrounded by two jelly layers (Livezey and Wright 1947). Ovum diameters are 1.5 to $1.75 \mathrm{~mm}$, but total egg diameters, including both jelly layers, are approximately $5 \mathrm{~mm}$ (Livezey and Wright 1947; Karlstrom 1962).

\section{Larvae:}

Body and tail musculature are black and the belly may be either black or gray (Bryce Maxell, pers. obs.). The tail fins are both clear with dendritic pigmentation, with the dorsal tail fin having more pigmentation (Bryce Maxell, pers. obs.). TL of 10-38 mm (Carpenter 1953; Corkran and Thoms 2006).

Juveniles and Adults:

The skin is dry and warty and large parotid glands are present behind the eye and tympanum. The hind feet each have two light brown digging "spades" on their soles, but the spades lack a sharp cutting edge (Black 1970a; Bryce Maxell, pers. obs.). A white stripe extends down the center of the back in older individuals, but may be absent or inconspicuous in younger individuals (Bryce Maxell, pers. obs.). Dorsal base color is olive green or light or dark brown with reddish or light brown color on the warts and small black spots over everything (Bryce Maxell, pers. obs.). Ventral color is cream to tan mottled with numerous dark blotches. SVL of 11-118 mm (Black 1970a; Bryce Maxell, pers. obs.).

\section{Similar Species:}

The geographic range of Great Plains toads and Canadian toads do not overlap with the geographic range of western toads. See the geographic range of Woodhouse's toads to see the limited areas of possible overlap. Adult Woodhouse's toads have parallel cranial crests on the snout and behind the eyes in the shape of an "L". Eggs and larvae of western toads, and Woodhouse's toads are very similar and may not be differentiable by even thoroughly trained herpetologists.

\section{Habitat Use/Natural History}

Found in a wide variety of habitats including wetlands, forests, woodlands, sagebrush, meadows, and floodplains in the mountains and mountain valleys (Brunson 1952; Carpenter 1953; Black 1970a; Campbell 1970c; Cavallo 1997; Hart et al. 1998). Adult and juvenile toads are freeze intolerant and overwinter and shelter in underground caverns, or more commonly in rodent burrows (Mullally 1952; Black 1970b; Smits 1984; Jones 1999). While smaller juveniles are active almost exclusively diurnally, adults are usually active at night except during the spring and at high elevation (Mullally 1958; Lillywhite et al. 1973; Sullivan 1996; Sullivan et al. 1996). Adults feed on a variety of invertebrates, but rely most heavily on ground dwelling coleopterans and hymenopterans and are known to eat smaller vertebrates including smaller individuals of their own species (Cunningham 1954; Moore and Strickland 1955; Mullally 1958; Livezey 1961; Campbell 1970a; Miller 1975, 1978; Hansen and Thomason 1991). Timing of breeding is dependent on temperature, snowmelt, and/or the presence of surface water from flooding and takes place from May to July in shallow areas of large and small lakes, beaver ponds, temporary ponds, slow-moving streams, and backwater channels of rivers (Black 1970a; Metter 1961). Water chemistry at most breeding sites generally has a high $\mathrm{pH}(>8.0)$, high conductivity, and 
high acid-neutralizing capacity (Koch and Peterson 1995). Females wrap egg strings around emergent vegetation or loose in clumps in shallow (usually less than $15 \mathrm{~cm}$ ) waters (Black 1970a; Hammerson 1999). Eggs hatch in approximately 5 days and tadpoles commonly form dense aggregations in shallow warmer waters as they feed on algae, detritus, and other dead tadpoles or adults (Black 1970b; Franz 1971; Loeffler 1998). Tadpoles.metamorphose in mass in 40 (Bryce Maxell, pers. obs.) to 75 (Loeffler 1998) days and metamorphs can be found in dense aggregations adjacent to breeding grounds (Turner 1952; Black 1969; Lillywhite and Wassersug 1974; Devito et al 1998). Adults and juveniles apparently use olfactory and celestial cues primarily to orient, respectively (Tracy and Dole 1969; Tracy 1971). Adults may move more than 800 meters in night, may move more than 4 kilometers away from water after breeding and can remain away from surface water for relatively long periods of time (Pimentel 1955; Tracy and Dole 1969; Campbell 1970; Loeffler 1998). Juveniles may disperse up to or more than 4 kilometers from their natal site (Sornborger 1979).

\section{$\underline{\text { Status and Conservation }}$}

Within the last twenty five years populations of western toads have undergone population crashes in Colorado, Utah, southeast Wyoming, and New Mexico (Stuart and Painter 1994; Ross et al. 1995; Corn et al. 1997; Loeffler 1998). Bufo boreas is now listed as endangered by the State of Colorado and considered a candidate species which is warranted, but precluded, for federal listing by the USFWS in the southern Rocky Mountains (Colorado, southeast Wyoming and northern New Mexico) (Ross et al. 1995; Loeffler 1998). The estimated cost of implementing the first four years of the recovery plan for the Southern Rocky Mountain population is one million twenty-five thousand dollars (Loeffler 1998). Reports of declines in western toad populations have also been reported in Oregon and California (Blaustein et al. 1994; Stebbins and Cohen 1995; Drost and Fellers 1996; Fisher and Shaffer 1996).

Until the late 1990's many biologists believed that populations in the northern Rocky Mountains had not undergone similar declines. However, surveys in the late 1990's revealed that toads were absent from a large number of their historic localities and that although they were still widespread across the landscape they occupied an extremely small proportion of suitable habitat (less than 10\% in most cases, but usually less than 5\%) (Werner and Reichel 1994, 1995; Reichel 1995, 1996, 1997b; Koch and Peterson 1995; Koch et al. 1996; Hendricks and Reichel 1996; Werner et al. 1998; reviewed by Maxell et al. 1998). As a result of these findings the USFS listed the western toad as a sensitive species in all Region 1 Forests (USDAFS 1999) and initiated a regional inventory program in Montana. The systematic inventory of standing water bodies in 40 randomly chosen $6^{\text {th }}$ level Hydrologic Unit Code (HUC) watersheds across western Montana during the summer of 2000 also found toads to be widespread, but extremely rare. Of the 40 watersheds that were surveyed toads were found in $11(27 \%)$, and of the 33 watersheds that contained suitable breeding habitat they were found breeding (eggs, larvae, or metamorphs observed) in 7 (21\%). However, of the 347 standing water bodies that were surveyed within these watersheds toads were only found at $13(3.7 \%)$, and were found breeding at only $9(2.6 \%)$. Furthermore, at sites where toads were observed, only small numbers of adults or relatively small numbers of eggs or larvae were observed. Similarly, in an inventory of approximately 400 standing water bodies in Glacier National Park during the summers of 1999 and 2000, toads were found and bred at approximately 5\% (Steve Corn, USGS BRD Aldo Leopold Institute, pers. comm.). Similar patterns have been observed on the Flathead Indian Reservation where 
breeding occurred at only four of nine historical sites in 1999 and 2000, and at other sites several years have been skipped between breeding events (Kirwin Werner, Salish Kootenai College, pers. comm.). Thus, the evidence to date suggests that western toads have either undergone a decline in the 1980s and are know in the process of recoverying, or they have undergone a decline and are continuing to decline because populations are small, isolated, and/or subject to one or more factors that are impacting populations separately or synergistically.

Risk factors relevant to the viability of populations of this species are likely to include all the risk factors described above As a supplement to this information managers may wish to refer to Loeffler (1998) who, for the recovery of toad populations in the Southern Rocky Mountains, reviews these and other general risk factors and provides management guidelines to mitigate their impacts. Individual studies that specifically identify risk factors or other issues relevant to the conservation of western toads include the following. (1) Carey (1993) observed the disappearance of several populations of western toads in the West Elk Mountains of Colorado between 1974 and 1982 and during this period found many toads with symptoms of red-leg disease, a common bacterial infection in amphibians and fish. She hypothesized that an unidentified environmental factor had caused sublethal stress of the toads, which caused immune response to be supressed leading to the systemic infection and death of toads. More recently the chytrid fungus Batrachochytrium dendrobatidis, which is suspected to be responsible for declines of amphibians in Australia, Central America, and the western United States has been found to have caused mass mortalities in western toad populations in Colorado during the summer of 1999 (Berger et al. 1998; Daszak et al. 1999, 2000; Morell 1999; Milius 1999, 2000; Carey 2000). As was observed for declines in the late 1970's and early 1980's only metamorphosed individuals died (Carey et al. 2000). The fungus only seems to attack keratinized tissues, so metamorphosed individuals with lots of keratinized tissues die and tadpoles with keratinized tissues only around the mouthparts survive until metamorphosis (Berger et al. 1998; Morell 1999). Another line of evidence to suggest that the chytrid fungus was responsible for declines in the late 1970's and early 1980's is that northern leopard frog populations in Colorado crashed at the same time that western toad populations did in the late and museum specimens of northern leopard frogs that were collected during these time period have now been found to have the chytrid fungus (Daszak 1999; Milius 2000). Thus, the chytrid fungus may be the most likely cause of declines of western toads and the near extirpation of northern leopard frogs in western Montana in the late 1970's and early 1980's and clearly represents a threat to populations today. Another fungus, Saprolegnia ferax, has been found to cause $95 \%$ mortality of an estimated 2,496,000 western toad embryos at a site in Oregon (Blaustein et al. 1994b). Spread of the fungus between egg strings is enhanced by the behavior of toads because females often deposit eggs communally (Kiesecker and Blaustein 1997). (2) Hailman (1984) found that western toads tended to congregate around roads in the late evening and early morning. Cunningham (1954) found hundreds of toads flattened on a highway the morning following a summer thunderstorm. (3) Olson $(1989,1992)$ reports that ravens killed large number of breeding western toads $(20 \%$ of the entire breeding population at one site) at three sites in the Oregon Cascades. The author speculates that human activity near these sites may serve to concentrate raven activity in the area and subsequently leads to toad predation. Similarly, Brothers (1994) found toads being preyed on by crows and Beiswenger (1981) found tadpoles being preyed upon by gray jays. Furthermore, Jones et al. (1999) report predation of western toad tadpoles, metamorphs, and adults by a number of avian and mammalian species that 
may be attracted to areas of human activity and/or subsidized by the presence of humans, subsequently leading to increased rates of predation. These animals included mallards, spotted sandpipers, robins, red fox, raccoon, and a domestic dog. Kagarise Sherman and Morton (1993) also report high levels of predation on breeding aggregations of the closely related Yosemite toad by Clark's nutcrackers, California Gulls, and ravens. Fisher and Shaffer (1996) implicate introduced bullfrog and fish predators in the decline of western toads in the Sacramento and San Joaquin Valleys in California. However, Jones et al. (1999) found that neither cutthroat trout or brook trout would prey on tadpoles and Licht (1968) found that toad eggs were not palatable to fish. Furthermore, both Drost and Fellers (1996) and Corn et al. (1997) found toads breeding at sites with and without fish. (4) After what may have been the first successful reproductive event at a site in southeastern Idaho in 10 years Bartelt (1998) documented the deaths of thousands of western toad metamorphs when 500-1,000 sheep were herded through the drying pond the toadlets were concentrated around. He found that hundreds of animals had been directly killed underfoot and hundreds more died soon afterward as a result of dessication because the vegetation they had been hiding in had been trampled to the point that it no longer provided a moist microhabitat. (5) Antimycin and rotenone, two commonly used piscicides, are both toxic to toad tadpoles (Loeffler 1998). (6) Johnson and Prine (1976) exposed juvenile western toads to the insecticides Abate, fenthion, chlorpyrifos-methyl, chlorpyrifos-ethyl, methylparathion, and the insect growth regulator Altosid for 24 hours at one half the concentrations usually applied in the field. They found that toads exposed to the insecticides reduced their activity levels and had lower tolerance to high temperatures than toads in the control group. (7) Porter and Hakanson (1976) found that a variety of heavy metals found in drainage water from mines in Colorado were highly lethal to western toad larvae. Furthermore, they found that lethal $\mathrm{pH}$ for tadpoles ranges from 3.1 to 4.0. Other studies report that no significant embryo mortality is observed for western toads until $\mathrm{pH}$ falls below 4.9, but embryos have an $\mathrm{LC}_{50}$ at $\mathrm{pH}$ less than or equal to 4.5 (Corn et al. 1989; Corn and Vertucci 1992; Vertucci and Corn 1996). (8) In Oregon Blaustein et al. (1994a) found that survival rates for western toad embryos was lower when they were exposed to ambient UV-B radiation than when they were shielded from UV-B radiation and attributed this to the presence of low levels of photolyase, an enzyme that is known to repair UVB damage to DNA. However, Kiesecker and Blaustein (1995) found that UV-B may only be impacting embryo survival as a result of a synergistic interaction with the fungus Saprolegnia ferax. They found that embryos had $95-100 \%$ survival rates when exposed to ambient UV-B radiation in the absence of Saprolegnia. However, when embryos were infected with Saprolegnia survival dropped to 50\% at ambient UV-B levels. Similarly, Corn (1998) failed to find a relationship between exposure to UV-B and embryo survival to hatching in Colorado and noted that a number of other studies have also failed to find a convincing impact of ambient levels of UV-B radiation on amphibian embryos. At artificially high levels of UV-B exposure Worrest and Kimeldorf (1975) report a decline in larval survivorship of western toads from 94$100 \%$ in controls to $0 \%, 17 \%$, and $41 \%$ for UV-B treatments exposed to 0,2 , and 4 hours of photoreactivating $(>315 \mathrm{~nm})$ light following UV-B exposure.

\section{$\underline{\text { Research and Management Suggestions }}$}

1. See research and management suggestions under all of the general risk factors described above. In addition, for the recovery of toad populations in the Southern Rocky Mountains Loeffler (1998) reviews these and other general risk factors and provides management guidelines to mitigate their impacts. 
2. Additional information is needed on their present distribution across their known range in Montana, especially on the Beartooth Plateau, in the southwest corner of the state between the Big Hole Valley and the Madison Mountain Range, along the upper Clark Fork River, and in the Big Belt and Highwood Mountain ranges. Their presence in the Big Snowy, Crazy, Highwood, Ruby, Tendoy, and Snow Crest Mountain Ranges is uncertain. Voucher specimens should be gathered at new found breeding localities, but vouchers should be limited to larvae or metamorphs.

3. Given the results of recent surveys, all previously documented breeding sites in western Montana should be resurveyed at least twice during an upcoming summer in order to identify possible changes in the short- and long-term regional status of western toad populations.

4. All known breeding sites should be monitored annually in order to determine the status of populations relative to various management activities and detect and prevent future declines.

5. Demographic vital rates reported in the scientific literature and recent information on site occupancy rates across the landscape should be used in metapopulation models in order to help determine whether populations in Montana are likely to persist over the long term (e.g., 25,50 , and 100 years).

6. Demographic vital rate information (fecundity, life stage specific survival rates, longevity, and migration and dispersal distances) should be gathered at a number of sites across western Montana in order to better understand the population and metapopulation dynamics of the species and identify mechanisms of mortality for all life history stages.

7. Museum specimens collected since the late 1970's should be examined for the presence of the chytrid fungus. Furthermore, because amphibians sold in pet stores may be introduced into the wild and act as vectors for pathogens, they should be examined and formally certified as free of pathogens such as the chytrid fungus.

8. Known toad breeding sites that are within grazing allotments should have livestock removed or fenced from the area at the time of breeding and at the time of metamorphosis in order to prevent mass mortality of aggregations of adults or metamorphs as a result of trampling.

9. Until the lethal and sublethal impacts of commonly used fertilizers, herbicides, and pesticides on all amphibian life history stages present in an area are examined they should not be applied within 100 meters of waterbodies or wetlands.

10. Before piscicides are used in fish removal projects the area should be surveyed for the presence of toad breeding, and/or eggs and tadpoles. If tadpoles are present in a site that is about to be treated, tadpoles can be netted, placed in holding tanks for a few days, and returned to the site after the piscicide has cleared.

Bibliography *indicates an article with information specific to Montana

*Adams, M.J., B.R. Hossack, R.A. Knapp, P.S. Corn, S.A. Diamond, P.C. Trenham, and D.B. Fagre. 2005. Distribution patterns of lentic-breeding amphibians in relation to ultraviolet radiation exposure in western North America. Ecosystems 8:488-500.

*Adams, S.B., D.A. Schmetterling, and M.K. Young. 2005. Instream movements by boreal toads (Bufo boreas boreas). Herpetological Review 36(1):27-33.

Aguirre, A. 1994. Declining toad populations. Conservation Biology 8(1): 7.

*Allen, J.A. 1874. Notes on the natural history of portions of Dakota and Montana Territories, being the substance of a report to the Secretary of War on the collections made by the North Pacific Railroad Expedition of 1873, General D.S. Stanley, Commander. Proceedings of the Boston Society of Natural History 17: 33-85. Pages 68-70. 
*Anderson, M.E. 1977. Aspects of the ecology of two sympatric species of Thamnophis and heavy metal accumulation with the species. M.S. Thesis, University of Montana. Missoula, MT. $147 \mathrm{pp}$.

Arnold, S.J. and R.J. Wassersug. 1978. Differential predation on metamorphic anurans by garter snakes (Thamnophis): social behavior as a possible defense. Ecology 59(5): 10141022.

*Atkinson, E.C. and M.L. Atkinson. 2003. Status of boreal toads on and adjacent to the Gallatin National Forest, Montana, with special reference to the Hebgen Lake and Bozeman Ranger Districts. Marmot's Edge Conservation. Report to the US Department of Agriculture. Forest Service, Bozeman, MT.

Awbrey, F.T. 1972. "Mating call" of a Bufo boreas male. Copeia 1972(30: 579-581.

Baldwin, R.A. 1974. The water balance response of the pelvic "patch" of Bufo punctatus and Bufo boreas. Comparative Biochemistry and Physiology A Comparative Physiology 47A: 1285-1295.

Barrentine, C.D. 1991a. Food habits of western toads (Bufo boreas halophilus) foraging from a residential lawn. Herpetological Review 22(3) 1991: 84-87.

Barrentine, C.D. 1991b. Survival of billbugs (Sphenophorus spp.) egested by western toads (Bufo boreas). Herpetological Review 22(1): 5.

Bartelt, P.E. 1998. Bufo boreas mortality. Herpetological Review 29(2): 96.

Bartelt, P.E. 2000. A biophysical analysis of habitat selection in western toads (Bufo boreas) in southeastern Idaho. Dissertation, Idaho State University. $112 \mathrm{p}$.

Bartelt, P.E. and C.R. Peterson. 1994. Riparian habitat utilization by western toads (Bufo boreas) and spotted frogs (Rana pretiosa) on the Targhee National Forest. USDA Forest Service Contract \# INT-93780-CCSA Final Report. 30 pp.

Bartelt, P.E. and C.R. Peterson. 1995. Effects of grazing on movements and habitat use of western toads (Bufo boreas) on the Targhee National Forest. Idaho State University, Pocatello, Idaho. $15 \mathrm{pp}$.

Bartelt, P.E. and C.R. Peterson. 2000. A description and evaluation of a plastic belt for attaching radio transmitters to western toads (Bufo boreas). Northwestern Naturalist 81: 122128.

Bartelt, P.E., C.R. Peterson, and R.W. Klaver. 2004. Sexual differences in the post-breeding movements and habitats selected by western toads (Bufo boreas) in southeastern Idaho. Herpetologica 60(4):455-467.

Baxter, G.T. and M.D. Stone. 1985. Amphibians and reptiles of Wyoming. Second Edition. Wyoming Game and Fish Department. 137 p.

*Beal, M.D. 1951. The occurrence and seasonal activity of vertebrates in the Norris and Gibbon Geyser Basins of Yellowstone National Park. M.S. Thesis. Utah State Agricultural College. Logan, Utah. $61 \mathrm{pp.}$

Beiswenger, R.E. 1978. Responses of Bufo tadpoles (Amphibian, Anura, Bufonidae) to laboratory gradients of temperature. Journal of Herpetology 12(4): 499-504.

Beiswenger, R.E. 1981. Predation by gray jays on aggregating tadpoles of the boreal toad (Bufo boreas). Copeia 1981(2): 459-460.

Belden, L.K., E.L. Wildy, and A.R. Blaustein. 2000. Juvenile western toads, Bufo boreas, avoid chemical cues of snakes fed juvenile, but not larval, conspecifics. Animal Behaviour 59: 871-875. 
Benard, M.F. and J.A. Fordyce. 2003. Are induced defenses costly? Consequences of predatorinduced defenses in western toads (Bufo boreas). Ecology 84(1): 68-78.

Biek, R., W.C. Funk, B.A. Maxell, and L.S. Mills. 2002. What is missing in amphibian decline research: Insights from ecological sensitivity analysis. Conservation Biology 16(3):728-734.

*Black, J.H. 1967. Toads of Montana. Montana Wildlife 1967(Spring): 22-28.

*Black, J.H. 1970a. Some aspects of the distribution, natural history and zoogeography of the toad genus Bufo in Montana. M.S. Thesis. University of Montana, Missoula, MT. 70 p.

*Black, J.H. 1970b. Unusual forms of boreal toads Bufo boreas boreas (Amphibia: Bufonidae) in Glacier National Park, Montana. Proceedings of Oklahoma Academy of Sciences 50: 127128.

*Black, J.H. 1971. The toad genus Bufo in Montana. Northwest Science 45: 156-162.

*Black, J.H. and J.N. Black. 1969. Postmetamorphic basking aggregations of the boreal toad (Bufo boreas boreas). Canadian Field Naturalist 83: 155-156.

*Black, J.H. and R.B. Brunson. 1971. Breeding behavior of the boreal toad, Bufo boreas boreas (Baird and Girard), in western Montana. Great Basin Naturalist 31(2): 109-113.

*Black, J.H. and R. Timken. 1976. Endangered and threatened amphibians and reptiles in Montana. p 36-37. In R.E. Ashton, Jr. (chair). Endangered and threatened amphibians and reptiles in the United States. Society for the Study of Amphibians and Reptiles Herpetological Circular 5: 1-65.

Blair, A.P. 1951. Note on the herpetology of the Elk Mountains, Colorado. Copeia 1951: 239240.

Blaustein, A.R. 1988. Ecological correlates and potential functions of kin recognition and kin association in anuran larvae. Behavioral Genetics 18: 449-464.

Blaustein, A.R., D.G. Hokit, R.K. O'Hara, and R.A. Holt. 1994. Pathogenic fungus contributes to amphibian losses in the Pacific Northwest. Biological Conservation 67: 251-254.

Blaustein, A.R., and D.H. Olson. 1991. Declining amphibians. Science 253: 1467.

*Blaustein, A.R., J.J. Beatty, H. Deanna, and R.M. Storm. 1995. The biology of amphibians and reptiles in old-growth forests in the Pacific Northwest. General Technical Report PNWGTR-337. Portland, OR: U.S. Department of Agriculture, Forest Service, Pacific Northwest Research Station. 98 p.

Blaustein, A.R., K.S. Chang, H.G. Lefcort and R.K. O'Hara 1990. Toad tadpole kin recognition: recognition of half siblings and the role of maternal cues. Ethology, Ecology and Evolution 2(2): 215-226.

Blaustein, A.R., P.D. Hoffman, D.G. Hokit, J.M. Kiesecker, S.C. Walls, and J.B. Hays. 1994. UV repair and resistance to solar UV-B in amphibian eggs: a link to population declines? Proceedings of the National Academy of Sciences 91: 1791-1795.

*Boundy, J. 2001. Herpetofaunal surveys in the Clark Fork Valley region, Montana. Herpetological Natural History 8: 15-26.

Boundy, J. and T.G. Balgooyen. 1988. Record lengths for some amphibians and reptiles from the western United States. Herpetological Review 19(2): 26-27.

Brodie, E.D. 1968. A case of interbreeding between Bufo boreas and Rana cascadae. Herpetologica 24: 86.

Brothers, D.R. 1994. Bufo boreas (Western Toad) predation. Herpetological Review 25(3): 117.

Brown, H.A. 1977. A case of interbreeding between Rana aurora and Bufo boreas (Amphibia, Anura). Journal of Herpetology 11(1): 92-94. 
*Brunson, R.B. 1952. Recent collections of Bufo boreas from western Montana. Proceedings of the Montana Academy of Sciences 11: 17-19.

*Brunson, R.B. 1955. Check list of the amphibians and reptiles of Montana. Proceedings of the Montana Academy of Sciences 15: 27-29.

*Brunson, R.B. and H.A. Demaree. 1951. The herpetology of the Mission Mountains, Montana. Copeia 1951: 306-308.

Bull, E.L. and B.C. Wales. 2004. Movements of western toads in burned and unburned forests in northeastern Oregon. Abstract. Northwestern Naturalist 85:69.

Burger, W.L., and A.N. Bragg. 1947. Notes on Bufo boreas (Baird and Girard) from the Gothic region of Colorado. Proceedings of the Oklahoma Academy of Sciences 27: 61-65.

Burton, S.R., D.A. Patla, and C.R. Peterson. 2002. Amphibians of Red Rock Lakes National Wildlife Refuge: occurrence, distribution, relative abundance, and habitat associations. Herpetology Laboratory, Department of Biological Sciences, Idaho State University, Pocatello, ID. 66 p.

Campbell, J.B. 1970a. Food habits of the boreal toad (Bufo boreas boreas) in the Colorado front range. Journal of Herpetology 14 or 4: 83-85.

Campbell, J.B. 1970b. Hibernacula of a population of Bufo boreas boreas in the Colorado Front Range. Herpetologica 26: 278-282.

Campbell, J.B. 1970c. Life history of Bufo boreas boreas in the Colorado Front Range. Ph.D. Dissertation, University of Colorado, Boulder. 110pp.

Campbell, J.B. 1970d. New elevational records for the boreal toad (Bufo boreas boreas). Arctic and Alpine Research 2: 157-159.

Campbell, J.B. 1972. Reproduction and transformation of Boreal toads in the Colorado Front Range. Journal of the Colorado-Wyoming Academy of Science 7:114.

Campbell, J.B. 1976. Environmental controls on boreal toad populations in the San Juan Mountains. Pp. 289-295. In: Ecological impacts of snowpack augmentation in the San Juan Mountains, Colorado. Steinhoff, H.W., and J.D. Ives (eds.). Final Report San Juan Ecology Project, Colorado State University Publications, Fort Collins.

Campbell, J.B., and W.G. Degenhardt. 1971. Bufo boreas in New Mexico. Southwestern Naturalist 16(2): 219.

Carey, C. 1976. Thermal physiology and energetics of boreal toads, Bufo boreas boreas. Ph.D. thesis. University of Michigan, Ann Arbor, Michigan.

Carey, C. 1978. Factors affecting body temperatures of toads. Oecologia 35: 197-219.

Carey, C. 1979a. Aerobic and anaerobic energy expenditure during rest and activity in montane Bufo b. boreas and Rana pipiens. Oecologia 39: 213-228.

Carey, C. 1979b. Effect of constant and fluctuating temperatures on resting and active oxygen consumption of toads, Bufo boreas. Oecologia 39: 201-212.

Carey, C. 1987. Status of a breeding population of the western toad (Bufo boreas boreas) at Lagunitas Campground, New Mexico. New Mexico Department of Game and Fish Contract \# 516-74-26: 1-23.

Carey, C. 1993. Hypothesis concerning the causes of the disappearance of Boreal toads from the mountains of Colorado. Conservation Biology 7(2):355-362.

Carey, C. 1994. A matter of time: response to Aguirre. Conservation Biology 8: 7-8.

Carey, C., B.C. Omundson, H. Ramsdell, L. Livo, and S. Brinkman. 1999. Disappearance of boreal toads in Colorado: a contaminant investigation. U.S. Fish and Wildlife Service, Grand Junction, CO. 
Carey, C., N. Cohen, and L. Rollins-Smith. 1999. Amphibian declines: an immunological perspective. Developmental and Comparative Immunology 23: 459-472.

Carey, C., P.S. Corn, M.S. Jones, L.J. Livo, E. Muths, and C.W. Loeffler. 2000. Environmental and life history factors that limit recovery in southern Rocky Mountain populations of boreal toads (Bufo boreas boreas). In: Status and Conservation of United States Amphibians, (ed Lannoo M. J.). University of California Press, Berkeley, California.

Carey, C., P.S. Corn, M.S. Jones, L.J. Livo, E. Muths, and C.W. Loeffler. 2005. Factors limiting the recovery of boreal toads (Bufo b. boreas). Pp. 222-236. In: Lannoo, M.J. (ed), Amphibian declines: the conservation status of United States species. University of California Press, Berkley, California.

*Carlson, J. (Coordinator, Montana Animal Species of Concern Committee). 2003. Montana Animal Species of Concern. Helena, MT: Montana Natural Heritage Program and Montana Fish, Wildlife, and Parks. In Press. 12p.

Carlton, J. 1993. BLF petitions to protect western boreal toad. Wild Earth 3(3): 14-15.

Carpenter, C.C. 1953. An ecological survey of the Herpetofauna of the Grand Teton-Jackson Hole area of WY Copeia 3: 170-174.

Carpenter, C.C. 1954. A study of amphibian movement in the Jackson Hole Wildlife Park. Copeia 1954(3): 197-200.

*Cavallo, B.J. 1997. Floodplain habitat heterogeneity and the distribution, abundance, and behavior of fishes and amphibians in the Middle Fork Flathead River Basin, Montana. M.S. Thesis. University of Montana, Missoula, MT. 133 p.

Chestnut, T. and C.M. Crisafulli. 2005. Mate selection in Western toads (Bufo boreas). Abstract. Northwestern Naturalist 86:88.

Chivers, D.P., J.M. Kiesecker, A. Marco, L. Erica and A.R. Blaustein. 1998. The effects of snake predation on metamorphosis of western toads, Bufo boreas (Amphibia, Bufonidae). Ethology 104(3): 185-193.

Chivers, D.P., J.M. Kiesecker, A. Marco, E.L. Wildy, and A.R. Blaustein. 1999. Shifts in life history as a response to predation in western toads (Bufo boreas). Journal of Chemical Ecology 25: 2455-2463.

Chivers, D.P., J.M. Kiesecker, E.L. Wildy, L.K. Belden, L.B. Kats, and A.R. Blaustein. 1999. Avoidance response of post-metamorphic anurans to cues of injured conspecifics and predators. Journal of Herpetology 33(3): 472-476.

Clark, R.J., C.R. Peterson, and P.E. Bartelt. 1993. The distribution, relative abundance, and habitat associations of amphibians on the Targhee National Forest. Final Report to the Targhee National Forest.

*Cook, F.R. 1977. Records of the boreal toad from the Yukon and Northern British Columbia. Canadian Field Naturalist 91(2): 185-186.

*Cooper, J.G. 1869. The fauna of Montana territory. American Naturalist 3: 124-127.

*Cope, E.D. 1872. Report on the recent reptiles and fishes of the survey, collected by Campbell Carrington and C.M. Dawes. pp. 467-469 In: F.V. Hayden, Preliminary report of the United States geological survey of Montana and portions of adjacent territories; being a fifth annual report of progress. 538 pp. 42nd Congress, 2nd Session, House Executive Document Number 326. Serial 1520.

*Cope, E.D. 1875. Check-list of North American Batrachia and Reptilia; with a systematic list of the higher groups, and an essay on geographical distribution. U.S. National Museum Bulletin 1(1): 1-104. 
*Cope, E.D. 1889. The Batrachia of North America. Bulletin of the U.S. National Museum 34: 1-525, figs. 1-119, pls. 1-86.

Corkran, C.C. 2002. Amphibian surveys in the backcountry of the Greater Yellowstone Ecosystem. Northwestern Naturalist 83(2):67-68.

Corkran, C.C. and C. Thoms. 2006. Amphibians of Oregon, Washington, and British Columbia. $2^{\text {nd }}$ Edition. Vancouver, B.C.: Lone Pine Publishing. $176 \mathrm{p}$.

Corn, P.S. 1993. Bufo boreas (Boreal Toad) predation. Herpetological Review 24(2): 57.

Corn, P.S. 1998. Effects of ultraviolet radiation on boreal toads in Colorado. Ecological Applications 8(1): 18-26.

Corn, P.S., B.R. Hossack, E. Muths, D.A. Palta, C.R. Peterson, and A.L. Gallant. 2005. Status of amphibians on the Continental Divide: surveys on a transect from Montana to Colorado, USA. Alytes 22(3-4):85-94.

Corn, P.S. and F.A. Vertucci. 1992. Descriptive risk assessment of the effects of acid deposition on Rocky Mountain Amphibians. Journal of Herpetology 26(4): 361-369.

Corn, P.S., M.L. Jennings and E. Muths. 1997. Survey and assessment of amphibian populations in Rocky Mountain National Park. Northwestern Naturalist 78: 34-55.

*Corn, P.S., E. Muths, and C.R. Peterson. 2008. U.S. Geological Survey Amphibian Research and Monitoring Initiative Rocky Mountain Region, 2007 Progress Report. Missoula, MT: Report to U.S. Geological Survey. 6 p.

Corn, P.S., W. Stolzenburg, and R.B. Bury. 1989. Acid precipitation studies in Colorado and Wyoming: interim report of surveys of montane amphibians and water chemistry. U.S. Fish and Wildlife Service Biological Report 89(40.26). Air Pollution and Acid Rain Report No. 26. $56 \mathrm{pp}$.

*Coues, E. and H.C. Yarrow. 1878. Notes on the herpetology of Dakota and Montana. Bulletin of the U.S. Geologic and Geographic Survey 4(1): 259-291.

Crisafulli, C.M., L.S.T. Kling, and A.P. McIntyre. 2005. The response of the Western toad (Bufo boreas) to the 1980 eruption of Mount St. Helens. Abstract. Northwestern Naturalist $86: 89$.

Cunningham, J.D. 1954. A case of cannabilism in the toad Bufo boreas halophilus. Herpetologica 10: 166.

Daszak, P., A.A. Cunningham and A.D. Hyatt. 2000. Emerging infectious diseases of wildlife threats to biodiversity and human health. Science 287: 443-449.

Daszak, P., L. Berger, A.A. Cunningham, A.D. Hyatt, D.E. Green, and R. Speare. 1999. Emerging infectious diseases and amphibian population declines. Emerging Infectious Diseases 5(6): 735-748.

Davis, T.M. and P.T. Gregory. 2003. Decline and local extinction of the Western Toad, Bufo boreas, on Southern Vancouver Island, British Columbia, Canada. Herpetological Review 34(4):350-352.

Devito, J., D.P. Chivers, J.M. Kiesecker, A. Marco, E.L. Wildy, and A.R. Blaustein. 1998. The effects of snake predation on metamorphosis of western toads (Bufo boreas) (Amphibia, Bufonidae). Ethology 104: 185-193.

Dickerson, K. 2002. Environmental contaminants program on-refuge investigations subactivity, final report: year 3. Department of the Interior U.S. Fish and Wildlife Service, Nationwide Malformed Amphibian Monitoring Program. 21p. +Appendices A-G.

Dole, J.W., B.B. Rose, and C.F. Baxter. 1985. Hyperosmotic saline environment alters feeding behavior in the western toad (Bufo boreas). Copeia 1985(3): 645-648. 
Dole, J.W., B.B. Rose, and K.H. Tachiki. 1981. Western toads (Bufo boreas) learn odor of prey insects. Herpetologica 37: 63-68.

Drost, C.A. and G.M. Fellers. 1996. Collapse of a regional frog fauna in the Yosemite area of the California Sierra Nevada, USA. Conservation Biology 10 (2): 414-425.

Eaton, B.R., C.L. Browne, C.A. Paszkowski, Z.C. Eaton, and R. Chapman. 2005. Bufo boreas (Western Toad). Herpetological Review 36(1):52.

Eaton, B.R., C. Grekul, C. Paskowski. 1999. An oberservation of interspecific amplexus between boreal, Bufo boreas, and Canadian, B. hemiophrys, toads, with a range extension for the boreal toad in Alberta. Canadian Field Naturalist 113(3): 512-513.

Engemann, R.M., and R.W. Connell. 1991. Boreal toad in Clear Creek County, Colorado. Northwestern Naturalist 71(3): 98.

*Enk, M. 1999. Preliminary results of amphibian monitoring on the Lewis and Clark National Forest. Intermountain Journal of Sciences 5(1-4): 48.

Feder, J.H. 1977. Hybridization and genetic divergence in the toads Bufo boreas and Bufo punctatus. American Zoologist 17(4): 972.

Feder, J.H. 1979. Natural hybridization and genetic divergence between the toads Bufo boreas and Bufo punctatus. Evolution 33(4): 1089-1097.

Ferguson, D.E. 1954. An interesting factor influencing Bufo boreas reproduction at high elevations. Herpetologica 10: 199

Fetcavitch, C. and L.J. Livo. 1999. Late-season boreal toad tadpoles. Northwestern Naturalist 79: $120-121$.

Fish, J.L. 1972. Growth and survival of anuran tadpoles (Bufo boreas and Rana aurora) in relation to acute gamma radiation, water temperature, and population density. $\mathrm{Ph} . \mathrm{D}$. Thesis, Washington State University. 91pp.

Fisher, R.N. and H.B. Shaffer. 1996. The decline of amphibians in California's Great Central Valley. Conservation Biology 10(5): 1387-1397.

*Flath, D.L. 2002. Reptile and amphibian surveys in the Madison-Missouri River Corridor, Montana. Annual Progress Report. 14pp.

*Franz, R. 1971. Notes on the distribution and ecology of the herpetofauna of northwestern Montana. Bulletin of the Maryland Herpetological Society 7: 1-10.

Garber, C.S. 1992. A survey for spotted frogs (Rana pretiosa), wood frogs (Rana sylvatica), and boreal toads (Bufo boreas) in Wyoming: interim report for the Laramie Range Mountains and Bighorn Mountains of Wyoming. Wyoming Natural Diversity Database. Laramie, WY. 15 pp. + appendix.

Garber, C.S. 1994. A status survey for spotted frogs (Rana pretiosa) wood frogs (Rana sylvatica) and boreal toads (Bufo boreas) in the mountains of southern and eastern Wyoming. U.S.F.W.S. Cooperative Agreement No. 14-48-0006-92-919.

Garber, C.S. 1995a. A survey for U.S. Forest Service listed "Sensitive" amphibians including the spotted frog (Rana pretiosa), leopard frog (Rana pipiens), tiger salamander (Ambystoma tigrinum) and the boreal toad (Bufo boreas) on the north half of the Shoshone National Forest. Report prepared by the Wyoming Natural Diversity Database, Laramie, WY, for the U.S. Forest Service, Shoshone National Forest, Cody, WY.

Garber, C.S. 1995b. Addendum Number 1 to "A status survey for spotted frogs (Rana pretiosa), wood frogs (Rana sylvatica) and boreal toads (Bufo boreas) in the mountains of southern and eastern Wyoming. Report prepared by the Wyoming Natural Diversity Database for the U.S. Fish and Wildlife Service, Denver, CO. 
*Goebel, A.M. 1996. Systematics and conservation of bufonids in North America and in the Bufo boreas species group. Ph.D. Dissertation. University of Colorado, Boulder, CO. 274 p.

Goebel, A.M. 1997. Molecular genetic determination of management units of the endandered boreal toad (Bufo boreas) in Colorado and southeast Wyoming. Unpublished report, Colorado Division of Wildlife.

Goebel, A.M. 2000. Genetic analysis of the southern Rocky Mountain group of Bufo boreas based on mitochondrial DNA sequence and nuclear AFLP restriction site data. In Jones, M.S. (ed.) Colorado Division of Wildlife Boreal Toad Research Progress 1999, April, 2000.

Goebel, A.M. 2005. Conservation systematics: the Bufo boreas species group. Pp. 210-221. In: Lannoo, M.J. (ed), Amphibian declines: the conservation status of United States species. University of California Press, Berkley, California.

Goebel, A.M., T.A. Ranker, P.S. Corn, and R.G. Olmstead. 2009. Mitochondrial DNA evolution in the Anaxyrus boreas species group. Molecular Phylogenetics and Evolution 50:209-225.

Goettl, J.P., Jr. 1997. Boreal toad (Bufo boreas) recovery plan (southern Rocky Mountain population). Colorado Division of Wildlife. $45 \mathrm{p}$.

Gorman, R.R. and D.E. Ferguson. 1970. Sun-compass orientation in the western toad (Bufo boreas). Herpetologica 26(1): 34-45.

*Guscio, C.G., B.R. Hossack, L.A. Eby, and P.S. Corn. 2008. Post-breeding habitat use by adult boreal toads (Bufo boreas) after wildfire in Glacier National Park, USA. Herpetological Conservation and Biology 3:55-62.

*Hailman, J.P. 1984. Bimodal nocturnal activity of the western toad (Bufo boreas) in relation to ambient light. Copeia 1984: 283-290

*Hammerson, G.A. 1999. Amphibians and reptiles in Colorado. Second Edition. University Press of Colorado and Colorado Division of Wildlife. 484 p.

Hansen, R.W. and B. Thomason. 1991. Contia tenuis (sharptail snake). Predation. Herpetological Review 22(2): 60-61.

*Hart, M.M., W.A. Williams, P.C. Thornton, K.P. McLaughlin, C.M. Tobalske, B.A. Maxell, D.P. Hendricks, C.R. Peterson, and R.L. Redmond. 1998. Montana atlas of terrestrial vertebrates. Montana Cooperative Wildlife Research Unit, University of Montana, Missoula, MT. 1302 p.

Hawkes, V.C. and M.A. Fraker. 2000. Observations of amphibians in the floodplain of a regulated northern river. Northwestern Naturalist 81(2):75.

Hayes, M.P. and C.B. Hayes. 2004. Bufo boreas boreas (Boreal Toad). Scats and Behavior. Herpetological Review 35(4):369-370.

Hayes, T.B., R. Chan, and P. Licht. 1993. Interactions of temperature and steroids on larval growth, development, and metamorphosis in a toad (Bufo boreas). Journal of Experimental Zoology 266(3): 206-215.

Hayes, T.B. and T.N. Gill. 1995. Hormonal regulation of skin gland development in the toad (Bufo boreas): the role of the thyroid hormones and corticosterone. Genetics and Comparative Endocrinology 99(2): 161-168.

Hayes, T.B. and P. Licht. 1995. Factors influencing testosterone metabolism by anuran larvae. Journal of Experimental Zoology 271(2): 112-119. 
Hayes, T.B. and T.H. Wu. 1995. Interdependence of corticosterone and thyroid hormones in toad larvae (Bufo boreas). 2. Regulation of corticosterone and thyroid hormones. Journal of Experimental Zoology 271(2): 103-111.

*Hendricks, P. 1997. Lee Metcalf National Wildlife Refuge preliminary amphibian and reptile investigations: 1996. Montana Natural Heritage Program, Helena, MT. 21 p.

*Hendricks, P. 1999. Amphibian and reptile survey of the Bureau of Land Management Miles City District, Montana. Montana Natural Heritage Program, Helena, MT. 80 p.

*Hendricks, P. 2000. Amphibian and reptile survey of the Thompson Chain of Lakes. A report to the Montana Department of Fish, Wildlife, and Parks. Montana Natural Heritage Program, Helena, MT. 15 p.

*Hendricks, P. and J.D. Reichel. 1996. Amphibian and reptile survey of the Bitterroot National Forest: 1995. Montana Natural Heritage Program, Helena, MT. 95 p.

Herreid, C.F., II. 1963. Range extension for Bufo boreas boreas. Herpetologica 19(3): 218.

Hews, D.K. 1988. Alarm response in larval western toads, Bufo boreas: release of larval chemicals by a natural predator and its effect on predator capture efficiency. Animal Behaviour 36: 125-133.

Hews, D.K. and A.R. Blaustein. 1985. An investigation of the alarm response in Bufo boreas and Rana cascadae. Behavior and Neural Biology 43: 47-57.

*Hill, S.R. and R.E. Moore. 1994a. Herpetological survey in the northern range of Yellowstone National Park. Investigator's Annual Reports Yellowstone National Park 1993. Yellowstone Center for Resources. pp. 96-97.

*Hill, S.R. and R.E. Moore. 1994b. Herpetological survey in the northern range of Yellowstone National Park. Annual Report to Yellowstone National Park. February 1, 1994. 21 p.

*Hilliard, J., H. Minkus, and M. Weber. 1997. Amphibian survey of the Birch Creek drainage, Beaverhead County. Wildland Studies Project, San Francisco State University, San Francisco, CA. 12 p.

Hillman, S.S. 1980. Physiological correlates of differential dehydration tolerance in anuran amphibians. Copeia 1980(1):125-129.

Horstman, G.P. 1998. Beetle and toad: an analysis of the predator-prey relationship of the predacious (sic) diving beetle (Coleoptera: Dytiscidae) and Colorado's endangered boreal toad (Bufo boreas boreas). Bulletin of the Chicago Herpetological Society 33: 164-170.

*Hossack, B.R. and P.S. Corn. 2007. Responses of pond-breeding amphibians to wildfire: short-term patterns in occupancy and colonization. Ecological Applications 17:1403-1410.

*Hossack, B.R. and P.S. Corn. 2008. Wildfire effects on water temperature and selection of breeding sites by the boreal toad (Bufo boreas) in seasonal wetlands. Herpetological Conservation and Biology 3:46-54.

*Hossack, B.R., D. Pilliod, and P.S. Corn. 2001a. Reptile and amphibian inventory at GrantKohrs Ranch National Historic Site and Little Bighorn Battlefield National Monument. USGS Northern Rocky Mountain Science Center, Aldo Leopold Wilderness Research Institute, Missoula, MT. 6 p.

*Hossack, B.R., D. Pilliod, and P.S. Corn. 2001b. Preliminary amphibian surveys of the National Bison Range, Lost Trail National Wildife Refuge, and Swan River National Wildlife Refuge: 2001. USGS Northern Rocky Mountain Science Center, Aldo Leopold Wilderness Research Institute, Missoula, MT. 15 p.

Hubbard, J. D. 1972. Some aspects of geographic variation in the Boreal toad, Bufo boreas boreas. Journal of the Colorado-Wyoming Academy of Science 7(2): 65-66. 
Huey, R.B. 1980. Sprint velocity of tadpoles (Bufo boreas) through metamorphosis. Copeia 1980(3):537-540.

Huey, R.B. and R.D. Stevenson. 1979. Integrating thermal physiology and ecology of ectotherms: a discussion of approaches. American Zoologist 19(1): 357-366.

James, M.T. and T.P. Maslin 1947. Notes on myiasis of the toad, Bufo boreas boreas Baird and Girard. Journal of the Washington Academy of Science 37(10): 366-368.

Jean, C., P. Hendricks, M. Jones, S. Cooper, and J. Carlson. 2002. Ecological communities on the Red Rock Lakes National Wildlife Refuge: inventory and review of aspen and wetland systems. Report to Red Rock Lakes National Wildlife Refuge. Montana Natural Heritage Program, Helena, Montana. 33 pp. plus appendices.

Jennings, M.R., J.J. Crayon, and R.L. Hothem. 2005. Bufo boreas halophilus (California Toad) and Rana catesbeiana (American Bullfrog). Amplexus. Herpetological Review 36(1):53.

Johnson, P.T.J., K.B. Lunde, R.W. Haight, J. Bowerman, and A.R. Blaustein. 2001. Ribeiroia ondatrae (Trematoda: Digenea) infection induces severe limb malformations in western toads (Bufo boreas) Canadian Journal of Zoology 79: 370-379.

Johnson, C.R. and J.E. Prine. 1976. The effects of sublethal concentrations of organophosphorus insecticides and an insect growth regulator on temperature tolerance in hydrated and dehydrated juvenile western toads (Bufo boreas). Comparative Biochemistry and Physiology 53A: 147-149.

*Jones, L.L.C., W.P. Leonard, and D.H. Olson (eds). 2005. Amphibians of the Pacific Northwest. Seattle, WA: Seattle Audubon Society. 227 p.

Jones, K.L. 1978. Status of Bufo boreas in New Mexico. Report to New Mexico Department of Game and Fish, Contract \# 519-66-8. 9pp.

Jones, M.S. (ed.). 1998. Boreal toad research progress report 1998. Colorado Division of Wildlife. $116 \mathrm{p}$.

Jones, M.S. (ed.). 1999. Boreal toad research progress report: 1998. Colorado Division of Wildlife, Ft. Collins, CO. 118 p.

Jones, M.S. (ed.). 2000. Boreal toad research progress report: 1999. April, 2000. Unpublished report. Colorado Division of Wildlife, Ft. Collins. 157 pp.

Jones, M.S. and J.P. Goettl. 1998. Henderson/Urad boreal toad studies. Pp. 21-82 In: Boreal Toad Research Progress Report, 1995-1997. Colorado Division of Wildlife.

Jones, M.S. and B. Stiles. 2000. Bufo boreas (Boreal Toad) Predation. Herpetological Review 31(2): 99.

Jones, M.S., J.P. Goettl, and L.J. Livo. 1999. Bufo boreas (boreal toad) Predation. Herpetological Review 30: 91.

Jordan, J.D., C.J. Rombough, C.A. Pearl, and B. McCreary. 2004. Cannibalism and predation by western toad (Bufo boreas boreas) larvae in Oregon, USA. Western North American Naturalist 64(3):403-405.

Kagarise S., C., and M.L. Morton. 1993. Population declines of Yosemite toads in the Eastern Sierra Nevada of California. Journal of Herpetology 27: 186-198.

Karlstrom, E.L. 1962. The toad genus Bufo in the Sierra Nevada of California; ecological and systematic relationships. Ph.D. Dissertation, University of California Berkeley. 95 pp.

Keinath, D. and J. Bennett. 2000. Distribution and status of the boreal toad (Bufo boreas boreas) in Wyoming. Wyoming Natural Diversity Database. University of Wyoming, Laramie, Wyoming. 23 pp. 
Kiesecker, J.M. and A.R. Blaustein. 1995. Synergism between UV-B radiation and a pathogen magnifies amphibian embryo mortality in nature. Proceedings of the National Academy of Sciences 92: 11049-11052.

Kiesecker, J.M. and A.R. Blaustein. 1997. Influences of egg laying behavior on pathogenic infection of amphibian eggs. Conservation Biology 11(1): 214-220.

Kiesecker, J.M., D.P. Chivers, and A.R. Blaustein. 1996. The use of chemical cues in predator recognition by western toad tadpoles. Animal Behaviour 52(6): 1237-1245.

*Koch, E.D. and C.R. Peterson. 1989. A preliminary survey of the distribution of amphibians and reptiles in Yellowstone National Park. pp. 47-49. In: Rare, sensitive and threatened species of the Greater Yellowstone Ecosystem, T.W. Clark, A.H. Harvey, R.D. Dorn, D.C. Genter, and C. Groves (eds.), Northern Rockies Conservation Cooperative , Montana Natural Heritage Program, The Nature Conservancy, and Mountain West Environmental Services. $153 \mathrm{p}$.

*Koch, E.D. and C.R. Peterson. 1995. The amphibians and reptiles of Yellowstone and Grand Teton National Parks. University of Utah Press. Salt Lake City, Utah. 188 pp.

*Koch, E.D., G. Williams, C.R. Peterson and P.S. Corn. 1996. Conference on declining and sensitive amphibians in the Northern Rockies and the Pacific Northwest: a summary paper. Idaho Herpetological Society Technical Bulletin and U.S. Fish and Wildlife Service Report, Boise, ID. 34 p.

Koller, R.L., and A.J. Gaudin. An analysis of helminth infections in Bufo boreas (Amphibia: Bufonidae) and Hyla regilla (Amphibia: Hylidae) in southern California. Southwestern Naturalist 21(4): 503-509.

Kruse, K.C. 1983. Optimal foraging by predacious diving beetle larvae on toad tadpoles. Oecologia 58: 383-388.

Lambert, B., C.R. Malleck, and B. Christman. 1999. Boreal toad surveys in Colorado: summer 1999. Prepared by the Colorado Natural Heritage Program for the Colorado Division of Wildlife and the U.S. Forest Service. 22 pp.

Lambert, B., C.R. Malleck, and K. Huhn. 2000. Boreal toad survey and monitoring project: 2000. Prepared by the Clorado Natural Hertiage Program for the Colorado Division of Wildlife and the U.S. Forest Service. 59pp. + appendices.

*Laselle, B.T. 2000. Association of wetland area with breeding activity for multiple amphibian species. Undergraduate Honors Thesis. Carroll College, Helena, MT. 18 p.

Licht, L.E. 1968. Unpalatability and toxicity of toad eggs. Herpetologica 24: 93-98.

Lillywhite, H.B., P. Licht and P. Chelgren. 1973. The role of behavioral thermoregulation in the growth energetics of the toad (Bufo boreas). Ecology 54: 375-383.

Lillywhite, H.B., and R.J. Wassersug. 1974. Comments on a postmetamorphic aggregation of Bufo boreas. Copeia 1974(4): 984-986.

Livezey, R.L. 1960. Description of the eggs of Bufo boreas exsul. Herpetologica 16:48.

Livezey, R.L. 1961. Food of adult and juvenile Bufo boreas exsul. Herpetologica 17(4): 267268.

*Livezey, R.L. and A.H. Wright. 1947. A synoptic key to salientian eggs of the United States. American Midland Naturalist 37: 179-222.

Livo, L.J. 1998a. Investigations of boreal toad (Bufo boreas) tadpole ecology. Pp. 115-146 In: Boreal Toad Research Progress Report, 1995-1997. Colorado Division of Wildlife.

Livo, L.J. 1998b. Predators of larval Bufo boreas. Colorado-Wyoming Academy of Science 38: 32. 
Livo, L.J. 1999. The role of predation in the early life history of Bufo boreas in Colorado. Ph.D. Dissertation, University of Colorado, Boulder. 197 pp.

Livo, L.J. and C. Fetkavich. 1998. Late-season boreal toad tadpoles. Northwestern Naturalist 79: $120-121$.

Livo, L.J. and B.A. Lambert. 2001. Bufo boreas (boreal toad) phoretic host. Herpetological Review 32(3): 179-180.

Livo, L.J., and D. Yeakley. 1997. Comparison of current with historical elevational range in the boreal toad, Bufo boreas. Herpetological Review 28(3): 143-144.

Loeffler, C. 2000. Report on the status and conservation of the boreal toad, Bufo boreas boreas in the Southern Rocky Mountains 2000. Boreal Toad Recovery Team, Colorado Division of Wildlife. $58 \mathrm{pp}$.

Loeffler, C. 2001. Conservation plan and agreement for the management and recovery of the Southern Rocky Mountain population of the boreal toad (Bufo boreas boreas). Boreal Toad Recovery Team and Technical Advisory Group, Colorado Division of Wildlife.

Loeffler, C. (ed.). 1998. Conservation plan and agreement for the management and recovery of the Southern Rocky Mountain population of the boreal toad (Bufo boreas boreas). Boreal Toad Recovery Team. 80 pp.

Loeffler, C. (ed.). 1999. Report on the status and conservation of the boreal toad (Bufo boreas boreas) in the Southern Rocky Mountains. Boreal Toad Recovery Team. 51pp.

Loeffler, C. (ed.). 2000. Report on the status and conservation of the boreal toad (Bufo boreas boreas) in the Southern Rocky Mountains. Boreal Toad Recovery Team. 58pp.

Loeffler, C. (ed). 2001. Conservation plan and agreement for the management and recovery of the southern Rocky Mountain population of the Boreal toad (Bufo boreas boreas). Boreal Toad Recovery Team. $97 \mathrm{p}$.

Long, C.A. 1964. The badger as a natural enemy of Ambystoma tigrinum and Bufo boreas. Herpetologica 20(2): 144.

Manis, M.L. 1981. The effects of the presence of conspecifics on the feeding behavior of three species of bufonid anurans. M.S. Thesis, Adelphi University. 52p.

*Manville, R.H. 1957. Amphibians and reptiles of Glacier National Park, Montana. Copeia 1957: 308-309.

Marco, A., J.M. Kiesecker, D.P. Chivers, and A.R. Blaustein. 1998. Sex recognition and mate choice by male western toads (Bufo boreas). Animal Behaviour 55: 1631-1635.

*Marnell, L.F. 1996. Amphibian survey of Glacier National Park, Montana. Abstract. Intermountain Journal of Sciences 2(2): 52.

*Marnell, L.F. 1997. Herpetofauna of Glacier National Park. Northwestern Naturalist 78: 1733.

Martin, D.L. 1988. Bufo boreas halophilus length record. Herpetological Review 19(2): 26.

*Martin, P.R. 1980. Terrestrial wildlife habitat inventory in southeastern Montana. Montana Department of Fish, Wildlife and Parks and Bureau of Land Management, Helena MT. 114 p.

*Martin, P.R., K. Dubois and H.B. Youmans. 1981. Terrestrial wildlife inventory in selected coal areas, Powder River resources area final report. Montana Department of Fish, Wildlife and Parks and Bureau of Land Management, Helena, MT. 288 p.

Martin, R.F. 1973. Osteology of North American Bufo: the americanus, cognatus, and boreas species groups. Herpetologica 29(4): 375-387. 
Matsuda, B.M., D.M. Green, and P.T. Gregory. 2006. Amphibians and reptiles of British Columbia. Victoria, B.C.: Royal British Columbia Museum. 266 p.

*Maxell, B.A. 2002. Amphibian and aquatic reptile inventories in watersheds in the South and Middle Forks of the Flathead River drainage that contain lakes being considered for application of piscicides and subsequent stocking of west slope cutthroat trout. Report to the Region 1 Office of the U.S. Forest Service and the Montana Department of Fish, Wildlife, and Parks. Montana Cooperative Wildlife Research Unit and Wildlife Biology Program, University of Montana, Missoula, MT. 62 pp.

*Maxell, B.A. 2004a. Amphibian and aquatic reptile inventories conducted on and around the Bitterroot National Forest 2000-2003. Report to Region 1 Office of the U.S. Forest Service, Bitterroot National Forest, Montana Department of Fish, Wildlife, and Parks, and Biological Resources Division of the U.S. Geological Survey. Missoula, MT: Montana Cooperative Wildlife Research Unit and Wildlife Biology Program, University of Montana. 128 p.

*Maxell, B.A. 2004b. Amphibian and aquatic reptile inventories conducted on and around the Thompson River 2003-2004. Report to Region 1 Office of the U.S. Forest Service and Plum Creek Timber Company. Missoula, MT: Montana Cooperative Wildlife Research Unit and Wildlife Biology Program. 83 p.

*Maxell, B.A. 2004c. Preliminary report on amphibian and aquatic reptile inventories conducted in the West Boulder River area during summer 2003. Report to Region 1 Office of the U.S. Forest Service, and the Montana Department of Fish, Wildlife, and Parks. Missoula, MT: Montana Cooperative Wildlife Research Unit and Wildlife Biology Program, University of Montana. 27 p.

*Maxell, B.A. 2004d. Report on amphibian and aquatic reptile inventories conducted on and around the Beaverhead-Deerlodge National Forest 2001-2003. Report to Region 1 Office of the U.S. Forest Service, Beaverhead-Deerlodge National Forest, Montana Department of Fish, Wildlife, and Parks, Montana State Office of the Bureau of Land Management, and Montana Department of Environmental Quality. Missoula, MT: Montana Cooperative Wildlife Research Unit and Wildlife Biology Program, University of Montana. 260 p.

*Maxell, B.A. 2005a. Amphibian and aquatic reptile inventories conducted on and around lands administered by the Missoula Field Office of the Bureau of Land Management. Report to Missoula Field Office of the Bureau of Land Management. Montana Natural Heritage Program, Helena, MT and Montana Cooperative Wildlife Research Unit and Wildlife Biology Program, University of Montana, Missoula, MT. 53 p.

*Maxell, B.A. 2005b. A review of monitoring methods and a multi-tiered scheme for assessing and monitoring the status of amphibians in Montana. Report to Montana Department of Environmental Quality, Region 1 Office of the U.S. Forest Service, Montana Department of Fish, Wildlife, and Parks, and Montana State Office of the Bureau of Land Management. Montana Natural Heritage Program, Helena, MT and Montana Cooperative Wildlife Research Unit and Wildlife Biology Program, University of Montana, Missoula, MT. 29 p. + Appendices.

*Maxell, B.A. 2006. Evaluation of Montana's lentic breeding amphibian survey methodology and variables correlated with species occupancy. Report to Montana Department of Environmental Quality. Montana Natural Heritage Program, Helena, MT and Montana Cooperative Wildlife Research Unit and Wildlife Biology Program, University of Montana, Missoula, MT. 49 p. 
*Maxell, B.A. 2009. State-wide assessment of status, predicted distribution, and landscapelevel habitat suitability of amphibians and reptiles in Montana. Ph.D. Dissertation. Missoula, MT: Wildlife Biology Program, University of Montana. 294 p.

*Maxell, B.A., P.S. Corn, P. Hendricks, T. Koch, C. Peterson, and J.K. Werner. 1998. Brief overview of boreal toad status in USFS Region 1. Unpublished letter to Region 1 Forest Service. 8 pp.

*Maxell, B.A. and D.G. Hokit. 1999. Amphibians and reptiles. Pages 2.1- 2.30. In G. Joslin and H. Youmans, committee chairs. Effects of recreation on Rocky Mountain wildlife: a compendium of the current state of understanding in Montana. Helena, MT: Committee on Effects of Recreation on Wildlife, Montana Chapter of the Wildlife Society.

*Maxell, B.A., K.J. Nelson, and S. Browder. 2002. Record clutch size and observations on breeding and development of the western toad (Bufo boreas) in Montana. Northwestern Naturalist. 83: 27-30.

*Maxell, B.A., J.K. Werner, P. Hendricks, and D. Flath. 2003. Herpetology in Montana: a history, status summary, checklists, dichotomous keys, accounts for native, potentially native, and exotic species, and indexed bibliography. Olympia, WA: Society for Northwestern Vertebrate Biology. Northwest Fauna 5: 1-138.

Maxson, L.R. 1984. Molecular probes of phylogeny and biogeography in toads of the widespread genus Bufo. Molecular Biology and Evolution 1: 345-356.

*Meis, N.J. 1999. The effects of mining effluent on amphibian breeding behavior and survival. Undergraduate Honors Thesis. Carroll College, Helena, MT. 21 p.

Metter, D.E. 1961. Water levels as an environmental factor in breeding season of Bufo boreas boreas. Copeia 1961(4): 488.

Milius, S. 1999. Killer skin fungus nails boreal toads. Science News 156: 219.

Milius, S. 2000. New frog-killing disease may not be so new. Science News 157: 133.

*Miller, J.D. 1975. Interspecific food relationships of anurans in northwestern Montana and fluoride accumulation in amphibians and reptiles in northwestern Montana. M.S. Thesis, University of Montana, Missoula, MT. $105 \mathrm{p}$.

*Miller, J.D. 1978. Observations on the diets of Rana pretiosa, Rana pipiens, and Bufo boreas from western Montana. Northwest Science 52(3): 243-249.

*Miller, M. 1995. Amphibian survey Birch Creek July 1995. Wildland Studies Project, San Francisco State University, San Francisco, CA. 9 p.

Monello, R.J. and R.G. Wright. 1999. Amphibian habitat preferences among artificial ponds in the Palouse Region of Northern Idaho. Journal of Herpetology 33(2): 298-303.

Moore, J.E. and E.H. Strickland. 1955. Further notes on the food of Alberta amphibians. American Midland Naturalist 52: 221-224.

Morton, M.L., and K.N. Sokolski. 1978. Sympatry in Bufo boreas and Bufo canorus and additional evidence of natural hybridization. Bulletin of the Southern California Academy of Sciences 77: 52-55.

Mullally, D.P. 1952. Habits and minimum temperatures of the toad Bufo boreas halophilus. Copeia 1952(4): 274-276.

Mullally, D.P. 1956. The relationships of the Yosemite and western toads. Herpetologica 12: 133-135.

Mullally, D.P. 1958. Daily period of activity of the western toad. Herpetologica 14: 29-31.

Mullally, D.P., and D.H. Powell. 1958. The Yosemite toad: northern range extension and possible hybridization with the western toad. Herpetologica 14: 31-34. 
Muths, E. 2003. Home range and movements of boreal toads in undisturbed habitat: Copeia 2003: 160-165.

Muths, E. and P.S. Corn. 1997. Basking by adult boreal toads (Bufo boreas boreas) during the breeding season. Journal of Herpetology 31: 426-428.

Muths, E. and P.S. Corn. 2000. Boreal toad In: Endangered animals, a reference guide to conflicting issues. R.P. Reading and B. Miller (eds.) Greenwood Press, Westport CT. Pp. 6065.

Muths, E., P.S. Corn, A.P. Pessier, and D.E. Green. 2003. Evidence for disease-related amphibian decline in Colorado. Biological Conservation 110: 357-365.

Muths, E., P.S. Corn, and T.R. Stanley. 2000. Use of Oxytetracycline in batch-marking postmetamorphic boreal toads. Herpetological Review 31(1): 28-32.

Muths, E., T.L. Johnson, and P.S. Corn. 2001. Experimental repatriation of boreal toad (Bufo boreas) eggs, metamorphs, and adults in Rocky Mountain National Park. Southwestern Naturalist 46(1): 106-113.

*Muths, E., R.E. Jung, L.L. Bailey, M.J. Adams, P.S. Corn, C.K. Dodd, Jr., G.M. Fellers, W.J. Sadinski, C.R. Schwalbe, S.C. Walls, R.N. Fisher, A.L. Gallant, W.A. Battaglin, and D.E. Green. 2005. Amphibian Research and Monitoring Initiative (ARMI): a successful start to a national program in the United States. Applied Herpetology 2:355-371.

Muths, E. and P. Nanjappa. 2005. Bufo boreas. pp. 392-396. In: M.J. Lannoo's Amphibian Declines: the conservation status of United States species. Berkley, CA: University of California Press. 1094 p.

*Muths, E., D.S. Pilliod, and L.J. Livo. 2008. Distribution and environmental limitations of an amphibian pathogen in the Rocky Mountains, USA. Biological Conservation 141:14841492.

Nesler, T.P. and J.P. Goettl. 1994. Boreal toad recovery plan, Colorado Division of Wildlife, Denver, Colorado. 22 pp. plus appendices.

Norman, B.R. 1988. Geographic distribution. Bufo boreas boreas (boreal toad). Herpetological Review 19(1): 16.

*Nussbaun, R., E. Brodie, Jr., and R. Storm. 1983. Amphibians and reptiles of the Pacific Northwest. University of Idaho Press, Moscow, Idaho. 322 .

O'Hara, R.K. 1981. Habitat selection behavior in three species of anuran larvae: environmental cues, ontogeny, and adaptive significance. Ph.D. dissertation, Oregon State University. Corvallis, Oregon. $154 \mathrm{pp}$.

O'Hara, R.K. and A.R. Blaustein. 1982. Kin preference behavior in Bufo boreas tadpoles. Behavioral Ecology and Sociobiology 11: 43-49.

Olson, D.H. 1988. The ecological and behavioral dynamics of breeding in three sympatric anuran amphibians. Ph.D. dissertation. Department of Zoology, Oregon State University, Corvallis, Oregon. $260 \mathrm{pp}$.

Olson, D.H. 1989. Predation on breeding Western toads (Bufo boreas). Copeia 1989(2):391397.

Olson, D.H. 1991. Ecological susceptibility of amphibians to population declines. Proceedings of the Symposium on Biodiversity of Northwestern California, October 28-30: 55-62.

Olson, D.H. 1992. Ecological susceptibility of amphibians to population declines. In: Harris R.R., D.E. Erman (tech. Coordinators) and H.M. Kerner (ed.). Proceedings of symposium on biodiversity of northwestern California. Davis, CA: University of California Wildland Resources Center. Report 29. p. 55-62. 
Olson, D.H., A.R. Blaustein, and R.K. O'Hara. 1986. Mating pattern variability among western toad (Bufo boreas) populations. Oecologia 70: 351-356.

Panik, H.R. and S. Barrett. 1994. Distributions of amphibians and reptiles along the Truckee River System. Northwest Science 68(3):197-204.

*Patla, D.A. 1998a. Amphibians and reptiles in the Old Faithful sewage treatment area. Report to Yellowstone Center for Resources, Yellowstone National Park. 10 September, 1998. Greater Yellowstone Ecosystem Amphibian Survey and Monitoring Program, Herpetology Laboratory, Department of Biological Sciences, Idaho State University, Pocatello, ID. 7 p.

*Patla, D.A. 1998b. Potential effects of native fish restoration projects on amphibians in Yellowstone National Park Part I. 20 November, 1998. Greater Yellowstone Ecosystem Amphibian Survey and Monitoring Program, Herpetology Laboratory, Department of Biological Sciences, Idaho State University, Pocatello, ID. 26 p.

*Patla, D.A. 1999a. Amphibians and reptiles along the grand loop road in Yellowstone National Park: Canyon Junction to Fishing Bridge Junction. December 11, 1999. Greater Yellowstone Ecosystem Amphibian Survey and Monitoring Program, Herpetology Laboratory, Department of Biological Sciences, Idaho State University, Pocatello, ID. 24 p.

*Patla, D.A. 1999b. Amphibians and reptiles of the Madison to Norris road improvement project area, Yellowstone National Park. 11 November, 1999. Greater Yellowstone Ecosystem Amphibian Survey and Monitoring Program, Herpetology Laboratory, Department of Biological Sciences, Idaho State University, Pocatello, ID. 17 p.

*Patla, D.A. 1999c. Amphibians and reptiles, Tower Junction to Canyon Village, Yellowstone National Park; addendum to previous report. 24 November, 1999. Greater Yellowstone Ecosystem Amphibian Survey and Monitoring Program, Herpetology Laboratory, Department of Biological Sciences, Idaho State University, Pocatello, ID. 10 p.

*Patla, D.A. 2000. Amphibians in potential native fish restoration areas, Yellowstone National Park Part II. 7 March, 2000. Greater Yellowstone Ecosystem Amphibian Survey and Monitoring Program, Herpetology Laboratory, Department of Biological Sciences, Idaho State University, Pocatello, ID. 22 p.

*Patla, D.A. 2001. Conservation assessment for the boreal toad (Bufo boreas boreas) on the Bridger-Teton National Forest, Wyoming. 27 March, 2001. Greater Yellowstone Ecosystem Amphibian Survey and Monitoring Program, Herpetology Laboratory, Department of Biological Sciences, Idaho State University, Pocatello, ID. 44 p.

*Patla, D.A. and C.R. Peterson. 1996a. Amphibians and reptiles along the Grand Loop Highway in Yellowstone National Park: Tower Junction to Canyon Village. 24 February, 1996. Greater Yellowstone Ecosystem Amphibian Survey and Monitoring Program, Herpetology Laboratory, Department of Biological Sciences, Idaho State University, Pocatello, ID. 49 p.

*Patla, D.A. and C.R. Peterson. 1996b. Amphibians and reptiles along the Grand Loop Highway in Yellowstone National Park: Arnica Creek to Little Thumb Creek. 1 August, 1996. Greater Yellowstone Ecosystem Amphibian Survey and Monitoring Program, Herpetology Laboratory, Department of Biological Sciences, Idaho State University, Pocatello, ID. 35 p.

*Patla, D.A. and C.R. Peterson. 1997. Amphibians and reptiles along the Grand Loop Highway in Yellowstone National Park: Mammoth Hot Springs to Norris Junction. 1 February, 1997. Greater Yellowstone Ecosystem Amphibian Survey and Monitoring Program, Herpetology Laboratory, Department of Biological Sciences, Idaho State University, Pocatello, ID. 60 p. 
*Patla, D.A. and C.R. Peterson. 1998. Amphibians of the Greater Yellowstone Ecosystem. Natural Resource Conservation Cooperative News 11(Autumn 1998): 10-11.

*Patla, D.A. and C.R. Peterson. 1999. Are amphibians declining in Yellowstone National Park? Yellowstone Science 7(1): 2-11.

*Patla, D.A. and C.R. Peterson. 2001. Status and trends of amphibian populations in the Greater Yellowstone Ecosystem, progress report, February 2001. Greater Yellowstone Ecosystem Amphibian Survey and Monitoring Program, Herpetology Laboratory, Department of Biological Sciences, Idaho State University, Pocatello, ID. 8 p.

Pearl, C.A. 2000. Bufo boreas (western toad) predation. Herpetological Review 31:233-234.

Pearl, C.A.and M.P. Hayes. 2002. Predation by Oregon spotted frogs (Rana pretiosa) on western toads (Bufo boreas) in Oregon. American Midland Naturalist 147(1): 145-152.

*Peterson, C.R., C.J. Askey, and D.A. Patla. 1993. Amphibians and reptiles along the Grand Loop and Fountain Freight Roads between Madison Junction and Biscuit Basin in Yellowstone National Park. 26 July, 1993. Greater Yellowstone Ecosystem Amphibian Survey and Monitoring Program, Herpetology Laboratory, Department of Biological Sciences, Idaho State University, Pocatello, ID. 45 p.

*Peterson, C.R., D.A. Patla, and S.R. Sullivan. 1995. Amphibians and reptiles along the Grand Loop Highway in Yellowstone National Park: Madison Junction to Norris Campground. 7 July, 1995. Greater Yellowstone Ecosystem Amphibian Survey and Monitoring Program, Herpetology Laboratory, Department of Biological Sciences, Idaho State University, Pocatello, ID. 64 p.

*Peterson, C.R., E.D. Koch and P.S. Corn. 1992. Monitoring amphibian populations in Yellowstone and Grand Teton National Parks final report to University of Wyoming. National Park Service Research Center, Laramie, WY. 37 p.

Peterson, J.A. and A.R. Blaustein. 1991. Unpalatability in anuran larvae as a defense against natural salamander predators. Ethology, Ecology and Evolution 3: 63-72.

Pimentel, R.A. 1955. Habitat distribution and movements of Bufo b. boreas, Baird and Girard. Herpetologica 11: 72.

Porter, K.R. and D.E. Hakanson. 1976. Toxicity of mine drainage to embryonic and larval boreal toads (Bufonidae: Bufo boreas). Copeia 1976: 327-331.

*Powell, R., J.T. Collins, and E.D. Hooper, Jr. 1998. A key to amphibians and reptiles of the Continental United States and Canada. University Press of Kansas, Lawrence, KS. 131 p.

Putnam, R.W. 1979. The basis for differences in lactic acid content after activity in different species of anuran amphibians. Physiological Zoology 52(4): 509-519.

Putnam, R.W. and A.F. Bennett. 1981. Thermal dependence of behavioural performance of anuran amphibians. Animal Behaviour 29(2): 502-509.

Putnam, R.W. and S.S. Hillman. 1977. Activity responses of anurans to dehydration. Copeia 1977(4): 746-749.

*Rauscher, R.L. 2000. Tiger salamander axolotls in southwest Montana, final report. Bozeman, MT: Montana Department of Fish, Wildlife and Parks. 28p.

*Reichel, J.D. 1995. Preliminary amphibian and reptile survey of the Lewis and Clark National Forest: 1994. Montana Natural Heritage Program, Helena, MT. 92 p.

*Reichel, J.D. 1996. Preliminary amphibian and reptile survey of the Helena National Forest: 1995. Montana Natural Heritage Program, Helena, MT. 87 p.

*Reichel, J.D. 1997a. Amphibian, reptile and northern bog lemming survey on the Rocky Mountain Front: 1996. Montana Natural Heritage Program, Helena, MT. 81 p. 
*Reichel, J.D. 1997b. Animal species of special concern in Montana. Montana Natural Heritage Program. Helena, MT. 9 p.

*Reichel, J.D. and D.L. Flath. 1995. Identification guide to the amphibians and reptiles of Montana. Montana Outdoors 26(3): 15-34.

*Reinhard, E.G. 1930. Miscellaneous note on Bufo boreas. Yellowstone Nature Notes 7(7): 46.

Robinson, M., M.P. Donovan, and T.D. Schwaner. 1998. Western toad (Bufo boreas) in southern Utah: notes on a single population along the east fork of the Sevier River. Great Basin Naturalist 58(1): 87-89.

*Rodgers, T.L., and W.L. Jellison. 1942. A collection of amphibians and reptiles from western Montana. Copeia 1942(1): 10-13.

*Roedel, M.D. and P. Hendricks. 1998a. Amphibian and reptile survey on the Bureau of Land Management Lewistown District: 1995-1998. Montana Natural Heritage Program, Helena, MT. $53 \mathrm{p}$.

*Roedel, M.D. and P. Hendricks. 1998b. Amphibian and reptile inventory on the Headwaters and Dillon Resource Areas in conjunction with Red Rocks Lakes National Wildlife Refuge: 1996-1998. Montana Natural Heritage Program, Helena, MT. 46 p.

Rogers, K., A. Schmidt, J. Wilkinson, and T. Merz. 2001. Effects of incidental UV-B radiation on periphyton in four alpine freshwater ecosystems in central Colorado: impacts on boreal toad tadpoles (Bufo boreas). Journal of Freshwater Ecology 16: 283-301.

Rogers, M.W., Jr. 1975. Development and behavior of larvae of the western toad (Bufo boreas). M.A. Thesis. Arlington, TX: University of Texas. 68p.

Ross, D.A., T.C. Esque, R.A. Fridell, and P. Hovingh. 1995. Historical distribution, current status, and a range extension of Bufo boreas in Utah. Herpetological Review 26(4): 187-189.

Russell, A.P., and A.M. Bauer. 2000. The amphibians and reptiles of Alberta. Second Edition. Calgary, AB: University of Calgary Press. 279 p.

Samollow, P.B. 1980. Selective mortality and reproduction in a natural population of Bufo boreas. Evolution 34(1): 18-39.

Savage, J.M. and F.W. Schuierer. 1981. The eggs of toads of the Bufo boreas group, with descriptions of the eggs of Bufo exsul and Bufo nelsoni. Bulletin of the Southern California Academy of Science 60: 93-99.

Scherff-Norris, K.L. 1997. Hatchery manual for the rearing and propagation of captive boreal toads (Bufo boreas). Colorado Department of Natural Resources, Colorado Division of Wildlife, Denver.

Scherff-Norris, K.L. 1999. Final Report: experimental reintroduction of boreal toads (Bufo boreas boreas). Colorado Division of Wildlife. 32pp.

*Schmetterling, D.A. and M.K. Young. 2008. Summer movements of boreal toads (Bufo boreas boreas) in two western Montana basins. Journal of Herpetology 42:111-123.

Schonberger, C.F. 1945. Food of some amphibians and reptiles of Oregon and Washington. Copeia 1945: 120-121.

Schueler, F.W. 1982. Sexual colour differences in Canadian western toads, Bufo boreas. Canadian Field Naturalist 96(3): 329-332.

Schuierer, F.W. 1962. Notes on two populations of Bufo exsul Myers and a commentary on speciation within the Bufo boreas group. Herpetologica 18(4): 262-267.

*Sestrich, C. 2004. Hebgen Reservoir amphibian survey. USDA Forest Service Annual Progress Report to PPL Montana. 22p. 
*Sestrich, C. 2007. 2006 Hebgen Reservoir amphibian survey. USDA Forest Service Annual Report to PPL Montana. West Yellowstone, MT: Gallatin National Forest, Hebgen Lake Ranger District. 75 p.

Shinn, E.A. and J.W. Dole. 1979a. Evidence for a role for olfactory cues in the feeding response of western toads (Bufo boreas). Copeia 1979(1): 1663-165.

Shinn, E.A. and J.W. Dole. 1979b. Lipid components of prey odors elicit feeding responses in western toads (Bufo boreas). Copeia 1979(2): 275-278.

Sivula, J.C., M.C. Mix, and D.S. McKenzie. 1972. Oxygen consumption of Bufo boreas boreas tadpoles during various developmental stages of metamorphosis. Herpetologica 28(4): 309313.

*Skinner, M.P. 1924. The Yellowstone Nature Book. A.C. McClurg Company, Chicago, IL. $221 \mathrm{p}$.

Smits, A.W. 1984. Activity patterns and thermal biology of the toad Bufo boreas halophilus. Copeia 198493): 689-696.

Smits, A.W. and D.L Crawford. 1984. Emergence of toads to activity: a statistical analysis of contributing cues. Copeia 1984(3): 696-701.

Sornborger, M.B. 1979. Population dynamics of the western toad, Bufo boreas halophilus, at Hidden Lake, Mt. San Jacinto State Park. Masters Thesis, California State Polytechnic University, Pomona, California. 77 pp.

*Stebbins, R.C. 2003. A field guide to western reptiles and amphibians. 3rd edition. New York, NY: Houghton Mifflin Co. 533 p.

Stebbins, R.C. and N.W. Cohen. 1995. A natural history of amphibians. Princeton University Press, Princeton, NJ. 316 p.

Stiverson, R.K. and G.C. Packard. 1974. The relation of blood hemoglobin concentration to body size in the boreal toad Bufo boreas. Journal of the Colorado-Wyoming Academy of Science 7(5): 77.

Stoyke, G. 1994. How to attract toads. Alberta Naturalist 24(1): 5.

Stuart, J.N. and C.W. Painter. 1994. A review of the distribution and status of the boreal toad (Bufo boreas boreas) in New Mexico. Bulletin of the Chicago Herpetological Society 29 (6):113-116.

Sullivan, S.R. 1996. Daily activity patterns of western toads (Bufo boreas) on the Targhee National Forest, Idaho. Honors Thesis, Carroll College, Helena, Montana.

*Sullivan, S.R. and C.R. Peterson. 1996. Amphibians and reptiles along the highway in Yellowstone National Park: Tower Junction to the Northeast Entrance. 25 February, 1996. Greater Yellowstone Ecosystem Amphibian Survey and Monitoring Program, Herpetology Laboratory, Department of Biological Sciences, Idaho State University, Pocatello, ID. 60 p.

Sullivan, S.R., P. Bartelt, and C. Peterson. 1996. Daily activity patterns of Western toads on the Targhee National Forest, Idaho. Intermountain Journal of Sciences 2(2): 61-62.

*Syslo, J. and L. Eby. 2005. Possible effects of Highway 93 expansion on a population of Western toads (Bufo boreas) in the Bitterroot Valley. Wildlife Biology Program University of Montana. pp. 11 plus figures.

Taylor, C.N., K.L. Oseen, and R.J. Wassersug. 2004. On the behavioral response of Rana and Bufo tadpoles to echinostomatoid cercariae: implications to synergistic factors influencing trematode infections in anurans. Canadian Journal of Zoology 82:701-706. 
Thompson, M.D. and A.P. Russell. 2000. Phylogeography of Ambystoma macrodactylum: post glacial range expansion and resultant genetic diversity. Field Summary Report No. 1. University of Calgary. Calgary, Canada. $39 \mathrm{p}$.

*Thompson, L.S. 1984. Distribution of Montana amphibians, reptiles, and mammals; first update. 1 May, 1984. Montana Audobon Council, Helena, MT. 2 p.

Thompson, P.D. 2004. Observations of boreal toad (Bufo boreas) breeding populations in northwestern Utah. Herpetological Review 35(4):342-344.

Thompson, P.D., R.A. Fridell, K.K. Wheeler, and C.L. Bailey. 2004. Distribution of Bufo boreas in Utah. Herpetological Review 35(3):255-257.

Tiekotter, K.L. 1977. A study of trematodes collected from toads of a Colorado alpine meadow. Proceedings of the Nebraska Academy of Science and Afiliated Societies 87:22.

*Timken, R. No Date. Amphibians and reptiles of the Beaverhead National Forest. Western Montana College, Dillon, MT. 16 p.

Tracy, C.R. 1971. Evidence for the use of celestial cues by dispersing immature California toads (Bufo boreas). Copeia 1971(1): 145-147.

Tracy, C.R. and J.W. Dole. 1969a. Evidence of celestial orientation by California toads (Bufo boreas) during breeding migration. Bulletin of Southern California Academy of Science 68(1): 10-18.

Tracy, C.R. and J.W. Dole. 1969b. Orientation of displaced California toads (Bufo boreas) to their breeding sites. Copeia 1969(40): 693-700.

*Turner, F.B. 1951. A checklist of the reptiles and amphibians of Yellowstone National Park with incidental notes. Yellowstone Nature Notes 25(3): 25-29.

*Turner, F.B. 1952. Peculiar aggregations of toadlets on Alum Creek. Yellowstone Nature Notes 26(5): 57-58.

*Turner, F.B. 1955. Reptiles and amphibians of Yellowstone National Park. Yellowstone Interpretive Series No. 5. Yellowstone Library and Museum Association. Yellowstone National Park, WY. 40 p.

*Turner, F.B. 1957. The ecology and morphology of Rana pretiosa pretiosa in Yellowstone Park, Wyoming. Ph.D. Dissertation, University of California, Berkeley, CA. 252 p.

*Turner, F.B. 1960. Population structure and dynamics of the western spotted frog, Rana $p$. pretiosa Baird and Girard, in Yellowstone Park, Wyoming. Ecological Monographs 30(3): 251-278.

*Tverdy, L. 2001. An analysis of the genotoxicity of mining effluent in toad tadpoles (Bufo boreas). Undergraduate Honors Thesis. Carroll College, Helena, MT. 21 p.

Tverdy, L.M., N.J. Meis, C.G. Wicher, and D.G. Hokit. 2005. Comet assay used to detect genotoxic effects of mining sediments in Western Toad tadpoles (Bufo boreas). Herpetological Review 36(2):152-155.

*[USDAFS] USDA Forest Service. 1999. Update of U.S. Forest Service Northern Region Sensitive Species list. 12 March, 1999. Region 1 U.S. Forest Service Supervisors Office, Missoula, MT. 20 p.

USDI Fish and Wildlife Service. 1994. Endangered and threatened wildlife and plants: 90 day finding and commencement of status review to petition listing of southern Rocky Mountain population of boreal toads as Endangered. Federal Register 59: 37439-37441.

*Van Denburgh, J. 1895. Annotated list of reptiles and batrachians. In: C.H. Gilbert and B.W. Evermann. A report upon investigations in the Columbia River Basin, with descriptions of four new species of fishes. Bulletin of United States Fish Commission 14(1894): 206-207. 
*Van Kirk, R., L. Benjamin, and D. Patla. 2000. Riparian area assessment and amphibian status in the watersheds of the Greater Yellowstone Ecosystem. Greater Yellowstone Coalition, Bozeman, MT. $102 \mathrm{p}$.

Vertucci, F.A. and P.S. Corn. 1996. Evaluation of episodic acidification and amphibian declines in the Rocky Mountains. Ecological Applications 6(2): 449-457.

*Vitt, L.J., J.P. Caldwell, and D.B. Shepard. 2005. Inventory of amphibians and reptiles in the Billings Field Office Region, Montana. Sam Noble Oklahoma Museum of Natural History and Department of Zoology, University of Oklahoma, Norman, OK. 33 p.

Waldman, B. 1986. Chemical ecology of kin recognition in anuran amphibians. Proceedings of an International Conference on Chemical Signals in Vertebrates 4: 225-242.

Walton, B.M., C.C. Peterson and A.F. Bennett. 1994. Is walking costly for anurans? The energetic cost of walking in the northern toad Bufo boreas halophilus. Journal of Experimental Biology 197: 165-178.

*Weisel, G.F. 1952. Animal names, anatomical terms, and some ethnozoology of the Flathead Indians. Journal of the Washington Academy of Sciences 42(11): 345-355.

*Werner, J.K., B.A. Maxell, P. Hendricks, and D. Flath. 2004. Amphibians and reptiles of Montana. Missoula, MT: Mountain Press Publishing Company. 262p.

*Werner, J.K. and J.D. Reichel. 1994. Amphibian and reptile survey of the Kootenai National Forest: 1994. Montana Natural Heritage Program, Helena, MT. 104 p.

*Werner, J.K. and J.D. Reichel. 1996. Amphibian and reptile monitoring/survey of the Kootenai National Forest: 1995. Montana Natural Heritage Program, Helena, MT. 115 p.

*Werner, J.K. and T. Plummer. 1994. Amphibian and reptile survey of the Flathead Indian Reservation 1993-1994. Salish Kootenai College, Pablo, MT. 55 p.

*Werner, J.K. and T. Plummer. 1995. Amphibian monitoring program on the Flathead Indian Reservation 1995. Salish Kootenai College, Pablo, MT. 46 p.

*Werner, J.K., T. Plummer, and J. Weaselhead. 1998a. Amphibians and reptiles of the Flathead Indian Reservation. Intermountain Journal of Sciences 4(1-2): 33-49.

*Werner, J.K., T. Plummer, and J. Weaselhead. 1998b. The status of amphibians on the Flathead Reservation, Montana. Intermountain Journal of Sciences 4(3-4): 88.

*Wicher, C.G. 2000. The effects of mining effluent on amphibian survivorship. Undergraduate Honors Thesis. Carroll College, Helena, MT. 18 p.

Wiedmer, M. and R.P. Hodge. 1996. Bufo boreas (western toad). Herpetological Review 27(3): 148.

Woodward, B. and S. Mitchell. 1985. The distribution of Bufo boreas in New Mexico. Report to New Mexico Department of Game and Fish, Contract \# 519-73-01. 25pp.

Worrest, R.C. and D.J. Kimeldorf. 1975. Photoreactivation of potentially lethal, UV-induced damage to boreal toad (Bufo boreas boreas) tadpoles. Life Science 17: 1545-1550.

Worrest, R.C. and D.J. Kimeldorf. 1976. Distortions in amphibian development induced by UV B enhancement 290-315 nanometers of simulated solar spectrum, Photochemistry and Photobiology 24: 377-382.

*[WWPC] Washington Water Power Company. 1995. 1994 wildlife report Noxon Rapids and Cabinet Gorge Reservoirs. Washington Water Power Company. Spokane, WA.

*Young, M.K. and D.A. Schmetterling. 2009. Age-related season variation in captures of stream-borne boreal toads (Bufo boreas boreas, Bufonidae) in western Montana. Copeia 2009:117-124. 
*Zisook, R., K. Almond, and B. Sharpe. 1996. Amphibian survey of the Birch Creek drainage, Beaverhead County. Wildland Studies Project. San Francisco State University, San Francisco, CA. 9 p. 


\section{Great Plains Toad (Bufo cognatus)}

Up-to-date distribution and status information can be found on the Montana Natural Heritage Program's TRACKER website at http://mtnhp.org

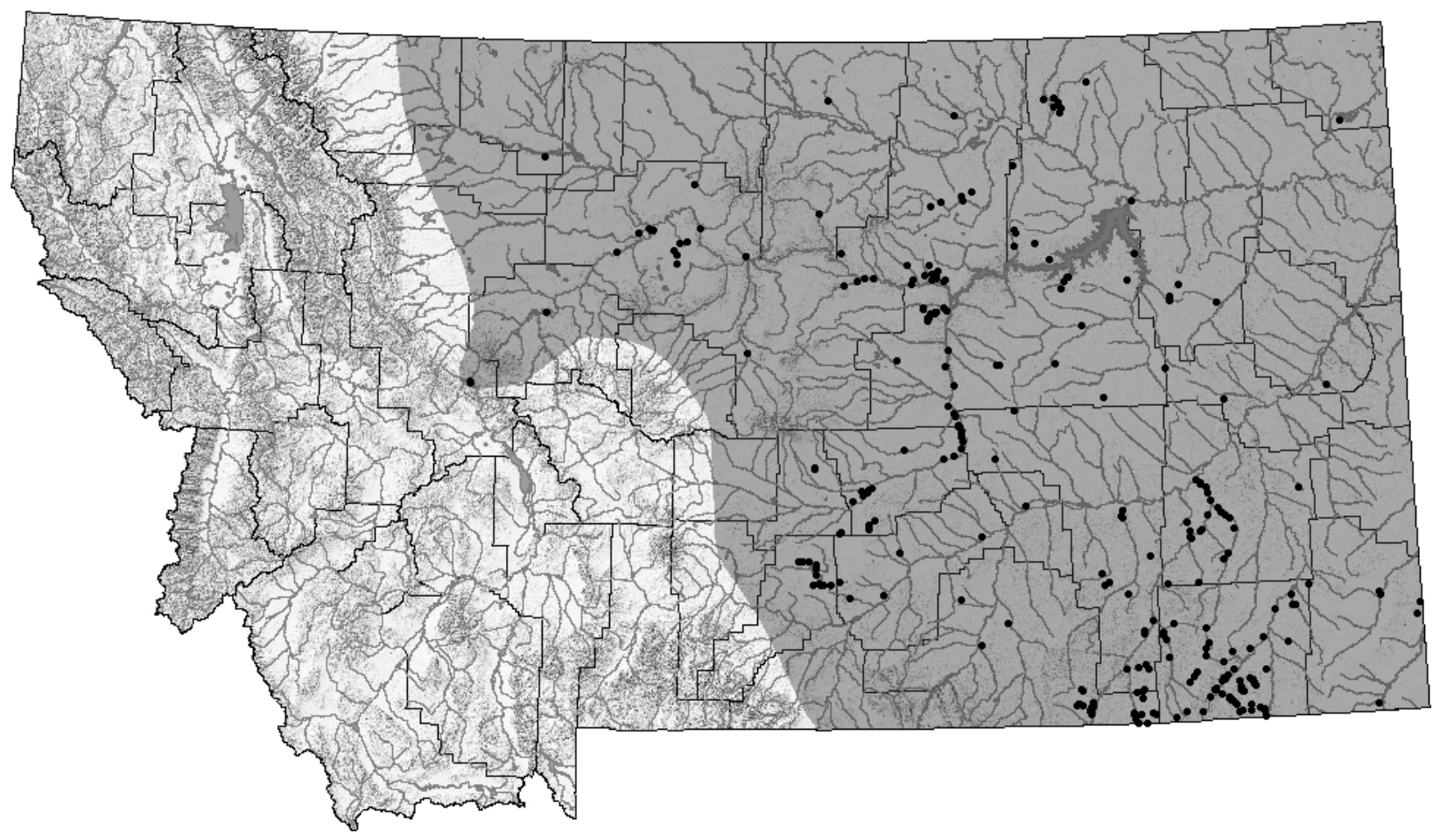

Distribution/Taxonomy

The Great Plains toad is recognized as a distinct species that ranges across the Great Plains from central Mexico to southeastern Alberta and in the desert southwest as far west as eastern California and as far north as southern Utah at elevations up to 2,440 M (8,000 ft) (Stebbins 2003; Goebel 1996). In Montana they have been sparsely documented across the plains east of Shelby, Great Falls, Lewiston, and Billings.

Maximum Elevation

$1,300 \mathrm{~m}(4,265 \mathrm{ft}) 6.8 \mathrm{~km}$ southeast of Wallop Butte in southwest Powder River County (Chris Hays and David Herasimtschuk; MTNHP 2008).

\section{Identification}

Eggs:

Laid communally in single or more rarely double strings containing 1,342 to 45,054 eggs (Bragg 1937a: Krupa 1994). Each ovum is black above, shaded progressively lighter to white below, and surrounded by two jelly layers, including the outer jelly layer that composes the string (Bragg 1937a). Ovum diameters are approximately $1.2 \mathrm{~mm}$, but total egg diameters, including the two jelly layers are approximately $2.0 \mathrm{~mm}$; jelly string widths between eggs are approximately $1.7 \mathrm{~mm}$ (Bragg 1937a).

\section{Larvae:}

Mottled brown and gray dorsally and with a light greenish-yellow and reddish iridescence ventrally (Bragg 1936). The dorsal tail fin is dendritically pigmented and highly arched while 
the ventral tail fin is of uniform width and transparent (Bragg 1936). TL of 8-29 mm (Bragg 1936; Bragg 1940)

Juveniles and Adults:

With the exception of small metamorphs a large bony plate or shield covers the snout from the tip of the snout to the front of the eyes. Also with the exception of small metamorphs cranial crests are present behind the eyes and also converge toward the shield on the snout to form a "V" shape between the eyes (Krupa 1990). Large parotid glands are present behind the eyes. The hind feet each have two dark digging "spades" on their soles. A white stripe usually extends down the center of the back and large paired green to brown blotches are present dorsally and are outlined or separated by white bands (Krupa 1990). Cream to white colored ventrally (Krupa 1990). SVL of 11-115 mm (Bragg 1937b; Bragg 1940; Krupa 1990).

Similar Species:

The geographic range of western toads does not overlap with the geographic range of Great Plains toads and adult western toads lack cranial crests. If present in Montana Canadian toads are probably limited to the extreme northeast corner of the state and adult Canadian toads either lack or have weakly developed cranial crests behind the eyes. Although overlap in habitat use exists Woodhouse's toads seem to be more commonly associated with sandy soils on floodplains while the Great plains toad is more commonly associated with heavier soils in upland habitats (Timken and Dunlap 1965). Adult Woodhouse's toads lack the shield on the tip of the snout and have "L" shaped cranial crests between and in back of each eye. Metamorph Woodhouse's toads lack the large paired dorsal blotches that are present on Great Plains Toads (Bragg 1937b). Eggs and larvae of Woodhouse's toads and Great Plains toads are very similar and may not be differentiable by even thoroughly trained herpetologists. However eggs and larvae of Woodhouse's toads are much more likely to be found in permanent or semi-permanent waters than those of Great Plains toads (Bragg 1940).

Habitat Use/Natural History

Found in floodplain habitats, but more common in upland grasslands with harder packed soils (Bragg 1940; Smith and Bragg 1949; Timken and Dunlap 1965). Adults lie dormant in rodent or self-excavated burrows when terrestrial conditions are not favorable, but emerge during warmer and moister periods to feed on a variety of terrestrial invertebrates (Bragg 1937a; Smith and Bragg 1949; Dimmitt and Ruibal 1980; Flowers and Graves 1994, 1995). Breeding takes place in clear shallow temporary pools almost exclusively after heavy late spring and summer rains when minimum temperatures are above 12 degrees Celsius (Bragg 1937a; Bragg 1940; Krupa 1994). Eggs are wrapped around vegetation on the pond bottom and hatch in 2-3 days (Bragg 1937a; Bragg 1940). Tadpoles metamorphose in 18 to 45 days (Bragg 1937b; Bragg 1940; Krupa 1994). Tadpoles are herbivorous and detritivorous (Bragg 1940). Creusere and Whitford (1976) found individuals 1,600 meters from the nearest breeding site, but is likely that they range farther than this. Population explosions and mass unidirectional migrations have been reported for local areas as well as regions as large as several thousand square miles in area (Bragg and Brooks 1958).

Status and Conservation

In the past 150 years Great Plains toads have only been documented at about 30 localities across 
the plains east of the Rocky Mountains and at the present time their status across this region is almost completely unknown. Risk factors relevant to the viability of populations of this species are likely to include grazing, use of pesticides and herbicides, nonindigenous species, road and trail development, on- and off-road vehicle use, development of water impoundments, habitat loss/fragmentation, and metapopulation impacts, all as described above. However, the lack of information on the distribution, status, habitat use, and basic biology of the species may currently represent the greatest risk to the viability of the species (i.e., the species could have undergone, or currently be undergoing, drastic declines but we lack any kind of baseline information that would allow us to make such a determination). Individual studies that specifically identify risk factors or other issues relevant to the conservation of Great Plains toads include the following. (1) Bragg (1937a) reports that all Great Plains toad eggs in pools that were heavily contaminated with fecal material from cattle died while other eggs in nearby uncontaminated pools survived. (2) Several authors report that large numbers are killed on highways by motor vehicles (Bragg 1940; Bragg and Brooks 1958; Hammerson 1999). Bragg and Brooks (1958) report a mean of 60 individuals per 30 linear feet of highway were killed on roads in North Dakota and Minnesota during a population explosion and mass migration event. (3) Hammerson (1999) notes that several populations have been extirpated due to residential and commercial development in Colorado. (4) Stuart (1995) found exotic bullfrogs preying on Great Plains toads. (5) Great Plains toads often occupyp prairie dog burrows and these burrows may serve as critical refugia for the species (Craig Knowles, Fauna West Wildlife Consultants, pers. comm.).

\section{$\underline{\text { Research and Management Suggestions }}$}

1. See research and management suggestions under all of the general risk factors described above with the exception of timber harvest, fire and fire management activities, and harvest and commerce.

2. More thorough documentation of their presence is needed across their entire range in the state.

3. Because morphologic characters have proved to be of little use, genetic tools should be developed to differentiate between tadpoles of B. cognatus and B. woodhousii.

4. Studies of their habitat use and population dynamics relative to prairie dog towns and grazing and dry and irrigated agricultural activities may be essential to their long term viability.

5. Until the lethal and sublethal impacts of commonly used fertilizers, herbicides, and pesticides on all amphibian life history stages present in an area are examined they should not be applied within 100 meters of waterbodies or wetlands.

6. Where populations are found to be in close proximity to areas of high human use the population impacts of vehicle use near known breeding or burrowing sites should be examined. If impacts are heavy or poorly understood then vehicle use should be curtailed or limited during major periods of activity (e.g., during breeding migrations/choruses or metamorphosis and dispersal).

Bibliography *indicates an article with information specific to Montana

Armentrout, D. and F.L. Rose. 1971. Some physiological responses to anoxia in the Great Plains toad (Bufo cognatus). Comparative Biochemistry and Physiology 38A(1): 447-455. Baxter, G.T. and M.D. Stone. 1985. Amphibians and reptiles of Wyoming. Second Edition. Wyoming Game and Fish Department. 137 p. 
Bieniak, A., and R. Watka. 1962. Vascularization of respiratory surfaces in Bufo cognatus Say and Bufo compactilis Wiegmann. Academy of Poland Science Services Science and Biology Bulletin 10: 9-12.

*Black, J.H. 1967. Toads of Montana. Montana Wildlife 1967(Spring): 22-28.

*Black, J.H. 1970. Some aspects of the distribution, natural history and zoogeography of the toad genus Bufo in Montana. M.S. Thesis. University of Montana, Missoula, MT. 70 p.

*Black, J.H. 1971. The toad genus Bufo in Montana. Northwest Science 45: 156-162.

Boundy, J. 1992. Bufo cognatus (Great Plains toad). Herpetological Review 23(4) 122.

Bragg, A.N. 1936. Notes on the breeding habits, eggs and embryos of Bufo cognatus with a description of the tadpole. Copeia 1936: 14-20.

Bragg, A.N. 1937a. A note on the metamorphosis of the tadpoles of Bufo cognatus. Copeia 1937: 227-228.

*Bragg, A.N. 1937b. Observations on Bufo cognatus with special references to breeding habits and eggs. American Midland Naturalist 18: 273-284.

Bragg, A.N. 1938. Observations on the natural history of Bufo cognatus Say. Proceedings of the Oklahoma Academy of Science 19: 41-42.

Bragg, A.N. 1939. Possible hybridization of Bufo cognatus and B. w. woodhousii. Copeia 1939(3): 173.

*Bragg, A.N. 1940. Observations on the ecology and natural history of Anura. I. Habits, habitat and breeding of Bufo cognatus Say. American Naturalist 74: 322-349, 424-438.

Bragg, A.N. 1950. Size range in adults of the toad Bufo cognatus. Copeia 1950(2): 153-154.

Bragg, A.N. 1958. A melanistic tendency in the Great Plains toad (Bufo cognatus). Southwest Naturalist 3(1-4): 229-230.

Bragg, A.N. and A.O. Weese. 1950. Observations on the ecology and natural history of Anura. XIV. Growth rates and age at sexual maturity of Bufo cognatus under natural conditions in central Oklahoma, p. 47-58. In researches on the amphibians of Oklahoma. University of Oklahoma Press, Norman, OK. 154 p.

Bragg, A.N. and C.C. Smith. 1942. Observations on the ecology and natural history of Anura. IX. Notes on breeding behavior in Oklahoma. Great Basin Naturalist 3: 33-50.

Bragg, A.N. and J. Bresler. 1950. Viability of the eggs of Bufo cognatus. Proceedings of the Oklahoma Academy of Science 32: 13-14.

Bragg, A.N. and M. Brooks. 1958. Social behavior in juveniles of Bufo cognatus Say. Herpetologica 14: 141-147.

Brown, L.E. and M.A. Ewert. 1971. A natural hybrid between the toads Bufo hemiophrys and Bufo cognatus in Minnesota. Journal of Herpetology 5(1): 78-82.

Brown, L.E. and J.R. Pierce. 1967. Male-male interactions and chorusing intensities of the Great Plains toad, Bufo cognatus. Copeia 1967(1): 149-154.

*Brunson, R.B. 1955. Check list of the amphibians and reptiles of Montana. Proceedings of the Montana Academy of Sciences 15: 27-29.

*Conant, R. and J.T. Collins. 1998. A field guide to reptiles and amphibians of eastern and central North America. $3^{\text {rd }}$ edition, expanded. New York, NY: Houghton Mifflin Co. 616 p.

*Cooper, S.V., C. Jean, and P. Hendricks. 2001. Biological survey of a prairie landscape in Montana's glaciated plains. Report to the Bureau of Land Management. Montana Natural Heritage Program, Helena, MT. 24 pp. plus appendices.

*Cope, E.D. 1879. A contribution to the zoology of Montana. American Naturalist 13(7): 432441. 
*Cope, E.D. 1889. The Batrachia of North America. Bulletin of the U.S. National Museum 34: $1-525$, figs. 1-119, pls. 1-86.

Cornejo, D.O. 1986. Larval community structure in four species of non-riparian Sonoran Desert anurans. M.S. Thesis, University of Arizona. $176 \mathrm{p}$.

Creusere, F.M. and W.G. Whitford. 1976. Ecological relationships in a desert anuran community. Herpetologica 32: 7-18.

Dimmitt, M.A. and R. Ruibal. 1980. Exploitation of food resources by spadefoot toads (Scaphiopus). Copeia 1980(4): 854-862.

*Dood, A.R. 1980. Terry Badlands nongame survey and inventory final report. Montana Department of Fish, Wildlife, and Parks and Bureau of Land Management, Helena, MT. 70 p.

Ewert, M.A. 1969. Seasonal movements of the toads Bufo americanus and Bufo cognatus in northwestern Minnesota. Ph.D. dissertation. University of Minnesota. 193 pp.

Flath, D.L. 2002. Reptile and amphibian surveys in the Madison-Missouri River Corridor, Montana. Annual Progress Report. 14pp.

Flowers, M.A. and B.M. Graves. 1994. Feeding ecology of juvenile great plains toad (Bufo cognatus) and woodhouse's toad (Bufo woudhousii). North Dakota Academy of Science Proceedings. 48: 22

Flowers, M.A. and B.M. Graves. 1995. Prey selectivity and size-specific diet changes in Bufo cognatus and Bufo woudhousii during early postmetamorphic ontogeny. Journal of Herpetology 29(4): 608-612.

Flowers, M.A. and B.M. Graves. 1997. Juvenile toads avoid chemical cues from snake predators. Animal Behaviour 53(3): 641-646.

Gates, M.T. 2005. Amphibian and reptile baseline survey: CX field study area. Report to Billings and Miles City Field Offices of Bureau of Land Management. Maxim Technologies, Billings, MT. 28pp + Appendices.

*Goebel, A.M. 1996. Systematics and conservation of bufonids in North America and in the Bufo boreas species group. Ph.D. Dissertation. University of Colorado, Boulder, CO. 274 p.

Goldberg, S.R. and C.R. Bursey. 1991. Helminths of three toads, Bufo alvarius, Bufo cognatus (Bufonidae), and Scaphiopus couchii (Pelobatidae), from southern Arizona (USA). Journal of the Helminthological Society of Washington 58(1): 142-146.

Goldberg, S.R., C.R. Bursey and I. Ramos. 1995. The component parasite community of three sympatric toad species, Bufo cognatus, Bufo debilis (Bufonidae), and Spea multiplicata (Pelobatidae) from New Mexico. Journal of the Helminthological Society of Washington 62(1): $57-61$.

Graves, B.M., C.H. Summers, and K.L. Olmstead. 1993. Sensory mediation of aggregation among postmetamorphic Bufo cognatus. Journal of Herpetology 27(3) 315-319.

Gray, M.J., D.L. Miller, and L.M. Smith. 2005. Coelomic response and signal range of implant transmitters in Bufo cognatus. Herpetological Review 36(3):285-288.

*Hart, M.M., W.A. Williams, P.C. Thornton, K.P. McLaughlin, C.M. Tobalske, B.A. Maxell, D.P. Hendricks, C.R. Peterson, and R.L. Redmond. 1998. Montana atlas of terrestrial vertebrates. Montana Cooperative Wildlife Research Unit, University of Montana, Missoula, MT. $1302 \mathrm{p}$.

Harvey, L.A. 1992. A skeletochronologic analysis of a high altitude population of Bufo cognatus. Bios 62(3/4): 232. 
Hayden, F.V. 1863. On the geology and natural history of the upper Missouri. Transactions of the American Philosophical Society New Series 12(1): 1-218 (pages 177-178).

*Hendricks, P. 1999. Amphibian and reptile survey of the Bureau of Land Management Miles City District, Montana. Montana Natural Heritage Program, Helena, MT. 80 p.

*Hendricks, P. and J.D. Reichel. 1996. Preliminary amphibian and reptile survey of the Ashland District, Custer National Forest: 1995. Montana Natural Heritage Program, Helena, MT. $79 \mathrm{p}$.

*Hendricks, P. and J.D. Reichel. 1998. Amphibian and reptile survey on Montana refuges: 1996. Montana Natural Heritage Program, Helena, MT. 19 p.

Holycross, A.T. and K.B. Malmos. 1992a. Bufo cognatus (Great Plains toad). Herpetological Review 23(1) 1992: 24.

Hossack, B.R., P.S. Corn, and D.S. Pilliod. 2005. Lack of significant changes in the herpetofauna of Theodore Roosevelt National Park, North Dakota, since the 1920s. American Midland Naturalist 154:423-432.

Jense, G.K. and R.L. Linder. 1970. Food habits of badgers in eastern South Dakota. Proceedings of the South Dakota Academy of Science 49: 37-41.

Johnson, K.H., G.L. Kurz, R.A. Olson and T.D. Whitson. 1994. Bufo cognatus (Great Plains toad). Herpetological Review 25(2): 74.

Johnson, W.E. and C.R. Propper. 1993. Effects of temperature and dehydration on feeding behavior of the Great Plains toad, Bufo cognatus. American Zoologist 33(5): 86A.

Kilgore, D.L., Jr. 1969. An ecological study of the swift fox (Vulpes velox) in the Oklahoma panhandle. American Midland Naturalist 83(2): 512-534.

Killebrew, F.C., K.B. Blair, H.M. Smith and D. Chiszar. 1995. Bufo cognatus (Great Plains toad). Herpetological Review 26(3): 151.

Krupa, J.J. 1986. Multiple egg clutch production in the Great Plains toad. Prairie Naturalist 18: 151-152.

Krupa, J.J. 1988a. Fertilization efficiency in the Great Plains toad (Bufo cognatus). Copeia 1988(3) 800-802.

Krupa, J.J. 1988b. Mate choice and mate location tactics in the Great Plains toad (Bufo cognatus). Ph.D. Dissertation, University of Oklahoma. $102 \mathrm{p}$.

Krupa, J.J. 1989. Alternative mating tactics in the Great Plains toad. Animal Behaviour 37(6): 1035-1043.

Krupa, J.J. 1990a. Advertisement call variation in the Great Plains toad. Copeia 1990: 884-886.

*Krupa, J.J. 1990b. Bufo cognatus Say. Great Plains Toad. Catalogue of American Amphibians and Reptiles 457.1-457.8.

Krupa, J.J. 1990c. Factors influencing advertisement calls of the Great Plains toad. Copeia (in press).

Krupa, J.J. 1994. Breeding biology of the Great Plains toad in Oklahoma. Journal of Herpetology 28: 217-224.

Krupa, J.J. 1995b. How likely is male mate choice among anurans? Behaviour 132(9-10): 643664.

Livo, L.J. 1990. Bufo cognatus (Great Plains toad). Microhabitat selection. Herpetological Review 21(3): 58.

Logier, E.B.S. 1931. Bufo cognatus cognatus from Alberta. Canadian Field Naturalist 45: 90.

Long, D.R. 1987. Reproductive and lipid patterns of a semiarid-adapted anuran, Bufo cognatus. Texas Journal of Science 39(1): 3-14. 
Mackay, W.P., S.J. Loring, T.M. Frost and W.G. Whitford. 1990. Population dynamics of a playa community in the Chihuahuan desert (New Mexico, USA). Southwestern Naturalist 35(4): 393-402.

*Martin, P.R. 1980. Terrestrial wildlife inventory in selected coal areas of Montana. Montana Department of Fish, Wildlife and Parks and Bureau of Land Management, Helena, MT. 84 p.

*Martin, P.R., K. Dubois and H.B. Youmans. 1981. Terrestrial wildlife inventory in selected coal areas, Powder River resources area final report. Montana Department of Fish, Wildlife and Parks and Bureau of Land Management, Helena, MT. 288 p.

Martin, R.F. 1973. Osteology of North American Bufo: the americanus, cognatus, and boreas species groups. Herpetologica 29(4): 375-387.

*Maxell, B.A. 2004. Preliminary report on amphibian and aquatic reptile inventories conducted on and around the Ashland District of the Custer National Forest in 2002 and 2004. Report to Ashland District of Custer Forest, Region 1 Office of the U.S. Forest Service, and Montana Department of Fish, Wildlife, and Parks. Missoula, MT: Montana Cooperative Wildlife Research Unit and Wildlife Biology Program, University of Montana. 93 p.

*Maxell, B.A. 2005. A review of monitoring methods and a multi-tiered scheme for assessing and monitoring the status of amphibians in Montana. Report to Montana Department of Environmental Quality, Region 1 Office of the U.S. Forest Service, Montana Department of Fish, Wildlife, and Parks, and Montana State Office of the Bureau of Land Management. Montana Natural Heritage Program, Helena, MT and Montana Cooperative Wildlife Research Unit and Wildlife Biology Program, University of Montana, Missoula, MT. 29 p. + Appendices.

*Maxell, B.A. 2009. State-wide assessment of status, predicted distribution, and landscapelevel habitat suitability of amphibians and reptiles in Montana. Ph.D. Dissertation. Missoula, MT: Wildlife Biology Program, University of Montana. 294 p.

*Maxell, B.A. and D.G. Hokit. 1999. Amphibians and reptiles. pp. 2.1-2.30. In: G. Joslin and H. Youmans, coordinators. Effects of recreation on Rocky Mountain wildlife: a review for Montana. Committee on Effects of Recreation on Wildlife, Montana Chapter of the Wildlife Society. 307 p.

McAllister, C.T. and S.E. Trauth. 1995. New host records for Myxidium serotinum (Protozoa: Myxosporea) from North American amphibians. Journal of Parasitology 81(3): 485-488.

*McEneaney, T. and J. Jensen. 1974. The reptiles and amphibians of the Charles M. Russell National Wildlife Range - 1974. Charles M. Russell National Wildlife Refuge. Lewistown, MT. 3 p.

Moore, J.E. 1953. Additional records of the toad Bufo cognatus in Alberta. Copeia 1953: 180181.

*Mosimann, J.E. and G.B. Rabb. 1952. The herpetology of Tiber Reservoir area, Montana. Copeia 1952: 23-27.

Mulcahy, D.G., M.R. Cummer, J.R. Mendelson III, B.L. Williams, and P.C. Ustach. 2002. Status and distribution of two species of Bufo in the Northeastern Bonneville Basin of Idaho and Utah. Herpetological Review 33(4):287-289.

Paulson, B.K. and V.H. Hutchison. 1987. Blood changes in Bufo cognatus following acute heat stress. Comparative Biochemistry and Physiology A Comparative Physiology 87(2): 461466. 
*Powell, R., J.T. Collins, and E.D. Hooper, Jr. 1998. A key to amphibians and reptiles of the Continental United States and Canada. University Press of Kansas, Lawrence, KS. $131 \mathrm{p}$. *[PRESI] Powder River Eagle Studies Incorporated. 1998a. Big Sky Mine 1997 wildlife monitoring studies. Powder River Eagle Studies Incorporated. Gillete, WY.

*[PRESI] Powder River Eagle Studies Incorporated. 1998b. Spring Creek Mine 1997 wildlife monitoring studies. Powder River Eagle Studies Incorporated. Gillete, WY.

Preston, W.B. 1986. The Great Plains toad, Bufo cognatus, an addition to the herpetofauna of Manitoba (Canada). Canadian Field Naturalist 100(1): 119-120.

Propper, C.R. and W.E. Johnson. 1994. Angiotensin II induces water absorption behavior in two species of desert anurans. Hormones and Behavior 28(1): 41-52.

*Reichel, J.D. 1995a. Preliminary amphibian and reptile survey of the Lewis and Clark National Forest: 1994. Montana Natural Heritage Program, Helena, MT. 92 p.

*Reichel, J.D. 1995b. Preliminary amphibian and reptile survey of the Sioux District of the Custer National Forest: 1994. Montana Natural Heritage Program, Helena, MT. 75 p.

*Roedel, M.D. and P. Hendricks. 1998. Amphibian and reptile survey on the Bureau of Land Management Lewistown District: 1995-1998. Montana Natural Heritage Program, Helena, MT. $53 \mathrm{p}$.

Rogers, J.S. 1972. Discriminant function analysis of morphological relationships within the Bufo cognatus species group. Copeia 1972(2): 381-383.

Rogers, J.S. 1973a. Biochemical and morphological analysis of potential introgression between Bufo cognatus and Bufo speciosus. American Midland Naturalist 90(1): 127-142.

Rogers, J.S. 1973b. Protein polymorphism, genic heterozygositya nd divergence in the toads Bufo cognatus and B. speciosus. Copeia 1973(2): 322-330.

Rogers, K.L. and L. Harvey. 1994. A skeletochronological assessment of fossil and recent Bufo cognatus from south-central Colorado. Journal of Herpetology 28: 133-140.

Rubial, R. 1962. The adaptive value of bladder water in the toad, Bufo cognatus. Physiological Zoology 35(3): 218-223.

Russell, A.P., and A.M. Bauer. 2000. The amphibians and reptiles of Alberta. Second Edition. Calgary, AB: University of Calgary Press. 279 p.

Say, T. 1823. In James, Stephen H. Long's Expedition of the Rocky Mountains. 1819-1820. Volume 2, p. 190.

Schmid, W.D. 1965. High temperature tolerance of Bufo hemiophrys and Bufo cognatus. Ecology 46(4): 559-560.

*Scow, K.L. 1980. Terrestrial wildlife survey American Colloid study area Phillips County, Montana. Western Technology and Engineering, Inc., Helena, MT.

Sievert, L. 1991. Thermoregulatory behaviour in the toads Bufo marinus and Bufo cognatus. Journal of Thermal Biology 16(5): 309-312.

Smith, C.C. and A.N. Bragg. 1949. Observations on the ecology and natural history of Anura, VII. Food and feeding habits of the common species of toads in Oklahoma. Ecology 30(3): 333-349.

*Smith, H.M. 1946. The tadpoles of Bufo cognatus Say. University of Kansas Publications Museum of Natural History 1(3): 93-96.

Smith, H.M., C.E. Bock and J.H. Bock. 1993a. Bufo cognatus (Great Plains toad). Herpetological Review 24(4): 152.

Smith, H.M., G.A. Hammerson, D. Chiszar and C. Ramotnik. 1993a. Bufo cognatus (Great Plains toad). Herpetological Review 24(4) 152-153. 
*Stebbins, R.C. 2003. A field guide to western reptiles and amphibians. 3rd edition. New York, NY: Houghton Mifflin Co. 533 p.

Stuart, J.N. 1995. Anura: Rana catesbeiana (Bullfrog). Diet. Herpetological Review 26(1): 33. Sullivan, B.K. 1982. Male mating behavior in the Great Plains toad (Bufo cognatus). Animal Behavior 30: 939-940.

Sullivan, B.K. 1983a. Sexual selection and mating system variation in the Great Plains toad (Bufo cognatus Say) and woodhouse's toad (Bufo woodhousei australis Shannon and Lowe). $\mathrm{Ph} . \mathrm{D}$. Dissertation, Arizona State University. $138 \mathrm{pp}$.

Sullivan, B.K. 1983b. Sexual selection in the Great Plains toad (Bufo cognatus). Behaviour 84(3-4): 258-264.

Sullivan, B.K. 1990. Natural hybrid between the Great Plains toad (Bufo cognatus) and the redspotted toad (Bufo punctatus) from central Arizona. Great Basin Naturalist 50(4) 1990: 371372.

Tester, J.R., A. Parker, and D.B. Siniff. 1965. Experimental studies of habitat preference and thermoregulation of Bufo americanus, B. hemiophrys, and B. cognatus. Journal of the Minnesota Academy of Sciences 33: 27-32.

*Thompson, L.S. and P.S. Nichols. 1982. Circle West wildlife monitoring study; fourth annual report for period March 1, 1981 - May 31, 1982. Circle West Technical Report No. 10. Montana Department of Natural Resources and Conservation, Helena, MT.

*Tihen, J.A. 1959. An interesting vertebral anomaly in a toad, Bufo cognatus. Herpetologica 15(1): 29-30.

*Timken, R.L. and D.G. Dunlap. 1965. Ecological distribution of the two species of Bufo in southeastern South Dakota. Proceedings of the South Dakota Academy of Sciences 44: 113117.

*Vitt, L.J., J.P. Caldwell, and D.B. Shepard. 2005. Inventory of amphibians and reptiles in the Billings Field Office Region, Montana. Sam Noble Oklahoma Museum of Natural History and Department of Zoology, University of Oklahoma, Norman, OK. 33 pp.

*[WESCO] Western Ecological Services Company. 1983a. Wildlife inventory of the Knowlton known recoverable coal resource area, Montana. Western Ecological Services Company, Novato, CA. 107 p.

*[WESCO] Western Ecological Services Company. 1983b. Wildlife inventory of the Southwest Circle known recoverable coal resource area, Montana. Western Ecological Services Company, Novato, CA. $131 \mathrm{p}$.

*Werner, J.K., B.A. Maxell, P. Hendricks, and D. Flath. 2004. Amphibians and reptiles of Montana. Missoula, MT: Mountain Press Publishing Company. 262p.

*Wheeler, G.C. and J. Wheeler. 1966. The amphibians and reptiles of North Dakota. University of North Dakota, Grand Forks, ND. 104 p. 


\section{Woodhouse's Toad (Bufo woodhousii)}

Up-to-date distribution and status information can be found on the Montana Natural Heritage Program's TRACKER website at http://mtnhp.org

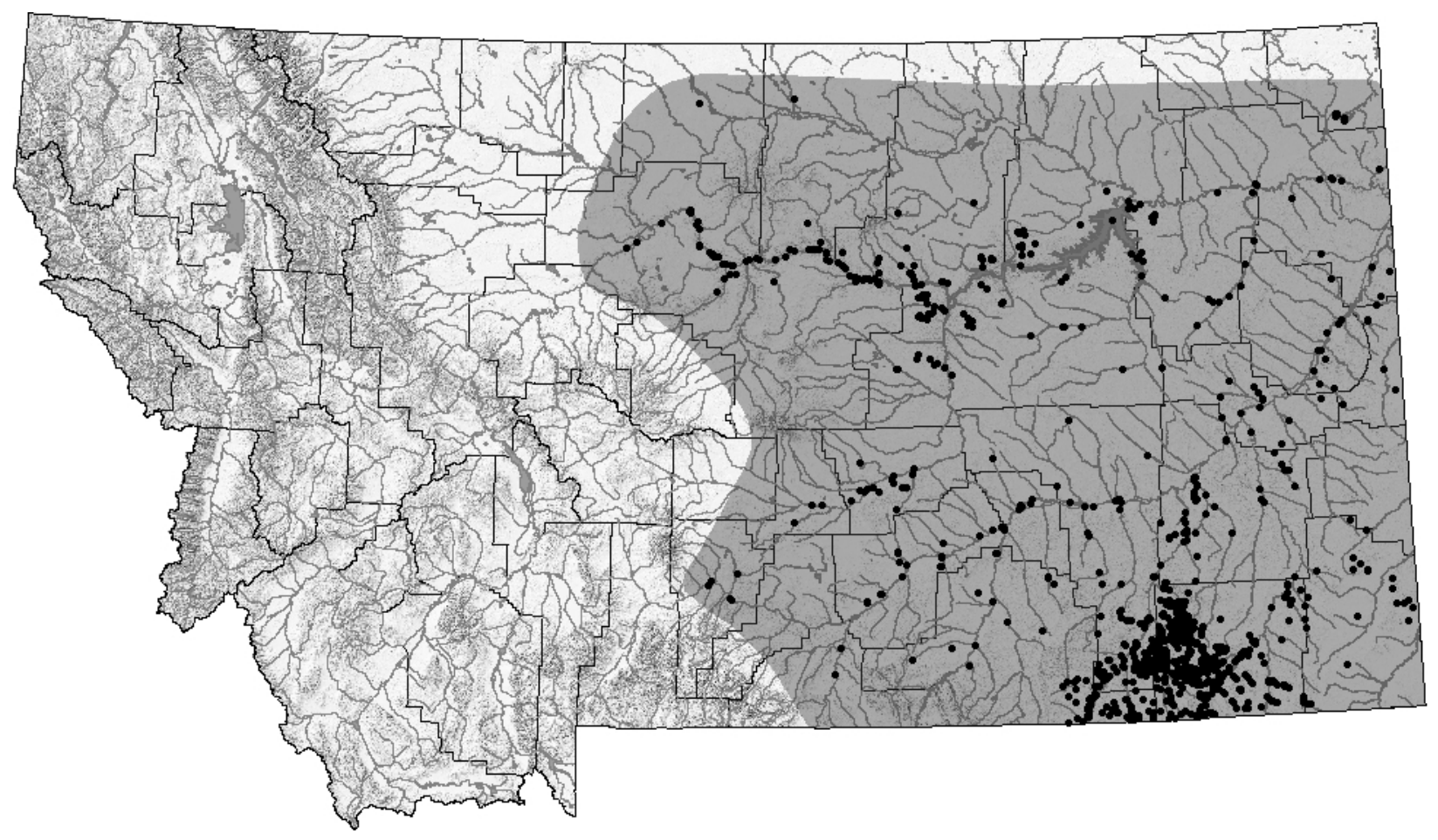

Distribution/Taxonomy

The systematics of the Woodhouse's toad species complex have a long history, but most authors now seem to agree that allozyme and call differentiation studies support evidence for the existence of two subspecies that range from southern Texas to northern Montana and North Dakota, across the desert southwest to northern Utah, and as isolated populations in Idaho, Washington and California (Stebbins 2003; Conant and Collins 1998; Gergus 1994 as cited in Sullivan et al. 1996; Sullivan et al. 1996). Across this range they have been reported at elevations up to 2,440 M (8,000 ft) (Hammerson 1999). Only the Woodhouse's toad, Bufo w. woodhousii, is present in Montana and they have been documented across the plains east of Livingston and Fort Benton and south of the Milk and Missour Rivers.

Maximum Elevation 1,326 m (4,350 ft) in Rosebud County (FWP Prairie Fish Survey Crew, MTNHP 2007).

\section{Identification}

\section{Eggs:}

Laid in long single or double strings containing up to, and possibly more than, 28,493 eggs (Smith 1934; Krupa 1995). Each ovum is black above, gray below, and is loose within the outer jelly string (Smith 1934). Ovum diameters are 1.0 to $1.4 \mathrm{~mm}$, but total egg diameters, including the outer jelly string are approximately $3.5 \mathrm{~mm}$ (Smith 1934).

Larvae:

Body and tail musculature is black to dark brown with gold flecking dorsally and laterally and 
gray to white ventrally (Youngstrom and Smith 1936). The dorsal tail fin is dendritically pigmented and the ventral tail fin is clear. TL of 2.5 to $35 \mathrm{~mm}$ (Youngstrom and Smith 1934; Hammerson 1999).

Juveniles and Adults:

With the exception of small metamorphs parallel cranial crests are found on the snout and behind the eyes in the shape of an "L". Large parotid glands are present behind the eyes. The hind feet each have two dark digging "spades" on their soles. A white stripe extends down the center of the back and is surrounded by a green and creamy yellowish mottling with more green toward the center line and more creamy yellow toward the lateral surface. Usually completely white ventrally, but some black spotting may be present (Bragg 1940; Bryce Maxell, pers. obs.). SVL of 10-120 mm (Smith 1934; Underhill 1960).

Similar Species:

See the geographic range of western toads to see possible areas of overlap. Adult western toads lack cranial crests and are rarely found in areas far from forests. Although overlap in habitat use exists the Great Plains toad is more commonly associated with heavier soils in upland habitats (Timken and Dunlap 1965). Adult Great Plains toads have a raised shield on the tip of the snout and the cranial crests between their eyes diverge to form a "V". Metamorph Great Plains toads have large paired dorsal blotches. Eggs and larvae of western toads, Great Plains toads, and Canadian toads are very similar and may not be differentiable by even thoroughly trained herpetologists. However eggs and larvae of Great Plains toads are more likely to be found in temporary waters and the Canadian toad, if present, is likely to only occur in the extreme northeast corner of the state.

\section{Habitat Use/Natural History}

Found in upland habitats with harder soils around areas with permanent waters, but most common in floodplain habitats with loose sandy soils (Bragg 1940; Timken and Dunlap 1965; Black 1970). Adults feed on a variety of invertebrates and shelter under surface debris, in rodent burrows, or in shallow, self excavated burrows when terrestrial conditions are not favorable (Bragg 1940; Smith and Bragg 1949; Clarke 1974; Labanick and Schleuter 1996; Flowers and Graves 1995; Swanson et al. 1996). Breeding usually takes place during or after spring or summer rains when temperatures are at least 10 degrees Celsius, but choruses may form in drier weather and larger breeding choruses may only form at or above 16 degrees Celsius (Breden 1988). Egg strings are wrapped around vegetation in shallow areas of lakes, reservoirs, river backwaters, floodplain pools, and irrigation ditches (Black 1970, Bryce Maxell, pers. obs.). Tadpoles hatch within three days, feed on algae and detritus, and usually transform in 5-8 weeks (Youngstrom and Smith 1936; Bragg 1940; Breden 1988). Adults are known to live up to 19 years of age (Engeman and Engeman 1996). Juveniles may not normally move more than a 200 meters from natal sites, but individuals are known to disperse up to 2 kilometers from natal breeding sites (Breden 1988).

\section{$\underline{\text { Status and Conservation }}$}

Woodhouse's toads are widely distributed and common in river valleys, smaller water courses with pools, and artificial permanent water bodies on the prairies east of the Rocky Mountains and island mountain ranges. However, their status north of the Missouri River is largely uncertain. 
Risk factors relevant to the viability of populations of this species are likely to include grazing, nonindigenous species and their management, road and trail development and on- and off-road vehicle use, development of water impoundments, and habitat fragmentation, all as described above. Individual studies that specifically identify risk factors or other issues relevant to the conservation of tiger salamanders include the following. (1) Taylor et al. (1999) found that Woodhouse's toad adults exposed to $0.0011 \mathrm{mg} / \mathrm{g}$ of toad (a level similar to levels commonly applied) of the pesticide Malathion suffered $40 \%$ mortality rates. Furthermore, when exposed to Malathion and subsequently injected with the bacteria Aeromonas hydrophila the mortality rate. Thus, the application of the pesticide clearly reduced the immune function of toads. Similarly, Ferguson and Gilbert (1967) found juvenile Woodhouse's toads to be very sensitive to the insecticides aldrin and dieldrin, but found that animals collected from sites that were contaminated with these chemicals exhibited up to a 200-fold increase in resistence over animals collected from pristine sites. Finally, Sanders (1970) studied the sensitivities of larval Woodhouse's toads to 18 pesticides and herbicides and found most of them to result in high rates of mortality when exposed for 48 or 96 hours. However, a number of pesticides and herbices had significant impacts on survival after a 24 hour exposure. The extent of the application of these herbicides and pesticides in Montana is not known, but it is likely that both herbicides and pesticides represent lethal and sublethal threats to Woodhouse's toad populations. (2) Bragg (1940) and Hammerson (1999) both report that thousands of Woodhouse's toads are killed by on roads near breeding sites. Furthermore, Barrass (1986) found that noise associated with highway traffic alters the reproductive behaviour of Woodhouse's toads. Animals were less likely to move toward a breeding chorus and were more likely to call closer to one another in an established chorus in the presence of highway noise. (3) Freda and Dunson (1986) found embryos were intolerant of low $\mathrm{pH}(\mathrm{pH} \leq 4.0)$ in the lab and were absent from all ponds with $\mathrm{pH}$ lower than 4.1. Furthermore, they found that larvae grew significantly slower in waters with $\mathrm{pH}$ less than 6.0. Pierce and Montgomery (1989) exposed larvae to short term acidic conditions (three days in water at $\mathrm{pH}=4.0$ ) and found that while short term exposures temporarily reduced the growth rates of individuals, long-term effects on growth, size at metamorphosis, and time to metamorphosis were not evident. (4) Many toad larvae are unpalatable to fish and may, therefore, have some resistance to the impacts of fish introductions. Kruse and Stone (1984) found that largemouth bass (Micropterus salmoides) learned to avoid feeding on Woodhouse's toad tadpoles because of their unpalatibility and aggregative behavior. However, bass did still prey on some tadpoles and the indirect effects of fish may still have considerable consequences. For example, Lawler (1989) found Woodhouse's toad tadpoles to greatly reduce activity levels in the presence of a fish predator. This decreases their foraging efficiency and increases their larval period, which exposes them to other predators for a longer period of time. (5) Bragg (1940) reports that they are preyed upon by bullfrogs. (6) Bragg (1940) notes that young toads are commonly used as fish bait in Oklahoma.

\section{Research and Management Suggestions}

1. See research and management suggestions under all of the general risk factors described above with the exception of timber harvest, fire and fire management activities, and harvest and commerce.

2. Documentation of their presence between the Yellowstone and Missouri Rivers is poor and their presence and/or status north of the Missouri and Milk Rivers and west of Fort Benton is uncertain. 
3. Studies of their habitat use and population dynamics relative to grazing and dry and irrigated agricultural activities would identify both positive and negative impacts of these activities.

4. Until the lethal and sublethal impacts of commonly used fertilizers, herbicides, and pesticides on all amphibian life history stages present in an area are examined they should not be applied within 100 meters of waterbodies or wetlands.

5. If populations are found in close proximity to areas of high human use the population impacts of vehicle use near known breeding or burrowing sites should be examined. If impacts are heavy or poorly understood then vehicle use should be curtailed or limited during major periods of activity (e.g., during breeding migrations/choruses or metamorphosis and dispersal).

Bibliography *indicates an article with information specific to Montana

Altig, R. and W. McDearman. 1975. Percent assimilation and clearance times of five anuran tadpoles. Herpetologica 31(1): 67-69.

Anderson, B.D., M.E. Feder and R.J. Full. 1991. Consequences of a gait change during locomotion in toads (Bufo woodhousei fowleri). Journal of Experimental Biology 158: 133148.

*Atkinson, E.C. and M.L. Atkinson. 2004. Amphibian and reptile survey of the Ashland and Sioux of the Custer National Forest with special emphasis on the Three-Mile Stewardship Area:2002. Marmot's Edge Conservation. 22 p.

Barrass, A.N. 1986. The effects of highway traffic noise on the phonotactic and associated reproductive behavior of selected anurans. Dissertation Abstracts International B Sciences and Engineering 46(8): 2609.

Barrass, A.N. and L.F. Cohn 1984. Variation of the spacing of calling male Bufo woodhousei and Hyla cinerea near highway noise. American Zoologist 24(3): 15A.

Baxter, G.T. and M.D. Stone. 1985. Amphibians and reptiles of Wyoming. Second Edition. Wyoming Game and Fish Department. 137 p.

*Bergeron, D.J. 1979. Terrestrial wildlife survey, Coal Creek Mine area, Montana 1977-1978. Western Technology and Engineering, Inc. Helena, MT.

*Black, J.H. 1967. Toads of Montana. Montana Wildlife 1967(Spring): 22-28.

*Black, J.H. 1970. Some aspects of the distribution, natural history and zoogeography of the toad genus Bufo in Montana. M.S. Thesis. University of Montana, Missoula, MT. 70 p.

*Black, J.H. 1971. The toad genus Bufo in Montana. Northwest Science 45: 156-162.

Blair, W.F. 1956. Comparative survival of hybrid toads (B. woodhousei X B. valliceps) in nature. Copeia 1956: 259-260.

Blem, C.R. 1992. Lipid reserves and body composition in postreproductive anurans. Comparative Biochemistry and Physiology A Comparative Physiology 103(4): 653-656.

*[BLM] Bureau of Land Managment. 1982. Bloomfield - North Fork baseline inventories wildlife. Bureau of Land Management, Miles City District Office. Miles City, MT. 61 p.

Boone, M.D. 2005. Juvenile frogs compensate for small metamorph size with terrestrial growth: Overcoming the effects of larval density and insecticide exposure. Journal of Herpetology 39(3):416-423.

Bragg, A.N. 1939. Possible hybridization of Bufo cognatus and B. w. woodhousii. Copeia 1939(3): 173. 
*Bragg, A.N. 1940. Observations on the ecology and natural history of Anura II. Habits, habitat, and breeding of Bufo woodhousei woodhousei (Girard) in Oklahoma. American Midland Naturalist 24: 306-321.

Bragg, A.N. and O. Sanders. 1951. A new subspecies of the Bufo woodhousii group of toads (Salientia: Bufonidae). Wasmann Journal of Biology 9: 363-378.

Breden, F. 1982. Population structure and ecology of the Fowler's toad, Bufo woodhousei fowleri, in the Indiana Dunes National Lakeshore. Ph.D. Dissertation, University of Chicago.

Breden, F. 1987. The effect of post-metamorphic dispersal on the population genetic structure of Fowler's Toad (Bufo woodhousei fowleri). Copeia 1987(2): 386-395.

Breden, F. 1988. Natural history and ecology of Fowler's toad (Bufo woodhousei fowleri) (Amphibia: Bufonidae), in the Indiana Dunes National Lakeshore (USA). Fieldiana Zoology No. 49: 1-16.

Breden, F., A. Lum, and R. Wassersug. 1982. Body size and orientation in aggregates of toad tadpoles Bufo woodhousei. Copeia 1982(3): 672-680.

Brown, L.E. 1970. Interspecies interaction as possible causes of racial size differences in the toads, Bufo americanus and Bufo woodhousei. Texas Journal of Science 21(3): 261-267.

Brown, L.E. 1971. Natural hybridization and reproductive ecology of two toad species in a disturbed environment. American Midland Naturalist 86(1): 78-85.

Brown, L.E. and J.A. Brownell. 1971. Relative survival of two toad species and their natural hybrids in a disturbed environment. American Midland Naturalist 86(1): 235-238.

*Brunson, R.B. 1955. Check list of the amphibians and reptiles of Montana. Proceedings of the Montana Academy of Sciences 15: 27-29.

*Burton, S.R., D.A. Patla, and C.R. Peterson. 2002. Amphibians of Red Rock Lakes National Wildlife Refuge: occurrence, distribution, relative abundance, and habitat associations. Herpetology Laboratory, Department of Biological Sciences, Idaho State University, Pocatello, ID. 66 p.

Bush, F.M. and E.F. Menhinick. 1962. The food of Bufo woodhousei fowleri. Herpetologica 18: 110-114.

*Butts, T.W. 1997. Mountain Inc. wildlife monitoring Bull Mountains Mine No. 1, 1996. Western Technology and Engineering. Helena, MT.

Calisi, R.M. 2005. Variation in Bidder's organ volume is attributable to reproductive status in Bufo woodhousii. Journal of Herpetology 39(4):656-659.

Chiszar, D. and H.M. Smith. 1992. Bufo woodhousii woodhousii (Woodhouse's toad). Herpetological Review 23(4): 122.

Chiszar, D. and H.M. Smith. 1993. Bufo woodhousii woodhousii (Woodhouse's toad). Herpetological Review 24(4): 153.

Clarke, R.D. 1972. The effect of toe clipping on survival in Fowler's toad (Bufo woodhousei fowleri). Copeia 1972: 182-185.

Clarke, R.D. 1974a. Activity and movement patterns in a population of Fowler's toad, Bufo woodhousei fowleri. American Midland Naturalist 91: 140-147.

Clarke, R.D. 1974b. Food habits of toads, genus Bufo (Amphibia:Bufonidae). American Midland Naturalist 91(1): 140-147.

Clarke, R.D. 1974c. Postmetamorphic growth rates in a natural population of Fower's toad (Bufo woodhousei fowleri). Canadian Journal of Zoology 52: 1489-1498.

Clarke, R.D. 1974d. The autoecology of Fowler's toad Bufo woodhousei fowleri Hinckley. Ph.D. Dissertation, Yale University. 182 p. 
Clarke, R.D. 1975. Post-metamorphic growth rates in a natural population of Fowler's toads (Bufo woodhouseii fowleri). Canadian Journal of Zoology 52: 1489-1498.

Clarke, R.D. 1977. Postmetamorphic survivorship of Fowler's toad (Bufo woodhousei fowleri). Copeia 1977(3): 594-597.

Claussen, D.L. 1974. Urinary bladder water reserves in the terrestrial toad, Bufo fowleri, and the aquatic frog, Rana clamitans. Herpetologica 30(4): 360-367.

Claussen, D.L. and J.R. Layne, Jr. 1983. Growth and survival of juvenile toads, Bufo woodhousei, maintained on four different diets. Journal of Herpetology 17(2): 107-112.

*Conant, R. and J.T. Collins. 1998. A field guide to reptiles and amphibians of eastern and central North America. $3^{\text {rd }}$ edition, expanded. New York, NY: Houghton Mifflin Co. 616 p.

*Cope, E.D. 1879. A contribution to the zoology of Montana. American Naturalist 13(7): 432441.

*Cope, E.D. 1889. The Batrachia of North America. Bulletin of the U.S. National Museum 34: 1-525, figs. 1-119, pls. 1-86.

Corn, P.S., E. Muths, and W.M. Iko. 2000. A comparison in Colorado of three methods to monitor breeding amphibians. Northwestern Naturalist 81:22-30.

*Coues, E. and H.C. Yarrow. 1878. Notes on the herpetology of Dakota and Montana. Bulletin of the U.S. Geologic and Geographic Survey 4(1): 259-291.

*Day, D., P.J. Farmer, and C.E. Farmer. 1989. Montco terrestrial wildlife monitoring report December, 1987 - July, 1989. Montco, Billings, MT, and Western Technology and Engineering, Inc. Helena, MT.

*[DCC] Decker Coal Company. 1998. 1997 Consolidated annual progress report. Decker Coal Company West, North and East Pits. Decker, MT.

*Dood, A.R. 1980. Terry Badlands nongame survey and inventory final report. Montana Department of Fish, Wildlife, and Parks and Bureau of Land Management, Helena, MT. 70 p.

Dodd, C.K., Jr. 1977. Immobility in juvenile Bufo woodhousei fowleri. Journal of the Mississippi Academy of Science 22: 90-94.

Engeman, R.M. and E.M. Engeman. 1996. Longevity of Woodhouse's toad in Colorado. Northwestern Naturalist 77: 23.

Engeman, R.M. and M.A. Engeman. 2003. Longevity of a Woodhouse's Toad. Northwestern Naturalist 84:45.

Fairchild, L. 1981. Mate selection and behavioral thermoregulation in Fowler's toads. Science 212: 950-951.

*Farmer, P. 1980. Terrestrial wildlife monitoring study, Pearl area, Montana June, 1978 - May, 1980. Western Technology and Engineering, Inc. Helena, MT.

Ferguson, D.E. and C.C. Gilbert. 1967. Tolerances of three species of anuran amphibians to five chlorinated hydrocarbon insecticides. Journal of the Mississippi Academy of Science. 13: $135-138$.

*Flath, D.L. 2002. Reptile and amphibian surveys in the Madison-Missouri River Corridor, Montana. Annual Progress Report. 14p.

Flowers, M.A. and B.M. Graves. 1994. Feeding ecology of juvenile great plains toad (Bufo cognatus) and Woodhouse's toad (Bufo woodhousii). North Dakota Academy of Science Proceedings. 48: 22. 
Flowers, M.A. and B.M. Graves. 1995. Prey selectivity and size-specific diet changes in Bufo cognatus and Bufo woudhousii during early postmetamorphic ontogeny. Journal of Herpetology 29(4): 608-612.

Force, E.R. 1925. Notes on reptiles and amphibians of Okmulgee County, Oklahoma. Copeia 1925(141): 25-27.

Freda, J. and W.A. Dunson. 1986. Effects of low $\mathrm{pH}$ and other chemical variables on the local distribution of amphibians. Copeia 1986: 454-466.

*Gates, M.T. 2005. Amphibian and reptile baseline survey: CX field study area. Report to Billings and Miles City Field Offices of Bureau of Land Management. Maxim Technologies, Billings, MT. 28pp + Appendices.

Gergus, E.W.A. 1994. Systematics and biogeography of Bufo microscaphus (Anura: Bufonidae), with a preliminary report on americanus group phylogeny. M.S. Thesis, San Diego State University.

Girard, C.F. 1854. Proceedings of the Academy of National Sciences, Philadelphia. Volume 7, p. 86.

Given, M.F. 1993. Vocal interactions in Bufo woodhousii fowleri. Journal of Herpetology 27(4): 447-452.

Given, M.F. 1996. Intensity modulation of advertisement calls in Bufo woodhousii fowleri. Copeia 1996(4): 970-977.

Goldberg, S.R., C.R. Bursey, K.B. Malmos, B.K. Sullivan and H. Cheam. 1996. Helminths of the southwestern toad, Bufo microscaphus, woodhouse's toad, Bufo woodhousii (Bufonidae), and their hybrids from central Arizona. Great Basin Naturalist 56(4): 369-374.

Green, D.M. 1989. Fowler's toad (Bufo woodhousii fowleri) in Canada: biology and population status. Canadian Field Naturalist 103(4): 486-496.

Green, D.M. 1992. Fowler's toads (Bufo woodhouseii fowleri) at Long Point, Ontario: changing abundance and implications for conservation. In: C.A. Bishop and K.E. Pettit (eds.), Declines in Canadian amphibian populations : designing a national monitoring strategy, pp. 37-45. Canadian Wildlife Service Occ. Publ 76, Ottawa.

Grogan, W.L., Jr., and P.G. Bystrak. 1973. Early breeding activity of Rana sphenocephala and Bufo woodhousei fowleri in Maryland. Bulletin of the Maryland Herpetological Society 9: 106.

Grubb, J.C. 1973. Olfactory orientation in Bufo woodhousei fowleri, Pseudacris clarki and Pseudacris streckeri. Animal Behavior 21(4): 726-732.

Hadfield, S. 1966. Observations on body temperature and activity in the toad Bufo woodhousei fowleri. Copeia 1966: 581-582.

Hammerson, G.A. 1999. Amphibians and reptiles in Colorado. Second Edition. University Press of Colorado and Colorado Division of Wildlife. $484 \mathrm{p}$.

Hardin, E.L. and J Janovy, Jr. 1988. Population dynamics of Distoichometra bufonis (Cestoda: Nematotaeniidae) in Bufo woodhousei. Journal of Parasitology 74(3): 360-365.

*Hart, M.M., W.A. Williams, P.C. Thornton, K.P. McLaughlin, C.M. Tobalske, B.A. Maxell, D.P. Hendricks, C.R. Peterson, and R.L. Redmond. 1998. Montana atlas of terrestrial vertebrates. Montana Cooperative Wildlife Research Unit, University of Montana, Missoula, MT. $1302 \mathrm{p}$.

*Hayden, F.V. 1863. On the geology and natural history of the upper Missouri. Transactions of the American Philosophical Society New Series 12(1): 1-218 (pages 177-178). 
*Hendricks, P. 1999. Amphibian and reptile survey of the Bureau of Land Management Miles City District, Montana. Montana Natural Heritage Program, Helena, MT. 80 p.

*Hendricks, P. and J.D. Reichel. 1996. Preliminary amphibian and reptile survey of the Ashland District, Custer National Forest: 1995. Montana Natural Heritage Program, Helena, MT. $79 \mathrm{p}$.

*Hendricks, P. and J.D. Reichel. 1998. Amphibian and reptile survey on Montana refuges: 1996. Montana Natural Heritage Program, Helena, MT. 19 p.

*Hossack, B.R. and P.S. Corn. 2001. Amphibian survey of Medicine Lake National Wildlife Refuge Complex: 2001. USGS Northern Rocky Mountain Science Center, Aldo Leopold Wilderness Research Institute, Missoula, MT. 13 p.

Hossack, B.R., P.S. Corn, and D.S. Pilliod. 2005. Lack of significant changes in the herpetofauna of Theodore Roosevelt National Park, North Dakota, since the 1920s. American Midland Naturalist 154:423-432.

Hranitz, J.M., W.J. Diehl and T.S. Klinger. 1992. Genetic diversity in insular, peninsular and mainland populations of Bufo woodhousei fowleri. Journal of the Mississippi Academy of Science 37(1):65.

Jilek, R. and R. Wolff. 1978. Occurrence of Spintectus gracilis Ward and Magath 1916 (Nematoda: Spiruroidea) in the toad Bufo woodhousei fowleri in Illinois. Journal of Parasitology 64(4): 619.

John-Alder, H.B., and P.J. Morin. 1990. Effects of larval density on jumping ability and stamina in newly metamorphosed Bufo woodhousii fowleri. Copeia 1990(3): 856-860.

Johnson, J.D. and T.J. LaDuc. 1994. Bufo woodhousii woodhousii (Woodhouse's toad) Herpetological Review 25(4):159.

Johnson, V.O. 1939. A supplementary note on the larvae of Bufo woodhousii woodhousii. Herpetologica 1: 162-164.

Jones, J.M. 1973. Effects of thirty years hyridization on the toads Bufo americanus and Bufo woodhousei fowleri at Bloomington, Indiana. Evolution 27: 435-448.

Kellner, A. and D.M. Green. 1995. Age structure and age at maturity in Fowler's toads (Bufo woodhousii fowleri) at their northern range limit. Journal of Herpetology 29(3): 485-489.

Klimstra, W.D. and C.W. Myers. 1965. Foods of the toad, Bufo woodehousi fowleri Hinckley. Transactions of the Illinois State Academy of Science 58: 757-764.

Krupa, J.J. 1995. Bufo woodhousi (Woodhouse's toad). Fecundity. Herpetological Review 26: 142-144.

Kruse, K.C., and B.M. Stone. 1984. Largemouth bass (Micropterus salmoides) learn to avoid feeding on toad (Bufo) tadpoles. Animal Behaviour 32(4):1035-1039.

Labanick, G.M. and R.A. Schlueter. 1976. Growth rates of recently transformed Bufo woodhousei fowleri. Copeia 1976(4): 824-826.

Labanick, G.M. and R.A. Schlueter. 1977. Diets of sympatric Acris crepitans and juvenile Bufo woodhousei fowleri in western Indiana. Proceedings of the Indiana Academy of Science 86: 460.

Landreth, H.F. and D.E. Ferguson. 1968. The sun compass of Fowler's toad (Bufo woodhousei fowleri). Behaviour 30: 27-43.

Laurin, G. and D.M. Green. 1990. Spring emergence and male chorus behavior in Fowler's toads, Bufo woodhousei fowleri, at Long Point, Ontario (Canada). Canadian Field Naturalist 104(3): 429-434. 
Lawler, S.P. 1989. Behavioral responses to predators and predation risk in four species of larval anurans. Animal Behaviour 38: 1039-1047.

Lawler, S.P. and P.J. Morin. 1993. Temporal overlap, competition, and priority effects in larval anurans. Ecology 74(1): 174-182.

Leary, C.J. 1996. Anura: Bufo woodhousii and B. americanus (woodhouse's toad and American toad). Vocalization. Herpetological Review 27(3): 139.

Lillywhite, H.B. 1978. Anuran thermoregulation: new insights from a field study of Bufo woodhousei. American Zoologist 18(3): 573.

Loftus Hills, J.J. 1975. The evidence for reproductive character displacement between the toads Bufo americanus and Bufo woodhousei fowleri. Evolution 29: 368-369.

Londos, P.L. and R.J. Brooks. 1988. Effect of temperature acclimation on locomotory performance curves in the toad, Bufo woodhousei woodhousei. Copeia 1988(1): 26-32.

Londos, P.L. and R.J. Brooks. 1990. Time course of temperature acclimation of locomotory performance in the toad, Bufo woodhousei woodhousei. Copeia 1990(3): 827-835.

Long, D.R. 1987. A comparison of energy substrates and reproductive patterns of two anurans, Acris crepitans and Bufo woodhousei. Comparative Biochemistry and Physiology A Comparative Physiology 87(1): 81-92.

*Martin, P.R. 1980a. Terrestrial wildlife habitat inventory in southeastern Montana. Montana Department of Fish, Wildlife and Parks and Bureau of Land Management, Helena MT. 114 p.

*Martin, P.R. 1980b. Terrestrial wildlife inventory in selected coal areas of Montana. Montana Department of Fish, Wildlife and Parks and Bureau of Land Management, Helena, MT. 84 p.

*Martin, P.R., K. Dubois and H.B. Youmans. 1981. Terrestrial wildlife inventory in selected coal areas, Powder River resources area final report. Montana Department of Fish, Wildlife and Parks and Bureau of Land Management, Helena, MT. 288 p.

Masta, S.E., N.M. Laurent, and E.J. Routman. 2003. Population genetic structure of the toad Bufo woodhousii: an empirical assessment of the effects of haplotype extinction on nested cladistic analysis. Molecular Ecology 12(6): 1541-1554.

*Matthews, W.L. 1979. Wibaux-Beach wildlife baseline study - nongame species. Bureau of Land Management, Miles City, MT. 93 p.

*Matthews, W.L. 1980. Wildlife of Prairie County Terry study area. Bureau of Land Management, Miles City, MT. 52 p.

*Matthews, W.L. 1981. Broadus-Pumpkin Creek baseline inventory - wildlife. Bureau of Land Management, Miles City, MT. 83 p.

*Maxell, B.A. 2000. Management of Montana's amphibians: a review of factors that may present a risk to population viability and accounts on the identification, distribution, taxonomy, habitat use, natural history, and the status and conservation of individual species. Report to USFS Region 1, Order Number 43-0343-0-0224. Missoula, MT: Wildlife Biology Program, University of Montana. $161 \mathrm{p}$.

*Maxell, B.A. 2004. Preliminary report on amphibian and aquatic reptile inventories conducted on and around the Ashland District of the Custer National Forest in 2002 and 2004. Report to Ashland District of Custer Forest, Region 1 Office of the U.S. Forest Service, and Montana Department of Fish, Wildlife, and Parks. Missoula, MT: Montana Cooperative Wildlife Research Unit and Wildlife Biology Program, University of Montana. 93 p. 
*Maxell, B.A. 2005. A review of monitoring methods and a multi-tiered scheme for assessing and monitoring the status of amphibians in Montana. Report to Montana Department of Environmental Quality, Region 1 Office of the U.S. Forest Service, Montana Department of Fish, Wildlife, and Parks, and Montana State Office of the Bureau of Land Management. Montana Natural Heritage Program, Helena, MT and Montana Cooperative Wildlife Research Unit and Wildlife Biology Program, University of Montana, Missoula, MT. 29 p. + Appendices.

*Maxell, B.A. 2009. State-wide assessment of status, predicted distribution, and landscapelevel habitat suitability of amphibians and reptiles in Montana. Ph.D. Dissertation. Missoula, MT: Wildlife Biology Program, University of Montana. 294 p.

*Maxell, B.A. and D.G. Hokit. 1999. Amphibians and reptiles. Pages 2.1-2.30. In G. Joslin and H. Youmans, committee chairs. Effects of recreation on Rocky Mountain wildlife: a compendium of the current state of understanding in Montana. Helena, MT: Committee on Effects of Recreation on Wildlife, Montana Chapter of the Wildlife Society.

*Maxell, B.A., J.K. Werner, P. Hendricks, and D. Flath. 2003. Herpetology in Montana: a history, status summary, checklists, dichotomous keys, accounts for native, potentially native, and exotic species, and indexed bibliography. Olympia, WA: Society for Northwestern Vertebrate Biology. Northwest Fauna 5: 1-138.

*McEneaney, T. and J. Jensen. 1974. The reptiles and amphibians of the Charles M. Russell National Wildlife Range - 1974. Charles M. Russell National Wildlife Refuge. Lewistown, MT. 3 p.

Mecham, W.R. 1962. Factors affecting secondary intergradation between two allopatric populations in the Bufo woodhousei complex. American Midland Naturalist 67: 282-304.

Mitchell, S.L. 1990. The mating system genetically affects offspring performance in Woodhouse's toad (Bufo woodhousei). Evolution 44(3): 502-519.

Morin, P.J., S.P. Lawler, and E.A. Johnson. 1988. Competition between aquatic insects and vertebrates: Interaction strength and higher order interactions. Ecology 69(5): 1401-1409.

Mulcahy, D.G., M.R. Cummer, J.R. Mendelson III, B.L. Williams, and P.C. Ustach. 2002. Status and distribution of two species of Bufo in the Northeastern Bonneville Basin of Idaho and Utah. Herpetological Review 33(4):287-289.

*Nussbaun, R., E. Brodie, Jr., and R. Storm. 1983. Amphibians and reptiles of the Pacific Northwest. University of Idaho Press, Moscow, Idaho. 322 p.

*[OEAR] Olson Elliot and Associates Research. 1985. 1983-1984 Wildlife monitoring report for the CX Ranch project. Olson Elliot and Associates Research. Helena, MT.

O'Connor, M.P. 1990. Thermoregulation in anuran amphibians: physiology, biophysics, and ecology. Ph.D. Dissertation, Colorado State University.

O'Connor, M.P. and C.R. Tracy. 1992. Thermoregulation by juvenile toads of Bufo woodhousei in the field and in the laboratory. Copeia 1992(3): 865-876.

Pack, H.J. 1922. Toads in regulating insect outbreaks. Copeia 107: 46-47.

Pierce, B.A. and J. Montgomery. 1989. Effects of short-term acidification on growth rates of tadpoles. Journal of Herpetology 23(2): 97-102.

*Powell, R., J.T. Collins, and E.D. Hooper, Jr. 1998. A key to amphibians and reptiles of the Continental United States and Canada. University Press of Kansas, Lawrence, KS. 131 p.

*[PRESI] Powder River Eagle Studies Incorporated. 1998a. Big Sky Mine 1997 wildlife monitoring studies. Powder River Eagle Studies Incorporated. Gillete, WY. 
*[PRESI] Powder River Eagle Studies Incorporated. 1998b. Spring Creek Mine 1997 wildlife monitoring studies. Powder River Eagle Studies Incorporated. Gillete, WY.

*Rauscher, R.L. 1998. Amphibian and reptile survey on selected Montana Bureau of Reclamation impoundments. Montana Department of Fish, Wildlife and Parks, Nongame Program, Bozeman, MT. 24 p.

*Reichel, J.D. 1995a. Preliminary amphibian and reptile survey of the Lewis and Clark National Forest: 1994. Montana Natural Heritage Program, Helena, MT. 92 p.

*Reichel, J.D. 1995b. Preliminary amphibian and reptile survey of the Sioux District of the Custer National Forest: 1994. Montana Natural Heritage Program, Helena, MT. 75 p.

*Reichel, J.D. 1996. Preliminary amphibian and reptile survey of the Helena National Forest: 1995. Montana Natural Heritage Program, Helena, MT. 87 p.

*Reichel, J.D. and D.L. Flath. 1995. Identification guide to the amphibians and reptiles of Montana. Montana Outdoors 26(3): 15-34.

*Roedel, M.D. and P. Hendricks. 1998a. Amphibian and reptile survey on the Bureau of Land Management Lewistown District: 1995-1998. Montana Natural Heritage Program, Helena, MT. $53 \mathrm{p}$.

*Roedel, M.D. and P. Hendricks. 1998b. Amphibian and reptile inventory on the Headwaters and Dillon Resource Areas in conjunction with Red Rocks Lakes National Wildlife Refuge: 1996-1998. Montana Natural Heritage Program, Helena, MT. 46 p.

*Russell, A.P. and A.M. Bauer. 1993. The amphibians and reptiles of Alberta. University of Alberta Press: Edmonton, Alberta. 264 p.

Ryan, M.J. 1991. Sexual selection and commmunication in frogs. Trends in Ecology and Evolution 6(11): 351-355.

Sanders, H.D. 1970. Pesticide toxicities to tadpoles of thet western chorus frog (Pseudacris triseriata) and Fowler's toad (Bufo woodhousei fowleri). Copeia 1970: 246-251.

Shannon, F.A. 1949. A western subspecies of Bufo woodhousei hitherto erroneously associated with Bufo compactilis. Bulletin of the Chicago Academy of Science 8: 301-312.

Shannon, F.A. and C.H. Lowe. 1955. A new subspecies of Bufo woodhousei from the inland southwest. Herpetologica 11: 185-190.

Sherman, E. 1980. Ontogenetic change in thermal tolerance of the toad Bufo woodhousii fowleri. Comparative Biochemistry and Physiology A Comparative Physiology 65(2): 227230.

Shively, J.N., J.G. Songer, S. Prchal, M.S. Keasey, III and C.O. Thoen. 1981. Mycobacterium marinum infection in Bufonidae. Journal of Wildlife Diseases 17(1): 3-7.

Smith, C.C. and A.N. Bragg. 1949. Observations on the ecology and natural history of Anura, VII. Food and feeding habits of the common species of toads in Oklahoma. Ecology 30(3): 333-349.

Smith, H.M. 1934. The amphibians of Kansas. American Midland Naturalist 15(4): 377-528.

*Stebbins, R.C. 2003. A field guide to western reptiles and amphibians. 3rd edition. New York, NY: Houghton Mifflin Co. 533 p.

Sullivan, B.K. 1982a. Sexual selection in Woodhouse's toad (Bufo woodhousei) I. Chorus organization. Animal Behavior 30(3): 680-686.

Sullivan, B.K. 1982b. Significance of site, temperature and call attributes to sexual selection in Bufo woodhousei australis. Journal of Herpetology 16(2): 103-106. 
Sullivan, B.K. 1983a. Sexual selection and mating system variation in the Great Plains toad (Bufo cognatus Say) and woodhouse's toad (Bufo woodhousei australis Shannon and Lowe). Ph.D. Dissertation, Arizona State University. 138 p.

Sullivan, B.K. 1983b. Sexual selection in Woodhouse's toad (Bufo woodhousei). II Female choice. Animal Behaviour 31: 1011-1017.

Sullivan, B.K. 1985. Sexual selection and mating system variation in anuran amphibians of the Arizona-Sonoran desert. Great Basin Naturalist 45(4): 688-696.

Sullivan, B.K. 1986a. Hybridization between the toads Bufo microsaphus and Bufo woodhousei in Arizona: morphological variation. Journal of Herpetology 20: 11-21.

Sullivan, B.K. 1986b. Intra-populational variation in the intensity of sexual selection in breeding aggregations of woodhouse's toad (Bufo woodhousei). Journal of Herpetology 20(1): 88-90.

Sullivan, B.K. 1989. Interpopulational variation in vocalizations of Bufo woodhousei. Journal of Herpetology 23(4): 368-373.

Sullivan, B.K. 1995. Temporal stability in hybridization between Bufo microscaphus and Bufo woodhousii (Anura: Bufonidae): Behavior and morphology. Journal of Evolutionary Biology 8(2): 233-247.

Sullivan, B.K. and T. Lamb. 1988. Hybridization between the toads Bufo microscaphus and Bufo woodhousii in Arizona: variation in release calls and allozymes. Herpetologica 44: 325333.

Sullivan, B.K. and M.R. Leek. 1986. Acoustic communication in Woodhouse's toad (Bufo woodhousei): I. Response of calling males to variation in spectral and temporal components of advertisement calls. Behaviour 98(1-4): 305-319.

Sullivan, B.K. and M.R. Leek. 1987. Acoustic communication in Woodhouse's toad (Bufo woodhousei): II. Response of females to variation in spectral and temporal components of advertisement calls. Behaviour 103(1-3): 16-26.

*Sullivan, B.K., K.B. Malmos and M.F. Given. 1996. Systematics of the Bufo woodhousii complex (Anura: Bufonidae): advertisement call variation. Copeia 1996: 274-280.

Sullivan, B.K., C.R. Propper, M.J. Demlong and L.A. Harvey. 1996. Natural hermaphroditic toad (Bufo microscaphus x Bufo woodhousii). Copeia 1996(2): 470-472.

Sullivan, B.K. and G.E. Walsberg. 1985. Call rate and aerobic capacity in woodhouse's toad (Bufo woodhousei). Herpetologica 41(4): 404-407.

Swanson, D.L., B.M. Graves and K.L. Koster. 1996. Freezing tolerance/intolerance and cryoprotectant synthesis in terrestrially overwintering anurans in the Great Plains, USA. Journal of Comparative Physiology B Biochemistry, Systematics and Environmental Physiology 166(2): 110-119.

Taylor, S.K., E.S. Williams, and K.W. Mills. 1999. Effects of malathion on disease susceptibility in Woodhouse's toads. Journal of Wildlife Diseases 35(3): 536-541.

*Thompson, L.S. and P.S. Nichols. 1982. Circle West wildlife monitoring study; fourth annual report for period March 1, 1981 - May 31, 1982. Circle West Technical Report No. 10. Montana Department of Natural Resources and Conservation, Helena, MT.

Thornton, W.A. 1955. Interspecific hybridization in Bufo woodhousei and Bufo valliceps. Evolution 9: 455-468.

Thornton, W.A. 1960. Population dynamics in Bufo woodhousei and Bufo valliceps. Texas Journal of Science (12) 176-200. 
*Timken, R. No Date. Amphibians and reptiles of the Beaverhead National Forest. Western Montana College, Dillon, MT. 16 p.

Timken, R.L. and D.G. Dunlap. 1965. Ecological distribution of the two species of Bufo in southeastern South Dakota. Proceedings of the South Dakota Academy of Sciences 44: 113117.

Tran, D.Y., K.V. Hoff and S.D. Hillyard. 1992. Effects of angiotensin II and bladder condition on hydration behavior and water uptake in the toad, Bufo woodhousei. Comparative Biochemistry and Physiology A Comparative Physiology 103(1): 127-130.

Tucker, J.K. and C.H. Theiling. 1994. Bufo woodhousii fowleri (Fowler's toad). Herpetological Review 25(1): 32.

*Turner, F.B. 1951. A checklist of the reptiles and amphibians of Yellowstone National Park with incidental notes. Yellowstone Nature Notes 25(3): 25-29.

*Turner, F.B. 1955. Reptiles and amphibians of Yellowstone National Park. Yellowstone Interpretive Series No. 5. Yellowstone Library and Museum Association. Yellowstone National Park, WY. 40 p.

Underhill, J.C. 1960. Breeding and growth in Woodhouse's toad. Herpetologica 16: 237-242.

*Van Kirk, R., L. Benjamin, and D. Patla. 2000. Riparian area assessment and amphibian status in the watersheds of the Greater Yellowstone Ecosystem. Greater Yellowstone Coalition, Bozeman, MT. $102 \mathrm{p}$.

Verma, N. and B.A. Pierce. 1994. Body mass, developmental stage, and interspecific differences in acid tolerance of larval anurans. Texas Journal of Science 46(4) 319-327.

*Vitt, L.J., J.P. Caldwell, and D.B. Shepard. 2005. Inventory of amphibians and reptiles in the Billings Field Office Region, Montana. Sam Noble Oklahoma Museum of Natural History and Department of Zoology, University of Oklahoma, Norman, OK. 33 pp.

*Waage, B.C. 1998. Western Energy Company Rosebud Mine 1997 annual wildlife monitoring report December 1, 1996 to November 30, 1997 survey period. Western Energy Company, Colstrip, MT.

Waltin, M. 1988. Relationships among metabolic, locomotory, and field measures of organismal performance in the Folwer's toad (Bufo woodhousei fowleri). Physiological Zoology 61: 107-118.

Wassersug, R.J., A.M. Lum and M.J. Potel. 1981. An analysis of school structure for tadpoles (Anura: Amphibia). Behavioral Ecology and Sociobiology 9(1): 15-22.

*Werner, J.K., B.A. Maxell, P. Hendricks, and D. Flath. 2004. Amphibians and reptiles of Montana. Missoula, MT: Mountain Press Publishing Company. 262p.

*[WESCO] Western Ecological Services Company. 1983a. Wildlife inventory of the Knowlton known recoverable coal resource area, Montana. Western Ecological Services Company, Novato, CA. 107 p.

*[WESCO] Western Ecological Services Company. 1983b. Wildlife inventory of the Southwest Circle known recoverable coal resource area, Montana. Western Ecological Services Company, Novato, CA. $131 \mathrm{p}$.

*[WESTECH] Western Technology and Engineering Incorporated. 1998. Wildlife monitoring Absaloka Mine area 1997. Western Technology and Engineering, Inc., Helena, MT.

*Wheeler, G.C. and J. Wheeler. 1966. The amphibians and reptiles of North Dakota. University of North Dakota, Grand Forks, ND. 104 p. 
*Wied, M.P. 1865. Verzeichniss der reptilien, welche auf einer reise in nordlichen America beobachtet wurden, von Maximilian, Prinzen zu Wied. Eigengangen bei der Akademie am 1, Juni 1865. Druck von E. Blochmann und Sohn, Dresden, Germany. 141 p.

Woodward, B.D. 1982a. Male persistence and mating success in Woodhouse's toad (Bufo woodhousei). Ecology 63(2): 583-585.

Woodward, B.D. 1982b. Sexual selection and nonrandom mating patterns in desert anurans (Bufo woodhousei, Scaphiopus couchi, S. multiplicatus, and S. bombifrons). Copeia 1982(2): 351-355. 28.

Woodward, B.D. 1984. Arrival to and location of Bufo woodhousei in the breeding pond. Effect on the operational sex ratio. Oecologia 62(2): 240-244.

Woodward, B.D. 1987. Interactions between Woodhouse's toad tadpoles (Bufo woodhousei) of mixed sizes. Copeia 1987(2): 380-386.

Yancey, F.D., II and K.J. Roberts, 1996. Bufo woodhousii woodhousii (Woodhouse's toad) Herpetological Review 27(3):148.

*Yarrow, H.C. 1882. Check list of North American reptilia and batrachia, with catalogue of specimens in the U.S. National Museum. United States National Museum Bulletin 24. 249 p.

Youngstrom, K.H. and H.M. Smith. 1936. Description of the larvae of Pseudacris triseriata and Bufo w. woodhousii. American Midland Naturalist 17: 629-633.

Zweifel, R.G. 1968a. Effects of temperature, body size and hybridization on mating calls of toads, Bufo a. americanus and Bufo woodhousei fowleri. Copeia 1968: 269-285. 


\section{Boreal Chorus Frog (Pseudacris maculata)}

Up-to-date distribution and status information can be found on the Montana Natural Heritage Program's TRACKER website at http://mtnhp.org

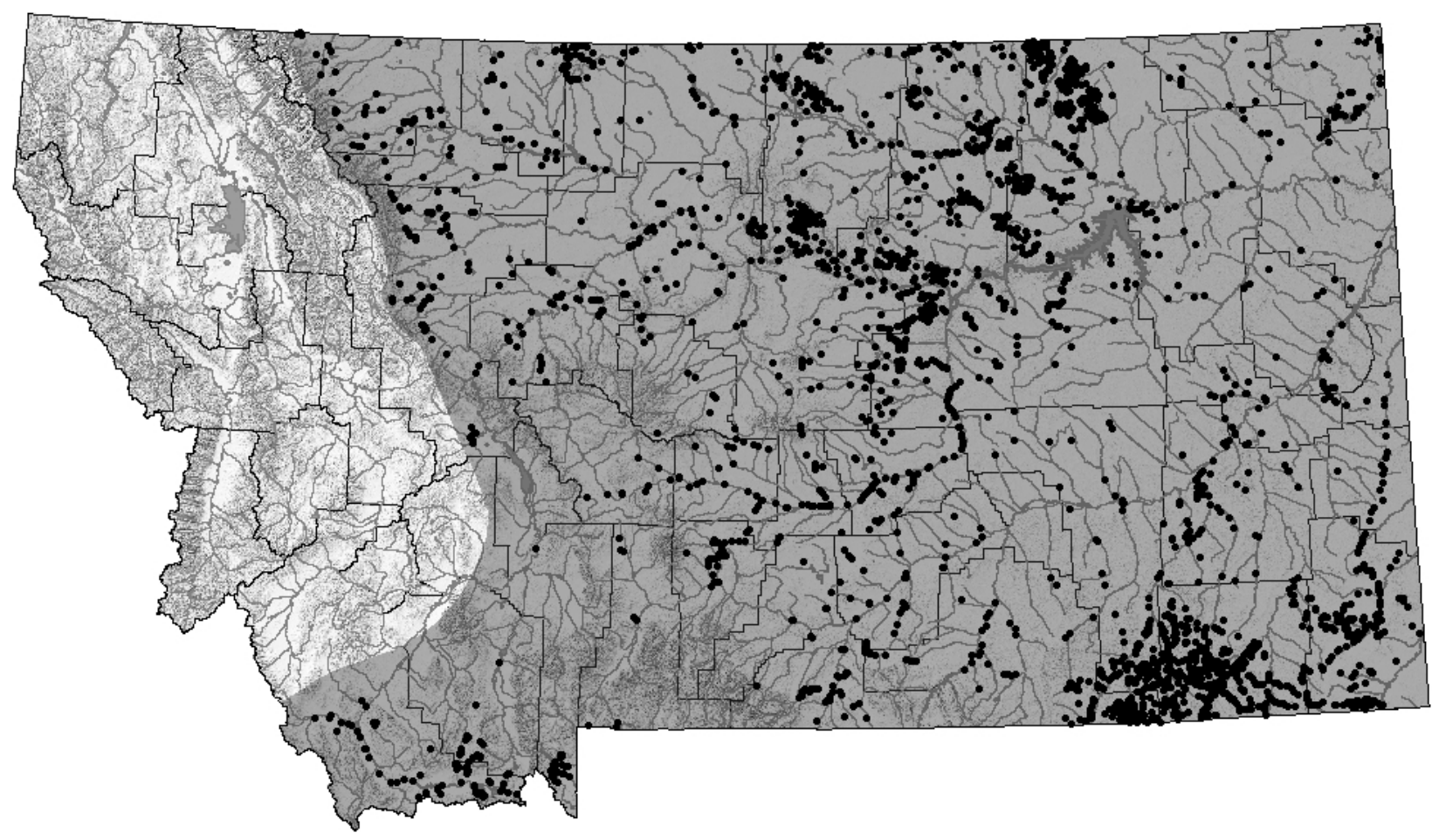

Distribution/Taxonomy

Although there is debate about whether subspecific or specific status should be assigned, most authorities recognize four geographic varieties of Pseudacris triseriata which range from Great Slave Lake and Hudson Bay to the Gulf of Mexico and from New Jersey to western Idaho at elevations up to 3,720 M (12,200 ft) (Hedges 1986; Platz and Forester 1988; Platz 1989; Conant and Collins 1998; Hammerson 1999). Only one variety, the boreal chorus frog, Pseudacris maculata (full species recognition) or Pseudacris triseriata maculata (subspecies recognition), is recognized as occuring in Montana. In Montana they have been documented east of the Continental Divide and the Big Hole Valley.

Maximum Elevation

2,841 m (9,320 ft) just east southeast of Black Butte in southern Madison County (Matt Bell; MTNHP 2008).

\section{Identification}

\section{Eggs:}

Although individual females are known to lay 137 to 793 (mean $=455, \mathrm{SE}=47, \mathrm{~N}=16$ at a site in Colorado) eggs at a time, eggs are usually deposited in a number of clutches a few centimeters in size containing 7 to 190 eggs (Pack 1920; Pettus and Angleton 1967). Each ovum is black above, white to cream below and is surrounded by a single layer of jelly (Bryce Maxell, pers. obs.). Ovum diameters are 0.8 to $1.3 \mathrm{~mm}$ (Pettus and Angleton 1967; Bryce Maxell, pers. obs.), but total egg diameters, including the jelly layer may vary from 4.0 to $6.0 \mathrm{~mm}$ (Bryce Maxell, pers. obs.). 
Larvae:

Eyes outside the outline of the body when viewed from above. Mottled with brown and gold dorsally and pale gold to clear ventrally (Bryce Maxell, pers. obs.). The dorsal tail fin is highly arched and dendritically pigmented with gold while the ventral tail fin is a uniform width and transparent (Bryce Maxell, pers. obs.). TL of 4.8-52 mm (Pettus and Angleton 1967; Hammerson 1999).

Juveniles and Adults:

The ends of the toes have minute disks or toe pads and there is little webbing between any of the toes (Bryce Maxell, pers. obs.). Dorsal base color is cream, gray, brown, or green, with three green, brown, or gray stripes or rows of spots dorsally and a one row laterally (Smith 1956; Corn 1980a; Bryce Maxell, pers. obs.). Cream colored ventrally, possibly with a few small black spots. SVL of 7.0-38 mm (Blair 1951; Pettus and Angleton 1967).

Similar Species:

The adults of all other frogs and toads in Montana are much larger and, with the exception of Pacific treefrogs, have webbing between the toes on their hind feet. With the exception of Pacific treefrogs, the eyes of the tadpoles of all the other frogs and toads in Montana do not stick out beyond the body outline when viewed from above. The geographic range of the Pacific treefrog does not overlap with the geographic range of the boreal chorus frog (see sections on distribution).

\section{Habitat Use/Natural History}

Typically found within 100 meters of permanent or temporary waters in grasslands, shrublands, or forest parklands (Kramer 1974; Roberts and Lewin 1979). Adults are freeze tolerant and overwinter and aestivate in underground rodent burrows or underneath thick vegetation or debris (Whitaker 1971; Swanson et al. 1996). Adults and juveniles feed on a variety of arthropods as well as their own shed skins and vegetation (Moore and Strickland 1954; Whitaker 1971). Although adults may call throughout the spring, summer, and early fall after rains or in irrigated fields, breeding takes place from late April to June in a variety of shallow water bodies (Cope 1879; Roberts and Lewin 1979; Bryce Maxell, pers. obs.). Females may deposit eggs over several days on grass stems or other emergent vegetation in only a few inches of water (Livezey 1952). Eggs usually hatch in 5 to 14 days and tadpoles metamorphose in approximately two months (Livezey 1952; Nussbaum et al. 1983). Tadpoles feed on a variety of algae (Whitaker 1971). Individuals may commonly undergo seasonal migrations of 250 meters, but apparently do not normally disperse more than 700 meters from their natal sites (Spencer 1964).

\section{$\underline{\text { Status and Conservation }}$}

With larvae being found in most temporary standing waterbodies and in shallower portions of permanent standing water bodies that lack fish boreal chorus frogs may be the most widely distributed and common amphibian species at low to mid elevations east of the Continental Divide. Risk factors relevant to the viability of populations of this species are likely to include all the general risk factors described above with the exception of timber harvest and harvest and commerce. Individual studies that specifically identify risk factors or other issues relevant to the conservation of boreal chorus frogs include the following. (1) Sanders (1970) studied the sensitivities of one week old chorus frog tadpoles to 16 pesticides and herbicides and found most 
of them to result in high rates of mortality when exposed for 48 or 96 hours. Powell et al. (1982) found that the insecticide fenthion formulated with either water or diesel oil had not bioaccumulated in adult chorus frogs three days after exposure at commonly applied levels. However, as noted by the authors it may be unlikely that the adults would bioaccumulate the pesticide because individuals would not be likely to have eaten insects that had been exposed (frogs do not normally eat dead prey). The authors warn that tadpoles may be more sensitive to bioaccumulation because they injest algae that would likely be contaminated. The relationship of the inactive and active ingredients in these pesticides to commonly applied pesticides in Montana is not known, but it is likely that both pesticides and herbicides may represent lethal and/or sublethal threats to boreal chorus frog populations. (2) Hecnar (1995) found that acute and chronic toxic effects of ammonium nitrate were observed in chorus frog tadpoles at concentrations that are commonly exceeded in agricultural areas. Acute exposures to ammonium nitrate fertilizers at $20 \mathrm{mg} / \mathrm{L}$ for 96 hours resulted in 50 percent mortality and significant weight loss in those individuals that survived. Chronic exposures to $10 \mathrm{mg} / \mathrm{L}$ for 100 days resulted in significantly lower survivorship. (3) Corn et al. (1997) found that boreal chorus frogs were commonly breeding at sites where trout were present, but noted that tadpoles of the species are often only found in heavily vegetated shallow water where they are not likely to be exposed to fish predation. (4) Corn et al. (1989) found that embryos from a clutch of boreal chorus frog eggs did not suffer significantly higher mortality rates until $\mathrm{pH}$ dropped below 5.2, but had an $\mathrm{LC}_{50}$ at $\mathrm{pH} 4.8$, and suffered $100 \%$ mortality at $\mathrm{pH}$ 4.6. However, at the larval stage, Kiesecker (1996) found that survival rate, growth rate, mass, and time to metamorphosis did not change when $\mathrm{pH}$ was at 4.5, 5.5, 6.0, and 7.0.

\section{$\underline{\text { Research and Management Suggestions }}$}

1. See research and management suggestions under all of the general risk factors described above with the exception of timber harvest, fire and fire management activities, and harvest and commerce.

2. Additional information is needed on their distribution within the triangle between the Big Belt Mountains, the Big Hole Valley, and the southeastern corner of the Beartooth Plateau. There presence in much of this area is uncertain and it is possible that they cross the Continental Divide into the upper Clark Fork watershed near Homestake, Pipestone, and Deerlodge passes.

3. Studies of their habitat use and population dynamics relative to grazing and dry and irrigated agricultural activities would identify both positive and negative impacts of these activities.

4. Until the lethal and sublethal impacts of commonly used fertilizers, herbicides, and pesticides on all amphibian life history stages present in an area are examined they should not be applied within 100 meters of waterbodies or wetlands.

Bibliography *indicates an article with information specific to Montana

*Atkinson, E.C. and M.L. Atkinson. 2004. Amphibian and reptile survey of the Ashland and Sioux of the Custer National Forest with special emphasis on the Three-Mile Stewardship Area:2002. Marmot's Edge Conservation. 22 p.

*Bauer, D. 1997. 1997 wildlife study Savage Mine report. Knife River Corporation, Savage Mine. Richland County, MT. 
*Beal, M.D. 1951. The occurrence and seasonal activity of vertebrates in the Norris and Gibbon Geyser Basins of Yellowstone National Park. M.S. Thesis. Utah State Agricultural College. Logan, Utah. 61 pp.

*Benson, K.R. 1978. Herpetology of the Lewis and Clark expedition 1804-1806. Herpetological Review 9(3): 87-91.

*Bergeron, D.J. 1978a. Terrestrial wildlife survey Divide Mine area, Montana 1977-1978. Western Technology and Engineering, Inc. Helena, MT.

*Bergeron, D.J. 1978b. Terrestrial wildlife survey P-M Mine area, Montana 1977-1978. Western Technology and Engineering, Inc. Helena, MT.

*Bergeron, D.J. 1979. Terrestrial wildlife survey, Coal Creek Mine area, Montana 1977-1978. Western Technology and Engineering, Inc. Helena, MT.

*Black, J.H. and A.N. Bragg. 1968. New additions to the herpetofauna of Montana. Herpetologica 24: 247.

*Black, J.H. and R. Timken. 1976. Endangered and threatened amphibians and reptiles in Montana. p 36-37. In: R.E. Ashton, Jr. (chair). Endangered and threatened amphibians and reptiles in the United States. Society for the Study of Amphibians and Reptiles. Herpetological Circular 5: 1-65.

Blair, A.P. 1951. Note on the herpetology of the Elk Mountains, Colorado. Copeia 1951: 239240.

Bleakney, S. 1959. Postglacial dispersal of the western chorus frog in eastern Canada. Canadian Field Naturalist 73: 197-205.

*BLM. 1982a. Bloomfield - North Fork baseline inventories - wildlife. Bureau of Land Management, Miles City District Office. Miles City, MT. 61 pp.

*BLM. 1982b. Moorhead baseline inventory - wildlife. Bureau of Land Management, Miles City District Office. Miles City, MT. 29 pp.

Bragg, A.N. 1948b. Observations on the life history of Pseudacris triseriata (Wied). Wassmann Collector 7(4): 149-168.

Britson, C.A. and R.E. Kissell, Jr. 1996. Effects of food type on developmental characteristics of an ephemeral pond-breeding anuran, Pseudacris triseriata feriarum. Herpetologica 52(3): 374-382.

*Brunson, R.B. 1955. Check list of the amphibians and reptiles of Montana. Proceedings of the Montana Academy of Sciences 15: 27-29.

*Burton, S.R., D.A. Patla, and C.R. Peterson. 2002. Amphibians of Red Rock Lakes National Wildlife Refuge: occurrence, distribution, relative abundance, and habitat associations. Herpetology Laboratory, Department of Biological Sciences, Idaho State University, Pocatello, ID. 66 p.

*Butts, T.W. 1997. Mountain Inc. wildlife monitoring Bull Mountains Mine No. 1, 1996. Western Technology and Engineering. Helena, MT.

Chantell, C.J. 1968. The osteology of Pseudacris (Amphibia: Hylidae). American Midland Naturalist 80(2): 381-391.

Chiszar, D. and D.J. Drew. 1991. Pseudacris triseriata (western chorus frog). Herpetological Review 22(4) 1991: 134.

Christian, K.A. 1976. Ontogeny of the food niche of Pseudacris triseriata. M.S. thesis, Colorado State University, Fort Collins. Vii +70 pp.

Christian, K.A. 1982. Changes in the food niche during postmetamorphic ontogeny of the frog Pseudacris triseriata. Copeia 1982(1): 73-80. 
Cochran, P.A. 1989. Notes on the phenology of the chorus frog, Pseudacris triseriata, in Du Page County, Illinois. Bulletin of the Chicago Herpetological Society 24(5): 89-90.

*Conant, R. and J.T. Collins. 1998. A field guide to reptiles and amphibians of eastern and central North America. $3^{\text {rd }}$ edition, expanded. New York, NY: Houghton Mifflin Co. 616 p.

Corkran, C.C. and C. Thoms. 2006. Amphibians of Oregon, Washington, and British Columbia. $2^{\text {nd }}$ Edition. Vancouver, B.C.: Lone Pine Publishing. 176 p.

Cook, F.R. 1964. Additional records and a correction of the type locality for the boreal chorus frog in northwestern Ontario. Canadian Field Naturalist 78: 186-192.

*Cooper, S.V., C. Jean, and P. Hendricks. 2001. Biological survey of a prairie landscape in Montana's glaciated plains. Report to the Bureau of Land Management. Montana Natural Heritage Program, Helena, MT. 24 pp. plus appendices.

*Cope, E.D. 1872. Report on the recent reptiles and fishes of the survey, collected by Campbell Carrington and C.M. Dawes. pp. 467-469. In: F.V. Hayden, Preliminary report of the United States geological survey of Montana and portions of adjacent territories; being a fifth annual report of progress. 538 pp. 42nd Congress, 2nd Session, House Executive Document Number 326. Serial 1520.

*Cope, E.D. 1875. Check-list of North American Batrachia and Reptilia; with a systematic list of the higher groups, and an essay on geographical distribution. U.S. National Museum Bulletin 1(1): 1-104.

*Cope, E.D. 1879. A contribution to the zoology of Montana. American Naturalist 13(7): 432441.

*Cope, E.D. 1889. The Batrachia of North America. Bulletin of the U.S. National Museum 34: 1-525, figs. 1-119, pls. 1-86.

*Corn, P.S. 1980a. Comment on the occurrence of Pseudacris clarki in Montana. Bulletin of the Chicago Herpetological Society 15(3): 77-78.

Corn, P.S. 1980b. Polymorphic reproductive behavior in male chorus frogs (Pseudacris triseriata). Journal of Colorado-Wyoming Academy of Sciences 12: 6-7.

Corn, P.S. 1986. Genetic and development studies of albino chorus frogs. Journal of Heredity 77(3): 164-168.

Corn, P.S., B.R. Hossack, E. Muths, D.A. Palta, C.R. Peterson, and A.L. Gallant. 2005. Status of amphibians on the Continental Divide: surveys on a transect from Montana to Colorado, USA. Alytes 22(3-4):85-94.

Corn, P.S., M.L. Jennings, and E. Muths. 1997. Survey and assessment of amphibian populations in Rocky Mountain National Park. Northwestern Naturalist 78: 34-55.

Corn, P.S. and E. Muths. 2004. Variable breeding phenology affects the exposure of amphibian embryos to ultraviolet radation. Ecology 83(11): 2958-2963.

Corn, P.S., E. Muths, and W.M. Iko. 2000. A comparison in Colorado of three methods to monitor breeding amphibians. Northwestern Naturalist 81:22-30.

*Corn, P.S., E. Muths, and C.R. Peterson. 2008. U.S. Geological Survey Amphibian Research and Monitoring Initiative Rocky Mountain Region, 2007 Progress Report. Missoula, MT: Report to U.S. Geological Survey. 6 p.

Corn, P.S., W. Stolzenburg, and R.B. Bury. 1989. Acid precipitation studies in Colorado and Wyoming: interim report of surveys of montane amphibians and water chemistry. U.S. Fish and Wildlife Service Biological Report 89(40.26). Air Pollution and Acid Rain Report No. 26. $56 \mathrm{pp}$. 
*Coues, E. and H.C. Yarrow. 1878. Notes on the herpetology of Dakota and Montana. Bulletin of the U.S. Geologic and Geographic Survey 4(1): 259-291.

*Day, D., P.J. Farmer, and C.E. Farmer. 1989. Montco terrestrial wildlife monitoring report December, 1987 - July, 1989. Montco, Billings, MT, and Western Technology and Engineering, Inc. Helena, MT.

*[DCC] Decker Coal Company. 1998. 1997 Consolidated annual progress report. Decker Coal Company West, North and East Pits. Decker, MT.

*Dood, A.R. 1980. Terry Badlands nongame survey and inventory final report. Montana Department of Fish, Wildlife, and Parks and Bureau of Land Management, Helena, MT. 70 p.

Dunlap, D.G. 1980. Comparative effects of thermal acclimation and season on metabolic compensation to temperature in the hylid frogs, Pseudacris triseriata and Acris crepitans. Comparative Biochemistry and Physiology A Comparative Physiology 66: 243-249.

Dunlap, D.G. 1989. The effects of differing photoperiods during thermal acclimation on oxygen consumption in the hylid frogs, Acris crepitans and Pseudacris triseriata. Comparative Biochemistry and Physiology A Comparative Physiology 94(3): 519-524.

Dupre, R.K. and J.W. Petranka. 1985. Ontogeny of temperature selection in larval amphibians. Copeia 1985(2): 462-467.

Durnin, K.B. and G.R. Smith. 2001. Effects of changing water volume on the tadpoles of two anuran species (Pseudacris triseriata and Rana blairi). Journal of Freshwater Ecology 16(3): 411-414.

*[EI] Econ Incorporated. 1984. Terrestrial wildlife inventory for the Lame Jones and Ismay coal lease tracts. Econ Incorporated. Helena, MT.

Edwards, J.R., K.L. Koster, and D.L. Swanson. 2000. Time course for cryoprotectant synthesis in the freeze-tolerant chorus frog, Pseudacris triseriata. Comparative Biochemistry and Physiology A, Comparative Physiology 125(3): 367-375.

*Farmer, P. 1980. Terrestrial wildlife monitoring study, Pearl area, Montana June, 1978 - May, 1980. Western Technology and Engineering, Inc. Helena, MT.

Garber, C.S. 1992. A survey for spotted frogs (Rana pretiosa), wood frogs (Rana sylvatica), and boreal toads (Bufo boreas) in Wyoming: interim report for the Laramie Range Mountains and Bighorn Mountains of Wyoming. Wyoming Natural Diversity Database. Laramie, WY. 15 pp. + appendix.

*Gates, M.T. 2005. Amphibian and reptile baseline survey: CX field study area. Report to Billings and Miles City Field Offices of Bureau of Land Management. Maxim Technologies, Billings, MT. 28pp + Appendices.

Geyer, R.E., Jr. 1969. The ecological host-parasite relatioships of Glypthelmins sp. (Trematoda: Brachycoelidae) and Pseudacris triseriata (Weid: 1839), with a description of the new species and notes on its life cycle. M.A. Thesis, Indiana State University.

Goldberg, S.R., C.R. Bursey, E.W.A. Gergus, B.K. Sullivan, and Q.A. Truong. 1996. Helminths from three treefrogs Hyla arenicolor, Hyla wrightorum, and Pseudacris triseriata (Hylidae) from Arizona. Journal of Parasitology 82(5): 833-835.

Grayson, D.K., P.W. Parmalee, R.L. Lyman and J.I. Mead. 1988. Danger Cave, Last Supper Cave, and Hanging Rock Shelter (USA): The faunas. Anthropological Papers of the American Museum of Natural History 66(1): 1-130.

Hammerson, G.A. 1999. Amphibians and reptiles in Colorado. Second Edition. University Press of Colorado and Colorado Division of Wildlife. $484 \mathrm{p}$. 
Harper, F. 1955. The type locality of Hyla triseriata. Proceedings of the Biological Society of Washington 68: 155-156.

*Hart, M.M., W.A. Williams, P.C. Thornton, K.P. McLaughlin, C.M. Tobalske, B.A. Maxell, D.P. Hendricks, C.R. Peterson, and R.L. Redmond. 1998. Montana atlas of terrestrial vertebrates. Montana Cooperative Wildlife Research Unit, University of Montana, Missoula, MT. $1302 \mathrm{p}$.

*Hayden, F.V. 1863. On the geology and natural history of the upper Missouri. Transactions of the American Philosophical Society New Series 12(1): 1-218 (pages 177-178).

Hecnar, S.J. 1995. Acute and chronic toxicity of ammonium nitrate fertilizer to amphibians. Environmental Toxicology and Chemistry 14(12): 2131-2137.

Hedges, S.B. 1986. An electrophoretic analysis of Holarctic Hylid frog evolution. Systematic Zoology 35(1): 1-21.

Heinrich, M.L. 1985. Pseudacris triseriata triseriata (western chorus frog). Reproduction. Herpetological Review 16(1): 24.

*Hendricks, P. 1999. Amphibian and reptile survey of the Bureau of Land Management Miles City District, Montana. Montana Natural Heritage Program, Helena, MT. 80 p.

*Hendricks, P. and J.D. Reichel. 1996. Preliminary amphibian and reptile survey of the Ashland District, Custer National Forest: 1995. Montana Natural Heritage Program, Helena, MT. $79 \mathrm{p}$.

*Hendricks, P. and J.D. Reichel. 1998. Amphibian and reptile survey on Montana refuges: 1996. Montana Natural Heritage Program, Helena, MT. 19 p.

*Hendricks, P. and M. Roedel. 2001. A faunal survey of the Centennial Valley Sandhills, Beaverhead County, Montana. Report to the U.S. Bureau of Land Management and U.S. Fish and Wildlife Service. Montana Natural Heritage Program, Helena, MT. 44 p.

Hess, J.B. 1969. Changes in frequency of the green-spot phenotype in piedmont populations of the chorus frog. Ph.D. dissertation, Colorado State University.

*Hill, S.R., Jr. 1995. Migratory chronology of adult tiger salamanders (Ambystoma tigrinum) and survey of larvae of the tiger salamander in the northern range of Yellowstone National Park. M.S. Thesis. Montana State University, Bozeman, MT. 72 p.

*Hill, S.R., Jr. and R.E. Moore. 1994a. Herpetological survey in the northern range of Yellowstone National Park. Investigator's Annual Reports Yellowstone National Park 1993. Yellowstone Center for Resources. pp. 96-97.

*Hill, S.R., Jr. and R.E. Moore. 1994b. Herpetological survey in the northern range of Yellowstone National Park. Annual Report to Yellowstone National Park. February 1, 1994. $21 \mathrm{p}$.

Hoppe, D.M. 1975. Selection pressures affecting color polymorphism in mintane populations of the boreal chorus frog (Pseudacris triseriata). Ph.D. Dissertation Colorado State University, Fort Collins. 100p.

Hoppe, D.M. 1978. Thermal tolerance in tadpoles of the chorus frogs Pseudacris triseriata. Herpetologica 34: 318-321.

Hoppe, D.M. and D. Pettus. 1974. Selection factors affcting dorsal color polymorphism in boreal chorus frogs. Journal of the Colorado-Wyoming Academy of Science 12(5): 73.

Hoppe, D.M. and D. Pettus. 1984. Developmental features influencing color polymorphism in chorus frogs. Journal of Herpetology 18: 113-120.

Horstman, G.P. 1995. Anura: Pseudacris triseriata (western chorus frog). Herpetological Review 26(4): 208. 
*Hossack, B. and K.J. Yale. 2002. Geographic Distribution. Pseudacris maculata. Herpetological Review 33(1): 63.

Hossack, B.R., P.S. Corn, and D.S. Pilliod. 2005. Lack of significant changes in the herpetofauna of Theodore Roosevelt National Park, North Dakota, since the 1920s. American Midland Naturalist 154:423-432.

Jacobs, D. 1950. Pseudacris nigrita triseriata on the north shore of Lake Superior. Copeia 1950(2): 154.

*Jones, L.L.C., W.P. Leonard, and D.H. Olson (eds). 2005. Amphibians of the Pacific Northwest. Seattle, WA: Seattle Audubon Society. 227 p.

Kehmeier, J., C. Wagner and L.J. Livo. 1996. Pseudacris triseriata (western chorus frog). Herpetological Review 27(3): 150.

Kiesecker, J. 1996. $\mathrm{pH}$ mediated predator-prey interactions between Ambystoma tigrinum and Pseudacris triseriata. Ecological Applications 6(4): 1325-1331.

Knowles, T.W. and P.D. Weigl. 1990. Thermal dependence of anuran burst locomotor performance. Copeia 1990(3): 796-802.

*Koch, E.D. and C.R. Peterson. 1989. A preliminary survey of the distribution of amphibians and reptiles in Yellowstone National Park. pp. 47-49. In: Rare, sensitive and threatened species of the Greater Yellowstone Ecosystem, T.W. Clark, A.H. Harvey, R.D. Dorn, D.C. Genter, and C. Groves (eds.), Northern Rockies Conservation Cooperative, Montana Natural Heritage Program, The Nature Conservancy, and Mountain West Environmental Services. $153 \mathrm{p}$.

*Koch, E.D. and C.R. Peterson. 1995. The amphibians and reptiles of Yellowstone and Grand Teton National Parks. University of Utah Press, Salt Lake City, UT. 188 p.

Kramer, D.C. 1973. Movements of western chorus frogs (Pseudacris triseriata triseriata) tagged with Co 60. Journal of Herpetology 7(3): 231-235.

Kramer, D.C. 1974. Home range of the western chorus frog (Pseudacris triserata triserata). Journal of Herpetology 8: 245-246.

Littlejohn, M.J. 1960. Call discrimination and potential reproductive isolation in Pseudacris triseriata females from Oklahoma. Copeia 1960(4): 370-371.

Livezey, R.L. 1952. Some observations on Pseudacris nigrita triseriata (Wied) in Texas. American Midland Naturalist 47: 372-381.

Livo, L.J., D. Chiszar and H.M. Smith. 1995. Anura: Pseudacris triseriata (western chorus frog). Herpetological Review 26(4): 208.

Livo, L.J., G.A. Hammerson, H.M. Smith, D. Chiszar, and S.P. Mackessy. 1998. Status of chorus frogs (genus Pseudacris) in southeastern Colorado. Bulletin of the Maryland Herpetological Society 34: 22-28.

Lord, R.D., Jr. and W.B. Davis. 1956. A taxonomic study of the relationship between Pseudacris nigrita triseriata Wied and Pseudacris clarki Baird. Herpetologica 12: 115-120.

*Lynch, C. 2000. North American Amphibian Monitoring Program's Montana frog-call survey: a report on a pilot program in south-central Montana started April 2000 and completed in June 2000. Zoo Montana Conservation Through Education Program, Billings MT. 39 p.

*Lynch, C. 2001. North American Amphibian Monitoring Program's Montana frog-call survey: report on year two of a program in south-central Montana started April 2001 and completed in June 2001. Zoo Montana Conservation Through Education Program, Billings MT. 12 p. 
MacArthur, D.L. and J.W.T. Dandy. 1982. Physiological aspects of overwintering in the boreal chorus frog (Pseudacris triseriata maculata). Comparative Biochemistry and Physiology 72A:137-141.

Mackessy, S.P., R. Donoho, J. Hobert, C. Montgomery and K. Waldron. 1996. Pseudacris triseriata maculata (boreal chorus frog). Herpetological Review 27(1): 30.

*Martin, P.R. 1980. Terrestrial wildlife habitat inventory in southeastern Montana. Montana Department of Fish, Wildlife and Parks and Bureau of Land Management, Helena MT. 114 p.

*Martin, P.R., K. Dubois and H.B. Youmans. 1981. Terrestrial wildlife inventory in selected coal areas, Powder River resources area final report. Montana Department of Fish, Wildlife and Parks and Bureau of Land Management, Helena, MT. 288 p.

Martof, B.S. 1961. Vocalization as an isolating mechanism in frogs. American Midland Naturalist 65(1): 118-126.

Matsuda, B.M., D.M. Green, and P.T. Gregory. 2006. Amphibians and reptiles of British Columbia. Victoria, B.C.: Royal British Columbia Museum. 266 p.

Matthews, T.C. 1968. Some evolutionary aspects of color polymorphism in a population of boreal chorus frogs. Ph.D. Dissertation, Colorado State University, Fort Collins, Colorado. $111 \mathrm{pp}$.

Matthews, T.C. 1971. Genetic changes in a population of boreal chorus frogs (Pseudacris triseriata) polymorphic for color. American Midland Naturalist 85: 208-221.

Matthews, T.C. and D. Pettus. 1966. Color inheritance in Pseudacris triseriata. Herpetologica 22(4): 269-275.

*Matthews, W.L. 1979. Wibaux-Beach wildlife baseline study - nongame species. Bureau of Land Management, Miles City, MT. 93 p.

*Matthews, W.L. 1980. Wildlife of Prairie County Terry study area. Bureau of Land Management, Miles City, MT. 52 p.

*Matthews, W.L. 1981. Broadus-Pumpkin Creek baseline inventory - wildlife. Bureau of Land Management, Miles City, MT. 83 p.

*Maxell, B.A. 2000. Management of Montana's amphibians: a review of factors that may present a risk to population viability and accounts on the identification, distribution, taxonomy, habitat use, natural history, and the status and conservation of individual species. Report to USFS Region 1, Order Number 43-0343-0-0224. Missoula, MT: Wildlife Biology Program, University of Montana. $161 \mathrm{p}$.

*Maxell, B.A. 2004a. Preliminary report on amphibian and aquatic reptile inventories conducted in the West Boulder River area during summer 2003. Report to Region 1 Office of the U.S. Forest Service, and the Montana Department of Fish, Wildlife, and Parks. Missoula, MT: Montana Cooperative Wildlife Research Unit and Wildlife Biology Program, University of Montana. $27 \mathrm{p}$.

*Maxell, B.A. 2004b. Report on amphibian and aquatic reptile inventories conducted on and around the Beaverhead-Deerlodge National Forest 2001-2003. Report to Region 1 Office of the U.S. Forest Service, Beaverhead-Deerlodge National Forest, Montana Department of Fish, Wildlife, and Parks, Montana State Office of the Bureau of Land Management, and Montana Department of Environmental Quality. Missoula, MT: Montana Cooperative Wildlife Research Unit and Wildlife Biology Program, University of Montana. 260 p.

* Maxell, B.A. 2005. A review of monitoring methods and a multi-tiered scheme for assessing and monitoring the status of amphibians in Montana. Report to Montana Department of 
Environmental Quality, Region 1 Office of the U.S. Forest Service, Montana Department of Fish, Wildlife, and Parks, and Montana State Office of the Bureau of Land Management. Montana Natural Heritage Program, Helena, MT and Montana Cooperative Wildlife Research Unit and Wildlife Biology Program, University of Montana, Missoula, MT. 29 p. + Appendices.

*Maxell, B.A. 2006. Evaluation of Montana's lentic breeding amphibian survey methodology and variables correlated with species occupancy. Report to Montana Department of Environmental Quality. Montana Natural Heritage Program, Helena, MT and Montana Cooperative Wildlife Research Unit and Wildlife Biology Program, University of Montana, Missoula, MT. 49 p.

*Maxell, B.A. 2009. State-wide assessment of status, predicted distribution, and landscapelevel habitat suitability of amphibians and reptiles in Montana. Ph.D. Dissertation. Missoula, MT: Wildlife Biology Program, University of Montana. 294 p.

*Maxell, B.A. and D.G. Hokit. 1999. Amphibians and reptiles. pp. 2.1-2.30. In G. Joslin and H. Youmans, coordinators. Effects of recreation on Rocky Mountain wildlife: a review for Montana. Committee on Effects of Recreation on Wildlife, Montana Chapter of the Wildlife Society. 307 p.

*Maxell, B.A., J.K. Werner, P. Hendricks, and D. Flath. 2003. Herpetology in Montana: a history, status summary, checklists, dichotomous keys, accounts for native, potentially native, and exotic species, and indexed bibliography. Olympia, WA: Society for Northwestern Vertebrate Biology. Northwest Fauna 5: 1-138.

McAllister, C.T., S.E. Trauth, and L.D. Gage. 1995. Vertebrate fauna of abandoned mines at Gold Mine Springs, Independence County, Arkansas. Arkansas Academy of Science Proceedings 49: 184-187.

*McEneaney, T. and J. Jensen. 1974. The reptiles and amphibians of the Charles M. Russell National Wildlife Range - 1974. Charles M. Russell National Wildlife Refuge. Lewistown, MT. 3 p.

Mecham, J.S. 1965. Genetic relationships and reproductive isolation in southeastern frogs of the genera Pseudacris and Hyla. American Midland Naturalist 74: 269-308.

Miller, K. and G.C. Packard. 1974. Critical thermal maximum: ecotypic variation between montane and piedmont chorus frogs (Pseudacris triseriata, Hylidae). Experientia 30: 355356.

Miller, P.H. 1977. A demographic study of the chorus frog (Pseudacris triseriata). M.S. Thesis. Colorado State University, Fort Collins, Colorado. 79 p.

Mittleman, M.B. and H.T. Gier. 1942. Notes on leoparad frogs. Proceedings of the New England Zoological Club, 20: 7-15.

Mittleman, M.B. and J.C. List. 1953. The generic differentiation of the swamp treefrogs. Copeia 1953:80-83.

Moore, J.E. and E.H. Strickland. 1954. Notes on the food of three species of Alberta amphibians. American Midland Naturalist 52: 221-224.

Moriarty, E.C. and D.C. Cannatella. 2004. Phylogenetic relationships of the North American chorus frog (Pseudacris: Hylidae). Molecular Phylogenetics and Evolution 30:409-420.

*Mosimann, J.E. and G.B. Rabb. 1952. The herpetology of Tiber Reservoir area, Montana. Copeia 1952: 23-27.

*[OEAR] Olson Elliot and Associates Research. 1985. 1983-1984 Wildlife monitoring report for the CX Ranch project. Olson Elliot and Associates Research. Helena, MT. 
Pack, H.J. 1920. Eggs of the swamp tree frog. Copeia 1920(77): 7.

Packard, G.C. 1971. Oxygen consumption of montane and piedmont chorus frogs (Pseudacris triseriata): a study of evolutionary temperature compensation. Physiological Zoologist 44: 90-97.

*Patla, D.A. 1997a. Changes in a population of spotted frogs in Yellowstone National Park between 1953 and 1995: the effects of habitat modification. M.S. Thesis. Idaho State University, Pocatello, ID. 215 p.

*Patla, D.A. 1997b. Potential impacts to amphibians and reptiles from the proposed Canyon contractor camp. 10 May 1997 (Supplement, 12 January 1998). Greater Yellowstone Ecosystem Amphibian Survey and Monitoring Program, Herpetology Laboratory, Department of Biological Sciences, Idaho State University, Pocatello, ID. 16 p.

*Patla, D.A. 1998a. Amphibians and reptiles in the Old Faithful sewage treatment area. Report to Yellowstone Center for Resources, Yellowstone National Park. 10 September, 1998. Greater Yellowstone Ecosystem Amphibian Survey and Monitoring Program, Herpetology Laboratory, Department of Biological Sciences, Idaho State University, Pocatello, ID. 7 p.

*Patla, D.A. 1998b. Potential effects of native fish restoration projects on amphibians in Yellowstone National Park Part I. 20 November, 1998. Greater Yellowstone Ecosystem Amphibian Survey and Monitoring Program, Herpetology Laboratory, Department of Biological Sciences, Idaho State University, Pocatello, ID. 26 p.

*Patla, D.A. 1999a. Amphibians and reptiles of the Madison to Norris road improvement project area, Yellowstone National Park. 11 November, 1999. Greater Yellowstone Ecosystem Amphibian Survey and Monitoring Program, Herpetology Laboratory, Department of Biological Sciences, Idaho State University, Pocatello, ID. 17 p.

*Patla, D.A. 1999b. Amphibians and reptiles, Tower Junction to Canyon Village, Yellowstone National Park; addendum to previous report. 24 November, 1999. Greater Yellowstone Ecosystem Amphibian Survey and Monitoring Program, Herpetology Laboratory, Department of Biological Sciences, Idaho State University, Pocatello, ID. 10 p.

*Patla, D.A. 1999c. Amphibians and reptiles along the grand loop road in Yellowstone National Park: Canyon Junction to Fishing Bridge Junction. December 11, 1999. Greater Yellowstone Ecosystem Amphibian Survey and Monitoring Program, Herpetology Laboratory, Department of Biological Sciences, Idaho State University, Pocatello, ID. 24 p.

*Patla, D.A. 2000. Amphibians in potential native fish restoration areas, Yellowstone National Park Part II. 7 March, 2000. Greater Yellowstone Ecosystem Amphibian Survey and Monitoring Program, Herpetology Laboratory, Department of Biological Sciences, Idaho State University, Pocatello, ID. 22 p.

*Patla, D.A. and C.R. Peterson. 1996a. Amphibians and reptiles along the Grand Loop Highway in Yellowstone National Park: Tower Junction to Canyon Village. 24 February, 1996. Greater Yellowstone Ecosystem Amphibian Survey and Monitoring Program, Herpetology Laboratory, Department of Biological Sciences, Idaho State University, Pocatello, ID. 49 p.

*Patla, D.A. and C.R. Peterson. 1996b. Amphibians and reptiles along the Grand Loop Highway in Yellowstone National Park: Arnica Creek to Little Thumb Creek. 1 August, 1996. Greater Yellowstone Ecosystem Amphibian Survey and Monitoring Program, Herpetology Laboratory, Department of Biological Sciences, Idaho State University, Pocatello, ID. 35 p. 
*Patla, D.A. and C.R. Peterson. 1997. Amphibians and reptiles along the Grand Loop Highway in Yellowstone National Park: Mammoth Hot Springs to Norris Junction. 1 February, 1997. Greater Yellowstone Ecosystem Amphibian Survey and Monitoring Program, Herpetology Laboratory, Department of Biological Sciences, Idaho State University, Pocatello, ID. 60 p.

*Patla, D.A. and C.R. Peterson. 1998. Amphibians of the Greater Yellowstone Ecosystem. Natural Resource Conservation Cooperative News 11(Autumn 1998): 10-11.

*Patla, D.A. and C.R. Peterson. 1999. Are amphibians declining in Yellowstone National Park? Yellowstone Science 7(1): 2-11.

*Patla, D.A. and C.R. Peterson. 2001. Status and trends of amphibian populations in the Greater Yellowstone Ecosystem, progress report, February 2001. Greater Yellowstone Ecosystem Amphibian Survey and Monitoring Program, Herpetology Laboratory, Department of Biological Sciences, Idaho State University, Pocatello, ID. 8 p.

Pearman, P.B. 1995. Effects of pond size and consequent predator density on two species of tadpoles. Oecologia 102(1): 1-8.

*Peterson, C.R., C.J. Askey, and D.A. Patla. 1993. Amphibians and reptiles along the Grand Loop and Fountain Freight Roads between Madison Junction and Biscuit Basin in Yellowstone National Park. 26 July, 1993. Greater Yellowstone Ecosystem Amphibian Survey and Monitoring Program, Herpetology Laboratory, Department of Biological Sciences, Idaho State University, Pocatello, ID. 45 p.

*Peterson, C.R., E.D. Koch and P.S. Corn. 1992. Monitoring amphibian populations in Yellowstone and Grand Teton National Parks final report to University of Wyoming. National Park Service Research Center, Laramie, WY. 37 p.

*Peterson, C.R., D.A. Patla, and S.R. Sullivan. 1995. Amphibians and reptiles along the Grand Loop Highway in Yellowstone National Park: Madison Junction to Norris Campground. 7 July, 1995. Greater Yellowstone Ecosystem Amphibian Survey and Monitoring Program, Herpetology Laboratory, Department of Biological Sciences, Idaho State University, Pocatello, ID. 64 p.

*Pettus, D. and G.M. Angleton. 1967. Comparative reproductive biology of montane and piedmont chorus frogs. Evolution 21: 500-507.

Pettus, D. and A.W. Spencer. 1964. Size and metabolic differences in Pseudacris triseriata (Anura) from different elevations. Southwestern Naturalist 9: 20-26.

Pinder, A.W., K.B. Storey, and G.R. Ultsch. 1992. Estivation and hibernation. Pp. 250-274 in M.E. Feder and W.W. Burggren (eds.) Environmental physiology of the amphibians. University of Chicago, Illinois.

*Platz, J.E. 1989. Speciation within the chorus frog Pseudacris triseriata: morphometric and mating call analyses of the boreal and western subspecies. Copeia 1989: 704-712.

*Platz, J.E. and D.C. Forester. 1988. Geographic variation in mating call among the four subspecies of the chorus frog: Pseudacris triseriata (Wied). Copeia 1988(4): 1062-1066.

Platz, J.E. and A. Lathrop. 1993. Body size and age assessment among advertising male chorus frogs. Journal of Herpetology 27(1): 109-111.

*Powell, R., J.T. Collins, and E.D. Hooper, Jr. 1998. A key to amphibians and reptiles of the Continental United States and Canada. University Press of Kansas, Lawrence, KS. 131 p.

Powell, G.V.N., L.R. DeWeese, and T.G. Lamont. 1982. A field evaluation of frogs as a potential source of secondary organophosphorus insecticide poisoning. Canadian Journal of Zoology 60: 2233-2235. 
*[PRESI] Powder River Eagle Studies Incorporated. 1998a. Big Sky Mine 1997 wildlife monitoring studies. Powder River Eagle Studies Incorporated. Gillete, WY.

*[PRESI] Powder River Eagle Studies Incorporated. 1998b. Spring Creek Mine 1997 wildlife monitoring studies. Powder River Eagle Studies Incorporated. Gillete, WY.

Ralin, D.B. 1970. Genetic compatability and a phylogeny of the temperate North American hylid fauna. Ph.D. Dissertation. Austin, TX: University of Texas.

*Rauscher, R.L. 1998. Amphibian and reptile survey on selected Montana Bureau of Reclamation impoundments. Montana Department of Fish, Wildlife and Parks, Nongame Program, Bozeman, MT. 24 p.

*Reichel, J.D. 1995a. Preliminary amphibian and reptile survey of the Lewis and Clark National Forest: 1994. Montana Natural Heritage Program, Helena, MT. 92 p.

*Reichel, J.D. 1995b. Preliminary amphibian and reptile survey of the Sioux District of the Custer National Forest: 1994. Montana Natural Heritage Program, Helena, MT. 75 p.

*Reichel, J.D. 1996. Preliminary amphibian and reptile survey of the Helena National Forest: 1995. Montana Natural Heritage Program, Helena, MT. 87 p.

*Reichel, J.D. 1997. Amphibian, reptile and northern bog lemming survey on the Rocky Mountain Front: 1996. Montana Natural Heritage Program, Helena, MT. 81 p.

*Reichel, J.D. and D.L. Flath. 1995. Identification guide to the amphibians and reptiles of Montana. Montana Outdoors 26(3): 15-34.

Roberts, W. and V. Lewin. 1979. Habitat utilization and population densities of the amphibians of northeastern Alberta. Canadian Field Naturalist 93(2): 144-154.

Roble, S.M. 1985. Observations on satellite males in Hyla chrysoscelis, Hyla picta, and Pseudacris triseriata. Journal of Herpetology 19(3): 432-436.

*Roedel, M.D. and P. Hendricks. 1998a. Amphibian and reptile survey on the Bureau of Land Management Lewistown District: 1995-1998. Montana Natural Heritage Program, Helena, MT. $53 \mathrm{p}$.

*Roedel, M.D. and P. Hendricks. 1998b. Amphibian and reptile inventory on the Headwaters and Dillon Resource Areas in conjunction with Red Rocks Lakes National Wildlife Refuge: 1996-1998. Montana Natural Heritage Program, Helena, MT. 46 p.

Russell, A.P., and A.M. Bauer. 2000. The amphibians and reptiles of Alberta. Second Edition. Calgary, AB: University of Calgary Press. 279 p.

Sanders, H.D. 1970. Pesticide toxicities to tadpoles of thet western chorus frog (Pseudacris triseriata) and Fowler's toad (Bufo woodhousei fowleri). Copeia 1970: 246-251.

Schmidt, K.P., P.W. Series, and D.M. Smith. 1952. The relationships of the chorus frogs, Pseudacris nigrita feriarum and Pseudacris n. triseriata. American Midland Naturalist 38(1): 162-190.

Schueler, F.W. 1986. Range extensions for hylid frogs in Manitoba. Blue Jay 44(3): 168-173.

*Scow, K.L. 1980. Terrestrial wildlife survey American Colloid study area Phillips County, Montana. Western Technology and Engineering, Inc., Helena, MT.

*Sestrich, C. 2004. Hebgen Reservoir amphibian survey. USDA Forest Service Annual Progress Report to PPL Montana. 22p.

*Sestrich, C. 2007. 2006 Hebgen Reservoir amphibian survey. USDA Forest Service Annual Report to PPL Montana. West Yellowstone, MT: Gallatin National Forest, Hebgen Lake Ranger District. $75 \mathrm{p}$.

Skelly, D.K. 1995. A behavioral trade-off and its consequences for the distribution of Pseudacris treefrog larvae. Ecology 76(1): 150-164. 
Skelly, D.K. 1996. Pond drying, predators, and the distribution of Pseudacris tadpoles. Copeia 1996(3): 599-605.

*Skinner, M.P. 1924. The Yellowstone Nature Book. A.C. McClurg Company, Chicago, IL. $221 \mathrm{p}$.

Smith, D.C. 1983. Factors controlling tadpole populations of the chorus frog (Pseudacris triseriata) on Isle Royale, Michigan. Ecology 64(3): 501-510.

Smith, D.C. 1987. Adult recruitment in chorus frogs: effect of size and date at metamorphosis. Ecology 68(2): 344-350.

Smith, D.C. 1990. Population structure and competition among kin in the chorus frog (Pseudacris triseriata). Evolution 44(6): 1529-1541.

Smith, D.C. and J. Van Buskirk. 1995. Phenotypic design, plasticity, and ecological performance in two tadpole species. American Naturalist 145(2): 211-233.

*Smith, H.M. 1934. The amphibians of Kansas. American Midland Naturalist 15(4): 377-528.

Smith, H.M., G.A. Hammerson, D. Chiszar and C. Ramotnik. 1993b. Pseudacris triseriata (western chorus frog). Herpetological Review 24(4): 153.

Smith, H.M., M. Laverty, and D. Chiszar. 1995. Anura: Pseudacris triseriata (western chorus frog). Herpetological Review 26(4): 208.

*Smith, P.W. 1956. The status, correct name, and geographic range of the boreal chorus frog. Proceedings of the Biological Society of Washington 69: 169-176.

Smith, P.W. and D.M. Smith. 1952. The relationship of the chorus frogs, Pseudacris nigrita feriarum and Pseudacris n. triseriata. American Midland Naturalist 48: 165-180.

Spencer, A.W. 1964a. An unusual phoretic host for the clam Psidium. Journal of the ColoradoWyoming Academy of Science 5(5): 43-44.

Spencer, A.W. 1964b. Movement in a population of Pseudacris triseriata. Journal of the Colorado-Wyoming Academy of Science 5(5): 44.

Spencer, A.W. 1964c. The relationship of dispersal and migration to gene flow in the boreal chorus frog. Ph.D. Dissertation. Colorado State University, Fort Collins, Colorado.

Spencer, A.W. 1971. Boreal chorus frogs (Pseudacris triseriata) breeding in the alpine in southwestern Colorado. Arctic and Alpine Research 3(4): 353.

*Stebbins, R.C. 2003. A field guide to western reptiles and amphibians. 3rd edition. New York, NY: Houghton Mifflin Co. 533 p.

*Sullivan, S.R. and C.R. Peterson. 1996. Amphibians and reptiles along the highway in Yellowstone National Park: Tower Junction to the Northeast Entrance. 25 February, 1996. Greater Yellowstone Ecosystem Amphibian Survey and Monitoring Program, Herpetology Laboratory, Department of Biological Sciences, Idaho State University, Pocatello, ID. 60 p.

Swanson, D.L., B.M. Graves and K.L. Koster. 1996. Freezing tolerance/intolerance and cryoprotectant synthesis in terrestrially overwintering anurans in the Great Plains, USA. Journal of Comparative Physiology B Biochemistry, Systematics and Environmental Physiology 166(2): 110-119.

*Thompson, L.S. and P.S. Nichols. 1982. Circle West wildlife monitoring study; fourth annual report for period March 1, 1981 - May 31, 1982. Circle West Technical Report No. 10. Montana Department of Natural Resources and Conservation, Helena, MT.

*Timken, R. No Date. Amphibians and reptiles of the Beaverhead National Forest. Western Montana College, Dillon, MT. 16 p.

Tordoff, W., III. 1969. Gene frequency differences among semi-isolated proximate populations of chorus forgs (Pseudacris). Journal of Herpetology 3: 194. 
Tordoff, W., III. 1980. Selective predation of gray jays (Perisoreus canadensis) upon boreal chorus frogs (Pseudacris triseriata). Evolution 34(5): 1004-1008.

Tordoff, W., III., and D. Pettus. 1977. Temporal stability of phenotypic frequencies in Pseudacris triseriata (Amphibia, Anura, Hylidae). Journal of Herpetology 11(2): 161-168.

Tordoff, W.D., D. Pettus, and T.C. Matthews. 1976. Microgeographic variation in gene frequency in Pseudacris triseriata (Amphibia, Anura, Hylidae). Journal of Herpetology 10(1): 35-40.

Travis, J. 1981a. Control of larval growth variation in a population of Pseudacris triseriata (Anura: Hylidae). Evolution 35(3): 423-432.

*Turner, F.B. 1951. A checklist of the reptiles and amphibians of Yellowstone National Park with incidental notes. Yellowstone Nature Notes 25(3): 25-29.

*Turner, F.B. 1952. Peculiar aggregations of toadlets on Alum Creek. Yellowstone Nature Notes 26(5): 57-58.

*Turner, F.B. 1955. Reptiles and amphibians of Yellowstone National Park. Yellowstone Interpretive Series No. 5. Yellowstone Library and Museum Association. Yellowstone National Park, WY. 40 p.

*Turner, F.B. 1957. The ecology and morphology of Rana pretiosa pretiosa in Yellowstone Park, Wyoming. Ph.D. Dissertation, University of California, Berkeley, CA. 252 p.

*Turner, F.B. 1960. Population structure and dynamics of the western spotted frog, Rana p. pretiosa Baird and Girard, in Yellowstone Park, Wyoming. Ecological Monographs 30(3): 251-278.

Ubelaker, J.E., D.W. Duszynski, and D.L. Beaver. 1967. Occurrence of the trematode, Glypthelmins pennsylvaniensis Cheng, 1961, in chorus frogs (Pseudacris triseriata) in Colorado. Bulletin of the Wildlife Disease Association 3: 177.

*Van Kirk, R., L. Benjamin, and D. Patla. 2000. Riparian area assessment and amphibian status in the watersheds of the Greater Yellowstone Ecosystem. Greater Yellowstone Coalition, Bozeman, MT. $102 \mathrm{p}$.

*Vitt, L.J., J.P. Caldwell, and D.B. Shepard. 2005. Inventory of amphibians and reptiles in the Billings Field Office Region, Montana. Sam Noble Oklahoma Museum of Natural History and Department of Zoology, University of Oklahoma, Norman, OK. 33 pp.

*[VTNWI] VTN Wyoming Incorporated. No Date. Second year's analysis of terrestrial wildlife on proposed mine access and railroad routes in southern Montana and northern Wyoming, March 1979 - February 1980. VTN Wyoming Incorporated. Sheridan, WY. 62 p.

*Waage, B.C. 1998. Western Energy Company Rosebud Mine 1997 annual wildlife monitoring report December 1, 1996 to November 30, 1997 survey period. Western Energy Company, Colstrip, MT.

Wassersug, R.J. and D.G. Sperry. 1977. The relationship of locomotion to differential predation on Pseudacris triseriata (Anura: Hylidae). Ecology 58: 830-839.

*Werner, J.K., B.A. Maxell, P. Hendricks, and D. Flath. 2004. Amphibians and reptiles of Montana. Missoula, MT: Mountain Press Publishing Company. 262p.

*[WESCO] Western Ecological Services Company. 1983a. Wildlife inventory of the Knowlton known recoverable coal resource area, Montana. Western Ecological Services Company, Novato, CA. 107 p.

*[WESCO] Western Ecological Services Company. 1983b. Wildlife inventory of the Southwest Circle known recoverable coal resource area, Montana. Western Ecological Services Company, Novato, CA. 131 p. 
*[WESTECH] Western Technology and Engineering Incorporated. 1991. Update on the wildlife resources of the Little Rocky Mountains environmental study area. Western Technology and Engineering, Inc., Helena, MT.

*[WESTECH] Western Technology and Engineering Incorporated. 1998. Wildlife monitoring Absaloka Mine area 1997. Western Technology and Engineering, Inc., Helena, MT.

Whitaker, J.A. 1971. A study of the western chorus frog (Pseudacris triseriata) in Vigo County, Indiana. Journal of Herpetology 5(3-4): 127-150.

*Wied, M.P. 1843. Travels in the interior of North America by Maximilian, Prince of Wied. With numerous engravings on wood, and a large map. Translated from the German by H. Evans Lloyd. To accompany the original series of eighty-one elaborately-coloured plates. Size, imperial folio. Ackerman and Co., London, England. 520 p.

*Wied, M.P. 1865. Verzeichniss der reptilien, welche auf einer reise in nordlichen America beobachtet wurden, von Maximilian, Prinzen zu Wied. Eigengangen bei der Akademie am 1, Juni 1865. Druck von E. Blochmann und Sohn, Dresden, Germany. 141 p.

Wied-Neuwied, A.P.M. 1838. Reise Nord-American, Vol. 1, Pt. 4, p. 249.

Wilson, A.K. 1994. Pseudacris triseriata triseriata (western chorus frog). Herpetological Review 25(4): 161.

Youngstrom, K.H. and H.M. Smith. 1936. Description of the larvae of Pseudacris triseriata and Bufo w. woodhousii. American Midland Naturalist 17: 629-633. 
Up-to-date distribution and status information can be found on the Montana Natural Heritage Program's TRACKER website at http://mtnhp.org

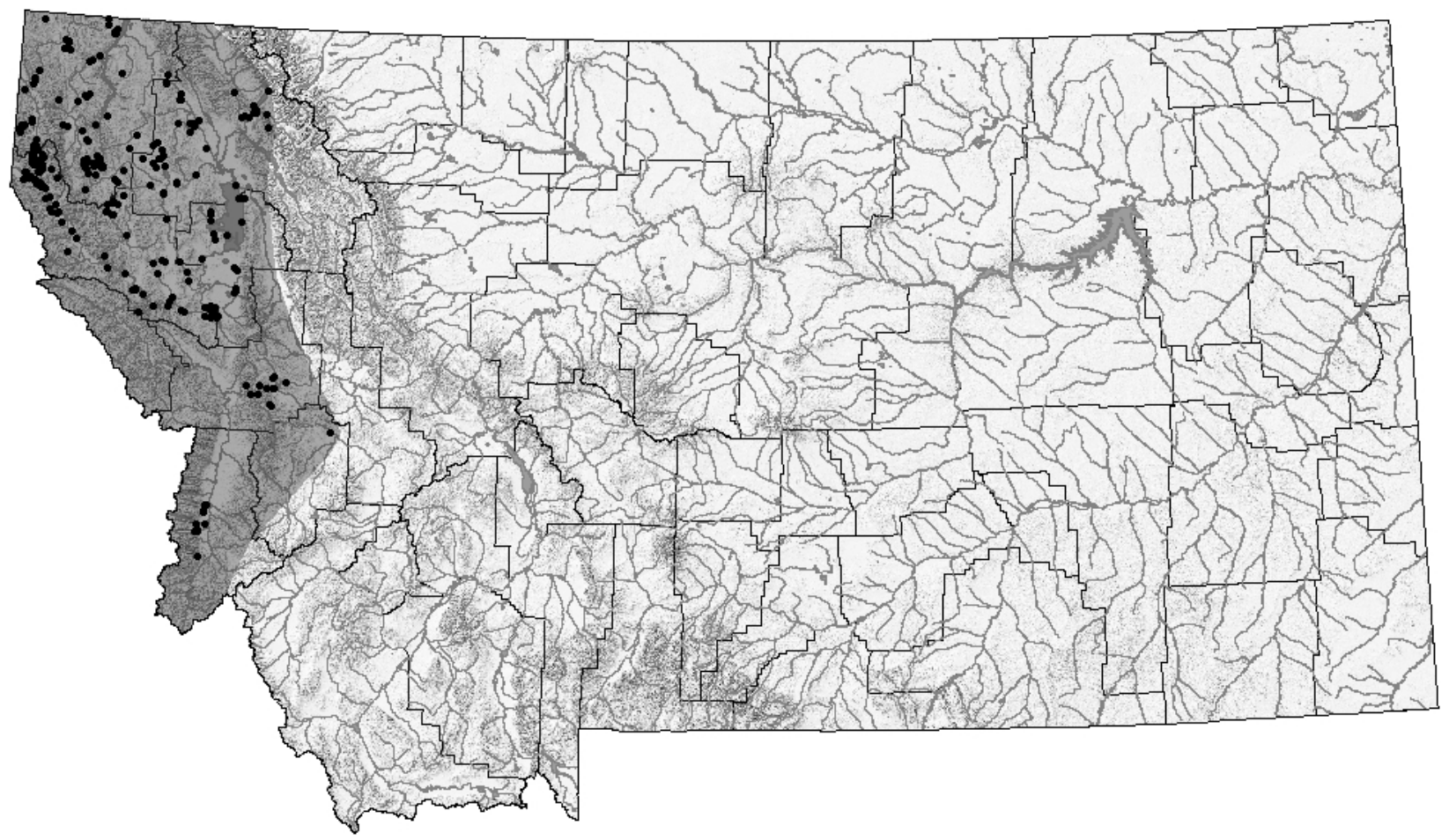

Distribution/Taxonomy

There is currently some debate as to whether the Pacific treefrog should be placed in genus Hyla or Pseudacris (Hedges 1986; Cocroft 1994). However, regardless of the generic name, a single distinct species is recognized as ranging from southern British Columbia through the Pacific Northwest and western Great Basin to the tip of Baja Mexico at elevations up to 3,536 M $(11,600 \mathrm{ft})$ (Stebbins 2003). In Montana they have been documented with a more or less continuous distribution north of the Missoula and Mineral County lines and west of the Mission, Swan, and Livingston Ranges. In addition isolated populations are present in the southern Bitterroot Valley near Lake Como, and at several locations along the Blackfoot River between Missoula and the junction of the Clearwater River and on the upper Clark Fork River between Missoula and Drummond.

Maximum Elevation

$1,810 \mathrm{~m}(5,940 \mathrm{ft})$ at headwaters of Skid Creek between Lydia Mountain and Sutton Mountain in northeast Lincoln County (Andy Brown and Tomi Sugahara; MTNHP 2008).

\section{Identification}

Eggs:

Although individual females are known to lay 500 to 750 eggs (Smith 1940), eggs are usually deposited in a number of clutches a few centimeters in size containing 18-119 eggs ( $\mathrm{X}=68, \mathrm{SD}$ $=26.5, \mathrm{~N}=25$ across 4 sites in northwest Montana) (Werner et al. 1998; Bryce Maxell, pers. obs.). Each ovum is dark gray to tan above, white to cream below, and is surrounded by two jelly layers (Gaudin 1965; Bryce Maxell, pers. obs.). Ovum diameters are approximately 1.3 
$\mathrm{mm}$, but total egg diameters, including the two jelly layers are 4.6 to $6.7 \mathrm{~mm}$ (Gaudin 1965).

\section{Larvae:}

Eyes are outside the outline of the body when viewed from above (Bryce Maxell, pers. obs.). Tail musculature and dorsal portion of the body are tan with brown mottling and metallic gold flecks. Irridescent copper color laterally and a clear to whitish color ventrally (Bryce Maxell, pers. obs.). The dorsal and ventral tail fins are clear with numerous brown and metallic gold flecks (Bryce Maxell, pers. obs.). TL of 8-55 mm (Bryce Maxell, pers. obs.).

Juveniles and Adults:

Toes are long, have large disks or pads at the end, and there is very little webbing. Virtually all individuals have a black stripe extending from the snout through the nostril, eye, and tympanum to just above the front leg (Bryce Maxell, pers. obs.). Dorsal color is commonly tan mottled with dark brown spots, but individuals that are solid green or green with black spots are also found (Schaub and Larsen 1978; Bryce Maxell, pers. obs.). A "Y" shaped brown patch is usually present on the brown color morphs (Bryce Maxell, pers. obs.). Ventral color is creamy white. SVL of 12-49 mm (Gaudin 1965; Werner et al. 1998).

Similar Species:

With the exception of boreal chorus frogs, adults of all the other frogs and toads in Montana have webbing between their hind toes. With the exception of boreal chorus frogs, the eyes of the tadpoles of all the other frogs and toads in Montana do not stick out beyond the body outline when viewed from above. The geographic range of boreal chorus frogs does not overlap with the geographic range of Pacific treefrogs (see sections on the distribution).

\section{Habitat Use/Natural History}

Usually not found far from forested habitats (Bryce Maxell, pers. obs.). Adults are freeze tolerant and are presumed to overwinter in underground rodent burrows, underneath thick vegetation or debris or in the crevices of rocks and logs (Brattstrom and Warren 1955; Croes and Thomas 2000). Adults and juveniles feed on a variety of arthropods, but mostly rely on smaller insects (Brattstrom and Warren 1955; Johnson and Bury 1965). Breeding takes place in April and May in shallow, warm, fishless waters which may or may not have emergent vegetation (Bryce Maxell, pers. obs.). Females deposit eggs on emergent vegetation at depths usually less than 20 centimeters in ponds that do not have a closed canopy (Bryce Maxell, pers. obs.) Eggs usually hatch in 10 to 14 days and tadpoles metamorphose in two or three months during mid summer (Bryce Maxell, pers. obs.). Tadpoles feed on algae, diatoms, detritus, and pollen (Kupferberg et al. 1994; Wagner 1986). Individuals are known to use terrestrial habitats several hundred meters away from their breeding pond and are known to travel as much as 1,000 meters in order to return to a breeding site they have been removed from (Brattstrom and Warren 1955; Jameson 1956, 1957). In northwestern Montana an individual was found at 1,456 meters $(4,774$ ft) elevation more than 3.25 kilometers from the nearest breeding site (Bryce Maxell, pers. obs.).

\section{$\underline{\text { Status and Conservation }}$}

Pacific treefrogs are commonly heard calling, and larvae are commonly found, in standing water bodies at lower elevations north of the Missoula and Mineral County lines and west of the Mission, Swan, and Livingston Mountain Ranges. However, they appear to be present in only a 
few isolated populations at the southern end of Bitterroot Valley near Lake Como, at several locations around the Blackfoot River between Missoula and the junction of the Clearwater River and around the upper Clark Fork River between Missoula and Drummond. Risk factors relevant to the viability of populations of this species are likely to include all the general risk factors described above with the exception of harvest and commerce. Individual studies that specifically identify risk factors or other issues relevant to the conservation of Pacific treefrogs include the following. (1) The eggs (Licht 1969) and larvae (Bryce Maxell, pers. obs.) of Pacific treefrogs are readily eaten by a number of trout species and fish may be expected to exclude treefrogs from habitats they occupy through predation. In the Palouse region of northern Idaho Monello and Wright (1999) found the presence of Pacific treefrogs to be highly negatively correlated with the presence of a variety of fish species, including largemouth bass, bluegill, channel catfish, and goldfish. Bradford (1989) found that Pacific treefrogs were not found in any of the 123 lakes where trout have been introduced for 173 lakes examined in the Sierra Nevada Mountains. Similarly, Yoon (1977) found that meadow pools occupied by trout were rarely if ever occupied by Pacific treefrogs or other amphibians in the Sierra Nevada. (2) Jameson (1956) reported that he felt that exotic bullfrogs had excluded Pacific treefrogs from several breeding sites and found that where bullfrogs were common in the Willamette valley that treefrog choruses, egg masses, or larvae were never found. Kupferberg (1993) also documented the decline of Pacific treefrog populations behind the invasion front of exotic bullfrogs. Kupferberg (1997) found that bullfrogs significantly reduced growth and larval survival of treefrogs. Finally, Kupferberg (1994) observed that when bullfrogs replaced native treefrogs, native garter snakes were not able to forage on the larger bullfrog tadpoles as efficiently as they had on the native treefrogs. (3) Johnson (1980) found that when three week old Pacific treefrog tadpoles were exposed to the insecticides temephos, fenthion, methyl parathion, chlorpyrifos, and malathion for 24 hours at lower concentrations than are applied in the field for mosquito control they became thermally stressed at lower temperatures than tadpoles in a control group. Furthermore, tadpoles exposed to methyl parathion at $100 \mathrm{ppb}$ or malathion at $500 \mathrm{ppb}$ reduced their activity levels compared to tadpoles in the control group, possibly reducing their foraging efficiency and growth and increasing the time required to reach metamorphosis. Also, as has been noted by other studies, Schuytema et al. (1995) found that two pesticides containing the active ingredient Guthion had very different effects on Pacific treefrog larvae because of the presence of different "inactive" ingredients in the pesticide formulation. Tadpoles were 5 times more sensitive to one formulation than another because of the differences in "inactive" ingredients. The relationship of the inactive and active ingredients in these pesticides to commonly applied pesticides in Montana is not known, but it is likely that both pesticides and herbicides may represent lethal and/or sublethal threats to Pacific treefrog populations. (4) A number of studies in the western United States have reported rear limb deformities in Pacific treefrogs (Hebard and Brunson 1963; Reynolds and Stephens 1984; Johnson 1999). Hebard and Brunson (1963) found rear limb deformities in 20-30 percent of metamorphosing frogs at a pond in the Flathead Valley in the late 1950s and early 1960s. More recently hind limb deformities have been found at the same site and appear to be the result of infection with the nematode parasite Ribeiroia which has been found to be responsible for limb deformites in a number of amphibians throughout the western United States (Johnson 1999; Pieter Johnson, Claremont Mckenna College, pers. comm.). Deformities apparently result from the amphibian larvae's response to the mechanical perturbation of the cysts the parasites form after they burrow through the larvae's body wall because mechanical implants of resin beads result in almost identical deformities (Sessions and 
Ruth 1990; Johnson et al. 1999) Animals that breed in ponds, including the one reported by Hebard and Brunson (1963) and recently revisited, which are eutrophic as a result of organic inputs from livestock or agricultural activities may support high numbers of planorbid snails (the first host of Ribeiroia), thereby increasing the rate of parasite infection and deformities (Johnson 1999). (5) Several studies have found that Pacific treefrog embryos seem to be particulary resilient to exposure to ambient and enhanced UV-B radiation levels, apparently as a result of the presence of high levels of photolyase, and enzyme that is known to repair UV-B damage to DNA (Blaustein et al. 1994; Kiesecker and Blaustein 1995; Davis et al. 1996; Hays et al. 1996; Ovaska 1997; Anzalone et al. 1998; Blaustein et al. 1998). However, lab studies have shown that tadpoles and metamorphs that are chronicly exposed to enhanced UV radiation have deformities and suffer higher mortality rates than those shielded from UV radiation or exposed to ambient levels of UV radiation (Hays et al. 1996; Ovaska 1997). (6) Pacific treefrog embryos are apparently less likely than other amphibians to be infected and suffer mortality from the fungus Saprolegnia ferox because of their habit of laying eggs in small isolated clumps rather than in communal masses (Kiesecker and Blaustein 1997). (7) Bradford et al. (1994) found that the $\mathrm{LC}_{50} \mathrm{pH}$ for Pacific treefrog embryos and hatchlings exposed for 7 days averaged 4.3 and that $\mathrm{pH}$ levels greater than or equal to 5.0 had no significant lethal or sublethal effects. (8) Weitzel and Panik (1993) reported that feral house cats either predated or mauled a number of Pacific treefrogs.

$\underline{\text { Research and Management Suggestions }}$

1. See research and management suggestions under all of the general risk factors described above with the exception of harvest and commerce.

2. Additional surveys are needed in order to determine whether they are present in the valley of the North Fork of the Flathead River, in the Whitefish Mountain Range, or in the Garnet Mountain Range between populations that have been documented on the Blackfoot and upper Clark Fork Rivers.

3. Government personnel and private citizens shoud be educated on the impacts of exotic warm water fishes and bullfrogs on Pacific treefrogs and other native amphibians and should be given suggestions on how to promote the persistence of native amphibians.

4. Removal of exotic warm water fishes and/or bullfrogs should be considered in areas that appear to be key habitats that ensure the survival of local sets of populations. This may particularly important for isolated populations at the southern end of the Bitterroot Valley and populations just east of Missoula. If fish removal can not be accomplished the impacts of these exotic species may be mitigated by constructing ephemeral water bodies that treefrogs can breed and metamorphose in, but exotic fish and bullfrogs cannot overwinter in.

5. Until the lethal and sublethal impacts of commonly used fertilizers, herbicides, and pesticides on all amphibian life history stages present in an area are examined they should not be applied within 100 meters of waterbodies or wetlands.

The population dynamics, habitat use, migration distance, and dispersal distance of adults are almost completely unknown in the region and should be investigated relative to timber harvest and fire management activities.

Bibliography *indicates an article with information specific to Montana

Allan, D.M. 1973. Some relationships of vocalization to behavior in the Pacific treefrog (Hyla regilla). Herpetologica 29(4): 366-371. 
*Anderson, M.E. 1977. Aspects of the ecology of two sympatric species of Thamnophis and heavy metal accumulation with the species. M.S. Thesis, University of Montana. Missoula, MT. 147 pp.

Anzalone, C.R., L.B. Kats and M.S. Gordon. 1998. Effects of solar UV-B radiation on embryonic development in Hyla cadaverina, Hyla regilla, and Taricha torosa. Conservation Biology 12: 646-653.

Arnold, S.J. 1986. Life history notes. Hyla regilla (Pacific treefrog). Herpetological Review 17(2): 44.

Awbrey, F.T. 1978. Social interaction among chorusing Pacific tree frogs (Hyla regilla). Copeia 1978(2): 208-214.

Babbitt, K.J., and G.W. Tanner. 1997. Effects of cover and predator identity on predation of Hyla squirrella tadpoles. Journal of Herpetology 52: 301-313.

Ball, R.W. and D.L. Jameson. 1966. Premating isolating mechanisms in sympatric and allopatric Hyla regilla and Hyla californiae. Evolution 20: 533-551.

Banta, B.H. 1961. On the concurrence of Hyla regilla in the Lower Colorado River, Clark County, Nevada. Herpetologica 17: 106-108.

Barber, P.H. 1999a. Patterns of gene flow and population genetic structure in the canyon treefrog, Hyla arenicolor (Cope). Molecular Ecology 8: 563-576.

Barber, P.H. 1999b. Phylogeography of the canyon treefrog, Hyla arenicolor (Cope) based on mitochondrial DNA sequence data. Molecular Ecology 8: 547-562.

Baumann, M. 1993. The Pacific treefrog (Hyla regilla). Vivarium 4(4): 32-33.

Blair, W.F. 1958. Call structure and species groups in U.S. treefrogs (Hyla). Southwestern Naturalist 5: 129-135.

*Blaustein, A.R., J.J. Beatty, H. Deanna, and R.M. Storm. 1995. The biology of amphibians and reptiles in old-growth forests in the Pacific Northwest. General Technical Report PNWGTR-337. Portland, OR: U.S. Department of Agriculture, Forest Service, Pacific Northwest Research Station. 98 p.

Blaustein, A.R., J.M. Kiesecker, D.P. Chivers, D.G. Hokit, A. Marco, L.K. Belden, and A. Hatch. 1998. Effects of ultraviolet radiation on amphibians: field experiments. American Zoologist 38: 799-812.

Blaustein, A.R., P.D. Hoffman, D.G. Hokit, J.M. Kiesecker, S.C. Walls, and J.B. Hays. 1994. UV repair and resistance to solar UV-B in amphibian eggs: a link to population declines? Proceedings of the National Academy of Sciences 91: 1791-1795.

*Boundy, J. 2001. Herpetofaunal surveys in the Clark Fork Valley region, Montana. Herpetological Natural History 8: 15-26.

Bowerman, J. and P.T.J. Johnson. 2003. Timing of trematode-related malformations in Oregon spotted frog and Pacific treefrogs. Northwestern Naturalist 84:142-145.

Bradford, D.F. 1989. Allotopic distribution of native frogs and introduced fishes in high Sierra Nevada lakes of California: Implication of the negative effect of fish introductions. Copeia 1989(3): 775-778.

Bradford, D.F., D.M. Graber, and F. Tabatabai. 1994. Population declines of the native frog, Rana muscosa, in Sequoia and Kings Canyon National Parks, California. Southwestern Naturalist 39(4): 323-327.

Bradford, D.F., C. Swanson, and M.S. Gordon. 1994. Effects of low $\mathrm{pH}$ and aluminum on amphibians at high elevation in Sierra Nevada, California. Canadian Journal of Zoology 72: 1272-1279. 
Brattstrom, B.H. and J.W. Warren. 1955. Observations on the ecology and behavior of the Pacific treefrog (Hyla regilla). Copeia 1955(3): 181-191.

Brenowitz, E.A. 1989. Neighbor call amplitude influences aggressive behavior and intermale spacing in choruses of the Pacific treefrog (Hyla regilla). Ethology 83(1): 69-79.

Brenowitz, E.A. and G.J. Rose. 1994. Behavioural plasticity mediates aggression in choruses of the Pacific treefrog. Animal Behaviour 47: 633-641.

Bridges, C.M. 1999. Effects of a pesticide on tadpole activity and predator avoidance behavior. Journal of Herpetology 33(2): 303-306.

Bronmark C. and P. Edenhamn. 1994. Does the presence of fish affect the distribution of tree frogs (Hyla arborea)? Conservation Biology 8(3): 841-845.

Brown, H.A. 1975. Embryonic temperature adaptations of the Pacific treefrog (Hyla regilla). Comparative Biochemistry and Physiology 51A: 863-873.

*Brunson, R.B. 1955. Check list of the amphibians and reptiles of Montana. Proceedings of the Montana Academy of Sciences 15: 27-29.

*Brunson, R.B. and H.A. Demaree. 1951. The herpetology of the Mission Mountains, Montana. Copeia 1951: 306-308.

Buchan, A., J. Charbonneau, K. Johnson, T. Englund, L. Sun, and S. Wagner. 2005. Project croak!: Balancing selection for color change in Pseudacris regilla--"It ain't easy bein' green". Abstract. Northwestern Naturalist 86:86.

Buchan, A., L. Sun, and R.S. Wagner. 2004. Seasonal demography as a consequence of metabolism, behavior, and color morphology in Pseudacris regilla. Abstract. Northwestern Naturalist 85:69.

Buchanan, B.W. 1993. Effects of enhanced lighting on the behavior of noctural frogs. Animal Behaviour. 45: 893-899.

Caldwell, J.P. 1987. Demography and life history of two species of chorus frogs (Anura: Hylidae) in South Carolina. Copeia 1987: 114-127.

Calhoun, R.E. and D.L. Jameson. 1970. Canonical correlation between variation in weather and variation in size in the Pacific tree frog, Hyla regilla, in southern California. Copeia 1970: 124-134.

Call, D.R., and J.G. Hallett. 1998. PCR primers for microsatellite loci in the anurans Rana luteiventris and Hyla regilla. Molecular Ecology 7: 1083-1090.

Case, S.M., P.G. Haneline, and M.F. Smith. 1975. Protein variation in several species of Hyla. Systematic Zoology 24: 281-295.

*Claussen, D.L. 1971. A comparative study of the thermal and water relations of the tailed frog, Ascaphus truei and the Pacific treefrog, Hyla regilla. Ph.D. Dissertation. Missoula, MT: University of Montana. $103 \mathrm{p}$.

*Claussen, D.L. 1973a. The thermal relations of the tailed frog (Ascaphus truei) and the Pacific treefrog (Hyla regilla). Comparative Biochemistry and Physiology 44a: 137-153.

*Claussen, D.L. 1973b. The water relations of the tailed frog, Ascaphus truei, and the Pacific treefrog, Hyla regilla. Comparative Biochemistry and Physiology. 44A: 155-171.

Cocroft, R.B. 1994. A cladistic analysis of chorus frog phylogeny (Hylidae: Pseudacris). Herpetologica 50(4): 420-437.

*Cope, E.D. 1875. Check-list of North American Batrachia and Reptilia; with a systematic list of the higher groups, and an essay on geographical distribution. U.S. National Museum Bulletin 1(1): 1-104. 
Corkran, C.C. and C. Thoms. 2006. Amphibians of Oregon, Washington, and British Columbia. $2^{\text {nd }}$ Edition. Vancouver, B.C.: Lone Pine Publishing. 176 p.

Croes, S.A. and R.E. Thomas. 2000. Freeze tolerance and cryoprotectant synthesis of the Pacific tree frog (Hyla regilla). Copeia 2000(3): 863-868.

Crump, M.L. 1984a. Intraclutch egg size variability in Hyla crucifer (Anura: Hylidae). Copeia 1984: 302-308.

Crump, M.L. 1984b. Ontogenetic changes in vulnerability to predation in tadpoles of Hyla pseudopuma. Herpetologica 40: 265-271.

Cunningham, J.D. and D.P. Mullally. 1956. Thermal factors in the ecology of the Pacific treefrog. Herpetologica 12: 68-79.

*Curtis, S. 1994. The big sleep. Montana Outdoors 25(6): 2-7.

Da Silva, H.R. 1997. Two character states new for hylines and the taxonomy of the genus Pseudacris. Journal of Herpetology 31(4): 609-613.

Davis, T.M., I.N. Flamarique, and K. Ovaska. 2000. Effects of UV-B on amphibian development: embryonic and larval survival of Hyla regilla and Rana pretiosa. Froglog 16: 3.

De Vito, J., D.P. Chivers, J.M. Kiesecker, L.K. Belden, and A.R. Blaustein. 1999. Effects of snake predation on aggregation and metamorphosis of Pacific treefrog (Hyla regilla) larvae. Journal of Herpetology 33(3): 504-507.

Duellman, W. 1970. The hylid frogs of Middle America Volume 2. Monograph of the Museum of Natural History, University of Kansas 1: 484-493.

Eakin, R.M. 1947. Stages in the normal development of Hyla regilla. University of California Publications in Zoology 51: 245-257.

Farrell, M.P. and J.A. MacMahon. 1969. An eco-physiological study of water economy in eight species of tree frogs (Hylidae). Herpetologica 25: 279-294.

Feaver, E.P. 1971. Breeding pool selection and larval mortality of three California amphibians: Ambystoma tigrinum californiense Gray, Hyla regilla Baird and Girard, and Scaphiopus hammondii hammondii Girard. M.S. Thesis, California State University at Fresno. 58p.

Foster, W.A. 1967. Chorus structure and vocal response in the Pacific treefrog (Hyla regilla). Herpetologica 23(2): 100-104.

*Franz, R. 1971. Notes on the distribution and ecology of the herpetofauna of northwestern Montana. Bulletin of the Maryland Herpetological Society 7: 1-10.

Friedl, T.W.P. and G.M. Klump. 1997. Some aspects of population biology in the European treefrog (Hyla arborea). Herpetologica 53(3): 321-330.

Gardner, J.D. 1995. Anura: Pseudacris regilla (Pacific Chorus Frog). Reproduction. Herpetological Review 26(1): 32.

Gaudin, A.J. 1965. Larval development of the tree frogs (Hyla regilla) and (Hyla californiae). Herpetologica 21(2): 117-130.

Gaudin, A.J. 1974. An osteological analysis of Holarctic tree frogs, family Hylidae. Journal of Herpetology 8(2): 141-152.

Gerlanc, N.M. and G.A. Kaufman. 2005. Habitat of origin and changes in water chemistry influence development of western chorus frogs. Journal of Herpetology 39(2):254-265.

Gildart, R.C. and J. Wassink. 1982. Montana wildlife. Montana Geographic Series. Number three. Montana Magazine, Inc. Helena, MT. 128 p. 
Goldberg, S.R. and C.R. Bursey. 2001. Persistence of the nematode, Oswaldocruzia pipiens (Molineidae) in the Pacific treefrog (Hyla regilla) (Hylidae) from California. Bulletin of the Southern California Academy of Sciences 100(1): 44-50.

Goldberg, S.R., C.R. Bursey, and E.W.A. Gergus. 2001. Helminth communities of subpopulations of the pacific treefrog (Hyla regilla) (Hylidae), from Baja California, Mexico. Southwestern Naturalist 46(2): 223-229.

Goodsell, J.A., and L.B. Kats. 1999. Effect of introduced mosquitofish on Pacific treefrogs and the role of alternative prey. Conservation Biology 13(4): 921-924.

Govindarajulu, P. 2000. Estimation of daily survival rates of Hyla regilla tadpoles in the wild. Northwestern Naturalist 81(2):74.

Hansen, L.J., D.L. Fabacher, R. Calfee. 2002. The role of the egg jelly coat in protecting Hyla regilla and Bufo canorus embryos form ultraviolet B radiation during development. Environmental Science and Pollution Research 9(6): 412-416.

*Hart, M.M., W.A. Williams, P.C. Thornton, K.P. McLaughlin, C.M. Tobalske, B.A. Maxell, D.P. Hendricks, C.R. Peterson, and R.L. Redmond. 1998. Montana atlas of terrestrial vertebrates. Montana Cooperative Wildlife Research Unit, University of Montana, Missoula, MT. $1302 \mathrm{p}$.

Hays, J.B., A.R. Blaustein, J.M. Kiesecker, P.D. Hoffman, I. Pandelova, D. Coyle, and T. Richardson. 1996. Developmental responses of amphibians to solar and artificial UVB sources: a comparative study. Photochemistry and Photobiology 64(3): 449-456.

*Hebard, W.B. and R.B. Brunson. 1963. Hind limb anomalies of a western Montana population of the pacific tree frog, Hyla regilla. Copeia 1963: 570-572.

Hedges, S.B. 1986. An electrophoretic analysis of Holarctic Hylid frog evolution. Systematic Zoology 35(1): 1-21.

*Hendricks, P. 2000. Amphibian and reptile survey of the Thompson Chain of Lakes. A report to the Montana Department of Fish, Wildlife, and Parks. Montana Natural Heritage Program, Helena, MT. 15 p.

*Hendricks, P. and J.D. Reichel. 1996. Amphibian and reptile survey of the Bitterroot National Forest: 1995. Montana Natural Heritage Program, Helena, MT. 95 p.

Hess, J.B. 1969. Genetic differences in duration of breeding season in chorus frogs. Journal of Herpetology 3: 194.

*Hossack, B., D. Pilliod, and S. Corn. 2001b. Preliminary amphibian surveys of the National Bison Range, Lost Trail National Wildife Refuge, and Swan River National Wildlife Refuge: 2001. USGS Northern Rocky Mountain Science Center, Aldo Leopold Wilderness Research Institute, Missoula, MT. 15 p.

Jameson, D.L. 1956. Growth, dispersal and survival of the Pacific tree frog. Copeia(1) 1956: 25-29.

Jameson, D.L. 1957. Population structure and homing responses in the Pacific treefrog. Copeia 1957(3): 221-228.

Jameson, D.L. 1966. Rate of weight loss of treefrogs at various temperatures and humidities. Ecology 47: 605-613.

Jameson, D.L. and S. Peguegnat. 1971. Estimation of relative viability and fecundity of color polymorphism in anurans. Evolution 25: 180-194.

Jameson, D.L., J.P. Mackey, and M. Anderson. 1973. Weather, climate, and the external morphology of Pacific tree toads. Evolution 27: 285-302. 
*Jameson, D.L., J.P. Mackey and R.C. Richmond. 1966. The systematics of the Pacific tree frog, Hyla regilla. Proceedings of the California Academy of Sciences 33(19): 551-620.

Jameson, D.L., W. Taylor and J. Mountjoy. 1970. Metabolic and morphological adaptation to heterogenous evironments by the Pacific tree toad, Hyla regilla. Evolution 24:75-89.

Johnson, C.R. 1980. The effects of five organophosphorus insecticides on thermal stress in tadpoles of the Pacific tree frog (Hyla regilla). Zoological Journal of the Linnean Society 69: 143-147.

Johnson, C.R. and R.B. Bury. 1965. Food of the Pacific treefrog (Hyla regilla) Baird and Girard, in northern California. Herpetologica 21: 56-58.

Johnson, P.T.J., K.B. Lunde, E.G. Ritchie, and A.E. Launer. 1999. The effect of trematode infection on amphibian limb development and survivorship. Science 284: 802-804.

*Johnson, P.T.J., K.B. Lunde, E.M. Thurman, E.G. Ritchie, S.N. Wray, D.R. Sutherland, J.M. Kapfer, T.J. Frest, J. Bowerman, and A.R. Blaustein. 2002. Parasite (Ribeiroia ondatrae) infection linked to amphibian malformations in the western United States. Ecological Monographs 72(2): 151-168.

*Jones, L.L.C., W.P. Leonard, and D.H. Olson (eds). 2005. Amphibians of the Pacific Northwest. Seattle, WA: Seattle Audubon Society. 227 p.

Jung, R.E. and C.H. Jagoe. 1995. Effects of low PH and aluminum on body size, swimming performance, and susceptibility to predation of green tree frog (Hyla cinerea) tadpoles. Canadian Journal of Zoology 73: 2171-2183.

Kiesecker, J.M. and A.R. Blaustein. 1995. Synergism between UV-B radiation and a pathogen magnifies amphibian embryo mortality in nature. Proceedings of the National Academy of Sciences 92: 11049-11052.

Kiesecker, J.M. and A.R. Blaustein. 1997. Influences of egg laying behavior on pathogenic infection of amphibian eggs. Conservation Biology 11(1): 214-220.

Kiesecker, J.M. and D.K. Skelly. 2001 Effects of disease and pond drying on gray tree frog growth, development, and survival. Ecology 82(7): 1956-1963.

King, J. and S. Wagner. 2005. Pacific Northwest amphibian management and application of glyphosate-based herbicides. Abstract. Northwestern Naturalist 86:102.

Koller, R.L., and A.J. Gaudin. An analysis of helminth infections in Bufo boreas (Amphibia: Bufonidae) and Hyla regilla (Amphibia: Hylidae) in southern California. Southwestern Naturalist 21(4): 503-509.

Kupferberg, S.J. 1993. Bullfrogs (Rana catesbeiana) invade a northern California river: A plague or species coexistence? Bulletin of the Ecological Society of America 74: 319-320.

Kupferberg, S.J. 1994. Exotic larval bullfrogs (Rana catesbeiana) as prey for native garter snakes: functional and conservation implications. Herpetological Review 25(3): 95-97.

Kupferberg, S.J. 1996. The ecology of native tadpoles (Rana boylii and Hyla regilla) and the impact of invading bullfrogs (Rana catesbeiana) in a northern California river. Ph.D. dissertation, University of California at Berkeley. Berkeley, CA. 289 p.

Kupferberg, S.J. 1997a. Bullfrog (Rana catesbeiana) invasion of a California river: the role of larval competition. Ecology 78: 1736-1751.

Kupferberg, S.J. 1997b. Facilitation of periphyton production by tadpole grazing: functional differences between species. Freshwater Biology 37(2): 427-439.

Kupferberg, S.J. 1998. Predator mediated patch use by tadpoles (Hyla regilla): risk balancing or consequence of motionlessness? Journal of Herpetology 32(1): 84-92. 
Kupferberg, S.J., J.C. Marks, and M.E. Power. 1994. Effects of variation in natural algal and detrital diets on larval anuran (Hyla regilla) life-history traits. Copeia 1994(2): 446-457.

Licht, L.E. 1969. Palatability of Rana and Hyla eggs. American Midland Naturalist 82: 296298.

Littlejohn, M. J. 1971. A reappraisal of mating call differentiation in Hyla cadaverina (Hyla californiae) and Hyla regilla. Evolution 25(1): 98-102.

Livezey, R.L. 1953. Late breeding of Hyla regilla Baird and Girard. Herpetologica 9: 73.

Loftus-Hills, J.J. and M.J. Littlejohn. 1971. Pulse repetition rate as the basis for mating call discrimination by two sympatric species of Hyla. Copeia 1971: 154-156.

Luddecke, H. and A. Amezquita. 1999. Assessment of disc clipping on the survival and behavior of the Andean frog Hyla labialis. Copeia 99: 824-830.

Mackey, 1958. Morphological variation among populations of the Pacific tree frog (Hyla regilla) at several elevations in western Oregon. Ph.D. thesis, University of Oregon, Eugene, Ore.

*Manville, R.H. 1957. Amphibians and reptiles of Glacier National Park, Montana. Copeia 1957: 308-309.

*Marnell, L.F. 1996. Amphibian survey of Glacier National Park, Montana. Abstract. Intermountain Journal of Sciences 2(2): 52.

*Marnell, L.F. 1997. Herpetofauna of Glacier National Park. Northwestern Naturalist 78: 17 33.

Matsuda, B.M., D.M. Green, and P.T. Gregory. 2006. Amphibians and reptiles of British Columbia. Victoria, B.C.: Royal British Columbia Museum. 266 p.

Matthews, K.R., K.L. Pope, H.K. Preisler, and R.A. Knapp. 2001. Effects of nonnative trout on pacific treefrogs (Hyla regilla) in the Sierra Nevada. Copeia 2001(4): 1130-1137.

*Maxell, B.A. 2000. Management of Montana's amphibians: a review of factors that may present a risk to population viability and accounts on the identification, distribution, taxonomy, habitat use, natural history, and the status and conservation of individual species. Report to USFS Region 1, Order Number 43-0343-0-0224. Missoula, MT: Wildlife Biology Program, University of Montana. $161 \mathrm{p}$.

*Maxell, B.A. 2002. Amphibian and aquatic reptile inventories in watersheds in the South and Middle Forks of the Flathead River drainage that contain lakes being considered for application of piscicides and subsequent stocking of west slope cutthroat trout. Report to the Region 1 Office of the U.S. Forest Service and the Montana Department of Fish, Wildlife, and Parks. Montana Cooperative Wildlife Research Unit and Wildlife Biology Program, University of Montana, Missoula, MT. 62 pp.

* Maxell, B.A. 2004a. Amphibian and aquatic reptile inventories conducted on and around the Bitterroot National Forest 2000-2003. Report to Region 1 Office of the U.S. Forest Service, Bitterroot National Forest, Montana Department of Fish, Wildlife, and Parks, and Biological Resources Division of the U.S. Geological Survey. Missoula, MT: Montana Cooperative Wildlife Research Unit and Wildlife Biology Program, University of Montana. 128 p.

*Maxell, B.A. 2004b. Amphibian and aquatic reptile inventories conducted on and around the Thompson River 2003-2004. Report to Region 1 Office of the U.S. Forest Service and Plum Creek Timber Company. Missoula, MT: Montana Cooperative Wildlife Research Unit and Wildlife Biology Program. 83 p.

*Maxell, B.A. 2005a. Amphibian and aquatic reptile inventories conducted on and around lands administered by the Missoula Field Office of the Bureau of Land Management. Report to 
Missoula Field Office of the Bureau of Land Management. Montana Natural Heritage Program, Helena, MT and Montana Cooperative Wildlife Research Unit and Wildlife Biology Program, University of Montana, Missoula, MT. $53 \mathrm{p}$.

*Maxell, B.A. 2005b. A review of monitoring methods and a multi-tiered scheme for assessing and monitoring the status of amphibians in Montana. Report to Montana Department of Environmental Quality, Region 1 Office of the U.S. Forest Service, Montana Department of Fish, Wildlife, and Parks, and Montana State Office of the Bureau of Land Management. Montana Natural Heritage Program, Helena, MT and Montana Cooperative Wildlife Research Unit and Wildlife Biology Program, University of Montana, Missoula, MT. 29 p. + Appendices.

*Maxell, B.A. 2006. Evaluation of Montana's lentic breeding amphibian survey methodology and variables correlated with species occupancy. Report to Montana Department of Environmental Quality. Montana Natural Heritage Program, Helena, MT and Montana Cooperative Wildlife Research Unit and Wildlife Biology Program, University of Montana, Missoula, MT. 49 p.

*Maxell, B.A. 2009. State-wide assessment of status, predicted distribution, and landscapelevel habitat suitability of amphibians and reptiles in Montana. Ph.D. Dissertation. Missoula, MT: Wildlife Biology Program, University of Montana. 294 p.

*Maxell, B.A. and D.G. Hokit. 1999. Amphibians and reptiles. pp. 2.1-2.30. In: G. Joslin and H. Youmans (coordinators). Effects of recreation on Rocky Mountain wildlife: a review for Montana. Helena, MT: Committee on Effects of Recreation on Wildlife, Montana Chapter of the Wildlife Society. 307 p.

*Maxell, B.A., J.K. Werner, P. Hendricks, and D. Flath. 2003. Herpetology in Montana: a history, status summary, checklists, dichotomous keys, accounts for native, potentially native, and exotic species, and indexed bibliography. Olympia, WA: Society for Northwestern Vertebrate Biology. Northwest Fauna 5: 1-138.

Maxson, L.R. 1978. Immunological evidence pertaining to relationships between Old World Hyla arborea (Amphibia, Anura, Hylidae) and North American Hyla. Journal of Herpetology 12: 98-100.

Maxson, L.R. and A.C. Wilson. 1974. Convergent morphological evolution detected by studying proteins of tree frogs in the Hyla eximia species group. Science 185: 66-68.

Maxson, L.R. and A.C. Wilson. 1975. Albumin evolution and organismal evolution in tree frogs (Hylidae). Systematic Zoology 24: 1-15.

McCollum, S.A. and J. Van Buskirk. 1996. Costs and benefits of a predator-induced polyphenism in the gray tree frog, Hyla chrysoscelis. Evolution 50: 583-593.

Mecham, J.S. 1965. Genetic relationships and reproductive isolation in southeastern frogs of the genera Pseudacris and Hyla. American Midland Naturalist 74: 269-308.

*Miller, J.D. 1975. Interspecific food relationships of anurans in northwestern Montana and fluoride accumulation in amphibians and reptiles in northwestern Montana. M.S. Thesis. Missoula, MT: University of Montana. 105 p.

Millzner, R. 1924. A larval acanthicephalid (Centrorhynchus californicus) sp. Nov., from the mesentery of Hyla regilla. University of California, Publications in Zoology 26: 225-227.

Monello, R.J. and R.G. Wright. 1999. Amphibian habitat preferences among artificial ponds in the Palouse Region of Northern Idaho. Journal of Herpetology 33(2): 298-303.

Moorf, S.E. 1979. Lek organization and mating strategies in the Pacific treefrog (Hyla regilla). M.Sc. Thesis. San Diego State University. 
Morey, S.R. 1990. Microhabitat selection and predation in the Pacific treefrog, Pseudacris regilla. Journal of Herpetology 24(3): 292-296.

Moriarty, E.C. and D.C. Cannatella. 2004. Phylogenetic relationships of the North American chorus frog (Pseudacris: Hylidae). Molecular Phylogenetics and Evolution 30:409-420.

Morin, P.J. 1987. Predation, breeding asynchrony, and the outcome of competition among treefrog tadpoles. Ecology 68: 675-683.

Munger, J.C., M. Gerber, K. Madrid, M.A. Carroll, W. Petersen and L. Heberger. 1998. US National Wetland inventory classifications as predictors of the occurrence of Columbia spotted frogs (Rana luteiventris) and Pacific treefrogs (Hyla regilla). Conservation Biology 12: $320-330$.

*[NDTI] Northrop, Devine, and Tarbell Incorporated. 1994. Cabinet Gorge and Noxon Rapids hydroelectric developments 1993 wildlife study. Northrop, Devine, and Tarbell Incorporated, Portland, ME. $197 \mathrm{p}$.

Needham, J.G. 1924. Observations on the life of the ponds at the head of Laguna canyon. Journal of Entomology and Zoology 16(1): 1-12.

*Nussbaun, R., E. Brodie, Jr., and R. Storm. 1983. Amphibians and reptiles of the Pacific Northwest. University of Idaho Press, Moscow, Idaho. 322 p.

O'Hara, R.K. and A.R. Blaustein. 1988. Hyla regilla and Rana pretiosa tadpoles fail to display kin recognition behaviour. Animal Behaviour 36(3): 946-948.

Ovaska, K., T.M. Davis, I.N. Flamarique. 1997. Hatching success and larval survival of the frogs Hyla regilla and Rana aurora under ambient and artificially enhanced solar ultraviolet radiation. Canadian Journal Zoology 75: 1081-1088.

Perrill, S.A. 1984. Male mating behavior in Hyla regilla. Copeia 1984(3): 727-732.

Perrill, S.A. and R.E. Daniel. 1983. Multiple egg clutches in Hyla regilla, $H$. cinerea, and $H$. gratiosa. Copeia 1983: 513-516.

Poinar, G.O., Jr. and G.M. Thomas. 1988. Infection of frog tadpoles (Amphibia) by insect parasitic nematodes (Rhabditida). Experientia 44(6): 528-531.

Pope, K.L. and K.R. Matthews. 2001. Movement ecology and seasonal distribution of mountain yellow-legged frog (Rana muscosa) in a high-elevation Sierra Nevada basin. Copeia 2001(3): 787-793

*Powell, R., J.T. Collins, and E.D. Hooper, Jr. 1998. A key to amphibians and reptiles of the Continental United States and Canada. University Press of Kansas, Lawrence, KS. 131 p.

*Reichel, J.D. and D.L. Flath. 1995. Identification guide to the amphibians and reptiles of Montana. Montana Outdoors 26(3): 15-34.

Reimchen, T.E. 1990. Introduction and dispersal of the Pacific Treefrog (Hyla regilla) on Queen Charlotte Islands, British Columbia. Canadian Field Naturalist 105: 288-290.

Relyea, R.A. and N. Mills. 2001. Predator-induced stress makes the pesticide carbaryl more deadly to gray treefrog tadpoles (Hyla versicolor). Proceedings of the National Academy of Sciences 98(5): 2491-2496.

Resnick, L.E. and D.L. Jameson. 1963. Color polymorphism in Pacific tree frogs. Science 142: 1081-1083.

Reynolds, T.D. and T.D. Stephens. 1984. Multiple ectopic limbs in a wild population of Hyla regilla. Great Basin Naturalist 44: 166-169.

Riley, D.R. 1981. The monophasic call of Hyla regilla (Anura: Hylidae). Copeia 1981: 230233. 
Ripplinger, J. and R.S. Wagner. 2004. Phylogeography of northern populations of the Pacific treefrog, Pseudacris regilla. Abstract. Northwestern Naturalist 85:118-125.

*Rodgers, T.L., and W.L. Jellison. 1942. A collection of amphibians and reptiles from western Montana. Copeia 1942(1): 10-13.

Rose, G.J. and E.A. Brenowitz. 1991. Aggressive thresholds of male pacific treefrogs for advertisement calls vary with amplitude of neighbors' calls. Ethology 89(3): 244-252.

Rose, G.J. and E.A. Brenowitz. 1997. Plasticity of aggressive thresholds in Hyla regilla: discrete accommodation to encounter calls. Animal Behaviour 53(2): 353-361.

Rose, G.J. and E.A. Brenowitz. 2002. Pacific treefrogs use temporal integration to differentiate advertisement from encounter calls. Animal Behaviour 63(6): 1183-1190.

Russell, R.W., S.J. Hecnar, and G.D. Haffner. 1995. Organochlorine pesticide residues in southern Ontario spring peepers. Environmental Toxicology and Chemistry 14(5): 815-817

Schaub, D.L. and J.H. Larsen, Jr. 1978. The reproductive ecology of the Pacific treefrog (Hyla regilla). Herpetologica 34(4): 409-416.

Schechtman, A.M. and J.B. Olson. 1941. Unusual temperature tolerance of an amhibian egg (Hyla regilla). Ecology 22(4): 409-410.

Schuytema, G.S. and A.V. Nebeker. 1999. Comparative toxicity of ammonium and nitrate compounds to Pacific treefrog and African clawed frog tadpoles. Enviromental Toxicology \& Chemistry 18(10): 2251-2257.

Schuytema, G.S., A.V. Nebeker, and W.L. Griffis. 1995. Comparative toxicity of Guthion and Guthion 2S to Xenopus laevis and Pseudacris regilla tadpoles. Bulletin of Environmental Contamination and Toxicology 54(3): 382-388.

Semlitsch, R.D., C.M. Bridges, and A.M. Welch. 2000. Genetic variation and a fitness tradeoff in the tolerance of gray treefrog (Hyla versicolor) tadpoles to the insecticide carbaryl. Oecologial 125(2): 179-185.

Semlitsch, R.D. and J.W. Gibbons. 1988. Fish predation in size-structured populations of treefrog tadpoles. Oecologia 75: 321-326.

Sessions, S.K., and S.B. Ruth. 1990. Explanation for naturally occurring supernumerary limbs in amphibians. Journal of Experimental Zoology 254(1): 38-47.

Smith, R.E. 1940. Mating and oviposition in the Pacific Coast tree toad. Science 92: 379-380.

Snyder, W.F. and D.L. Jameson. 1965. Multivariate geographic variation of mating call in populations of the Pacific tree frog (Hyla regilla). Copeia 1965(2): 129-142.

Soiseth, C.R. 1992. The $\mathrm{pH}$ and acid neutralizing capacity of ponds containing Pseudacris regilla larvae in an alpine basin of the Sierra Nevada. California Fish and Game 78(1): 11 19.

Sparling, D.W., G.M. Fellers, and L.L. McConnell. 2001. Pesticides and amphibian population declines in California, USA. Environmental Toxicology and Chemistry 20(7): 1591-1595.

*Stebbins, R.C. 2003. A field guide to western reptiles and amphibians. 3rd edition. New York, NY: Houghton Mifflin Co. 533 p.

Stiebler, I.B. and P.M. Narins. 1990. Temperature-dependence of auditory nerve response properties in the frog. Hearing Research 46(1-2): 63-82.

Straughan, I.R. 1975. An analysis of the mechanisms of mating call discrimination in the frogs Hyla regilla and $H$. cadaverina. Copeia 1975: 415-424.

*Test, F.C. 1898. A contribution to the knowledge of the variations of the tree frog (Hyla regilla). Proceedings of the United States National Museum 21: 477-492. 
*Thompson, M.D. and A.P. Russell. 2000. Phylogeography of Ambystoma macrodactylum: post glacial range expansion and resultant genetic diversity. Field Summary Report No. 1. University of Calgary. Calgary, Canada. $39 \mathrm{p}$.

*Timken, R. No Date. Amphibians and reptiles of the Beaverhead National Forest. Western Montana College, Dillon, MT. $16 \mathrm{p}$.

Travis, J. 1980. Phenotypic variation and the outcome of interspecific competition in hylid tadpoles. Evolution 34: 40-50.

*[USFWS] US Fish and Wildlife Service. 1994. Endangered and threatened wildlife and plants; animal candidate review for listing as endangered or threatened species. Federal Register 59(219): 58982-59028.

Vogt, T. and D.L. Jameson. 1970. Chronological correlation between change in weather and change in morphology of the Pacific tree frog in southern California. Copeia 1970(1): 135144.

Vos, C.C. and A.H.P. Stumpel. 1996. Comparison of habitat isolation parameters in relation to fragmented distribution patterns in the tree frog (Hyla arborea). Landscape Ecology 11(4): 203-214.

Wagner, W.E., Jr. 1986. Tadpoles and pollen: observations on the feeding behavior of Hyla regilla larvae. Copeia 1986(3): 802-804.

Warner, S.C., W.A. Dunson, and J. Travis. 1991. Interaction of pH, density, and priority effects on the survivorship and growth of two species of hylid tadpoles. Oecologia 88: 331-339.

Warner, S.C., J. Travis, and W.A. Dunson. 1993. Effect of $\mathrm{pH}$ variation on interspecific competition between two species of hylid tadpoles. Ecology 74(1): 183-194.

Wassersug, R.J. 1976b. Internal oral features in Hyla regilla (Anura: Hylidae) larvae: an ontogenetic study. Occasional Papaers Museum of Natural History, University of Kansas 49: $1-24$.

Waters, D.L. 1992. Pseudacris regilla (Pacific chorus frog). Herpetological Review 23(1): 2425.

Watkins, T.B. 1996. Predator-mediated selection on burst swimming performance in tadpoles of the Pacific tree frog (Pseudacris regilla). Physiological Zoology 69(1): 154-167.

Weitzel, N.H. and H.R. Panik. 1993. Long-term fluctuations of an isolated population of the Pacific chorus frog (Pseudacris regilla) in northwestern Nevada. Great Basin Naturalist 53(4): 379-384.

Wente, W.H. and J.B. Phillips. 2003. Fixed green and brown color morphs and a novel colorchanging morph of the Pacific tree frog (Hyla regilla). American Naturalist 162(4): 461-473.

Wente, W.H. 2001. Microhabitat choice in the Pacific treefrog (Hyla regilla): characteristics of a complex color polymorphism and implications for the development of assortative mate choice within an interbreeding population. Ph.D. Dissertation. Bloomington, IN: Indiana University.

Wente, W.H. and J.B. Phillips. 2005. Seasonal color change in a population of Pacific treefrogs (Pseudacris regilla). Journal of Herpetology 39(1):161-165.

*Werner, J.K., B.A. Maxell, P. Hendricks, and D. Flath. 2004. Amphibians and reptiles of Montana. Missoula, MT: Mountain Press Publishing Company. 262p.

*Werner, J.K. and J.D. Reichel. 1994. Amphibian and reptile survey of the Kootenai National Forest: 1994. Montana Natural Heritage Program, Helena, MT. 104 p.

*Werner, J.K. and J.D. Reichel. 1996. Amphibian and reptile monitoring/survey of the Kootenai National Forest: 1995. Montana Natural Heritage Program, Helena, MT. 115 p. 
*Werner, J.K. and T. Plummer. 1994. Amphibian and reptile survey of the Flathead Indian Reservation 1993-1994. Salish Kootenai College, Pablo, MT. 55 p.

*Werner, J.K. and T. Plummer. 1995. Amphibian monitoring program on the Flathead Indian Reservation 1995. Salish Kootenai College, Pablo, MT. 46 p.

*Werner, J.K., T. Plummer, and J. Weaselhead. 1998a. Amphibians and reptiles of the Flathead Indian Reservation. Intermountain Journal of Sciences 4(1-2): 33-49.

*Werner, J.K., T. Plummer, and J. Weaselhead. 1998b. The status of amphibians on the Flathead Reservation, Montana. Intermountain Journal of Sciences 4(3-4): 88.

White, M. and J.A. Kolb. 1974. A preliminary study of Thamnophis near Sagehen Creek, California. Copeia 1974: 126-136.

Whitney, C.L. 1973. The role of vocalizations in spacing out and mate selection in Pacific tree frogs. M.S. Thesis, The University of British Columbia, Vancouver, British Columbia.

Whitney, C.L. 1980. The role of the 'ecounter' call in spacing of Pacific treefrogs (Hyla regilla). Canadian Journal of Zoology 58: 75-78.

Whitney, C.L. 1981. The monophasic call of Hyla regilla (Anura: Hylidae). Copeia 1981: 230233.

Whitney, C.L. and J.R. Krebs. 1975a. Mate selection in Pacific tree frogs. Nature 255: 325327.

Whitney, C.L. and J.R. Krebs. 1975b. Spacing and calling in Pacific tree frogs (Hyla regilla). Canadian Journal of Zoology 53: 1519-1527.

*[WWPC] Washington Water Power Company. 1995. 1994 wildlife report Noxon Rapids and Cabinet Gorge Reservoirs. Washington Water Power Company. Spokane, WA.

Yoon, D. 1977. The effect of introduced fish on the amphibian life in Westfall Meadow. Yosemite Nature Notes 46: 69-70. 


\section{American Bullfrog (Rana catesbeiana)}

Up-to-date distribution and status information can be found on the Montana Natural Heritage Program's TRACKER website at http://mtnhp.org

\section{EXOTIC SPECIES}

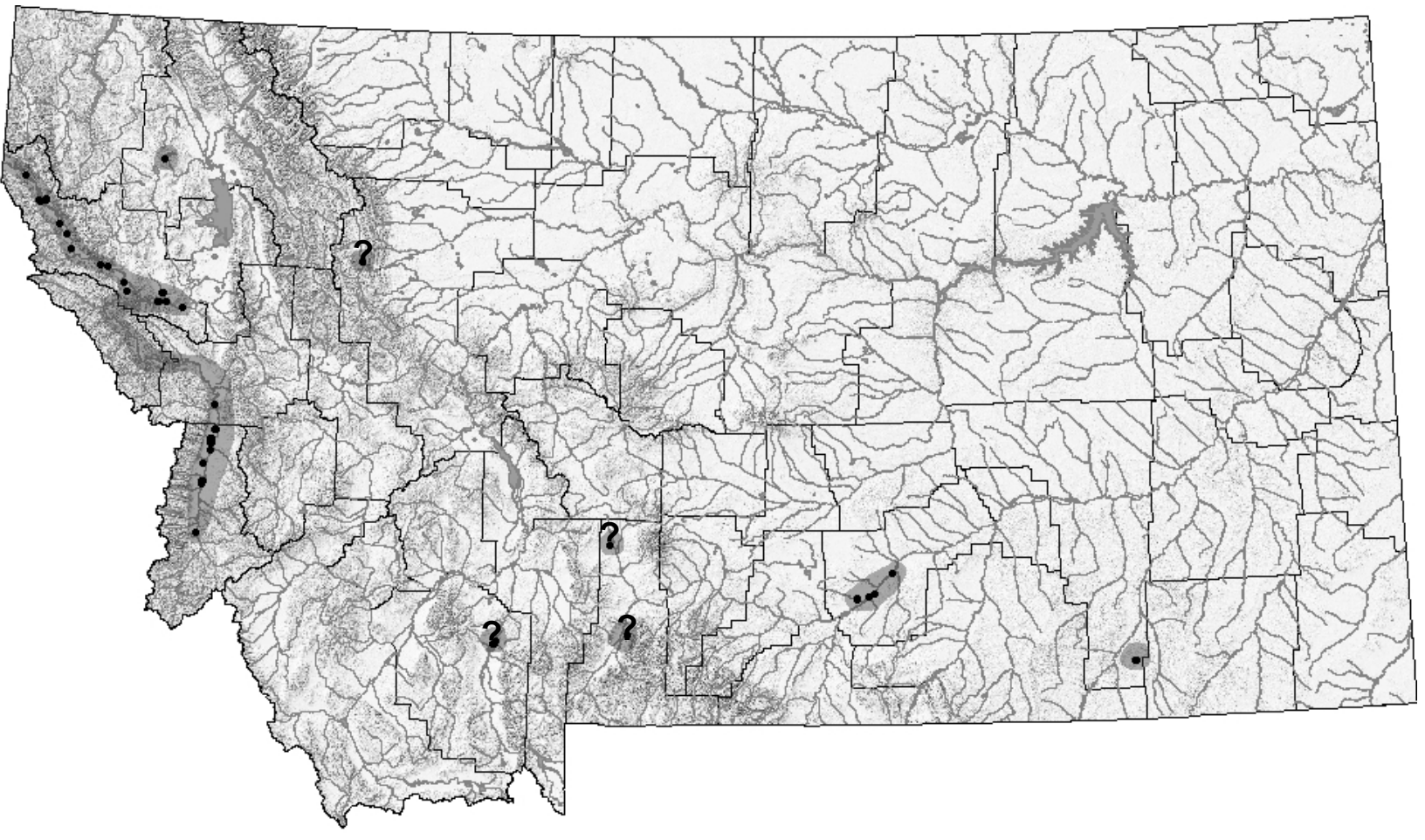

Distribution/Taxonomy

The bullfrog is recognized as a distinct species with a native range east of a line extending from northwest Wisconsin to south central Texas (Bury and Whelan 1984; Wiese 1990). However, they have now been widely introduced throughout the western United States and around the world at elevations that are typically lower than 1,900 M (6,234 ft) (Bury and Whelan 1984). They were first introduced in Montana sometime prior to 1968 and have now been documented with an almost continuous distribution in the valley bottoms along the Bitterroot River downstream of Darby, the Clark Fork River downstream of Missoula, and the Flathead River downstream of Dixon (Black 1969a, 1969b; Werner and Reichel 1994; Reichel 1995a; Hendricks and Reichel 1996b; Werner et al. 1998; Bryce Maxell, pers. obs.). In addition reproducing populations have been reported in Laurel, Billings, and Fort Peck, and individual adults have been reported in Helena, Belgrade, near Silver City northwest of Helena, near Lake Koocanusa near the Canadian border and in Carter County.

Maximum Elevation

1,203 m (3,946 ft) in Flathead County (Werner et al. 2004).

\section{Identification}

\section{Eggs:}

Deposited in a thin film, a few eggs thick, containing from 3,000 to 47,840 eggs, and spread out over a large surface area (Howard 1983; McAuliffe 1978 as cited in Bury and Whelan 1984; Bryce Maxell, pers. obs.). Each ovum is black above, whitish below, and is surrounded by a single jelly layer (Bryce Maxell, pers. obs.). Ovum diameters are 1.2-1.7 mm, but, total egg 
diameters, including the jelly layer, are 6.4-10.4 mm (Livezey and Wright 1947).

Larvae:

Tadpoles smaller than approximately a TL of $25 \mathrm{~mm}$ are black with transverse gold bands on the dorsal side of the head and body and with a patch of gold ventrally (Altig 1970; Corkran and Thoms 2006). The body and tail musculature of larger tadpoles are olive green to yellow in base color with flecks of yellow and numerous round black dots (Bryce Maxell, pers. obs.). The tail fins of larger tadpoles are clear to yellow in base color with flecks of yellow and round dots and flecks of black (Bryce Maxell, pers. obs.). The ventral body surface of larger tadpoles is creamy white to bright yellow (Bryce Maxell, pers. obs.). TL of 3-178 mm (Corkran and Thoms 2006; Wright and Wright 1949).

Juveniles and Adults:

A fold of skin extends from the back of the eye, over the tympanum, down to the front leg. The tympanum is approximately the same size as the eye in females, but is much larger than the eye in males. Dorsal base color varies from pale green to dark olive green with small dark spots (usually on smaller individuals) or dark mottling (usually on larger individuals) (Bryce Maxell, pers. obs.). Ventral color is cream to bright yellow with gray to dark olive green mottling usually present but giving way to a solid bright yellow throat patch in males (Bryce Maxell, pers. obs.). SVL of 39-220 mm and weighing up to 908 grams (Lutterschmidt et al. 1996; Thomas and Wogan 1999; Bryce Maxell, pers. obs.).

Similar Species:

Adult northern leopard frogs and Columbia spotted frogs both have tympanums smaller than their eyes, have white stripes extending from the tip of their snout to their front leg, and lack the fold of skin extending from the back of the eye, over the tympanum, down to the front leg. Larval northern leopard frogs and Columbia spotted frogs are smaller, do not have a creamy yellow ventral color, and do not have round black dots on their dorsal surface and tail musculature. Northern leopard frogs and Columbia spotted frogs lay their eggs soon after snow melt in the spring and their egg masses are round or globular. See sections on distribution to identify possible regions of co-occurrence of bullfrogs and Columbia spotted frogs or northern leopard frogs.

\section{Habitat Use/Natural History}

Bullfrogs are highly aquatic and appear to be mostly limited to warmer permanent water bodies with abundant emergent and/or aquatic vegetation (Giermakowski 1998; Bryce Maxell, pers. obs.). Individuals are rarely found more than a few meters from the edge of the water (Raney 1940; Bryce Maxell, pers. obs.). So far they seem to have been unable to invade colder waters and high elevations in Montana, but there is some evidence that they may be adapting to colder water beaver ponds at some localities (Nussbaum et al. 1983; Werner and Plummer 1995). Adults feed on a variety of invertebrates and vertebrates and may frequently cannibalize smaller individuals (Bury and Whelan 1984; Bryce Maxell, pers. obs.; see below). Adults and larvae overwinter in shallow standing or flowing permanent waters on the bottom's surface (Stinner et al. 1994). Breeding takes place in warmer weather from late June through late August and females deposit eggs in a thin layer on the surface of warmer waters (Bryce Maxell, pers. obs.). Eggs subsequently sink onto submerged vegetation and hatch in three to five days (Bury and 
Whelan 1984) and tadpoles overwinter. In Montana tadpoles have been found to overwinter once and metamorphose the following summer when in warmer or more ephemeral waters or overwinter twice, so that two larval cohorts are present, in cooler or more permanent waters (Bryce Maxell, pers. obs.). Tadpoles feed on a variety of algae and bacteria, are commonly coprophagous, and may feed on eggs and smaller tadpoles (Steinwascher 1978; Ehrlich 1979; Kiesecker and Blaustein 1997). Tadpoles are commonly found with predatory fish because they are apparently not very palatable or nutritious (Lewis et al. 1961; Kirk 1967; Kruse and Francis 1977; Kats et al. 1988). Furthermore, tadpoles release chemicals that have actually been shown to inhibit reproduction in some fish (Boyd 1975). Adults typically do not move more than a few hundred meters within a season and show strong homing abilities when displaced (McAtee 1921; Raney 1940; Durham and Bennett 1963; Currie and Bellis 1969). However individuals have been known to move up to 2.8 kilometers and have been found in temporary pools up to 1.6 kilometers from permanent water (Ingram and Raney 1943; Willis et al. 1956; Hammerson 1999).

Status and Impacts on Native Species

In Montana they have been documented with an almost continuous distribution in the valley bottoms along the Bitterroot River downstream of Darby, the Clark Fork River downstream of Missoula, and the Flathead River downstream of Dixon (Hendricks and Reichel 1996b; Werner and Reichel 1996; Werner et al. 1998). In addition reproducing populations have been reported in Laurel, Billings, and Fort Peck, and individual adults have been reported in Helena, Belgrade, near Silver City northwest of Helena, and near Lake Koocanusa near the Canadian border. The impetus for bullfrog introduction in the western United States and in Montana seems largely to be due to their use as a recreational hunting and food item, apparently, in some cases, as a result of native frogs having already declined because of human hunting and consumption (Bury and Whelan 1984; Jennings and Hayes 1985). Unfortunately, bullfrogs continue to be introduced into new sites from source populations in and outside of Montana (Bryce Maxell, pers. obs.) despite the fact that unauthorized introduction or transplantation of wildlife into the natural environment is prohibited by Montana law (Levell 1995; MCA 87-5-711). Bullfrogs represent a major predation and competition threat to native amphibians and other vertebrate and invertebrate species. Bullfrogs have been implicated in the declines of a number of amphibian species throughout the western United States and around the world (Dumas 1966; Black 1969a; Moyle 1973; Hammerson 1982, 1999; Bury and Whelan 1984; Hayes and Jennings 1988; Schwalbe and Rosen 1988; Kupferberg 1994; Lanoo et al. 1994; Arano et al. 1995; Rosen et al. 1995; Stebbins and Cohen 1995; Kupferberg 1997; Lawler et al. 1999; however, see Hayes and Jennings 1986; and Corn 1994). All 3 life history stages of amphibians may be subject to direct predation by adult bullfrogs (e.g., Korschgen and Baskett 1963; Carpenter and Morrison 1973; Bury and Whelan 1984; Clarkson and DeVos 1986; Werner et al. 1995). Additionally, both the eggs and larvae of native amphibians may be preyed upon by larval bullfrogs (e.g., Ehrlich 1979; Kiesecker and Blaustein 1997). Furthermore, egg, larval and adult amphibians are also likely to be indirectly effected by the threat of predation due to (1) adult avoidance of oviposition sites where predators are present (e.g., Resetarits and Wilbur 1989), (2) decreased larval foraging as a result of competition or staying in refuges to avoid predators (e.g., Kiesecker 1997; Kiesecker and Blaustein 1998), and (3) decreased adult foraging and growth rates as a result of avoiding areas with bullfrogs. Native amphibian larvae or adults may also be subject to chemically mediated interference competition (e.g., Petranka 1989; Griffiths et al. 1993) or exploitative 
competition for resources (e.g., Kupferberg 1997). Finally, native predators such as garter snakes that are dependent on larval or adult amphibians as a food source may also be impacted as a result of the loss of native amphibian larvae and the presence of larger bullfrog tadpoles and adults that they are unable to efficiently forage on (e.g., Kupferberg 1994). In addition to impacts on native amphibians, bullfrogs are known to prey on a variety of invertebrates (Carpenter and Morrison 1973) and vertebrates including young waterfowl, passerine birds, warm and cold water fishes, crayfish, snails, shrews, mice, bats, turtles, muskrat, lizards, young alligators, garter snakes, rattlesnakes, and a variety of plant matter (Korschgen and Moyle 1955; Lewis 1962; Korschgen and Baskett 1963; Black 1969a, Tyler and Hoestenbach 1979; Bury and Whelan 1984; Clarkson and DeVos 1986; Schwalbe and Rosen 1988; Stuart 1995; Crayon 1998). The current impact of bullfrogs on the native herpetofauna in Montana is not fully known. Black (1969a) reported that bullfrogs seemed to be having a negative impact on northern leopard frog (Rana pipiens) and Columbia spotted frog (Rana luteiventris) populations in the Bitterroot Valley with the disappearance of some northern leopard frog populations apparently occurring at that time. However, northern leopard frog populations have now been extirpated from virtually all of their former range in western Montana so it is unlikely that bullfrogs were responsible for their declines unless they acted as a vector for disease. Native long-toed salamanders, Columbia spotted frogs, Pacific treefrogs, painted turtles, and western terrestrial and common garter snakes appear not to have suffered widespread extirpation as a result of bullfrog introduction and many of these species are known to have breeding populations that are syntopic with breeding populations of bullfrogs at a few localities were fish have not been introduced in Ravalli and Sanders Counties (Werner and Plummer 1995; Bryce Maxell, pers. obs.). Corn and Hendricks (1998) found a number of invertebrates in the stomachs of 21 bullfrogs at Lee Metcalf National Wildlife Refuge, and found only one vertebrate, an unidentified fish. Thus, while bullfrogs may be responsible for local declines or extirpations from isolated breeding sites they do not appear to have caused widespread declines of the native amphibians. However, this does not mean that they are currently having no impact or will not cause extirpations of amphibians, invertebrates, or other vertebrates as they become more widespread.

$\underline{\text { Research and Management Suggestions }}$

1. Additional surveys are needed in the areas surrounding known or reported sites of introduction across the state, especially in eastern Montana.

2. The rate of spread of all bullfrog populations should be monitored in conjunction with native amphibian populations in the area in order to identify the impacts of bullfrogs.

3. The impacts of bullfrogs on egg, larval, and adult life history stages should be thoroughly examined using field and laboratory experiments.

4. The public should be educated on the possible impacts of bullfrogs on native communities and be made aware of the fact that it is illegal to introduce them into the wild in Montana.

5. Where possible, bullfrog populations should be removed. Removal may be accomplished by altering habitats from permanent waters that support exotic bullfrogs, fish, and aquatic weeds to ephemeral habitats that support native species. Removal may also be accomplished by surrounding waterbodies with a drift fence and subsequently draining the water body in the late fall after bullfrogs have moved into overwintering sites.

6. Individuals can then either be captured by hand or left to dessicate and/or freeze. The Montana state legislature could further prohibit the introduction of bullfrogs by 
designating them a species that is detrimental to Montana's native flora and fauna (Levell 1995; MCA 87-5-712).

Bibliography *indicates an article with information specific to Montana

Adams, M.J. 1997. Experimental analysis of tadpole mortality factors: effects of bullfrogs and exotic fish in the puget lowlands, Washington. Ph. D. dissertation, University of Washington. $137 \mathrm{p}$.

Adams, M.J. 2000. Pond permanence and the effects of exotic vertebrates on anurans. Ecological Applications 10(2): 559.

Adams, M.J., R.B. Bury, and S.A. Swarts. 1998. Amphibians of the Fort Lewis Military Reservation, Washington: sampling techniques and community patterns. Northwestern Naturalist 79:12-18.

Albertini, G. and B. Lanza. 1987. Rana castesbeiana Shaw, 1892 in Italy. Alytes 6(3-4): 117129.

*Altig, R. 1970. A key to the tadpoles of the continental United States and Canada. Herpetologica 26: 180-207.

Amborski, R.L., T.G. Snider III, R.L. Thune and D.D. Culley, Jr. 1983. A non-hemolytic, group B Streptococcus infection of cultured bullfrogs, (Rana catesbeiana), in Brazil. Journal of Wildlife Diseases 19(3): 180-184.

Anonymous. 1993. The bullfrog. Ohio Department of Agriculture Division of Conservation Bureau of Science Research Bulletin 32 and 32A. 3p.

Arano, B., G. Llorente, M. Garcia-Paris, and P. Herrero. 1995. Species translocation menaces Iberian waterfrogs. Conservation Biology 9(1): 196-198

Aronson, L.R. 1943. Oviposition in the green frog (Rana clamitans) and the bullfrog (Rana catesbeiana). American Museum Nov. 1224:1-6.

Ashley, H., P. Katti, and E. Frieden. 1968. Urea excretion in the bullfrog tadpole. Effect of temperature, metamorphosis and thyroid hormones. Developmental Biology 17: 293-307.

Auburn, J.S. and D.H. Taylor. 1979. Polarized light perception and orientation in larval bullfrogs Rana catesbeiana. Animal Behaviour 27: 658-668.

Austin, J.D., J.A. Dávila, S.C. Lougheed, and P.T. Boag. 2003. Genetic evidence for femalebiased dispersal in the bullfrog, Rana catesbeiana (Ranidae). Molecular Ecology 12:31653172.

Austin, J.D., S.C. Lougheed, and P.T. Boag. 2004. Controlling for the effects of history and nonequilibrium conditions in gene flow estimates in northern bullfrog (Rana catesbeiana) populations. Genetics 168(3):1491-1506.

Bagnara, J.T. and J.J. Kollross. 1956. Abbreviated larval period of Rana catesbeiana in Iowa. Proceedings of the Iowa Academy of Science 63: 729-731.

Baker, R.H. 1972. The bullfrog. A Texas wildlife resource. Texas Game Fish Oyster Community Bulletin 23. 7pp.

Bee, M.A. 2004. Within-individual variation in bullfrog vocalizations: implications for a vocally mediated social recognition system. Journal of the Acoustical Society of America 116(6):3770-3781.

Bee, M.A. and A.C. Bowling. 2002. Socially mediated pitch alteration by territorial male bullfrogs, Rana catesbeiana. Journal of Herpetology 36(1):140-143.

Beringer, J., and T.R. Johnson. 1995. Rana catesbeiana (Bullfrog): Diet. Herpetological Review 26:98. 
Berrill, M., S. Bertram, L. McGillivray, M. Kolohon, and B. Pauli. 1994. Effects of low concentrations of forest-use pesticides on frog embyos and tadpoles. Environmental Toxicology and Chemistry 13(4): 657-664.

Berrill, M., S. Bertram, P. Toswill, and V. Campbell. 192. Is there a bullfrog decline in Ontario? P. 32-36, In: C.A. Bishop and K.E. Pettit (eds.). Declines in Canadian amphibian populations: designing a natural strategy. Occasional Papers No 76. Canadian Wildlife Service.

Birdsall, C.W., C.E. Grye, and A. Anderson. 1986. Lead concentrations in bullfrog Rana catesbeiana and green frog $R$. clamitans tadpoles inhabiting highway drainages. Environmental Pollution A. 40: 233-247.

*Black, J.H. 1969a. Yes - there are bullfrogs in Montana. Montana Outdoors 1969: 4.

*Black, J.H. 1969b. The frog genus Rana in Montana. Northwest Science 43(4): 191-195.

*Black, J.H. 1970. Amphibians of Montana. Montana Wildlife, Montana Fish and Game Commission. Animals of Montana Series 1970(1): 1-32.

Black, J.H. 1974. Bullfrog eating a bird. Herpetological Review 5: 104.

*Black, J.H. and A.N. Bragg. 1968. New additions to the herpetofauna of Montana. Herpetologica 24: 247.

Blair, A.P. 1963. Notes on anuran behavior, especially Rana catesbeiana. Herpetologica 19: 151.

Bohnsack, K. 1952. Terrestrial hibernation of the bullforg (Rana catesbeiana Shaw). Copeia 1952: 114.

Boily, M.H., V.E. Berube, P.A. Spear, C. BeBlois, and N. Dassylva. 2005. Hepatic retinoids of bullfrogs in relation to agricultural pesticides. Environmental Toxicology and Chemistry 24(5):1099-1106.

Bolek, M.G. and J. Janovy, Jr. 2004. Rana catesbeiana (Bullfrog). Gigantic tadpole. Herpetological Review 35(4):376-377.

Boone, M.D., E.E. Little, and R.D. Semlitsch. 2004. Overwintered bullfrog tadpoles negatively affect salamanders and anurans in native amphibian communities. Copeia 3:683-690.

Boone, M.D. and R.D. Semlitsch. 2003. Interactions of bullfrog tadpole predators and an insecticide: predation release and facilitation. Oecologia 137(4): 610-616.

*Boundy, J. 2001. Herpetofaunal surveys in the Clark Fork Valley region, Montana. Herpetological Natural History 8: 15-26.

Boutilier, R.G., M.L. Glass, and N. Heisler. 1986. The relative distribution of pulmocutaneous blood flow in Rana catesbeiana: effects of pulmonary or cutaneous hypoxia. Journal of Experimental Biology 126: 33-39.

Bowerman, J. 2003. Bullfrogs and spotted frogs in central Oregon: Differences in tolerance to hypoxia may restrict bullfrog invasion of spotted frog habitat. Abstract. Northwestern Naturalist 84:95.

Boyd, S.H. 1971. The reproductive inhibition of Poecilia reticulata in the presence of water conditioned by Rana catesbeiana tadpoles. M.S. Thesis. Southeastern Massachusetts University. 46pp.

Boyd, S.H. 1975. Inhibition of fish reproduction by Rana catesbeiana larvae. Physiological Zoology 48: 225-234.

Brodie, E.D. 1968. A case of interbreeding between Bufo boreas and Rana cascadae. Herpetologica 24: 86. 
Brooks, G.R., Jr. 1964. An analysis of the food habits of the bullfrog (Rana catesbeiana) by body size, sex, mouth, and habitat. Virginia Journal of Science 15: 173-186.

Brown, L.E. 1974. Behavioral reactions of bullfrogs while attempting to eat toads. Southwestern Naturalist 19: 335-336.

Brown, R.E. 1972. Size variation and food habits of larval bullfrogs, Rana catesbeiana Shaw, in western Oregon. Dissertation. Oregon State University, Corvallis, Oregon, USA.

Bruggers, R.L. 1974. Food habits of bullfrogs in northwest Ohio. Ohio Journal of Science 73: 185-188.

Bruggers, R.L. and W.B. Jackson. 1974. Eye-lens weight of the bullfrog (Rana catesbeiana) related to larval development, transformation, and age of adults. Ohio Journal of Science 74: 282-286.

Burggren, W.W. and N.H. West. 1982. Changing respiratory importance of gills, lungs, and skin during metamorphosis in the bullfrog Rana catesbeiana. Respiratory Physiology 47: 151-164.

Burggren, W.W., M.E. Feder, and A.W. Pinder. 1983. Temperature and the balance between aerial and aquatic respiration in larvae of Rana berlandeiri and Rana catesbeiana. Physiological Zoology 56: 263-273.

Bury, R.B., and J.A. Whelan. 1984. Ecology and management of the bullfrog. USFWS Resource Publication 155: 1-23.

Capranica, R.R. 1968. The vocal repertoire of the bullfrog (Rana catesbeiana). Behaviour 31: 302-325.

Carlander, K.D. and R.B. Moorman. 1950. The bullfrog and his next of kin. Iowa Conservationist 9: 33-38.

Carpenter, H.L. and E.O. Morrison. 1973. Feeding behavior of the bullfrog, Rana catesbeiana, in north central Texas. Bios 44: 188-193.

Carr, A.H., R.L. Amborski, D.D. Culley, Jr. and G.F. Amborski. 1976. Aerobic bacteria in the intestinal tracts of bullfrogs (Rana catesbeiana) maintained at low temperatures. Herpetologica 32: 239-244.

Cauble, K. and R.S. Wagner. 2004. Herbicide effects on metamorphosis of amphibian larvae. Abstract. Northwestern Naturalist 85:70.

Cecil, S.G. and J.J. Just. 1979. Survival rate, population density and development of a naturally occurring anuran larvae (Rana catesbeiana). Copeia 1979: 447-453.

Clarkson, R.W. and J.C. DeVos, Jr. 1986. The bullfrog, Rana catesbeiana Shaw, in the lower Colorado River, Arizona, California. Journal of Herpetology 20: 42-49.

Cohen, N.W., and W.E. Howard. 1958. Bullfrog food and growth at the San Joaquin Experimental Range, California. Copeia 1958(3): 223-225.

Collins, J.P. 1975. A comparative study of the life history strategies in a community of frogs. Dissertation. University of Michigan, Ann Arbor, Michigan, USA.

Collins, J.P. 1979. Intrapopulation variation in the body size at metamorphosis and timing of metamorphosis in the bullfrog, Rana catesbeiana. Ecology 60: 738-749.

Combs, A., G. Hess, C. Chapman, A. Stovall, Z. Burns, S. Matthews, and J.D. Goins. 2005. Rana catesbeiana (American Bullfrog). Diet. Herpetological Review 36(4): 439.

*Conant, R. and J.T. Collins. 1998. A field guide to reptiles and amphibians of eastern and central North America. $3^{\text {rd }}$ edition, expanded. New York, NY: Houghton Mifflin Co. 616 p.

Cook, D. and M. Jennings. 2001. Rana aurora draytonii (California red-legged frog) predation. Herpetological Review 32(3): 182-183. 
Corkran, C.C. and C. Thoms. 2006. Amphibians of Oregon, Washington, and British Columbia. $2^{\text {nd }}$ Edition. Vancouver, B.C.: Lone Pine Publishing. 176 p.

*Corn, J. and P. Hendricks. 1998. Lee Metcalf National Wildlife Refuge bullfrog and painted turtle investigations: 1997. Montana Natural Heritage Program, Helena, MT. 20 p.

Corn, P.S. 1994. What we know and don't know about amphibian declines in the west. p. 5967. In W. Covington and L. DeBano (tech. coords.), Sustainable ecological systems: implementing an ecological approach to land management. USDA Forest Service, Rocky Mountain Forest and Range Experimental Station, Ft. Collins, Colorado. General Technical Report RM-247.

Corse, W.A. and D.E. Metter. 1980. Economics, adult feeding and larval growth of Rana catesbeiana in a fish hatchery. Journal of Herpetology 14: 231-238.

Crawshaw, L.I., R.N. Rausch, P. Wollmuth, and E.J. Bauer. 1992. Seasonal rhythms of development and temperature selection in larval bullforgs (Rana catesbeiana Shaw). Physiological Zoology 65: 346-359.

Crayon, J.J. 1998. Rana catesbeiana (bullfrog) diet. Herpetological Review 29(4): 232.

Cross, C.L. and S.L. Gerstenberger. 2002. Rana catesbeiana. Diet. Herpetological Review 33(2):129-130.

Crowder, W.C., M. Nie, and G.R. Ultsch. 1998. Oxygen uptake in bullfrog tadpoles (Rana catesbeiana). Journal of Experimental Zoology 280: 121-134.

Culley, D.D., Jr. 1973. Use of bullfrogs in biological research. American Zoologist 13: 85-90.

Culley, D.D., Jr. 1981. Have we turned the corner on bullfrog culture? Aquaculture Magazine 7: 20-24.

Culley, D.D., Jr., N.D. Horseman, R.L. Amborski, and S.P. Meyers. 1978. Current status of amphibain culture with emphasis on nutrition, diseases and reproduction of the bullfrog (Rana catesbeiana). Proceedings of the World Mariculture Society 9: 653-669.

Currie, W. and E.D. Bellis. 1969. Home range and movements of the bullfrog, Rana catesbeiana Shaw, in an Ontario pond. Copeia 1969(4): 688-692.

DeGrauw, E. 2002. Lymphatic and plasma volume determinations in Rana catesbeiana and Bufo marinus. Northwestern Naturalist 83(2):68.

Dietrich, S.E. 1960. Field observations of a bullfrog attack on a bluebird. Bulletin of the Philadelphia Herpetological Society 8(1): 16.

Dowe, B.J. 1979. The effect of time of oviposition and microenvironment on growth of larval bullfrogs (Rana catesbeiana) in Arizona. M.S. Thesis, Arizona State University, Tempe. 55 pp.

*Dumas, P.C. 1966. Studies of the Rana species complex in the Pacific Northwest. Copeia 1966(1): 60-74.

Durham, L., and G.W. Bennett. 1963. Age, growth and homing in the bullfrog. Journal of Wildlife Management 27(1): 107-123.

Ehrlich, D. 1979. Predation by bullfrog tadpoles (Rana catesbeiana) on eggs and newly hatched larvae of the plains leopard frog (Rana blairi). Bulletin of the Maryland Herpetological Society $15: 25-26$.

Eklov, P. 2000. Chemical cues from multiple predator-prey interactions induce changes in behavior and growth of anuran larvae. Oecologia 123: 192-199.

Elinson, R.P. 1981. Have you seen a bullfrog-green frog hybrid? Herpetological Review 12:104.

Emlen, S.T. 1968. Territoriality in the bullfrog, Rana catesbeiana. Copeia 1968(2): 240-243. 
Emlen, S.T. 1976. Lek organization and mating strategies in the bullfrog. Behavioral Ecology and Sociobiology 1: 283-313.

Emlen, S.T. 1977. "Double clutching" and its possible significance in the bullfrog. Copeia 1977(4): 749-751.

Evenson, E.J. 1978. The dietary effects of Rana catesbeiana on Micropterus salmoides. M.S. Thesis. University of Nebraska at Lincoln. $24 \mathrm{p}$.

Fellers, G.M., D.E. Green, and J.E. Longcore. 2001. Oral chytridiomycosis in mountain yellowlegged frogs (Rana muscosa). Copeia 2001(4): 945-953.

Fenton, M.H. 1928. Scientific method of bullfrog culture in connection with muskrat farming. Pickerel, Ontario. 53pp. [publisher unknown].

Fenton, M.H. 1932. Scientific method of raising jumbo bullfrogs. Chariton Fur Corp., Chicago, Illinois. 80pp.

Ferguson, D.E., J.P. McKeown, O.S. Bosarge, and H.F. Landreth. 1968. Sun-compass orientation of bullfrogs. Copeia 1968: 230-235.

Fisher, R.N. and H.B. Shaffer. 1996. The decline of amphibians in California's Great Central Valley. Conservation Biology 10(5): 1387-1397.

Forbes, M.R., D.L. McRuer, and P.L. Rutherford. 2004. Prevalence of Aeromonas hydrophilia in relation to timing and duration of breeding in three species of ranid frogs. Ecoscience 11(3):282-285.

Fordham, C.L., J.D. Tessari, H.S. Ramsdell, and T.J.Keefe. 2001. Effects of malathion on survival, growth development, and equilibrium posture of bullfrog tadpoles (Rana catesbeiana). Environmental Toxicology and Chemistry 20(1): 179-184.

Friet, S.C. 1993. Aquatic overwintering of the bullfrog (Rana catesbeiana) during natural hypoxia in an ice-covered pond. M.S. Thesis, Dalhousie University.

Frost, S.W. 1935. The food of Rana catesbeiana Shaw. Copeia 1935: 15-18.

Fulk, F.D. and J.O. Whitaker, Jr. 1969. The food of Rana catesbeiana in three habitats in Owen County, Indiana. Proceedings of the Indiana Academy of Science 78: 491-496.

Funkhouser, A. 1976. Observations on pancreas: body weight ratio change during development of the bullforg (Rana catesbeiana). Herpetologica 32: 370-371.

George, I.D. 1938. Late external sex distinction of the bullfrog (Rana catesbeiana) based on tympanum measurements. Proceedings of the Louisiana Academy of Science 4: 255-259.

George, I.D. 1940. A study of the life history of the bullfrog (Rana catesbeina Shaw) at Baton Rouge, Louisiana. Dissertation. University of Michigan, Ann Arbor, Michigan, USA.

Gerstenberger, S. and R. Pearson. 2002. Mercury concentrations in bullfrogs (Rana catesbeiana) collected from a southern Nevada, USA, wetland. Bulletin of Environmental Contamination and Toxicology 69(2): 210-218.

Giermakowski, J.T. 1998. Microhabitat separation between the bullfrog (Rana catesbeiana) and the Columbia spotted frog (Rana luteiventris) in Western Montana. Undergraduate Thesis. Wildlife Biology Program, University of Montana, Missoula, MT. 27 p.

Glorioso, J.C., G.F. Amborski, and D.D. Culley. 1973. Microbiological studies on septicemic bullfrogs (Rana catesbeiana). American Journal of Veterinary Research 335: 1241-1245.

Goodyear, C.P. and R. Altig. 1971. Orientation of bullfrogs (Rana catesbeiana) during metamorphosis. Copeia 1971: 362-364.

Gradwell, N. 1970. The function of the ventral velum during gill irrigation I Rana catesebeiana. Canadian Journal of Zoology 50: 481-499. 
Gradwell, N. 1972a. Gill irrigation in Rana catesbeiana. I. On the anatomical basis. Canadian Journal of Zoology 50: 481-499.

Gradwell, N. 1972b. Gill irrigation in Rana catesbeiana. II. On the musculoskeletal mechanism. Canadian Journal of Zoology 50: 501-521.

Gradwell, N. and B. Walcott. 1971. Dual functional and structural properties of the interhyoideus muscle of the bullfrog tadpole (Rana catesbeiana). Journal of Experimental Zoology 176: 193-218.

Green, D.M. 1978. Northern leopard frogs and bullfrogs on Vancouver Island. Canadian Field Naturalist 92: 78-79.

Griffiths, R.A., J. Denton, and A.L.C. Wong. 1993. The effect of food level on competition in tadpoles: interference mediated protothecan algae? Journal of Animal Ecology 62: 274-279.

Hammerson, G.A. 1982. Bullfrog eliminating leopard frogs in Colorado? Herpetological Review 13: 115-116.

Hammerson, G.A. 1999. Amphibians and reptiles in Colorado. Second Edition. University Press of Colorado and Colorado Division of Wildlife. $484 \mathrm{p}$.

*Hart, M.M., W.A. Williams, P.C. Thornton, K.P. McLaughlin, C.M. Tobalske, B.A. Maxell, D.P. Hendricks, C.R. Peterson, and R.L. Redmond. 1998. Montana atlas of terrestrial vertebrates. Montana Cooperative Wildlife Research Unit, University of Montana, Missoula, MT. $1302 \mathrm{p}$.

Haskell, W.L. 1956. Bullfrog study-lower Colorado River. Arizona Game and Fish Report 3839.

Hayes, M.P. and M.R. Jennings. 1986. Decline of ranid frog species in western North America: are bullfrogs (Rana catesbeiana) responsible? Journal of Herpetology 20(4): 490-509.

Hayes, M.P. and M.R. Jennings. 1988. Habitat correlates of distribution of the California redlegged frog (Rana aurora draytonii) and the foothill yellow-legged frog (Rana boylii): implications for management. pp. 144-158. In: R.C. Szaro, K.E. Severson, and D.R. Patton, technical coordinators. Management of amphibians, reptiles, and small mammals in North America. General Technical Report RM-166. U.S. Forest Service, Rocky Mountain Forest and Range Experiment Station, Fort Collins, Colorado.

Hayes, M.P. and J. Warner. 1985. Rana catesbeiana (bullfrog). Food. Herpetological Review 16: 109.

Hedeen, S.E. 1949. Premetamorphic growth of Rana catesbeiana in southwestern Ohio. Ohio Journal of Science 75: 182-183.

Heller, J.A. 1927. Brewer's mole as food of the bullfrog. Copeia 4: 116.

*Hendricks, P. 1997. Lee Metcalf National Wildlife Refuge preliminary amphibian and reptile investigations: 1996. Montana Natural Heritage Program, Helena, MT. 21 p.

*Hendricks, P. 1999. Amphibian and reptile survey of the Bureau of Land Management Miles City District, Montana. Montana Natural Heritage Program, Helena, MT. 80 p.

*Hendricks, P. and J.D. Reichel. 1996a. Amphibian and reptile survey of the Bitterroot National Forest: 1995. Montana Natural Heritage Program, Helena, MT. 95 p.

*Hendricks, P. and J.D. Reichel. 1996b. Preliminary amphibian and reptile survey of the Ashland District, Custer National Forest: 1995. Montana Natural Heritage Program, Helena, MT. $79 \mathrm{p}$.

*Hendricks, P. and J.D. Reichel. 1998. Amphibian and reptile survey on Montana refuges: 1996. Montana Natural Heritage Program, Helena, MT. 19 p. 
Hewitt, O.H. 1950. The bullfrog as a predator on ducklings. Journal of Wildlife Management 14: 244.

Höbel, G. 2005. Rana clamitans (Green Frog) and Rana catesbeiana (American Bullfrog). Reproduction. Herpetological Review 36(4):439-440.

Hoff, J.G. and S.A. Moss. 1974. A distress call in the bullfrog (Rana catesbeiana). Copeia 1974: 533-534.

Holman, J.A. 1957. Bullfrog predation on the eastern spadefoot (Scaphiopus holbrooki). Copeia 1957: 229.

Hopkins, W.A., J. Congdon and J.K. Ray. 2000. Incidence and impact of axial malformations in larval bullfrogs (Rana catesbeiana) developing in sites polluted by a coal-burning power plant. Environmental Toxicology and Chemistry 19(4): 862-868.

Horseman, N.D., A.H. Meier and D.D. Culley, Jr.. 1976. Daily variations in the effects of disturbance on growth, fattening, and metamorphosis in the bullfrog (Rana catesbeiana) tadpole. Journal of Experimental Zoology 198(3): 353-358.

Hovey, T.E. and D.R. Bergen. 2003. Rana catesbeiana (Bullfrog). Herpetological Review 24(4):360-361.

Howard, R.D. 1978a. The evolution of mating strategies in bullfrogs (Rana catesbeiana). Evolution 32: 850-871.

Howard, R.D. 1978b. The influence of male-defended oviposition sites on early embryo mortality in bullfrogs. Ecology 59(4): 789-798.

Howard, R.D. 1979. Estimating reproductive success in natural populations. American Naturalist 114(2): 221-231.

Howard, R.D. 1980. Male age-size distribution and mating success in bullfrogs. In: R.D. Alexander and D.W. Tinkle, editors. Natural selection and social behavior: recent research and new theory. Chiron Press, Newton, Massachusetts, USA.

Howard, R.D. 1981. Sexual dimorphism in bullfrogs. Ecology 62: 303-310.

Howard, R.D. 1983. Sexual selection and variation in reproductive success in a long-lived organism. American Naturalist 122: 301-325.

Howard, W.E. 1950. Birds as bullfrog food. Copeia 1950: 152.

Hutchinson, V.H. and I.G. Hill. 1978. Thermal selection of bullfrogs tadpoles (Rana catesbeiana) at different stages of development and acclimation temperatures. Journal of Thermal Biology 3: 57-60.

Ingram, W.M. and E.C. Raney. 1943. Additional studies on the movement of tagged bullfrogs, Rana catesbeiana Shaw. American Midland Naturalist 29: 239-241.

Jennings, M.R., J.J. Crayon, and R.L. Hothem. 2005. Bufo boreas halophilus (California Toad) and Rana catesbeiana (American Bullfrog). Amplexus. Herpetological Review 36(1):53.

Jennings, M.R. and M.P. Hayes. 1985. Pre-1900 overharvest of California red-legged frogs (Rana aurora draytonii): the inducement for bullfrog (Rana catesbeiana) introduction. Herpetologica 41(1): 94-103.

*Jones, L.L.C., W.P. Leonard, and D.H. Olson (eds). 2005. Amphibians of the Pacific Northwest. Seattle, WA: Seattle Audubon Society. 227 p.

Justis, C.S. and D.H. Taylor. 1976. Extraocular photoreception and compass orientation in larval bullfrogs (Rana catesbeiana). Copeia 1976: 98-105.

Kats, L.B., J.W. Petranka, and A. Smith. 1988. Antipredator defenses and the persistence of amphibian larvae with fishes. Ecology 69(6): 1865-1870. 
Kiesecker, J.M. 1997. The effects of pathogens, UV-B radiation, and introduced species on amphibians in the Pacific Northwest. Ph.D. dissertation, Oregon State University. Corvallis, OR. 194 p.

Kiesecker, J.M. and A.R. Blaustein. 1997. Population differences in responses of red-legged frogs (Rana aurora) to introduced bullfrogs. Ecology 78: 1752-1760.

Kiesecker, J.M. and A.R. Blaustein. 1998. Effects of introduced bullfrogs and smallmouth bass on microhabitat use, growth, and survival of native red-legged frogs (Rana aurora). Conservation Biology 12: 776-787.

Kiesecker, J.M., C.L. Miller, and A.R. Blaustein. 2001. Potential mechanisms underlying the displacement of native red-legged frogs by introduced bullfrogs. Ecology 82(7): 1964-1970.

Kirk, W.L. 1964. The nutritional value of bullfrog tadpoles (Rana catesbeiana) as forage for the largemouth bass (Micropterus salmoides). M.S. Thesis, Southern Illinois University. 29p.

Kirkpatrick, R.D. 1982. Rana catesbeiana (bullfrog). Food. Herpetological Review 13: 17.

Klimstra, W.D. 1949. Early bullfrog transformation. Copeia 1949(3): 231.

Kmieciak, R. 2004. Red-winged blackbird and bullfrog. Colorado Birds 38(2):91.

Korschgen, L.J. and D.L. Moyle. 1955. Food habits of the bullfrog in central Missouri farm ponds. American Midland Naturalist 54: 332-341.

Korschgen, L.J. and T.S. Baskett. 1963. Foods of impoundment and stream dwelling bullfrogs in Missouri. Herpetologica 19(2): 89-99.

Krupa, J.J. 2002. Temporal shift in diet in a population of American Bullfrog (Rana catesbeiana) in Carlsbad Caverns National Park. Southwestern Naturalist 47(3): 461-467.

Kruse, K.C. and M.G. Francis. 1977. A predation deterrent in larvae of the bullfrog, Rana catesbeiana. Transactions of the American Fisheries Society 106(3): 248-252.

Kupferberg, S.J. 1993. Bullfrogs (Rana catesbeiana) invade a northern California river: a plague or species coexistence? Bulletin of the Ecological Society of America 74: 319-320.

Kupferberg, S.J. 1994. Exotic larval bullfrogs (Rana catesbeiana) as prey for native garter snakes: functional and conservation implications. Herpetological Review 25(3): 95-97.

Kupferberg, S.J. 1996. The ecology of native tadpoles (Rana boylii and Hyla regilla) and the impact of invading bullfrogs (Rana catesbeiana) in a northern California river. Ph.D. Dissertation, University of California at Berkeley. Berkeley, CA. 289 pp.

Kupferberg, S.J. 1997. Bullfrog (Rana catesbeiana) invasion of a California river: the role of larval competition. Ecology 78: 1736-1751.

Lannoo, M. J., K. Lang, T. Waltz, and G.S. Phillips. 1994. An altered amphibian assemblage: Dickinson County, Iowa, 70 years are Frank Blanchard's Survey. American Midland Naturalist 131:311-319.

Lardie, R.L. 1963. A brief review of the bullfrog as a conservation problem with particular reference to its occurrence in Washington State. TriCor (Western Herpetological Society) 3: 7-9.

Larson, P.M. and S.M. Reilly. 2002. Functional morphology of feeding and gill irrigation in the Anuran Tadpole: electromyography and muscle function in larval Rana catesbeiana. Journal of Morphology 255: 202-214.

Lawler, S.P., D. Dritz, T. Strange and M. Holyoak. 1999. Effects of introduced mosquitofish and bullfrogs on the threatened California red-legged frog. Conservation Biology 13(3): 613-622.

Lee, D.S. 1969. Notes on the feeding behavior behavior of cave-dwelling bullfrogs. Herpetologica 25: 211-212. 
Lefcort, H., and S.M. Eiger. 1993. Antipredatory behaviour of feverish tadpoles: implications for pathogen transmission. Behaviour 126: 13-27.

Lewis, W.M. 1962. Stomach contents of bullfrogs (Rana catesbeiana) taken from a minnow hatchery. Transactions of the Illinois State Academy of Science 55: 80-83.

Lewis, W.M., G.E. Gunning, E. Lyles and W.L. Bridges. 1961. Food choice of largemouth bass as a function of availability and vulnerability of food items. Transactions of the American Fisheries Society 90: 277-280.

Licht, L.E. 1969. Palatability of Rana and Hyla eggs. American Midland Naturalist 82: 296298.

Lillywhite, H.B. 1970. Behavioral temperature regulation in the Bullfrog (Rana catesbeiana). Copeia 1970: 158-168.

Lillywhite, H.B. 1971. Temperature selection by the bullfrog, Rana catesbeiana. Comparative Biochemistry and Physiology A 40: 213-227.

*Livezey, R.L. and A.H. Wright. 1947. A synoptic key to salientian eggs of the United States. American Midland Naturalist 37: 179-222.

Lombardi, J.V., T.R. Perpetuo, C.M. Ferreira, J.G. Machado-Neto, and H.L.A. Marques. 2002. Acute toxicity of the fungicide copper oxychloride to tadpoles of the bullfrog Rana catesbeiana. Bulletin of Environmental Contamination and Toxicology 69(3): 415-420.

Lopez, T.J., and L.R. Maxson. 1990. Life history notes: Rana catesbeiana. Herpetological Review 21: 90.

Lotshaw, D.P. 1977. Temperature adaptation and effects of thermal acclimation in Rana sylvatica and Rana catesbeiana. Comparative Biochemistry and Physiology A 56: 287-294.

Lutterschmidt, W.I., G.A. Marvin, and V.H. Hutchison. 1996. Rana catesbeiana (bullfrog). Record size. Herpetological Review 27(2): 74-75.

Mahon, R. and K. Aiken. 1977. The establishment of the North American bullfrog (Rana catesbeiana) (Amphibia, Anura, Ranidae) in Jamaica. Journal of Herpetology 11: 197-199.

Matsuda, B.M., D.M. Green, and P.T. Gregory. 2006. Amphibians and reptiles of British Columbia. Victoria, B.C.: Royal British Columbia Museum. 266 p.

*Maxell, B.A. 2000. Management of Montana's amphibians: a review of factors that may present a risk to population viability and accounts on the identification, distribution, taxonomy, habitat use, natural history, and the status and conservation of individual species. Report to USFS Region 1, Order Number 43-0343-0-0224. Missoula, MT: Wildlife Biology Program, University of Montana. $161 \mathrm{p}$.

Maxell, B.A. 2002. Amphibian and aquatic reptile inventories in watersheds in the South and Middle Forks of the Flathead River drainage that contain lakes being considered for application of piscicides and subsequent stocking of west slope cutthroat trout. Report to the Region 1 Office of the U.S. Forest Service and the Montana Department of Fish, Wildlife, and Parks. Missoula, MT: Montana Cooperative Wildlife Research Unit and Wildlife Biology Program, University of Montana. $62 \mathrm{p}$.

* Maxell, B.A. 2004a. Amphibian and aquatic reptile inventories conducted on and around the Bitterroot National Forest 2000-2003. Report to Region 1 Office of the U.S. Forest Service, Bitterroot National Forest, Montana Department of Fish, Wildlife, and Parks, and Biological Resources Division of the U.S. Geological Survey. Missoula, MT: Montana Cooperative Wildlife Research Unit and Wildlife Biology Program, University of Montana. $128 \mathrm{p}$.

* Maxell, B.A. 2004b. Amphibian and aquatic reptile inventories conducted on and around the Thompson River 2003-2004. Report to Region 1 Office of the U.S. Forest Service and Plum 
Creek Timber Company. Missoula, MT: Montana Cooperative Wildlife Research Unit and Wildlife Biology Program. 83 p.

*Maxell, B.A. 2004c. Preliminary report on amphibian and aquatic reptile inventories conducted on and around the Ashland District of the Custer National Forest in 2002 and 2004. Report to Ashland District of Custer Forest, Region 1 Office of the U.S. Forest Service, and Montana Department of Fish, Wildlife, and Parks. Missoula, MT: Montana Cooperative Wildlife Research Unit and Wildlife Biology Program, University of Montana. $93 \mathrm{p}$.

*Maxell, B.A. 2004d. Report on amphibian and aquatic reptile inventories conducted on and around the Beaverhead-Deerlodge National Forest 2001-2003. Report to Region 1 Office of the U.S. Forest Service, Beaverhead-Deerlodge National Forest, Montana Department of Fish, Wildlife, and Parks, Montana State Office of the Bureau of Land Management, and Montana Department of Environmental Quality. Missoula, MT: Montana Cooperative Wildlife Research Unit and Wildlife Biology Program, University of Montana. 260 p.

* Maxell, B.A. 2005. Amphibian and aquatic reptile inventories conducted on and around lands administered by the Missoula Field Office of the Bureau of Land Management. Report to Missoula Field Office of the Bureau of Land Management. Montana Natural Heritage Program, Helena, MT and Montana Cooperative Wildlife Research Unit and Wildlife Biology Program, University of Montana, Missoula, MT. 53 p.

*Maxell, B.A. 2009. State-wide assessment of status, predicted distribution, and landscapelevel habitat suitability of amphibians and reptiles in Montana. Ph.D. Dissertation. Missoula, MT: Wildlife Biology Program, University of Montana. 294 p.

*Maxell, B.A. and D.G. Hokit. 1999. Amphibians and reptiles. pp. 2.1-2.30. In G. Joslin and H. Youmans, coordinators. Effects of recreation on Rocky Mountain wildlife: a review for Montana. Committee on Effects of Recreation on Wildlife, Montana Chapter of the Wildlife Society. 307 p.

*Maxell, B.A., J.K. Werner, P. Hendricks, and D. Flath. 2003. Herpetology in Montana: a history, status summary, checklists, dichotomous keys, accounts for native, potentially native, and exotic species, and indexed bibliography. Olympia, WA: Society for Northwestern Vertebrate Biology. Northwest Fauna 5: 1-138.

McAtee, W.L. 1921. Homing and other habits of the bullfrog. Copeia 1921: 39-40.

McAuliffe, J.R. 1978. Biological survey and management of sport-hunted bullfrog populations in Nebraska. Nebraska Game and Parks Commission, Lincoln, Nebraska. 78 pp.

McCoy, C.J. 1967. Diet of bullfrogs (Rana catesbeiana) in central Oklahoma farm ponds. Proceedings of the Oklahoma Academy of Science 48:44-45.

McGrath, E.A. and M.M. Alexander. 1979. Observations on the exposure of larval bullfrogs to fuel oil. Proceedings of the Northeast Fish and Wildlife Conference 80: 45-51.

McIntyre, P.B. and S.A. McCollum. 2000. Responses of bullfrog tadpoles to hypoxia and predators. Oecologia 125: 301-308.

McKamie, J.A. and G. Heidt. 1974. A comparison of spring food habits of the bullfrog (Rana catesbeiana) in three habitats of central Arkansas. Southwestern Naturalist 19: 107-111.

Minton, J.E. 1949. Coral snake preyed upon by the bullfrog. Copeia 1949: 288.

Mitchell, J.C. and L. McGranaghan. 2005. Albinism in American bullfrog (Rana catesbeiana) tadpoles from Virginia. Banisteria 25:51.

Moore, J.A. 1942a. Embryonic temperature tolerance and rate of development in Rana catesbeiana. Biology Bulletin, 83: 375-388. 
Moosman, D.L. 2005. Rana catesbeiana (Bullfrog). Microhabitat. Herpetological Review 36:298.

Moyle, P.B. 1973. Effects of introduced bullfrogs, Rana catesbeiana on the native frogs of the San Joaquin Valley, California. Copeia 1973(1): 18-22.

Mulla, M.S. 1963. Toxicity of organochlorine insecticides to the mosquito fish Gambusia affinis and the bullfrog Rana catesbeiana. Mosquito News 23(4): 299-303.

Mullen, D.A. 1976. Geographic distribution: Rana catesbeiana. Herpetological Review 7: 122.

Neck, R.W. 1981. Probable native population of bullfrog (Rana catesbeiana) in south Texas. Herpetological Review 12: 68.

Needham, J.G. 1905. The summer food of the bullfrog (Rana catesbeiana Shaw) at Saranac Inn. New York State Museum Bulletin 86:9-15.

Nie, M., J.D. Crim and G.R. Ultsch. 1999. Dissolved oxygen, temperature, and habitat selection by bullfrog (Rana catesbeiana) tadpoles. Copeia 1999(1): 153-162.

*Nussbaun, R., E. Brodie, Jr., and R. Storm. 1983. Amphibians and reptiles of the Pacific Northwest. University of Idaho Press, Moscow, Idaho. 322 p.

Olson, D.H. 1991. Ecological susceptibility of amphibians to population declines. Proceedings of the Symposium on Biodiversity of Northwestern California, October 28-30: 55-62.

*Patla, D.A. and C.R. Peterson. 2001. Status and trends of amphibian populations in the Greater Yellowstone Ecosystem, progress report, February 2001. Greater Yellowstone Ecosystem Amphibian Survey and Monitoring Program, Herpetology Laboratory, Department of Biological Sciences, Idaho State University, Pocatello, ID. 8 p.

Pearl, C.A. and D.E. Green. 2005. Rana catesbeiana (American Bullfrog). Chytridiomycosis. Herpetological Review 36:305-306.

Pearl, C.A., M.P. Hayes, R. Haycock, J.D. Engler, and J. Bowerman. 2005. Observations of interspecific amplexus between western North American ranid frogs and the introduced American bullfrog (Rana catesbeiana) and an hypothesis concerning breeding interference. American Midland Naturalist 154(1):126-134.

Pearl, C.A., M.J. Adams, R.B. Bury, and B. McCreary. 2004. Asymmetrical effects of introduced bullfrogs (Rana catesbeiana) on native Ranid frogs in Oregon. Copeia 1:11-20.

Perez, M.E. 1951. The food of Rana catesbeiana in Puerto Rico. Herpetologica 7: 102-104.

Petranka, J.W. 1989. Chemical interference competition in tadpoles: does it occur outside laboratory aquaria? Copeia 1989: 921-930.

Pinder, A.W. 1987. Cutaneous diffusing capacity increases during hypoxia in cold submerged bullfrogs (Rana catesbeiana). Respiration Physiology 70: 85-95.

Pine, R.H. 1975. Star-nosed mole eaten by bull frog. Mammalia 39: 713-714.

*Powell, R., J.T. Collins, and E.D. Hooper, Jr. 1998. A key to amphibians and reptiles of the Continental United States and Canada. University Press of Kansas, Lawrence, KS. 131 p.

Pryor, G.S. 2003. Growth rates and digestive abilities of Bullfrog tadpoles (Rana catesbeiana) fed algal diets. Journal of Herpetology 37(3):560-566.

Pryor, G.S. and K.A. Bjorndal. 2005. Effects of the nematode Gyrinicola batrachiensis on development, gut morphology, and fermentation in bullfrog tadpoles (Rana catesbeiana): a novel mutalism. Journal of Experimental Zoology Part A Comparative Experimental Biology 303A(8):704-712.

Raimondo, S.M., C.L. Rowe and J.D. Congdon. 1998. Exposure to coal ash impacts swimming performance and predator avoidance in larval bullfrogs (Rana catesbeiana). Journal of Herpetology 32(2): 289-292. 
Raney, E.C. 1940. Summer movements of the bullfrog, Rana catesbeiana Shaw, as determined by the jaw-tag method. American Midland Naturalist 23(3): 733-745.

Raney, E.C. and W.M. Ingram. 1940. Growth of tagged frogs in nature. Bulletin of the Ecological Society of America 21(4):30.

Raney, E.C. and W.M. Ingram. 1941. Growth of tagged frogs (Rana catesbeiana Shaw and Rana clamitans Daudin) under natural conditions. American Midland Naturalist 26: 201206.

*Reichel, J.D. 1995. Preliminary amphibian and reptile survey of the Sioux District of the Custer National Forest: 1994. Montana Natural Heritage Program, Helena, MT. 75 p.

*Reichel, J.D. and D.L. Flath. 1995. Identification guide to the amphibians and reptiles of Montana. Montana Outdoors 26(3): 15-34.

Relyea, R.A., and E.E. Werner. 1999. Quantifying the relation between predator-induced behavior and growth performance in larval anurans. Ecology 80(6): 2117-2124.

Resetarits, W.J., Jr. and H.M. Wilbur. 1989. Choice of oviposition site by Hyla chrysoscelis: role of predators and competitors. Ecology 70: 220-228.

* Roedel, M.D. and P. Hendricks. 1998a. Amphibian and reptile inventory on the Headwaters and Dillon Resource Areas in conjunction with Red Rocks Lakes National Wildlife Refuge: 1996-1998. Montana Natural Heritage Program, Helena, MT. 46 p.

*Roedel, M.D. and P. Hendricks. 1998b. Amphibian and reptile survey on the Bureau of Land Management Lewistown District: 1995-1998. Montana Natural Heritage Program, Helena, MT. $53 \mathrm{p}$.

Rogers, C.P. 1996. Rana catesbeiana (bullfrog) predation. Herpetological Review 27(2): 75.

Rosen, P.C. and C.R. Schwalbe. 1995. Bullfrogs: introduced predators in southwestern wetlands. In: LaRoe ET, G.S. Farris, C.E. Puckett, P.D. Doran, and M.J. Mac (eds.). Our living resources: a report to the nation on the distribution, abundance, and health of U.S. plants, animals, adn ecosystems. Washington, D.C.: U.S. Department of the Interior, National Biological Service. p 452-454.

Rosen, P.C., C.R. Schwalbe, D.A. Parizek Jr., P.A. Holm and C.H. Lowe. 1995. Introduced aquatic vertebrates in Chiricahua region: effects on declining native ranid frogs. U.S. Forest Service General Technical Report RM 264: 251-261.

Rowe, C.L., O.M. Kinney, and J.D. Congdon. 1998. Oral deformities in tadpoles of the bullfrog (Rana catesbeiana) caused by conditions in a polluted habitat. Copeia 1: 244-246.

Rowe, C.L., O.M. Kinney, A.P. Fiori, and J.D. Congdon. 1996. Oral deformities in tadpoles (Rana catesbeiana) associated with coal ash deposition: effects on grazing ability and growth. Freshwater Biology 36: 723-730.

Ryan, M.J. 1978. A thermal property of the Rana catesbeiana (Amphiba, Anura, Ranidae) egg mass. Journal of Herpetology 12: 247-248

Ryan, M.J. 1980. The reproductive behavior of the bullfrog (Rana catesbeiana). Copeia 1980(1): 108-114.

Schroeder, E.E. 1975. The reproductive cycle in the male bullfrog (Rana catesbeiana) in Missouri. Transactions of the Kansas Academy of Science 77: 31-35.

Schroeder, E.E. and T.S. Baskett. 1968. Age estimation, growth rates and population structure in Missouri bullfrogs. Copeia 1968(3): 583-592.

Schwalbe, C.R. and P.C. Rosen. 1988. Preliminary report on effect of bullfrogs on wetland herpetofaunas in southeastern Arizona. Pp. 166-173. In: R.C. Szaro, K.E. Severson, and D.R. Patton, technical coordinators. Management of amphibians, reptiles, and small 
mammals in North America. General Technical Report RM-166. U.S. Forest Service, Rocky Mountain Forest and Range Experiment Station, Fort Collins, Colorado.

Schwartz, J.J., M.A. Bee, and S.D. Tanner. 2000. A behavioral and neurobiological study of the responses of gray treefrogs, Hyla versicolor, to the calls of a predator, Rana catesbeiana. Herpetologica 56(1): 27-37.

Seale, D. 1973. Impact of amphibian larval populations on an aquatic community. Dissertation. Washington University, St. Louis, Missouri, USA.

Secor, S.M. 2005. Physiological responses to feeding, fasting and estivation for anurans. Journal of Experimental Biology 208(13):2595-2608.

Shaw. 1802. General Zoology, Vol. 3, Pt. 1, p. 106, pl. 33.

Shirose, L.J. 1990. Population ecology of the postmetamorphic bullfrog (Rana catesbeiana Shaw) in Algonquin Provincial Park, Ontario. M.S. Thesis, University of Guelph, Guelph, Ontario, Canada.

Shirose, L.J. and R.J. Brooks. 1995. Age structure, mortality, and longevity in syntopic populations of three species of ranid frogs in central Ontario. Canadian Journal of Zoology 73: $1878-1886$.

Shirose, L.J., R.J. Brooks, J.R. Barta, and S.S. Desser. 1993. Intersexual differences in growth, mortality, and size at maturity in bullfrogs in central Ontario. Canadian Journal of Zoology 71: 2363-2369.

Skelly, D.K. 1992. Field evidence for a cost of behavioral antipredator response in a larval amphibian. Ecology 73: 704-708.

Smith, A.K. 1977. Attraction of bullfrogs (Amphibia, Anura, Ranidae) to distress calls of immature frogs. Journal of Herpetology 11: 234-235.

Smith, G.R. 1999. Among family variation in tadpole (Rana catesbeiana) responses to density. Journal of Herpetology 33(1): 167-169.

Smith, G.R., D.A. Vaala, H.A. Dingfelder, and K.G. Temple. 2004. Effects of nitrite on bullfrog (Rana catesbeiana) tadpoles from central Ohio, USA. Bulletin of Environmental Contamination and Toxicology 72(5):1012-1016.

Smith, H.M., R. Mixter, and T. Spangler. 1966. The bullfrog and other reptiles and amphibians in western South Dakota. Journal of the Ohio Herpetological Society 5: 106-107.

Soileau, C. 1977. Froglegs forever (or bye-bye bullfrog)? La Conservation 29: 4-7.

*Stebbins, R.C. 2003. A field guide to western reptiles and amphibians. 3rd edition. New York, NY: Houghton Mifflin Co. 533 p.

Stebbins, R.C. and N.W. Cohen. 1995. A natural history of amphibians. Princeton University Press, Princeton, NJ. 316 p.

Steinwascher, K. 1978. The effect of coprophagy on the growth of Rana catesbeiana tadpoles. Copeia 1978(1): 130-134.

Stewart, M.M. and P. Sandison. 1972. Comparative food habits of sympatric mink frogs, bullfrogs, and green frogs. Journal of Herpetology 6: 241-244.

Stewart, R.E., S.A. Reese, and G.R. Ultsch. 2004. The physiology of hibernation in Canadian leopard frog (Rana pipiens) and bullfrogs (Rana catesbeiana). Physiological and Biochemical Zoology 77(1):65-73.

Stinner, J., N. Zarlinga, and S. Orcutt. 1994. Overwintering behavior of adult bullfrogs, Rana catesbeiana, in northeastern Ohio. Ohio Journal of Science 94(1): 8-13.

Storer, T.I. 1922. The eastern bullfrog in California. California Fish and Game 8: 219-224. 
Storm, R.M. 1952. Interspecific mating behavior in Rana aurora and Rana catesbeiana. Herpetologica 8: 108.

Stoutamire, R. 1932. Bullfrog farming and froging in Florida. State of Florida, Department of Agriculture Bulletin (n.s.) 56: 1-12.

Stuart, J.N. 1995. Anura: Rana catesbeiana (Bullfrog). Diet. Herpetological Review 26(1): 33.

Stumpel, A.H.P. 1992. Successful reproduction of introduced bullfrogs Rana catesbeiana in northwestern Europe: a potential threat to indigenous amphibians. Biological Conservation 60: 61-62.

Suggs, D.N. and A.M. Simmons. 2005. Information theory analysis of patterns of modulation in the advertisement call of the male bullfrog, Rana catesbeiana. Journal of the Acoustical Society of America 117(Part1)(4):2330-2337.

Taylor, R.J. and E.D. Micheal. 1971. Habitat effects on monthly foods of bullfrogs in eastern Texas. Proceedings of the Conference of the Southeastern Association of Game Fish Commerce 25: 176-186.

Terres, J.K. 1968. Kingfishers eating bullfrog tadpoles. Auk 85: 140.

Thomas, L.A., and G.O.U. Wogan. 1999. Rana catesbiana (bullfrog) record size. Herpetological Review 30(4): 223.

Thrall, J. 1971. Excavation of pits by juvenile Rana catesbeiana. Copeia 1971: 751-752.

Thrall, J. 1972. Food, feeding, and digestive physiology of the larval bullfrog (Rana catesbeiana Shaw). Dissertation Illinois State University 33B: 1861.

Treanor, R.R. 1975. Management of the bullfrog (Rana catesbeiana) resource in California. California Department of Fish and Game, Inland Fisheries Administration Report 75-1. 30p.

Treanor, R.R. and S.J. Nicola. 1972. A preliminary study of the commercial and sporting utilization of the bullfrog, Rana catesbeiana Shaw, in California. Inland Fisheries Administrative Report No. 72-4, California Department of Fish and Game. Sacramento, California.

Tucker, J.K. and M.E. Sullivan. 1975. Unsuccessful attempts by bullfrogs to eat toads. Transactions of the Illinois State Academy of Science 68: 167.

Tyler, J.D. and R.D. Hoestenbach, Jr. 1979. Differences in food of bullfrogs (Rana catesbeiana) from pond and stream habitats in southwestern Oklahoma. Southwestern Naturalist 24: 33-38.

*Van Kirk, R., L. Benjamin, and D. Patla. 2000. Riparian area assessment and amphibian status in the watersheds of the Greater Yellowstone Ecosystem. Greater Yellowstone Coalition, Bozeman, MT. $102 \mathrm{p}$.

Veldhoen, N. and C.C. Helbing. 2001. Detection of environmental endocrine-disruptor effects on gene expression in live Rana catesbeiana tadpoles using a tail fin biopsy technique. Environmental Toxicology and Chemistry 20(12): 2704-2708.

Viosca, P., Jr. 1931. Principles of bullfrog (Rana catesbeiana) culture. Transactions of the American Fisheries Society 61: 262-269.

Viosca, P., Jr. 1934. Principles of bullfrog culture. Southern Biological Supply Co., New Orleans, Louisiana. 31pp.

Viparina, S. and J.J. Just. 1975. The life period, growth and differentiation of Rana catesbeiana larvae occurring in nature. Copeia 1975(1): 103-109.

*Vitt, L.J., J.P. Caldwell, and D.B. Shepard. 2005. Inventory of amphibians and reptiles in the Billings Field Office Region, Montana. Sam Noble Oklahoma Museum of Natural History and Department of Zoology, University of Oklahoma, Norman, OK. 33 p. 
Wassersug, R.J. 1972. The mechanism of ultraplanktonic entrapment of anuran larvae. Journal of Morphology 137: 279-288.

Weis, J.S. 1975. The effect of DDT on tail regeneration in Rana pipiens and R. catesbeiana tadpoles. Copeia 1975: 765-767.

Weiwandt, T.A. 1969. Vocalization, aggressive behavior, and territoriality in the bullfrog, Rana catesbeiana. Copeia 1969(2): 276-285.

Werner, E.E., G.A. Wellborn, and M.A. McPeek. 1995. Diet composition in postmetamorphic bullfrogs and green frogs: implications for interspecific predation and competition. Journal of Herpetology 29: 600-607.

*Werner, J.K., B.A. Maxell, P. Hendricks, and D. Flath. 2004. Amphibians and reptiles of Montana. Missoula, MT: Mountain Press Publishing Company. 262p.

*Werner, J.K. and J.D. Reichel. 1994. Amphibian and reptile survey of the Kootenai National Forest: 1994. Montana Natural Heritage Program, Helena, MT. 104 p.

*Werner, J.K. and J.D. Reichel. 1996. Amphibian and reptile monitoring/survey of the Kootenai National Forest: 1995. Montana Natural Heritage Program, Helena, MT. 115 p.

*Werner, J.K. and T. Plummer. 1994. Amphibian and reptile survey of the Flathead Indian Reservation 1993-1994. Salish Kootenai College, Pablo, MT. 55 p.

*Werner, J.K. and T. Plummer. 1995. Amphibian monitoring program on the Flathead Indian Reservation 1995. Salish Kootenai College, Pablo, MT. 46 p.

*Werner, J.K., T. Plummer, and J. Weaselhead. 1998a. Amphibians and reptiles of the Flathead Indian Reservation. Intermountain Journal of Sciences 4(1-2): 33-49.

*Werner, J.K., T. Plummer, and J. Weaselhead. 1998b. The status of amphibians on the Flathead Reservation, Montana. Intermountain Journal of Sciences 4(3-4): 88.

Werner, Y.L. 2003. Mechanical leverage in the middle ear of the American bullfrog, Rana catesbeiana. Hearing Research 175:54-65.

Wiese, R.J. 1985. Ecological aspects of the bullfrog in northeastern Colorado. M.S. Thesis, Colorado State University, Fort Collins, Colorado.

*Wiese, R.J. 1990. Genetic structure of native and introduced populations of the bullfrog, a successful colonist. Ph.D. Dissertation. Fort Collins, CO: Colorado State University. 113 p.

Wiewandt, T.A. 1969. Vocalization, aggressive behavior, and territoriality in the bullfrog, Rana catesbeiana. Copeia 1969(2): 276-285.

Wilcox, J.T. 2005. Rana catesbeiana (American Bullfrog). Diet. Herpetological Review 36:306.

Willis, Y.L., D.L. Moyle, and T.S. Baskett. 1956. Emergence, breeding, hibernation, movements and transformation of the bullfrog, Rana catesbeiana in Missouri. Copeia 1956(1): 30-41.

Willson, J.D. and M.E. Dorcas. 2004. A comparison of aquatic drift fences with traditional funnel trapping as a quatitative method for sampling amphibians. Herpetological Review 35(2):148-150.

Wollmuth, I.P. and I.I. Crawshaw. 1988. The effect of development and season on temperature selection in bullfrog tadpoles. Physiological Zoology 61: 461-469.

Wright, A.H. and A.A. Wright. 1949. Handbook of frogs and toads of the United States and Canada. 3rd ed. Comstock Publishing Company Inc. Ithaca, NY. 640 p.

*[WWPC] Washington Water Power Company. 1995. 1994 wildlife report Noxon Rapids and Cabinet Gorge Reservoirs. Washington Water Power Company. Spokane, WA. 


\section{Columbia Spotted Frog (Rana luteiventris)}

Up-to-date distribution and status information can be found on the Montana Natural Heritage Program's TRACKER website at http://mtnhp.org

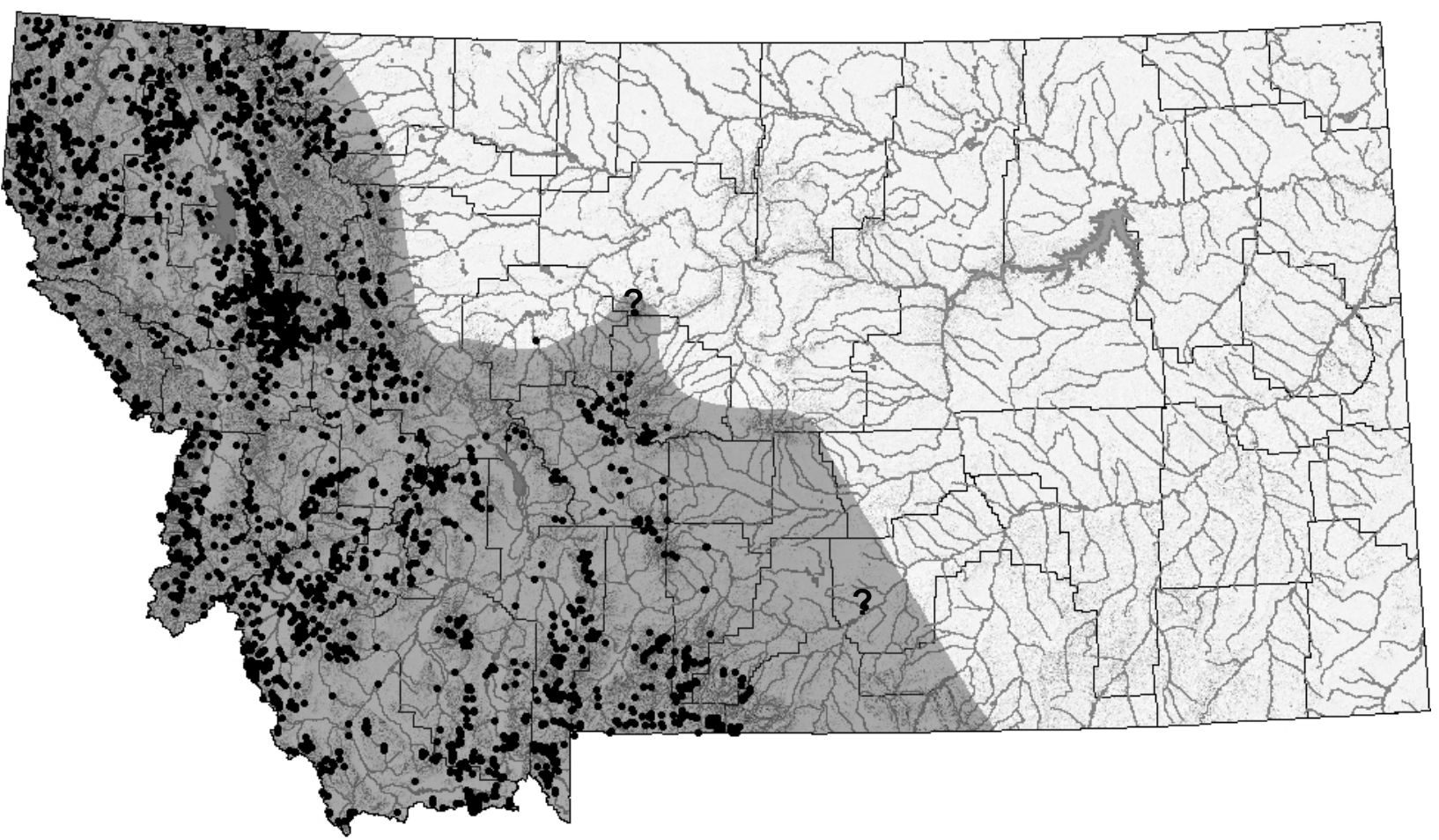

Distribution/Taxonomy

Based on allozyme and morphological evidence the Columbia spotted frog, Rana luteiventris, is currently recognized as a distinct species with a more or less continuous distribution along the Northern Rocky Mountains from the southwestern Yukon to central Idaho and with isolated populations located in the Bighorn Mountains of Wyoming, and at isolated springs and mountain tops in Utah, Nevada, Idaho, and Oregon (Green et al. 1996; Green et al. 1997; Reaser 2000). However, the species' taxonomy may require future division into three or more subspecies or weakly differentiated full species in order to adequately represent the genetic differentiation of glacial relict populations that are isolated in several portions of Utah and Nevada, (Green et al. 1997; David Bos, Brigham Young University, pers. comm.). If future taxonomic subdivisions are made all populations north of south central Idaho would likely be the same species or subspecies (Green et al. 1997). Across their range Columbia spotted frogs are found at elevations up to 3,050 M (10,000 ft) (Stebbins 2003).

Maximum Elevation

2,947 m (9,670 ft) in Park County (Maxell et al. 2003).

\section{Identification}

\section{Eggs:}

Eggs are laid in a single grapefruit sized globular mass and are usually laid communally with a few to more than a hundred other egg masses (Bryce Maxell, pers. obs.). Egg masses contain from 308 to 2,403 eggs per mass $(X=983, S D=348, N=30$ for completely counted egg masses at 8 low elevation sites in northwest Montana) (Bryce Maxell, pers. obs.). Each ovum is black above and laterally, cream to white at the very bottom, and is surrounded by two jelly layers 
(Svihla 1935; Bryce Maxell, pers. obs.). Ovum diameters are 2-3 mm (Svihla 1935; Morris and Tanner 1969; Bryce Maxell, pers. obs.). Total egg diameters, including the jelly layers, are usually 10-12 mm, but may vary from 8 to $21 \mathrm{~mm}$ (Svihla 1935; Turner 1958; Morris and Tanner 1969; Bryce Maxell, pers. obs.).

Larvae:

Body and tail musculature are mottled with light and dark brown spots, black spots, and flecks of metallic gold on a light tan to dark brown background (Bryce Maxell, pers. obs.). The ventral body surface is pale yellow and often has a metallic copper sheen toward the edges (Bryce Maxell, pers. obs.). The tail is about twice the length of the body and the dorsal and ventral tail fins are clear to yellowish with flecks of black and metallic gold. TL of 7-90 (Svihla 1935; Wishard 1977; Bryce Maxell, pers. obs.).

Juveniles and Adults:

A white to yellowish stripe extends from the tip of the snout laterally underneath the eye to just above the front limb. Dorsal base color varies from light tan to reddish or dark green with small black spots that are irregular in outline and usually have a light spot in their center (Turner 1959a). At higher elevations large adults are often a reddish brown base color dorsally. Ventral color is white to cream in all individuals, but larger animals are usually salmon in color on their thighs and in some individuals the salmon color extends from the feet to the middle of the belly with patches on the throat as well (Turner 1959a; Bryce Maxell, pers. obs.). SVL of 17-90 mm (Bryce Maxell, pers. obs.).

Similar Species:

Adult northern leopard frogs lack red or salmon color on their ventral surface and their dorsal surface has large, oval shaped, black spots that are regular in outline and are surrounded with a white halo. Adult bullfrogs lack the white to yellowish stripe on the lateral portion of the snout, have tympanums that are the same size or larger than their eye, and have a fold of skin extending from the back of their eye, over their tympanum, down to their front leg. Larval northern leopard frogs have tails that are less than twice their body length, do not have large flecks of black on their body or tail, and lack a metallic copper sheen on the lateral edges of their ventral surfaces. Larval bullfrogs have a bright to creamy yellow ventral surface, have perfectly round black dots on their dorsal surface and tail musculature, and attain much larger sizes. Northern leopard frog egg diameters are approximately one-half those of Columbia spotted frogs because their jelly envelopes are much smaller (see descriptions) and their egg masses are usually attached underwater (Ross et al. 1994). Bullfrog eggs are laid in the middle of the summer and are spread out in a thin layer over the surface or bottom of a pond rather than a globular mass. See sections on distribution to identify possible regions of co-occurrence of spotted frogs and northern leopard frogs or bullfrogs.

\section{Habitat Use/Natural History}

Spotted frogs are normally highly aquatic and are usually not found far from the marshy edges of ponds and lakes or the algae covered pools of springs or streams. However, they commonly bask and forage outside the water several meters from the waters edge (Bryce Maxell, pers. obs.). Adults feed on a variety of aquatic and terrestrial invertebrates (Moore and Strickland 1955; Turner 1959b; Miller 1978), but may commonly cannibalize smaller individuals as well (Pilliod 
1999). Adults overwinter underwater in larger permanent water bodies or in springs or streams (Turner 1960; Patla 1997) and may move throughout the winter to areas of higher oxygen concentration (Evelyn Bull, USFS Pacific Northwest Research Station, pers. comm.). Individuals may aestivate in mud under rocks in extremely dry conditions (Ross et al. 1999). Breeding occurs from mid March to mid June depending on snow melt, temperature and elevation (Bryce Maxell, pers. obs.). Females deposit egg masses communally in shallow waters (usually no more than 10-15 centimeters deep) with emergent vegetation (usually sedges), but egg masses are usually not attached to vegetation (Bryce Maxell, pers. obs.). Eggs usually hatch in 5 to 21 days and tadpoles metamorphose in 8 to 16 weeks during mid summer to late fall depending on elevation and water and air temperatures (Turner 1958; Morris and Tanner 1969; Bryce Maxell, pers. obs.). Tadpoles feed on a variety of algae as well as detritus, bacteria, and the remains of other dead tadpoles (Burke 1933; Morris and Tanner 1969). Adults typically do not move more than 50 meters within a season (Hollenbeck 1974; Patla 1997), but may move up to 1.5 kilometers to a seasonal breeding, foraging, or overwintering site (Engle 2000) and are known to disperse up to 6 or 7 kilometers (Reaser 1996a; Janice Engle, Boise State University, pers. comm.; Bryce Maxell, pers. obs.).

\section{$\underline{\text { Status and Conservation }}$}

Columbia spotted frogs are the most common frog in the mountains and mountain valleys of western Montana and can be expected to be found in the majority of water bodies that contain emergent vegetation and do not have fish or bullfrogs. However, their presence and/or status in the Big Snowy, Highwood, and Bighorn Mountains is uncertain. Risk factors relevant to the viability of populations of this species in Montana are likely to include grazing, fire and fire management activities, nonindigenous species and their management, development of water impoundments, and habitat fragmentation, all as described above. Individual studies that specifically identify risk factors or other issues relevant to the conservation of Columbia spotted frogs include the following. (1) In 1993, the United States Fish and Wildlife Service found that isolated "distinct population segments" of Columbia spotted frogs (at the time they were still known as spotted frogs Rana pretiosa) throughout Utah, Nevada and southern Idaho were warranted for listing as a threatened species under the Endangered Species Act, but that their listing was precluded by other species with higher priorities for listing (USFWS 1993). Several mechanisms of decline have been proposed for the isolated populations of Columbia spotted frogs in Utah, Nevada, and southern Idaho (Koch et al. 1996). Turner (1962a) reported on the decline of Columbia spotted frogs in Nevada in the early and mid 1900s because of intensive water utilization for irrigation, and the introduction of bass and bullfrogs. Thirty-five years later Reaser $(1996 b, 1997,2000)$ reported on further population declines in Nevada and attributed declines to alteration of natural hydrologic regimes for irrigation and livestock watering, livestock grazing, loss of beaver, and introduction of exotic bullfrogs and warm and cold water fishes. Hovingh (1993) noted that the following as factors that have contributed to the decline of Columbia spotted frog populations in the Wasatch Mountains and Bonneville basin in Utah: (a) habitat loss and fragmentation by highways, dams, reservoirs, urbanization, and the loss of natural flood disturbances because of water diversions and the channeling of rivers; (b) livestock grazing in riparian and wetland habitats; and (c) introduction of raccoons, bullfrogs, crayfish, bass, and trout. For a population inhabiting an isolated set of springs in Utah Cuellar (1994) reported that all ponds used by cattle had dark reddish water as a result of dung eutrophication, and lacked any aquatic vegetation, invertebrates, or frogs. Ross et al. (1999) found crushed 
individuals at the bottom of the hoove prints of cattle and reported that a decline in habitat appeared to be at least in part due to cattle grazing in the riparian areas. The construction of a dam on the Provo River in north central Utah extirpated many populations as a result of flooding of habitats (Wilkinson 1996). Populations in southwest Idaho are threatened by habitat loss as a result of livestock grazing impacts on riparian areas (Munger in Koch et al. 1996). It is likely that many of the known and postulated mechanisms of decline for the isolated southern populations pose threats to the viability of populations of Columbia spotted frogs in Montana. (2) Exotic warm and cold water fish have been implicated in the declines and losses of local Columbia spotted frog populations in Montana, Oregon, and Idaho. In Glacier National Park Marnell (1997) reported that fish were found within the same general wetland complexes in only 16 of $68(23 \%)$ of the sites where frogs were found. Furthermore, at the sites where spotted frogs were found with fish they were almost always found in satellite pools isolated from the fish or in densely vegetated sloughs. With a few exceptions this same general pattern of cooccurrence only where isolated pools, dense vegetation, or some other physical barrier from the fish exists has been observed in the Bitterroot and Cabinet Mountains in Montana (Bryce Maxell, pers. obs.). On the Palouse Prairie in northen Idaho Monello and Wright (1999) found spotted frogs to be excluded from all water bodies containing fish, including those containing gold fish. Similarly, although Columbia spotted frogs cooccurred with fish at $69 \%$ of 55 lakes surveyed in the Big Horn Crags in central Idaho, frogs only successfully reproduced at $1(2 \%)$ of these lakes (Pilliod et al. in Koch et al. 1996). Thus, stocked lakes in this region appeared to be population "sinks" and persistence in a basin may be dependent on the number and location of stocked sites (Pilliod et al. in Koch et al. 1996). In northeast Oregon Bull and Hayes (2000) found the numbers of metamorphosed frogs at a site was inversely correlated with the presence of longnose dace and rainbow trout. (3) Bullfrogs, which were introduced into Montana sometime prior to 1968, have apparently extirpated Columbia spotted frogs from a number of sites along the Bitterroot, lower Flathead, and lower Clark Fork Rivers (Black 1969a, 1969b; Giermakowski 1998; Werner et al. 1998; Bryce Maxell, pers. obs.). However, sizable Columbia spotted frog populations have been found in close proximity with bullfrogs on the floodplain of the Bitterroot River near spring brooks. Spring brooks provide summer habitat and overwintering sites for Columbia spotted frogs which are apparently too cold for bullfrogs (Cavallo 1997; Bryce Maxell, pers. obs.) and, therefore, provide important refuges for Columbia spotted frogs around the flood plains of the mountain valleys. (4) Manipulation of water levels in water impoundments can result in direct and indirect mortality of amphibian larvae and eggs. For example, during the summer of 1998, fluctuating water levels in Cabinet Gorge Reservoir in northwest Montana led to the dessication of Columbia spotted frog eggs and larvae when water levels dropped for power generation (Bryce Maxell, pers. obs.). (5) Kirk (1988) found a large number of dead adults in Oregon as the result of spraying with DDT $(0.65-0.72 \mathrm{~kg}$ DDT/ha) to control Douglas fir tussock moth. Subsequent examination of the tissues of the dead frogs showed them to be heavily contaminated with DDT and its analogs relative to live individuals collected at the same site. (6) In northeast Oregon Bull and Hayes (2000) found that the numbers of egg masses, metamorphosed frogs, and adult frogs found at grazed and ungrazed ponds did not differ. (7) Patla $(1997 ; 1998)$ and Patla and Peterson (1999) reported declines in a population in Yellowstone National Park as the result of highway construction and construction of an underground water pumping system which changed migratory habitat and the local hydrological regime, respectively. (8) Lefcort et al. (1998) reported reduced survival of Columbia spotted frog larvae when exposed to experimental chambers with heavy metal contaminated soils from a 
EPA Superfund site in northern Idaho. Larval survival was 0.875 in controls, 0.20 in heavily contaminated soil and 0.175 in less contaminated soil. Thus, average survival in the superfund soils represented an almost 80 percent reduction in larval survival. Furthermore, they found that exposure to most heavy metal contaminants had sublethal effects in that they greatly reduced the ability of tadpoles to respond to chemical cues from a fish predator. (9) Blaustein et al. (1999) found that spotted frogs had relatively high levels of photolyase, and enzyme that is known to repair UV-B damage to DNA, as compared with other amphibian species. Furthermore, at a number of field sites, hatching success was unaffected by exposure to ambient levels of UV-B. Davis et al. (1996) found that embryo survival was above $80 \%$ for those exposed to ambient or no UV-B radiation, but dropped to $56 \%$ in those exposed to UV-B radiation enhanced to $15-30 \%$ above ambient levels at mid day. Furthermore, few of the larvae survived when exposed to the enhanced UV-B radiation. (10) Reinking et al. (1980) found that aldosterone levels in blood plasma were over three times higher in animals held in captivity for three weeks than animals in the wild, indicating that animals face high levels of stress when held in captivity and possibly when being handled in the wild. (11) Historic loss of beaver may be causing gradual habitat loss in some mountain ranges in Montana as sites fill in with sediments and are no longer being replaced (Grant Hokit, Carroll College, pers. comm.; Bryce Maxell, pers. obs.).

\section{Research and Management Suggestions}

1. See research and management suggestions under all of the general risk factors described above with the exception of harvest and commerce.

2. Documentation of their presence is poor in the area between the east front of the Rockies and the Swan Mountain Range south of Glacier Park, in the area between the Gallatin Range the Big Hole Valley and the Elkorn Mountains, in the Big Belt Mountains, and on the AbsarokaBeartooth Plateau. In addition their presence in the Big Snowy, Highwood, and Bighorn Mountains is uncertain.

3. Local and landscape wide impacts of fish introductions should be examined in order to develop fish stocking guidelines that will allow for the persistence of individual populations and connectivity between sets of local populations or metapopulations.

Fish stocking at both high and low elevation sites should only be carried out where fish have previously been stocked and in areas where they are contained in a limited number of water bodies (i.e., introduction in one lake in a basin will not result in the colonization of other lakes in the basin).

4. Fish removal should be considered in areas that appear to be key habitats that ensure the survival of local sets of populations.

5. The public should be educated on the possible impacts of bullfrogs on native communities and be made aware of the fact that it is illegal to introduce them into the wild in Montana.

6. Where possible, bullfrog populations should be removed. Removal may be accomplished by altering habitats from permanent waters that support exotic bullfrogs, fish, and aquatic weeds to ephemeral habitats that support native species. Removal may also be accomplished by surrounding waterbodies with a drift fence and subsequently draining the water body in the late fall after bullfrogs have moved into overwintering sites. Individuals can then either be captured by hand or left to dessicate and/or freeze.

7. Until the lethal and sublethal impacts of commonly used fertilizers, herbicides, and pesticides on all amphibian life history stages present in an area are examined they should not be applied within 100 meters of waterbodies or wetlands. 
8. In areas where livestock grazing is common, studies of the habitat use and population dynamics of Columbia spotted frogs relative to grazing impacts should be conducted.

9. The impacts of the loss of beaver, the creation of water impoundments with fluctuating water levels, and fish introductions, may be mitigated by the creation of ephemeral pools.

Bibliography *indicates an article with information specific to Montana

*Adams, M.J., B.R. Hossack, R.A. Knapp, P.S. Corn, S.A. Diamond, P.C. Trenham, and D.B. Fagre. 2005. Distribution patterns of lentic-breeding amphibians in relation to ultraviolet radiation exposure in western North America. Ecosystems 8:488-500.

*Amish, S.J. 2006. Ecosystem engineering: beaver and the population structure of Columbia spotted frogs in western Montana. M.S. Thesis. Missoula, MT: University of Montana. 96 p.

Ammon, E.M., C.R. Gorley, K.W. Wilson, D.A. Ross, and C.R. Peterson. 2003. Advances in habitat restoration for the Columbia spotted frog (Rana luteiventris): a case study from the Provo River population. In: Proceedings: California riparian systems: processes and floodplains management, ecology, and restoration. Sacramento, CA: Riparian Habitat Joint Venture and Western Section of The Wildlife Society:348-356.

*Anderson, M.E. 1977. Aspects of the ecology of two sympatric species of Thamnophis and heavy metal accumulation with the species. M.S. Thesis, University of Montana. Missoula, MT. 147 pp.

Baird, S.F. and C.F. Girard. 1853. Proceedings of the Academy of National Sciences, Philadelphia, Volume 6, p. 378.

Bartelt, P.E. and C.R. Peterson. 1994. Riparian habitat utilization by western toads (Bufo boreas) and spotted frogs (Rana pretiosa) on the Targee National Forest. USDA Forest Service Contract \# INT-93780-CCSA Final Report. 30 p.

*Bartoletti, F.J. 2000. Impact of stream corridors on breeding populations of Rana luteiventris. Undergraduate Honors Thesis. Carroll College, Helena, MT. 15 p.

*Beal, M.D. 1951. The occurrence and seasonal activity of vertebrates in the Norris and Gibbon Geyser Basins of Yellowstone National Park. M.S. Thesis. Utah State Agricultural College. Logan, Utah. $61 \mathrm{p}$.

Bissonette, J.A. and B.C. Larson. 1991. Annotated bibliography for the spotted frog (Rana pretiosa). Utah State Cooperative Wildlife Research Unit Miscellaneous Report 91(2): 1-20.

*Black, J.H. 1969a. Yes - there are bullfrogs in Montana. Montana Outdoors 1969: 4.

*Black, J.H. 1969b. The frog genus Rana in Montana. Northwest Science 43(4): 191-195.

*Black, J.H. and R. Timken. 1976. Endangered and threatened amphibians and reptiles in Montana. p 36-37. In: R.E. Ashton, Jr. (chair). Endangered and threatened amphibians and reptiles in the United States. Society for the Study of Amphibians and Reptiles Herpetological Circular 5: 1-65.

*Blaustein, A.R., J.J. Beatty, H. Deanna, and R.M. Storm. 1995. The biology of amphibians and reptiles in old-growth forests in the Pacific Northwest. General Technical Report PNWGTR-337. Portland, OR: U.S. Department of Agriculture, Forest Service, Pacific Northwest Research Station. 98 p.

Blaustein, A.R., J.B. Hays, P.D. Hoffman, D.P. Chivers, J.M. Kiesecker, W.P. Leonard, A. Marco, D.H. Olson, J.K. Reaser, and R.G. Anthony. 1999. DNA repair and resistance to UV-B radiation in western spotted frogs. Ecological-Applications 9(3): 1100-1105. 
Blouin, M. 2001. Microsatellite DNA testing of Columbia spotted frog toe samples. Unpublished report. On file with: USDA Forest Service, Pacific Northwest Research Station, 1401 Gekeler Lane, La Grande, OR 97850.

Bodley, K.T. 2003. The effects of the presence of dragonfly predators on the morphology of the Columbia spotted frog (Rana luteiventris). Undergraduate Honors Thesis. Carroll College, Helena, MT. 13 p.

*Bos, D.H. 2000. Conservation genetics and phylogeography of the Columbia spotted frog (Rana luteiventris). M.S. Thesis. Department of Zoology, Brigham Young University. Provo, Utah. 42 p.

*Bos, D.H. and J.W. Sites, Jr. 2001. Phylogeography and conservation genetics of the Columbia spotted frog (Rana luteiventris; Amphibia, Ranidae). Molecular Ecology 10: 1499-1513.

Boulenger, G.A. 1920. A monograph of the American frogs of the genus Rana. Proceedings of the American Academy of Arts and Sciences 55: 411-480.

*Boundy, J. 2001. Herpetofaunal surveys in the Clark Fork Valley region, Montana. Herpetological Natural History 8: 15-26.

Briggs, J.L., Sr. 1987. Breeding biology of the Cascade frog, Rana cascadae, with comparisons to Rana aurora and Rana pretiosa. Copeia 1987: 241-245.

Brues, C.T. 1924. Observations on animal life in the thermal waters of Yellowstone Park, with a consideration of the thermal environment. Proceedings of the American Academy of Arts and Sciences 59(15): 371-437.

*Brues, C.T. 1932. Further studies on the fauna of North American Hot Springs. Proceedings of the American Academy of Arts and Sciences 67(7): 184-303.

*Brunson, R.B. 1955. Check list of the amphibians and reptiles of Montana. Proceedings of the Montana Academy of Sciences 15: 27-29.

*Brunson, R.B. and H.A. Demaree. 1951. The herpetology of the Mission Mountains, Montana. Copeia 1951: 306-308.

Bull, E.L. 2000. Comparisons of two radio transmitter attachments on Columbia spotted frogs (Rana luteiventris). Herpetological Review 31(1): 26-28.

Bull, E.L. 2003. Diet and prey availability of Columbia spotted frogs in northeastern Oregon. Northwest Science 77:349-356.

Bull, E.L. 2005. Ecology of the Columbia spotted frog in northeastern Oregon. General Technical Report PNW-GTR-640. U.S. Department of Agriculture, Forest Service, Pacific Northwest Research Station. Portland, OR. 46 p.

Bull, E.L. and J.A. Whelan. 1984. Ecology and management of the bullfrog. Resource Publication 155. U.S. Fish and Wildlife Service. 23p.

Bull, E.L. and M.P. Hayes. 2000. Livestock effects on reproduction of the Columbia spotted frog. Journal of Range Management 53: 293-296.

Bull, E.L. and M.P. Hayes. 2001. Post-breeding season movements of Columbia spotted frogs (Rana luteiventris) in northeastern Oregon. Western North American Naturalist 61(1): 119123.

Bull, E.L. and M.P. Hayes. 2002. Overwintering of Columbia spotted frog in northeastern Oregon. Northwest Science 76 (2):141-147.

Bull, E.L. and D.B. Marx. 2002. Influence of fish and habitat on amphibian communities in high elevation lakes in northeastern Oregon. Northwest Science 76(3): 241-249. 
Bull, E.L. and J.F. Shepherd. 2003. Water temperature at oviposition sites of Rana luteiventris in northeastern oregon. Western North American Naturalist 63(1): 108-113.

Bull, E.L. and B.C. Wales. 2001. Effects of disturbance on amphibians of conservation concern in eastern Oregon and Washington. Northwest Science 75: 174-179.

Burke, V. 1933. Bacteria as food for vertebrates. Science 78(2018): 194-195.

*Burton, S.R., D.A. Patla, and C.R. Peterson. 2002. Amphibians of Red Rock Lakes National Wildlife Refuge: occurrence, distribution, relative abundance, and habitat associations. Herpetology Laboratory, Department of Biological Sciences, Idaho State University, Pocatello, ID. 66 p.

Call, D.R. and J.G. Hallett. 1998. PCR primers for microsatellite loci in the anurans Rana luteiventris and Hyla regilla. Molecular Ecology 7: 1083-1090.

Carpenter, C.C. 1953. Aggregation behavior of tadpoles of Rana pretiosa pretiosa. Herpetelogica 9: 77-78.

*Case, S.M. 1976. Evolutionary studies in selected North American frogs of the genus Rana (Amphibia, Anura). Ph.D. Dissertation. University of California, Berkeley, CA. 157 p.

*Case, S.M. 1978. Biochemical systematics of members of the genus Rana native to western North America. Systematic Zoology 27: 299-311.

*Cavallo, B.J. 1997. Floodplain habitat heterogeneity and the distribution, abundance, and behavior of fishes and amphibians in the Middle Fork Flathead River Basin, Montana. M.S. Thesis. University of Montana, Missoula, MT. 133 p.

*Cooper, J.G. 1869. The fauna of Montana territory. American Naturalist 3: 124-127.

*Cope, E.D. 1872. Report on the recent reptiles and fishes of the survey, collected by Campbell Carrington and C.M. Dawes. pp. 467-469. In: F.V. Hayden, Preliminary report of the United States geological survey of Montana and portions of adjacent territories; being a fifth annual report of progress. 538 pp. 42nd Congress, 2nd Session, House Executive Document Number 326. Serial 1520.

*Cope, E.D. 1875. Check-list of North American Batrachia and Reptilia; with a systematic list of the higher groups, and an essay on geographical distribution. U.S. National Museum Bulletin 1(1): 1-104.

*Cope, E.D. 1879. A contribution to the zoology of Montana. American Naturalist 13(7): 432441.

*Cope, E.D. 1883. Notes on the geographic distribution of Batrachia and Reptilia in western North America. Proceedings of the Academy of Natural Sciences of Philadelphia 35: 10-35.

*Cope, E.D. 1889. The Batrachia of North America. Bulletin of the U.S. National Museum 34: 1-525, figs. 1-119, pls. 1-86.

Corkran, C.C. and C. Thoms. 2006. Amphibians of Oregon, Washington, and British Columbia. $2^{\text {nd }}$ Edition. Vancouver, B.C.: Lone Pine Publishing. 176 p.

*Corn, J. and P. Hendricks. 1998. Lee Metcalf National Wildlife Refuge bullfrog and painted turtle investigations: 1997. Montana Natural Heritage Program, Helena, MT. 20 p.

*Corn, P.S., B.R. Hossack, E. Muths, D.A. Palta, C.R. Peterson, and A.L. Gallant. 2005. Status of amphibians on the Continental Divide: surveys on a transect from Montana to Colorado, USA. Alytes 22(3-4):85-94.

*Corn, P.S., E. Muths, and C.R. Peterson. 2008. U.S. Geological Survey Amphibian Research and Monitoring Initiative Rocky Mountain Region, 2007 Progress Report. Missoula, MT: Report to U.S. Geological Survey. 6 p. 
Cuellar, O. 1994. Ecological observations on Rana pretiosa in western Utah. Alytes 12(3): 109-121.

Cuellar, O. 1996. Taxonomic status of the western spotted frog. Biogeographica (Paris) 72(4): 145-150.

*Daugherty, C.H., L.B. Daugherty, F.W. Allendorf, L.N. Wishard, and N.J. Mitchell. 1976. Adaptive heat retention in giant egg masses of Rana pretiosa. University of Montana, Department of Zoology. Missoula, Montana. 9 p.

*Daugherty, C.H., L.N. Wishard, and L.B. Daugherty. 1978. Sexual dimorphism in an anuran response to severe thermal stress. Journal of Herpetology 12(3): 431-432.

Davis, A.B. and P.A. Verrell. 2005. Demography and reproductive ecology of the Columbia spotted frog (Rana luteiventris) across the Palouse. Canadian Journal of Zoology 83(5):702711.

Davis, T.M., I.N. Flamarique, and K. Ovaska. 2000. Effects of UV-B on amphibian development: embryonic and larval survival of Hyla regilla and Rana pretiosa. Froglog 16: 3 .

*Dumas, P.C. 1964. Species-pair allopatry in the genera Rana and Phrynosoma. Ecology 45: 178-181.

*Dumas, P.C. 1966. Studies of the Rana species complex in the Pacific Northwest. Copeia 1966(1): 60-74.

Dunlap, D.G. 1955. Inter- and intraspecific variation in Oregon frogs of the genus Rana. American Midland Naturalist 54: 314-331.

Dunlap, D.G. 1977. Wood and western spotted frogs (Amphibia, Anura, Ranidae) in the Big Horn Mountains of Wyoming. Journal of Herpetology 11: 85-87.

Engle, J. 2000. Columbia spotted frog Great Basin population (Owyhee Mountains subpopulation) long-term monitoring plan.

Engle, J. 2001a. Columbia spotted frog project: the translocation of 2 male Columbia spotted frogs between sites within an element of occurrence in the Owyhee subpopulation of the Great Basin population. Section 6, Endangerd Species Act Threatened and Endangered Species Project E-26-1.

Engle, J. 2001b. Population biology and natural history of Columbia spotted frogs (Rana luteiventris) in the Owyhee uplands of southwestern Idaho: implications for monitoring and management. Masters Thesis-Boise State University.

Engle, J.C. and J.C. Munger. 1998. Population structure of spotted frogs in the Owyhee Mountains. Techinical Bulletin 98-20. Boise, ID: Idaho Bureau of Land Management. 10p.

*Enk, M. 1999. Preliminary results of amphibian monitoring on the Lewis and Clark National Forest. Intermountain Journal of Sciences 5(1-4): 48.

*Farmer, P. and K. Burgess. 1983. Jardine area baseline terrestrial wildlife study May 15, 1981 - May 15, 1982. Western Technology and Engineering Inc. Helena, MT.

Ferguson, D.E. 1954. An annotated list of the amphibians and reptiles of Union County, Oregon. Herpetologica 10:149-152.

*Flath, D.L. 2002. Reptile and amphibian surveys in the Madison-Missouri River Corridor, Montana. Annual Progress Report. 14p.

*Franz, R. 1971. Notes on the distribution and ecology of the herpetofauna of northwestern Montana. Bulletin of the Maryland Herpetological Society 7: 1-10.

*Funk, W.C. 2004. Patterns and consequences of dispersal in Columbia Spotted Frogs (Rana luteiventris). Ph.D. Dissertation. University of Montana. 139p. 
*Funk, W.C., M.S. Blouin, P.S. Corn, B.A. Maxell, D.S. Pilliod, S. Amish, and F.W. Allendorf. 2005. Population structure of Columbia spotted frogs (Rana luteiventris) is strongly affected by the landscape. Molecular Ecology 14:483-496.

*Funk, W.C., A.E. Greene, P.S. Corn, and F.W. Allendorf. 2004. High dispersal in a frog species suggests that it is vulnerable to habitat fragmentation. Biology Letters 1(1):13-16

*Funk, W.C., C.A. Pearl, H.M. Draheim, M.J. Adams, T.D. Mullins, and S.M. Haig. 2008. Range-wide phylogeographic analysis of the spotted frog complex (Rana luteiventris and Rana pretiosa) in northwestern North America. Molecular Phylogenetics and Evolution 49:198-210.

Garber, C.S. 1992. A survey for spotted frogs (Rana pretiosa), wood frogs (Rana sylvatica), and boreal toads (Bufo boreas) in Wyoming: interim report for the Laramie Range Mountains and Bighorn Mountains of Wyoming. Wyoming Natural Diversity Database. Laramie, WY. 15 pp. + appendix.

Garber, C.S. 1994. A status survey for spotted frogs (Rana pretiosa) wood frogs (Rana sylvatica) and boreal toads (Bufo boreas) in the mountains of southern and eastern Wyoming. U.S.F.W.S. Cooperative Agreement No. 14-48-0006-92-919.

Garber, C.S. 1995a. A survey for U.S. Forest Service listed "Sensitive" amphibians including the spotted frog (Rana pretiosa), leopard frog (Rana pipiens), tiger salamander (Ambystoma tigrinum) and the boreal toad (Bufo boreas) on the north half of the Shoshone National Forest. Report prepared by the Wyoming Natural Diversity Database, Laramie, WY, for the U.S. Forest Service, Shoshone National Forest, Cody, WY.

Garber, C.S. 1995b. Addendum Number 1 to "A status survey for spotted frogs (Rana pretiosa) wood frogs (Rana sylvatica) and boreal toads (Bufo boreas) in the mountains of southern and eastern Wyoming. Report prepared by the Wyoming Natural Diversity Database for the U.S. Fish and Wildlife Service, Denver, CO.

Gibbons, M.M. and T.K. McCarthy. 1984. Growth, maturation and survival of frogs Rana temporaria L. Holarctic Ecology 7:419-427.

*Giermakowski, J.T. 1998. Microhabitat separation between the bullfrog (Rana catesbeiana) and the Columbia spotted frog (Rana luteiventris) in Western Montana. Undergraduate Thesis. Wildlife Biology Program, University of Montana, Missoula, MT. 27 p.

Gittins, S.P., J.E. Steeds, and R. Williams. 1982. Population age-structure of the common toad (Bufo bufo) at a lake in mid-Wales determined from annual growth rings in the phalanges, British Journal of Herpetology 6:249-252.

Goraya, J., Y. Wang and J.M. Conlon. 2000. Peptides with antimicrobial activity from four different familes isolated from the skins of the North American frogs Rana luteiventris, Rana berlandie and Rana pipiens. European Journal of Biochemistry 267(3): 894-900.

Green, D.M. 1985. Natural hybrids between the frogs, Rana cascadae and Rana pretiosa (Anura: Ranidae). Herpetologica 41(3): 262-267.

*Green, D.M. 1986a. Systematics and evolution of Western North American frogs allied to Rana aurora and Rana boylii: karyological evidence. Systematic Zoology 35(3): 273-282.

*Green, D.M. 1986b. Systematics and evolution of Western North American frogs allied to Rana aurora and Rana boylii: electrophoretic evidence. Systematic Zoology 35(3): 283-296.

*Green, D.M., H. Kaiser, T.F. Sharbel, J. Kearsley, and K.R. McAllister. 1997. Cryptic species of spotted frogs, Rana pretiosa complex, in western North America. Copeia 1997(1): 1-8. 
*Green, D.M., T.F. Sharbel, J. Kearsley, and H. Kaiser. 1996. Postglacial range fluctuation, genetic subdivision and speciation in the western North American spotted frog complex, Rana pretiosa. Evolution 50: 374-390.

*Greer, K.R. 1955a. The otter's diet - good or bad? Montana Wildlife 5(3): 14-17. Montana Fish and Game Department, Helena, MT.

*Greer, K.R. 1955b. Yearly food habits of the river otter in the Thompson Lakes Region, Northwestern Montana, as indicated by scat analysis. American Midland Naturalist 54: 299313.

*Griffin, J.S. 2002. Spotted frog (Rana luteiventris) dispersal in the Lower Lump Drainage. Undergraduate Honors Thesis. Carroll College, Helena, Montana. 18 p.

Guarino, F.M., F. Angelini, and M. Cammarota. 1995. A skeletochronological analysis of three syntopic amphibian species from southern Italy. Amphibia-Reptilia 16:297-302.

Haertel, J.D. and R.M. Storm. 1970. Experimental hybridization between Rana pretiosa and Rana cascadae. Herpetologica 26: 436-446.

Hall, J.C. 1994. Central processing of communication sounds in the anuran auditory system. American Zoologist 34(6): 670-684.

*Hart, M.M., W.A. Williams, P.C. Thornton, K.P. McLaughlin, C.M. Tobalske, B.A. Maxell, D.P. Hendricks, C.R. Peterson, and R.L. Redmond. 1998. Montana atlas of terrestrial vertebrates. Montana Cooperative Wildlife Research Unit, University of Montana, Missoula, MT. $1302 \mathrm{p}$.

Hatch, K. (Coordinator). 2000. Conference on biology and conservation of the spotted frog (Rana luteiventris). March 9, 2000. Reno, Nevada.

*Hayes, M.P. and D.M. Krempels. 1986. Vocal sac variation among frogs of the genus Rana from Western North America. Copeia 1986: 927-936.

Hayes, M.P. and M.R. Jennings. 1986. Decline of ranid frog species in western North America: are bullfrogs (Rana catesbeianna) responsible? Journal of Herpetology 20:490-509.

*Hendricks, P. 1997. Lee Metcalf National Wildlife Refuge preliminary amphibian and reptile investigations: 1996. Montana Natural Heritage Program, Helena, MT. 21 p.

*Hendricks, P. 2000. Amphibian and reptile survey of the Thompson Chain of Lakes. A report to the Montana Department of Fish, Wildlife, and Parks. Montana Natural Heritage Program, Helena, MT. 15 p.

*Hendricks, P. and J.D. Reichel. 1996. Amphibian and reptile survey of the Bitterroot National Forest: 1995. Montana Natural Heritage Program, Helena, MT. 95 p.

Herreid, C.F. and S. Kinney. 1967. Temperature and development of the wood frog, Rana sylvatica, in Alaska. Ecology 48:579-590.

*Hill, S.R., Jr. 1995. Migratory chronology of adult tiger salamanders (Ambystoma tigrinum) and survey of larvae of the tiger salamander in the northern range of Yellowstone National Park. M.S. Thesis. Montana State University, Bozeman, MT. 72 p.

*Hill, S.R., Jr. and R.E. Moore. 1994a. Herpetological survey in the northern range of Yellowstone National Park. Investigator's Annual Reports Yellowstone National Park 1993. Yellowstone Center for Resources. pp. 96-97.

*Hill, S.R., Jr. and R.E. Moore. 1994b. Herpetological survey in the northern range of Yellowstone National Park. Annual Report to Yellowstone National Park. February 1, 1994. $21 \mathrm{p}$. 
*Hilliard, J., H. Minkus, and M. Weber. 1997. Amphibian survey of the Birch Creek drainage, Beaverhead County. Wildland Studies Project, San Francisco State University, San Francisco, CA. 12 p.

*Hillis, D.M. and S. Davis. 1986. Evolution of ribosomal DNA: Fifty million years of recorded history in the frog genus Rana. Evolution 40: 1275-1288.

*Hollenbeck, R.R. 1974. Growth rates and movements within a population of Rana pretiosa pretiosa Baird and Girard in south central Montana. Ph.D. Dissertation. Montana State University, Bozeman, MT. 66 p.

*Hollenbeck, R.R. 1975. Growth rates, breeding ages, and sex ratios within a population of Rana p. pretiosa Baird and Girard in south central Montana. Abstract. Journal of the Colorado-Wyoming Academy of Science 7(6): 44-45.

*Hollenbeck, R.R. 1976. Movements within a population of Rana pretiosa pretiosa Baird and Girard in south central Montana. Abstract. Journal of the Colorado-Wyoming Academy of Science 8(1): 72-73.

*Hollenbeck, R.R. 1978. Growth rates and mortality patterns in anurans. Abstract. Journal of the Colorado-Wyoming Academy of Science 10(1): 49-50.

*Hossack, B. and P.S. Corn. 2004. Responses of pond-breeding amphibians to wildfire in Glacier National Park. Abstract. Northwestern Naturalist 85:78.

*Hossack, B.R. and P.S. Corn. 2007. Responses of pond-breeding amphibians to wildfire: short-term patterns in occupancy and colonization. Ecological Applications 17:1403-1410.

*Hossack, B., D. Pilliod, and P.S. Corn. 2001a. Reptile and amphibian inventory at GrantKohrs Ranch National Historic Site and Little Bighorn Battlefield National Monument. USGS Northern Rocky Mountain Science Center, Aldo Leopold Wilderness Research Institute, Missoula, MT. $6 \mathrm{p}$.

*Hossack, B.R., D. Pilliod, and P.S. Corn. 2001b. Preliminary amphibian surveys of the National Bison Range, Lost Trail National Wildife Refuge, and Swan River National Wildlife Refuge: 2001. USGS Northern Rocky Mountain Science Center, Aldo Leopold Wilderness Research Institute, Missoula, MT. 15 p.

Hovingh, P. 1986. Biogeographic aspects of leeches, mollusks, and amphibians in the intermountain region. Great Basin Naturalist 46: 736-744.

Hovingh, P. 1993. Aquatic habitats, life history observations, and zoogeographic considerations of the spotted frog (Rana pretiosa) in Tule Valley, Utah. Great Basin Naturalist 53(2): 168179.

Hovingh, P. 1997. Amphibians in the eastern Great Basin (Nevada and Utah USA): a geographical study with paleozoological models and conservation implications. Herpetological Natural History 5: 97-134.

James, J.D. 1998. Status of the Columbia Spotted Frog (Rana luteiventris) in Alberta. Alberta Wildlife Status Report 17: 1-22.

Jennrich, R.I. and F.B. Turner. 1969. Measurement of non-circular home range. Journal of Theoretical Biology 1969(22): 227-237.

Johnson, O.W. 1965. Early development, embryonic temperature tolerance and rate of development in Rana pretiosa luteiventris Thompson. Ph.D. Dissertation, Oregon State University, Corvallis, Oregon.

*Johnson, P.T.J., K.B. Lunde, E.M. Thurman, E.G. Ritchie, S.N. Wray, D.R. Sutherland, J.M. Kapfer, T.J. Frest, J. Bowerman, and A.R. Blaustein. 2002. Parasite (Ribeiroia ondatrae) 
infection linked to amphibian malformations in the western United States. Ecological Monographs 72(2): 151-168.

Kirk, J.J. 1988. Western spotted frog (Rana pretiosa) mortality following forest spraying of DDT. Herpetological Review 19(3): 51-53.

*Knight, J. 1999. Geographic variation in morphology between two groups of Rana luteiventris in western Montana. Undergraduate Honors Thesis. Carroll College, Helena, MT. 24 p.

*Koch, E.D. and C.R. Peterson. 1989. A preliminary survey of the distribution of amphibians and reptiles in Yellowstone National Park. pp. 47-49. In: Rare, sensitive and threatened species of the Greater Yellowstone Ecosystem, T.W. Clark, A.H. Harvey, R.D. Dorn, D.C. Genter, and C. Groves (eds.), Northern Rockies Conservation Cooperative , Montana Natural Heritage Program, The Nature Conservancy, and Mountain West Environmental Services. $153 \mathrm{p}$.

*Koch, E.D. and C.R. Peterson. 1995. The amphibians and reptiles of Yellowstone and Grand Teton National Parks. University of Utah Press, Salt Lake City, UT. 188 p.

*Koch, E.D., G. Williams, C.R. Peterson and P.S. Corn. 1996. Conference on declining and sensitive amphibians in the Northern Rockies and the Pacific Northwest: a summary paper. Idaho Herpetological Society Technical Bulletin and U.S. Fish and Wildlife Service Report, Boise, ID. 34 p.

*Laselle, B.T. 2000. Association of wetland area with breeding activity for multiple amphibian species. Undergraduate Honors Thesis. Carroll College, Helena, MT. 18 p.

Leclair, R., Jr. and G. Laurin. 1996. Growth and body size in populations of mink frogs Rana septentrionalis from two latitudes. Ecography 19:296-304.

Lefcort, H., R.A. Meguire, L.H. Wilson, and W.F. Ettinger. 1998. Heavy metals alter the survival, growth, metamorphosis, and antipredatory behavior of Columbia spotted frog (Rana luteiventris) tadpoles. Archives of Environmental Contaminants and Toxicology 35: 447456.

Lefcort, H., S.M. Thomson, E.E. Cowles, H.L. Harowicz, B.M. Livaudais, W.E. Roberts, and W.F. Ettinger. 1999. Ramifications of predator avoidance: predator and heavy-metalmediated competition between tadpoles and snails. Ecological Applications 9(4): 1477-1489.

Leonard, W.P. and E.L. Bull. 2005. Columbia spotted frogs, Rana luteiventris. pp. 212-215. In: Jones, L.L.C., W.P. Leonard, and D.H. Olson (eds). Amphibians of the Pacific Northwest. Seattle, WA: Seattle Audubon Society. 227 p.

Leonard, W.P., N.P. Leonard, R.M. Storm, and P.E. Petzel. 1996. Rana pretiosa (spotted frog). Behavior and reproduction. Herpetological Review 27(4): 195.

Licht, L.E. 1969. Comparative breeding behavior of the red-legged frog (Rana aurora aurora) and the western spotted frog (Rana pretiosa pretiosa) in southwestern British Columbia. Canadian Journal of Zoology 47: 1287-1299.

Licht, L.E. 1974. Survival of embryos, tadpoles, and adults of the frogs Rana aurora and Rana pretiosa sympatric in southwestern British Columbia. Canadian Journal of Zoology 52: 613627.

*Licht, L.E. 1975. Comparative life history features of the western spotted frog, Rana pretiosa, from low and high-elevation populations. Canadian Journal of Zoology 53: 1254-1257.

Licht, L.E. 1986a. Comparative escape behavior of sympatric Rana aurora and Rana pretiosa. American Midland Naturalist 115: 239-247. 
Licht, L.E. 1986b. Food and feeding behavior of sympatric red-legged frogs, Rana aurora, and spotted frogs, Rana pretiosa, in southwestern British Columbia. Canadian Field Naturalist 100(1): 22-31.

Lindeman, P.V. 1990. Rana pretiosa (spotted frog). Herpetological Review 21(2): 38.

Logier, E.B.S. 1932. Some account of the amphibians and reptiles of British Columbia. Transactions of the Royal Canadian Institute 18: 311-336.

*Manville, R.H. 1957. Amphibians and reptiles of Glacier National Park, Montana. Copeia 1957: 308-309.

*Marnell, L.F. 1996. Amphibian survey of Glacier National Park, Montana. Abstract. Intermountain Journal of Sciences 2(2): 52.

*Marnell, L.F. 1997. Herpetofauna of Glacier National Park. Northwestern Naturalist 78: 1733.

Matsuda, B.M., D.M. Green, and P.T. Gregory. 2006. Amphibians and reptiles of British Columbia. Victoria, B.C.: Royal British Columbia Museum. 266 p.

*Maxell, B.A. 2000. Management of Montana's amphibians: a review of factors that may present a risk to population viability and accounts on the identification, distribution, taxonomy, habitat use, natural history, and the status and conservation of individual species. Report to USFS Region 1, Order Number 43-0343-0-0224. Missoula, MT: Wildlife Biology Program, University of Montana. $161 \mathrm{p}$.

*Maxell, B.A. 2002. Amphibian and aquatic reptile inventories in watersheds in the South and Middle Forks of the Flathead River drainage that contain lakes being considered for application of piscicides and subsequent stocking of west slope cutthroat trout. Report to the Region 1 Office of the U.S. Forest Service and the Montana Department of Fish, Wildlife, and Parks. Montana Cooperative Wildlife Research Unit and Wildlife Biology Program, University of Montana, Missoula, MT. 62 p.

* Maxell, B.A. 2004a. Amphibian and aquatic reptile inventories conducted on and around the Bitterroot National Forest 2000-2003. Report to Region 1 Office of the U.S. Forest Service, Bitterroot National Forest, Montana Department of Fish, Wildlife, and Parks, and Biological Resources Division of the U.S. Geological Survey. Missoula, MT: Montana Cooperative Wildlife Research Unit and Wildlife Biology Program, University of Montana. 128 p.

* Maxell, B.A. 2004b. Amphibian and aquatic reptile inventories conducted on and around the Thompson River 2003-2004. Report to Region 1 Office of the U.S. Forest Service and Plum Creek Timber Company. Missoula, MT: Montana Cooperative Wildlife Research Unit and Wildlife Biology Program. 83 p.

*Maxell, B.A. 2004c. Preliminary report on amphibian and aquatic reptile inventories conducted in the West Boulder River area during summer 2003. Report to Region 1 Office of the U.S. Forest Service, and the Montana Department of Fish, Wildlife, and Parks. Missoula, MT: Montana Cooperative Wildlife Research Unit and Wildlife Biology Program, University of Montana. $27 \mathrm{p}$.

*Maxell, B.A. 2004d. Report on amphibian and aquatic reptile inventories conducted on and around the Beaverhead-Deerlodge National Forest 2001-2003. Report to Region 1 Office of the U.S. Forest Service, Beaverhead-Deerlodge National Forest, Montana Department of Fish, Wildlife, and Parks, Montana State Office of the Bureau of Land Management, and Montana Department of Environmental Quality. Missoula, MT: Montana Cooperative Wildlife Research Unit and Wildlife Biology Program, University of Montana. 260 p. 
*Maxell, B.A. 2005a. Amphibian and aquatic reptile inventories conducted on and around lands administered by the Missoula Field Office of the Bureau of Land Management. Report to Missoula Field Office of the Bureau of Land Management. Montana Natural Heritage Program, Helena, MT and Montana Cooperative Wildlife Research Unit and Wildlife Biology Program, University of Montana, Missoula, MT. $53 \mathrm{p}$.

*Maxell, B.A. 2005b. A review of monitoring methods and a multi-tiered scheme for assessing and monitoring the status of amphibians in Montana. Report to Montana Department of Environmental Quality, Region 1 Office of the U.S. Forest Service, Montana Department of Fish, Wildlife, and Parks, and Montana State Office of the Bureau of Land Management. Montana Natural Heritage Program, Helena, MT and Montana Cooperative Wildlife Research Unit and Wildlife Biology Program, University of Montana, Missoula, MT. 29 p. + Appendices.

*Maxell, B.A. 2006. Evaluation of Montana's lentic breeding amphibian survey methodology and variables correlated with species occupancy. Report to Montana Department of Environmental Quality. Montana Natural Heritage Program, Helena, MT and Montana Cooperative Wildlife Research Unit and Wildlife Biology Program, University of Montana, Missoula, MT. 49 p.

*Maxell, B.A. 2009. State-wide assessment of status, predicted distribution, and landscapelevel habitat suitability of amphibians and reptiles in Montana. Ph.D. Dissertation. Missoula, MT: Wildlife Biology Program, University of Montana. 294 p.

*Maxell, B.A. and D.G. Hokit. 1999. Amphibians and reptiles. pp. 2.1-2.30. In G. Joslin and H. Youmans, coordinators. Effects of recreation on Rocky Mountain wildlife: a review for Montana. Committee on Effects of Recreation on Wildlife, Montana Chapter of the Wildlife Society. 307 p.

*Maxell, B.A., J.K. Werner, P. Hendricks, and D. Flath. 2003. Herpetology in Montana: a history, status summary, checklists, dichotomous keys, accounts for native, potentially native, and exotic species, and indexed bibliography. Olympia, WA: Society for Northwestern Vertebrate Biology. Northwest Fauna 5: 1-138.

McAvoy, S.A. 2003. Wetland characteristics associated with amphibian presence in the Rocky Mountain Region. Undergraduate Honors Thesis. Carroll College, Helena, MT. 23 p.

*Middendorf, L.J. 1957. Observations on the early spring activities of the western spotted frog (Rana pretiosa) in Gallatin County, Montana. Proceedings of the Montana Academy of Sciences 17: 55-56.

*Miller, J.D. 1975. Interspecific food relationships of anurans in northwestern Montana and fluoride accumulation in amphibians and reptiles in northwestern Montana. M.S. Thesis, University of Montana, Missoula, MT. 105 p.

*Miller, J.D. 1978. Observations on the diets of Rana pretiosa, Rana pipiens, and Bufo boreas from western Montana. Northwest Science 52(3): 243-249.

*Miller, M. 1995. Amphibian survey Birch Creek July 1995. Wildland Studies Project, San Francisco State University, San Francisco, CA. 9 p.

*Mitchell, T. 2005. A geometric morphometric analysis of tail morphology in the Columbia Spotted frog, Rana lutieventris. Undergraduate Thesis. Carroll College, Helena, Montana. $17 \mathrm{pp}$.

Monello, R.J. and R.G. Wright. 1999. Amphibian habitat preferences among artificial ponds in the Palouse Region of Northern Idaho. Journal of Herpetology 33(2): 298-303. 
Moore, J.E. and E.H. Strickland. 1955. Further notes on the food of Alberta amphibians. American Midland Naturalist 52: 221-224.

Morris, R.L. and W.W. Tanner. 1969. The ecology of the western spotted frog, Rana pretiosa pretiosa Baird \& Girard: a life history study. Great Basin Naturalist 29(2): 45-81.

Munger, J.C., B.R. Barnett, and A. Ames. 1997. 1996 Sawtooth Wilderness amphibian survey. A challenge cost share agreement between the Sawtooth National Forest, USDA, Forest Service, and Boise State University. Boise, ID: Boise State University. 10p.

Munger, J.C., M. Gerber, K. Madrid, M.A. Carroll, W. Petersen and L. Heberger. 1998. US National Wetland inventory classifications as predictors of the occurrence of Columbia spotted frogs (Rana luteiventris) and Pacific treefrogs (Hyla regilla). Conservation Biology 12: 320-330.

Munger, J.C., C.R. Peterson, M. McDonald, T. Carrigan. 1997. Conservation strategy for the Columbia Spotted Frog (Rana luteiventris) in Idaho. Submitted to Idaho State Conservation Effort, February 28, 1997. 12 p.

*Muths, E., R.E. Jung, L.L. Bailey, M.J. Adams, P.S. Corn, C.K. Dodd, Jr., G.M. Fellers, W.J. Sadinski, C.R. Schwalbe, S.C. Walls, R.N. Fisher, A.L. Gallant, W.A. Battaglin, and D.E. Green. 2005. Amphibian Research and Monitoring Initiative (ARMI): a successful start to a national program in the United States. Applied Herpetology 2:355-371.

*Muths, E., D.S. Pilliod, and L.J. Livo. 2008. Distribution and environmental limitations of an amphibian pathogen in the Rocky Mountains, USA. Biological Conservation 141:14841492.

*[NDTI] Northrop, Devine, and Tarbell Incorporated. 1994. Cabinet Gorge and Noxon Rapids hydroelectric developments 1993 wildlife study. Northrop, Devine, and Tarbell Incorporated, Portland, ME. $197 \mathrm{p}$.

O'Hara, R.K. and A.R. Blaustein. 1988. Hyla regilla and Rana pretiosa tadpoles fail to display kin recognition behaviour. Animal Behaviour 36(3): 946-948.

*Patla, D.A. 1997a. Changes in a population of spotted frogs in Yellowstone National Park between 1953 and 1995: the effects of habitat modification. M.S. Thesis. Idaho State University, Pocatello, ID. 215 p.

*Patla, D.A. 1997b. Potential impacts to amphibians and reptiles from the proposed Canyon contractor camp. 10 May 1997 (Supplement, 12 January 1998). Greater Yellowstone Ecosystem Amphibian Survey and Monitoring Program, Herpetology Laboratory, Department of Biological Sciences, Idaho State University, Pocatello, ID. 16 p.

*Patla, D.A. 1998a. Amphibians and reptiles in the Old Faithful sewage treatment area. Report to Yellowstone Center for Resources, Yellowstone National Park. 10 September, 1998. Greater Yellowstone Ecosystem Amphibian Survey and Monitoring Program, Herpetology Laboratory, Department of Biological Sciences, Idaho State University, Pocatello, ID. 7 p.

*Patla, D.A. 1998b. Potential effects of native fish restoration projects on amphibians in Yellowstone National Park Part I. 20 November, 1998. Greater Yellowstone Ecosystem Amphibian Survey and Monitoring Program, Herpetology Laboratory, Department of Biological Sciences, Idaho State University, Pocatello, ID. 26 p.

*Patla, D.A. 1998c. The effects of habitat modification on spotted frogs in Yellowstone National Park. Froglog 28(August 1998): 1-2.

*Patla, D.A. 1999a. Amphibians and reptiles of the Madison to Norris road improvement project area, Yellowstone National Park. 11 November, 1999. Greater Yellowstone 
Ecosystem Amphibian Survey and Monitoring Program, Herpetology Laboratory, Department of Biological Sciences, Idaho State University, Pocatello, ID. 17 p.

*Patla, D.A. 1999b. Amphibians and reptiles, Tower Junction to Canyon Village, Yellowstone National Park; addendum to previous report. 24 November, 1999. Greater Yellowstone Ecosystem Amphibian Survey and Monitoring Program, Herpetology Laboratory, Department of Biological Sciences, Idaho State University, Pocatello, ID. 10 p.

*Patla, D.A. 1999c. Amphibians and reptiles along the grand loop road in Yellowstone National Park: Canyon Junction to Fishing Bridge Junction. December 11, 1999. Greater Yellowstone Ecosystem Amphibian Survey and Monitoring Program, Herpetology Laboratory, Department of Biological Sciences, Idaho State University, Pocatello, ID. 24 p.

*Patla, D.A. 2000. Amphibians in potential native fish restoration areas, Yellowstone National Park Part II. 7 March, 2000. Greater Yellowstone Ecosystem Amphibian Survey and Monitoring Program, Herpetology Laboratory, Department of Biological Sciences, Idaho State University, Pocatello, ID. 22 p.

*Patla, D.A. and C.R. Peterson. 1994. The effects of habitat modification on a spotted frog population in Yellowstone National Park. pp 135-144. In: Harlow, H.J. and M. Harlow (eds.) University of Wyoming, National Park Service Research Center, 18th annual report. University of Wyoming, Laramie, WY.

*Patla, D.A. and C.R. Peterson. 1996a. Amphibians and reptiles along the Grand Loop Highway in Yellowstone National Park: Tower Junction to Canyon Village. 24 February, 1996. Greater Yellowstone Ecosystem Amphibian Survey and Monitoring Program, Herpetology Laboratory, Department of Biological Sciences, Idaho State University, Pocatello, ID. 49 p.

*Patla, D.A. and C.R. Peterson. 1996b. Amphibians and reptiles along the Grand Loop Highway in Yellowstone National Park: Arnica Creek to Little Thumb Creek. 1 August, 1996. Greater Yellowstone Ecosystem Amphibian Survey and Monitoring Program, Herpetology Laboratory, Department of Biological Sciences, Idaho State University, Pocatello, ID. 35 p.

*Patla, D.A. and C.R. Peterson. 1997. Amphibians and reptiles along the Grand Loop Highway in Yellowstone National Park: Mammoth Hot Springs to Norris Junction. 1 February, 1997. Greater Yellowstone Ecosystem Amphibian Survey and Monitoring Program, Herpetology Laboratory, Department of Biological Sciences, Idaho State University, Pocatello, ID. 60 p.

*Patla, D.A. and C.R. Peterson. 1998. Amphibians of the Greater Yellowstone Ecosystem. Natural Resource Conservation Cooperative News 11(Autumn 1998): 10-11.

*Patla, D.A. and C.R. Peterson. 1999. Are amphibians declining in Yellowstone National Park? Yellowstone Science 7(1): 2-11.

*Patla, D.A. and C.R. Peterson. 2001. Status and trends of amphibian populations in the Greater Yellowstone Ecosystem, progress report, February 2001. Greater Yellowstone Ecosystem Amphibian Survey and Monitoring Program, Herpetology Laboratory, Department of Biological Sciences, Idaho State University, Pocatello, ID. 8 p.

Pearl, C.A., M.J. Adams, R.B. Bury, and B. McCreary. 2004. Asymmetrical effects of introduced bullfrogs (Rana catesbeiana) on native ranid frogs in Oregon, USA. Copeia 1120.

*Peterson, C.R., C.J. Askey, and D.A. Patla. 1993. Amphibians and reptiles along the Grand Loop and Fountain Freight Roads between Madison Junction and Biscuit Basin in Yellowstone National Park. 26 July, 1993. Greater Yellowstone Ecosystem Amphibian 
Survey and Monitoring Program, Herpetology Laboratory, Department of Biological Sciences, Idaho State University, Pocatello, ID. 45 p.

*Peterson, C.R., D.A. Patla, and S.R. Sullivan. 1995. Amphibians and reptiles along the Grand Loop Highway in Yellowstone National Park: Madison Junction to Norris Campground. 7 July, 1995. Greater Yellowstone Ecosystem Amphibian Survey and Monitoring Program, Herpetology Laboratory, Department of Biological Sciences, Idaho State University, Pocatello, ID. 64 p.

*Peterson, C.R., E.D. Koch, and P.S. Corn. 1992. Monitoring amphibian populations in Yellowstone and Grand Teton National Parks final report to University of Wyoming. National Park Service Research Center, Laramie, WY. 37 p.

Pilliod, D.S. 1999. Rana luteiventris (Columbia spotted frog) cannibalism. Herpetological Review 30(2): 93.

Pilliod, D.S. 2001. Ecology and conservation of high-elevation amphibian populations in historically fishless watersheds with introduced trout. Ph.D. Dissertation. Pocatello, ID: Idaho State University. 125 p.

Pilliod, D.S. 2002. Clark's Nutcracker (Nucifraga columbiana) predation on tadpoles of the Columbia Spotted frog (Rana luteiventris). Northwestern Naturalist 83(2):59-61.

Pilliod, D.S. 2005. Conserving amphibian habitats in montane environments: A case study of Columbia spotted frogs (Rana luteiventris). Abstract. Northwestern Naturalist 86:112.

Pilliod, D.S., C.R. Peterson, and P.I. Ritson. 2002. Seasonal migration of Columbia spotted frogs (Rana luteiventris) among complimentary resources in a high mountain basin. Canadian Journal of Zoology 80: 1849-1862.

*Powell, R., J.T. Collins, and E.D. Hooper, Jr. 1998. A key to amphibians and reptiles of the Continental United States and Canada. University Press of Kansas, Lawrence, KS. 131 p.

*Rauscher, R.L. 2000. Tiger salamander axolotls in southwest Montana, final report. Bozeman, MT: Montana Department of Fish, Wildlife and Parks. 28p.

Reaser, J.K. 1996a. Rana pretiosa (spotted frog) vagility. Herpetological Review 27: 196-197.

Reaser, J.K. 1996b. Spotted frog: catalyst for sharing common ground in the riparian ecosystems of Nevada's range landscape. U.S. Forest Service General Technical Report INT 343: 32-39.

Reaser, J.K. 1997. Amphibian declines: conservation science and adaptive management. Ph.D. Dissertation, Stanford University, Palo Alto, CA. 148 p.

Reaser, J.K. 2000. Demographic analysis of the Columbia spotted frog (Rana luteiventris): case study in spatiotemporal variation. Canadian Journal of Zoology 78(7): 1158-1167.

Reaser, J.K. and D.S. Pilliod. 2005. Columbia spotted frog (Rana luteiventris). In: Lannoo, M.J. ed. Status and conservation of United States amphibians. Berkley, CA: University of California Press:559-563.

Reaser, J.K. and R.E. Dexter, 1996. Rana pretiosa (spotted frog): toe clipping effects. Herpetological Review 27(4): 195-196.

Reaser, J.K., and R.E. Dexter. 1996. Rana pretiosa (spotted frog) predation. Herpetological Review 27(2): 75.

*Reichel, J.D. 1995. Preliminary amphibian and reptile survey of the Lewis and Clark National Forest: 1994. Montana Natural Heritage Program, Helena, MT. 92 p.

*Reichel, J.D. 1996. Preliminary amphibian and reptile survey of the Helena National Forest: 1995. Montana Natural Heritage Program, Helena, MT. 87 p. 
*Reichel, J.D. 1997. Amphibian, reptile and northern bog lemming survey on the Rocky Mountain Front: 1996. Montana Natural Heritage Program, Helena, MT. 81 p.

*Reinking, L.N., C.H. Daugherty, and L.B. Daugherty. 1980. Plasma aldosterone concentrations in wild and captive western spotted frogs (Rana pretiosa). Comparative Biochemistry and Physiology 65A(4): 517-518.

*Roberts, W.E. 1997. Rana pretiosa. Predation. Herpetological Review 28(2): 86.

*Rodgers, T.L. and W.L. Jellison. 1942. A collection of amphibians and reptiles from western Montana. Copeia 1942(1): 10-13.

*Roedel, M.D. and P. Hendricks. 1998a. Amphibian and reptile survey on the Bureau of Land Management Lewistown District: 1995-1998. Montana Natural Heritage Program, Helena, MT. $53 \mathrm{p}$.

*Roedel, M.D. and P. Hendricks. 1998b. Amphibian and reptile inventory on the Headwaters and Dillon Resource Areas in conjunction with Red Rocks Lakes National Wildlife Refuge: 1996-1998. Montana Natural Heritage Program, Helena, MT. 46 p.

Ross, D.A., D.W. Kuehn, and M.C. Stanger. 1994. Rana pretiosa (spotted frog) reproduction. Herpetological Review 25(3): 118.

Ross, D.A., J.K. Reaser, P. Kleeman, and D.L. Drake. 1999. Rana luteiventris. (Columbia spotted frog) mortality and site fidelity. Herpetological Review 30(3): 163.

Ross, D.A. and B.J. Richardson. 1995. Rana pretiosa (spotted frog) basking behavior. Herpetological Review 26(4): 203.

Russell, A.P., and A.M. Bauer. 2000. The amphibians and reptiles of Alberta. Second Edition. Calgary, AB: University of Calgary Press. 279 p.

Russell, K.R. and R.L. Wallace. 1992. Occurrence of Halipegus occidualis (Digenea: Derogenidae) and other trematodes in Rana pretiosa (Anura: Ranidae) from Idaho, USA. Transactions of the American Microscopical Society 111(2): 122-127.

*Ryan, S.A. 1980. Frog study of the Kicking Horse Reservoir on the Flathead Indian Reservation. Confederated Salish and Kootenai Tribal Wildlife Division, Pablo, MT. 3 p.

*Sestrich, C. 2004. Hebgen Reservoir amphibian survey. USDA Forest Service Annual Progress Report to PPL Montana. 22p.

*Sestrich, C. 2007. 2006 Hebgen Reservoir amphibian survey. USDA Forest Service Annual Report to PPL Montana. West Yellowstone, MT: Gallatin National Forest, Hebgen Lake Ranger District. $75 \mathrm{p}$.

*Simons, R.W. 2002. The effect of predation on tadpole morphology of the spotted frog (Rana luteiventris). Undergraduate Honors Thesis. Carroll College, Helena, MT. 10 p.

*Skinner, M.P. 1924. The Yellowstone Nature Book. A.C. McClurg Company, Chicago, IL. $221 \mathrm{p}$.

*Stebbins, R.C. 2003. A field guide to western reptiles and amphibians. 3rd edition. New York, NY: Houghton Mifflin Co. 533 p.

*Stebbins, R.C. and N.W. Cohen. 1995. A natural history of amphibians. Princeton University Press, Princeton, NJ. 316 p.

*Sullivan, S.R. and C.R. Peterson. 1996. Amphibians and reptiles along the highway in Yellowstone National Park: Tower Junction to the Northeast Entrance. 25 February, 1996. Greater Yellowstone Ecosystem Amphibian Survey and Monitoring Program, Herpetology Laboratory, Department of Biological Sciences, Idaho State University, Pocatello, ID. 60 p. Svihla, A. 1935. Notes on the western spotted frog, Rana p. pretiosa. Copeia 1935: 119-122. 
Sype, W.E. 1975. Breeding habits, embryonic thermal requirements and embryonic amd larval development of the Cascade frog, Rana cascadae Slater. Ph.D. Dissertation. Corvallis, OR: Oregon State University. 113p.

*Syslo, J. and L. Eby. 2005. Possible effects of Highway 93 expansion on a population of Western toads (Bufo boreas) in the Bitterroot Valley. Wildlife Biology Program University of Montana. pp. 11 plus figures.

*Test, F.C. 1893. Annotated list of reptiles and batrachians collected. In: B.W. Evermann. A reconnaisance of the streams and lakes of western Montana and northwestern Wyoming. Bulletin of United States Fish Commission 11(1891): 57-59.

Thompson, H.B. 1913. Description of a new subspecies of Rana pretiosa from Nevada. Proceedings of the Biological Society of Washington 26: 53-56.

*Thompson, M.D. and A.P. Russell. 2000. Phylogeography of Ambystoma macrodactylum: post glacial range expansion and resultant genetic diversity. Field Summary Report No. 1. University of Calgary. Calgary, Canada. $39 \mathrm{p}$.

*Thompson, M.D. and A.P. Russell. 2001. Phylogeography of Ambystoma macrodactylum: post glacial range expansion and resultant genetic diversity. Field Summary Report No. 2. University of Calgary, Calgary, Canada. $65 \mathrm{p}$.

*Timken, R. No Date. Amphibians and reptiles of the Beaverhead National Forest. Western Montana College, Dillon, MT. 16 p.

Toline, C.A.. 1999. Mitochondrial and nuclear DNA variation within and among populations of Columbia spotted frog (Rana luteiventris) in Utah. M.S. Thesis. Logan, UT: Utah State University.

*Turner, F.B. 1951. A checklist of the reptiles and amphibians of Yellowstone National Park with incidental notes. Yellowstone Nature Notes 25(3): 25-29.

*Turner, F.B. 1952. Peculiar aggregations of toadlets on Alum Creek. Yellowstone Nature Notes 26(5): 57-58.

*Turner, F.B. 1955. Reptiles and amphibians of Yellowstone National Park. Yellowstone Interpretive Series No. 5. Yellowstone Library and Museum Association. Yellowstone National Park, WY. 40 p.

*Turner, F.B. 1957. The ecology and morphology of Rana pretiosa pretiosa in Yellowstone Park, Wyoming. Ph.D. Dissertation, University of California, Berkeley, CA. 252 p.

*Turner, F.B. 1958a. Life history of the western spotted frog in Yellowstone National Park. Herpetologica 14: 96-100.

*Turner, F.B. 1958b. Some parasites of the western spotted frog, Rana pretiosa pretiosa, in Yellowstone National Park, Wyoming. Journal of Parasitology 44(2): 182.

*Turner, F.B. 1959a. An analysis of the feeding habits of Rana pretiosa pretiosa in Yellowstone National Park, Wyoming. American Midland Naturalist 61(2): 403-413.

*Turner, F.B. 1959b. Pigmentation in the spotted frog, Rana pretiosa pretiosa, in Yellowstone Park, Wyoming. American Midland Naturalist 61(1): 162-176.

*Turner, F.B. 1959c. Variation in skeletal proportions of Rana pretiosa pretiosa in Yellowstone Park, Wyoming. Copeia 1959: 63-68.

*Turner, F.B. 1960a. Population structure and dynamics of the western spotted frog, Rana $p$. pretiosa Baird and Girard, in Yellowstone Park, Wyoming. Ecological Monographs 30(3): 251-278.

*Turner, F.B. 1960b. Postmetamorphic growth in anurans. American Midland Naturalist 64(2): 327-338. 
*Turner, F.B. 1962a. An analysis of geographic variation and distribution of Rana pretiosa. American Philosophical Society Yearbook 1962: 325-328.

*Turner, F.B. 1962b. The demography of frogs and toads. Quarterly Review of Biology 37(4): 303-314.

*Turner, F.B., and P.C. Dumas. 1972. Rana pretiosa. Catalogue of American Amphibians and Reptiles 119.1-119.4.

*[USFWS] US Fish and Wildlife Service. 1993. Endangered and threatened wildlife and plants; finding on petition to list the spotted frog. Federal Register 58(87): 27260-27263.

*[USFWS] US Fish and Wildlife Service. 1994. Endangered and threatened wildlife and plants; animal candidate review for listing as endangered or threatened species. Federal Register 59(219): 58982-59028.

Utah Division of Wildlife Resources. 1993. Distribution of the spotted frog along the Wasatch Front in Utah 1991-1992. April 13, 1993, Salt Lake City, pp. 1-25.

Utah Division of Wildlife Resources. 1994. Distribution, habitat use, and relative abundance indices of spotted frogs in the West Desert, Utah, 1993. January 24, 1994, Salt Lake City, pp. 1-49.

Utah Division of Wildlife Resources. 1998. Conservation agreement for spotted frog. January 22, 1998, Salt Lake City, pp. 1-18.

*Van Denburgh, J. 1895. Annotated list of reptiles and batrachians. In: C.H. Gilbert and B.W. Evermann. A report upon investigations in the Columbia River Basin, with descriptions of four new species of fishes. Bulletin of United States Fish Commission 14(1894): 206-207.

*Van Kirk, R., L. Benjamin, and D. Patla. 2000. Riparian area assessment and amphibian status in the watersheds of the Greater Yellowstone Ecosystem. Greater Yellowstone Coalition, Bozeman, MT. $102 \mathrm{p}$.

*Vitt, L.J., J.P. Caldwell, and D.B. Shepard. 2005. Inventory of amphibians and reptiles in the Billings Field Office Region, Montana. Sam Noble Oklahoma Museum of Natural History and Department of Zoology, University of Oklahoma, Norman, OK. 33 p.

Waitz, J.A. 1959. Parasites infesting R. luteiventris and R. pipiens. M.S. Thesis. Moscow, ID: University of Idaho.

*Weisel, G.F. 1952. Animal names, anatomical terms, and some ethnozoology of the Flathead Indians. Journal of the Washington Academy of Sciences 42(11): 345-355.

*Werner, J.K., B.A. Maxell, P. Hendricks, and D. Flath. 2004. Amphibians and reptiles of Montana. Missoula, MT: Mountain Press Publishing Company. 262p.

*Werner, J.K. and J.D. Reichel. 1994. Amphibian and reptile survey of the Kootenai National Forest: 1994. Montana Natural Heritage Program, Helena, MT. 104 p.

*Werner, J.K. and J.D. Reichel. 1996. Amphibian and reptile monitoring/survey of the Kootenai National Forest: 1995. Montana Natural Heritage Program, Helena, MT. 115 p.

*Werner, J.K. and T. Plummer. 1994. Amphibian and reptile survey of the Flathead Indian Reservation 1993-1994. Salish Kootenai College, Pablo, MT. 55 p.

*Werner, J.K. and T. Plummer. 1995. Amphibian monitoring program on the Flathead Indian Reservation 1995. Salish Kootenai College, Pablo, MT. 46 p.

*Werner, J.K., T. Plummer, and J. Weaselhead. 1998a. Amphibians and reptiles of the Flathead Indian Reservation. Intermountain Journal of Sciences 4(1-2): 33-49.

*Werner, J.K., T. Plummer, and J. Weaselhead. 1998b. The status of amphibians on the Flathead Reservation, Montana. Intermountain Journal of Sciences 4(3-4): 88. 
*Werner, J.K., J. Weaselhead, and T. Plummer. 1999. The accuracy of estimating eggs in anuran egg masses using weight or volume measurements. Herpetological Review 30(1): 3031.

Whitaker, J.A., Jr., S.P. Cross, J.M. Skovlin and C. Maser 1983. Food habits of the spotted frog (Rana pretiosa) from managed sites in Grant County, Oregon. Northwest Science 57(2):147154.

*Wicher, C.G. 2000. The effects of mining effluent on amphibian survivorship. Undergraduate Honors Thesis. Carroll College, Helena, MT. 18 p.

Wilkinson, T. 1996. Utah ushers its frogs toward oblivion. High Country News, No. 19: 1, 1013. May 27, 1996.

*Wishard, L.N. 1977. Larval growth in Rana pretiosa: ecological and genetic factors. M.S. Thesis. University of Montana, Missoula, MT. $80 \mathrm{p}$.

*[WWPC] Washington Water Power Company. 1995. 1994 wildlife report Noxon Rapids and Cabinet Gorge Reservoirs. Washington Water Power Company. Spokane, WA.

*Wyrick, A.C. 2004. Demography of the Columbia spotted frog (Rana luteiventris) in the presence or absence of fish in the Absaroka-Beartooth Wilderness, Montana. M.S. Thesis. Missoula, MT: University of Montana. $118 \mathrm{p}$.

*Yeager, D.C. 1926. Miscellaneous notes. Yellowstone Nature Notes 3(4): 7.

*Zisook, R., K. Almond, and B. Sharpe. 1996. Amphibian survey of the Birch Creek drainage, Beaverhead County. Wildland Studies Project. San Francisco State University, San Francisco, CA. 9 p. 


\section{Northern Leopard Frog (Rana pipiens)}

Up-to-date distribution and status information can be found on the Montana Natural Heritage Program's TRACKER website at http://mtnhp.org

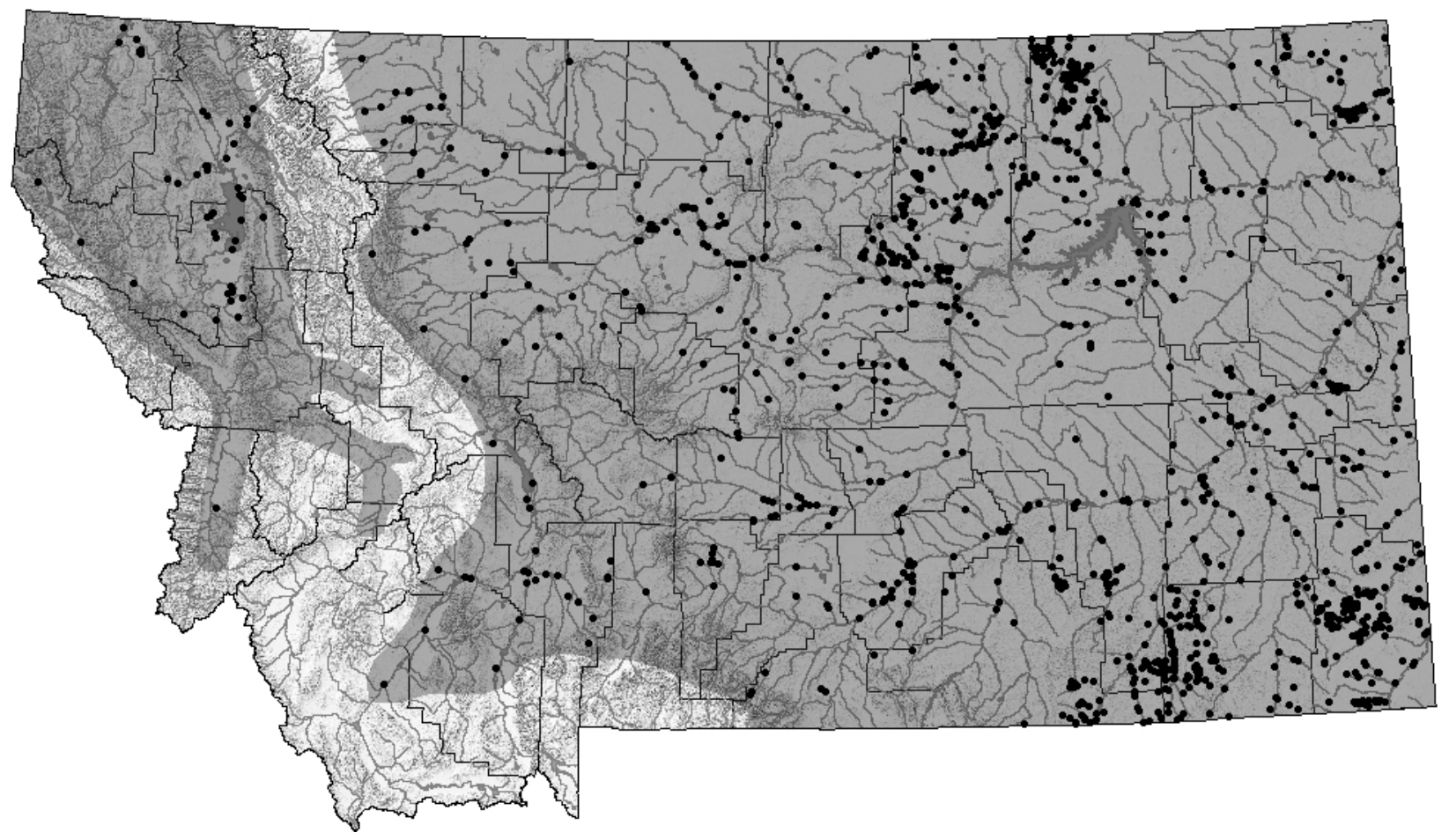

Distribution/Taxonomy

Rana pipiens has a complex taxonomic history, but is now recognized as a distinct species that historically ranged from Newfoundland and northern Alberta in the north to the Great Lakes region, the desert Southwest, and the Great Basin in the south (Pace 1974; Dunlap and Platz 1981; Hillis 1988). In addition a number of isolated populations historically existed in the Pacific Northwest and California (Stebbins 2003). Across this range populations have been documented at elevations up to 3,350 M (11,000 ft) (Hammerson 1999). In Montana they have historically been documented across the eastern plains and in many of the mountain valleys on both sides of the Continental Divide. Unfortunately, over the last few decades northern leopard frog populations have undergone declines and extinctions across much of the western portion of their range (Stebbins and Cohen 1995). Most northern leopard frog populations in western Montana apparently became extinct sometime in the late 1970s or early 1980s when virtually no amphibian studies were being conducted in the state. Only two population centers are now known to exist in western Montana, one near Kalispell and one near Eureka (Werner et al. 1998; Kirwin Werner, Salish Kootenai College, pers. comm.). In addition, out of 47 historic sites revisited in the mid 1990s in central Montana, northern leopard frogs were only found at $9(19 \%)$ (Reichel 1995a, 1996; Koch et al. 1996). Populations in southeastern Montana still seem to be widespread and abundant (Reichel 1995b; Hendricks and Reichel 1996; Koch et al. 1996).

Maximum Elevation

2,042 m (6,700 ft) in Judith Basin County (Maxell et al. 2003). 


\section{$\underline{\text { Identification }}$}

\section{Eggs:}

Eggs are laid in a single orange to grapefruit sized globular mass and are laid individually or communally in groups of up to three dozen egg masses (Nussbaum et al. 1983). Egg masses contain from 645 to 6,272 eggs $(X=3,045, N=68$ for completely counted egg masses at five sites in Colorado and Wyoming) (Corn and Livo 1989). Each ovum is black above, white below, and is surrounded by two jelly layers (Livezey and Wright 1947). Ovum diameters are approximately $1.7 \mathrm{~mm}$, but total egg diameters, including the jelly layers, are approximately 5.0 $\mathrm{mm}$ (Livezey and Wright 1947).

Larvae:

Body and tail musculature are dark brown to olive or gray with flecks of light gold or silver and black (Bryce Maxell, pers. obs.). The tail musculature may be pale (Corkran and Thoms 2006). The lateral body surface has a larger proportion of light gold or silver flecks and the ventral body surface is silvery white to transparent (Bryce Maxell, pers. obs.). The tail fine is clear to yellowish with black and light gold or silver flecks (Bryce Maxell, pers. obs.). TL of 5.5-100 mm (Livo 1981 as cited in Hammerson 1999; Hammerson 1999).

Juveniles and Adults:

White to cream stripes extend from the tip of the snout laterally underneath the eye to just above the base of the front limb and from just behind each eye to the base of the hind limbs (Bryce Maxell, pers. obs.). Dorsal base color is either green or brown with large, oval shaped, black spots that are regular in outline and are surrounded with a light halo (Fogleman et al. 1980). Individuals occasionally have a blue light blue base color (Black 1969; Hammerson 1999). Ventral color is white to cream with some pinkish patches, especially on the feet (Bryce Maxell, pers. obs.). SVL of 18-110 mm (Nussbaum et al. 1983; Hammerson 1999).

\section{Similar Species:}

Adult Columbia spotted frogs often have red or salmon color on their ventral surface and their dorsal surface has small, irregularly shaped black spots with white or light yellow centers. Adult bullfrogs lack the white to yellowish stripe on the lateral portion of the snout, have tympanums that are the same size or larger than their eye, and have a fold of skin extending from the back of their eye, over their tympanum, down to their front leg. Larval Columbia spotted frogs have tails that are usually twice their body length, have large flecks of black on their body or tail, and often have a metallic copper sheen on the lateral edges of their ventral surfaces. Larval bullfrogs have a bright to creamy yellow ventral surface, have perfectly round black dots on their dorsal surface and tail musculature, and attain much larger sizes. Columbia spotted frog egg diameters are approximately twice those of northern leopard frogs because their jelly envelopes are much larger (see descriptions) and their egg masses are usually at the water's surface and not attached to vegetation (Ross et al. 1994). Bullfrog eggs are laid in the middle of the summer and are spread out in a thin layer over the surface or bottom of a pond rather than a globular mass. See sections on distribution to identify possible regions of co-occurrence of northern leopard frogs and Columbia spotted frogs or bullfrogs. 


\section{Habitat Use/Natural History}

Northern leopard frogs are typically found in and adjacent to permanent slow moving or standing water bodies with considerable vegetation. However, they may range widely into moist meadows, grassy woodlands and even agricultural areas (Nussbaum et al. 1983). In Montana adults are found primarily in riparian habitats or on the prairies near permanent waters without tall dense vegetation (Mosiman and Rabb 1952, Black 1969, Miller 1978). Adults feed on a variety of invertebrates, but may cannibalize smaller individuals and injest plant matter incidentally (Knowlton 1944; Moore and Strickland 1954; Whitaker 1961; Linzey 1967; Miller 1975, 1978). Adults overwinter on the bottom surface of permanent water bodies, under rubble in streams, or in underground crevices that do not freeze (Rand 1950; Emery et al. 1972; Cunjak 1986). Breeding occurs in March and April and females deposit egg masses singly or communally in waters $7-25 \mathrm{~cm}$ deep attached to vegetation under the water's surface (Corn and Livo 1989; Werner and Reichel 1996; Hammerson 1999). Eggs hatch in 4 to 15 days and tadpoles metamorphose in 58 to 105 days (Corn 1981; Livo 1981 as cited in Hammerson 1999). Tadpoles feed on a variety of algae as well as detritus (DeBenedictis 1974). Adults typically do not move more than 50 meters within a seasonal homerange, but may migrate several hundred to a thousand or more meters between seasonal homeranges (Dumas 1964; Dole 1965a; Dole 1965b; Dole 1967; Dole 1968). Juveniles are known to disperse up to 8.0 kilometers from their natal ponds to their adult seasonal territories (Dole 1971; Seburn et al. 1997).

\section{$\underline{\text { Status and Conservation }}$}

Within the last twenty to twenty five years northern leopard frog populations have declined and been extirpated from large portions of the area from the western plains of Colorado, Wyoming, Montana, and Alberta westward to Oregon and Washington (Roberts 1981, 1987, 1992; Corn and Fogleman 1984; Baxter and Stone 1985; Stebbins and Cohen 1995; Koch et al. 1996; Leonard and McAllister 1996; Leonard et al. 1999; Hammerson 1999). Suggested causes of declines in northern leopard frog populations in this and other areas of the country included loss of wetlands and natural hydrological regimes, introductions of game fish, mosquitofish, and bullfrogs, application of pesticides and herbicides, and drought (Roberts 1981, 1987, 1992; Corn and Fogleman 1984; Koch and Peterson 1995; Stebbins and Cohen 1995; Leonard and McAllister 1996; Leonard et al. 1999; Hammerson 1999). While it is likely that all of these factors have played a role in the decline and extirpation of local northern leopard frog populations, many of the declines and extirpations were apparently associated with regional mass mortality events between 1973 and 1982 because declines were observed in relatively pristine areas as well (Roberts 1981, 1987, 1991; 1992; Corn and Fogleman 1984; Koch and Peterson 1995). Reintroduction programs have been initiated in Alberta (Roberts 1991) and have been called for in Washington state (Leonard et al. 1999).

The same general timeline for declines is evident in western Montana. Northern leopard frog populations were encountered and found to be apparently healthy by a number of masters and doctoral degree students between 1967 and 1977 (Black 1967, 1970; Miller 1975; Anderson 1977; Daugherty et al. 1978). A student at the Salish-Kootenai College noted that while he found northern leopard frogs near Kicking Horse Reservoir on the Flathead Indian Reservation during the summer of 1980, local fisherman reported that they had noticed a definite decrease in the number of leopard frogs in the area (Ryan 1980). Very little, if any, work was conducted on amphibians in Montana in the 1980s and surveys in the 1990s failed to find northern leopard 
frogs at any of the historical sites that were revisited and only found two remaining populations in all of western Montana west of the Continental Divide (Werner and Plummer 1994, 1995; Werner and Reichel 1994, 1996; Hendricks and Reichel 1996a; Koch et al. 1996; Werner et al. 1998). Furthermore, while surveys during the 1990s found them to be common east of the island mountain ranges in eastern Montana, the appeared to have been extirpated from $80 \%$ of historic localities on the northwestern plains (Reichel 1995a, 1995b; Hendricks and Reichel 1996; Koch et al. 1996; Reichel 1996b; Reichel 1997; Hendricks and Reichel 1998; Rauscher 1998; Roedel and Hendricks 1998a, 1998b; Hendricks 1999).

As a result of these findings the USFS listed the northern leopard frog as a sensitive species in all Region 1 Forests (USDAFS 1999). Risk factors relevant to the viability of populations of this species are likely to include all the risk factors described above. Individual studies that specifically identify risk factors or other issues relevant to the conservation of northern leopard frogs include the following. (1) In conjunction with similar observations for western toads Carey (1993) observed the disappearance of two populations of northern leopard frogs in the West Elk Mountains of Colorado between 1974 and 1982. During this period she found leopard frogs with symptoms of red-leg disease, a common bacterial infection in amphibians and fish. She hypothesized that an unidentified environmental factor had caused sublethal stress of both species, which caused immune response to be supressed, leading to the systemic infection and death. More recently the chytrid fungus Batrachochytrium dendrobatidis, which is suspected to be responsible for declines of amphibians in Australia, Central America, and the western United States has been found to have caused mass mortalities in northern leopard frog populations in southern Arizona during the summer of 1999 (Berger et al. 1998; Daszak et al. 1999, 2000; Morell 1999; Milius 1999). As was observed for declines in the late 1970's and early 1980's only metamorphosed individuals died (Morell 1999). The fungus only seems to attack keratinized tissues, so metamorphosed individuals with lots of keratinized tissues die and tadpoles with keratinized tissues only around the mouthparts survive until metamorphosis (Berger et al. 1998; Morell 1999). Furthermore, it now appears that the chytrid fungus was responsible for declines in the late 1970's and early 1980's as well because museum specimens of northern leopard frogs that were collected during these time period have now been found to have the chytrid fungus (Carey 1999; Daszak 1999; Milius 2000). Thus, the chytrid fungus may be the most likely cause of declines of northern leopard frog populations in the western United States and in western Montana in the late 1970's and early 1980's and clearly represents a threat to populations today. In support of Carey's (1993) immunosuppression hypothesis Maniero and Carey (1997) found that northern leopard frogs exposed to low temperatures (5 degrees C) significantly reduced the animal's immune response. Thus, leopard frogs may be particularly susceptible to the chytrid fungus or other pathogens when emerging in the early spring or in the late fall or winter or when faced with some other environmental stressor (Carey et al. 1999). (2) Berrill et al. (1993) found that the pyrethroid pesticides permethrin and fenvalerate did not cause significant mortality of embryos when they were exposed to commonly applied levels for 22 to 96 hours. However, tadpole growth and response to a potential predator was delayed following exposure. Berrill et al. (1994) found that the insecticide fenitrothion and the herbicides triclopyr and hexazinone had no effects on embryos, but the fenitrothion and triclopyr did kill or paralyze new hatchlings at concentrations of 2.4 to $4.8 \mathrm{ppm}$ and 4.0 to $8.0 \mathrm{ppm}$, respectively. Berrill and Bertram (1997) found that northern leopard frog embryos exposed to 6 herbicides (hexazinone, triclopyr ester, triallate, trifluralin, glyphosate, and bromoxynil) and 3 insecticides (permethrin, 
fenvalerate, and fenitrothion) at levels that are commonly found in areas where they are used on forests or crops in Canada hatched successfully with no unusual mortality. However, when tadpoles were exposed to the same levels they suffered partial paralysis and the authors note that they would be likely to suffer high rates of mortality. Kaplan and Overpeck (1964) and Kaplan and Glaczenski (1965) found that a variety of organophosphate and halogenated hydrocarbon pesticides caused both red and white blood cell counts to decline in adult northern leopard frogs and chronic exposures to concentrations of $1 \mathrm{ppm}$ caused death in some individuals. Dial and Dial (1987) found that the aquatic herbicides diquat and paraquat did not reduce embryo survival or change hatching time when applied at concentrations of 0.1 to $2.0 \mathrm{ppm}$. However, at the same concentrations young tadpoles suffered significant mortality from both chemicals and 15 day old tadpoles suffered significant mortality from paraquat. (3) Hecnar (1995) found that acute and chronic toxic effects of ammonium nitrate were observed in northern leopard frog tadpoles at concentrations that are commonly exceeded in agricultural areas. Acute exposures to ammonium nitrate fertilizers at $20 \mathrm{mg} / \mathrm{L}$ for 96 hours resulted in 50 percent mortality and significant weight loss in those individuals that survived. Chronic exposures to $10 \mathrm{mg} / \mathrm{L}$ for 100 days resulted in significantly lower survivorship. Cameron (1940) found that well water containing $1 \mathrm{ppm}$ flourine caused embryo development to slow and time to hatching to decrease. Lande and Guttman (1973) found that embryos were not affected by copper sulfate at concentrations up to $1.56 \mathrm{mg} /$ liter of copper, but the $\mathrm{LD}_{50}$ for tadpoles was $0.15 \mathrm{mg} /$ liter and tadpole growth rates were decreased at concentrations of 0.06. (4) Hamilton (1941) found that rotenone applied at 0.1 $\mathrm{mg} / \mathrm{L}$ caused mortality in larval through metamorphic life history stages of Rana pipiens over an 8 to 24 hour time period, respectively. Furthermore, Burress (1982) found that Pro-Noxfish applied at $5 \mu \mathrm{L} / \mathrm{L}$ caused substantial mortality in Rana pipiens. (5) Black (1969a) felt that exotic bullfrogs introduced in the Bitterroot Valley had lead to declines in northern leopard frog populations in the area. Similarly, Hammerson (1982) documented a decline in the abundance of northern leopard frogs as bullfrog numbers increased at a site in Colorado. (6) Vatnick et al. (1999) found that adult northern leopard frogs prefered a neutral $\mathrm{pH}$ in a choice test and found that when they were exposed to water of $\mathrm{pH} 5.5$ for 10 days they suffered $72 \%$ mortality while those exposed to a $\mathrm{pH}$ of 7.0 suffered only $3.5 \%$ mortality. Furthermore, frogs appeared to be much more sensitive to low $\mathrm{pH}$ immediately after emergence from hibernation. Those exposed to a $\mathrm{pH}$ of 5.5 immediately after emerging from all died within 4 days while frogs exposed after they had completed breeding activities only suffered $58 \%$ mortality over a 10 day period. Freda et al. (1991) report that a $\mathrm{pH}$ below 4.6 causes mortality of embryos to increase significantly from controls and all embryos die when exposed to a $\mathrm{pH}$ of 4.2-4.5. Corn and Vertucci (1992) report an $\mathrm{LC}_{50}$ of embryos at a $\mathrm{pH}$ of 4.5. Freda and Dunson (1985) found that tadpoles raised at a $\mathrm{pH}$ of 4.4 grew slower than siblings raised at a $\mathrm{pH}$ of 5.8. Furthermore, older tadpoles had higher survival rates at low $\mathrm{pH}$ than younger tadpoles. Schlicter (1981) found that sperm motility decreased below pH 6.5 and no embroys survived below a pH of 4.8. Long et al. (1995) found that low $\mathrm{pH}$ and UV-B acted synergistically to cause mortality in northern leopard frog embryos. Freda et al. (1990) found that at a $\mathrm{pH}$ below 4.8, aluminum complexed with dissolved organic carbon and became toxic to tadpoles. (7) Nash et al. (1970) found that loud noises resulted in an immobility reaction in leopard frogs. This could leave them at greater risk of mortality from traffic or heavy machinery. (8) Ankley et al. (2000) found that limb deformities were more prevalent when tadpoles were exposed to higher levels of UV-B radiation. 
Research and Management Suggestions

1. See research and management suggestions under all of the general risk factors described above. The two populations that are known to remain in the western part of the state should thoroughly protected from the negative impacts of all management activities.

2. All historic breeding sites across the state (in western Montana in particular) should be revisited at least twice during an upcoming summer in order to identify possible changes in the short- and long-term regional status of populations.

3. A formal monitoring program should be established to detect declines and/or mechanisms behind declines for the two remnant populations west of the Continental Divide as well as for a number of randomly selected populations across the eastern plains.

4. Demographic vital rates reported in the scientific literature should be used to model the long term viability of the two populations that are known to remain in western Montana (e.g., 25, 50 , and 100 years).

5. Demographic vital rate information (fecundity, life stage specific survival rates, longevity, and migration and dispersal distances) should be gathered at the two known sites in western Montana in order to better understand the population dynamics of the species and identify mechanisms of mortality for all life history stages.

6. Museum specimens collected since the 1970's should be examined for the presence of the chytrid fungus. Furthermore, because amphibians sold in pet stores may be introduced into the wild and act as vectors for pathogens, they should be examined and formally certified as free of pathogens such as the chytrid fungus.

7. The Forest Service, the state of Montana, and tribal wildlife agencies should initiate habitat improvement projects around the remaining populations in western Montana and should strongly consider initiating a captive breeding and reintroduction program at historical sites across western Montana while locally adapted source populations still exist. Prior to initiating a reintroduction program genetic studies are recommended in order to determine the genetic variation within and between the remaining populations and populations on the eastern plains and in eastern Washington so that it is made certain that source populations are themselves native. Because reintroductions of adult amphibians are often unsuccessful due to their philopatric nature and tendency to attempt to home, reintroductions may be most successful if embryos are translocated and adequate overwintering habitat is provided at the sites of reintroduction.

8. Until the lethal and sublethal impacts of commonly used fertilizers, herbicides, and pesticides on all amphibian life history stages present in an area are examined they should not be applied within 100 meters of waterbodies or wetlands.

9. Before piscicides are used in fish removal projects the area should be surveyed for the presence of northern leopard frog breeding, and/or eggs and tadpoles. If tadpoles are present in a site that is about to be treated, tadpoles can be netted, placed in holding tanks for a few days, and returned to the site after the piscicide has cleared.

Bibliography *indicates an article with information specific to Montana

Adama, D.B., M.A. Beaucher, and K. Lansley. 2002. Northern Leopard frogs in British Columbia. Northwestern Naturalist 83:62.

*Allen, J.A. 1874. Notes on the natural history of portions of Dakota and Montana Territories, being the substance of a report to the Secretary of War on the collections made by the North 
Pacific Railroad Expedition of 1873, General D.S. Stanley, Commander. Proceedings of the Boston Society of Natural History 17: 33-85. Pages 68-70.

Allran, J.W. and W.H. Karasov. 2000. Effects of atrazine and nitrate on northern leopard frog (Rana pipiens) larvae exposed in the laboratory from posthatch through metamorphosis. Environmental Toxicology and Chemistry 19(11): 2850-2855.

*Altig, R. 1970. A key to the tadpoles of the continental United States and Canada. Herpetologica 26(2): 180-207.

*Anderson, M.E. 1977. Aspects of the ecology of two sympatric species of Thamnophis and heavy metal accumulation with the species. M.S. Thesis, University of Montana. Missoula, MT. 147 pp.

Ankley, G.T., J.E. Tietge, D.L. DeFoe, K.M. Jensen, G.W. Holcombe, E.J. Durhan, and S.A. Diamond. 1998. Effects of ultraviolet light and methoprene on survival and development of Rana pipiens. Environmental Toxicology and Chemistry 17: 2530-2542.

Ankley, G.T., J.E. Tietge, G.W. Holcombe, D.L. DeFoe, S.A. Diamond, K.M. Jensen, and S.J. Degitz. 2000. Effects of laboratory ultraviolet radaition and natural sunlight on survival and development of Rana pipiens. Canadian Journal of Zoology 78: 1092-1100.

Ankley, G.T., J.E. Tietge, and S.J. Degitz. 2000. Effects of laboratory ultraviolet radiation and natural sunlight on survival and development of Rana pipiens. Canadian Journal of Zoology 78(6): 1092-1100.

Ankley, G.T., S.A. Diamond, J.E. Tietge, G.W. Holcombe, K.M. Jensen, D.L. DeFoe, and R. Peterson. 2002. Assessment of the risk of solar ultraviolet radiation to amphibians. I. dosedependent induction of hindlimb malformations in the northern leopard frog (Rana pipiens). Environmental Science and Technology 36(13): 2853-2858.

*Atkinson, E.C. and M.L. Atkinson. 2004. Amphibian and reptile survey of the Ashland and Sioux of the Custer National Forest with special emphasis on the Three-Mile Stewardship Area:2002. Marmot's Edge Conservation. 22 p.

Bailey, M. 2004. Northern leopard frogs in a golf course water hazard. Blue Jay 62(1):43-45.

*Bauer, D. 1997. 1997 wildlife study Savage Mine report. Knife River Corporation, Savage Mine. Richland County, MT.

Baxter, G.T. 1952. Notes on growth and the reproductive cycle of the leopard frog (Rana pipiens) Schreber, in southern Wyoming. Journal of the Colorado-Wyoming Academy of Science 4: 91.

*Baxter, G.T. and M.D. Stone. 1985. Amphibians and reptiles of Wyoming. Second Edition. Wyoming Game and Fish Department. 137 p.

Beauregard N. and R. Leclair Jr. 1988. Multivariate analysis of the summer habitat of Rana pipiens Schreber, in Lac Saint Pierre (Quebec, Canada). Pp. 129-143. In: R.C. Szaro, K.E. Severson, and D.R. Patton, technical coordinators. Management of amphibians, reptiles, and small mammals in North America. General Technical Report RM-166. U.S. Forest Service, Rocky Mountain Forest and Range Experiment Station, Fort Collins, Colorado.

Berger, L., R. Speare, P. Daszak, D.E. Green, A.A. Cunningham, C.L. Goggin, R. Slocombe, M.A. Ragan, A.D. Hyatt, K.R. McDonald, H.B. Hines, K.R. Lips, G. Marantelli and H. Parkes. 1998. Chytridiomycosis causes amphibian mortality associated with population declines in the rain forests of Australia and Central America. Proceedings of the National Academy of Sciences 95: 9031-9036.

*Bergeron, D.J. 1978a. Terrestrial wildlife survey Divide Mine area, Montana 1977-1978. Western Technology and Engineering, Inc. Helena, MT. 
*Bergeron, D.J. 1978b. Terrestrial wildlife survey P-M Mine area, Montana 1977-1978. Western Technology and Engineering, Inc. Helena, MT.

*Bergeron, D.J. 1979. Terrestrial wildlife survey, Coal Creek Mine area, Montana 1977-1978. Western Technology and Engineering, Inc. Helena, MT.

Bernstein, G.S. 1952. Sperm aggutination in the egg jelly of the frogs Rana pipiens, Scherber and R. clamitans, Latreille. Biology Bulletin, 103: 285.

Berrill, M. and S. Bertram. 1997. Effects of pesticides on amphibian embryos and larvae. In: D.M. Green (ed.) Amphibians in decline: Canadian studies of a global problem. Society for the Study of Amphibians and Reptiles, Herpetological Conservation 1: 233-245.

Berrill, M., S. Bertram, A. Wilson, S. Louis, D. Brigham and C. Stromberg. 1993. Lethal and sublethal impacts of pyrethroid insecticides on amphibian embryos and tadpoles. Environmental Toxicology and Chemistry 12(3): 525-539.

Berrill, M., S. Bertram, L. McGillivray, M. Kolohon, and B. Pauli. 1994. Effects of low concentrations of forest-use pesticides on frog embyos and tadpoles. Environmental Toxicology and Chemistry 13(4): 657-664.

*Black, J.H. 1967. A blue leopard frog from Montana. Herpetologica 23(4): 314-315.

*Black, J.H. 1969a. Yes - there are bullfrogs in Montana. Montana Outdoors 1969: 4.

*Black, J.H. 1969b. The frog genus Rana in Montana. Northwest Science 43(4): 191-195.

*Black, J.H. 1970. Amphibians of Montana. Montana Wildlife, Montana Fish and Game Commission. Animals of Montana Series 1970(1): 1-32.

*BLM. 1982a. Bloomfield - North Fork baseline inventories - wildlife. Bureau of Land Management, Miles City District Office. Miles City, MT. 61 pp.

*BLM. 1982b. Moorhead baseline inventory - wildlife. Bureau of Land Management, Miles City District Office. Miles City, MT. 29 pp.

*Boundy, J. 2001. Herpetofaunal surveys in the Clark Fork Valley region, Montana. Herpetological Natural History 8: 15-26.

Bovbjerg, R.V. 1965. Experimental studies on the dispersal of the frog (Rana pipiens). Proceedings of the Iowa Academy of Science 72: 412-418.

Bovbjerg, R.V. and A.M. Bovbjerg. 1964. Summer emigrations of the frog (Rana pipiens) in northwestern Iowa. Proceedings of the Iowa Academy of Science 71: 511-518.

Bresler, J.B. 1964. Pigmentation characteristics of Rana pipiens: Tympanum spot, line on upper jaw, and spots on upper eyelids. American Midland Naturalist 72: 382-389.

Brodkin, M.A., M.P. Simon, A.M. DeSantis and K.J. Boyer. 1992. Response of Rana pipiens to graded doses of the bacterium Pseudomonas aeruginosa. Journal of Herpetology 26(4): 490495.

Browder, L.W. 1967a. Pigmentation in Rana pipiens: a study of spotting patterns in the leopard frog. Ph.D. Dissertation. University of Minnesota.

Browder. L.W. 1967b. Pigmentation in Rana pipiens. I. Inheritance of the speckle mutation. Journal of Heredity 52: 301-304.

Browder, L.W. and J. Davison. 1964. Spotting variations in the leopard frog: A test for the genetic basis in the Rana pipiens "burnsi" variant. Journal of Heredity 55: 234-241.

Brown, L.E. 1973. Speciation in the Rana pipiens complex. American Zoologist 13: 73-79. Brown, L.E. 1992. Rana blairi. Catalogue of American Amphibians and Reptiles 536: 1-6. Brown, L.E. and J. R. Brown. 1972. Call types of the Rana pipiens complex in Illinois. Science 176:928-929. 
*Brunson, R.B. 1955. Check list of the amphibians and reptiles of Montana. Proceedings of the Montana Academy of Sciences 15: 27-29.

*Brunson, R.B. and H.A. Demaree. 1951. The herpetology of the Mission Mountains, Montana. Copeia 1951: 306-308.

Burress, R.M. 1982. Effects of synergized rotenone on nontarget organisms in ponds. In U.S. Fish and Wildlife Service, Washington DC, Investigations in Fish Control No. 91, pp. 1-7.

*Burton, S.R., D.A. Patla, and C.R. Peterson. 2002. Amphibians of Red Rock Lakes National Wildlife Refuge: occurrence, distribution, relative abundance, and habitat associations. Herpetology Laboratory, Department of Biological Sciences, Idaho State University, Pocatello, ID. 66 p.

*Butts, T.W. 1997. Mountain Inc. wildlife monitoring Bull Mountains Mine No. 1, 1996. Western Technology and Engineering. Helena, MT.

Cameron, J.A. 1940. Effects of fluorine on hatching and hatching stage in Rana pipiens. Ecology 21(2): 288-292.

Carey, C. 1979. Aerobic and anaerobic energy expenditure during rest and activity in montane Bufo b. boreas and Rana pipiens. Oecologia 39: 213-228.

Carey, C. 1993. Hypothesis concerning the causes of the disapperance of the boreal toads from the mountains of Colorado. Conservation Biology 7(2): 355-360.

Carey, C., N. Cohen, and L. Rollins-Smith. 1999. Amphibian declines: an immunological perspective. Developmental and Comparative Immunology 23: 459-472.

*Case, S.M. 1978. Biochemical systematics of members of the genus Rana native to western North America. Systematic Zoology 27: 299-311.

Clarkson, R.W. and J.C. Rorabaugh. 1989. Status of leopard frogs (Rana pipiens complex: Ranidae) in Arizona and southeastern California. Southwestern Naturalist 34: 531-538.

*Cochran, D.M. 1961. Type specimens of reptiles and amphibians in the United States National Museum. United States National Museum Bulletin 220: 1-291.

Collins, J.P. and M.A. Lewis. 1979. Overwintering tadpoles and breeding season variation in the Rana pipiens complex in Arizona. Southwestern Naturalist 24(2): 371-396.

*Conant, R. and J.T. Collins. 1998. A field guide to reptiles and amphibians of eastern and central North America. $3^{\text {rd }}$ edition, expanded. New York, NY: Houghton Mifflin Co. 616 p.

*Cooper, S.V., C. Jean, and P. Hendricks. 2001. Biological survey of a prairie landscape in Montana's glaciated plains. Report to the Bureau of Land Management. Montana Natural Heritage Program, Helena, MT. 24 pp. plus appendices.

*Cope, E.D. 1875. Check-list of North American Batrachia and Reptilia; with a systematic list of the higher groups, and an essay on geographical distribution. U.S. National Museum Bulletin 1(1): 1-104.

*Cope, E.D. 1879. A contribution to the zoology of Montana. American Naturalist 13(7): 432441.

*Cope, E.D. 1889. The Batrachia of North America. Bulletin of the U.S. National Museum 34: 1-525, figs. 1-119, pls. 1-86.

Corcoran, M.F and J. Travis. 1980. A comparison of the karyotypes of the frogs Rana areolata, Rana sphenocephala and Rana pipiens. Herpetologica 36: 296-300.

Corkran, C.C. and C. Thoms. 2006. Amphibians of Oregon, Washington, and British Columbia. $2^{\text {nd }}$ Edition. Vancouver, B.C.: Lone Pine Publishing. 176 p. 
Corn, P.S. 1979. Size at metamorphosis and growth rates of juvenile frogs from montane populations of Rana pipiens. Journal of the Colorado-Wyoming Academy of Science 11(1): 90.

Corn, P.S. 1981. Field evidence for a relationship between color and developmental rate in the northern leopard frog (Rana pipiens). Herpetologica 37(3): 155-160.

Corn, P.S. 1982. Selection pressures affecting a dorsal color polymorphism in Rana pipiens. Ph.D. Dissertation. Fort Collins, CO. Colorado State University.

Corn, P.S., E. Muths, and W.M. Iko. 2000. A comparison in Colorado of three methods to monitor breeding amphibians. Northwestern Naturalist 81:22-30.

Corn, P.S. and F.A. Vertucci. 1992. Descriptive risk assessment of the effects of acid deposition on Rocky Mountain Amphibians. Journal of Herpetology 26(4): 361-369.

Corn, P.S. and J.C. Fogleman. 1984. Extinction of montane populations of the northern leopard frog (Rana pipiens) in Colorado. Journal of Herpetology 18(2): 147-152.

Corn, P.S. and L.J. Livo. 1989. Leopard frog and wood frog reproduction in Colorado and Wyoming. Northwestern Naturalist 70: 1-9.

Corn, P.S., M.L. Jennings, and E. Muths. 1997. Survey and assessment of amphibian populations in Rocky Mountain National Park. Northwestern Naturalist 78: 34-55.

*Coues, E. and H.C. Yarrow. 1878. Notes on the herpetology of Dakota and Montana. Bulletin of the U.S. Geologic and Geographic Survey 4(1): 259-291.

Cousineau, M. and K. Rogers. 1991. Observations on sympatric Rana pipiens, R. blairi, and their hybrids in eastern Colorado. Journal of Herpetology 25: 114-116.

Croshaw, D.A. 2005. Cryptic behavior is independent of dorsal color polymorphism in juvenile northern leopard frogs (Rana pipiens). Journal of Herpetology 39(1):125-129.

Cuellar, H.S. 1971. Levels of genetic compatibility of Rana areolata with southwestern members of the Rana pipiens complex (Anura: Ranidae). Evolution 25: 399-409.

Cunjak, R.A. 1986. Winter habitat of northern leopard frogs (Rana pipiens) in a southern Ontario stream. Canadian Journal of Zoology 64: 255-257.

Daszak, P., A.A. Cunningham and A.D. Hyatt. 2000. Emerging infectious diseases of wildlife threats to biodiversity and human health. Science 287: 443-449.

Daszak, P., L. Berger, A.A. Cunningham, A.D. Hyatt, D.E. Green, and R. Speare. 1999. Emerging infectious diseases and amphibian population declines. Emerging Infectious Diseases 5(6): 735-748.

*Daugherty, C.H., L.N. Wishard, and L.B. Daugherty. 1978. Sexual dimorphism in an anuran response to severe thermal stress. Journal of Herpetology 12(3): 431-432.

Davidson, J. 1961. A study of spotting patterns in the leopard frog. Journal of Heredity 52: 301-304.

*Day, D., P.J. Farmer, and C.E. Farmer. 1989. Montco terrestrial wildlife monitoring report December, 1987 - July, 1989. Montco, Billings, MT, and Western Technology and Engineering, Inc. Helena, MT.

*[DCC] Decker Coal Company. 1998. 1997 Consolidated annual progress report. Decker Coal Company West, North and East Pits. Decker, MT.

DeBenedictis, P.A. 1974. Interspecific competition between tadpoles of Rana pipiens and Rana sylvatica: an experimental field study. Ecological Monographs 44: 129-151.

Di Berrardino, M.A. 1962. The karyotype of Rana pipiens and investigation of its stability during embryonic differentiation. Developmental Biology 5: 101-126. 
Dial, N.A. and C.A. Baurer Dial. 1987. Lethal effects of diquat and paraquat on developing frog embryos and 15 -day-old tadpoles (Rana pipiens). Bulletin of Environmental Contamination and Toxicology 38: 1006-1011.

Dole, J.W. 1963. Movements and spatial relations of Rana pipiens in spring and summer in northern Michigan. Ph.D. Dissertation. Ann Arbor, MI. University of Michigan. 288p.

Dole, J.W. 1965a. Spatial relations in natural populations of the leopard frog (Rana pipiens) Schreber, in northern Michigan. American Midland Naturalist 74: 464-478.

Dole, J.W. 1965b. Summer movement of adult leopard frogs (Rana pipiens) Schreber, in northern Michigan. Ecology 46(3): 236-255.

Dole, J.W. 1967a. Spring movements of leopard frogs (Rana pipiens) Schreber, in northern Michigan. American Midland Naturalist 78(1): 167-181.

Dole, J.W. 1967b. The role of substrate moisture and dew in the water economy of leopard frogs (Rana pipiens). Copeia 1967(1): 141-149.

Dole, J.W. 1968. Homing in leopard frogs (Rana pipiens). Ecology 49(3): 386-399.

Dole, J.W. 1971. Dispersal of recently metamorphosed leopard frogs (Rana pipiens). Copeia 1971(2): 221-228.

Dole, J.W. 1972. The role of olfaction and audition in the orientation of leopard frogs (Rana pipiens). Herpetologica 28(3): 258-260.

*Dood, A.R. 1980. Terry Badlands nongame survey and inventory final report. Montana Department of Fish, Wildlife, and Parks and Bureau of Land Management, Helena, MT. 70 p.

Drake, C.J. 1914. The food of Rana pipiens Schreber. Ohio Naturalist 14: 257-269.

*Dumas, P.C. 1964. Species-pair allopatry in the genera Rana and Phrynosoma. Ecology 45: 178-181.

*Dumas, P.C. 1966. Studies of the Rana species complex in the Pacific Northwest. Copeia 1966(1): 60-74.

Dunlap, D.G. 1979. Hemoglobin phenotypes in the frogs Rana pipiens, Rana blairi, and their hybrids and a backcross. Comparative Biochemistry and Physiology B. 62:167-173.

Dunlap, D.G. 1982. Linkage analysis of the transferrin, albumin, and hemoglobin loci in leopard frogs. Journal of Heredity 73: 247-248.

*Dunlap, D.G. and J.E. Platz. 1981. Geographic variation of proteins and call in Rana pipiens from the northcentral United States. Copeia 1981: 876-879.

Dunlap, D.G. and K.C. Kruse. 1976. Frogs of the Rana pipiens complex in the northern and central plains states. Southwest Naturalist 20(4): 559-571.

Eddy, S.B. 1976. Population ecology of the leopard frog, Rana pipiens pipiens Schreber, at Delta Marsh, Manitoba. M.S. Thesis, University of Manitoba, 84 pp.

Ehrlich, D. 1979. Predation by bullfrog tadpoles (Rana catesbeiana) on eggs and newly hatched larvae of the plains leopard frog (Rana blairi). Bulletin of the Maryland Herpetological Society 15: 25-26.

*[EI] Econ Incorporated. 1984. Terrestrial wildlife inventory for the Lame Jones and Ismay coal lease tracts. Econ Incorporated. Helena, MT.

Emery, A.R., A.H. Berst, and K. Kodaira. 1972. Under-ice observations of wintering sites of leopard frogs. Copeia 1972(1): 123-126.

*Enk, M. 1999. Preliminary results of amphibian monitoring on the Lewis and Clark National Forest. Intermountain Journal of Sciences 5(1-4): 48. 
*Farmer, P. 1980. Terrestrial wildlife monitoring study, Pearl area, Montana June, 1978 - May, 1980. Western Technology and Engineering, Inc. Helena, MT.

*Farmer, P. and S.B. Heath. 1987. Wildlife baseline inventory, Rock Creek study area, Sanders County, Montana. Western Technology and Engineering, Inc. Helena, MT.

Fernandez, P.J. and J.T. Bagnara. 1995. Recent changes in leopard frog distribution in the White Mountains of east central Arizonia. Declining Amphibian Populations Task ForceSouthwestern United States Working Group.

*Flath, D.L. 1998. Species of special interest or concern. Montana Department of Fish, Widlife and Parks, Helena, MT. March, 1998. 7 p.

*Flath, D.L. 2002. Reptile and amphibian surveys in the Madison-Missouri River Corridor, Montana. Annual Progress Report. 14p.

Fogleman, J.C. 1974. The distribution and inheritance of a dorsal color polymorphism in the leopard frog (Rana pipiens). Masters Thesis, Colorado State University.

Fogleman, J.C., P.S. Corn, and D. Pettus. 1980. The genetic basis of a dorsal color polymorphism in Rana pipiens. Journal of Heredity 71: 439-440.

Fontenot, L.W., G.P. Noblet and S.G. Platt. 1994. Rotenone hazards to amphibians and reptiles. Herpetological Review 25(4):150-156.

Force, E.R. 1925. Notes on reptiles and amphibians of Okmulgee County, Oklahoma. Copeia 1925(141): 25-27.

Force, E.R. 1933. The age of attainment of sexual maturity of the leopard frog (Rana pipiens) (Shreber), in northern Michigan. Copeia 1933(3): 128-131.

*Franz, R. 1971. Notes on the distribution and ecology of the herpetofauna of northwestern Montana. Bulletin of the Maryland Herpetological Society 7: 1-10.

Freda, J. and D.G. McDonald. 1990. The effects of aluminum on the leopard frog (Rana pipiens): life stage comparions and aluminum uptake. Canadian Journal of Fish and Aquatic Science 47217-224.

Freda, J., V. Cavdek, and D.G. McDonald. 1990. Role of organic complexation in the toxicity of aluminum to Rana pipens embryos and Bufo americanus tadpoles. Canadian Journal of Fisheries and Aquatic Sciences 47: 217-224.

Freda, J. and W.A. Dunson. 1984. Sodium balance of amphibian larvae exposed to low environmental pH. Physiological Zoology 57(4): 435-443.

Freda, J. and W.A. Dunson. 1985. Field and laboratory studies of ion balance and growth rates of ranid tadpoles chronically exposed to low $\mathrm{pH}$. Copeia 1985: 415-423.

Freda, J., W.J. Sadinski, and W.A. Dunson. 1991. Long term monitoring of amphibian populations with respect to the effects of acidic deposition. Water, Air, and Soil Pollution 55: 445-462.

Frost, J.S. 1982. Functional genetic similarity between geographically separated populations of Mexican leopard frogs (Rana pipiens complex). Systematic Zoology 31: 57-67.

Frost, J.S. 1983. Comparative feeding and breeding strategies of a sympatric pair of leopard frogs (Rana pipiens complex). Journal of Experimental Zoology 225: 135-140.

Frost, J.S. and J.E. Platz. 1983. Comparative assessment of modes of reproductive isolation among four species of leopard frogs (Rana pipiens complex). Evolution 37: 66-78.

Frost, J.S. and J.T. Bagnara. 1976. A new species of leopard frog (Rana pipiens complex) from northwestern Mexico. Copeia 1976: 332-38. 
Frost, J.S. and J.T. Bagnara. 1977. Sympatry between Rana blairi and the southern from of the leopard frog in southeastern Arizona. (Anura:Ranidae). Southwestern Naturalist 22: 443453.

Gaizick, L., G. Gupta, and E. Bass. 2001. Toxicity of chlorypyrifos to Rana pipiens embryos. Bulletin of Environmental Contamination and Toxicology 66(3): 386.

Gallant, N. and K. Teather. 2001. Differences in size, pigmentation, and fluctuating asymmetry in stressed and nonstressed northern leopard frogs (Rana pipiens). Ecoscience 8(4): 430-436.

Garber, C.S. 1992. A survey for spotted frogs (Rana pretiosa), wood frogs (Rana sylvatica), and boreal toads (Bufo boreas) in Wyoming: interim report for the Laramie Range Mountains and Bighorn Mountains of Wyoming. Wyoming Natural Diversity Database. Laramie, WY. 15 pp. + appendix.

Garber, C.S. 1995a. A survey for U.S. Forest Service listed "Sensitive" amphibians including the spotted frog (Rana pretiosa), leopard frog (Rana pipiens), tiger salamander (Ambystoma tigrinum) and the boreal toad (Bufo boreas) on the north half of the Shoshone National Forest. Report prepared by the Wyoming Natural Diversity Database, Laramie, WY, for the U.S. Forest Service, Shoshone National Forest, Cody, WY.

Garber, C.S. 1995b. Addendum Number 1 to "A status survey for spotted frogs (Rana pretiosa) wood frogs (Rana sylvatica) and boreal toads (Bufo boreas) in the mountains of southern and eastern Wyoming. Report prepared by the Wyoming Natural Diversity Database for the U.S. Fish and Wildlife Service, Denver, CO.

*Gates, M.T. 2005. Amphibian and reptile baseline survey: CX field study area. Report to Billings and Miles City Field Offices of Bureau of Land Management. Maxim Technologies, Billings, MT. 28pp + appendices.

Gendron, A.D., D.J. Marcogliese, S. Barbeau, M.-S Christin, P. Brousseau, S. Ruby, D. Cyr, and M. Fournier. 2003. Exposure of leopard frogs to a pesticide mixture affects life history characteristics of the lungworm Rhabdias ranae. Oecologia 135(3): 469-476.

Gibbs, E.L. 1963. An effective treatment for redleg disease in Rana pipiens. Laboratory Animal Care 13: 781-783.

Gibbs, E.L. 1973. Rana pipiens: Health and disease-how little we know. American Zoologist 13: 93-96.

Gilbert, M., R. Leclair, Jr. and R. Fortin. 1994. Reproduction of the northern leopard frog (Rana pipiens) in floodplain habitat in the Richelieu River, P. Quebec, Canada. Journal of Herpetology 28: 465-470.

Gilliespie, H. and J.W. Crenshaw. 1966. Hemoglobin variation in Rana pipiens (Amphibia:Anura). Copeia 1966: 889-893.

Gillis, J. E. 1975. Characterization of a hybridizing complex of leopard frogs. Ph.D. Dissertation, Colorado State University, Fort Collins CO xi +125 pp.

Gillis, J. E. 1979. Adaptive differences in the water economics of two species of leopard frogs from eastern Colorado. Journal of Herpetology 13: 445-450.

Glennemeier, K.A. amd R.J. Denver. 2001. Sublethal effects of chronic exposure to an organochlorine compound on northern leopard frog (Rana pipiens) tadpoles. Environmental Toxicology 16(4): 287-297.

Glennemeier, K.A. and R.J. Denver. 2002a. Role for corticoids in mediating the reponse of Rana pipiens tadpoles to intraspecific competition. Journal of Experimental Zoology 292(1): 32-40. 
Glennemeier, K.A. and R.J. Denver. 2002b. Small changes in whole-body corticosterone content affect larval Rana pipiens fitness components. General and Comparative Endocrinology 127(1):16-25.

Golden, D.R., G.R. Smith, and J.E. Rettig. 2001. Effects of age and group size on habitat selection and activity level in Rana pipiens tadpoles. Herpetological Journal 11(2): 69-74.

Goraya, J., Y. Wang and J.M. Conlon. 2000. Peptides with antimicrobial activity from four different familes isolated from the skins of the North American frogs Rana luteiventris, Rana berlandie and Rana pipiens. European Journal of Biochemistry 267(3): 894-900.

Greding, E.J. 1972. Call specificity and hybrid compatability between Rana pipiens and three other species Rana species in Central America. Copeia 1972: 383-385.

Green, D.M. 1978. Northern leopard frogs and bullfrogs on Vancouver Island. Canadian Field Naturalist 92: 78-79.

Gromko, H.M. F.S. Mason, and S.J. Smith-Gill. 1973. Analysis of the crowding effect in Rana pipiens tadpoles. Journal of Experimental Zoology 186: 63-72.

Hamilton, H.L. 1941. The biological action of rotenone on freshwater animals. Proceedings of the Iowa Academy of Science 48:467-479.

Hammerson, G.A. 1982. Bullfrog eliminating leopard frogs in Colorado? Herpetological Review 13: 115-116.

Hammerson, G.A. 1999. Amphibians and reptiles in Colorado. Second Edition. University Press of Colorado and Colorado Division of Wildlife. $484 \mathrm{p}$.

*Hanson, J. No Date. Report on Youngs Creek. U.S. Fish and Wildlife Service. Hardin, MT. $14 \mathrm{p}$.

Hardy, J.D. Jr., and J.H. Gillllepsie. 1976. Hybridization between Rana pipiens and Rana palustris in a modified natural enviroment. Bulletin of the Midland Herpetelogical Society 12: 41-53.

Harris, M.L., L. Chora and J.P. Bogart. 2000. Species- and age-related differences in susceptibility to pesticide exposure for two amphibians, Rana pipiens, and Bufo americanus. Bulletin of Environmental Contamination and Toxicology 64(2): 263-270.

*Hart, M.M., W.A. Williams, P.C. Thornton, K.P. McLaughlin, C.M. Tobalske, B.A. Maxell, D.P. Hendricks, C.R. Peterson, and R.L. Redmond. 1998. Montana atlas of terrestrial vertebrates. Montana Cooperative Wildlife Research Unit, University of Montana, Missoula, MT. $1302 \mathrm{p}$.

*Hayden, F.V. 1863. On the geology and natural history of the upper Missouri. Transactions of the American Philosophical Society New Series 12(1): 1-218 (pages 177-178).

Hayes, M.P. and M.R. Jennings. 1986. Decline of ranid frog species in western North America: are bullfrogs (Rana catesbeiana) responsible? Journal of Herpetology 20(4): 490509.

Hayes, T.B., K. Haston, M. Tsui, A. Hoang, C. Haeffele, and A. Vonk. 2002. Feminization of male frogs in the wild. Nature 419: 895-896.

Hayes, T.B., K. Haston, M. Tsui, A. Hoang, C. Haeffele, and A. Vonk. 2003. Atrazine-induced hermaphroditism at $0.1 \mathrm{ppb}$ in American leopard frogs (Rana pipiens): laboratory and field evidence. Environmnetal Health Perspectives 111(4): 568-575.

Hecnar, S.J. 1995. Acute and chronic toxicity of ammonium nitrate fertilizer to amphibians. Environmental Toxicology and Chemistry 14(12): 2131-2137.

Hecnar, S.J. and R.T. M'Closkey. 1996. Regional dynamics and the status of amphibians. Ecology 77: 2091-2097. 
Hecnar, S.J. and R.T. M'Closkey. 1997. Changes in the composition of a Ranid frog community following bullfrog extinction. American Midland Naturalist 137: 145-150.

Heinen, J.T. and G. Hammond. 1997. Antipredator behaviors of newly metamorphosed green frogs (Rana clamitans) and leopard frogs (R. pipiens) in encounters with eastern garter snakes (Thamnophis s. sirtalis). American Midland Naturalist 137(1): 136-144.

Hendricks, F.S. 1973. Intestinal contents of Rana pipiens Schreber (Ranidae) larvae. Southwestern Naturalist 18: 99-101.

*Hendricks, P. 1996. Status of amphibians and reptiles in Western Montana. Abstract. Intermountain Journal of Sciences 2(2): 45.

*Hendricks, P. 1999. Amphibian and reptile survey of the Bureau of Land Management Miles City District, Montana. Montana Natural Heritage Program, Helena, MT. 80 p.

*Hendricks, P. 2000. Amphibian and reptile survey of the Thompson Chain of Lakes. A report to the Montana Department of Fish, Wildlife, and Parks. Montana Natural Heritage Program, Helena, MT. 15 p.

*Hendricks, P. and J.D. Reichel. 1996a. Amphibian and reptile survey of the Bitterroot National Forest: 1995. Montana Natural Heritage Program, Helena, MT. 95 p.

*Hendricks, P. and J.D. Reichel. 1996b. Preliminary amphibian and reptile survey of the Ashland District, Custer National Forest: 1995. Montana Natural Heritage Program, Helena, MT. $79 \mathrm{p}$.

*Hendricks, P. and J.D. Reichel. 1998. Amphibian and reptile survey on Montana refuges: 1996. Montana Natural Heritage Program, Helena, MT. 19 p.

Hillis, D.M. 1981. Premating isolating mechanisms among three species of the Rana pipiens complex in Texas and southern Oklahoma. Copeia 1981: 312-319.

Hillis, D.M. 1988. Systematics of the Rana pipiens complex: puzzle and paradigm. Annual Review of Ecology and Systematics 19: 39-63.

*Hillis, D.M. and S. Davis. 1986. Evolution of ribosomal DNA: Fifty million years of recorded history in the frog genus Rana. Evolution 40: 1275-1288.

Hillis, D.M., J.S. Frost, and D.A. Wright. 1983. Phylogeny and biogeography of the Rana pipiens complex: a biochemical evaluation. Systematic Zoology 32(2): 132-143.

Hine, R.L., B.L. Les and B.F. Hellmich. 1981. Leopard frog populations and mortality in Wisconsin. Wisconsin Dept. of Natural Resources Technical Bulletin No. 122. 39 pp.

Hine, R.L., B.L. Les, B.F. Hellmich and R.C. Vogt. 1981. Leopard frog populations and mortality in Wisconsin, 1974-76. Wisconsin Dept. of Natural Resources Technical Bulletin No. 122. Madison, WI. 39p.

Hird, D.W., S.L. Diesch, R.G. McKinnell, E. Gorham, F.B. Martin, S.W. Kurtz and C. Dubrovolny. 1981. Aeromonas hydrophila in wild-caught frogs and tadpoles (Rana pipiens) in Minnesota. Laboratory Animal Science 31(2): 166-169.

Hlynka, L.J. 1970. Helminths in Rana pipiens Schreber, and Bufo hemiophrys Cope, from the Delta Marshes, Manitoba. M.S. Thesis, University of Manitoba. 110 pp.

Hofman, D.E. 1991. 1990 central region leopard frog inventory. Unpubl. Rept., Alberta Fish and Wildife Division, Red Deer, AB. 8p.

Hofman, D.E. 1992. 1992 leopard frog monitoring project, Princes Spring, Alberta. Unpubl. Rept., Alberta Fish and Wildlife Division, Red Deer, AB. 12 pp.

Hofman, D.E. 1994a. 1994 northern leopard frog census, Princes Spring, Alberta. Unpubl. Rept., Alberta Fish and Wildlife Division, Red Deer, AB. 6 pp. 
Hofman, D.E. 1994b. 1993 leopard frog monitoring project, Princes Spring, Alberta. Unpubl. Rept., Alberta Fish and Wildlife Division, Red Deer, AB. 7 pp.

Hofman, D.E. 1995. 1995 northern leopard frog census, Princes Spring, Alberta. Unpubl. Rept., Alberta Fish and Wildlife Division, Red Deer, AB. 6 pp.

Hoppe, D.M. and R.G. McKinnell. 1994. Pattern polymorphism in leopard frogs of Minnesota and contiguous states. North Dakota Academy of Sciences Proceedings 48: 23.

*Hossack, B.R. and P.S. Corn. 2001. Amphibian survey of Medicine Lake National Wildlife Refuge Complex: 2001. USGS Northern Rocky Mountain Science Center, Aldo Leopold Wilderness Research Institute, Missoula, MT. 13 p.

Hossack, B.R., P.S. Corn, and D.S. Pilliod. 2005. Lack of significant changes in the herpetofauna of Theodore Roosevelt National Park, North Dakota, since the 1920s. American Midland Naturalist 154:423-432.

Hunter, B.R., D.L. Carlson, E.D. Seppanen, P.S. Killian, B.K. McKinnell, and R.G. McKinnell. 1989. Are renal carcinomas increasing in Rana pipiens after a decade of reduced prevalence. American Midland Naturalist 122: 307-312.

Hupf, T.H. 1977. Natural histories of two species of leopard frogs, Rana blairi and Rana pipiens, in a zone of sympatry in northeastern Nebraska. M.S. Thesis, University of Nebraska, Lincoln, Nebraska. 125 pp.

Hutchinson, V.H. and M.J. Dady. 1964. The viability of Rana pipiens and Bufo terrestris submerged at different temperatures. Herpetologica 20: 149-162.

Jaeger, J.R., B.R. Riddle, R.D. Jennings, and D.F. Bradford. 2001. Rediscovering Rana onca: Evidence for phylogenetically distinct leopard frogs from the border region of Nevada, Utah, and Arizona. Copeia 2001(2): 339-354.

*Jones, L.L.C., W.P. Leonard, and D.H. Olson (eds). 2005. Amphibians of the Pacific Northwest. Seattle, WA: Seattle Audubon Society. 227 p.

Kaplan, H.M., T.J. Arnholt, and J.E. Payne. 1967. Toxicity of lead nitrate solutions for frogs (Rana pipiens). Laboratory Animal Care 17(2): 240-246.

Kaplan, H.M. and J.G. Overpeck. 1964. Toxicity of halogenated hydrocarbon insecticides for the frog Rana pipiens. Herpetologica 20: 163-169.

Kaplan, H.M. and S.S. Glaczenski. 1965. Hematological effects of organophosphate insecticides in the frog (Rana pipiens). Life Science 4: 1213-1219.

Kauffeld, C.F. 1937. The status of the leopard frogs Rana brachycephala and Rana pipiens. Herpetologica 1: 84-87.

Kilby, J.D. 1945. A biological analysis of the food and feeding habits of two frogs, Hyla cinerea and Rana pipiens Sphenocephala. Quarterly Journal of the Florida Academy of Sciences 8: 71-104.

Kimberling, D.N., A.R. Ferreira, S.M. Shuster and P. Keim. 1996. RAPD marker estimation of genetic structure among isolated northern leopard frog populations in the south-western USA. Molecular Ecology 5(4): 521-529.

Knowlton, G.F. 1944. Some insect food of Rana pipiens. Copeia 1944(2): 119.

*Koch, E.D., G. Williams, C.R. Peterson and P.S. Corn. 1996. Conference on declining and sensitive amphibians in the Northern Rockies and the Pacific Northwest: a summary paper. Idaho Herpetological Society Technical Bulletin and U.S. Fish and Wildlife Service Report, Boise, ID. 34 p. 
Kocher, T.D. 1986. Genetic differentiation during speciation in the Rana pipiens and Ambystoma tigrinum species complexes. Ph.D. Dissertation, University of Colorado, Boulder, Colorado.

Kocher, T.D. and R.D. Sage. 1986. Further genetic analyses of a hybrid zone between leopard frogs (Rana pipiens complex) in central Texas. Evolution 40: 21-33.

Korky, J.K. 1978. Differentiation of the larvae of members of the Rana pipiens complex in Nebraska. Copeia 1978: 455-459.

Kruse, K.C. 1981. Phonotactic responses of female northern leopard frogs (Rana pipiens) to Rana blairi, a presumed hybrid, and conspecific mating trills. Journal of Herpetology 15: 145-150.

Kruse, K.C. and D.G. Dunlap. 1976. Serum albumins and hybridization in two species of the Rana pipiens complex in the north central United States. Copeia 1976: 394-396.

Lambers, J.H.R., J.S. Clark, and B. Beckage. 2002. Density-dependent mortality and the latitudinal gradient in species diversity. Nature 6890: 732-734.

Lande, S.P. and S.I. Guttman. 1973. The effects of copper sulfate on the growth and mortality rate of Rana pipiens tadpoles. Herpetologica 29: 22-27.

Larson, K.A. 2004. Advertisement call complexity in Northern Leopard frogs, Rana pipiens. Copeia 3:676-682

Leclair, R., Jr. and J. Castanet. 1987. A skeletochronological assessment of age and growth in the frog Rana pipiens Schreber (Amphibia, Anura) from Quebec. Copeia 1987: 361-369.

Lee, P.A. 1965. Histological and biochemical analysis of the annual cycle of growth and secretion in the oviduct of Rana pipiens. Ph.D. Thesis, University of Michigan.

Leonard, W.P. and K.R. McAllister. 1996. Past distribution and current status of the Northern Leopard frog (Rana pipiens) in Washington. Washington Dept. of Fish and Wildlife Special Publication, Feb. 1996. 17 pp.

Leonard, W.P., K.R. McAllister, and R.C. Friesz. 1999. Survey and assessment of northern leopard frog (Rana pipiens) populations in Washington State. Northwestern Naturalist 80: 51-60.

Levine, R.P., J.A. Monroy, and E.L. Brainard. 2004. Contribution of eye retraction to swallowing performace in the northern leopard frog, Rana pipiens. Journal of Experimental Biology 207(8):1361-1368.

Lewis, W.M., G.E. Gunning, E. Lyles and W.L. Bridges. 1961. Food choice of largemouth bass as a function of availability and vulnerability of food items. Transactions of the American Fisheries Society 90: 277-280.

Licht, L.E. 1991. Habitat selection of Rana pipiens and Rana sylvatica during exposure to warm and cold temperatures. American Midland Naturalist 125: 259-268.

Linzey, D.W. 1967. Food of the leopard frog (Rana p. pipiens) in Central New York. Herpetologica 23(1): 11-17

Littlejohn, M.J., and R.S. Oldham. 1968. Rana pipiens complex: mating call structure and taxonomy. Science 162: 1003-1005.

*Livezey, R.L. and A.H. Wright. 1947. A synoptic key to salientian eggs of the United States. American Midland Naturalist 37: 179-222.

Livo, L.J. 1981. Leopard frog (Rana pipiens) reproduction in Boulder County, Colorado. M.A. Thesis, University of Colorado, Denver, Colorada. 94 p.

Long, L. E., L. S. Saylor and M. E. Soule. 1995. A pH/UV-B synergism in amphibians. Conservation Biology. 9(5): 1301-1303. 
Lucke, B. 1934. A neoplastic disease of the frog Rana pipiens. American Journal of Cancer 20: 352-379.

*Lynch, C. 2000. North American Amphibian Monitoring Program's Montana frog-call survey: a report on a pilot program in south-central Montana started April 2000 and completed in June 2000. Zoo Montana Conservation Through Education Program, Billings MT. 39 p.

*Lynch, C. 2001. North American Amphibian Monitoring Program's Montana frog-call survey: report on year two of a program in south-central Montana started April 2001 and completed in June 2001. Zoo Montana Conservation Through Education Program, Billings MT. 12 p.

Lynch, J.D. 1978. The distribution of leopard frogs (Rana blairi and Rana pipiens) (Amphibia, Anura, Ranidae) in Nebraska. Journal of Herpetology 12: 157-162.

Maniero, G.D. and C. Carey. 1997. Changes in selected aspects of immune function in the leopard frog (Rana pipiens) associated with exposure to cold. Journal of Comparative Physiology B 167: 256-263.

Manion, J.J. and L. Cory. 1952. Winter kill of Rana pipiens in shallow ponds. Herpetology 33: 430-435.

*Marnell, L.F. 1997. Herpetofauna of Glacier National Park. Northwestern Naturalist 78: 1733.

*Martin, P.R. 1980a. Terrestrial wildlife habitat inventory in southeastern Montana. Montana Department of Fish, Wildlife and Parks and Bureau of Land Management, Helena MT. 114 p.

*Martin, P.R. 1980b. Terrestrial wildlife inventory in selected coal areas of Montana. Montana Department of Fish, Wildlife and Parks and Bureau of Land Management, Helena, MT. 84 p.

*Martin, P.R., K. Dubois, and H.B. Youmans. 1981. Terrestrial wildlife inventory in selected coal areas, Powder River resources area final report. Montana Department of Fish, Wildlife and Parks and Bureau of Land Management, Helena, MT. 288 p.

Matsuda, B.M., D.M. Green, and P.T. Gregory. 2006. Amphibians and reptiles of British Columbia. Victoria, B.C.: Royal British Columbia Museum. 266 p.

*Matthews, W.L. 1979. Wibaux-Beach wildlife baseline study - nongame species. Bureau of Land Management, Miles City, MT. 93 p.

*Matthews, W.L. 1980a. Wibaux-Beach comparison study: Sydney, Glendive and Plevna Study Areas. Bureau of Land Management, Miles City, MT. 50 p.

*Matthews, W.L. 1980b. Wildlife of Prairie County Terry study area. Bureau of Land Management, Miles City, MT. 52 p.

*Matthews, W.L. 1981. Broadus-Pumpkin Creek baseline inventory - wildlife. Bureau of Land Management, Miles City, MT. 83 p.

*Maxell, B.A. 2000. Management of Montana's amphibians: a review of factors that may present a risk to population viability and accounts on the identification, distribution, taxonomy, habitat use, natural history, and the status and conservation of individual species. Report to USFS Region 1, Order Number 43-0343-0-0224. Missoula, MT: Wildlife Biology Program, University of Montana. $161 \mathrm{p}$.

*Maxell, B.A. 2002. Amphibian and aquatic reptile inventories in watersheds in the South and Middle Forks of the Flathead River drainage that contain lakes being considered for application of piscicides and subsequent stocking of west slope cutthroat trout. Report to the Region 1 Office of the U.S. Forest Service and the Montana Department of Fish, Wildlife, 
and Parks. Montana Cooperative Wildlife Research Unit and Wildlife Biology Program, University of Montana, Missoula, MT. 62 pp.

* Maxell, B.A. 2004a. Amphibian and aquatic reptile inventories conducted on and around the Bitterroot National Forest 2000-2003. Report to Region 1 Office of the U.S. Forest Service, Bitterroot National Forest, Montana Department of Fish, Wildlife, and Parks, and Biological Resources Division of the U.S. Geological Survey. Missoula, MT: Montana Cooperative Wildlife Research Unit and Wildlife Biology Program, University of Montana. 128 p.

*Maxell, B.A. 2004b. Amphibian and aquatic reptile inventories conducted on and around the Thompson River 2003-2004. Report to Region 1 Office of the U.S. Forest Service and Plum Creek Timber Company. Missoula, MT: Montana Cooperative Wildlife Research Unit and Wildlife Biology Program. 83 p.

*Maxell, B.A. 2004c. Preliminary report on amphibian and aquatic reptile inventories conducted in the West Boulder River area during summer 2003. Report to Region 1 Office of the U.S. Forest Service, and the Montana Department of Fish, Wildlife, and Parks. Missoula, MT: Montana Cooperative Wildlife Research Unit and Wildlife Biology Program, University of Montana. $27 \mathrm{p}$.

*Maxell, B.A. 2004d. Preliminary report on amphibian and aquatic reptile inventories conducted on and around the Ashland District of the Custer National Forest in 2002 and 2004. Report to Ashland District of Custer Forest, Region 1 Office of the U.S. Forest Service, and Montana Department of Fish, Wildlife, and Parks. Missoula, MT: Montana Cooperative Wildlife Research Unit and Wildlife Biology Program, University of Montana. $93 \mathrm{p}$.

*Maxell, B.A. 2004e. Report on amphibian and aquatic reptile inventories conducted on and around the Beaverhead-Deerlodge National Forest 2001-2003. Report to Region 1 Office of the U.S. Forest Service, Beaverhead-Deerlodge National Forest, Montana Department of Fish, Wildlife, and Parks, Montana State Office of the Bureau of Land Management, and Montana Department of Environmental Quality. Missoula, MT: Montana Cooperative Wildlife Research Unit and Wildlife Biology Program, University of Montana. 260 p.

*Maxell, B.A. 2005a. Amphibian and aquatic reptile inventories conducted on and around lands administered by the Missoula Field Office of the Bureau of Land Management. Report to Missoula Field Office of the Bureau of Land Management. Montana Natural Heritage Program, Helena, MT and Montana Cooperative Wildlife Research Unit and Wildlife Biology Program, University of Montana, Missoula, MT. 53 p.

*Maxell, B.A. 2005b. A review of monitoring methods and a multi-tiered scheme for assessing and monitoring the status of amphibians in Montana. Report to Montana Department of Environmental Quality, Region 1 Office of the U.S. Forest Service, Montana Department of Fish, Wildlife, and Parks, and Montana State Office of the Bureau of Land Management. Montana Natural Heritage Program, Helena, MT and Montana Cooperative Wildlife Research Unit and Wildlife Biology Program, University of Montana, Missoula, MT. 29 p. + Appendices.

*Maxell, B.A. and D.G. Hokit. 1999. Amphibians and reptiles. pp. 2.1-2.30. In: G. Joslin and H. Youmans, coordinators. Effects of recreation on Rocky Mountain wildlife: a review for Montana. Committee on Effects of Recreation on Wildlife, Montana Chapter of the Wildlife Society. 307 p.

*Maxell, B.A., J.K. Werner, P. Hendricks, and D. Flath. 2003. Herpetology in Montana: a history, status summary, checklists, dichotomous keys, accounts for native, potentially 
native, and exotic species, and indexed bibliography. Olympia, WA: Society for Northwestern Vertebrate Biology. Northwest Fauna 5: 1-138.

McAlister, W.H. 1962. Variation in Rana pipiens Schreber in Texas. American Midland Naturalist 67: 334-363.

*McEneaney, T. and J. Jensen. 1974. The reptiles and amphibians of the Charles M. Russell National Wildlife Range - 1974. Charles M. Russell National Wildlife Refuge. Lewistown, MT. 3 p.

McKinnell, R.G. 1980. Continued diminished prevalence of the Lucke renal andenccarcinoma in Minnesota leopard frogs. American Mindland Naturalist 104: 402-404.

McKinnell, R.G., D.M. Hoppe, and B.K. McKinnell. 2005. Monitoring pigment pattern morphs of northern leopard frogs. Pp. 328-337. In: Lannoo, M.J. (ed). Amphibian declines: the conservation status of United States species. University of California Press, Berkley, California.

McKinnell, R.G. and V.L. Ellis. 1972. Herpesviruses in tumors of postspawning Rana pipiens. Cancer Research, 32: 1154-1159.

Mecham, J.S. 1968a. Evidence of reproductive isolation between two populations of the frog, Rana pipiens, in Arizona. Southwestern Naturalist 13: 35-44.

Mecham, J.S. 1968b. Studies on evolutionary effects of isolation in the Rana pipiens complex. Yearbook of the American Philosophy Society 1968: 314-316.

Mecham, J.S. 1969. New information from experimental crosses on genetic relationships within the Rana pipiens species group. Journal of Experimental Zoology 170: 169-180.

Mecham, J.S. 1971. Vocalizations of the leopard frog, Rana pipiens, and three related Mexican species. Copeia 1971: 505-516.

Mecham, J.S., M.J. Littlejohn, R.S. Oldham, L.E. Brown, J.R. Brown. 1973. A new species of leopard frog (Rana pipiens complex) from the plains of the central United States.

Occassional Papers of Museum of Texas Technical University 18: 1-11.

Merrell, D.J. 1965. The distribution of the dominant burnsi gene in the leopard frog. Evolution 19: 69-85.

Merrell, D.J. 1968. A comparison of the estimated size and the "effective size" of breeding populations of the leopard frog (Rana pipiens). Evolution 22: 274-283.

Merrell, D.J. 1970. Migration and gene dispersal in Rana pipiens. American Zoologist 10: 4752.

Merrell, D.J. 1977. Life history of the leopard frog, Rana pipiens, in Minnesota. Bell Museum of Natural History Occasional Paper 15: 23 pp.

Merrell, D.J. and C.F. Rodell. 1968. Seasonal selection in the leopard frog. Evolution 22: 284288.

Meteyer, C.U., I.K. Loeffler, J.G. Burkhart, K.A. Converse, E. Green, J.C. Helgen, S. Kersten, R. Levey, L. Eaton-Poole, and J.F. Fallon. 2000. Hind limb malformations in free-living northern leopard frogs (Rana pipiens) from Maine, Minnesota, and Vermont suggest multiple etiologies. Teratology 60: 151-171.

Milius, S. 2000. New frog-killing disease may not be so new. Science News 157: 133.

*Miller, J.D. 1975. Interspecific food relationships of anurans in northwestern Montana and fluoride accumulation in amphibians and reptiles in northwestern Montana. M.S. Thesis. Missoula, MT: University of Montana. $105 \mathrm{p}$.

*Miller, J.D. 1978. Observations on the diets of Rana pretiosa, Rana pipiens, and Bufo boreas from western Montana. Northwest Science 52(3): 243-249. 
Moore, J.A. 1941. Developmental rates of hybrids between Rana pipiens and Rana sphenocephala. Proceedings of the Society of Experimental Biology Med., 47: 207-210.

Moore, J.A. 1942. Study of embryonic temperature tolerance and rate of development in Rana pipiens from different lattitudes. Yearbook of the American Philosophy Society, 1942: 175178.

Moore, J.A. 1944. Geographic variation in Rana pipiens Schreber of eastern North America. Bulletin of the American Museum of Natural History 82: 345-369.

Moore, J.A. 1946. Hybridization between Rana palustris and different geographical forms of Rana pipiens. Proceedings of the National Academy of Science USA 32: 209-212.

Moore, J.A. 1947. Hybridization between Rana pipiens from Vermont and eastern Mexico. Proceedings of the National Academy of Science USA 33: 72-75.

Moore, J.A. 1949. Geographic variation of adaptive characters in Rana pipiens Schreber. Evolution 3(1): 1-24.

Moore, J.A. 1950. Further studies on Rana pipiens racial hybrids. American Naturalist 84: 247254.

Moore, J.A. 1975. Rana pipiens - the changing paradigm. American Zoologist 15: 837-849.

Moore, J.E. and E.H. Strickland. 1954. Notes on the food of three species of Alberta amphibians. American Midland Naturalist 52: 221-224.

Morell, V. 1999. Are pathogens felling frogs? Science 284: 728-731.

*Mosimann, J.E. and G.B. Rabb. 1952. The herpetology of Tiber Reservoir area, Montana. Copeia 1952: 23-27.

Muths, E. 2003. A radio transmitter belt for small Ranid frogs. Herpetological Review 34(4):345-348.

Nash, R.F., G.G. Gallup, Jr. and M.K. McClure. 1970. The immobility reaction in leopard frogs (Rana pipiens) as a function of noise-induced fear. Psychonometric Science 21(3): 155-156.

Noble, G.K. and L.R. Aronson. 1942. The sexual behavior of Anura. 1. The normal mating pattern of Rana pipiens. Bulletin American Museum of Natural History 80: 127-142.

Noland, R. and G.R. Ultsch. 1981. The roles of temperature and dissolved oxygen in microhabitat selection by the tadpole of a frog (Rana pipiens) and a toad (Bufo terrestris). Copeia 1981: 645-652.

*Nussbaum, R., E. Brodie, Jr., and R. Storm. 1983. Amphibians and reptiles of the Pacific Northwest. University of Idaho Press, Moscow, Idaho. 322 p.

Oldham, R.S. 1974. Mate attraction by vocalization in members of the Rana pipiens complex. Copeia 1974(4): 982-984.

*[OEAR] Olson Elliot and Associates Research. 1985. 1983-1984 Wildlife monitoring report for the CX Ranch project. Olson Elliot and Associates Research. Helena, MT.

*Pace, A.E. 1974. Systematic and biological studies of the leopard frogs (Rana pipiens complex) of the United States. Miscellaneous Publications of the Museum of Zoology, University of Michigan 148: 1-140.

*Patla, D.A. and C.R. Peterson. 1998. Amphibians of the Greater Yellowstone Ecosystem. Natural Resource Conservation Cooperative News 11(Autumn 1998): 10-11.

*Patla, D.A. and C.R. Peterson. 2001. Status and trends of amphibian populations in the Greater Yellowstone Ecosystem, progress report, February 2001. Greater Yellowstone Ecosystem Amphibian Survey and Monitoring Program, Herpetology Laboratory, Department of Biological Sciences, Idaho State University, Pocatello, ID. 8 p. 
Platz, J.E. 1972. Sympatric interaction between two forms of leopard frogs (Rana pipiens complex) in Texas. Copeia 1972: 232-240.

Platz, J.E. 1976. Biochemical and morphological variation of leopard frogs in Arizona. Copeia 1976: 660-672.

Platz, J.E. and A.L. Platz. 1973. Rana pipiens complex: hemoglobin phenotypes of sympatric and allopatric populations in Arizona. Science 179: 1334-1336.

Pope, S.E., L. Fahrig, and H.G. Merriam. 2000. Landscape complementation and metapopulation effects on leopard frog populations. Ecology 81(9): 2498-2508.

Porter, W.P. and C.R. Tracy. 1974. Modeling the effects of temperature changes on the ecology of the garter snake and leopard frog. Pages 594-609. In: Gibbons, J.W. and R.R. Sharitz (eds.). Thermal ecology symposium: U.S. Atomic Energy Commission Conference 730505. Government Printing Office, Washington, D.C.

Post, D.D. 1972. Species differentiation in the Rana pipiens complex. Ph.D. dissertation, Colorado State University, Fort Collins, CO. 137 pp.

Post, D.D. and D. Pettus. 1966. Variation in Rana pipiens (Anura: Ranidae) of eastern Colorado. Southwestern Naturalist 11: 476-482.

Post, D.D. and D. Pettus. 1967. Sympatry of two members of the Rana pipiens complex in Colorado. Herpetologica 23: 323.

*[PRESI] Powder River Eagle Studies Incorporated. 1998a. Big Sky Mine 1997 wildlife monitoring studies. Powder River Eagle Studies Incorporated. Gillete, WY.

*[PRESI] Powder River Eagle Studies Incorporated. 1998b. Spring Creek Mine 1997 wildlife monitoring studies. Powder River Eagle Studies Incorporated. Gillete, WY.

*Powell, R., J.T. Collins, and E.D. Hooper, Jr. 1998. A key to amphibians and reptiles of the Continental United States and Canada. University Press of Kansas, Lawrence, KS. 131 p.

Pritchard-Lande, S. and S. I. Guttman. The effects of copper sulfate on the growth and mortality rate of Rana pipiens tadpoles. Herpetological 29(1): 22-27.

Quaye, M.O. 1973. The taxonomy of the lung-worm Rhabdias Stiles and Hassall, (Nematoda), parasitic in Bufo hemiophrys Cope and Rana pipiens Schreber, and the interspecific relationship of helminths in the lungs of these amphibians. M.S. Thesis, University of Manitoba. $93 \mathrm{p}$.

Rand, A.S. 1950. Leopard frogs in caves in winter. Copeia 1950(4): 324.

*Rauscher, R.L. 1998. Amphibian and reptile survey on selected Montana Bureau of Reclamation impoundments. Montana Department of Fish, Wildlife and Parks, Nongame Program, Bozeman, MT. 24 p.

*Reichel, J.D. 1995a. Preliminary amphibian and reptile survey of the Lewis and Clark National Forest: 1994. Montana Natural Heritage Program, Helena, MT. 92 p.

*Reichel, J.D. 1995b. Preliminary amphibian and reptile survey of the Sioux District of the Custer National Forest: 1994. Montana Natural Heritage Program, Helena, MT. 75 p.

*Reichel, J.D. 1996a. Status of amphibians and reptiles in Eastern Montana. Abstract. Intermountain Journal of Sciences 2(2): 57.

*Reichel, J.D. 1996b. Preliminary amphibian and reptile survey of the Helena National Forest: 1995. Montana Natural Heritage Program, Helena, MT. 87 p.

*Reichel, J.D. 1997. Amphibian, reptile and northern bog lemming survey on the Rocky Mountain Front: 1996. Montana Natural Heritage Program, Helena, MT. 81 p.

*Reichel, J.D. and D.L. Flath. 1995. Identification guide to the amphibians and reptiles of Montana. Montana Outdoors 26(3): 15-34. 
Richards, C.M. 1958. The inhibition of growth in crowded Rana pipiens tadpoles. Physiological Zoology 31: 138-151.

Rittschoff, D. 1975. Some aspects of the natural history and ecology of the leopard frog, Rana pipiens. Ph.D. Dissertation, University of Michigan. $212 \mathrm{p}$.

Roberts, W. 1987. The northern leopard frog - endangered in Alberta. Provincial Museum of Alberta Natural History Occassional Paper No. 9: 137-138.

Roberts, W.E. 1981. What happened to the leopard frogs? Alberta Naturalist 11: 1-4.

Roberts, W. 1987. The northern leopard frog - endangered in Alberta. Provincial Museum of Alberta Natural History Occassional Paper No. 9: 137-138.

Roberts, W.E. 1991. An action plan for the recovery of the northern leopard frog in Alberta. Pp. 199-200. In: G.L. Holroyd, G. Burns, and H.C. Smith (eds). Proceedings of the second Endangered Species and Prairie Conservation Workshop. Providencial Museum Alberta Natural History Occassional Papers No. 15, Edmonton, AB. 284 p.

Roberts, W.E. 1992. Declines in amphibian populations in Alberta. In: Declines in Canadian Amphibian Populations: Designing a National Monitoring Strategy, (Bishop, C.A. and K. E. Pettit, eds.), Occassional Paper 67, Canadian Wildlife Service.

*Roedel, M.D. and P. Hendricks. 1998a. Amphibian and reptile survey on the Bureau of Land Management Lewistown District: 1995-1998. Montana Natural Heritage Program, Helena, MT. $53 \mathrm{p}$.

*Roedel, M.D. and P. Hendricks. 1998b. Amphibian and reptile inventory on the Headwaters and Dillon Resource Areas in conjunction with Red Rocks Lakes National Wildlife Refuge: 1996-1998. Montana Natural Heritage Program, Helena, MT. 46 p.

Rosen, P.C., C.R. Schwalbe, D.A. Parizek, Jr., P.A. Holm, and C.H. Lowe. 1995. Introduced aquatic vertebrates in Chiricahua region: effects on declining native ranid frogs. U.S. Forest Service General Technical Report RM 264: 251-261.

Rosine, W.N. 1952. Notes on the occurrence of polydactylism in a second species of Amphibia in Muskee Lake, Colorado. Journal of the Colorado-Wyoming Academy of Science 4(4): 100.

Ross, D.A., D.W. Kuehn and M.C. Stanger. 1994. Rana pretiosa (spotted frog) reproduction. Herpetological Review 25(3): 118.

Ruibal, R. 1955. A study of altitudinal races in Rana pipiens. Evolution 9: 322-338.

Ruibal, R. 1959. The ecology of a brackish water population of Rana pipiens. Copeia 1959(4): 315-322.

Ruibal, R. 1962. The ecology and genetics of a desert population of Rana pipiens. Copeia 1962: 189-195.

Russell, A.P., and A.M. Bauer. 2000. The amphibians and reptiles of Alberta. Second Edition. Calgary, AB: University of Calgary Press. 279 p.

*Ryan, S.A. 1980. Frog study of the Kicking Horse Reservoir on the Flathead Indian Reservation. Confederated Salish and Kootenai Tribal Wildlife Division, Pablo, MT. 3 p.

Sage, R.D. and R.K. Selander. 1979. Hybridization between species of the Rana pipiens complex in central Texas. Evolution 33: 1069-1088.

Salthe, S.N. 1969. Geographic variation of the lactate dehydrogenases of Rana pipiens and Rana palustris. Biochemistry and Genetics 2: 271-303.

Sanders, O. 1973. A new leopard frog (Rana berlandieri brownorum) from southern Mexico. Journal of Herpetology 7(2): 87-92. 
Schlichter, L.C. 1981. Low $\mathrm{pH}$ affects the fertilization and development of Rana pipiens eggs. Canadian Journal of Zoology 59: 1963-1969.

Schmidt, R.S. 1968. Chuckle calls of the leopard frog (Rana pipiens). Copeia 1968(3): 561569.

Schoonover, L.J., and W.H. Marshall. 1951. Food habits of the raccoon (Procyon lotor hirtus) in north-central Minnesota. Journal of Mammalogy 32: 422-428.

Schotthoefer, A. M., A.V. Koehler, C.U. Meteyer, and R.A. Cole. 2003. Influence of Ribeiroia ondatrae (Trematoda: Digenea) infection on limb development and survival of northern leopard frogs (Rana pipiens): effects of hoststage and parasite-exposure level. Canadian Journal of Zoology 81(7): 1144-1153.

Schreber, H. 1782. Beitrag zur Naturegeschichte der Frosche. Der Naturforscher 18: 182-193.

Schueler, F.W. 1979. Geographic variation in skin pigmentation and dermal glands in the Northern leopard frog, Rana pipiens. Ph.D. Thesis, University of Toronto.

Schueler, F.W. 1982. Geographic variation in skin pigmentation and dermal glands in the northern leopard frog, Rana pipiens. National Museum of Canada Publication in Zoology 16: $80 \mathrm{p}$.

Scott, N.J., Jr. and R.D. Jennings. 1985. The tadpoles of five species of New Mexican leopard frogs. Occassional Paper of the Museum of Southwestern Biology 3: 1-21.

*Scow, K.L. 1980. Terrestrial wildlife survey American Colloid study area Phillips County, Montana. Western Technology and Engineering, Inc., Helena, MT.

Seburn, C.N.L. 1992a. Leopard frog project-field report 1991. Unpubl. Rept. For World Wildlife Fund Canada (Prairie for Tomorrow) and Alberta Forestry, Lands and Wildlife, Edmonton, AB. 59+ pp.

Seburn, C.N.L. 1992b. Management plan for the northern leopard forg in Alberta. Unpubl. Rept., Alberta Forestry, Lands, and Wildlife, Edmonton, AB. 52 pp.

Seburn, C.N.L. 1993. Leopard frog project- progress report 1992. Unpubl. Report for Alberta Forestry, Lands and Wildlife, Edmonton, AB. 32 pp.

Seburn, C.N.L. 1994. Leopard frog project- progress report 1993. Unpubl. Report for Alberta Forestry, Lands and Wildlife, Edmonton, AB. 15 pp.

Seburn, C.N.L. and D.C. Seburn. 1996. Status report on western populations of the northern leopard frog (Rana pipiens) in Canada. Prepared for the Committee on the Status of Endangered Wildlife in Canada, Ottawa, ON.

Seburn, C.N.L., D.C. Seburn, and C.A Paszkowski. 1997. Northern leopard frog (Rana pipiens) dispersal in relation to habitat. In: D.M. Green (ed.) Amphibians in decline: Canadian studies of a global problem. Society for the Study of Amphibians and Reptiles, Herpetological Conservation 1: 64-72.

Seburn, D.C. 1994. Public sightings of northern leopard frogs. Alberta Naturalist 24: 3-4.

Shinn, E.A. and J.W. Dole. 1978. Evidence for a role for olfactory cues in the feeding response of leopard frogs (Rana pipiens). Herpetologica 34(2): 167-172.

Shivers, C.A. and J.M. James. 1970. Morphology and histochemistry of the oviduct and eggjelly layers in the frog, Rana pipiens. Anatomical Record 166: 541-556.

Shumway, W. 1940. Stages in the development of Rana pipiens. I. External form, Anatomical Record 78: 138-148.

Simmons, H.M. 2001. Habitat use and movement of Northern Leopard frogs (Rana pipiens) in Potholes Reservoir, Grant County, Washington. Northwestern Naturalist 82(2):81. 
Simon, M.P., I. Vatnick., H.A. Hopey, K. Butler, C. Korver, C. Hilton, R. S. Weimann, and M.A. Brodkin. 2002. Effects of acid exposure on natural resistance and mortality of adult Rana pipiens. Journal of Herpetology 36: 697-699.

Sredl, M.J. and D.L. Waters. 1995. Status of (most of the) leopard frogs in Arizonia. Declining Amphibian Populations Task Force- Southwestern United States Working Group. Abstracts from January 5 \& 6, 1995 Annual Meeting, Phoenix, AZ.

*Stebbins, R.C. 2003. A field guide to western reptiles and amphibians. 3rd edition. New York, NY: Houghton Mifflin Co. 533 p.

*Stebbins, R.C. and N.W. Cohen. 1995. A natural history of amphibians. Princeton University Press. Princeton, NJ. 316 pp.

Sternthal, D.E. 1974. Olfactory and visual cues in the feeding behavior of the leopard frog (Rana pipiens). Zeitschrift fur Tierpsychologie 34: 239-246.

Stewart, R.E., S.A. Reese, and G.R. Ultsch. 2004. The physiology of hibernation in Canadian leopard frog (Rana pipiens) and bullfrogs (Rana catesbeiana). Physiological and Biochemical Zoology 77(1):65-73.

Stopper, G.F., L. Hecker, R.A. Franssen, and S.K. Sessions. 2002. How trematodes cause limb deformities in amphibians. Journal of Experimental Zoology 294:252-263.

Taylor, A.C. and J.J. Kollross. 1946. Stages in the development of Rana pipiens larvae. Anatomical Record 94: 7-23.

*Test, F.C. 1893. Annotated list of reptiles and batrachians collected. In B.W. Evermann. A reconnaisance of the streams and lakes of western Montana and northwestern Wyoming. Bulletin of United States Fish Commission 11(1891): 57-59.

*Thompson, L.S. 1984. Biogeography of Montana: preliminary observations on major faunal and floristic distribution patterns. Abstract. Proceedings of the Montana Academy of Sciences 43: 40-41.

*Thompson, L.S. and P.S. Nichols. 1982. Circle West wildlife monitoring study; fourth annual report for period March 1, 1981 - May 31, 1982. Circle West Technical Report No. 10. Montana Department of Natural Resources and Conservation, Helena, MT.

*Timken, R. No Date. Amphibians and reptiles of the Beaverhead National Forest. Western Montana College, Dillon, MT. 16 p.

*Turner, F.B. 1951. A checklist of the reptiles and amphibians of Yellowstone National Park with incidental notes. Yellowstone Nature Notes 25(3): 25-29.

*Turner, F.B. 1955. Reptiles and amphibians of Yellowstone National Park. Yellowstone Interpretive Series No. 5. Yellowstone Library and Museum Association. Yellowstone National Park, WY. 40 p.

Ultsch, G.R., S.A. Reese, and E.R. Stewart. 2004. Physiology of hibernation in Rana pipiens: metabolic rate, critical oxygen tension, and the effects of hypoxia on several plasma variables. Journal of Experimental Zoology 301A(2):169-176.

Ultsch, G.R., T.E. Graham, and C.E. Crocker. 2000. An aggregation of overwintering leopard frog (Rana pipiens) and common map Turtles (Graptemys geographica) in northern Vermont. Canadian Field Naturalist 114(2): 314-315.

*Van Denburgh, J. 1895. Annotated list of reptiles and batrachians. In C.H. Gilbert and B.W. Evermann. A report upon investigations in the Columbia River Basin, with descriptions of four new species of fishes. Bulletin of United States Fish Commission 14(1894): 206-207. 
*Van Kirk, R., L. Benjamin, and D. Patla. 2000. Riparian area assessment and amphibian status in the watersheds of the Greater Yellowstone Ecosystem. Greater Yellowstone Coalition, Bozeman, MT. $102 \mathrm{p}$.

Vatnick, M.A. Brodkin, M.P. Simon, B.W. Grant, C.R. Conte, M. Gleave, R. Myers, and M.M. Sadoff. 1999. The effects of exposure to mild acidic conditions on adult frogs (Rana pipiens and Rana clamitans): mortality rates and $\mathrm{pH}$ preferences. Journal of Herpetology 33(3): 370374.

*Vitt, L.J., J.P. Caldwell, and D.B. Shepard. 2005. Inventory of amphibians and reptiles in the Billings Field Office Region, Montana. Sam Noble Oklahoma Museum of Natural History and Department of Zoology, University of Oklahoma, Norman, OK. 33 pp.

Volpe, E.P. 1954. Hybrid viability between Rana pipiens from Wisconsin and Mexico. Tulane Studies in Zoology 1:111-123.

*[VTNWI] VTN Wyoming Incorporated. Second year's analysis of terrestrial wildlife on proposed mine access and railroad routes in southern Montana and northern Wyoming, March 1979 - February 1980. VTN Wyoming Incorporated. Sheridan, WY. 62 p.

*Waage, B.C. 1998. Western Energy Company Rosebud Mine 1997 annual wildlife monitoring report December 1, 1996 to November 30, 1997 survey period. Western Energy Company, Colstrip, MT.

Wagner, G. 1997. Status of the Northern Leopard Frog (Rana pipiens) in Alberta. Alberta Wildlife Status Report No. 9. 34 p.

Waitz, J.A. 1959. Parasites infesting R. luteiventris and R. pipiens. M.S. Thesis. University of Idaho.

Wassersug, R.J. 1976a. The identification of leopard frog tadpoles. Copeia 1976: 413-414.

Waye, H.L. 2001. Teflon tubing as radio transmitter belt material for northern leopard frogs (Rana pipiens). Herpetological Review 32(2): 88-89.

Weed, A.C. 1922. New frogs from Minnesota. Proceedings of the Biological Society of Washington 35: 107-110.

Weick, S.E., M.G. Knutson, B.C. Knights, and B.C. Pember. 2005. A comparison of internal and external radio transmitters with northerm leopard frogs (Rana pipiens). Herpetological Review 36(4):415-421.

Weis, J.S. 1975. The effect of DDT on tail regeneration in Rana pipiens and R. catesbeiana tadpoles. Copeia 1975: 765-767.

*Weisel, G.F. 1952. Animal names, anatomical terms, and some ethnozoology of the Flathead Indians. Journal of the Washington Academy of Sciences 42(11): 345-355.

Werner, E.E. 1992. Competitive interactions between wood frog and northern leopard frog larvae: the influence of size and activity. Copeia 1992: 26-35.

*Werner, J.K. 2003. Status of the Northern Leopard Frog (Rana pipiens) in western Montana. Northwestern Naturalist 84:24-30.

*Werner, J.K., B.A. Maxell, P. Hendricks, and D. Flath. 2004. Amphibians and reptiles of Montana. Missoula, MT: Mountain Press Publishing Company. 262p.

*Werner, J.K. and J.D. Reichel. 1994. Amphibian and reptile survey of the Kootenai National Forest: 1994. Montana Natural Heritage Program, Helena, MT. 104 p.

*Werner, J.K. and J.D. Reichel. 1996. Amphibian and reptile monitoring/survey of the Kootenai National Forest: 1995. Montana Natural Heritage Program, Helena, MT. 115 p.

*Werner, J.K. and T. Plummer. 1994. Amphibian and reptile survey of the Flathead Indian Reservation 1993-1994. Salish Kootenai College, Pablo, MT. 55 p. 
*Werner, J.K. and T. Plummer. 1995. Amphibian monitoring program on the Flathead Indian Reservation 1995. Salish Kootenai College, Pablo, MT. 46 p.

*Werner, J.K., T. Plummer, and J. Weaselhead. 1998a. Amphibians and reptiles of the Flathead Indian Reservation. Intermountain Journal of Sciences 4(1-2): 33-49.

*Werner, J.K., T. Plummer, and J. Weaselhead. 1998b. The status of amphibians on the Flathead Reservation, Montana. Intermountain Journal of Sciences 4(3-4): 88.

*Wershler, C.R. 1992. Northern leopard frog monitoring-1991. Report By Sweetgrass Consultants Ltd. For WWF Canada (Prairie for Tomorrow) and Alberta Forestry, Lands and Wildlife, Edmonton, AB. 10+ pp.

*[WESCO] Western Ecological Services Company. 1983a. Wildlife inventory of the Knowlton known recoverable coal resource area, Montana. Western Ecological Services Company, Novato, CA. 107 p.

*[WESCO] Western Ecological Services Company. 1983b. Wildlife inventory of the Southwest Circle known recoverable coal resource area, Montana. Western Ecological Services Company, Novato, CA. $131 \mathrm{p}$.

*[WESTECH] Western Technology and Engineering Incorporated. 1991. Update on the wildlife resources of the Little Rocky Mountains environmental study area. Western Technology and Engineering, Inc., Helena, MT.

*[WESTECH] Western Technology and Engineering Incorporated. 1998. Wildlife monitoring Absaloka Mine area 1997. Western Technology and Engineering, Inc., Helena, MT.

Whitaker, J.A., Jr. 1961. Habitat and food of mouse-trapped young Rana pipiens and Rana clamitans. Herpetologica 17(3): 173-279.

*Wied, M.P. 1843. Travels in the interior of North America by Maximilian, Prince of Wied. With numerous engravings on wood, and a large map. Translated from the German by $\mathrm{H}$. Evans Lloyd. To accompany the original series of eighty-one elaborately-coloured plates. Size, imperial folio. Ackerman and Co., London, England. 520 p.

*Wied, M.P. 1865. Verzeichniss der reptilien, welche auf einer reise in nordlichen America beobachtet wurden, von Maximilian, Prinzen zu Wied. Eigengangen bei der Akademie am 1, Juni 1865. Druck von E. Blochmann und Sohn, Dresden, Germany. 141 p.

Wolff, J.B., M.J. Lee, and C.W. Anderson. 2004. Contribution of the submentalis muscle to feeding mechanics in the leopard frog, Rana pipiens. Journal of Experimental Zoology 301A(8):666-673.

*[WWPC] Washington Water Power Company. 1995. 1994 wildlife report Noxon Rapids and Cabinet Gorge Reservoirs. Washington Water Power Company. Spokane, WA. Yaremko, L. 1994. Northern leopard frog project- field report 1994. Report for Fish and Wildlife Services, Edmonton, AB. 85p.

*Yarrow, H.C. 1882. Check list of North American reptilia and batrachia, with catalogue of specimens in the U.S. National Museum. United States National Museum Bulletin 24. 249 p. Zenisek, C.J. 1963. A study of the natural history and ecology of the leopard frog, Rana pipiens (Schreber). Ph.D. dissertation, Ohio State University, Columbus, Ohio. 153 pp. 


\section{Snapping Turtle (Chelydra serpentina)}

Up-to-date distribution and status information can be found on the Montana Natural Heritage Program’s TRACKER website at http://mtnhp.org

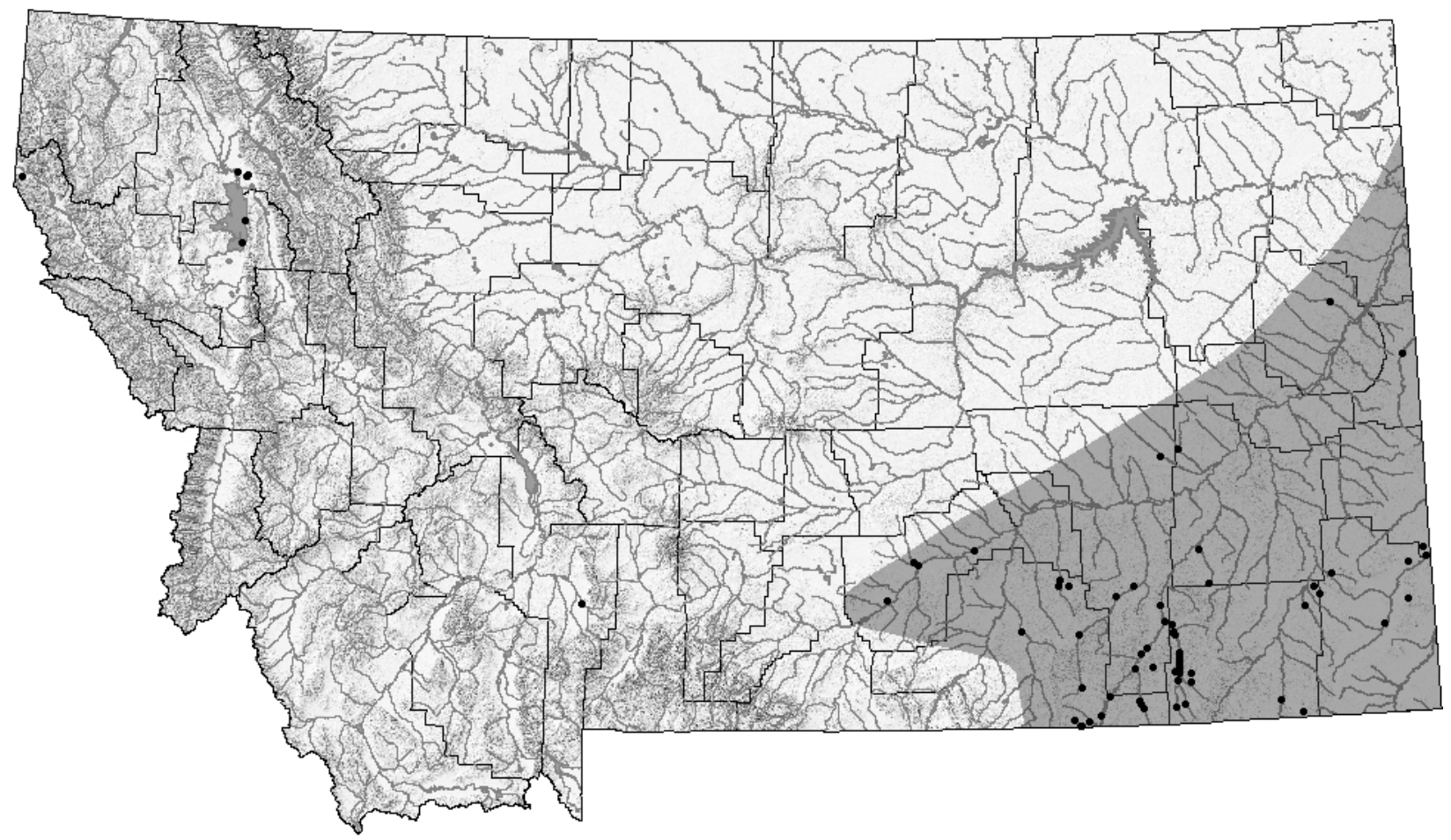

* Point observations outside of shaded native range are introduced animals/populations.

Distribution/Taxonomy

The Snapping Turtle (Chelydra serpentina) ranges along the Pacific Coast from Nova Scotia to Florida, and westerly to the Rocky Mountain front, from southeastern Manitoba to Texas and Mexico (Ernst et al. 1994). Two subspecies are recognized; the Florida Snapping Turtle (C. serpentina osceola) and the subspecies inhabiting Montana, the Eastern Snapping Turtle (C. serpentina serpentina) (Crother et al. 2008). In Montana, native populations are found from Carter County, east to Carbon and Stillwater counties, and northeasterly to McCone County. Most records are from the southeastern portion of the state in the Yellowstone River system and tributaries, especially along the Tongue River drainage. Currently, there are no confirmed Montana records from the Missouri River or its tributaries. Introduced populations exist in Flathead, Lake, Sanders, and Gallatin Counties (Maxell et al. 2003, MTNHP 2006).

Maximum Elevation

1,158 m (3,800 ft) in Big Horn County (Maxell et al. 2003).

$\underline{\text { Identification }}$

Juveniles and Adults:

Snapping Turtles are large, stout turtles with an adult carapace length (CL) typically $20-35 \mathrm{~cm}$ (8-14 inches), but grow larger in populations of the southern United States (Degenhardt et al. 1996). Adults usually weigh 4.5-16 kilograms (10-35 lbs). However, one Montana individual found in the Redwater River reached 32 pounds (Aderhold 1980) and another Montana specimen reportedly reached 48 pounds (Werner et al. 2004). Snapping Turtles have a long tail about the 
length of the carapace (dorsal shell), with three rows of distinct sawtooth-shaped projections. The plastron (ventral shell) is brown with three keels that are more easily discerned in younger individuals. In older individuals, a good portion of the carapace is usually covered with algae. The cream-yellow plastron is greatly reduced compared to other turtles, and forms a cross-like shape. It has a large head with slightly hooked upper jaw. They have long necks with tubercles on the dorsal surface. They have webbed toes and powerful claws. The anal vent of the male usually extends past the posterior edge of the carapace, whereas it is found anterior to the rim in females. Males will usually grow larger than females (Hammerson 1999).

Hatchlings:

Hatchings are dark brown to black with conspicuous ridges on their carapace. The carapace measure 2.5-3.8 cm (1-1.5 inches) in length (Ernst et al. 1994, Werner et al. 2004).

Eggs:

Chelydra serpentina eggs white and round with and somewhat pliable. They range from 23-33 $\mathrm{mm}$ in length, averaging $27-28 \mathrm{~mm}$.

Similar Species:

The Snapping Turtle is the only Montana turtle with a reduced plastron covering less than half of the ventral surface, keeled scutes on the carapace, and a tail approximately as long as the carapce. There is no bright orange or yellow coloration as found on the painted turtle, and their carapace is hard, unlike the soft, leathery shell of the Spiny Softshell (Black 1970, 1971, Werner et al. 2004).

Habitat Use/Natural History

Habitat use by Snapping Turtles in Montana is probably similar to elsewhere in their range, but local studies are lacking and there is little qualitative information available. They have been captured or observed in backwaters along major rivers, at smaller reservoirs, and in smaller streams and creeks with permanent flowing water and sandy or muddy bottoms (Reichel 1995, Hendricks and Reichel 1996, Gates 2005, Paul Hendricks, pers. obs.). They have also been observed in temporary pools along small intermittent streams near Decker, Montana (M. Gates, pers. obs.). Freshwater habitats with a soft mud bottom and with cover such as abundant aquatic vegetation or submerged brush and logs are preferred (Hammerson 1999). Although found most often in shallower water, an Ontario individual was observed by R. J. Brooks regularly diving 10 meters to the bottom of a lake (Ernst et al. 1994. Temporary ponds and reserviors may also be occupied. Hatchlings and juveniles tend to occupy shallower sites than mature individuals in the same water bodies. They are mostly bottom dwellers, where they spend much of their time. Although highly aquatic, they may make long movements overland if their pond or marsh dries (Baxter and Stone 1985, Ernest et al. 1994, Hammerson 1999). Snapping Turtles have a high water loss gradient (0.64 grams/hour), and therefore are at risk out of water in warm or dry conditions and they rarely bask out of water. Aerial basking is more common in cooler environments in the northern portions of their range (Ernst et al. 1994) and has been observed on the Tongue River of southeastern Montana (Matt Gates, pers. obs.). 
No specific migratory information for Montana is currently available. Research from other locations indicates that the Snapping Turtle may migrate up to several miles between the water bodies and nesting areas. Evidence suggests that adults may use the sun as a navigational guide during overland migrations (Ernst et al. 1994). Some may travel a few kilometers between summer range and winter hibernation sites, while others overwinter within their summer range (Brown and Brooks 1994). In Ontario, the distances traveled to nesting sites ranged from 370 to 2020 meters (mean 1053 meters), and movements were greatest from spring to mid-July (Pettit et al. 1995). Distances traveled by C. serpentina in South Dakata ranged from 0 to 6.05 kilometers, but averaged just $1.1 \mathrm{~km}$ (Hammer 1969).

In Iowa males can reach sexual maturity by their fifth year and females as early as their seventh year (Christiansen and Burken 1979). However, in some populations maturity is not reached before 15 years. The youngest mature female known from Michigan was 12 years. In Ontario the average age of first nesting ranged from 17-19 years. Virtually no reproductive data exists specific to Montana. However, Montana populations likely exhibit traits similar to those elsewhere. Warming temperatures trigger nesting behavior in females. Obbard and Brooks (1987) developed a model to predict the onset of nesting activity from temperature data in Ontario. Females may travel several kilometers to locate a suitable nest site. Obbard and Brooks (1980) reported a round trip distance of $16 \mathrm{~km}$ to a nest site and back (Ernst et al. 1994). Nests are usually built in open areas a hundred meters or more from water; excavated in soft sand, loam, vegetation debris, sawdust piles, and beaver and muskrat lodges. Females generally dig nests from 7-18 cm (Congdon et al. 1987, Ernst et al. 1994, Hammerson 1999). In northern regions, eggs are generally deposited in late May to early June. Recorded clutch sizes range from 6 to 104, but typically 20-40 eggs are laid. Clutch size tends to increase from southerly to northerly latitudes Eggs incubate for 55-125 days (usually75-95) before hatching, with incubation period increasing with latitude. The sex of each hatchling is determined by each egg's temperature during a critical developmental period ("temperature dependent sex determination). Relatively cooler temperatures produce females and warmer temperatures produce males. The sex ratio of hatchlings is commonly 1:1 (Ernst et al. 1994). Nest site selection is critical for survival of hatchlings. Eggs burried in moister substrate generally support better embryonic development and larger hatchlings, whereas eggs in drier environments (Morris et al. 1983). The incubation environment of eggs can later effect growth and viability of young Snapping Turtles (McKnight and Gutzke (1993). Bobyn and Brooks (1994) suggest incubation temperature and moisture limit the northern distribution of C. serpentina.

Snapping turtle diets have not been studied in Montana, but they are known to eat about anything that can be captured while foraging in the water. They eat many kinds of vertebrates (fish, amphibians, reptiles, aquatic birds, small mammals), invertebrates (insects, spiders, crustaceans, mollusks, leeches, sponges), various plants and algae, and carrion (Pell 1940, Ernst et al. 1994). Diet appears to be dependent on availablity. In New York and Massachusetts, specimens collected from marshy lackes consumed 90\% plant material, but individuals from small streams consumed 100\% crayfish (Pell 1940). Young Snapping Turtles often search actively for food, but adults generally lie in ambush to seize their prey (Ernst et al. 1994). This species is known to eat nine orders of insects (ants, beetles, and moths the most abundant), and spiders, scorpions, ticks, and mites have been reported in the diet (Hammerson 1999). 
Snapping Turtles frequently incur high rates of nest predation by various animals, particularly skunks, raccoons, foxes, bears, crows, and snakes (Congdon et al. 1987, Ernst et al. 1994, Hammerson 1999). In Michigan, eggs and young typically incur 60-100\% predation, primarily by raccons (Harding 1997). Temple (1987) suggest that next predation increases near habitat edges. Racoons, coyotes, river otters, bears, and often humans prey on adults; herons, bitterns, hawks, eagles, various predatory fish, and bullfrogs prey on hatchlings and juveniles (Ernst et al. 1994). Compared with other species C. serpentina, uses very aggressive display postures to thwart potential predators, such as facing its attacker and lifting its legs in various positons while gaping its mouth. (Dodd et al. 1975). Snapping Turtles are often parasitized by leaches (Placobdella spp.) and a protozoan blood parasite (Haemogregarina balli). An Ontario individual reportedly had 768 leaches attached (Brooks et al. 1990). Despite high rates of investation, Brown and Brooks (1994) found that these parasites do not negatively affect reproductive output. Humans are the only recorded predators in Montana (Paul Hendricks, pers. obs.).

Snapping Turtles are known to hibernate independently or in groups. They overwinter in lakes, ponds, streams, or marshes; in bottom mud, in or under submerged logs or debris, under overhanging banks, in muskrat tunnels, or in the saturated soil of pastures (Meeks and Ultsch 1990). They sometimes overwinter in shallow, anoxic water but survivorship is higher in normoxic condition. Underwater winter movements are not uncommon. In Ontario, $C$. serpentina emerged from winter dormancy when water reached about 7.5 degrees Celsuis (Obbard and Brooks 1981a, Meeks 1990, Brown and Brooks 1994).

Populations of Snapping Turtles greatly vary regionally, locally, and temporally (Froese and Burghardt 1975); therefore, population data from other states cannot be extrapolated to Montana with any accuracy. In Ontario, males occupied relatively stable, overlapping home ranges; summer ranges were 0.4 to 2.3 hectares (Galbraith et al. 1987). Also in Ontario, July to August foraging home ranges in three sites during one year were 2.3 to 18.1 hectares (means fell between 5 and 9 hectares); home range length was about 550 to 1990 meters; home range size did not vary with habitat productivity (Brown et al. 1994). In another Ontario study, home range size over a year was 1.0 to 28.4 hectares, averaging about 9 hectares for females and about 2 to 3 hectares for males (Pettit et al. 1995). Densities in marshes of South Dakota reached one per 2 acres (Hammer 1969).

Egg survival is usually low, not more than 0.22 , and adult survival generally high, over 0.90 . A population in Ontario, Canada, was characterized as stable, with adult female annual survivorship greater than 0.95; later, a great increase in adult mortality occurred, apparently due primarily to otter predation on hibernating turtles; there was no compensatory density-dependent response in reproduction and recruitment (Brooks et al. 1991, Iverson 1991) In Michigan, actual annual survivorship of juveniles was over 0.65 by age 2 and averaged 0.77 between ages 2 and 12 years; annual survivorship of adult females ranged from 0.88 to 0.97 . Population stability was most sensitive to changes in adult or juvenile survival and less sensitive to changes in age at sexual maturity, nest survival, or fecundity (Congdon et al. 1994). In South Dakata Hammer (1969) reported that predators destroyed 59\% of nests, and that emergence in undisturbed nests was less than 20\% (Hammer 1969). Snapping Turtles may be limited in range in the north by overwintering mortality (Obbard 1981). Snapping Turtles are relatively long-lived. In an 
Ontario population, females have an average lifespan of 40 years (Galbraith and Brooks 1989), and average lifespan of a South Carolina population was 28 years (Ernst et al 1994). The record for a captive individual is 47 years (Werner et al. 2004).

\section{$\underline{\text { Status and Conservation }}$}

Although this species is common in many parts of its range, it is rare in Montana, having been recorded in only a few watersheds of southeastern Montana. Due to this restricted range and the lack of information this species in Montana, it is considered a state species of concern, and is listed as sensitive by the Bureau of Land Management. Studies identifying or addressing specific risk factors for $C$. serpentina in Montana are lacking. However, documented studies and other issues pertaining to their conservation include the following: (1) Roads often have negative impacts on population size and distribution of reptiles, and particularly turtles. High road density has been positively correlated to low population size. This has lead to absence of species in road-developed areas and lead to local extirpations. (Rudolph et al. 1998, Jochimsen et al. 2004). C. serpentina females often migrate over a kilometer to reach suitable nesting sites (Obbard and Brooks 1981a), which makes them particularly vulnerable to road kill. During a three year study in Ontario, Haxton (2000) noted that 30.5\% of all turtles observed were killed on roads. (2) Snapping turtles, particularly in northern populations take over 15 years to attain sexual maturity, have extended reproductive lifespans, high natural adult survival rates, and extended longevity. Egg and hatchling mortality is also often very high attributing to a low annual reproductive potential. These are life history traits are typical of long-lived species vulnerable to adult mortality. Minimum levels of natural (e.g. winter kill) or human-caused mortality to mature adults can have serious negative impacts to populations. Due to this low reproductive potential, seriously diminished populations can take years to recover (Brooks et al. 1988, Brooks et al. 1991, Congdon et al. 1994, Congdon et al. 1995). (3) Snapping Turtles are a long-lived bottom dwellers that can store environmental contaminants their body fat, muscle tissue, liver, and eggs making them particularly susceptible to bioaccumulation. They often carry high concentrations of organochlorine contaminants such as polychlorinated biphenyls (PCBs) (Brooks et al. 1988, Harding 1997). (4) Popular for meat and soup dishes, C. serpentina are managed as game animals in many states. Due to their low reproductive potential, overharvesting can decimate local populations, which can take years to recover (Brooks et al. 1988). Harvesting of adults is more detrimental to long-term population viability than high levels of egg and hatchling mortality, which normally occur. Human harvesting of $C$. serpentina in Montana is not well documented, but may occur where they are abundant. (5) Dams and large reservoirs on rivers (e.g. Fort Peck Dam and Reservoir) may inhibit population continuity to some degree, judging by the apparent lack of viable populations on the Missouri River in Montana (Maxell et al. 2003). However, there is no quantitative data to verify this. Snapping Turtles will travel large distances overland and therefore may be able to bypass some dams.

\section{Research and Management Suggestions}

1. More thorough documentation of $C$. serpentina presence across its historic range in Montana is needed, especially in areas of residential and industrial development.

2. Annual monitoring of known populations to assess changes and identify threats should be undertaken.

3. Introduced populations should be eliminated as quickly as possible to prevent proliferation and avoid negative effects on native species. Control measures should be conducted year 
round with emphasis on the mating and nesting period (May-June) because they are more easily spotted and captured during this period. Aquatic hoop traps baited with malodorous meats are likely to have the greatest chance of capture.

4. Studies of population dynamics in relation to roads and highways are needed to identify any negative impacts and develop effective measures to reduce them. For example, areas with significantly high road mortality should be identified so that innovative structures, such as wall-and-culvert arrays ("critter culverts”), can be installed to allow the safe passage beneath roads.

5. Baseline and monitoring studies should be undertaken to investigate potential impacts of oil and gas development on $C$. serpentina habitat and populations. Emphasis should be placed on water quality of inhabited streams and ponds in the area of recent coal-bed-methane development near known populations in southeastern Montana.

6. Due to a substantial lack of data in Montana, the public and scientific community should be encouraged to report findings or undertake studies of population demography and ecology, dispersal, nesting success, and other life history characteristics. Fisherman should be encouraged to report incidences of unintentional catches. Routine surveys for Snapping Turtles in appropriate habitats could be made a standard part of the field duties of fisheries biologists. Management personnel should collect dead individuals to collect data on size, sex, and food consumption.

7. Well-used nesting sites, or high-quality potential nesting areas, should be identified, protected, and monitored.

8. The occurrence and degree of unregulated harvesting for food should be examined and considered in management decisions.

Bibliography *indicates an article with information specific to Montana

Abel, B. 1992. Snapping turtle attacks on trumpeter swan cygnets in Wisconsin. Passenger Pigeon 54(3): 209-213.

*Aderhold, M. 1980. The 32-pound snapper of Redwater River. Montana Outdoors 11(4): 9-10. Albers, P.H., L. Sileo, and B.M. Mulhem. 1986. Effects of environmental contaminants on snapping turtles of a tidal wetland. Archives of Environmental Contamination and Toxicology 15(1): 39-49.

Anderson, J.T. and A.M. Anderson. 1996. Chelydra serpentina serpentina (common snapping turtle). Herpetological Review 27(3): 150.

Applegate, R.D., R.C. Spencer, and F.M. Trasko. 1995. Extensions to the known range for three Maine reptiles. Canadian Field Naturalist 109(4): 444-446.

Asch, R.P. 1951. A preliminary report on the size, egg number, incubation period, and hatching in the common snapping turtle, Chelydra serpentina. Virginia Academy of Science 29: 312.

Ashley, E.P. and J.T. Robinson. 1996. Road mortality of amphibians, reptiles and other wildlife on the Long Point causeway, Lake Erie, Ontario. Canadian Field Naturalist 110: 403-412.

*Atkinson, E.C. and M.L. Atkinson. 2004. Amphibian and reptile survey of the Ashland and Sioux of the Custer National Forest with special emphasis on the Three-Mile Stewardship Area:2002. Marmot's Edge Conservation. 22 p.

Avery, H.W. and L.J. Vitt. 1984. How to get blood from a turtle. Copeia 1984: 209-210. Baker, M.R. 1986. Falcaustra sp. (Nematoda: Kathlaniidae) parasitic in turtles and frogs in Ontario (Canada). Canadian Journal of Zoology 64(1): 228-237. 
Baldwin, F.M. 1925b. The relation of body to environmental temperature in turtles, Chrysemys marginata belli (Gray) and Chelydra serpentina (Linn.). Biology Bulletin 48: 432-445.

*Baxter, G.T. and M.D. Stone. 1985. Amphibians and reptiles of Wyoming. Second edition. Wyoming Game and Fish Department, Cheyenne.

Bickham, J.W. and J.L. Carr. 1983. Taxonomy and phylogeny of the higher categories of cruptodiran turtles based on a cladistic analysis of chromosomal data. Copeia 1983:918-932.

Bishop, C.A., R.J. Brooks, J.H. Carey, P. Ng, R.J. Norstrom, and D.R.S. Lean. 1991. The case for a cause-effect linkage between environmental contamination and development in eggs of the common snapping turtle (Chelydra serpentina serpentina) from Ontario, Canada. Journal of Toxicology and Environmental Health 33(4): 521-548.

*Black, J. H. 1970. Turtles of Montana. Animals of Montana Series, No. 2, Montana Wildlife 1970 (Fall):26-31.

*Black, J.H. and J.N. Black. 1971. Montana and its turtles. International Turtle and Tortoise Society 1971(May-July): 10-11, 34-35.

Bleakney, S. 1957. A snapping turtle, Chelydra serpentina serpentina, containing eighty-three eggs. Copeia 1957: 143.

*BLM. 1982b. Moorhead baseline inventory - wildlife. Bureau of Land Management, Miles City District Office. Miles City, MT. 29 p.

Bobyn, M.L. and R.J. Brooks. 1994a. Incubation conditions as potential factors limiting the northern distribution of snapping turtles, Chelydra serpentina. Canadian Journal of Zoology 72(1): 28-37.

Bobyn, M.L. and R.J. Brooks. 1994b. Interclutch and interpopulation variation in the effects of incubation conditions on sex, survival and growth of hatchling turtles (Chelydra serpentina). Journal of Zoology 233(2): 233-257.

Boice, R., Q.C. Boice, and R.C. Williams. 1974. Competition and possible dominance in turtles, toads and frogs. Journal of Comparative Physiology and Psychology 86:1116-1131.

Bolek, M.G. 2001. Chelydra serpentina (common snapping turtle) and Emydoidea blandingii (Blanding's turtle) parasites. Herpetological Review 32(1): 37-38.

Bonin, J., J.L. DesGranges, C.A. Bishop, J. Rogrigue, A. Gendron, and J.E. Elliott. 1995. Comparative study of contaminants in the mudpuppy (Amphibia) and the common snapping turtle (Reptilia), St. Lawrence River, Canada. Archives of Environmental Contamination and Toxicology 28(2): 184-194.

Boulenger, G.A. 1902. On the southern snapping turtle (C. rossignonii). Annals and Magazine of Natural History (7)9(69): 49-51.

Brittle, D. 1991. Chelydra serpentina (snapping turtle). Catesbeiana 11(2): 39.

Brooks, R.J., D.A. Galbraith, and J.A. Layfield. 1990. Occurrence of Placobdella parasitica (Hirudinea) on snapping turtles, Chelydra serpentina, in southeastern Ontario. Journal of Parasitology 76(2): 190-195.

Brooks, R.J., D.A. Galbraith, and M.L. Bobyn. 1989. Intraspecific variation in measures of life history in the common snapping turtle, Chelydra serpentina. In: Proceedings of the First World Congfess of Herpetology. University of Kent, Canterbury, U.K., 11-19 September 1989. The Durrell Institute. Canterbury, Kent, U.K. p. 42.

Brooks, R.J., G.P. Brown, and D.A. Galbraith. 1991. Effects of a sudden increase in natural mortality of adults on a population of the common snapping turtle (Chelydra serpentina). Canadian Journal of Zoology 69: 1314-1320. 
Brooks, R.J., D.A. Galbraith, E.G. Nancekivell and C.A. Bishop. 1988. Developing management guidelines for snapping turtles. Pp. 174-179 In: R.C. Szaro, K.E. Severson, and D.R. Patton, technical coordinators. Management of amphibians, reptiles, and small mammals in North America. General Technical Report RM-166. U.S. Forest Service, Rocky Mountain Forest and Range Experiment Station, Fort Collins, Colorado.

Brooks, R.J., M.L. Bobyn, D.A. Galbraith, J.A. Layfield, and E.G. Nancekivell. 1991. Maternal and environmental influences on growth and survival of embryonic and hatchling snapping turtles (Chelydra serpentina). Canadian Journal of Zoology 69: 2667-2676.

Brown, G.P. 1992. Thermal and spatial ecology of a northern population of snapping turtles, Chelydra serpentina. M.S. Thesis, University of Guelph. Guelph, Ontario.

Brown, G.P. and R.J. Brooks. 1991. Thermal and behavioural responses to feeding in freeranging turtles, Chelydra serpentina. Journal of Herpetology 25(3): 273-278.

Brown, G.P. and R.J. Brooks. 1993. Sexual and seasonal differences in activity in northern population of snapping turtles, Chelydra serpentina. Herpertologica 49(3): 311-318.

Brown, G.P. and R.J. Brooks. 1994. Characteristics of and fidelity to hibernacula in a northern population of snapping turtles, Chelydra serpentina. Copeia 1994: 222-226.

Brown, G.P., C.A. Bishop, and R.J. Brooks. 1994. Growth rate, reproductive output, and temperature selection of snapping turtles in habitats of different productivities. Journal of Herpetology 28(4): 405-410.

Brown, G.P., R.J. Brooks, and J.A. Layfield. 1990. Radiotelemetry of body temperatures of free-ranging snapping turtles (Chelydra serpentina) during summer. Canadian Journal of Zoology 68(8): 1689-1663.

Brown, G.P., R.J. Brooks, E. Siddall, and S.S. Desser. 1994. Parasites and reproductive output in the snapping turtle, Chelydra serpentina. Copeia 1994(1): 228-231.

*Brunson, R.B. 1955. Check list of the amphibians and reptiles of Montana. Proceedings of the Montana Academy of Sciences 15: 27-29.

Budhabhatti, J., and E.O. Moll. 1990. Chelydra serpentina (common snapping turtle). Feeding behavior. Herpetological Review 21(1): 19.

Burke, A.C. 1989. Development of the turtle carapace: implications for the evolution of a novel Bauplan. Journal of Morphology 199(3): .363-378.

Burke, A.C., and P. Alberch. 1985. The development and homology of the chelonian carpus and tarsus. Journal of Morphology 186(1): 119-131.

Burke, V.J, R.D. Nagle, M. Ostentoski, and J.D. Congdon. 1993. Common snapping turtles associated with ant mounds. Journal of Herpetology 27: 114-115.

Cagle, F.R. 1944a. A technique for obtaining turtle eggs for study. Copeia 1944: 60.

Cagle, F.R. 1948. The growth of turtles in Lake Glendale, Illinois. Copeia 1948: 197-203.

Carr, A.F. 1952. Handbook of turtles: the turtles of the United States, Canada, and Baja California. Cornell University Press, Ithaca, New York.

Chiszar, D. and H.M. Smith. 1995. Chelydra serpentina serpentina (common snapping turtle). Herpetological Review 26(4): 208.

Chiszar, D., R.L. Holland, C. Ristau, and H.M. Smith. 1994. Chelydra serpentina serpentina (common snapping turtle). Herpetological Review 25(4): 162.

Christiansen, J.L. and R.R. Burken. 1979. Growth and maturity of the snapping turtle (Chelydra serpentina) in Iowa. Herpetologica 35: 261-266.

Cink, C.L. 1991. Snake predation on nestling eastern phoebes followed by turtle predation on snake. Kansas Ornithological Society Bulletin 42(3): 29. 
Coaker, M. 1993. The common snapping turtle (Chelydra serpentina) of North America. Southwestern Herpetologists Society Journal 2(3): 33-34.

Cochran, P.A. and L. Marks. 1990. Chelydra serpentina (snapping turtle). Herpetological Review 21(2): 38.

Collins, J.T. 1991. A new taxonomic arrangement for some North American amphibians and reptiles. Herpetological Review 22:42-43.

Congdon, J.D. and J.W. Gibbons. 1990. The evolution of turtle life histories. Pp. 45-54. In: Life history and ecology of the slider turtle. Edited by J.W. Gibbons. Smithsonian Institution Press, Washington, D.C., U.S.A.

Congdon, J.D., A.E. Dunham and R.C. van Loben Sels. 1994. Demographics of common snapping turtles (Chelydra serpentina): implications for conservation and management of long-lived organisms. American Zoologist 34: 397-408.

Congdon, J.D., G.L. Breitenbach, R.C. van Loben Sels, and D.W. Tinkle. 1987. Reproduction and nesting ecology of snapping turtles (Chelydra serpentina) in southeastern Michigan (USA). Herpetologica 43(1): 39-54.

Congdon, J.D., A.E. Dunham, R.C. van Loben Sels, and J.T. Austin. 1995. Life histories and demographics of long-lived organisms: implications for management and conservation. U.S.F.S. General Technical Report. RM 264: 624-630.

Congdon, J.D., S.W. Gotte, S.W., and R.W. Mcdiarmid. 1992. Ontogenetic changes in habitat use by juvenile turtles, Chelydra serpentina and Chrysemys picta. Canadian Field Naturalist 106(2): 241-248.

*Cope, E.D. 1875. Check-list of North American Batrachia and Reptilia; with a systematic list of the higher groups, and an essay on geographical distribution. U.S. National Museum Bulletin 1(1): 1-104.

Costanzo, J.P., J.B. Iverson, M.F. Wright, and R.E. Lee, Jr. 1995. Cold hardiness and overwintering strategies of hatchlings in an assemblage of northern turtles. Ecology 76(6): 1772-1785.

*Coues, E. and H.C. Yarrow. 1878. Notes on the herpetology of Dakota and Montana. Bulletin of the U.S. Geologic and Geographic Survey 4(1): 259-291.

Crother, B.I. (ed.) 2008. Scientific and standard English names of amphibians and reptiles of North America north of Mexico. SSAR Herpetological Circular No. 37:1-84.

Cunnington, D.C. and R.J. Brooks. 1996. Bet-hedging theory and eigenelasticity: a comparison of the life histories of loggerhead sea turtles (Caretta caretta) and snapping turtles (Chelydra serpentina). Canadian Journal of Zoology 74(2): 291-296.

*Curtis, S. 1994. The big sleep. Montana Outdoors 25(6): 2-7.

Daigle, C., A. Desrosiers, and J. Bonin. 1994. Distribution and abundance of common map Turtles, Graptemys geographica, in the Ottawa River, Quebec. Canadian Field Naturalist 108(1): 84-86.

Darrow, T.D. 1961. Food habits of western painted and snapping turtles in southeastern South Dakota and eastern Nebraska. Unpubl. MS Thesis, University of South Dakota, Vermillion.

*Day, D., P.J. Farmer, and C.E. Farmer. 1989. Montco terrestrial wildlife monitoring report December, 1987 - July, 1989. Montco, Billings, MT, and Western Technology and Engineering, Inc. Helena, MT.

*[DCC] Decker Coal Company. 1998. 1997 Consolidated annual progress report. Decker Coal Company West, North and East Pits. Decker, MT. 
De Santis, B., B. Sheafor, H.M. Smith, and D. Chiszar. 1995. Chelydra serpentina serpentina (common snapping turtle). Herpetological Review 26(3): 154.

Decker, J.D. 1967. Motility of the turtle embryo, Chelydra serpentina (Linne.). Science 157: 952-954.

Degenhardt, W.G., C.W. Painter, and A.H. Price. 1996. Amphibians and reptiles of New Mexico. Albuquerque, NM: University of New Mexico Press. 431 p.

Dinkelacker, S.A., J.P. Costanzo, and R.E. Lee Jr. 2005. Anoxia tolerance and freeze tolerance in hatchling turtles. Journal of Comparative Physiology B Biochemical Systemic and Environmental Physiology 175(3):209-217.

Distel, C. 2005. Chelydra serpentina serpentina (Common Snapping Turtle). Flatulence. Herpetological Review 36:310.

Dixon, J.R., O.W. Thornton, Jr. 1996. Chelydra serpentina serpentina (common snapping turtle). Herpetological Review 27(1): 31.

Dodd, C.K., Jr. and E.D. Brodie, Jr. 1975. Notes on the defensive behavior of the snapping turtle, Chelydra serpentina. Herpetologica 31: 286-288.

Dunham, A.E. and K.L. Overall. 1994. Population responses to environmental change: Life history variation, individual-based models, and the population dynamics of short-lived organisms. American Zoologist 34(3): 382-396.

Dunson, W.A. 1986. Estuarine populations of the snapping turtle (Chelydra) as a model for the evolution of marine adaptations in reptiles. Copeia 1986:741-756.

*Ernst, C.H. and R.W. Barbour. 1972. Turtles of the world. Smithsonian Institution Press, Washington, D.C.

*Ernst, C.H., J.W. Gibbons, and S.S. Novak. 1988. Chelydra. Catalogue of American Amphibians and Reptiles 419.1-419.4.

*Ernst, C.H., R.W. Barbour, and J.E. Lovich. 1994. Turtles of the United States and Canada. Smithsonian Institution Press, Washington, D.C. 578 p.

Ewert, M.E. 1979. The embryo and its egg: development and natural history. In Turtles: perspecgtives and research. Edited by M. Harless and H. Morlock. John Wiley and Sons, Inc., New York. pp. 333-413.

Ewert, M.E. and C.E. Nelson. 1991. Sex determination in turtles: diverse patterns and some possible adaptive values. Copeia 1991: 50-69.

Ewert, M.A. 1976. Nests, nesting, and aerial basking in Macroclemys under natural conditions and comparisons with Chelydra (Testudinae, Chelydridae). Herpetologica 32: 150-156.

Ewert, M.A., J.W. Lang, and C.E. Nelson. 2005. Geographic variation in the pattern of temperature-dependent sex determination in the American snapping turtle (Chelydra serpentina). Journal of Zoology (London) 265(1):81-95.

*Farmer, P. 1980. Terrestrial wildlife monitoring study, Pearl area, Montana June, 1978 - May, 1980. Western Technology and Engineering, Inc. Helena, MT.

Feinberg, J.A. and K. Hoffmann. 2004. Chelydra serpentina (Snapping Turtle) and Scaphiopus holbrookii (Eastern Spadefoot). Diet. Herpetological Review 35(4):380.

Fergus, C. 1985. Out of their element, turtles bend the regulations. Oceans 18(1): 66-67.

*Feuer, R.C. 1966. Variation in snapping turtles, Chelydra serpentina Linnaeus: a study in quantitative systematics. Ph.D. Dissertation. University of Utah, Salt Lake City, UT. 264 p.

Feuer, R.C. 1971a. Ecological factors in success and dispersal of the snapping turtle Chelydra serpentina (Linnaeus). Bulletin of Philadelphia Herpetology Soc. 19: 3-14. 
Feuer, R.C. 1971b. Intergradation of the snapping turtles Chelydra serpentina serpentina (Linnaeus, 1758) and Chelydra serpentina osceola Stejneger, 1918. Herpetologica 27(4): 379-384.

Finkler, M.S. and D.L. Claussen. 1997. Use of the tail in terrestrial locomotor activities of juvenile Chelydra serpentina. Copeia 1997: 884-887.

Finkler, M.S. and D.L. Knickerbocker. 2000. Influence of hydric conditions during incubation and population on overland movement of neonatal snapping turtles. Journal of Herpetology 34(3): 452-455.

Finneran, L.C. 1947. A large clutch of eggs of Chelydra serpentina serpentina (linnaeus). Herpetologica 3: 182.

Frair, W. 1972. Taxonomic relations among chelydrid and kinosternid turtles elucidated by serological tests. Copeia 1972:97-108.

Fraser, G. 1994. Possible predation of a Forster's tern chick by a snapping turtle. Prairie Naturalist 26(1): 33-35.

Frazer, N.B., J.W. Gibbons, and T.J. Owens. 1990. Turtle trapping: preliminary tests of conventional wisdom. Copeia 1990(4): 1150-1152.

Froese, A. D. and G. M. Burghardt. 1975. A dense natural population of the common snapping turtle (Chelydra serpentina). Herpetologica 31:204-208.

Froese, A.D. 1974. Aspects of space use in the common snapping turtle, Chelydra s. serpentina. Unpubl. Ph.D. Thesis, University of Tennessee, Knoxville.

Froese, A.D. 1978. Habitat preferences of the common snapping turtle, Chelydra s. serpentina (Reptilia, Testudines, Chelydridae). Journal of Herpetology 12: 53-58.

Froese, A.D. and G.M. Burghardt. 1974. Food competition in captive juvenile snapping turtles, Chelydra serpentina. Animal Behavior 22: 735-740.

Gaffney, E.S. 1975b. Phylogeny of the chelydrid turtles: a study of shared derived characters of the skull. Fieldiana, Geology 33: 157-178.

Gaffney, E.S. 1984a. Historical analysis of theories of chelonian relationship. Systematic Zoology 33:283-301.

Gaffney, E.S. 1984b. Progress towards a natural hierarchy of turtles. Studia Geologica Salmanticensia (Studia Palaeocheloniologica I) 1:125-131.

Galbraith, D.A. 1994. Ecology research on snapping turtles (Chelydra serpentina) in Ontario, Canada. Asra Journal 1994: 23-49.

Galbraith, D.A. and R.J. Brooks. 1987a. Addition of annual lines in adult snapping turtles Chelydra serpentina. Journal of Herpetology 21: 359-363.

Galbraith, D.A. and R.J. Brooks. 1987b. Survivorship of adult females in a northern population of common snapping turtles, Chelydra serpentina. Canadian Journal of Zoology 65(7): 1581-1586.

Galbraith, D.A. and R.J. Brooks. 1989. Age estimates for snapping turtles. Journal of Wildlife Management 53(2): 502-508.

Galbraith, D.A., B.N. White, R.J. Brooks, and P.T. Boag. 1993. Multiple paternity in clutches of snapping turtles (Chelydra serpentina) detected using DNA fingerprints. Canadian Journal of Zoology 71(2): 318-324.

Galbraith, D.A., C.A. Bishop, R.J. Brooks, W.L. Simser, and K.P. Lampman. 1988. Factors affecting the density of populations of common snapping turtles (Chelydra serpentina serpentina). Canadian Journal of Zoology 66(5): 1233-1240. 
Galbraith, D.A., C.J. Graesser, and R.J. Brooks. 1988. Egg retention by a snapping turtle, Chelydra serpentina, in central Ontario (Canada). Canadian Field Naturalist 102(4): 734.

Galbraith, D.A., M.W. Chandler, and R.J. Brooks. 1987. The fine structure of home ranges of male Chelydra serpentina: are snapping turtles territorial. Canadian Journal of Zoology 65(11): 2623-2629.

Galbraith, D.A., R.J. Brooks, and M.E. Obbard. 1989. The influence of growth rate on age and body size at maturity in female snapping turtles (Chelydra serpentina). Copeia 1989(4): 896904.

Garbin, C.P. 1992. Performance of hatchling snapping turtles (Chelydra serpentina) on singlefood diets: a comparison of three commercial foods. Bulletin of the Chicago Herpetological Society 27(12): 249-251.

*Gates, M.T. 2005. Amphibian and reptile baseline survey: CX field study area. Report to Billings and Miles City Field Offices of Bureau of Land Management. Maxim Technologies, Billings, MT. 28pp + Appendices.

Gatten, R.E. 1980. Aerial and aquatic oxygen uptake by freely-diving snapping turtles (Chelydra serpentina). Oecologia 46: 266-271.

Gaunt, A.S. and C. Gans. 1969. Mechanics of respiration in the snapping turtle, Chelydra serpentina (Linne.). Journal of Morphology 128: 195-228.

Gerholdt, J.E. and B. Oldfield. 1987. Life history notes. Chelydra serpentina serpentina (common snapping turtle). Size. Herpetological Review 18(4): 73.

Gettinger, R.D., G.L. Paukstis, and G.C. Packard. 1984. Influence of hydric environment on oxygen consumption by embryonic turtles Chelydra serpentina and Trionyx spiniferus. Physiological Zoology 57: 468-473.

Gibbons, J.W. 1968b. Growth rates of the common snapping turtle, Chelydra serpentina, in a polluted river. Ibid 24: 266-267.

Gibbons, J.W. and D.H. Nelson. 1978. The evolutionary significance of delayed emergence from the nest by hatchling turtles. Evolution 32: 297-303.

*Gibbons, J.W., S.S. Novak and C.H. Ernst. 1988. Chelydra serpentina. Catalogue of American Amphibians and Reptiles 420.1-420.4.

Graff, H. and H. Graff. 1991. Snapping turtle (Chelydra serpentina). Newsletter of the Australian Society of Herpetologists Inc. 34(6): 131-133.

Graham, T.E. and R.W. Perkins. 1976. Growth of the common snapping turtle, Chelydra serpentina, in a polluted marsh. Maryland Herpetological Society Bulletin 12: 123-125.

Gutzke, W.H.N. 1984. Modification of the hydric environment by eggs of snapping turtles (Chelydra serpentina). Canadian Journal of Zoology 62(12): 2401-2403.

Gutzke, W.H.N. and D. Crews. 1988. Embyonic temperature determines adult sexuality in a reptile. Nature 332: 832-834.

Haas, A. 1985. Year-long outdoor behavior of the snapping turtle Chelydra serpentina serpentina in southern Germany (Testudines, Chelydridae). Salamandra 21(1): 1-9.

Hamilton, W.J., Jr. 1940. Observations on the reproductive behavior of the snapping turtle. Copeia 1940: 124-126.

Hammer, D.A. 1969. Parameters of a marsh snapping turtle population, Lacreek Refuge, South Dakota. Journal of Wildlife Management 33(4): 995-1005.

Hammer, D.A. 1971a. Reproductive behavior of the common snapping turtle. Canadian Herpetological Society 1: 9-13.

Hammer, D.A. 1971b. The durable snapping turtle. Natural History 80: 59-65. 
Hammerson, G.A. 1999. Amphibians and reptiles in Colorado, second edition. University Press of Colorado. Niwot, Colorado. 484 pp. Society 27:121-127.

*Hanson, J. No Date. Report on Youngs Creek. U.S. Fish and Wildlife Service. Hardin, MT. $14 \mathrm{p}$.

Harding, J.H. 1997. Amphibians and reptiles of the Great Lakes region. University of Michigan Press, Ann Arbor.

*Hart, M.M., W.A. Williams, P.C. Thornton, K.P. McLaughlin, C.M. Tobalske, B.A. Maxell, D.P. Hendricks, C.R. Peterson, and R.L. Redmond. 1998. Montana atlas of terrestrial vertebrates. Montana Cooperative Wildlife Research Unit, The University of Montana. Missoula, Montana vii +1302 p.

Haxton, T. 2000. Road mortality of snapping turtles, Chelydra serpentina, in central Ontario during their nesting period. The Canadian Field Naturalist 114(1): 106.

*Hayden, F.V. 1858. Catalogue of the collections in geology and natural history, obtained by the expedition under command of Lieutenant G.K. Warren, Topographical Engineers. pp. 104-105. In: F.N. Shubert (1981) Explorer on the northern plains: Lieutenant Gouverneur K. Warren's preliminary report of explorations in Nebraska and Dakota, in the years 1855-'56'57. Engineer Historical Studies No. 2. Office of the Chief of Engineers, Washington, DC. $125 \mathrm{p}$.

*Hayden, F.V. 1863. On the geology and natural history of the upper Missouri. Transactions of the American Philosophical Society New Series 12(1): 1-218 (pages 177-178).

Hebert, C.E., V. Glooshenko, G.D. Haffner, and R. Lazar. 1993. Organic contaminants in snapping turtle (Chelydra serpentina) populations from southern Ontario, Canada. Archives of Environmental Contamination and Toxicology 24(1): 35-43.

Hemphill, N. and W. Worthey. 1994. Do predaceous turtles affect stream fishes? International Vereinigung Fuer Theoretische Und Angewandte Limnologie Verhandlungen 25(4): 21052107.

*Hendricks, P. 1999. Amphibian and reptile survey of the Bureau of Land Management Miles City District, Montana. Montana Natural Heritage Program, Helena, MT. 80 p.

*Hendricks, P. and J.D. Reichel. 1996. Preliminary amphibian and reptile survey of the Ashland District, Custer National Forest: 1995. Montana Natural Heritage Program, Helena, MT. 79 p.

Hogg, D.M. 1975. The snapping turtles of Wye Marsh. Ontario Fish and Wildlife Review 14: 16-20.

Holland, R.L., H.M. Smith, and D. Chiszar. 1995b. Testudines: Chelydra serpentina serpentina (common snapping turtle). Herpetological Review 26(4): 209.

Holman, A.J. 1988. The status of Michigan's Pleistocene herpetofauna. Michigan Academician 20(2): 125-132.

Holman, J.A. and J.N. McDonald. 1986. A Late Quaternary herpetofauna from Saltville, Virginia (USA). Brimleyana 12: 85-100.

Hotaling, E.C., D.C. Wilhoft, and S.B. McDowell. 1985. Egg position and weight of hatchling snapping turtles, Chelydra serpentina, in natural nests. Journal of Herpetology 19(4): 534536.

Hoyt, J.S.Y. 1941. The incubation period of the snapping turtle. Copeia 1941: 180.

Humphrey, R., D. Chiszar, and H.M. Smith. 1995. Chelydra serpentina (snapping turtle). Herpetological Review 26(2): 106. 
Iverson, J.B. 1991. Patterns of survivorship in turtles (order Testudines). Canadian Journal of Zoology 69: 385-391.

Iverson, J.B. 1992a. A revised checklist with distribution maps of the turtles of the world. Paust Printing, Richmond, Indiana.

Iverson, J.B., H. Higgins, A. Sirulnik, and C. Griffiths. 1997. Local and geographic variation in the reproductive biology of the snapping turtle (Chelydra serpentina). Herpetologica 53(1): 96-117.

Janzen, F.J. 1990. Egg size and hatching success of snapping turtle eggs: evaluation of natural selection. American Zoologist 30: 55A.

Janzen, F.J. 1992. Heritable variation for sex ratio under environmental sex determination in the common snapping turtle (Chelydra serpentina). Genetics 131(1): 155-161.

Janzen, F.J. 1993. An experimental analysis of natural selection on body size of hatchling turtles. Ecology 74(2): 332-341.

Janzen, F.J. 1994b. Temperature-dependent sex determination influences the mortality of hatchling snapping turtles in nature. American Zoologist 34(5): 9A.

Janzen, F.J. 1995. Experimental evidence for the evolutionary significance of temperature dependent sex determination. Evolution 49(5): 864-873.

Janzen, F.J. and S. O’Steen. 1990. An instance of male combat in the common snapping turtle (Chelydra serpentina). Bulletin of the Chicago Herpetological Society 25(1): 11.

Kinneary, J.J. 1992. The effect of water salinity on growth and oxygen consumption of snapping turtle (Chelydra serpentina) hatchlings from an estuarine habitat. Journal of Herpetology 26(4): 461-467.

Kinneary, J.J. 1993. Salinity relations of Chelydra serpentina in a Long Island estuary. Journal of Herpetology 27(4): 441-446.

Kiviat, E. 1980. A Hudson River tidemarsh snapping turtle population. Transactions Northeastern Section Wildlife Society 158-168.

Kiviat, E. 1994. Consider the snapping turtle. Conservationist 48(5-6): 36-41.

Knight, T.W., J.A. Layfield, and R.J. Brooks. 1990. Nutritional status and mean selected temperature of hatchling snapping turtles (Chelydra serpentina): is there a thermophilic response to feeding? Copeia 1990: 1067-1072.

Ladd, C.G. and G.G. Galbraith. 1989. Chelydra s. serpentina (common snapping turtle). Herpetological Review 20(1): 14.

Lagler, K.F. and V.C. Applegate. 1943. Relationship between the length and the weight in the snapping turtle Chelydra serpentina Linnaeus. American Naturalist 77: 476-478.

Lawniczak, C.J. and M.A. Teece. Spatial mobilization of calcium and magnesium from the eggshell of the snapping turtle, Chyledra serpentina. Journal of Herpetology 39(4):659-664.

Layfield, J.A., D.A. Galbraith, and R.J. Brooks. 1988. A simple method to mark hatchling turtles. Herpetological Review 19(4): 78-79.

Loncke, D.J. and M.E. Obbard. 1977. Tag success, dimensions, clutch size and nesting site fidelity for the snapping turtle, Chelydra serpentina, (Reptilia, Testudines, Chelydridae) in Algongquin Park, Ontario, Canada. Journal of Herpetology 11: 243-244.

Long, C.A., J.E. Long, and C.A. Long. 1987. A listing of known amphibians and reptiles from Washington Island, Lake Michigan, with new records of the milk snake and red-bellied snake. Jack-Pine Warbler 65(3-4): 39. 
Lovich, J.E. and J.W. Gibbons. 1996. Conservation of covert species: protecting species we don't even know. Proceedings: conservation restoration and managemen of turtles and tortoises, and international conference. State University of New York, Purchase.

Mahmoud, I.Y. and R.V. Cyrus. 1992. The testicular cycle of the common snapping turtle, Chelydra serpentina, in Wisconsin. Herpetologica 48(2): 193-201.

Manlius, N. 1996. Pectoral girdle and forelimb structure of the leatherback turtle Dermochelys coriacea Vandelli, 1761 (Chelonii, Dermochelyidae) compared with four other chelonian species. Bulletin de la Societe Herpetologique de France 1996: 1-18.

*Martin, P.R. 1980a. Terrestrial wildlife habitat inventory in southeastern Montana. Montana Department of Fish, Wildlife and Parks and Bureau of Land Management, Helena MT. 114 p.

*Martin, P.R. 1980b. Terrestrial wildlife inventory in selected coal areas of Montana. Montana Department of Fish, Wildlife and Parks and Bureau of Land Management, Helena, MT. 84 p.

*Martin, P.R., K. Dubois, and H.B. Youmans. 1981. Terrestrial wildlife inventory in selected coal areas, Powder River resources area final report. Montana Department of Fish, Wildlife and Parks and Bureau of Land Management, Helena, MT. 288 p.

*Matthews, W.L. 1979. Wibaux-Beach wildlife baseline study - nongame species. Bureau of Land Management, Miles City, MT. 93 p.

*Maxell, B.A. 2004a. Preliminary report on amphibian and aquatic reptile inventories conducted on and around the Ashland District of the Custer National Forest in 2002 and 2004. Report to Ashland District of Custer Forest, Region 1 Office of the U.S. Forest Service, and Montana Department of Fish, Wildlife, and Parks. Montana Cooperative Wildlife Research Unit and Wildlife Biology Program, University of Montana, Missoula, MT. 93p.

*Maxell, B.A. 2004b. Report on amphibian and aquatic reptile inventories conducted on and around the Beaverhead-Deerlodge National Forest 2001-2003. Report to Region 1 Office of the U.S. Forest Service, Beaverhead-Deerlodge National Forest, Montana Department of Fish, Wildlife, and Parks, Montana State Office of the Bureau of Land Management, and Montana Department of Environmental Quality. Missoula, MT: Montana Cooperative Wildlife Research Unit and Wildlife Biology Program, University of Montana. 260 p.

*Maxell, B.A. 2009. State-wide assessment of status, predicted distribution, and landscapelevel habitat suitability of amphibians and reptiles in Montana. Ph.D. Dissertation. Missoula, MT: Wildlife Biology Program, University of Montana. 294 p.

*Maxell, B. A., and D. G. Hokit. 1999. Amphibians and reptiles. Pages 2.1-2.30, In Effects of recreation on Rocky Mountain wildlife: a compendium of the current state of understanding in Montana (G. Joslin and H. Youmens, coordinators). Committee on Effects of Recreation on Wildlife, Montana Chapter of the Wildlife Society. $307 \mathrm{pp}$.

*Maxell, B.A., J.K. Werner, P. Hendricks, and D.L. Flath. 2003. Herpetology in Montana: a history, status summary, checklists, dichotomous keys, accounts for native, potentially native, and exotic species, and indexed bibliography. Northwest Fauna Number 5. 138 pp.

Mayeaux, M.H. 1996. A possible constraint to high-density culture of male common snapping turtles Chelydra serpentina at consistently warm temperatures. Journal of the World Aquaculture Society 27(1): 137-139.

McAllister, C.T. 1988. New county records for amphibians and reptiles of north central Texas. Herpetological Review 19(3): 61-62. 
McAllister, C.T., S.J. Upton, and S.E. Trauth. 1990. Coccidian parasites (Apicomplexa: Eimeriidae) of Chelydra serpentina (Testudines: Chelydridae) from Arkansas and Texas, U.S.A., with descriptions of Isospora Chelydrae sp. nov. and Eimeria serpentina sp. nov. Canadian Journal of Zoology 68(5): 865-868.

McAlpine, D.F. and G. Godin. 1986. New records of snapping turtles, Chelydra serpentina, and painted turtles, Chrysemys picta, from New Brunswick. Canadian Field Naturalist 100(1):63-68.

McAlpine, D.F. and G. Godin. 1986. Snapping turtles, Chelydra serpentina, new record and painted turtles, Chrysemys picta, new record from New Brunswick (Canada). Canadian Field Naturalist 100(1): 63-68.

*McEneaney, T. and J. Jensen. 1974. The reptiles and amphibians of the Charles M. Russell National Wildlife Range - 1974. Charles M. Russell National Wildlife Refuge. Lewistown, MT. 3 p.

McKnight, C.M. and W.H.N. Gutzke. 1993. Effects of the embryonic environment and of hatchling housing conditions on growth of young snapping turtles (Chelydra serpentina). Copeia 1993(2): 475-482.

Medem, F. 1977. Contribucion al conocimiento sobre la taxonomia, distribucion geografica y ecologia de la tortuga "bache" (Chelydra serpentina acutirostris). Caldasia 12(56):41-98.

Meeks, R.L. and G.R. Ultsch. 1990. Overwintering behavior of snapping turtles. Copeia 1990(3): 880-884.

Meylan, P.A., C.A. Stevens, M.E. Barnwell, and E.D. Dohm. 1992. Observations on the turtle community of Rainbow Run, Marion Co., Florida. Florida Scientist 55(4): 219-228.

Miller, K. 1993. The improved performance of snapping turtles (Chelydra serpentina) hatched from eggs incubated on a wet substrate persists through the neonatal period. Journal of Herpetology 27(2): 228-233.

Miller, K. and G.C. Packard. 1992. The influence of substrate water potential during incubation on the metabolism of embryonic snapping turtles (Chelydra serpentina). Physiological Zoology 65(1): 172-187.

Miller, K., G.C. Packard, and M.J. Packard. 1987. Hydric conditions during incubation influence locomotor perrformance of hatchling snapping turtles. Journal of Experimental Biology 127: 401-412.

Miller, K., G.F. Birchard, and G.C. Packard. 1989. Chelydra serpentina (common snapping turtle). Fecundity. Herpetological Review 20(3): 69.

Mitchell, J.C. 1995. Abnormal coloration in a common snapping turtle (Chelydra serpentina serpentina) from Virginia. Banisteria 6 1995:32-33.

Mitchell, J.C. and M.C. Odom. 1995. Record clutch size for Chelydra serpentina (Testudines: Chelydridae) in Virginia. Brimleyana 22: 73-75.

Mitchell, J.C. and R.O. De Sa. 1994. Terrapene carolina carolina (Eastern Box Turtle) reproduction. Herpetological Review 25(2): 64.

Mitsukuri, K. 1895. How many times does a snapping turtle lay eggs in one season? Zoological Magazine of Tokyo 6: 143-147.

Moll, D. and F.J. Dodd, Jr. 1985. New records for Chelydra serpentina rossignoni in Belize. Bulletin of the Maryland Herpetological Society 21(1): 34-37.

Moravec, F. and M.D. Little. 2004. Redescription of Dracunculus globocephalus Mackin, 1927 (Nematoda: Dracunculidae), a parasite of the snapping turtle, Chelydra serpentina. Folia Parasitologica (Ceske Budejovice) 51(4):339-345. 
Morris, K.A., G.C. Packard, T.J. Boardman, G.L. Paukstis, and M.J. Packard. 1983. Effect of the hydric environment on growth of embryonic snapping turtles (Chelydra serpentina). Herpetologica 39: 272-285.

Mosimann, J.E. and J.R. Bider. 1960. Variation, sexual dimorphism, and maturity in a Quebec population of the common snapping turtle, Chelydra serpentina. Canadian Journal of Zoology 38: 19-38.

*[MTNHP] Montana Natural Heritage Program. 2006. Point Observation Database. Montana Natural Heritage Program, Helena, MT. Accessed April 25, 2006.

Murphy, G.G. and J.F. Sharber, Jr. 1973. Preliminary analysis of activity of the common snapping turtle, Chelydra serpentina, as determined by biotelemetry. Journal of the Tennessee Academy of Science 48: 56.

Netten, H. and F. Zuurmond. 1985. Offspring of the common snapping turtle Chelydra serpentina in the reptile zoo Iguana. Lacerta 44(3): 42-43.

Norris-Elye, L.T.S. 1949. The common snapping turtle (Chelydra serpentina) in Manitoba. Canadian Field Naturalist 63: 145-157.

Obbard, M.E. 1983. Population ecology of the common snapping turtle, Chelydra serpentina, in north-central Ontario. Ph.D. Thesis, University of Guelph, Guelph, Ontario.

Obbard, M.E. 1985. Can we safely harvest snapping turtles in Ontario? Canadian Amphibian Reptiles Conservation Society 23: 1-4.

Obbard, M.E. and R.J. Brooks. 1979. Factors affecting basking in a northern population of the common snapping turtle, Chelydra serpentina. Canadian Journal of Zoology 57: 435-440.

Obbard, M.E. and R.J. Brooks. 1980. Nesting migrations of the snapping turtle (Chelydra serpentina). Herpetologica 36: 158-162.

Obbard, M.E. and R.J. Brooks. 1981a. A radio-telemetry and mark-recapture study of activity in the common snapping turtle, Chelydra serpentina. Copeia 1981: 630-637.

Obbard, M.E. and R. J. Brooks. 1981b. Fate of overwintered clutches of the common snapping turtle (Chelydra serpentina) in Algonquin Park, Ontario, Canada. Canadian Field Naturalist 95:350-352.

Obbard, M.E. and R.J. Brooks. 1987. Prediction of the onset of the annual nesting season of the common snapping turtle, Chelydra serpentina. Herpetologica 43: 324-328.

*[OEAR] Olson Elliot and Associates Research. 1985. 1983-1984 Wildlife monitoring report for the CX Ranch project. Olson Elliot and Associates Research. Helena, MT.

Overmann, S.R., and J.J. Krajicek. Snapping turtles (Chelydra serpentina) as biomonitors of lead contamination of the big river in Missouri's old lead belt. Environmental Toxicological Chemistry 14(4): 689-695.

Packard, G.C. and M.J. Packard. 1990b. Patterns of survival at subzero temperatures by hatchling painted turtles and snapping turtles. Journal of Experimental Zoology 254(2): 223236.

Packard, G.C., G.L. Paukstis, T.J. Boardman, and W.H.N. Gutzke. 1985. Daily and seasonal variation in hydric conditions and temperature inside nests of common snapping turtles (Chelydra serpentina). Canadian Journal of Zoology 63(10): 2422-2429.

Packard, G.C., K. Miller, and M.J. Packard. 1992. A protocol for measuring water potential in subterranean nests of reptiles. Herpetologica 48(2): 202-209.

Packard, G.C., K. Miller, and M.J. Packard. 1993. Environmentally induced variation in body size of turtles hatching in natural nests. Oecologica 93(3): 445-448. 
Packard, G.C., K. Miller, M.J. Packard, and G.F. Birchard. 1999. Environmentally induced variation in body size and condition in hatchling snapping turtles (Chelydra serpentina). Canadian Journal of Zoology 77: 278-289.

Packard, G.C., K.A. Ruble, M.J. Packard. 1993. Hatchling snapping turtles overwintering in natural nests are inoculated by ice in frozen soil. Journal of Thermal Biology 18(4): 185188.

Packard, G.C., M.J. Packard, and K. Miller. 1990. Chelydra serpentina (common snapping turtle). Fecundity. Herpetological Review 21(4): 92.

Packard, G.C., M.J. Packard, K. Miller, and T.J. Boardman. 1985. Influence of water potential and temperature on eggs of snapping turtles (Chelydra serpentina) incubating on different types of substrates. American Zoology 25: 134A.

Packard, G.C., M.J. Packard, K. Miller, and T.J. Boardman. 1987. Influence of moisture, temperature, and substrate on snapping turtle eggs and embryos. Ecology 68: 983-993.

Packard, G.C., T.L. Taigen, M.J. Packard, and T.J. Boardman. 1980. Water relations of pliableshelled eggs of common snapping turtles (Chelydra serpentina). Canadian Journal of Zoology 58: 1404-1411.

Packard, M.J. 1980. Ultrastructural morphology of the shell and shell membrane of eggs of common snapping turtles (Chelydra serpentina). J. Morphol. 165: 187-204.

Paterson, W.B. and S.S. Desser. 1976. Observations on Haemogregarina balli sp.n. from the common snapping turtle, Chelydra serpentina. Journal of Protozoology 23: 294-301.

Pell, S.M. 1940. Notes on the food habits of the common snapping turtle. Copeia 1940: 131.

Pell, S.M. 1941. Notes on the habits of the common snapping turtle, Chelydra serpentina (Linn.) in central New York. M.S. Thesis, Ithaca, NY: Cornell University.

Petitt, K.E., C.A. Bishop, and R.J. Brooks. 1995. Home range and movements of the common snapping turtle, Chelydra serpentina serpentina, in a coastal wetland of Hamilton Harbour, Lake Ontario, Canada. Canadian Field Naturalist 109(2): 192-200.

Petokas, P.J. and M.M. Alexander. 1980. The nesting of Chelydra serpentina in northern New York. Journal of Herpetology 14:239-244.

Pettit, K.E., C.A. Bishop, and R.J. Brooks. 1995. Home range and movements of the common snapping turtle, Chelydra serpentina serpentina, in a coastal wetland of Hamilton Harbour, Lake Ontario, Canada. Canadian Field Naturalist 109(2): 192-200.

Phillips, C.A., W.W. Dimmick, and J.L. Carr. 1996. Conservation genetics of the common snapping turtle (Chelydra serpentina). Conservation Biology 10(2): 397-405.

Pisani, G.R. 2004. Chelydra serpentina (common snapping turtle) mating behavior. Journal of Kansas Herpetology 12:17.

Platt, T.R. 1988. Hapalorhynchus brooksi, new species (Trematoda: Spirorchiidae) from the snapping turtle (Chelydra serpentina), with notes on Hapalorhynchus gracilis and Hapalorhynchus stunkardi. Proceedings of the Helminthological Society of Washington 55(2): 317-323.

Porchuk, B.D. and R.J. Brooks. 1995. Coluber constrictor (blue racer), Elaphe vulpina (eastern fox snake) and Chelydra serpentina (snapping turtle). Reproduction. Herpetological Review 26(3): 148.

Pritchard, P.C.H. 1979a. Encyclopedia of turtles. T.F.H. Publications, Hong Kong.

Pryor, G.S. 1996. Observations of shorebird predation by snapping turtles in eastern Lake Ontario. Wilson Bulletin 108(1): 190-192. 
Punzo, F. 1975. Studies on the feeding behavior, diet, nesting habits and temperature relationships of Chelydra serpentina osceola (Chelonia: Chelydridae). Journal of Herpetology 9: 207-210.

Raney, E.C. and R.A. Josephson. 1954. Record of combat in the snapping turtle, Chelydra serpentina. Copeia 1954: 228.

Redmer, M. 1986. Herpetofauna observed by a CHS member in northern Minnesota. Chicago Herpetological Society Newsletter 1986:1

*Reichel, J.D. 1995. Preliminary amphibian and reptile survey of the Sioux District of the Custer National Forest: 1994. Montana Natural Heritage Program, Helena, MT. 75 p.

*Reichel, J.D. and D.L. Flath. 1995. Identification guide to the amphibians and reptiles of Montana. Montana Outdoors 26(3): 15-34.

Rhen, T. and J.W. Lang. 1994. Temperature-dependent sex determination in the snapping turtle: manipulation of the embryonic sex steroid environment. General and Comparative Endocrinology 96(2): 243-254.

Rhen, T. and J.W. Lang. 1995. Phenotypic plasticity for growth in the common snapping turtle: effects of incubation temperature, clutch, and their interaction. American Naturalist 146(5): 726-747.

Richmond, N.D. 1958. The status of the Florida snapping turtle, Chelydra osceola stejneger. Copeia 1958:41-43.

Robinson, C. and J.R. Bider. 1988. Nesting synchrony - a strategy to decrease predation of snapping turtle (Chelydra serpentina) nests. Journal of Herpetology 22(4): 470-473.

Roff, D.A. 1994. Evolution of dimorphic traits: Effect of directional selection on heritability. Heredity 72(1): 36-41.

Roh, B.R. 1994a. Chelydra serpentina serpentina (common snapping turtle). Herpetological Review 25(4): 162-163.

Saumure, R.A. 1996. Chelydra serpentina serpentina (common snapping turtle). Herpetological Review 27(3): 150.

Schuett, G.W. and R.E. Gatten. 1980. Thermal preference in snapping turtles (Chelydra serpentina). Copeia 1980: 149-152.

Schwab, D. 1988a. Field notes. Chelydra serpentina serpentina (common snapping turtle). Catesbeiana 8(2): 33.

Schwab, D. 1991. Chelydra serpentina serpentina (common snapping turtle). Catesbeiana 11(1): 19.

Scott, A.F. and E. Twombly. 1994. Pond-dwelling amphibians of Land Between The Lakes (Kentucky and Tennessee): a quantitative survey. Journal of the Tennessee Academy of Science 69(2): 52-58.

Shipman, P.A., D.R. Edds, and D. Blex. 1994. Macroclemys temminckii (alligator snapping turtle) and Chelydra serpentina (common snapping turtle). Agonistic behavior. Herpetological Review 25(1): 24-25.

Sims, P.A., G.C. Packard, and P.L. Chapman. 2001. The adaptive strategy for overwintering by hatchling snapping turtles (Chelydra serpentina). Journal of Herpetology 35(3): 514-517.

Sperger, R.H., R. Humphrey, D. Chiszar, and H.M. Smith. 1995a. Chelydra serpentina serpentina (common snapping turtle). Herpetological Review 26(1): 43.

*Stebbins, R.C. 2003. A field guide to western reptiles and amphibians. 3rd edition. New York, NY: Houghton Mifflin Co. 533 p. 
Stevenson, D. and D. Crowe. 1992a. Chelydra serpentina osceola (Florida snapping turtle). Herpetological Review 23(3): 87-88.

Steyermark, A.C. and J.R. Spoila. 2001. Effects of maternal identity and incubation temperature on hatching and hatchling morphology in snapping turtles, Chelydra serpentina. Copeia 2001(1): 129-135.

Storey, K.B. 1990. Life in a frozen state: adaptive strategies for natural freeze tolerance in amphibians and reptiles. American Journal of Physiology 258: R559-R568.

Street, H.M. 1989. Semipalmated sandpiper captured by turtle. Ontario Birds 7(2): 70.

Struger, J., J.E. Elliot, C.A. Bishop, M.E. Obbard, R.J. Norstrom, D.V. Weseloh, M. Simon, and P. Ng. 1993. Environmental contaminants in eggs of the common snapping turtle (Chelydra serpentina serpentina) from the Great Lakes-St. Lawrence River Basin of Ontario, Canada (1981,1984). Journal of Great Lakes Research 19(4): 681-694.

Stuart, J.N. 1995. Notes on aquatic turtles of the Rio Grande drainage, New Mexico. Bulletin of the Maryland Herpetological Society 31(3): 147-157.

Stuart, J.N. and C.S. Clark. 1991. Chelydra serpentina serpentina (common snapping turtle). Herpetological Review 22(4): 134.

Stuart, J.N. and C.W. Painter. 1988. Geographic distribution. Chelydra serpentina serpentina (common snapping turtle). Herpetological Review 19(1): 21.

Temple, S.A. 1987. Predation on turtle nests increases near ecological edges. Copeia 1987(1): 250-252.

Thorp, T.J. and L.S. Clark. 1994. Common snapping turtle eats duck eggs. Wilson Bulletin 106(2): 416.

Tobey, F.J. 1989a. Chelydra serpentina serpentina (common snapping turtle). Catesbeiana 9(2): 35.

Tuberville, T.D. and V.J. Burke. 1994. Do flag markers attract turtle nest predators? Journal of Herpetology 28(4): 514-516.

Tuberville, T.D., J.W. Gibbons, and J.L. Greene. Invasion of new aquatic habitats by male freshwater turtles. Copeia 3:713-715.

Tucker, J.K. 1994a. An "easy" method to remove common snapping turtles (Chelydra serpentina) from Legler hoop traps. Herpetological Review 25(1): 13.

Tucker, J.K. and F.J. Janzen. 1997. Incidence of twinning in turtles. Copeia 1997(1): 166-173.

Tucker, J.K. and J.T. Lamer. 2004. Another challenge in snapping turtle (Chelydra serpentina) conservation. Turtle and Tortoise Newsletter 8:10-11.

Ultsch, G.R. and D. Lee. 1983. Radiotelemetric observations of watering snapping turtles (Chelydra serpentes) in Rhode Island. Journal of the Alabama Academy of Science 54: 200206.

Upton, S.J., D.K. Odell, and M.T. Walsh. 1990. Eimeria caretta, new species (Apicomplexa: Eimeriidae) from the loggerhead sea turtle, Caretta caretta (Testudines). Canadian Journal of Zoology 68(6): 1268-1269.

*Vitt, L.J., J.P. Caldwell, and D.B. Shepard. 2005. Inventory of amphibians and reptiles in the Billings Field Office Region, Montana. Sam Noble Oklahoma Museum of Natural History and Department of Zoology, University of Oklahoma, Norman, OK. 33 p.

Vogt, R.C. and O. Flores-Villela. 1992. Effects of incubation temperature on sex determination in a community of Neotropical freshwater turtles in southern Mexico. Herpetologica 48(3): 265-270. 
*[VTNWI] VTN Wyoming Incorporated. No Date. Second year's analysis of terrestrial wildlife on proposed mine access and railroad routes in southern Montana and northern Wyoming, March 1979 - February 1980. VTN Wyoming Incorporated. Sheridan, WY. 62 p.

*Waage, B.C. 1998. Western Energy Company Rosebud Mine 1997 annual wildlife monitoring report December 1, 1996 to November 30, 1997 survey period. Western Energy Company, Colstrip, MT.

Walker, D., P.E. Moler, K.A. Buhlmann, and J.C. Avise. 1998. Phylogeographic uniformity in mitochondrial DNA of the snapping turtle (Chelydra serpentina). Animal Conservation 1: 55-60.

Walley, H.D. 1993. Chelydra serpentina (snapping turtle): Predation. Herpetological Review 24(4): 148-149.

Watermolen, D.J. 1990a. Chelydra serpentina (snapping turtle). Herpetological Review 21(1): 24.

Watermolen, D.J. 1990b. Chelydra serpentina (snapping turtle). Herpetological Review 21(2): 38.

Weidl, D.A. 1985. Wildlife observations along Saskatchewan’s Souris River 1978-1979. Blue Jay 43(4): 248-252.

Wermuth, H. and R. Martens. 1977. Liste der rezenten amphibien und reptilien: testudines, crocodilia, rhynchocephalia. Das Tierreich 100.

*Werner, J. K., B. A. Maxell, P. Hendricks, and D. L. Flath. 2004. Amphibians and reptiles of Montana. Mountain Press. Missoula, Montana. 262 p.

*Werner, J.K. and J.D. Reichel. 1996. Amphibian and reptile monitoring/survey of the Kootenai National Forest: 1995. Montana Natural Heritage Program, Helena, MT. 115 p.

*[WESTECH] Western Technology and Engineering Incorporated. 1998. Wildlife monitoring Absaloka Mine area 1997. Western Technology and Engineering, Inc., Helena, MT.

White, J.B. and G.G. Murphy. 1973. The reproductive cycle and sexual dimorphism of the common snapping turtle, Chelydra serpentina serpentina. Herpetologica 29: 240-246.

Whiting, M.J. and A.H. Price. 1994. Not the last picture show: New collection records from Paris, Texas (and other places). Herpetological Review 25(3): 130.

Wilhoft, D.C. 1986. Eggs and hatchling components of the snapping turtle (Chelydra serpentina). Comparative Biochemistry and Physiology A Comparative Physiology 84(3): 483-486.

Wilhoft, D.C., E. Hotaling and P. Franks. 1983. Effects of temperature on sex determination in the embryos of snapping turtles, Chelydra serpentina. Journal of Herpetology 17: 38-42

Wilhoft, D.C., M.G. Del Baglivo, and M.D. Del Baglivo. 1979. Observations on mammalian predation of snapping turtle nests. Journal of Herpetology 13: 435-438.

Will, B.D., D. Chiszar, and H.M. Smith. 1995. Testudines: Chelydra serpentina serpentina (common snapping turtle). Herpetological Review 26(4): 208.

Willey, J.S. and R.W. Blob. 2004. Tail kinematics of juvenile common snapping turtles during aquatic walking. Journal of Herpetology 38(3):360-369.

Williams, D. and A. Norden. 1992. An albino snapping turtle (Chelydra serpentina) from Calvert County, Maryland. Maryland Naturalist 36(1-2): 21-22.

Williamson, L.U., J.R. Spotila, and E.A. Standora. 1989. Growth, selected temperature, and CTM of young snapping turtles, Chelydra serpentina. Journal of Thermal Biology 14: 3339.

Wilson, A.K. 1994. Chelydra serpentina (snapping turtle). Herpetological Review 25(1): 32. 
Wilson, R. and A. Wilson. 1992. Adult mallard killed by snapping turtle. Passenger Pigeon 54(1):95.

Wood, J.T. 1953. Protective behavior and photic orientation in hatchling snapping turtles, Chelydra serpentina (Linne), in an aquatic environment. Journal of Elisha Mitchell Science Society 68: 54-59.

World Conservation Union. 1991. Tortoises and freshwater turtles: an action plan for their conservation. IUCN/SSC Tortoise and Freshwater Turtle Specialist Group, Gland, Switzerland.

Yntema, C.L. 1960. Effects of various temperatures on the embryonic development of Chelydra serpentina. Anatomical Record 136: 305-306.

Yntema, C.L. 1968. A series of stages in the embryonic development of Chelydra serpentina. Journal of Morphology 125: 219-251.

Yntema, C.L. 1970a. Observations on females and eggs of the common snapping turtle, Chelydra serpentina. American Midland Naturalist 84: 69-76.

Yntema, C.L. 1970b. Temperature levels and periods of sex determination during incubation of eggs of Chelydra serpentina. Journal of Morphology 159: 17-28.

Yntema, C.L. 1970c. Twinning in the common snapping turtle, Chelydra serpentina. Anatomical Record 166: 491-498.

Yntema, C.L. 1971. Incidence and survival of twin embryos of the common snapping turtle, Chelydra serpentina. Copeia 1971: 755-758.

Yntema, C.L. 1976. Effects of incubation temperatures on sexual differentiation in the turtle, Chelydra serpentina. Journal of Morphology 150: 453-462.

Yntema, C.L. 1978. Incubation times for eggs of the turtle Chelydra serpentina (Testudines: Chelydridae) at various temperatures. Herpetologica 34: 274-277.

Yntema, C.L. 1979. Temperature levels and periods of sex determination during incubation of eggs of Chelydra serpentina. Ibid. 159: 17-28.

Yntema, C.L. 1981. Characteristics of gonads and oviducts in hatchlings and young of Chelydra serpentina resulting from three incubation temperatures. Journal of Morphology 167: 297-304. 


\section{Painted Turtle (Chrysemys picta)}

Up-to-date distribution and status information can be found on the Montana Natural Heritage Program's TRACKER website at http://mtnhp.org

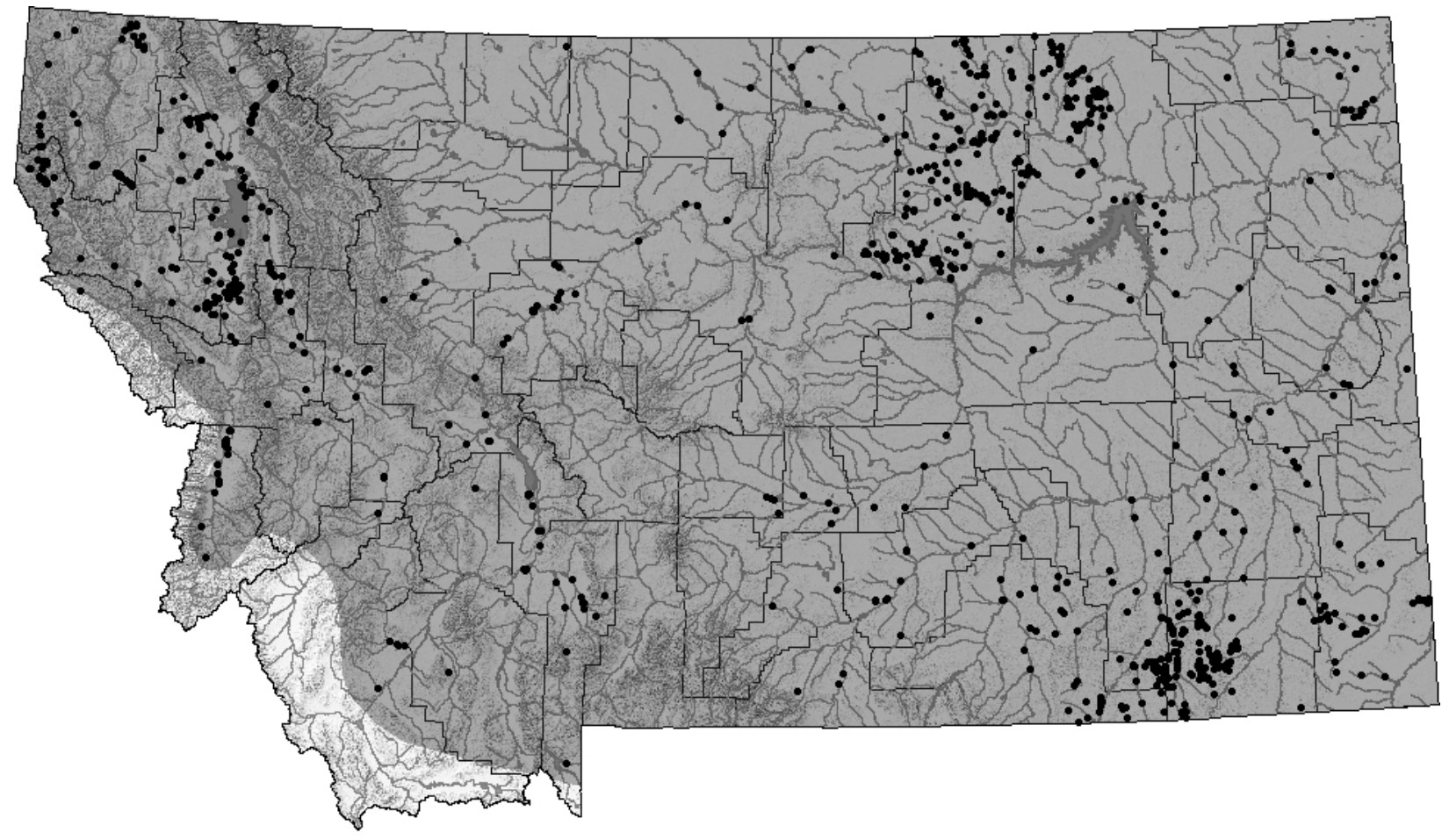

\section{Distribution/Taxonomy}

The western painted turtle (Chrysemys picta belli) in Montana is one of four subspecies of Chrysemys picta whose range extends across much of North America and southern Canada. The eastern painted turtle, C. p. picta, is generally found in southeastern Canada, the northeastern U.S. and into southeastern U.S.; the midland painted turtle, C. p. marginata is documented in a few mid-western states, the western painted turtle, C. p. belli is found in the western U.S. and Canadian provinces, and the southern painted turtle, C. p. dorsalis is generally located in the southcentral and southeastern U.S. states (NatureServe 2006). Chrysemys dorsalis (C.p. dorsalis) has been recognized as a distinct species from Chrysemys picta by Starkey et al. (2003) based upon molecular data. Disagreements on this point as a result of apparent intergrades in western Kentucky, southern Illinois, and southeastern Missouri leave the debate open if $C$. dorsalis is indeed conspecific with C. picta (NatureServe 2006). The painted turtle is found throughout Montana at lower elevations, with only a few counties in the central portion of the state lacking documented observations (Werner et al. 2004).

\section{Maximum Elevation}

1,993 m (6,539 ft) in Duck Creek Bay of Hebgen Reservoir in Gallatin County (Clint Sestrich, Adam Kehoe, and Kyle Salzman, MTNHP 2008).

\section{Identification}

Eggs:

Eggs are white, smooth, and oval, about $31 \mathrm{~mm}$ (1.2 in) long. Initially flexible, the shell gradually becomes firmer as water is absorbed (Ernst et al 1994, Werner et al. 2004). Clutch size 
can range from 6-21 eggs; eggs are laid in a nest dug into sandy, loamy, or other friable soil (Ernst et al. 1994, Russell and Bauer 2000). Nest digging and egg laying can take up to four hours (Ernst et al. 1994), after which the eggs are covered over with soil. Poor weather conditions, such as extreme heat or drought can delay nesting (Lindeman 1989, Ernst et al. 1994).

Juveniles and Adults:

The Painted Turtle is named for highly decorative yellow or reddish orange markings on its carapace and yellow markings on its legs, tail, and head. The plastron is a brilliant yellow or reddish-orange with a large olive, loosely symmetrical blotch in the center, while the carapace is mainly olive to black with more distinct yellow or reddish-orange markings along its outer edge. Striking yellow lines along the head and neck are distinctive for this species. Yellow markings on the fore and hind legs and tail are also present, but less obvious than those on the head. The plastron is a brilliant yellow or reddish-orange with a large olive, loosely symmetrical blotch in the center. Brighter than adults, juveniles are otherwise similar in coloration. Adult females are larger than males; carapace length can vary from 8-18 cm (3.2 to 7.1 inches) (Werner et al. 2004). Sexual maturity appears more a consequence of size in males (maturity occurs when plastron lengths of 70-95), rather than age, and enhanced growth can shorten the average age of maturity of four years to two (Ernst et al. 1994). Females generally mature at 6-10 years of age at which time their plastron length ranges from 97-128 mm (Ernst et al. 1994). Mature males have a flat plastron, long forefeet claws, and rear vent located beyond the edge of the carapace, while the forefeet claws of the female are relatively short with the vent located at or inside the rear edge of the carapace (Hammerson 1999). Juveniles are distinguishable by a deep crease in the abdominal plastron shields and hatchlings have a keeled carapace and vivid orange plastron (Hammerson 1999).

Similar Species:

Lacking the distinct bright coloration, it is unlikely other turtle species in the state would be confused with the Painted Turtle. The spiny softshell (Apalone spinifera) is smooth and creamy light brown in coloration with a relatively pointed head and flat pancake-like appearance. The snapping turtle (Chelydra serpentina) has a dark brown, grey, or black carapace without contrasting coloration patterns anywhere on the shell or body. The spiny softshell is found in the central and eastern portions of the state, along the Missouri and Yellowstone Rivers and their main tributaries; while the snapping turtle is limited to the central and southern portions of eastern Montana (Werner et al. 2004).

Habitat Use/Natural History

An animal of aquatic environments, the Painted Turtle prefers slow-moving shallow waterways (streams, marshes, ponds, lakes and creeks) with soft mud bottoms and aquatic vegetation. Partially submerged logs and rocks for basking are desirable habitat features. Painted turtles become active in late March or early April and may be observed basking on sun exposed banks, rocks, or logs in ponds, lakes, reservoirs, and streams. Nesting generally occurs from May until mid-July, with the majority of nesting activity in June and early July. Christens and Bider (1987) found a consistent correlation between the mean temperature of the previous year for the current year's nest initiation date for nests in Quebec, Canada. The flask-shaped nests are dug with the hind feet into rain-soaked soil, or soil sometimes softened with bladder water during digging 
(Ernst et al. 1994). Nests are placed in terrestrial habitats and may range up to 600 meters from water, where the eggs are left to incubate on their own (Ernst et al. 1994, Hammerson 1999). Nest placement and the associated microsite characteristics are important as the sex of the incubating eggs is determined by temperature (cooler temperatures produce males, warmer produce females). While females may lay up to three clutches of eggs in one breeding season, Iverson and Smith (1993) reported an unusual 4 clutches for two females. Tinkle (et al. 1981) estimated that $30-50 \%$ of females may not reproduce every year. Egg size and clutch size increase with female body size (Hammerson 1999).

The majority of nesting occurs during the afternoon hours, with a smaller proportion of nests initiated in the morning (Ernst et al. 1994). Nesting may occur early or late into the summer. Nests that hatch later in the breeding season may exhibit delayed emergence, e.g. the young overwinter in the nest. Even though Brettenbach et al. (1984) found greater survivorship of nests in Michigan if covered by a beneficial layer of snow, substantial mortality of overwintering hatchlings can occur (Nagle et al. 1999). Nest mortality (resulting from predation) can be high especially for those nests placed closer, rather than farther, from a water source (Christens and Bider 1987). In Christens and Bider’s (1987) study, hatchlings overwintering in the nest survived early predation, suggesting that open nests may trigger olfactory clues and make early predation more likely. Behaviorally, juveniles and hatchlings may differ from mature individuals in habitat use. In Michigan, Congdon (et al. 1992) found that the hatchlings and juveniles were found in more shallow areas of marsh habitat. This behavior could result from greater food resources available or an attempt to avoid the larger predators present in deeper water (Hammerson 1999). In addition to living and dead plants, painted turtles may consume a wide variety of living or dead organisms including: worms, leeches, insect larvae, pupae, and adults, as well as beetles, damselflies, dragonflies, water striders, water mites, spiders, mayflies, springtails, mosquitoes, crustaceans, snails, clams, frogs, and fish (Ernst et al. 1994, Hammerson 1999). In small marsh systems, the home range size may be very small (e.g., average of 1.2 ha in Michigan) (Rowe 2003), whereas in rivers, individual home range sizes are generally much larger (e.g., 7-26 km (MacCulloch and Secoy 1983, NatureServe 2006). This turtle species may colonize areas only seasonally wet, but must return to permanent waters for winter hibernation. Adult mortality can occur for individuals overwintering in areas prone to both drought and widely ranging winter temperatures. Christiansen and Bickham (1989) discovered more than 100 painted turtles frozen to death when the pond in which they were hibernating had frozen to the bottom.

\section{Status and Conservation}

The painted turtle is the most abundant turtle species in Montana; both the spiny softshell and snapping turtle have much smaller ranges, fewer recorded observations, and are more likely to be collected for harvest (Maxell and Hokit 1999, Werner et al 2004). At the time the comprehensive summaries of amphibians and reptiles in Montana (Maxell et al. 2003, Werner et al. 2004) were published, the painted turtle was documented in 41 counties, broadly distributed across both the western and eastern portions of the state. Counties absent of records are generally located in the central portion of the state. State records are comprised of 392 observations in 40 counties, with 60 museum voucher records from 19 counties. The distribution of this species reflects its relative abundance compared to the two other turtle species in Montana. Specific state status information on the painted turtle is not available for Montana. 
Global trends over the short term are identified as stable, and relatively stable over the long term (NatureServe 2006).

Studies identifying or addressing specific risk factors for $C$. serpentina in Montana are lacking; however, documented studies and other issues pertaining to their conservation include the following: (1) During the breeding season, females are quite sensitive to disturbance while on nesting forays; human activity (e.g. fishing) can disrupt nesting activity even from a distance (Hammerson 1999). (2) Artificially high mammalian predator numbers resulting from humanaugmented food resources can result in lower abundance of local turtle populations. While the raccoon (Procyon lotor) is the most detrimental native predator in all life stages of this turtle species (Ross 1988, Ernst 1994), other native predators of painted turtle nests include the thirteen-lined ground squirrel (Spermophilus tridecemlineatus), chipmunk (Tamias), squirrel (Sciurus), striped skunk (Mephitis mephitis), badger (Taxidea), coyote (Canis latrans), fox (Vulpes vulpes), raven (Corvus corax), garter snake (Thamnophis radix), and other snakes (Coluber). Hatchlings and small juveniles may fall prey to giant water beetles (Memiptera: Belostomatidae, Hammerson 1999). Young turtles are under threat of predation by muskrats (Ondatra), mink (Mustela), raccoon (Procyon lotor), snapping turtles (Chelydra), snakes (Coluber), bullfrog (Rana), large fish (Micropterus, Ictalurus), herons (Ardea), and water bugs (Hemiptera) (Ernst et al. 1994, Maxell and Hokit 1999). In addition to raccoons, adult turtles may be preyed upon by eagles (Haliaeetus), osprey (Pandion), and hawks (Buteo). (3) Fowle's (1996) mortality study in Montana reported most turtles found dead on the road occurring from late May to mid July consisted of $43 \%$ adult males, $26 \%$ adult females, and 31\% of unknown sex, including juveniles. Densities of adult turtles were positively correlated with pond distance from the highway, and proportionally more juveniles and fewer adults were found at ponds closest to the highway, implying that roadkill mortality may be killing proportionally more adults (Fowle 1996). (4) Ernst (1999) notes that, notwithstanding all of the potential wild predators, the greatest source of mortality for painted turtles is probably human caused: road kills, habitat destruction, pet trade, indiscriminate shooting and pesticide poisoning.

Research and Management Suggestions

1. More thorough documentation of painted turtle presence across its range in Montana is needed, especially in areas of high recreational use and those locations with the potential for residential and industrial development.

2. Studies of population dynamics in relation to highways and other roads within areas of known painted turtle populations are needed to identify species responses to these habitat perturbations and develop effective measures for mitigation of negative impacts, e.g. the installation of innovative structures such as amphibian-reptile walls and culverts to allow the safe passage of animals.

3. The impacts of motor vehicles and indiscriminate shooting should be examined where populations are found in close proximity to areas of high human use. This pertains especially to any areas where off-road vehicle use is permitted.

4. Studies investigating the impact of new energy production facilities that affect local water sources, i.e. coal bed methane, should be undertaken to identify impact on painted turtles (and other water-dependent fauna). 
Bibliography *indicates an article with information specific to Montana

Ackerman, R.A., R.C. Seagrave, R. Dmi'el, and A. Ar. 1985. Water and heat exchange between parchment-shelled reptile eggs and their surroundings. Copeia 1985(3): 703-711.

Almeida, V.M.F., L.T. Buck, and P.W. Hochachka. 1994. Substrate and acute temperature effects on turtle heart and liver mitochondria. American Journal of Physiology 266(3 PART 2): R858-R862.

Anderson, C. W. and J. Keifer. 1996. Extraretinal photoreceptors in the caudal mesencephalon of the turtle, Chrysemys picta. American Zoology 36(5): 74A.

*Anderson, M.E. 1977. Aspects of the ecology of two sympatric species of Thamnophis and heavy metal accumulation with the species. M.S. Thesis. Missoula, MT: University of Montana. 147 p.

Anderson, P.K. 1958. The photic responses and water-approach behavior of hatchling turtles. Copeia 1958: 211-215.

Andrews, K.D. 1996. An endochondral rather than a dermal origin for scleral ossicles in cryptodiran turtles. Journal of Herpetology 30(2): 257-260.

Ashe, V.M., D. Chiszar, and H.M. Smith. 1975. Behavior of aquatic and terrestrial turtles on a visual cliff. Chelonia 2(4): 3-7.

*Atkinson, E.C. and M.L. Atkinson. 2004. Amphibian and reptile survey of the Ashland and Sioux of the Custer National Forest with special emphasis on the Three-Mile Stewardship Area:2002. Marmot's Edge Conservation. 22 p.

Attaway, M.B., G.C. Packard, and M.J. Packard. 1996. Hatchling painted turtles survive only brief freezing of body fluids. American Zoology 36(5): 34A.

Babcock, H.L. 1933. The eastern limit of range for Chrysemys picta marginata. Copeia 1933(2): 101.

Baker, M.R. 1979. Serpinema/ spp. (Nematoda: camallanidae) from turtles of North America and Europe. Canadian Journal of Zoology 57(4): 934-939.

Balcombe, J.P., and L.E. Licht. 1986. Some aspects of the ecology of the midland painted turtle, Chrysemys picta marginata, in Wye Marsh, Ontario (Canada). Canadian Field Naturalist 9(3): 98-100.

Baldwin, E.A., M.N. Marchand, and J.A. Litvaitis. 2004. Terrestrial habitat use by nesting painted turtles in landscapes with different levels of fragmentation. Northeastern Naturalist 11(1): 41-48.

Barone, M.C. and F.A. Jacques. 1975. The effects of induced cold torpor and time of year on blood coagulation in Pseudemys scripta elegans and. Chrysemys picta belli. Comparative Biochemistry Physiology A 50(4): 717-721.

Bayless, L.E. 1975. Population parameters for Chrysemys picta in a New York pond. American Midland Naturalist 93(1):168-176.

Beall, R.J. and C.A. Privitera. 1973. Effects of cold exposure on cardiac metabolism of the turtle C. picta. American Journal of Physiology 224: 435-441.

Beane, J.C. and K.E. Douglass. Chrysemys picta picta (Eastern Painted Turtle). Predation. Herpetological Review 36:310.

Belmore, B. 1985. Early spring turtle observations in Massachusetts. Northern Ohio Association of the Herpetological Notes 12(7): 10.

*Benson, K.R. 1978. Herpetology of the Lewis and Clark expedition 1804-1806. Herpetological Review 9(3): 87-91. 
Bider, J.R. and W. Hoeck. 1971. An efficient and apparently unbiased sampling technique for population studies of painted turtles. Herpetologica 27(4): 481-484.

Birchard, G.F. and G.C. Packard. 1996. Heart rate during supercooling in hatchling turtles. American Zoology 36(5): 34A.

Birchard, G.F. and G.C. Packard. 1997. Cardiac activity in supercooled hatchlings of the painted turtle (Chrysemys picta). Journal of Herpetology 31(1): 166-169.

Bishop, S.C. and F.J.W. Schmidt. 1931. The painted turtles of the genus Chrysemys. Zoological Ser. Field. Museum of Natural History 18: 123-139.

Black, J.H. and A.H. Black. 1987. Western painted turtle in Grant County, Oregon. Great Basin Naturalist 47(2): 344.

*Black, J.H. and J.N. Black. 1971. Montana and its turtles. International Turtle and Tortoise Society 1971(May-July): 10-11, 34-35.

Blau, A. and A.S. Powers. 1989. Discrimination learning in turtle after lesions of the dorsal cortex or basal forebrain. Psychobiology 17(4): 445-449.

Bleakney, J.S. 1958. Postglacial dispersal of the turtle Chrysemys picta. Herpetologica 14: 101104.

*BLM. 1982. Moorhead baseline inventory - wildlife. Bureau of Land Management, Miles City District Office. Miles City, MT. 29 p.

Boback, S., L. Shelley, C. Montgomery, and J. Hobert, E. Bergman, B. Hill, S.P. Mackessy. 1996. Chrysemys picta bellii (western painted turtle). Herpetological Review 27(4): 210.

Boundy, J. 1991. A possible native population of the painted turtle, Chrysemys picta, in Arizona. Bulletin of Chicago Herpetology Society 26(2):33.

*Boundy, J. 2001. Herpetofaunal surveys in the Clark Fork Valley region, Montana. Herpetological Natural History 8: 15-26.

Bowen, K.D. and F.J. Janzen. Rainfall and depredation of nests of the painted turtle, Chrysemys picta. Journal of Herpetology 39(4):649-652.

Bowen, K.D., R.J. Spencer, and F.J. Janzen. 2005. A comparative study of environmental factors that affect nesting in Australian and North American freshwater turtles. Journal of Zoology (London) 267(4):397-404.

Braid, M.R. 1974. A Bal-Chatri trap for basking turtles. Copeia 1974(2):539-540.

Brettenbach, G.L., J.D. Congdon, and R.C. Van Loben Sels. 1984. Winter temperatures of Chrysemys picta nests in Michigan: effects on hatchling survival. Herpetologica 40(1): 7681.

Britson, C.A. and W.H.N. Gutzke. 1993. Antipredator mechanisms of hatchling freshwater turtles. Copeia 1993(2): 435-440.

Brockelman, W.Y. 1975. Competition, the fitness of offspring, and optimal clutch size. American Naturalist 109: 677-699.

Brooks, D.R. 1981. Raw similarity measures of shared parasites: an empirical tool for determining host phylogenetic relationships? Systems of Zoology 30(2): 203-207.

Brown, E.E. 1992. Notes on amphibians and reptiles of the western Piedmont of North Carolina. Journal of the Elisha Mitchell Scientific Society 108(1): 38-54.

*Brunson, R.B. 1955. Check list of the amphibians and reptiles of Montana. Proceedings of the Montana Academy of Sciences 15: 27-29.

*Brunson, R.B. and H.A. Demaree. 1951. The herpetology of the Mission Mountains, Montana. Copeia 1951: 306-308. 
Buck, L.T. and P.E. Bickler. 1995. Role of adenosine in nmda receptor modulation in the cerebral cortex of an anoxia-tolerant turtle (Chrysemys picta belli). Journal of Experimental Biology 198(7): 1621-1628.

Buck, L.T., P.W. Hochachka, A. Schoen, E. Gnaiger. 1993. Microcalorimetric measurement of reversible metabolic suppression induced by anoxia in isolated hepatocytes. American Journal of Physiology 265(5 PART 2): R1014-R1019.

Buck, L.T., S.C. Land, S.C., and P.W. Hochachka. 1993. Anoxia-tolerant hepatocytes: Model system for study of reversible metabolic suppression. American Journal Of Physiology 265(1 Part 2): R49-R56.

*Burroughs, R.D. 1961. The natural history of the Lewis and Clark expedition. Michigan State University Press. 340 p.

Bury, R.B. and D.J. Germano. 2003. Differences in habitat use by Blanding's Turtles (Emydoidea blandingii) and Painted Turtles (Chrysemys picta) in the Nebraska Sandhills. American Midland Naturalist 149(1): 241-244.

Bury, R.B., J.H. Wolfheim, and R.A. Luckenbach. 1979. Agonistic behavior in free-living painted turtles (Chrysemys picta belli). Biological Behavior 1979: 227-239.

*Butts, T.W. 1997. Mountain Inc. wildlife monitoring Bull Mountains Mine No. 1, 1996. Western Technology and Engineering. Helena, MT.

Cagle, F.R. 1937. Egg laying habits of the slider turtle (Pseudemys troosti), the painted turtle (Chrysemys picta) and the musk turtle (Sternotherus odoratus). Tennessee Academy of Science 12: 225-235.

Cagle, F.R. 1942. Turtle populations in southern Illinois. Copeia 1942(3): 155-162.

Cagle, F.R. 1954. Observations on the life cycles of painted turtles (genus Chrysemys). American Midland Naturalist 52: 225-235.

Cagle, K.D., G.C. Packard, K. Miller, and M.J. Packard. 1993. Effects of the microclimate in natural nests on development of embryonic painted turtles, Chrysemys picta. Functional Ecology 7(6): 653-660.

Callard, I.P. and V. Abrams-Motz. 1985. Hormonal regulation of myometrial activity in the turtle, Chrysemys picta. American Zoology 25(4): 117A.

Callard, I.P., E.V. Callard, V. Lance, and S. Eccles. 1976. Seasonal changes in testicular structure and function and the effects of gonadotropins in the freshwater turtle, Chrysemys picta. General Comparative Endocrinology 30: 347-356.

Callard, I.P., V. Lance, A.R. Salhanick, and D. Barad. 1978. The annual ovarian cycle of Chrysemys picta: correlated changes in plasma steroids and parameters of Vitellogenesis. General Comparative Endocrinology 35(1): 245-257.

Cameron, J.N. 1989. The respiratory physiology of animals. Oxford University Press, New York.

Carey, M.G. and K.B. Aubry. 1988. Geographic distribution. Chrysemys picta belli (western painted turtle). Herpetological Review 19(3): 61.

Carley, W.W. and I.P. Callard. 1980. Gonadotropin binding by ovarian tissues of the turtle Chrysemys picta. American Zoology 20(4): 792.

Case, D.J. and W.C. Scharf. 1985. Additions to the birds and land vertebrates of north Manitou Island. Jack-Pine Warber 63(1): 17-23.

Casper, G. 1987. New herpetological records for Wisconsin, USA. Bulletin of the Chicago Herpetological Society 22(5): 95. 
Chan, C.Y., J. Hounsgaard, and C. Nicholson. 1988. Effects of electric fields on transmembrane potential and excitability of turtle cerebellar Purkinje cells in vitro. Journal of Physiology (Cambridge) 402: 751-771.

*Cheek, W.K. 1995. Population and biomass estimation of turtles at Spring Meadow State Park, Helena, Montana. Undergraduate Honors Thesis. Carroll College, Helena, MT. 29 p.

Chiszar, D. and H.M. Smith. 1993a. Additions to the known herpetofauna of Banner County, Nebraska. Bulletin of the Chicago Herpetological Society 28(6): 118-119.

Chiszar, D. and H.M. Smith. 1993b. Chrysemys picta bellii (western painted turtle). Herpetological Review 24(4): 254.

Chiva, M., D. Kulak, and H.E. Kasinsky. 1989. Sperm basic proteins in the turtle Chrysemys picta: Characterization and evolutionary implications. Journal of Experimental Zoology 249(3): 329-333.

Christens, E. and J.P. Bider. 1986. Reproductive ecology of the painted turtle (Chrysemys picta marginata) in southwestern Quebec. Canadian Journal of Zoology 64: 914-920.

Christens, E. and J.P. Bider. 1987. Nesting activity and hatching success of the painted turtle (Chrysemys picta marginata) in southwestern Quebec. Herpetologica 43(1): 55-65.

Christiansen, J. 1986. North American reptiles. 1. Golden turtles (Chrysemys picta). Nordisk Herpetologisk Forening 29(2): 43-58.

Christiansen, J.L. and E.O. Moll. 1973. Latitudinal reproductive variation within a single subspecies of painted turtle, Chrysemys picta bellii. Herpetologica 29(2):152-163.

Christiansen, J.L. and J.W. Bickham. 1989. Possible historic effects of pond drying and winterkill on the behavior of Kinosternon flavescens and Chrysemys picta. Journal of Herpetology 23(1): 91-94.

Churchill, T.A. and K.B. Storey. 1991. Metabolic response to freezing by organs of hatchling painted turtles Chrysemys picta marginata and Chrysemys picta bellii. Canadian Journal of Zoology 69(12): 2978-2984.

Churchill, T.A. and K.B. Storey. 1992a. Natural freezing survival by painted turtles Chrysemys picta marginata and C. picta bellii. American Journal of Physiology 262(3)(ii): R530-R537.

Churchill, T.A. and K.B. Storey. 1992b. Natural freeze tolerance in painted turtle hatchlings: a metabolic assessment. Cryobiology 29(6): 760.

Churchill, T.A. and K.B. Storey. 1992c. Responses to freezing exposure of hatchling turtles Trachemys scripta elegans: Factors influencing the development of freeze tolerance by reptiles. Journal of Experimental Biology 167(0): 221-233.

Claussen, D.L. and P.A. Zani. 1991. Allometry of cooling, supercooling and freezing in the freeze-tolerant turtle Chrysemys picta. American Journal of Physiology 261(3 Part 2): R626R632.

Claussen, D.L. and Y. Kim. 1993. The effects of cooling, freezing, and thawing on cardiac and skeletal muscle of the turtle, Chrysemys picta. Journal of Thermal Biology 18(2):91-101.

Cochran, P.A. 1986. The herpetofauna of the Weaver Dunes, Wabasha County, Minnesota (USA). Prairie Naturalist 18(3): 143-150.

Cochran, P.A. 1987. Life history notes, Graptemys geographica (map turtle). Adult mortality. Herpetological Review 18(2): 37.

Cochran, P.A. 1988. Chrysemys picta (painted turtle). Herpetological Review 19(1): 21.

Cochran, P.A. 1992. New locality observations for some amphibians and reptiles in Wisconsin. Bulletin of the Chicago Herpetological Society 27(3): 64. 
Colt, L.C., R.A. Saumure, and S. Baskinger. 1995. First record of the algal genus Basicladia (Chlorophyta, Cladophorales) in Canada. Canadian Field Naturalist 109(4): 454-455.

Congdon, J.D. and D.W. Tinkle. 1982. Reproductive energetics of the painted turtle (Chrysemys picta). Herpetologica 38(1): 228-337.

Congdon, J.D. and J.W. Gibbons. 1985. Egg components and reproductive characteristics of turtles: Relationships to body size. Herpetologica 41(2): 194-205.

Congdon, J.D. and J.W. Gibbons. 1987. Morphological constraint on egg size: A challenge to optimal egg size theory? Proceedings of the National Academy of Sciences of the United States of America 84(12): 4145-4147.

Congdon, J.D. and R.E. Gatten. 1989. Movements and energetics of nesting Chrysemys picta. Herpetologica 45(1): 94-100.

Congdon, J.D., S.W. Gotte, and R.W. McDiarmid. 1992. Ontogenetic changes in habitat use by juvenile turtles, Chelydra serpentina and Chrysemys picta. Canadian Field Naturalist 106(2): 241-248.

Cooley, C.R., A.O. Floyd, A. Dolinger, and P.B. Tucker. 2003. Demography and diet of the painted turtle (Chrysemys picta) at high-elevation sites in south-western Colorado. Southwestern Naturalist 48(1): 47-53.

*Cooper, S.V., C. Jean, and P. Hendricks. 2001. Biological survey of a prairie landscape in Montana's glaciated plains. Report to the Bureau of Land Management. Montana Natural Heritage Program, Helena, MT. 24 pp. plus appendices.

*Cope, E.D. 1872. Report on the recent reptiles and fishes of the survey, collected by Campbell Carrington and C.M. Dawes. pp. 467-469. In: F.V. Hayden, Preliminary report of the United States geological survey of Montana and portions of adjacent territories; being a fifth annual report of progress. 538 pp. 42nd Congress, 2nd Session, House Executive Document Number 326. Serial 1520.

*Cope, E.D. 1875. Check-list of North American Batrachia and Reptilia; with a systematic list of the higher groups, and an essay on geographical distribution. U.S. National Museum Bulletin 1(1): 1-104.

*Corn, J. and P. Hendricks. 1998. Lee Metcalf National Wildlife Refuge bullfrog and painted turtle investigations: 1997. Montana Natural Heritage Program, Helena, MT. 20 p.

Costanzo, J.P. 1982. Heating and cooling rates of Terrapene ornate and Chrysemys picta in water. Biosensors and Bioelectronics 53(3):159-166. 8 p.

Costanzo, J.P., M.F. Wright, and R.E. Lee. 1990. Freeze tolerance and intolerance in hatchling turtles. Cryobiology 27(6): 678.

*Coues, E. and H.C. Yarrow. 1878. Notes on the herpetology of Dakota and Montana. Bulletin of the U.S. Geologic and Geographic Survey 4(1): 259-291.

Crawford, K.M. 1991a. The effect of temperature and seasonal acclimatization on renal function of painted turtles, Chrysemys picta. Comparative Biochemistry and Physiology A 99(3): 375-380.

Crawford, K.M. 1991b. The winter environment of painted turtles, Chrysemys picta: temperature, dissolved oxygen, and potential cues for emergence. Canadian Journal of Zoology 69(9): 2493-2498.

Crawford, K.M. 1994. Patterns of energy substrate utilization in overwintering painted turtles, Chrysemys picta. Biochemistry and Physiology A Comparative Physiology 109(2): 495-502. 
Crocker, C.E., R.A. Feldman, G.R. Ultsch, and D.C. Jackson. 2000. Overwintering behavior and physiology of eastern painted turtles (Chrysemys picta picta) in Rhode Island. Canadian Journal of Zoology 78(6): 936.

Cserr, H.F., M. DePasquale, and D.C. Jackson. 1988. Brain and cerebrospinal fluid ion composition after long-term anoxia in diving turtles. American Journal of Physiology 255(2)(Ii): R338-R343.

D'Allessandro, S.E. and C.H. Ernst. 1995. Additional geographical records for reptiles in Virginia. Herpetology Review 26(4):212-213.

Darrow, T.D. 1961. Food habits of western painted and snapping turtles in southeastern South Dakota and eastern Nebraska. M.S. Thesis, University of South Dakota, Vermillion.

Davis, J.D., and C.G. Jackson, Jr. 1973. Notes on the courtship of a captive male Chrysemys scripta taylori. Herpetologica 29: 62-64.

*Day, D., P.J. Farmer, and C.E. Farmer. 1989. Montco terrestrial wildlife monitoring report December, 1987 - July, 1989. Montco, Billings, MT, and Western Technology and Engineering, Inc. Helena, MT.

*[DCC] Decker Coal Company. 1998. 1997 Consolidated annual progress report. Decker Coal Company West, North and East Pits. Decker, MT.

DePari, J.A. 1996. Overwintering in the nest chamber by hatchling painted turtles, Chrysemys picta, in northern New Jersey. Chelonian Conservation Biology 2(1):5-12.

DeRosa, C.T. 1978. A comparison of orientation mechanisms in aquatic, semi-aquatic and terrestial turtles (Trionyx spinifer, Chrysemys picta and Terrapene c. carolina). Ph.D. Dissertation. Miami University 99p.

DeRosa, C.T. and D.H. Taylor. 1978. Sun-compass orientation in the painted turtle, Chrysemys picta (Reptilia, Testudines, Testudinidae). Journal of Herpetology 12(1): 25-28.

DeRosa, C.T. and D.H. Taylor. 1980. Homeward orientation mechanisms in three species of turtles (Trionyx spinifer, Chrysemys picta, and Terrapene carolina). Behavioral Ecology and Sociobiololgy 7(1):15-23.

DeRosa, C.T. and D.H. Taylor. 1982. A comparison of compass orientation mechanisms in three turtles (Trionyx spinifer, Chrysemys picta, and Terrapene carolina). Copeia 1982: 394399.

Dimond, M.T. 1979. Sex differentiation and incubation temperature in turtles. American Zoology 19(3): 981.

Dimond, M.T. 1983. Sex of turtle hatchlings as related to incubation temperature. Annual Reptile Symposium on Captive Propagation and Husbandry Proceedings 6 1982[1983]: 88101, illustr.

*Dood, A.R. 1980. Terry Badlands nongame survey and inventory final report. Montana Department of Fish, Wildlife, and Parks and Bureau of Land Management, Helena, MT. 70 p.

Drought, J.F. 1987. Chrysemys picta marginata (midland painted turtle). Herpetological Review 18(1): 21.

Dubois, W. 1982. Testis structure and function in the fresh water turtle Chrysemys picta. Ph.D. Dissertation, Boston University Graduate School. 205 p.

Dubois, W., J. Pudney, and I.P. Callard. 1988. The annual testicular cycle in the turtle, Chrysemys picta: a histochemical and electron microscopic study. General and Comparative Endocrinology 71(2): 191-204. 
Dunson, W.A. and H. Heatwole. 1986. Effect of relative shell size in turtles on water and electrolyte composition. American Journal of Physiology 250(6)(Ii): R1133-R1137.

*[EI] Econ Incorporated. 1984. Terrestrial wildlife inventory for the Lame Jones and Ismay coal lease tracts. Econ Incorporated. Helena, MT.

*Elrod, M.J. 1902. A biological reconnoissance in the vicinity of Flathead Lake. Bulletin of the University of Montana Number 10, Biological Series Number 3. pp. 89-182, + 27 plates.

Ernst, C.H. 1964. Social dominance and aggressiveness in a juvinile Chrysemys picta picta. Bulletin of the Philadelphia Herpetological Society 13: 18-19.

Ernst, C.H. 1967. Intergradation between the painted turtles Chrysemys picta picta and Chrysemys picta dorsalis. Copeia 1967: 131-136.

Ernst, C.H. 1970. The status of the painted turtle, Chrysemys picta, in Tennessee and Kentucky. Journal of Herpetology 4: 39-45.

*Ernst, C.H. 1971a. Chrysemys picta. Catalogue of American Amphibians and Reptiles: 106.1106.4.

Ernst, C.H. 1971b. Growth of the painted turtle, Chrysemys picta, in southeastern Pennsylvania. Herpetologica 27(2): 135-141.

Ernst, C.H. 1971c. Population dynamics and activity cycles of Chrysemys picta in southeastern Pennsylvania. Journal of Herpetology 5: 151-160.

Ernst, C.H. 1971d. Seasonal incidence of leech infestation on the painted turtle Chrysemys picta. Journal of Parasitology 57: 32.

Ernst, C.H. 1971e. Sexual cycles and maturity of the turtle, Chrysemys picta. Biology Bulletin 140(2): 191-200.

Ernst, C.H. 1972. Temperature-activity relationship in the painted turtle, Chrysemys picta. Copeia 1972(2): 217-222.

Ernst, C.H. 1974. Effects of Hurricane Agnes on a painted turtle population. Journal of Herpetology 8(3): 237-240.

*Ernst, C.H. 1988. Chrysemys. Catalogue of American Amphibians and Reptiles 438.1-438.8.

Ernst, C.H. and B.S. McDonald, Jr. 1989. Preliminary report on enhanced growth and early maturity in a Maryland population of painted turtles, Chrysemys picta. Bulletin of the Maryland Herpetological Society 25(4): 135-143.

Ernst, C.H. and E. M. Ernst. 1973. Biology of Chrysemys picta bellii in southwestern Minnesota. Journal of the Minnesota Academy of Science 38(2, 3): 77-80.

*Ernst, C.H. and E.M Ernst. 1971a. Chrysemys picta. Catalogue of American Amphibians and Reptiles 106: 1-106.

Ernst, C.H. and E.M. Ernst. 1971b. The taxonomic status and zoogeography of the painted turtle, Chrysemys picta, in Pennsylvania. Herpetologica 27(4) :390-396.

Ernst, C.H. and E.M. Ernst. 1980. Relationships between North American turtles of the Chrysemys complex as indicated by their Endoparasitic Helminths. Proceedings of the Biological Society in Washington 93(2): 339-345.

Ernst, C.H. and J.A. Fowler. 1977. Taxonomic status of the turtle, Chrysemys picta, in the Northern peninsula of Michigan. Proceedings of the Biological Society of Washington 90(3): 685-689.

*Ernst, C.H., J.E. Lovich, and R.W. Barbour. 1994. Turtles of the United States and Canada. Washington, D.C. Smithsonian Press. 578 p. 
Essner, R. and A.J. Hendershott. 1996. County records for reptiles and amphibians in Missouri found in the vertebrate museum at Southeast Missouri State University. Herpetology Review 27(4):218.

Etchberger, C.R., M.A. Ewert, B.A. Raper, and C.E. Nelson. 1992. Do low incubation temperatures yield females in painted turtles? Canadian Journal of Zoology 70(2): 391-394.

Evans, L.T. 1940a. Effects of light and hormones upon the activity of young turtles, Chrysemys picta. Biology Bulletin 79(2): 370-371.

Evans, L.T. 1940b. Effects of testosterone propionate upon social dominance in young turtles, Chrysemys picta. Biology Bulletin 79: 371.

*Farmer, P. 1980. Terrestrial wildlife monitoring study, Pearl area, Montana June, 1978 - May, 1980. Western Technology and Engineering, Inc. Helena, MT.

*Farmer, P. and S.B. Heath. 1987. Wildlife baseline inventory, Rock Creek study area, Sanders County, Montana. Western Technology and Engineering, Inc. Helena, MT.

Feder, M.E. 1983. The relation of air breathing and locomotion to predation on tadpoles, Rana berlandieri, by turtles. Physiological Zoology 56(4): 522-531.

Federal Highway Administration, United States Department of Transportation. Critter Crossings, Linking Habitats and Reducing Roadkill. Amphibian-reptile wall and culverts. http://www.fhwa.dot.gov/environment/wildlifecrossings/amphibin.htm

Fishbeck, D.W. and E.C. Bovee. 1993. Two new amoebae, Striamoeba sparolata n. sp. and Flamella tiara n. sp., from fresh water. Ohio Journal of Science 93(5): 134-139.

Foster, B.J., D.W. Sparks, and J.E. Duchamp. 2003. Urban herpetology I: New distribution records of amphibians and reptiles from Hendricks County, Indiana. Herpetological Review 34(4):395.

*Fowle S.C. 1996a. Effects of roadkill mortality on the western painted turtle (Chrysemys picta bellii) in the Mission Valley, western Montana. In: Evink G., D. Ziegler, P. Garrett, and J. Berry (eds). Highways and movement of wildlife: Improving habitat connections and wildlife passageways across highway corridors. Proceedings of the Florida Department of Transportation/Federal Highway Administration Transportation-Related Wildlife Mortality Seminar Apr 30-May 2, 1996. Orlando, Florida. P. 205-223.

*Fowle, S.C. 1996b. The painted turtle in the Mission Valley of western Montana. M.S. Thesis. University of Montana, Missoula. 101 p.

*Fowle, S.C. 1996c. The effects of roadkill mortality on the western painted turtle in the Mission Valley, Western Montana. Intermountain Journal of Sciences 2(2): 39.

*Fowle, S.C. 1996d. The painted turtle in the Mission Valley of western Montana. M.S. Thesis. University of Montana, Missoula, MT. $101 \mathrm{p}$.

*Franz, R. 1971. Notes on the distribution and ecology of the herpetofauna of northwestern Montana. Bulletin of the Maryland Herpetological Society 7: 1-10.

Frazer, N.B., J.W. Gibbons, and J.L. Greene. 1991. Growth, survivorship and longevity of painted turtles (Chrysemys picta) in a southwestern Michigan marsh. American Midland Naturalist 125: 245-258.

Frazer, N.B., J.W. Gibbons, and J.L. Greene. 1993. Temporal variation in growth rate and age at maturity of male painted turtles, Chrysemys picta. American Midland Naturalist 130: 314324.

Funk, G.D. and W.K. Milsom. 1987. Changes in ventilation and breathing pattern produced by changing body temperature and inspired carbon dioxide concentration in turtles. Respiration Physiology 67(1): 37-52. 
Gamache, N. 1989a. A season in the life of the turtle. Manitoba Naturalists Society Bulletin 14(1): 3, illustr.

Gamache, N. 1989b. Activity time allocation and diving behavior in the western painted turtle, Chrysemys picta bellii. M.S. Thesis. University Manitoba. 215p.

Ganzhorn, D. and P. Licht. 1983. Regulation of seasonal Gonadal cycles by temperature in the painted turtle, Chrysemys picta. Copeia 1983(2): 347-358.

Gapp, D.A. and J.M. Polak. 1983. The endocrine pancreas of the turtle, Chrysemys picta. American Zoology 23(4): 910.

Garbin, C.P. and J. Rowe. 1992. An initial study of hatchling food preferences and group feeding behaviors of four species of Nebraskan turtles. Bulletin of the Chicago Herpetolical Society 27(3):57-62.

*Gates, M.T. 2005. Amphibian and reptile baseline survey: CX field study area. Report to Billings and Miles City Field Offices of Bureau of Land Management. Maxim Technologies, Billings, MT. 28pp + Appendices.

Gatten, R.E. 1981. Anaerobic metabolism in freely diving painted turtles (Chrysemys picta). Jouranl of Experimental Zoology 216(3): 377-385.

Gee, R.J. 1988. The anterior nervous system in the praesoma of five species of the genus Neoechinorhynchus (Acanthocephala: Neoechinorhynchidae) from turtles. Canadian Journal of Zoology 66(4): 782-789.

Gelatt, T.S. and J.D. Kelley. 1995. Western painted turtles, Chrysemys picta bellii, basking on a nesting common loon, Gavia immer. Canadian Field Naturalist 109(4): 456-45.

Gemmell, D.J. 1970. Some observations on the nesting of the western painted turtle, Chrysemys picta belli, in northern Minnesota. Canadian Field Naturalist 84: 308-309.

Giannoukos, G., D.O. Toft, and I.P. Callard. 1991. Immunorecognition of progesterone receptors (pr) in the turtle, Chrysemys picta, by avian monoclonal antibodies. American Zoology 31(5): 13A.

Gibbons, J.W. 1967a. Population dynamics and ecology of the painted turtle, Chrysemys picta. Unpubl. Ph.D. Dissertation, Michigan State University, East Lansing, Michigan.

Gibbons, J.W. 1967b. Variation in growth rates in three populations of the painted turtle, Chrysemys picta. Herpetologica 23(4): 296-303.

Gibbons, J.W. 1968a. Food of the turtle, Chrysemys picta, in a polluted river. American Midland Naturalist 80: 559-562.

Gibbons, J.W. 1968b. Population structure and survivorship in the painted turtle, Chrysemys picta. Copeia 1968: 260-268.

Gibbons, J.W. 1968c. Reproductive potential, activity, and cycles in the painted turtle, Chrysemys picta. Ecology 49: 399-409.

Gibson, G. and J. McCracken. 1993. Turtles at the tip. Long Point Bird Observers Newsletter (Port Rowan, Ontario, Canada) 25(3):15.

*Gildart, R.C. and J. Wassink. 1982. Montana wildlife. Montana Geographic Series. Number three. Montana Magazine, Inc. Helena, MT. 128 p.

Gist, D.H., J.A. Michaelson, and J.M. Jones. 1990. Autumn mating in the painted turtle, Chrysemys picta. Herpetologica 46(3): 331-336.

Gist, D.H., R.A. Hess, and R.J. Thurston. 1992. Cytoplasmic droplets of painted turtle spermatozoa. Journal of Morphology 214(2): 153-158. 
Glass, M.L., R.G. Boutilier, and N. Heisler. 1985. Effects of body temperature on respiration, blood gases and acid-base status in the turtle Chrysemys picta bellii. Journal of Experimental Biology 114(0): 37-52.

Gordon, D.M. 1990. Geographic variation in painted turtles, Chrysemys picta, from eastern Ontario and southern Quebec (Canada). Canadian Field Naturalist 104(3): 347-353.

Gotte, S.W. 1992. Chrysemys picta picta (eastern painted turtle). Predation. Herpetological Review 23(3): 80.

Graf, V. 1973. De lange characteristics for the fresh-water turtle Chrysemys picta picta, and the pigeon Columba livia. Vision Research 13(10):1815-1822.

Graham, T.E. 1973. Temperature-photoperiod effects on diel locomotor activity and thermal selection in the turtles, Chrysemys picta (schneider), Clemmys guttata (schneider), and Sternotherus odoratus (latreille). Ph.D. Dissertation. University of Rhode Island 179p. 1972.

Graham, T.E. and V.H. Hutchison. 1978. Locomotor activity in Chrysemys picta: response to asynchronous cycles of temperature and photoperiod. Copeia 1978 (2): 364-367.

Graham, T.E. and V.H. Hutchison. 1979. Effect of temperature and photoperiod acclimatization on thermal preferences of selected freshwater turtles. Copeia 1979(1):165-169.

Grayson, K.L. and M.E. Dorcas. 2004. Seasonal temperature variation in the painted turtle (Chrysemys picta). Herpetologica 60(3):325-336.

*Greer, K.R. 1955b. Yearly food habits of the river otter in the Thompson Lakes Region, Northwestern Montana, as indicated by scat analysis. American Midland Naturalist 54: 299313.

Griffin, K.A. and D.H. Pletscher. 2006. Potential effects of highway mortality and habitat fragmentation on a population of painted turtles in Montana. Final Report to the Montana Department of Transportation and the U.S. Department of Transportation Federal Highway Administration. Missoula, MT: Wildlife Biology Program. 44 p. + Appendices.

Griffin, K.A. 2007. Spatial population dynamics of western painted turtles in a wetland ecosystem in northwestern Montana. Ph.D. Dissertation. Missoula, MT. Wildlife Biology Program. $221 \mathrm{p}$.

Grogan, W.L., Jr. and G.L. Williams. 1973. Notes on hatchling painted turtles, Chrysemys p. picta, from Maryland. Bulletin of the Maryland Herpetological Society 9(4):108-110.

Groves, J.D. 1983. Taxonomic status and zoogeography of the painted turtle Chrysemys picta (testudines: emydidae), in Maryland. American Midland Naturalist 109(2):274-279.

Gutzke, W.H.N. 1985. The influence of environmental factors on eggs and hatchlings of painted turtles (Chrysemys picta). Ph.D. Dissertation. Fort Collins, CO: Colorado State University 120p.

Gutzke, W.H.N. and G.C. Packard. 1985. Hatching success in relation to egg size in painted turtles (Chrysemys picta). Canadian Journal of Zoology 63(1): 67-70.

Gutzke, W.H.N. and G.C. Packard. 1986. Sensitive periods for the influence of the hydric environment on eggs and hatchlings of painted turtles (Chrysemys picta). Physiological Zoology 59(3): 337-343.

Gutzke, W.H.N., G.C. Packard, M.J. Packard, and T.J. Boardman. 1987. Influence of the hydric and thermal environments on eggs and hatchlings of painted turtles (Chrysemys picta). Herpetologica 43(3): 393-404.

Gutzke, W.H.N. and G.L. Paukstis. 1984. A low threshold temperature for sexual differentiation in the painted turtle. Copeia 1984: 546-547 
Hahn, M.E., A. Poland, E. Glover, and J.J. Stegeman. 1994. Photoaffinity labeling of the Ah receptor: Phylogenetic survey of diverse vertebrate and invertebrate species. Archives of Biochemistry and Biophysics 310(1): 218-228.

*Halm, J.B. 1930. Goofus birds. Montana Wildlife 3(5): 6-7.

Hammerson, G. A. 1999. Amphibians and reptiles in Colorado, second edition. University Press of Colorado. Niwot, Colorado. 484 pp.

Harding, J.H. and K. Latinen. 1982. Chrysemys picta (painted turtle). Coloration. Herpetology Review 13(1):19.

Harms, H.K., R.T. Paitz, R.M. Bowden, and F.J. Janzen. 2005. Age and season impact resource allocation to eggs and nesting behavior in the painted turtle. Physiological and Biochemical Zoology 78(6):966-1004.

Harris, C.G. 1983. A sighting of the western painted turtle from Morgan Creek, Killdeer badlands, Saskatchewan. Blue Jay 41(3):145.

Hart, D.R. 1980. Resource partitioning among louisiana turtles of the genus. Chrysemys. Ph.D. Dissertation. Tulane University. 126p.

Hart, D.R. 1982. Growth of painted turtles, Chrysemys picta, in Manitoba and Louisiana. Canadian Field Naturalist 96(2): 127-130.

*Hart, M.M., W.A. Williams, P.C. Thornton, K.P. McLaughlin, C.M. Tobalske, B.A. Maxell, D.P. Hendricks, C.R. Peterson, and R.L. Redmond. 1998. Montana atlas of terrestrial vertebrates. Montana Cooperative Wildlife Research Unit, The University of Montana. Missoula, Montana vii $+1302 \mathrm{p}$.

Hartman, W.L. 1958. Intergradation between two subspecies of painted turtle, genus Chrysemys. Copeia 1958: 261-265.

Hartweg, N. 1944. Spring emergence of painted turtle hatchlings. Copeia 1944: 20-22.

Hartweg, N. 1946. Confirmation of overwintering in painted turtles. Copeia 1946: 255.

*Hayden, F.V. 1858. Catalogue of the collections in geology and natural history, obtained by the expedition under command of Lieutenant G.K. Warren, Topographical Engineers. pp. 104-105. In: F.N. Shubert (1981) Explorer on the northern plains: Lieutenant Gouverneur K. Warren's preliminary report of explorations in Nebraska and Dakota, in the years 1855-'56'57. Engineer Historical Studies No. 2. Office of the Chief of Engineers, Washington, DC. $125 \mathrm{p}$.

*Hayden, F.V. 1863. On the geology and natural history of the upper Missouri. Transactions of the American Philosophical Society New Series 12(1): 1-218 (pages 177-178).

Hayes, F.E. 1986. Intraspecific kleptoparasitism and aggression in the midland painted turtle (Chrysemys picta marginata). Bulletin of the Marland Herpetological Society 22(4):175177.

*Hendricks, P. 1997. Lee Metcalf National Wildlife Refuge preliminary amphibian and reptile investigations: 1996. Montana Natural Heritage Program, Helena, MT. 21 p.

*Hendricks, P. 1999. Amphibian and reptile survey of the Bureau of Land Management Miles City District, Montana. Montana Natural Heritage Program, Helena, MT. 80 p.

*Hendricks, P. 2000. Amphibian and reptile survey of the Thompson Chain of Lakes. A report to the Montana Department of Fish, Wildlife, and Parks. Montana Natural Heritage Program, Helena, MT. $15 \mathrm{p}$.

*Hendricks, P. and J.D. Reichel. 1996a. Amphibian and reptile survey of the Bitterroot National Forest: 1995. Montana Natural Heritage Program, Helena, MT. 95 p. 
*Hendricks, P. and J.D. Reichel. 1996b. Preliminary amphibian and reptile survey of the Ashland District, Custer National Forest: 1995. Montana Natural Heritage Program, Helena, MT. $79 \mathrm{p}$.

*Hendricks, P. and J.D. Reichel. 1998. Amphibian and reptile survey on Montana refuges: 1996. Montana Natural Heritage Program, Helena, MT. 19 p.

Herbert, C.V. 1984. The physiological responses of the turtle, Chrysemys picta bellii, to apnea, as a function of temperature. Ph.D. dissertation, Brown University. 155 p.

Herbert, C.V. and D.C. Jackson. 1985a. Temperature effects on the responses to prolonged submergence in the turtle Chrysemys picta bellii. I. Blood acid-base and ionic changes during and following anoxic submergence. Physiological Zoology 58: 655-669.

Herbert, C.V. and D.C. Jackson. 1985b. Temperature effects on the responses to prolonged submergence in the turtle Chrysemys picta bellii. II. metabolic rate, blood acid-base and ionic changes, and cardiovascular function in aerated and anoxic water. Physiological Zoology 58: 670-681.

Ho, S., J. L'Italien, and I.P. Callard. 1980. Studies on reptilian yolk: Chrysemys vitellogenin and Phosvitin. Comparative Biochemisrty and Physiology B 65(1): 139-144.

Hoberg, T., and C. Gause. 1989. Reptiles \& amphibians of North Dakota. North Dakota Outdoors 55(1):7-18.

Holland, R.L. and H.M. Smith, and D. Chiszar. 1995. Testudines: Chrysemys picta bellii (western painted turtle). Herpetological Review 26(4): 209.

Holland, R.L., D. Chiszar, C. Ristau, and H.M. Smith. 1994. Chrysemys picta bellii (western painted turtle). Herpetological Review 25(4): 163.

Holliman, R.B., J.E. Fisher, and J.C. Parker. 1971. Studies on Spirorchis parvus (stunkard, 1923) and its pathological effects on Chrysemys picta picta. Journal of Parasitology 57(1): 71-77.

Holman, J.A. 1977. Comments on turtles of the genus Chrysemys gray. Herpetologica 33(3): 274-276.

Holman, J.A. 1986. Turtles from the Late Wisconsinan of west-central Ohio. American Midland Naturalist 116(1): 213-214.

Holman, J.A. and D.C. Fisher. 1993. Late Pleistocene turtle remains (Reptilia: Testudines) from southern Michigan. Michigan Academician 25(4): 491-499.

Holman, J.A. and J.N. Mcdonald. 1986. A late quaternary herpetofauna from Saltville, Virginia (USA). Brimleyana 0(12): 85-100.

Holman, J.A. and K.D. Andrews. 1994. North American Quaternary cold-tolerant turtles: Distributional adaptations and constraints. Boreas (Oslo) 23(1): 44-52.

Holman, J.A. and S.G. Clouthier. 1995. Pleistocene herpetofaunal remains from the East Milford mastodon site (ca. 70000-80000 BP), Halifax County, Nova Scotia. Canadian Journal of Earth Sciences 32(2): 210-215, illustr.

Hooper, D.F. 1992. Turtles, snakes and salamanders of east-central Saskatchewan. Blue Jay 50(2): 72-77.

*Hossack, B.R. and P.S. Corn. 2001. Amphibian survey of Medicine Lake National Wildlife Refuge Complex: 2001. USGS Northern Rocky Mountain Science Center, Aldo Leopold Wilderness Research Institute, Missoula, MT. 13 p.

Hossack, B.R., P.S. Corn, and D.S. Pilliod. 2005. Lack of significant changes in the herpetofauna of Theodore Roosevelt National Park, North Dakota, since the 1920s. American Midland Naturalist 154:423-432. 
*Hossack, B.R, D. Pilliod, and P.S. Corn. 2001a. Reptile and amphibian inventory at GrantKohrs Ranch National Historic Site and Little Bighorn Battlefield National Monument. USGS Northern Rocky Mountain Science Center, Aldo Leopold Wilderness Research Institute, Missoula, MT. 6 p.

*Hossack, B., D. Pilliod, and S. Corn. 2001b. Preliminary amphibian surveys of the National Bison Range, Lost Trail National Wildife Refuge, and Swan River National Wildlife Refuge: 2001. USGS Northern Rocky Mountain Science Center, Aldo Leopold Wilderness Research Institute, Missoula, MT. 15 p.

Hutchinson, V.H. and R.J. Kosh. 1965. The effect of photoperiod on the critical thermal maxima of painted turtles (Chrysemys picta). Herpetologica 20: 233-238.

Hutchison, V.H. and J. Maness. 1979. The role of behavior in temperature acclimation and tolerance in ectotherms. American Zoolologist 19(1): 367-384.

Iverson, J.B. 1982a. Biomass in turtle populations: a neglected subject. Oecologia 55(1): 6976.

Iverson, J.B. 1982b. Ontogenetic changes in relative skeletal mass in the painted turtle Chrysemys picta. Journal of Herpetologica 16(4): 412-414.

Iverson, J.B. and G.R. Smith. 1993. Reproductive ecology of the painted turtle (Chrysemys picta) in the Nebraska Sandhills and across its range. Copeia 1993(1): 1-21.

Iverson, J.B., C.P. Balgooyen, K.K. Byrd, and K.K. Lyddan. 1993. Latitudinal variation in egg and clutch size in turtles. Canadian Journal of Zoology 71: 2448-2461.

Jackson, D.C. 1987. Cardiovascular function in turtles during anoxia and acidosis: in vivo and in vitro studies. American Zoologist 27(1): 49-58.

Jackson, D.C., E.A. Arendt, K. Inman, R.G. Lawler, G. Panol, and J.S. Wasser. 1991. Phosphorus-31 NMR study of normoxic and anoxic perfused turtle heart during graded carbon dioxide and lactic acidosis. American Journal of Physiology 260(6 Part 2): R1130R1136.

Jackson, D.C., H. Shi, J.H. Singer, P.H. Hamm, R.G. Lawler. 1995. Effects of input pressure on in vitro turtle heart during anoxia and acidosis: A 31P-NMR study. American Journal of Physiology 268(3 PART 2): R683-R689.

Jackson, D.C., J.H. Singer, and P.T. Downey. 1991. Oxidative cost of breathing in the turtle Chrysemys picta bellii. American Journal of Physiology 261(5 Part 2): R1325-R1328.

Janzen, F.J. 1994a. Climate change and temperature-dependent sex determination in reptiles. Proceedings of the National Academy of Sciences of the United States of America 91(16): 7487-7490.

Janzen, F.J. 1994b. Vegetational cover predicts the sex ratio of hatchling turtles in natural nests. Ecology 75(6):1593-1599.

Janzen, F.J. and C.L. Morjan. 2002. Egg size, incubation temperature, and posthatching growth in Painted turtles (Chrysemys picta). Journal of Herpetology 36(2):308-311.

Janzen, F.J., G.L. Paukstis, and E.D. Brodie, III. 1992. Observations on basking behavior of hatchling turtles in the wild. Journal of Herpetology 26(2): 217-279.

Jennings, M.R. 1987. Status of the western painted turtle (Chrysemys picta bellii) in Arizona. Journal of the Arizona-Nevada Academy of Science 22(2): 129-133.

Johnson, C.A. 1968. Parasites of the gastrointestinal tract of aquatic turtles from Kuderna lake, Lee County, Alabama, and three new species of parasites from the southern United States and Mexico. M.S. Thesis, Auburn University 81 p. 
Johnson, R.M. 1954. The painted turtle, Chrysemys picta, in eastern Tennessee. Copeia 1954(4): 298-299.

Karch, A.P. and R.J. Brooks. 1999. Northern painted turtles (Chrysemys picta): simultaneously abundant and rare. Canadian Amphibian and Reptile Conservation Network.

Kepenis, V. and J.J. McManus. 1974. Bioenergetics of young painted turtles, Chrysemys picta. Comparative Biochemistry and Physiology 48A: 309-317.

Kingsmill, S. 1990. Room temperature. When its winter home freezes, so does the painted turtle. Nature Canada (Ottawa) 19(1): 11-12.

Knight, A.W. and J.W. Gibbons. 1968. Food of the painted turtle, Chrysemys picta, in a polluted river. American Midland Naturalist 80(2): 558-562.

Kofron, C.P. and A.A. Schreiber. 1987. Observations on aquatic turtles in a northeastern Missouri marsh. Southwestern Naturalist 32(4):517-521.

Kolbe, J.J. and F.J. Janzen. 2002. Spatial and temporal dynamics of turtle nest predation: edge effects. - Oikos 99: 538-544.

Koper, N. and R.J. Brooks. 2000. Environmental constraints on growth of painted turtles (Chrysemys picta) in northern climates. Herpetologica 56(4): 421.

Lefevre, K. and R.J. Brooks. 1995. Effects of sex and body size on basking behavior in a northern population of the painted turtle, Chrysemys picta. Herpetologica 51(2): 217-224.

Legler, J.M. 1954. Nesting habits of the western painted turtle, Chrysemys picta bellii (Gray). Herpetologica 10: 137-144.

Leuteritz, T.E. and C.J. Manson. 1996. Preliminary observations on the effects of human perturbation on basking behavior in the midland painted turtle (Chrysemys picta marginata). Bulletin of the Maryland Herpetological Society 32(1): 16-23.

Licht, P., G.L. Breitenbach, and J.D. Congdon. 1985. Seasonal cycles in testicular activity, gonadotropin and thyroxine in the painted turtle, Chrysemys picta, under natural conditions. General and Comparative Endocrinology 59(1): 130-139.

Lindeman, P.V. 1988. Comparative life history of the painted turtle, Chrysemys picta, in the inland Pacific Northwest. M.S. Thesis, University of Idaho, Moscow, Idaho.

Lindeman, P.V. 1989. Chrysemys picta belli (western painted turtle). Egg retention. Herpetological Review 20(3): 69.

Lindeman, P.V. 1990a. Chrysemys picta bellii (western painted turtle). Herpetology Review 21(2):38-39.

Lindeman, P.V. 1990b. Closed and open model estimates and tests of model assumptions for two populations of the turtle, Chrysemys picta. Journal of Herpetology 24: 78-81.

Lindeman, P.V. 1991. Survivorship of overwintering hatchling painted turtles, Chrysemys picta, in northern Idaho (USA). Canadian Field Naturalist 105(2): 263-266.

Lindeman, P.V. 1992. Nest-site fixity among painted turtles (Chrysemys picta) in northern Idaho. Northwestern Naturalist 73(1): 27-30.

Lindeman, P.V. 1993. Aerial basking by hatchling freshwater turtles. Herpetological Review 24(3): 84-87.

Lindeman, P.V. 1996. Comparative life history of painted turtles (Chrysemys picta) in two habitats in the inland Pacific Northwest. Copeia 1996: 114-130.

Lindeman, P.V. 1997. Does life-history variation in the turtle Chrysemys picta have a subspecific component? Journal of Herpetology 31(1): 155-161. 
Lindeman, P.V. and F.W. Rabe. 1990. Effect of drought on the western painted turtle, Chrysemys picta belli, in a small wetland ecosystem. Journal of Freshwater Ecology 5(3): 359-364.

Lindeman, P.V., and A. F. Scott. 2001. Over three decades of persistence of a small and apparently isolated population of painted turtles (Chrysemys picta) in a Kentucky reservoir. Chelonian Conservation and Biology 4:206-208.

Linderman, P.V. 1988. Comparative life history of the painted turtle, Chrysemys picta, in the inland Pacific Northwest. M.S. Thesis. Moscow: ID: University of Idaho. 102 p.

Litwin, S.C. 1975a. Aggressive behavior during basking in Chrysemys picta. 55th Annual Meeting of the American Society of Ichthyology and Herpetology: 50.

Litwin, S.C. 1975b. Basking activity in the Eastern painted turtle, Chrysemys picta picta. M.S. Thesis. New Brunswick, NJ: Rutgers University.

Livo, L.J. 1996. Shell game. Colorado Outdoors 45(5): 16-20.

Lovich, J.E. 1988. Aggressive basking behavior in eastern painted turtles (Chrysemys picta picta). Herpetologica 44(2): 197-202.

Lovich, J.E. 1990. Gaping behavior in basking eastern painted turtles. Journal of the Pennsylvania Academy of Science 64(2): 78-80.

Lowell, W.R. 1990. Aerobic metabolism and swimming energetics of the painted turtle, Chrysemys picta. Experimental Biology (Berlin) 48(6): 349-355.

Macartney, J.M. and P.T. Gregory. 1985. The western painted turtle in Kikomun Creek Provincial Park. Report, submitted to Parks Branch, British Columbia, Canada.

MacCulloch, R. D. and D. M. Secoy. 1983. Movement in a river population of Chrysemys picta belli in southern Saskatchewan. Journal of Herpetology 17: 283-285.

MacCulloch, R.D. 1980. Some aspects of the ecology of the western painted turtle, Chrysemys picta belli (gray), in southern Saskatchewan, with reference to movement and growth. M.S. Thesis. University of Regina.

MacCulloch, R.D. 1981. Variation in the shell of Chrysemys picta belli from southern Saskatchewan. Journal of Herpetology 15(2):181-185.

MacCulloch, R.D. and D.M. Secoy. 1983. Demography, growth, and food of western painted turtles, Chrysemys picta belli (gray), from southern Saskatchewan. Canadian Journal of Zoology 61(7): 1499-1509.

Maginniss, L.A., S.S. Tapper, and L.S. Miller. 1983. Effect of chronic cold and submergence on blood oxygen transport in the turtle, Chrysemys picta. Respiration Physiology 53(1): 1529.

Mahmoud, I.Y. 1968. Nesting behavior in the western painted turtle, Chrysemys picta belli. Herpetologica 24: 158-162.

Mak, P., S. Ho, and I.P. Callard. 1983. Characterization of an estrogen receptor in the turtle testis. General Comparative Endocrinology 52(2): 182-189.

Makris, V. and A.J. Rotermund. 1989. High energy organophosphate levels in the myocardia of cold acclimated and cold-hypoxic freshwater turtles, Chrysemys picta. Comparative Biochemistry and Physiology A 92(2): 259-262.

*Manville, R.H. 1957. Amphibians and reptiles of Glacier National Park, Montana. Copeia 1957: 308-309.

Manwell, C. and C.V. Schlesinger. 1966. Polymorphism of turtle hemoglobin and geographical differences in the frequency of variants of Chrysemys picta "slow" hemoglobin - an example of "temperature anti-adaptation?" Comparative Biochemistry and Physiology 18: 627-637. 
Marchand, M.N. and J.A. Litvaitis. 2004. Effects of habitat features and landscape composition on the population structure of a common aquatic turtle in a region undergoing rapid development. Conservation Biology 18:758-767.

*Marnell, L.F. 1997. Herpetofauna of Glacier National Park. Northwestern Naturalist 78: 17-33.

*Martin, P.R. 1980a. Terrestrial wildlife habitat inventory in southeastern Montana. Montana Department of Fish, Wildlife and Parks and Bureau of Land Management, Helena MT. 114 p.

*Martin, P.R. 1980b. Terrestrial wildlife inventory in selected coal areas of Montana. Montana Department of Fish, Wildlife and Parks and Bureau of Land Management, Helena, MT. 84 p.

*Martin, P.R., K. Dubois, and H.B. Youmans. 1981. Terrestrial wildlife inventory in selected coal areas, Powder River resources area final report. Montana Department of Fish, Wildlife and Parks and Bureau of Land Management, Helena, MT. 288 p.

Mason, E.B. 1977. Serum thyroxine levels in Chrysemys picta marginata (Reptilia, Testudines, Testudinidae) exposed to different thermal environments. Journal of Herpetological 11(2): 232-234.

*Matthews, W.L. 1979. Wibaux-Beach wildlife baseline study - nongame species. Bureau of Land Management, Miles City, MT. 93 p.

*Matthews, W.L. 1980. Wibaux-Beach comparison study: Sydney, Glendive and Plevna Study Areas. Bureau of Land Management, Miles City, MT. 50 p.

*Matthews, W.L. 1981. Broadus-Pumpkin Creek baseline inventory - wildlife. Bureau of Land Management, Miles City, MT. 83 p.

Maurer, E.F. 1995. Chrysemys picta belli (western painted turtle). Feeding behavior. Herpetology Review 26(1):34.

Maurer, E.F. 1995. Testudines: Chrysemys picta belli (Western Painted Turtle). Feeding Behavior. Herpetological Review 26(1): 34.

*Maxell, B.A. 2002. Amphibian and aquatic reptile inventories in watersheds in the South and Middle Forks of the Flathead River drainage that contain lakes being considered for application of piscicides and subsequent stocking of west slope cutthroat trout. Report to the Region 1 Office of the U.S. Forest Service and the Montana Department of Fish, Wildlife, and Parks. Missoula, MT: Montana Cooperative Wildlife Research Unit and Wildlife Biology Program, University of Montana. 62 p.

*Maxell, B.A. 2004a. Amphibian and aquatic reptile inventories conducted on and around the Bitterroot National Forest 2000-2003. Report to Region 1 Office of the U.S. Forest Service, Bitterroot National Forest, Montana Department of Fish, Wildlife, and Parks, and Biological Resources Division of the U.S. Geological Survey. Missoula, MT: Montana Cooperative Wildlife Research Unit and Wildlife Biology Program, University of Montana. 128 p.

*Maxell, B.A. 2004b. Amphibian and aquatic reptile inventories conducted on and around the Thompson River 2003-2004. Report to Region 1 Office of the U.S. Forest Service and Plum Creek Timber Company. Missoula, MT: Montana Cooperative Wildlife Research Unit and Wildlife Biology Program. 83 p.

*Maxell, B.A. 2004c. Preliminary report on amphibian and aquatic reptile inventories conducted in the West Boulder River area during summer 2003. Report to Region 1 Office of the U.S. Forest Service, and the Montana Department of Fish, Wildlife, and Parks. Missoula, MT: Montana Cooperative Wildlife Research Unit and Wildlife Biology Program, University of Montana. 27 p. 
*Maxell, B.A. 2004d. Preliminary report on amphibian and aquatic reptile inventories conducted on and around the Ashland District of the Custer National Forest in 2002 and 2004. Report to Ashland District of Custer Forest, Region 1 Office of the U.S. Forest Service, and Montana Department of Fish, Wildlife, and Parks. Missoula, MT: Montana Cooperative Wildlife Research Unit and Wildlife Biology Program, University of Montana. $93 \mathrm{p}$.

*Maxell, B.A. 2004e. Report on amphibian and aquatic reptile inventories conducted on and around the Beaverhead-Deerlodge National Forest 2001-2003. Report to Region 1 Office of the U.S. Forest Service, Beaverhead-Deerlodge National Forest, Montana Department of Fish, Wildlife, and Parks, Montana State Office of the Bureau of Land Management, and Montana Department of Environmental Quality. Missoula, MT: Montana Cooperative Wildlife Research Unit and Wildlife Biology Program, University of Montana. 260 p.

*Maxell, B.A. 2005. Amphibian and aquatic reptile inventories conducted on and around lands administered by the Missoula Field Office of the Bureau of Land Management. Report to Missoula Field Office of the Bureau of Land Management. Montana Natural Heritage Program, Helena, MT and Montana Cooperative Wildlife Research Unit and Wildlife Biology Program, University of Montana, Missoula, MT. 53 p.

*Maxell, B.A. 2006. Evaluation of Montana's lentic breeding amphibian survey methodology and variables correlated with species occupancy. Report to Montana Department of Environmental Quality. Montana Natural Heritage Program, Helena, MT and Montana Cooperative Wildlife Research Unit and Wildlife Biology Program, University of Montana, Missoula, MT. 49 p.

*Maxell, B.A. 2009. State-wide assessment of status, predicted distribution, and landscapelevel habitat suitability of amphibians and reptiles in Montana. Ph.D. Dissertation. Missoula, MT: Wildlife Biology Program, University of Montana. 294 p.

*Maxell, B.A. and D.G. Hokit. 1999. Amphibians and reptiles. Pp. 2.1- 2.30. In: G. Joslin and H. Youmans (committee chairs). Effects of recreation on Rocky Mountain wildlife: a compendium of the current state of understanding in Montana. Helena, MT: Committee on Effects of Recreation on Wildlife, Montana Chapter of the Wildlife Society. 307 p.

*Maxell, B.A., J.K. Werner, P. Hendricks, and D.L. Flath. 2003. Herpetology in Montana: a history, status summary, checklists, dichotomous keys, accounts for native, potentially native, and exotic species, and indexed bibliography. Northwest Fauna Number 5. 138 p.

McAlpine, D.F. and G. Godin. 1986. New records of snapping turtles, Chelydra serpentina, and painted turtles, Chrysemys picta, from New Brunswick. Canadian Field Naturalist 100(1):63-68.

McAuliffe, J.R. 1975. A preliminary report on some aspects of the life history of the western painted turtle (/Chrysemys picta belli/) in Douglas County, Nebraska. Proceedings of the Nebraska Academy of Science 85: 17-18.

McAuliffe, J.R. 1978. Seasonal migrational movements of a population of the western painted turtle, Chrysemys picta bellii (Reptilia, Testudines, Testudinae). Journal of Herpetology 12(2): 143-149.

*McEneaney, T. and J. Jensen. 1974. The reptiles and amphibians of the Charles M. Russell National Wildlife Range - 1974. Charles M. Russell National Wildlife Refuge. Lewistown, MT. 3 p.

McKenna, K.C. 2001. Chrysemys picta (painted turtle) trapping. Herpetological Review 32(3): 184. 
Meseth, E.H. and O.J. Sexton. 1963. Response of painted turtles, Chrysemys picta, to removal of surface vegetation. Herpetologica 19: 52-56.

Midtgaard, J. 1992a. Membrane properties and synaptic responses of Golgi cells and stellate cells in the turtle cerebellum in vitro. Journal of Physiology (Cambridge) 457: 329-354.

Midtgaard, J. 1992b. Stellate cell inhibition of Purkinje cells in the turtle cerebellum in vitro. Journal of Physiology (Cambridge) 457: 355-367.

*Miller, J.D. 1975. Interspecific food relationships of anurans in northwestern Montana and fluoride accumulation in amphibians and reptiles in northwestern Montana. M.S. Thesis, University of Montana, Missoula, MT. 105 p.

Milsom, W.K. 1979. Pulmonary receptors and their role in the control of breathing in turtles. Ph.D. dissertation, University British Columbia.

Milsom, W.K. and P. Chan. 1986. The relationship between lung volume, respiratory drive and breathing pattern in the turtle, Chrysemys picta. Journal of Experimental Biology 120(0): 233-248.

Mitchell, J.C. 1981. Some aspects of the population ecology of the freshwater turtles Chrysemys picta and Sternotherus odoratus in Virginia. Virginia Journal of Science 32(3): 96.

Mitchell, J.C. 1982. Population ecology and demography of the freshwater turtles Chrysemys picta and Sternotherus odoratus. Ph.D. dissertation, University of Tennessee 173p. 1982.

Mitchell, J.C. 1984. Female reproductive cycles in syntopic populations of the freshwater turtles Chrysemys picta and Sternotherus odoratus in Central Virginia. Virginia Journal of Sciences 35(2):86.

Mitchell, J.C. 1985a. Female reproductive cycle and life history attributes in a Virginia (USA) population of painted turtles, Chrysemys picta. Journal of Herpetology 19(2): 218-226.

Mitchell, J.C. 1985b. Variation in the male reproductive cycle in a population of painted turtles, Chrysemys picta, from Virginia (USA). Herpetologica 41(1): 45-51.

Mitchell, J.C. 1988. Population ecology and life histories of the freshwater turtles Chrysemys picta and Sternotherus odoratus in an urban lake. Herpetological Monographs 2: 40-61.

Mitchell, J.C. 1990. Movement patterns of two species of freshwater turtles in an urban Virginia Lake. Virginia Journal of Science 41(2):57.

Mitchell, J.C. and B.V. Mcavoy. 1990. Enteric bacteria in natural populations of freshwater turtles in Virginia (USA). Virginia Journal of Science 41(3): 233-242.

Moll, D.L. 1974. Notes on the behavior of Isle Royale painted turtles(Chrysemys picta bellii). Journal of Herpetology 8(3): 254-255.

Moll, E.O. 1973. Latitudinal and intersubspecific variation in reproduction of the painted turtle, Chrysemys picta. Herpetologica 29(4):307-318.

Monagas, W.R. and R.E. Gatten. 1983. Behavioural fever in the turtles Terrapene Carolina and Chrysemys picta. Journal of Thermal Biology 8(3): 285-288.

Morjan, C.L. and N. Valenzuela. 2001. Is ground-nuzzling by female turtles associated with soil surface temperatures? Journal of Herpetology 35(4): 668-672.

Morlock, H., S. Herrington, and M. Oldham. 1972. Weight loss during food deprivation in the eastern painted turtle, Chrysemys picta picta. Copeia 1972(2): 392-394.

Motz, V.A. 1986. Regulation of the reproductive tract in the fresh water turtle, Chrysemys picta: role of ovarian steroids, relaxin and Arginine vasotocin. Ph.D. dissertation, Boston University. 
Motz, V.A. and I.P. Callard. 1988. Seasonal variations in oviductal activity, extensibility, and tensile strength in Chrysemys picta. General and Comparative Endocrinology 72(3): 453460.

Motz, V.A. and I.P. Callard. 1991. Seasonal variations in oviductal morphology of the painted turtle, Chrysemys picta. Journal of Morphology 207(1): 59-72.

*Moulton, G. (ed.). 1983. The journals of the Lewis and Clark expedition. University of Nebraska Press. Lincoln, Nebraska. Volumes 4, 5, 8, 9 and 10.

Muir, J.H. 1989. A description of the painted turtles (Chrysemys picta ssp.) from Town Creek, Jackson County, Alabama. Bulletin of the Chicago Herpetological Society 24(1): 9-10, illustr.

Musacchia, X.J. and M.L. Sievers. 1956. Effect of induced cold torpor on the blood of Chrysemys picta. American Journal of Physiology 187: 99-102.

Nagle, R.D., O.M. Kinney, J.D. Congdon, and C.W. Beck. 2000. Winter survivorship of hatching painted turtles (Chrysemys picta) in Michigan. Canadian Journal of Zoology 78(2): 226-233.

NatureServe. 2006. NatureServe Explorer: An online encyclopedia of life [web application]. Version 4.7 . NatureServe, Arlington, Virginia. Available: http://www.natureserve.org/explorer. (Accessed: March 20, 2006 ).

*[NDTI] Northrop, Devine, and Tarbell Incorporated. 1994. Cabinet Gorge and Noxon Rapids hydroelectric developments 1993 wildlife study. Northrop, Devine, and Tarbell Incorporated, Portland, ME. 197 p.

Nichols, J.T. 1933. Further notes on painted turtles. Copeia 1933: 41-42.

Nicol, S.C., M.L. Glass, and N. Heisler. 1983. Comparison of directly determined and calculated plasma bicarbonate concentration in the turtle Chrysemys picta bellii at different temperatures. Journal of Expimental Biology 107: 521-525.

Nijs, J. 1993. Resistance of the eggs of the southern painted turtle, Chrysemys picta dorsalis, to experimental low temperatures. Bulletin of the Chicago Herpetological Society 28(8): 165166.

Nijs, J. 1994. A further experiment on the resistance to cooling of freshly laid eggs of Chrysemys picta dorsalis. Bulletin of the Chicago Herpetological Society 29(12): 268.

Nijs, J. 1995. An incubator with daily temperature fluctuations: a better way to incubate eggs from turtles with temperature-dependent sex determination. Bulletin of the Chicago Herpetological Society 30(7): 141-144.

Norman, M.D. 1989. Preliminary survey of the freshwater turtles of the Blackwater River. Catesbeiana 9(1): 9-14.

Northcutt, R.G. 1968. The telencephalon of the western painted turtle (Chrysemys picta belli). Ph.D. dissertation, University of Illinois (Urbana-Champaign). 170 p.

*[OEAR] Olson Elliot and Associates Research. 1985. 1983-1984 Wildlife monitoring report for the CX Ranch project. Olson Elliot and Associates Research. Helena, MT.

Olson, J.M. 1984. Effect of seasonal acclimatization on metabolic enzyme activity in Chrysemys picta marginata. American Zoology 24(3): 97A.

Olson, J.M. 1987. The effect of seasonal acclimatization on metabolic-enzyme activities in the heart and pectoral muscle of painted turtles Chrysemys picta marginata. Physiological Zoology 60(1): 149-158. 
Olson, J.M. and K.M. Crawford. 1989. The effect of seasonal acclimatization on the buffering capacity and lactate dehydrogenase activity in tissues of the freshwater turtle Chrysemys picta marginata. Journal of Experimental Biology 145: 471-476.

Olson, R.E. 1987. Minnesota herpetological records. Bulletin of the Maryland Herpetological Society 23(3): 101-104.

Owen, P.J. and M.R. Wells. 1976. Insecticide residues in two turtle species following treatment with DDT. Bulletin of Environmental Contaminants and Toxicology 15(4): 406-411.

Packard, G.C, M.J. Packard, and G.F. Birchard. 1989. Sexual differentiation and hatching success by painted turtles incubating in different thermal and hydric environments. Herpetologica 45(4):385-392.

Packard, G.C. 1997. Temperatures during winter in nests with hatchling painted turtles (Chrysemys picta). Herpetologica 53(1): 89-95.

Packard, G.C. and F.J. Janzen. 1996. Interpopulational variation in the cold-tolerance of hatchling painted turtles. Journal of Thermal Biology 21(3): 183-190.

Packard, G.C. and M.J. Packard. 1990. Patterns of survival at subzero temperatures by hatchling painted turtles and snapping turtles. Journal of Experimental Zoology 254(2): 233-236.

Packard, G.C. and M.J. Packard. 1993a. Delayed inoculative freezing is fatal to hatchling painted turtles (Chrysemys picta). Cryo Letters 14(5): 273-284.

Packard, G.C. and M.J. Packard. 1993b. Hatchling painted turtles (Chrysemys picta) survive exposure to subzero temperatures during hibernation by avoiding freezing. Journal of Comparative Physiology B 163(2): 147-152.

Packard, G.C. and M.J. Packard. 1995a. A review of the adaptive strategy used by hatchling painted turtles to survive in the cold. Herpetological Review 26(1): 8-12.

Packard, G.C. and M.J. Packard. 1995b. The basis for cold tolerance in hatchling painted turtles (Chrysemys picta). Physiological Zoology 68(1): 129-148, illustr.

Packard, G.C. and M.J. Packard. 1997. Type of soil affects survival by overwintering hatchlings of the painted turtle. Journal of Thermal Biology 22(1): 55-58.

Packard, G.C. and M.J. Packard. 2004. To freeze or not to freeze: adaptations for overwintering by hatchlings of the North American painted turtle. Journal of Experimental Biology 207(17):2897-2906.

Packard, G.C., M.J. Packard, C.L. Morjan, and F.J. Janzen. 2002. Cold-tolerance of hatchling Painted turtles (Chrysemys picta bellii) from the southern limit of distribution. Journal of Herpetology 36(2):300-304.

Packard, G.C., M.J. Packard, and G.F. Birchard. 1989. Sexual differentiation and hatching success by painted turtles incubating in different thermal and hydric environments. Herpetologica 45(4): 385-392.

Packard, G.C., M.J. Packard, and L. Benigan. 1991. Sexual differentiation, growth, and hatching success by embryonic painted turtles incubated in wet and dry environments at fluctuating temperatures. Herpetologica 47(1):125-132.

Packard, G.C., M.J. Packard, J.W. Lang, and J.K. Tucker. 1999. Tolerance for freezing in hatchling turtles. Journal of Herpetology 33(4): 536-543.

Packard, G.C., M.J. Packard, P.L. McDaniel, and L.L. McDaniel. 1989. Tolerance of hatchling painted turtles to subzero temperatures. Canadian Journal of Zoology 67(4): 828-830.

Packard, G.C., M.J. Packard, and T.J. Boardman. 1981. Patterns and possible significance of water exchange by flexible-shelled eggs of painted turtles (Chrysemys picta). Physiological Zoology 54(1):165-178. 
Packard, G.C., M.J. Packard, T.J. Boardman, K.A. Morris, and R.D. Shuman. 1983. Influence of water exchanges by flexible-shelled eggs of painted turtles Chrysemys picta on metabolism and growth of embryos. Physiological Zoology 56(2): 217-230.

Packard, G.C., S.L. Fasano, M.B. Attaway, L.D. Lohmiller, and T.L. Lynch. 1996. A field study of cold-tolerance in hatchling painted turtles. American Zoology 36(5): 67A.

Packard, G.C., S.L. Fasano, M.B. Attaway, L.D. Lohmiller, and T.L. Lynch. 1997. Thermal environment for overwintering hatchlings of the painted turtle (Chrysemys picta). Canadian Journal of Zoology 75(3): 401-406.

Packard, M.J. and G.C. Packard. 1986. Effect of water balance on growth and calcium mobilization of embryonic painted turtles (Chrysemys picta). Physiological Zoology 59(4): 398-405.

Palmer, B.D. 1988. Eggshell and albumen formation in turtles. American Zoology 28(4): 49A.

Pang, P.K.T., S. Harvey, R. Fraser, and T. Kaneko. 1988. Parathyroid hormone-like immunoreactivity in brains of tetrapod vertebrates. American Journal of Physiology 255(4)(Ii): R635-R642.

Parker, P.G. and H.H. Whiteman. 1993. Genetic diversity in fragmented populations of Clemmys guttata and Chrysemys picta marginata as shown by DNA fingerprinting. Copeia 1993(3):841-846.

Parmenter, R.R. 1980. Effects of food availability and water temperature on the feeding ecology of pond sliders (Chrysemys s. scripta). Copeia 1980: 503-514.

Paukstis, G.L., R.D. Shuman, and F.J. Janzen. 1989. Supercooling and freeze tolerance in hatchling painted turtles (Chrysemys picta). Canadian Journal of Zoology 67(4): 1082-1084.

Paukstis, G.L., W.H.N. Gutzke, and G.C. Packard. 1984. Effects of substrate water potential and fluctuating temperatures on sex ratios of hatchling painted turtles (Chrysemys picta). Canadian Journal of Zoology 62(8): 1491-1494.

Pavalko, P. 1986. Shell and scute anomalies in some midwestern turtles. Bulletin of the Chicago Herpetological Society 21(1-2): 36-38.

Pearse, A.S. 1923. The growth of the painted turtle. Biology Bulletin 45: 145-148.

Peterson, C.C. 1987. Thermal relations of hibernating painted turtles, Chrysemys picta. Journal of Herpetology 21(1): 16-20.

Peterson, C.C. and A. Kruegl. 2005. Peaked temporal pattern of embryonic metabolism in an emydid turtle (Chrysemys picta picta). Journal of Herpetology 39(4):678-681.

Petokas, P.J. and M.M. Alexander. 1979. A new trap for basking turtles. Herpetological Review 10(3): 90.

Petrillo, M., C.A. Ritter, and A.S. Powers. 1994. A role for acetylcholine in spatial memory in turtles. Physiology \& Behaviour 56(1): 135-141.

Platt, T.R. 1977. A survey of the helminth fauna of two turtle species from northwestern Ohio. Ohio Journal of Science 77(2):97-98.

Platt, T.R. 1983a. Redescription of Capillaria serpentina harwood, 1932, (nematoda: trichuroidea) from freshwater turtles in virginia. Canadian Journal of Zoology 61(9):21852189.

Platt, T.R. 1983b. The rediscovery of capillaria serpentina (nematoda: trichuroidea) from fresh-water turtles in virginia. Virginia Journal of Science 34(3):133.

Platt, T.R. 1990. Aphanospirorchis kirki n. gen., n. sp. (Digenea: spirorchidae), a parasite of the midland painted turtle, Chrysemys picta marginata, from northwestern Indiana, with comments on the proper spelling of the family name. Journal of Parasitology 76(5): 650-652. 
Plude, J.L. and I.Y. Mahmoud. 1989. Corticosteroid secretion in Vitro by interrenal tissue of the painted turtle, Chrysemys picta. American Zoology 29(4): 138A.

Plummer, M.V. 1977. Activity, habitat and population structure in the turtle, Trionyx muticus. Copeia 1977:431-44.

Postupalsky, S. and J.P. Kleiman. 1965. Osprey preys on turtle. Wilson Bulletin 77(4): 401402.

Pough, F.H. and M.B. Pough. 1968. The systematic status of painted turtles (Chrysemys) in the northeastern United States. Copeia 1968: 612-618.

Powell, C.B. 1967. Female sexual cycles of Chrysemys picta and Clemmys insculpta in Nova Scotia. Canadian Field Naturalist 81: 134-140.

*[PRESI] Powder River Eagle Studies Incorporated. 1998a. Big Sky Mine 1997 wildlife monitoring studies. Powder River Eagle Studies Incorporated. Gillete, WY.

*[PRESI] Powder River Eagle Studies Incorporated. 1998b. Spring Creek Mine 1997 wildlife monitoring studies. Powder River Eagle Studies Incorporated. Gillete, WY.

Quinn, A.J. and J.L. Christiansen. 1972. The relationship between pond bottom type and growth rate of western painted turtles Chrysemys picta bellii in Iowa, a preliminary report. Procedings of the Iowa Academy of Science 78: 67-69.

Raney, E.C. and E.A. Lachner. 1942. Summer food of Chrysemys picta marginata, in Chautauqua Lake, New York. Copeia 1942: 83-85.

Ratterman, R.J. and R.A. Ackerman. 1986a. Water exchange and nest environment fluctuations of painted turtle (Chrysemys picta) eggs during natural incubation. Proceedings of the Iowa Academy of Science 93(1).

Ratterman, R.J. and R.A. Ackerman. 1986b. Water exchange and nest temperatures of painted turtle (Chrysemys picta) eggs during natural incubation. American Zoologist 26(4):52A.

Ratterman, R.J. and R.A. Ackerman. 1987. The environment and water exchange of painted turtle (Chrysemys picta) eggs during natural incubation. Procedings of the Iowa Academy of Science 94(1):237.

Ratterman, R.J. and R.A. Ackerman. 1989. The water exchange and hydric microclimate of painted turtle (Chrysemys picta) eggs incubating in field nests. Physiological Zoology 62(5): 1059-1079.

*Rauscher, R.L. 1998. Amphibian and reptile survey on selected Montana Bureau of Reclamation impoundments. Montana Department of Fish, Wildlife and Parks, Nongame Program, Bozeman, MT. 24 p.

Ream, C. and R. Ream. 1966. The influence of sampling methods on the estimation of population structure in painted turtles. American Midland Naturalist 75: 325-338.

*Reichel, J.D. 1995a. Preliminary amphibian and reptile survey of the Lewis and Clark National Forest: 1994. Montana Natural Heritage Program, Helena, MT. 92 p.

*Reichel, J.D. 1995b. Preliminary amphibian and reptile survey of the Sioux District of the Custer National Forest: 1994. Montana Natural Heritage Program, Helena, MT. 75 p.

*Reichel, J.D. 1996b. Preliminary amphibian and reptile survey of the Helena National Forest: 1995. Montana Natural Heritage Program, Helena, MT. 87 p.

*Reichel, J.D. 1997. Amphibian, reptile and northern bog lemming survey on the Rocky Mountain Front: 1996. Montana Natural Heritage Program, Helena, MT. 81 p.

Rhodin, A.G.J. and G.H. Mittelhauser. 1994. Maximum size and clutch size records for eastern painted turtles, Chrysemys picta picta, from mid-coastal Maine. Chelonian Conservation and Biology 1(2): 148-150, illustr. 
Rice, M.E. and J. Cammack. 1991. Anoxia-resistant turtle brain maintains ascorbic acid content in vitro. Neuroscience Letters 132(2): 141-145.

Riley, D., J.C. Reese, and I.P. Callard. 1988. Hepatic progesterone receptors: characterization in the turtle Chrysemys picta. Endocrinology 123(2): 1195-1201.

Risen, K.W. 1992. Unusual feeding behavior observed for king rail. Loon 64(3): 162-163.

Risher, J.F. and D.L. Claussen. 1987. The effects of cold acclimation on electrocardiogram parameters in five species of turtles. Comparative Biochemistry and Physiology A 87(1): 7380.

*Rodgers, T.L., and W.L. Jellison. 1942. A collection of amphibians and reptiles from western Montana. Copeia 1942(1): 10-13.

*Roedel, M.D. and P. Hendricks. 1998a. Amphibian and reptile survey on the Bureau of Land Management Lewistown District: 1995-1998. Montana Natural Heritage Program, Helena, MT. 53 p.

*Roedel, M.D. and P. Hendricks. 1998b. Amphibian and reptile inventory on the Headwaters and Dillon Resource Areas in conjunction with Red Rocks Lakes National Wildlife Refuge: 1996-1998. Montana Natural Heritage Program, Helena, MT. 46 p.

Rose, F.L. and W.G. Weaver, Jr. 1966. Two new species of Chrysemys (=Pseudemys) from the Florida Pliocene. Tulane Studies in Geology 5(1): 41-48.

Ross, D.A. 1988. Chrysemys picta (painted turtle). Predation. Herpetological Review 19(4): 85-87, illustr.

Ross, D.A. 1989. Population ecology of painted and Blanding's turtles (Chrysemys picta and Emydoidea blandingi) in Central Wisconsin (USA). Transactions of the Wisconsin Academy of Sciences Arts and Letters 77(0): 77-84.

Rowe, J.W. 1992. Comparative life-histories of the painted turtle (Chrysemys picta) in western Nebraska. Unpubl. Ph.D. Dissertation, University of Nebraska, Lincoln.

Rowe, J.W. 1994a. Egg size and shape variation within and among Nebraskan painted turtle (Chrysemys picta bellii) populations: Relationships to clutch and maternal body size. Copeia 1994(4): 1034-1040.

Rowe, J.W. 1994b. Reproductive variation and the egg size-clutch size trade-off within and among populations of painted turtles (Chrysemys picta bellii). Oecologial (Berlin) 99(1-2): 35-44.

Rowe, J.W. 1995. Hatchling size in the turtle Chrysemys picta belli from western Nebraska: Relationships to egg and maternal body size. Journal of Herpetology 29(1): 73-79.

Rowe, J.W. 1997. Growth rate, body size, sexual dimorphism and morphometric variation in four populations of painted turtles (Chrysemys picta bellii) from Nebraska. American Midland Naturalist 138: 174-188.

Rowe, J.W. 2003. Activity and movements of midland painted turtles (Chrysemys picta marginata) living in a small marsh system on Beaver Island, Michigan. Journal of Herpetology 37: 342-353.

Rowe, J.W., K.A. Coval, and M.R. Dugan. 2005. Nest placement, nest-site fidelity and nesting movements in midland painted turtles (Chrysemys picta marginata) on Beaver Island, Michigan. American Midland Naturalist 154(2):383-397.

Rowe, J.W. and K. Bowen. 2005. Diet of midland painted turtles (Chrysemys picta marginata) in a northern lake Michigan Bay. Herpetological Review 36(4):382-384.

Rowe, C.L. and S.M. Kelly. 2005. Marking hatchling turtles via intraperitoneal placement of PIT tags: Implications for long-term study. Herpetological Review 36(4):408-410. 
Rowe, J.W. and W. Parsons. 2000. Diet of the midland painted turtle (Chrysemys picta marginata) on Beaver Island, Michigan. Herpetological Review 31(1): 16-17.

Rowe, J.W., K.A. Coval, and K.C. Cambell. 2003. Reproductive characteristics of female midland painted turtles (Chrysemys picta marginata) from a population on Beaver Island, Michigan. Copeia 2: 326-336.

Rubinsky, B., J.S. Hong, and K.B. Storey. 1994. Freeze tolerance in turtles: Visual analysis by microscopy and magnetic resonance imaging. American Journal of Physiology 267(4 PART 2): R1078-R1088.

Rucknagel, K.P. and G. Braunitzer. 1988. Hemoglobins of reptiles. The primary structure of the major and minor hemoglobin component of adult western painted turtle (Chrysemys picta bellii). Biological Chemistry Hoppe-Seyler 369(2): 123-131.

Russell, A. P. and A. M. Bauer. 2000. The Amphibians and Reptiles of Alberta: A field guide and primer of boreal herpetology. University of Calgary Press, Toronto, Ontario. 279 p.

Sarrafizadeh, R. and J.C. Houk. 1994. Anatomical organization of the limb premotor network in the turtle (Chrysemys picta) revealed by in vitro transport of biocytin and neurobiotin. Journal of Comparative Neurology 344(1): 137-159.

*Schmidt, K.P. 1953. A checklist of North American Amphibians and Reptiles. Sixth edition. American Society of Icthyologists and Herpetologists. 280 p.

Schwab, D. 1986. Field notes: Chrysemys picta picta (eastern painted turtle): Isle of Wight County, town of Smithfield, St. Rt. 10, 0.7 km E. of St. Rt. 10 (Bus.). June 2, 1986. Catesbeiana 6(2): 15.

Schwab, D. 1989. Chrysemys picta picta (eastern painted turtle). Catesbeiana 9(2): 34.

Schwarzkopf, L. 1984. The effect of temperature on sex determination and nest-site selection in painted turtles, Chrysemys picta (Gray, 1844). M.S. Thesis. Guelph, Ontario: University of Guelph.

Schwarzkopf, L. and R.J. Brooks. 1985a. Application of operative environmental temperatures to analysis of basking behavior in Chrysemys picta. Herpetologica 41(2): 206-212.

Schwarzkopf, L. and R.J. Brooks. 1985b. Sex determination in northern painted turtles (Chrysemys picta): Effect of incubation at constant and fluctuating temperatures. Canadian Journal of Zoology 63(11): 2543-2547.

Schwarzkopf, L. and R.J. Brooks. 1986. Annual variations in reproductive characteristics of painted turtles (Chrysemys picta). Canadian Journal of Zoology 64: 1148-1151.

Schwarzkopt, L. and R.J. Brooks. 1987. Nest-site selection and offspring sex ratio in painted turtles, Chrysemys picta. Copeia 1987(1): 53-61.

*Scow, K.L. 1980. Terrestrial wildlife survey American Colloid study area Phillips County, Montana. Western Technology and Engineering, Inc., Helena, MT.

Scribner, K.T., J.D. Congdon, R.K. Chesser, and M.H. Smith. 1993. Annual differences in female reproductive success affect spatial and cohort-specific genotypic heterogeneity in painted turtles. Evolution 47(5): 1360-1373.

Seidel, M.E. 2002. Hemoglobin variation and comments on systematic relationships in the turtle family Emydidae. Copeia 4: 1118-1121.

Seidel, M.E., and H.M. Smith. 1986. Chrysemys, Pseudemys, Trachemys (Testudines: Emydidae): did Agassiz have it right? Herpetologica 42: 242-248.

*Sestrich, C. 2007. 2006 Hebgen Reservoir amphibian survey. USDA Forest Service Annual Report to PPL Montana. West Yellowstone, MT: Gallatin National Forest, Hebgen Lake Ranger District. 75 p. 
Sexton, O.J. 1957. Notes concerning turtle hatchlings. Copeia 1957: 229-230.

Sexton, O.J. 1959a. A method of estimating the age of painted turtles for use in demographic studies. Ecology 40: 716-718.

Sexton, O.J. 1959b. Spatial and temporal movements of a population of the painted turtle, Chrysemys picta marginata (Agassiz). Ecological Monographs 29: 113-140.

Sexton, O.J. 1965. The annual cycle of growth and shedding in the midland painted turtle, Chrysemys picta marginata. Copeia 1965: 314-318.

Siddall, M.E. and S.S. Dessers. 1992. Prevalence and intensity of Haemogregarina balli (Apicomplexa: Adeleina: Haemogregarinidae) in three turtle species from Ontario, with observations on intraerythrocytic development. Canadian Journal of Zoology 70(1): 123128.

Sievert, L.M., G.A. Sievert, and P.V. Cupp. 1988. Metabolic rate of feeding and fasting juvenile midland painted turtles, Chrysemys picta marginata. Comparative Biochemistry and Physiology A 90(1): 157-160.

Sinclair, A.G. and R.M. Alexander. 1987. Estimates of forces exerted by the jaw muscles of some reptiles. Journal of Zoology (London) 213(1): 107-115, illustr.

Skinner, M.P. 1924. The Yellowstone Nature Book. A.C. McClurg Company, Chicago, IL. $221 \mathrm{p}$.

Smith, C.C. and S.D. Fretwell. 1974. The optimal balance between size and number of offspring. American Naturalist 108: 499-506.

Smith, H.M. and D. Chiszar. 1995. Chrysemys picta bellii (western painted turtle). Herpetological Review 26(3): 154.

Smith, H.M., D.C. Kritsky, and R.L. Holland. 1969. Reticulate melanism in the painted turtle. Journal of Herpetology 3: 173-176.

Snow, J.E. 1980. Second clutch laying by painted turtles. Copeia 1980: 534-536. Snow, J.E. 1982. Predation on painted turtle nests: nest survival as a function of nest age. Canadian Journal of Zoology 60: 3290-3292.

Sobota, M. 1990. Chrysemys picta (painted turtle). Herpetological Review 21(1): 24. Somers, K.M. 1986. Multivariate allometry and removal of size with principal component analysis. Systematic Zoology 35(3): 359-368.

Sperger, R.H., R. Humphrey, D. Chiszar, and H.M. Smith. 1995. Chrysemys picta bellii (western painted turtle). Herpetological Review 26(1): 43.

St. Clair, R. and P.T. Gregory. 1990. Factors affecting the northern range limit of painted turtles (Chrysemys picta): winter acidosis or freezing? Copeia 1990(4): 1083-1089.

St. Clair, R., P.T. Gregory, and J.M. Macartney. 1994. How do sexual differences in growth and maturation interact to determine size in northern and southern painted turtles? Canadian Journal of Zoology 72(8): 1436-1443.

*St. John, A. 2002. Reptiles of the Northwest: California to Alaska; Rockies to the Coast. Renton, WA: Lone Pine Publishing. 272 p.

Starkey, D. E., H. B. Shaffer, R. L. Burke, M.R.J. Forstner, J. B. Iverson, F. J. Janzen, A.G.J. Rhodin, and G. R. Ultsch. 2003. Molecular systematics, phylogeography, and the effects of Pleistocene glaciation in the painted turtle (Chrysemys picta) complex. Evolution 57: 119128.

*Stebbins, R.C. 2003. A field guide to western reptiles and amphibians. 3rd edition. New York, NY: Houghton Mifflin Co. 533 p. 
Stone, P.A., J.B. Hauge, A.F. Scott, C. Guyer, and J.L. Dobie. 1993. Temporal changes in two turtle assemblages. Journal of Herpetology 27(1): 13-23.

Storey, K.B., D.G. Mcdonald, J.G. Duman, and J.M. Storey. 1991. Blood chemistry and ice nucleating activity in hatchling painted turtles. Cryo Letters 12(6): 351-358.

Storey, K.B., J.M. Storey, P.S.J. Brooks, T.A. Churchill, and R.J. Brooks. 1988. Hatchling turtles survive freezing during winter hibernation. Proceedings of the National Academy of Sciences of the United States of America 85(21): 8350-8354, illustr.

Strang, C.A. 1983. Spatial and temporal activity patterns in two terrestrial turtles. Journal of Herpetology 17: 43-47.

Taylor, G.M. and E. Nol. 1989. Movements and hibernation sites of overwintering painted turtles in southern Ontario. Canadian Journal of Zoology 67(8): 1877-1881.

*Thompson, L.S. and P.S. Nichols. 1982. Circle West wildlife monitoring study; fourth annual report for period March 1, 1981 - May 31, 1982. Circle West Technical Report No. 10. Montana Department of Natural Resources and Conservation, Helena, MT.

Thornhill, G.M. 1982. Comparative reproduction of the turtle, Chrysemys scripta elegans, in heated and natural lakes. Journal of Herpetology 16: 347-353.

*Timken, R. No Date. Amphibians and reptiles of the Beaverhead National Forest. Western Montana College, Dillon, MT. 16 p.

Tinkle, D.W., J.D. Congdon, and P.C. Rosen. 1981. Nesting frequency and success: implications for the demography of painted turtles. Ecology 62: 1426-1432.

Trobec, T.N. and J.G. Stanley. 1971. Uptake of ions and water by the painted turtle, Chrysemys picta. Copeia 1971: 537-542.

Tucker, J.K. 1978. Variation in reproductive potential and growth in Chrysemys picta within a single body of water. Bulletin of the Maryland Herpetological Society 14: 223-232.

Tucker, J.K., R.S. Funk, and G.L. Paukstis. 1978. The adaptive significance of egg morphology in two turtles (Chrysemys picta and Terrapene carolina). Bulletin of the Maryland Herpetological Society 14: 10-24.

*Turner, F.B. 1951. A checklist of the reptiles and amphibians of Yellowstone National Park with incidental notes. Yellowstone Nature Notes 25(3): 25-29.

*Turner, F.B. 1955. Reptiles and amphibians of Yellowstone National Park. Yellowstone Interpretive Series No. 5. Yellowstone Library and Museum Association. Yellowstone National Park, WY. 40 p.

Ultsch, G.R. 1985. The viability of nearctic freshwater turtles submerged in anoxia and normoxia at 3 and 10 Celsius. Comparative Biochemistry and Physiology A 81(3): 607-612.

Ultsch, G.R. and B.M. Cochran. 1994. Physiology of northern and southern musk turtles (Sternotherus odoratus) during simulated hibernation. Physiological Zoology 67(1): 263-281

Ultsch, G.R. and D.C. Jackson. 1982a. Long-term submergence at $3^{\circ} \mathrm{C}$ of the turtle, Chrysemys picta bellii, in normoxic and severely hypoxic water: II. Extracellular ionic responses to extreme lactic acidosis. Journal of Experimental Biology 96: 29-43.

Ultsch, G.R. and D.C. Jackson. 1982b. Long-term submergence at $3^{\circ} \mathrm{C}$ of the turtle Chrysemys picta bellii in normoxic and severely hypoxic water: III. Effects of changes in ambient Po2 and subsequent air-breathing. Journal of Experimental Biology 97: 87-99.

Ultsch, G.R. and D.C. Jackson. 1995. Acid-base status and ion balance during simulated Hibernation in freshwater turtles from the northern portions of their ranges. Journal of Experimental Zoology 273(6): 482-493. 
Ultsch, G.R., G.M. Ward, C.M. LeBerte, B.R. Kuhajda, and E.R. Stewart. 2001. Intergradation and origins of subspecies of the turtle Chrysemys picta: morphological comparisons. Candian Journal of Zoology 79: 485-498.

Ultsch, G.R., M.E. Carwile, C.E. Crocker, and D. Jackson. 1999. The physiology of hibernation among painted turtles: the eastern painted turtle (Chrysemys picta picta). Physiological Biochemical and Zoology 72: 493-501.

Ultsch, G.R., R.W. Hanley, and T.R. Bauman. 1985. Responses to anoxia during simulated hibernation in northern and southern painted turtles. Ecology 66(2): 388-395.

Van Vlaenderen, R. and R.J. Brooks. 1999. Geographic variation in the life history of the painted turtle, (Chrysemys picta). Canadian Amphibian and Reptile Conservation Network.

*Vitt, L.J., J.P. Caldwell, and D.B. Shepard. 2005. Inventory of amphibians and reptiles in the Billings Field Office Region, Montana. Sam Noble Oklahoma Museum of Natural History and Department of Zoology, University of Oklahoma, Norman, OK. 33 p.

Vogt, R.C. and J.J. Bull. 1984. Ecology of hatchling sex ratio in map turtles. Ecology 65(2): 582-587.

*[VTNWI] VTN Wyoming Incorporated. No Date. Second year's analysis of terrestrial wildlife on proposed mine access and railroad routes in southern Montana and northern Wyoming, March 1979 - February 1980. VTN Wyoming Incorporated. Sheridan, WY. 62 p.

*Waage, B.C. 1998. Western Energy Company Rosebud Mine 1997 annual wildlife monitoring report December 1, 1996 to November 30, 1997 survey period. Western Energy Company, Colstrip, MT.

*Walcheck, K. 1976. Montana Wildlife 170 years ago. Montana Outdoors 7(4): 15-30. Walker, W.F., Jr. 1971. A structural and functional analysis of walking in the turtle, Chrysemys picta marginata. Journal of Morphology 134: 195-214.

Warburton, S.J. and D.C. Jackson. 1995. Turtle (Chrysemys picta bellii) shell mineral content is altered by exposure to prolonged anoxia. Physiological Zoology 68(5): 783-798.

Wasser, J.S., E.A. Meinertz, S.Y. Chang, R.G. Lawler, and D.C. Jackson. 1992. Metabolic and cardiodynamic responses of isolated turtle hearts to ischemia and reperfusion. American Journal of Physiology 262(3 Part 2): R437-R443.

Wasser, J.S., S.J. Warburton, and D.C. Jackson. 1991. Extracellular and intracellular acid-base effects of submergence anoxia and nitrogen breathing in turtles. Respiration Physiology 83(2): 239-252.

Watermolen, D.J. 1990. Chrysemys picta (painted turtle). Herpetological Review 21(1): 26.

Waters, J.H. 1964. Subspecific intergradation in the Nantucket Island, Massachusetts, population of the turtle Chrysemys picta. Copeia 1964: 550-553.

Waters, J.H. 1969. Additional observations of southeastern Massachusetts insular and mainland populations of painted turtles, Chrysemys picta. Copeia 1969: 179-182.

Waye, H.L. and C. Gillies. 1999. Chrysemys picta bellii hatchling emergence. Herpetological Review 30(2): 94-95.

Weaver, W.G. and F.L. Rose. 1967. Systematics, fossil history, and evolution of the genus Chrysemys. Tulane Studies in Zoology 14: 63-73.

Weaver, W.G., Jr. and J.S. Robertson. 1967. A re-evaluation of fossil turtles of the Chrysemys scripta group. Tulane Studies in Geology 5(2).

*Weisel, G.F. 1952. Animal names, anatomical terms, and some ethnozoology of the Flathead Indians. Journal of the Washington Academy of Sciences 42(11): 345-355. 
Weisrock, D.W. and F.J. Janzen. 1999. Thermal fitness-related consequences of nest location in painted turtles (Chrysemys picta). Functional Ecology 13: 94-101.

*Werner, J.K., B.A. Maxell, P. Hendricks, and D.L. Flath. 2004. Amphibians and reptiles of Montana. Mountain Press. Missoula, Montana. 262 p.

*Werner, J.K. and J.D. Reichel. 1994. Amphibian and reptile survey of the Kootenai National Forest: 1994. Montana Natural Heritage Program, Helena, MT. 104 p.

*Werner, J.K. and J.D. Reichel. 1996. Amphibian and reptile monitoring/survey of the Kootenai National Forest: 1995. Montana Natural Heritage Program, Helena, MT. 115 p.

*Werner, J.K. and T. Plummer. 1994. Amphibian and reptile survey of the Flathead Indian Reservation 1993-1994. Salish Kootenai College, Pablo, MT. 55 p.

*Werner, J.K. and T. Plummer. 1995. Amphibian monitoring program on the Flathead Indian Reservation 1995. Salish Kootenai College, Pablo, MT. 46 p.

*Werner, J.K., T. Plummer, and J. Weaselhead. 1998. Amphibians and reptiles of the Flathead Indian Reservation. Intermountain Journal of Sciences 4(1-2): 33-49.

*[WESCO] Western Ecological Services Company. 1983a. Wildlife inventory of the Knowlton known recoverable coal resource area, Montana. Western Ecological Services Company, Novato, CA. 107 p.

*[WESCO] Western Ecological Services Company. 1983b. Wildlife inventory of the Southwest Circle known recoverable coal resource area, Montana. Western Ecological Services Company, Novato, CA. 131 p.

*[WESTECH] Western Technology and Engineering Incorporated. 1998. Wildlife monitoring Absaloka Mine area 1997. Western Technology and Engineering, Inc., Helena, MT.

Whillans, F.H. and E.J. Crossman. 1977. Morphological parameters and spring activities in a central Ontario population of Midland Painted Turtle, Chrysemys picta marginata (Agassiz). Canadian Field Naturalist 91: 47-57.

*Wied, M.P. 1865. Verzeichniss der reptilien, welche auf einer reise in nordlichen America beobachtet wurden, von Maximilian, Prinzen zu Wied. Eigengangen bei der Akademie am 1, Juni 1865. Druck von E. Blochmann und Sohn, Dresden, Germany. 141 p.

Wilbur, H.M. 1975a. A growth model for the turtle Chrysemys picta. Copeia (2): 337-343.

Wilbur, H.M. 1975b. The evolutionary and mathematical demography of the turtle Chrysemys picta. Ecology 56: 64-77.

Wilson, D.S. 1998. Nest-site selection: microhabitat variation and its effects on the survival of turtle embryos. Ecology 79(6):1884-1892.

Woolverton, E. 1961. Winter survival of hatchling painted turtles in northern Minnesota. Copeia 1961: 109.

Woolverton, E. 1963. Winter survival of hatchling painted turtles in northern Minnesota. Copeia 1963: 569-570.

*[WWPC] Washington Water Power Company. 1995. 1994 wildlife report Noxon Rapids and Cabinet Gorge Reservoirs. Washington Water Power Company. Spokane, WA.

*Yarrow, H.C. 1882. Check list of North American reptilia and batrachia, with catalogue of specimens in the U.S. National Museum. United States National Museum Bulletin 24: 1-249

*Yeager, D.C. 1929. Reptiles of Yellowstone Park with notes on the Amphibia. Yellowstone Nature Notes. Yellowstone National Park Library, Mammoth, WY. 12 p.

Zani, P.A. and D.L. Claussen. 1994. Voluntary and forced terrestrial locomotion in juvenile and adult painted turtles, Chrysemys picta. Copeia 1994(2): 466-471. 
Zani, P.A. and D.L. Claussen. 1995. Effects of extrinsic load on locomotion in painted turtles (Chrysemys picta). Copeia 1995(3): 735-738.

Zweifel, R.G. 1989. Long-term ecological studies on a population of painted turtles, Chrysemys picta, on Long Island, New York (USA). American Museum Novitates 0(2952): 1-55. 


\section{Spiny Softshell (Apalone spinifera)}

Up-to-date distribution and status information can be found on the Montana Natural Heritage Program's TRACKER website at http://mtnhp.org

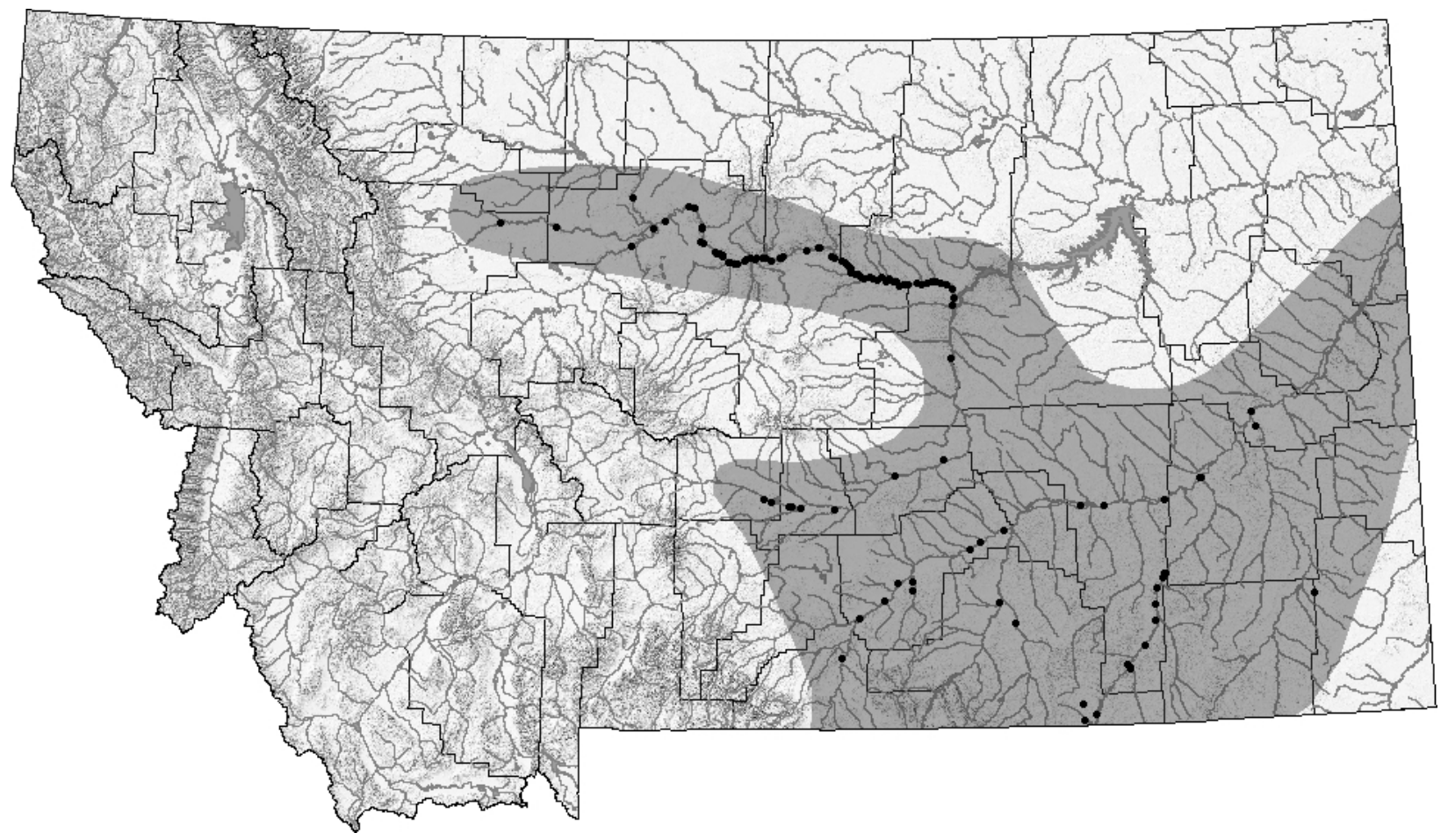

Distribution/Taxonomy

The spiny softshell is one of three North American turtle species formerly in the genus Trionyx that were moved Apalone by Meylan (1987). Other authors (Webb 1990, Ernst et al. 1994, Hammerson 1999, Stebbins 2003) have retained the spiny softshell in Trionyx. Molecular data (Weisrock and Janzen 2000) indicate a genetic dichotomy between populations of spiny softshell north and west of Louisiana and populations from the Gulf Coast in southeastern North America. The spiny softshell is divided into seven subspecies, six of which are present north of Mexico (Webb 1962, 1973, Ernst et al. 1994). The subspecies present in Montana is the western spiny softshell, A. spinifera hartwegi (Conant and Goin 1948, Webb 1962, 1973, Ernst et al 1994). The spiny softshell is found from Montana east to southern Quebec, south in the west through northern and eastern Wyoming, eastern Colorado, New Mexico and Texas to northern Mexico, and east through the Midwest west of the Appalachian Mountains in the northeast, and throughout the Gulf region and southeastern United States to the Florida panhandle, to elevations

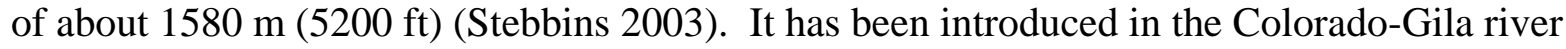
system of Arizona and in New Jersey (Webb 1973). There are disjunct populations in several areas around the periphery of the range. Populations in Montana are isolated from the remainder of the species and subspecies range, and merit genetic examination. In Montana, there are known from 14 counties east of the Continental Divide. There is an obvious absence of records along the Missouri River at and below Fort Peck Reservoir, and few records from the Musselshell River in central Montana (Maxell et al. 2003, Werner et al. 2004). Available records suggest that the Missouri and Yellowstone populations within Montana are isolated from each other. 
Maximum Elevation

1,097 m (3,600 ft) in Big Horn County (Maxell et al. 2003).

\section{Identification}

Juveniles and Adults:

The shell is flattened ("pancake-like"), with flexible edges and covered with leathery skin. Small conical tubercles or "spines" are present on the front edge of the carapace above the neck. The snout is tubular and flexible, with a ridge along the inner margin of each nostril. The lips are fleshy and cover sharp-edged jaws. Limbs are flat, and the toes are broadly webbed. Carapace coloration is olive-brown, brown, or grayish, with a cream or yellowish margin. The plastron is unmarked and cream to yellowish in coloration (Webb 1962, Ernst et al. 1994, Hammerson 1999, Stebbins 2003). In mature males, the carapace is like sandpaper in texture, and marked with small dark spots or circles. The tail is thick and long, with the vent well beyond the rear edge of the carapace. In mature females, the carapace is not notably like sandpaper in texture, is more generally mottled or marked with blotches, the tubercles at the front edge of the carapace are more prominent than in males, and the tail is relatively short. Juveniles generally are like adults in appearance, with overall characteristics that are female-like, except the carapace coloration, which is male-like. In hatchlings, the carapace is olive to tan, with small dark circles, spots, or dashes, and a yellowish margin bordered by a black line. Adult females can reach 54 $\mathrm{cm}$ in carapace length (CL), while males are smaller by an average of $10 \mathrm{~cm}$, and reach about 22 $\mathrm{cm}$ in carapace length. For example a study in southeastern Montana produced fourteen males ranging from 14.8-21.6 cm CL (290-730 grams), and 23 males ranging from 28.3-43.8 cm CL (2080-6700 grams) (Gates 2005). Hatchlings are about 3-4 cm in carapace length.

\section{Eggs:}

Eggs are white, smooth, spherical, thick-shelled and brittle, and about 24-32 $\mathrm{mm}$ in diameter. Clutch size can range from as few as 4 eggs to as many as 40 (typically 12-18), with eggs deposited in flask-shaped nests that are covered with soil (Webb 1962, Miller et al. 1989, Ernst et al. 1994, Hammerson 1999).

\section{Similar Species:}

The spiny softshell differs from other Montana turtles by having a flattened and leathery shell that is soft and lacks horny plates, and by the presence of a pointed snout with tubular nostrils. The smooth softshell (A. muticus), which occurs in the Missouri River in South Dakota and southern North Dakota (Hoberg and Gause 1989, Ballinger et al. 2000), differs from the spiny softshell by lacking the ridge on the inner margin of each tubular nostril and the absence of tubercles or spines along the front edge of the carapace (Ernst et al. 1994).

\section{Habitat Use/Natural History}

The spiny softshell is primarily an animal of riverine systems, but also inhabits marshy creeks, bayous, oxbows, lakes, irrigation canals, and impoundments (Webb 1962, Ernst et al. 1994, Hammerson 1999, Stebbins 2003). A soft bottom with some aquatic vegetation appears to be essential, and sandbars and/or mudflats, as well as partially submerged debris (trees, fallen logs, brush), are usually present. In shallow water, young spiny softshells bury themselves in soft sand and silt in an attempt to seek refuge and concealment (Baxter and Stone 1985). In Iowa, females seemed to prefer open water more than did males (Williams and Christiansen 1981). 
Because spiny softshells dehydrate quickly when out of water, they are seldom seen far from water. However, they will move overland when exposed to falling water levels (Williams and Christiansen 1981). They burrow into the bottoms of permanent water bodies, either shallow or relatively deep (0.5-7.0 m), where they hibernate (Graham and Graham 1997, Plummer and Burnley 1997). Hibernation sites may occur within the summer home range or a few $\mathrm{km}$ from summer nesting areas. Habitat use by spiny softshells in Montana is probably similar to elsewhere in the range, but studies are lacking and there is little qualitative information available. They are encountered most often in the larger rivers and their tributaries. Adult males and females have been observed basking together on partially submerged logs in backwater sites of slow-moving water, on sandy and muddy riverbanks, and on partially submerged rocks in shallow water along major rivers. Hatchlings have been found in shallow water at rivers edge, burrowing into silty substrate with emergent vegetation present (Paul Hendricks, pers. obs.). A small-scale trapping and visual encounter survey conducted on a six-mile stretch of the upper Tongue River in southeastern Montana concluded that the most successful trapping locations were near sandbar islands adjacent to pools with a soft organic bottom. Additionally, stretches of river with exposed boulders and basking logs produced the most visual observations (Gates 2005). In Vermont, spiny softshells migrated about $3 \mathrm{~km}$ between riverine wintering sites and river mouth nesting sites near Lake Champlain. Migratory movements were most extensive in spring and fall (Graham and Graham 1997). Annual home range size for male spiny softshells in Arkansas was 784-2310 m (average $1750 \mathrm{~m}$ ) of stream length, and 683-2145 m (average 1400 m) for females (Plummer et al. 1997). During the active season, they were very mobile, and made movements on $85 \%$ of days. Adults are active from April to October (usually May to September) in Kentucky, Tennessee, and Colorado (Robinson and Murphy 1978, Ernst et al. 1994, Hammerson 1999), and are similar elsewhere in the range (Webb 1962). Water temperatures of $12^{\circ} \mathrm{C}$ appear to determine when animals enter or emerge from hibernation in Vermont (Graham and Graham 1997). Adults emerge earlier and remain active longer into fall, than do juveniles. The length of the active season increases with decrease in latitude (Webb 1962). The period of activity in Montana is poorly documented, with records from early June to late July (Hendricks and Reichel 1996, Hendricks 1999). Mating occurs shortly after emerging from winter dormancy, in April or May. Nesting may begin in late May and extend into August, but usually occurs in June and July in Tennessee and Colorado (Robinson and Murphy 1978, Hammerson 1999). Eggs are laid in flask-shaped burrows excavated in coarse sand or fine gravel, to depths of 10-25 cm. Colorado nests contained 15-39 eggs (Miller et al. 1989, Hammerson 1999), but as few as 3 eggs have been reported in Indiana (Webb 1962). During the reproductive season, eggs may be laid in two clutches, but there is no evidence for production of multiple clutches throughout the species range (Robinson and Murphy 1978, Hammerson 1999). Eggs hatch in about 60-80 days. Most hatching occurs in August to September in Colorado. In some families of turtles, incubation temperature determines the sex of hatchlings, but this effect of incubation temperature does not appear to pertain to spiny softshells (Vogt and Bull 1982). Some hatchlings may overwinter in the nest and emerge the following spring, although there is no solid evidence that this occurs (Ernst et al. 1994, Hammerson 1999). Little information is available from Montana on any aspect of the reproductive biology of this species. A small juvenile with a carapace length of $4.0 \mathrm{~cm}$ was captured in mid-July on the Missouri River (Paul Hendricks, pers. obs.). Individuals may live up to 50 years (based on the relationship between growth rate and observed carapace size). Females mature at a carapace length of about $25 \mathrm{~cm}$ (89 years of age), and males mature earlier (4-5 years) at a carapace length of about $16 \mathrm{~cm}$ 
(Breckenridge 1955, Webb 1962). The oldest female of known age (a captive zoo animal) lived 25 years (Ernst et al. 1994). Nevertheless, little quantitative information is available on survival rate and longevity. Spiny softshells forage in the water, often on the bottom in shallow with vegetation, and are considered generalist carnivores. Major foods include crayfish, aquatic insects (at least seven Orders), and fishes; mollusks, worms, isopods, amphibians, carrion, and vegetation are also taken (Webb 1962, Ernst et al. 1994, Hammerson 1999). The diet in an Iowa study (Williams and Christiansen 1981) was about 25\% insects, 36.5\% fish as carrion, 5.8\% small fish as live prey, and 55\% crayfish, with plant material in $61 \%$ of stomachs. Prey may be chased, ambushed, or flushed and pursued. The diet in Montana has not been studied.

\section{$\underline{\text { Status and Conservation }}$}

At the time the comprehensive summaries of amphibians and reptiles in Montana (Maxell et al. 2003, Werner et al. 2004) were published, there were about 70 total records for spiny softshell from 13 counties, with records scattered east of the Continental Divide along the Missouri River and tributaries between the confluence of the Musselshell River and Fort Benton, also low on the Marias River downstream from Tiber Reservoir, and along the Yellowstone River and tributaries between Edgar (Carbon County) and Glendive (Dawson County), and included the Clark Fork of the Yellowstone, Bighorn, Tongue, and Powder rivers. Populations in parts of the Missouri River (especially the Wild and Scenic portion) appear to be robust, with 21 and 24 individuals observed opportunistically on each of two float trips between Coal Banks and Judith landings in July 2003 and 2004 (Paul Hendricks, pers. obs.). On the Tongue River near Brandenburg (Rosebud County), several basking adults were observed in three consecutive years (Hendricks 1999). On a six-mile stretch of the upper Tongue River, near Decker, a short, five-day trapping survey produced 37 Spiny Softshell captures at 14 of 30 trap locations without any recaptures, and an additional 60 individuals were seen basking while traversing the river (Gates 2005). This suggests a healthy population may be present in this region of the river. However, population density and trend estimates remain unavailable for any locality in Montana, including areas of recent surveys. In the Arkansas River of central Kansas, the population density of spiny softshells was estimated to be 500-700 individuals per river mile (Capron 1987), probably a value exceeding that in Montana. Connectivity of populations is unknown; the Missouri River population above Ft. Peck appears to be isolated from the Yellowstone River population, and spiny softshells in the Musselshell River may be isolated from the remainder of the Missouri River population. All spiny softshells in Montana appear to be isolated from the remainder of the species range in the United States, as there are no confirmed records from North Dakota (there is an old record from Fort Union, but the collection locality is uncertain; Maxell et al. 2003), and the nearest records in the Missouri River are from southeastern South Dakota (Hoberg and Gause 1989, Ballinger et al. 2000). Status on the Marias River is also uncertain. Spiny softshells were not reported by Mosimann and Rabb (1952) near the site of Tiber Reservoir prior to its flooding, but have been seen in recent years far downstream nearer the confluence with the Missouri River. At the local scale, limited data from other states suggest this species is relatively sedentary, with most movements restricted to about $3 \mathrm{~km}$ of stream or river (Graham and Graham 1997, Plummer et al. 1997). Given the limited distance spiny softshells move over land, populations are vulnerable to habitat fragmentation, especially by dams or other water diversion projects. Risk factors relevant to the viability of populations of this species are likely to include habitat loss/fragmentation, dam construction, water diversion, pollutants (including herbicides and pesticides), accidental take during recreational fishing, mining of sand 
and gravel, and off-road vehicle use (Hammerson 1999). However, perhaps the greatest risk to maintaining viable populations of spiny softshell in Montana is the lack of baseline data on its distribution, status, habitat use, and basic biology (Maxell and Hokit 1999), which are needed to monitor trends and recognize dramatic declines when and where they occur. Few studies address or identify risk factors. Throughout much of its range, the spiny softshell has been sought for food (Carr 1952), and is sometimes killed because of the erroneous belief that spiny softshells are harmful to fish populations (Webb 1962). The impact of accidental and intentional take by fisherman in Montana is unknown.

\section{Research and Management Suggestions}

1. See research and management suggestions under all general risk factors described above. More thorough documentation of the species' distribution across its range on the Missouri and Yellowstone river drainages in Montana is needed to determine if populations in these two major river drainages are no longer connected.

2. Genetic studies are needed from throughout Montana to determine a) the number of discrete genetic populations that are present in Montana, and b) the degree of genetic divergence that has occurred between the population(s) in Montana from populations elsewhere in the species' range.

3. Studies of habitat use are needed, especially as they relate to damming, water diversion, water releases, and the formation of sand and gravel bars where nesting occurs, to identify species responses to these habitat perturbations and develop effective measures for mitigation of negative impacts.

4. Studies of the food habits are needed to address concerns of sport fishermen over competition for fish.

5. Studies of population demography and dynamics are needed. Spiny softshells are long-lived, so excessive loss of adults from harvest, pollution, habitat loss, or other disturbances can have significant negative consequences for maintaining populations of this species, especially given the limited ability of spiny softshells to breach habitat barriers and enable recolonization.

6. Traditional nesting areas need to be identified and protected from human and human-related disturbance. Baseline predation rates on nests need to be measured, and nest predators identified, so that impact of nest predators can be anticipated if predator populations increase.

7. Routine surveys for spiny softshells in appropriate habitats should be made a standard part of field duties for fisheries biologists. Records should be taken and maintained of the incidental take by anglers, who should be encouraged to report any captured turtles. A variety of data could be collected from harvested animals including, carapace length, sex, and diet.

Bibliography *indicates an article with information specific to Montana

Allen, E.R. 1982. Life history notes, Testudines, Trionyx ferox (Florida softshell). Size. Herpetological Review 13:49.

*Allen, J.A. 1874. Notes on the natural history of portions of Dakota and Montana Territories, being the substance of a report to the Secretary of War on the collections made by the North Pacific Railroad Expedition of 1873, General D.S. Stanley, Commander. Proceedings of the Boston Society of Natural History 17: 33-85. Pages 68-70.

*Audubon, M.R. (ed.). 1960. Audubon and his journals. Volume 2. Dover Publications Incorporated. New York, NY. 
Ballinger, R. E., J. W. Meeker, and M. Thies. 2000. A checklist and distribution maps of the amphibians and reptiles of South Dakota. Transactions of the Nebraska Academy of Sciences 26:29-46.

Baxter, G. T., and M. D. Stone. 1985. Amphibians and reptiles of Wyoming. Second edition. Wyoming Game and Fish Department, Cheyenne, Wyoming. 137 p.

*Benson, K.R. 1978. Herpetology of the Lewis and Clark expedition 1804-1806. Herpetological Review 9(3): 87-91.

Bickham, J.W., J.J. Bull, and J.M Leglar. 1983. Karyotypes and evolutionary relationships of trionychoid turtles. Cytologia 48: 177-183.

*Black, J. H. 1970. Turtles of Montana. Animals of Montana Series, No. 2, Montana Wildlife 1970 (Fall):26-31.

*Black, J.H. and J.N. Black. 1971. Montana and its turtles. International Turtle and Tortoise Society 1971(May-July): 10-11, 34-35.

*Black, J.H. and R. Timken. 1976. Endangered and threatened amphibians and reptiles in Montana. Pp. 36-37. In: R.E. Ashton, Jr. (chair). Endangered and threatened amphibians and reptiles in the United States. Society for the Study of Amphibians and Reptiles Herpetological Circular 5: 1-65.

Breckenridge, W. J. 1955. Observations on the life history of the soft-shelled turtle Trionyx ferox, with especial reference to growth. Copeia 1955:5-9.

Breckenridge, W.J. 1960. A spiny soft-shelled turtle nest study. Herpetologica 16(4): 284-285.

Burghardt, G.M., B. Ward, and R. Rosscoe. 1996. Problem of reptile play: environmental enrichment and play behaviour in a captive Nile soft-shelled turtle, Trionyx triunguis. Zoo Biology 15(3): 223-238.

*Burroughs, R.D. 1961. The natural history of the Lewis and Clark expedition. Michigan State University Press. 340 p.

Capron, M. 1987. Selected observations on south-central Kansas turtles. Kansas Herpetological Society Newsletter 67:13-15.

Carpenter, C.C. 1981. Life history notes: Trionyx spiniferus. Herpetological Review 12(3): 82.

Carpenter, K. 1981. Preneural in the evolution of Trionyx. Copeia2: 456-457.

*Carr, A. 1952. Handbook of turtles: the turtles of the United States, Canada, and Baja California. Cornell University Press, Ithaca, New York. 542 p.

Cochran, P.A. 1986. Some observations on the herpetofauna of the University of Wisconsin Madison Campus. Bulletin of the Chicago Herpetological Society 21(1-2): 138-141.

Cochran, P.A. and D.R. McConville. 1983. Feeding by Trionyx spiniferus in backwaters of the upper Mississippi River. Journal of Herpetology 17(1): 86-88.

Cochran, P.A. and J.D. Lyons. 1986. New distributional records for Wisconsin (USA) amphibians and reptiles. Transactions of the Wisconsin Academy of Sciences Arts and Letters 74(0): 138-141.

Coldiron, R.W. 1974. Possible funtions of ornament in labyrinthodont amphibians. Occaisional Papers of Museum of Natural History University of Kansas 33:1-19.

Conant, R. and C.J. Goin. 1948. A new subspecies of soft-shelled turtle from the central United States, with comments on the application of the name Amyda. Occassional Papers of the Museum of Zoology University of Michigan 510: 1-19 +2 pls.

*Coues, E. and H.C. Yarrow. 1878. Notes on the herpetology of Dakota and Montana. Bulletin of the U.S. Geologic and Geographic Survey 4(1): 259-291. 
Daigle, C., P. Galois, and Y. Chagnon. 2002. Nesting activities of an eastern spiny softshell turtle, Apalone spinifera. Canadian Field Naturalist 116:104-107.

Dalrymple, G.H. 1977. Intraspecific variation in the cranial feeding mechanism of turtles of the genus Trionyx (Reptilia, Testudines, Trionychidae). Journal of Herpetology 11:255-285.

Dalrymple, G.H. 1979. Packaging problems of head retraction in trionychid turtles. Copeia 1979:655-660.

*Day, D., P.J. Farmer, and C.E. Farmer. 1989. Montco terrestrial wildlife monitoring report December, 1987 - July, 1989. Montco, Billings, MT, and Western Technology and Engineering, Inc. Helena, MT.

*[DCC] Decker Coal Company. 1998. 1997 Consolidated annual progress report. Decker Coal Company West, North and East Pits. Decker, MT.

Drought, J.F. 1987b. Testudines. Trionyx spiniferus spiniferus (eastern spiny softshell). Herpetological Review 18(1): 21.

Dunson, W.A. 1960. Aquatic respiration in Trionyx spinifer asper. Herpetologica 16(4): 277283.

Dunson, W.A. 1967. Relationship between length and weight in the spiny softshell turtle. Copeia 1967: 483-485.

*Ernst, C.H., J.E. Lovich, and R.W. Barour. 1994. Turtles of the United States and Canada. Washington, D.C.: Smithsonian Institution Press.

Fitch, H.S. and M.V. Plummer. 1975. A preliminary ecological study of the soft-shelled turtle Trionyk muticus in the Kansas River. Israel Journal of Zoology 24: 28-42.

*Flath, D.L. 1998. Species of special interest or concern. Montana Department of Fish, Widlife and Parks, Helena, MT. March, 1998. 7 p.

Frair, W. 1983. Serological survey of softshells with other turtles. Journal of Herpetology 17:75-79.

Galois, P., M. Leveille, L. Bouthillier, C. Daigle, and S. Parren. 2002. Movement patterns, activity, and home range of the eastern spiny softshell turtle (Apalone spinifera) in northern Lake Champlain, Quebec, Vermont. Journal of Herpetology 36:402-411.

Gardner, J.D., A.P. Russel, and D.B. Brinkman. 1995. Systematics and taxonomy of softshelled turtles (Family Trionychidae) from the Judith River Group (mid-Campanian) of North America. Canadian Journal of Earth Science. 32:631-643.

*Gates, M.T. 2005. Amphibian and reptile baseline survey: CX field study area. Report to Billings and Miles City Field Offices of Bureau of Land Management. Maxim Technologies, Billings, MT. 28pp + Appendices.

Gibbons, J. W., D. E. Scott, T. J. Ryan, K. A. Buhlmann, T. D. Tuberville, B. S. Metts, J. L. Greene, T. Mills, Y. Leiden, S Poppy, and C. T. Winne. 2000. The global decline of reptiles, déjà vu amphibians. BioScience 50:653-666.

Graham, T.E. and A.A. Graham. 1991. Trionyx spiniferus spiniferus (eastern spiny softshell). Burying behavior. Herpetological Review 22(2): 56-57.

Graham, T.E. and A.A. Graham. 1997. Ecology of the eastern spiny softshell, Apalone spinifera spinifera, in the Lamoille River, Vermont. Chelonian Conservation and Biology 2(3): 363369.

Greenbaum, E. and J.L. Carr. 2001. Sexual differentiation in the spiny softshell turtle (Apalone spinifera), a species with genetic sex determination. Journal of Experimental Zoology 290(2):190-200. 
Halk, J.H. 1986a. Life history notes. Trionyx spiniferus (spiny softshell turtle). Size. Herpetological Review 17(4): 91.

Halk, J.H. 1986b. Life history notes: Trionyx spiniferus. Herpetological Review 17(3): 65

Hammerson, G. A. 1999. Amphibians and reptiles in Colorado, second edition. University Press of Colorado. Niwot, Colorado. 484 pp. Society 27:121-127.

*Hayden, F.V. 1858. Catalogue of the collections in geology and natural history, obtained by the expedition under command of Lieutenant G.K. Warren, Topographical Engineers. pp. 104-105. In: F.N. Shubert (1981) Explorer on the northern plains: Lieutenant Gouverneur K. Warren's preliminary report of explorations in Nebraska and Dakota, in the years 1855-'56'57. Engineer Historical Studies No. 2. Office of the Chief of Engineers, Washington, DC. $125 \mathrm{p}$.

*Hayden, F.V. 1863. On the geology and natural history of the upper Missouri. Transactions of the American Philosophical Society New Series 12(1): 1-218 (pages 177-178).

*Hendricks, P. 1999. Amphibian and reptile survey of the Bureau of Land Management Miles City District, Montana. Montana Natural Heritage Program, Helena, MT. 80 p.

*Hendricks, P. and J.D. Reichel. 1996. Preliminary amphibian and reptile survey of the Ashland District, Custer National Forest: 1995. Montana Natural Heritage Program, Helena, MT. $79 \mathrm{p}$.

*Hendricks, P. and J.D. Reichel. 1998. Amphibian and reptile survey on Montana refuges: 1996. Montana Natural Heritage Program, Helena, MT. 19 p.

Hoberg, T. and C. Gause. 1989. Reptiles \& amphibians of North Dakota. North Dakota Outdoors 55(1):7-18.

Hoff, G. and D.O. Trainer. 1973. Arboviruses in reptiles:isolation of a Bunyamwera group viru, from a Naturally Infected turtle. Journal of Herpetology 7(2) :55-62.

*Matthews, W.L. 1979. Wibaux-Beach wildlife baseline study - nongame species. Bureau of Land Management, Miles City, MT. 93 p.

*Maxell, B.A. 2004. Preliminary report on amphibian and aquatic reptile inventories conducted on and around the Ashland District of the Custer National Forest in 2002 and 2004. Report to Ashland District of Custer Forest, Region 1 Office of the U.S. Forest Service, and Montana Department of Fish, Wildlife, and Parks. Montana Cooperative Wildlife Research Unit and Wildlife Biology Program, University of Montana, Missoula, MT. 93p.

*Maxell, B.A., and D.G. Hokit. 1999. Amphibians and reptiles. Pages 2.1-2.30, In: Effects of recreation on Rocky Mountain wildlife: a compendium of the current state of understanding in Montana (G. Joslin and H. Youmens, coordinators). Committee on Effects of Recreation on Wildlife, Montana Chapter of the Wildlife Society. $307 \mathrm{pp}$.

*Maxell, B.A., J.K. Werner, P. Hendricks, and D.L. Flath. 2003. Herpetology in Montana: a history, status summary, checklists, dichotomous keys, accounts for native, potentially native, and exotic species, and indexed bibliography. Northwest Fauna Number 5. 138 p. *McEneaney, T. and J. Jensen. 1974. The reptiles and amphibians of the Charles M. Russell National Wildlife Range - 1974. Charles M. Russell National Wildlife Refuge. Lewistown, MT. 3 p.

Meylan, P.A. 1982. The squamate reptiles of the Inglis IA fauna (Irvintonian: Citrus County, Florida:. Bulletin of Florida State Museum of Biological Science 27:1-85.

Meylan, P.A. 1987. The phylogenetic relationships of soft-shelled turtles (family Trionychidae). Bulletin of the American Museum of Natural History 186(1): 1-101. 
Meylan, P.A. and R.G. Webb. 1988. Trionyx swinhoei (Gray) 1873, a valid species of living soft-shelled turtle (Family Trionychidae) from China. Journal of Herpetology 22.

Miller, K., G.F. Birchard, M.J. Packard, and G.C. Packard. 1989. Trionyx spiniferus (spiny softshell turtle). Fecundity. Herpetological Review 20(2): 56.

Miller, K., G.C. Packard and M.J. Packard. 1989. Life history notes: Trionyx spiniferus. Herpetological Review 20(2): 56.

*Mosimann, J. E., and G. B. Rabb. 1952. The herpetology of the Tiber Reservoir area, Montana. Copeia 1952:23-27.

*Moulton, G. (ed.). 1983. The journals of the Lewis and Clark expedition. University of Nebraska Press. Lincoln, Nebraska. Volumes 4, 5, 8, 9 and 10.

*[OEAR] Olson Elliot and Associates Research. 1985. 1983-1984 Wildlife monitoring report for the CX Ranch project. Olson Elliot and Associates Research. Helena, MT.

Oldham, M.J. 1990. Ontario herpetological summary. Pp. 195-205. In: Allen, G.M., Eagles, P.F.J. \& Price, S.D. [eds]. Conserving Carolinian Canada. Conservation biology in the deciduous forest region. University of Waterloo Press, Waterloo, Ontario. 1990: i-xii, 1-346.

Packard, G.C. and M.J. Packard. 1990. Growth of embryonic softshell turtles is unaffected by uremia. Canadian Journal of Zoology 68(5) 1990: 841-844.

Packard, G.C., T.L. Taigen, M.J. Packard, and T.J. Boardman. 1981. Changes in mass of eggs of soft-shell turtles (Trionyx spiniferus) incubated under hydric conditions simulating those of natural nests. Journal of Zoology 193: 81-90.

Packard, G.C., T.L. Taigen, T.J. Boardman, M.J. Packard, and C.R. Tracy. 1979. Changes in mass of softshell turtle (Trionyx spiniferus) eggs incubated on substrates differing in water potential. Herpetologica 35: 78-86.

Packard, M.J. and G.C. Packard. 1979. Structure of the shell and tertiary membranes of eggs of softshell turtles (Trionyx spiniferus). Journal of Morphology 159: 131-143.

Packard, M.J. and G.C. Packard. 1991. Sources of calcium, magnesium, and phosphorus for embryonic soft-shell turtles (Trionyx spiniferus). Journal of Experimental Zoology 258(2): 151-157.

Parmalee, P.W. 1989. Muskrat predation on softshell turtles. Journal of the Tennessee Academy of Science 64(4): 225-227.

Platt, S.G. and C.G. Brantley. 1991. Apalone spinifera (spiny softshell). Behavior. Herpetological Review 22: 57.

Plummer, M.V. 1976. Some aspects of nesting success in the turtle, Trionyx muticus. Herpetologica 32: 353-359.

Plummer, M.V. 1977b. Reproduction and growth in the turtle Trionyx muticus. Copeia 1977:440-447.

Plummer, M. V., and J. C. Burnley. 1997. Behavior, hibernacula, and thermal relations of softshell turtles (Trionyx spiniferus) overwintering in a small stream. Chelonian Conservation and Biology 2:489-493.

Plummer, M.V., N.E. Mills, and S.L. Allen. 1997. Activity, habitat, and movement patterns of softshell turtles (Trionyx spiniferus) in a small stream. Chelonian Conservation Biology 2:514-520.

Plummer, M.V., T.L. Crabill, N.E. Mills, and S.L. Allen. 2005. Body temperatures of freeranging softshell turtles (Apalone spinifera) in a small stream. Herpetological Review 36(4):371-375. 
*[PRESI] Powder River Eagle Studies Incorporated. 1998. Spring Creek Mine 1997 wildlife monitoring studies. Powder River Eagle Studies Incorporated. Gillete, WY.

Reese, S.A., D.C. Jackson, and G.R. Ultsch. 2003. Hibernation in feshwater turtles: softshell turtles (Apalone spinifera) are the most intolerant of anoxia among North American species. Journal of Comparative Physiology B Biochemical Systemic and Environmental Physiology 173(3):263-268.

* Reichel, J.D. 1995. Preliminary amphibian and reptile survey of the Lewis and Clark National Forest: 1994. Montana Natural Heritage Program, Helena, MT. 92 p.

*Reichel, J.D. 1996. Preliminary amphibian and reptile survey of the Helena National Forest: 1995. Montana Natural Heritage Program, Helena, MT. 87 p.

*Reichel, J.D. and D.L. Flath. 1995. Identification guide to the amphibians and reptiles of Montana. Montana Outdoors 26(3): 15-34.

Roberts, N.C. 1985. A preliminary report on the status of Chelydridae, Trioncychidae[Trionychidae], and Testidinidae[Testudinidae] in the region of Baja California, Mexico. Desert Tortoise Council Proceedings of Symposium 7: 154-161.

Robertson, S.L. and E.N. Smith. 1982. Evaporative water loss in the spiny soft-shelled turtle Trionyx spiniferus. Physiological Zoology 55(2): 124-129.

Robinson, K.M. and G.G. Murphy. 1978. The reproductive cycle of the eastern spiny softshell turtle (Trionyx spiniferus spiniferus). Herpetologica 34(2): 137-140.

*Roedel, M.D. and P. Hendricks. 1998a. Amphibian and reptile survey on the Bureau of Land Management Lewistown District: 1995-1998. Montana Natural Heritage Program, Helena, MT. 53 p.

*Roedel, M.D. and P. Hendricks. 1998b. Amphibian and reptile inventory on the Headwaters and Dillon Resource Areas in conjunction with Red Rocks Lakes National Wildlife Refuge: 1996-1998. Montana Natural Heritage Program, Helena, MT. 46 p.

Seidel, M.E. 1975. Osmoregulation in the turtle Trionyx spiniferus from brackish and freshwater. Copeia 1975: 124-128.

Shaffer, H.B., P. Meylan, and M.L. McKnight. 1997. Tests of turtle phylogeny: molecular, morphological, and paleontological approaches. Systemic Biology 46:235-268.

Sheil, C.A. 2003. Osteology and skeletal development of Apalone spinifera (Reptilia:Testudines:Trionychidae). Journal of Morphology 256:42-78.

Smith, E.N., S.L. Robertson, and S.R. Adams. 1981. Thermoregulation of the spiny soft-shelled turtle Trionyx spiniferus. Physiological Zoology 54(1): 74-80.

*Stebbins, R.C. 2003. A field guide to western reptiles and amphibians. 3rd edition. New York, NY: Houghton Mifflin Co. 533 p.

Stone, P.A., J.L. Dobie, and R.P. Henry. 1992a. Cutaneous surface area and bimodal respiration in soft-shelled (Trionyx spiniferus), stinkpot (Stemotherus odoratus), and mud turtles (Kinostemon subrubrum). Physiological Zoology 65(2): 311-330.

Stone, P.A., J.L. Dobie, and R.P. Henry. 1992b. The effect of aquatic oxygen levels on diving and ventilatory behavior in soft-shelled (Trionyx spiniferus), stinkpot (Sternotherus odoratus), and mud turtles (Kinosternon subrubrum). Physiological Zoology 65(2): 331-345.

Stuart, J.N. 1988. Geographic distributin. Trionyx spiniferus emoryi (Texas spiny softshell). Herpetological Review 19(1): 22.

Tucker, J.K. and D.A. Warner. 1998. Apalone spinifera (Spiny Softshell) reproduction. Herpetological Review 29(4): 234. 
*Vitt, L.J., J.P. Caldwell, and D.B. Shepard. 2005. Inventory of amphibians and reptiles in the Billings Field Office Region, Montana. Sam Noble Oklahoma Museum of Natural History and Department of Zoology, University of Oklahoma, Norman, OK. 33 pp.

Vogt, R.C. and J.J. Bull. 1982. Genetic sex determination in the spiny softshell Trionyx spiniferus (Testudines: Trionychidae)? Copeia 1982: 699-700.

Vose, R.L. 1964. Nesting habits of the soft shelled turtles (Trionyx species). Proceedings of the Minnesota Academy of Science 31: 122-124.

*Walcheck, K. 1976. Montana Wildlife 170 years ago. Montana Outdoors 7(4): 15-30.

Watermolen, D.J. 2004. Softshell turtles (Apalone spp.) as bald eagle prey. Bulletin of the Chicago Herpetological Society 39(4):69-70.

*Webb, R.G. 1962. North American soft-shelled turtles (Family Trionychidae). University of Kansas Publications, Museum of Natural History 13(10): 429-611.

*Webb, R.G. 1973. Trionyx spiniferus. Catalogue of American Amphibians and Reptiles 140.1-140.4.

*Webb, R.G. 1990. Trionyx. Catalogue of American Amphibians and Reptiles 487.1-487.7.

*Weisrock, D.W. 1997. Molecular phylogenetics of north American softshell turtles. M.S. Thesis. Ames, IA: Iowa State University.

*Weisrock, D.W. and F.J. Janzen. 2000. Comparative molecular phylogeography of North American softshell turtles (Apalone): implications for regional and wide-scale historical evolutionary forces. Molecular Phylogenetics and Evolution 14(1): 152-164.

*Werner, J. K., B. A. Maxell, P. Hendricks, and D. L. Flath. 2004. Amphibians and reptiles of Montana. Mountain Press. Missoula, Montana. 262 pp.

*Wied, M.P. 1865. Verzeichniss der reptilien, welche auf einer reise in nordlichen America beobachtet wurden, von Maximilian, Prinzen zu Wied. Eigengangen bei der Akademie am 1, Juni 1865. Druck von E. Blochmann und Sohn, Dresden, Germany. 141 p.

Williams, T.A. and J.L. Christiansen. 1981. The niches of two sympatric softshell turtles, Trionyx muticus and Trionyx spiniferus, in Iowa. Journal of Herpetology 15: 303-308.

Wood, R.C. 1979. First record of a fossil Trionychid skull from Africa. Herpetological Review 35(4): 360-364.

Zangerl, R. 1939. The homology of the shell elements in turtles. Journal of Morphology 65:383-406. 


\section{Northern Alligator Lizard (Elgaria coerulea)}

Up-to-date distribution and status information can be found on the Montana Natural Heritage Program's TRACKER website at http://mtnhp.org

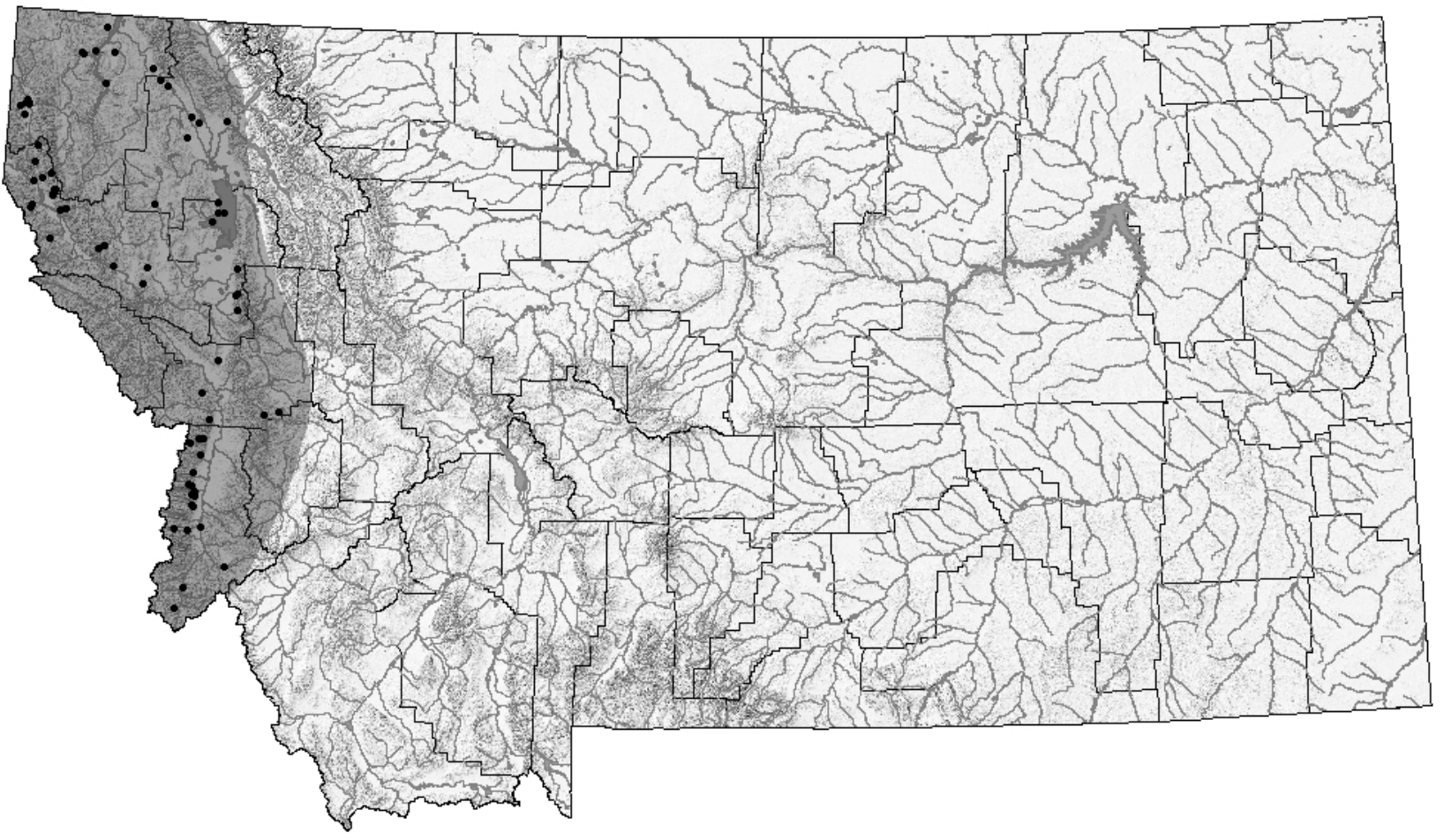

\section{Distribution/Taxonomy}

The northern alligator lizard is one of seven species currently recognized in the genus Elgaria (Good 1988a, b); it was formerly included in the genus Gerrhonotus (Lais 1976). Four intergrading subspecies of northern alligator lizard (Elgaria coerulea coerulea, E. c. palmeri, E. c. principis, and E. c. shastensis) are recognized, with the northwestern alligator lizard (E. c. pincipis) the form present in Montana (Fitch 1938, Lais 1976, Werner et al. 2004). The northern alligator lizard is found west of the Continental Divide, from southern British Columbia in the north, south into northern Idaho and western Montana, and through northern and western Washington, western Oregon, the Coast Ranges and Sierra Nevada in California. Disjunct populations are present in southeast Oregon, northeast California, and northwestern Nevada along the state border (Lais 1976, Nussbaum et al. 1983, Vindum and Arnold 1997, St. John 2002, Stebbins 2003), at elevations from sea level to $3200 \mathrm{~m}$ (10,500 ft). The species also occurs on some coastal islands off Washington and California. In Montana, there are about 75 records from six counties west of the Continental Divide, including a specimen from Wild Horse Island in Flathead Lake (Maxell et al. 2003, Werner et al. 2004).

Maximum Elevation

1,618 m (5,310 ft) in Ravalli County (Maxell et al. 2003).

\section{Identification}

Juveniles and Adults:

The body is elongate and the legs are short. The back is brown, tan, or gray to olive, yellow, or greenish. Juveniles have a broad reddish-tan stripe running the length of the back. The dark 
sides of the body are often checkered with small dark patches, and there is a distinctive dark patch around the eye (Stebbins 2003). The belly scale rows are edged with a darker area, giving the white to pale gray belly a banded appearance. There is a distinctive fold of skin running along each side of the body, extending between the legs, and revealing small granular scales when spread apart. Males have larger and broader triangular-shaped heads than do females. Adult northern alligator lizards are $7.0-10.0 \mathrm{~cm}$ snout-vent length and up to $20.0 \mathrm{~cm}$ in total length. Newly born young are about $2.0-3.0 \mathrm{~cm}$ snout-vent length and $7.5 \mathrm{~cm}$ total length (Pimentel 1959, Vitt 1973, Nussbaum et al. 1983, Werner et al. 2004).

\section{Eggs:}

The northern alligator lizard is viviparous and does not lay eggs. Eggs develop internally and females give birth to live young. Broods include 2-15 young (typically 3-6), averaging about 4 (Lewis 1946, Pimentel 1959, Vitt 1973, Nussbaum et al. 1983, St. John 2002, Stebbins 2003).

\section{Similar Species:}

Body morphology (elongate body with short legs) and presence of a longitudinal fold of skin on each side of the body separates the northern alligator lizard from other lizards native to Montana. Western skinks have a shiny appearance, distinct longitudinal stripes of brown, black, and golden-yellow, and a blue tail in juveniles and young adults. Greater short-horned lizards are flattened, widened through the body, and "prickly." The pale bellies of common sagebrush lizard and western fence lizard lack darkened edging that gives the belly a banded appearance, they sometimes have blue patches on the belly and throat, and both species also feel rough when handled, due to the keeled scales (St. John 2002, Stebbins 2003). Only the western skink is broadly sympatric with the northern alligator lizard in western Montana, although the western fence lizard is present at one locality (in Sanders County) within its Montana range (Werner et al. 2004).

\section{Habitat Use/Natural History}

The northern alligator lizard occurs in areas cooler and more humid than tolerated by most lizards, but it also requires some sunny clearings as well. It is found in coastal strand communities of stabilized dunes, mixed coniferous forest, often in grassy grown-over areas at margins of woodlands, in clear cuts, sometimes near streams with riparian strips of aspen or other tree and shrub species, sometimes dense, and in juniper-sagebrush and rabbitbrush habitats (Svihla 1942, Lais 1976, Stewart 1979, Nussbaum et al. 1983, Vindum and Arnold 1997, St. John 2002, Stebbins 2003). In these habitats it occurs on the ground often under downed wood and rocks, and in leaf and needle litter. Habitat use in Montana has not been the subject of study, but records associated with encounters provide a sense of habitat requirements. Several observations of northern alligator lizards have been made on south-facing slopes, in or at the margins of fine to coarse talus. Sometimes these sites have had little canopy cover, but more often there has been some cover of Douglas-fir, ponderosa pine, and a variety of shrubby species (serviceberry, ninebark, mock orange), and a litter layer of dried leaves and conifer needles, and are sometimes fairly close to streams (Place 1989, Werner and Reichel 1994, Hendricks and Reichel 1996, Werner et al. 1998, Boundy 2001, Paul Hendricks, pers. obs.). Home range size has not been reported, but adults in coastal Washington are gregarious in early spring and fall, concentrating in localized hibernation sites (Vitt 1973), and at a coastal California location most animals were relatively sedentary, usually being recaptured within $10 \mathrm{~m}$ of initial capture site; 
marked lizards were never found outside the 1.5 ha study plot (Stewart 1985). Mating occurs in April and May in coastal Washington (Svihla 1942, Lewis 1946, Vitt 1973), and elsewhere in the Pacific Northwest (Nussbaum et al. 1983). Gestation is about three months, with a single brood of young born in August-September in coastal California and Washington (Lewis 1946, Vitt 1973, Stewart 1985). No information is available from Montana on any aspect of the reproductive biology of this species. Females in northern California reach sexual maturity in about 32 months, or their third year (Stewart 1985), with larger females producing larger clutches and young (Pimentel 1959, Stewart 1979). There appears to be no size dimorphism between the sexes, although sometimes within populations females may be larger (Stewart 1985). No information is available on longevity of northern alligator lizards, but late age of maturity and low fecundity suggest long life expectancy (Vitt 1973, Stewart 1985). Annual mortality in a coastal California population was $46 \%$ for all juvenile size classes and $27 \%$ for adults (Stewart 1985), with adult female survivorship exceeding that of adult males. Adults and juveniles actively forage, albeit not widely and sometimes haltingly in a slow stalk or propelled snake-like, with the legs folded at the sides (Nussbaum et al. 1983, Place 1989, St. John 2002). Hunting is mainly by sight, but there is evidence that they can identify prey by odor (Cooper 1990), hence one reason for high rates of tongue-flicking. Arthropods form most of the diet, but slugs and earthworms are also taken. Other prey types also include snails, spiders, millipedes, centipedes, and ticks, and captives have eaten neonatal mice (Cooper 1990, Stebbins 2003).

\section{$\underline{\text { Status and Conservation }}$}

At the time the comprehensive summaries of amphibians and reptiles in Montana (Maxell et al. 2003, Werner et al. 2004) were published, there were 74 total records for northern alligator lizard from six counties west of the Continental Divide, with records concentrated near the Idaho state line, and extending east to the western base of the Whitefish Range and west slope of the Mission Mountains. With so few records, the current status in Montana is largely uncertain. The northern alligator lizard has not been documented in Glacier National Park (Marnell 1997), but has been reported south of there in the Mission Mountains on the east side of the Flathead Valley (Brunson and Demaree 1951, Werner et al. 1998). There is also a noticeable absence of records between the lower Clark Fork River and the Flathead Valley, despite seemingly suitable habitat in that region, and the eastern extent of the range in Montana is poorly defined. Because the northern alligator lizard has not been the focus of life history or population studies in Montana, it is difficult to identify conservation needs. At the local scale, limited data from California and Washington indicate this species is relatively sedentary and gregarious (Vitt 1973, Stewart 1985). Thus, populations appear vulnerable to habitat fragmentation, especially where valley bottom habitat is developed or dramatically altered. Population density measurements are not available for Montana, and are few overall; a two-year mark-recapture study at a coastal California site resulted in a mean monthly estimate of 142-167 lizards for the 1.5 ha study area, and an average density of 95-111 lizards when adjusted for juvenile mortality (Stewart 1985). In British Columbia, they may be locally abundant, but are usually distributed fairly sparsely (Gregory and Campbell 1984). To summarize, risk factors relevant to the viability of populations of this species are likely to include habitat loss/fragmentation, fire, road and trail development, quarrying, river/stream impoundment, and use of pesticides and herbicides. However, perhaps the greatest risk to maintaining viable populations of northern alligator lizard in Montana is the lack of baseline data on its distribution, status, habitat use, and basic biology (Maxell and Hokit 1999), which are needed to monitor trends and recognize dramatic declines 
when and where they occur. No studies address or identify risk factors. Presence of northern alligator lizards in "cut-over areas" indicates some degree of tolerance to canopy removal, so long as ground cover remains (Nussbaum et al. 1983). Some vegetative cover or talus appears to be desirable in areas where foraging occurs. Invasion of exotic weeds into occupied habitat has and continues to occur in western Montana, but it is unclear how associated habitat changes may affect populations. Use of chemical agents to control weed and insect pest infestations could depress populations of northern alligator lizards, which feed on ground-dwelling arthropods. Several alligator lizards died in the laboratory after they ate caterpillars of the cinnabar moth, an introduced pest control agent for controlling poisonous tansy ragweed, and there is a possibility that this exotic moth may have adverse effects on northern alligator lizard populations (Nussbaum et al. 1983).

\section{Research and Management Suggestions}

1. See research and management suggestions under all general risk factors described above, with the exception of water impoundments/recreational facilities and harvest/commerce.

2. More thorough documentation of northern alligator lizard presence across its range in Montana is needed, especially between the lower Clark Fork River and the Flathead Valley, and the region east of Missoula and Ravalli counties. All of northwestern Montana needs focused surveys to determine potential connectivity among possibly isolated populations.

3. Studies of habitat use and population dynamics are needed, especially as they relate to livestock grazing, logging, and agricultural practices, to identify species responses to these habitat perturbations and develop effective measures for mitigation of any negative impacts that are identified.

4. Ground cover of rocks and woody debris should be maintained in occupied areas where timber harvest and other management actions are undertaken.

5. The direct and indirect impacts of insecticides, herbicides, and insect pest control agents used in weed and pest control programs need to be assessed, as use of these chemicals and insect agents could impact populations by eliminating prey or through direct poisoning. Monitoring of populations in areas already impacted by exotic weeds is desirable.

Bibliography *indicates an article with information specific to Montana

Banta, B.H., C.R. Mahrdt, and K.R. Beaman. 1996. Reptilia: Squamata: Sauria: Anguidae: Elgaria panamintina. Catalogue of American Amphibians and Reptiles 629.1-629.4.

*Boundy, J. 2001. Herpetofaunal surveys in the Clark Fork Valley region, Montana. Herpetological Natural History 8: 15-26.

Bowker, R.W. 1987. Elgaria kingi (arizona alligator lizard). Aantipredator behavior. Herpetological Review 18(4): 73, 75.

Bowker, R.W. 1988a. A comparative behavioral study and taxonomic analysis of Gerrhonotine lizards. Ph.D. dissertation, Arizona StateUniversity 139p. 1988.

Bowker, R.W. 1988b. Comparative courtship behavior of Gerrhonotine lizards. Journal of the Arizona-Nevada Academy of Science 23(Suppl.): 13.

Bowker, R.W. 1994. Elgaria kingi (arizona alligator lizard). Size. Herpetological Review 25(3): 121.

*Brunson, R.B. 1955. Check list of the amphibians and reptiles of Montana. Proceedings of the Montana Academy of Sciences 15: 27-29. 
*Brunson, R.B. and H.A. Demaree. 1951. The herpetology of the Mission Mountains, Montana. Copeia 1951: 306-308.

Cooper, W.E. 1990. Prey odor discrimination by anguid lizards. Herpetologica 46(2): 183-190.

Cooper, W.E. 1995. Strike-induced chemosensory searching by the anguid lizard Elgaria coerulea. Amphibia-Reptilia 16(2): 147-156.

*Cope, E.D. 1875. Check-list of North American Batrachia and Reptilia; with a systematic list of the higher groups, and an essay on geographical distribution. U.S. National Museum Bulletin 1(1): 1-104.

Criley, B.B. 1986. The cranial ostelogy of gerrhonotiform lizards. American Midland Naturalist 80:199-219.

*Farmer, P. and S.B. Heath. 1987. Wildlife baseline inventory, Rock Creek study area, Sanders County, Montana. Western Technology and Engineering, Inc. Helena, MT.

*Fitch, H.S. 1934a. A shift of specific names in the genus Gerrhonotus. Copeia 1934: 172-173.

*Fitch, H.S. 1934b. New alligator lizards from the Pacific Coast. Copeia 1934: 6-7.

*Fitch, H.S. 1935. Natural history of the alligator lizards. Transactions of the Academy of Sciences in St. Louis 29: 1-38, 4 pls.

*Fitch, H.S. 1938. A systematic account of the alligator lizards (Gerrhonotus) in the western United States and lower California. American Midland Naturalist 20: 381-424.

*Franz, R. 1971. Notes on the distribution and ecology of the herpetofauna of northwestern Montana. Bulletin of the Maryland Herpetological Society 7: 1-10.

Freeman, D.M., D.K. Hendrix, D. Shah, L.F. Fan, and T.F. Weiss. 1993. Effect of lymph composition on an in vitro preparation of the alligator lizard cochlea. Hearing Research 65(1-2): 83-98.

Gibbons, J.W., D. E. Scott, T.J. Ryan, K.A. Buhlmann, T.D. Tuberville, B.S. Metts, J.L. Greene, T. Mills, Y. Leiden, S. Poppy, and C.T. Winne. 2000. The global decline of reptiles, déjà vu amphibians. BioScience 50:653-666.

Goldberg, S.R. and C.R. Bursey. 1991. Gastrointestinal helminths of the northwestern alligator lizard, Gerrhonotus coeruleus principis (Anguidae). Journal of the Helminthological Society of Washington 58(2): 246-248.

*Good, D.A. 1985. Studies of interspecific and intraspecific variation in the alligator lizards (Lacertillia: Anguidae: Gerrhonotinae). Ph.D. Dissertation. University of California at Berkeley, Berkeley, CA. 622 p.

*Good, D.A. 1987a. A phylogenetic analysis of cranial osteology in the gerrhonotine lizards (Lacertillia: Anguidae). Journal of Herpetology 21(4): 285-297.

Good, D.A. 1987b. An allozyme analysis of anguid subfamilial relationships (Lacertilia: anguidae). Copeia 1987(3): 696-701.

*Good, D.A. 1988a. Allozyme variation and phylogenetic relationships among the species of Elgaria (Squamata: Anguidae). Herpetologica 44(2): 154-162.

*Good, D.A. 1988b. Phylogenetic relationships among gerrhonotine lizards: an analysis of external morphology. University of California Publications in Zoology 121: 1-139.

Good, D.A. 1995. Cranial ossification in the northern alligator lizard, Elgaria coerulea (Squamata, Anguidae). Amphibia-Reptilia 16(2): 157-166.

Gregory, P. T., and R. W. Campbell. 1984. The reptiles of British Columbia. British Columbia Provincial Museum, Victoria, British Columbia. $102 \mathrm{p}$.

Grismer, L.L. 1988. Geographic variation, taxonomy, and biogeography of the anguid genus Elgaria (Reptilia: Squamata) in Baja California, Mexico. Herpetologica 44(4): 431-439. 
*Hart, M.M., W.A. Williams, P.C. Thornton, K.P. McLaughlin, C.M. Tobalske, B.A. Maxell, D.P. Hendricks, C.R. Peterson, and R.L. Redmond. 1998. Montana atlas of terrestrial vertebrates. Missoula, MT: Montana Cooperative Wildlife Research Unit, The University of Montana. Missoula, Montana vii +1302 p.

*Hendricks, P. 1997. Lee Metcalf National Wildlife Refuge preliminary amphibian and reptile investigations: 1996. Montana Natural Heritage Program, Helena, MT. 21 p.

*Hendricks, P. and J.D. Reichel. 1996. Amphibian and reptile survey of the Bitterroot National Forest: 1995. Montana Natural Heritage Program, Helena, MT. 95 p.

Kingsbury, B.A. 1992. The thermal ecology of the southern alligator lizard, Elgaria multicarinata. Ph.D. Dissertation. University of California Riverside. 119p.

Kingsbury, B.A. 1993. Thermoregulatory set points of the eurythermic lizard Elgaria multicarinata. Journal of Herpetology 27(3): 241-247.

Kingsbury, B.A. 1994a. Field metabolic rates of a eurythermic lizard. Herpetologica 51(2): 155-159.

Kingsbury, B.A. 1994b. Thermal constraints and eurythermy in the lizard Elgaria multicarinata. Herpetologica 50(3): 266-273.

Kingsbury, B.A. 1995. Field metabolic rates of a eurythermic lizard. Herpetologica 51(2): 155159.

*Lais, P.M. 1976. Gerrhonotus coeruleus. Catalogue of American Amphibians and Reptiles 178.1-178.4.

Lewis, T. H. 1946. Notes on reptiles from the state of Washington. Copeia 1946:155-159.

Loeza-Corichi, A. and O. Flores-Villela. 1995. Elgaria kingii (madrean alligator lizard). Herpetologial Review 26(2): 108.

*Marnell, L. F. 1997. Herpetofauna of Glacier National Park. Northwestern Naturalist 78:17-33.

* Maxell, B.A. 2004a. Amphibian and aquatic reptile inventories conducted on and around the Bitterroot National Forest 2000-2003. Report to Region 1 Office of the U.S. Forest Service, Bitterroot National Forest, Montana Department of Fish, Wildlife, and Parks, and Biological Resources Division of the U.S. Geological Survey. Missoula, MT: Montana Cooperative Wildlife Research Unit and Wildlife Biology Program, University of Montana. 128 p.

*Maxell, B.A. 2004b. Amphibian and aquatic reptile inventories conducted on and around the Thompson River 2003-2004. Report to Region 1 Office of the U.S. Forest Service and Plum Creek Timber Company. Missoula, MT: Montana Cooperative Wildlife Research Unit and Wildlife Biology Program. 83 p.

*Maxell, B.A. 2004c. Report on amphibian and aquatic reptile inventories conducted on and around the Beaverhead-Deerlodge National Forest 2001-2003. Report to Region 1 Office of the U.S. Forest Service, Beaverhead-Deerlodge National Forest, Montana Department of Fish, Wildlife, and Parks, Montana State Office of the Bureau of Land Management, and Montana Department of Environmental Quality. Missoula, MT: Montana Cooperative Wildlife Research Unit and Wildlife Biology Program, University of Montana. 260 p.

* Maxell, B.A. 2005. Amphibian and aquatic reptile inventories conducted on and around lands administered by the Missoula Field Office of the Bureau of Land Management. Report to Missoula Field Office of the Bureau of Land Management. Montana Natural Heritage Program, Helena, MT and Montana Cooperative Wildlife Research Unit and Wildlife Biology Program, University of Montana, Missoula, MT. 53 p. 
*Maxell, B.A. 2009. State-wide assessment of status, predicted distribution, and landscapelevel habitat suitability of amphibians and reptiles in Montana. Ph.D. Dissertation. Missoula, MT: Wildlife Biology Program, University of Montana. 294 p.

*Maxell, B.A., and D.G. Hokit. 1999. Amphibians and reptiles. Pages 2.1-2.30. In: G. Joslin and H. Youmans (coordinators). Effects of recreation on Rocky Mountain wildlife: a compendium of the current state of understanding in Montana. Helena, MT: Committee on Effects of Recreation on Wildlife, Montana Chapter of the Wildlife Society. 307 p.

*Maxell, B.A., J.K. Werner, P. Hendricks, and D.L. Flath. 2003. Herpetology in Montana: a history, status summary, checklists, dichotomous keys, accounts for native, potentially native, and exotic species, and indexed bibliography. Northwest Fauna Number 5. 138 pp.

*[NDTI] Northrop, Devine, and Tarbell Incorporated. 1994. Cabinet Gorge and Noxon Rapids hydroelectric developments 1993 wildlife study. Northrop, Devine, and Tarbell Incorporated, Portland, ME. 197 p.

Nussbaum, R. A., E. D. Brodie, Jr., and R. M. Storm. 1983. Amphibians and reptiles of the Pacific Northwest. University of Idaho Press. Moscow, Idaho. 332 p.

Pimentel, R. A. 1959. Positive embryo-maternal size correlation in the northern alligator lizard, Gerrhonotus coeruleus principis. Herpetologica 15:6-8.

*Place, C.B., III. 1989. Mountain Gator. Montana Outdoors 20(4): 27-29.

*Rodgers, T.L., and W.L. Jellison. 1942. A collection of amphibians and reptiles from western Montana. Copeia 1942(1): 10-13.

Rutherford, P.L. and P.T. Gregory. 2003a. Habitat use and movement patterns of northern alligator lizards (Elgaria coerulea) and western skinks (Eumeces skiltonianus) in southeastern British Columbia. Journal of Herpetology 37: 98-106

Rutherford, P.L. and P.T. Gregory. 2003b. How age, sex, and reproductive condition affect retreat-site selection and emergence patterns in a temperate-zone lizard, Elgaria coerulea. Ecoscience 10(1):24-32.

Smith, H.M. 1986. The generic allocation of two species of mexican anguid lizards. Bulletin of the Maryland Herpetological Society 22(1): 21-22. 1986.

Spengler, J.C. and H.M. Smith. 1983. Intact exuviae in lizards. Bulletin of the Maryland Herpetological Society 19(1):24-26.

Sprackland, R.G. 1991. Alligator lizards. Tropical Fish Hobbyist 39(7): 136-140.

Stebbins, R.C. 1958. A new alligator lizard form the Panamint Mountains, Inyo County, California. American Museum of Novitates 1883:1-27.

*Stebbins, R.C. 2003. A field guide to western reptiles and amphibians. 3rd edition. New York, NY: Houghton Mifflin Co. 533 p.

Stewart, J.R. 1979. The balance between number and size of young in the live bearing lizard Gerrhonotus coeruleus. Herpetologica 35:342-350.

Stewart, J.R. 1985. Growth and survivorship in a California population of Gerrhonotus coerulens, with comments on intraspecific variation in adult female size. American Midland Naturalist 113: 30-44.

*St. John, A. 2002. Reptiles of the Northwest: California to Alaska; Rockies to the Coast. Renton, WA: Lone Pine Publishing. 272 p.

Svihla, A. 1942. Mating behavior of the northern alligator lizard. Copeia 1942(1): 52. Tihen, J.A. 1949. The genera of gerrhonotine lizards. American Midland Naturalist 41(3): $580-601$. 
*Timken, R. No Date. Amphibians and reptiles of the Beaverhead National Forest. Western Montana College, Dillon, MT. 16 p.

Vindum, J.V. and E.N. Arnold. 1997. The northern alligator lizard (Elgaria coerulea) from Nevada. Herpetological Review 28: 100.

Vitt, L. J. 1973. Reproductive biology of the anguid lizard, Gerrhonotus coeruleus principis Herpetologica 29:176-184.

Waddick, J.W. and H.M. Smith. 1974. The significance of scale characters in evaluation of the lizard genera Gerrhonotus, Elgaria, and Barisia. Great Basin Naturalist 34(4): 257-266.

*Werner, J.K., B.A. Maxell, P. Hendricks, and D.L. Flath. 2004. Amphibians and reptiles of Montana. Mountain Press. Missoula, Montana. 262 p.

*Werner, J.K. and J.D. Reichel. 1994. Amphibian and reptile survey of the Kootenai National Forest: 1994. Montana Natural Heritage Program, Helena, MT. 104 p.

*Werner, J.K. and J.D. Reichel. 1996. Amphibian and reptile monitoring/survey of the Kootenai National Forest: 1995. Montana Natural Heritage Program, Helena, MT. 115 p.

*Werner, J.K. and T. Plummer. 1994. Amphibian and reptile survey of the Flathead Indian Reservation 1993-1994. Salish Kootenai College, Pablo, MT. 55 p.

*Werner, J.K. and T. Plummer. 1995. Amphibian monitoring program on the Flathead Indian Reservation 1995. Salish Kootenai College, Pablo, MT. 46 p.

*Werner, J.K., T. Plummer, and J. Weaselhead. 1998. Amphibians and reptiles of the Flathead Indian Reservation. Intermountain Journal of Sciences 4(1-2): 33-49. 


\section{Greater Short-horned Lizard (Phrynosoma hernandesi)}

Up-to-date distribution and status information can be found on the Montana Natural Heritage Program's TRACKER website at http://mtnhp.org

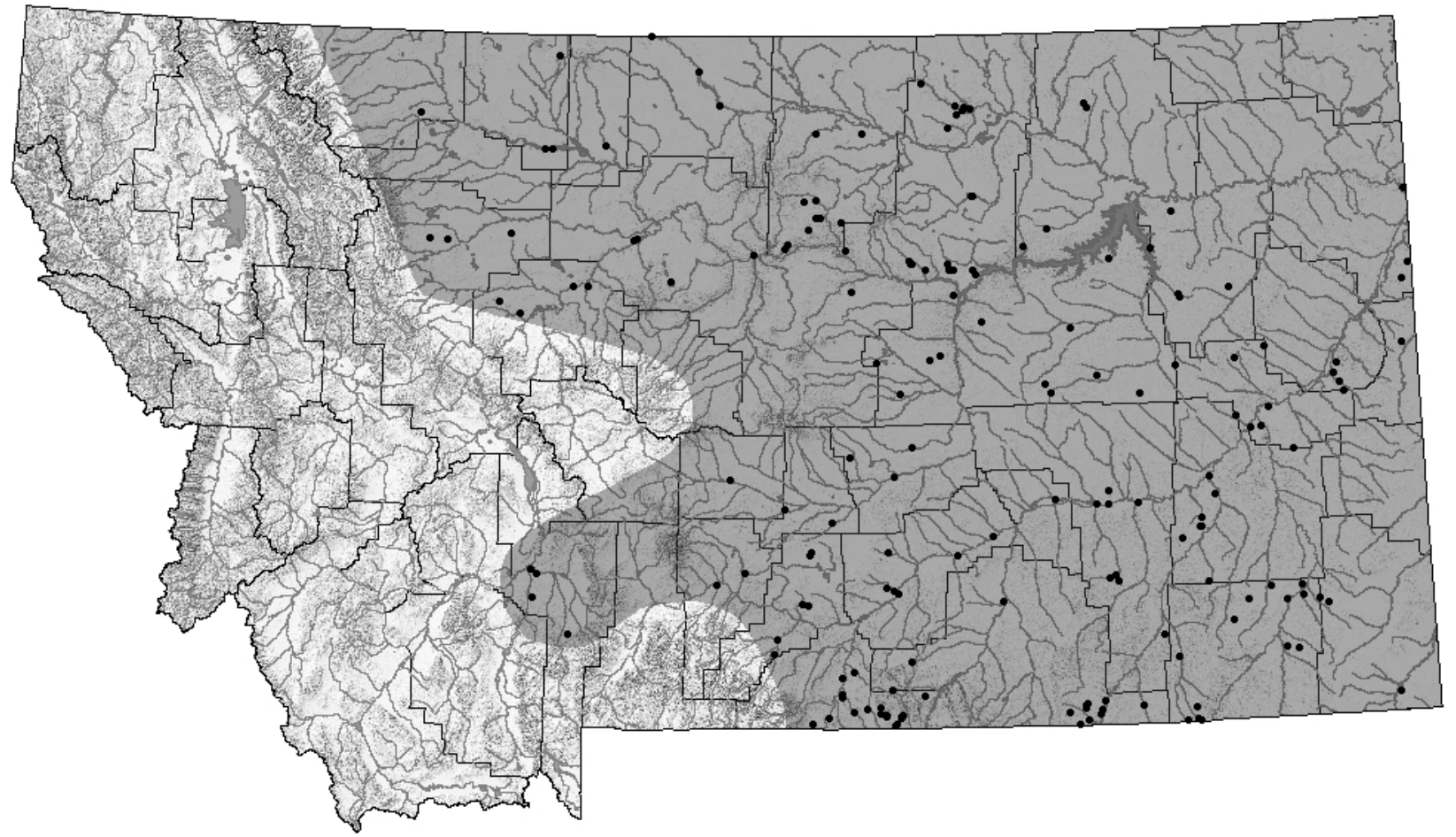

Distribution/Taxonomy

The short-horned lizard was recently split into the Pigmy Short-horned Lizard (Phrynosoma douglasii), the northwestern short-horned lizard subspecies prior to the split, and the Greater Short-horned Lizard (Zamudio et al. 1997, Hammerson 1999, Stebbins 2003), encompassing the other five subspecies prior to the reclassification (Reeve 1952). Analyses of genetic and morphological traits (Zamudio et al. 1997) also failed to support the validity of any subspecific differentiation across the range of the greater short-horned lizard. The greater short-horned lizard is found from southeastern Alberta and southwestern Saskatchewan south through eastern Montana, the western Dakotas, Wyoming, western Nebraska, Colorado, Utah, eastern Nevada, New Mexico, Arizona, and western Texas to southern Durango (Stebbins 2003), at elevations to $3355 \mathrm{~m}$ (11,000 ft) or more (Montanucci 1981, Hammerson 1999). The range limit in the vicinity of southeastern Idaho, western Wyoming, northern Utah, and northern Nevada has not been precisely determined (Baxter and Stone 1985, Hammerson 1999, St. John 2002, Stebbins 2003). In Montana, there are over 147 records from 27 counties east of the Continental Divide. There is an obvious absence of records between the Missouri and Musselshell rivers in central Montana (Maxell et al. 2003, Werner et al. 2004) that could reflect limited survey effort in that region.

Maximum Elevation

$1981 \mathrm{~m}$ (6,500 ft) in Carbon County (Maxell et al. 2003). 


\section{$\underline{\text { Identification }}$}

Juveniles and Adults:

The greater short-horned lizard is viviparous, eggs develop internally and females give birth to live young. Broods can include up to 30 neonates or more, averaging about 12-18 (Smith 1941, Goldberg 1971, Ashton and Ashton 1998, Hammerson 1999), although broods are smaller in the north of their range (Powell and Russell 1991b, Hammerson 1999). The body is broad and flattened. The back is spiny, especially noticeable in a single row of scales fringing each side of the body. Spines at the back of the head are stubby and about as long as they are wide at their base (Hammerson 1999, Stebbins 2003). A noticeably wide and deep notch separates the right and left horns at the back of the head (St. John 2002). Coloration of the back can be shades of gray, brown, or pink, usually blending cryptically with the soil, and can vary somewhat from region to region, as well as at single localities and even single broods (Ashton and Ashton 1998). There are typically two paired rows of dark brown blotches on the back that are often edged in white. Maximum total length is about $15 \mathrm{~cm}$ (Hammerson 1999, St. John 2002, Stebbins 2003). In males there is a swelling at the base of the tail, and the tail is proportionally longer than in females. Females outweigh males (18 g versus $10 \mathrm{~g}$ ) and attain greater snout-vent lengths ( $7 \mathrm{~cm}$ versus $5 \mathrm{~cm}$ ) (Powell and Russell 1985b, James et al. 1997). Newborn young are generally adult-like in appearance, with a broad and flattened body shape. They are about 2.0-2.5 cm snout-vent length and weigh about $0.7-0.8 \mathrm{~g}$, growing up to $3.8 \mathrm{~cm}$ by the time of first hibernation (Goldberg 1971, Powell and Russell 1991b, Ashton and Ashton 1998).

\section{Similar Species:}

The broad flattened body separates this lizard from the other lizard species regularly documented in Montana, and the range overlaps only with the common sagebrush lizard. The pigmy shorthorned lizard (Phrynosoma douglasi) is present in adjacent southeastern Idaho and has been reported once from the Centennial Valley, Beaverhead County, in extreme southwestern Montana (Maxell et al. 2003). Adults of the pigmy short-horned lizard are much smaller than the greater short-horned lizard, they lack the wide notch between the horns on the back of the head that gives the head of the greater short-horned lizard a "heart-shape" appearance when viewed from above, and the small horns on the back of the head project almost vertically, rather than horizontally as in the greater short-horned lizard (St. John 2002, Werner et al. 2004).

\section{Habitat Use/Natural History}

The greater short-horned lizard is an animal of short-grass and mixed-grass (Stipa and Bouteloua) prairies, sagebrush and other shrubland types, and open coniferous forest in mountains. They often occur in open, shrubby or wooded areas (e.g., piñon-juniper, pine-oak woodlands) with sparse vegetation at ground level and easy access to sunlight. Soil substrate may vary from rocky to sandy, but loose soil is usually present (Hammerson 1999, Stebbins 2003). In Alberta and Saskatchewan, greater short-horned lizard is often found in coulees and small canyons associated with streams and rivers in terrain of exposed "badland" shale, with a ground cover that includes creeping juniper (Juniperus horizontalis) (Powell and Russell 1991a, 1998, Powell et al. 1998). In Colorado, this species was encountered frequently in prairie dog colonies (Clark et al. 1982). Habitat use in Montana has not been the subject of study, but this species occurs in sagebrush and grassland habitats, sometimes in the presence of sedimentary rock outcrops (limestone, sandstone) and glacial drift, and in areas with open stands of limber pine and Utah juniper or ponderosa pine (Mosimann and Rabb 1952, Werner 1974, Hendricks 
1999, Vitt et al. 2005). Favored areas in Montana tend to have a relatively high percentage of open bare ground and loose soil. Home ranges of radio-tagged individuals in Alberta ranged from 4.4-2400 $\mathrm{m}^{2}$ (James et al. 1998), with movements by females exceeding $100 \mathrm{~m}$ over a one week period prior to mating, and as much as $266 \mathrm{~m}$ during the week prior to hibernation. Home ranges may actually be larger, because individuals are relatively sedentary but make irregular long movements that vary with the season (Powell and Russell 1998). The greater short-horned lizard does not appear to be territorial (Powell and Russell 1998), although it exhibits some degree of site fidelity. A juvenile displaced 400m returned to its capture site in less than a year and was subsequently captured twice more at this location (Pianka and Parker 1975). Adults mate shortly after emerging from winter dormancy in late March to early June, depending on elevation and latitude. Young are born about two or three months after eggs are fertilized, mostly during early July to early August in Arizona (Smith 1941, Goldberg 1971), and late July to early August in Colorado, southern Wyoming, and Alberta (Powell and Russell 1991b, Ashton and Ashton 1998, Hammerson 1999). Size of eight litters from Alberta ranged from 6-13 young (Laird and Leech 1980, Powell and Russell 1998), one litter from Wyoming included 13 young, five litters in Colorado ranged from 14-18 young (Hammerson 1999), and 12 litters from Arizona included 9-30 young (Smith 1941, Goldberg 1971). Little information is available from Montana on any aspect of the reproductive biology of this species. Ten captive adult females from near Warren, Carbon County, gave birth in the first week of August (J. Barron, pers. comm.), and young about 3.0-3.5 cm snout-vent length have been observed in this area in August and early September (Hendricks 1999, Paul Hendricks, pers. obs.). Sexual maturity of females is attained by the age of two years in Colorado (their third calendar year), at about 5-6 cm snoutvent length (Hammerson 1999). In Alberta, males apparently reach sexual maturity in the second year, following their first winter dormancy, although females appear to mature later (Powell and Russell 1985b, 1998). Sexual maturity is reached by two years of age in the southwestern states (Pianka and Parker 1975). Mature females are larger, on average, than males. Little information is available on survival rate and longevity. Recapture data suggested high juvenile mortality in Alberta, whereas adult survival was considered relatively high (Powell and Russell 1991b, 1998). This pattern appears to be the norm for other horned lizard species (Pianka and Parker 1975). Adults and juveniles are "sit-and-wait" predators that hunt mainly by sight. Ants and beetles are the most frequent foods across the range, but several other orders of arthropods are also taken (Pianka and Parker 1975, Laird and Leech 1980, Montanucci 1981, Powell and Russell 1984, Hammerson 1999). The diet in Montana is virtually undescribed; stomach contents of three individuals from coulees near the Marias River, Toole County, included mostly ants with a few beetles, grasshoppers, and spiders (Mosimann and Rabb 1952).

\section{Status and Conservation}

At the time the comprehensive summaries of amphibians and reptiles in Montana (Maxell et al. 2003, Werner et al. 2004) were published, there were about 130 total records for greater shorthorned lizard from 27 counties, with records generally widely scattered across the state east of the Continental Divide. Cope (1879) considered the greater short-horned lizard about the most abundant reptile (second only to the Prairie Rattlesnake, Crotalus viridus) along the Missouri River, but it is no longer thought common anywhere in Montana, with the possible exception of some of the counties bordering Wyoming (Maxell et al. 2003). Populations in Carbon County appear to be robust (Vitt et al. 2005, J. Barron, pers. comm.), with many recent sightings (Barron reported 140 individuals near Warren in 2004) during favorable conditions. However, trend 
estimates remain unavailable for any locality in Montana, including areas of recent surveys. Connectivity of populations is unknown. Large gaps of a hundred $\mathrm{km}$ or more exist between some documented occurrences north of the Missouri River, and status is uncertain west of the Mussellshell River and south of the Missouri River. At the local scale, limited data suggest this species is relatively sedentary, with some degree of site fidelity, although females may move 100 m or more prior to mating or winter dormancy (Pianka and Parker 1975, James et al. 1997, Powell and Russell 1998). Thus, populations appear vulnerable to habitat fragmentation. Densities of this species have not been determined with any degree of accuracy, but are thought to be generally low (considerably < 50 individual/ha) (Pianka and Parker 1975, Powell and Russell 1985b), although perhaps locally fairly common (Hammerson 1999). Risk factors relevant to the viability of populations of this species are likely to include habitat loss/fragmentation, grazing, fire, road and trail development, on- and off-road vehicle use, use of pesticides and herbicides, oil and gas development, and surface mining. However, perhaps the greatest risk to maintaining viable populations of greater short-horned lizard in Montana is the lack of baseline data on its distribution, status, habitat use, and basic biology (Maxell and Hokit 1999), which are needed to monitor trends and recognize dramatic declines when and where they occur. Few studies address or identify risk factors. In an Idaho study (Reynolds 1979), the closely related pigmy short-horned lizard was four times more abundant in sagebrush habitat than in sites dominated by exotic crested wheatgrass, and more abundant in sagebrush habitat grazed by sheep than in ungrazed sagebrush and either grazed or ungrazed crested wheatgrass. A greater abundance of invertebrates may explain the preference for sagebrush over crested wheatgrass habitat (Reynolds 1979). More open ground for basking in grazed sagebrush may explain its preference over ungrazed sagebrush (Reynolds 1979, Hammerson 1999). Local extirpations of greater short-horned lizard in Colorado have occurred in areas of intense cultivation and urban expansion, although this species seems to do well in areas used for livestock grazing (Hammerson 1999), perhaps because grazing reduces vegetative cover. Increased vehicular traffic in areas of oil and gas exploration and development have probably reduced populations in parts of Colorado (Hammerson 1999). Use of insecticides to control grasshopper infestations could also depress populations of this species, which feeds on these and other ground-dwelling insect species.

\section{$\underline{\text { Research and Management Suggestions }}$}

1. See research and management suggestions under all general risk factors described above, with the exception of water impoundments/recreational facilities and harvest/commerce.

2. More thorough documentation of greater short-horned lizard presence across its range in Montana is needed, especially north of the Missouri River, the region between it and the Musselshell River, and extreme southeastern Montana, to determine potential connectivity among possibly isolated populations.

3. Efforts should be made to determine if historically documented populations still remain in the upper Missouri River watershed upstream of Canyon Ferry Reservoir. If populations are found, conservation measures are warranted.

4. Studies of habitat use and population dynamics are needed, especially as they relate to livestock grazing, agricultural activities (including CRP landscapes), areas of oil and gas field development, and surface mine reclamation, to identify species responses to these habitat perturbations and develop effective measures for mitigation of negative impacts. 
5. Reduction of sagebrush cover to promote grass growth for livestock should be avoided or carefully assessed in areas occupied by common sagebrush lizards. Dense grass growth reduces the ability of lizards to move and increases the likelihood that fire will kill shrub cover, making the impacted area unsuitable for recolonization by greater short-horned lizard. Thus, moderate grazing may be beneficial to shrub habitats favored by this species. When and where shrub cover reduction is deemed desirable, it should be conducted in a way to retain a mosaic of cover conditions, including the presence of moderately tall shrubs (sagebrush and rabbitbrush in particular) at a relatively fine scale, to accommodate habitat requirements in home ranges that are fairly small.

6. Reliance upon prairie dog colonies by greater short-horned lizards deserves study in central Montana, as loss of prairie dog colonies could negatively impact local lizard populations in the short term. Exploration of this relationship is also merited to determine what role, if any, the dramatic reduction in habitat occupied by prairie dogs may have had on lizard populations during the last century.

7. The impacts of motor vehicles should be examined where populations are found in close proximity to areas of high human use. This pertains especially to any areas where off-road vehicle use is permitted.

8. The role of insecticides and herbicides in pest control programs of rangeland areas occupied by greater short-horned lizards needs to be determined, as use of these chemicals could severely impact lizard populations by eliminating a significant portion of their prey.

Bibliography *indicates an article with information specific to Montana

*Allen, J.A. 1874. Notes on the natural history of portions of Dakota and Montana Territories, being the substance of a report to the Secretary of War on the collections made by the North Pacific Railroad Expedition of 1873, General D.S. Stanley, Commander. Proceedings of the Boston Society of Natural History 17: 33-85. Pages 68-70.

Ashton, K.G. and K.L. Ashton. 1998. Phrynosoma douglasii (Short-horned Lizard). Reproduction. Herpetological Review 29:168-169.

Ballinger, R.E., J.W. Meeker, and M. Thies. 2000. A checklist and distribution maps of the amphibians and reptiles of South Dakota. Transactions of the Nebraska Academy of Sciences 26:29-46.

Baxter, G.T. and M.D. Stone. 1985. Amphibians and reptiles of Wyoming. Second edition. Wyoming Game and Fish Department, Cheyenne, Wyoming. 137 p.

Beauchamp, B., B. Wone, S. Bros, and M. Kutilek. 1998. Habitat use of the flat-tailed horned lizard (Phrynosoma mcallii) in a disturbed environment. Journal of Herpetology 32(2): 210216.

Benson, K.R. 1978. Herpetology of the Lewis and Clark expedition 1804-1806. Herpetological Review 9(3): 87-91.

*Brunson, R.B. 1955. Check list of the amphibians and reptiles of Montana. Proceedings of the Montana Academy of Sciences 15: 27-29.

*Burroughs, R.D. 1961. The natural history of the Lewis and Clark expedition. Michigan State University Press. $340 \mathrm{p}$.

Chandler, J.D. 1965. Horned toad record. The Blue Jay 23(2): 92.

Clark, T.W., T.M. Campbell, III, D.G. Socha, and D.E. Casey. 1982. Prairie dog colony attributes and associated vertebrate species. Great Basin Naturalist 42:572-582. 
*Cooper, J.G. 1860. Report upon the reptiles collected on the survey. In: Reports of explorations and surveys to ascertain the most practicable and economical route for a railroad from the Mississippi River to the Pacific Ocean. Volume 12, Book 2, Part 3, Number 4. pp. 292-306, +14 pls. 36th Congress, 1st session, House Executive Document Number 56. Serial 1055.

*Cooper, J.G. 1869a. The fauna of Montana territory. American Naturalist 3: 124-127.

*Cooper, J.G. 1869b. Notes on the fauna of the upper Missouri. American Naturalist 3: 294-299.

*Cooper, S.V., C. Jean, and P. Hendricks. 2001. Biological survey of a prairie landscape in Montana's glaciated plains. Report to the Bureau of Land Management. Montana Natural Heritage Program, Helena, MT. 24 pp. plus appendices.

*Cope, E.D. 1872. Report on the recent reptiles and fishes of the survey, collected by Campbell Carrington and C.M. Dawes. pp. 467-469. In: F.V. Hayden, Preliminary report of the United States geological survey of Montana and portions of adjacent territories; being a fifth annual report of progress. 538 pp. 42nd Congress, 2nd Session, House Executive Document Number 326. Serial 1520.

*Cope, E.D. 1875. Check-list of North American Batrachia and Reptilia; with a systematic list of the higher groups, and an essay on geographical distribution. U.S. National Museum Bulletin 1(1): 1-104.

*Cope, E.D. 1879. A contribution to the zoology of Montana. American Naturalist 13(7): 432441.

*Cope, E.D. 1900. The crocodilians, lizards and snakes of North America. Report of the U.S. National Museum 1898: 153-1270.

Corn, P.S. and L.J. Gingerich. 1987. Phrynosoma douglassii brevirostre (eastern short-horned lizard). Herpetological Review 18(1): 20.

*Coues, E. and H.C. Yarrow. 1878. Notes on the herpetology of Dakota and Montana. Bulletin of the U.S. Geologic and Geographic Survey 4(1): 259-291.

Dammann, J. 1949. Birth of eighteen young Phrynosoma douglassi Hernandes. Herpetologica 5: 144.

*Dood, A.R. 1980. Terry Badlands non-game survey and inventory final report. Montana Department of Fish, Wildlife, and Parks and Bureau of Land Management, Helena, MT. 70 p.

*Dumas, P.C. 1964. Species-pair allopatry in the genera Rana and Phrynosoma. Ecology 45: $178-181$.

*Farmer, P. 1980. Terrestrial wildlife monitoring study, Pearl area, Montana June, 1978 - May, 1980. Western Technology and Engineering, Inc. Helena, MT.

*Gates, M.T. 2005. Amphibian and reptile baseline survey: CX field study area. Report to Billings and Miles City Field Offices of Bureau of Land Management. Maxim Technologies, Billings, MT. 28pp + Appendices.

Gentry, A.F. 1885. A review of the genus Phrynosoma. Proceedings of the Academy of Natural Sciences of Philadelphia 1885: 138-148.

Gibbons, J.W., D.E. Scott, T.J. Ryan, K.A. Buhlmann, T.D. Tuberville, B.S. Metts, J.L. Greene, T. Mills, Y. Leiden, S. Poppy, and C.T. Winne. 2000. The global decline of reptiles, déjà vu amphibians. BioScience 50:653-666.

Girard, C. 1852. A monographic essay on the genus Phrynosoma. Appendix C - Reptiles by Baird, S.F. and C. Girard. Exploration of the Valley of the Great Salt Lake of Utah, 
Including a Route Through the Rocky Mountains. Lippincott, Grambo, and Co., Philadelphia. Pp. 354-365.

Goldberg, S.R. 1971. Reproduction in the short-horned lizard Phrynosoma douglassi in Arizona. Herpetologica 27(3): 311-314.

Guyer, C. 2006. Phrynosoma douglasii (pigmy short-horned lizard) copulatory position. Herpetological Review 37(1):91-92.

Guyer, C. and A.D. Linder. 1985a. Growth and population structure of the short-horned lizard (Phrynosoma douglassi) and the sagebrush lizard (Sceloporus graciosus) in southeastern Idaho. Northwest Science 59(4): 294-303.

Guyer, C. and A.D. Linder. 1985b. Thermal ecology and activity patterns of the short-horned lizard (Phrynosoma douglassi) and the sagebrush lizard (Sceloporus graciosus) in southeastern Idaho (USA). Great Basin Naturalist 45(4): 607-614.

Hammerson, G. A. 1999. Amphibians and reptiles in Colorado, Second Edition. Niwot, CO: University Press of Colorado. 484 p.

Hammerson, G.A. and H.M. Smith. 1991. The correct spelling of the name of the short-horned lizard of North America. Bulletin of the Maryland Herpetological Society 27(3): 121-127.

*Hart, M.M., W.A. Williams, P.C. Thornton, K.P. McLaughlin, C.M. Tobalske, B.A. Maxell, D.P. Hendricks, C.R. Peterson, and R.L. Redmond. 1998. Montana atlas of terrestrial vertebrates. Montana Cooperative Wildlife Research Unit, The University of Montana. Missoula, Montana vii +1302 p.

Heath, J.E. 1965. Temperature regulation and diurnal activity in horned lizards. University of California Publications in Zoology 64: 97-136.

*Hendricks, P. 1999. Amphibian and reptile survey of the Bureau of Land Management Miles City District, Montana. Montana Natural Heritage Program, Helena, MT. 80 p.

*Hendricks, P. and J.D. Reichel. 1998. Amphibian and reptile survey on Montana refuges: 1996. Montana Natural Heritage Program, Helena, MT. 19 p.

Hoberg, T. and C. Gause. 1989. Reptiles \& amphibians of North Dakota. North Dakota Outdoors 55(1):7-18.

Hornbeck, G.E. and J.E. Green. 1990. A reconnaissance field survey of the eastern short-horned lizard and its habitat in Samedan Manyberries 9-13-4-5 W4M. Delta Environmental Management Group Ltd. Calgary, AB. 27p.

Hornbeck, G.E. and J.E. Green. 1991. Year two of a reconnaissance field survey of the eastern short-horned lizard and its habitat in Samedan Manyberries 9-13-4-5 W4M. Delta Environmental Management Group Ltd. Calgary, AB. 17p.

Hossack, B.R., P.S. Corn, and D.S. Pilliod. 2005. Lack of significant changes in the herpetofauna of Theodore Roosevelt National Park, North Dakota, since the 1920s. American Midland Naturalist 154:423-432.

James J.D., A.P. Russell, and G.L. Powell. 1997. Status of the eastern short-horned lizard (Phrynosoma douglassii brevirostre) in Alberta. Alberta Environmental Protection, Wildlife Management Divison, Wildlife Status Report No. 5, Edmonton, AB. 1-20.

Jennings, M.R. 1987. Impact of the curio trade for San Diego horned lizards (Phrynosoma coronatum blainvillii) in the Los Angeles basin, California: 1885-1930. Journal of Herpetology 21(4): 356-358.

Knowlton, G.F. and J.S. Stanford. 1942. Reptiles eaten by birds. Copeia 1942:186.

*Koch, E.D. and C.R. Peterson. 1995. Amphibians \& reptiles of Yellowstone and Grand Teton national parks. University of Utah Press. Salt Lake City, Utah. 188 p. 
Laird, M. and R. Leech. 1980. Observations on the short-horned lizard in southeastern Alberta. Blue Jay 38(4): 214-218.

Linder, A.D. 1989. Short-horned lizard Phrynosoma douglassi. pp. 50-51. In: T.W. Clark, A.H. Harvey, R.D. Dorn, D.L. Genter, and C. Groves (eds). Rare, sensitive, and threatened species of the greater Yellowstone ecosystem.

Lynn, R.T. 1963. Comparative behavior of the horned lizards, genus Phrynosoma, of the United States. Ph.D. Dissertation, University of Oklahoma, Norman. vi + 76p.

Lynn, R.T. 1965. A comparative study of display behavior in Phrynosoma (Iguanidae). Southwestern Naturalist 10: 25-30.

Lyon, R.E. 1986. Helminth parasites of six lizard species from southern Idaho. Proceedings of the Helminthological Society of Washington 53(2): 291-293.

*Martin, P.R. 1980a. Terrestrial wildlife habitat inventory in southeastern Montana. Montana Department of Fish, Wildlife and Parks and Bureau of Land Management, Helena MT. 114 p.

*Martin, P.R. 1980b. Terrestrial wildlife inventory in selected coal areas of Montana. Montana Department of Fish, Wildlife and Parks and Bureau of Land Management, Helena, MT. 84 p.

*Martin, P.R., K. Dubois and H.B. Youmans. 1981. Terrestrial wildlife inventory in selected coal areas, Powder River resources area final report. Montana Department of Fish, Wildlife and Parks and Bureau of Land Management, Helena, MT. 288 p.

*Matthews, W.L. 1979. Wibaux-Beach wildlife baseline study - nongame species. Bureau of Land Management, Miles City, MT. 93 p.

*Matthews, W.L. 1981. Broadus-Pumpkin Creek baseline inventory - wildlife. Bureau of Land Management, Miles City, MT. 83 p.

*Maxell, B.A. 2004. Preliminary report on amphibian and aquatic reptile inventories conducted on and around the Ashland District of the Custer National Forest in 2002 and 2004. Report to Ashland District of Custer Forest, Region 1 Office of the U.S. Forest Service, and Montana Department of Fish, Wildlife, and Parks. Montana Cooperative Wildlife Research Unit and Wildlife Biology Program, University of Montana, Missoula, MT. 93p.

*Maxell, B.A. 2009. State-wide assessment of status, predicted distribution, and landscapelevel habitat suitability of amphibians and reptiles in Montana. Ph.D. Dissertation. Missoula, MT: Wildlife Biology Program, University of Montana. 294 p.

*Maxell, B.A. and D.G. Hokit. 1999. Amphibians and reptiles. Pp. 2.1-2.30. In: G. Joslin and H. Youmans (committee chairs). Effects of recreation on Rocky Mountain wildlife: a compendium of the current state of understanding in Montana. Helena, MT: Committee on Effects of Recreation on Wildlife, Montana Chapter of the Wildlife Society. 307 p.

*Maxell, B.A., J.K. Werner, P. Hendricks, and D.L. Flath. 2003. Herpetology in Montana: a history, status summary, checklists, dichotomous keys, accounts for native, potentially native, and exotic species, and indexed bibliography. Northwest Fauna Number 5. 138 pp.

*McEneaney, T. and J. Jensen. 1974. The reptiles and amphibians of the Charles M. Russell National Wildlife Range - 1974. Charles M. Russell National Wildlife Refuge. Lewistown, MT. 3 p.

Meyer, D.E. 1966. Drinking habits in the earless lizard, Holbrookia maculata, and in two species of horned lizards (Phrynosoma). Copeia 1966: 126-128.

Milne, L.J. and M.J. Milne. 1950. Notes on the behavior of horned toads. American Midland Naturalist 44: 720-741. 
Milner, B.J. 1979. Northern short-horned lizard in southeastern Alberta. Alberta Naturalist 9: 90-92.

Moll, E.O. 2004. Patronyms of the pioneer west. IX. Phrynosoma hernandesi (Girard, 1858) greater short-horned lizard. Sonoran Herpetologist 17(6):58-61.

Montanucci, R.R. 1979. Notes on systematics of horned lizards allied to Phrynosoma orbiculare (lacertilia: iguanidae). Herpetologica 35(2): 116-124.

Montanucci, R.R. 1981. Habitat separation between Phrynosoma douglassi and P. orbiculare (lacertilia: iguanidae) in Mexico. Copeia 1981(1): 147-153.

Montanucci, R.R. 1984. Breeding, captive care and longevity of the short-horned lizard Phrynosoma douglassi. International Zoological Yearbook 23: 148-156.

Montannuci, R.R. 1987. A phylogenetic study of the horned lizards, genus Phrynosoma, based on skeletal and external morphology. Los Angeles, CA: Natural History Museum of Los Angeles County. Contributions in Science 390:1-36.

Montanucci, R.R. 1989a. Maintenance and propagation of horned lizards (Phrynosoma) in captivity. Bulletin of Chicago Herpetological Society 24: 229-238.

Montanucci, R.R. 1989b. The relationship of morphology to diet in the horned lizard genus Phrynosoma. Herpetologica 45(2): 208-216.

Montanucci, R.R. 1996. Morphological variation in the gular fold in the horned lizard genus, Phrynosoma (Iguania: Phrynosomatidae). Herpetologica 52(1): 46-55.

Montanucci, R.R. and B.E. Baur. 1982. Mating and courtship-related behaviors of the shorthorned lizard, Phrynosoma douglassi. Copeia 1982(4): 971-974.

*Mosimann, J.E. and G.B. Rabb. 1952. The herpetology of Tiber Reservoir area, Montana. Copeia 1952: 23-27.

*Moulton, G. (ed.). 1983. The journals of the Lewis and Clark expedition. University of Nebraska Press. Lincoln, Nebraska. Volumes 4, 5, 8, 9 and 10.

Nero, R.W. 1957. Records of the horned toad in Saskatchewan. Blue Jay 15: 119-120.

New, E.R. 1991. Drilling in short-horned lizard country. CADE/CAODC Conference Publications, Calgary, AB.

*[OEAR] Olson Elliot and Associates Research. 1985. 1983-1984 Wildlife monitoring report for the CX Ranch project. Olson Elliot and Associates Research. Helena, MT.

Pack, H.J. 1918. Some habits of the pygmy horned lizard. Copeia 1918(63): 91-92.

Parker, G.H. 1938. The color changes in lizards; particularly in Phrynosoma. Journal of Experimental Biology 15(1): 48-73.

Phillips, J.A. and H.J. Harlow. 1981. Elevation of upper voluntary temperatures after shielding the parietal eye of horned lizards (Phrynosoma douglassi). Herpetologica 37(4):199-205.

Phillips, J.A., H.J. Harlow, and C.L. Ralph. 1980. Set-point shifts of behavioral thermoregulation in horned lizards after parietal eye manipulation. American Zoologist 20(4): 732.

Pianka, E.R. and W.S. Parker. 1975. Ecology of horned lizards: a review with special reference to Phrynosoma platyrhinos. Copeia 1975(1): 141-162.

Powell, G.L. 1980. Diet of the short-horned lizard in Alberta. American Zoologist 20(4): 842.

Powell, G.L. 1982. The eastern short-horned lizard in Alberta: basic field ecology of northern marginal populations. M.S. Thesis. Calgary, Alberta: University of Calgary.

Powell, G.L. and A.P. Russell. 1984. The diet of the eastern short-horned lizard (Phrynosoma douglassi brevirostre) in Alberta and its relationship to sexual size dimorphism. Canadian Journal of Zoology 62(3): 428-440. 
Powell, G.L. and A.P. Russell. 1985a. Field thermal ecology of the eastern short-horned lizard (Phrynosoma douglassi brevirostre) in southeastern Alberta. Canadian Journal of Zoology 63: 228-238.

Powell, G.L. and A.P. Russell. 1985b. Growth and sexual size dimorphism in Alberta (Canada) populations of the eastern short-horned lizard, Phrynosoma douglassi brevirostre. Canadian Journal of Zoology 63(1): 139-154.

Powell, G.L. and A.P. Russell. 1991a. Distribution of the eastern short-horned lizard (Phrynosoma douglassi brevirostre) in Alberta, Canada. Northwestern Naturalist 72(1): 2126.

Powell, G.L. and A.P. Russell. 1991b. Parturition and clutch characteristics of short-horned lizards (Phrynosoma douglassii brevirostre) from Alberta. Canadian Journal of Zoology 69(11): 2759-2764.

Powell, G.L. and A.P. Russell. 1992a. A preliminary survey of the distribution and abundance of the eastern short-horned lizard (Phrynosoma douglassii brevirostre) in Alberta. A report submitted to the Recreation, Parks, and Wildlife Foundation, Edmonton, Alberta. 135pp.

Powell, G.L. and A.P. Russell. 1992b. The staus of the short-horned lizard (Phrynosoma douglassii) in Canada. Committee on the Status of Endangered Wildlife in Canada, Ottawa, ON. 22p.

Powell, G.L. and A.P. Russell. 1993a. The range and status of the Eastern Short-horned Lizard in the Canadian Prairies. Provincial Museum of Alberta Natural History Occassional Paper 19: 279-290.

Powell, G.L. and A.P. Russell. 1993b. A radiotelemetric study of movement and thermal ecology in an Alberta population of the eastern short-horned lizard (Phrynosoma douglassii brevirostre). A report submitted to the Fish and Wildlife Branch, Alberta Forestry, Lands and Wildlife, 7th Floor, O.S. Longman Building, 6909-116th St., Edmonton, Alberta T6H 4P2.

Powell, G.L. and A.P. Russell. 1994a. A radiotelemetric study of movement, thermal ecology, and hibernation site selection in an Alberta population of the eastern short-horned lizard (Phrynosoma douglassii brevirostre). A report submitted to Alberta Environmental Protection, Fish and Wildlife Division, 7th Floor, O.S. Longman Building, 6909-116th St., Edmonton, Alberta T6H 4P2.

Powell, G.L. and A.P. Russell. 1994b. Movement, thermal ecology, seasonal activity, and overwintering behavior in an Alberta population of the eastern short-horned lizard (Phrynosoma douglassii brevirostre). A report submitted to Alberta Environmental Protection, Fish and Wildlife Division, 7th Floor, O.S. Longman Building, 6909-116th St., Edmonton, Alberta T6H 4P2.

Powell, G.L. and A.P. Russell. 1996. Short-horned lizards (Phrynosoma douglassii brevirostre) in Grasslands National Park: a report on the 1995 field season. Report to Parks Canada, Val Marie, SK. 74p.

Powell, G.L. and A.P. Russell. 1998. The status of Short-horned lizards(Phrynosoma douglasi) and (P. hernandezi) in Canada. Canadian Field Naturalist 112(1):1-16.

Powell, G.L., A.P. Russell, and P.J. Fargey. 1998. The distribution of the Short-horned Lizard Phrynosoma hernandesi in Saskatchewan, Canada. Northwestern Naturalist 79: 19-26.

Presch, W. 1969. Evolutionary osteology and relationships of the horned lizard genus Phrynosoma (Family Iguanidae). Copeia 1969: 250-275. 
*[PRESI] Powder River Eagle Studies Incorporated. 1998b. Spring Creek Mine 1997 wildlife monitoring studies. Powder River Eagle Studies Incorporated. Gillete, WY.

Prieto, A.A., Jr. and W.G. Whitford. 1971. Physiological responses to temperature in the horned lizards, Phrynosoma cornutum and Phrynosoma douglassii. Copeia 1971(3): 498-504.

*Rauscher, R.L. 1998. Amphibian and reptile survey on selected Montana Bureau of Reclamation impoundments. Montana Department of Fish, Wildlife and Parks, Nongame Program, Bozeman, MT. 24 p.

Reeder, T.W. 1995. Phylogenetic relationships among phrynosomatid lizards as inferred from mitochondrial ribosomal DNA sequences: substitutional bias and information content of transitions relative to transversion. Molecular Phylogenetics and Evolution 4(2): 203-222.

Reeder, T.W. and J.J. Wiens. 1996. Evolution of the lizard family Phrynosomatidae as inferred from diverse types of data. Herpetologcial Monographs 0(10): 43-84.

Reeder, T.W. and R.R. Montanucci. 2001. Phylogenetic analysis of the horned lizards (Phrynosomatidae: Phrynosoma): evidence from mitochondrial DNA and morphology. Copeia 2001(2): 309-323.

*Reeve, W.L. 1952. Taxonomy and distribution of the horned lizard genus Phrynosoma. Kansas University Science Bulletin 34(14): 817-960.

*Reichel, J.D. 1995a. Preliminary amphibian and reptile survey of the Lewis and Clark National Forest: 1994. Montana Natural Heritage Program, Helena, MT. 92 p.

*Reichel, J.D. 1995b. Preliminary amphibian and reptile survey of the Sioux District of the Custer National Forest: 1994. Montana Natural Heritage Program, Helena, MT. 75 p.

*Reichel, J.D. 1996. Preliminary amphibian and reptile survey of the Helena National Forest: 1995. Montana Natural Heritage Program, Helena, MT. 87 p.

*Reichel, J.D. 1997. Amphibian, reptile and northern bog lemming survey on the Rocky Mountain Front: 1996. Montana Natural Heritage Program, Helena, MT. 81 p.

Reynolds, T.D. 1979. Response of reptiles populations to different land management practices on the Idaho national engineering laboratory site. Great Basin Naturalist 39(3): 255-262.

*Roedel, M.D. and P. Hendricks. 1998a. Amphibian and reptile survey on the Bureau of Land Management Lewistown District: 1995-1998. Montana Natural Heritage Program, Helena, MT. 53 p.

*Roedel, M.D. and P. Hendricks. 1998b. Amphibian and reptile inventory on the Headwaters and Dillon Resource Areas in conjunction with Red Rocks Lakes National Wildlife Refuge: 1996-1998. Montana Natural Heritage Program, Helena, MT. 46 p.

Schowalter, D.B. 1976. New distribution records of the horned lizard in Alberta. Blue Jay 37: 26-27.

Sherbrooke, W.C. 1997. Physiological (rapid) change of color in horned lizards (Phrynosoma) of arid habitats: hormonal regulation, effects of temperature, and role in nature. AmphibiaReptilia 18: 155-175.

Sherbrooke, W.C., E.R. Brown, and J.L. Brown. 2002. Phrynosoma hernandesi (short-horned lizard). Successful open-mouthed threat defense. Herpetological Review 33(3):208.

Sherbrooke, W.C. and F. Mendoza-Quijano. 2001. Phrynosoma braconnieri (Short-tailed Horned Lizard). Defensive Behavior. Herpetological Review 36(1):65-66.

Sherbrooke, W.C. and M.D. Greenfield. 2002. Phrynosoma hernandesi (short-horned lizard). Defensive hiss. Herpetological Review 33(3):208-209.

*Skinner, M.P. 1924. The Yellowstone Nature Book. A.C. McClurg Company, Chicago, IL. $221 \mathrm{p}$. 
Smith, C.F. 1941. Birth of horned toads. Copeia 1941:114.

Smith, H.M., K. Adler, D. Chiszar, and F. Van Breukelen. 1999. Phrynosoma hernandesi: correct spelling. Herpetological Review 30(2): 74-76.

Smith, W. 1993. An assessment of short-horned lizard habitat and use. Manyberries Badlands, Alberta. A report submitted to the Fish and Wildlife Branch, Alberta Forestry, Lands and Wildlife, 7th Floor, O.S. Longman Building, 6909-116th St., Edmonton, Alberta T6H 4P2.

Snethen, D.G. 1989. An investigation of reptiles of the lower Reynolds Creek area, Owyhee County, Idaho. Journal of the Idaho Academy of Science 25(1/2): 24-25.

*Stebbins, R.C. 2003. A field guide to western reptiles and amphibians. 3rd edition. New York, NY: Houghton Mifflin Co. 533 p.

*St. John, A. 2002. Reptiles of the Northwest: California to Alaska; Rockies to the Coast. Renton, WA: Lone Pine Publishing. 272 p.

*Thompson, L.S. and P.S. Nichols. 1982. Circle West wildlife monitoring study; fourth annual report for period March 1, 1981 - May 31, 1982. Circle West Technical Report No. 10. Montana Department of Natural Resources and Conservation, Helena, MT. Tower, G.H. 1902. The traffic in souvenir toads. Sunset 9(1): 18-19.

*Turner, F.B. 1951. A checklist of the reptiles and amphibians of Yellowstone National Park with incidental notes. Yellowstone Nature Notes 25(3): 25-29.

*Turner, F.B. 1955. Reptiles and amphibians of Yellowstone National Park. Yellowstone Interpretive Series No. 5. Yellowstone Library and Museum Association. Yellowstone National Park, WY. 40 p.

*[USFWS] US Fish and Wildlife Service. 1994. Endangered and threatened wildlife and plants; animal candidate review for listing as endangered or threatened species. Federal Register 59(219): 58982-59028.

*Vitt, L.J., J.P. Caldwell, and D.B. Shepard. 2005. Inventory of amphibians and reptiles in the Billings Field Office Region, Montana. Sam Noble Oklahoma Museum of Natural History and Department of Zoology, University of Oklahoma, Norman, OK. 33 p.

*[VTNWI] VTN Wyoming Incorporated. No Date. Second year's analysis of terrestrial wildlife on proposed mine access and railroad routes in southern Montana and northern Wyoming, March 1979 - February 1980. VTN Wyoming Incorporated. Sheridan, WY. 62 p.

*Waage, B.C. 1998. Western Energy Company Rosebud Mine 1997 annual wildlife monitoring report December 1, 1996 to November 30, 1997 survey period. Western Energy Company, Colstrip, MT.

*Werner, J.K. 1974. Geographic Distribution. Phrynosoma douglasii brevirostre. Herpetological Review 5(1): 20.

*Werner, J.K., B.A. Maxell, P. Hendricks, and D.L. Flath. 2004. Amphibians and reptiles of Montana. Missoula, MT: Mountain Press. 262 p.

*[WESCO] Western Ecological Services Company. 1983. Wildlife inventory of the Southwest Circle known recoverable coal resource area, Montana. Western Ecological Services Company, Novato, CA. $131 \mathrm{p}$.

*Yarrow, H.C. 1882. Check list of North American reptilia and batrachia, with catalogue of specimens in the U.S. National Museum. United States National Museum Bulletin 24. 249 p.

*Zamudio, K.R. 1996. Ecological, evolutionary, and applied aspects of lizard life histories. Ph.D. Dissertation. Seattle, WA: University of Washington. 167 p. 
Zamudio, K.R. 1998. The evolution of female-biased sexual size dimorphism: a populationlevel comparative study in horned lizards (phrynosoma). Evolution 52: 1821-1833.

*Zamudio, K.R., K.B. Jones, and R.H. Ward. 1997. Molecular systematics of the short-horned lizards: biogeography and taxonomy of a widespread species complex. Sysematic Biolology 46: 284-305. 


\section{Common Sagebrush Lizard (Sceloporus graciosus)}

Up-to-date distribution and status information can be found on the Montana Natural Heritage Program’s TRACKER website at http://mtnhp.org

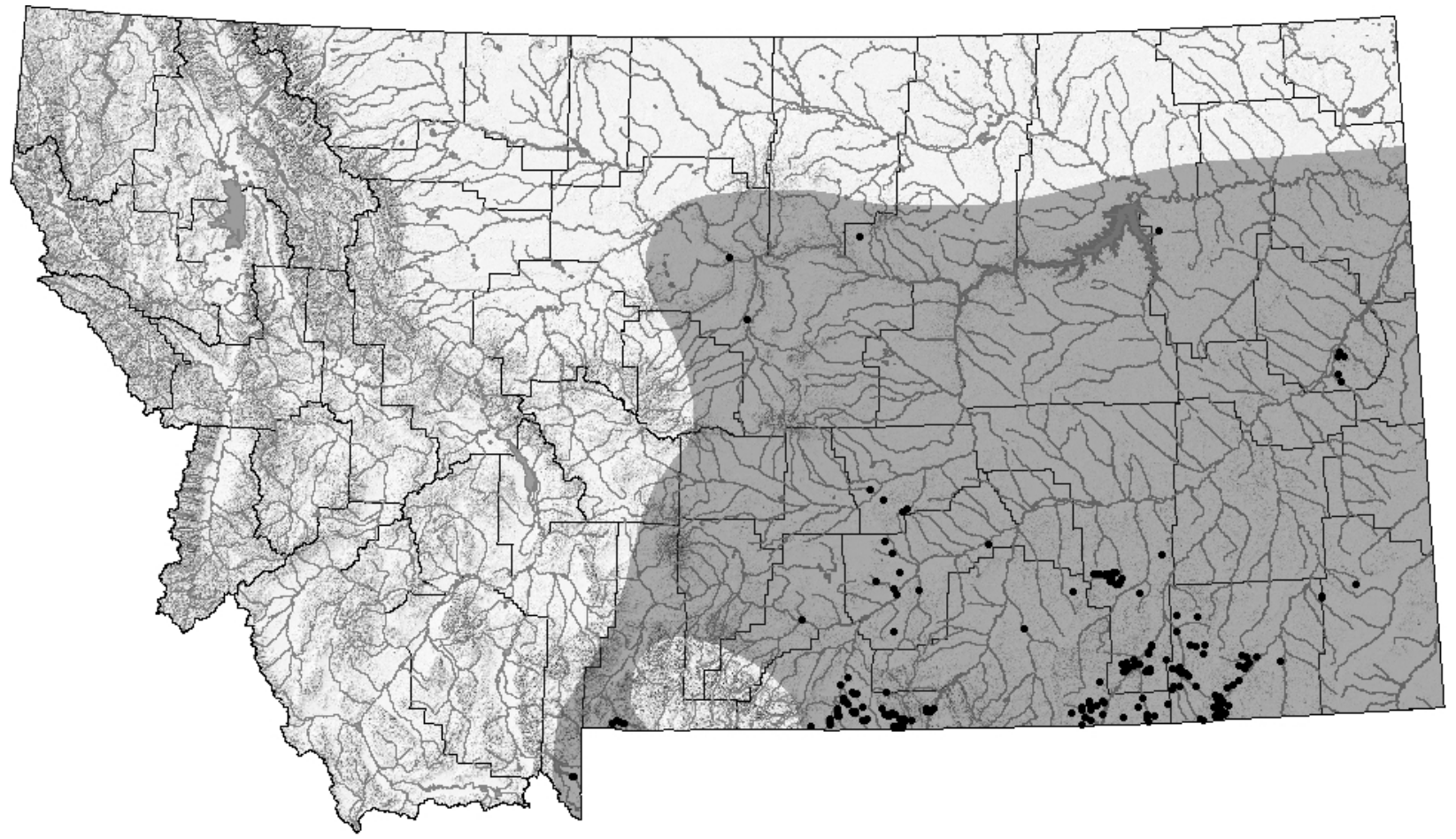

Distribution/Taxonomy

The common sagebrush lizard is a member of a large genus of North American lizards found from Panama to the Canadian border. Three subspecies are currently recognized: the disjunct sand dune lizard, S. g. arenicolous, of southeast New Mexico and adjacent Texas (Degenhardt and Jones 1972) has been elevated to full species status since Censky's (1986) sagebrush lizard species account. Two subspecies are restricted to Pacific coastal states of the U.S. and Baja Peninsula of Mexico. The northern sagebrush lizard, Sceloporus graciosus graciosus, occupies the majority of the species' range, and occurs from northern Arizona and northwestern New Mexico, north through Nevada, Utah, Wyoming, eastern Oregon, central Washington and southern Idaho, at elevations to $3200 \mathrm{~m}(10,500 \mathrm{ft})$ in the southwestern states (Nussbaum et al. 1983, Censky 1986), reaching the northeastern limits of its range in Montana and North Dakota (Hoberg and Gause 1989, Maxell et al. 2003, Werner et al. 2004). In Montana, there are scattered records east of the Continental Divide across the south-central and southeastern counties north to the Missouri River.

Maximum Elevation

1,999 m (6,560 ft) in Gallatin County (Rawson and Pils 2005).

Identification

Eggs:

Eggs are white, leathery, and oval, about $13 \mathrm{~mm}(0.5 \mathrm{in})$ long and $8 \mathrm{~mm}$ (0.3 in) wide. Clutch size is 2-7 and clutches are laid in loose soil in shallow cavities, often at the base of a shrub (Nussbaum et al. 1983, Hammerson 1999, Werner et al. 2004). 
Juveniles and Adults:

The body is small and narrow. The back is covered with small spiny, keeled scales, and usually has a pale dorsolateral stripe on each side. Scales on the rear of the thigh are very small and often granular. Dorsal coloration is brown, olive or gray, with a bluish or greenish tinge. The sides of the body and neck often have a rusty-orange hue. Ventral surfaces of females are white or yellowish, while males have blue lateral abdominal patches and blue mottling on the throat (absent or very faint in females). Maximum snout-vent length is about $6.5 \mathrm{~cm}$. Maximum total length is about $15 \mathrm{~cm}$, with the tail length about 1.5 times the snout-vent length. Mature females are slightly larger than males. Mature males have enlarged postanal scales with two hemipenal swellings on the underside at the base of the tail. Gravid females may develop more intense reddish-orange color along the sides. Hatchlings are 2.3-2.8 cm snout-vent length, but otherwise adult-like in appearance (Nussbaum et al. 1983, Koch and Peterson 1995, Hammerson 1999, St. John 2002, Werner et al. 2004).

\section{Similar Species:}

The common sagebrush lizard lacks the broad flattened body and fringe of prominent spines on each side of the body that are present in the greater short-horned lizard, the only other Montana lizard with which the common sagebrush lizard overlaps in range. It differs from the western fence lizard (Sceloporus occidentalis) by having pale dorsolateral stripes rather than a checkered pattern of darker triangular blotches in rows across the back. The dorsal scales of the common sagebrush lizard are also less prickly and pointed and the blue throat patch in males is less pronounced. The northern alligator lizard has a prominent skin fold on the side of the body. The western skink has smooth shiny and flat dorsal scales, and juveniles and young skinks have conspicuous blue tails. Common sagebrush lizards have keeled or spiny scales, not flattened and shiny, and they never have a blue tail. Western fence lizard, northern alligator lizard and western skink are found only in northwestern Montana west of the Continental Divide (St. John 2002, Werner et al. 2004).

\section{Habitat Use/Natural History}

The common sagebrush lizard is an animal of shrub-steppe habitats, preferring rocky outcrops or sandy soils in sagebrush and antelope bitterbrush communities, and also occupying manzanita, mountain mahogany, and Ceanothus brushland, pinyon-juniper woodland, and open ponderosa pine and Douglas-fir forests (Kerfoot 1968, Marcellini and Mackey 1970, Tinkle 1973, Tinkle et al. 1993, Green et al. 2001). In Yellowstone National Park, lizards are found at higher elevations in geothermal areas on rhyolite-covered hillsides with common juniper and lodgepole pine, and with woody debris scattered on the ground (Mueller 1967, Algard 1968, Koch and Peterson 1995). Habitat use in Montana has not been the subject of study, but this species occurs in sagesteppe habitats, sometimes in the presence of sedimentary rock outcrops (limestone, sandstone) and in areas with open stands of limber pine and Utah juniper or ponderosa pine (Hendricks 1996, Hendricks and Hendricks 2002, Vitt et al. 2005). Favored areas tend to have a high percentage of open bare ground and a component of low to tall shrubs. Although a ground dweller, the common sagebrush lizard will sometimes perch up to 1-2 m above ground in low shrubs and trees (Adolph 1990, Hammerson 1999). Rodent burrows, shrubs, logs, and leaf litter are used for cover when disturbed (Nussbaum et al. 1983). Home ranges may be relatively small, averaging 400-600 $\mathrm{m}^{2}$ in Utah (Burkholder and Tanner 1974). Across much of the range, eggs are laid during May-July (Tinkle et al. 1993, Hammerson 1999). Most females in Colorado 
and Utah produce two clutches each year. Clutch size is usually 3-7 eggs. Eggs hatch in 45-75 days, beginning in early to mid-August in Colorado and Utah, mid-to late August in west-central California (Tinkle et al. 1993, Hammerson 1999). During three summers in Yellowstone National Park, first hatchlings were noted 10-13 August (Mueller and Moore 1969). Hatchling snout-vent length in Colorado, Utah and California is about 2.5-2.7 cm (Ferguson and Brockman 1980, Tinkle et al. 1993, Hammerson 1999), with a growth rate of about 1 mm/week..

Essentially no information is available from Montana on any aspect of the reproductive biology of this species. Juveniles $2.8 \mathrm{~cm}$ snout-vent length were collected in mid- to late September in southern Carbon County, indicating eggs hatched sometime in late August or early September (Hendricks 1999, Paul Hendricks, pers. obs.). Sexual maturity is attained in the first year in the southern portions of the range or second year in the northern portions of the range, although a significant percentage of females in Utah may not mature until their third year (Tinkle 1973, Tinkle et al. 1993, Hammerson 1999). Females in southern Utah produce their first clutch at an age of 22-24 months. Mean annual survival rate of young and adults is quite variable, but averages about $45 \%$ in Utah (Tinkle et al. 1993), although as many as three-fourths of hatchlings may die (Tinkle 1973, Burkholder and Tanner 1974, Hammerson 1999). Males and females in southern Utah can live for at least six years (Tinkle et al. 1993). Adults and juveniles are "sitand-wait" predators that hunt mainly by sight, and the diversity of food items indicates prey is taken largely opportunistically (Burkholder and Tanner 1974). Ants, beetles, moths, and termites are the most abundant of nine orders of insects in the diet. Spiders, scorpions, pseudoscorpions, ticks, and mites have also been reported as foods, and adults sometimes eat hatchling lizards (Burkholder and Tanner 1974, Rose 1976a, Koch and Peterson 1995, Hammerson 1999).

\section{Status and Conservation}

At the time the comprehensive summaries of amphibians and reptiles in Montana (Maxell et al. 2003, Werner et al. 2004) were published, there were only 73 total records from 13 counties east of the Continental Divide for common sagebrush lizard. Most records are from Big Horn, Carbon, Powder River, and Rosebud counties. Populations in Carbon and Powder River counties appear to be robust (Vitt et al. 2005, BAM, pers. obs.), with many recent sightings during favorable conditions, although size and trend estimates remain unavailable for any locality in Montana, including areas of recent surveys. Connectivity of populations is unknown; gaps of several hundred kilometers exist between documented occurrences along the Missouri River, the lower Yellowstone River, and the concentration of records in south-central Montana. At the local scale, removal experiments show recolonization from adjacent areas can rapidly occur in unaltered habitat (M’Closkey et al. 1997). Densities of this species can be as high as 200 individuals/ha (Tinkle 1973). Risk factors relevant to the viability of populations of this species are likely to include habitat loss/fragmentation, grazing, fire, road and trail development, on- and off-road vehicle use, use of pesticides and herbicides, oil and gas development, and surface mining. However, perhaps the greatest risk to maintaining viable populations of common sagebrush lizard in Montana is the lack of baseline data on its distribution, status, habitat use, and basic biology (Maxell and Hokit 1999), which are needed to monitor trends and recognize dramatic declines when and where they occur. Few studies address or identify risk factors. In an Idaho study (Reynolds 1979), common sagebrush lizards were more abundant in ungrazed than grazed sagebrush. They were also more abundant in sagebrush (regardless of grazing treatment) than sites dominated by introduced crested wheatgrass following sagebrush removal, possibly because there was more bare ground available in the sage habitat, which could facilitate the 
ability to bask and move quickly while hunting or escaping predators. The preference for areas with a significant shrub component, $>40 \%$ bare ground, and $<5 \%$ grass cover has also been observed in Oregon (Green et al. 2001), who also noted habitat loss in the region of their study due to proliferation of invasive plants and conversion of shrub-steppe to cropland. Hammerson (1999) suggested that rangeland "improvements" for livestock, involving sagebrush removal to promote grass communities, could result in local population declines in Colorado.

\section{Research and Management Suggestions}

1. More thorough documentation of the species' presence across its range in Montana is needed, especially along the Missouri and Yellowstone rivers and the region between them to determine potential connectivity among apparently isolated populations.

2. Studies of habitat use and population dynamics as they relate to livestock grazing, agricultural activities (including CRP lands), and surface mine reclamation are needed to identify species responses to these habitat perturbations and develop effective mitigation measures.

3. Measures should be taken to prevent invasion of rock outcrop and barren ground habitats by weeds such as Japanese Brome (Bromus tectorum) which reduce basking and foraging habitat.

4. The impacts of motor vehicles should be examined where populations are found in close proximity to areas of high human use. This pertains especially to any areas where off-road vehicle use is permitted.

Bibliography *indicates an article with information specific to Montana

Adolph, S.C. 1987. Physiological and behavioral ecology of the lizards Sceloporus occidentalis and Sceloporus graciosus. Ph.D. Dissertation. Seattle, WA: University of Washington. 121p.

Adolph, S.C. 1990a. Influence of behavioral thermoregulation on microhabitat use by two Sceloporus lizards. Ecology 71(1): 315-327.

Adolph, S.C. 1990b. Perch height selection by juvenile Sceloporus lizards: Interspecific differences and relationship to habitat use. Journal of Herpetology 24(1): 69-75.

*Algard, G.A. 1968. Distribution, temperature and population studies of Sceloporus graciosus graciosus in Yellowstone National Park. M.S. Thesis. Bozeman, MT: Montana State University. $34 \mathrm{p}$.

*Allen, J.A. 1874. Notes on the natural history of portions of Dakota and Montana Territories, being the substance of a report to the Secretary of War on the collections made by the North Pacific Railroad Expedition of 1873, General D.S. Stanley, Commander. Proceedings of the Boston Society of Natural History 17: 33-85. Pages 68-70.

*Beal, M.D. 1951. The occurrence and seasonal activity of vertebrates in the Norris and Gibbon Geyser Basins of Yellowstone National Park. M.S. Thesis. Logan, UT: Utah State Agricultural College. $61 \mathrm{p}$.

*Bergeron, D.J. 1978a. Terrestrial wildlife survey Divide Mine area, Montana 1977-1978. Western Technology and Engineering, Inc. Helena, MT.

*Bergeron, D.J. 1978b. Terrestrial wildlife survey P-M Mine area, Montana 1977-1978. Western Technology and Engineering, Inc. Helena, MT.

*Bergeron, D.J. 1979. Terrestrial wildlife survey, Coal Creek Mine area, Montana 1977-1978. Western Technology and Engineering, Inc. Helena, MT. 
*Brunson, R.B. 1955. Check list of the amphibians and reptiles of Montana. Proceedings of the Montana Academy of Sciences 15: 27-29.

Burkholder, G.L. and W.W. Tanner. 1974. Life history and ecology of the Great Basin sagebrush swift, Sceloporus graciosus graciosus Baird and Girard, 1852. BYU Science Bulletin Biological Series 14(5): 1-42.

*Butts, T.W. 1997. Mountain Inc. wildlife monitoring Bull Mountains Mine No. 1, 1996. Western Technology and Engineering. Helena, MT.

Carpenter, C.C. 1978. Comparative display behavior in the genus Sceloporus (Iguanidae). Milwaukee Public Museum Contributions to Biology and Geology 18: 1-71.

Censky, E.J. 1986. Sceloporus graciosus. Catalogue of American Amphibians and Reptiles 386.1-386.4.

Congdon, J.D. and D.W. Tinkle. 1982. Energy expenditure in free-ranging sagebrush lizards (Sceloporus graciosus). Canadian Journal of Zoology 60: 1412-1416.

*Cooper, J.G. 1869. Notes on the fauna of the upper Missouri. American Naturalist 3: 294-299.

*Cope, E.D. 1900. The crocodilians, lizards and snakes of North America. Report of the U.S. National Museum 1898: 153-1270.

Cuellar, O. 1993. Lizard population ecology: a long term community study. Bulletin D’Ecologie 24(2-4): 109-149.

*Day, D., P.J. Farmer, and C.E. Farmer. 1989. Montco terrestrial wildlife monitoring report December, 1987 - July, 1989. Montco, Billings, MT, and Western Technology and Engineering, Inc. Helena, MT.

Degenhardt, W.G. and K.L. Jones. 1972. A new sagebrush lizard, Sceloporus graciosus, from New Mexico and Texas. Herpetologica 28:212-217.

Deslippe, R.J. and R.T. M'Closkey. 1991. An experimental test of mate defense in an iguanid lizard (Sceloporus graciosus). Ecology 72(4): 1218-1224.

*Dood, A.R. 1980. Terry Badlands nongame survey and inventory final report. Montana Department of Fish, Wildlife, and Parks and Bureau of Land Management, Helena, MT. 70 p.

Etheridge, R. 1964. The skeletal morphology and systematic relationships of sceloporine lizards. Copeia 1964(4): 610-631.

*Farmer, P. 1980. Terrestrial wildlife monitoring study, Pearl area, Montana June, 1978 - May, 1980. Western Technology and Engineering, Inc. Helena, MT.

Ferguson, G.W. 1971. Observations on the behavior and interactions of two sympatric Sceloporus in Utah. American Midland Naturalist 86: 190-196.

Ferguson, G.W. and T. Brockman. 1980. Geographic differences of growth rate of Sceloporus lizards (Sauria: Iguanidae). Copeia 1980: 259-264.

Fitch, H.S. 1978. Sexual size differences in the genus Sceloporus. University of Kansas Science Bulletin 51(13): 441-461.

*Gates, M.T. 2005. Amphibian and reptile baseline survey: CX field study area. Report to Billings and Miles City Field Offices of Bureau of Land Management. Maxim Technologies, Billings, MT. 28pp + Appendices.

Germaine, S.S. and H.L. Germaine. 2003. Lizard distributions and reproductive success in a ponderosa pine forest. Journal of Herpetology 37(4):645-652.

Gibbons, J.W., D.E. Scott, T.J. Ryan, K.A. Buhlmann, T.D. Tuberville, B.S. Metts, J.L. Greene, T. Mills, Y. Leiden, S. Poppy, and C.T. Winne. 2000. The global decline of reptiles, déjà vu amphibians. BioScience 50:653-666. 
Goldberg, S.R. and C.R. Bursey. 1989. Physaloptera retusa (Nematoda, Physalopteridae) in naturally infected sagebrush lizards, Sceloporus graciosus (Iguanidae). Journal of Wildlife Diseases 25(3): 425-429.

Goldberg, S.R. and C.R. Bursey. 1991. Duration of attachment by mites and ticks on the iguanid lizards Sceloporus graciosus and Uta stansburiana. Journal of Wildlife Diseases 27(4): 719-722.

Goldberg, S.R., C.R. Bursey, and C.T. McAllister. 1995. Gastrointestinal helminths of nine species of Sceloporus lizards (Phrynosomatidae) from Texas. Journal of the Helminthological Society of Washington 62(2): 188-196.

Goldberg, S.R., C.R. Bursey, and R. Tawil. 1994. Gastrointestinal helminths of Sceloporus lizards (Phrynosomatidae) from Arizona. Journal of the Helminthological Society of Washington 61(1): 73-83.

Green, G.A., K.B. Livezey, and R.L. Morgan. 2001. Habitat selection by northern sagebrush lizards (Sceloporus graciosus graciosus) in the Columbia Basin, Oregon. Northwestern Naturalist 82:111-115.

Grismer, L.L. 1994. Food observations on the endemic Sierra San Pedro Martir garter snake (Thamnophis elegans hueyi) from Baja California, Mexico. Herpetological Natural History 2(1): 107-108.

Guyer, C. 1978. Comparative ecology of the short-horned lizard (Phrynosoma douglassi) and the sagebrush lizard (Sceloporous graciosus). M.S. Thesis, Idaho State University. 130 p.

Guyer, C. 1991. Orientation and homing behavior as a measure of affinity for the home range in two species of Iguanid lizards. Amphibia-Reptilia 12(4): 373-384.

Guyer, C. and A.D. Linder. 1985a. Growth and population structure of the short-horned lizard (Phrynosoma douglassi) and the sagebrush lizard (Sceloporus graciosus) in southeastern Idaho. Northwest Science 59(4): 294-303.

Guyer, C. and A.D. Linder. 1985b. Thermal ecology and activity patterns of the short-horned lizard (Phrynosoma douglassi) and the sagebrush lizard (Sceloporus graciosus) in southeastern Idaho (USA). Great Basin Naturalist 45(4): 607-614.

Hall, W.P. 1973. Comparative population cytogenetics, speciation, and evolution of the crevice using species of Sceloporus. Ph.D. Dissertation. Cambridge, MS: Harvard University.

Hammerson, G. A. 1999. Amphibians and reptiles in Colorado, Second Edition. Niwot, CO: University Press of Colorado. $484 \mathrm{p}$.

*Hart, M.M., W.A. Williams, P.C. Thornton, K.P. McLaughlin, C.M. Tobalske, B.A. Maxell, D.P. Hendricks, C.R. Peterson, and R.L. Redmond. 1998. Montana atlas of terrestrial vertebrates. Montana Cooperative Wildlife Research Unit, The University of Montana. Missoula, Montana vii +1302 p.

*Hendricks, P. 1996. Preliminary amphibian and reptile survey of the Ashland District, Custer National Forest: 1995. Montana Natural Heritage Program. Helena, MT. 79 p.

*Hendricks, P. 1999. Amphibian and reptile survey of the Bureau of Land Management Miles City District, Montana. Montana Natural Heritage Program, Helena, MT. 80 p.

*Hendricks, P. and J.D. Reichel. 1996. Preliminary amphibian and reptile survey of the Ashland District, Custer National Forest: 1995. Montana Natural Heritage Program, Helena, MT. $79 \mathrm{p}$.

*Hendricks, P. and L.N. Hendricks. 2002. Predatory attack by green-tailed towhee on sagebrush lizard. Northwestern Naturalist 83:57-59. 
Hoberg, T. and C. Gause. 1989. Reptiles \& amphibians of North Dakota. North Dakota Outdoors 55(1):7-18.

Horstman, G. 1995. Sceloporus graciosus graciosus (northern sagebrush lizard). Herpetological Review 26(1): 45.

Hossack, B.R., P.S. Corn, and D.S. Pilliod. 2005. Lack of significant changes in the herpetofauna of Theodore Roosevelt National Park, North Dakota, since the 1920s. American Midland Naturalist 154:423-432.

James, S.E. and R.T. M'Closkey. 2002. Patterns of microhabitat use in a sympatric lizard assemblage. Canadian Journal of Zoology 80(12):2226-2234.

Jameson, E.W., Jr. 1974. Fat and breeding cycles in a montane population of Sceloporus graciosus. Journal of Herpetology 8(4): 311-322.

Kahn, W.C. 1960. Observations on the effect of a burn on a population of Sceloporus occidentalis. Ecology 41: 358-359.

*Kerfoot, W.C. 1968. Geographic variability of the lizard, Sceloporus graciosus Baird and Girard, in the eastern part of its range. Copeia 1968: 139-152.

Knowlton, G.F. 1953. Some insect food of Sceloporus g. graciosus. Herpetologica 9: 70.

Knowlton, G.F. and J.S. Stanford. 1942. Reptiles eaten by birds. Copeia 1942: 186.

*Koch, E.D. and C.R. Peterson. 1989. A preliminary survey of the distribution of amphibians and reptiles in Yellowstone National Park. pp. 47-49. In: T.W. Clark, A.H. Harvey, R.D. Dorn, D.C. Genter, and C. Groves (eds). Rare, sensitive and threatened species of the Greater Yellowstone Ecosystem. Northern Rockies Conservation Cooperative , Montana Natural Heritage Program, The Nature Conservancy, and Mountain West Environmental Services. 153 p.

*Koch, E. D., and C. R. Peterson. 1995. Amphibians \& reptiles of Yellowstone and Grand Teton national parks. Salt Lake City, UT: University of Utah Press. 188 p.

Knox, S.C., C. Chambers, and S.S. Germaine. 2001. Habitat associations of the sagebrush lizard (Sceloporus graciosus): potential responsess of an ectotherm to ponderosa pine forest rehabilitation. USFS Rocky Mountain Research Station Preoceedings RMRS-P 22:95-98.

Larsen, K.R. and W.W. Tanner. 1975. Evolution of the scleroporine lizards (Iguanidae). Great Basin Naturalist 35: 1-20.

Lemos-Espinal, J.A., G.R. Smith, and R.E. Ballinger. 1996. Covariation of egg size, clutch size, and offspring survivorship in the genus Sceloporus. Bulletin of the Maryland Herpetological Society 32(2): 58-66.

Lynch, J.D. 1985. Annotated checklist of the amphibians and reptiles of Nebraska.

Transactions of the Nebraska Academy of Sciences 13: 33-57.

Marcellini, D. and J.P. Mackey. 1970. Habitat preferences of the lizards Sceloporus occcidentalis and S. graciosus. Herpetologica 26: 51-56.

*Martin, P.R. 1980a. Terrestrial wildlife habitat inventory in southeastern Montana. Montana Department of Fish, Wildlife and Parks and Bureau of Land Management, Helena MT. 114p.

*Martin, P.R. 1980b. Terrestrial wildlife inventory in selected coal areas of Montana. Montana Department of Fish, Wildlife and Parks and Bureau of Land Management, Helena, MT. 84 p.

*Martin, P.R., K. DuBois and H.B. Youmans. 1981. Terrestrial wildlife inventory in selected coal areas, Powder River resources area final report. Montana Department of Fish, Wildlife and Parks and Bureau of Land Management, Helena, MT. 288 p. 
Martins, E.P. 1991. Individual and sex differences in the use of the push-up display by the sagebrush lizard, Sceloporus graciosus. Animal Behaviour 41(3): 403-416.

Martins, E.P. 1993a. A comparative study of the evolution of Sceloporus pushup displays. American Naturalist 142: 994-1018.

Martins, E.P. 1993b. Contextual use of the push-up display by the sagebrush lizard, Sceloporus graciosus. Animal Behaviour 45(1): 25-36.

Martins, E.P. 1994. Structural complexity in a lizard communication system: the Sceloporus graciosus "push-up" display. Copeia 1994(4): 944-955.

Martins, E.P., A.N. Bissell, and K.K. Morgan. 1998. Population diffferences in a lizard communicative display: evidence for rapid change in structure and function. Animal Behaviour 56(5):1113-1119.

Martins, E.P., T.J. Ord, and S.W. Davenport. 2005. Combining motions into complex displays: playbacks with a robotic lizard. Behavioral Ecology and Sociobiology 58(4):351-360.

*Maxell, B.A. 2004. Preliminary report on amphibian and aquatic reptile inventories conducted on and around the Ashland District of the Custer National Forest in 2002 and 2004. Report to Ashland District of Custer Forest, Region 1 Office of the U.S. Forest Service, and Montana Department of Fish, Wildlife, and Parks. Missoula, MT: Montana Cooperative Wildlife Research Unit and Wildlife Biology Program, University of Montana. 93 p.

*Maxell, B.A. 2009. State-wide assessment of status, predicted distribution, and landscapelevel habitat suitability of amphibians and reptiles in Montana. Ph.D. Dissertation. Missoula, MT: Wildlife Biology Program, University of Montana. 294 p.

*Maxell, B.A. and D.G. Hokit. 1999. Amphibians and reptiles. Pp. 2.1-2.30. In: G. Joslin and H. Youmans (committee chairs). Effects of recreation on Rocky Mountain wildlife: a compendium of the current state of understanding in Montana. Helena, MT: Committee on Effects of Recreation on Wildlife, Montana Chapter of the Wildlife Society. 307 p.

*Maxell, B.A., J.K. Werner, P. Hendricks, and D. Flath. 2003. Herpetology in Montana: a history, status summary, checklists, dichotomous keys, accounts for native, potentially native, and exotic species, and indexed bibliography. Olympia, WA: Society for Northwestern Vertebrate Biology. Northwest Fauna 5: 1-138.

M'Closkey, R.T., S.J. Hecnar, D.R. Chalcraft, and J.E. Cotter. 1998. Size distributions and sex ratios of colonizing lizards. Oecologica (Berlin) 116(4):501-509.

M'Closkey, R.T., S.J. Hecnar, D.R. Chalcraft, J.E. Cotter, J. Johnston, and R. Poulin. 1997. Colonization and saturation of habitats by lizards. Oikos 78:283-290.

Mendez-de la Cruz, F.R., M. Villagran-Santa Cruz, and R.M. Andrews. 1998. Evolution of viviparity in the lizard genus Sceloporus. Herpetologica 54(4): 521-532.

Morrison, M.L. and L.S. Hall. 1999. Habitat characteristics of reptiles in pinyon-juniper woodland. Great Basin Naturalist 59(3):288-291.

Morrison, R.L. and L. Powell. 1988. New distributional records of lizards in Wyoming (USA). Transactions of the Nebraska Academy of Sciences 16(0): 85-86.

Morrison, R.L. and S.K. Frost-Mason. 1991. Ultrastructural analysis of iridophore organellogenesis in a lizard, Sceloporus graciosus (Reptilia: Phrynosomatidae). Journal Of Morphology 209(2): 229-239.

*[MTNHP] Montana Natural Heritage Program. 2006. Point Observation Database. Montana Natural Heritage Program, Helena, MT. Accessed April 24, 2006. 
*Mueller, C.F. 1967. Temperature and energy characteristics of the sagebrush lizard in Yellowstone National Park. Ph.D. Dissertation. Montana State University, Bozeman, MT. $38 \mathrm{p}$.

*Mueller, C.F. 1969. Temperature and energy characteristics of the sagebrush lizard (Sceloporus graciosus) in Yellowstone National Park. Copeia 1969:153-160.

*Mueller, C.F. 1970a. Temperature acclimation in two species of Sceloporus. Herpetologica 26(1): 83-85.

*Mueller, C.F. 1970b. Energy utilization in the lizards Sceloporus graciosus and Sceloporus occidentalis. Journal of Herpetology 4(3-4): 131-134.

*Mueller, C.F. and R.E. Moore. 1969. Growth of the sagebrush lizard Sceloporus graciosus, in Yellowstone National Park. Herpetologica 25(1): 35-38.

Nussbaum, R. A., E. D. Brodie, Jr., and R. M. Storm. 1983. Amphibians and reptiles of the Pacific Northwest. University of Idaho Press. Moscow, Idaho. 332 p.

*[OEAR] Olson Elliot and Associates Research. 1985. 1983-1984 Wildlife monitoring report for the CX Ranch project. Olson Elliot and Associates Research. Helena, MT.

*Patla, D.A. 1998. Amphibians and reptiles in the Old Faithful sewage treatment area. Report to Yellowstone Center for Resources, Yellowstone National Park. 10 September, 1998. Greater Yellowstone Ecosystem Amphibian Survey and Monitoring Program, Herpetology Laboratory, Department of Biological Sciences, Idaho State University, Pocatello, ID. 7 p.

*Patla, D.A. and C.R. Peterson. 1996. Amphibians and reptiles along the Grand Loop Highway in Yellowstone National Park: Tower Junction to Canyon Village. 24 February, 1996. Greater Yellowstone Ecosystem Amphibian Survey and Monitoring Program, Herpetology Laboratory, Department of Biological Sciences, Idaho State University, Pocatello, ID. 49 p.

*Peterson, C.R., C.J. Askey, and D.A. Patla. 1993. Amphibians and reptiles along the Grand Loop and Fountain Freight Roads between Madison Junction and Biscuit Basin in Yellowstone National Park. 26 July, 1993. Greater Yellowstone Ecosystem Amphibian Survey and Monitoring Program, Herpetology Laboratory, Department of Biological Sciences, Idaho State University, Pocatello, ID. 45 p.

*Peterson, C.R., D.A. Patla, and S.R. Sullivan. 1995. Amphibians and reptiles along the Grand Loop Highway in Yellowstone National Park: Madison Junction to Norris Campground. 7 July, 1995. Greater Yellowstone Ecosystem Amphibian Survey and Monitoring Program, Herpetology Laboratory, Department of Biological Sciences, Idaho State University, Pocatello, ID. 64 p.

*[PRESI] Powder River Eagle Studies Incorporated. 1998a. Big Sky Mine 1997 wildlife monitoring studies. Powder River Eagle Studies Incorporated. Gillete, WY.

*[PRESI] Powder River Eagle Studies Incorporated. 1998b. Spring Creek Mine 1997 wildlife monitoring studies. Powder River Eagle Studies Incorporated. Gillete, WY.

*Rauscher, R.L. 1998. Amphibian and reptile survey on selected Montana Bureau of Reclamation impoundments. Montana Department of Fish, Wildlife and Parks, Nongame Program, Bozeman, MT. 24 p.

*Rawson, J.M. and A. Pils. 2005. Range extension for the northern sagebrush lizard in southwest Montana. Northwest Science 79(4) 281-285.

Reed, K.M., P.D. Sudman, J.W. Sites, and I.F. Greenbaum. 1990. Synaptonemal complex analysis of sex chromosomes in two species of Sceloporus. Copeia 4: 1122-1129.

*Reichel, J.D. 1995a. Preliminary amphibian and reptile survey of the Lewis and Clark National Forest: 1994. Montana Natural Heritage Program, Helena, MT. 92 p. 
*Reichel, J.D. 1995b. Preliminary amphibian and reptile survey of the Sioux District of the Custer National Forest: 1994. Montana Natural Heritage Program, Helena, MT. 75 p.

Reynolds, T. D. 1979. Response of reptile populations to different land management practices on the Idaho National Engineering Laboratory Site. Great Basin Naturalist 39:255-262.

*Roedel, M.D. and P. Hendricks. 1998a. Amphibian and reptile survey on the Bureau of Land Management Lewistown District: 1995-1998. Montana Natural Heritage Program, Helena, MT. 53 p.

*Roedel, M.D. and P. Hendricks. 1998b. Amphibian and reptile inventory on the Headwaters and Dillon Resource Areas in conjunction with Red Rocks Lakes National Wildlife Refuge: 1996-1998. Montana Natural Heritage Program, Helena, MT. 46 p.

Rose, B.R. 1976a. Dietary overlap of Sceloporus occidentalis and S. gracious. Copeia 1976: 818-820.

Rose, B.R. 1976b. Habitat and prey selection of Sceloporus occidentalis and Sceloporus graciosus. Ecology 57: 531-541.

Sears, M.W. 2005a. Goegraphic variation in the life history of the sagebrush lizard: the role of thermal constraints on activity. Oecologia (Berlin) 143(1):25-36.

Sears, M.W. 2005b. Resting metabolic expenditure as a potential source of variation in growth rates of the sagebrush lizard. Comparative Biochemistry and Physiology Part A Molecular and Integrative Physiology 140(2):171-177.

Sears, M.W. and M.J. Angilletta Jr. 2003. Life-history variation in the sagebrush lizard: phenotypic plasticity or local adaptation? Ecology 84(6):1624-1634.

*Sestrich, C. 2007. 2006 Hebgen Reservoir amphibian survey. USDA Forest Service Annual Report to PPL Montana. West Yellowstone, MT: Gallatin National Forest, Hebgen Lake Ranger District. 75 p.

Sinervo, B. and S.C. Adolph. 1989. Thermal sensitivity of growth rate in hatchling Sceloporus lizards: Environmental, behavioral and genetic aspects. Oecologia 78(3): 411-419.

Sinervo, B. and S.C. Adolph. 1994. Growth plasticity and thermal opportunity in Sceloporus lizards. Ecology 75(3): 776-790.

Sites, J.W., Jr., C.A. Porter, and P. Thompson. 1987. Genetic structure and chromosomal evolution in the Sceloporus grammicus complex. National Geographic Research 3(3): 343362.

Sites, J.W., Jr., J.W. Archie, C.J. Cole, and V.O. Flores. 1992. A review of phylogenetic hypotheses for lizards of the genus (Phrynosomatidae): implications for ecological and evolutionary studies. Bulletin American Museum of Natural History (213): 1-110.

Sites, J.W., Jr., P. Thompson, and C.A. Porter. 1988. Cascading chromosomal speciation in lizards: a second look. Pacific Science 42(1-2): 89-104.

*Skinner, M.P. 1924. The Yellowstone Nature Book. A.C. McClurg Company, Chicago, IL. $221 \mathrm{p}$.

Smith, H.M. 1991. Three new records of lizards in Ouray County, Colorado. Bulletin of the Chicago Herpetological Society 26(10): 223.

*St. John, A. 2002. Reptiles of the Northwest: California to Alaska; Rockies to the Coast. Renton, WA: Lone Pine Publishing. 272 p.

Stebbins, R.C. 1948. Additional observations on home ranges and longevity in the lizard Sceloporus graciosus. Copeia 1948:20-22.

*Stebbins, R.C. 2003. A field guide to western reptiles and amphibians. 3rd edition. New York, NY: Houghton Mifflin Co. 533 p. 
Stebbins, R.C. and H.B. Robinson. 1946. Further analysis of populations of the lizard Sceloporus g. graciosus. University of California (Berkeley) Publications in Zoology 48: 149-168.

*Thompson, L.S. 1984. Biogeography of Montana: preliminary observations on major faunal and floristic distribution patterns. Proceedings of the Montana Academy of Sciences 43: 4041.

Thompson, P. and J.W. Sites, Jr. 1986a. Comparison of population structure in chromosomally polytypic and monotypic species of Sceloporus (Sauria: Iguanidae) in relation to chromosomally-mediated speciation. Evolution 40(2): 303-314.

Thompson, P. and J.W. Sites, Jr. 1986b. Two aberrant karyotypes in the sagebrush lizard (Sceloporus graciosus): Triploidy and a "supernumerary" oddity. Great Basin Naturalist 46(2): 224-227.

*Timken, R. No Date. Amphibians and reptiles of the Beaverhead National Forest. Western Montana College, Dillon, MT. 16 p.

Tinkle, D.W. 1973. A population analysis of the sagebrush lizard, Sceloporus graciosus, in southern Utah. Copeia 1973: 284-296.

Tinkle, D.W., A.E. Dunham, and J.D. Congdon. 1993. Life history and demographic variation in the lizard Sceloporus graciosus: a long-term study. Ecology 74(8): 2413-2429.

*Turner, F.B. 1951. A checklist of the reptiles and amphibians of Yellowstone National Park with incidental notes. Yellowstone Nature Notes 25(3): 25-29.

*Turner, F.B. 1955. Reptiles and amphibians of Yellowstone National Park. Yellowstone Interpretive Series No. 5. Yellowstone Library and Museum Association. Yellowstone National Park, WY. 40 p.

*[USFWS] US Fish and Wildlife Service. 1994. Endangered and threatened wildlife and plants; animal candidate review for listing as endangered or threatened species. Federal Register 59(219): 58982-59028.

*Vitt, L.J., J.P. Caldwell, and D.B. Shepard. 2005. Inventory of amphibians and reptiles in the Billings Field Office Region, Montana. Sam Noble Oklahoma Museum of Natural History and Department of Zoology, University of Oklahoma, Norman, OK. 33 pp.

*[VTNWI] VTN Wyoming Incorporated. No Date. Second year's analysis of terrestrial wildlife on proposed mine access and railroad routes in southern Montana and northern Wyoming, March 1979 - February 1980. VTN Wyoming Incorporated. Sheridan, WY. 62 p.

*Waage, B.C. 1998. Western Energy Company Rosebud Mine 1997 annual wildlife monitoring report December 1, 1996 to November 30, 1997 survey period. Western Energy Company, Colstrip, MT.

*Werner, J.K., B.A. Maxell, P. Hendricks, and D. Flath. 2004. Amphibians and reptiles of Montana. Missoula, MT: Mountain Press Publishing Company. 262p.

Werschkul, D.F. 1982. Species-habitat relationships in an Oregon cold desert lizard community. Great Basin Naturalist 42(3): 380-384. 


\section{Western Fence Lizard (Sceloporus occidentalis)}

Up-to-date distribution and status information can be found on the Montana Natural Heritage Program’s TRACKER website at http://mtnhp.org

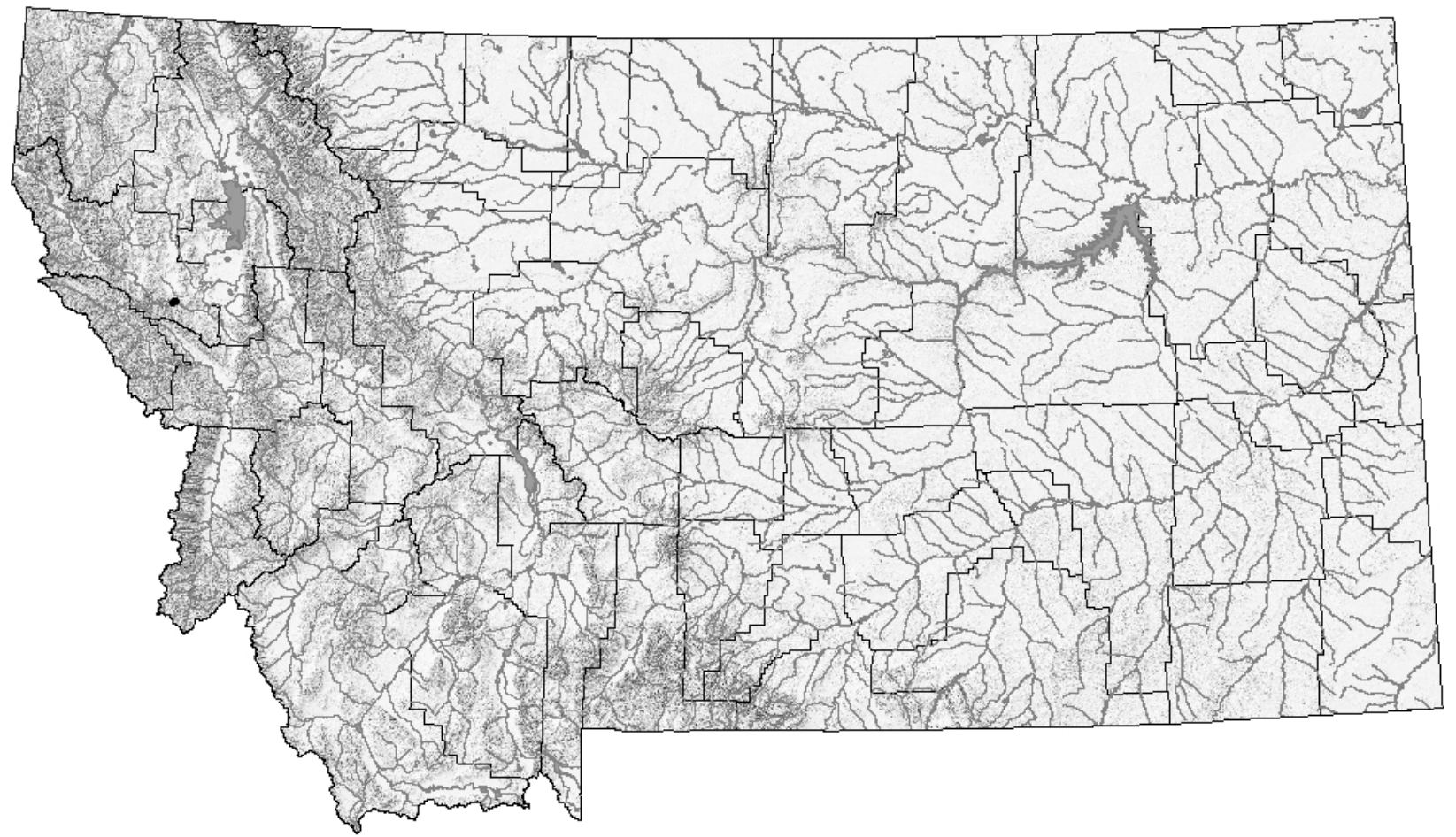

Distribution/Taxonomy

The western fence lizard is a member of a large genus of North American lizards found from Panama to the Canadian border. The closest relatives include five additional species in the Udulatus group (Wiens and Reeder 1997). The western fence lizard occurs from northern Washington, south through Oregon, southwestern Idaho, Nevada, western Utah, and most of California, into Mexico to northwestern Baja California, at elevations from sea level in Washington, Oregon, and California to 3,300 m (10,800 ft) in California (Nussbaum et al. 1983, St. John 2002, Stebbins 2003). Six subspecies are currently recognized. The subspecies present in Montana is the northwestern fence lizard (S. o. occidentalis), which is found along the Cascade Mountains. In Montana, there is a single known population, along the lower Flathead River near Perma on the Flathead Indian Reservation in Sanders County (Werner 2008, Werner et al. 2004). The Montana population is isolated east of the main range of the species by about $250 \mathrm{~km}$ (150 miles). It is unknown for certain whether this population is native or introduced, but it seems likely that the population was introduced via a train because a major rail line is immediately adjacent to the population and the population seems to be expanding (Werner 2008).

Maximum Elevation

$762 \mathrm{~m}$ (2,500 ft) in Sanders County (Werner et al. 2004).

\section{Identification}

\section{Eggs:}

Eggs are white, leathery, and oval, about $14 \mathrm{~mm}(0.5 \mathrm{in})$ long and $8 \mathrm{~mm}$ (0.3 in) wide. Clutch size is usually 4-17 eggs (averaging about 8). Clutches are laid in loose soil in shallow cavities 
(Nussbaum et al. 1983, Werner et al. 2004).

Juveniles and Adults:

The body is somewhat narrow and elongate. The back is grayish overall, and covered with pointed, keeled scales, giving the body a prickly appearance. There are 5-10 rows of dark brown or black, checkered or V-shaped, rows or bands running across the back, and there may be a light-colored border to the back edges of the bars. Dark and light patches dot the sides of the body, and the rear surfaces of the legs have some pale yellow or orange coloration. There are large solid blue lateral abdominal patches, with a matching solid blue throat. Males have larger, more intense blue patches, sometimes lacking in females, and have black or dark gray bordering the blue areas. Young animals have little or no blue on the abdomen and throat, and are in coloration like adult females, hatchlings also lack the yellow or arrange on the legs (St. John 2002, Stebbins 2003, Werner et al. 2004). Maximum snout-vent length is about $9.5 \mathrm{~cm}$ for both sexes. Maximum total length is about $18 \mathrm{~cm}$, with the tail length about equal to the snout-vent length. Mature females and males are roughly of equal size. Hatchlings are 2.2-2.8 cm snoutvent length, but otherwise adult-like in appearance (Davis 1967, Tanner and Hopkin 1972, Nussbaum et al. 1983, St. John 2002, Werner et al. 2004).

Similar Species:

The western fence lizard differs from the common sagebrush lizard (Sceloporus graciosus) by having a checkered pattern of darker triangular blotches in rows or bars across the back rather than pale dorsolateral stripes. The dorsal scales of the common sagebrush lizard are also much less prickly and pointed and the blue throat patch in males is less pronounced than in the western fence lizard. The northern alligator lizard has a prominent skin fold on the side of the body and short legs. The western skink has smooth, shiny, and flat dorsal scales, and juvenile and young adult skinks have conspicuous blue tails. Western fence lizards have keeled scales that give the body a prickly appearance; the scales are not flattened and shiny, and they never have a blue tail. The western fence lizard lacks the broad flattened body and fringe of prominent spines on each side of the body that are present in the greater short-horned lizard (St. John 2002, Stebbins 2003, Werner et al. 2004). Western fence lizard, northern alligator lizard, and western skink are found only in northwestern Montana west of the Continental Divide, while the common sagebrush lizard and greater short-horned lizard are present in Montana only east of the Divide (Maxell et al. 2003, Werner et al. 2004).

\section{Habitat Use/Natural History}

The western fence lizard is an animal of shrub-steppe habitats and open mixed deciduous and conifer forests, absent only from shady dense forest and extremely arid desert (Nussbaum et al. 1983, St. John 2002, Stebbins 2003). In northern California adults were often present in areas with some shade, in open pine forest under trees and shrubs (manzanita), but also off the ground in trees and shrubs, and also were found on or near rocks (Marcellini and Mackey 1970). Juveniles frequented grassy areas more than adults, but climbed less and were found less often under trees. All ages favored areas with rocks and fallen logs and other objects upon which to bask or under which they sought refuge. In central California, western fence lizards tended to avoid grasslands, were present in low numbers in dense, short-stature oak woodland, were more abundant in larger stature oak woodland with grassland clearings, and favored large-stature oak woodland with large fallen logs and abundant downed wood (Davis and Ford 1983). In southern 
California, in an area of recently burned chaparral (Quercus, Adenostoma, Ceanothus), individuals often were found perching on charred branches, perhaps to enhance concealment from predators (Lillywhite and North 1974). In Nevada, western fence lizards were found in areas of basalt cap rock dominated by piñon-juniper habitat with shallow soils, but also many rock outcrops; oak, skunkbush, and sagebrush were dominant shrubby species (Tanner and Hopkin 1972). Habitat use in Montana has not been the subject of study. The only known site along the Flathead River is an area of rocky terrain dominated by shrubby vegetation (Maxell et al. 2003, Werner et al. 2004, pers. comm.). Favored areas throughout the range appear to have a high percentage of open bare ground and a component of low to tall shrubs or trees, as well as rocks and the presence of downed woody material. Although a ground dweller, the western fence lizard will often perch above ground in low shrubs and trees; adults tend to perch higher that juveniles, and perch height is higher off the ground at lower elevation sites (Marcellini and Mackey 1970, Adolph 1990). Home ranges may be relatively small, with a maximum in Nevada of about $6,750 \mathrm{~m}^{2}$ (1.67 acres) for adult males and $1950 \mathrm{~m}^{2}(0.48$ acres $)$ for adult females (Tanner and Hopkin 1972); mean home ranges for males and females, respectively, were 2390 $\mathrm{m}^{2}$ (0.59 acres) and $385 \mathrm{~m}^{2}$ (0.095 acres). Mean home ranges for all age classes in central California were $<150 \mathrm{~m}^{2}$ (Davis and Ford 1983). Home range size among sites is influenced by habitat structure, among other factors, which differed greatly between the two cited studies. Across much of the range, eggs are laid during late April-July (Nussbaum et al. 1983, St. John 2002, Stebbins 2003). Egg laying in the laboratory by females from a moderate-elevation site in Nevada occurred in late June and early July (Tanner and Hopkin 1972), and a study females from a low-elevation site in southern California contained oviducal eggs from April to July (Goldberg 1973). Smaller females produce only 1-2 clutches per year, but larger females at low elevation sites may produce 3 clutches (Goldberg 1973). Clutch size is as few as 4 eggs but may be as large as 15; mean size of 15 clutches from Nevada was 11.2 eggs, with a range of 7-15 (Tanner and Hopkin 1972). Eggs hatch in 50-60 days, mostly in early to mid-August in Nevada and central California but continuing into late September in favorable years (Davis 1967, Tanner and Hopkin 1972, Nussbaum et al 1983). No information is available from Montana on any aspect of the reproductive biology of this species, although multiple age classes are present at the only occupied site, indicating successful reproduction has occurred (Maxell et al. 2003). Sexual maturity is attained in the spring of the second year, following the second hibernation (Tanner and Hopkin 1972, Nussbaum et al. 1983). Young adults breed and lay their first clutch when 2123 months old. Mean annual survival rate of young and adults is probably quite variable; in Nevada, survival of marked juveniles was estimated to be about 28\% (Tanner and Hopkin 1972). Males and females in central California and Nevada can live to five or more years (Davis 1967, Tanner and Hopkins 1972). Adults and juveniles are "sit-and-wait" predators that hunt mainly by sight, but they also run and leap after flying insects (Tanner and Hopkin 1972). The diversity of food items taken indicates prey is taken largely opportunistically. Ants were the most abundant dietary items in Nevada (Tanner and Hopkin 1972), but beetles, Lepidoptera larvae, true flies, crickets and grasshoppers, true bugs, as well as spiders and the occasional scorpion, were taken. A similar diversity of arthropod prey is represented in stomach analyses of western fence lizards from central and northern California, and southeastern Oregon (Johnson 1965, Rose 1976, Whitaker and Maser 1981).

$\underline{\text { Status and Conservation }}$

At the time the comprehensive summaries of amphibians and reptiles in Montana (Maxell et al. 
2003, Werner et al. 2004) were published, there was only one documented site in Montana for western fence lizard, discovered in 2002 near Perma, Sanders County. This remains the only documented population as of 2008 (Werner 2008). The Montana population is isolated by about $250 \mathrm{~km}$ (150 miles) from the nearest populations in Washington and Idaho. It seems likely that the population was introduced via a train because a major rail line is immediately adjacent to the population and the population seems to be expanding (Werner 2008). Another indication that this population is not native is the fact that an earlier survey of the Flathead Indian Reservation (Werner et al. 1998) failed to document this lizard species, even though several of the survey sites were in the Lower Flathead River area. Additional surveys along the lower Flathead River and genetic evaluation of the population to determine its status as native or introduced are both important conservation measures that need to be taken. If the population is introduced, control measures should be inacted as soon as possible while the population is small. If the population is determined to possibly be native, then protective measures should be put in place as soon as possible. Few studies address or identify risk factors. Western fence lizard can persist in recently burned chaparral areas (Lillywhite and North 1974), indicating a level of tolerance for extreme habitat disturbance. However, alterations to rangelands could influence grass and exotic weed encroachment, which could increase the deleterious effects of fire on western fence lizard populations. Their preference for rocky sites could help buffer them from some negative effects of fire. Use of chemical pest control agents for weeds and insects could negatively impact directly or indirectly their preferred arthropod prey.

\section{Research and Management Suggestions}

1. See research and management suggestions under all general risk factors described above, with the exception of water impoundments/recreational facilities and harvest/commerce.

2. More thorough surveys for western fence lizard across its possible range in Montana, especially along the Lower Flathead and Lower Clark Fork rivers, are needed to determine the native status of the species in the state.

3. Genetic samples from the Lower Flathead River population should be compared to similar material in Idaho and Washington to help determine if the population is native or introduced. If the population is determined to possibly be native, then protective measures should be put in place as soon as possible. If genetic information indicates the population is introduced, control measures should be inacted as soon as possible while the population is small. Any eradication program will need to be done with the approval of the Tribal Council of the Flathead Indian Reservation, and in conjunction with tribal biologists.

4. Studies of habitat use, population size, and population dynamics of this population are of interest, regardless of the native status of the population. If the population is indeed introduced, these studies could help determine how well a population of this species can adapt to environmental conditions that lie outside its normal range.

Bibliography *indicates an article with information specific to Montana

Adolph, S. C. 1990. Perch height selection by juvenile Sceloporus lizards: interspecific differences and relationships to habitat use. Journal of Herpetology 24:69-75.

Beane, J.C. 2006. Sceloporus undulatus hyacinthinus (northern fence lizard) fire avoidance behavior. Herpetological Review 37(1):92.

Davis, J. 1967. Growth and size of the western fence lizard (Sceloporus occidentalis). Copeia 1967:721-731. 
Davis, J., and R. G. Ford. 1983. Home range in the western fence lizard (Sceloporus occidentalis occidentalis). Copeia 1983:933-940.

Eisen, R.J. and D.F. DeNardo. 2000. Life history of a malaria parasite (Plasmodium mexicanum) in its host, the western fence lizard (Sceloporus occidentalis): host testosterone as a source of seasonal and among-host variation? Journal of Parasitology 86(5):1041-1045.

Eisen, R.J., L. Eisen, and R.S. Lane. 2001. Prevalence and abundance of Ixodes pacificus immatures (Acari: Ixodidae) infesting western fence lizards (Sceloporus occidentalis) in northern California: temporal trends and environmental correlates. Journal of Parasitology 87(6):1301-1307.

Fitch, H.S. 1940. A field study of the growth and behavior of the fence lizard. University of California Publications in Zoology 44: 151-172.

Gibbons, J.W., D.E. Scott, T.J. Ryan, K.A. Buhlmann, T.D. Tuberville, B.S. Metts, J.L. Greene, T. Mills, Y. Leiden, S. Poppy, and C.T. Winne. 2000. The global decline of reptiles, déjà vu amphibians. BioScience 50:653-666.

Goldberg, S.R. 1973. Ovarian cycle of the western fence lizard, Sceloporus occidentalis. Herpetologica 29:284-289.

Johnson, C.R. 1965. The diet of the Pacific fence lizard, Sceloporus occidentalis occidentalis (Baird and Girard), from northern California. Herpetologica 21:114-117.

Lillywhite, H.B., and F. North. 1974. Perching behavior of Sceloporus occidentalis in recently burned chaparral. Copeia 1974:256-257.

Marcellini, D., and J.P. Mackey. 1970. Habitat preferences of the lizards, Sceloporus occidentalis and S. graciosus (Lacertilia, Iguanidae). Herpetologica 26:51-56.

Massot, M., R.B. Huey, J. Tsuji, and F.H. van Berkum. 2003. Genetic, prenatal, and postnatal correlates of dispersal in hatchling fence lizards (Sceloporus occidentalis). Behavioral Ecology 14(5):650-655.

Mathews, C.G. and C.J. Amlaner. 2000. Eye states and postures of the Western Fence lizard (Sceloporus occidentalis) with spatial reference to asynchronous eye closure and behavioral sleep. Journal of Herpetology 34(3):472-475.

Maxell, B.A., and D.G. Hokit. 1999. Amphibians and reptiles. Pages 2.1-2.30, In Effects of recreation on Rocky Mountain wildlife: a compendium of the current state of understanding in Montana (G. Joslin and H. Youmens, coordinators). Committee on Effects of Recreation on Wildlife, Montana Chapter of the Wildlife Society. 307 pp.

Maxell, B.A., J.K. Werner, P. Hendricks, and D.L. Flath. 2003. Herpetology in Montana: a history, status summary, checklists, dichotomous keys, accounts for native, potentially native, and exotic species, and indexed bibliography. Northwest Fauna Number 5. 138 p.

Niewiarowski, P.H., M.J. Angilletta, Jr., and A.D. Leaché. 2004. Phylogenetic comparative analysis of life-history variation among populations of the lizard Sceloporus undulatus: an example and prognosis. Evolution 58:619-633.

Nussbaum, R. A., E. D. Brodie, Jr., and R. M. Storm. 1983. Amphibians and reptiles of the Pacific Northwest. University of Idaho Press. Moscow, Idaho. 332 p.

Quinn, V.S., M. Klukosky, and D.K. Hews. 2001. Longevity of paint marks and the lack of effect on survivorship and growth of Sceloporus lizards. Herpetological Review 32(2):9293.

Roe, J.H., W.A. Hopkins, and L.G. Talent. 2005. Effects of body mass, feeding, and circadian cycles on metabolism in the lizard Sceloporus occidentalis. Journal of Herpetology 39(4):595-603. 
Rose, B. R. 1976. Dietary overlap of Sceloporus occidentalis and S. graciosus. Copeia 1976:818-820.

Sabo, J.L. and M.E. Power. 2002. River-watershed exchange: effects of riverine subsides on riparian lizards and their terrestrial prey. Ecology 83(7):1860-1869.

Sabo, J.L. and M. Ku. 2004. Sceloporus occidentalis (Western Fence Lizard). Failed predation by snake. Herpetological Review 35(4):396-397.

Schall, J.J. 2000. Prevalence of the tick, Ixodes pacificus, on Western Fence lizards, Sceloporus occidentalis: Trends by gender, size, season, site, and mite infestation. Journal of Herpetology 34(1):160-163.

Sheldahl, L.A. and E.P. Martins. 2000. The territorial behavior of the western fence lizard, Sceloporus occidentalis. Herpetologica 56(4):469-479.

St. John, A. 2002. Reptiles of the Northwest: California to Alaska; Rockies to the Coast. Renton, WA: Lone Pine Publishing. 272 p.

Stebbins, R.C. 2003. A field guide to western reptiles and amphibians. Third edition. Houghton Mifflin Company, Boston, Massachusetts. 533 p.

Tanner, W.W., and J.M. Hopkin. 1972. Ecology of Sceloporus occidentalis longipes Baird and Uta stansburiana Baird and Girar on Rainier Mesa, Nevada Test Site, Nye County, Nevada. Brigham Young University Science Bulletin, Biological Series Volume 15, No. 4.

*Werner, J.K. 2008. Status of the western fence lizard in Montana. Abstract. 2008 Joint Meetings of the Society for Northwestern Vertebrate Biology, Montana Chapter of the Wildlife Society, and Partners for Amphibian and Reptile Conservation. Missoula, MT. February 25-29, 2008.

*Werner, J.K., B.A. Maxell, P. Hendricks, and D.L. Flath. 2004. Amphibians and reptiles of Montana. Mountain Press. Missoula, Montana. 262 p.

Werner, J.K., T. Plummer, and J. Weaselhead. 1998. Amphibians and reptiles of the Flathead Indian Reservation. Intermountain Journal of Sciences 4:33-49.

Whitaker, J.O., Jr., and C. Maser. 1981. Food habits of seven species of lizards from Malheur County, southeastern Oregon. Northwest Science 55:202-208.

Wiens, J. J., and T. W. Reeder. 1997. Phylogeny of the spiny lizards (Sceloporus) based on molecular and morphological evidence. Herpetological Monographs 11:1-101.

Zani, P.A. 2001. Clinging performance of the western fence lizard, Sceloporus occidentalis. Herpetologica 57(4): 423-432. 


\section{Western Skink (Eumeces skiltonianus)}

Up-to-date distribution and status information can be found on the Montana Natural Heritage Program’s TRACKER website at http://mtnhp.org

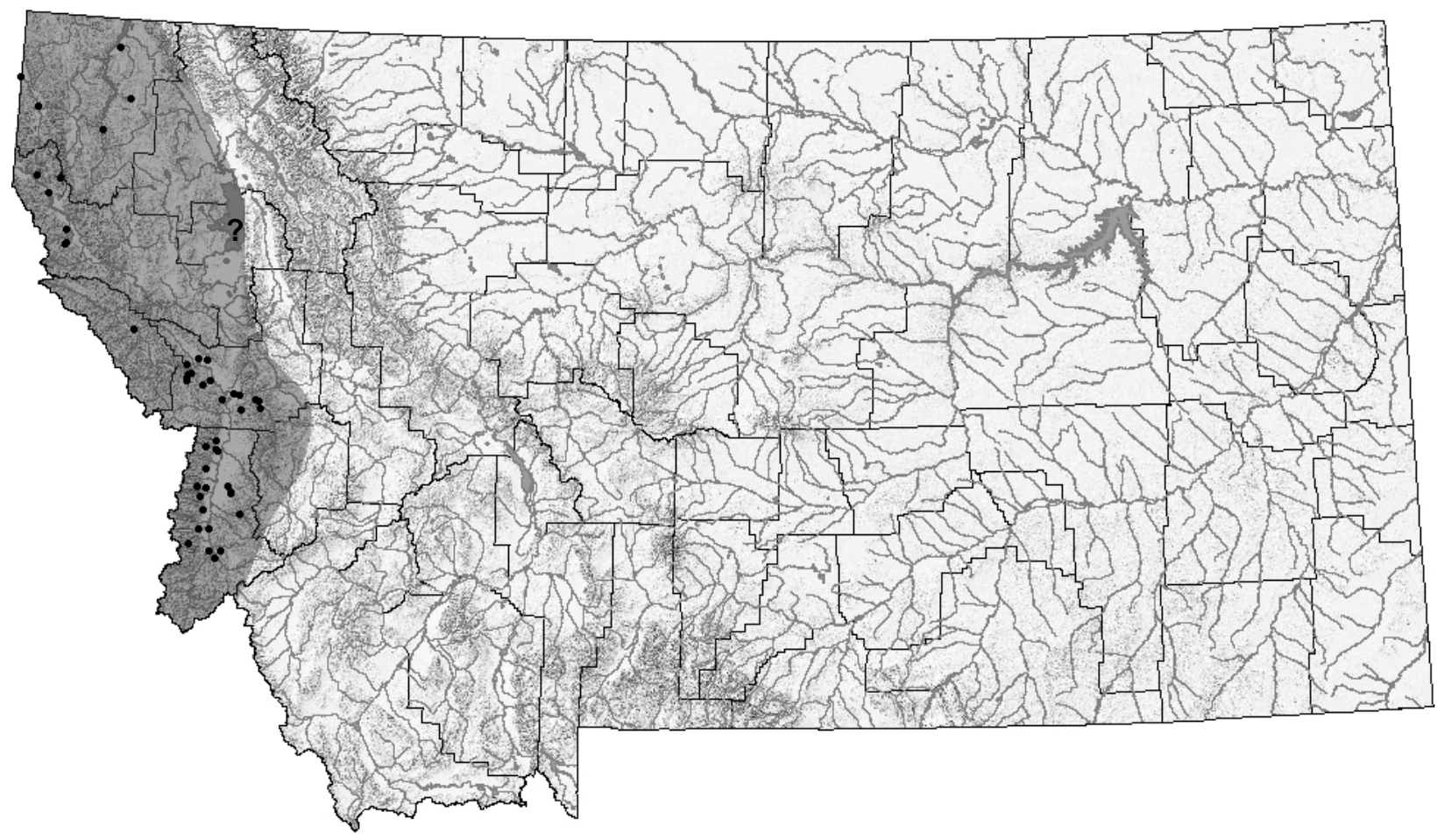

Distribution/Taxonomy

The western skink is the most widespread, and possibly the most abundant, skink in western North America, being found west of the Continental Divide from southern British Columbia in the north, south through eastern Washington, Idaho, western Montana, Oregon, northern and coastal California, Nevada, western Utah, northwestern Arizona, and southwestern California, to northern Baja California (Rodgers and Fitch 1947, Tanner 1988, Richmond and Reeder 2002), at elevations to about $2530 \mathrm{~m}$ (8300 ft). Four subspecies are sometimes recognized (Tanner 1988, Stebbins 2003): Eumeces skiltonianus skiltonianus in the northern Rocky Mountains and Pacific Coast, E. s. utahensis in the core of the Great Basin, E. s. interparietalis of extreme southwest California and northern Baja California, and E. s. lagunensis isolated in the southern half of Baja California. Recent analyses of genetic and morphological traits from throughout the range of the western skink (Richmond and Reeder 2002) support the validity of the earlier classification of Tanner (1957), with three subspecies of western skink and the isolated subspecies E. s. lagunensis of southern Baja California considered a full species, the San Lucan skink ( $E$. lagunensis). The form of western skink so far documented in Montana is Skilton's skink (E. s. skiltonianus), although the Great Basin skink (E. s. utahensis) is present in parts of Idaho abutting Beaverhead County, where suitable habitat occurs on both sides of the state boundary (Maxell et al. 2003). In Montana, there are about 50 records from five counties west of the Continental Divide; reports from Flathead County need verification (Maxell et al. 2003, Werner et al. 2004). Given the species known distribution in Idaho, it is possible that the species is present in portions of Beaverhead County. 
Maximum Elevation

1,707 m (5,600 ft) in Missoula County (Ortega and Pearson 2001, Maxell et al. 2003).

\section{Identification}

\section{Eggs:}

Eggs are white, leathery, oval, and about 12-15 mm in length. Clutch size is typically 2-6 eggs, but up to 10 may be laid (Tanner 1957, Nussbaum et al. 1983, St. John 2002, Stebbins 2003). Eggs are laid in a cavity in the ground under a rock or log, and are guarded by the female.

Juveniles and Adults:

The body of the western skink is slender and elongate, with a tail that is about as long as the remainder of the body. The body is covered in smooth and rounded scales, and has an overall shiny appearance. Dorsal coloration consists of brown, black, and golden-yellow or creamcolored longitudinal stripes that extend from the nose to the anterior portion of the tail. Young animals are similar in appearance to adults, but have a brilliant blue tail that becomes progressively duller with age. The belly is light gray to cream-colored, with faint greenish-blue mottling. Males develop reddish-orange coloration on the chin and sides of head during the breeding season. Adults are about 5.0-8.0 cm snout-vent length and up to $19.0 \mathrm{~cm}$ total length (Tanner 1957, St. John 2002, Stebbins 2003, Werner et al. 2004). Some individuals may have a stumpy tail, resulting from tail autotomy in response to predator attack (Vitt et al. 1977, St. John 2002, Paul Hendricks, pers. obs.).

Similar Species:

The western skink is the only lizard in Montana with a body that appears smooth and shiny, and whose tail is blue in juveniles and young adults. Western skinks lack a skin fold on the side of the body (present in the northern alligator lizard with which it is sympatric), and keeled scales (present on greater short-horned lizard, northern sagebrush lizard, and western fence lizard). Other Montana lizards do not display distinct dorsal stripes, which are present on the western skink (St. John 2002, Werner et al. 2004).

\section{Habitat Use/Natural History}

The western skink occupies grasslands, chaparral, open juniper-sage shrublands, piñon-juniper woodlands, pine-oak forests, and mixed conifer forest. Grassy openings and rocky areas near streams in the above habitats are frequented, where western skinks often found under dried leaves, flat rocks, and other ground cover (Nussbaum et al. 1983, St. John 2002), but dry hillsides with some shading are also occupied. It can also be found in downed decaying wood. This lizard tends to be less abundant in dense shrub cover (Tanner 1957), although it may forage in such sites. They do not appear to inhabit areas with deep soils or sand, although both sexes dig burrows that may be up to $50 \mathrm{~cm}$ long. Habitat use in Montana has been little studied. In Sanders County, western skinks were found in open stands of ponderosa pine in or near talus, and at meadow edges (Boundy 2001). In Mineral, Missoula, and Ravalli counties, skinks were found in Agropyron spicatum-Poa sandbergii grasslands on southwest aspects. These sites were gently rolling $(<20 \%$ slope) with imbedded rocky areas, to rocky and steep terrain (average slope of 30\%) with scattered ponderosa pine and Douglas-fir, imbedded in a matrix of montane coniferous forest (Ortega and Pearson 2001). Many of these occupied sites supported moderate to high densities of exotic spotted knapweed (Centaurea maculosa). Home range size has not 
been reported, but females probably restrict movement to small areas once eggs are laid, as they often remain with their clutches until eggs hatch (Tanner 1943, 1957). Western skinks appear to be somewhat gregarious, further suggesting that home ranges may be relatively small, although this species does not seem to be territorial (Tanner 1957). Mating in parts of Utah occurs through May and into June, a few weeks after emergence from winter dormancy (Tanner 1957). Eggs are laid in Utah during the first two weeks of July. Timing of egg laying in coastal California is similar to Utah (Rodgers and Memmler 1943), although some clutches are laid by mid- and late June (Van Denburgh 1922, Tanner 1943, 1957). A single clutch is produced (Fitch 1970). The number of eggs in eight Utah clutches was 2-5, but as many as ten eggs have been reported (St. John 2002). Eggs hatch in at least 30 days (Rodgers and Memmler 1943), in August and September, with an estimated full incubation period of 40-60 days (Werner et al. 2004). No information is available from Montana on any aspect of the reproductive biology of this species; adults and juveniles have been reported from early April to October (Werner and Reichel 1994, Hendricks and Reichel 1996, Boundy 2001, Ortega and Pearson 2001). In Utah, males reach sexual maturity when two years old (Tanner 1957), and apparently so do females. There appears to be no size dimorphism between the sexes, although males appear to have longer legs (Rodgers and Fitch 1947). No information is available on survival rate and longevity of western skinks, but reproducing once per season (Fitch 1970) suggests that they may be relatively long-lived (Vitt et al. 1977). Adults and juveniles actively forage, albeit haltingly and in a "cat-like" stalk (Tanner 1957, Nussbaum et al. 1983, St. John 2002), hunting mainly by sight and remaining near cover. Arthropods form the diet. Several orders of insects (including beetles, crickets, grasshoppers, and moths) as well as spiders, centipedes, and sow bugs (terrestrial isopods) are taken (Tanner 1957), although ants are rarely consumed.

\section{Status and Conservation}

At the time the comprehensive summaries of amphibians and reptiles in Montana (Maxell et al. 2003, Werner et al. 2004) were published, there were 51 total records for western skink from five counties west of the Continental Divide, with records concentrated near the Idaho state line. With so few records, the current status in Montana is largely uncertain. The western skink has not been documented in or near Glacier National Park (Brunson and Demaree 1951, Marnell 1997), and the few reports from the Flathead Valley require verification (Werner et al. 1998). There is also a noticeable absence of records north of the Kootenai River in Lincoln County, and east of Missoula and Ravalli counties, despite seemingly suitable habitat in both regions. At the local scale, limited data from elsewhere suggest this species is relatively sedentary and gregarious (Tanner 1957). Thus, populations appear vulnerable to habitat fragmentation. Densities of this species have not been determined, but trapping data indicate they may sometimes be locally fairly abundant (Ortega and Pearson 2001). Risk factors relevant to the viability of populations of this species are likely to include habitat loss/fragmentation, fire, road and trail development, quarrying, and use of pesticides and herbicides. However, perhaps the greatest risk to maintaining viable populations of western skink in Montana is the lack of baseline data on its distribution, status, habitat use, and basic biology (Maxell and Hokit 1999), which are needed to monitor trends and recognize dramatic declines when and where they occur. Few studies address or identify risk factors. In Utah, western skinks appeared to decline at sites following dramatic increase in sagebrush cover (Tanner 1957). Some open terrain is needed to allow sunlight to warm shelter and nesting cover of flattened rocks and wood. However, some vegetative cover appears to be required for shelter while foraging. Invasion of exotic weeds into 
occupied habitat has and continues to occur in western Montana (Ortega and Pearson 2001), but it is unclear how associated habitat changes may affect skink populations. Use of chemical agents to control weed and insect pest infestations could depress populations of skinks, which feed on ground-dwelling arthropods.

\section{$\underline{\text { Research and Management Suggestions }}$}

1. See research and management suggestions under all general risk factors described above, with the exception of water impoundments/recreational facilities and harvest/commerce.

2. More thorough documentation of western skink presence across its range in Montana is needed, especially north of the Kootenai River, the Flathead Valley, and the region east of Missoula and Ravalli counties. All of northwestern Montana needs focused surveys to determine potential connectivity among possibly isolated populations.

3. Studies of habitat use and population dynamics are needed, especially as they relate to livestock grazing, logging, sagebrush and juniper encroachment, and agricultural practices, to identify species responses to these habitat perturbations and develop effective measures for mitigation of negative impacts.

4. Reduction of sagebrush cover to promote grass growth for livestock should be avoided or carefully assessed in areas occupied by the western skink. Dense grass growth increases the likelihood that fire will kill shrub cover, perhaps making the impacted area unsuitable for occupancy by western skinks. However, moderate grazing may be beneficial to shrub and meadow habitats favored by this species, by preventing shrub cover from becoming too dense. When and where shrub cover manipulation is deemed desirable, it should be conducted in a way to retain a mosaic of cover conditions, including the presence of moderately tall shrubs (sagebrush in particular) at a relatively fine scale, to accommodate habitat requirements in home ranges that are fairly small. Ground cover of rocks and woody debris should be maintained.

5. The affects of application of insecticides and herbicides need to be determined, as use of these chemicals could severely impact lizard populations by eliminating a significant portion of their prey. Monitoring of skink populations in areas already impacted by exotic weeds in very desirable.

Bibliography *indicates an article with information specific to Montana

*Black, J.H. and R. Timken. 1976. Endangered and threatened amphibians and reptiles in Montana. p 36-37. In: R.E. Ashton, Jr. (chair). Endangered and threatened amphibians and reptiles in the United States. Society for the Study of Amphibians and Reptiles

Herpetological Circular 5: 1-65.

*Boundy, J. 2001. Herpetofaunal surveys in the Clark Fork Valley region, Montana. Herpetological Natural History 8: 15-26.

*Brunson, R.B. 1955. Check list of the amphibians and reptiles of Montana. Proceedings of the Montana Academy of Sciences 15: 27-29.

*Brunson, R.B., and H.A. Demaree, Jr. 1951. The herpetology of the Mission Mountains, Montana. Copeia 1951:306-308.

Cooper, W.E. 1990. Chemical detection of predators by a lizard, the broad-headed skink (Eumeces laticeps). Journal of Experimental Zoology 256(2): 162-167.

Cooper, W.E. and L.J. Vitt. 1985. Blue tails and autonomy: enhancement of predation avoidance in juvenile skinks. Zeitschrif fuer Tierpsychologie 70(4): 265-276. 
Cooper, W.E. and L.J. Vitt. 1991. Influence of detectability and ability to escape on natural selection of conspicuous autonomous defenses. Canadian Journal of Zoology 69(3): 757764.

*Coues, E. and H.C. Yarrow. 1878. Notes on the herpetology of Dakota and Montana. Bulletin of the U.S. Geologic and Geographic Survey 4(1): 259-291.

Farley, C.T. and M.G. Emshwiller. 1993. Does maximum power output limit running speed? American Zoologist 33(5): 141A.

Farley, C.T. and M.G. Emshwiller. 1996. Efficiency of uphill locomotion in nocturnal and diurnal lizards. Journal of Experimental Biology 199(3): 587-592.

*Farmer, P. and S.B. Heath. 1987. Wildlife baseline inventory, Rock Creek study area, Sanders County, Montana. Western Technology and Engineering, Inc. Helena, MT.

Fitch, H.S. 1970. Reproductive cycles in lizards and snakes. University of Kansas Miscellaneous Publication No. 52. 247 p.

Fowlie, W.J. 1973. Occurrence of the western skink, Eumeces skiltonianus, along the Mojave River, Victorville, San Bernardino County, California. Herpeton 7(1):1-3.

*Franz, R. 1971. Notes on the distribution and ecology of the herpetofauna of northwestern Montana. Bulletin of the Maryland Herpetological Society 7: 1-10.

Germaine, S.S. and H.L. Germaine. 2003. Lizard distributions and reproductive success in a ponderosa pine forest. Journal of Herpetology 37(4):645-652.

Gibbons, J. W., D. E. Scott, T. J. Ryan, K. A. Buhlmann, T. D. Tuberville, B. S. Metts, J. L. Greene, T. Mills, Y. Leiden, S Poppy, and C. T. Winne. 2000. The global decline of reptiles, déjà vu amphibians. BioScience 50:653-666.

Goldberg, S.R. 2005. Reproductive cycle of the western skink, Eumeces skiltonianus (Sauria: Scincidae) in southern California. Texas Journal of Science 57(3):295-301.

Grismer, L.L. 1996. Geographic variation, taxonomy, and distribution of Eumeces skiltonianus and E. lagunensis (Squamata: Scincidae) in Baja California, Mexico. Amphibia-Reptilia 17(4): 361-375.

*Hart, M.M., W.A. Williams, P.C. Thornton, K.P. McLaughlin, C.M. Tobalske, B.A. Maxell, D.P. Hendricks, C.R. Peterson, and R.L. Redmond. 1998. Montana atlas of terrestrial vertebrates. Montana Cooperative Wildlife Research Unit, The University of Montana. Missoula, Montana vii +1302 p.

*Hendricks, P. 1997. Lee Metcalf National Wildlife Refuge preliminary amphibian and reptile investigations: 1996. Montana Natural Heritage Program, Helena, MT. 21 p.

*Hendricks, P. and J.D. Reichel. 1996. Amphibian and reptile survey of the Bitterroot National Forest: 1995. Montana Natural Heritage Program, Helena, MT. 95 p.

*Marnell, L.F. 1997. Herpetofauna of Glacier National Park. Northwestern Naturalist 78:17-33.

*Maxell, B.A. 2004a. Amphibian and aquatic reptile inventories conducted on and around the Bitterroot National Forest 2000-2003. Report to Region 1 Office of the U.S. Forest Service, Bitterroot National Forest, Montana Department of Fish, Wildlife, and Parks, and Biological Resources Division of the U.S. Geological Survey. Missoula, MT: Montana Cooperative Wildlife Research Unit and Wildlife Biology Program, University of Montana. 128 p.

*Maxell, B.A. 2004b. Amphibian and aquatic reptile inventories conducted on and around the Thompson River 2003-2004. Report to Region 1 Office of the U.S. Forest Service and Plum Creek Timber Company. Missoula, MT: Montana Cooperative Wildlife Research Unit and Wildlife Biology Program. 83 p. 
*Maxell, B.A. 2004c. Report on amphibian and aquatic reptile inventories conducted on and around the Beaverhead-Deerlodge National Forest 2001-2003. Report to Region 1 Office of the U.S. Forest Service, Beaverhead-Deerlodge National Forest, Montana Department of Fish, Wildlife, and Parks, Montana State Office of the Bureau of Land Management, and Montana Department of Environmental Quality. Missoula, MT: Montana Cooperative Wildlife Research Unit and Wildlife Biology Program, University of Montana. 260 p.

* Maxell, B.A. 2005. Amphibian and aquatic reptile inventories conducted on and around lands administered by the Missoula Field Office of the Bureau of Land Management. Report to Missoula Field Office of the Bureau of Land Management. Montana Natural Heritage Program, Helena, MT and Montana Cooperative Wildlife Research Unit and Wildlife Biology Program, University of Montana, Missoula, MT. 53 p.

*Maxell, B.A. 2009. State-wide assessment of status, predicted distribution, and landscapelevel habitat suitability of amphibians and reptiles in Montana. Ph.D. Dissertation. Missoula, MT: Wildlife Biology Program, University of Montana. 294 p.

*Maxell, B.A. and D.G. Hokit. 1999. Amphibians and reptiles. Pp. 2.1- 2.30. In: G. Joslin and H. Youmans (committee chairs). Effects of recreation on Rocky Mountain wildlife: a compendium of the current state of understanding in Montana. Helena, MT: Committee on Effects of Recreation on Wildlife, Montana Chapter of the Wildlife Society. 307 p.

*Maxell, B.A., J.K. Werner, P. Hendricks, and D.L. Flath. 2003. Herpetology in Montana: a history, status summary, checklists, dichotomous keys, accounts for native, potentially native, and exotic species, and indexed bibliography. Northwest Fauna Number 5. 138 p.

Morrison, M.L., P.A. Aignerm, L.A. Nordstrom, and L.S. Hall. 1999. Habitat characteristics os sympatric Gilbert's and western skinks. Herpetological Review 30(1):18-20.

Murphy, R.W., W.E. Cooper, Jr., and W.S. Richardson. 1983. Phylogenetic relationships of the North American five-lined skinks, genus Eumeces (Sauria: Scincidae). Herpetologica 39: 200-211.

Mushinksy, H.R. 1992. Natural-history and abundance of southeastern 5-lined skinks, Eumeces inexpectatus, on a periodically burned sandhill in Florida. Herpetologica 48: (3) 307-312.

*[NDTI] Northrop, Devine, and Tarbell Incorporated. 1994. Cabinet Gorge and Noxon Rapids hydroelectric developments 1993 wildlife study. Northrop, Devine, and Tarbell Incorporated, Portland, ME. 197 p.

*Nussbaum, R.A., E.D. Brodie, Jr., and R.M. Storm. 1983. Amphibians and reptiles of the Pacific Northwest. University of Idaho Press. Moscow, Idaho. 332 p.

*Ortega, Y.K. and D.E. Pearson. 2001. Occurrences of the western skink (Eumeces skiltonianus) in grasslands of western Montana. Northwestern Naturalist 82: 125-126.

Punzo, F. 1982. Clutch and egg size in several species of lizards from the desert southwest. Journal of Herpetology 16(4):414-417.

Richmond, J.Q. and T.W. Reeder. 2002. Evidence for parallel ecological speciation in scincid lizards of the Eumeces skiltonianus species group (Squamata: Scincidae). Evolution 56(7): 1498-1513.

*Rodgers, T.L. and H.S. Fitch. 1947. Variation in the skinks (Reptilia: Lacertilia) of the skiltonianus group. University of California Publications in Zoology 48(4): 169-220.

*Rodgers, T.L., and W.L. Jellison. 1942. A collection of amphibians and reptiles from western Montana. Copeia 1942(1): 10-13.

Rodgers, T.L. and V.H. Memmler. 1943. Growth in the western blue-tailed skink. Transactions of the San Diego Society of Natural History 10:63-67. 
Rutherford, P.L. and P.T. Gregory. 2003. Habitat use and movement patterns of northern alligator lizards (Elgaria coerulea) and western skinks (Eumeces skiltonianus) in southeastern British Columbia. Journal of Herpetology 37: 98-106.

*Stebbins, R.C. 2003. A field guide to western reptiles and amphibians. 3rd edition. New York, NY: Houghton Mifflin Co. 533 p.

*St. John, A. 2002. Reptiles of the Northwest: California to Alaska; Rockies to the Coast. Renton, WA: Lone Pine Publishing. $272 \mathrm{p}$.

Swaim, K.E. and S.M. McGinnis. 1992. Habitat associations of the Alameda whipsnake. Transactions of Western Section Wildland Society Vol. 28. p. 107-111.

Tanner, W.W. 1957. A taxonomic and ecological study of the western skink (Eumeces skiltonianus). Great Basin Naturalist 17(3-4): 59-94.

Tanner, W.W. 1988. Eumeces skiltonianus (Baird and Girard). Western Skink. Catalogue of American Amphibians and Reptiles 447.1-447.4.

Taylor, E.H. 1935. A taxonomic study of the cosmopolitan scincoid lizards of the genus Eumeces with an account of the distribution and relationships of its species. The Kansas University Science Bulletin 23: 1-643.

*Timken, R. No Date. Amphibians and reptiles of the Beaverhead National Forest. Western Montana College, Dillon, MT. 16 p.

Vitt, L.J., J.D. Congdon, and N.A. Dickson. 1977. Adaptive strategies and energetics of tail autotomy in lizards. Ecology 58(2): 326-337.

*Werner, J.K., B.A. Maxell, P. Hendricks, and D. Flath. 2004. Amphibians and reptiles of Montana. Missoula, MT: Mountain Press Publishing Company. 262p.

*Werner, J.K. and J.D. Reichel. 1994. Amphibian and reptile survey of the Kootenai National Forest: 1994. Montana Natural Heritage Program, Helena, MT. 104 p.

*Werner, J.K. and J.D. Reichel. 1996. Amphibian and reptile monitoring/survey of the Kootenai National Forest: 1995. Montana Natural Heritage Program, Helena, MT. 115 p.

*Werner, J.K. and T. Plummer. 1994. Amphibian and reptile survey of the Flathead Indian Reservation 1993-1994. Salish Kootenai College, Pablo, MT. 55 p.

*Werner, J.K. and T. Plummer. 1995. Amphibian monitoring program on the Flathead Indian Reservation 1995. Salish Kootenai College, Pablo, MT. 46 p.

*Werner, J.K., T. Plummer, and J. Weaselhead. 1998. Amphibians and reptiles of the Flathead Indian Reservation. Intermountain Journal of Sciences 4(1-2): 33-49. 


\section{Rubber Boa (Charina bottae)}

Up-to-date distribution and status information can be found on the Montana Natural Heritage Program’s TRACKER website at http://mtnhp.org

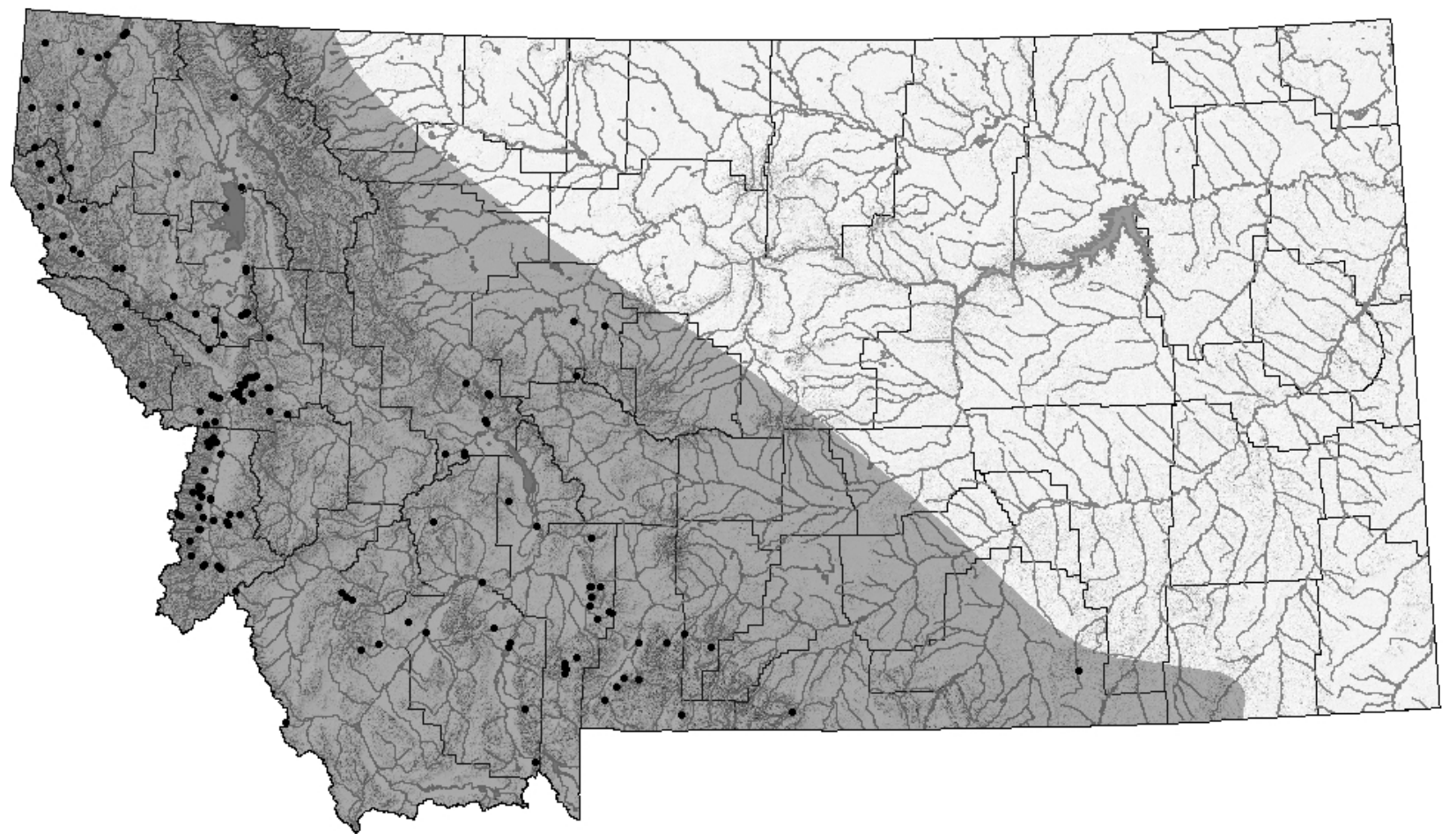

Distribution/Taxonomy

The rubber boa ranges from the northern Rocky Mountains west to the pacific coast and south into California, Nevada and portions of Utah (Stewart 1977, Werner et al. 2004). Three subspecies of rubber boa are recognized, although there has been considerable debate about subspecies designations (Nussbaum and Hoyer 1974, Stewart 1977, Rodriguez-Robles et al. 2001). Of the three subspecies, only the Northern rubber boa (Charina bottae bottae) occurs in Montana. The species has been documented in 16 western counties and was also recently documented in eastern Bighorn County, a $185 \mathrm{~km}$ range extension from the previous eastern most record near Red Lodge.

Maximum Elevation

2,200 m (7,220 ft) in Madison County (Lynda Saul, pers. com., MTNHP 2007).

\section{Identification}

Neonates:

Newborns are lighter in color than adults and are typically tan/pink dorsally with a yellow/cream ventral side. Newborns weigh 7-8 g and total length averages 215 mm (8.5 in.) (Erwin 1964, Hoyer 1974, Nussbaum et al. 1983, Werner et al. 2004).

Juveniles and Adults:

Total length ranges from 36-71 cm (14-28 in.) with females reaching greater lengths than males (Russell and Bauer 2000, Werner et al. 2004). Dorsal coloration is typically brown, tan or even olive fading to yellow ventrally sometimes with orange, brown or black mottling. Key features of the rubber boa are the uniformly wide body and blunt, wedge-shaped head. Small uniform scales 
and chin shields relatively identical in size to adjacent scales are also key features. Tail is short ending in a rounded plate. Downward facing anal spurs (remnant hind limbs) on each side of the cloacal opening are well-developed in males and in females the spurs typically project straight toward the rear. Eyes are small with vertical pupils and there are 9-11 upper labial (lip) scales (Nussbaum and Hoyer 1974, Nussbaum et al. 1983, Russell and Bauer 2000, Werner et al. 2004).

Similar species:

The rubber boa's uniform, tube-like shape and coloration easily distinguishes this species from other snakes in Montana.

Habitat use/Natural History

Rubber boas can be found under rocks, logs, and by searching through rotting stumps (Nussbaum et al. 1983, Werner et al. 2004) and also under man-made debris such as boards, metal roofing, and cardboard (Hoyer 1974, Hoyer and Stewart 2000a). Individuals have even been observed climbing trees and swimming (Russell and Bauer 2000, St. John 2002, Werner et al. 2004). Rubber boas are most associated with forested habitats in Montana, however, use of non-forested habitats has been recorded in other regions (Hoyer 1974, Nussbaum et al. 1983). Most records of rubber boas in Montana are close to areas with high human densities and the species may be more common than previously thought (Maxell et al. 2003). Activity occurs from April-October even in temperatures as low as $10^{\circ} \mathrm{C}\left(50^{\circ} \mathrm{F}\right)$. Rubber boas hibernate for the remainder of the year and although accounts are limited, hibernacula were found in rock outcroppings in California (Hoyer and Stewart 2000a) and St. John (2002) discovered communal hibernation even in sawdust piles. Rubber boas breed in the spring and young are live-born between late summer and early fall with litters ranging from 2-8 (Nussbaum et al. 1983, Russell and Bauer 2000, Werner et al. 2004). The time required to reach sexual maturity is unknown, however, Werner et al. (2004) report that individuals with a total length $\geq 360 \mathrm{~mm}$ (14 in.) can breed and Nussbaum et al. (1983) state that maturity is reached at lengths $\geq 450 \mathrm{~mm}$ (18 in.) for females and $545 \mathrm{~mm}$ (21.5 in.) for males in Oregon. Most foraging occurs at night and the diet consists largely of small mammals that they kill through constriction (Rodriguez-Robles et al. 1999, Hoyer and Stewart 2000b). Rubber boas are especially effective at locating and consuming nests of young rodents (Rodriguez-Robles 1999) even using their tail to fend off adult mice when preying on the nestlings (Hoyer 1974, Hoyer and Stewart 2000b). The tail may also be used as defense against other predators such as raptors and weasels (Werner et al. 2004). Little is known about the life history of rubber boas in the wild, however, individuals in captivity can live for more than 18 years (Werner et al. 2004).

\section{Status and Conservation}

Observations of rubber boas in Montana are rare, but are often associated with areas of human activity, indicating that this cryptic species is relatively common and is just observed relatively infrequently. There is little research that addresses the conservation status or impacts of anthropogenic disturbances to rubber boas in Montana. For example, no studies have assessed the potential impacts of habitat alteration to rubber boas. Individual studies that specifically identify risk factors or other issues relevant to the conservation of rubber boas include the following: (1) Specimens have been collected as a result of roadway mortality (Ortenburger 1921), but we do not know the level of impact roads may have on rubber boa populations. Roadways have been shown to have negative impacts to other reptile and amphibian populations 
(Maxell and Hokit 1999) but research that has linked roadways to population level parameters typically involved species concentrated within a particular habitat, such as frogs and turtles near ponds (Maxell and Hokit 1999). Roadways could have negative impacts in areas where rubber boas are highly concentrated, such as adjacent to hibernacula. Snake mortality on roadways, at times in great numbers, has been documented widely with some drivers even purposely swerving to kill snakes (Langley et al. 1989, Krivda 1993, Rosen and Lowe 1994, Hammerson 1999). Negative impacts to herpetofauna from off-road vehicle (ORV) use have been documented. Both reptiles and their associated prey were less abundant in areas with high ORV use compared to areas with no ORV use (Maxell and Hokit 1999). (2) Generally, snakes near human population centers or areas with high levels of recreational use can experience mortality from humans, predation from pets or even predation from small carnivores that can exist at higher densities near human concentrations (Maxell and Hokit 1999). Stuart et al. (2001) found snakes entangled in plastic netting that is commonly used to protect fruit trees and gardens from pests. (3) Although the rubber boa is extremely docile and non-venomous, a general lack of knowledge about snakes coupled with deeply anchored fears sometimes leads humans to destroy snakes on sight, regardless of the species (Dodd 1993, Maxell and Hokit 1999). (4) Chemical contamination may adversely affect snakes (Werner et al. 2004). However, changes in agricultural practices and federal laws can sometimes mitigate these impacts. For example, DDT levels in snakes have declined since the banning of the pesticide (Fleet and Plapp 1978). Snakes may bioaccumulate pollutants and may be used as valuable bioindicators of overall environmental health (Bauerle et al. 1975, Stafford et al. 1976, Anderson 1977).

\section{Research and Management Suggestions}

1. Overwintering habits of rubber boas should be investigated to ascertain whether they hibernate communally and if so what the characteristics of these hibernation sites are in Montana.

2. If future research delineates characteristics of rubber boa hibernacula sites, efforts should be made to avoid these sites when constructing roads and ORV trails.

3. The lack of research on wild rubber boa ecology is startling. Research that explores any aspect of wild rubber boa ecology would enhance our understanding of this species. Studies that explore foraging behavior, dispersal, survival, and breeding habits would be most beneficial initially.

4. Outreach programs that provide the public with scientifically accurate and lucid information about snakes should be encouraged and supported whenever possible.

Bibliography *indicates an article with information specific to Montana

*Agerter, K.S. 1932. A record snake found. Yellowstone Nature Notes 9(6-7): 33-34.

*Albertson, H. 1928. A new genus for Yellowstone. Yellowstone Nature Notes 5(9): 6-7.

*Anderson, M.E. 1977. Aspects of the ecology of two sympatric species of Thamnophis and heavy metal accumulation within the species. M.S. Thesis. Missoula, MT: University of Montana.

Bartholomew, B.D. and C. Lleyson. 1993. Charina bottae (rubber boa). Food. Herpetological Review 24(3): 105-106.

Bauerle, B., D.L. Spencer, and W. Wheeler. 1975. The use of snakes as a pollution indicator species. Copeia. 1975(2): 366-368. 
Blainville, H.M.D. 1835. Nouvelles Annales du Museum D'Histoire Naturelle De Paris, Vol. 4, p. 289, pl. 26, figs. 1, 1 b.

*Boundy, J. 2001. Herpetofaunal surveys in the Clark Fork Valley region, Montana. Herpetological Natural History 8: 15-26.

*Brunson, R.B. 1955. Check list of the amphibians and reptiles of Montana. Proceedings of the Montana Academy of Sciences 15: 27-29.

*Brunson, R.B. and H.A. Demaree. 1951. The herpetology of the Mission Mountains, Montana. Copeia 1951: 306-308.

Carpenter, C.C. 1953b. An ecological survey of the Herpetofauna of the Grand Teton-Jackson Hole area of WY Copeia 3: 170-174.

*Cope, E.D. 1875. Check-list of North American Batrachia and Reptilia; with a systematic list of the higher groups, and an essay on geographical distribution. U.S. National Museum Bulletin 1(1): 1-104.

Copper, W.A., C.P. Ohmart, and D.L. Dahlsten. 1978. Predation by a rubber boa on chestnutbacked chickadees in an artificial nesting site. Western Birds 9(1):41-42.

Cunningham, J.D. 1966b. Observations on the taxonomy and natural history of the rubber boa, Charina bottae. Southwestern Naturalist 11: 298-299.

Degenhardt, W.G., C.W. Painter, and A.H. Price. 1996. Amphibians and reptiles of New Mexico. University of New Mexico Press. Albuquerque, NM. 431 pp.

Devitt, T.J., R.I. Hill, and S.E. Cameron. 2005. Charina bottae (rubber boa). Diet. Herpetological Review 36(2):189-190.

Dodd, C.K., Jr. 1993. Strategies for snake conservation. Pp. 363-393. In: R.A. Seigel and J.T. Collins (eds). Snakes - ecology and behavior. McGraw-Hill, NY. 414 p.

Dorcas, M.E. and C.R. Peterson. 1994. Body temperature variation in free-ranging rubber boas (Charina Bottae). Journal of Idaho Academy of Science 30(1):9 p.

Dorcas, M.E. and C.R. Peterson. 1997. Head-body temperature differences in free-ranging rubber boas. Journal of Herpetology 31(1): 87-93.

Dorcas, M.E., C.R. Peterson, and M.E.T. Flint. 1997. The thermal biology of digestion in rubber boas (Charina bottae): physiology, behavior, and environmental constraints. Physiological Zoology 70(3): 292-300.

*Ernst, C.H. and E.M. Ernst. 2003. Snakes of the United States and Canada. Washington D.C.: Smithsonian Books.

Erwin, D.B. 1964. Some findings on newborn rubber boas, Charina b. bottae. Copeia 1964: 222-223.

Erwin, D.B. 1974. Taxonomic status of the southern rubber boa, Charina bottae umbratica . Copeia 1974: 996-997.

*Farmer, P. and S.B. Heath. 1987. Wildlife baseline inventory, Rock Creek study area, Sanders County, Montana. Western Technology and Engineering, Inc. Helena, MT.

Fleet, R.R., and F.W. Plapp, Jr. 1978. DDT residues in snakes decline since DDT ban. Bulletin of Environmental Contaminants and Toxicology. 19: 383-388.

*Franz, R. 1971. Notes on the distribution and ecology of the herpetofauna of northwestern Montana. Bulletin of the Maryland Herpetological Society 7: 1-10.

Hammerson, G.A. 1999. Amphibians and reptiles in Colorado. University Press of Colorado. Niwot, CO. 484 p.

Hansen, R.W. and C. Uptain. 1984. Charina bottae (rubber boa). Herpetological Review 15(4):114 p. 
*Hart, M.M., W.A. Williams, P.C. Thornton, K.P. McLaughlin, C.M. Tobalske, B.A. Maxell, D.P. Hendricks, C.R. Peterson, and R.L. Redmond. 1998. Montana atlas of terrestrial vertebrates. Montana Cooperative Wildlife Research Unit, The University of Montana. Missoula, Montana vii +1302 p.

*Hendricks, P. 1997. Lee Metcalf National Wildlife Refuge preliminary amphibian and reptile investigations: 1996. Montana Natural Heritage Program, Helena, MT. 21 p.

*Hendricks, P. 1999. Amphibian and reptile survey of the Bureau of Land Management Miles City District, Montana. Montana Natural Heritage Program, Helena, MT. 80 p.

*Hendricks, P. and J.D. Reichel. 1996. Amphibian and reptile survey of the Bitterroot National Forest: 1995. Montana Natural Heritage Program, Helena, MT. 95 p.

Hoyer, R.F. 1974. Description of a rubber boa (Charina bottae) population from western Oregon. Herpetologica 30(3): 275-283.

Hoyer, R.F. and G.R. Stewart. 2000a. Biology of the rubber boa (Charina bottae), with emphasis on C.b. umbratica. Part I: Capture, size, sexual dimorphism, and reproduction. Journal of Herpetology 34(3): 348-354.

Hoyer, R.F. and G.R. Stewart. 2000b. Biology of the rubber boa (Charina bottae), with emphasis on C.b. umbratica. Part II: Diet, antagonists, and predators. Journal of Herpetology 34(3): 354-360.

Kaban, L.W. 1978. A comparative study of organ placement in Charina bottae and Lichanura roseofusca (Serpentes: Boidae). M.S. Thesis, California State University (Long Beach). 77 p.

Klauber, L.M. 1943b. The subspecies of the rubber boa, Charina. Transactions of the San Diego Society of Natural History 10(7): 83-90.

Kluge, A.G. 1993. Calabaria and the phylogeny of erycine snakes. Zoological Journal of the Linnean Society 107(4): 293-351.

*Koch, E.D. and C.R. Peterson. 1989. A preliminary survey of the distribution of amphibians and reptiles in Yellowstone National Park. pp. 47-49. In: Rare, sensitive and threatened species of the Greater Yellowstone Ecosystem, T.W. Clark, A.H. Harvey, R.D. Dorn, D.C. Genter, D. and C. Groves (eds.). Northern Rockies Conservation Cooperative, Montana Natural Heritage Program, The Nature Conservancy, and Mountain West Environmental Services. 153 p.

Krivda, W. 1993. Road kills of migrating garter snakes at The Pas, Manitoba. Blue Jay. 51(4): 197-198.

Langley, W.M., H.W. Lipps, and J.F. Theis. 1989. Responses of Kansas motorists to snake models on a rural highway. Transactions of the Kansas Academy of Science. 92(1-2): 43-48.

Linder, A.D. 1963. Ophiophagy by the rubber boa. Herpetologica 19(2): 143 p.

Macey, R.J. 1983. Charina bottae bottae (Pacific rubber boa). Food. Herpetological Review 14(1):19 p.

*Manville, R.H. 1957. Amphibians and reptiles of Glacier National Park, Montana. Copeia 1957: 308-309.

*Marnell, L.F. 1997. Herpetofauna of Glacier National Park. Northwestern Naturalist 78: 1733.

*Maxell, B.A. 2002b. Amphibian and aquatic reptile inventories in watersheds in the South and Middle Forks of the Flathead River drainage that contain lakes being considered for application of piscicides and subsequent stocking of west slope cutthroat trout. Report to the Region 1 Office of the U.S. Forest Service and the Montana Department of Fish, Wildlife, 
and Parks. Missoula, MT: Montana Cooperative Wildlife Research Unit and Wildlife Biology Program, University of Montana. 62 p.

*Maxell, B.A. 2004a. Amphibian and aquatic reptile inventories conducted on and around the Bitterroot National Forest 2000-2003. Report to Region 1 Office of the U.S. Forest Service, Bitterroot National Forest, Montana Department of Fish, Wildlife, and Parks, and Biological Resources Division of the U.S. Geological Survey. Missoula, MT: Montana Cooperative Wildlife Research Unit and Wildlife Biology Program, University of Montana. 128 p.

*Maxell, B.A. 2004b. Amphibian and aquatic reptile inventories conducted on and around the Thompson River 2003-2004. Report to Region 1 Office of the U.S. Forest Service and Plum Creek Timber Company. Missoula, MT: Montana Cooperative Wildlife Research Unit and Wildlife Biology Program. 83 p.

* Maxell, B.A. 2004c. Preliminary report on amphibian and aquatic reptile inventories conducted in the West Boulder River area during summer 2003. Report to Region 1 Office of the U.S. Forest Service, and the Montana Department of Fish, Wildlife, and Parks. Missoula, MT: Montana Cooperative Wildlife Research Unit and Wildlife Biology Program, University of Montana. 27 p.

*Maxell, B.A. 2004d. Report on amphibian and aquatic reptile inventories conducted on and around the Beaverhead-Deerlodge National Forest 2001-2003. Report to Region 1 Office of the U.S. Forest Service, Beaverhead-Deerlodge National Forest, Montana Department of Fish, Wildlife, and Parks, Montana State Office of the Bureau of Land Management, and Montana Department of Environmental Quality. Missoula, MT: Montana Cooperative Wildlife Research Unit and Wildlife Biology Program, University of Montana. 260 p.

*Maxell, B.A. 2005. Amphibian and aquatic reptile inventories conducted on and around lands administered by the Missoula Field Office of the Bureau of Land Management. Report to Missoula Field Office of the Bureau of Land Management. Montana Natural Heritage Program, Helena, MT and Montana Cooperative Wildlife Research Unit and Wildlife Biology Program, University of Montana, Missoula, MT. 53 p.

*Maxell, B.A. 2009. State-wide assessment of status, predicted distribution, and landscapelevel habitat suitability of amphibians and reptiles in Montana. Ph.D. Dissertation. Missoula, MT: Wildlife Biology Program, University of Montana. 294 p.

*Maxell, B.A. and D.G. Hokit. 1999. Amphibians and reptiles. Pp. 2.1- 2.30. In: G. Joslin and H. Youmans (committee chairs). Effects of recreation on Rocky Mountain wildlife: a compendium of the current state of understanding in Montana. Helena, MT: Committee on Effects of Recreation on Wildlife, Montana Chapter of the Wildlife Society. 307 p.

*Maxell, B.A., J.K. Werner, P. Hendricks, and D. Flath. 2003. Herpetology in Montana: a history, status summary, checklists, dichotomous keys, accounts for native, potentially native, and exotic species, and indexed bibliography. Olympia, WA: Society for Northwestern Vertebrate Biology. Northwest Fauna 5: 1-138.

Michaels, S.J. 1985a. Candoia carinata (Solomon Island boa). Ophiophagy. Herpetological Review 16(2) 1985: 54 p.

Michaels, S.J. 1985b. Orphiophagy in two captive boids, Eunectes murinus and Candoia carinata paulsoni. Bulletin of the Chicago Herpetological Society 20(1): 25-26.

*[MTNHP] Montana Natural Heritage Program. 2006. Point Observation Database. Montana Natural Heritage Program, Helena, MT. Accessed April 25, 2006.

*Nussbaum, R.A. and R.F. Hoyer. 1974. Geographic variation and the validity of subspecies in the rubber boa, Charina bottae (Blainville). Northwest Science 48:219-229. 
Nussbaum, R.A., E.D. Brodie Jr., and R.M. Storm. 1983. Amphibians and reptiles of the Pacific Northwest. University of Idaho Press. Moscow, ID. 332 pp.

*Ortenburger, A.I. 1921. An eastern record and note on Charina bottae (Blainville). Copeia 1921: 84 p.

*Patla, D.A. 1998. Amphibians and reptiles in the Old Faithful sewage treatment area. Report to Yellowstone Center for Resources, Yellowstone National Park. 10 September, 1998. Greater Yellowstone Ecosystem Amphibian Survey and Monitoring Program, Herpetology Laboratory, Department of Biological Sciences, Idaho State University, Pocatello, ID. 7 p.

*Patla, D.A. 1999a. Amphibians and reptiles of the Madison to Norris road improvement project area, Yellowstone National Park. 11 November, 1999. Greater Yellowstone Ecosystem Amphibian Survey and Monitoring Program, Herpetology Laboratory, Department of Biological Sciences, Idaho State University, Pocatello, ID. 17 p.

*Patla, D.A. 1999c. Amphibians and reptiles along the grand loop road in Yellowstone National Park: Canyon Junction to Fishing Bridge Junction. December 11, 1999. Greater Yellowstone Ecosystem Amphibian Survey and Monitoring Program, Herpetology Laboratory, Department of Biological Sciences, Idaho State University, Pocatello, ID. 24 p.

*Patla, D.A. and C.R. Peterson. 1996. Amphibians and reptiles along the Grand Loop Highway in Yellowstone National Park: Tower Junction to Canyon Village. 24 February, 1996. Greater Yellowstone Ecosystem Amphibian Survey and Monitoring Program, Herpetology Laboratory, Department of Biological Sciences, Idaho State University, Pocatello, ID. 49 p.

Peabody, R.B., A.J. Judith, E.D. Brodie, Jr. 1975. Intraspecific escape from ingestion of the rubber boa, Charina bottae. Journal of Herpetolica 9(2): 237 p.

Peterson, C.R. and M.E. Dorcas. 1992. The use of automated data-acquisition techniques in monitoring amphibian and reptile populations. Pp. 369-378. In: D.R. McCullough and R.H. Barrett (eds). Wildlife 2001: populations. New York, NY: Elsevier Applied Science. 1,163p.

*Peterson, C.R., C.J. Askey, and D.A. Patla. 1993. Amphibians and reptiles along the Grand Loop and Fountain Freight Roads between Madison Junction and Biscuit Basin in Yellowstone National Park. 26 July, 1993. Greater Yellowstone Ecosystem Amphibian Survey and Monitoring Program. Pocatello, ID: Herpetology Laboratory, Department of Biological Sciences, Idaho State University. 45 p.

*Peterson, C.R., D.A. Patla, and S.R. Sullivan. 1995. Amphibians and reptiles along the Grand Loop Highway in Yellowstone National Park: Madison Junction to Norris Campground. 7 July, 1995. Greater Yellowstone Ecosystem Amphibian Survey and Monitoring Program, Herpetology Laboratory, Department of Biological Sciences, Idaho State University, Pocatello, ID. 64 p.

*Place, C.B., III. 1992. Meet the rubber boa. Montana Outdoors 23(5): 35-37.

*Pope, P.H. 1931. A new record for the rubber snake, Charina bottae. Yellowstone Nature Notes 8(9): 70 p.

*Rauscher, R.L. 1998. Amphibian and reptile survey on selected Montana Bureau of Reclamation impoundments. Montana Department of Fish, Wildlife and Parks, Nongame Program, Bozeman, MT. 24 p.

Rehak, I. 1986. Charina bottae in the terrarium. Akvarium Terarium 29(6): 31-32.

*Reichel, J.D. 1995a. Preliminary amphibian and reptile survey of the Lewis and Clark National Forest: 1994. Montana Natural Heritage Program, Helena, MT. 92 p. 
*Reichel, J.D. 1996b. Preliminary amphibian and reptile survey of the Helena National Forest: 1995. Montana Natural Heritage Program, Helena, MT. 87 p.

*Reichel, J.D. 1997. Amphibian, reptile and northern bog lemming survey on the Rocky Mountain Front: 1996. Montana Natural Heritage Program, Helena, MT. 81 p.

*Reichel, J.D. and D.L. Flath. 1995. Identification guide to the amphibians and reptiles of Montana. Montana Outdoors 26(3): 15-34.

*Rodgers, T.L., and W.L. Jellison. 1942. A collection of amphibians and reptiles from western Montana. Copeia 1942(1): 10-13.

Rodríguez-Robles, J.A., G.R. Stewart, and T.J. Papenfuss. 2001. Mitochondrial DNA-based phylogeography of North American rubber boas, Charina bottae (Serpentes: Boidae). Molecular Phylogenetics and Evolution 18(2): 227-237.

*Roedel, M.D. and P. Hendricks. 1998a. Amphibian and reptile survey on the Bureau of Land Management Lewistown District: 1995-1998. Montana Natural Heritage Program, Helena, MT. 53 p.

*Roedel, M.D. and P. Hendricks. 1998b. Amphibian and reptile inventory on the Headwaters and Dillon Resource Areas in conjunction with Red Rocks Lakes National Wildlife Refuge: 1996-1998. Montana Natural Heritage Program, Helena, MT. 46 p.

Rosen, P.C., and C.H. Lowe. 1994. Highway mortality of snakes in the Sonoran desert of southern Arizona. Biological Conservation. 68: 143-148.

Spiess, P. and M. Smith. 1998. The rubber boa Charina bottae. Reptile and Amphibian Magazine 56:26-29.

*St. John, A. 2002. Reptiles of the Northwest: California to Alaska; Rockies to the Coast. Renton, WA: Lone Pine Publishing. 272 p.

Stafford, D.P., F.W. Plapp, Jr., and R.R. Fleet. 1976. Snakes as indicators of environmental contamination: relation of detoxifying enzymes and pesticide residues to species occurrence in three aquatic ecosystems. Archives of Environmental Contamination and Toxicology. 5: 15-27.

*Stebbins, R.C. 2003. A field guide to western reptiles and amphibians. 3rd edition. New York, NY: Houghton Mifflin Co. 533 p.

Stejneger, L. 1890. On the snakes of the genus Charina. Proceedings of the United States National Museum 13: 177-181.

*Stewart, G.R. 1977. Charina, C. bottae. Catalogue of American Amphibians and Reptiles 205.1-205.2.

Stuart, J.N., M.L. Watson, T.L. Brown, and C. Eustice. 2001. Plastic netting: an entanglement hazard to snakes and other wildlife. Herpetological Review. 32: 162-164.

*Tanner, V.M. 1933. A study of the variation of the dorsal scale rows of Charina bottae (Blainville). Copeia 1933: 81-84.

Tanner, V.M. and W. Tanner. 1939. Notes on Charina bottae in Utah; reproduction and distribution. Great Basin Naturalist 1(1): 27-30.

*Timken, R. No Date. Amphibians and reptiles of the Beaverhead National Forest. Western Montana College, Dillon, MT. 16 p.

*Turner, F.B. 1951. A checklist of the reptiles and amphibians of Yellowstone National Park with incidental notes. Yellowstone Nature Notes 25(3): 25-29.

*Turner, F.B. 1955. Reptiles and amphibians of Yellowstone National Park. Yellowstone Interpretive Series No. 5. Yellowstone Library and Museum Association. Yellowstone National Park, WY. 40 p. 
Van der Pols, J. 1988. Care, breeding and other things worth knowing about the rubber boa, Charina bottae bottae (Blainville). Litteratura Serpentium English Edition 8(6): 244-254.

Van Heest, R.W. and J.A. Hay. 2000. Charina bottae (Rubber boa). Antipredator behavior. Herpetological Review 31(3): 177 p.

Weaver, R.E. 2005. Charina bottae (rubber boa). Relative prey mass. Herpetological Review 36(2):189 p.

Weisman, C.M. 1988. Morphometric and electrophoretic comparison between the Pacific rubber boa (Charina bottae bottae) and the southern rubber boa (Charina bottae umbratica). M.S. Thesis. California State Polytechnic University (Pomona). 44 p.

Welp, L., W. Fertig, and G. Jones. 1998a. Ecological Evaluation of the Potential Tensleep Canyon Research Natural Area Within the Bighorn National Forest, Washakie County, Wyoming. Report prepared by the Wyoming Natural Diversity Database, Laramie, WY.

Welp, L., W. Fertig, and G. Jones. 1998b. Ecological Evaluation of the Potential Tongue River Research Natural Area Within the Bighorn National Forest, Sheridan County, Wyoming. Report prepared by the Wyoming Natural Diversity Database, Laramie, WY.

*Werner, J.K., B.A. Maxell, P. Hendricks, and D. Flath. 2004. Amphibians and reptiles of Montana. Missoula, MT: Mountain Press Publishing Company. 262p.

*Werner, J.K. and J.D. Reichel. 1994. Amphibian and reptile survey of the Kootenai National Forest: 1994. Montana Natural Heritage Program, Helena, MT. 104 p.

*Werner, J.K. and J.D. Reichel. 1996. Amphibian and reptile monitoring/survey of the Kootenai National Forest: 1995. Montana Natural Heritage Program, Helena, MT. 115 p.

*Werner, J.K. and T. Plummer. 1995. Amphibian monitoring program on the Flathead Indian Reservation 1995. Salish Kootenai College, Pablo, MT. 46 p.

*Werner, J.K., T. Plummer, and J. Weaselhead. 1998. Amphibians and reptiles of the Flathead Indian Reservation. Intermountain Journal of Sciences 4(1-2): 33-49.

*[WESTECH] Western Technology and Engineering Incorporated. 1993. Diamond Hill project wildlife baseline survey. Western Technology and Engineering, Inc., Helena, MT.

*Yeager, D.C. 1929. Reptiles of Yellowstone Park with notes on the Amphibia. Yellowstone Nature Notes. Yellowstone National Park Library, Mammoth, WY. 12 p. 


\section{Eastern Racer (Coluber constrictor)}

Up-to-date distribution and status information can be found on the Montana Natural Heritage Program's TRACKER website at http://mtnhp.org

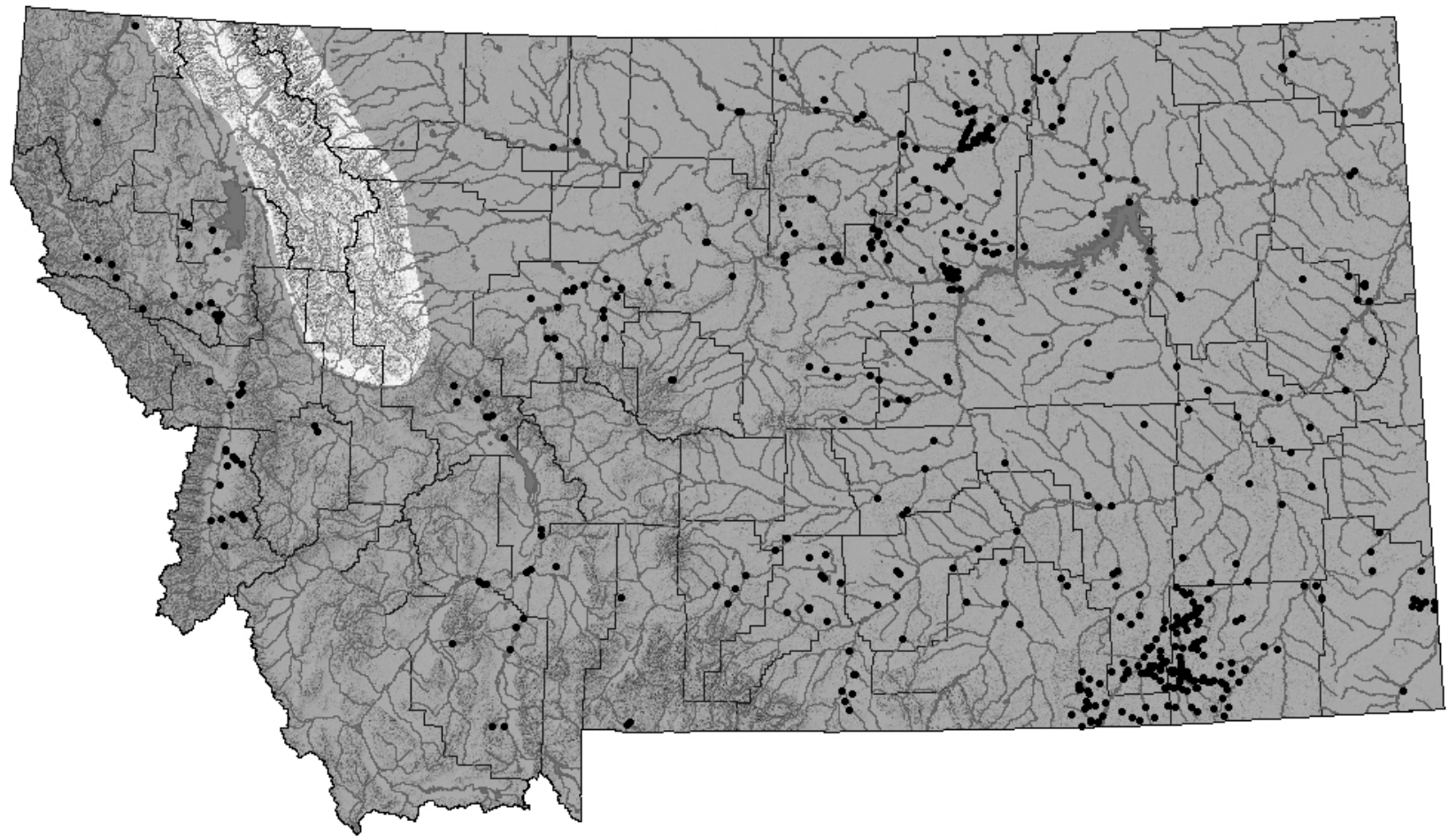

Distribution/Taxonomy

As its common name implies, much of the range of the eastern racer is in the eastern United States. However, it is found across the midwest and portions of the Dakotas linking it to Montana into the pacific northwest and southern British Columbia. Fringes and pockets of eastern racers are also found in California, Nevada, Utah, Wyoming, Colorado, Arizona, and Mew Mexico (Wilson 1978, Hammerson 1999, Russell and Bauer 2000, Werner et al. 2004). Currently there are 11 subspecies of Coluber constrictor recognized but only C. c. flaviventris, the eastern yellow-bellied racer, has been confirmed in Montana. Most records of this species in Montana are from the eastern part of the state and the drier valleys of western Montana (Maxell et al. 2003).

Maximum Elevation

2,012 m (6,600 ft) in Madison County (Maxell et al. 2003).

Identification

Juveniles and Adults:

Slender with uniform blue, gray, or olive coloration and smooth scales dorsally and yellow coloration ventrally. Underside of chin is white or cream and eyes are large with round pupils (Werner et al. 2004). Adult racers range 58-122 cm (23-48 in.) in total length and females are typically larger than males. There are 7-8 upper and 9-10 lower labial (lip) scales. 
Neonates:

Newborn racers have a series of red/brown blotches dorsally interspersed with lighter colored scales and smaller brown spots along their sides giving them a banded appearance. Newborns average $33 \mathrm{~cm}$ (13 in.) in total length and weigh approximately $5.5 \mathrm{~g}$ (Swain and Smith 1978, Werner et al. 2004). When young racers reach a total length of approximately $69 \mathrm{~cm}$ (27 inches) in their second year this banded appearance fades into uniform adult coloration (Hammerson 1999, Werner et al. 2004).

Eggs:

White, oval with a granular surface. Eggs are approximately $33 \mathrm{~mm}$ (1.3 in.) in length by $19 \mathrm{~mm}$ (0.75 in.) in width and are laid in groups of about 9-12, however, clutch size can vary widely (Hammerson 1999, Russell and Bauer 2000, Werner et al. 2004) and is closely correlated with female body length (Rosen 1991). Swain and Smith (1978) found an average weight of $8.7 \mathrm{~g} / \mathrm{egg}$ for 89 eggs in Colorado.

Similar species:

Because of their banded appearance juvenile eastern racers can be confused with gophersnakes (Pituophis catenifer), however, gophersnakes have keeled scales (ridged scales).

\section{Habitat use/Natural History}

Eastern racers are typically found in open habitat including prairie, sagebrush, badlands, and valley bottom grasslands (Hammerson 1999, Werner et al. 2004). While racers are largely terrestrial, inhabiting rodent burrows and spaces under rocks, boards, and vegetation during spring and summer, they have also been observed climbing shrubs and trees and even swimming (Degenhardt et al. 1996, Hammerson 1999, Werner et al. 2004). Racers are active from late April to October (Hammerson 1999, Werner et al. 2004) and are most active during the day when the sun can warm body temperatures to approximately $30^{\circ} \mathrm{C}\left(86^{\circ} \mathrm{F}\right)$ (Plummer and Congdon 1996, Werner et al. 2004). Hibernation lasts from late October through April and is often communal and can even occur with other snake species (Swain and Smith 1978, Hammerson 1999). Hibernacula have been found in rock piles, talus, and even abandoned wells and home foundations (Brown and Parker 1976, Herrington 1988, Hammerson 1999). Racers breed after emerging from hibernation in the spring and subsequent dispersal distance to summer range averaged $339 \mathrm{~m}(1,113 \mathrm{ft})$ in a population of C.c. flaviventris in Kansas (Brown and Parker 1976). Brown and Parker (1976) found average dispersal distances from hibernacula to summer ranges for C.c. mormon in Utah averaged $289 \mathrm{~m}$ (948 ft) and $739 \mathrm{~m}$ (2,425 ft) during 1966 and 1971-1972, respectively. Roughly $90 \%$ of adult females lay eggs in late-June/early July (Hammerson 1999) and the females may deposit eggs in shallow burrows, abandoned rodent burrows, or rotting logs (Porchuk and Brooks 1995, Brown and Parker 1976, Hammerson 1999). Swain and Smith (1978) even found a communal nest with over 100 eggs under a large rock in Colorado. Eggs will hatch in late August/early September and growth of hatchlings is best in years with abundant precipitation. Individuals can breed in their second spring, however, most females will deposit their first clutch of eggs at age four (Hammerson 1999). Survival over the hibernation period is high (>90\%), but on average $60 \%$ of adults survive annually with only $20 \%$ of juveniles surviving their first year (Hammerson 1999). Racers forage widely using rapid locomotion to locate prey (Herzog and Burghardt 1974, Plummer and Congdon 1996). Mean home range size for racers in Kansas was 2.9 ha (7.2 ac) and 1.8 ha (4.5 ac) for males and 
females, respectively. Rosen (1991) found that larger C.c. foxii moved farther between relocations than did smaller individuals, indicating that larger racers had larger home ranges possibly due to increased energetic demands. Largely opportunistic, racers consume their prey alive and without constriction as their scientific name suggests (Werner et al. 2004). Small mammals, grasshoppers, crickets, amphibians, and birds are all consumed by racers (Schonberger 1945, Rosen 1991, Hammerson 1999, Werner et al. 2004). Racers have even been documented eating other snake species (Hammerson 1999). Red-tailed hawks (Buteo jamaicensis) have been observed killing racers and it is likely that a suite of other animals prey on racers as well (Hammerson 1999). Racers can be relatively long-lived in the wild with a small percentage of individuals within a population $\geq 10$ years old (Hammerson 1999).

\section{Status and Conservation}

Eastern racers are common and have been documented in 40 counties and on both sides of the Continental Divide in Montana (Maxell et al. 2003). There is some debate whether C.c. flaviventris occurs east of the divide and C.c. mormon occurs west of the divide, however, research has not been conducted to ascertain whether this separation, or integration, occurs (Maxell et al. 2003). Similar to other species of snakes, eastern racers may be negatively impacted by disturbance to their hibernacula. Because they are ectothermic, snakes do not respond to human disturbance as effectively at cooler temperatures, such as the overwintering period, than they would at warmer temperatures (Prior and Weatherhead 1994). In addition, because eastern racers can concentrate in large numbers and display substantial site fidelity year after year (Brown and Parker 1976, Swain and Smith 1978), they can be impacted by even small, localized disturbance if it occurs near hibernacula or nesting sites. For example, roadways and off-road vehicle (ORV) use may impact eastern racers if they occur near hibernacula or intersect movement to such areas. Snake mortality on roadways, at times in great numbers, has been documented widely with some drivers even purposely swerving to kill snakes (Langley et al. 1989, Krivda 1993, Rosen and Lowe 1994). In general, snakes near human population centers or areas with high levels of recreational use can experience mortality from humans, predation from pets or even predation from small carnivores that can exist at higher densities near human concentrations (Maxell and Hokit 1999). Although eastern racers are not venomous, they can bite when provoked (Degenhardt et al. 1996) and a general lack of knowledge about snakes coupled with deeply anchored fears sometimes leads humans to destroy snakes on sight, regardless of the species (Dodd 1993, Maxell and Hokit 1999). In addition, popular large-scale rattlesnake roundups are known to kill not only thousands of the targeted species, but also many other incidental species including racers (Weir 1992). Near homes and construction sites plastic netting, commonly used to protect fruit trees and gardens from pests, has also been found to entangle and kill racers (Stuart et al. 2001). Although eastern racers are beneficial to farmers through consumption of agricultural pests and possibly disease control, mowing has been shown to kill large numbers of eastern racers (Degenhardt et al. 1996, Hammerson 1999, Werner et al. 2004). Chemical contamination may adversely affect snakes (Werner et al. 2004), however changes in agricultural practices and federal laws can sometimes mitigate these impacts. For example, DDT levels in snakes have declined since the banning of the pesticide (Fleet and Plapp 1978). Snakes may harbor pollutants indicative of overall environmental health (Bauerle et al. 1975, Stafford et al. 1976, Anderson 1977), thereby adding to the value of their conservation and persistence. In addition, rattlesnakes consume deer mice and other rodents which may help 
control the spread of harmful viruses such as hantavirus (Degenhardt et al. 1996).

$\underline{\text { Research and Management Suggestions }}$

1. If location is known, protect hibernation and nesting sites from disturbance or destruction.

2. Whenever possible, avoid disturbance to talus, rock piles, and outcroppings.

3. Outreach programs that provide the public with scientifically accurate and lucid information about snakes should be encouraged and supported whenever possible.

4. Research that addresses genetic distinctions and distribution of C.c. flaviventris and C.c. mormon in Montana would be beneficial.

Bibliography *indicates an article with information specific to Montana

*Allen, J.A. 1874. Notes on the natural history of portions of Dakota and Montana Territories, being the substance of a report to the Secretary of War on the collections made by the North Pacific Railroad Expedition of 1873, General D.S. Stanley, Commander. Proceedings of the Boston Society of Natural History 17: 33-85.

*Anderson, M.E. 1977. Aspects of the ecology of two sympatric species of Thamnophis and heavy metal accumulation within the species. M.S. Thesis. University of Montana, Missoula, MT.

*Atkinson, E.C. and M.L. Atkinson. 2004. Amphibian and reptile survey of the Ashland and Sioux of the Custer National Forest with special emphasis on the Three-Mile Stewardship Area: 2002. Marmot's Edge Conservation. 22 p.

Auffenberg, W. 1949. The racer, Coluber constrictor stejnegerianus in Texas. Herpetologica 5: 53-58.

Auffenberg, W. 1955. A reconsideration of the racer, C. constrictor, in eastern United States. Tulane Studies in Zoology 2(6): 89-155.

Bauerle, B., D.L. Spencer, and W. Wheeler. 1975. The use of snakes as a pollution indicator species. Copeia. 1975(2):366-368.

Bealor, M.T. and G.M. Burghardt. 2002. Coluber constrictor constrictor (northern black racer). Ingestion of plant material. Herpetological Review 33(3):210 p.

*Bergeron, D.J. 1978a. Terrestrial wildlife survey Divide Mine area, Montana 1977-1978. Western Technology and Engineering, Inc. Helena, MT.

*Bergeron, D.J. 1978b. Terrestrial wildlife survey P-M Mine area, Montana 1977-1978. Western Technology and Engineering, Inc. Helena, MT.

*Bergeron, D.J. 1979. Terrestrial wildlife survey, Coal Creek Mine area, Montana 1977-1978. Western Technology and Engineering, Inc. Helena, MT.

*BLM. 1982a. Bloomfield - North Fork baseline inventories - wildlife. Bureau of Land Management, Miles City District Office. Miles City, MT. 61 p.

*BLM. 1982b. Moorhead baseline inventory - wildlife. Bureau of Land Management, Miles City District Office. Miles City, MT. 29 p.

*Boundy, J. 2001. Herpetofaunal surveys in the Clark Fork Valley region, Montana. Herpetological Natural History 8: 15-26.

Brothers, D.R. 1994. Serpentes: Elaphe obsoleta (Ratsnake) reproduction. Herpetological Review 25(3): 124 p.

Brown, W.S. 1973. Ecology of the racer, Coluber constrictor mormon (serpentes, colubridae), in a cold temperate desert in northern Utah. Ph.D. Thesis, University Utah. 218 p. 
Brown, W.S. and W.S. Parker. 1974. Population structure and demography of the snake, Coluber constrictor, in Utah. American Zoology 14: 1294 p.

Brown, W.S. and W.S. Parker. 1976. Movement ecology of Coluber constrictor near communal hibernacula. Copeia 1976(2): 225-242.

Brown, W.S. and W.S. Parker. 1984. Growth, reproduction, and demography of the racer, Coluber constrictor mormon, in northern Utah. Pp. 13-40. In: R.A. Seigel (ed.)

Contributions to Vertebrate Ecology and Systematics: A tribute to Henry S. Fitch. Special Publication University of Kansas Museum of Natural History 10 p.

Brown, W.S., W.S. Parker, and J.A. Elder. 1974. Thermal and spatial relationships of two species of colubrid snakes during hibernation. Herpetologica 30(1): 32-38.

*Brunson, R.B. 1955. Check list of the amphibians and reptiles of Montana. Proceedings of the Montana Academy of Sciences 15: 27-29.

Burgdorf, S.J., D.C. Rudolph, R.N. Conner, D. Saenz, and R.R. Schaefer. 2005. A successful trap design for capturing large terrestrial snakes. Herpetological Review 36(4):421-424.

Burger, J. 1990. Effects of incubation temperature on behavior of young black racers (Coluber constrictor) and kingsnakes (Lampropeltis getulus). Journal of Herpetology 24(2): 158-163.

Burger, J., R.T. Zappalorti, and M. Gochfeld. 1999. Defensive behaviors of pine snakes (Pituophis melanoleucus) and black racers (Coluber constrictor) to disturbance during hibernation. Herpetological Natural History 7(1):59-66.

*Butts, T.W. 1997. Mountain Inc. wildlife monitoring Bull Mountains Mine No. 1, 1996. Western Technology and Engineering. Helena, MT.

Cale, W.G. and J.W. Gibbons. 1972. Relationships between body size, size of the fat bodies, and total lipid content of the canebrake rattlesnake (Crotalus horridus) and the black racer (Coluber constrictor. Herpetological 28(1): 51-53.

Campbell, C.A., D.W. Perrin, J.M. Macartney, B. Porchuk, F.R. Cook, and R.J. Brooks. 1991. Status report on the Racer, Coluber constrictor. Committee on the status of endangered wildlife in Canada (COSEWIC).

Cavitt, J.F. 2000. Fire and a tallgrass prairie reptile community: effects on relative abundance and seasonal activity. 34(1): 12-20.

Chiszar, D. and H.M. Smith. 1993c. Coluber constrictor flaviventris (eastern yellowbelly racer). Herpetological Review 24(4): 155 p.

Chiszar, D., J.D. Drew, and H.M. Smith. 1992. Coluber constrictor flaviventris (eastern yellowbelly racer). Herpetological Review 23(3): 90 p.

Church, D.R. and J.C. Mitchell. Coluber contrictor constrictor (nothern black racer). Winter activity. Herpetological Review 91(1):62-63.

Com, P.S. and R.B. Bury. 1986. Morphological variation and zoogeography of racers (Coluber constrictor) in the central Rocky Mountains. Herpetologica 42(2): 258-264.

Cook, D.G. and F.J. Aldridge. 1984. Coluber constrictor priapus (southern black racer). Food. Herpetological Review 15(2):49 p.

Cook, F.R. and C.G.V.Z. De Jong. 1975. Eastern yellow-bellied racer in central southern Saskatchewan. Canadian Field Naturalist 89: 174-175.

*Cooper, S.V., C. Jean, and P. Hendricks. 2001. Biological survey of a prairie landscape in Montana's glaciated plains. Report to the Bureau of Land Management. Montana Natural Heritage Program, Helena, MT. 24 p. plus appendices. 
Cooper, W.E., G.M. Gordon, and W.S. Brown. 2000. Behavioural responses by hatchling racers (Coluber constrictor) from two geographically distinct populations to chemical stimuli from potential prey and predeators. Amphibia-reptilia 21(1): 103 p.

*Cope, E.D. 1900. The crocodilians, lizards and snakes of North America. Report of the U.S. National Museum 1898: 153-1270.

Corn, P.S. and R.B. Bury. 1986. Morphological variation and zoogeography of racers (Coluber constrictor) in the Central Rocky Mountains. Herpetologica 42(2): 258-264.

*Coues, E. and H.C. Yarrow. 1878. Notes on the herpetology of Dakota and Montana. Bulletin of the U.S. Geologic and Geographic Survey 4(1): 259-291.

Creer, D.A. 2005. Correlations between ontogenetic change in color pattern and antipredator behavior in the racer, Coluber constrictor. Ethology 111(3):287-300.

*Day, D., P.J. Farmer, and C.E. Farmer. 1989. Montco terrestrial wildlife monitoring report December, 1987 - July, 1989. Montco, Billings, MT, and Western Technology and Engineering, Inc. Helena, MT.

Degenhardt, W.G., C.W. Painter, and A.H. Price. 1996. Amphibians and reptiles of New Mexico. Albuquerque, NM: University of New Mexico Press. 431 p.

Dodd C.K., Jr. 1993. Strategies for snake conservation. Pages 363-393. In: R.A. Seigel and J.T. Collins (eds). Snakes - ecology and behavior. New York, NY: McGraw-Hill. 414 p.

Dodd, C.K., Jr. and R. Franz. 1995. Seasonal abundance and habitat use of selected snakes trapped in xeric and mesic communities of north-central Florida. Bulletin of the Florida Museum of Natural History 38(1-9): 43-67.

*Dood, A.R. 1980. Terry Badlands nongame survey and inventory final report. Montana Department of Fish, Wildlife, and Parks and Bureau of Land Management, Helena, MT. 70 $\mathrm{p}$.

Dyer, W.G. 1994. Some helminths of the racer, Coluber constrictor, and the eastern hognose snake, Heterodon platirhinos, in southern Illinois. Transactions of the Illinois State Academy of Science 87(1-2): 43-45.

Dyer, W.G. and S.R. Ballard. 1989. Ochetosomatid digeneans from Illinois (USA) snakes. Transactions of the Illinois State Academy of Science 82(3-4): 159-162.

*[EI] Econ Incorporated. 1984. Terrestrial wildlife inventory for the Lame Jones and Ismay coal lease tracts. Econ Incorporated. Helena, MT.

Engeman, R.M., T.A. Scripps, and T.G. Bonzer. 1984. Coluber constrictor mormon (western yellow-belly racer). Behavior. Herpetological Review 15(4): 112 p.

*Ernst, C.H. and E.M. Ernst. 2003. Snakes of the United States and Canada. Washington D.C.: Smithsonian Books.

*Farmer, P. 1980. Terrestrial wildlife monitoring study, Pearl area, Montana June, 1978 - May, 1980. Western Technology and Engineering, Inc. Helena, MT.

*Farmer, P. and K. Burgess. 1983. Jardine area baseline terrestrial wildlife study May 15, 1981 - May 15, 1982. Western Technology and Engineering Inc. Helena, MT.

Finley, K.J. and M.A. Jasieniuk. 1978. The eastern yellow-bellied racer in canada. Blue Jay 36(2): 88-91.

Fitch, H.S. 1963. Natural history of the racer, coluber constrictor. University of Kansas Museum of Natural History Publication 15(8): 351-468.

Fitch, H.S. 2004. The effect of female size on number of eggs or young snakes. Journal of Kansas Herpetology 9:11-12. 
Fitch, H.S. 2005. Observations on wandering of juvenile snakes in northeastern Kansas. Journal of Kansas Herpetology 13:11-12.

*Fitch, H.S., W.S. Brown and W.S. Parker. 1981. Coluber mormon, a species distinct from Coluber constrictor. Transactions of the Kansas Academy of Sciences 84(4): 196-203.

Fleet, R.R., and F.W. Plapp, Jr. 1978. DDT residues in snakes decline since DDT ban. Bulletin of Environmental Contaminants and Toxicology. 19: 383-388.

Foley, G.W. 1971. Perennial communal nesting in the black racer (Coluber constrictor). Herpetological Review 3: 41 p.

*Franz, R. 1971. Notes on the distribution and ecology of the herpetofauna of northwestern Montana. Bulletin of the Maryland Herpetological Society 7: 1-10.

*Gates, M.T. 2005. Amphibian and reptile baseline survey: CX field study area. Report to Billings and Miles City Field Offices of Bureau of Land Management. Maxim Technologies, Billings, MT. 28pp + Appendices.

Geiger, R.A. and T.F. Winsor. 1977. 239pu contamination in snakes inhabiting the rocky flats plant site. Health Physiology 33(2): 145-148.

*Gildart, R.C. and J. Wassink. 1982. Montana wildlife. Montana Geographic Series. Number three. Montana Magazine, Inc. Helena, MT. 128 p.

Glidewell, J. 1974. Records of the snake Coluber constrictor (reptilia: colubridae) from New Mexico and the Chihuahuan desert of Texas. Southwestern Naturalist 19(2): 215-217.

Greene, H.W. 1984. Taxonomic status of the western racer (Coluber constrictor mormon). Journal of Herpetology 18(2):210-211.

Green, J.J. and V.A. Cobb. 2005. Coluber constrictor (Racer). Reproduction. Herpetological Review 36: $32 \mathrm{p}$.

Guillette, L.J., Jr. and W.P. Sullivan, 1983. Coluber constrictor flaviventris (eastern yellowbelly racer). Reproduction. Herpetological Review 14(1): 19 p.

Guyer, C. and M.S. Laska. 1996. Coluber (Masticophis) mentovarius (tropical racer). Predation. Herpetological Review. 27(4): 203 p.

Hammerson, G.A. 1987. Thermal biology of the snake Coluber constrictor in west-central California (USA). Journal of Thermal Biology 12(3): 195-198.

Hammerson, G.A. 1999. Amphibians and reptiles in Colorado. Niwot, CO: University Press of Colorado. $484 \mathrm{p}$.

Hammerson, G.A., L. Valentine, and L.J. Livo. 1991a. Coluber constrictor (racer). Herpetological Review 22(2): 67 p.

*Hart, M.M., W.A. Williams, P.C. Thornton, K.P. McLaughlin, C.M. Tobalske, B.A. Maxell, D.P. Hendricks, C.R. Peterson, and R.L. Redmond. 1998. Montana atlas of terrestrial vertebrates. Montana Cooperative Wildlife Research Unit, The University of Montana. Missoula, Montana vii +1302 p.

Hayes, M.P. 1985. Coluber constrictor priapus (southern black racer). Food. Herpetological Review 16(3): 78 p.

Hayrend, F.L. and A. Call. 1951. Growth and age in the western striped racer and great basin rattlesnake. Herpetologica 7: 28-40.

Hayslett, M.S. 1992. Field notes. Coluber constrictor constrictor (northern black racer). Catesbeiana 12(2): 46-47.

*Hendricks, P. 1999. Amphibian and reptile survey of the Bureau of Land Management Miles City District, Montana. Montana Natural Heritage Program, Helena, MT. 80 p. 
*Hendricks, P. and J.D. Reichel. 1996a. Amphibian and reptile survey of the Bitterroot National Forest: 1995. Montana Natural Heritage Program, Helena, MT. 95 p.

*Hendricks, P. and J.D. Reichel. 1996b. Preliminary amphibian and reptile survey of the Ashland District, Custer National Forest: 1995. Montana Natural Heritage Program, Helena, MT. 79 p.

*Hendricks, P. and J.D. Reichel. 1998. Amphibian and reptile survey on Montana refuges: 1996. Montana Natural Heritage Program, Helena, MT. 19 p.

Herrington, R.E. 1988. Talus use by amphibians and reptiles in the Pacific Northwest. Pages 216-221 in R.C. Szaro, K.E. Severson, and D.R. Patton, technical coordinators. Management of amphibians, reptiles, and small mammals in North America. General Technical Report RM-166. U.S. Forest Service, Rocky Mountain Forest and Range Experiment Station. Fort Collins, CO.

Herzog, H.A., Jr. and G.M. Burghardt. 1974. Prey movement and predatory behavior of juvenile western yellow-bellied racers, Coluber constrictor mormon. Herpetologica 30(3): 285-289.

Hirth, H.F., R.C. Pendleton, A.C. King, and T.R. Downard. 1969. Dispersal of snakes from a hibernaculum in northwestern Utah. Ecology 50: 332-339.

Hoberg, T. and C. Gause. 1989. Reptiles \& amphibians of North Dakota. North Dakota Outdoors 55(1):7-18.

Hobert, J., R. Dunoho, C. Montgomery, K. Waldron, and S.P. Mackessy. 1996. Coluber constrictor flaviventris (eastern yellowbelly racer). Herpetological Review 27(1): 33.

Holman, J.A. 1994. A "lower eocene colubrid-like" snake (reptilia: serpentes) from New Jersey is holocene. Journal of Vertebrate Paleontology 14(1): 132-133.

Hossack, B.R., P.S. Corn, and D.S. Pilliod. 2005. Lack of significant changes in the herpetofauna of Theodore Roosevelt National Park, North Dakota, since the 1920s. American Midland Naturalist 154:423-432.

*Hossack, B.R., D. Pilliod, and P.S. Corn. 2001. Reptile and amphibian inventory at GrantKohrs Ranch National Historic Site and Little Bighorn Battlefield National Monument. USGS Northern Rocky Mountain Science Center, Aldo Leopold Wilderness Research Institute, Missoula, MT. 6 p.

Hudson, R. and G. Carl. 1983. Coluber constrictor flaviventris (eastern yellowbelly racer). Coloration. Herpetological Review 14(1): 19p.

Iverson, J.B., H. Higgins, A.G. Sirulnik, and C.A. Young. 1995. Coluber constrictor flaviventris (eastern yellow-bellied racer). Nesting. Herpetological Review 26(3): 147-148.

Jayne, B.C. and J.D. Davis. 1991. Kinematics and performance capacity for the concertina locomotion of a snake (Coluber constrictor). Journal of Experimental Biology 156(0): 539556.

Kasprzak, W., W. Golec, and E. Hadas. 1989. Epizootics of reptilian Amoebiasis at the zoological gardens of Poznan (Poland); epidemiological and chemotaxonomic studies. Acta Protozoology 28(3-4): 285-291. 1989.

Keller, W.L. and E.J. Heske. 2000. Habitat use by three species of snakes at the middle fork fish and wildlife area, Illinois. Journal of Herpetology 34(4): 558-564.

Keller, W.L. and E.J. Heske. 2002. Coluber contrictor (racer). Reproduction. Herpetological Review 33(4):2002.

Keogh, J.S. and F.P. DeSerto. 1994. Temperature dependent defensive behavior in three species of North American colubrid snakes. Journal of Herpetology 28(2): 258-261. 
Klimstra, W.D. 1959. Foods of the racer, Coluber constrictor, in southern Illinois. Copeia 1959: 210-214.

Knight, A. and D.P. Mindell. 1994. On the phylogenetic relationship of Colubrinae, Elapidae, and Viperidae and the evolution of front-fanged venom systems in snakes. Copeia 1994(1): $1-9$.

Kreba, R. 1978. Observations of an eastern yellow-bellied racer in captivity. Blue Jay 36(2): 94-98.

Krivda, W. 1993. Road kills of migrating garter snakes at The Pas, Manitoba. Blue Jay. 51(4): 197-198.

Langley, W.M., H.W. Lipps, and J.F. Theis. 1989. Responses of Kansas motorists to snake models on a rural highway. Transactions of the Kansas Academy of Science. 92(1-2): 43-48.

Lemke, D.E. and E.L. Schneider. 1988. Distribution of the spotted racer (Coluber constrictor anthicus) in Arkansas. Southwestern Naturalist 33(4): 499-500.

Lillywhite, H.B. 1985b. Trailing movements and sexual behavior in Coluber constrictor. Journal of Herpetology 19(2): 306-308.

Livo, L.J. 1988. Distributional records of amphibians and reptiles from Colorado. Herpetological Review 19(3): 61 p.

Lopez, T..J. and L.R. Maxson. 1995. Mitochondrial DNA sequence variation and genetic differentiation among colubrine snakes (Reptilia: Colubridae: Colubrinae). Biochemical Systematics and Ecology 23(5): 487-505.

Lowichik, A. and R.G. Yaeger. 1987. Ecological aspects of snake Hemogregarine infections from two habitats in southeastern Louisiana. Journal of Parasitology 73(6): 1109-1115.

Lynch, W. 1978. Death-feigning in the eastern yellow-bellied racer. Blue Jay 36(2): 92-93. Madison, D.M. 1978. Behavioral and sociochemical susceptilbility of meadow voles (Microtus pennsylvanicus) to snake predators. American Midland Naturalist 100(1): 23-28.

*Manville, R.H. 1957. Amphibians and reptiles of Glacier National Park, Montana. Copeia 1957: 308-309.

*Marnell, L.F. 1997. Herpetofauna of Glacier National Park. Northwestern Naturalist 78: 17-33.

*Martin, P.R. 1980a. Terrestrial wildlife habitat inventory in southeastern Montana. Montana Department of Fish, Wildlife and Parks and Bureau of Land Management, Helena MT. 114 p.

*Martin, P.R. 1980b. Terrestrial wildlife inventory in selected coal areas of Montana. Montana Department of Fish, Wildlife and Parks and Bureau of Land Management, Helena, MT. 84 p.

*Martin, P.R., K. Dubois and H.B. Youmans. 1981. Terrestrial wildlife inventory in selected coal areas, Powder River resources area final report. Montana Department of Fish, Wildlife and Parks and Bureau of Land Management, Helena, MT. 288 p.

*Matthews, W.L. 1979. Wibaux-Beach wildlife baseline study - nongame species. Bureau of Land Management, Miles City, MT. 93 p.

*Matthews, W.L. 1980. Wildlife of Prairie County Terry study area. Bureau of Land Management, Miles City, MT. 52 p.

*Matthews, W.L. 1981. Broadus-Pumpkin Creek baseline inventory - wildlife. Bureau of Land Management, Miles City, MT. 83 p.

*Maxell, B.A. 2004a. Amphibian and aquatic reptile inventories conducted on and around the Bitterroot National Forest 2000-2003. Report to Region 1 Office of the U.S. Forest Service, Bitterroot National Forest, Montana Department of Fish, Wildlife, and Parks, and Biological Resources Division of the U.S. Geological Survey. Missoula, MT: Montana Cooperative Wildlife Research Unit and Wildlife Biology Program, University of Montana. 128 p. 
*Maxell, B.A. 2004b. Amphibian and aquatic reptile inventories conducted on and around the Thompson River 2003-2004. Report to Region 1 Office of the U.S. Forest Service and Plum Creek Timber Company. Missoula, MT: Montana Cooperative Wildlife Research Unit and Wildlife Biology Program. 83 p.

*Maxell, B.A. 2004c. Preliminary report on amphibian and aquatic reptile inventories conducted on and around the Ashland District of the Custer National Forest in 2002 and 2004. Report to Ashland District of Custer Forest, Region 1 Office of the U.S. Forest Service, and Montana Department of Fish, Wildlife, and Parks. Missoula, MT: Montana Cooperative Wildlife Research Unit and Wildlife Biology Program, University of Montana. $93 \mathrm{p.}$

*Maxell, B.A. 2004d. Report on amphibian and aquatic reptile inventories conducted on and around the Beaverhead-Deerlodge National Forest 2001-2003. Report to Region 1 Office of the U.S. Forest Service, Beaverhead-Deerlodge National Forest, Montana Department of Fish, Wildlife, and Parks, Montana State Office of the Bureau of Land Management, and Montana Department of Environmental Quality. Missoula, MT: Montana Cooperative Wildlife Research Unit and Wildlife Biology Program, University of Montana. 260 p.

*Maxell, B.A. 2005a. Amphibian and aquatic reptile inventories conducted on and around lands administered by the Missoula Field Office of the Bureau of Land Management. Report to Missoula Field Office of the Bureau of Land Management. Montana Natural Heritage Program, Helena, MT and Montana Cooperative Wildlife Research Unit and Wildlife Biology Program, University of Montana, Missoula, MT. 53 p.

*Maxell, B.A. 2009. State-wide assessment of status, predicted distribution, and landscapelevel habitat suitability of amphibians and reptiles in Montana. Ph.D. Dissertation. Missoula, MT: Wildlife Biology Program, University of Montana. 294 p.

*Maxell, B.A. and D.G. Hokit. 1999. Amphibians and reptiles. Pp. 2.1-2.30. In: G. Joslin and H. Youmans (committee chairs). Effects of recreation on Rocky Mountain wildlife: a compendium of the current state of understanding in Montana. Helena, MT: Committee on Effects of Recreation on Wildlife, Montana Chapter of the Wildlife Society. 307 p.

*Maxell, B.A., J.K. Werner, P. Hendricks, and D. Flath. 2003. Herpetology in Montana: a history, status summary, checklists, dichotomous keys, accounts for native, potentially native, and exotic species, and indexed bibliography. Olympia, WA: Society for Northwestern Vertebrate Biology. Northwest Fauna 5: 1-138.

*McEneaney, T. and J. Jensen. 1974. The reptiles and amphibians of the Charles M. Russell National Wildlife Range - 1974. Charles M. Russell National Wildlife Refuge. Lewistown, MT. 3 p.

Mcintosh, A.G.D. and P.T. Gregory. 1976. Predation on a bat by a western yellow- bellied racer. Canadian Field Naturalist 90(1): 73 p.

Meshake, W.E., Jr. and B. Ferster. 1995. Two species of snakes prey on Cuban treefrogs in southern Florida. Florida Field Naturalist 23(4): 97-98.

*Mosimann, J.E. and G.B. Rabb. 1952. The herpetology of Tiber Reservoir area, Montana. Copeia 1952: 23-27.

Nagle, R.D., R.C. van Loben Sels, and J.D. Congdon. 1995. Observations of agonistic and mutualistic interactions between birds and non-avian vertebrates on the E. S. George Reserve, Michigan. Canadian Field Naturalist 109(4): 464-466.

Noble, G.K. 1937. Sense organs involved in courtship of Storeria, Thamnophis and other snakes. Bulletin of the American Museum of National History 73: 673-725. 
Nolan, W.F. and H.M. Frankel. 1982. Effects of temperature on ventilation and acid-base status in the black racer snake, Coluber constrictor. Comparative Biochemistry and Physiology A 73(1): 57-61.

*[OEAR] Olson Elliot and Associates Research. 1985. 1983-1984 Wildlife monitoring report for the CX Ranch project. Olson Elliot and Associates Research. Helena, MT.

Olson, D.J. and R.E. Warner. 2003. Comparison of artificial cover and line transects for the capture of grassland snakes. Herpetological Review 34(3):215-218.

Ortenburger, A.I. 1928. Whipsnakes and racers. Genera Masticophis and Coluber. Memorial University of Michigan Museum 1: 1-214.

Packard, G.C. and M.J. Packard. 1987. Water relations and nitrogen excretion in embryos of the oviparous snake Coluber constrictor. Copeia 2: 395-406.

Packard, M.J., G.C. Packard, and W.H.N. Gutzke. 1984. Calcium metabolism in embryos of the oviparous snake Coluber constrictor. Journal of Experimental Biology 110: 99-112.

Perry, R.W., R.E. Brown, and D.C. Rudolph. 2001. Mutual mortality of great horned owl and southern black racer: a potential risk of raptors preying on snakes. Wilson Bulletin 113(3):345-347.

Plummer, M.V. and J.D. Congdon. 1992. Life history: Coluber constrictor (black racer). Predation. Herpetological Review 23(3): 80-81.

Plummer, M.V. and J.D. Congdon. 1994. Radiotelemetric study of activity and movements of racers (Coluber constrictor) associated with a Carolina Bay in South Carolina. Copeia 1994(1): 20-26.

Plummer, M.V. and J.D. Congdon. 1996. Rates of metabolism and water flux in free-ranging racers, Coluber constrictor. Copeia 1: 8-14.

Porchuk, B.D. and R.J. Brooks. 1995. Coluber constrictor (blue racer), Elaphe vulpina (eastern fox snake) and Chelydra serpentina (snapping turtle). Reproduction. Herpetological Review 26(3): 148 p.

Pregill, G.K. 1977. Axial myology of the racer (Coluber constrictor) with emphasis on the neck region. Transactions of the San Diego Society of Natural History 18(11): 185-206.

*[PRESI] Powder River Eagle Studies Incorporated. 1998a. Big Sky Mine 1997 wildlife monitoring studies. Powder River Eagle Studies Incorporated. Gillete, WY.

*[PRESI] Powder River Eagle Studies Incorporated. 1998b. Spring Creek Mine 1997 wildlife monitoring studies. Powder River Eagle Studies Incorporated. Gillete, WY.

Printiss, D.J. 1994. Coluber constrictor priapus (southern black racer). Prey. Herpetological Review 25(2): 70 p.

Prior, K.A., and P.J. Weatherhead. 1994. Response of free-ranging eastern Massasauga rattlesnakes to human disturbance. Journal of Herpetology. 28(2): 255-257.

*Rauscher, R.L. 1998. Amphibian and reptile survey on selected Montana Bureau of Reclamation impoundments. Montana Department of Fish, Wildlife and Parks, Nongame Program, Bozeman, MT. 24 p.

*Reichel, J.D. 1995a. Preliminary amphibian and reptile survey of the Lewis and Clark National Forest: 1994. Montana Natural Heritage Program, Helena, MT. 92 p.

*Reichel, J.D. 1995b. Preliminary amphibian and reptile survey of the Sioux District of the Custer National Forest: 1994. Montana Natural Heritage Program, Helena, MT. 75 p.

*Reichel, J.D. 1996b. Preliminary amphibian and reptile survey of the Helena National Forest: 1995. Montana Natural Heritage Program, Helena, MT. 87 p. 
*Reichel, J.D. 1997. Amphibian, reptile and northern bog lemming survey on the Rocky Mountain Front: 1996. Montana Natural Heritage Program, Helena, MT. 81 p.

Resetar, Alan. 1988. Distribution and Ecology of Amphibians and Reptiles in Selected Areas of Lake, Porter, Laporte and Newton Counties, Indiana with Special Emphasis on State-Listed Species. Prepared for Indiana Department of Natural Resources Nongame and Endangered Wildlife Program. 109 p.

Robinson, J.M. III, R.S. Brodey, and J.M. Robinson, Jr. 1974. Winter records of garter and black snakes. Bulletin of the Philadelphia Herpetological Society 22: 33-34.

*Rodgers, T.L., and W.L. Jellison. 1942. A collection of amphibians and reptiles from western Montana. Copeia 1942(1): 10-13.

*Roedel, M.D. and P. Hendricks. 1998a. Amphibian and reptile survey on the Bureau of Land Management Lewistown District: 1995-1998. Montana Natural Heritage Program, Helena, MT. 53 p.

*Roedel, M.D. and P. Hendricks. 1998b. Amphibian and reptile inventory on the Headwaters and Dillon Resource Areas in conjunction with Red Rocks Lakes National Wildlife Refuge: 19961998. Montana Natural Heritage Program, Helena, MT. 46 p.

Roh, B.R. 1994b. Coluber constrictor flaviventris (eastern yellowbelly racer). Herpetological Review 25(4): 166 p.

Rosen, P.C. 1989. Coluber constrictor paludicola (Everglades racer). Foraging. Herpetologial Review 20(3): 71 p.

Rosen, P.C. 1991. Comparative ecology and life history of the racer (Coluber constrictor) in Michigan. Copeia 1991:897-909.

Rosen, P.C., and C.H. Lowe. 1994. Highway mortality of snakes in the Sonoran desert of southern Arizona. Biological Conservation. 68: 143-148.

Roth, J.J. and D. Chiszar. 1992. Coluber constrictor mormon (western yellowbelly racer). Herpetological Review 23(3): 90-91.

Russell, A.P., and A.M. Bauer. 2000. The amphibians and reptiles of Alberta. Second Edition. Calgary, AB: University of Calgary Press. 279 p.

Schatti, B. 1987. The phylogenetic significance of morphological characters in the holarctic racers of the genus Coluber Linnaeus, 1758 (Reptilia, Serpentes). Amphibia-Reptilia 8(4): 401-416.

Schatti, B. and L.D. Wilson. 1986. Coluber. Catalogue of American Amphibians and Reptiles 399.1-399.4.

Schonberger, C.F. 1945. Food of some amphibians and reptiles of Oregon and Washington. Copeia 1945: 120-121.

Schwab, D. 1985. Field notes: Coluber constrictor constrictor (northern black racer): Sussex County, Virginia, Co. Rt. 604, 1 km S of US 460 and 5 km west of Wakefield. 7 June 1985. Catesbeiana 5(2): 15 p.

Schwab, D. 1988b. Field notes Coluber constrictor constrictor (northern black racer). Catesbeiana 8(2): $32 \mathrm{p}$.

Sexton, O.J. and S.R. Hunt. 1980. Temperature relationships and movements of snakes (Elaphe obsoleta, Coluber constrictor) in a cave hibernaculum. Herpetologica 36(1): 20-26.

Smith, H.M. 1971. Distribution of the racer Coluber constrictor in Mexico. Journal of Herpetology 5: 212-214.

Smith, H.M., C.E. Bock, and J.H. Bock. 1993. Coluber constrictor flaviventris (eastern yellowbelly racer). Herpetological Review 24(4): 155 p. 
Smith, L.L., R. Franz, and C.K. Dodd, Jr. 1993. Additions to the herpetofauna of Egmont Key, Hillsborough County, Florida. Florida Scientist 56(4): 231-234.

Somers, P.H., L.J. Livo, R.R.J. Smith, D. Chiszar, and H.M. Smith. 1995. Coluber constrictor mormon (Western yellowbelly racer). Herpetological Review 26(3): 156 p.

Sperger, R.H., R. Humphrey, D. Chiszar, and H.M. Smith. 1995c. Coluber constrictor flaviventris (eastern yellowbelly racer). Herpetological Review 26(1): 46 p.

*St. John, A. 2002. Reptiles of the Northwest: California to Alaska; Rockies to the Coast. Renton, WA: Lone Pine Publishing. 272 p.

Stafford, D.P., F.W. Plapp, Jr., and R.R. Fleet. 1976. Snakes as indicators of environmental contamination: relation of detoxifying enzymes and pesticide residues to species occurrence in three aquatic ecosystems. Archives of Environmental Contamination and Toxicology. 5: 15-27.

*Stebbins, R.C. 2003. A field guide to western reptiles and amphibians. 3rd edition. New York, NY: Houghton Mifflin Co. 533 p.

Stinner, J.N. 1987a. Cardiovascular and metabolic responses to temperature in Coluber constrictor. American Journal of Physiology 253: 222-227.

Stinner, J.N. and D.L. Ely. 1993. Blood pressure during routine activity, stress, and feeding in black racer snakes (Coluber constrictor). American Journal of Physiology 264: R79-R84.

Stinner, J.N. and R.L. Wardle. 1988. Effect of temperature upon carbon dioxide stores in the snake Coluber constrictor and the turtle Chrysemys scripta. Journal of Experimental Biology 137(0): 529-548.

Stinner, J.N., M.R. Grguric, and S.L. Beaty. 1996. Ventilatory and blood acid-base adjustments to a decrease in body temperature from 30 to 10 degree $C$ in black racer snakes Coluber constrictor. Journal of Experimental Biology 199(4): 815-823.

Stovall, R.H. 1976. Observations on the micro- and ultrastructure of the visual cells of certain snakes (Reptilia, Serpentes, Colubridae). Journal of Herpetology 10(4): 269-275.

Stuart, J.N. 1992. Coluber constrictor (racer). Herpetological Review 23(3): 90 p.

Stuart, J.N., M.L. Watson, T.L. Brown, and C. Eustice. 2001. Plastic netting: an entanglement hazard to snakes and other wildlife. Herpetological Review. 32(3): 162-164.

Stuart, L.C. 1930. An extension of the range of Coluber constrictor mormon (Baird and Girard). Copeia 1930: 44 p.

Swain, T.A. and H.M. Smith. 1977. Communal nesting in the blue racer in Colorado (Reptilia: Serpentes). Journal of the Colorado-Wyoming Academy of Science 9(1): 45 p.

Swain, T.A. and H.M. Smith. 1978. Communal nesting in Coluber constrictor in Colorado (Reptilia: Serpentes). Herpetologica 34(2): 175-177.

Taggart, T.W. and C. Schmidt. 2002. Geographic distribution. Coluber constrictor. Journal of Kansas Herpetology 2:10 p.

*Thompson, L.S. and P.S. Nichols. 1982. Circle West wildlife monitoring study; fourth annual report for period March 1, 1981 - May 31, 1982. Circle West Technical Report No. 10. Montana Department of Natural Resources and Conservation, Helena, MT.

*Timken, R. No Date. Amphibians and reptiles of the Beaverhead National Forest. Western Montana College, Dillon, MT. 16 p.

Tobey, F.J. 1989b. Coluber constrictor constrictor (northern black racer). Catesbeiana 9(2): 35 p.

Tucker, J.K. and G.L. Paukstis. 1995. Coluber constrictor foxii (blue racer). Herpetological Review 26(1): 46 p. 
Tumlison, R. and J. Gann. 1988. Distribution of the spotted racer (Coluber constrictor anthicus) in Arkansas. Southwestern Naturalist 33(4): 500-501.

Upton, S.J., C.T. McAllister, and S.E. Trauth. 1994. Caryospora masticophis n. sp. (Apicomplexa) from Masticophis flagellum and Coluber constrictor (Serpentes) in Arkansas, U.S.A. Transactions of the American Microscopical Society 113(3): 395-399.

Van Devender, R.W. and P.F. Nicoletto. 1983. Lower Wilson Creek, Caldwell County, North Carolina (USA): A thermal refugium for reptiles? Brimleyana 0(9): 21-32.

Vann, S., H. Hedden, A. Jones, and K. Fox. 2005. Coluber constrictor constrictor (Northern Black Racer). Behavior. Herpetological Review 36: 322 p.

Visher, S.S. 1914. A preliminary report of the biology of Harding County, northwestern South Dakota. South Dakota Geological Survey Bulletin No. 6. State Publishing Co., Pierre, SD. 126 p.

Vitt, L.J. 1974. Body temperatures of high latitude reptiles. Copeia 1974(1): 255-256.

*Vitt, L.J., J.P. Caldwell, and D.B. Shepard. 2005. Inventory of amphibians and reptiles in the Billings Field Office Region, Montana. Sam Noble Oklahoma Museum of Natural History and Department of Zoology, University of Oklahoma, Norman, OK. 33 p.

*[VTNWI] VTN Wyoming Incorporated. No Date. Second year's analysis of terrestrial wildlife on proposed mine access and railroad routes in southern Montana and northern Wyoming, March 1979 - February 1980. VTN Wyoming Incorporated. Sheridan, WY. 62 p.

*Waage, B.C. 1998. Western Energy Company Rosebud Mine 1997 annual wildlife monitoring report December 1, 1996 to November 30, 1997 survey period. Western Energy Company, Colstrip, MT.

Walton, B.M., B.C. Jayne, and A.F. Bennett. 1989. The cost of locomotion in the snake, Coluber constrictor. American Zoologists 29(4): 22A.

Walton, M., B.C. Jayne, and A.F. Bennett. 1990. The energetic cost of limbless locomotion. Science 249(4968): 524-527.

Webb, R.G. 2001. Proposed deletion of two colubrid snakes from the Mexican state of Durango herpetofauna. Herpetological Review 32: 159-160.

Weir, J. 1992. The Sweetwater rattlesnake round-up: A case study in environmental ethics. Conservation Biology. 6: 116-127.

*Werner, J.K., B.A. Maxell, P. Hendricks, and D. Flath. 2004. Amphibians and reptiles of Montana. Missoula, MT: Mountain Press Publishing Company. 262p.

*Werner, J.K. and J.D. Reichel. 1994. Amphibian and reptile survey of the Kootenai National Forest: 1994. Montana Natural Heritage Program, Helena, MT. 104 p.

*Werner, J.K. and J.D. Reichel. 1996. Amphibian and reptile monitoring/survey of the Kootenai National Forest: 1995. Montana Natural Heritage Program, Helena, MT. 115 p.

*Werner, J.K. and T. Plummer. 1994. Amphibian and reptile survey of the Flathead Indian Reservation 1993-1994. Salish Kootenai College, Pablo, MT. 55 p.

*Werner, J.K. and T. Plummer. 1995. Amphibian monitoring program on the Flathead Indian Reservation 1995. Salish Kootenai College, Pablo, MT. 46 p.

*Werner, J.K., T. Plummer, and J. Weaselhead. 1998a. Amphibians and reptiles of the Flathead Indian Reservation. Intermountain Journal of Sciences 4(1-2): 33-49.

*[WESCO] Western Ecological Services Company. 1983a. Wildlife inventory of the Knowlton known recoverable coal resource area, Montana. Western Ecological Services Company, Novato, CA. 107 p. 
*[WESCO] Western Ecological Services Company. 1983b. Wildlife inventory of the Southwest Circle known recoverable coal resource area, Montana. Western Ecological Services Company, Novato, CA. 131 p.

*[WESTECH] Western Technology and Engineering Incorporated. 1991. Update on the wildlife resources of the Little Rocky Mountains environmental study area. Western Technology and Engineering, Inc., Helena, MT.

*[WESTECH] Western Technology and Engineering Incorporated. 1998. Wildlife monitoring Absaloka Mine area 1997. Western Technology and Engineering, Inc., Helena, MT.

*Wied, M.P. 1865. Verzeichniss der reptilien, welche auf einer reise in nordlichen America beobachtet wurden, von Maximilian, Prinzen zu Wied. Eigengangen bei der Akademie am 1, Juni 1865. Druck von E. Blochmann und Sohn, Dresden, Germany. 141 p.

Wilson, L.D. 1970. The racer Coluber constrictor (Serpentes: Colubridae) in Louisiana and eastern Texas. Texas Journal of Science 22: 67-85.

*Wilson, L.D. 1978. Coluber constrictor. Catalogue of American Amphibians and Reptiles 218.1-218.4.

Withgott, J.H. 1996. Post-prandial chemosensory searching in black rat snakes. Animal Behaviour 52(4): 775-781.

Wozniak, E.J. and S.R. Telford, Jr. 1991. The fate of Hepatozoon species naturally infecting Florida black racers and watersnakes in potential mosquito and soft tick vectors, and histological evidence of pathogenicity in unnatural host species. International Journal For Parasitology 21(5): 511-516.

Wozniak, E.J. and S.R. Telford. 1990. The fate of reptilian hepatozoon sp. in potential mosquito and soft tick vectors and experimentally infected lizard hosts. American Society of Parasitologists Annual Meeting Program Abstracts 65: 65 p.

Wright, A.S. 1987. Coluber constrictor, the black racer. Welch, K.R. Handbook on the maintenance of reptiles in captivity. Robert E. Kreiger, Florida. 1987: i-v, 1-156. Chapter pagination: 55-56.

Wright, R.A.S. 1988. Field notes: Coluber constrictor constrictor (black racer): Buckingham County, U.S. Rt. 60, 1.7mi. E of Mt. Rush, Virginia. 3 July 1986. Catesbeiana 8(1): 15 p. 


\section{Western Hog-nosed Snake (Heterodon nasicus)}

Up-to-date distribution and status information can be found on the Montana Natural Heritage Program’s TRACKER website at http://mtnhp.org

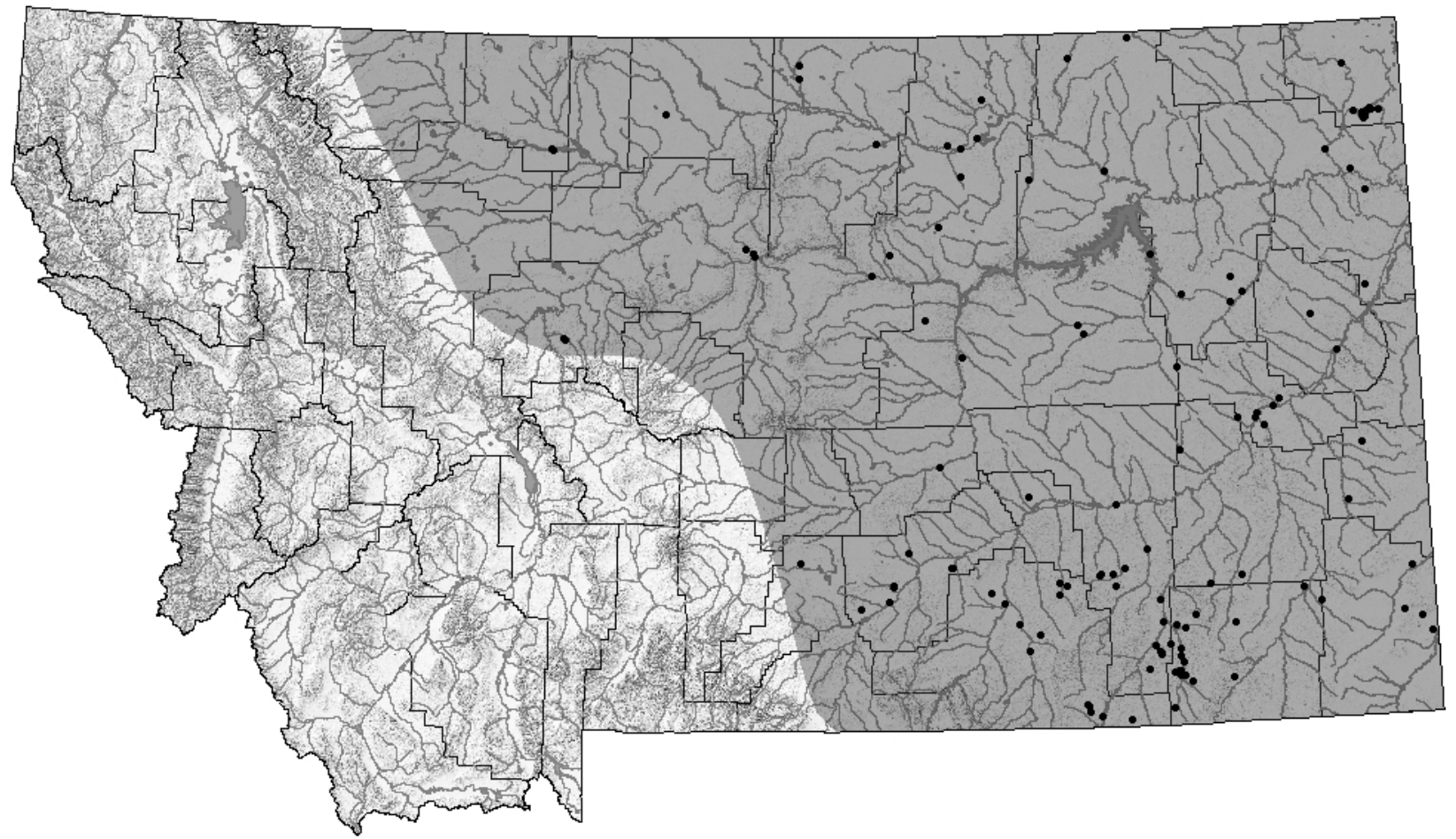

Distribution/Taxonomy

The Western Hog-nosed Snake is primarily found in the northern Great Plains, ranging from southern Alberta southward along to northeastern New Mexico and northern Oklahoma, and northeasterly to Illinois, Wisconsin, and northwestern Indiana, and northwesterly to southern Manitoba (Ernst and Ernst 2003). Of the three subspecies of Western Hog-nosed Snake found in North America the subspecies that occurs in Montana is Heterodon nasicus nasicus. The remaining two subspecies occur well to the south of Montana from southwestern New Mexico south into Mexico and in Missouri. H. n. nasicus is distributed primarily along the major river corridors in the Great Plains region of eastern and north-central Montana (Werner et al. 2004). In Montana, there are about 58 records from 28 counties east of the Continental Divide.

Maximum Elevation

1,286 m (4220 ft) in Cascade County (Gerald Painter, pers. com., MTNHP 2007).

\section{Identification}

\section{Juveniles and Adults:}

The Western Hog-nosed Snake is a stout, heavy bodied species with a snout that is upturned much like a digging spade or trowel. The dorsal scales are keeled with 23 or fewer rows of dorsal scales at midbody (Hammerson 1999). The underside of the tail is primarily black and the prefrontal scales are separated by small scales. Total length for males in Kansas averages $55 \mathrm{~cm}$ and $65 \mathrm{~cm}$ for females. Maximum TL is $154 \mathrm{~cm}$ (Ernst and Ernst 2003). Males typically have 35 or more grayish brown, deep cinnamon, or chocolate brown blotches along mid dorsal line between head and vent while females may have greater than 40 blotches (Walley and Eckerman 1999, Hammerson 1999). The anal plate and subcaudals are divided, while ventrals range from 129-147 
in males and 139-156 in females (Walley and Eckerman 1999).

Neonates:

Hatchlings are resemble adults in pattern but are generally brighter in color. They measure 14-20 cm total body length (Ernst and Ernst (2003).

Eggs:

Eggs are primarily not adherent, white, and smooth and between 26-38 mm long and 14-23 mm wide (Platt 1969, Iverson 1995 in Hammerson). Eggs are typically deposited in July in a shallow excavation.

Similar Species:

The Prairie Rattlesnake (Crotalus viridis) and the Gophersnake (Pituophis catenifer) have a similar banded or blotched body pattern. However, $H$. nasicus has a unique and distinctive upturned snout and lacks a rattle.

Habitat Use/Natural History

The Western Hog-nosed Snake prefers plains and savannahs with well drained sandy or gravelly soil where it can easily burrow or dig out prey. Populations throughout the species range appear to be highly correlated with coarse alluvial and marine soils/deposits (Eckerman 1996). Where soils are appropriate $H$. nasicus can also be found in semi-agricultural areas. However, areas of intensive cropping may reduce habitat availability (Hammerson 1999). While specific habitat use in Montana has been little studied, it appears that preferred habitat in Montana likely includes sandy alluvial beds and river banks as well as loose soil below sandstone outcrops (Werner et al. 2004). Documented occurrences and predicted range of $H$. nasicus in Montana indicate this species preference for alluvial river systems and their tributaries (Werner et al. 2004). The annual activity period for Western Hog-nosed Snake is typically between late April/early May and October. H. nasicus is diurnal, being active primarily in the morning and evening, and retreating to temporary burrows dug in loose soil with its snout at night (Platt 1969). Werner et al (2004) suggests that dispersal range in Montana is 200 yards or less per day. Studies in Kansas found a movement of 408 meters in 17 days for a male during the breeding season (Platt 1969). Emergence from hibernation typically occurs in April/May with males often wandering widely to seek out sedentary females by following scent trails (Ernst and Ernst 2003). Mating generally occurs in May. However, some mating may occur late in the year and females have been found to store sperm over winter from fall matings (Ernst and Ernst 2003). Courtship behavior has not been described. Eggs are laid in shallow (to $10 \mathrm{~cm}$ ) nests excavated in loose or sandy soil in July, with clutches containing 2 to as many as 24 eggs (Ernst and Ernst 2003). Hatching occurs from midAugust to mid -September with an estimated full incubation period of 30-60 days. H. nasicus does not hibernate communally and by October individuals dig burrows below the frostline in sandy or course soil and enter hibernation until the following spring (Ernst and Ernst 2003). Males reach sexual maturity between 2-3 years while females reach maturity between 3-4 years (Hammerson 1999). Platt (1969) concluded that juveniles constitute the bulk of the population and that only about 30 percent of a Kansas population was four years or older. Maximum life expectancy in the wild appears to be approximately 8 years (Platt 1969). Population data for this species appear to be meager. However, in a study in Kansas, Platt (1969) found in two populations as 57 and 121 snakes, with densities of 2.8 and 6.0/ha, respectively. H. nasicus primarily uses 
sight and scent to detect prey (Ernst and Ernst 2003). Buried prey is excavated with the upturned snout, while above ground prey are seized with wide open mouth. Like other Heterodon species, $H$. nasicus consumes a relatively large percentage of amphibians. However, $H$. nasicus relies less on amphibians than other species in this genus. Amphibian prey includes those in the genera Bufo, Spea, and Scaphiopus. Heterodon spp. are adapted to eating toads using their large mouths, mobile maxillae, and elongated posterior maxillary teeth that hold and deflate inflated toads (Kroll 1976). Other food items include bird eggs, small mammals, and invertebrates (Ernst and Ernst 2003). H. nasicus also contain slightly toxic saliva secretions, which have caused mild envenomations in some humans (McAlister 1963, Kapus 1964, Grogan 1974, Morris 1985). Predators include hawks, crows, and coyotes. Hog-nosed snakes are well known for their "death feigning" defensive behavior where they vomit, exudes feces, rolls over on its back, and extends its tongue from its mouth (Gehlbach 1970, Kroll 1977) Individual defensive behaviors vary among individuals. Prior to death-feigning, they will often inflate their body, spread their necks, hiss, and pretend to strike. However, they almost never bite (Degenhardt et al. 1996).

\section{$\underline{\text { Status and Conservation }}$}

Western Hog-nosed Snakes appear to be sparsely distributed in the Great Plains region of eastern and north central Montana. In addition, documented occurrences of the species in the state have declined in recent years, and the status of H. nasicus in Montana is uncertain (Werner et. al 2004). $H$. nasicus is currently listed as a species of special concern in Montana. However, it is unclear if this is simply due to a lack of intensive surveys and secretive nature of the species, 2) limited and/or patchy distribution of suitable habitat and appropriate soils, or 3) an actual decline in this species abundance in Montana. The fact that this species does not typically reach sexual maturity until their third or fourth year may potentially contribute to naturally low population numbers. Risk factors relevant to the viability of populations of this species are likely to include conversion to intensive agriculture, amphibian prey declines, habitat loss/fragmentation, road and trail development, overgrazing, and use of pesticides and herbicides. However, perhaps the greatest risk to maintaining viable populations in Montana is the lack of baseline data on its distribution, status, and habitat use. These data are needed to monitor trends and recognize dramatic declines when and where they occur within Montana. Over its range, $H$. nasicus has apparently decreased in numbers and is now protected in several states (Ernst and Ernst 2003). Studies identifying or addressing specific risk factors for $H$. nasicus are lacking. However, documented studies and other issues pertaining to their conservation include the following: (1) Roads often have negative impacts on population size and distribution of snakes and other reptiles. High road density has been positively correlated to low population size, and restriction to roadless areas, which can lead to local extirpations (Rudolph et al. 1998, Jochimsen et al. 2004). While this has not been studied directly on $\mathrm{H}$. nasicus in Montana, populations are probably affected in areas of high road density. A high percentage of observation records in Montana and Alberta are road-killed individuals (MTNHP 2007). Similarly, a large numbers of road-killed specimens have been observed in Alberta. Their tendency to bask on roads in morning hours makes them particularly vulnerable. However, their small home ranges and nonmigratory habits make this less of a risk for populations in roadless areas (Wright and Didiuk 1998). (2) Little data exists on the effects of agricultural activities on $H$. nasicus. However, agricultural activities generally have significant negative impacts on snake habitat (Russell and Bauer 2000). Much of Montana's native prairie is now under cultivation, with 5,589,905 hectares classified as agricultural lands in 1997 (Redmond et al. 1998). Furthermore, a fairly recent increasing trend in cropland conversion is evident with 1.2 
million acres of native prairie were converted to cropland between 1982-1997, much of which is located in within the natural range of $H$. nasicus. Wright and Didiuk (1998) suggest that in Alberta agricultural activities constitute the greatest risk factor to $H$. nasicus populations by destroying habitat which creates barriers to dispersal, by direct killing during plowing and harvesting activities, and by ingestion of pesticides and herbicides. (3) (Wright and Didiuk 1998) suggest that oil and gas development in Alberta may pose a threat via road-building, high traffic, and creation of long trenches which are known to trap other snake species. Coal Bed Methane Development may also pose similar threats via increased road development and traffic associated with development (Jochimsen et al. 2004). (4) There is evidence that the Western Toad (Bufo boreas) and the Northern Leopard Frog (Rana pipiens) have experienced declines in western Montana, primarily from infections of chytrid fungus (Batrachochytrium dendrobatidis) (Maxell 2000). If significant amphibian declines occur in eastern Montana from the similar pathogens or other causes, it could pose an indirect threat (Wootton 1994) to H. nasicus populations by limiting a primary food source. (5) Western Hog-nosed snakes are often mistaken for rattlesnakes and intentionally killed due to their intimidating appearance and defensive behavior. Ranchers and farmers erroneously call this species the "puff adder" in many parts of their range and consider them dangerous. (Dgenhardt et al 1996, Wright and Didiuk 1998).

\section{Research and Management Suggestions}

1. Documented occurrences of H. nasicus in Montana are relatively few between 1990 and 2000 (Maxell et al. 2003). It is unclear if this is due to a decline in abundance in the state, or lack of intensive surveys and secretive nature of the species.

2. More intensive surveys for this species in suitable habitat throughout its predicted range are recommended.Concurrent monitoring of $H$. nasicus and local prey populations, such as Bufo woodhousii, Pseudacris maculata, and Rana pipiens may be useful for evaluating the effects of potential future amphibian declines.

3. Practical methods for evaluating the impact of conversion of habitat to agricultural activities should be explored. Questions to be addressed include determining the percentage of the landscape that needs to remain in native vegetation for populations to remain viable.

4. Systematic baseline surveys and long-term monitoring should be conducted in known populations that occur within Montana's cold bed methane development areas to assess potential impacts from road development and habitat fragmentation as well as possible indirect effects to prey populations.

5. Studies of habitat use and population dynamics are needed, especially as they relate to livestock grazing, logging, sagebrush and juniper encroachment, and agricultural practices, to identify species responses to these habitat perturbations and develop effective measures for mitigation of negative impacts.

6. The role of insecticides and herbicides in pest control programs of areas occupied by Western Hog-nosed Snake needs to be determined, as use of these chemicals could severely impact snake populations by eliminating a significant portion of their prey, directly or indirectly. Monitoring of $H$. nasicus populations in areas already impacted by exotic weeds is also very desirable.

7. To avoid direct persecution by humans, the correct identification and harmless nature of this species should be emphasized by biologists and land managers while disseminating information to the general public through public outreach activities. 
Bibliography *indicates an article with information specific to Montana

Alberta Environmental Protection. 1996. The status of Alberta wildlife. Natural Resources Service, Wildlife Management Division. 44 pp.

*Allen, J.A. 1874. Notes on the natural history of portions of Dakota and Montana Territories, being the substance of a report to the Secretary of War on the collections made by the North Pacific Railroad Expedition of 1873, General D.S. Stanley, Commander. Proceedings of the Boston Society of Natural History 17: 33-85. Pages 68-70.

Allen, R. 1994. A profile of the western hognose snake (Heterodon nasicus). Rephiberary 199: 9-10.

Bakker, J. 1997. Striking nest behaviour of Heterodon nasicus nasicus. Litteratura Serpentium English Edition 17(1):10-11.

Baxter, G.T., and M.D. Stone. 1985. Amphibians and reptiles of Wyoming. 2nd ed. Wyoming Game and Fish Department, Cheyenne.

Blake, P. 1993. Success with odour manipulation and western hognose snakes, Heterodon nasicus nasicus. Herptile 18(2): 60-61.

*BLM. 1982b. Moorhead baseline inventory - wildlife. Bureau of Land Management, Miles City District Office. Miles City, MT. 29 pp.

Bonnet, X., G. Naulleau, and R. Shrine. 1999. The dangers of leaving home: Dispersal and mortality in snakes. Biological Conservation 89: 39-50.

Braddell, D.L. 1984. A western record for the plains hognose snake in Manitoba. Blue Jay 42(4): 196 p.

Bragg, A.N. 1960. Is Heterodon venomous? Herpetologica 16(2): 121-123.

Brant, R. 1993a. A failed attempt to breed the western hog-nose snake, Heterodon nasicus nasicus. Herptile 18(2): 62-64.

Brant, R. 1993b. Successful breeding of the western hog-nosed snake, Heterodon nasicus nasicus. A case of double clutching. Herptile 18(3): 130-132.

Brown, C., C. Foster, J. Spivey-White, and J. Hesletine. 2003. Feeding behaviour in monitor lizards and snakes; does direction of prey ingestion influence prey handling? Herpetological Bulletin 83:26-29.

*Brunson, R.B. 1955. Check list of the amphibians and reptiles of Montana. Proceedings of the Montana Academy of Sciences 15: 27-29.

Burghardt, G.M. and H.W. Greene. 1988. Predator simulation and duration of death feigning in neonate hognose snakes. Animal Behaviour 36: 1842-1843.

*Burroughs, R.D. 1961. The natural history of the Lewis and Clark expedition. Michigan State University Press. 340 p.

Censky, E.J. and C.J. McCoy. 1985. Geographic distribution. Heterodon nasicus nasicus (Plains hognose snake). Herpetological Review 16(2): 60 p.

Cobb, V.A. and L.M. Cobb. 1991. New county records for amphibians and reptiles of east Texas. Herpetological Review 22(1): 27-28.

Collins, J.T. 1982. Amphibians and reptiles in Kansas. University of Kansas, Lawrence.

*Conant, R. and J.T. Collins. 1998. A field guide to reptiles and amphibians of eastern and central North America. $3^{\text {rd }}$ edition, expanded. New York, NY: Houghton Mifflin Co. 616 p.

*Cooper, S.V., C. Jean, and P. Hendricks. 2001. Biological survey of a prairie landscape in Montana's glaciated plains. Report to the Bureau of Land Management. Montana Natural Heritage Program, Helena, MT. 24 pp. plus appendices. 
*Cope, E.D. 1875. Check-list of North American Batrachia and Reptilia; with a systematic list of the higher groups, and an essay on geographical distribution. U.S. National Museum Bulletin 1(1): $1-104$.

*Cope, E.D. 1879. A contribution to the zoology of Montana. American Naturalist 13(7): 432441.

*Coues, E. and H.C. Yarrow. 1878. Notes on the herpetology of Dakota and Montana. Bulletin of the U.S. Geologic and Geographic Survey 4(1): 259-291.

Degenhardt, W.G., C.W. Painter, and A.H. Price. 1996. Amphibians and reptiles of New Mexico. Albuquerque, NM: University of New Mexico Press. 431 p.

Dodd, C.K., Jr. 1987. Status, conservation, and management. Pp. 478-513. In: R.A. Seigel, J.T. Collins and S.S. Novak (eds). Snakes: ecology and evolutionary biology. New York, NY: McMillan.

*Dood, A.R. 1980. Terry Badlands nongame survey and inventory final report. Montana Department of Fish, Wildlife, and Parks and Bureau of Land Management, Helena, MT. 70 p.

Edgren, R.A. 1952. A synopsis of the snakes of the genus Heterodon, with the diagnosis of a new race of Heterodon nasicus Baird and girard. Natural History Miscellanea 112: 1-4.

Edgren, Richard A. 1955. The natural history of the hognosed snakes, genus Heterodon: a review. Herpetologica 11: 105-117.

*[EI] Econ Incorporated. 1984. Terrestrial wildlife inventory for the Lame Jones and Ismay coal lease tracts. Econ Incorporated. Helena, MT.

*Ernst, C.H. and E.M. Ernst. 2003. Snakes of the United States and Canada. Washington D.C.: Smithsonian Books.

*Flath, D.L. 1998. Species of special interest or concern. Montana Department of Fish, Widlife and Parks, Helena, MT. March, 1998. 7 p.

Fuller, S.R. 1981. A case of envenomation by a western hognose snake, Heterodon n. nasicus. Northern Ohio Association of Herpetological Notes 9(1): 11 p.

*Gates, M.T. 2005. Amphibian and reptile baseline survey: CX field study area. Report to Billings and Miles City Field Offices of Bureau of Land Management. Maxim Technologies, Billings, MT. 28pp + Appendices.

Gehlbach, F.R. 1970. Death-feigning and erratic behavior in leptotyphlopid, colubrid, and elapid snakes. Herpetologica 26: 24-34.

*Gildart, R.C. and J. Wassink. 1982. Montana wildlife. Montana Geographic Series. Number three. Montana Magazine, Inc. Helena, MT. 128 p.

Goldberg, S.R. 2004. Reproduction in the western hognose snake, Heterodon nasicus (Serpentes: Colubridae) from the southwestern part of its range. Texas Journal of Science 56(3): 267-273.

Grogan, W.L., Jr. 1974. Effects of accidental envenomation from the saliva of the eastern hognose snake, Heterodon platyrhinos. Herpetologica 30: 248-249.

Hammack, S.H. 1991. Heterodon nasicus kennerlyi (mexican hognose snake). Oophagy. Herpetological Review 22(4): $132 \mathrm{p}$.

Hammerson, G.A., 1999. Amphibians and Reptiles in Colorado. University Press of Colorado and Colorado Division of Wildlife, Niwot, Colorado.

*Hart, M.M., W.A. Williams, P.C. Thornton, K.P. McLaughlin, C.M. Tobalske, B.A. Maxell, D.P. Hendricks, C.R. Peterson, and R.L. Redmond. 1998. Montana atlas of terrestrial vertebrates. Montana Cooperative Wildlife Research Unit, The University of Montana. Missoula, Montana vii + 1302 p. 
*Hendricks, P. 1999. Amphibian and reptile survey of the Bureau of Land Management Miles City District, Montana. Montana Natural Heritage Program, Helena, MT. 80 p.

*Hendricks, P. and J.D. Reichel. 1996b. Preliminary amphibian and reptile survey of the Ashland District, Custer National Forest: 1995. Montana Natural Heritage Program, Helena, MT. 79 p.

*Hendricks, P. and J.D. Reichel. 1998. Amphibian and reptile survey on Montana refuges: 1996. Montana Natural Heritage Program, Helena, MT. 19 p.

Hoberg, T. and C. Gause. 1989. Reptiles \& amphibians of North Dakota. North Dakota Outdoors 55(1):7-18.

*Hossack, B.R. and P.S. Corn. 2001. Amphibian survey of Medicine Lake National Wildlife Refuge Complex: 2001. USGS Northern Rocky Mountain Science Center, Aldo Leopold Wilderness Research Institute, Missoula, MT. 13 p.

Hossack, B.R., P.S. Corn, and D.S. Pilliod. 2005. Lack of significant changes in the herpetofauna of Theodore Roosevelt National Park, North Dakota, since the 1920s. American Midland Naturalist 154:423-432.

Hunziker, R. 1990. The best defense: an introduction to hognose snakes. Tropical Fish Hobbyist 39(4): 106-108, 110-115.

Iverson, J.B. 1985. Heterodon nasicus (western hognose snake). Reproduction. Herpetological Review 26(4): 206 p.

Iverson, J.B. 1995. Heterodon nasicus (western hognose snake). Reproduction. Herpetological Review 26(4): 206 p.

Jochimsen, Denim M., Charles R. Peterson, Kimberly M. Andrews, and J. Whitfield Gibbons. 2004. A literature review of the effects of roads on amphibians and reptiles and the measures used to minimize those effects. Idaho Fish and Game Department and USDA Forest Service.

Kapus, E.J. 1964. Anatomical evidence for Heterodon being poisonous. Herpetologica 20(2): 137-138.

Kolbe, J.J. 1999. Size and demographic structure of an isolated population of western hognose snakes, Heterodon nasicus, in northwestern Illinois. Bulletin of the Chicago Herpetological Society 34(6):149-152.

Kroll, J.C. 1973. Comparative physiological ecology of eastern and western hognose snakes (Heterodon platyrhinos and H. nasicus). Ph.D. Thesis, Texas A\&M University 261 p. 1973.

Kroll, J.C. 1977. Self-wounding while death feigning by western hognose snakes (Heterodon nasicus). Copeia 1977(2): 372-373.

Kugelberg, A. 1991. Western hognosed snake, Heterodon n. nasicus. Newsletter of the Australian Society of Herpetologists Incorporated 34(7): 147-149.

Lazcano, D., Jr. 1988. Life history notes. Heterodon nasicus kennerlyi (Mexican hognose snake). Coloration. Herpetological Review 19(2): 36 p.

Leavesley, L.K. 1987. Natural History and Thermal Relations of the Western Hognose Snake (Heterodon nasicus) in Southwestern Manitoba. M.S. Thesis. University of Manitoba, Winnipeg, Manitoba. 160 p.

Lowe, D. 1997. Keeping and breeding the western hognose snake (Heterodon nasicus). Herptile 22(2):89-92.

*Martin, P.R. 1980. Terrestrial wildlife inventory in selected coal areas of Montana. Montana Department of Fish, Wildlife and Parks and Bureau of Land Management, Helena, MT. 84 p.

*Martin, P.R., K. Dubois and H.B. Youmans. 1981. Terrestrial wildlife inventory in selected coal areas, Powder River resources area final report. Montana Department of Fish, Wildlife and Parks and Bureau of Land Management, Helena, MT. 288 p. 
*Matthews, W.L. 1979. Wibaux-Beach wildlife baseline study - nongame species. Bureau of Land Management, Miles City, MT. 93 p.

*Matthews, W.L. 1980b. Wildlife of Prairie County Terry study area. Bureau of Land Management, Miles City, MT. 52 p.

*Matthews, W.L. 1981. Broadus-Pumpkin Creek baseline inventory - wildlife. Bureau of Land Management, Miles City, MT. 83 p.

Mattison, C. 1992. Reproduction in the dusty hognose snake, Heterodon nasicus gloydi. Litteratura Serpentium English Edition 12(5): 98-101.

*Maxell, B.A. 2004. Preliminary report on amphibian and aquatic reptile inventories conducted on and around the Ashland District of the Custer National Forest in 2002 and 2004. Report to Ashland District of Custer Forest, Region 1 Office of the U.S. Forest Service, and Montana Department of Fish, Wildlife, and Parks. Missoula, MT: Montana Cooperative Wildlife Research Unit and Wildlife Biology Program, University of Montana. 93 p.

*Maxell, B.A. 2009. State-wide assessment of status, predicted distribution, and landscapelevel habitat suitability of amphibians and reptiles in Montana. Ph.D. Dissertation. Missoula, MT: Wildlife Biology Program, University of Montana. 294 p.

*Maxell, B.A. and D.G. Hokit. 1999. Amphibians and reptiles. Pp. 2.1- 2.30. In: G. Joslin and H. Youmans (committee chairs). Effects of recreation on Rocky Mountain wildlife: a compendium of the current state of understanding in Montana. Helena, MT: Committee on Effects of Recreation on Wildlife, Montana Chapter of the Wildlife Society. 307 p.

*Maxell, B.A., J.K. Werner, P. Hendricks, and D. Flath. 2003. Herpetology in Montana: a history, status summary, checklists, dichotomous keys, accounts for native, potentially native, and exotic species, and indexed bibliography. Olympia, WA: Society for Northwestern Vertebrate Biology. Northwest Fauna 5: 1-138.

McAlister, W.H. 1963. Evidence of mild toxicity in the saliva of the hognose snake (Heterodon). Herpetologica 19: 132-137.

McCallum, M.L. 1995. Heterodon nasicus (western hognose snake). Herpetological Review 26(1): $46 \mathrm{p}$.

*McEneaney, T. and J. Jensen. 1974. The reptiles and amphibians of the Charles M. Russell National Wildlife Range - 1974. Charles M. Russell National Wildlife Refuge. Lewistown, MT. 3 p.

Montgomery, C. and S.P. Mackessy. 1999. Heterodon nasicus nasicus (plains hognose snake). Lack of paralysis following vertebral disjunction. Herpetological Review 30(4):227-228.

Moore, J.E. 1953. The hog-nosed snake in Alberta. Herpetologica 9: 173 p.

Morris, M.A. 1985. Envenomation from the bite of Heterodon nasicus (Serpentes: Colubridae). Herpetologica 41(3): 361-363.

*Mosimann, J.E. and G.B. Rabb. 1952. The herpetology of Tiber Reservoir area, Montana. Copeia 1952: 23-27.

*Moulton, G. (ed.). 1983. The journals of the Lewis and Clark expedition. University of Nebraska Press. Lincoln, Nebraska. Volumes 4, 5, 8, 9 and 10.

*[MTNHP] Montana Natural Heritage Program. 2006. Point Observation Database. Montana Natural Heritage Program, Helena, MT. Accessed April 25, 2006.

Painter, C.W., B.R. Tomberlin, and J.P. Brastad. 1996. Serpentes: Heterodon nasicus kennerlyi (Mexican hognose snake): Maximum size. Herpetological Review 27(4): 203-204.

Pendlebury, G.B. 1976b. The western hognose snake, Heterodon nasicus nasicus, in Alberta. Canadian Field Naturalist 90(4): 416-422. 
Perez-Ramos, E. 1987. Heterodon nasicus. Herpetological Review 18(3): 56 p.

Perkins, C.B. 1949. A key to the snakes of the United States, 2nd Edition. Bulletin of the Zoological Society of San Diego 24: 1-79.

*Platt, D.R. 1969. Natural History of the hognose snakes Heterodon platyrhinos and Heterodon nasicus. University of Kansas Publications, Museum of Natural History 18(4): 253-420.

*Platt, D.R. 1983. Heterodon. Catalogue of American Amphibians and Reptiles 315.1-315.2.

Platt, D.R. 1989. Seasonal activity of snakes on a sand prairie. Proceedings of the North American Prairie Conference 11: 251-254.

Plummer, M.V. and N.E. Mills. 2000. Spatial ecology and survivorship of resident and translocated hognose snakes (Heterodon platirhinos). Journal of Herpetology 34(4): 565-575.

*Powell, R., J.T. Collins, and E.D. Hooper, Jr. 1998. A key to amphibians and reptiles of the Continental United States and Canada. University Press of Kansas, Lawrence, KS. 131 p.

*[PRESI] Powder River Eagle Studies Incorporated. 1998a. Big Sky Mine 1997 wildlife monitoring studies. Powder River Eagle Studies Incorporated. Gillete, WY.

*[PRESI] Powder River Eagle Studies Incorporated. 1998b. Spring Creek Mine 1997 wildlife monitoring studies. Powder River Eagle Studies Incorporated. Gillete, WY.

*Rauscher, R.L. 1998. Amphibian and reptile survey on selected Montana Bureau of Reclamation impoundments. Montana Department of Fish, Wildlife and Parks, Nongame Program, Bozeman, MT. 24 p.

*Redmond, R.L., M.M. Hart, J.C. Winne, W.A. Williams, P.C. Thornton, Z. Ma, C.M. Tobalske, M.M. Thornton, K.P. McLaughlin, T.P. Tady, F.B. Fisher, S.W. Running. 1998. The Montana gap analysis project: final report. Montana Cooperative Wildlife Research Unit, University of Montana, Missoula, MT. 136 p. + appendices.

Rehak, I. 1990b. On the reproductive biology of Heterodon nasicus. Akvarium Terarium 33(8): 30-32.

*Reichel, J.D. 1995a. Preliminary amphibian and reptile survey of the Lewis and Clark National Forest: 1994. Montana Natural Heritage Program, Helena, MT. 92 p.

*Reichel, J.D. 1995b. Preliminary amphibian and reptile survey of the Sioux District of the Custer National Forest: 1994. Montana Natural Heritage Program, Helena, MT. 75 p.

*Reichel, J.D. 1997. Amphibian, reptile and northern bog lemming survey on the Rocky Mountain Front: 1996. Montana Natural Heritage Program, Helena, MT. 81 p.

*Roedel, M.D. and P. Hendricks. 1998a. Amphibian and reptile survey on the Bureau of Land Management Lewistown District: 1995-1998. Montana Natural Heritage Program, Helena, MT. 53 p.

Roth, J.J., B.J. Johnson, and H.M. Smith. 1989. The western hognose snake, Heterodon nasicus, west of the continental divide in Colorado, and its implications. Bulletin of the Chicago Herpetological Society 24(9): 161-163.

Rudolph, D.C., S.J. Burdorf, R.N. Conner, and J.G. Dickson. 1998. The impact of roads on the timber rattlesnake (Crotalus horridus), in eastern Texas. p. 236-240. In: G.L. Evink, P. Garrett, D. Zeigler and J. Berry (eds.) Proceedings of the international conference on wildlife ecology and transportation. February 10-12, 1998. Fort Meyers, Florida.

Russell, A.P., and A.M. Bauer. 2000. The amphibians and reptiles of Alberta. Second Edition. Calgary, AB: University of Calgary Press. 279 p.

Sexton, O.J. 1979. Remarks on defensive behavior of hognose snakes, Heterodon. Herpetological Review 10: 86-87. 
Smith, H.M. 1991a. Range extensions of three reptile species in northern Mexico. Bulletin of the Maryland Herpetological Society 27(4): 216-218.

Smith, H.M. and F.N. White. 1955. Adrenal enlargement and its significance in the hognose snakes. (Heterodon). Herpetologica 11: 137-144.

Smith, P.W. and H.M. Smith. 1962. The sytematic and biogeographic status of two Illinois snakes. C.C. Adams Center for Ecological Studies Occasional Papers of the Museum 5: 1-10.

Smith, W. and C. Wershler. 1989. Pilot project on the study of the Western Hognose Snake in Alberta. Paper for Alberta Forestry, Lands and Wildlife by Sweetgrass Consultants Ltd., Calgary, AB. 17 p.

*Stebbins, R.C. 2003. A field guide to western reptiles and amphibians. 3rd edition. New York, NY: Houghton Mifflin Co. 533 p.

*Thompson, L.S. and P.S. Nichols. 1982. Circle West wildlife monitoring study; fourth annual report for period March 1, 1981 - May 31, 1982. Circle West Technical Report No. 10. Montana Department of Natural Resources and Conservation, Helena, MT.

Travis, C.A., D. Chiszar, and H.M. Smith. Heterodon nasicus (western hognose snake). Herpetological Review 27(4): 212 p.

*Vitt, L.J., J.P. Caldwell, and D.B. Shepard. 2005. Inventory of amphibians and reptiles in the Billings Field Office Region, Montana. Sam Noble Oklahoma Museum of Natural History and Department of Zoology, University of Oklahoma, Norman, OK. 33 p.

*[VTNWI] VTN Wyoming Incorporated. No Date. Second year's analysis of terrestrial wildlife on proposed mine access and railroad routes in southern Montana and northern Wyoming, March 1979 - February 1980. VTN Wyoming Incorporated. Sheridan, WY. 62 p.

*Waage, B.C. 1998. Western Energy Company Rosebud Mine 1997 annual wildlife monitoring report December 1, 1996 to November 30, 1997 survey period. Western Energy Company, Colstrip, MT.

*Walcheck, K. 1976. Montana Wildlife 170 years ago. Montana Outdoors 7(4): 15-30.

Walley, H.D. and C.M. Eckerman. 1999. Heterodon nasicus. Catalogue of American Amphibians and Reptiles 698.1-698.10.

Webb, R.G. and C.M. Eckerman. 1998. Neotype and type locality of the western hognose snake, Heterodon nasicus (Serpentes: Colubridae). Texas Journal of Science 50(2): 99-106

*Werner, J.K., B.A. Maxell, P. Hendricks, and D. Flath. 2004. Amphibians and reptiles of Montana. Missoula, MT: Mountain Press Publishing Company. 262p.

*[WESCO] Western Ecological Services Company. 1983b. Wildlife inventory of the Southwest Circle known recoverable coal resource area, Montana. Western Ecological Services Company, Novato, CA. 131 p.

*[WESTECH] Western Technology and Engineering Incorporated. 1998. Wildlife monitoring Absaloka Mine area 1997. Western Technology and Engineering, Inc., Helena, MT.

Wilkie, B. 1996. Force feeding snakes. My experience with rattle snakes and western hognose snakes. Rephiberary 221:10 p.

Wootton, J.T. 1994. The nature and consequences of indirect effects in ecological communities. Annual Review of Ecological Systematics 25:443-446.

*Wright, A.H. and A.A. Wright. 1957. Handbook of snakes of the United States and Canada, 2 Volumes. Cornell University Press, Comstock Publishing Associates, Ithaca, NY. 1105 p.

Wright, J. and A. Didiuk. 1998. Status of the plains hognose snake (Heterodon nasicus nasicus) in Alberta. Alberta Environmental Protection, Fisheries \& Wildlife Management Divison, and Alberta Conservation Association, Wildlife Status Report No. 15, Edmonton, AB. 26 p. 
*Yarrow, H.C. 1882. Check list of North American reptilia and batrachia, with catalogue of specimens in the U.S. National Museum. United States National Museum Bulletin 24: 249 p. Young, R.A. 1992. Effects of Duvernoy's gland secretions from the eastern hognose snake, Heterodon platyrhinos, on smooth muscle and neuromuscular junction. Toxicon 30(7): 775779. 


\section{Smooth Greensnake (Opheodrys vernalis)}

Up-to-date distribution and status information can be found on the Montana Natural Heritage Program’s TRACKER website at http://mtnhp.org

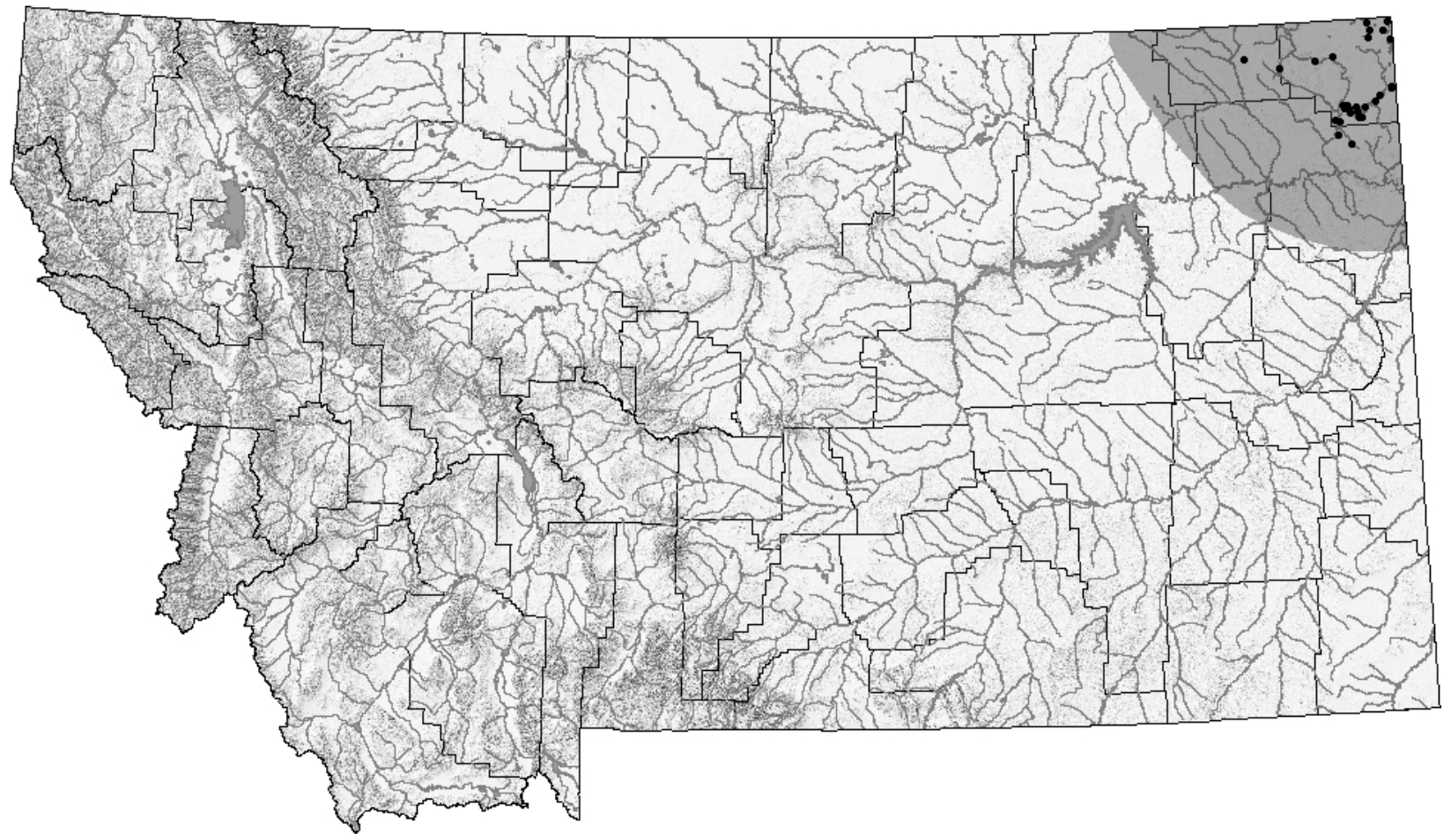

Distribution/Taxonomy

The Smooth Greensnake has a mostly continuous range throughout the northeastern United States from Nova Scotia south to northern Virginia and northwesterly to the upper Midwest, where its range becomes widely scattered further west and south. Isolated populations exist as far west as Utah, Colorado, and New Mexico, and as far south as Texas and part of Mexico (Ernst and Ernst 2003, Stebbins 2003). In Montana, Smooth Greensnakes have been observed from only three northeastern counties: Sheridan, Daniels, and Roosevelt Counties (Black and Bragg 1968, Hendricks 1999, Maxell 2003). These observations are located on the periphery of their range, crossing the Saskatchewan and North Dakota borders into Montana's Glaciated Dark Brown Prairie and Coteau Lakes Upland Ecoregions (Woods et al. 2003). Three subspecies have been proposed (including O. v. blanchardi in Montana) based primarily on clinal variation in numbers of ventral and caudal scales (Grobman 1941, Smith 1963, Grobman 1992a, Grobman 1992b). However, these subspecies are currently unrecognized by most herpetologists due to overlap in morphology and a lack of molecular evidence (Collins 1992). Additionally, some herpetologists have designated a new genus, Liochlorophis, for the Smooth Greensnake based on morphological and physiological differences between it and the Rough Greensnake (O. aestivus) (Oldham and Smith 1991, Hammerson 1999).

Maximum Elevation

847 m (2,780 ft) in Daniels County (Werner et al. 2004).

\section{Identification}

The Smooth Greensnake is a small, thin, unpatterned, bright green snake with smooth (unkeeled) dorsal scales and a uniform white to cream ventral surface, sometimes becoming yellowish 
toward the tail. The anal plate is divided, and there is a single anterior temporal scale. There are usually 8 (occasionally seven) lower labials and usually seven (occasionally six) yellowish upper labials. Each nostril is centered within a single scale. There are 15 midbody dorsal scale rows, 106-154 ventrals, and 59-102 subcaudals. Individuals rarely exceed $50 \mathrm{~cm}$ (20 inches) total body length (TBL), but females are generally larger and have been known to reach $80 \mathrm{~cm}$ (32 inches) TBL. Females can become sexually mature as short as $28 \mathrm{~cm}$ TBL, while males may mature at $30 \mathrm{~cm}$ TBL. Dead or preserved specimens turn bluish (St. John 2002). Recently hatched neonates may have gray, olive, or brown backs and range from 8.3-16.7 cm (mean 13.3) TBL (Wright and Wright 1957, Smith 1963, Powell et al. 1998, Ernst and Ernst 2003, Werner et al. 2004). Eggs are approximately $25 \mathrm{~cm}$ (1 inch), and are white and oval with thin shells and blunt ends (Werner et al. 2004).

Similar Species:

Eastern Racers (Coluber constrictor) also have unkeeled scales and are a generally a uniform green in Montana, but they are always much larger as adults. Hatchling and juvenile Eastern Racers, which may be similar in size to Smooth Greensnakes, have a distinct banded or blotched pattern before they mature. Unlike $O$. vernalis, the Eastern Racer has two anterior temporal scales, and each nostril is centered between two scales. Additionally, C. constrictor has an elongated preocular scale that enters the upper labial row (Degenhardt et al. 1996, Ernst and Ernst 2003, Stebbins 2003, Werner et al. 2004).

\section{Habitat Use/Natural History}

Smooth Greensnakes prefer mesic habitat such as wet prairies, meadows, marshes, open forests, and riparian corridors with lush shrubby and herbaceous cover. They are secretive, and often found under cover objects such as logs, bark, boards, and rocks (Smith 1963, Hammerson 1999, Ernst and Ernst 2003). Home range, population, and migratory data is absent in Montana and lacking elsewhere. In the Midwest, Smooth Greensnakes are thought to be locally common at some locations, but appear to be becoming rare or extirpated in others (Harding 1997). Smooth Greensnakes emerge from hibernacula in late spring to early summer. Data on post-emergence behavior and courtship is absent in Montana and poorly documented elsewhere, but mating is known to occur shortly after emergence in May (Collins 1993), but has been observed as early as April 15th in Pennsylvania (Ernst and Ernst 2003), and as late as August in southern Canada. Females inseminated in late summer or fall probably store their sperm overwinter before fertilization occurs in the spring, as with other colubrid snakes (Dymond and Fry 1932, Hammerson 1999, Werner et al. 2004). Data collected by Smith, et al. (1991) in Colorado suggest that females do not reproduce every year and that sexual maturity is not reached until the third calendar year (Hammerson 1999). Females are oviparous, laying one or two clutches of eggs under stones, boards, logs, and inside rotting wood (Smith 1963). Northern populations typically oviposit from late July through August, although no data exists for Montana. Eggs are typically incubated for 3-4 weeks before hatching, but Michigan females have oviposited very late in embryogenesis, just four days prior to hatching. In Michigan and Ontario, clutch size varied from 3 to 12 eggs, averaging approximately 7 (Hammerson 1999, Ernst and Ernst 2003). Females will occasionally nest communally at high quality nest sites. Egg-groups numbering 27 and 31, each from three different females have been found in choice nest-sites in rotting logs (Cook 1964, Fowler 1966). In Manitoba, Gregory (1975) located three gravid females near, each with five eggs, in a good nest site underneath a wooden platform. Grobman (1989) found that 
larger females deposit more eggs than smaller females, and that in eastern populations clutch size decreases with an increase in latitude. This suggests that Montana females probably produce fewer eggs on average than populations studied at lower latitudes. Smooth Greensnakes are primarily diurnal, with most activity occurring at warmer times of the day, although they have been observed in the evening on warm asphalt (Hammerson 1999). In Illinois, Seibert and Hagen (1947) found they were most active at air temperatures between 21-30 degrees Celsius. Smooth Greensnakes are primarily ground dwellers, but have been known to climb into low shrubs to bask or forage (Degenhardt et al. 1996, Ernst and Ernst 2003). Multiple individuals are often found together under objects, suggesting they are somewhat communal. Smooth Greensnakes primarily prey on invertebrates, particularly small insects. Documented prey includes ants, maggots, grasshoppers, crickets, beetles, grubs, spiders, centipedes, millipedes, slugs, snails, salamanders, and small crayfish (Wright and Wright 1957, Hammerson 1999, Ernst and Ernst 2003). Documented predators include gartersnakes, chickens, hawks, and cats. Their cryptic green coloration helps them avoid detection from predators. If cornered or seized, their last modes of defense are the release foul smelling cloacal secretions, and sometimes they will gape their mouths and pretend to strike, although they never bite (Cochran 1987, Hammerson 1999). Overwintering usually takes place in September at northern latitudes. They have been observed conducting prehibernation movements as early as late August between 5,000 and 6,000 feet in the Black Hills, South Dakota (Smith 1963). Overwintering occurs underground, and has been observed in ant mounds, mammal burrows, gravel banks, and spaces between granite slabs. O. vernalis may hibernate communally with other species, including Thamnophis radix and Thamnophis sirtalis. (Criddle 1937, Lachner 1942, Degenhardt et al. 1996, Ernst and Ernst 2003).

\section{$\underline{\text { Status and Conservation }}$}

In Montana, Smooth Greensnakes have a very restricted range, occupying a portion of just the three northeastern counties. There have only been 43 recorded observations, but 35 of those have come in the last 10 years. This lack of records may reflect a low abundance at the periphery of their range, or simply a lack of reported sightings and formal surveys in the region, which is sparsely populated and dominated by private lands. (1) Smooth Greensnakes consume large numbers of insects and is therefore probably most successful where they are plentiful. In Montana, they found in a very small region primarily used for grazing and crop production. Therefore, heavy use of insecticides is a concern since it may affect this species both by direct poisoning and indirectly through prey reduction. In Indiana, Minton (1972) reported that two Smooth Greensnakes died from direct poisoning after insecticide application (Ernst and Ernst 1972). (2) Over-grazing, especially along riparian corridors, can trample and alter vegetation and soil structure, which are important components of $O$. vernalis habitat, and therefore could affect local populations. Grazing is known to reduce the abundance of many invertebrates (Hutchingson and King 1980), which could directly affect prey availability for O. vernalis. (3) Although effects of road mortality have not been directly studied in $O$. vernalis, studies on other snakes indicate roads often have negative impacts on population size and distribution. High road density has been positively correlated to low population size, which leads to populations being restricted to pockets with low road density. This may lead to isolation or restricted interaction between populations (Rudolph et al. 1998, Jochimsen et al. 2004). This is of particular concern in Montana, where Smooth Greensnakes appear to be rare, and are found within a very restricted area. 
Research and Management Suggestions

1. Need to identify the southern and western extents of the species distribution in Montana.

2. Abundance, and local habitat use need to be more accurately assessed either by conducting systematic surveys in suitable habitat, or by encouraging local landowners and resource managers to report observations.

3. If located, overwintering hibernacula should be protected to avoid mass mortalities, especially if hibernacula potentially support large numbers of snakes.

4. Conduct outreach programs in the area to educate locals on the rarity, sensitivity, and potential benefits (e.g. insect predation) of this species. This could be beneficial in helping to avoid intentional killings and raise interest in protecting high-quality habitat.

5. Conduct research on Smooth Greensnake ecology and natural history to fill the void of information in Montana for this species.

6. If herbicides must be used near known O. vernalis populations, glyphosate (Roundup) should be avoided and 2,4-D should be used as an alternative. Relyea (2005) found Roundup completely eliminated 2 species of tadpoles and nearly exterminated a third, while 2,4-D had no direct observable effect on tadpoles.

Bibliography *indicates an article with information specific to Montana

*Black, J.H. and A.N. Bragg. 1968. New additions to the herpetofauna of Montana. Herpetologica 24: 247.

*Black, J.H. and R. Timken. 1976. Endangered and threatened amphibians and reptiles in Montana. Pp. 36-37. In R.E. Ashton, Jr. (chair). Endangered and threatened amphibians and reptiles in the United States. Society for the Study of Amphibians and Reptiles Herpetological Circular 5: 1-65.

Blahnik, J.F. and P.A. Cochran. 1994. Opheodrys vernalis (smooth green snake). Herpetological Review 25(2): 77.

Blanchard, F.N. 1933. Eggs and young of the smooth green snake, Liopeltis vernalis. Papers of the Michigan Academy of Science, Arts and Letters 27: 493-508.

Brodman, R., S. Cortwright, and A. Resetar. 2002. Historical changes of reptiles and amphibians of northwest Indiana fish and wildlife properties. American Midland Naturalist 147:135-144.

Brown, L.E. 1994. Occurrence of smooth green snakes in a highly polluted microenvironment in central Illinois prairie. Prairie Naturalist 26(2): 155-156.

*Brunson, R.B. 1955. Check list of the amphibians and reptiles of Montana. Proceedings of the Montana Academy of Sciences 15: 27-29.

Casper, G.S. 1996. Opheodrys vernalis (smooth green snake). Herpetological Review 27(4): 214.

Cochran, P.A. 1987. Opheodrys vernalis (smooth green snake). Behavior. Herpetological Review 18(2): 36-37.

Collins, J.T. 1992. Reply to Grobman on variation in Opheodrys aestivus. Herpetological Review 23:15-16.

Cook, F.R. 1964. Communal egg laying in the smooth green snake. Herpetologica 20: 206.

*Cooper, J.G. 1869. The fauna of Montana territory. American Naturalist 3: 124-127.

*Coues, E. and H.C. Yarrow. 1878. Notes on the herpetology of Dakota and Montana. Bulletin of the U.S. Geologic and Geographic Survey 4(1): 259-291. 
Cox, D.L., T.J. Koob, R.P. Mecham, and O.J. Sexton. 1984. External incubation alters the composition of squamate egg-shells. Comparative Biochemistry and Physiology B Comparative Biochemisty 79(3): 481-488.

Criddle, S. 1937. Snakes from an ant hill. Copeia 2:142.

Cundall, D. 1986. Variations of the cephalic muscles in the colubrid snake genera Entechinus, Opheodrys, and Symphimus. Journal of Morphology 187(1): 1-21.

DeFusco, R.P., D. Chiszar, and H.M. Smith. 1994. Liochlorophis vernalis blanchardi (smooth green snake). Herpetological Review 25(2): 77.

Degenhardt, W.G., C.W. Painter, and A.H. Price. 1996. Amphibians and reptiles of New Mexico. Albuquerque, NM: University of New Mexico Press. 431 p.

Dymond, J.R. and F.E.J. Fry. 1932. Notes on the breeding habits of the green snake (Liopeltis vernalis). Copeia 2:102.

*Ernst, C.H. and E.M. Ernst. 2003. Snakes of the United States and Canada. Smithsonian Books. Washington D.C.

Finch, D.M. 1992. Threatened, endangered, and vulnerable species of terrestrial vertebrates in the Rocky Mountain Region. General Technical Report RM-215. USDA, Forest Service, Rocky Mountain Forest and Range Experiment Station, Ft. Collins CO. 38 p.

*Flath, D.L. 1998. Species of special interest or concern. Montana Department of Fish, Widlife and Parks, Helena, MT. March, 1998. 7 p.

Fowler, J.A. 1966. A communal nesting site for the smooth green snake in Michigan. Herpetologica 22: 231.

Gordon, D.M. and F.R. Cook. 1980. An aggregation of gravid snakes in the Quebec Laurentians. Canadian Field Naturalist 94(4): 456-457.

Gregory, P.T. 1977. Life history observations of three species of snakes in Manitoba. Canadian Field Naturalist 91(1): 19-27.

Grobman, A.B. 1941. A contribution to the knowledge of variation in (Opheodrys vernalis) (Harlan), with the description of a new subspecies. Miscellaneous Publications Museum of Zoolology, University of Michigan 50: 7-38.

Grobham, A.B. 1989. Clutch size and female length in Opheodrys vernalis. Herpetological Review 20(4): 84-85.

Grobman, A.B. 1991. Does the smooth green snake occur in Missouri? Transactions of the Missouri Academy of Science 25(0): 1-3.

Grobman, A.B. 1992a. Metamerism in the snake Opheodrys vernalis, with a description of a new subspecies. Journal of Herpetology 26(2): 175-186.

Grobman, A.B. 1992b. On races, clines, and common names in Opheodrys. Herpetological Review 23: 14-15.

Groves, J.D. 1976. A note on the eggs and young of the smooth green snake, opheodrys vernalis in Maryland. Bulletin of the Maryland Herpetological Society 12(4): 131-132.

Worthington, R.D. 1973. Remarks on the distribution of the smooth green snake, Opheodrys vernalis blanchardi grobman in Texas. Southwestern Naturalist 18(3): 344-346.

Groves, J.D. 1977. A note on the eggs and young of the smooth green snake, /Opheodrys vernalis/ in Maryland. Bulletin of the Maryland Herpetological Society 12(4): 131-132.

Hammerson, G.A. 1999. Amphibians and Reptiles in Colorado. University Press of Colorado and Colorado Division of Wildlife, Niwot, Colorado.

Harding, J.H., 1997. Amphibians and Reptiles of the Great Lakes Region. University of Michigan Press, Ann Arbor, Michigan. 
Harlan, R. 1827. Genera of North American Reptilia, and a synopsis of the species. Journal of the Academy of National Sciences, Philadelphia 5: 317-372; 6: 7-38.

*Hart, M.M., W.A. Williams, P.C. Thornton, K.P. McLaughlin, C.M. Tobalske, B.A. Maxell, D.P. Hendricks, C.R. Peterson, and R.L. Redmond. 1998. Montana atlas of terrestrial vertebrates. Montana Cooperative Wildlife Research Unit, The University of Montana. Missoula, Montana vii + 1302 p.

*Hayden, F.V. 1858. Catalogue of the collections in geology and natural history, obtained by the expedition under command of Lieutenant G.K. Warren, Topographical Engineers. pp. 104-105. In: F.N. Shubert (1981) Explorer on the northern plains: Lieutenant Gouverneur K. Warren's preliminary report of explorations in Nebraska and Dakota, in the years 1855-'56'57. Engineer Historical Studies No. 2. Office of the Chief of Engineers, Washington, DC. 125 p.

*Hayden, F.V. 1863. On the geology and natural history of the upper Missouri. Transactions of the American Philosophical Society New Series 12(1): 1-218 (pages 177-178).

Heinen, J.T. 1994. Antipredator behavior of newly metamorphosed American toads (Bufo a. americanus), and mechanisms of hunting by eastern garter snakes (Thamnophis S. sirtalis). Herpetologica 50(2): 137-145.

*Hendricks, P. 1999. Amphibian and reptile survey of the Bureau of Land Management Miles City District, Montana. Montana Natural Heritage Program, Helena, MT. 80 p.

Hoberg, T. and C. Gause. 1989. Reptiles \& amphibians of North Dakota. North Dakota Outdoors 55(1):7-18.

Holman, J.A. and F. Grady. 1994. A Pleistocene herpetofauna from Worm Hole Cave, Pendleton County, West Virginia. NSS Bulletin 56(1): 46-49.

Holman, J.A. and R.L. Richards. 1981. Late pleistocene occurrence in southern Indiana of the smooth green snake, Opheodrys vernalis. Journal of Herpetology 15(1): 123-125.

*Hossack, B. and S. Corn. 2001. Amphibian survey of Medicine Lake National Wildlife Refuge Complex: 2001. USGS Northern Rocky Mountain Science Center, Aldo Leopold Wilderness Research Institute, Missoula, MT. 13 p.

Hutchinson, K.J., and K.L. King. 1980. The effects of sheep stocking level on invertebrate abundance, biomass and energy utilization in a temperate, south grassland. Journal of Applied Ecology. 17:369-387.

Jochimsen, D.M., C.R. Peterson, K.M. Andrews, and J.W. Gibbons. 2004. A literature review of the effects of roads on amphibians and reptiles and the measures used to minimize those effects. Idaho Fish and Game Department and USDA Forest Service.

Lachner, E.A. 1942. An aggregation of snakes and salamanders during hibernation. Copeia 4:262-263.

Lawson, R. 1983. Opheodrys vernalis (smooth green snake). Reproduction. Herpetological Review 14(1): 20.

Livo, L.J., D. Chiszar, and H.M. Smith. 1996. Liochlorophis (=Opheodrys) vernalis (smooth green snake). Herpetological Review 27(3): 154.

Mara, W.P. 1996. Green Snakes. Neptune City, NJ: T.F.H. Publications, 1996.

*Maxell, B.A. 2009. State-wide assessment of status, predicted distribution, and landscapelevel habitat suitability of amphibians and reptiles in Montana. Ph.D. Dissertation.

Missoula, MT: Wildlife Biology Program, University of Montana. 294 p.

*Maxell, B.A. and D.G. Hokit. 1999. Amphibians and reptiles. Pp. 2.1- 2.30. In: G. Joslin and H. Youmans (committee chairs). Effects of recreation on Rocky Mountain wildlife: a 
compendium of the current state of understanding in Montana. Helena, MT: Committee on Effects of Recreation on Wildlife, Montana Chapter of the Wildlife Society. 307 p.

*Maxell, B.A., J.K. Werner, P. Hendricks, and D. Flath. 2003. Herpetology in Montana: a history, status summary, checklists, dichotomous keys, accounts for native, potentially native, and exotic species, and indexed bibliography. Olympia, WA: Society for Northwestern Vertebrate Biology. Northwest Fauna 5: 1-138.

Minear, J. 1986. The nesting habits of the smooth green snake. Redstart 53(3): 113.

*[MTNHP] Montana Natural Heritage Program. 2006. Point Observation Database. Montana Natural Heritage Program, Helena, MT. Accessed April 24, 2006.

Oldham, J.C. and H.M. Smith. 1987. Taxonomic significance of the intrinsic integumentary muscles of Opheodrys. Journal of the Colorado-Wyoming Academy of Science 19(1): 18.

Oldham, J.C. and H.M. Smith. 1991. The generic status of the smooth green snake, Opheodrys vernalis. Bulletin of the Maryland Herpetological Society 27(4): 201-215.

*Powell, R., J.T. Collins, and E.D. Hooper, Jr. 1998. A key to amphibians and reptiles of the Continental United States and Canada. University Press of Kansas, Lawrence, KS. 131 p.

Radaj, R.H. 1981. Opheodrys v. vernalis (smooth green snake). Reproduction. Herpetological Review 12: 80.

Redmer, M. 1987. Notes on the eggs and hatchlings of the smooth green snake, Opheodrys vernalis, in Dupage County, Illinois. Bulletin of the Chicago Herpetological Society 22(9): 149.

Relyea, Rick A. 2005. The impact of insecticides and herbicides on the biodiversity and productivity of aquatic communities. Ecological Applications 15(2), 2005:618-627.

Robins, C.R. 1952. Variation in the greensnake, Opheodrys vernalis, from the Black Hills, South Dakota. Copeia 1952(3): 191-192.

Rudolph, D.C., S.J. Burdorf, R.N. Conner, and J.G. Dickson. 1998. The impact of roads on the timber rattlesnake (Crotalus horridus), in eastern Texas. Pp. 236-240. In: G.L. Evink, P. Garrett, D. Zeigler and J. Berry (eds.) Proceedings of the international conference on wildlife ecology and transportation. February 10-12, 1998. Fort Meyers, Florida.

Rundquist, E.M. 1979. The status of Bufo debilis and Opheodrys vernalis in Kansas. Transaction of the Kansas Academy of Science 82(1): 67-70.

Schlauch, F.C. 1975. Agonistic behavior in a suburban Long Island population of the smooth green snake, Opheodrys vernalis. Engelhardtia 6(2): 25-26.

Schmidt, K.P. and W.L. Necker. 1936. The scientific name of the American smooth green snake. Herpetologica 1: 63-64.

Smith, H.M. 1963. The taxonomic status of the Black Hills population of smooth greensnakes. Herpetologica 19(4): 256-261.

Smith, H.M. and D. Thompson. 1993. Four reptiles newly recorded from Ouray County, Colorado. Bulletin of the Chicago Herpetological Society 28(4): 78-79.

Smith, H.M., G.A. Hammerson, J.J. Roth, and D. Chiszar. 1991. Distributional addenda for the smooth green snake (Opheodrys vernalis) in western Colorado, and the status of its subspecies. Bulletin of the Maryland Herpetological Society 27(2): 99-106.

Stafford, D.P., F.W. Plapp, Jr., and R.R. Fleet. 1976. Snakes as indicators of environmental contamination: relation of detoxifying enzymes and pesticide residues to species occurrence in three aquatic ecosystems. Archives of Environmental Contamination and Toxicology 5: $15-27$. 
*Stebbins, R.C. 2003. A field guide to western reptiles and amphibians. 3rd edition. New York, NY: Houghton Mifflin Co. 533 p.

Stille, W.T. 1954. Observations on the reproduction and distribution of the green snake, Opheodrys vernalis (Harlan) Chicago Academy of Science and Natural History Miscellaneous 127: 1-11.

Stuart, J.N. 2002. Liochlorophis (Opheodrys) vernalis (Smooth Green Snake). Reproduction. Herpetological Review 33(2):140-141.

Stuart, J.N. and C.W. Painter. 1993. Notes on hibernation of the smooth green snake Opheodrys vernalis, in New Mexico. Bulletin of the Maryland Herpetological Society 29(3): 140-142.

Stuart, J.N. and W.G. Degenhardt. 1990. Opheodrys vernalis blanchardi (western smooth green snake). Herpetological Review 21(1): 23.

Walley, H.D. 2003. Liochlorophis, L. vernalis. Catalogue of American Amphibians and Reptiles 776: 1-13.

Waters, R.M. 1993. Seasonal prey preference by the smooth green snake. M.S. Thesis. Central Michigan University. 54p. 1993.

*Werner, J.K., B.A. Maxell, P. Hendricks, and D. Flath. 2004. Amphibians and reptiles of Montana. Missoula, MT: Mountain Press Publishing Company. 262p.

Woods, A. J., J.M. Omernik, J.A. Nesser, J. Shelden, J.A. Comstock, and S.H. Azevedo. 2002, Ecoregions of Montana, $2^{\text {nd }}$ edition (coor poster with map, descriptive text, summary tables, and photographs). Map Scale 1:1,500,000.

Worthington, R.D. 1973. Remarks on the distribution of the smooth green snake, Opheodrys vernalis Blanchardi grobman in Texas. Southwestern Naturalist 18(3): 344-346.

*Wright, A.H. and A.A. Wright. 1957. Handbook of snakes of the United States and Canada, 2 Volumes. Cornell University Press, Comstock Publishing Associates, Ithaca, NY. 1105 p. 


\section{Milksnake (Lampropeltis triangulum)}

Up-to-date distribution and status information can be found on the Montana Natural Heritage Program's TRACKER website at http://mtnhp.org

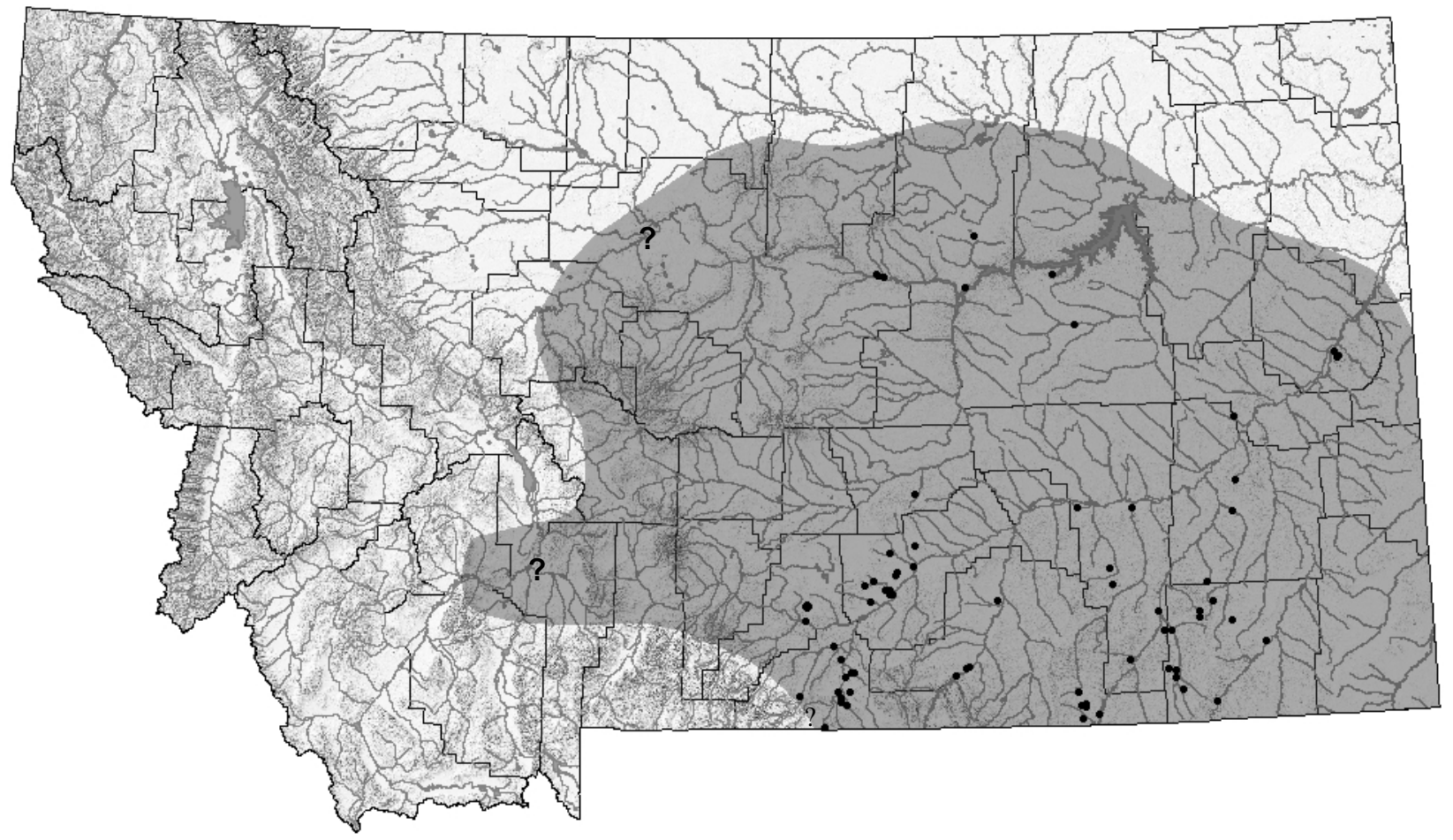

Distribution/Taxonomy

Milksnakes are distributed widely throughout the eastern and central United States west to the Rocky Mountains. Eastern Montana marks the northern limit for this species in the west and there are also pockets of milksnakes in Utah, eastern Wyoming, eastern Colorado, Arizona, and New Mexico (Stebbins 2003, Werner et al. 2004). There are 25 subspecies of milksnake in North America with the pale milksnake (L. t. multistriata) being the only subspecies found in Montana. Pale milksnakes are also found in parts of Wyoming, South Dakota, and Nebraska. Milksnakes have been documented in 10 counties in eastern Montana and there are unconfirmed records in 4 additional counties in central Montana.

Maximum Elevation Record

1257 m (4,124 ft) in Carbon County (Laurie Vitt, pers. com., MTNHP 2007).

\section{Identification}

\section{Eggs:}

Oval, white, slightly granular, and sticky. Length $36 \mathrm{~mm}$ (1.4 in.) and width $14 \mathrm{~mm}$ (0.56 in.). Individual weight for each egg is approximately 2-4 g. Clutch size ranges from 4-13 and is positively correlated with female body size (Fitch and Fleet 1970, Groves and Sachs 1973, Degenhardt et al. 1996, Hammerson 1999, Werner et al. 2004).

Young:

Similar coloration pattern to adults but total length is just 16-29 cm (6.2-11.3 in.) (Hammerson 1999, Werner et al. 2004). 
Adults:

Milksnakes possess alternating orange, black, and white rings along the length of their body. For milksnakes in Montana, repeating pattern may not meet underneath and be true rings, but rather are saddles of alternating color. Dorsal scales smooth. White/yellow coloration and repeating black marking at saddle edges ventrally. Neck is short and thick leading to a rounded snout often mottled with black. Pupils are round and there are 7-8 upper labial (lip) and 8-10 lower labial scales. Total length for adults ranges $41-71 \mathrm{~cm}$ (16-28 in.) with males attaining sizes slightly longer than females (Hammerson 1999, St John 2002, Werner et al. 2004).

Similar species:

The pale milksnakes' brightly banded coloration easily distinguishes it from other snake species in Montana.

Habitat use/Natural History

Milksnakes inhabit grasslands of eastern Montana. Largely nocturnal they will spend the daylight hours under cover in burrows near rock outcroppings, juniper hillsides, riparian zones, or perhaps under construction debris and near buildings such as barns (Dyrkacz 1977, Williams 1988, Degenhardt et al. 1996, Hammerson 1999, Werner et al. 2004). Milksnakes appear highly adaptable in their microhabitat selection. For example, Henderson et al. (1980) routinely found L. t. triangulum during the day under a piece of steel that overlaid an abandoned rodent burrow along a roadside in Wisconsin. In addition to locating milksnakes under pieces of metal, logs, and stumps, Fitch and Fleet (1970) described flat rocks as a favorite shelter for milksnakes during the day because of the ambient heat gained from the sun-warmed object. Henderson et al. (1980) found similar movements to sun-warmed objects during the day for milksnakes in Wisconsin. Dyrkacz (1977) studied two populations of L.t. triangulum in Illinois that occupied abandoned quarries that were used extensively by humans as dumps. These snakes were regularly found under man-made debris such as car hoods, plyboard, and carpet. Barten (1981) even described finding a pregnant female under a lawnmower in North Carolina. Although mostly active at night when temperatures range $18^{\circ}-26^{\circ} \mathrm{C}\left(64^{\circ}-79^{\circ} \mathrm{F}\right)$, milksnakes may be observed in daylight particularly when the ground is wet (Hammerson 1999, Werner et al. 2004). Milksnakes will emerge from hibernation in April or May and breed shortly after. Males can be quite aggressive during mating often biting the neck of the female during copulation (Fitch and Fleet 1970, Hammerson 1999). Adults are sexually mature at 3-4 years (Fitch and Fleet 1970). Females will lay 4-13 eggs, sometimes communally, during late June or early July under cover or in burrows. (Fitch and Fleet 1970, Dyrkacz 1977, Henderson et al. 1980, Werner et al. 2004). Newborns will emerge in late summer and likely will not feed prior to hibernation (Fitch and Fleet 1970, Groves and Sachs 1973, Tryon and Murphy 1982). Movement data for milksnakes are limited, however, adults in Kansas moved 76-396 m (250-1,300 ft) in a season and were estimated to have home ranges 20 ha (50 ac) in size (Fitch and Fleet 1970). Milksnakes return to hibernacula in October and may overwinter with other species of snakes (Hammerson 1999). Descriptions of den sites are limited but Henderson et al. (1980) discovered milksnakes denning in an embankment of a railroad track and Hammerson (1999) noted discovery of milksnakes emerging from a den in a rock crevice in Colorado. Abandoned rodent burrows are likely used for overwintering as well (Degenhardt et al. 1996). Milksnakes are opportunistic predators that forage widely in their search for prey. Milksnakes will constrict larger prey or eat smaller prey without constriction (Werner et al. 2004). Fitch and Fleet (1970) found that milksnakes in 
Kansas largely consumed skinks (Eumeces spp.), but they also ate small mammals such as deer mice (Peromyscus maniculatus). Mendoza and Ruiz-Pina (1995) found evidence of milksnake predation on shrews (Sorex sp.). Hammerson (1999) noted that several studies have recorded milksnake consumption of bird and reptile eggs and Werner et al. (2004) report that earthworms and even insects can make up a portion of the milksnakes' diet. Small mammals are major food items in the diet of the larger subspecies L. t. triangulum (Williams 1988). Werner et al. (2004) cite raptors, coyotes (Canis latrans), and badgers (Taxidea taxus) as likely predators of milksnakes. In addition, Gurrola-Hidalgo and Chavez (1996) observed a gray hawk (Buteo nitidus) capture and eat a L. t. nelsoni. Milksnakes are non-venomous, but will coil their bodies, vibrate their tails, and even strike when threatened (Werner et al. 2004). However, some subspecies of $L$. triangulum will use their tails as decoys to avoid predation. For example, Smith (2001) observed a threatened individual weave through vegetation in a manner that made the tail of the animal appear as the head region. Most large individuals in the wild are 6-10 years old while milksnakes in captivity may live to 20 years (Fitch and Fleet 1970, Hammerson 1999).

\section{Status and Conservation}

The milksnake is considered a Species of Concern by Montana Department of Fish, Wildlife, and Parks and the Montana Natural Heritage Program. Milksnakes have been documented only on the east side on the Continental Divide in Montana and the distribution of milksnakes in the state is based on a small number of specimens (Maxell et al. 2003). There is no information on the status of milksnake populations in Montana. Because of its nocturnal habits and relatively low human density in its region of occurrence, the milksnake may be more common than records indicate (Werner et al. 2004). Little is known about overwintering sites of milksnakes. However, because of the concentration of possibly large numbers of individuals and their inability to move about at cold temperatures, disturbance to hibernacula can negatively impact milksnakes. Furthermore, milksnakes are thought to hibernate with other snake species (Werner et al. 2004) making hibernacula important for overall snake conservation. Snake mortality on roadways, at times in great numbers, has been documented widely with some drivers even purposely swerving to kill snakes (Langley et al. 1989, Krivda 1993, Rosen and Lowe 1994, Hammerson 1999). Drykacz (1977) recorded instances of milksnakes being killed on roadways in Illinois and Mendoza and Ruiz Pina (1995) found a road-killed individual in Mexico. Milksnakes have been found on roadways at night (Hammerson 1999) and may be attracted to these areas because of their retained heat from the afternoon's sun (Henderson et al. 1980). In general, snakes near human population centers or areas with high levels of recreational use can experience mortality from humans, predation from pets or even predation from small carnivores that can exist at higher densities near human concentrations (Maxell and Hokit 1999). A general lack of knowledge about snakes coupled with deeply anchored fears sometimes leads humans to destroy snakes on sight, regardless of the species (Dodd 1993, Maxell and Hokit 1999). Hammerson (1999) documented snake mortality, at times quite brutal, at campgrounds and human recreation sites in Colorado. In addition, popular large-scale rattlesnake roundups are known to kill not only thousands of the targeted species, but also many other incidental species as well (Weir 1992, Arena et al. 1995). Chemical contamination may adversely affect snakes (Werner et al. 2004), however changes in agricultural practices and federal laws can sometimes mitigate these impacts. For example, DDT levels in snakes have declined since the banning of the pesticide (Fleet and Plapp 1978). Snakes may harbor pollutants indicative of overall environmental health (Bauerle et al. 1975, Stafford et al. 1976, Anderson 1977), thereby adding to the value of their 
conservation and persistence. Arguments for snake conservation have also been made on the basis of controlling rodent populations and hence, diseases, such as plague and hantavirus (Degenhardt et al. 1996).

\section{$\underline{\text { Research and Management Suggestions }}$}

1. If location is known, protect hibernation sites from disturbance or destruction.

2. Outreach programs that provide the public with scientifically accurate and lucid information about snakes should be encouraged and supported whenever possible.

3. Determining the distribution of milksnakes throughout the state would be beneficial. This could be done through active inventory efforts and increased reporting of sightings from resource managers and the public.

4. The lack of research on milksnakes in the wild is startling. Research that explores any aspect of wild milksnake ecology would enhance our understanding of this species. Studies that explore overwintering behavior and sites, foraging behavior, dispersal, survival, and breeding habits would be most beneficial initially.

Bibliography *indicates an article with information specific to Montana

*Anderson, M.E. 1977. Aspects of the ecology of two sympatric species of Thamnophis and heavy metal accumulation within the species. M.S. Thesis. University of Montana. Missoula, MT.

Arena, P. C., C. Warwick, and D. Duvall. 1995. Rattlesnake round-ups. Pp. 313-324. In: Wildlife and recreationists: Coexistence through management and research. R. L. Knight and K. J. Gutzwiller, eds. Island Press. Washington, D.C.

Armstrong, M. P., D. Frymire, and E. J. Zimmerer. 2001. Analysis of sympatric populations of Lampropeltis triangulum syspila and Lampropeltis triangulum elapsoides, in western Kentucky and adjacent Tennessee with relation to the taxonomic status of the scarlet kingsnake. Journal of Herpetology 35:688-693.

Badman, J.A., L. Neinaber, D.F. DeNardo, and A.T. Holycross. 2003. Milksnakes (Lampropeltis triangulum) from Cochise County: notes on captive breeding and pattern. Sonoran Herpetologist 16(2):15.

Barten, S.L. 1981. Reproduction of Lampropeltis triangulum elapsoides from Onslow County, North Carolina. Herpetological Review 12(2): 62.

Bauerle, B., D.L. Spencer, and W. Wheeler. 1975. The use of snakes as a pollution indicator species. Copeia. 1975(2): 366-368.

Blair, K.B., H.M. Smith, and D. Chiszar. 1994. Albinism and distributional records for Lampropeltis triangulum (Reptilia: Serpentes) in Panhandle Texas. Bulletin of the Maryland Herpetological Society 30(1): 1-5.

Blanchard, F.N. 1920. A synopsis of the king snakes: genus Lampropeltis, Fitzinger. Occassional Papers Museum of Zoology, University of Michigan 87: 1-7.

Blanchard, F.N. 1921. A revision of the king snakes: genus Lampropeltis. United States National Museum Bulletin 114: 1-260.

Blatchford, D. 1985. The Jalisco milk snake (Lampropeltis triangulum arcifera). Herptile 10(3): 85-89.

Blaney, R.M. 1973. Lampropeltis. Catalogue of American Amphibians and Reptiles 150.1150.2 . 
Boundy, J. 1994a. County records for Texas amphibians and reptiles. Herpetological Review 25(3): 129.

Boundy, J. 1994b. Range extensions for Louisiana amphibians and reptiles. Herpetological Review 25(3): 128-129.

*Brunson, R.B. 1955. Check list of the amphibians and reptiles of Montana. Proceedings of the Montana Academy of Sciences 15: 27-29.

Burger, J. 1990a. Effects of incubation temperature on behavior of young black racers (Coluber constrictor) and kingsnakes (Lampropeltis getulus). Journal of Herpetology 24(2): 158-163.

Chiszar, D. and H.M. Smith. 1992b. Lampropeltis triangulum celaenops (New Mexico milk snake). Herpetological Review 23(4): 124.

Cohen, H.J. 1987. Lampropeltis triangulum hondurensis (Honduran milk snake). Maximum size. Herpetological Review 18(2): 36.

Cohen, H.J. 1987. Life history notes, Lampropeltis triangulum hondurensis (Honduran milk snake). Maximum size. Herpetological Review 18(2): 36.

Collins, J.T., S.L. Collins, and K.J. Irwin. 1993. Lampropeltis triangulum (milk snake). Herpetological Review 24(3): 110.

*Cope, E.D. 1861. Catalogue of the Colubridae in the museum of the Academy of Natural Sciences of Philadelphia. Part 3. Proceedings of the Academy of Natural Sciences Philadelphia 12: 553-566.

*Cope, E.D. 1875. Check-list of North American Batrachia and Reptilia; with a systematic list of the higher groups, and an essay on geographical distribution. U.S. National Museum Bulletin 1(1): 1-104.

*Coues, E. and H.C. Yarrow. 1878. Notes on the herpetology of Dakota and Montana. Bulletin of the U.S. Geologic and Geographic Survey 4(1): 259-291.

Cox, T.M. 1983. A review of "pattern variation and evolution of the mountain kingsnake, Lampropeltis zonata" (by R.G. Zweifel) and a discussion of the relationship between $L$. zonata and L. triangulum. Northern Ohio Association Herpetology Notes 10(6): 14-17.

Dean, J.N., J.L. Glenn, and R.C. Straight. 1980. Bilateral cleft labial and palate in the progeny of a Crotalus viridis viridis Rafinesque. Herpetological Review 11(4): 91-92.

Degenhardt, W.G., C.W. Painter, and A.H. Price. 1996. Amphibians and reptiles of New Mexico. Albuquerque, NM: University of New Mexico Press. 431 p.

*Dood, A.R. 1980. Terry Badlands nongame survey and inventory final report. Montana Department of Fish, Wildlife, and Parks and Bureau of Land Management, Helena, MT. 70 p.

Dodd, C.K., Jr. 1993. Strategies for snake conservation. Pp. 363-393. In: R.A. Seigel and J.T. Collins (eds). Snakes - ecology and behavior. New York, NY: McGraw-Hill. 414 p.

Dyrkacz, S. 1977. The natural history of the eastern milk snake (Reptilia, Serpentes, Colubridae) in a disturbed environment. Journal of Herpetology 11(2): 155-159.

*Ernst, C.H. and E.M. Ernst. 2003. Snakes of the United States and Canada. Washington D.C.: Smithsonian Books.

Ewing, P.J., M.D. Setser, E.L. Stair, B. Waurzyniak, and R.L. Cowell. 1991. Myxosarcoma in a Sinaloan milksnake. Journal of the American Veterinary Medical Association 199(12): 1775-1776.

Fitch, H.S. and R.R. Fleet. 1970. Natural history of the milk snake (Lampropeltis triangulum) in northeastern Kansas. Herpetologica 26: 387-396. 
*Flath, D.L. 1998. Species of special interest or concern. Montana Department of Fish, Widlife and Parks, Helena, MT. March, 1998. 7 p.

Fleet, R.R., and F.W. Plapp, Jr. 1978. DDT residues in snakes decline since DDT ban. Bulletin of Environmental Contaminants and Toxicology. 19: 383-388.

Frost, D.R., and J.T. Collins. 1988. Nomenclatural notes on reptiles of the United States. Herpetological Review 19(4): 73-74.

Fuller, S. 1981. Simultaneous copulation by Mexican milk snakes. Northern Ohio Association Herpetology Notes 8(6): 7.

Fuller, S. 1982. Successful treatment of eastern milk snake (Lampropeltis t. triangulum) with "emtryl." Northern Ohio Association Herpetology Notes 10(3): 11.

Garrett, C.M. 1992. Lampropeltis triangulum amaura (Louisiana milk snake). Herpetological Review 23(1): 27.

*Gates, M.T. 2005. Amphibian and reptile baseline survey: CX field study area. Report to Billings and Miles City Field Offices of Bureau of Land Management. Maxim Technologies, Billings, MT. 28pp + Appendices.

Gertler, P.E. and J.Morales. 1980. Snake predation on Marmosa noctivaga. Journal of Mammalogy 61(2): 381.

Gillingham, J.C., C.C. Carpenter, B.J. Brecke, and J.B. Murphy. 1977. Courtship and copulatory behavior of the Mexican milk snake, Lampropeltis triangulum sinaloae (Colubridae). Southwestern Naturalist 22(2): 187-194.

Grogan, W.L., Jr. 1985. New distributional records for Maryland reptiles and amphibians. Bulletin of the Maryland Herpetological Society 21(2): 74-75.

Groves, J.D. and P.S. Sachs. 1974. Eggs and young of the scarlet king snake, Lampropeltis triangulum elapsoides. Journal of Herpetology 7(4): 389-390.

Gurrola, H.M.A. and C.N. Chavez. 1996. Serpentes: Lampropeltis triangulum nelsoni (milk snake). Predation. Herpetological Review 27(2): 83.

Hammack, S.H. 1989. Reproduction of the Colombian milk snake, Lampropeltis triangulum andesiana at the Dallas zoo. International Zoo Yearbook 28: 172-177.

Hammerson, G.A. 1999. Amphibians and reptiles in Colorado. University Press of Colorado. Niwot, CO. 484 pp.

*Hart, M.M., W.A. Williams, P.C. Thornton, K.P. McLaughlin, C.M. Tobalske, B.A. Maxell, D.P. Hendricks, C.R. Peterson, and R.L. Redmond. 1998. Montana atlas of terrestrial vertebrates. Montana Cooperative Wildlife Research Unit, The University of Montana. Missoula, Montana vii +1302 p.

*Hayden, F.V. 1858. Catalogue of the collections in geology and natural history, obtained by the expedition under command of Lieutenant G.K. Warren, Topographical Engineers. pp. 104-105. In: F.N. Shubert (1981) Explorer on the northern plains: Lieutenant Gouverneur K. Warren's preliminary report of explorations in Nebraska and Dakota, in the years 1855-'56'57. Engineer Historical Studies No. 2. Office of the Chief of Engineers, Washington, DC. $125 \mathrm{p}$.

*Hayden, F.V. 1863. On the geology and natural history of the upper Missouri. Transactions of the American Philosophical Society New Series 12(1): 1-218 (pages 177-178).

Hecht, M.K., and D. Marien. 1956. The coral snake mimic problem: a reinterpretation. Journal of Morphology. 98: 335-365. 
Hedges, S.B. 1977. The presence of the scarlet kingsnake, Lampropeltis triangulum elapsoides holbrook (Reptilia, Serpentes, Colubridae), in the Florida Keys. Herpetological Review 8(4): 125-126.

Heinrich, M.L. and H.E. Klaassen. 1985. Side dominance in constricting snakes. Journal of Herpetology 19(4): 531-533.

Henderson, R.W., M.H. Binder, R.A. Sajdak, and J.A. Buday. 1980. Aggregating behavior and exploitation of subterranean habitat by gravid eastern milksnakes (Lampropeltis $t$. triangulum). Milwaukee Public Musuem Contributions to Biology and Geology 32: 9p.

*Hendricks, P. 1999. Amphibian and reptile survey of the Bureau of Land Management Miles City District, Montana. Montana Natural Heritage Program, Helena, MT. 80 p.

Herman, D.W. 1979. Captive reproduction in the scarlet kingsnake, Lampropeltis triangulum elapsoides (Holbrook). Herpetological Review 10(4): 115.

Hibbitts, T.D., M.P. Hibbitts, and T.J. Hibbitts. 1996. New distributional records of reptiles from western and trans-Pecos Texas, USA. Herpetological Review 27(4): 217-218.

Hingley, K.J. 1987. The eastern milk snake: Lampropeltis t. triangulum. Snake Keeper 1(11): 4.

Hingley, K.J. 1991. Failure to breed the Mexican milk snake, Lampropeltis triangulum annulata. Herptile 16(3): 123-124.

Hoberg, T. and C. Gause. 1989. Reptiles \& amphibians of North Dakota. North Dakota Outdoors 55(1):7-18.

Holycross, A.T. and C. Schwalbe. 1995. Lampropeltis triangulum (milk snake). Herpetological Review 26(1): 46.

Howard, C.J. 1985. Husbandry and breeding of the Honduran milk snake (Lampropeltis triangulum hondurensis) at Twycross Zoo. Herptilological Review. 10(3): 81-84.

Irwin, K.J. and S.L. Collins. 1996. Lampropeltis triangulum (milk snake). Herpetological Review 27(1): 34.

Kamb, A.H. 1978. Unusual feeding behavior of the red milk snake, Lampropeltis triangulum syspila (lacepede). Transactions of the Kansas Academy of Science 81(3): 273.

*Kennicott, R. 1860. Descriptions of new species of North American Serpents in the Museum of the Smithsonian Institution, Washington. Proceedings of the Academy of Natural Sciences of Philadelphia 12: 328-338.

Kirkwood, J.K. and C. Gili. 1994. Food consumption in relation to bodyweight in captive snakes. Research in Veterinary Science 57(1): 35-38.

Klaphake, E., C. Cross, S. Patton, and L. Head. 2005. Gastric impaction in a milk snake, Lampropeltris triangulaum, caused by Kalicephalus sp. Journal of Herpetological Medicine and Surgery 15(1):21-23.

Klein, J. 1975. Headfirst prey ingestion by newborn Elaphe and Lampropeltis. Copeia 1975: 366.

Klemens, M.W. 1995. New distributional records of amphibians and reptiles from New Hampshire. Herpetological Review 26(1): 49.

Kraus, F. and G.W. Schuett. 1981. An intergrade Lampropeltis triangulum from west Texas. Herpetological Review 12(2): 53.

Krivda, W. 1993. Road kills of migrating garter snakes at The Pas, Manitoba. Blue Jay. 51(4): 197-198. 
Lane, M. and D. Schwab. 1986. Field notes: Lampropeltis t. triangulum X L. t. elapsoides (coastal plains milksnake): City of Suffolk, the Great Dismal Swamp National Wildlife Refuge, Hudnell Ditch, 1.7 km S. of New Ditch. April 15, 1986. Catesbeiana 6(2): 14.

Langley, W.M., H.W. Lipps, and J.F. Theis. 1989. Responses of Kansas motorists to snake models on a rural highway. Transactions of the Kansas Academy of Science. 92(1-2): 43-48.

*Martin, P.R. 1980b. Terrestrial wildlife inventory in selected coal areas of Montana. Montana Department of Fish, Wildlife and Parks and Bureau of Land Management, Helena, MT. 84 p.

*Martin, P.R., K. Dubois and H.B. Youmans. 1981. Terrestrial wildlife inventory in selected coal areas, Powder River resources area final report. Montana Department of Fish, Wildlife and Parks and Bureau of Land Management, Helena, MT. 288 p.

*Matthews, W.L. 1981. Broadus-Pumpkin Creek baseline inventory - wildlife. Bureau of Land Management, Miles City, MT. 83 p.

*Maxell, B.A. 2004a. Preliminary report on amphibian and aquatic reptile inventories conducted on and around the Ashland District of the Custer National Forest in 2002 and 2004. Report to Ashland District of Custer Forest, Region 1 Office of the U.S. Forest Service, and Montana Department of Fish, Wildlife, and Parks. Missoula, MT: Montana Cooperative Wildlife Research Unit and Wildlife Biology Program, University of Montana. 93 p.

*Maxell, B.A. 2004b. Report on amphibian and aquatic reptile inventories conducted on and around the Beaverhead-Deerlodge National Forest 2001-2003. Report to Region 1 Office of the U.S. Forest Service, Beaverhead-Deerlodge National Forest, Montana Department of Fish, Wildlife, and Parks, Montana State Office of the Bureau of Land Management, and Montana Department of Environmental Quality. Missoula, MT: Montana Cooperative Wildlife Research Unit and Wildlife Biology Program, University of Montana. 260 p.

*Maxell, B.A. 2009. State-wide assessment of status, predicted distribution, and landscapelevel habitat suitability of amphibians and reptiles in Montana. Ph.D. Dissertation. Missoula, MT: Wildlife Biology Program, University of Montana. 294 p.

*Maxell, B.A. and D.G. Hokit. 1999. Amphibians and reptiles. Pp. 2.1- 2.30. In: G. Joslin and H. Youmans (committee chairs). Effects of recreation on Rocky Mountain wildlife: a compendium of the current state of understanding in Montana. Helena, MT: Committee on Effects of Recreation on Wildlife, Montana Chapter of the Wildlife Society. 307 p.

*Maxell, B.A., J.K. Werner, P. Hendricks, and D. Flath. 2003. Herpetology in Montana: a history, status summary, checklists, dichotomous keys, accounts for native, potentially native, and exotic species, and indexed bibliography. Olympia, WA: Society for Northwestern Vertebrate Biology. Northwest Fauna 5: 1-138.

McAllister, C.T., R. Ward, and K.L. Williams. 1987. Noteworthy milk snakes (Lampropeltis triangulum) from Texas. Southwestern Naturalist 32(3): 406-408.

McCrystal, H.K., R.H. Dean, and J.R. Dixon. 1984. Lampropeltis triangulum annulata (Mexican milk snake). Size. Herpetological Review 15(1): 19.

*McEneaney, T. and J. Jensen. 1974. The reptiles and amphibians of the Charles M. Russell National Wildlife Range - 1974. Charles M. Russell National Wildlife Refuge. Lewistown, MT. 3 p.

Mendoza Quijano, F., and C.A. Rodriguez Yanez. 1992. Lampropeltis triangulum smithi (ncn). Size. Herpetological Review 23(4): 120. 
Mendoza, Q.F. and H.A. Ruiz-Pina. 1995. Serpentes: Lampropeltis triangulum smithi. (Smith's Milk Snake). Prey. Herpetological Review 26(3): 148-149.

Mendoza, Q.F. and Y.C.A. Rodriguez. 1992. Lampropeltis triangulum smithi (NCN). Size. Herpetological Review 23(4): 120.

Mendoze, Q.F. and P.H.A. Ruiz. 1995. Lampropeltis triangulum smithi. (Smith's milk snake). Prey. Herpetological Review 26(3): 148-149.

Michaels, S.J. 1989. Some observations on multiple egg clutches and a case of delayed fertilization in a colony of captive Pueblan milk snakes, Lampropeltis triangulum campbelli. Bulletin of the Chicago Herpetological Society 24(6): 109-111.

Miller, R. and G. Grall. 1978. Reproductive data on Lampropeltis triangulum temporalis from Maryland. Bulletin of the Maryland Herpetological Society 14(1): 36-38.

Mitchell, J.C. 1980. Notes on Lampropeltis triangulum (Colubridae) from northern Jalisco, Mexico. Southwestern Naturalist 25(2): 269.

Mount, R.H. 1986b. Eastern milk snake. pp 68-69. In: Mount, R.H. [Ed.] Vertebrate animals of Alabama in need of special attention. Alabama Agricultural E xperiment Station, Auburn, Alabama. 124 p.

Mount, R.H. 1986d. Red milk snake. pp. 69 In: Mount, R.H. [Ed.] Vertebrate animals of Alabama in need of special attention. Alabama Agricultural Experiment Station, Auburn, Alabama. 124 p.

*Nelson, D.J. 1948. Lampropeltis triangulum gentilis in Montana. Herpetologica 4: 170.

*Nelson, D.J. 1950. Lampropeltis triangulum gentilis in Montana. Herpetologica 6: 41.

Norrie, S.G. 1985. Comparisons between the natural and captive environments of the Sinaloan milk snake (Lampropeltis triangulum sinaloae). Herpetological Review 10(3): 90-92.

Painter, C.W. and R.D. Jennings. 1996. Lampropeltis triangulum celaenops (New Mexico milk snake). Herpetological Review 27(4): 213.

Parmley, D. 1994. Reevaluation of the extinct kingsnake Lampropeltis intermedius Brattstrom (Colubridae) with comments on the ancestry of Lampropeltis triangulum. Herpetological Natural History 2(2): 83-84.

Perez-Higareda, G. and H.M. Smith. 1987. Geographic distribution, Lampropeltis triangulum polyzona (Veracruz milk snake). Herpetological Review 18(2): 41.

Peters, J.A., and M.B. Orejas. 1986. Part 1. Snakes. Peters, J.A., Donoso-Barros, R., OrejasMiranda, B. \& Vanzolini, P.E. Catalogue of the Neotropical Squamata. Smithsonian Institution Press, Washington, D.C. \& London. 347 p.

Peterson, K.H., D. Lazcano, G.R.D. Jacobo. 1995. Captive reproduction in the Mexican milksnake Lampropeltis triangulum annulata. Litteratura Serpentium English Edition 15(5): 128-132.

*[PRESI] Powder River Eagle Studies Incorporated. 1998a. Big Sky Mine 1997 wildlife monitoring studies. Powder River Eagle Studies Inc. Gillete, WY.

*[PRESI] Powder River Eagle Studies Incorporated. 1998b. Spring Creek Mine 1997 wildlife monitoring studies. Powder River Eagle Studies Inc. Gillete, WY. Quinn, H.R. 1983. Two new subspecies of Lampropeltis triangulum from Mexico. Transactions of the Kansas Academy of Science 86(1): 113-135.

Rau, M.E., J. Doyle, and D. Gordon. 1978. The parasites of the wild animals of Quebec. 2. The parasites of frogs and snakes of the Ile Perrot region. Naturaliste Canadien 105(1): 56-57.

Rehak, I. 1985. The scarlet king snake Lampropeltis triangulum elapsoides. Akvarium Terarium 28(4): 31-32. 
Rehak, I. 1988. On the species of king snake Lampropeltis triangulum. Akvarium Terarium 31(2): 24-25.

Rehak, I. 1990. Bionomics of Lampropeltis triangulum hondurensis in captivity. Akvarium Terarium 33(7): 24-26.

*Reichel, J.D. 1996b. Preliminary amphibian and reptile survey of the Helena National Forest: 1995. Montana Natural Heritage Program, Helena, MT. 87 p.

*Roedel, M.D. and P. Hendricks. 1998a. Amphibian and reptile survey on the Bureau of Land Management Lewistown District: 1995-1998. Montana Natural Heritage Program, Helena, MT. 53 p.

*Roedel, M.D. and P. Hendricks. 1998b. Amphibian and reptile inventory on the Headwaters and Dillon Resource Areas in conjunction with Red Rocks Lakes National Wildlife Refuge: 1996-1998. Montana Natural Heritage Program, Helena, MT. 46 p.

Rodríguez, M.C. and H. Drummond. 2000. Exploitation of avian nestlings and lizards by insular Milksnakes, Lampropeltis triangulum. Journal of Herpetology 34(1):139-142.

Rosen, P.C., and C.H. Lowe. 1994. Highway mortality of snakes in the Sonoran desert of southern Arizona. Biological Conservation. 68: 143-148.

Roth, J.J. and H.M. Smith. 1990b. The milksnake, Lampropeltis triangulum, in northwest Colorado. Bulletin of the Chicago Herpetological Society 25(1): 6-7.

Schaefer, K., D. Chiszar, and H.M. Smith. 1995. Lampropeltis triangulum gentilis (central plains milk snake). Herpetological Review 26(2): 110.

Schuett, G.W. 1994. Lampropeltis triangulum (milk snake). Herpetological Review 25(4): 167. Setser, K.W., D.G. Mulcahy, and B.L. Williams. 2003. Lampropeltis triangulum (Milk Snake). Herpetological Review 34(2):150.

Sharp, S. and M. Dobson. 1993. The Honduran milksnake, Lampropeltis triangulum hondurensis. Herptile 18(2): 65-68.

Smith, H.M., C. Ristau, T. Bell, M. Bell, and D. Chiszar. 1995. Serpentes: Lampropelitis triangulum multistriata X Taylori (pale X Utah milk snake intergrade). Herpetological Review 26(4): 210.

Smith, K.G. 2001. Lampropeltis triangulum triangulum (Eastern milk snake) antipredator behavior. Herpetological Review 32(4): 263-264.

*St. John, A. 2002. Reptiles of the Northwest: California to Alaska; Rockies to the Coast. Renton, WA: Lone Pine Publishing. 272 p.

Stafford, D.P., F.W. Plapp, Jr., and R.R. Fleet. 1976. Snakes as indicators of environmental contamination: relation of detoxifying enzymes and pesticide residues to species occurrence in three aquatic ecosystems. Archives of Environmental Contamination and Toxicology. 5: $15-27$.

*Stebbins, R.C. 2003. A field guide to western reptiles and amphibians. 3rd edition. New York, NY: Houghton Mifflin Co. 533 p.

Strimple, P. 1991. Captive reproduction in the scarlet kingsnake, Lampropeltis triangulum elapsoides (Holbrook, 1838). Litteratura Serpentium English Edition 11(3): 50-52.

*Tanner, W.W. and R.B. Loomis. 1957. A taxonomic and distributional study of the western subspecies of the milk snake, Lampropeltis doliata. Transactions of the Kansas Academy of Science 60(1): 12-42.

Tryon, B.W. and J.B. Murphy. 1982. Miscellaneous notes on the reproductive biology of reptiles. 5. Thirteen varieties of the genus Lampropeltis, species mexicana, triangulum and zonata. Transactions of the Kansas Academy of Science 85(2): 96-119. 
Upton, S.J., C.T. McAllister, P.S. Freed, and S.M. Barnard. 1989. Cryptosporidium spp. in wild and captive reptiles. Journal of Wildlife Diseases 25(1): 20-30.

Van der Rijst, H. 1992. A colourful mistake. On coral snakes, king snakes and Erythrolamprus. Nordisk Herpetologisk Forening 35(1): 4-7.

Vance, T. 1994. Lampropeltis triangulum amaura (Louisiana milk snake). Herpetological Review 25(2): 77.

Van Devender, R.W. and P.F. Nicoletto. 1983. Lower Wilson Creek, Caldwell County, North Carolina (USA): A thermal refugium for reptiles? Brimleyana 0(9): 21-32.

*Vitt, L.J., J.P. Caldwell, and D.B. Shepard. 2005. Inventory of amphibians and reptiles in the Billings Field Office Region, Montana. Sam Noble Oklahoma Museum of Natural History and Department of Zoology, University of Oklahoma, Norman, OK. 33 p.

Vojtisek, V. 1994. Incubation of the eggs of Lampropeltis triangulum sinaloae. Akvarium Terarium 37(7): 34-37.

Vojtisek, V. 1995. Periodic molting in the milk snake Lampropeltis triangulum sinaloae. Akvarium Terrarium 38(6): 32-33.

*Waage, B.C. 1998. Western Energy Company Rosebud Mine 1997 annual wildlife monitoring report December 1, 1996 to November 30, 1997 survey period. Western Energy Company, Colstrip, MT.

Wagner, E. 1982. Lampropeltis triangulum (milk snake). Coloration. Herpetological Review 13(1): 18.

Weinstein, S.A., C.F. Dewitt, and L.A. Smith. 1992. Variability of venom-neutralizing properties of serum from snakes of the colubrid genus Lampropeltis. Journal of Herpetology 26(4): 452-461.

Weir, J. 1992. The Sweetwater rattlesnake round-up: A case study in environmental ethics. Conservation Biology. 6: 116-127.

*Werner, J.K., B.A. Maxell, P. Hendricks, and D. Flath. 2004. Amphibians and reptiles of Montana. Missoula, MT: Mountain Press Publishing Company. 262p.

Whipple, J.F. and J.T. Collins. 1988. First complete clutch record for the central plains milk snake (Lampropeltis triangulum gentilis) in Kansas. Transactions of the Kansas Academy of Science 91(3-4): 187-188.

*Williams, K.L. 1970. Systematics of the colubrid snake Lampropeltis triangulum Lacepede. Ph.D. Dissertation. Louisiana State University. 369 p.

*Williams, K.L. 1978. Systematics and natural history of the American milk snake, Lampropeltis triangulum. Milwaukee Public Musuem Contributions to Biology and Geology 2:1-258.

*Williams, K.L. 1988. Systematics and natural history of the American milksnake, Lampropeltis triangulum. Second revised edition. Milwaukee Public Museum, Milwaukee, WI. $175 \mathrm{p}$.

*Williams, K.L. 1989. Systematics and natural history of the American milksnake, Lampropeltis triangulum. Second revised edition. 192 pp.

*Williams, K.L. 1994. Lampropeltis triangulum. Catalogue of American Amphibians and Reptiles 594.1-594.10.

Winstel, A. 1987. Captive breeding and rearing of the eastern milk snake, Lampropeltis $t$. triangulum. Northern Ohio Association Herpetology Notes 15(1): 9-10.

Winstel, A. 1991. Captive husbandry of the eastern milk snake (Lampropeltis t. triangulum). Vivarium 2(6): 16-17, 28. 
*Yarrow, H.C. 1882. Check list of North American reptilia and batrachia, with catalogue of specimens in the U.S. National Museum. United States National Museum Bulletin 24. 249 p.

Yeomans, L. 1988. Care and breeding of the Honduran milk snake - (Lampropeltis triangulum hondurensis) - and a case of dicephalism. Herpetological Review 13(1): 5-8. 


\section{Gophersnake (Pituophis catenifer)}

Up-to-date distribution and status information can be found on the Montana Natural Heritage Program’s TRACKER website at http://mtnhp.org

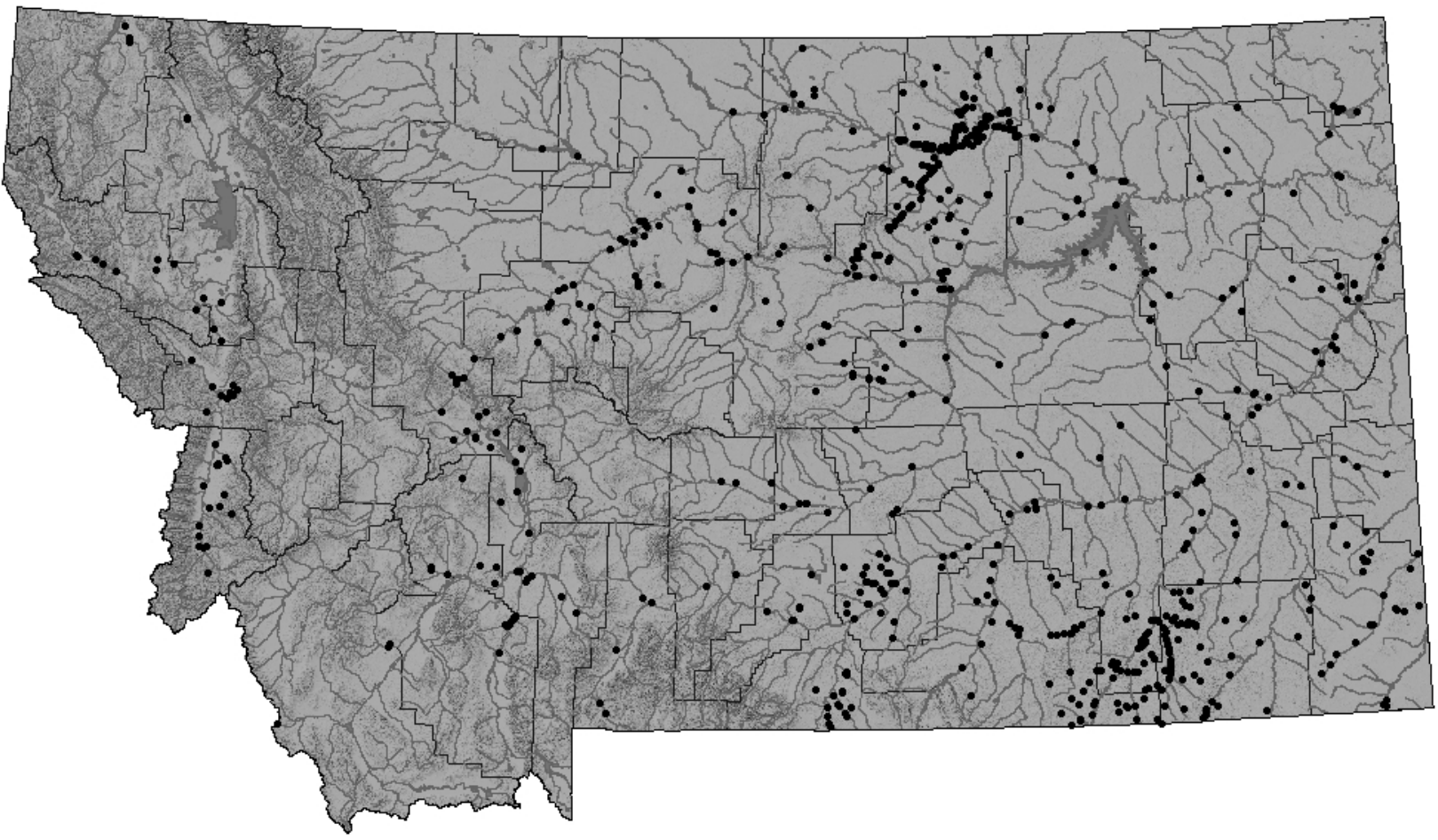

Distribution/Taxonomy

Gophersnakes, or bullsnakes, range from southern Alberta and Saskatchewan into Montana, across the central U.S. into the desert Southwest and California. They also inhabit most of Oregon and the eastern half of Washington (Werner et al. 2004). There is much debate about subspecies designations within $P$. catenifer and $P$. melanoleucus, in fact, some scientists consider the Montana gophersnake a subspecies of P. melanoleucus (Hammerson 1999, Rodriguez-Robles and De Jesus-Escobar 2000, Werner et al. 2004). In addition, several subspecies of $P$.

melanoleucus are distributed throughout the U.S. with pockets reaching as far as New Jersey and Florida (Conant and Collins 1998). We consider P. catenifer the species found in Montana and it has been documented in 42 counties.

Maximum Elevation

2,225 m (7,300 ft) in Beaverhead County (Barbara Garcia, pers. com., MTNHP 2007).

\section{Identification}

\section{Eggs:}

Oval and white with a leathery shell. Eggs are sticky, will adhere to one another, and are typically $2.5 \mathrm{~cm}$ (1 in.) wide and 5-7 cm (2-2.75 in.) long and weigh approximately $25 \mathrm{~g}$ (Imler 1945, Gutzke et al. 1985, Hammerson 1999, Werner et al. 2004). Clutch size is variable ranging between 2-24 eggs (Degenhardt et al. 1996, Werner et al. 2004) and is positively correlated with female body size (Imler 1945, Nussbaum et al. 1983, Diller and Wallace 1996).

Young:

Newborns resemble adults although key characteristics are not as easily discernible (Werner et al 
2004). Weight for hatchlings ranges from $12-22 \mathrm{~g}$ and total length is $36-51 \mathrm{~cm}$ (14-20 in.) (Imler 1945, Nussbaum et al. 1983, Diller and Wallace 1996, Werner et al. 2004).

Adults:

Adults are tan/brown, with black, dark brown, or brick red blotches dorsally extending to tail tip. Black blotches also occur on either side and down center of yellow/cream underside. Blotches along side of tail may join giving ringed appearance. Head is slightly wider than body with a small elevated ridge between the eyes and prominent, wedge-shaped scale at the snout tip. Often a vertical black band runs from the eye to the lip and there are black bars where labial (lip) scales meet. Montana's largest snake, adults range 91-152 cm (3-5 ft) with individuals capable of reaching lengths $>243 \mathrm{~cm}(8 \mathrm{ft}$ ) (Nussbaum et al 1983, Degenhardt et al. 1996, Werner et al. 2004). There is no difference in size between sexes (Diller and Wallace 1996).

Similar species:

Prairie Rattlesnakes (Crotalus viridis) have vertical pupils and juvenile racers (Coluber constrictor) are much smaller and have smooth scales dorsally. Gophersnakes may vibrate their tails when provoked, however, there is no morphological rattle present as in the rattlesnake.

\section{Habitat use/Natural History}

Gophersnakes occupy open habitats such as prairie, sagebrush, and drier valley bottoms in Montana. Within fairly open habitats they are generalists and can also be found near buildings, rock piles, and talus (Nussbaum et al. 1983, Diller and Johnson 1988, Diller and Wallace 1996, Werner et al. 2004). Although they have been observed swimming and climbing trees, gophersnakes are largely terrestrial and frequent rodent burrows. An efficient burrower itself, the gophersnake will use its snout to dig and its head to scoop during excavation (Burger and Zappalorti 1986, Hammerson 1999). On hot summer days, $>35^{\circ} \mathrm{C}\left(95^{\circ} \mathrm{F}\right)$, gophersnakes can die in a relatively short time if exposed to direct sun and they will move to shade under vegetation or into burrows (Imler 1945, Werner et al. 2004). Because of the gophersnakes’ preferred body temperature, $30^{\circ} \mathrm{C}\left(86^{\circ} \mathrm{F}\right)$, its activities are usually restricted to mornings and late evenings, but occasionally they will be active on warm nights or relatively cool days (Degenhardt et al. 1996, Diller and Wallace 1996, Hammerson 1999). Gophersnakes will breed soon after emergence from hibernation in April or May. Males will breed in their second or third year, whereas females typically will not breed until at least their third year (Diller and Wallace 1996, Hammerson 1999). In a study of gophersnakes in southwestern Idaho, Diller and Wallace (1996) found that $97 \%$ of females bred annually. Because female gophersnakes lay eggs and do not give birth to live young, they may be less dependent on fat reserves to achieve successful reproduction. This reproductive trait may also result in fecundity parameters being less sensitive to fluctuations in prey abundance (Diller and Wallace 1996). Burger and Zappalorti (1986) found that most female P. m. melanoleucus deposited eggs, which hatch in September/October, within 64 m (210 $\mathrm{ft}$ ) of known hibernacula. P. melanoleucus hatchling behavior, and presumably predation risk, can be affected by incubation temperatures. Hatchlings incubated as eggs at medium temperatures $\left(26^{\circ}, 28^{\circ} \mathrm{C} ; 79^{\circ}, 82^{\circ} \mathrm{F}\right)$ performed better in lab experiments than those incubated at $\operatorname{cool}\left(21^{\circ}, 23^{\circ} \mathrm{C} ; 70^{\circ}, 73^{\circ} \mathrm{F}\right)$ or hot $\left(30^{\circ}, 32^{\circ} \mathrm{C} ; 8^{\circ}, 90^{\circ} \mathrm{F}\right)$ temperatures (Burger 1989b). After breeding, gophersnakes will move to summer range, sometimes at distances of more than $1.6 \mathrm{~km}$ (1.0 mi.) (Imler 1945, Werner et al. 2004). Burger and Zappalorti (1986) noted that male P. $m$.

melanoleucus dispersed farther than females from hibernacula in the Pine Barrens of New Jersey. 
Gophersnakes return to hibernacula in October and communal overwintering is common and can even occur with other species (Brown and Parker 1976, Diller and Wallace 1996, Hammerson 1999). Hibernacula have been found in talus, rock piles, rock crevices, and rodent burrows (Brown and Parker 1976, Herrington 1988, Degenhardt et al. 1996). Gophersnakes and their associated subspecies' will not necessarily avoid human establishments (Hammerson 1999, Burger and Zappalorti 1986) and may overwinter under abandoned buildings and related debris. Although some body mass is lost during hibernation, the majority of adults (75-89\%) survive the winter period while 20-29\% of juveniles survive (Imler 1945, Nussbaum et al. 1983, Hammerson 1999). Gophersnakes are opportunistic predators that forage widely and frequently kill their prey through constriction (Diller and Johnson 1988, Diller and Wallace 1996). Although studies show that gophersnakes consume mainly rodents, Amstrup and McEneaney (1980) noted

gophersnakes preying on long-eared owl (Asio otus) nestlings in Montana and Imler (1945) estimated that in some years bird eggs comprised $60 \%$ of their diet in western Nebraska. Because they are not sedentary predators, gophersnakes can have relatively large home ranges.

Rodriguez-Robles (2003) found home range sizes ranged from 0.9-1.8 ha (2.2-4.4 ac) for 4 adult male gophernsakes in California. Daily movements can be as far as $155 \mathrm{~m}$ (508 ft), with adults capable of moving $2.4 \mathrm{~km}$ (1.5 mi.) in a season (Imler 1945, Werner et al. 2004). A suite of predators will consume gophersnakes, including red-tailed hawks (Buteo jamaicensis), Swainson's hawks (Buteo swainsoni), badgers (Taxidea taxus) and even other snakes (Hammerson 1999). Prairie dogs (Cynomys spp.) and ground squirrels have killed gophersnakes as well, although this was likely a result of self-defense. Gophersnakes can live for over 30 years in captivity and individuals in the wild may live for 15 years (Boundy and O’Brien 1988, Hammerson 1999).

\section{$\underline{\text { Status and Conservation }}$}

Gophersnakes are common and occur on both sides of the Continental Divide in Montana, although most records are from the eastern portion of the state (Maxell et al. 2003). As with other species of snakes, gophersnakes can be impacted by disturbance to their hibernacula and nesting sites. Gophersnakes show substantial site fidelity for overwintering sites year after year and even small disturbances to these sites may negatively impact the snake. At body temperatures of $4^{\circ} \mathrm{C}\left(41^{\circ} \mathrm{F}\right)$ the gophersnake's ability to move is wholly impaired (Landreth 1972) and they may not respond to human disturbance as effectively at cooler temperatures, such as the overwintering period, than they would at warmer temperatures (Prior and Weatherhead 1994). In addition, both $P$. catenifer and $P$. melanoleucus have been shown to nest communally making these areas important for snake conservation as well (Burger and Zappalorti 1986, Hammerson 1999). However, unless the location is known through research or incidental observations, it is difficult to have a disturbance mitigation measure for nest sites because gophersnakes typically nest in rodent burrows or self-excavated burrows. Roadways and off-road vehicle (ORV) use may impact gophersnakes, particularly if they occur near hibernacula or intersect movement to such areas. Snake mortality on roadways, at times in great numbers, has been documented widely with some drivers even purposely swerving to kill snakes (Langley et al. 1989, Krivda 1993, Rosen and Lowe 1994, Hammerson 1999). In general, snakes near human population centers or areas with high levels of recreational use can experience mortality from humans, predation from pets or even predation from small carnivores that can exist at higher densities near human concentrations (Maxell and Hokit 1999). Hammerson (1999) documented gophersnake mortality, at times quite brutal, at campgrounds and human recreation sites in 
Colorado. At a wildlife refuge in Nebraska, large numbers of gophersnakes were killed by wildlife managers in an effort to increase duck nest productivity (Imler 1945). Gophersnakes are sometimes mistaken for rattlesnakes, but are not venomous, however they can bite when provoked (Arnold 1929). A general lack of knowledge about snakes coupled with deeply anchored fears sometimes leads humans to destroy snakes on sight, regardless of the species (Dodd 1993, Maxell and Hokit 1999). In addition, popular large-scale rattlesnake roundups are known to kill not only thousands of the targeted species, but also many other incidental species including gophersnakes (Weir 1992, Arena et al. 1995). Near homes and construction sites plastic netting, commonly used to protect fruit trees and gardens from pests, has also been found to entangle and kill gophersnakes (Stuart et al. 2001). Although gophersnakes are beneficial to farmers through consumption of agricultural pests, mowing has been shown to kill large numbers (Hammerson 1999). While individual gophersnakes near population centers may experience direct mortality from humans, populations can persist in substantially altered, semi-agricultural landscapes and their associated towns (Hammerson 1999). Farmers may consider gophersnakes beneficial because they consume prey that farmers consider pests, such as deer mice (Peromyscus maniculatus) and ground squirrels (Spermophilus spp.) (Diller and Johnson 1988). Arguments for gophersnake conservation have even been made on the basis of controlling rodent populations and hence, diseases, such as plague and hantavirus (Degenhardt et al. 1996). Chemical contamination may adversely affect snakes (Werner et al. 2004), however changes in agricultural practices and federal laws can sometimes mitigate these impacts. For example, DDT levels in snakes have declined since the banning of the pesticide (Fleet and Plapp 1978). Ohlendorf et al. (1998) found that a population of gophersnakes in California harbored higher than average levels of selenium and postulated that predators of gophersnakes may be negatively affected through consumption of contaminated snakes. Snakes may harbor pollutants indicative of overall environmental health (Bauerle et al. 1975, Stafford et al. 1976, Anderson 1977), thereby adding to the value of their conservation and persistence.

\section{$\underline{\text { Research and Management Suggestions }}$}

1. If location is known, protect hibernation and nesting sites from disturbance or destruction.

2. Whenever possible, avoid disturbance to talus, rock piles, and outcroppings.

3. Outreach programs, especially those reaching farmers, that provide the public with scientifically accurate and lucid information about gophersnakes should be encouraged and supported whenever possible. Emphasizing gophersnakes’ rodent and disease control possibilities is encouraged.

4. Roadways kill large numbers of gophersnakes in some regions. Research that addresses these impacts at a population level and can examine the efficacy of culvert use/mitigations for movement would be beneficial.

Bibliography *indicates an article with information specific to Montana

*Allen, J.A. 1874. Notes on the natural history of portions of Dakota and Montana Territories, being the substance of a report to the Secretary of War on the collections made by the North Pacific Railroad Expedition of 1873, General D.S. Stanley, Commander. Proceedings of the Boston Society of Natural History 17: 33-85. Pages 68-70.

Allen, R. 1996. Profile of the bull snake. Rephiberary 222: 11-12.

*Amstrup, S.C. and T.P. McEneaney. 1980. Bull snake kills and attempts to eat long-eared owl nestlings. Wilson Bulletin 92(3): 402. 
*Anderson, M.E. 1977. Aspects of the ecology of two sympatric species of Thamnophis and heavy metal accumulation within the species. M.S. Thesis. University of Montana, Missoula, MT.

*Arnold, M.L. 1929. Bull snakes do bite! Yellowstone Nature Notes 6(9): 6.

*Atkinson, E.C. and M.L. Atkinson. 2004. Amphibian and reptile survey of the Ashland and Sioux of the Custer National Forest with special emphasis on the Three-Mile Stewardship Area: 2002. Marmot's Edge Conservation. 22 p.

Bartley, G.R. 1996. Successful breeding of: Pituophis melanoleucus affinis. Herptile 21(2): 6166.

Bauer, D. 1997. 1997 wildlife study Savage Mine report. Knife River Corporation, Savage Mine. Richland County, MT.

Bauerle, B.A. 1972. Biological productivity of snakes of the Pawnee site. D.A. Thesis. University of Northern Colorado. 86p.

Beasom, S.L. and O.H. Pattee. 1975. An encounter between a turkey and a Bullsnake. Wilson Bulletin 87(2): 281-282.

Bechtel, E.R. and T. Whitecar. 1983. Genetics of striping in the gopher snake, Pituophis melanoleucus. Journal of Herpetology 17(4): 362-370.

Bechtel, H.B., J.W. Nelson, and E. Bechtel. 1980. Histochemnical demonstration of two types of albinism in San Diego gopher snakes (Pituophis melanoleucus annectens) by use of dopa reaction. Copeia 1980(4): 932-935.

*Bergeron, D.J. 1978a. Terrestrial wildlife survey Divide Mine area, Montana 1977-1978. Western Technology and Engineering, Inc. Helena, MT.

*Bergeron, D.J. 1978b. Terrestrial wildlife survey P-M Mine area, Montana 1977-1978. Western Technology and Engineering, Inc. Helena, MT.

*Bergeron, D.J. 1979. Terrestrial wildlife survey, Coal Creek Mine area, Montana 1977-1978. Western Technology and Engineering, Inc. Helena, MT.

Best, L.B. 1977. Bullsnake preys on rough-winged swallow nest. Condor 79(4): 509.

Birger, J., R.T. Zappalorti, J. Dowdell, T. Geordiadis, J. Hill, and M. Gochfeld. 1992. Subterranean predation on pine snakes (Pituophis melanoleucus). Journal of Herpetology 26(3): 259-263.

Blatchford, D. 1990. The effect of different incubation temperatures on bullsnakes (Pituophis melanoleucus) behavior and physiology.]. Nordisk Herpetologisk Forening 33(6): 173-177.

Bledsoe, B.W. 1979. Life cycle of Sarcocystis sp. in deer mice and gopher snakes. Ph.D. Dissertation. University of Illinois (Urbana-Champaign). 145p.

*BLM. 1982a. Bloomfield - North Fork baseline inventories - wildlife. Bureau of Land Management, Miles City District Office. Miles City, MT. 61 pp.

*BLM. 1982b. Moorhead baseline inventory - wildlife. Bureau of Land Management, Miles City District Office. Miles City, MT. 29 pp.

*Boundy, J. 2001. Herpetofaunal surveys in the Clark Fork Valley region, Montana. Herpetological Natural History 8: 15-26.

Boundy, J. and J.P. O’Brien. 1988. A longevity record for a colubrid snake. Bulletin of the Chicago Herpetological Society 23(7): 107.

Brown, W.S., and W.S. Parker. 1976. Movement ecology of Coluber constrictor near communal hibernacula. Copeia 1976(2): 225-242. 
*Brown, W.S. and W.S. Parker. 1982. Niche dimensions and resource partitioning in a great basin desert snake community. U.S. Fish and Wildlife Service Wildlife Resources Report 13: 59-81.

*Brunson, R.B. 1955. Check list of the amphibians and reptiles of Montana. Proceedings of the Montana Academy of Sciences 15: 27-29.

Bryson, R.W., Jr. 2006. Pituophis catenifer (gopher snake) diet. Herpetological Review 37(1):95.

Bullock, R.E. 1981. Tree climbing bullsnakes. Blue Jay 39(3): 139-140.

Bullock, R.E., and W.W. Tanner. 1966. A comparative osteological study of two species of Colubridae (Pituophis and Thamnophis). Brigham Young University Science Bulletin 8(3): $1-29$.

Burger, J. 1989a. Following of conspecific and avoidance of predator chemical cues by pine snakes (Pituophis melanoleucus). Journal of Chemical Ecology 15(3): 799-806.

Burger, J. 1989b. Incubation temperature has long-term effects on behaviour of young pine snakes (Pituophis melanoleucus). Behavioral Ecology and Sociobiology 24(4): 201-207.

Burger, J. 1990. Response of hatchling pine snakes (Pituophis melanoleucus) to chemical cues of sympatric snakes. Copeia 1990(4): 1160-1163.

Burger, J. 1991a. Effects of incubation temperature on behavior of hatchling pine snakes: Implications for reptilian distribution. Behavioral Ecology and Sociobiology 28(4): 297-303.

Burger, J. 1991b. Response to prey chemical cues by hatchling pine snakes (Pituophis melanoleucus): effects of incubation temperature and experience. Journal of Chemical Ecology 17(6): 1069-1078.

Burger, J. 1992. Trace element levels in pine snake hatchlings: tissue and temporal differences. Archives of Environmental Contamination and Toxicology 22(2): 209-213.

Burger, J. and M. Gochfeld. 1985. Behavioural development: nest emergence of young pine snakes (Pituophis melanoleucus). Journal of Comparative Psychology 99(2): 150-159.

Burger, J. and R.T. Zappalorti. 1986. Nest site selection by pine snakes, Pituophis melanoleucus, in the New Jersey Pine Barrens. Copeia 1986: 116-121.

Burger, J. and R.T. Zappalorti. 1988a. Effects of incubation temperature on sex ratios in pine snakes: differential vulnerability of males and females. American Naturalist 132(4): 492505.

Burger, J. and R.T. Zappalorti. 1988b. Habitat use in free-ranging pine snakes, Pituophis melanoleucus, in New Jersey Pine Barrens. Herpetologica 44:48-55.

Burger, J. and R.T. Zappalorti. 1989. Habitat use by pine snakes (Pituophis melanoleucus) in the New Jersey Pine Barrens: individual and sexual variation. J. Herpetol. 23:68-73.

Burger, J. and R.T. Zappalorti. 1991. Nesting behavior of pine snakes (Pituophis $m$. melanoleucus) in the New Jersey Pine Barrens. J. Herpetol. 25:152-160.

Burger, J. and R.T. Zappalorti. 1992. Philopatry and nesting phenology of pine snakes Pituophis melanoleucus in the New Jersey Pine Barrens. Behavioral and Ecological Sociobiology 30:331-336.

Burger, J., R.T. Zappalorti, J. Dowdell, T. Georgiadis, J. Hill, and M. Gochfeld. 1992. Subterranean predation on pine snakes (Pituophis melanoleucus). Journal of Herpetology 26(3): 259-263.

Burger, J., R.T. Zappalorti, and M. Gochfeld. 1987. Developmental effects of incubation temperature on hatchling pine snakes Pituophis melanoleucus. Comparative Biochemistry and Physiology A 87(3): 727-732. 
Burger, J., R.T. Zappalorti, M. Gochfeld, W.I. Boarman, M. Caffrey, V. Doig, S.D. Garber, B. Lauro, and M. Mikovsky. 1988. Hibernacula and summer den sites of pine snakes (Pituophis melanoleucus) in the New Jersey pine barrens. Journal of Herpetology 22(4): 425-433.

Burger, J., W. Boarman, L. Kurzava, and M. Gochfeld. 1991. Effect of experience with pine (Pituophis melanoleucus) and king (Lampropeltis getulus) snake odors on Y-maze behavior of pine snake hatchlings. Journal of Chemical Ecology 17(1): 79-88.

Burken, R.R., P.W. Wertz, and D.T. Downing. 1985. The effect of lipids on transepidermal water permeation in snakes. Comparative Biochemistry and Physiology A 81(2): 213-216.

Burns, G., A. Ramos, and A. Muchlinski. 1996. Fever response in North American snakes. Journal of Herpetology 30(2): 133-139.

*Butts, T.W. 1997. Mountain Inc. wildlife monitoring Bull Mountains Mine No. 1, 1996. Western Technology and Engineering. Helena, MT.

Carpenter, C.C. 1982. The bullsnake as an excavator. Journal of Herpetology 16(4): 394-401.

Carter, R. 1982. An observation on feeding a captive bullsnake. Bulletin of the Chicago Herpetological Society 17(4): 101.

Chapman, G. 1995. The black pine snake, Pituophis melanoleucus lodingi; captive breeding and subsequent health problems. Herptile 20(1): 41-44.

Chiszar, D. and H.M. Smith. 1993. Pituophis catenifer sayi (bullsnake). Herpetological Review 24(4): 156.

Chiszar, D., C. Castro, J.B. Murphy, and H.M. Smith. 1989. Discriminations between thermally different rodent carcasses by bull snakes (Pituophis melanoleucus) and cobras (Naja pallida and Aspidelaps scutatus). Bulletin of the Chicago Herpetological Society 24(10): 181-183.

Chiszar, D., V. Lipetz, K. Scudder, and E. Pasanello. 1980. Rate of tongue flicking by bull snakes and pine snakes (Pituophis melanoleucus) during exposure to food and non-food odors. Herpetologica 36(3): 225-231.

Cliburn, J.W. 1975. The hemipenis of pituophis melanoleucus. Journal of Herpetology 9(2): 254-255.

Cliburn, J.W. 1976. Observations of ecdysis in the black pine snake, pituophis melanoleucus lodingi (Reptilia, Serpentes, Colubridae). Journal of Herpetology 10(4): 299-301.

*Conant, R. and J.T. Collins. 1998. A field guide to reptiles and amphibians of eastern and central North America. $3^{\text {rd }}$ edition, expanded. New York, NY: Houghton Mifflin Co. 616 p.

Conners, J.S. 1986. A captive breeding of the great basin gopher snake, Pituophis melanoleucus deserticola. Herpetological Review 17(1): 12-13.

*Cooper, J.G. 1869. The fauna of Montana territory. American Naturalist 3: 124-127.

*Cooper, S.V., C. Jean, and P. Hendricks. 2001. Biological survey of a prairie landscape in Montana's glaciated plains. Report to the Bureau of Land Management. Montana Natural Heritage Program, Helena, MT. 24 pp. plus appendices.

*Cope, E.D. 1900. The crocodilians, lizards and snakes of North America. Report of the U.S. National Museum 1898: 153-1270.

Coss, R.G. 1993. Evolutionary persistence of ground squirrel anti-snake behavior: reflections on Burton's commentary. Ecological Physiology 5(2): 171-194.

Coss, R.G. and J.E. Biardi. 1997. Individual variation in the antisnake behavior of California ground squirrels (Spermophilus beecheyi). Journal of Mammalogy 78(2): 294-310. 
Coss, R.G., K.L. Guse, N.S. Poran, and D.G. Smith. 1993. Development of antisnake defenses in California ground squirrels (Spermophilus beecheyi): II. Microevolutionary effects of relaxed selection from rattlesnakes. Behaviour 124(1-2): 137-164.

*Coues, E. and H.C. Yarrow. 1878. Notes on the herpetology of Dakota and Montana. Bulletin of the U.S. Geologic and Geographic Survey 4(1): 259-291.

Daszak, P. and A. Cunningham. 1995. A report of intestinal sarcocystosis in the bullsnake (Pituophis melanoleucus sayi) and a re-evaluation of Sarcocystis sp. from snakes of the genus Pituophis. Journal of Wildlife Diseases 31(3): 400-403.

*Day, D., P.J. Farmer, and C.E. Farmer. 1989. Montco terrestrial wildlife monitoring report December, 1987 - July, 1989. Montco, Billings, MT, and Western Technology and Engineering, Inc. Helena, MT.

*[DCC] Decker Coal Company. 1998. 1997 Consolidated annual progress report. Decker Coal Company West, North and East Pits. Decker, MT.

de Queiroz, A. 1984. Effects of prey type on the prey handling behavior of the bullsnake, Pituophis melanoleucus. Journal of Herpetology 18: 333-336.

Deeming, D.C. 1989. The residues in the eggs of squamate reptiles at hatching. Herpetological Journal 1(9): 381-385.

Degenhardt, W.G., C.W. Painter, and A.H. Price. 1996. Amphibians and reptiles of New Mexico. Albuquerque, NM: University of New Mexico Press. 431 p.

Diani, A.R. 1974. A comparative study of the ophidian digestive tract. Ph.D. Thesis, Saint Louis University 269p. 1974.

Diller, L.V. 1981. Comparative ecology of Great Basin rattlesnakes (Crotalus viridis lutosus) and Great Basin gopher snakes (Pituophis melanoleucus deserticola) and their impact on small mammal populations in the Snake River Birds of Prey Area. Ph.D. Dissertation. University of Idaho, Moscow.

Diller, L.V. and D.R. Johnson. 1988. Food habits, consumption rates, and predation rates of western rattlesnakes and gopher snakes in southwestern Idaho. Herpetologica 44(2): 228233.

Diller, L.V. and R.L. Wallace. 1996. Comparative ecology of two snake species (Crotalus viridis and Pituophis melanoleucus) in southwestern Idaho. Herpetologica 52(3): 343-360.

Donsworth, D. 1993. A record of keeping and successfully breeding from the northern pine snake, Pituophis melanoleucus melanoleucus, during the season 1992-1993. Herptile 18(3): 113-117.

*Dood, A.R. 1980. Terry Badlands nongame survey and inventory final report. Montana Department of Fish, Wildlife, and Parks and Bureau of Land Management, Helena, MT. 70 p.

Dodd, C.K., Jr. 1993. Strategies for snake conservation. Pp. 363-393. In: R.A. Seigel and J.T. Collins (eds). Snakes - ecology and behavior. New York, NY: McGraw-Hill. 414 p.

Eakle, W.L. and T.G. Grubb. 1986. Prey remains from golden eagle nests in central Arizona. Western Birds 17(2): 87-89.

*[EI] Econ Incorporated. 1984. Terrestrial wildlife inventory for the Lame Jones and Ismay coal lease tracts. Econ Incorporated. Helena, MT.

Eichholz, M.W. and W.D. Koenig. 1992. Gopher snake attraction to birds' nests. Southwestern Naturalist 37: 293-298.

*Elmore, F.H. 1954. Gopher snake vs. ground squirrel. Yellowstone Nature Notes 28(3): 3536. 
Engeman, R.M. and J.J. Delutes, III. 1994. Pituophis melanoleucus deserticola (great basin gopher snake). Behavior. Herpetological Review 25(3): 125.

*Ernst, C.H. and E.M. Ernst. 2003. Snakes of the United States and Canada. Washington D.C.: Smithsonian Books.

Ervin, S. and C. Rose. 1973. Gopher snake predation on the common bushtit. Auk 90(3): 682683.

*Farmer, P. 1980. Terrestrial wildlife monitoring study, Pearl area, Montana June, 1978 - May, 1980. Western Technology and Engineering, Inc. Helena, MT.

Fleet, R.R., and F.W. Plapp, Jr. 1978. DDT residues in snakes decline since DDT ban. Bulletin of Environmental Contaminants and Toxicology. 19: 383-388.

Francis, A.M., J.P. Hailman, and G.E. Woolfenden. 1989. Mobbing by Florida scrub jays: behavior, sexual asymmetry, role of helpers and ontogeny. Animal Behaviour 38(5): 795816.

*Franz, R. 1971. Notes on the distribution and ecology of the herpetofauna of northwestern Montana. Bulletin of the Maryland Herpetological Society 7: 1-10.

Franz, R. 1992. Florida pine snake, Pituophis melanoleucus mugitus barbour. Rare and Endangered Biota of Florida: Amphibians and Reptiles. Paul E. Moler (ed). Vol. III. p. 254258.

Frier, J.A. and R.T. Zappalorti. 1983. Reptile and amphibian management techniques. Transactons of the Northeast Fish and Wildlife Conference 40:142-148.

Galen, C. and C. Bohn. 1979. Gopher snake preys on western big-eared bat. Murrelet 60(1): 27-28.

*Gates, M.T. 2005. Amphibian and reptile baseline survey: CX field study area. Report to Billings and Miles City Field Offices of Bureau of Land Management. Maxim Technologies, Billings, MT. 28pp + Appendices.

Glup, S.S. and L.L. McDaniel. 1988. Bullsnake predation on waterfowl nests on Valentine National Wildlife Refuge, Nebraska. U.S. Forest Service General Technical Report RM 154:149-152.

Godshalk, C.P., D.M. MacCoy, J.S. Patterson, and B.C. McKiernan. 1986. Gastric hypertrophy associated with cryptosporidiosis in a snake. Journal of the American Veterinary Medical Association 189(9): 1126-1128.

Godwin, J.C. and P.N. Lahanas. 1984. Pituophis melanoleucus (pine snake). Herpetological Review 15(1): 21.

Goldberg, S.R. and W.S. Parker. 1975. Seasonal testicular histology of the Colubrid snakes, Masticophis taeniatus and Pituophis melanoleucus. Herpetologica 31(3): 317-322.

Goldthwaite, R.O. 1989. Ground squirrel antipredator behavior: time, chance and divergence. Ph.D. Dissertation. University of California (Davis). 111p.

Goldthwaite, R.O., R.G. Coss, and D.H. Owings. 1990. Evolutionary dissipation of an antisnake system: differential behavior by California and arctic ground squirrels in aboveand below-ground contexts. Behaviour 112(3/4): 246-269.

Graczyk, T.K., R. Owens, and M.R. Cranfield. 1996. Diagnosis of subclinical cryptosporidiosis in captive snakes based on stomach lavage and cloacal sampling. Veterinarian Parasitology $67(3,4): 143-151$.

Greenwald, O.E. 1971a. The effect of body temperature on oxygen consumption and heart rate in the Sonora gopher snake, Pituophis catenifer affinis hallowell. Copeia 1971(1): 98-106. 
Greenwald, O.E. 1971b. The effect of temperature on the oxygenation of gopher snake blood. Comparative Biochemistry and Physiology 40A: 865-870.

Greenwald, O.E. 1974. Thermal dependence of striking and prey capture by gopher snakes. Copeia 1974(1): 141-148.

Greenwald, O.E. 1978. Kinematics and time relations of prey capture by gopher snakes. Copeia 1978(2): 263-268.

Grismer, L.L. 1997. The distribution of Pituophis melanoleucus and P. vertebralis in northern Baja California, Mexico. Herpetological Review 28:68-70.

Grismer, L.L. 2001. Comments on the taxonomy of gopher snakes from Baja California. Mexico: a reply to Rodriguez-Robles and de Jesus-Escobar. Herpetological Review 32: 8182.

Grismer, L.L. and C.R. Mahrdt. 1996. Pituophis melanoleucus annectens (San Diego gopher snake). Herpetological Review 27(1): 35.

Grothe, S., C.R. Peterson, and C.H. Trost. 1991. Red-tailed hawk predation on snakes: the effects of weather and snake activity. Northwest Science 65(2): 70.

Gutzke, W.H.N. and G.C. Packard. 1987. Influence of the hydric and thermal environments on eggs and hatchlings of bull snakes Pituophis melanoleucus. Physiological Zoology 60(1): 917.

Gutzke, W.H.N., G.L. Paukstis, and L.L. McDaniel. 1985. Skewed sex ratios for adult and hatchling bullsnakes, Pituophis melanoleucus, in Nebraska (USA). Copeia 1985(3): 649652.

Hammerson, G.A. 1999. Amphibians and reptiles in Colorado. University Press of Colorado. Niwot, CO. 484 pp.

*Hart, M.M., W.A. Williams, P.C. Thornton, K.P. McLaughlin, C.M. Tobalske, B.A. Maxell, D.P. Hendricks, C.R. Peterson, and R.L. Redmond. 1998. Montana atlas of terrestrial vertebrates. Montana Cooperative Wildlife Research Unit, The University of Montana. Missoula, Montana vii +1302 p.

Haywood, C.A. and R.W. Harris. 1971. Fight between rock squirrel and bullsnake. Texas Journal of Science 22(4): 427.

*Hendricks, P. 1997. Lee Metcalf National Wildlife Refuge preliminary amphibian and reptile investigations: 1996. Montana Natural Heritage Program, Helena, MT. 21 p.

*Hendricks, P. 1999. Amphibian and reptile survey of the Bureau of Land Management Miles City District, Montana. Montana Natural Heritage Program, Helena, MT. 80 p.

*Hendricks, P. and J.D. Reichel. 1996a. Amphibian and reptile survey of the Bitterroot National Forest: 1995. Montana Natural Heritage Program, Helena, MT. 95 p.

*Hendricks, P. and J.D. Reichel. 1996b. Preliminary amphibian and reptile survey of the Ashland District, Custer National Forest: 1995. Montana Natural Heritage Program, Helena, MT. 79 p.

*Hendricks, P. and J.D. Reichel. 1998. Amphibian and reptile survey on Montana refuges: 1996. Montana Natural Heritage Program, Helena, MT. 19 p.

Hennessy, D.F. 1982. Functional significance of variation in predator harassment. Ph.D. Dissertation, University of California, Davis, California. 119 P.

Hennessy, D.F. and D.H. Owings 1978. Snake species discrimination and the role of olfactory cues in the snake-directed behavior of the California ground squirrel. Behaviour 65(1-2): 115-124. 
Herrington, R.E. 1988. Talus use by amphibians and reptiles in the Pacific Northwest. Pages 216-221 in R.C. Szaro, K.E. Severson, and D.R. Patton, technical coordinators. Management of amphibians, reptiles, and small mammals in North America. General Technical Report RM-166. U.S. Forest Service, Rocky Mountain Forest and Range Experiment Station. Fort Collins, CO.

Hicks, M. 1984. Some notes on the Louisiana pine snake. Northern Ohio Association Herpetological Notes 11(11): 11-12.

Hirsch, S.M. and R.C. Bolles. 1980. Ability of prey to recognize predators. Zeitschrift Fuer Tierpsychologie 54(1): 71-84.

Hirschkom, D. 1987. Pituophis melanoleucus catenifer - Pacific gopher snake. Litteratura Serpentium English Edition 7(1): 47.

Hirschkorn, D. 1986a. Breeding results. Pituophis melanoleucus annectans. Litteratura Serpentium English Edition 6(4): 158-159.

Hirschkorn, D. 1986b. Erfahrungen bei der Pflege und Zucht der Selten gehaltenen Bullennatter Pituophis melanoleucus catenifer. Herpetofauna (Weinstadt) 8 No. 43: 13-16.

Hoberg, T. and C. Gause. 1989. Reptiles \& amphibians of North Dakota. North Dakota Outdoors 55(1):7-18.

Horstman, G. 1995. Pituophis catenifer deserticola (Great Basin gopher snake). Herpetological Review 26(1): 47.

Hossack, B.R., P.S. Corn, and D.S. Pilliod. 2005. Lack of significant changes in the herpetofauna of Theodore Roosevelt National Park, North Dakota, since the 1920s. American Midland Naturalist 154:423-432.

Howard, W.E. 1949. Gopher snakes killed trying to swallow cottontail. Copeia 1949: 289.

Howitz, J.L. 1986. Bull snake predation on black-capped chickadee nest. Loon 58(3): 132.

Huey, R.B. and R.D. Stevenson. 1979. Integrating thermal physiology and ecology of ectotherms: a discussion of approaches. American Zoologist 19(1): 357-366.

Imler, R. 1939 and 1940. Waterfowl nesting studies and experimental bullsnake control, Crescent Lake Refuge, Nebraska, and LaCreek Refuge, South Dakota. Report to U.S. Fish and Wildlife Service (Biological Survey).

Imler, R.H. 1945. Bullsnakes and their control on a Nebraska Wildlife Refuge. Journal of Wildlife Management 9(4): 265-273.

Iverson, J.B. 1990. Sex ratios in snakes: a cautionary note. Copeia 1990(2): 571-573.

Jacobson, E.R., W. Ferris, J.T. Bagnara, W.O. Iverson. 1989. Chromatophoromas in a pine snake. Pigment Cell Research 2(1): 26-33.

Jennings, M.R., G.B. Rathbun, and C.A. Langtimm. 1996. Pituophis melanoleucus catenifer (Pacific gopher snake). Prey. Herpetological Review 27(1): 26.

Kapfer, J.M. and C.T. Benell. 2005. Pituophis catenifer sayi (Bullsnake). Predation. Herpetological Review 36:326.

Kennard, C. 1980. Intraspecific hybridization between a female northern pike snake and male San Diego gopher snake. Bulletin of the Philadelphia Herpetological Society 28: 3-5.

Kingery, H.E. and U.C. Kingery. 1995. Gopher snake as predator at long-billed curlew and rough-winged swallow nests. Colorado Field Ornithology Journal 29(1): 18-19.

Kirschkom, D. 1986. Breeding results. Pituophis melanoleucus catenifer. Litteratura Serpentium English Edition 6(4): 157-158.

Kissner, K.J. and J. Nicholson. 2003. Bullsnakes (Pituophis catenifer sayi) in AlbertaL literature review and data compilation. Alberta Species at Risk Report 62: 1-20. 
Klauber, L.M. 1946. The gopher snakes of Baja California, with descriptions of new subspecies of Pituophis catenifer. Transactions of the San Diego Society of Natural History 11: 1-40.

Klauber, L.M. 1947. Classification and ranges of the gopher snakes of the genus Pituophis in the western United States. Bulletin of the Zoological Society of San Diego. 22: 1-81.

Kneeland, M.C., J.L. Koprowski, and M.C. Corse. 1995. Potential predators of Chiricahua fox squirrels (Sciurus nayaritensis chiricahuae). Southwestern Naturalist 40(3): 340-342.

Knight, J.L. 1986. Variation in snout morphology in the North American snake (Pituophis melanoleucus) (Serpentes; Colubridae). Journal of Herpetology 20(1): 77-79.

*Koch, E.D. and C.R. Peterson. 1989. A preliminary survey of the distribution of amphibians and reptiles in Yellowstone National Park. pp. 47-49. In: Rare, sensitive and threatened species of the Greater Yellowstone Ecosystem, T.W. Clark, A.H. Harvey, R.D. Dorn, D.C. Genter, and C. Groves (eds.), Northern Rockies Conservation Cooperative, Montana Natural Heritage Program, The Nature Conservancy, and Mountain West Environmental Services. 153 p.

Krivda, W. 1993. Road kills of migrating garter snakes at The Pas, Manitoba. Blue Jay. 51(4): 197-198.

Landreth, H.F. 1972. Physiological responses of Elaphe obsoleta and Pituophis melanoleucus to lowered ambient temperatures. Herpetologica 28(4): 376-380.

Langley, W.M., H.W. Lipps, and J.F. Theis. 1989. Responses of Kansas motorists to snake models on a rural highway. Transactions of the Kansas Academy of Science. 92(1-2): 43-48.

Leonard, W.P. and E. Phenix. 1994. Pituophis melanoleucus (gopher snake). Herpetological Review 25(4): 168.

Licht, P. and A.F. Bennett. 1972. A scaleless snake: tests of the role of reptilian scales in water loss and heat transfer. Copeia 1972(4): 702-707.

Lilley, T. 1985. Albinism in snakes. Freshwater and Marine Aquarium 8(10): 68-69.

Lillywhite, H.B. 1985. Postural edema and blood pooling in snakes. Physiological Zoology 58(6): 759-766.

Lipetz, V. 1977. Behavior of bull snakes during prolonged exposure to food and other odors. Journal of the Colorado-Wyoming Academy of Science 9(1): 2.

Loughry, W.J. 1987. Differences in experimental and natural encounters of black-tailed prairie dogs with snakes. Animal Behaviour 35(5): 1568-1570.

Mader, D.R., C.C. Horvath, and J. Paul-Murphy. 1985. The hematocrit and serum profile of the gopher snake (Pituophis melanoleucas catenifer). Journal of Zoo Animal Medicine 16(4): 139-140.

*Manville, R.H. 1957. Amphibians and reptiles of Glacier National Park, Montana. Copeia 1957: 308-309.

*Marnell, L.F. 1997. Herpetofauna of Glacier National Park. Northwestern Naturalist 78: 1733.

Marr, N.V. 1985. Gopher snake preys on northern oriole nestlings. Murrelet 66(3): 95-97.

*Martin, P.R. 1980a. Terrestrial wildlife habitat inventory in southeastern Montana. Montana Department of Fish, Wildlife and Parks and Bureau of Land Management, Helena MT. 114 p.

*Martin, P.R. 1980b. Terrestrial wildlife inventory in selected coal areas of Montana. Montana Department of Fish, Wildlife and Parks and Bureau of Land Management, Helena, MT. 84 p. 
*Martin, P.R., K. Dubois and H.B. Youmans. 1981. Terrestrial wildlife inventory in selected coal areas, Powder River resources area final report. Montana Department of Fish, Wildlife and Parks and Bureau of Land Management, Helena, MT. 288 p.

Martin, W.F. and Huey, R.B. 1971. The function of the epiglottis in sound production (hissing) of Pituophis melanoleucus. Copeia 1971(4): 752-754.

*Martindale, P. 1929. The bull snake at close range. Yellowstone Nature Notes 6(6): 4.

*Matthews, W.L. 1979. Wibaux-Beach wildlife baseline study - nongame species. Bureau of Land Management, Miles City, MT. 93 p.

*Matthews, W.L. 1980a. Wibaux-Beach comparison study: Sydney, Glendive and Plevna Study Areas. Bureau of Land Management, Miles City, MT. 50 p.

*Matthews, W.L. 1980b. Wildlife of Prairie County Terry study area. Bureau of Land Management, Miles City, MT. $52 \mathrm{p}$.

*Matthews, W.L. 1981. Broadus-Pumpkin Creek baseline inventory - wildlife. Bureau of Land Management, Miles City, MT. 83 p.

*Maxell, B.A. 2002. Amphibian and aquatic reptile inventories in watersheds in the South and Middle Forks of the Flathead River drainage that contain lakes being considered for application of piscicides and subsequent stocking of west slope cutthroat trout. Report to the Region 1 Office of the U.S. Forest Service and the Montana Department of Fish, Wildlife, and Parks. Missoula, MT: Montana Cooperative Wildlife Research Unit and Wildlife Biology Program, University of Montana. $62 \mathrm{p}$.

*Maxell, B.A. 2004a. Amphibian and aquatic reptile inventories conducted on and around the Bitterroot National Forest 2000-2003. Report to Region 1 Office of the U.S. Forest Service, Bitterroot National Forest, Montana Department of Fish, Wildlife, and Parks, and Biological Resources Division of the U.S. Geological Survey. Missoula, MT: Montana Cooperative Wildlife Research Unit and Wildlife Biology Program, University of Montana. 128 p.

*Maxell, B.A. 2004b. Amphibian and aquatic reptile inventories conducted on and around the Thompson River 2003-2004. Report to Region 1 Office of the U.S. Forest Service and Plum Creek Timber Company. Missoula, MT: Montana Cooperative Wildlife Research Unit and Wildlife Biology Program. 83 p.

*Maxell, B.A. 2004c. Preliminary report on amphibian and aquatic reptile inventories conducted in the West Boulder River area during summer 2003. Report to Region 1 Office of the U.S. Forest Service, and the Montana Department of Fish, Wildlife, and Parks. Missoula, MT: Montana Cooperative Wildlife Research Unit and Wildlife Biology Program, University of Montana. $27 \mathrm{p}$.

*Maxell, B.A. 2004d. Preliminary report on amphibian and aquatic reptile inventories conducted on and around the Ashland District of the Custer National Forest in 2002 and 2004. Report to Ashland District of Custer Forest, Region 1 Office of the U.S. Forest Service, and Montana Department of Fish, Wildlife, and Parks. Missoula, MT: Montana Cooperative Wildlife Research Unit and Wildlife Biology Program, University of Montana. $93 \mathrm{p}$.

*Maxell, B.A. 2004e. Report on amphibian and aquatic reptile inventories conducted on and around the Beaverhead-Deerlodge National Forest 2001-2003. Report to Region 1 Office of the U.S. Forest Service, Beaverhead-Deerlodge National Forest, Montana Department of Fish, Wildlife, and Parks, Montana State Office of the Bureau of Land Management, and Montana Department of Environmental Quality. Missoula, MT: Montana Cooperative Wildlife Research Unit and Wildlife Biology Program, University of Montana. 260 p. 
*Maxell, B.A. 2005a. Amphibian and aquatic reptile inventories conducted on and around lands administered by the Missoula Field Office of the Bureau of Land Management. Report to Missoula Field Office of the Bureau of Land Management. Montana Natural Heritage Program, Helena, MT and Montana Cooperative Wildlife Research Unit and Wildlife Biology Program, University of Montana, Missoula, MT. 53 p.

*Maxell, B.A. 2009. State-wide assessment of status, predicted distribution, and landscapelevel habitat suitability of amphibians and reptiles in Montana. Ph.D. Dissertation. Missoula, MT: Wildlife Biology Program, University of Montana. 294 p.

*Maxell, B.A. and D.G. Hokit. 1999. Amphibians and reptiles. Pp. 2.1-2.30. In: G. Joslin and H. Youmans (committee chairs). Effects of recreation on Rocky Mountain wildlife: a compendium of the current state of understanding in Montana. Helena, MT: Committee on Effects of Recreation on Wildlife, Montana Chapter of the Wildlife Society. 307 p.

*Maxell, B.A., J.K. Werner, P. Hendricks, and D. Flath. 2003. Herpetology in Montana: a history, status summary, checklists, dichotomous keys, accounts for native, potentially native, and exotic species, and indexed bibliography. Olympia, WA: Society for Northwestern Vertebrate Biology. Northwest Fauna 5: 1-138.

Maxson, G.A.D. 1981. Arboreal nest predation by a bullsnake. Loon 53(1): 61-62.

McAllister, C.T. 1984. Pituophis melanoleucus sayi (bullsnake). Herpetological Review 15(3): 78.

*McEneaney, T. and J. Jensen. 1974. The reptiles and amphibians of the Charles M. Russell National Wildlife Range - 1974. Charles M. Russell National Wildlife Refuge. Lewistown, MT. 3 p.

Merli, J. 1992. Nesting habits of the northern pine snake (Pituophis m. melanoleucus). Vivarium 4(1): 16-19.

Miller, J.E. and B.D. Leopold. 1992. Population influences: Predators. In James G. Dickson, ed. The wild turkey: Biology and management, p.119-128. Stackpole Books, Harrisburg, Pennsylvania.

Mitchell, J.C. and C.A. Pague. 1987. A review of reptiles of special concern in Virginia. Virginia Journal of Science 38(2): 84.

Moon, B.R. 2000. The mechanics of swallowing and the muscular control of diverse behaviors in gopher snakes. The Journal of Experimental Biology 203: 2589-2601.

Moore, J.P. 1893. The eggs of Pituophis melanoleucus. American Naturalist 27: 878-885.

Moriarty, J. 1991. Reintroduction of bullsnakes into the Crow-Hassan prairie restoration. Final report submitted to Nongame Wildlife Program, Minnesota Department of Natural Resources. 6 pp.

Morris, M.A. 1986. Anesthesia of snakes (Pituophis melanoleucus and Python regius) fed ether-killed rats. Herpetological Review 17(4): 88.

*Mosimann, J.E. and G.B. Rabb. 1952. The herpetology of Tiber Reservoir area, Montana. Copeia 1952: 23-27.

Mount, R.H. 1986a. Black pine snake. Mount, R.H. [Ed.] Vertebrate animals of Alabama in need of special attention. Alabama Agricultural Experiment Station, Auburn, Alabama. 1986: i-xiv, 1-124. Chapter pagination: 35-36.

Mount, R.H. 1986b. Northern pine snake. Mount, R.H. [Ed.] Vertebrate animals of Alabama in need of special attention. Alabama Agricultural Experiment Station, Auburn, Alabama. 1986: i-xiv, 1-124. Chapter pagination: 70-71. 
*[MTNHP] Montana Natural Heritage Program. 2006. Point Observation Database. Montana Natural Heritage Program, Helena, MT. Accessed April 24, 2006.

Niedrach, R.J. 1971. Bull snake and common grackles. Wilson Bulletin 83: 317-318.

Nussbaum, R.A., E.D. Brodie, Jr., and R.M. Storm. 1983. Amphibians and reptiles of the Pacific Northwest. University Press of Idaho. Moscow, ID. 332 pp.

*[OEAR] Olson Elliot and Associates Research. 1985. 1983-1984 Wildlife monitoring report for the CX Ranch project. Olson Elliot and Associates Research. Helena, MT.

Ohlendorf, H.M., R.L. Hothem, and T.W. Aldrich. 1988. Bioaccumulation of selenium by snakes and frogs in the San Joaquin Valley, California (USA). Copeia 1988(3): 704-710.

Olsen, U. 1986. North American reptiles 2. Bullsnake - in nature and in the vivarium. Nordisk Herpetologisk Forening 29(4): 90-106.

Olson, R.E. 1995. Important herpetological notes for northern Illinois and southern Wisconsin. Bulletin of the Maryland Herpetological Society 31(2): 96.

Owings, D.H. and W.J. Loughry. 1985. Snake-elicited jump-yipping by black-tailed prairie dogs: ontogeny and snake specificity. Zeitschrift Fuer Tierpsychologie 70: 177-200.

Pack, H.J. 1919. Note on food habits of the bull snake. Copeia 68: 16.

Packard, M.J. and G.C. Packard. 1988. Sources of calcium and phosphorus during embryogenesis in bullsnakes (Pituophis melanoleucus). Journal of Experimental Zoology 246(2): 132-138.

Palmer, A.C. 1985. Second generation intraspecific hybrids of Pituophis melanoleucus. Bulletin of the Chicago Herpetological Society 20(1): 21-22.

Parker, W.S. 1974. Comparative ecology of two colubrid snakes, Masticophis t. taeniatus (hallowell) and Pituophis melanoleucus deserticola stejneger, in northern Utah. Ph.D. Thesis, University of Utah 307p.

Parker, W.S. and W.S. Brown. 1980. Comparative ecology of two Colubrid snakes, Masticophis t. taeniatus and Pituophis melanoleucus deserticola, in northern Utah. Milwauke Public Museum Publishers Biology Geology 7: 104p.

*Patla, D.A. and C.R. Peterson. 1997. Amphibians and reptiles along the Grand Loop Highway in Yellowstone National Park: Mammoth Hot Springs to Norris Junction. 1 February, 1997. Greater Yellowstone Ecosystem Amphibian Survey and Monitoring Program, Herpetology Laboratory, Department of Biological Sciences, Idaho State University, Pocatello, ID. 60 p.

Peabody, F.E. 1958. A Kansas drought recorded in growth zones of a bullsnake. Copeia 1958: 91-94.

Peery, T.E. 1932. Miscellaneous note on a bull snake. Yellowstone Nature Notes 9(6-7): 31. Perez-Higareda, G. 1981. The occurrence of Pituophis melanoleucus sayi in Veracruz (Serpentes: Colubridae). Bulletin of the Maryland Herpetological Society 17(2): 64-67.

Pfaffenberger, G.S., N.M. Jorgensen, and D.D. Woody. 1989. Parasites of prairie rattlesnakes (Crotalus viridis viridis) and gopher snakes (Pituophis melanoleucus sayi) from the eastern high plains of New Mexico (USA). Journal of Wildlife Diseases 25(2): 305-306.

*Platt, D.R. 1984. Growth of bullsnakes (Pituophis melanoleucus sayi) on a sand prairie in south central Kansas. pp. 41-56. In: R.A. Seigel, L.E. Hunt, J.L. Knight, L. Malaret, and N.L. Zuschlag (eds). Vertebrate Ecology and Systematics.

Poran, N.S. and R.G. Coss. 1990. Development of antisnake defenses in California ground squirrels (Spermophilus beecheyi): I. behavioral and immunological relationships. Behaviour 112(3-4): 222-245. 
*[PRESI] Powder River Eagle Studies Incorporated. 1998a. Big Sky Mine 1997 wildlife monitoring studies. Powder River Eagle Studies Incorporated. Gillete, WY.

*[PRESI] Powder River Eagle Studies Incorporated. 1998b. Spring Creek Mine 1997 wildlife monitoring studies. Powder River Eagle Studies Incorporated. Gillete, WY.

Prior, K.A., and P.J. Weatherhead. 1994. Response of free-ranging eastern Massasauga rattlesnakes to human disturbance. Journal of Herpetology. 28(2): 255-257.

Raiti, P. 1993. Occult coccidiosis in a bullsnake, Pituophis melanoleucus ssp. Bulletin of the Association of Amphibian and Reptilian Veterinarians 3(1): 5-6.

Ramirez, B.A., M.A. Gutierrez, and R.A. Gonsalez. 1995. Clutch Sizes in a Community of Snakes from the Mountains of the Valley of Mexico. Herpetological Review 26(1): 12-13.

Randall, J.A., S.M. Hatch, and E.R. Hekkala. 1995. Inter-specific variation in anti-predator behavior in sympatric species of kangaroo rat. Behavioral Ecology and Sociobiology 36(4): 243-250.

*Rauscher, R.L. 1998. Amphibian and reptile survey on selected Montana Bureau of Reclamation impoundments. Montana Department of Fish, Wildlife and Parks, Nongame Program, Bozeman, MT. 24 p.

*Reichel, J.D. 1995. Preliminary amphibian and reptile survey of the Sioux District of the Custer National Forest: 1994. Montana Natural Heritage Program, Helena, MT. 75 p.

*Reichel, J.D. 1996. Preliminary amphibian and reptile survey of the Helena National Forest: 1995. Montana Natural Heritage Program, Helena, MT. 87 p.

*Reichel, J.D. 1997. Amphibian, reptile and northern bog lemming survey on the Rocky Mountain Front: 1996. Montana Natural Heritage Program, Helena, MT. 81 p.

Reichling, S.B. 1988. Reproduction in captive Louisiana pine snakes, Pituophis melanoleucus ruthveni. Herpetological Review 19(4): 77-78.

Reichling, S.B. 1990. Reproductive traits of the Louisiana pine snake Pituophis melanoleucus ruthveni (Serpentes: Colubridae). Southwestern Naturalist 35(2): 221-222.

Reichling, S.B. 1995. The taxonomic status of the Louisiana pine snake (Pituophis melanoleucus ruthveni) and its relevance to the evolutionary species concept. Journal of Herpetology 29(2): 186-198.

Robbins, A.C. 1991. Anatomy drawing of a nonpoisonous (gopher) snake. Bulletin of the Chicago Herpetological Society 26(5): 110.

Roberts, C. 1991. Notes on the captive breeding, care and hibernation of the northern pine snake, Pituophis melanoleucus melanoleucus. Herptile 16(2): 68-69.

*Rodgers, T.L., and W.L. Jellison. 1942. A collection of amphibians and reptiles from western Montana. Copeia 1942(1): 10-13.

Rodriguez-Robles, J.A. 1998. Alternative perspectives on the diet of gopher snakes (Pituophis catenifer, Colubridae): literature records versus stomach contents of wild and museum specimens. Copeia 1998: 463-466.

Rodriguez-Robles, J.A. 2002. Feeding ecology of the North American gopher snake (Pituophis catenifer, Colubridae). Biological Journal of the Linnean Society 77(2):165-183.

Rodriguez-Robles, J.A. 2003. Home ranges of gopher snakes (Pituophis catenifer, Colubridae) in central California. Copeia 2003(2):391-396.

Rodriguez-Robles, J.A. and J.M. De Jesus-Escobar. 2000. Molecular systematics of New World gopher, bull, and pinesnakes (Pituophis: Colubridae), a transcontinental species complex. Molecular Phylogenetics and Evolution 14(1): 35-50. 
*Roedel, M.D. and P. Hendricks. 1998a. Amphibian and reptile survey on the Bureau of Land Management Lewistown District: 1995-1998. Montana Natural Heritage Program, Helena, MT. 53 p.

*Roedel, M.D. and P. Hendricks. 1998b. Amphibian and reptile inventory on the Headwaters and Dillon Resource Areas in conjunction with Red Rocks Lakes National Wildlife Refuge: 1996-1998. Montana Natural Heritage Program, Helena, MT. 46 p.

Rosen, P.C., and C.H. Lowe. 1994. Highway mortality of snakes in the Sonoran desert of southern Arizona. Biological Conservation. 68: 143-148.

Roth, J.J. and H.M. Smith. 1990. Pituophis melanoleucus deserticola (Great Basin gopher snake). Herpetological Review 21(2): 41.

Schroder, R.C. 1950. Hibernation of blue racers and bull snakes in western Illinois. Chicago Acadamy of Science and Natural History Miscellaneous 75: 1-2.

*Scow, K.L. 1980. Terrestrial wildlife survey American Colloid study area Phillips County, Montana. Western Technology and Engineering, Inc., Helena, MT.

*Skinner, M.P. 1924. The Yellowstone Nature Book. A.C. McClurg Company, Chicago, IL. $221 \mathrm{p}$.

Smith, G.R. and J.B. Iverson. 1993. Reactions to odor trails in bullsnakes. Journal of Herpetology 27(3): 333-335.

Smith, H.M. and D. Thompson. 1993. Four reptiles newly recorded from Ouray County, Colorado. Bulletin of the Chicago Herpetological Society 28(4): 78-79.

Smith, H.M. and J.P. Kennedy. 1951. Pituophis melanoleucus ruthveni in eastern Texas and its bearing on the status of Pituophis catenifer. Herpetologica 7: 93-96.

Speake, D.W. 1986. Florida pine snake. In: Mount, R.H. [Ed.] Vertebrate animals of Alabama in need of special attention. Alabama Agricultural Experiment Station, Auburn, Alabama. 1986: i-xiv, 1-124. Chapter pagination: 36-37.

*St. John, A. 2002. Reptiles of the Northwest: California to Alaska; Rockies to the Coast. Renton, WA: Lone Pine Publishing. 272 p.

Stafford, D.P., F.W. Plapp, Jr., and R.R. Fleet. 1976. Snakes as indicators of environmental contamination: relation of detoxifying enzymes and pesticide residues to species occurrence in three aquatic ecosystems. Archives of Environmental Contamination and Toxicology. 5: 15-27.

*Stebbins, R.C. 2003. A field guide to western reptiles and amphibians. 3rd edition. New York, NY: Houghton Mifflin Co. 533 p.

Sterner, R.T., B.E. Peterson, S.A. Shumake, S.E. Gaddis, J.B. Bourassa, T.A. Felix, G.R. McCann, K.A. Crane, and A.D. Ames. 2002. Movements of a bullsnake (Pituophis catenifer) following predation of a radio-collared northern pocket gopher (Thomomys talpoides). Western North American Naturalist 62(2):240-242.

Stevenson, D. and D. Crowe. 1992. Pituophis melanoleucus mugitus (Florida pine snake). Herpetological Review 23(3): 92.

Stinner, J.N. 1981. Pulmonary anatomy, gas exchange, and acid-base balance in the gopher snake, Pituophis melanoleucus catenifer. Ph.D. Dissertation. University of California Riverside. 146p.

Stinner, J.N. 1982. Functional anatomy of the lung of the snake Pituophis melanoleucus. American Journal of Physiology 243(3): R251-R257. 
Stinner, J.N. 1987. Gas exchange and air flow in the lung of the snake, Pituophis melanoleucus. Journal of Comparative Physiology B Biochemical Systems Environmental Physiology 157(3): 307-314.

Stuart, J.N., M.L. Watson, T.L. Brown, and C. Eustice. 2001. Plastic netting: an entanglement hazard to snakes and other wildlife. Herpetological Review. 32(3): 162-164.

Stull, O.G. 1940. Variations and relationships in the snakes of the genus Pituophis. Bulletin of the U.S. National Museum - Smithsonian Institution, Washington, D.C. 175: 1-225.

Sullivan, B.K. 1981. Observed differences in body temperature and associated behavior of four snake species. Journal of Herpetology 15(2): 245-246.

*Sweet, S.S. 1985. Geographic variation, convergent crypsis and mimicry in gopher snakes (Pituophis melanoleucus) and western rattlesnakes (Crotalus viridis). Journal of Herpetology 19(1): 55-67.

*Sweet, S.S. and W.S. Parker. 1990. Pituophis melanoleucus (Daudin). Pine, bull, and gopher snakes. Catalogue of American Amphibians and Reptiles 474: 1-8.

*Sweet, S.S. and W.S. Parker. 1990. Pituophis melanoleucus. Catalogue of American Amphibians and Reptiles 474.1-474.8.

Thomas, R.A., B.J. Davis, and M.R. Culbertson. 1976. Notes on variation and range of the Louisiana pine snake, (Pituophis melanoleucus ruthveni) stull (Reptilia: Serpentes: Colubridae). Journal of Herpetology 10(3): 252-257.

Thompson, B.C. and C.L. Turner. 1980. Bull snake predation at a cliff swallow nest. Murrelet 61(1): 35-36.

*Thompson, L.S. and P.S. Nichols. 1982. Circle West wildlife monitoring study; fourth annual report for period March 1, 1981 - May 31, 1982. Circle West Technical Report No. 10. Montana Department of Natural Resources and Conservation, Helena, MT.

*Timken, R. No Date. Amphibians and reptiles of the Beaverhead National Forest. Western Montana College, Dillon, MT. 16 p.

Timm, K.I., R.J. Sonn, and B.D. Hultgren. 1988. Coccidioidomycosis in a Sonoran gopher snake, Pituophis melanoleucus affinis. Journal of Medical and Veterinary Mycology 26(2): 101-104.

Towers, S.R. and R.G. Coss. 1991. Antisnake behavior of Columbian ground squirrels (Spermophilus columbianus). Journal of Mammalogy 72(4): 776-783.

Tucker, J.K. 1994. Noteworthy distributional records from some snakes from Jersey and Madison Counties, Illinois. Herpetological Review 25(2): 79-80.

Tucker, J.K. 1995. Notes on Road-Killed snakes and their implications on habitat modification due to summer flooding on the Mississippi River in West Central Illinois. Transactions of the Illinois State Academy of Science 88(1-2): 61-71.

*Turner, F.B. 1951. A checklist of the reptiles and amphibians of Yellowstone National Park with incidental notes. Yellowstone Nature Notes 25(3): 25-29.

*Turner, F.B. 1955. Reptiles and amphibians of Yellowstone National Park. Yellowstone Interpretive Series No. 5. Yellowstone Library and Museum Association. Yellowstone National Park, WY. 40 p.

Van Denburgh, J. 1920. A further study of variation in the gopher snakes of western North America. Proceedings of the California Academy of Sciences (4), 10: 1-27.

Van Denburgh, J. and J.R. Slevin. 1919. The gopher snakes of western North America. Proceedings of the California Academy of Sciences 9(6): 197-220. 
Van der Eerdn, H. 1989. Successful breeding of the bullsnake (Pituophis melanoleucus sayi). Litteratura Serpentium English Edition 9(3): 129-132.

Vandeventer, T.L. and R.A. Young. 1989. Rarities of the longleaf: the black and Louisiana pine snakes. Vivarium 1(4): 32-36.

Vejersley, L.O. 1985. Breeding results: Pituophis melanoleucus catenifer. Litteratura Serpentium 5(2): 77.

*Vitt, L.J., J.P. Caldwell, and D.B. Shepard. 2005. Inventory of amphibians and reptiles in the Billings Field Office Region, Montana. Sam Noble Oklahoma Museum of Natural History and Department of Zoology, University of Oklahoma, Norman, OK. 33 p.

*[VTNWI] VTN Wyoming Incorporated. No Date. Second year's analysis of terrestrial wildlife on proposed mine access and railroad routes in southern Montana and northern Wyoming, March 1979 - February 1980. VTN Wyoming Incorporated. Sheridan, WY. 62 p.

*Waage, B.C. 1998. Western Energy Company Rosebud Mine 1997 annual wildlife monitoring report December 1, 1996 to November 30, 1997 survey period. Western Energy Company, Colstrip, MT.

Weaver, R.E. 2004. Pituophis catenifer (Gopher Snake). Diet. Herpetological Review 35(2):179-180.

Weir, J. 1992. The Sweetwater rattlesnake round-up: A case study in environmental ethics. Conservation Biology. 6: 116-127.

*Weisel, G.F. 1952. Animal names, anatomical terms, and some ethnozoology of the Flathead Indians. Journal of the Washington Academy of Sciences 42(11): 345-355.

Wellstead, C.F. 1981. Behavioral observation in bullsnakes. Herpetological Review 12(1): 6.

*Werner, J.K., B.A. Maxell, P. Hendricks, and D. Flath. 2004. Amphibians and reptiles of Montana. Missoula, MT: Mountain Press Publishing Company. 262p.

*Werner, J.K. and J.D. Reichel. 1994. Amphibian and reptile survey of the Kootenai National Forest: 1994. Montana Natural Heritage Program, Helena, MT. 104 p.

*Werner, J.K. and J.D. Reichel. 1996. Amphibian and reptile monitoring/survey of the Kootenai National Forest: 1995. Montana Natural Heritage Program, Helena, MT. 115 p.

*Werner, J.K. and T. Plummer. 1994. Amphibian and reptile survey of the Flathead Indian Reservation 1993-1994. Salish Kootenai College, Pablo, MT. 55 p.

*Werner, J.K. and T. Plummer. 1995. Amphibian monitoring program on the Flathead Indian Reservation 1995. Salish Kootenai College, Pablo, MT. 46 p.

*Werner, J.K., T. Plummer, and J. Weaselhead. 1998. Amphibians and reptiles of the Flathead Indian Reservation. Intermountain Journal of Sciences 4(1-2): 33-49.

*[WESCO] Western Ecological Services Company. 1983a. Wildlife inventory of the Knowlton known recoverable coal resource area, Montana. Western Ecological Services Company, Novato, CA. 107 p.

*[WESCO] Western Ecological Services Company. 1983b. Wildlife inventory of the Southwest Circle known recoverable coal resource area, Montana. Western Ecological Services Company, Novato, CA. $131 \mathrm{p}$.

West, C. 1995. Notes on the captive breeding of the northern pine snake (Pityophis melanoleucus melanoleucus). Herptile 20(3): 109-111.

*[WESTECH] Western Technology and Engineering Incorporated. 1993. Diamond Hill project wildlife baseline survey. Western Technology and Engineering, Inc., Helena, MT. 
*[WESTECH] Western Technology and Engineering Incorporated. 1998. Wildlife monitoring Absaloka Mine area 1997. Western Technology and Engineering, Inc., Helena, MT. 


\section{Terrestrial Gartersnake (Thamnophis elegans)}

Up-to-date distribution and status information can be found on the Montana Natural Heritage Program's TRACKER website at http://mtnhp.org

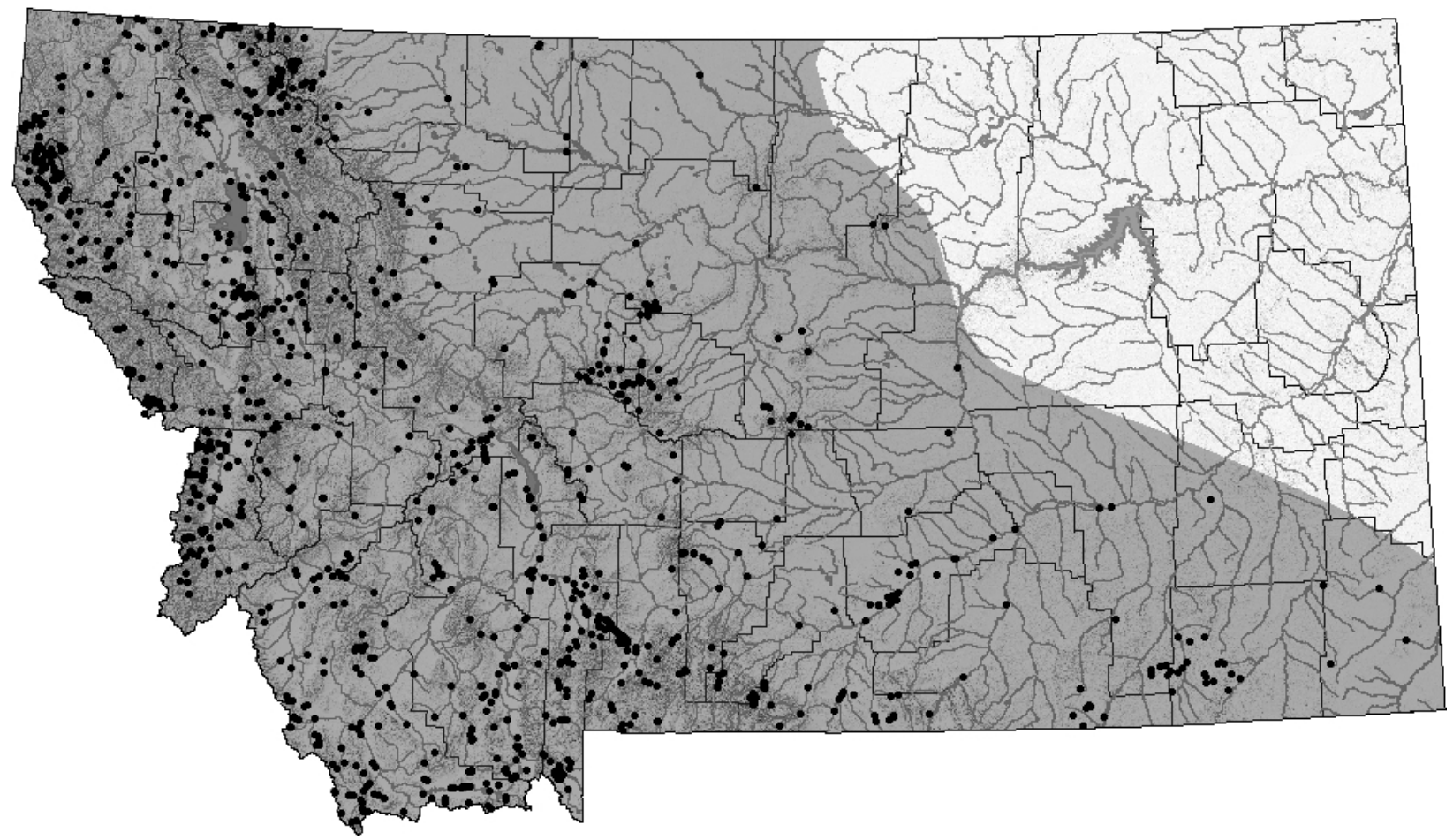

\section{Distribution/Taxonomy}

There is some debate as to the number of subspecies in the Terrestrial Gartersnake complex and more genetic studies are needed (Fox 1951, Bronikowski and Arnold 2001). However, most experts currently recognize five subspecies of Thamnophis elegans in western North America, north of Mexico (Fitch 1983, Rossman 1996). The only subspecies found in Montana, the Intermountain Wandering Gartersnake (Thamnophis elegans vagrans), has the most extensive distribution on the continent, ranging from southern British Columbia, Alberta, and Saskatchewan southward to New Mexico, Arizona, and Nevada (Rossman et al. 1996, Stebbins 2003). Genetic studies by Arnold and Bronikowski (2001) suggest that deep genetic lineages occur within $T$. elegans vagrans. Likewise, strong behavioral variations between populations have been noted, but these differences are not apparent from phenotypic characteristics (Arnold 1977, Ayers and Arnold 1983). In Montana T. elegans is absent only from the northeastern Great Plains where mountainous terrain is absent. One of the most common and adaptable reptiles in Montana, it occupies a variety of habitats from river bottoms to sites above treeline.

Maximum Elevation

2,765 m (9,071 ft) in Carbon County (Werner et al. 2004). However, the species has been recorded at 3,182 $\mathrm{m}(10,440 \mathrm{ft})$ in the headwaters of a drainage flowing into Montana between the east and west summits of Beartooth Pass and immediately south of the state line in Park County, Wyoming (Hendricks 1996). 


\section{Identification}

Adults have a dusky base body color of gray, grayish brown, and infrequently black. Similar to other Montana gartersnakes, there are three strips extending the length of the body: two pale side-stripes are found on the second and third scale rows and a single yellow, orange, or white stripe is located down the middle of the back. Two rows of staggered dark spots are located on each side between the side stripes and dorsal stripe. Unique to this species, the upper row of dark spots overlaps the dorsal stripe slightly. Dark blotches are also located on each side of the neck at the dorsal base of the skull. The belly is pale or bluish with uniform dark flecking along the center of the ventral scales. The dorsal scales are keeled with 19 or 21 rows at midbody. As with all gartersnakes, their anal plate is undivided. The Terrestrial Gartersnake has usually 8 upper labial scales and 10 lower labial scales. The crease between each upper labial scale is black. As with other gartersnakes, females usually have longer snout-to-vent lengths (SVL) and proportionally shorter tail lengths than males (Fitch 1940, Fitch 1983, Rossman 1995, Powell et al. 1998, Stebbins 2003). Black gartersnake morphs, lacking stripes, have been found along the upper Missouri River, but have not been positively differentiated from the Common Gartersnake (Grant Hokit, pers. comm.). Newborn and juvenile Terrestrial Gartersnakes resemble adults in coloration and overall appearance, but are lighter in color and have somewhat lighter stripes. Farr (1988) reported an average size of $17.6 \mathrm{~cm}$ SVL for neonates in southeastern British Columbia.

Similar Species:

Gartersnakes are the only snakes in Montana with lateral striping. The Common Gartersnake usually has a darker body color with brighter stripes giving the striping much more contrast, whereas stripes on the Terrestrial Gartersnake are less striking (Koch and Peterson 1995). Terrestrial Gartersnakes usually have eight upper labial scales, while our other two species, the Common Gartersnake (Thamnophis sirtalis) and the Plain's Gartersnake (Thamnophis radix), usually have only seven. The Plain's Gartersnake has its lateral stripes located on the third and fourth scale rows, while both the Common Gartersnake and the Terrestrial Gartersnake have theirs on the second and third scale rows.

\section{Habitat Use/Natural History}

Terrestrial Gartersnakes inhabit a wide variety of terrestrial and aquatic environments. Most prefer riparian woodlands or banks of water bodies such as streams, lake and pond margins, and wetlands. However, our subspecies, T. e. vagrans, appears to be more tolerant of drought conditions (Fitch 1949) occupying drier uplands habitats more often than other subspecies. Where the ranges of the Terrestrial Gartersnake and Common Gartersnake (Thamnophis sirtalis) overlap, the Terrestrial Gartersnake appears to be more of a generalist, occupying about twice as many watersheds as the Common Gartersnake. At higher elevations it prefers rocky cliffs and brush covered talus slopes, and is occasionally found along mountain lakes lacking vegetation and marshy shores (Maxell 2004). Thamnophis elegans usually emerge from winter hibernacula from late March to mid-May, depending on elevation and general weather conditions. They are also usually the first species to surface, exhibiting a wider tolerance for cold temperatures. In Wyoming, males emerged an average of three weeks prior to females and stayed near the hibernacula in preparation of courtship with females (Graves and Duval 1990, Rossman 1995). Unusually warm weather or unique local conditions may bring gartersnakes out of their hibernacula earlier. At Mammoth Hot Springs, Wyoming, an active Terrestrial Gartersnake was 
seen in February, presumably because of warm conditions created by nearby thermal vents (Koch and Peterson 1995). Courtship usually begins in early spring after emergence from hibernacula. However, in two populations in British Columbia, Farr (1988) reported courtship in early September. Successful fall mating is possible via an ability of females to store sperm through the winter (Stewart 1972). Sexually mature males (37-40 cm SVL) seek females (sexually mature at $42-46 \mathrm{~cm} \mathrm{SVL}$ ) by following pheromone trails released from glands in the cloacal region of the female. Multiple males may try to copulate with a single female at once forming "mating balls" of several intertwined individuals (Koch and Peterson 1995, Ashton 1999). Terrestrial Gartersnakes are viviparous, giving birth to live young from July through September. Three to twenty-seven neonates have been reported (Tanner 1949, Degenhardt et al. 1996, Kasper and Kasper 1997). However, average clutch size has been reported at just 7.5 in a New Mexico population. Similarly, a literature review by Ernst and Ernst (2003) report average clutch size of 8.7 among eight different litters. Clutch size is positively correlated with increased maternal SVL (Farr, 1988, Degenhardt et al. 1996). Norman (1978) has reported natural hybridization between T. elegans and T. sirtalis, although this has not been confirmed in Montana. T. elegans can live up to six years in nature (Werner et al. 2004), and captive specimens have lived over 20 years (Schuett et al. 1997). After mating, individuals will either remain in or near the den area or will migrate to foraging areas, dependent upon weather conditions and available foraging habitat. The longest recorded migration distance from hibernacula to a foraging area was two kilometers, taking place over a span of 7 days (Graves and Duvall 1990). After migration to foraging areas, movements within home ranges are more limited. The greatest distance traveled by a Terrestrial Gartersnake in New Mexico was only 357 meters over a span of 12 days and the greatest distance measured within one day was 67 meters (Fleharty 1967). Terrestrial Gartersnakes are generalist predators, feeding on numerous vertebrates and invertebrates. Individuals near wetlands prey on adult frogs, tadpoles, fish, mammals, small birds, leeches, and earthworms (Fitch 1940, Tanner 1949, Lystrup 1952, Thompson 2004). Geographic variation in diet exists, depending on resource availability. However, propensity to feed on amphibians is found in Montana and across their range, with foraging success positively correlated with amphibian abundance and diversity (Fitch 1940, Anderson 1977, Arnold 1977, Kephart and Arnold 1982, Jennings et al. 1992). Gartersnakes are known to congregate on shorelines during times of amphibian metamorphosis taking advantage of the physical limitations of amphibians at this life stage (Wassersug 1978). On a lakeshore in northern California, T. elegans was observed consuming metamorphic toads at a rate greater than one per minute (Kephart and Arnold 1982). In the Bitterroot Mountains of western Montana, Thompson (2004) found that dependence on amphibians for two species of gartersnake, $T$. elegans and T. sirtalis, was greater at high elevation sites, and that T. elegans was more dependent on larval Spotted Frogs (Rana luteiventris) than T. sirtalis, which generally consumed both larvae and adults. Despite a strong preference for amphibians in some areas, Terrestrial Gartersnakes are opportunistic feeders when their primary prey is unavailable, consuming various in many habitat types. James et al. (1982) observed 39 instances of T. elegans consuming White-crowned Sparrow nestlings in the northern California. Terrestrial Gartersnakes occasionally restrict or coil small mammals to immobilize them before consumption (Gregory et al. 1980). Terrestrial Gartersnakes overwinter underground in mammal burrows, fractured bedrock, rocky talus slopes, roadbeds, beneath boulders, old wells, and under building foundations. They are often the last snake to enter their hibernacula in the fall. They frequently share the underground cavity with other snakes, such as Common Gartersnakes 
(Thamnophis sirtalis), Prairie Rattlesnakes (Crotalus viridis), Racers (Coluber constrictor), Rubber Boas (Charinae bottae), Milksnakes (Lampropeltis triangulum), and Gopher Snakes (Pituophis catenifer) (Brown et al. 1974, Hammerson 1986, Degenhardt et al. 1996).

\section{Status and Conservation}

In Montana, and throughout their range, Terrestrial Gartersnakes appear to be common, often with high local population densities (Rossman et al 1996, MAIP). While no density studies have been conducted in Montana, a British Columbia study estimated a density of 2.8 per hectare (Farr 1988). Although successful in many habitats unaltered streams with high-quality riparian habitat probably support the highest densities (Szaro el al. 1985). T. elegans is less secretive than other snakes, often concentrating around aquatic habitat, and is locally abundant in many parts of its range. These characteristics increase its capture probability relative to other snakes, making it an excellent subject for method viability studies, which can be extrapolated to other snake species of semi-aquatic habitats (Szaro et al. 1988). Despite the successful adaptability of Terrestrial Gartersnakes, some populations can be negatively affected by the following. (1) Populations may be showing declines in areas where anurans continue to disappear, such as high elevation water bodies (Jennings et al. 1992). In the Sierra Nevada, researches discovered the probability of finding T. elegans in lakes with amphibians was 30 times greater than lakes where they were absent. At a 1,044 lake complex, where $80 \%$ of the lakes contained non-native trout, amphibians only occupied $19 \%$ of the lakes and no gartersnakes were found at any lake. In contrast, at a 1,059-lake complex, where only $40 \%$ of the lakes contained non-native trout, amphibians were found $52 \%$ of the lakes and 62 gartersnakes were found at 33 of these lakes (Matthews et al. 2002). (2) Over-grazing, especially along riparian corridors, can trample vegetation and alter soil structure, which are both important components of T. elegans habitat, and may significantly affect local populations (Kauffman and Krueger 1984, Szaro et al. 1985). Szaro et al. (1985) inventoried T. elegans along a third-order stream in northern New Mexico along grazed portions and within two one-kilometer long cattle exclosures. He found five times as many snakes in the exclosure even though snakes were more difficult to locate than in the open grazed areas. Furthermore, grazing is known to reduce the abundance of many invertebrates (Hutchingson and King 1980), which can both directly and indirectly affect prey availability for T. elegans. (3) Although effects of road mortality have not been directly studied in T. elegans, studies on other snakes indicate roads often have negative impacts on population size and distribution. High road density has been positively correlated to low population size, which leads to populations being restricted to pockets with low road density. This may lead to isolation or restricted interaction between populations (Rudolph et al. 1998, Jochimsen et al. 2004). (4) In general, any alteration of habitat has the potential to affect gartersnake populations in unapparent ways. For example, large-scale disturbances, such as mining, may alter rock and vegetation structure, which can affect prey availability and hiding cover. Even thermoregulation, which limits essential behavioral and physiological capacities, such as digestion, oxygen consumption, tongue flicking, locomotion, and reproductive success (Stevenson et al. 1985, Arnold et al. 1995), can be affected. For example, in northeastern California, Huey et al. (1989) found that $T$. elegans had narrow structural preferences for rock retreats. They preferred rocks of mid thickness $(20-40 \mathrm{~cm}$ ), presumably because thicker rocks would not heat to their preferred range, while thin rocks would quickly heat to intolerably high temperatures. Therefore, it may be presumed that disturbances which decrease structural diversity may negatively affect $T$. elegans. (5) The Terrestrial Gartersnake's tendency to utilize a small home range, its place as 
predator on the food chain, and its habit of consuming both aquatic and terrestrial prey, make it highly susceptible to bioaccumulation of heavy metals, and therefore, an excellent bioindicator of pollutants that may be entering the environment. Anderson (1977) compared the content of lead and mercury of gartersnakes from six riparian sites in Lake and Flathead counties with two sites known to have industrial pollution, Fred Bur Creek (contaminated with mercury) and an area surrounding an East Helena smelter (contaminated with lead). As suspected, concentrations of lead were approximately three times higher at East Helena and concentrations of mercury nearly twice as high at Fred Bur Creek than concentrations of those metals at the control sites in Lake and Flathead counties. Despite adequate habitat, Terrestrial Gartersnakes were rarely observed at the heavily polluted sites, qualitatively suggesting poor population viability caused by these heavy metals.

\section{Research and Management Suggestions}

1. Manage for viable amphibian populations at high elevations water bodies, where T. elegans is more dependent on amphibians.

2. Monitor local amphibian populations and T. elegans populations concurrently to identify potential effects of amphibian declines.

3. Limit non-native game fish introductions, especially at high elevation lakes where T. elegans is most dependent on anurans.

4. Investigate the extent of impacts to T. elegans populations by disturbances to riparian corridors, wetlands, and other water bodies by over-grazing, timber harvest, agriculture, and mining.

5. Grazing exclosures should be constructed along stream reaches on heavily impacted streams to promote regeneration of streamside vegetation and higher organic debris.

6. Long-term affects of road building on Terrestrial Gartersnake populations should be investigated in areas of increased road development.

7. Areas with dense road development, such as regions being developed for Coal Bed Natural Gas extraction, should be particularly targeted for baseline surveys and post-development monitoring.

8. Discharge of heavy metals, pesticides, and herbicides should be avoided near areas with high concentrations of T. elegans. Liver and muscle tissue samples of T. elegans can be taken at sites with suspected exposure to pollutants to assess bioaccumulation of heavy metals in the environment (Stafford et al. 1976, Anderson 1977).

9. Land managers should avoid unnecessary disturbance of known hibernacula and foraging habitat.

10. Care should be taken that easily-overlooked high-quality microhabitats, such as pockets of forest with downed woody debris and rock outcrops near riparian areas, are preserved.

Bibliography *indicates an article with information specific to Montana

Alfaro, M.E. 2003. Sweeping and striking: a kinematic study of the trunk during caprture in three thamnophiine snakes. Journal of Experimental Biology 206(14): 2381-2392.

Alfaro, M.E. and S.J. Arnold. 2001. Molecular systematics and evoloution of Regina and the Thamnophiine snakes. Molecular Phylogenetics and Evolution 21: 408-423.

*Anderson, M.E. 1977. Aspects of the ecology of two sympatric species of Thamnophis and heavy metal accumulation with the species. M.S. Thesis. Missoula, MT: University of Montana. $147 \mathrm{p}$. 
Arnold, S.J. 1977. Polymorphism and geographic variation in the feeding behavior of the garter snake, T. elegans. Science 197: 676-678.

Arnold, S.J. 1980. Inheritance and evolution of reproductive traits in garter snakes. American Zoologist 20(4): 781.

Arnold, S.J. 1981a. Behavioral variation in natural populations I. Phenotypec, genetic, and environmental correlations between chemoreceptive responses to prey in the garter snake, $T$. elegans. Evolution 35: 489-509.

Arnold, S.J. 1981b. Behavioral variation in natural populations II. The inheritance of a feeding response in crosses between geographic races of the garter snake, T. elegans. Evolution 35:510-515.

Arnold, S.J. 1982. A quantitative approach to antipredator performance: salamander defense against snake attack. Copeia 1982(2): 247-253.

Arnold, S.J. 1988. Quantitative genetics and selection in natural populations: microevolution of vertebral numbers in the garter snake Thamnophis elegans. In: Weir, B.S., Eisen, E.J., Goodman, M. \& Namkoong, G. [Eds]. Proceedings of the Second International Conference on Quantitative Genetics. Sinauer Associates, Inc., Sunderland, Massachusetts. 724 p.

Arnold, S.J. and C.R. Peterson. 2002. A model for optimal reaction norms: the case of the pregnant garter snake and her temperature-sensitive embryos. American Naturalist 160(3):306-316.

Arnold, S.J., C.R. Peterson, and J. Gladstone. 1995. Behavioural variation in natural populations. VII. Maternal body temperature does not affect juvenile thermoregulation in a garter snake. Animal Behavior 50(3): 623-633.

Arnold, S.J., K.C. Kelley, and J. Gladstone. 1993. Population variation in locomotor performance of juvenile garter snakes (Thamnophis elegans). American Zoologist 33(5): 25A.

Arnold, S.J. and P.C. Phillips. 1999. Hierarchical comparison of genetic variance-covariance matrices. II. Coastal-inland divergence in the garter snake, Thamnophis elegans. Evolution 53: 1516-1527.

Arnold, S.J. and R.J. Wassersug. 1978. Differential predation on metamorphic anurans by garter snakes (Thamnophis): social behavior as a possible defense. Ecology 59(5): 10141022.

Ashton, K.G. 1999. Thamnophis elegans vagrans (wandering garter snake). Mating. Herpetol. Rev. 30:104.

*Atkinson, E.C. and M.L. Atkinson. 2004. Amphibian and reptile survey of the Ashland and Sioux of the Custer National Forest with special emphasis on the Three-Mile Stewardship Area:2002. Marmot's Edge Conservation. 22 p.

Ayres, F.A. and S.J. Arnold. 1983. Behavioral variation in natural populations. IV. Mendelian models and heritability of a feeding response in the garter snake, T. elegans. Heredity 51: 405-413.

Bailey, R.M. 1949. Temperature tolerance of gartersnakes in hibernation. Ecology 30: 238242.

Barker, B.S., S.J. Arnold, and M.E. Pfrender. 2003. Comparisons of inheritance matrices in three populations of the garter snake (Thamnophis elegans). Abstract. Northwestern Naturalist 84:94. 
Beal, M.D. 1951. The occurrence and seasonal activity of vertebrates in the Norris and Gibbon Geyser Basins of Yellowstone National Park. M.S. Thesis. Utah State Agricultural College. Logan, Utah. 61 pp.

Bellemin, J.M. and G.R. Stewart. 1977. Diagnostic characters and color convergence of the garter snakes (Thamnophis elegans terrestris) and (Thamnophis couchii atratus) along the central California coast. Bulletin of the Southern California Academy of Science 76(2): 7384.

*Benson, K.R. 1978. Herpetology of the Lewis and Clark expedition 1804-1806. Herpetological Review 9(3): 87-91.

Benton, M.J. 1980. Geographic variation in the garter snakes, $T$. sirtalis, of the north-central U.S., a multivariate study. Zoological Journal of the Linnean Society 68:307-323.

Berner, N.J. 1988. Molecular basis of the difference in oxygen affinity between maternal and fetal blood in the viviparous garter snake, Thamnophis elegans. M.S. Thesis, University of Idaho. $40 \mathrm{p}$.

Berner, N.J., and R.L. Ingermann. 1988. Molecular basis of the difference in oxygen affinity between maternal and fetal red blood cells in the viviparous garter snake Thamnophis elegans. Journal of Experimental Biology 140: 437-454.

*Boundy, J. 2001. Herpetofaunal surveys in the Clark Fork Valley region, Montana. Herpetological Natural History 8: 15-26.

Boundy, J. and D. A. Rossman. 1995. Allocation and status of the garter snake names Coluber infernalis Blainville, Eutaenia sirtalis tetrataenia Cope, and Eutaenia imperialis Coues and Yarrow. Copeia 1995:236-240.

Bourguignon, T. 2002. Garter snakes, origins, care and species. Stuttgart:Verlag Eugen Ulmer. 2002.

Breitenbach, R.P. 1951. Large fish for a small snake. Yellowstone Nature Notes 25(6): 70.

Brent, C.M. and P.T. Gregory. 1995. Movements and habitat use in gravid and nongravid female garter snakes (Colubridae: Thamnophis). Journal of Zoology 236(4): 543-561.

Brodie, E.D. III and E.D. Brodie, Jr. 1990. Tetrodotoxin resistance in garter snakes: an evolutionary response of predators to dangerous prey. Evolution 44: 651-659.

Brodie, E.D. III and E.D. Brodie, Jr. 1991. Evolutionary response of predators to dangerous prey: reduction of toxicity of newts and resistance of garter snakes in island populations. Evolution 45: 221-224.

Brodie, E.D., Jr. and M.S. Tumbarello. 1978. The antipredator functions of Dendrobates auratus (Amphibia, Anura, Dendrobatidae) skin secretions in regard to a snake predator (Thamnophis). Journal of Herpetology 12: 264-265.

Bronikowski, A.M. 2000. Experimental evidence for the adaptive evolution of growth rate in the garter snake Thamnophis elegans. Evolution 54(5): 1760.

Bronikowski, A.M. and S.J. Arnold. 1999. The evolutionary ecology of life history variation in the garter snake Thamnophis elegans. Ecology 80(7): 2314-2325.

Bronikowski, A.M. and S.J. Arnold. 2001. Cytochrome b phylogeny does not match subspecific classification in the western terrestrial garter snake, Thamnophis elegans. Copeia (2) 508513.

*Brunson, R.B. 1955. Check list of the amphibians and reptiles of Montana. Proceedings of the Montana Academy of Sciences 15: 27-29.

*Brunson, R. B. and H. A. Demaree. 1951. The herpetology of the Mission Mountains, Montana. Copeia 1951: 306-308. 
Bull, E.L. and M.P. Hayes. 2000. Livestock effects on reproduction of the Columbia spotted frog. Journal of Range Management 53: 293-296.

Bullock, R.E., and W.W. Tanner. 1966. A comparative osteological study of two species of Colubridae (Pituophis and Thamnophis). Brigham Young University Science Bulletin 8(3): $1-29$.

Burghardt, G.M. 1964. Stimulus control of the prey attack response in native garter snakes. Psychonomic Science 4: 37-38.

Burghardt, G.M. 1969. Comparative prey-attack studies in newborn snakes of the genus Thamnophis. Behaviour 33: 77-114.

Burghardt, G.M. 1970. Intraspecific geographical variation in chemical food cue preference of newborn garter snakes (Thamnophis sirtalis). Behaviour 36: 246-257.

Burghardt, G.M. 1992. Prior exposure to prey cues influences chemical prey preferences and prey choice in neonatal garter snakes. Animal Behavior 44: 787-789.

Burghardt, G.M. and D. Denny. 1983. Effects of prey movement and prey odor on feeding in garter snakes. Zeitschrift fur Tierpsychologie 62: 329-347.

Burghardt, G.M., H.C. Wilcoxon, and J.A. Czaplicki. 1973. Conditioning in garter snakes: aversion to palatable prey induced by delayed illness. Animal Learning and Behavior 1: 317320.

Burghart, G.M. and C.H. Pruitt. 1975. Role of the tongue and senses in feeding of naïve and experienced garter snakes. Physiology and Behavior 14: 185-194.

*Burroughs, R.D. 1961. The natural history of the Lewis and Clark expedition. Michigan State University Press. 340 pp.

Butler, R. 1985. The captive care and breeding of Thamnophis elegans terrestris. Herptological Review 10(2): 34-38.

*Butts, T.W. 1997. Mountain Inc. wildlife monitoring Bull Mountains Mine No. 1, 1996. Western Technology and Engineering. Helena, MT.

Campbell, R.W. 1969. Notes on some foods of the wandering garter snake on Mittlenatch Island, British Columbia. Syesis 2: 183-187.

Carpenter, C.C. 1951. Young goldfinches eaten by garter snake. Wilson Bull. 63: 117-118.

Carpenter, C.C. 1952. Growth and maturity of the three species of Thamnophis in Michigan. Copeia 1952: 237-243.

Carpenter, C.C. 1955. The garter snake. Science Monthly 81: 248-252.

Charland, M.B. 1991. Anesthesia and transmitter implantation effects on gravid garter snakes (Thamnophis sirtalis and T. elegans). Herpetological Review 22(2): 46-47.

Charland, M.B. 1993. Reproductive ecology of female garter snakes (Thamnophis) in southeastern British Columbia. Ph.D. Dissertation, University of Victoria (Canada) 226p. 1991.

Charland, M.B. 1995. Thermal consequences of reptilian viviparity: thermoregulation in gravid and non-gravid garter snakes (Thamnophis). Journal of Herpetology 29(3): 383-390.

Charland, M.B and P.T. Gregory. 1995. Movements and habitat use in gravid and non-gravid female garter snakes (Colubridae: Thamnophis). Journal of Zoology (London) 236(4): 543561.

Cochran, P.A. 1986. Opportunistic scavenging by a garter snake in Colorado. Bulletin of the Chicago Herpetological Society 21(3-4): 94-95.

*Cooper, J.G. 1869. The fauna of Montana territory. American Naturalist 3: 124-127. 
*Cope, E.D. 1872. Report on the recent reptiles and fishes of the survey, collected by Campbell Carrington and C.M. Dawes. pp. 467-469. In: F.V. Hayden, Preliminary report of the United States geological survey of Montana and portions of adjacent territories; a fifth annual report of progress. 538 pp. 42nd Congress, 2nd Session, House Executive Document Number 326. Serial 1520.

*Cope, E.D. 1875. Check-list of North American Batrachia and Reptilia; with a systematic list of the higher groups, and an essay on geographical distribution. U.S. National Museum Bulletin 1(1): 1-104.

*Cope, E.D. 1891. A critical review of the characters and variations of the snakes of North America. Proceedings of the U.S. National Museum 14(882): 589-694.

*Cope, E.D. 1900. The crocodilians, lizards and snakes of North America. Report of the U.S. National Museum 1898: 153-1270.

*Corn, J. and P. Hendricks. 1998. Lee Metcalf National Wildlife Refuge bullfrog and painted turtle investigations: 1997. Montana Natural Heritage Program, Helena, MT. 20 p.

Costanzo, J.P. 1988. Recovery from ice-entombment in garter snakes. Herpetological Review 19(4): 76-77.

*Coues, E. and H.C. Yarrow. 1878. Notes on the herpetology of Dakota and Montana. Bulletin of the U.S. Geologic and Geographic Survey 4(1): 259-291.

Cowan, I. and W.B.M. Hick. 1951. A comparative study of the myology of the head region in three species of Thamnophis (Reptilia, Orphidia). Transactions of the Royal Society Canadian Section 5(45): 19-60.

Crews, D., B. Camazine, M. Diamond, R. Mason, R.R. Tokarz, and W.R. Garstka. 1984. Hormonal independence of courtship behavior in the male garter snake. Hormones and Behavior 18: 29-41.

Crews, D. and W.R. Gartska. 1982. The ecological physiology of a garter snake. Scientific American 247: 159-168.

Cunningham, J.D. 1955. Notes on the ecology of Thamnophis e. elegans (Baird and Girard). Herpetologica 11: 152.

*Cutter, R. 1930a. Ike and Mike. Yellowstone Nature Notes 7(7): 41.

*Cutter, R. 1930b. Miscellaneous note on garter snakes. Yellowstone Nature Notes 7(9): 62. de Queiroz, A. and R. Lawson. 1994. Phylogenetic relationships of the garter snakes based on DNA sequence and allozyme variation. Biological Journal of the Linnean Society 53: 209-229.

De Queiroz, A. and R.R. Groen. 2001. The inconsistent and inefficient constricting behavior of Colorado western terrestrial garter snakes, Thamnophis elegans. Journal of Herpetology 35(3):450-460.

Devine, M.C. 1976. Species discrimination in mate selection by free-living male garter snakes and experimental evidence for the role of pheromones. Herpetological Review 71: 79.

Devine, M.C. 1977. Copulatory plugs, restricted mating opportunities, and reproductive competition among male garter snakes. Nature 267: 345-346.

Drummond, H.M. 1980. Aquatic foraging in some new world natricine snakes: generalists and specialists, and their behavioral evolution. Ph.D. Dissertation, University of Tennessee 204p. 1980.

Drummond, H. 1983. Aquatic foraging in garter snakes: a comparison of specialists and generalists. Behaviour 86: 1-30. 
Drummond, H. and C.M. Garcia. 1989. Limitations of a generalist: a field comparison of foraging snakes. Behaviour 108(1-2): 23-43.

Drummond, H. and G.M. Burghardt. 1983. Geographic variation in the foraging behavior of the garter snake, Thamnophis elegans. Behavior of Ecological Sociobiology 12(1): 43-48.

*Elliott, A.E. 1931. Another fish story. Yellowstone Nature Notes 8(9): 69.

*Ernst, C.H. and E.M. Ernst. 2003. Snakes of the United States and Canada. Washington D.C.: Smithsonian Books.

*Farmer, P. 1986. Chartam project baseline wildlife study. Western Technology and Engineering, Inc. Helena, MT.

*Farmer, P. and S.B. Heath. 1987. Wildlife baseline inventory, Rock Creek study area, Sanders County, Montana. Western Technology and Engineering, Inc. Helena, MT.

Farr, D.R. 1988. The ecology of garter snakes, Thamnophis sirtalis and T. elegans, in southeastern British Columbia. Unpubl. M.S. Thesis, University of Victoria, BC, Canada.

Farr, D.R. and P.T. Gregory. 1991. Sources of variation in estimating litter characteristics of the garter snake, Thamnophis elegans. Journal of Herpetology 25(3): 261-268.

Feder, M. E. and S.J. Arnold. 1982. Anaerobic metabolism and behavior during predatory encounters between snakes (Thamnophis elegans) and salamanders. (Plethodon Jordani). Oecologia 53(1): 93-97.

Finley, R.B., Jr., D. Chiszar, and H.M. Smith. 1994. Field observations of salivary digestion of rodent tissue by the wandering garter snake, Thamnophis elegans vagrans. Bulletin of the Chicago Herpetological Society 29(1): 5-6.

Finneran, L.C. 1949. A sexual aggregation of the garter snake Thamnophis butleri. Copeia 1949: $141-144$.

*Fitch, H.S. 1940. A biogeographical study of the ordinoides artenkries of garter snakes (genus Thamnophis). University of California Publications in Zoology 44(1): 1-150.

Fitch, H.S. 1941. The feeding habits of California garter snakes. California Fish and Game 27: 1-32.

Fitch, H.S. 1948. Further remarks concerning Thamnophis ordinoides and its relatives. Copeia 1948(2): 121-126.

Fitch, H.S. 1949. Study of snake populations in central California. American Midland Naturalist 41(3): 513-579.

Fitch, H.S. 1980. Remarks concerning certain western garter snakes of the Thamnophis elegans complex. Transactions of Kansas Academy of Sciences 83: 106-113.

*Fitch, H.S. 1983. Thamnophis elegans. Catalogue of American Amphibians and Reptiles 320.1-320.4.

Fitch, H.S. and T.P. Maslin. 1961. Occurrence of the garter snake, Thamnophis sirtalis, in the Great Plains and Rocky Mountains. University of Kansas Publications, Museum of Natural History 13(5): 289-308.

Fleharty, E.D. 1967. Comparative ecology of Thamnophis elegans, T. cyrtopsis, and T. rufipunctatus in New Mexico. Southwestern Naturalist 12: 207-230.

Flowers, M.A. and B.M. Graves. 1997. Juvenile toads avoid chemical cues from snake predators. Animal Behavior 53(3): 641-646.

Ford, N.B. 1976. Sex pheromone trailing behavior in three species of garter snake (Thamnophis). M.S. Thesis. University of Oklahoma.

Ford, N.B. 1978. Evidence for species specificity of pheromone trails in two sympatric garter snakes, Thamnophis. Herpetological Review 9: 10. 
Ford, N.B. 1979. Aspects of pheromone trailing in garter snakes (Thamnophis). Ph.D. Dissertation. Miami University (Ohio).

Ford, N.B. 1981. Seasonality of pheromone trailing behavior in two species of farter snake, Thamnophis (Colubridae). Southwestern Naturalist 264: 385-388.

Ford, N.B. 1996. Behavior of garter snakes. pp.90-116. In: Rossman, D.A., N.B. Ford, and R.A. Seigel (eds). The Garter Snakes: Evolution and Ecology. Norman, OK: University of Oklahoma Press.

Ford, N.B. and G.A. Shuttlesworth. 1986. Effects of variation in food intake on locomotory performance of juvenile garter snakes. Copeia 1986(4): 999-1001.

Fouquette, M.J., Jr. 1954. Food competition among four sympatric species of garter snakes. Texas Journal of Science 6: 172-188.

Fox, W. 1948a. The relationships of the garter snake, Thamnophis ordinoides. Copeia 1948(2): 113-120.

Fox, W. 1948b. Effect of temperature on development of scutellation in the garter snake, Thamnophis elegans atratus. Copeia 1948(4): 252-262.

Fox, W. 1951. Relationships among the garter snakes of the Thamnophis elegans rassenkreis. University of California Publication of Zoology 50(5): 485-530.

Fox, W. 1952a. Notes on the feeding habits of Pacific coast garter snakes. Herpetologica 8: 4-8.

Fox, W. 1952b. Seasonal variation in the male reproductive system of Pacific coast garter snakes. Journal of Morphology 90: 481-554.

Fox, W. 1954. Genetic and environmental variation in the timing of the reproductive cycles of male garter snakes. Journal of Morphology 95: 415-450.

Fox, W. 1955. Mating aggregations of garter snakes. Herpetologica 11: 176.

Fox, W. and H.C. Dessauer. 1964. Collection of garter snakes for blood studies. Yearbook of American Philosophy Society 1964: 263-266.

Fox, W., C. Gordon, and M.H. Fox. 1961. Morphological affect of low temperatures during the embryonic development of the garter snake, Thamnophis elegans. Zoologica 46: 57-71.

*Franz, R. 1971. Notes on the distribution and ecology of the herpetofauna of northwestern Montana. Bulletin of the Maryland Herpetological Society 7: 1-10.

Gardner, J.B. 1955. A ball of garter snakes. Copeia 1955(4): 310.

Gardner, J.B. 1957. A garter snake "ball." Copeia 1957: 48.

Garland, T., Jr. 1994. Quantitative genetics of locomotor behavior and physiology in a garter snake. In: Boake, R.B. (ed.), Quantitative Genetic Studies of Behavioral Evolution. University of Chicago Press, Chicago, Illinois.

Garland, T., Jr. and A.F. Bennett. 1990. Quantitative genetics of maximal oxygen consumption in a garter snake. American Journal of Physiology 259: R986-R992.

Garland, T., Jr. and S.J. Arnold. 1983. Effects of a full stomach on locomotory performance of juvenile garter snakes (Thamnophis elegans). Copeia 1983(4): 1092-1096.

Garner, T.W.J. and K.W. Larsen. 2005. Multiple paternity in the western terrestrial garter snake, Thamnophis elegans. Canadian Journal of Zoology 83(5):656-663.

*Gates, M.T. 2005. Amphibian and reptile baseline survey: CX field study area. Report to Billings and Miles City Field Offices of Bureau of Land Management. Maxim Technologies, Billings, MT. 28pp + Appendices.

Gehlbach, F.R., J.F. Watkins, and J.C. Kroll. 1971. Pheromone trail-following studies of typhlopid, leptotyphlopid, and colubrid snakes. Behaviour 40: 282-294. 
Goellner, R. 1975. Garter snakes as toxic as rattler. St. Louis Herpetological Society Newsletter 2: 8-9.

Goldberg, S.R. 2004. Reproduction in the western terrestrial garter snake, Thamnophis elegans (Serpentes, Colubridae) from Arizona. Journal of the Arizona-Nevada Academy of Science 36(2):77-80.

Gomez, H.F., M. Davis, S. Phillips, P. McKinney, and J. Brent. 1994. Human envenomation from a wandering garter snake. Annals of Emergency Medicine 23(5): 1119-1122.

Graves, B.M. and D. Duvall. 1990. Spring emergence patterns of wandering garter snakes and prairie rattlesnakes in Wyoming. Journal of Herpetology 24(4): 351-356.

*Greer, K.R. 1955a. The otter's diet - good or bad? Montana Wildlife 5(3): 14-17. Montana Fish and Game Department, Helena, MT.

*Greer, K.R. 1955b. Yearly food habits of the river otter in the Thompson Lakes Region, Northwestern Montana, as indicated by scat analysis. American Midland Naturalist 54: 299313.

Gregory, P.T. 1967. Feeding habits and diet overlap of three species of garter snakes (Thamnophis) on Vancouver Island. Canadian Journal of Zoology 56: 1967-1974.

Gregory, P.T. 1984a. Correlations between body temperature and environmental factors and their variations with activity in garter snakes (Thamnophis). Canadian Journal of Zoology 62(11): 2244-2249.

Gregory, P.T. 1984b. Habitat, diet, and composition of assemblages of garter snakes (Thamnophis) at 8 sites on Vancouver Island. Canadian Journal of Zoology 62: 2013-2022.

Gregory, P.T. 1990. Temperature differences between head and body in garter snakes (Thamnophis) at a den in Central British Columbia (Canada). Journal of Herpetology 24(3): 241-245.

Gregory, P.T. and A.G.D. McIntosh. 1980. Thermal niche overlap in garter snakes (Thamnophis) on Vancouver Island. Canadian Journal of Zoology 58(3): 351-355.

Gregory, P.T. and C.J. Prelypchan. 1994. Analysis of variance of first-year growth in captive garter snakes (Thamnophis elegans) by family and sex. Journal of Zoology 232(2): 313-322.

Gregory, P.T. and K.M. Skebo. 1998. Trade-offs between reproductive traits and the influence of food intake during pregnancy in the garter snake, Thamnophis elegans. American Naturalist 151: 477-486.

Gregory, P.T., J.M. Macartney, and D.H. Rivard. 1980. Small mammal predation and prey handling behavior by the garter snake Thamnophis elegans. Herpetologica 36(1): 87-93.

Halpern, M. and J.L. Kubie. 1980. Chemical access to the vomeronasal organs of garter snakes. Physiological Behavior 24: 367-371.

Halpern, M. and N. Frumin. 1979. Roles of the vomeronasal and olfactory systems in prey attack and feeding in adult garter snakes. Physiological Behavior 22: 1183-1189.

Hamilton, W.J., Jr. 1951. The food and feeding behavior of the garter snake in New York. American Midland Naturalist 46(2): 385-390.

*Hart, M.M., W.A. Williams, P.C. Thornton, K.P. McLaughlin, C.M. Tobalske, B.A. Maxell, D.P. Hendricks, C.R. Peterson, and R.L. Redmond. 1998. Montana atlas of terrestrial vertebrates. Montana Cooperative Wildlife Research Unit, The University of Montana. Missoula, Montana vii +1302 p.

*Hayden, F.V. 1858. Catalogue of the collections in geology and natural history, obtained by the expedition under command of Lieutenant G.K. Warren, Topographical Engineers. pp. 104-105. In: F.N. Shubert (1981) Explorer on the northern plains: Lieutenant Gouverneur K. 
Warren's preliminary report of explorations in Nebraska and Dakota, in the years 1855-'56'57. Engineer Historical Studies No. 2. Office of the Chief of Engineers, Washington, DC. $125 \mathrm{p}$.

*Hayden, F.V. 1863. On the geology and natural history of the upper Missouri. Transactions of the American Philosophical Society New Series 12(1): 1-218 (pages 177-178).

Hebard, W.B. 1950. Relationships and variation in the garter snakes, genus Thamnophis, of the Puget Sound region of Washington state. Herpetologica 6: 97-101.

Heller, S. and M. Halpern. 1981. Laboratory observations on conspecific and congeneric scent trailing in garter snakes (Thamnophis). Behavioral Neural Biology 33(3): 372-377.

*Hendricks, P. 1996. Geographical distribution. Thamnophis elegans vagrans. Herpetological Review 27(2): 89.

*Hendricks, P. 1997. Lee Metcalf National Wildlife Refuge preliminary amphibian and reptile investigations: 1996. Montana Natural Heritage Program, Helena, MT. 21 p.

*Hendricks, P. 1999. Amphibian and reptile survey of the Bureau of Land Management Miles City District, Montana. Montana Natural Heritage Program, Helena, MT. 80 p.

*Hendricks, P. 2000. Amphibian and reptile survey of the Thompson Chain of Lakes. A report to the Montana Department of Fish, Wildlife, and Parks. Montana Natural Heritage Program, Helena, MT. 15 p.

*Hendricks, P. and J.D. Reichel. 1996a. Amphibian and reptile survey of the Bitterroot National Forest: 1995. Montana Natural Heritage Program, Helena, MT. 95 p.

*Hendricks, P. and J.D. Reichel. 1996b. Preliminary amphibian and reptile survey of the Ashland District, Custer National Forest: 1995. Montana Natural Heritage Program, Helena, MT. 79 p.

*Hendricks, P. and J.D. Reichel. 1998. Amphibian and reptile survey on Montana refuges: 1996. Montana Natural Heritage Program, Helena, MT. 19 p.

*Hendricks, P. and M. Roedel. 2001. A faunal survey of the Centennial Valley Sandhills, Beaverhead County, Montana. Report to the U.S. Bureau of Land Management and U.S. Fish and Wildlife Service. Montana Natural Heritage Program, Helena, MT. 44 p.

Herman, J.K. and R.L. Ingermann. 1996. Effects of hypoxia and hyperoxia on oxygen-transfer properties of the blood of a viviparous snake. Journal of Experimental Biology 199(9): 2061-2070.

Hicks, J.W., M.L. Riedesel, and M.L. Glass. 1979. Ventilative and gas exchange in Thamnophis elegans after acute and chronic exposure to various thermal environments. Journal of the Colorado-Wyoming Academy of Science 11(1): 99-100.

Highfill, D.R. 1976. Function of the corpora lutea of pregnancy in the garter snake (Thamnophis elegans). Ph.D. Dissertation. University of Idaho. 52p.

*Hill, S.R. and R.E. Moore. 1994a. Herpetological survey in the northern range of Yellowstone National Park. Annual Report to Yellowstone National Park. February 1, 1994. 21 p.

*Hill, S.R. and R.E. Moore. 1994b. Herpetological survey in the northern range of Yellowstone National Park. Investigator's Annual Reports Yellowstone National Park 1993. Yellowstone Center for Resources. pp. 96-97.

*Hill, S.R., Jr. 1995. Migratory chronology of adult tiger salamanders (Ambystoma tigrinum) and survey of larvae of the tiger salamander in the northern range of Yellowstone National Park. M.S. Thesis. Montana State University, Bozeman, MT. 72 p. 
*Hilliard, J., H. Minkus, and M. Weber. 1997. Amphibian survey of the Birch Creek drainage, Beaverhead County. Wildland Studies Project, San Francisco State University, San Francisco, CA. 12 p.

Hirth, H.F., R.C. Pendleton, A.C. King, and T.R. Downard. 1969. Dispersal of snakes from a hibernaculum in northwestern Utah. Ecology 50: 332-339.

Hogg, J.B. 1974. Color convergence in the garter snakes Thamnophis elegans terrestris and Thamnophis couchi atratus along the central California coast. M.S. Thesis, California State Polytechnic University (Pomona). $95 \mathrm{p}$.

*Hossack, B.R., D. Pilliod, and P.S. Corn. 2001. Preliminary amphibian surveys of the National Bison Range, Lost Trail National Wildife Refuge, and Swan River National Wildlife Refuge: 2001. USGS Northern Rocky Mountain Science Center, Aldo Leopold Wilderness Research Institute, Missoula, MT. 15 .

Huey, R.B., C.R. Peterson, S.J. Arnold, and W.P. Porter. 1988. The thermal consequences of retreat site selection by garter snakes. American Zoologist 28(4): 46A.

Huey, R.B., C.R. Peterson, S.J. Arnold, and W.P. Porter. 1989. Hot rocks and not-so-hot rocks: retreat-site selection by garter snakes and its thermal consequences. Ecology 70(4): 931-944.

Hutchinson, K.J., and Kathleen L. King. 1980. The effects of sheep stocking level on invertebrate abundance, biomass and energy utilization in a temperate, south grassland. Journal of Applied Ecology. 17:369-387.

Ingermann, R.L., N.J. Berner, and F.R. Ragsdale. 1991a. Changes in red cell ATP concentration and oxygen-affinity following birth in the neonatal garter snake, Thamnophis elegans. Journal of Experimental Biology 157: 579-584.

Ingermann, R.L., N.J. Berner, and F.R. Ragsdale. 1991b. Effect of pregnancy and temperature on red cell oxygen-affinity in the viviparous snake Thamnophis elegans. Journal of Experimental Biology 156(0): 399-406.

James, D.K., L. Petrinovich, T.L. Patterson, and A.H. James. 1983. Predation of whitecrowned sparrow nestlings by the western terrestrial garter snake in San Francisco, California. Copeia 1983(2): 511-513.

Jansen, D.W. 1980. Possible functions of Duvernoy's gland in the wandering garter snake (Thamnophis elegans vagrans). American Zoologist 20(4): 962.

Jansen, D.W. 1981. Allometric growth of the skull of Thamnophis elegans vagrans: adaptive potentials. American Zoologist 21(4): 958.

Jansen, D.W. 1987. The myonecrotic effect of Duvernoy's gland secretion of the snake Thamnophis elegans vagrans. Journal of Herpetology 21(1): 81-83.

Jennings, M.R., D.F. Bradford and D.F. Johnson. 1992. Dependence of the garter snake Thamnophis elegans on amphibians in the Sierra Nevada of California. Journal of Herpetology 26: 503-505.

Jochimsen, Denim M., Charles R. Peterson, Kimberly M. Andrews, and J. Whitfield Gibbons. 2004. A literature review of the effects of roads on amphibians and reptiles and the measures used to minimize those effects. Idaho Fish and Game Department and USDA Forest Service.

Johnson, M.L. 1947. The status of the elegans subspecies of Thamnophis with description of a new subspecies from Washington State. Herpetologica 3: 159-165.

Kardong, K.V. and D.L. Luchtel. 1986. Ultrastructure of Duvernoy's gland from the wandering garter snake, Thamnophis elegans vagrans (Serpentes, Colubridae). Journal of Morphology 188(1): 1-14. 
Kasper, S. and S.N. Kasper. 1997. Serpentes: Thamnophis elegans vagrans (wandering garter snake). Paralysis. Herpetological Review 28(1): 46.

Kauffman, J.B. and W.C. Krueger. 1984. Livestock impacts on riparian ecosystems and streamside management implications: a review. Journal of Range Management 37(5):430436.

Kelly, K.C., S.J. Arnold, and J. Gladstone. 1997. The effects of substrate and vertebral number on locomotion in the garter snake Thamnophis elegans. Functional Ecology 11: 189-198.

Kephart, D.G. 1981. Population ecology and population structure of Thamnophis elegans and Thamnophis sirtalis. Ph.D. Dissertation. University of Chicago.

Kephart, D.G. 1982. Microgeographic variation in the diets of garter snakes. Oecologia 52(2): 287-291.

Kephart, D.G. and S.J. Arnold. 1982. Garter snake diets in a fluctuating environment: a sevenyear study. Ecology 63(5): 1232-1236.

Kingery, U.C. and H.E. Kingery. 2003. Standoff at a Chatfield marsh: house wrens and a garter snake. Colorado Birds 37(4):190-191.

*Koch, E.D. and C.R. Peterson. 1989. A preliminary survey of the distribution of amphibians and reptiles in Yellowstone National Park. pp. 47-49. In: Rare, sensitive and threatened species of the Greater Yellowstone Ecosystem, T.W. Clark, A.H. Harvey, R.D. Dorn, D.C. Genter, and C. Groves (eds.), Northern Rockies Conservation Cooperative , Montana Natural Heritage Program, The Nature Conservancy, and Mountain West Environmental Services. 153 p.

Kubie, J.L., J. Cohen, and M. Halpern. 1978. Shedding enhances the sexual attractiveness of oestradiol treated garter snakes and their untreated penmates. Animal Behavior 26: 562-570.

Kubie, J.L. and M. Halpern. 1979. Chemical senses involved in garter snake prey trailing. Journal of Comparative Physiological Psychology 93: 648-667.

Lawson, R. 1987. Molecular studies of thamnophiine snakes: The phylogeny of the genus nerodia. Journal of Herpetology 21:140-157.

Lawson, R. and H.C. Dessauer. 1979. Biochemical genetics and systematics of garter snakes of the Thamnophis-elegans-couchii-ordinoides complex. Occasional Papers of the Museum of Zoology of Louisiana State University 56: 1-24.

Licht, E.L. 1985. Thamnophis elegans vagrans (gray garter snake), longevity. Bulletin of the Maryland Herpetological Society 21(4): 150.

Lind, A.J. and Hartwell H.W., Jr. 1994. Ontogenetic changes in foraging behavior and habitat use by the Oregon garter snake, Thamnophis atratus hydrophilus. Animal Behavior 48(6): 1261-1273.

Littrell, E.E. 1983. A study of the effects of bolero $10 \mathrm{~g}$ on the mountain garter snake, Thamnophis elegans elegans. California Fish and Game 69(3): 186-187.

*Lystrup, H.T. 1952. A garter snake captures a young bird. Yellowstone Nature Notes 26(1): 10-11.

Macartney, J.M. and P.T. Gregory. 1981. Differential susceptibility of sympatric garter snake species to amphibian secretions. American Midland Naturalist 106: 271-281.

Manier, M.K. 2003. Does natural variation at neutral molecular markers reflect ecological variation in garter snakes? Abstract. Northwestern Naturalist 84:105.

Manier, M.K. 2005. Ecological correlates of population genetic structure for two coexisting garter snake species. Abstract. Northwestern Naturalist 86:106. 
*Manville, R.H. 1957. Amphibians and reptiles of Glacier National Park, Montana. Copeia 1957: 308-309.

*Marnell, L.F. 1997. Herpetofauna of Glacier National Park. Northwestern Naturalist 78: 17-33.

Mason, R.T. and D. Crews. 1985. Female mimicry in garter snakes. Nature 316: 59-60.

Mason, R.T. and D. Crews. 1986. Pheromone mimicry in garter snakes, pp. 279-283. In: D. Duvall, D. Muller-Schwarze, and R.M. Silverstein (eds). Chemical Signals in Vertebrates. Vol. 4. New York, NY: Plenum Publishing Co.

Mason, R.T., J.W. Chinn, and D. Crews. 1987. Sex and seasonal differences in the skin lipids of garter snakes. Comparative Biochemistry and Physiology 87B: 999-1003.

Matthews, K.R., R.A. Knapp, and K.L. Pope. 2002. Garter snake distributions in high-elevation aquatic ecosystems: is there a link with declining amphibian populations and nonnative trout introductions? Journal of Herpetology 36: 16-22.

*Maxell, B.A. 2002. Amphibian and aquatic reptile inventories in watersheds in the South and Middle Forks of the Flathead River drainage that contain lakes being considered for application of piscicides and subsequent stocking of west slope cutthroat trout. Report to the Region 1 Office of the U.S. Forest Service and the Montana Department of Fish, Wildlife, and Parks. Missoula, MT: Montana Cooperative Wildlife Research Unit and Wildlife Biology Program, University of Montana. 62 p.

* Maxell, B.A. 2004a. Amphibian and aquatic reptile inventories conducted on and around the Bitterroot National Forest 2000-2003. Report to Region 1 Office of the U.S. Forest Service, Bitterroot National Forest, Montana Department of Fish, Wildlife, and Parks, and Biological Resources Division of the U.S. Geological Survey. Missoula, MT: Montana Cooperative Wildlife Research Unit and Wildlife Biology Program, University of Montana. 128 p.

*Maxell, B.A. 2004b. Amphibian and aquatic reptile inventories conducted on and around the Thompson River 2003-2004. Report to Region 1 Office of the U.S. Forest Service and Plum Creek Timber Company. Missoula, MT: Montana Cooperative Wildlife Research Unit and Wildlife Biology Program. 83 p.

*Maxell, B.A. 2004c. Preliminary report on amphibian and aquatic reptile inventories conducted in the West Boulder River area during summer 2003. Report to Region 1 Office of the U.S. Forest Service, and the Montana Department of Fish, Wildlife, and Parks. Missoula, MT: Montana Cooperative Wildlife Research Unit and Wildlife Biology Program, University of Montana. $27 \mathrm{p}$.

*Maxell, B.A. 2004d. Preliminary report on amphibian and aquatic reptile inventories conducted on and around the Ashland District of the Custer National Forest in 2002 and 2004. Report to Ashland District of Custer Forest, Region 1 Office of the U.S. Forest Service, and Montana Department of Fish, Wildlife, and Parks. Missoula, MT: Montana Cooperative Wildlife Research Unit and Wildlife Biology Program, University of Montana. $93 \mathrm{p.}$

*Maxell, B.A. 2004e. Report on amphibian and aquatic reptile inventories conducted on and around the Beaverhead-Deerlodge National Forest 2001-2003. Report to Region 1 Office of the U.S. Forest Service, Beaverhead-Deerlodge National Forest, Montana Department of Fish, Wildlife, and Parks, Montana State Office of the Bureau of Land Management, and Montana Department of Environmental Quality. Missoula, MT: Montana Cooperative Wildlife Research Unit and Wildlife Biology Program, University of Montana. 260 p.

*Maxell, B.A. 2005. Amphibian and aquatic reptile inventories conducted on and around lands administered by the Missoula Field Office of the Bureau of Land Management. Report to 
Missoula Field Office of the Bureau of Land Management. Montana Natural Heritage Program, Helena, MT and Montana Cooperative Wildlife Research Unit and Wildlife Biology Program, University of Montana, Missoula, MT. 53 p.

*Maxell, B.A. 2006. Evaluation of Montana’s lentic breeding amphibian survey methodology and variables correlated with species occupancy. Report to Montana Department of Environmental Quality. Montana Natural Heritage Program, Helena, MT and Montana Cooperative Wildlife Research Unit and Wildlife Biology Program, University of Montana, Missoula, MT. 49 p.

*Maxell, B.A. 2009. State-wide assessment of status, predicted distribution, and landscapelevel habitat suitability of amphibians and reptiles in Montana. Ph.D. Dissertation. Missoula, MT: Wildlife Biology Program, University of Montana. 294 p.

*Maxell, B.A. and D.G. Hokit. 1999. Amphibians and reptiles. Pp. 2.1- 2.30. In: G. Joslin and H. Youmans (committee chairs). Effects of recreation on Rocky Mountain wildlife: a compendium of the current state of understanding in Montana. Helena, MT: Committee on Effects of Recreation on Wildlife, Montana Chapter of the Wildlife Society. 307 p.

*Maxell, B.A., J.K. Werner, P. Hendricks, and D. Flath. 2003. Herpetology in Montana: a history, status summary, checklists, dichotomous keys, accounts for native, potentially native, and exotic species, and indexed bibliography. Olympia, WA: Society for Northwestern Vertebrate Biology. Northwest Fauna 5: 1-138.

Mead, R.A., V.P. Eroschenko, and D.R. Highfill. 1981. Effects of progesterone and estrogen on the histology of the oviduct of the garter snake, Thamnophis elegans. General Comparison of Endocrinology 45(3): 345-354.

*Miller, J.D. 1975. Interspecific food relationships of anurans in northwestern Montana and fluoride accumulation in amphibians and reptiles in northwestern Montana. M.S. Thesis, University of Montana, Missoula, MT. 105 p.

Minton, S.A. and S.A. Weinstein. 1987. Colubrid snake venoms: Immunologic relationships, electrophoretic patterns. Copeia 1987(4): 993-1000.

Morey, S.R. 1990. Microhabitat selection and predation in the Pacific treefrog, Pseudacris regilla. Journal of Herpetology 24(3): 292-296.

*Mosimann, J.E. and G.B. Rabb. 1952. The herpetology of Tiber Reservoir area, Montana. Copeia 1952: 23-27.

Motychak, J.E., E.D. Brodie, Jr., and E.D. Brodie III. 1999. Evolutionary response of predators to dangerous prey: preadaptation and the evolution of tetrodotoxin resistance in garter snakes. Evolution 53: 1528-1535.

*Moulton, G. (ed.). 1983. The journals of the Lewis and Clark expedition. University of Nebraska Press. Lincoln, Nebraska. Volumes 4, 5, 8, 9 and 10.

Nicol, J.T., R. Demaree, and D.M. Wootton. 1985. Levinseniella ophidea, new species (Trematoda: Microphallidae) from the western garter snake, Thamnophis elegans and the bullfrog, Rana catesbeiana. Proceedings of The Helminthological Society of Washington 52(2): 180-183.

Noble, G.K. 1937. Sense organs involved in courtship of Storeria, Thamnophis and other snakes. Bulletin of the American Museum of National History 73: 673-725.

Noble, G.K. and H.J. Clausen. 1936. The aggregation behavior of Storeria, Thamnophis, and other snakes. Ecological Monographs VI: 269-316.

Osypka, N.M. and S.J. Arnold. 2000. The development effect of sex ratio on a sexually dimorphic scale count in the garter snake Thamnophis elegans. 34(1): 1-5. 
Panik, H.R. and S. Barrett. 1994. Distribution of amphibians and reptiles along the Truckee River system. Northwest Science 68(3): 197-204.

*Patla, D.A. 1998a. Amphibians and reptiles in the Old Faithful sewage treatment area. Report to Yellowstone Center for Resources, Yellowstone National Park. 10 September, 1998. Greater Yellowstone Ecosystem Amphibian Survey and Monitoring Program, Herpetology Laboratory, Department of Biological Sciences, Idaho State University, Pocatello, ID. 7 p.

*Patla, D.A. 1998b. Potential effects of native fish restoration projects on amphibians in Yellowstone National Park Part I. 20 November, 1998. Greater Yellowstone Ecosystem Amphibian Survey and Monitoring Program, Herpetology Laboratory, Department of Biological Sciences, Idaho State University, Pocatello, ID. 26 p.

*Patla, D.A. 1999a. Amphibians and reptiles of the Madison to Norris road improvement project area, Yellowstone National Park. 11 November, 1999. Greater Yellowstone Ecosystem Amphibian Survey and Monitoring Program, Herpetology Laboratory, Department of Biological Sciences, Idaho State University, Pocatello, ID. 17 p.

*Patla, D.A. 1999b. Amphibians and reptiles, Tower Junction to Canyon Village, Yellowstone National Park; addendum to previous report. 24 November, 1999. Greater Yellowstone Ecosystem Amphibian Survey and Monitoring Program, Herpetology Laboratory, Department of Biological Sciences, Idaho State University, Pocatello, ID. 10 p.

*Patla, D.A. 1999c. Amphibians and reptiles along the grand loop road in Yellowstone National Park: Canyon Junction to Fishing Bridge Junction. December 11, 1999. Greater Yellowstone Ecosystem Amphibian Survey and Monitoring Program, Herpetology Laboratory, Department of Biological Sciences, Idaho State University, Pocatello, ID. 24 p.

*Patla, D.A. and C.R. Peterson. 1996a. Amphibians and reptiles along the Grand Loop Highway in Yellowstone National Park: Tower Junction to Canyon Village. 24 February, 1996. Greater Yellowstone Ecosystem Amphibian Survey and Monitoring Program, Herpetology Laboratory, Department of Biological Sciences, Idaho State University, Pocatello, ID. 49 p.

*Patla, D.A. and C.R. Peterson. 1996b. Amphibians and reptiles along the Grand Loop Highway in Yellowstone National Park: Arnica Creek to Little Thumb Creek. 1 August, 1996. Greater Yellowstone Ecosystem Amphibian Survey and Monitoring Program, Herpetology Laboratory, Department of Biological Sciences, Idaho State University, Pocatello, ID. 35 p.

*Patla, D.A. and C.R. Peterson. 1997. Amphibians and reptiles along the Grand Loop Highway in Yellowstone National Park: Mammoth Hot Springs to Norris Junction. 1 February, 1997. Greater Yellowstone Ecosystem Amphibian Survey and Monitoring Program, Herpetology Laboratory, Department of Biological Sciences, Idaho State University, Pocatello, ID. 60 p.

Peterson, C.C., B.M. Walton, and A.F. Bennett. 1999. Metabolic costs of growth in free-living garter snakes and the energy budgets of ectotherms. Functional Ecology 13: 500-507.

Peterson, C.R. 1978. Constriction in the wandering garter snake. American Zoologist 18(3): 649.

Peterson, C.R. 1979. Body temperature variation in free-living wandering garter snakes. American Zoologist 19(3): 975.

Peterson, C.R. 1981. Body temperature and energy balance in wandering garter snakes. American Zoologist 21(4): 957.

Peterson, C.R. 1982. Body temperature variation in free-living garter snakes (Thamnophis elegans vagrans). Ph.D. Dissertation. Pullman, WA: Washington State University. 186p. 
Peterson, C.R. 1987. Daily variation in the body temperatures of free-ranging garter snakes. Ecology 68(1): 160-169.

Peterson, C.R., A.J. Vitale, and V.A. Cobb. 1989. Measuring the acitivity patterns of freeranging animals with radio-telemetry. American Zoologist 29(4): 43A.

*Peterson, C.R., C.J. Askey, and D.A. Patla. 1993. Amphibians and reptiles along the Grand Loop and Fountain Freight Roads between Madison Junction and Biscuit Basin in Yellowstone National Park. 26 July, 1993. Greater Yellowstone Ecosystem Amphibian Survey and Monitoring Program, Herpetology Laboratory, Department of Biological Sciences, Idaho State University, Pocatello, ID. 45 p.

*Peterson, C.R., D.A. Patla, and S.R. Sullivan. 1995. Amphibians and reptiles along the Grand Loop Highway in Yellowstone National Park: Madison Junction to Norris Campground. 7 July, 1995. Greater Yellowstone Ecosystem Amphibian Survey and Monitoring Program, Herpetology Laboratory, Department of Biological Sciences, Idaho State University, Pocatello, ID. 64 p.

Peterson, C.R. and H.J. Fabian. 1984. Thamnophis elegans vagrans (wandering garter snake). Coloration. Herpetological Review 15(4): 113.

Petersen, C.R. and S.J. Arnold. 1986. Individual variation in the thermoregulatory behavior of free-ranging garter snakes, Thamnophis elegans. American Zoologist 26(4): 112A.

Porter, W.P. and C.R. Tracy. 1974. Modeling the effects of temperature changes on the ecology of the garter snake and leopard frog. Pages 594-609. In: J.W. Gibbons and R.R. Sharitz (eds). Thermal ecology symposium: U.S. Atomic Energy Commission Conference 730505. Washington, D.C.: Government Printing Office.

Queiroz, A. and R.R. Groen. 2001. The inconsistent and inefficient constricting behavior of Colorado western terrestrial garter snakes, Thamnophis elegans. Journal of Herpetology 35(3): 450-460.

Rahn, H. 1940. Sperm viability in the uterus of the garter snake, Thamnophis. Copeia 1940: 109-115.

*Rauscher, R.L. 1998. Amphibian and reptile survey on selected Montana Bureau of Reclamation impoundments. Montana Department of Fish, Wildlife and Parks, Nongame Program, Bozeman, MT. 24 p.

*Rauscher, R.L. 2000. Tiger salamander axolotls in southwest Montana, final report. Bozeman, MT: Montana Department of Fish, Wildlife and Parks. 28p.

Reaser, J.K. and R.E. Dexter. 1996. Anura: Rana pretiosa (spotted frog). Predation. Herpetological Review 27(2): 75.

*Reichel, J.D. 1995a. Preliminary amphibian and reptile survey of the Lewis and Clark National Forest: 1994. Montana Natural Heritage Program, Helena, MT. 92 p.

*Reichel, J.D. 1995b. Preliminary amphibian and reptile survey of the Sioux District of the Custer National Forest: 1994. Montana Natural Heritage Program, Helena, MT. 75 p.

*Reichel, J.D. 1996. Preliminary amphibian and reptile survey of the Helena National Forest: 1995. Montana Natural Heritage Program, Helena, MT. 87 p.

*Reichel, J.D. 1997. Amphibian, reptile and northern bog lemming survey on the Rocky Mountain Front: 1996. Montana Natural Heritage Program, Helena, MT. 81 p.

*Reinhard, E.G. 1930. Another snake note. Yellowstone Nature Notes 7(7): 39.

Ridenhour, B.J., E.D. Brodie, Jr., and E.D. Brodie III. 1999. Effects of repeated injection of tetrodotoxin on growth and resistance to tetrodotoxin in the garter snake Thamnophis sirtalis. Copeia 1999: 531-535. 
*Rodgers, T.L., and W.L. Jellison. 1942. A collection of amphibians and reptiles from western Montana. Copeia 1942(1): 10-13.

Rodriguez-Robles, J.A. 1998. Alternative perspectives on the diet of gopher snakes (Pituophis catenifer, Colubridae): literature records versus stomach contents of wild and museum specimens. Copeia 1998: 463-466.

*Roedel, M.D. and P. Hendricks. 1998a. Amphibian and reptile survey on the Bureau of Land Management Lewistown District: 1995-1998. Montana Natural Heritage Program, Helena, MT. 53 p.

*Roedel, M.D. and P. Hendricks. 1998b. Amphibian and reptile inventory on the Headwaters and Dillon Resource Areas in conjunction with Red Rocks Lakes National Wildlife Refuge: 1996-1998. Montana Natural Heritage Program, Helena, MT. 46 p.

Rosenberg, H.I. 1973. Functional anatomy of pulmonary ventilation in the garter snake, Thamnophis elegans. Journal of Morphology 140(2): 171-184.

Rossman, D.A. 1963. Relationships of the elegans complex of the garter snakes genus Thamnophis. Yearbook of the American Philosophical Society. 1963: 347-348.

Rossman, D.A. 1979. Morphological evidence for taxonomic partitioning of the Thamnophis elegans complex (serpentes, colubridae). Occasional Papers of the Museum of Zoology, Louisiana State University 55: 12p.

*Rossman, D.A., N.B. Ford, and R.A. Seigel. 1996. The garter snakes: evolution and ecology. University of Oklahoma Press, Norman, OK. 332 p.

*Ruthven, A.G. 1908. Variations and genetic relationships of the gartersnakes. Bulletin of the U.S. National Museum 61(7): 1-201.

Schuett, G.W., P.J. Fernandez, W.F. Gergits, N.J. Casna, D. Chiszar, H.M. Smith, J.B. Mitton, S.P. Mackessey, R.A. Odum, and M.J. Demlong. 1997. Production of offspring in the absence of males: Evidence for facultative parthenogenesis in bisexual snakes. Herpetological Natural History 5:1-10.

Scott, J.R. 1978. Thermal biology of the wandering garter snake. Ph.D. Dissertation, Colorado State University, Fort Collins, Colorado.

Scott, N.J., Jr. and A.L. Aquino-Shuster. 1989. The effects of freezing on formalin preservation of specimens of frogs and snakes. Collections Forum 5(2): 41-46.

Scott, J.R. and D. Pettus. 1979. Effects of seasonal acclimation on the perferred body temperature of (thamnophis elegans vagrans). Journal of Thermal Biology 4(4): 307-309.

Scott, J.R., C.R. Tracy, and D. Pettus. 1982. A biophysical analysis of daily and seasonal utilization of climate space by a montane snake. Ecology 63(2): 482-493.

Seidel, M.E. and R.G. Lindeborg. 1973. Lags in metabolic response to temperature of two garter snakes, Thamnophis elegans and Thamnophis radix. Herpetological 29(4): 358-360.

Seigel, R.A. 1996. Ecology and conservation of garter snakes: masters of plasticity, pp. 55-89. In: D.A. Rossman, N.B. Ford, and R.A. Seigel (eds)., The Garter Snakes: Evolution and Ecology. Norman, OK: University of Oklahoma Press.

*Sestrich, C. 2007. 2006 Hebgen Reservoir amphibian survey. USDA Forest Service Annual Report to PPL Montana. West Yellowstone, MT: Gallatin National Forest, Hebgen Lake Ranger District. $75 \mathrm{p}$.

Seyler, C. and S.J. Arnold. 2005. Selection on coloration in the garter snake Thamnophis elegans. Abstract. Northwestern Naturalist 86:115.

Shine, R., M.M. Olsson, and R.T. Mason. 2000. Chastity belts in garter snakes: the functional significance of mating plugs. Biological Journal of the Linnean Society 70: 377-390. 
Shine, R., M.M. Olsson, M.P. LeMaster, I.T. Moore, and R.T. Mason. 2000a. Are snakes right handed? Asymetry in hemipenis size and usage in garter snakes (Thamnophis sirtalis). Behavioral Ecology 11(4): 411-415.

Shine, R., M.M. Olsson, M.P. LeMaster, I.T. Moore, and R.T. Mason. 2000b. Body size enhances mating success in male garter snakes. Animal Behaviour Forum 59: F4-F11.

*Skinner, M.P. 1924. The Yellowstone Nature Book. A.C. McClurg Company, Chicago, IL. $221 \mathrm{p}$.

Smith, H. 1942. The synonomy of the garter snakes (Thamnophis), with notes on Mexican and Central American species. Zoologica 27: 97-123.

Smith, H.M., G.L. Smith, and D. Chiszar. A new record and review of partially scaleless snakes. Bulletin of the Maryland Herpetological Society 32(4): 107-112.

Smith, P.W. 1956. The geographical distribution and constancy of the semifasciata pattern in the eastern garter snake. Herpetologica 12: 81-84.

Soderquist, T.R. and N.R. Middlebrook. 1984. New herpetological records from Arizona north of the Grand Canyon. Herpetological Review 15(4): 115.

*St. John, A. 2002. Reptiles of the Northwest: California to Alaska; Rockies to the Coast. Renton, WA: Lone Pine Publishing. 272 p.

Stafford, D.P., F.W. Plapp, Jr., and R.R. Fleet. 1976. Snakes as indicators of environmental contamination: relation of detoxifying enzymes and pesticide residues to species occurrence in three aquatic ecosystems. Archives of Environmental Contamination and Toxicology 5: $15-27$.

*Stebbins, R.C. 2003. A field guide to western reptiles and amphibians. 3rd edition. New York, NY: Houghton Mifflin Co. 533 p.

Stevenson, R.D., C.R. Peterson and J. Tsuji. 1982. Locomotion, digestion and tongue flicking of the garter snake, Thamnophis elegans, at different body temperatures. America Zoologist 22(4): 916.

Stevenson, R.D., C.R. Peterson, and J.S. Tsuji. 1985. The thermal dependence of locomotion, tongue flicking, digestion and oxygen consumption in the wandering garter snake Thamnophis elegans. Physiological Zoology 58(1): 46-57.

Stewart, F.R. 1968. Some observations on the natural history of two Oregon garter snakes. Journal of Herpetology 2: 71-86.

Stewart, G.R. 1972. An unusual record of sperm storage in a female garter snake (genus Thamnophis). Herpetologica 28: 346-347.

Storey, K.B. 1996. Metabolic adaptations supporting anoxia tolerance in reptiles: Recent advances. Comparative Biochemisty and Physiology B 113(1): 23-35.

Stuart, J.N. 1987. Serpentes. Thamnophis elegans vagrans (wandering garter snake). Herpetological Review 18(1): 21.

*Sullivan, S.R. and C.R. Peterson. 1996. Amphibians and reptiles along the highway in Yellowstone National Park: Tower Junction to the Northeast Entrance. 25 February, 1996. Greater Yellowstone Ecosystem Amphibian Survey and Monitoring Program, Herpetology Laboratory, Department of Biological Sciences, Idaho State University, Pocatello, ID. 60 p.

Szaro, R.C., S.C. Belfit, J.K. Aitkin, and J.N. Rinne. 1985. Impact of grazing on a riparian garter snake. Pp. 359-363. In: R.R. Johnson, C.D. Ziebell, D.r. Patton, P.F. Ffolliott and F.H. Hamre (technical coordinators). Riparian ecosystems and their management: reconciling conflicting uses. General Technical Report RM-120. U.S. Forest Service, Rocky Mountain Forest and Range Experiment Station, Fort Collins, Colorado. 
Szaro, R.C., S.C. Belfit, J.K. Aitkin, and R.D. Babb. 1988. The use of timed fixed-area plots and a mark-recapture technique in assessing riparian garter snake populations. U.S. Forerst Service General Technical Report RM-166: 239-246.

Tanner, W.W. 1949. Food of the wandering garter snake, Thamnophis elegans vagrans (Baird \& Girard), in Utah. Herpetologica 5: 85-86.

Tanner, W.W. 1950. Variation in scale and color pattern of the wander garter snake, in Utah and southern Idaho. Herpetologica 6: 194-196.

Tanner, W.W. and C.H. Lowe. 1989. Variations in Thamnophis elegans with descriptions of new subspecies. Great Basin Naturalist 49(4): 511-516.

*Test, F.C. 1893. Annotated list of reptiles and batrachians collected. In: B.W. Evermann. A reconnaisance of the streams and lakes of western Montana and northwestern Wyoming. Bulletin of United States Fish Commission 11(1891): 57-59.

*Thompson, A. 2004. Population characteristics, diet, and body condition of terrestrial (Thamnophis elegans) and common (Thamnophis sirtalis) gartersnakes in two high elevation watersheds in western Montana. Undergraduate Thesis. Missoula, MT: Wildlife Biology Program, University of Montana. 35 p.

*Thompson, L.S. 1985. Montana's explorers the pioneer naturalists 1805-1864. Montana Magazine, Inc., Helena, MT. 109 p.

*Timken, R. No Date. Amphibians and reptiles of the Beaverhead National Forest. Western Montana College, Dillon, MT. 16 p.

*Todd, F. 1965. Scale variation among garter snakes with particular emphasis on the upper and lower labials. Unpublished research project for Dr. R.B. Brunson. 27 p.

*Turner, F.B. 1951. A checklist of the reptiles and amphibians of Yellowstone National Park with incidental notes. Yellowstone Nature Notes 25(3): 25-29.

*Turner, F.B. 1952. Duel in the sun. Yellowstone Nature Notes 26(5): 59-60.

*Turner, F.B. 1955. Reptiles and amphibians of Yellowstone National Park. Yellowstone Interpretive Series No. 5. Yellowstone Library and Museum Association. Yellowstone National Park, WY. 40 p.

*Turner, F.B. 1957. The ecology and morphology of Rana pretiosa pretiosa in Yellowstone Park, Wyoming. Ph.D. Dissertation, University of California, Berkeley, CA. 252 p.

Van Denburgh, J. and J.R. Slevin. 1918. The garter-snakes of Western North America. Proceedings of the California Academy of Sciences Series 4, 8: 181-270.

Velhagen, W.A. and A.H. Savitzky. 1998. Evolution of embryonic growth in thamnophiine snakes. Copeia 1998: 549-558.

Vest, D.K. 1981a. Envenomation following the bite of a wandering garter snake (Thamnophis elegans vagrans). Clinical Toxicology 18(5): 537-579.

Vest, D.K. 1981b. The toxic Duvernoy's secretion of the wandering garter snake, Thamnophis elegans vagrans. Toxicon 19(6): 831-839.

*Vitt, L.J., J.P. Caldwell, and D.B. Shepard. 2005. Inventory of amphibians and reptiles in the Billings Field Office Region, Montana. Sam Noble Oklahoma Museum of Natural History and Department of Zoology, University of Oklahoma, Norman, OK. 33 p.

*[VTNWI] VTN Wyoming Incorporated. No Date. Second year's analysis of terrestrial wildlife on proposed mine access and railroad routes in southern Montana and northern Wyoming, March 1979 - February 1980. VTN Wyoming Incorporated. Sheridan, WY. 62 p.

*Walcheck, K. 1976. Montana Wildlife 170 years ago. Montana Outdoors 7(4): 15-30.

Wallace, G.J. 1938. A garter snake with a brood of 73 young. Copeia 1938: 205. 
Waye, H.L. 1999. Size and age structure of a population of Western Terrestrial Garter Snakes (Thamnophis elegans). Copeia 1999(3):819-823.

Waye, H.L. and P.T. Gregory. 1993. Choices of neonate Thamnophis elegans vagrans between conspecific, congeneric, and heterogeneric odors. Journal of Herpetology 27(4): 435-441.

Waye, H.L. and P.T. Gregory. 1998. Determining the age of garter snakes (Thamnophis spp.) by means of skeletochronology. Canadian Journal of Zoology 76: 288-294.

Weaver, R.E. 2003. Thamnophis elegans (Western Terrestrial Garter Snake). Herpetological Review 35(3):278.

Weaver, R.E. and B.A. Bauer. 2005. Diet and foraging behavior of the wandering garter snake (Thamnophis elegans vagrans) at Umtanum Creek, Kittitas County, Washington. Abstract. Northwestern Naturalist 86:121.

Webb, R.G. 1976. A review of the garter snake (Thamnophis elegans) in Mexico. Natural History Museum of Los Angeles County Contributions to Science No. 284. 13 p.

Weisel, G.F. 1952. Animal names, anatomical terms, and some ethnozoology of the Flathead Indians. Journal of the Washington Academy of Sciences 42(11): 345-355.

Weitzel, N.H. and H.R. Panik. 1993. Long-term fluctuations of an isolated population of the Pacific chorus frog (Pseudacris regilla) in northwestern Nevada. Great Basin Naturalist 53(4): 379-384.

Weldon, P.J. 1982. Responses to ophiophagous snakes by snakes of the genus Thamnophis. Copeia 1982(4): 788-794.

Welsh, H.H. Jr. and A.J. Lind. 2000. Evidence of lingual-luring by an aquatic snake. Journal of Herpetology 34(1): 67-74.

*Werner, J.K., B.A. Maxell, P. Hendricks, and D. Flath. 2004. Amphibians and reptiles of Montana. Missoula, MT: Mountain Press Publishing Company. 262p.

*Werner, J.K. and J.D. Reichel. 1994. Amphibian and reptile survey of the Kootenai National Forest: 1994. Montana Natural Heritage Program, Helena, MT. 104 p.

*Werner, J.K. and J.D. Reichel. 1996. Amphibian and reptile monitoring/survey of the Kootenai National Forest: 1995. Montana Natural Heritage Program, Helena, MT. 115 p.

*Werner, J.K. and T. Plummer. 1994. Amphibian and reptile survey of the Flathead Indian Reservation 1993-1994. Salish Kootenai College, Pablo, MT. 55 p.

*Werner, J.K. and T. Plummer. 1995. Amphibian monitoring program on the Flathead Indian Reservation 1995. Salish Kootenai College, Pablo, MT. 46 p.

*Werner, J.K., T. Plummer, and J. Weaselhead. 1998. Amphibians and reptiles of the Flathead Indian Reservation. Intermountain Journal of Sciences 4(1-2): 33-49.

White, M. and J.A. Kolb. 1974. A preliminary study of Thamnophis near Sagehen Creek, California. Copeia 1974(1): 126-136.

Williams, B.L., E.D. Brodie, Jr., and E.D. Brodie III. 2002. Comparisons between toxic effects of tetrodotoxin administered orally and by intraperitoneal injection to the garter snake Thamnophis sirtalis. Journal of Herpetology 36: 112-115.

Wood, J.T. 1945. Variation in length of newly-born garter snakes. Copeia 1945: 118.

Wright, D.L.., K.V. Kardong, and D.L. Bentley. 1979. The functional anatomy of the teeth of the western terrestrial garter snake, Thamnophis elegans. Herpetologica 35(3): 223-228.

[WWPC] Washington Water Power Company. 1995. 1994 wildlife report Noxon Rapids and Cabinet Gorge Reservoirs. Washington Water Power Company. Spokane, WA. 
*Yarrow, H.C. 1882. Check list of North American reptilia and batrachia, with catalogue of specimens in the U.S. National Museum. United States National Museum Bulletin 24. 249 p.

Yeager, C.P., G.M. Burghardt, and L. Lyman-Henley. 1996. Prey handling in three species of garter snakes (Thamnophis): novelty, interference, and facilitation effects. Manuscript in preparation.

*Yeager, D.C. 1926. Miscellaneous notes. Yellowstone Nature Notes 3(4): 7.

*Yeager, D.C. 1929. Reptiles of Yellowstone Park with notes on the Amphibia. Yellowstone Nature Notes. Yellowstone National Park Library, Mammoth, WY. 12 p.

*Zisook, R., K. Almond, and B. Sharpe. 1996. Amphibian survey of the Birch Creek drainage, Beaverhead County. Wildland Studies Project. San Francisco State University, San Francisco, CA. 9 p. 


\section{Plains Gartersnake (Thamnophis radix)}

Up-to-date distribution and status information can be found on the Montana Natural Heritage Program’s TRACKER website at http://mtnhp.org

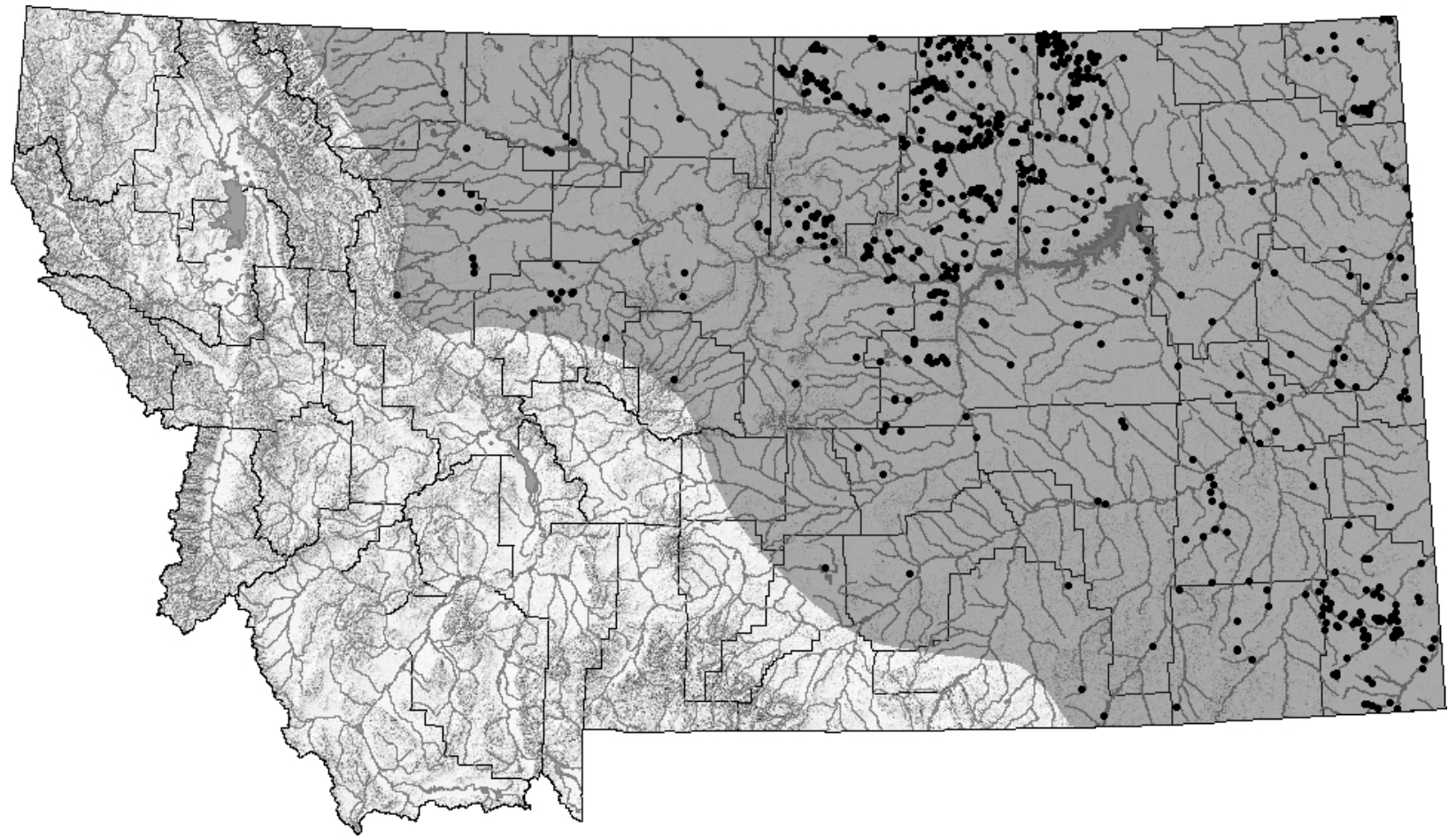

Distribution/Taxonomy

Appropriately named, the Plains Gartersnake (Thamnophis radix) is found primarily in the Great Plains, ranging from southern Alberta and Manitoba south to northeastern New Mexico and northern Oklahoma, and westerly to Illinois, Wisconsin, and northwestern Indiana. A small disjunct population is located in Ohio, and another is found in southern Indiana and Illinois. Formerly, two subspecies were recognized based on ventral and dorsal scale counts; $T$. $r$. radix and T. r. haydeni (Smith 1949). However, due to overlapping morphology, this split has been disregarded by most herpetologists and no subspecies are currently recognized (Rossman et al. 1996, Stebbins 2003). In Montana, Plains Gartersnakes range across the Great Plains region, but appear absent at higher elevations of the island mountain ranges. They range from Glacier County, east to Sheridan County, south to Carter County and Bighorn County, and northwesterly to Lewis and Clark County (Ernst 1989, Werner et al. 2004, MTNHP 2007).

Maximum Elevation

1,652 m (5,420 ft) in Lewis and Clark County (Maxell et al. 2003).

\section{Identification}

Juveniles and Adults:

Thamnophis radix is relatively long gartersnake with a total length (TL) typically ranging 13-34 inches (33-80 cm), but has been recorded as long as $109.2 \mathrm{~cm}$ TL (Rossman et al. 1996, Werner et al. 2004). Base body color is usually brownish gray to black, and the anal plate is divided. As with all of Montana's gartersnakes, three lateral stripes extend the length of the body: a distinct orange to red dorsal stripe is located down the center of its back, and two pale yellow side stripes are found on the third and fourth scale rows above the ventral scales. On lighter individuals, two 
rows of alternating black spots can be seen on either side of the side stripes, and red flecks are sometimes visible between the dorsal and side strips. Plains Gartersnakes usually have seven upper labial scales (occasionally 8) and ten lower labials (occasionally 9 or 11) (Wright and Wright 1957, Rossman et al 1996, Powell et al. 1998). The creases between the upper labial scales are black. The ventral surface is pale white, yellow, or bluish-gray with black spots along each side, and occasionally in the center (Werner et al 2004). Dorsal scales are keeled, usually with 21 rows at midbody. Some individuals have light spots on their parietal scales. Females have 135 to 174 ventral scales and 54 to 74 subcaudals. Males have 138-175 ventral scales and 64 to 88 subcaudals. Adult females have wider heads and longer total lengths than males, but males have relative tail lengths averaging 2.1\% to 3.3\% longer than females (Rossman et al. 1996, Ernst and Ernst 2003).

Neonates:

Plain's Gartersnakes are viviparous, giving birth to live young. Neonates closely resemble adults in pattern, but vary in size from approximately 15-25 cm (6-10 inches) TL (Werner et al 2004). Females neonates have larger heads and shorter tails than males (Ernst and Ernst 2003).

Similar Species:

Gartersnakes are the only snakes in Montana with lateral stripes. On the Plains Gartersnake, the dorsal stripe is a distinct orange or red rather than yellowish, rather than yellow as in $T$. sirtalis and T. elegans. The Plain's Gartersnake is Montana's only gartersnake with its side stripes located on the third and fourth dorsal scale rows, rather than on the second and third rows as with Montana's other two gartersnakes. Like $T$. sirtalis, $T$. radix usually has seven upper labial scales, whereas the Terrestrial Gartersnake usually has eight (Rossman et al. 1996, Werner et al 2004).

Habitat Use/Natural History

Plains Gartersnakes generally inhabit open areas such as grasslands, fields, meadows, poplar stands, and rock outcroppings. Usually a water source is found nearby such sluggish streams, marshes, ponds, and reservoirs. However, they are less dependent on wetland habitat than $T$. sirtalis, straying greater distances from water as observed in Minnesota populations that occur sympatrically with T. sirtalis (Rossman et al. 1996, Ernst and Ernst 2003, MTHNP 2006). In Montana Plains gartersnakes emerge in April or May. Shortly after emergence, adults begin courtship and mating activities, but they have been observed mating in June and may mate in the fall prior to hibernation (Degenhardt et al. 1996, Hammerson 1999). Sexually maturity is reached between two and three years when over $36 \mathrm{~cm}$ total length, with males generally maturing earlier than females (Degenhardt et al. 1996, Rossman 1996). Females may not reproduce every year (Hammerson 1999). Courting begins when the female secretes a pheromone from her dorsal skin which attracts males. After shedding, the release of this pheromone is increased, enhancing their sexual attractiveness (Kubie et al. 1978). Richard Seigel has observed up to six males mating a single female, forming a small "mating ball” (Rossman et al. 1996). Males crawl to the female and press their head along her body while making rippling motions along their body and occasionally flicking their tongues along her back. Eventually a male mounts aligns his cloacal region with hers. If receptive, the female will lift her tail allowing insertion of the male's hemipenis. After insemination, a copulatory plug is inserted by the male, which temporarily deters mating by other males for at least 48 hours. This 
serves as a form of intersexual competition, and may also serve to protect the female from successive copulations, which could make her vulnerable to predation (Devine 1977, Ross and Crews 1978, Rossman et al. 1996). Females give birth to live young from late July through early September. Clutch size ranges from 50-60, but is usually 10-20. However, this varies regionally and no data is available for Montana. Clutch size of six females ranged from 14-54 in Manitoba, and 5-20 in Colorado. This regional variation may be due to a number of factors, such as local environmental conditions or size and diet of the female (Gregory 1977, Rossman et al. 1996, Ernst and Ernst 2003). Similar to other Gartersnakes, males generally migrate greater distances than females throughout the year (Dalrymple and Reichenbach 1984), although neither move far during the summer. Various studies have shown dispersal rates as small as 2 meter/day to no greater than 76 meters over several months (Ernst and Ernst 2003). Daily activity patterns vary seasonally, with mid-day activity common in the spring and fall and activity restricted to the morning and evenings during mid-summer (Dalrymple and Reichenbach 1984, Rossman et al. 1996). Air temperatures between 21 and 29 degrees Celsius (70-84 degrees F) are preferred (Werner et al. 2004). In Minnesota, Ernst and Ernst (2003) have observed T. radix feeding on breeding chorus frogs (Pseudacris triseriata) after dark. Plains Gartersnakes spend an average of 1.4 hours/day on the surface, while gravid females spend about 2.8 hours/day at the surface. During the mating season, males spend an average of 4.8 hours/day compared with 2.8 hours/day for males. T. radix uses odor trails to locate prey by transferring airborne molecules from their tongue to their vomeronasal organ in their mouth through tongue-flicking (Kubi and Halpern 1979). Diet varies with seasonal prey availability. In Missouri, T. radix fed primarily on earthworms in the spring and fall, but consumed virtually none in the summer when their diet consisted of $80 \%$ juvenile and adult frogs. The switch to frogs was concurrent with their time of metamorphosis from larvae, when their abundance was highest (Seigel 1996). Similar to the diet of T. sirtalis, T. radix commonly consume amphibians, fish, earthworms, and leeches. Although no prey data is available in Montana, elsewhere T. radix have been recorded consuming various toads (Bufo spp.), spadefoots (Spea spp.) chorus frogs (Pseudacris spp.), Northern Leopard Frogs (Rana pipiens), Tiger salamanders (Ambystoma tigrinum), passerine birds, rodents, and grasshoppers (Degenhardt et al. 1996, Ernst and Ernst 2003). To avoid predation, T. radix show a will first run, exhibiting more a high rate of fleeing compared with other Thamnophis initial defense behaviors. However, when cornered or tired, they exhibit varied defense behaviors, such as striking with an open or closed mouth (usually without biting), rolling into a ball, and lifting and shaking its tail while coiled or extended (Arnold and Bennett 1984). T. radix also releases feces and foul-smelling secretions from their cloaca when captured to deter predators (Rossman 1999). In New Mexico, T. radix may has been observed avoiding danger by submerging itself in muddy water for long periods (Degenhardt et al. 1996). Similar to other gartersnakes, T. radix tails will break off when pulled firmly and continue wriggling to divert a predator's attention. However, tails will not grow back to their original size or shape (Rossman et al. 1996). Predation has not been documented in Montana, but elsewhere predators include the Western Hog-nosed Snakes (Heterodon nasicus), Eastern Racers (Coluber constrictor), Milksnakes (Lampropeltis triangulum), hawks, American crows (Corvus brachyrhynchos), various predatory mammals, and Bullfrogs (Rana catesbeiana) (Hammerson 1999, Ernst and Ernst 2003, Werner et al. 2004). In migratory populations of T. radix in Alberta, Lawson and Secoy (1991) concluded that $T$. radix used solar cues to navigate their return to communal hibernacula in the fall. Plains Gartersnakes have been found hibernating communally with Smooth Greensnakes (Opheodrys vernalis) in an anthill in Manitoba (Cridle 1937), and in crayfish burrows in Ohio 
(Dalrymple and Reichenbach 1984). Other hibernacula include the burrows of various small mammals, rock crevices, wells, and building foundations (Ernst and Ernst 2003, Werner et al 2004). Population data is unavailable in Montana, but Plains Gartersnakes have been estimated at densities higher than any other species of Thamnophis in natural populations, ranging from to 52-123 individuals/ha in Ohio to 320/ha in Colorado (Dalrymple and Reichenbach 1986, Rossman et al. 1996). In Ohio, mortality rates were much higher for neonates, 8-12\% per month, than for adults, just 1.4-2.9\% per month (Dalrymple and Reichenbach 1986). Annual mortality rate in an Illinois population was estimated at $20 \%$. Longevity in the wild is unknown, but a captive individual reportedly survived over eight years (Ernst and Ernst 2003).

\section{$\underline{\text { Status and Conservation }}$}

Despite a lack of quantitative data, Plains Gartersnakes appear to be relatively common and secure throughout their historic range in eastern and central Montana. However, observation records in south central Montana are scarce despite suitable habitat. It is unclear if this is due to their absence from this region or a lack of reported observations. Although apparently secure in Montana small disjunct populations have become threatened in Arkansas and Ohio (Dalrymple and Reichenbach 1984, Ernst and Ernst 2003). Therefore, the following may become potential conservation concerns for some populations. (1) Roads often have negative impacts on population size and distribution of snakes and other reptiles. High road density has been positively correlated to low population size, and restriction to roadless areas, which can lead to local extirpations. (Rudolph et al. 1998, Jochimsen et al. 2004). While this has not been studied exclusively on $T$. radix in Montana, many populations are probably affected in areas of high road density. Road-killed T. radix are not uncommon in eastern Montana and many are found basking on roads (Matt Gates, pers. obs.). In Ohio where, T. radix is state-listed as endangered, Dalrymple and Reichenbach (1984) found that both road-kills and mowing operations in wildlife management areas significantly increased mortality. In Colorado, large numbers have reportedly been killed by trains (Hammerson 1999). (2) There is evidence that the Western Toad (Bufo boreas) and the Northern Leopard Frog (Rana pipiens) have experienced declines in western Montana (Maxell 2000). If significant amphibian declines occur in eastern Montana, it could pose an indirect threat (Wootton 1994) to T. radix populations by limiting a primary food source. (3) Over-grazing, along riparian corridors, can trample vegetation and alter soil structure, and is known to reduce the abundance of many invertebrates (Hutchingson and King 1980) and amphibians (Maxell 2000), which potentially could both directly and indirectly affect prey availability for T. radix, especially where alternative water bodies are limited. (4) Many snakes show their highest mortality rates during active periods, such as mate-searching, migrations to and from hibernacula, or dispersals of neonates after birth. Causes of mortality during such dispersals included natural predation, domesticated animals, and road kill (Bonnet et al. 1999, Hammerson 1999).

\section{Research and Management Suggestions}

1. The limits of the distribution in south central Montana should be identified. This can be done by conducting systematic surveys in suitable habitat, or by educating the public (e.g. local landowners and resource managers) to identify $T$. radix and encouraging them to report observations.

2. Monitor amphibian populations and T. radix populations concurrently to identify and deter any potential declines. 
3. To avoid road-kills at times of heavy mortality (fall) in wildlife management areas in Ohio, Dalrymple and Reichenbach (1984) suggested rerouting traffic, installing road bumps to reduce vehicle speeds, and erecting signs to warn motorists of basking snakes. Similar steps can be taken in Montana management areas where high road mortalities are identified.

4. Due to a lack of life history and population ecology information for Plains gartersnakes within Montana, an effort should be made to conduct appropriate studies, or at least report life history observations. This data can aid in making local management decisions.

Bibliography *indicates an article with information specific to Montana

Andry, M.L., M.W. Luttges, and R.I. Gamow. 1971. Temperature effects on spontaneous and evoked neural activity in the garter snake. Experimental Neurology 31: 32-44.

Anton, T.G. 2000. Thamnophis radix (plains garter snake) predation. Herpetological Review 31(1):47.

Arnold, S.J. and A.F. Bennett. 1984a. Behavioural variation in natural populations. III: Antipredator displays in the garter snake Thamnophis radix. Animal Behavior 32(4): 11081118.

Arnold, S.J. and A.F. Bennett. 1984b. Behavioral variation in natural populations. V. Morphological correlates of locomotion in the garter snake (T. radix). Biological Journal of Linnean Society 34: 175-190.

*Atkinson, E.C. and M.L. Atkinson. 2004. Amphibian and reptile survey of the Ashland and Sioux of the Custer National Forest with special emphasis on the Three-Mile Stewardship Area: 2002. Marmot's Edge Conservation. 22 p.

Bailey, R.M. 1949. Temperature tolerance of gartersnakes in hibernation. Ecology 30: 238242.

*Baird, S.F. and C.F. Girard. 1853. Catalogue of North American Reptiles., Pt. 1, p. 34-35.

Bavetz, M.J. 1993. Thamnophis radix radix (eastern Plains garter snake). Herpetological Review 24(2): 69.

*Baxter, G.T., and M.D. Stone. 1985. Amphibians and reptiles of Wyoming. 2nd ed. Wyoming Game and Fish Department, Cheyenne.

Begun, D., J.L. Kubie, M. Plough-O'Keefe, and M. Halpern. 1988. Conditioned discrimination of airborne odorants by garter snakes (Thamnophis radix and T. sirtalis sirtalis). Journal of Comparative Psychology 102(1): 35-43.

Blackburn, D.G. and R.L. Lorenz. 2003a. Transmission EM of the chorioallantoic placenta of Thamnophis radix and T. sirtalis. Journal of Morphology 256(2):171-186.

Blackburn, D.G. and R.L. Lorenz. 2003b. Transmission EM of the omphalallantoic placenta of Thamnophis radix and T. sirtalis. Journal of Morphology 256(2):187-204.

*BLM. 1982a. Bloomfield - North Fork baseline inventories - wildlife. Bureau of Land Management, Miles City District Office. Miles City, MT. 61 pp.

*BLM. 1982b. Moorhead baseline inventory - wildlife. Bureau of Land Management, Miles City District Office. Miles City, MT. 29 pp.

Bonnet, X., G. Naulleau, and R. Shrine. 1999. The dangers of leaving home: Dispersal and mortality in snakes. Biological Conservation 89: 39-50.

Brodie, E.D., III. 1993. Consistency of individual differences in anti-predator behaviour and colour pattern in the garter snake Thamnophis ordinoides. Animal Behavior 45:851-861.

*Brunson, R.B. 1955. Check list of the amphibians and reptiles of Montana. Proceedings of the Montana Academy of Sciences 15: 27-29. 
Bruynonckx, H. 1985. Herbivorous Thamnophis? Litteratura Serpentium 5(2): 69-70.

Burghardt, G.M. 1969. Comparative prey-attack studies in newborn snakes of the genus Thamnophis. Behaviour 33: 77-114.

Busby, W.H., J.R. Parmelee. 1996. Historical changes in a herpetofaunal assemblage in the Flint Hills of Kansas. American Midland Naturalist 135(1): 81-91.

Chiszar, D., T. Carter, L. Knight, L. Simonsen, and S. Taylor. 1976. Investigatory behavior in the plains gartersnake (Thamnophis radix) and several additional species. Animal Learning and Behavior 4: 273-278.

Chiszar, D., D. Featherman, R. Fuerst, and H.M. Smith. 1994. Observations on the herpetofauna of the indian reservations of southwestern South Dakota. Bulletin of the Chicago Herpetological Society 29(12): 269-270.

Chiszar, D., K. Scudder, and L. Knight. 1976. Rate of tongue flicking by garter snakes (Thamnophis radix haydeni) and rattlesnakes (Crotalus v. viridis, Sistrurus catenatus tergeminus, and Sistrurus catenatus edwardsi) during prolonged exposure to food odors. Behavioral Biology 18(2): 273-283.

Chiszar, D., S.V. Taylor, C.W. Radcliffe, H.M. Smith, and B. O'Connell. 1981. Effects of chemical and visual stimuli upon chemosensory searching by garter snakes and rattlesnakes. Journal of Herpetology 15(4): 415-424.

Cieslak, E.S. 1945. Relations between the reproductive cycle and the pituitary gland in the snake Thamnophis radix. Physiological Zoology 18: 299-329.

*Cochran, D.M. 1961. Type specimens of reptiles and amphibians in the United States National Museum. United States National Museum Bulletin 220: 1-291.

Conant, R., E.S. Thomas, and R.L. Rausch. 1945. The plains garter snake, Thamnophis radix, in Ohio. Copeia 1945: 61-67.

*Cooper, S.V., C. Jean, and P. Hendricks. 2001. Biological survey of a prairie landscape in Montana's glaciated plains. Report to the Bureau of Land Management. Montana Natural Heritage Program, Helena, MT. 24 pp. plus appendices.

Cooper, W.E. 1992. Post-bite elevation in tongue-flick rate by neonatal garter snakes (Thamnophis radix). Ethology 91(4): 339-345.

*Cope, E.D. 1875. Check-list of North American Batrachia and Reptilia, with a systematic list of the higher groups, and an essay on geographical distribution. U.S. National Museum Bulletin 1(1): 1-104.

*Cope, E.D. 1900. The crocodilians, lizards and snakes of North America. Report of the U.S. National Museum 1898: 153-1270.

*Coues, E. and H.C. Yarrow. 1878. Notes on the herpetology of Dakota and Montana. Bulletin of the U.S. Geologic and Geographic Survey 4(1): 259-291.

Cridle, S. 1937. Snakes from an ant hill. Copeia 1937:142.

Dalrymple, G.H. and N.G. Reichenbach. 1981. Interactions between the prairie garter snake (Thamnophis radix) and the common gartersnake ( $T$. sirtalis) in Killdeer Plains, Wyandot County, Ohio. Ohio Biological Survey Biology Notes 15: 244-250.

Dalrymple, G.H. and N.G. Reichenbach. 1984. Management of an endangered species of snake in Ohio, USA. Biological Conservation 30(3): 195-200.

Daszak, P., A.A. Cunningham, and A.D. Hyatt. 2000. Emerging infectious diseases of wildlifethreats to biodiversity and human health. Science 287:443-449. 
*Day, D., P.J. Farmer, and C.E. Farmer. 1989. Montco terrestrial wildlife monitoring report December, 1987 - July, 1989. Montco, Billings, MT, and Western Technology and Engineering, Inc. Helena, MT.

Degenhardt, W.G., C.W. Painter, and A.H. Price. 1996. Amphibians and reptiles of New Mexico. Albuquerque, NM: University of New Mexico Press. 431 p.

de Jong, J. 1986. Breeding results. Thamnophis radix. Litteratura Serpentium English Edition 6(2): 74.

de Queiroz, A. and R. Lawson. 1994. Phylogenetic relationships of the garter snakes based on DNA sequence and allozyme variation. Biological Journal of the Linnean Society 53(3): 209-229.

Devine, M.C. 1977. Copulatory plugs, restricted mating opportunities, and reproductive competition among male garter snakes. Nature 267: 345-346.

Dill, C.D. 1972. Reptilian core temperatures: variation within individuals. Copeia 1972(3): 577-579.

*Dood, A.R. 1980. Terry Badlands nongame survey and inventory final report. Montana Department of Fish, Wildlife, and Parks and Bureau of Land Management, Helena, MT. 70 p.

Dodd, C.K., Jr. 1987. Status, conservation, and management. Pp. 478-513. In: R.A. Seigel, J.T. Collins and S.S. Novak (eds). Snakes: ecology and evolutionary biology. New York, NY: McMillan.

Doughty, P. 1994. Critical thermal minima of garter snakes (Thamnophis) depend on species and body size. Copeia 1994(2): 537-540.

*[EI] Econ Incorporated. 1984. Terrestrial wildlife inventory for the Lame Jones and Ismay coal lease tracts. Econ Incorporated. Helena, MT.

Engeman, R.M., I.M. Engeman, and A.N. Engeman. 2002. Thamnophis radix (plains garter snake) Brood size. Herpetological Review 33(1):59.

*Ernst, C.H. 1989. Geographic Distribution. Thamnophis radix haydenii (western plains garter snake). Herpetological Review 20(3): 76.

*Ernst, C.H., and E.M. Ernst. 2003. Snakes of the United States and Canada. Smithsonian Books. Washington D.C.

Fitch, H.S. 2003. Tail loss in garter snakes. Herpetological Review 34(3):212-213.

Ford, N.B. 1996. Behavior of garter snakes. pp.90-116. In: D.A. Rossman, N.B. Ford, and R.A. Seigel (eds). The Garter Snakes: Evolution and Ecology. Norman, OK: University of Oklahoma Press.

Ford, N.B. and J.R. Low. 1984. Sex pheromone source location by garter snakes: a mechanism for detection of direction in nonvolatile trails. Journal of Chemical Ecology 10(8): 11931199.

Ford, N.B. and C.W. Schofield. 1984. Species specificity of sex pheromone trails in the plains garter snake, Thamnophis radix. Herpetologica 40: 51-55.

*Gates, M.T. 2005. Amphibian and reptile baseline survey: CX field study area. Report to Billings and Miles City Field Offices of Bureau of Land Management. Maxim Technologies, Billings, MT. 28pp + Appendices.

Graves, B.M. and M. Halpern. 1988. Neonate plains garter snakes (Thamnophis radix) are attracted to conspecific skin extracts. Journal of Comparative Psychology 102(3): 251-253.

Gregory, P.T. 1977. Life history observations of three species of snakes in Manitoba. Canadian Field Naturalist 91(1): 19-27. 
Halloy, M. and G.M. Burghardt. 1990. Ontogeny of fish capture and ingestion in four species of garter snakes (Thamnophis). Behaviour 112(3-4): 299-318.

Hammerson, G.A., 1999. Amphibians and Reptiles in Colorado. University Press of Colorado and Colorado Division of Wildlife, Niwot, Colorado.

Harding, James H., 1997. Amphibians and Reptiles of the Great Lakes Region. University of Michigan Press, Ann Arbor, Michigan.

Hart, D.R. 1975. A quantitative niche comparison of the western plains garter snake (Thamnophis radix haydeni) and the red-sided garter snake (Thamnophis sirtalis parietalis) in allopatric and sympatric regions of Manitoba's interlake district. M.S. Thesis, University of Manitoba. $76 \mathrm{p}$.

Hart, D.R. 1979. Niche relationships of Thamnophis radix haydeni and Thamnophis sirtalis parietalis in the interlake district of Manitoba. Tulane Students of Zoology and Botany 21(2): 125-140.

*Hart, M.M., W.A. Williams, P.C. Thornton, K.P. McLaughlin, C.M. Tobalske, B.A. Maxell, D.P. Hendricks, C.R. Peterson, and R.L. Redmond. 1998. Montana atlas of terrestrial vertebrates. Montana Cooperative Wildlife Research Unit, The University of Montana. Missoula, Montana vii +1302 p.

Heckrotte, C. 1960. The effect of environmental factors on the locomotory activity of the plains garter snake (Thamnophis radix radix). Ph.D. Dissertation. University of Illinois (UrbanaChampaign). 66p.

Heckrotte, C. 1975. Temperature and light effects on the circadian rhythm and locomotory activity of the plains garter snake (Thamnophis radix haydeni). Journal of Interdisciplinary Cycle Research 6(4): 279-290.

*Hendricks, P. 1999. Amphibian and reptile survey of the Bureau of Land Management Miles City District, Montana. Montana Natural Heritage Program, Helena, MT. 80 p.

*Hendricks, P. and J.D. Reichel. 1996. Preliminary amphibian and reptile survey of the Ashland District, Custer National Forest: 1995. Montana Natural Heritage Program, Helena, MT. 79 p.

*Hendricks, P. and J.D. Reichel. 1998. Amphibian and reptile survey on Montana refuges: 1996. Montana Natural Heritage Program, Helena, MT. 19 p.

Hoberg, T. and C. Gause. 1989. Reptiles \& amphibians of North Dakota. North Dakota Outdoors 55(1):7-18.

Holtzman, D.A., G.R. Eyck, and D. Begun. 1989. Artificial hibernation of garter (Thamnophis sp.) and corn (Elaphe guttata guttata) snakes. Herpetological Review 20(3): 67-68.

*Hossack, B.R. and P.S. Corn. 2001. Amphibian survey of Medicine Lake National Wildlife Refuge Complex: 2001. USGS Northern Rocky Mountain Science Center, Aldo Leopold Wilderness Research Institute, Missoula, MT. 13 p.

Hossack, B.R., P.S. Corn, and D.S. Pilliod. 2005. Lack of significant changes in the herpetofauna of Theodore Roosevelt National Park, North Dakota, since the 1920s. American Midland Naturalist 154:423-432.

Hutchinson, K.J., and Kathleen L. King. 1980. The effects of sheep stocking level on invertebrate abundance, biomass and energy utilization in a temperate, south grassland. Journal of Applied Ecology. 17:369-387.

Jochimsen, Denim M., Charles R. Peterson, Kimberly M. Andrews, and J. Whitfield Gibbons. 2004. A literature review of the effects of roads on amphibians and reptiles and the measures used to minimize those effects. Idaho Fish and Game Department and USDA Forest Service. 
Kauffman, J.B. and W.C. Krueger. 1984. Livestock impacts on riparian ecosystems and streamside management implications: a review. Journal of Range Management 37(5):430436.

Kerfin, J. 2001. Variation in thermal biology as a function of body size in Thamnophis radix. M.S. Thesis. Dekalb, IL: Northern Illinois University.

*Koch, E.D., and C.R. Peterson. 1995. Amphibians and reptiles of Yellowstone and Grand Teton National Parks. Salt Lake City: University of Utah Press.

Kubie, J.L., J. Cohen, and M. Halpern. 1978. Shedding enhances the sexual attractiveness of oestradiol treated garter snakes and their untreated penmates. Animal Behavior 26: 562-570.

Kubie, J.L. and M. Halpern. 1979. Chemical senses involved in garter snake prey trailing. Journal of Comparative Physiological Psychology 93: 648-667.

Lachner, E.A. 1942. An aggregation of snakes and salamanders during hibernation. Copeia 1942:262-263.

Lawson, P.A. and D.M. Secoy. 1991. The use of solar cues as migratory orientation guides by the plains garter snake, Thamnophis radix. Canadian Journal of Zooogy 69(10): 2700-2702.

Lesch, M.E. and J.D. Fawcett. 1978. Preliminary observations on the life history of the western plains garter snake, Thamnophis radix haydeni, in Douglas County, Nebraska. Proceedings of the Nebraskan Academy of Science 88: 17.

*Martin, P.R. 1980. Terrestrial wildlife inventory in selected coal areas of Montana. Montana Department of Fish, Wildlife and Parks and Bureau of Land Management, Helena, MT. 84 p.

*Martin, P.R., K. Dubois and H.B. Youmans. 1981. Terrestrial wildlife inventory in selected coal areas, Powder River resources area final report. Montana Department of Fish, Wildlife and Parks and Bureau of Land Management, Helena, MT. 288 p.

Matity, J.G., D.P. Chivers, and R.J.F. Smith. 1994. Population and sex differences in antipredator responses of breeding fathead minnows (Pimephales promelas) to chemical stimuli from garter snakes (Thamnophis radix and $T$. sirtalis). Journal of Chemical Ecology 20(8): 2111-2121.

Matthews, K.R., R.A. Knapp, and K.L. Pope. 2002. Garter snake distributions in high-elevation aquatic ecosystems: is there a link with declining amphibian populations and nonnative trout introductions? Journal of Herpetology 36: 16-22.

*Matthews, W.L. 1979. Wibaux-Beach wildlife baseline study - nongame species. Bureau of Land Management, Miles City, MT. 93 p.

*Matthews, W.L. 1980a. Wibaux-Beach comparison study: Sydney, Glendive and Plevna Study Areas. Bureau of Land Management, Miles City, MT. 50 p.

*Matthews, W.L. 1980b. Wildlife of Prairie County Terry study area. Bureau of Land Management, Miles City, MT. 52 p.

*Matthews, W.L. 1981. Broadus-Pumpkin Creek baseline inventory - wildlife. Bureau of Land Management, Miles City, MT. 83 p.

*Maxell, B.A. 2000. Management of Montana's amphibians: a review of factors that may present a risk to population viability and accounts on the identification, distribution, taxonomy, habitat use, natural history, and the status and conservation of individual species. Report to USFS Region 1, Order Number 43-0343-0-0224. University of Montana, Wildlife Biology Program. Missoula, MT. 161 p.

*Maxell, B.A. 2004. Preliminary report on amphibian and aquatic reptile inventories conducted on and around the Ashland District of the Custer National Forest in 2002 and 2004. Report 
to Ashland District of Custer Forest, Region 1 Office of the U.S. Forest Service, and Montana Department of Fish, Wildlife, and Parks. Missoula, MT: Montana Cooperative Wildlife Research Unit and Wildlife Biology Program, University of Montana. 93 p.

*Maxell, B.A. 2009. State-wide assessment of status, predicted distribution, and landscapelevel habitat suitability of amphibians and reptiles in Montana. Ph.D. Dissertation. Missoula, MT: Wildlife Biology Program, University of Montana. 294 p.

*Maxell, B.A. and D.G. Hokit. 1999. Amphibians and reptiles. Pp. 2.1-2.30. In: G. Joslin and H. Youmans (committee chairs). Effects of recreation on Rocky Mountain wildlife: a compendium of the current state of understanding in Montana. Helena, MT: Committee on Effects of Recreation on Wildlife, Montana Chapter of the Wildlife Society. 307 p.

*Maxell, B.A., J.K. Werner, P. Hendricks, and D. Flath. 2003. Herpetology in Montana: a history, status summary, checklists, dichotomous keys, accounts for native, potentially native, and exotic species, and indexed bibliography. Olympia, WA: Society for Northwestern Vertebrate Biology. Northwest Fauna 5: 1-138.

*Mosimann, J.E. and G.B. Rabb. 1952. The herpetology of Tiber Reservoir area, Montana. Copeia 1952: 23-27.

*[MTNHP] Montana Natural Heritage Program. 2006. Montana Amphibian Inventory and Monitoring Program Database. Montana Natural Heritage Program, Helena, MT. Accessed April 14, 2006.

Murphy, J.C. and R.M. Curry. 2000. A case of parthenogenesis in the plains garter snake, Thamnophis radix. Bulletin of the Chicago Herpetological Society 35(2):17-19.

Nero, R.W. 2002. Unusually large plains garter snake. Blue Jay 60(3):183.

Ostermeier, P. 1992. Scale variation of the great plains gartersnake, Thamnophis radix. Proceedings of the Nebraska Academy of Science 102: 36.

Perkins, C.B. 1949. A key to the snakes of the United States, 2nd Edition. Bull. Zool. Soc. San Diego 24: 1-79.

Platvoet, H.J. 1989. Breeding results. Thamnophis radix haydeni. Litteratura Serpentium English Edition 9(2): 89-90.

Platvoet, H.J. 1990. Breeding results. Thamnophis radix haydeni. Litteratura Serpentium English Edition 10(6): 267.

Platvoet, H.J. 1991. Thamnophis radix haydeni. Litteratura Serpentium English Edition 11(5): 114.

Potts, R. 1995. Observations on the eastern plains garter snake, Thamnophis radix radix. Herptological Review 20(2): 88-91.

Powell, R. and D.D. Smith. 1983. Thamnophis radix haydeni (western plains garter snake). Herpetological Review 14(3): 85.

*Powell, R., J.T. Collins, and E.D. Hooper, Jr. 1998. A key to amphibians and reptiles of the Continental United States and Canada. University Press of Kansas, Lawrence, KS. 131 p. Rauch, J.C. 1978. Integumentary bloodvascular system in garter snakes (Thamnophis sirtalis parietalis and Thamnophis radix). Canadian Journal of Zoology 56(3): 469-476.

*Rauscher, R.L. 1998. Amphibian and reptile survey on selected Montana Bureau of Reclamation impoundments. Montana Department of Fish, Wildlife and Parks, Nongame Program, Bozeman, MT. 24 p.

Redmer, M. 1988. Two instances of reptile prey discarded by avian predators. Bulletin of the Chicago Herpetological Society 23(2): 28. 
Redmer, M. and J.P. Zaworski. 1987. Notes on two red plains garter snakes, Thamnophis radix radix, from Illinois. Bulletin of the Chicago Herpetological Society 22(11): 179.

*Reichel, J.D. 1995a. Preliminary amphibian and reptile survey of the Lewis and Clark National Forest: 1994. Montana Natural Heritage Program, Helena, MT. 92 p.

*Reichel, J.D. 1995b. Preliminary amphibian and reptile survey of the Sioux District of the Custer National Forest: 1994. Montana Natural Heritage Program, Helena, MT. 75 p.

*Reichel, J.D. 1997. Amphibian, reptile and northern bog lemming survey on the Rocky Mountain Front: 1996. Montana Natural Heritage Program, Helena, MT. 81 p.

*Roedel, M.D. and P. Hendricks. 1998. Amphibian and reptile survey on the Bureau of Land Management Lewistown District: 1995-1998. Montana Natural Heritage Program, Helena, MT. $53 \mathrm{p}$.

Ross, P., Jr. and D. Crews. 1977. Influence of the seminal plug on mating behaviour in the garter snake. Nature 267(5609): 344-345.

Ross, P., Jr. and D. Crews. 1978. Stimuli influencing mating behavior in the garter snake, Thamnophis radix. Behavioral Ecology and Sociobiology 4(2): 133-142.

*Rossman, D.A., N.B. Ford, and R.A. Seigel. 1996. The garter snakes: evolution and ecology. University of Oklahoma Press, Norman, OK. 332 p.

Rudolph, D.C., S.J. Burdorf, R.N. Conner, and J.G. Dickson. 1998. The impact of roads on the timber rattlesnake (Crotalus horridus), in eastern Texas. Pp. 236-240. In: G.L. Evink, P.

Garrett, D. Zeigler and J. Berry (eds.) Proceedings of the international conference on wildlife ecology and transportation. February 10-12, 1998. Fort Meyers, Florida.

*Ruthven, A.G. 1908. Variations and genetic relationships of the gartersnakes. Bulletin of the U.S. National Museum 61(7): 1-201.

*Scow, K.L. 1980. Terrestrial wildlife survey American Colloid study area Phillips County, Montana. Western Technology and Engineering, Inc., Helena, MT.

Scudder-Davis, R.M. and G.M. Burghardt. 1987. Diet and growth in juveniles of the garter snakes Thamnophis sirtalis infernalis and Thamnophis radix radix. Growth 51(1): 74-85.

Secoy, D.M. 1970. Aberrant head scalation in Thamnophis radix haydeni (Kennicott). Journal of Herpetology 4: 91-92.

Secoy, D.M. 1979. Investigatory behavior of plains garter snakes, Thamnophis radix (reptilia: colubridae), in tests of repellent chemicals. Canadian Journal of Zoology 57(3): 691-693.

Seidel, M.E. and R.G. Lindeborg. 1973. Lags in metabolic response to temperature of two garter snakes, Thamnophis elegans and Thamnophis radix. Herpetological 29(4): 358-360.

Seigel, R.A. 1985. The foraging ecology and resource partitioning patterns of two species of garter snakes. Ph.D. Dissertation. University of Kansas. 138p.

Seigel, R.A. 1996. Ecology and conservation of garter snakes: masters of plasticity, pp. 55-89. In: Rossman, D.A., N.B. Ford, and R.A. Seigel (eds.), The Garter Snakes: Evolution and Ecology, University of Oklahoma Press, Norman.

Shine, R., B. Phillips, H. Waye, M. LeMaster, and R.T. Mason. 2004. Species-isolating mechanisms in a mating system with male mate choice (garter snakes, Thamnophis spp.). Canadian Journal of Zoology 82(7):1091-1098.

*Smith, A.G. 1949. The subspecies of the plains garter snake, Thamnophis radix. Bulletin of the Chicago Academy of Sciences. 8(14): 285-300.

Smith, H.M. and D. Chiszar. 1981. An observation on winter emergence of a garter snake, Thamnophis radix. Bulletin of the Maryland Herpetological Society 17: 107-109. 
Stafford, D.P., F.W. Plapp, Jr., and R.R. Fleet. 1976. Snakes as indicators of environmental contamination: relation of detoxifying enzymes and pesticide residues to species occurrence in three aquatic ecosystems. Archives of Environmental Contamination and Toxicology 5: $15-27$.

Stanford, K.M. and R.B. King. 2004. Growth, survival and reproduction in a Northern Illinois population of the plains gartersnake, Thamnophis radix. Copeia 3:465-478.

*Stebbins, R.C. 2003. A field guide to western reptiles and amphibians. 3rd edition. New York, NY: Houghton Mifflin Co. 533 p.

Szaro, R.C., S.C. Belfit, J.K. Aitkin, and J.N. Rinne. 1985. Impact of grazing on a riparian garter snake. U.S. Forest Service General Technical Report RM 120: 359-363.

Terrick, T.D., R.L. Mumme, and G.M. Burghardt. 1995. Aposematic coloration enhances chemosensory recognition of noxious prey in the garter snake Thamnophis radix. Animal Behaviour 49(4): 857-866.

*Thompson, L.S. and P.S. Nichols. 1982. Circle West wildlife monitoring study; fourth annual report for period March 1, 1981 - May 31, 1982. Circle West Technical Report No. 10. Montana Department of Natural Resources and Conservation, Helena, MT.

Tucker, J.K. 1994c. Thamnophis radix (plains garter snake). Herpetological Review 25(4): 168.

Van het Meer, J. 1986. My experiences with the garter snake Thamnophis radix haydeni. Lacerta 44(7): 116-117.

Van het Meer, J. 1988. The genus Thamnophis, part 4: Thamnophis radix haydeni. Litteratura Serpentium English Edition 8(5): 207-21.

Van het Meer, J. 1989a. The genus Thamnophis, part 5: Thamnophis (radix) butleri. Litteratura Serpentium English Edition 9(1): 4-8.

Van het Meer, J. 1989b. The genus Thamnophis, part 6: Thamnophis (radix) brachystoma. Litteratura Serpentium English Edition 9(2): 63-67.

*Vitt, L.J., J.P. Caldwell, and D.B. Shepard. 2005. Inventory of amphibians and reptiles in the Billings Field Office Region, Montana. Sam Noble Oklahoma Museum of Natural History and Department of Zoology, University of Oklahoma, Norman, OK. 33 p.

*[VTNWI] VTN Wyoming Incorporated. No Date. Second year's analysis of terrestrial wildlife on proposed mine access and railroad routes in southern Montana and northern Wyoming, March 1979 - February 1980. VTN Wyoming Incorporated. Sheridan, WY. 62 p.

*Walcheck, K. 1976. Montana Wildlife 170 years ago. Montana Outdoors 7(4): 15-30.

Wang, R.T. and M. Halpern. 1980a. Light and electron microscopic observations on the normal structure of the vomeronasal organ of garter snakes. Journal of Morphology 164(1): 47-67.

Wang, R.T. and M. Halpern. 1980b. Scanning electron microscopic studies of the surface morphology of the vomeronasal epithelium and olfactory epithelium of garter snakes. American Journal of Anatomy 157(4): 399-428.

*Werner, J.K., B.A. Maxell, P. Hendricks, and D. Flath. 2004. Amphibians and reptiles of Montana. Missoula, MT: Mountain Press Publishing Company. 262p.

*[WESCO] Western Ecological Services Company. 1983a. Wildlife inventory of the Knowlton known recoverable coal resource area, Montana. Western Ecological Services Company, Novato, CA. 107 p.

*[WESCO] Western Ecological Services Company. 1983b. Wildlife inventory of the Southwest Circle known recoverable coal resource area, Montana. Western Ecological Services Company, Novato, CA. 131 p. 
*[WESTECH] Western Technology and Engineering Incorporated. 1998. Wildlife monitoring Absaloka Mine area 1997. Western Technology and Engineering, Inc., Helena, MT.

*Wied, M.P. 1865. Verzeichniss der reptilien, welche auf einer reise in nordlichen America beobachtet wurden, von Maximilian, Prinzen zu Wied. Eigengangen bei der Akademie am 1, Juni 1865. Druck von E. Blochmann und Sohn, Dresden, Germany. 141 p.

Wolverkamp, J. 1985. Breeding results: Thamnophis radix haydeni. Litteratura Serpentium 5(2): 76.

Wootton, J.T. 1994. The nature and consequences of indirect effects in ecological communities. Annual Review of Ecological Systematics 25:443-446.

*Wright, A.H. and A.A. Wright. 1957. Handbook of snakes of the United States and Canada, 2 Volumes. Cornell University Press, Comstock Publishing Associates, Ithaca, NY. 1105 p.

*Yarrow, H.C. 1882. Check list of North American reptilia and batrachia, with catalogue of specimens in the U.S. National Museum. United States National Museum Bulletin 24. 249 p.

Yeager, C.P. and G.M. Burghardt. 1991. Effect of food competition on aggregation: Evidence for social recognition in the plains garter snake (Thamnophis radix). Journal of Comparative Psychology 105(4): 380-386.

Zwart, P., G.M. Dorrestein, F.C. Stades, and B.H. Broer. 1979. Vasectomy in the garter snake (Thamnophis sirtalis radix). Journal of Zoological Animal Medicine 10(1): 17-21. 


\section{Common Gartersnake (Thamnophis sirtalis)}

Up-to-date distribution and status information can be found on the Montana Natural Heritage Program’s TRACKER website at http://mtnhp.org

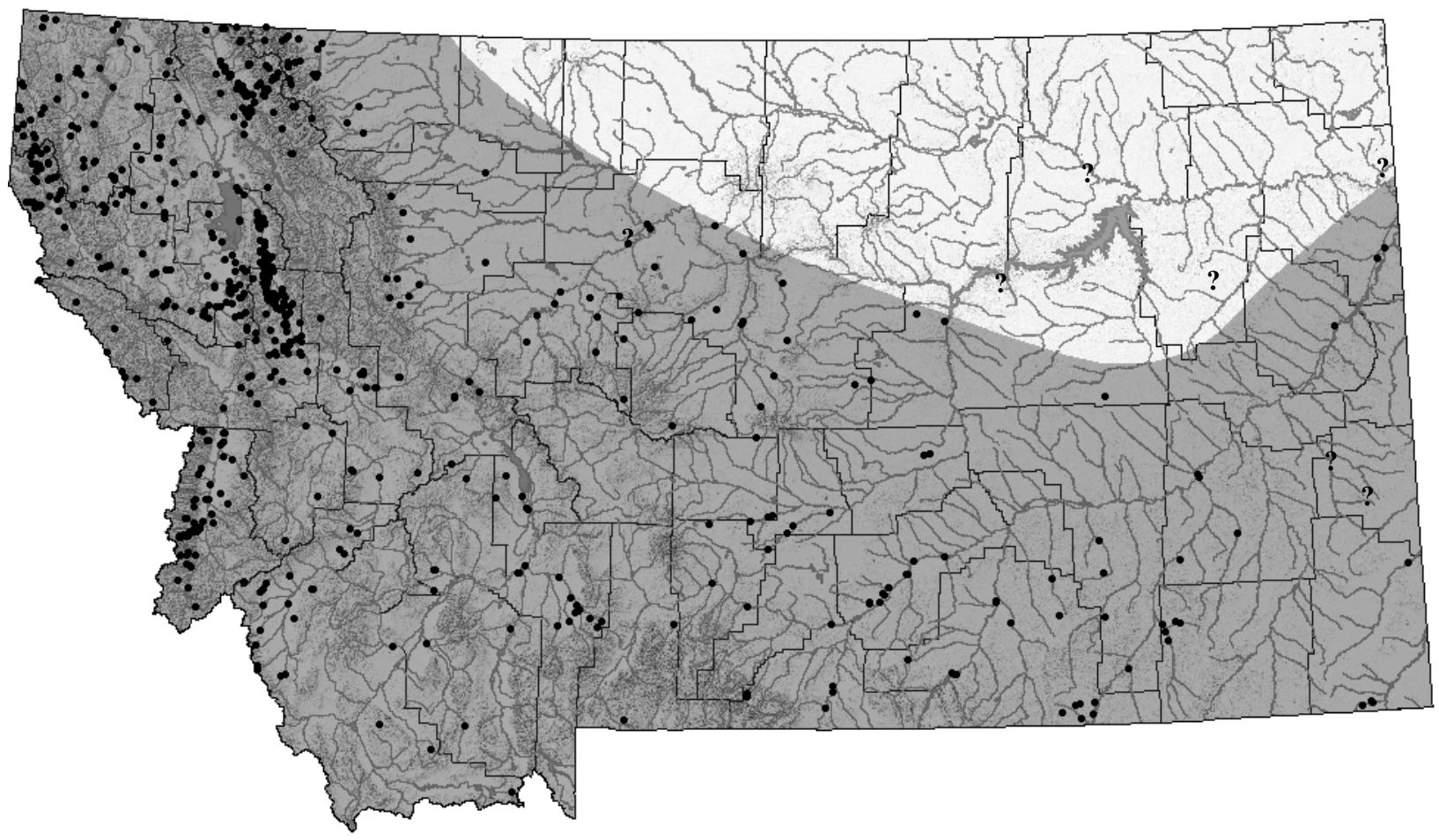

Distribution/Taxonomy

The Common Gartersnake (Thamnophis sirtalis) is the widest ranging reptile in North America, occurring coast to coast from British Columbia to Nova Scotia, south across Florida and west to southern California, while absent only from the American southwest. T. sirtalis extends much farther north than any other reptile, reaching across the southern border of the Northwest Territories. There are currently eleven recognized subspecies of Common Gartersnake on the continent, two of which reside in Montana: the Red-sided Gartersnake (T. sirtalis parietalis) and the Valley Gartersnake (T. sirtalis fitchi) (Rossman et al. 1996, Stebbins 2003). Generally, T. s. fitchi occurs west of the Continental Divide, while T. s. parietalis is found primarily east of the divide. However, these ranges are not clearly defined and there is likely some overlap and hybridization in western Montana (Fitch and Maslin 1961, Maxell 2000). Common Gartersnakes are found primarily in the mountainous to semi-mountainous regions of the Montana, including the island ranges, very few observations recorded in the eastern portion of the state. This gap in distribution may indicate a natural pattern, a regional extirpation, a lack recorded sightings, or observations being misidentified as the Plains Gartersnake (Thamnophis radix) (Rossman et al. 1996, Maxell 2003).

Maximum Elevation Record 2,444 m (8,020 ft) in Beaverhead County (Werner et al. 2004). 


\section{$\underline{\text { Identification }}$}

Juveniles and Adults:

As with all of Montana's gartersnakes, the anal plate is undivided and three stripes extend the length of the body: two yellow side stripes located on the second and third scale rows above the ventral scales, and one yellow dorsal stripe centered down the middle of the back. Adults have a base body color that is usually brownish gray, gray, or black. Alternating red or black spots are usually present between the dorsal and side stripes. Common Gartersnakes have seven upper labial scales (infrequently 8 and rarely 6) and ten lower labials (occasionally 9 or 11) (Wright and Wright 1957, Anderson 1977, Powell et all 1998, Stebbins 2003). The ventral surface is mostly unmarked and a pale yellow, bluish, or grey. Dorsal scales are keeled, with 19 rows at midbody. Many individuals have whitish or pale yellow spots on their parietal scales. Males have knobbed ridges on each side of the anal plate, which may facilitate mating. Females have 128 to 174 ventrals and 52 to 93 subcaudals. Males have 133 to 178 ventrals and 61 to 97 subcaudals. Adult males are usually shorter than females with an SVL 83\% that of females and males weigh just over half their weight. The posterior pair of chin shields is usually longer than the anterior pair (Perkins 1949, Fitch 1980, Rossman et al. 1996, Powell et al. 1998). T. sirtalis occasionally occurs in a stripeless, black phase throughout its range. Black morphs have been found in Lake County (Anderson 1977) and along the upper Missouri River, but these were not positively differentiated from T. elegans (Grant Hokit, Carroll College, pers. comm.). Bittner et al. (2002) suggests these melanistic individuals may have a selective thermoregulatory advantage, particularly in large females, by facilitating precise body temperature control during pregnancy, which may increase fecundity, and allow females to give birth earlier; thereby increasing neonate survivorship.

Neonates:

Newborn T. sirtalis closely resemble adults in pattern, but are sometimes more distinctly striped (Koch and Peterson 1995). Neonates can vary in size from 12-27.8 cm TL, but average approximately $17 \mathrm{~cm}$. Newborn males are generally larger than females (Fitch 1965, Degenhardt et al. 1996, Ernst and Ernst 2003).

Subspecies:

Despite intergradations between subspecies T. s. fitchi and T. s. parietalis in western Montana, they can generally be differentiated by color and patterning. In parietalis, red marks can be found on the upper half of the dorsolateral area, whereas in fitchi red markings are absent or barely visible on the upper half. The basal color of the dorsolateral area is very dark to black on fitchi, but is usually paler in parietalis. On parietalis the red blotches may overlap the lateral stripes and occasionally invade the ventrals, whereas the blotches are rarely as low on fitchi. Furthermore, fitchi usually lack the pair of small black spots located on the anterior edge of each ventral scale, which are usually visible on parietalis (Fitch and Maslin 1961, Fitch 1980).

\section{Similar Species:}

The red and black spots between the dorsal stripe and side stripes of $T$. sirtalis are absent in the Terrestrial Gartersnake. Generally, the Common Gartersnake has a darker body color with brighter lateral stripes making its striping more distinct than the Terrestrial Gartersnake's (Koch and Peterson 1995). The Common Gartersnake and the Plain's Gartersnake normally have seven upper labial scales, while the Terrestrial Gartersnake usually has eight, although variations in 
upper labial counts are not uncommon in Montana (Anderson 1977). The Plain's Gartersnake's dorsal strip is a noticeable bright orange to brick red rather than yellow, and their side stripes are located on the third and fourth scale rows rather than the second and third. Additionally, the creases between upper labial scales of $T$. sirtalis lack the heavy black pigmentation typically present on Montana's other gartersnakes (Hammerson 1999).

\section{Habitat Use/Natural History}

T. sirtalis is found in a variety of habitats from deciduous forests, rivers, ponds, marshes, swamps, ditches, meadows, pastures, fence rows, outbuildings, quarries, and trash dumps. Regardless of habitat, they are usually associated with moist or wet vegetation, especially in the Rocky Mountain west, and are regularly seen foraging along shorelines of permanent water (Baxter and Stone 1985, Rossman et al 1996, Ernst and Ernst 2003). In Montana, Common Gartersnakes are associated with the mountainous regions of the state, but are not usually found at the higher elevations, where T. elegans appear to replace them (Baxter and Stone 1985, Werner et al. 2004, MTNHP 2007). In western Montana, T. sirtalis has been found in approximately one-half the watersheds that T. elegans was documented (MTNHP 2007). This more heterogeneous distribution indicates that $T$. sirtalis has more specialized habitat requirements, which could be a result of their greater preference for amphibian prey (Thompson 2004). Despite being the most studied reptile in North America (Rossman et al. 1996), virtually no significant demographic vital rate information (fecundity, survival rates, longevity, denning habits, and dispersal distances) has been collected in Montana. In the west, most significant life history studies of $T$. sirtalis have been conducted on large migratory populations at northern latitudes in Alberta and Manitoba (Gregory 1977b), and in southern populations of Kansas (Fitch 1965). These studies have revealed significant regional differences in life history and behavior. Common Gartersnakes are one of the first species to emerge from their hibernacula, surfacing as early as mid-March to April at lower elevations to June at higher elevations (Fitch 1965, Ernst and Ernst 2003). At large communal dens (supporting thousands of individuals) in Manitoba, males begin emerging in large numbers in late April, reaching peak numbers by mid-May and while females surface more gradually. Upon emergence, the sudden increase in temperature and light experienced, triggers courtship and mating. (Aleksiuk and Gregory 1974b, Bona-Gallo and Licht 1983). Although mating typically occurs early, before dispersal to summer foraging grounds, it can occur into late June and occasionally in the fall. (Fox 1955, Fitch 1965, Medonca and Crews 1989). Courting begins as the female secretes a pheromone that attracts males, sometimes in large numbers that form a "mating ball," of multiple males around a single female (Crews and Garstka 1982). After being contacted by a male, the female may try to escape, remain still, or make a head-jerk movement. The male often struggles with the female for a period before eventually mounting her back and continually pressing his chin along her dorsum while moving anteriorly until his cloaca is aligned with hers. At this stage the male will make rippling movements along his body, shake his tail gently, and then try to lift the female's tail with his own. After a period of five minutes to over an hour, the female will allow insertion of a hemipenis. Insemination usually lasts only a few minutes (Fitch 1965). Afterward, a copulatory plug is inserted by the male which temporarily deters mating by other males as a form of intersexual competition (Devine 1977). However, multiple paternity has been recorded in $T$. sirtalis (Rossman et al. 1996). In the large communal denning populations of Manitoba, Pfrender et al. (2001) has observed males that release female pheromones which induce homosexual courtship and copulation by other males. However, these "she-males" also mate 
with females more often than normal males, indicating a selective advantage (Ernst and Ernst 2003). In the case of fall mating, females retain the sperm through the winter and successfully fertilize in the spring (Ernst and Ernst 2003). Fox (1956) found that T. sirtalis sperm can potentially remain viable for over a year. Soon after copulation, females migrate to summer foraging grounds. Males often remain near the hibernacula attempting to mate multiple times before dispersing toward the end of May. Mating activity near northern communal dens can last up to 1.5 months (Gregory 1974b, Shine et al. 2001). Generally, males become sexually mature in one or two years when over $40 \mathrm{~cm}$ snout-to-vent length (SVL), and females in 2 or 3 years when over $50 \mathrm{~cm}$ SVL (Fitch, 1965, Rossman et al. 1996). Females tend to reproduce annually in southern populations but rarely do so in northern populations (Larsen, 1986, Gregory and Larsen 1989). Gravid females are usually found singly but may aggregate in the late summer before giving birth, perhaps because survivorship of neonates increases with higher numbers, or possibly due to limited availability of parturition refuges. In Manitoba, groups of gravid $T$. sirtalis females have been found around rock piles, building foundations, and wooden platforms (Gregory 1975) Females are viviparous, giving birth to live young in early August or September. Generally, most litters average 10-15 young with larger females producing more young. Neonates grow from about 6 to 9.5 inches $(15-24 \mathrm{~cm})$ during their first year (Tanner 1949, Rossman et al. 1996). With the short growing season at the high latitudes is important that northern $T$. sirtalis populations navigate rapidly between overwintering/breeding areas and foraging grounds, which can often be large distances in migratory populations. Migrations of 4.3 to 17.7 kilometers have been recorded in Manitoba (Gregory 1974b, Gregory and Stewart 1975) and up to $9 \mathrm{~km}$ in Alberta (Lawson 1989) (Rossman et al 1996). Behavioral studies conducted by Lawson (1989) in northern Alberta indicated these migratory populations use solar orientation in conjunction with an internal clock to navigate, and that juveniles may follow pheromone trails of adults to locate dens in the first year. These navigational abilities have also been found in southern nonmigratory populations, although at lower levels (Lawson 1994). Common Gartersnakes are primarily diurnal, but can be active at night during hot or dry weather (Degenhardt et al. 1996). They are commonly associated with wetland habitat throughout their range, including Montana. Therefore dietary studies have often shown a preference for amphibians (Fitch 1941b). Some populations have shown $90 \%$ amphibian consumption in their diet (Ernst and Ernst 2003). However, prey selection is dependent on availability and size of the snake (White and Kolb 1974). Of 375 prey items analyzed by Fitch (2001) in Kansas, most were amphibians, including eight species at multiple life stages. Fitch also found prey preference dependent on age and sex: first year young primarily consumed earthworms, while small mammals were an important diet source for females, whereas smaller males rarely consumed them. Daily activity and foraging patterns can also be influenced by temperature. At a fish hatchery in British Columbia, Nelson and Gregory (2000) found that numbers active of fisheating snakes increased at the warmest portions of the day when they could withstand cool water, whereas snakes foraging terrestrially at nearby sites avoided these temperatures by foraging during the morning and evening. Common Gartersnakes are known to eat fish, amphibians, worms, passerine birds, shore birds, bird eggs, mollusks, crustaceans, spiders, insects, and small snakes (Ruthven 1908, Fitch 1965, Drummond 1983, Hayward 2002) Specific prey reported in Montana includes leeches (Haemopis grandis and Erpobdella punctata), slugs (Deroceras sp.), amphibians (Rana luteiventris, Rana pipiens, Bufo boreas, Ambystoma macrodactylum, Hyla regilla), voles (Microtus sp.), Sparrows (Spizella sp.), and earth worms (Lumbricus sp.) (Anderson 1977, Thompson 2004). In sympatric populations, T. sirtalis has a diet more 
specialized to amphibians, while the diet of T. elegans is more diverse (Fitch 1941b). In western Montana, Anderson (1977) noted that T. sirtalis consumed 46\% amphibians, while T. elegans consumed just 20\% amphibians. Both species also favored were leaches, which made up $41 \%$ of T. sirtalis and $44 \%$ of $T$. elegans diets. At high elevation water bodies in Montana, anurans, particularly Spotted Frogs (Rana luteiventris), become the main food source for both species, with $T$. sirtalis showing a preference for juveniles and adults and $T$. elegans preferring larvae (Thompson 2004). Common gartersnakes are not skilled fish hunters and are generally only capable of capturing them when found in enclosed areas, such as shallow drying pools or fish hatcheries. In Oregon, T. sirtalis is known to consume tadpoles of the introduced Bullfrog (Rana catesbeiana) (Rossman et al. 1996), which is also invading Montana (Maxell 2003, MTNHP 2007). Common Gartersnakes have become specially adapted to consuming toxic amphibians. They have evolved immunity to toxic toads (genera; Bufo, Spea, Scaphiopus, and Gastrophryne) (Koch and Peterson 1995, Degenhardt et al. 1996) and Rough-skinned Newts (Taricha granulosa). They are up to 2,000 times less susceptible to T. granulosa toxins where their range overlaps. The level of resistance corresponds with the abundance of newts and their toxicity level along a geographic gradient (Nussbaum et al 1983, Brodie et al 2002). In Oregon, Williams et al. (2002) noted that some individuals could assess the level of toxicity of individual newts, regurgitating newts that exceed their toxicity resistance level, while consuming the others. Common predators of $T$. sirtalis include raccoons, various birds of prey, Eastern Racers, shrews, weasels, and coyotes (Ernst and Ernst 2003). Their first defense against predators is to run. Their striping may aid in avoiding capture by creating an illusion that they are traveling slower than actuality causing predators to miss (Koch and Peterson 1995), or by simply making it difficult to for predators to focus on them (Brodie 1993). When caught or cornered, they will inflate their lungs and flatten their head, while exuding feces, foul smelling musk secretions and uric acid. They can also be aggressive, inflating their lungs and flattening their head while exuding foul-smelling musk secretions, feces, and uric acid. Larger individuals may aggressively strike and bite, sometimes drawing blood (Ernst and Ernst 2003, Werner et al. 2003). When grasped firmly, $T$. sirtalis tails can break and continue wriggling to divert the predator's attention. The tails will grow back, although not to their original size or shape. Individuals with these stubbed tails swim and crawl more slowly and therefore are likely at greater risk of predation (Fitch 2003). Common Gartersnakes aggregate near hibernacula up to six weeks before retreating underground. They overwinter below frost-line in mammal burrows, rock crevices, talus slopes, gravel banks, earth dams, causeways, old wells, ant mounds, crayfish burrows, beaver and muskrat lodges, stumps and rotting logs. They are sometimes found completely or partially submersed in water, which may inhibit freezing (Lachner 1942, Costanzo 1989b). With an ability to function at temperatures lower than any other reptile (Fitch 1965), northern populations are well-adapted behaviorally and physiologically to survive the long winters and short growing seasons at high latitudes (Aleksuik 1976, Crews and Garstka 1982). In northern Alberta, a hibernating individual's temperature ranged 1.8 to 6.5 degrees Celsius through the winter (Rossman et al 1996), and cloacal temperatures of emerging males have been recorded as low as 0.5 degrees Celsius. Overwintering conditions are best when hibernacula stay wet enough to avoid desiccation and the temperature stays slightly above freezing. However, they are able to endure short periods above frost-line at temperatures low as -2 to -3 degrees Celsius, although large numbers often freeze to death (Bailey 1949, Fitch 1965 Churchill and Story 1992). Common Gartersnakes hibernate singly or communally, sometimes in very large numbers from 500-600 (Aleksiuk 1976b) to over 10,000 in the limestone sinkholes of Manitoba 
(Larsen and Gregory 1989). Gregory (1974b) suggests that communal denning has an adaptive advantage for the short growing seasons of northern climates by insuring snakes are together to breed immediately after emergence. Similar nearby hibernacula go virtually unused in some years, indicating communal denning is not due to a lack of available dens. Aggregations may also have a thermoregulatory advantage by maintaining higher body temperatures during long northern winters (Aleksiuk 1977). Due to an absence of local data, it is unclear if similar-sized denning aggregations exist in Montana. However, similar climate, landscape, and ecology are present, suggesting aggregations probably exist. Groups of 7-10 individuals were observed in late August in the Bitterroot Mountains of western Montana aggregating around temporary pools with high densities of Columbia Spotted Frog larvae (Bryce Maxell, pers. obs.). Common Gartersnakes have been reported hibernating communally with other snakes found in Montana; the Smooth Greensnake (Opheodrys vernalis) and Milksnake (Lampropeltis triangulum) (Lachner 1942). Outside of Montana, typical summer population densities have been documented from 1.7/ha in Manitoba to 45-89/ha in Ohio. Likewise, average home range (or “activity range”) data varies regionally from approximately $8100 \mathrm{~m} 2$ (0.8 ha) in Michigan (Carpenter 1952a) to 142,000 m2 (14 ha) in Kansas (Fitch 1965). In Montana, Anderson (1977) reported a dispersal distance of at least $2 \mathrm{~km}$. Adult annual survival rates range from 34\% in Manitoba (Gregory 1977b) to 50\% in Kansas (Fitch 1965), to 67\% in the Northwest Territories (Larsen and Gregory 1989). Depending on the region, annual survivorships of neonates ranged from $29 \%$ to $43 \%$, and $33 \%$ to $50 \%$ of smaller snakes have been known to die while overwintering in hibernacula, (Rossman et al. 1996). Common Gartersnakes can survive at least nine years in nature (Werner et al 2004), although average longevity is probably much less. In Manitoba, Larsen and Gregory (1989) noted that 34 individuals at an annual denning site had survived at least six years. In captivity, a specimen reportedly lived over 14 years (Ernst and Ernst 2003).

\section{$\underline{\text { Status and Conservation }}$}

Common Gartersnakes are well distributed across the state and appear to be secure in west and south-central Montana. However, observation records in the northern and eastern Great Plains region of Montana are scarce. It is unknown if this is due to their actual absence, or a lack of reported observations. As suggested by Fitch and Maslin (1961), records that do exist may be misidentified T. radix, which are common in the region. Therefore, their status in Montana's Great Plains region cannot currently be assessed. Fitch (2001) noted that large denning aggregations, mating behavior, and dispersal patterns found at denning sites in Manitoba are not universal traits of $T$. sirtalis, but behaviors resulting from selective pressures at the northern limits of their range since these behaviors had not been noted at more southerly latitudes, such as Kansas. With this regional variability and lack of local data, it is difficult to characterize Montana population, but it is likely they exhibit characteristics of both northern and southern populations due to the variability in climate and ecosystems found across the state. Despite this adaptability and their secure status, the following items are potential conservation concerns for the Common Gartersnake. (1) T. sirtalis populations may be showing declines in areas where anurans continue to disappear, such as high elevation water bodies. In mountain lakes of the Sierra Nevada, researches discovered the probability of finding a similar species (Thamnophis elegans) in lakes with amphibians was 30 times greater than in lakes without amphibians. Introduction of non-native trout was positively correlated with the reduction of the amphibian and gartersnake populations (Matthews et al. 2002). There is evidence that the Western Toad 
(Bufo boreas) and the Northern Leopard Frog (Rana pipiens) have experienced declines in western Montana, which could pose an indirect threat (Wootton 1994) to local T. sirtalis populations, especially at higher elevations where alternative prey and foraging habitat may be more scarce (Jennings 1992, Anderson 2004). For example, T. sirtalis cannot successfully preyswitch to fish because they lack the adequate fish capturing ability that the often sympatric $T$. elegans possesses (Drummond 1983), making them more vulnerable to amphibian reductions (Rossman et al. 1996). Furthermore, Peterson and Koch (1995) suggest that the apparent decline in Common Gartersnakes in Yellowstone and Grand Teton National Parks is related to the significant declines of Northern Leopard Frogs and Western toads, both of which have been linked to the spread of both Batrachochytrium dendrobatidis (chytrid fungus) (Daszak et al. 1999), non-native species introductions, and other causes (Maxell 2000). (2) Over-grazing, especially along riparian corridors, can trample vegetation and alter soil structure, which are both important components of gartersnake habitat (Kauffman and Krueger 1984, Szaro et al. 1985). Szaro et al. (1985) found five times as many Terrestrial Gartersnakes along a stream in ungrazed cattle exclosures than along grazed portions. Common Gartersnakes are probably similarly affected along heavily grazed wetland margins. Furthermore, grazing is known to reduce the abundance of many invertebrates (Hutchingson and King 1980) and amphibians, which can both directly and indirectly affect prey availability. (3) Roads often have negative impacts on population size and distribution of snakes and other reptiles. High road density has been positively correlated to low population size, and restriction to roadless areas, which can lead to local extirpations. (Rudolph et al. 1998, Jochimsen et al. 2004). While this has not been studied exclusively on $T$. sirtalis in Montana, some populations are likely affected in areas of high road density or where roads intersect travel corridors, and T. sirtalis is often observed basking on roads (Paul Hendricks, pers. obs.). J. Chan reported more than 10,000 T. sirtalis parietalis killed by cars in one fall while returning to den sites in northern Manitoba (Rossman 1996). (4) Many snakes show their highest mortality rates during active periods, such as mate-searching, egglaying migrations, migrations to hibernacula, or dispersals of neonates after birth. Causes of mortality during such dispersals included natural predation, domesticated animals, and road kill (Bonnet et al. 1999). (5) Large aggregations of overwintering T. sirtalis may be susceptible to any hibernacula disturbance, and by large scale collecting for the scientific or pet trades. After spring emergence, populations in Manitoba were greatly reduced by such collecting (Rossman et al 1996). (6) The Common Gartersnake’s tendency to utilize a small home range, its place as predator on the food chain, and its habit of consuming both aquatic and terrestrial prey, make them highly susceptible to bioaccumulation pesticides and heavy metals, and therefore an excellent bioindicator of these pollutants where they enter the environment (Stafford et al. 1976, Anderson 1977). Anderson (1977) compared the content of heavy metals in gartersnakes from six riparian control sites in Lake and Flathead counties with two sites known to have industrial pollution, Fred Bur Creek (contaminated with mercury) and an area surrounding an East Helena smelter (contaminated with lead). Concentrations of lead were approximately three times higher at East Helena and concentrations of mercury nearly twice as high at Fred Bur Creek than concentrations of those metals at the control sites. Despite adequate habitat, gartersnakes were rarely observed at the heavily polluted sites, qualitatively suggesting poor population viability caused by these heavy metals. (7) T. sirtalis shows remarkable regional variability in life history and behavior, evidenced by studies in contrasting environments. For example, the large denning aggregations, long distance migrations, massive mortalities, presence of she-males, and formation of "mating balls" are absent in Kansas populations (Fitch 2001). Even within the 
northern latitudes of Canada significant differences in reproductive traits exist between eastern and western populations (Gregory and Larsen 1993). Due to the lack of data for Montana, coupled the diversity in landscape, climate, and habitat encompassed by the state, it is possible that Montana T. sirtalis populations have similarly diverse characteristics depending upon local landscape, climate, and habitat. Therefore, while probably secure regionally, local populations may have specific vulnerabilities not found in other populations, which may go unnoticed while making management decisions.

\section{$\underline{\text { Research and Management Suggestions }}$}

1. Initially, thorough surveys should be conducted to identify the northern boundary of $T$. sirtalis distribution in eastern Montana north of the Yellowstone River. This can be done by conducting systematic surveys in suitable habitat, or by educating the public (e.g. local landowners and resource managers) to discern $T$. radix from $T$. sirtalis and encouraging them to report observations.

2. Manage for viable amphibian populations, especially anurans, which are important in assuring viable gartersnake populations at high elevations. (e.g. limit predatory gamefish introductions in mountain lakes).

3. Monitor local amphibian populations and T. elegans populations concurrently to identify potential effects of shifts in amphibian abundance.

4. Through research, monitoring, and management actions investigate and minimize the extent of anthropogenic impacts to $T$. sirtalis populations. For example, as strong bioindicators, gartersnakes can be monitored for heavy metals and pesticides near areas subject to exposure.

5. Grazing exclosures can be constructed along selected portions of heavily impacted wetland margins to promote vegetation regeneration.

6. If large denning aggregations are located, such as those found in Manitoba and Alberta, juxtaposition of dispersal routes and human dangers (roads, domesticated animals, collecting, etc.) should be studied and considered in local management decisions.

7. Hibernacula supporting such aggregations should be protected from large scale poaching to support the scientific and pet trade.

8. Long-term affects of road-building on Common Gartersnake populations should be investigated in areas of increased road development. Areas with dense road development, such as regions being developed for coal bed natural gas extraction, should be particularly targeted for baseline surveys and post-development monitoring.

9. Due to the extreme regional variability of $T$. sirtalis, evidence of specialization at the local level, and a lack of in-state data, broad generalizations about demographic vital rate data and life history information should not be made from nationwide data, but rather be assessed at the local level before making management decisions for a restricted area.

10. Life history and ecological studies for T. sirtalis should be conducted within the state to aid with these assessments.

Bibliography *indicates an article with information specific to Montana

Aleksiuk, M. 1970. The effects of in vivo light and temperature acclimation on in vivo responses of heart rate to temperature in a cold-climate reptile, Thamnophis sirtalis parietalis. Canadian Journal of Zoology 48: 1155-1161. 
Aleksiuk, M. 1971a. An isoenzymic basis for instantaneous cold compensation in reptiles: lactate dehydrogenase kinetics in T. sirtalis. Comparative Biochemistry and Physiology 40B: 671-681.

Aleksiuk, M. 1971b. Temperature dependent shifts in the metabolism of a cool temperate reptile Thamnophis sirtalis parietalis. Comparative Biochemistry and Physiology 39A: 495503.

Aleksiuk, M. 1976a. Metabolic and behavioral adjustments to temperature changes in the redsided garter snake (Thamnophis sirtalis parietalis): an integrated approach. Journal of Thermal Biology I: 153-156.

Aleksiuk, M. 1976b. Reptilian hibernation: evidence of adaptive strategies in Thamnophis sirtalis parietalis. Copeia 1976: 170-178.

Aleksiuk, M. 1977. Cold-induced aggregative behavior in the red-sided garter snake (Thamnophis sirtalis parietalis). Herpetologica 33: 98-101.

Aleksiuk, M. and K.W. Stewart. 1971. Seasonal changes in the body composition of the garter snake (Thamnophis sirtalis parietalis) at northern latitudes. Ecology 52: 485-490.

Aleksiuk, M. and P.T. Gregory. 1974. Regulation of seasonal mating behaviour in Thamnophis sirtalis parietalis. Copeia 1974: 681-689.

Allen, E. and D. Crews. 1992. Sexual behavior and 2-deoxyglucose uptake in male red-sided Garter snakes (Thamnophis sirtalis parietalis). Brain Behavior and Evolution 40(1): 17-24.

*Anderson, M.E. 1977. Aspects of the ecology of two sympatric species of Thamnophis and heavy metal accumulation with the species. M.S. Thesis, University of Montana. Missoula, MT. 147 pp.

Andry, M.L., M.W. Luttges, and R.I. Gamow. 1971. Temperature effects on spontaneous and evoked neural activity in the garter snake. Experimental Neurology 31: 32-44.

Arnold, S.J. 1978. Some effects of early experience on feeding responses in the common garter snake, T. sirtalis. Animal Behavior 26: 455-462.

Arnold, S.J. 1992. Behavioural variation in natural populations: VI. Prey responses by two species of garter snakes in three regions of sympatry. Animal Behaviour 44(4): 705-719.

Arnold, S.J. and C.R. Peterson. 1989. A test for temperature effects on the ontogeny of shape in the garter snake Thamnophis sirtalis. Physiological Zoology 62(6): 1316-1333.

Arnold, S.J. and R.J. Wassersug. 1978. Differential predation on metamorphic anurans by garter snakes (Thamnophis): social behavior as a possible defense. Ecology 59(5): 10141022.

Bailey, R.M. 1949. Temperature tolerance of gartersnakes in hibernation. Ecology 30: 238242.

Barry, S. J., M. R. Jennings, and H. M. Smith. 1996. Current subspecific names for western Thamnophis sirtalis. Herpetological Review 27:172-173.

Batlett, D., J.P. Mortola, and E.J. Doll. 1986. Respiratory mechanics and control of the ventilatory cycle in the garter snake (Thamnophis sirtalis). Respiration Physiology 64(1): 13-28.

Barton, A.J. 1952. A new size record for the eastern gartersnake, Thamnophis sirtalis sirtalis. Copeia 1952: 190-191.

Baxter, G.T., and M.D. Stone. 1985. Amphibians and reptiles of Wyoming. 2nd ed. Wyoming Game and Fish Department, Cheyenne. 
Begun, D., J.L. Kubie, M. Plough-O'Keefe, and M. Halpern. 1988. Conditioned discrimination of airborne odorants by garter snakes (Thamnophis radix and T. sirtalis sirtalis). Journal of Comparative Psychology 102(1): 35-43.

Benton, M.J. 1980. Geographic variation in the garter snakes, T. sirtalis, of the north-central U.S., a multivariate study. Zoological Journal of the Linnean Society 68:307-323.

Bern, C. and H.A. Herzog, Jr. 1994. Stimulus control of defensive behaviors of garter snakes (Thamnophis sirtalis): Effects of eye spots and movement. Journal of Comparative Psychology 108(4): 353-357.

Bernardino, F.S., Jr., and G.H. Dalrymple. 1992. Seasonal activity and road mortality of the snakes of the Pa-hay-okee wetlands of Everglades National Park, USA. Biological Conservation 62(2): 71-75.

Bittner, T.D. 2000. The evolutionary significance of melanism in the common garter snake, Thamnophis sirtalis. Unpubl. Ph.D. Dissertation, Northern Illinois University, DeKalb.

Bittner, T.D. 2003. Polymorphic Clay Models of Thamnophis sirtalis Suggest Patterns of Avian Predation. Ohio Journal of Science 103(3): 62-66.

Bittner, T.D., R.B. King, and J.M. Kerfin. 2002. Effects of body size and melanism on the thermal biology of garter snakes (Thamnophis sirtalis). Copeia 2: 477-482.

Blackburn, D.G. and R.L. Lorenz. 2003a. Transmission EM of the chorioallantoic placenta of Thamnophis radix and T. sirtalis. Journal of Morphology 256(2):171-186.

Blackburn, D.G. and R.L. Lorenz. 2003b. Transmission EM of the omphalallantoic placenta of Thamnophis radix and T. sirtalis. Journal of Morphology 256(2):187-204.

Blaesing, M.E. 1979. Some aspects of the ecology of the eastern garter snake (Thamnophis sirtalis sirtalis) in a semi-disturbed habitat in West-Central Illinois. Journal of Herpetology 13: 177-181.

Blanchard, F.C. 1943. A test of fecundity of the garter snake Thamnophis sirtalis sirtalis (Linnaeus) in the year of insemination. Papers of the Michigan Academy of Science, Arts and Letters 28: 313-316.

Blanchard, F.N. and F.C. Blanchard. 1940. Factors determining the time of birth in garter snakes Thamnophis sirtali sirtalis (Linnaeus). Papers of the Michigan Academy of Science, Arts and Letters 26: 161-176.

Blanchard, F.N. and F.C. Blanchard. 1941. The inheritance of melanism in the garter snake Thamnophis sirtalis sirtalis (Linnaeus) and some evidence of effective autumn mating. Papers of the Michigan Academy of Science, Arts and Letters 26: 161-176.

Blanchard, F.N. and F.C. Blanchard. 1942. Mating of the garter snake, Thamnophis sirtalis (linnaeus). Papers of the Michigan Academy of Science, Arts and Letters 27: 215-234.

Bleakney, S. 1959. Thamnophis sirtalis sirtalis (Linnaeus) in eastern Canada, redescription of T. s. pallidula Allen. Copeia 1959(1): 52-56.

Bona-Gallo, A. and P. Licht. 1983. Effects of temperature on sexual receptivity and ovarian recrudescence in the garter snake, Thamnophis sirtalis parietalis. Herpetologica 39: 173182.

Bonnet, X., G. Naulleau, and R. Shrine. 1999. The dangers of leaving home: Dispersal and mortality in snakes. Biological Conservation 89: 39-50.

*Boundy, J. 2001. Herpetofaunal surveys in the Clark Fork Valley region, Montana. Herpetological Natural History 8: 15-26.

*Breitenbach, R.P. 1951. Large fish for a small snake. Yellowstone Nature Notes 25(6): 70. 
Brenner, F.J., E.K. Brenner, and P.E. Brenner. 1992. Analysis of drift fence arrays as a census method for vertebrate communities on a proposed mine site. Journal of the Pennsylvania Academy of Science 65(3): 117-122.

Brodie, E.D., Jr., B.J. Ridenhour, and E.D. Brodie III. 2002. The evolutionary response of predators to dangerous prey: Hotspots and coldspots in the geographic mosaic of coevolution between garter snakes and newts. Evolution 56:2067-2082.

Brodie, E.D. Jr., and E.D. Brodie III. 2002. The evolutionary response of predators to dangerous prey: Garter snakes and newts. Northwestern Naturalist 83(2):65.

Brodie, E.D., Jr. and M.S. Tumbarello. 1978. The antipredator functions of Dendrobates auratus (Amphibia, Anura, Dendrobatidae) skin secretions in regard to a snake predator (Thamnophis). Journal of Herpetology 12: 264-265.

Brodie, E.D., III. 1993. Consistency of individual differences in anti-predator behaviour and colour pattern in the garter snake Thamnophis ordinoides. Animal Behavior 45:851-861.

Brodie, E.D. III, C.R. Feldman, C.T. Hanifin, J.E. Motychak, D.G. Mucahy, B.L. Williams, and E.D. Brodie Jr. 2005. Parallel arms races between garter snakes and newts involving tetrodotoxin as the phenotypic interface of coevolution. Journal of Chemical Ecology 31(2):343-356.

Brodie, E.D. III and E.D. Brodie, Jr. 1990. Tetrodotoxin resistance in garter snakes: an evolutionary response of predators to dangerous prey. Evolution 44: 651-659.

Brodie, E.D. III and E.D. Brodie, Jr. 1991. Evolutionary response of predators to dangerous prey: reduction of toxicity of newts and resistance of garter snakes in island populations. Evolution 45: 221-224.

Brodie, E.D. III, E.D. Brodie, Jr., and J.E. Motychak. 2002. Recovery of garter snakes (Thamnophis sirtalis) from the effects of tetrodotoxin. Journal of Herpetology 36: 95-98.

Bronikowski, A.M. 1997. The sources and consequences of individual growth rate variation in the western terrestrial garter snake. Ph.D. Dissertation. The University of Chicago, Chicago, IL.

*Brunson, R.B. 1955. Check list of the amphibians and reptiles of Montana. Proceedings of the Montana Academy of Sciences 15: 27-29.

*Brunson, R.B. and H.A. Demaree. 1951. The herpetology of the Mission Mountains, Montana. Copeia 1951: 306-308.

Bull, E.L. and M.P. Hayes. 2000. Livestock effects on reproduction of the Columbia spotted frog. Journal of Range Management 53: 293-296.

Burger, J. 2001. The behavioral response of basking Northern water (Nerodia sipedon) and Easter Garter (Thamnophis sirtalis) snakes to pedestrians in a New Jersey park. Urban Ecosystems 5: 119-129.

Burghardt, G.M. 1964. Stimulus control of the prey attack response in native garter snakes. Psychonomic Science 4: 37-38.

Burghardt, G.M. 1969. Comparative prey-attack studies in newborn snakes of the genus Thamnophis. Behaviour 33: 77-114.

Burghardt, G.M. 1970. Intraspecific geographical variation in chemical food cue preference of newborn garter snakes (Thamnophis sirtalis). Behaviour 36: 246-257.

Burghardt, G.M. 1975. Chemical prey preference polymorphism in newborn garter snakes, Thamnophis sirtalis. Behaviour 52: 202-225.

Burghardt, G.M. 1992. Prior exposure to prey cues influences chemical prey preferences and prey choice in neonatal garter snakes. Animal Behaviour 44: 787-789. 
Burghardt, G.M., H.C. Wilcoxon, and J.A. Czaplicki. 1973. Conditioning in garter snakes: aversion to palatable prey induced by delayed illness. Animal Learning and Behavior 1: 317320.

Burghardt, G.M. and M.A. Krause. 1999. Plasticity of foraging behavior in garter snakes (Thamnophis sirtalis) reared on different diets. Journal of Comparative Psychology 113: 277-285.

Burghardt, G.M. and P.J. Chmura. 1993. Strike-induced chemosensory searching by ingestively naive garter snakes (Thamnophis sirtalis). Journal of Comparative Psychology 107(1): 116121.

Burt, M.D. 1928. The relation of size to maturity in the garter snakes, Thamnophis sirtalis sirtalis and T. sauritus sauritus. Copeia 1928: 8-12.

*Butts, T.W. 1997. Mountain Inc. wildlife monitoring Bull Mountains Mine No. 1, 1996. Western Technology and Engineering. Helena, MT.

Carpenter, C.C. 1948. An erythristic Thamnophis sirtalis sirtalis. Herpetologica 4: 211-212.

Carpenter, C.C. 1951. Young goldfinches eaten by garter snake. Wilson Bulletin 63: 117-118.

Carpenter, C.C. 1952a. Comparative ecology of the common garter snake (Thamnophis s. sirtalis), the ribbon snake (Thamnophis s. sauritus), and Butler's garter snake (Thamnophis butleri) in mixed populations. Ecological Monographs 22:235-258.

Carpenter, C.C. 1952b. Growth and maturity of the three species of Thamnophis in Michigan. Copeia 1952: 237-243.

Carpenter, C.C. 1955. The garter snake. Science Monthly 81: 248-252.

Carpenter, C.C. 1956. Body temperatures in three species of Thamnophis. Ecology 37: 732735.

Charland, M.B. 1991. Anesthesia and transmitter implantation effects on gravid garter snakes (Thamnophis sirtalis and Thamnophis elegans). Herpetological Review 22(2): 46-47.

Charland, M.B. and P.T. Gregory. 1995. Movements and habitat use in gravid and nongravid female garter snakes (Colubridae: Thamnophis). Journal of Zoology (London) 236: 543-561.

Chieffelin, C.D. and A. De Queiroz. 1991. Temperature and defense in the common garter snake: Warm snakes are more aggressive than cold snakes. Herpetologica 47(2): 230-237.

Churchill, T.A. and K.B. Storey. 1992. Freezing survival of the garter snake Thamnophis sirtalis parietalis. Canadian Journal of Zoology 70(1): 99-105.

*Cochran, D.M. 1961. Type specimens of reptiles and amphibians in the United States National Museum. United States National Museum Bulletin 220: 1-291.

Cook, F. 1964. Further comments on the proposed rejection of the neotype and type-locality of Thamnophis sirtalis (Linnaeus, 1758) (Reptilia) Z. N. (S.) 1600. Bulletin of Zoological Nomenclature 21(5): 327-328.

*Cope, E.D. 1872. Report on the recent reptiles and fishes of the survey, collected by Campbell Carrington and C.M. Dawes. pp. 467-469 In: F.V. Hayden, Preliminary report of the United States geological survey of Montana and portions of adjacent territories; being a fifth annual report of progress. 538 pp. 42nd Congress, 2nd Session, House Executive Document Number 326. Serial 1520.

*Cope, E.D. 1875. Check-list of North American Batrachia and Reptilia; with a systematic list of the higher groups, and an essay on geographical distribution. U.S. National Museum Bulletin 1(1): 1-104.

*Cope, E.D. 1891. A critical review of the characters and variations of the snakes of North America. Proceedings of the U.S. National Museum 14(882): 589-694. 
*Cope, E.D. 1900. The crocodilians, lizards and snakes of North America. Report of the U.S. National Museum 1898: 153-1270.

*Corn, J. and P. Hendricks. 1998. Lee Metcalf National Wildlife Refuge bullfrog and painted turtle investigations: 1997. Montana Natural Heritage Program, Helena, MT. 20 p.

Costanzo, J.P. 1985. The bioenergetics of hibernation in the eastern garter snake Thamnophis sirtalis sirtalis. Physiological Zoology 58(6): 682-692.

Costanzo, J.P. 1986. Influences of hibernaculum microenvironment on the winter life history of the garter snake (Thamnophis sirtalis). Ohio Journal of Science 86(5): 199-204.

Costanzo, J.P. 1988. Recovery from ice-entombment in garter snakes. Herpetological Review 19(4): 76-77.

Costanzo, J.P. 1989a. Conspecific scent trailing by garter snakes (Thamnophis sirtalis) during autumn: Further evidence for use of pheromones in den location. Journal of Chemical Ecology 15(11): 2531-2538.

Costanzo, J.P. 1989b. Effects of humidity, temperature, and submergence behavior on survivorship and energy use in hibernating garter snakes, Thamnophis sirtalis. Canadian Journal of Zoology 67(10): 2486-2492.

Costanzo, J.P., D.L. Claussen, and R.E. Lee, Jr. 1988. Natural freeze tolerance in a reptile. Cryo Letters 9(6): 380-385.

*Coues, E. and H.C. Yarrow. 1878. Notes on the herpetology of Dakota and Montana. Bulletin of the U.S. Geologic and Geographic Survey 4(1): 259-291.

Cover, J. F., Jr. and D. M. Boyer. 1988. Captive reproduction of the San Francisco garter snake Thamnophis sirtalis Tetrataenia. Herpetological Review 19: 29-30, 32-33.

Cowan, A. 1992. An assessment of commercial and recreational management options for the red-sided garter snake in Manitoba. M.S. Thesis, University of Manitoba, Manitoba, Canada. $141 \mathrm{pp}$.

Crews, D. 1976. Hormonal control of male courtship behavior and female attractivity in the garter snake (Thamnophis sirtalis). Hormones and Behavior 7: 451-460.

Crews, D., B. Camazine, M. Diamond, R. Mason, R.R. Tokarz, and W.R. Garstka. 1984. Hormonal independence of courtship behavior in the male garter snake. Hormones and Behavior 18: 29-41.

Crews, D., M.A. Diamond, J. Whiitier, and R. Mason. 1985. Small male body size in garter snake (Thamnophis sirtalis parietalis) depends on testes. American Journal of Physiology 249(1 part 2): R62-R66.

Crews, D., R. Robker, and M. Mendonca. 1993. Seasonal fluctuations in brain nuclei in the redsided garter snake and their hormonal control. Journal of Neuroscience 13(12): 5356-5364.

Crews, D. and W.R. Gartska. 1982. The ecological physiology of a garter snake. Scientific American 247: 159-168.

Cridle, S. 1937. Snakes from an ant hill. Copeia 1937:142.

*Cutter, R. 1930a. Ike and Mike. Yellowstone Nature Notes 7(7): 41.

*Cutter, R. 1930b. Miscellaneous note on garter snakes. Yellowstone Nature Notes 7(9): 62.

Dalrymple, G.H. and N.G. Reichenbach. 1981. Interactions between the prairie garter snake (Thamnophis radix) and the common gartersnake (T. sirtalis) in Killdeer Plains, Wyandot County, Ohio. Ohio Biological Survey Biology Notes 15: 244-250.

Dalrymple, G.H., T.M. Steiner, R.J. Nodell, and F.S. Bernardino, Jr. 1991. Seasonal activity of the snakes of Long Pine Key, Everglades National Park (Florida, USA). Copeia 1991(2): 294-302. 
Daszak, P., A.A. Cunningham and A.D. Hyatt. 2000. Emerging infectious diseases of wildlifethreats to biodiversity and human health. Science 287:443-449.

Degenhardt, W.G., C.W. Painter, and A.H. Price. 1996. Amphibians and reptiles of New Mexico. Albuquerque, NM: University of New Mexico Press. 431 p.

Devine, M.C. 1976. Species discrimination in mate selection by free-living male garter snakes and experimental evidence for the role of pheromones. Herpetological Review 71: 79.

Devine, M.C. 1977. Copulatory plugs, restricted mating opportunities, and reproductive competition among male garter snakes. Nature 267: 345-346.

Dial, B.E., R.E. Gatten, Jr., and S. Kamel. 1987. Energetics of concertina locomotion in Bipes biporus (Reptilia: Amphisbaenia). Copeia 1987(2): 470-477.

Dickinson, J.A. 1979. The effects of artificial cover availability on the ecology of the garter snake, Thamnophis s. sirtalis. M.S. Thesis, Central Michigan University.

Dohm, M.R. and T. Garland, Jr. 1993. Quantitative genetics of scale counts in the garter snake, Thamnophis sirtalis. Copeia 1993(4): 987-1002.

Drummond, H. 1983. Aquatic foraging in garter snakes: a comparison of specialists and generalists. Behaviour 86: 1-30.

Dunlap, K.D. and J.W. Lang. 1990. Offspring sex ratio varies with maternal size in the common garter snake, Thamnophis sirtalis. Copeia 1990: 568-570.

*Elliott, A.E. 1931. Another fish story. Yellowstone Nature Notes 8(9): 69.

Engelstoft, C. and K.E. Ovaska. 2000. Artificial cover-objects as a method for sampling snakes (Contia tenuis and Thamnophis spp.) in British Columbia. Northwestern Naturalist 81:35-43.

*Ernst, C.H. and E.M. Ernst. 2003. Snakes of the United States and Canada. Washington D.C.: Smithsonian Books.

Etheridge, K. 1993. Thyroxine-induced changes in metabolic rate and cytochrome oxidase activity in Thamnophis sirtalis: Effects of nutritional status. General and Comparative Endocrinology 91(1): 66-73.

Evans, G.O. and W.E. China. 1966. Opinion 771. Thamnophis sirtalis Linnaeus, 1758 (Reptilia): rejection under the plenary powers of the neotype specimen designated for that species by Opinion 385. Bulletin of Zoological Nomenclature 23(1): 38-40.

*Farmer, P. 1986. Chartam project baseline wildlife study. Western Technology and Engineering, Inc. Helena, MT.

*Farmer, P. and K. Burgess. 1983. Jardine area baseline terrestrial wildlife study May 15, 1981 - May 15, 1982. Western Technology and Engineering Inc. Helena, MT.

*Farmer, P. and S.B. Heath. 1987. Wildlife baseline inventory, Rock Creek study area, Sanders County, Montana. Western Technology and Engineering, Inc. Helena, MT.

Farr, D.R. 1988. The ecology of garter snakes, Thamnophis sirtalis and T. elegans, in southeastern British Columbia. Unpubl. M.S. Thesis, University of Victoria, BC, Canada.

Feldman, C.R. and J.A. Wilkinson. 2000. Rana muscosa (Mountain Yellow-legged Frog). Predation. Herpetological Review 31: 102.

Fetterolf, P.M. 1979. Common garter snake predation on ring-billed gull chicks. The Canadian Field Naturalist 93: 317-318.

*Fitch, H.S. 1940. A biogeographical study of the ordinoides artenkries of garter snakes (genus Thamnophis). University of California Publications in Zoology 44(1): 1-150.

Fitch, H.S. 1941a. Geographic variation in garter snakes of the species Thamnophis sirtalis in the Pacific Coast region of North America. American Midland Naturalist 26 (3): 570-592. 
Fitch, H.S. 1941b. The feeding habits of California garter snakes. California Fish and Game 27: 1-32.Fitch, H.S. 1965. An ecological study of the garter snake, Thamnophis sirtalis. University of Kansas Museum of Natural History Publication 15(10):493-564.

Fitch, H.S. 1965. An ecological study of the garter snake, Thamnophis sirtalis. University of Kansas Museum of Natural History Publication 15(10):493-564.

*Fitch, H.S. 1980. Thamnophis sirtalis. Catalogue of American Amphibians and Reptiles 270.1-270.4.

Fitch, H.S. 1993. Relative abundance of snakes in Kansas. Transactions of the Kansas Academy of Science 96(3-4): 213-224.

Fitch, H.S. 2001. Further study of the garter snake, Thamnophis sirtalis, in Northeastern Kansas. Scientific Papers Natural History Museum The University of Kansas 19:1-6.

Fitch, H.S. 2003. Tail loss in garter snakes. Herpetological Review 34(4):212-213.

Fitch, H.S. 2004. The effect of female size on number of eggs or young snakes. Journal of Kansas Herpetology 9:11-12.

Fitch, H.S. 2005. Observations on wandering of juvenile snakes in northeastern Kansas. Journal of Kansas Herpetology 13:11-12.

Fitch, H.S. and H.W. Shirer. 1971. A radiotelemetric study of spatial relationships in some common snakes. Copeia 1971: 118-128.

*Fitch, H.S. and T.P. Maslin. 1961. Occurrence of the garter snake, Thamnophis sirtalis, in the Great Plains and Rocky Mountains. University of Kansas Publications, Museum of Natural History 13(5): 289-308.

Ford, N.B. 1978. Evidence for species specificity of pheromone trails in two sympatric garter snakes, Thamnophis. Herpetological Review 9: 10.

Ford, N.B. 1979. Aspects of pheromone trailing in garter snakes (Thamnophis). Ph.D. Dissertation, Miami University (Ohio).

Ford, N.B. 1981. Seasonality of pheromone trailing behavior in two species of garter snake, Thamnophis (Colubridae). Southwestern Naturalist 26: 385-388.

Ford, N.B. 1982. Species specificity of sex pheromone trails of sympatric and allopatric garter snakes (Thamnophis). Copeia 1982: 10-13.

Ford, N.B. 1996. Behavior of garter snakes. pp.90-116. In: D.A. Rossman, N.B. Ford, and R.A. Seigel (eds). The Garter Snakes: Evolution and Ecology. Norman, OK: University of Oklahoma Press.

Foster, B.J., D.W. Sparks, and J.E. Duchamp. 2003. Urban herpetology I: New distribution records of amphibians and reptiles from Hendricks County, Indiana. Herpetological Review 34(4):395.

Fouquette, M.J., Jr. 1954. Food competition among four sympatric species of garter snakes. Texas Journal of Science 6: 172-188.

Fox, W. 1951. The status of the garter snake Thamnophis sirtalis tetrataenia. Copeia 1951(4): 257-267.

Fox, W. 1952. Seasonal variation in the male reproductive system of Pacific coast garter snakes. Journal of Morphology 90: 481-554.

Fox, W. 1954. Genetic and environmental variation in the timing of the reproductive cycles of male garter snakes. Journal of Morphology 95: 415-450.

Fox, W. 1955. Mating aggregations of garter snakes. Herpetologica 11: 176.

Fox, W. 1956. Seminal recepticles of snakes. Anatatomical Record 124(3): 519-540. 
Fox, W. and H.C. Dessauer. 1964. Collection of garter snakes for blood studies. Yearbook of American Philosophy Society 1964: 263-266.

*Franz, R. 1971. Notes on the distribution and ecology of the herpetofauna of northwestern Montana. Bulletin of the Maryland Herpetological Society 7: 1-10.

Furilla, R.A. and D. Bartlett. 1988. Intrapulmonary receptors in the garter snake (Thamnophis sirtalis). Respiration Physiology 74(3): 311-322.

Fuchs, J.L. and G.M. Burghardt. 1971. Effects of early feeding experience on the responses of garter snakes to food chemicals. Learning and Motivation 2(3): 271-279.

Galbraith, DA. 2001. Arboreal courtship behaviour by eastern garter snakes, Thamnophis sirtalis sirtalis, in September in Bruce County, Ontario. Canadian Field Naturalist 115(2): 347-348.

Garland, T., Jr. 1988. Genetic basis of activity metabolism: I. Inheritance of speed, stamina, and antipredator displays in the garter snake Thamnophis sirtalis. Evolution 42(2): 335-350.

Garland, T., Jr. 1994. Quantitative genetics of locomotor behavior and physiology in a garter snake. In: Boake, R.B. (ed.), Quantitative Genetic Studies of Behavioral Evolution. University of Chicago Press, Chicago, Illinois.

Garland, T., Jr. and A.F. Bennett. 1990. Quantitative genetics of maximal oxygen consumption in a garter snake. American Journal of Physiology 259: R986-R992.

Garner, T.W.J. 1998. A molecular investigation of population structure and paternity in the common garter snake, Thamnophis sirtalis. M.S. Thesis. Victoria, B.C.: University of Victoria.

Garner, T.W.J., P.B. Pearman, P.T. Gregory, G. Tomio, S.G. Wischniowski, and D.J. Hosken. 2004. Microsatellite markers developed from Thamnophis elegans and Thamnophis sirtalis and their utility in three species of garter snakes. Molecular Ecology Notes 4(3): 369-371.

Garstka, W.R. and D. Crews. 1981. Female sex pheromone in the skin and circulation of a garter snake. Science 214: 681-683.

Garstka, W.R. and D. Crews. 1985. Mate preference in garter snakes. Herpetologica 41(1): 919.

Garstka, W.R., B. Camazine, and D. Crews. 1982. Interactions of behavior and physiology during the annual reproductive cycle of the red-sided garter snake (Thamnophis sirtalis parietalis). Herpetologica 38: 104-123.

Garstka, W.R., R.R. Tokarz, M. Diamond, A. Halpert, and D. Crews. 1985. Behavioral and physiological control of yolk synthesis and deposition in the female red-sided garter snake (Thamnophis sirtalis parietalis). Hormones and Behavior 19(2): 137-153.

*Gates, M.T. 2005. Amphibian and reptile baseline survey: CX field study area. Report to Billings and Miles City Field Offices of Bureau of Land Management. Maxim Technologies, Billings, MT. 28pp + Appendices.

Geddes, G.C. 2005. The heart of the matter: an unfortunate Thamnophis sirtalis. Bulletin of the Chicago Herpetological Society 40(4):65.

Gibson, A.R. 1978. The ecological significance of a colour polymorphism in the common gargter snake, Thamnophis sirtalis (L.). Ph.D. Dissertation, University of Toronto, Toronto, Ontario.

Gibson, A.R. and J.B. Falls. 1979. Thermal biology of the common garter snake Thamnophis sirtalis (L.). I. Temporal variation, environmental effects and sex differences. Oecologia 43: 79-97. 
Gibson, A.R. and J.B. Falls. 1988. Melanism in the common garter snake: a Lake Erie phenomenon. Pp. 231-245. In: J.F. Downhower (ed). The Biography of the Island Region of Western Lake Erie, Ohio State University Press, Columbus.

Gibson, A.R., D.A. Smucny, and J. Kollar. 1989. The effects of feeding and ecdysis on temperature selection by young garter snakes in a simple thermal mosaic. Canadian Journal of Zoology 67(1): 19-23.

Gillingham, J.C. and J.A. Dickenson. 1980. Postural orientation during courtship in the Eastern garter snake, Thamnophis s. sirtalis. Behavioral Neural Biology 28: 211-217.

Gillingham, J.C., J. Rowe, and M.A. Weins. 1990. Chemosensory orientation and earthworm location by foraging eastern garter snakes (Thamnophis s. sirtalis). In: MacDonald, D.W., D. Muller-Schwarze, and S.E. Natynezuk (eds.), Chemical Signals in Vertebrates, Vol. 5. Oxford University Press, Oxford.

Gochfeld, M. 1975. The decline of the eastern garter snake, Thamnophis s. sirtalis in a rural residential section of Westchester Co., New York. Engelhardtia 6(3):23-24.

Graves, B.M., M. Halpern, and J.C. Gillingham. 1993. Effects of vomeronasal system deafferentation on home range use in a natural population of eastern garter snakes, Thamnophis sirtalis. Animal Behaviour 45(2): 307-311.

Greenwell, M.G., M. Hall, and O.J. Sexton. 1984. Phenotypic basis for a feeding change in an insular population of garter snakes (Thamnophis sirtalis). Developmental Psychobiology 17(5): 457-464.

Gregory, P.T. 1967. Feeding habits and diet overlap of three species of garter snakes (Thamnophis) on Vancouver Island. Canadian Journal of Zoology 56: 1967-1974.

Gregory, P.T. 1971. Overwintering populations and homing of the red-sided garter snake (Thamnophis sirtalis parietalis) at a northern latitude. M.S. Thesis. Winnipeg, Manitoba: University of Manitoba.

Gregory, P.T. 1973. Population dynamics and summer dispersal of the red-sided garter snake (Thamnophis sirtalis parietalis). Ph.D. Disseration. Winnipeg, Manitoba: University of Manitoba.

Gregory, P.T. 1974a. Life history parameters of a population of red-sided garter snakes (Thamnophis sirtalis parietalis) adapted to a rigorous and fluctuating environment. Ph.D. Dissertation. Winnipeg, Manitoba: University of Manitoba.

Gregory, P.T. 1974b. Patterns of spring emergence of the red-sided garter snake (Thamnophis sirtalis parietalis) in the inter-lake region of Manitoba. Canadian Journal of Zoology 52: 1063-1069.

Gregory, P.T. 1975. Aggregations of gravid snakes in Manitoba, Canada. Copeia 1975: 185186.

Gregory, P.T. 1977a. Life history observations of three species of snakes in Manitoba. Canadian Field Naturalist 91(1): 19-27.

Gregory, P.T. 1977b. Life-history parameters of the red-sided garter snake (Thamnophis sirtalis parietalis) in an extreme environment, the Interlake region of Manitoba. National Museum of Natural Sciences. (Ottawa) Publications in Zoology No. 13. Pp. 1-44.

Gregory, P.T. 1978. Feeding habits and diet overlap of three species of garter snakes (Thamnophis) on Vancouver Island. Canadian Journal of Zoology 56: 1967-1974.

Gregory, P.T. 1984. Habitat, diet and composition of assemblages of garter snakes (Thamnophis) at eight sites on Vancouver Island (Canada). Canadian Journal of Zoology 62(10): 2013-2022. 
Gregory, P.T. 2001. Feeding, thermoregulation, and offspring viability in gravid garter snakes (Thamnophis sirtalis): What makes laboratory results believable? Copeia 2: 365-371.

Gregory, P.T. and A.G.D. McIntosh 1980. Thermal niche overlap in garter snakes (Thamnophis) on Vancouver Island. Canadian Journal of Zoology 58(3): 351-355.

Gregory, P.T. and K.J. Nelson. 1991. Predation on fish and intersite variation in the diet of common garter snakes, Thamnophis sirtalis, on Vancouver Island (Canada). Canadian Journal of Zoology 69(4): 988-994.

Gregory, P.T. and K.J. Nelson. 1992. Erratum: predation on fish and intersite variation in the diet of common garter snakes, Thamnophis sirtalis, on Vancouver Island. Canadian Journal of Zoology 70: 2501.

Gregory, P.T. and K.W. Larsen. 1993. Geographic variation in reproductive characteristics among Canadian populations of the common garter snake (Thamnophis sirtalis). Copeia 1993(4): 946-958.

Gregory, P.T. and K.W. Larsen. 1996. Are there any meaningful correlates of geographic lifehistory variation in the garter snake, Thamnophis sirtalis? Copeia 1996(1): 183-189.

Gregory, P.T. and K.W. Stewart. 1975. Long-distance dispersal and feeding strategy of the redsided garter snake (Thamnophis sirtalis parietalis) in the interlake of Manitoba. Canadian Journal of Zoology 53: 238-245.

Grudzien, T.A., B.J. Huebner, A. Cvetkovic, and G.R. Joswiak. 1992. Multivariate analysis of head shape in Thamnophis sirtalis sirtalis (Serpentes: Colubridae) among island and mainland populations from northeastern Lake Michigan. American Midland Naturalist 127(2): 339-347.

Halpern, M. and J.L. Kubie. 1980. Chemical access to the vomeronasal organs of garter snakes. Physiological Behavior 24: 367-371.

Halpern, M. and N. Frumin. 1979. Roles of the vomeronasal and olfactory systems in prey attack and feeding in adult garter snakes. Physiological Behavior 22: 1183-1189.

Halpert, A.P., W.R. Garstka, and D. Crews. 1983. Sperm transport and storage and its relation to the annual sexual cycle of the female red-sided garter snake, Thamnophis sirtalis parietalis. M.S. Thesis.

Hammerson, G.A., 1999. Amphibians and Reptiles in Colorado. University Press of Colorado and Colorado Division of Wildlife, Niwot, Colorado.

Hamilton, W.J., Jr. 1951. The food and feeding behavior of the garter snake in New York. American Midland Naturalist 46(2): 385-390.

Harding, James H., 1997. Amphibians and Reptiles of the Great Lakes Region. Ann Arbor, MI: University of Michigan Press.

Hart, D.R. 1975. A quantitative niche comparison of the western plains garter snake (Thamnophis radix haydeni) and the red-sided garter snake (Thamnophis sirtalis parietalis) in allopatric and sympatric regions of Manitoba's interlake district. M.S. Thesis. University of Manitoba. $76 \mathrm{p}$.

Hart, D.R. 1979. Niche relationships of Thamnophis radix haydeni and Thamnophis sirtalis parietalis in the interlake district of Manitoba. Tulane Students of Zoology and Botany 21(2): 125-140.

*Hart, M.M., W.A. Williams, P.C. Thornton, K.P. McLaughlin, C.M. Tobalske, B.A. Maxell, D.P. Hendricks, C.R. Peterson, and R.L. Redmond. 1998. Montana atlas of terrestrial vertebrates. Montana Cooperative Wildlife Research Unit, The University of Montana. Missoula, Montana vii + 1302 p. 
Hawley, A.W. and M. Aleksiuk. 1976. The influence of photoperiod and temperature on seasonal testicular recrudescence in the red-sided garter snake (Thamnophis sirtalis parietalis). Comparative Biochemistry and Physiology 53A: 215-221.

Hawley, A.W.L. and M. Aleksiuk. 1975. Thermal regulation of spring mating behavior in the red-sided garter snake (Thamnophis sirtalis parietalis). Canadian Journal of Zoology 53: 768-776.

Hawley, A.W.L. and M. Aleksiuk. 1976. Sexual receptivity in the female red-sided garter snake (Thamnophis sirtalis parietalis). Copiea 1976: 401-404.

Hayes, F.E. 1989. Antipredator behavior of recently metamorphosed toads (Bufo americanus americanus) during encounters with garter snakes (Thamnophis sirtalis sirtalis). Copeia 1989(4): 1011-1015.

Hayward, J.L. 2002. Common garter snake predation on ring-billed gull chicks in Washington. Northwestern Naturalist 83: 25-26.

Heckrotte, C. 1967. Relations of body temperature, size, and crawling speed of the common garter snake, Thamnophis s. sirtalis. Copeia 1967(4): 759-763.

Heinen, J.T. 1993. Substrate choice and predation risk in newly metamorphosed American toads Bufo americanus: An experimental analysis. American Midland Naturalist 130(1): 184-192.

Heinen, J.T. 1994. Antipredator behavior of newly metamorphosed American toads (Bufo a. americanus), and mechanisms of hunting by eastern garter snakes (Thamnophis S. sirtalis). Herpetologica 50(2): 137-145.

Heinen, J.T. 1995. Predator cues and prey responses: A test using eastern garter snakes (Thamnophis sirtalis) and American toads (Bufo americanus). Copeia 1995(3): 738-741.

Heinen, J.T. and G. Hammond. 1997. Antipredator behaviors of newly metamorphosed green frogs (Rana clamitans) and leopard frogs (R. pipiens) in encounters with eastern garter snakes (Thamnophis s. sirtalis). American Midland Naturalist 137(1): 136-144.

Hemming, F. 1956. The specific names for the common North American snakes known respectively as the common garter snake and the eastern ribbon snake. Opinions and Declarations of the International Commision on Zoological Nomenclature 12(6): 217-223.

*Hendricks, P. 1997. Lee Metcalf National Wildlife Refuge preliminary amphibian and reptile investigations: 1996. Montana Natural Heritage Program, Helena, MT. 21 p.

*Hendricks, P. 1999. Amphibian and reptile survey of the Bureau of Land Management Miles City District, Montana. Montana Natural Heritage Program, Helena, MT. 80 p.

*Hendricks, P. 2000. Amphibian and reptile survey of the Thompson Chain of Lakes. A report to the Montana Department of Fish, Wildlife, and Parks. Montana Natural Heritage Program, Helena, MT. 15 p.

*Hendricks, P. and J.D. Reichel. 1996. Amphibian and reptile survey of the Bitterroot National Forest: 1995. Montana Natural Heritage Program, Helena, MT. 95 p.

*Hendricks, P. and J.D. Reichel. 1998. Amphibian and reptile survey on Montana refuges: 1996. Montana Natural Heritage Program, Helena, MT. 19 p.

Hebard, W.B. 1950. Relationships and variation in the garter snakes, genus Thamnophis, of the Puget Sound region of Washington state. Herpetologica 6: 97-101.

Hermes, L.M. and K.B. Storey. 1993. Antioxidant defenses in the tolerance of freezing and anoxia by garter snakes. American Journal of Physiology 265(3 PART 2): R646-R652.

Herzog, H.A., Jr. 1990. Experimental modification of defensive behaviors in garter snakes, Thamnophis sirtalis. Journal of Comparative Psychology 104: 334-339. 
Herzog, H.A., Jr., B.B. Bowers, and G.M. Burghardt. 1992. Development of antipredator responses in snakes: V. Species differences in ontogenetic trajectories. Developmental Psychobiology 25(3): 199-211.

Herzog, H.A., Jr. and J.M. Schwartz. 1990. Geographical variation in the anti-predator behavior of the neonate garter snake, Thamnophis sirtalis. Animal Behaviour 40(3):597-601.

*Hilliard, J., H. Minkus, and M. Weber. 1997. Amphibian survey of the Birch Creek drainage, Beaverhead County. Wildland Studies Project, San Francisco State University, San Francisco, CA. 12 p.

Hnida, J.A. and R.J. Carpenter. 2004. Thamnophis sirtalis parietalis (Red-sided Garter Snake). Endoparasites. Herpetological Review 35(1):75.

Hoberg, T. and C. Gause. 1989. Reptiles \& amphibians of North Dakota. North Dakota Outdoors 55(1):7-18.

Hoffman, L.H. 1970. Placentation in the garter snake, Thamnophis sirtalis. Journal of Morphology 131: 57-88.

Holtzmann, D.A. 2001. Thamnophis sirtalis sirtalis (eastern garter snake) courtship behavior. Herpetological Review 32(2): 110.

Holtzman, D.A., E. Gordon, and M. Halpern. 1993. Developmental changes in cytochrome oxidase histochemistry in the main and accessory olfactory bulbs of embryonic and neonatal garter snakes (Thamnophis sirtalis spp.). Journal of Morphology 218(3): 323-332.

Hoskins, M.A.H. and M. Aleksiuk. 1973. Effects of temperature, photoperiod, and season on in vitro rates of tissues from Thamnophis sirtalis parietalis, a cold climate reptile. Comparative Biochemistry and Physiology 45A(3): 737-756.

*Hossack, B., D. Pilliod, and S. Corn. 2001a. Reptile and amphibian inventory at Grant-Kohrs Ranch National Historic Site and Little Bighorn Battlefield National Monument. USGS Northern Rocky Mountain Science Center, Aldo Leopold Wilderness Research Institute, Missoula, MT. 6 p.

*Hossack, B.R., D. Pilliod, and P.S. Corn. 2001b. Preliminary amphibian surveys of the National Bison Range, Lost Trail National Wildife Refuge, and Swan River National Wildlife Refuge: 2001. USGS Northern Rocky Mountain Science Center, Aldo Leopold Wilderness Research Institute, Missoula, MT. 15 p.

Hutchinson, K.J. and Kathleen L. King. 1980. The effects of sheep stocking level on invertebrate abundance, biomass and energy utilization in a temperate, south grassland. Journal of Applied Ecology. 17:369-387.

Inger, R.F. 1946. Restriction of the type locality of Thamnophis sirtalis. Copeia 1946(4): 254.

Jacobs, G.H., J.A. Fenwick, M.A. Crognale, and J.F. Deegan. 1992. The all-cone retina of the garter snake: Spectral mechanisms and photopigment. Journal of Comparative Physiology A 170(6): 701-707.

Janzen, F.J., J.G. Krenz, T.S. Haselkorn, E.D. Brodie, and E.D. Brodie. 2002. Molecular phylogeography of common garter snakes (Thamnophis sirtalis) in western North America: implications for regional historical forces. Molecular Ecology 11(9): 1739-1752.

Jayne, B.C. and A.F. Bennett. 1989. The effect of tail morphology on locomotor performance of snakes: A comparison of experimental and correlative methods. Journal of Experimental Zoology 252(2): 126-133.

Jayne, B.C. and A.F. Bennett. 1990. Selection on locomotor performance capacity in a natural population of garter snakes. Evolution 44(5): 1204-1229. 
Jochimsen, Denim M., Charles R. Peterson, Kimberly M. Andrews, and J. Whitfield Gibbons. 2004. A literature review of the effects of roads on amphibians and reptiles and the measures used to minimize those effects. Idaho Fish and Game Department and USDA Forest Service.

Joy, J.E. and D. Crews. 1985. Social dynamics of group courtship behavior in male red-sided garter snakes (Thamnophis sirtalis parietalis). Journal of Comparative Psychology 99(2): 145-149.

Joy, J.E. and D. Crews. 1987. Hibernation in garter snakes (Thamnophis sirtalis parietalis): Seasonal cycles of cold tolerance. Comparative Biochemistry and Physiology A Comparative Physiology 87(4): 1097-1102.

Joy, J.E. and D. Crews. 1988. Male mating success in red-sided garter snakes: size is not important. Animal Behavior 36(6): 1839-1841.

Justy, G.M. and F.F. Mallory. 1985. Thermoregulatory behavior in the northern water snake, Nerodia sipedon sipedon, and the eastern garter snake, Thamnophis sirtalis sirtalis. Canadian Field Naturalist 99(2): 246-249.

Kauffman, J.B. and W.C. Krueger. 1984. Livestock impacts on riparian ecosystems and streamside management implications: a review. Journal of Range Management 37(5):430436.

Kephart, D.G. 1981. Populaton ecology and population structure of Thamnophis elegans and Thamnophis sirtalis. Ph.D. Dissertation. Univeristy of Chicago.

King, R.B. 1988. Polymorphic populations of the garter snake Thamnophis sirtalis near Lake Erie (Canada, USA). Herpetologica 44(4): 451-458.

King, R.B. 1989. Body size variation among island and mainland snake populations. Herpetologica 45(1): 84-88.

King, R.B. 2003. Mendelian Inheritance of Melanism in the Garter Snake Thamnophis sirtalis. Herpetologica 59(4): 484-489.

Kissner, K.J., G. Blouin-Demers, and P.J. Weatherhead. 2000. Sexual dimorphism in malodorousness of musk secretions of snakes. Journal of Herpetology 34(3): 491-493.

Knight, G.E. and G. Burnstock. 1995. Responses of the aorta of the garter snake (Thamnophis sirtalis parietalis) to purines. British Journal of Pharmacology 114(1): 41-48.

Knight, G.E. and G. Burnstock. 1993. Acetylcholine induces relaxation via the release of nitric oxide from endothelial cells of the garter snake (Thamnophis sirtalis parietalis) aorta. Comparative Biochemistry and Physiology C 106(2): 383-388.

*Koch, E.D. and C.R. Peterson. 1989. A preliminary survey of the distribution of amphibians and reptiles in Yellowstone National Park. pp. 47-49. In: T.W. Clark, A.H. Harvey, R.D. Dorn, D.C. Genter, and C. Groves (eds). Rare, sensitive and threatened species of the Greater Yellowstone Ecosystem. Northern Rockies Conservation Cooperative , Montana Natural Heritage Program, The Nature Conservancy, and Mountain West Environmental Services. $153 \mathrm{p}$.

*Koch, E.D., and C.R. Peterson. 1995. Amphibians and reptiles of Yellowstone and Grand Teton National Parks. Salt Lake City: University of Utah Press.

*Koch, E.D., G. Williams, C.R. Peterson and P.S. Corn. 1996. Conference on declining and sensitive amphibians in the Northern Rockies and the Pacific Northwest: a summary paper. Idaho Herpetological Society Technical Bulletin and U.S. Fish and Wildlife Service Report, Boise, ID. $34 \mathrm{p}$.

Konvalinka, R.R. and S.E. Trauth. 2003. Thamnophis sirtalis sirtalis (Eastern Garter Snake). Predation. Herpetological Review 34(4):378. 
Krause, M. A. and G.M. Burghardt. 2001. Neonatal plasticity and adult foraging behavior in garter snakes (Thamnophis sirtalis) from two nearby but ecologically dissimilar habitats. Herpetological Monographs (15): 100-123.

Krause, M. A., G.M. Burghardt, and J.C. Gillingham. 2003. Body size plasticity and local variation of relative head and body size sexual dimorphism in garter snakes (Thamnophis sirtalis). Journal of Zoology 261(4): 399-407.

Krause, M.A. 2000. Plasticity of morphology, chemoreception, and predatory behavior in garter snakes (Thamnophis sirtalis). Ph.D. Dissertation, University of Tennessee, Knoxville.

Krohmer, R.W. and D. Crews. 1989. Control of length of the courtship season in the red-sided garter snake, Thamnophis sirtalis parietalis: The role of temperature. Canadian Journal of Zoology 67(4): 987-993.

Krohmer, R.W., M. Grassman, and D. Crews. 1987. Annual reproductive cycle in the male redsided garter snake, Thamnophis sirtalis parietalis: Field and laboratory studies. General and Comparative Endocrinology 68(1): 64-75.

Kubie, J.L. and M. Halpern. 1979. Chemical senses involved in garter snake prey trailing. Journal of Comparative Physiological Psychology 93: 648-667.

Kwaga, J. and J.O. Iversen. 1993. Isolation of Yersinia enterocolitica (0:5,27 biotype 2) from a common garter snake. Journal of Wildlife Diseases 29(1): 127-129.

Lachner, E.A. 1942. An aggregation of snakes and salamanders during hibernation. Copeia 1942:262-263.

Lagler, K.F. and J.G. Salyer. 1945. Influence of availability on the feeding habits of the common garter snake. Copeia 1945(3): 159-162.

Langkilde, T., R. Shine, and R.T. Mason. 2004. Predatory attacks to the head vs. body modify behavioral repsonses of garter snakes. Ethology 110(12):937-947.

Larsen, K.W. and P.T. Gregory. 1989. Population size and survivorship of the common garter snake, Thamnophis sirtalis, near the northern limit of its distribution. Holartic Ecology 12(2): 81-86.

Larsen, K.W., P.T. Gregory, and R. Antoniak. 1993. Reproductive ecology of the common garter snake Thamnophis sirtalis at the northern limit of its range. American Midland Naturalist 129:336-345.

Larsen, K.W. 1986. Ecology of the common garter snake, Thamnophis sirtalis, at the northern limit of its range. Unpubl. M.S. Thesis, University of Victoria, Victoria, B.C.

Larsen, K.W. 1987. Movements and behavior of migratory garter snakes, Thamnophis sirtalis. Canadian Journal of Zoology 65(9): 2241-2247.

Larsen, K.W. and P.T. Gregory. 1989. Population size and survivorship of the common garter snake, Thamnophis sirtalis, near the northern limit of its distribution. Holartic Ecology 12(2): 81-86.

Larsen, K.W., P.T. Gregory, and R. Antoniak. 1993. Reproductive ecology of the common garter snake Thamnophis sirtalis at the Northern limit of its range. American Midland Naturalist 129(2): 336-345.

Lawson, P.A. 1989. Orientation abilities and mechanisms in a northern migratory population of the common garter snake (Thamnophis sirtalis). Musk-Ox 37: 110-115.

Lawson, P.A. 1994. Orientation abilities and mechanisms in nonmigratory populations of garter snakes (Thamnophis sirtalis and T. ordinoides). Copeia 1994(2): 263-274.

Lawson, R. and R.B. King. 1996. Gene flow and melanism in Lake Erie garter snake populations. Biological Journal of the Linnean Society 59(1): 1-19. 
LeMaster, M.P and R.T. Mason. 2003. Pheromonally Mediated Sexual Isolation Among Denning Populations of Red-Sided Garter Snakes, Thamnophis sirtalis parietalis. Journal of Chemical Ecology 29(4): 1027-1043.

LeMaster, M.P. and R.T. Mason. 2001. Evidence for a female sex pheromone mediating male trailing behavior in the redsided garter snake, Thamnophis sirtalis parietalis. Chemoecology 11(4): 149-152.

LeMaster, M.P., I.T. Moore, and R.T. Mason. 2001. Conspecific trailing behaviour of red-sided garter snakes, Thamnophis sirtalis parietalis, in the natural environment. Animal Behaviour 61: 827-833.

Leonard, W.P. and N.P. Leonard. 1996. Serpentes: Thamnophis sirtalis pickeringii (Puget Sound garter snake). Foraging and arboreality. Herpetological Review 27(2): 84.

Logier, E.B.S. 1929. Melanism in the garter snake, Thamnophis sirtalis, in Ontario. Copeia 1929: 83-84.

Low, J. 2005. Synthetic netting nabs serpents. Journal of Kansas Herpetology 13:9.

Lutterdchmidt, D.I., M.P. LeMaster, and R.T. Mason. 2005. Minimal over-wintering temperaturess of red-sided garter snakes: A possible cue for emergence? Abstract. Northwestern Naturalist 86:106.

Lyman-Henley, L.P. and G.M. Burghardt. 1995. Diet, litter, and sex effects on chemical prey preference, growth, and site selection in two sympatric species of Thamnophis. Herpetological Monographs 0(9): 140-160.

Lysenko, S. and J.E. Gillis. 1980. The effect of ingestive status on the thermoregulatory behavior of Thamnophis sirtalis sirtalis and Thamnophis sirtalis parietalis. Journal of Herpetology 14: 155-159.

Lystrup, H.T. 1952. A garter snake captures a young bird. Yellowstone Nature Notes 26(1): 10-11.

Macartney, J.M. and P.T. Gregory. 1981. Differential susceptibility of sympatric garter snake species to amphibian secretions. American Midland Naturalist 106: 271-281.

Macartney, J.M., K.W. Larsen, and P.T. Gregory. 1989. Body temperatures and movements of hibernating snakes (Crotalus and Thamnophis) and thermal gradients of natural hibernacula. Canadian Journal of Zoology 67(1): 108-114.

Maclay, B.B.K., M.A. Hunter, and M.P. Hayes. 2004. Thamnophis sirtalis coninnus (Redspotted garter Snake). Predation. Herpetological Review 35(1):74.

MacMillan, S. 1995. Restoration of an extirpated red-sided garter snake Thamnophis sirtalis parietalis population in the interlake region of Manitoba, Canada. Biological Conservation 72(1): 13-16.

Manier, M.K. 2005. Ecological correlates of population genetic structure for two coexisting garter snake species. Abstract. Northwestern Naturalist 86:106.

*Manville, R.H. 1957. Amphibians and reptiles of Glacier National Park, Montana. Copeia 1957: 308-309.

*Marnell, L.F. 1997. Herpetofauna of Glacier National Park. Northwestern Naturalist 78: 1733.

Martof, B.S. 1954. Variation in a large litter of garter snakes, Thamnophis sirtalis sirtalis. Copeia 1954(2): 100-105.

Mason, R.T. 1993. Chemical ecology of the red-sided garter snake, Thamnophis sirtalis parietalis. Brain Behavior and Evolution 41: 261-268. 
Mason, R.T. and D. Crews. 1985. Female mimicry in garter snakes. Nature (London) 316: 5960.

Mason, R.T. and D. Crews. 1986. Pheromone mimicry in garter snakes, pp. 279-283. In: Duvall, D., D. Muller-Schwarze, and R.M. Silverstein (eds). Chemical Signals in Vertebrates, Vol. 4. Plenum Publ. Co., New York.

Matity, J.G., D.P. Chivers, and R.J.F. Smith. 1994. Population and sex differences in antipredator responses of breeding fathead minnows (Pimephales promelas) to chemical stimuli from garter snakes (Thamnophis radix and T. sirtalis). Journal of Chemical Ecology 20(8): 2111-2121.

Matthews, K.R., R.A. Knapp, and K.L. Pope. 2002. Garter snake distributions in high-elevation aquatic ecosystems: is there a link with declining amphibian populations and nonnative trout introductions? Journal of Herpetology 36: 16-22.

*Matthews, W.L. 1980. Wibaux-Beach comparison study: Sydney, Glendive and Plevna Study Areas. Bureau of Land Management, Miles City, MT. 50 p.

Mattlin, R.H. 1948. A large litter of Thamnophis s. sirtalis. Herpetologica 4: 149.

* Maxell, B.A. 2002. Amphibian and aquatic reptile inventories in watersheds in the South and Middle Forks of the Flathead River drainage that contain lakes being considered for application of piscicides and subsequent stocking of west slope cutthroat trout. Report to the Region 1 Office of the U.S. Forest Service and the Montana Department of Fish, Wildlife, and Parks. Missoula, MT: Montana Cooperative Wildlife Research Unit and Wildlife Biology Program, University of Montana. 62 p.

* Maxell, B.A. 2004a. Amphibian and aquatic reptile inventories conducted on and around the Bitterroot National Forest 2000-2003. Report to Region 1 Office of the U.S. Forest Service, Bitterroot National Forest, Montana Department of Fish, Wildlife, and Parks, and Biological Resources Division of the U.S. Geological Survey. Missoula, MT: Montana Cooperative Wildlife Research Unit and Wildlife Biology Program, University of Montana. 128 p.

* Maxell, B.A. 2004b. Amphibian and aquatic reptile inventories conducted on and around the Thompson River 2003-2004. Report to Region 1 Office of the U.S. Forest Service and Plum Creek Timber Company. Missoula, MT: Montana Cooperative Wildlife Research Unit and Wildlife Biology Program. 83 p.

*Maxell, B.A. 2004c. Preliminary report on amphibian and aquatic reptile inventories conducted in the West Boulder River area during summer 2003. Report to Region 1 Office of the U.S. Forest Service, and the Montana Department of Fish, Wildlife, and Parks. Missoula, MT: Montana Cooperative Wildlife Research Unit and Wildlife Biology Program, University of Montana. $27 \mathrm{p}$.

*Maxell, B.A. 2004d. Preliminary report on amphibian and aquatic reptile inventories conducted on and around the Ashland District of the Custer National Forest in 2002 and 2004. Report to Ashland District of Custer Forest, Region 1 Office of the U.S. Forest Service, and Montana Department of Fish, Wildlife, and Parks. Missoula, MT: Montana Cooperative Wildlife Research Unit and Wildlife Biology Program, University of Montana. 93 p.

*Maxell, B.A. 2004e. Report on amphibian and aquatic reptile inventories conducted on and around the Beaverhead-Deerlodge National Forest 2001-2003. Report to Region 1 Office of the U.S. Forest Service, Beaverhead-Deerlodge National Forest, Montana Department of Fish, Wildlife, and Parks, Montana State Office of the Bureau of Land Management, and 
Montana Department of Environmental Quality. Missoula, MT: Montana Cooperative Wildlife Research Unit and Wildlife Biology Program, University of Montana. 260 p.

*Maxell, B.A. 2005a. Amphibian and aquatic reptile inventories conducted on and around lands administered by the Missoula Field Office of the Bureau of Land Management. Report to Missoula Field Office of the Bureau of Land Management. Montana Natural Heritage Program, Helena, MT and Montana Cooperative Wildlife Research Unit and Wildlife Biology Program, University of Montana, Missoula, MT. 53 p.

*Maxell, B.A. 2006. Evaluation of Montana’s lentic breeding amphibian survey methodology and variables correlated with species occupancy. Report to Montana Department of Environmental Quality. Montana Natural Heritage Program, Helena, MT and Montana Cooperative Wildlife Research Unit and Wildlife Biology Program, University of Montana, Missoula, MT. 49 p.

*Maxell, B.A. 2009. State-wide assessment of status, predicted distribution, and landscapelevel habitat suitability of amphibians and reptiles in Montana. Ph.D. Dissertation. Missoula, MT: Wildlife Biology Program, University of Montana. 294 p.

*Maxell, B.A. and D.G. Hokit. 1999. Amphibians and reptiles. Pp. 2.1-2.30. In: G. Joslin and H. Youmans (committee chairs). Effects of recreation on Rocky Mountain wildlife: a compendium of the current state of understanding in Montana. Helena, MT: Committee on Effects of Recreation on Wildlife, Montana Chapter of the Wildlife Society. 307 p.

*Maxell, B.A., J.K. Werner, P. Hendricks, and D. Flath. 2003. Herpetology in Montana: a history, status summary, checklists, dichotomous keys, accounts for native, potentially native, and exotic species, and indexed bibliography. Olympia, WA: Society for Northwestern Vertebrate Biology. Northwest Fauna 5: 1-138.

*McEneaney, T. and J. Jensen. 1974. The reptiles and amphibians of the Charles M. Russell National Wildlife Range - 1974. Charles M. Russell National Wildlife Refuge. Lewistown, MT. 3 p.

Mendonca, M.T. and D. Crews. 1989. Effect of fall mating on ovarian development in the redsided garter snake. American Journal of Physiology 257(6): 1548-1550.

Mendonca, M.T. and D. Crews. 1990. Mating-induced ovarian recrudescence in the red-sided garter snake. Journal of Comparative Physiology A Sensory Neural and Behavioral Physiology 166(5): 629-632.

Mendonca, M.T. and D. Crews. 1996. Effects of ovariectomy and estrogen replacement on attractivity and receptivity in the red-sided garter snake (Thamnophis sirtalis parietalis). Journal of Comparative Physiology A 178(3): 373-381.

Mendonca, M.T., D. Daniels, C. Faro, and D. Crews. 2003. Differential Effects of Courtship and Mating on Receptivity and Brain Metabolism in Female Red-Sided Garter Snakes (Thamnophis sirtalis parietalis). Behavioral Neuroscience 117(1): 144-149.

Mendonca, M.T., A.J. Tousignant, and D. Crews. 1995. Seasonal changes and annual variability in daily plasma melatonin in the red-sided garter snake (Thamnophis sirtalis parietalis). General and Comparative Endocrinology 100(2): 226-237.

Mendonca, M.T., A.J. Tousignant, and D. Crews. 1996a. Courting and noncourting male redsided garter snakes, Thamnophis sirtalis parietalis: Plasma melatonin levels and the effects of pinealectomy. Hormones and Behavior 30(2): 176-185.

Mendonca, M.T., A.J. Tousignant, and D. Crews. 1996b. Pinealectomy, melatonin, and courtship behavior in male red-sided garter snakes (Thamnophis sirtalis parietalis). Journal of Experimental Zoology 274(1): 64-74. 
*Miller, J.D. 1975. Interspecific food relationships of anurans in northwestern Montana and fluoride accumulation in amphibians and reptiles in northwestern Montana. M.S. Thesis, University of Montana, Missoula, MT. 105 p.

Moore, I.T., J.P. Lerner, and R.T. Mason. 2000. Relationships between annual cycles of testosterone, corticosterone, and body condition in male red-spotted garter snakes, Thamnophis sirtalis concinnus. Physiological and Biochemical Zoology 73(3): 307.

Moore, I.T., M.P. LeMaster, and R.T. Mason. 2000a. Behavioural and hormonal responses to capture stress in the male red-sided garter snake, Thamnophis sirtalis parietalis. Animal Behaviour 59(3): 529.

Moore, I.T., M.P. LeMaster, and R.T. Mason. 2000b. Relationships between Annual Cycles of Testosterone, Corticosterone, and Body Condition in Male Red-spotted Garter Snakes, Thamnophis sirtalis concinnus. Physiological and Biochemical Zoology 73(3): 307.

Motychak, J.E., E.D. Brodie, Jr., and E.D. Brodie III. 1999. Evolutionary response of predators to dangerous prey: preadaptation and the evolution of tetrodotoxin resistance in garter snakes. Evolution 53: 1528-1535.

*[MTNHP] Montana Natural Heritage Program. 2006. Montana Amphibian Inventory and Monitoring Program Database. Montana Natural Heritage Program, Helena, MT. Accessed April 14, 2006.

Munro, D.F. 1948. Mating behavior and seasonal cloacal discharge of a female Thamnophis sirtalis parietalis. Herpetologica 4: 185-188.

[NDTI] Northrop, Devine, and Tarbell Incorporated. 1994. Cabinet Gorge and Noxon Rapids hydroelectric developments 1993 wildlife study. Northrop, Devine, and Tarbell Incorporated, Portland, ME. 197 p.

Nelson, K.J. and P.T. Gregory. 2000. Activity patterns of garter snakes, Thamnophis sirtalis, in relation to weather conditions at a fish hatchery on Vancouver Island, British Columbia. Journal of Herpetology 34(1): 32-40.

Noble, G.K. 1937. Sense organs involved in courtship of Storeria, Thamnophis and other snakes. Bulletin of the American Museum of National History 73: 673-725.

O'Donnell, R.P., N.B. Ford, R. Shine, and R.T. Mason. 2004. Male red-sided garter snakes, Thamnophis sirtalis parietalis, determine female mating status form pheromone trails. Animal Behaviour 68(4):677-683.

*[OEAR] Olson Elliot and Associates Research. 1985. 1983-1984 Wildlife monitoring report for the CX Ranch project. Olson Elliot and Associates Research. Helena, MT.

Olson, D.J. and R.E. Warner. 2001. Grassland snakes diet. Herpetological Review 32(3): 186187.

Olson, D.J. and R.E. Warner. 2003. Comparison of artificial cover and line transects for the capture of grassland snakes. Herpetological Review 34(3):215-218.

*Perkins, C.B. 1949. A key to the snakes of the United States, 2nd Edition. Bulletitn of the Zoological Society of San Diego 16: 1-63.

Peterson, C.C., B.M. Walton, and A.F. Bennett. 1998. Intrapopulation variation in ecological energetics of the garter snake Thamnophis sirtalis, with analysis of the precision of doubly labeled water measurements. Physiological Zoology 71: 333-349.

Peterson, C.C., B.M. Walton, and A.F. Bennett. 1999. Metabolic costs of growth in free-living garter snakes and the energy budgets of ectotherms. Functional Ecology 13: 500-507.

Pfrender, M., R.T. Mason, J.T. Wilmslow, and R. Shine. 2001. Thamnophis sirtalis parietalis (red-sided gartersnake) male-male copulation. Herpetological Review 32(1): 52. 
Placyk, J.S. and G.M. Burghardt Jr. 2005. Geographic variation in the frequency of scarring and tail stubs in eastern gartersnakes (Thamnophis s. sirtalis) from Michigan, USA. AmphibiaReptilia 26(3):353-358.

Poly, W.J. and A.K. Wilson. 2003. Thamnophis sirtalis sirtalis (Eastern Garter Snake). Predation. Herpetological Review 34(4):378.

Porter, W.P. and C.R. Tracy. 1974. Modeling the effects of temperature changes on the ecology of the garter snake and leopard frog. Pages 594-609. In: Gibbons, J.W. and R.R. Sharitz (eds.). Thermal ecology symposium: U.S. Atomic Energy Commission Conference 730505. Government Printing Office, Washington, D.C.

Pough, F.H. 1977. Ontogenetic change in blood oxygen capacity and maximum activity in garter snakes (Thamnophis sirtalis). Journal of Comparative Physiology B116: 337-345.

*Powell, R., J.T. Collins, and E.D. Hooper, Jr. 1998. A key to amphibians and reptiles of the Continental United States and Canada. University Press of Kansas, Lawrence, KS. 131 p.

Rahn, H. 1940. Sperm viability in the uterus of the garter snake, Thamnophis. Copeia 1940: 109-115.

Rauch, J.C. 1978. Integumentary bloodvascular system in garter snakes (Thamnophis sirtalis parietalis and Thamnophis radix). Canadian Journal of Zoology 56(3): 469-476.

Rehmeier, R.L. and R.S. Matlack. 2004. Thamnophis sirtalis (common garter snake) Diet. Journal of Kansas Herpetology 11:15.

*Reichel, J.D. 1995a. Preliminary amphibian and reptile survey of the Lewis and Clark National Forest: 1994. Montana Natural Heritage Program, Helena, MT. 92 p.

*Reichel, J.D. 1995b. Preliminary amphibian and reptile survey of the Sioux District of the Custer National Forest: 1994. Montana Natural Heritage Program, Helena, MT. 75 p.

*Reichel, J.D. 1996a. Status of amphibians and reptiles in Eastern Montana [abstract]. Intermountain Journal of Sciences 2(2):57.

*Reichel, J.D. 1996b. Preliminary amphibian and reptile survey of the Helena National Forest: 1995. Montana Natural Heritage Program, Helena, MT. 87 p.

*Reichel, J.D. 1997. Amphibian, reptile and northern bog lemming survey on the Rocky Mountain Front: 1996. Montana Natural Heritage Program, Helena, MT. 81 p.

Reichenbach, N.G. and G.H. Dalrymple. 1986. Energy use, life histories, and the evaluation of potential competition in two species of garter snake. Journal of Herpetology 20(2): 133-153.

*Reinhard, E.G. 1930. Another snake note. Yellowstone Nature Notes 7(7): 39.

Ridenhour, B.J., E.D. Brodie, Jr., and E.D. Brodie III. 1999. Effects of repeated injection of tetrodotoxin on growth and resistance to tetrodotoxin in the garter snake Thamnophis sirtalis. Copeia 1999: 531-535.

Rivera, G., A.H. Savitzky, and J.A. Hinkley. 2005. Mechanical properties of the integument of the common gartersnake, Thamnophis sirtalis (Serpentes: Colubridae). Journal of Experimental Biology 208(15):2913-2922.

*Rodgers, T.L., and W.L. Jellison. 1942. A collection of amphibians and reptiles from western Montana. Copeia 1942(1): 10-13.

*Roedel, M.D. and P. Hendricks. 1998a. Amphibian and reptile survey on the Bureau of Land Management Lewistown District: 1995-1998. Montana Natural Heritage Program, Helena, MT. 53 p.

*Roedel, M.D. and P. Hendricks. 1998b. Amphibian and reptile inventory on the Headwaters and Dillon Resource Areas in conjunction with Red Rocks Lakes National Wildlife Refuge: 1996-1998. Montana Natural Heritage Program, Helena, MT. 46 p. 
*Rossman, D.A., N.B. Ford, and R.A. Seigel. 1996. The garter snakes: evolution and ecology. University of Oklahoma Press, Norman, OK. 332 p.

Ruben, J.A. 1976b. Reduced nocturnal heat loss associated with ground litter burrowing by the California red-sided garter snake Thamnophis sirtalis infernalis. Herpetologica 32: 323-325.

Rudolph, D.C., S.J. Burdorf, R.N. Conner, and J.G. Dickson. 1998. The impact of roads on the timber rattlesnake (Crotalus horridus), in eastern Texas. Pp. 236-240. In: G.L. Evink, P. Garrett, D. Zeigler and J. Berry (eds.) Proceedings of the international conference on wildlife ecology and transportation. February 10-12, 1998. Fort Meyers, Florida.

*Ruthven, A.G. 1908. Variations and genetic relationships of the gartersnakes. Bulletin of the U.S. National Museum 61(7): 1-201.

Sattler, P., and S. Guttman. 1976. An electrophoretic analysis of Thamnophis sirtalis from western Ohio. Copeia 1976: 352-356.

Say, T. 1823. In: James, Stephen H. Long's Expedition of the Rocky Mountains. 1819-1820. Volume 1, p. 186.

Schaeffel, F. and A. De Queiroz. 1990. Alternative mechanisms of enhanced underwater vision in the garter snakes Thamnophis melanogaster and Thamnophis couchii. Copeia 1990(1): 50-58.

Schwartz, J.M., G.F. McCracken, and G.M. Burghardt. 1989. Multiple paternity in wild populations of the garter snake, Thamnophis sirtalis. Behavioral Ecology and Sociobiology 25(4): 269-274.

Scribner, S.J. and P.J. Weatherhead. 1995. Locomotion and antipredator behaviour in three species of semi-aquatic snakes. Canadian Journal of Zoology 73(2): 321-329.

Scudder-Davis, R.M. and G.M. Burghardt. 1987. Diet and growth in juveniles of the garter snakes Thamnophis sirtalis infernalis and Thamnophis radix radix. Growth 51(1): 74-85.

Seigel, R.A. 1996. Ecology and conservation of garter snakes: masters of plasticity, pp. 55-89. In: D.A. Rossman, N.B. Ford, and R.A. Seigel (eds). The Garter Snakes: Evolution and Ecology. Norman, OK: University of Oklahoma Press.

Seigel, R.A., and H.S. Fitch. 1985. Annual variation in reproduction in snakes in a fluctuating environment. Journal of Animal Ecology 54(2): 497-506.

Sexton, O.J. and J.E. Bramble. 1994. Post-hibernation behavior of a population of garter snakes (Thamnophis sirtalis). Amphibia-Reptilia 15(1): 9-20.

Shine, R., B. Phillips, H. Waye, M. LeMaster, and R.T. Mason. 2001. Benefits of female mimicry in snakes. Nature 414:267.

Shine, R., B. Phillips, H. Waye, M. LeMaster, and R.T. Mason. 2004. Species-isolating mechanisms in a mating system with male mate choice (garter snakes, Thamnophis spp.). Canadian Journal of Zoology 82(7):1091-1098.

Shine, R, M.J. Elphrick, P.S. Harlow, I.T. Moore, M.P. LeMaster, and R.T. Mason. 2001. Movements, mating, and dispersal of red-sided gartersnakes (Thamnophis sirtalis parietalis) from a communal den in Manitoba. Copeia 2001:82-91.

Shine, R., P. Harlow, and R.T. Mason. 2000. The transvestite serpent: why do male garter snakes court (some) other males. Animal Behaviour 59(2): 349.

Shine, R., P.S. Harlow, M.J. Elphick, M.M. Olsson, and R.T. Mason. 2000. Conflicts between courtship and thermoregulation: the thermal ecology of amorous male garter snakes (Thamnophis sirtalis parietalis, Colubridae). Physiological and Biochemical Zoology 73: 508-516. 
Shine, R., T. Langkilde, M. Wall, and R.T. Mason. 2005a. Alternative male mating tactics in garter snakes, Thamnophis sirtalis parietalis. Animal Behaviour 70(2):387-396.

Shine, R., T. Langkilde, M. Wall, and R.T. Mason. 2005b. The fitness correlates of scalation asymmetry in garter snakes Thamnophis sirtalis parietalis. Functional Ecology 19(2):306314.

Shine, R., M. Lemaster, M.Wall, T. Langkilde, and R. Mason. 2004. Why did the snake cross the road? Effects of roads on movement and location of mates by garter snakes (Thamnophis sirtalis parietalis). Ecology and Society 9(1): 9.

Shine, R. and R.T. Mason. 2001. Serpentine cross-dressers. Natural History 110(1): 56-61.

Shine, R. and R.T. Mason. 2005a. Do a male garter snake's energy stores limit his reproductive effort? Canadian Journal of Zoology 83(10):1265-1270.

Shine, R. and R.T. Mason. 2005b. Does large body size in males evolve to facilitate forcible insemination? A study on garter snakes. Evolution 59(11):2426-2432.

Shine, R., R.P. O'Donnell, T. Langkilde, M.D. Wall, and R.T. Mason. 2005. Snakes in search of sex: the relation between mate-locating ability and mating success in male garter snakes. Animal Behaviour 69(6):1251-1258.

Shine, R., M.M. Olsson, and R.T. Mason. 2000a. Are snakes right-handed? Asymmetry in hemipenis size and usage in gartersnakes (Thamnophis sirtalis). Behavioral ecology 11(4): 411.

Shine, R., M.M. Olsson, M.P. LeMaster, I.T. Moore, and R.T. Mason. 2000a. Are snakes right handed? Asymetry in hemipenis size and usage in garter snakes (Thamnophis sirtalis). Behavioral Ecology 11: 411-415.

Shine, R., M.M. Olsson, M.P. LeMaster, I.T. Moore, and R.T. Mason. 2000b. Body size enhances mating success in male garter snakes. Animal Behaviour Forum 59: F4-F11.

Shine, R., M.M. Olsson, M.P. Lemaster, I.T. Moore, and R.T. Mason. 2000c. Effects of sex, body size, temperature, and location on the antipredator tactics of free-ranging gartersnakes (Thamnophis sirtalis, Colubridae). Behavioral Ecology 11: 239-245.

Shine, R., M.M. Olsson, and R.T. Mason. 2000b. Chastity belts in garter snakes: the functional significance of mating plugs. Biological Journal of the Linnean Society 70: 377-390.

Shine, R., M.M. Olsson, and R.T. Mason. 2000c. Conflicts between Courtship and Thermoregulation: The Thermal Ecology of Amorous Male Garter Snakes (Thamnophis sirtalis parietalis, Colubridae). Physiological and Biochemical Zoology 73(4): 508.

Shine, R., M. Wall, T. Langkilde, and R.T. Mason. 2005a. Battle of the sexes: forcibly inseminating male garter snakes target courtship to more vulnerable females. Animal Behaviour 70(5):1133-1140.

Shine, R., M. Wall, T. Langkilde, and R.T. Mason. 2005b. Do female garter snakes evade males to avoid harassment or to enhance mate quality? American Naturalist 165(6):660-668.

Shine, R., M. Wall, T. Langkilde, and R.T. Mason. 2005c. Scaling the heights: thermally driven arboreality in garter snakes. Journal of Thermal Biology 30(3):179-185.

Shively, S.H. and J.C. Mitchell. 1994. Thamnophis sirtalis sirtalis (eastern garter snake). Albinism. Herpetological Review 25(1): 30.

*Skinner, M.P. 1924. The Yellowstone Nature Book. A.C. McClurg Company, Chicago, IL. $221 \mathrm{p}$.

Smith, D.A., I.K. Barker, and O.B. Allen. 1988a. The effect of ambient temperature and type of wound on healing of cutaneous wounds in the common garter snake (Thamnophis sirtalis). Canadian Journal of Veterinary Research 52(1): 120-128. 
Smith, D.A., I.K. Barker, and O.B. Allen. 1988b. The effect of certain topical medications on healing of cutaneous wounds in the common garter snake (Thamnophis sirtalis). Canadian Journal of Veterinary Research 52(1): 129-133.

Smith, D.L. 1972. Movements of eastern garter snakes (Thamnophis sirtalis sirtalis) tagged with radioactive cobalt. Unpubl. Ed.D. Thesis, Ball State University, Muncie, Indiana.

Smith, H. 1942. The synonomy of the garter snakes (Thamnophis), with notes on Mexican and Central American species. Zoologica 27: 97-123.

Smith, M.T. and R.T. Mason. 1997. Gonadotropin antagonist modulates courtship behavior in male red-sided garter snakes, Thamnophis sirtalis parietalis. Physiology \& Behavior 61(1): 137-143.

Smith, M.T., F.L. Moore, and R.T. Mason. 1997. Neuroanatomical distribution of chicken-I gonadotropin-releasing hormone (cGnRH-I) in the brain of the male red-sided garter snake. Brain Behavior and Evolution 49(3): 137-148.

Smith, P.W. 1956. The geographical distribution and constancy of the semifasciata pattern in the eastern garter snake. Herpetologica 12: 81-84.

Sode, F. 1991. Oxygen binding characteristics of whole-blood and hemoglobin from the snake Thamnophis sirtalis. Comparative Biochemistry and Physiology B 100(4): 697-704.

Sperry, W.I. 1903. Variation in the common garter snake (Thamnophis sirtalis). 5th Report of the Michigan Academy of Science 175-179.

*St. John, A. 2002. Reptiles of the Northwest: California to Alaska; Rockies to the Coast. Renton, WA: Lone Pine Publishing. 272 p.

Stafford, D.P., F.W. Plapp, Jr., and R.R. Fleet. 1976. Snakes as indicators of environmental contamination: relation of detoxifying enzymes and pesticide residues to species occurrence in three aqutic ecosystems. Archieves of Environmental Contamination and Toxicology 5: 15-27.

*Stebbins, R.C. 2003. A field guide to western reptiles and amphibians. 3rd edition. New York, NY: Houghton Mifflin Co. 533 p.

Stewart, G.R. 1965. Thermal ecology of the garter snakes Thamnophis sirtalis concinnus (Hallowell) and Thamnophis ordinoides (Baird and Girard). Herpetologica 21: 81-102.

Stewart, G.R. 1968. Some observations on the natural history of two Oregon garter snakes. Journal of Herpetology 2: 71-86.

Stewart, G.R. 1972. An unusual record of sperm storage in a female garter snake ( genus Thamnophis). Herpetologica 28: 346-347.

Szaro, R.C., S.C. Belfit, J.K. Aitkin, and J.N. Rinne. 1985. Impact of grazing on a riparian garter snake. U.S. Forest Service General Technical Report RM 120: 359-363.

Takats, L. 2002. Red-sided garter snake (Thamnophis sirtalis parietalis) relocation and education project. Final Report. Alberta Species at Risk Report 30:1-17.

Tanner, V.M. 1949. Notes on the number, length, and weight of young garter snakes. Great Basin Naturalist 9(3-4):51-54.

Tanner, W.W. 1988b. Status of Thamnophis sirtalis in Chihuahua, Mexico (Reptilia: Colubridae). Great Basin Naturalist 48(4): 499-507.

Taylor, B.M. and P.M.C. Davies. 1981. Changes in the weight dependence of metabolism during the sloughing cycle of the snake Thamnophis sirtalis parietalis. Comparative Physiology 69: 113-119.

Teather, K.L. 1991. The relative importance of visual and chemical cues for foraging in new born blue-striped garter snakes (Thamnophis sirtalis similis). Behaviour 117(3-4): 255-261. 
ter Borg, J.P. 2005. The common garter snake (Thamnophis sirtalis), a simple manual. Lacerta 63(5):208-218.

*Test, F.C. 1893. Annotated list of reptiles and batrachians collected. In B.W. Evermann. A reconnaisance of the streams and lakes of western Montana and northwestern Wyoming. Bulletin of United States Fish Commission 11(1891): 57-59.

*Thompson, A. 2004. Population characteristics, diet, and body condition of terrestrial (Thamnophis elegans) and common (Thamnophis sirtalis) gartersnakes in two high elevation watersheds in western Montana. Undergraduate Thesis. Missoula, MT: Wildlife Biology Program, University of Montana. 35 p.

*Timken, R. No Date. Amphibians and reptiles of the Beaverhead National Forest. Western Montana College, Dillon, MT. 16 p.

Tinkle, D.W. 1957. Ecology, maturation, and reproduction of Thamnophis sirtalis proximus. Ecology 38: 69-77.

*Todd, F. 1965. Scale variation among garter snakes with particular emphasis on the upper and lower labials. Unpublished research project for Dr. R.B. Brunson. 27 pp.

Tucker, J.K., D.W. Soergel, and J.B. Hatcher. 1995. Flood-associated activities of some reptiles and amphibians at Carlyle Lake, Fayette County, Illinois. Transactions of the Illinois State Academy of Science 88(1-2): 73-81.

*Turner, F.B. 1951. A checklist of the reptiles and amphibians of Yellowstone National Park with incidental notes. Yellowstone Nature Notes 25(3): 25-29.

*Turner, F.B. 1952b. Duel in the sun. Yellowstone Nature Notes 26(5): 59-60.

*Turner, F.B. 1955. Reptiles and amphibians of Yellowstone National Park. Yellowstone Interpretive Series No. 5. Yellowstone Library and Museum Association. Yellowstone National Park, WY. 40 p.

Van Denburgh, J. and J.R. Slevin. 1918. The garter-snakes of Western North America. Proceedings of the California Academy of Sciences, Series 8(6): 181-270.

Velhagen, W.A. and A.H. Savitzky. 1998. Evolution of embryonic growth in thamnophiine snakes. Copeia 1998: 549-558.

Vincent, T.K. 1971. Resistance to cold stress in the red-sided garter snake Thamnophis sirtalis parietalis. M.S. Thesis, University of Manitoba, Winnipeg, Canada.

Vincent, T.K. 1976. Cold resistance in the garter snake Thamnophis sirtalis parietalis. Ph.D. Thesis, University of Regina, Regina, Sask.

Vincent, T.K. and D.M. Secoy. 1978. The effects of annual variation in temperature on the cold resistance in a northern population of the red-sided garter snake, Thamnophis sirtalis parietalis (Reptilia, Serpentes, colubridae). Journal of Herpetology 12: 291-294.

*Vitt, L.J., J.P. Caldwell, and D.B. Shepard. 2005. Inventory of amphibians and reptiles in the Billings Field Office Region, Montana. Sam Noble Oklahoma Museum of Natural History and Department of Zoology, University of Oklahoma, Norman, OK. 33 p.

*[VTNWI] VTN Wyoming Incorporated. No Date. Second year's analysis of terrestrial wildlife on proposed mine access and railroad routes in southern Montana and northern Wyoming, March 1979 - February 1980. VTN Wyoming Incorporated. Sheridan, WY. 62 p.

*Waage, B.C. 1998. Western Energy Company Rosebud Mine 1997 annual wildlife monitoring report December 1, 1996 to November 30, 1997 survey period. Western Energy Company, Colstrip, MT.

Wang, D. and C.M. Halpern. 1992. Immunological analysis of chemoattractive proteins from earthworm to garter snakes. Comparative Biochemistry and Physiology B 101(4): 601-610. 
Wallace, G.J. 1938. A garter snake with a brood of 73 young. Copeia 1938: 205.

Watkins, T.B. 1996. Predator-mediated selection on burst swimming performance in tadpoles of the Pacific tree frog, Pseudacris regilla. Physiological Zoology 69(1): 154-167.

Waye, H.L., D.I. Lutterschmidt, and R.T. Mason. 2002. Metabolic costs of hibernation and mating in Thamnophis sirtalis parietalis. Northwestern Naturalist 83(2):88.

Waye, H.L. and P.T. Gregory. 1998. Determining the age of garter snakes (Thamnophis spp.) by means of skeletochronology. Canadian Journal of Zoology 76: 288-294.

Weil, M.R. 1895. Comparison of plasma and testicular testosterone levels during the active season in the common garter snake, Thamnophis sirtalis. Comparative Biochemistry and Physiology A 81(3): 585-588.

*Weisel, G.F. 1952. Animal names, anatomical terms, and some ethnozoology of the Flathead Indians. Journal of the Washington Academy of Sciences 42(11): 345-355.

*Werner, J.K., B.A. Maxell, P. Hendricks, and D. Flath. 2004. Amphibians and reptiles of Montana. Missoula, MT: Mountain Press Publishing Company. 262p.

*Werner, J.K. and J.D. Reichel. 1994. Amphibian and reptile survey of the Kootenai National Forest: 1994. Montana Natural Heritage Program, Helena, MT. 104 p.

*Werner, J.K. and J.D. Reichel. 1996. Amphibian and reptile monitoring/survey of the Kootenai National Forest: 1995. Montana Natural Heritage Program, Helena, MT. 115 p.

*Werner, J.K. and T. Plummer. 1994. Amphibian and reptile survey of the Flathead Indian Reservation 1993-1994. Salish Kootenai College, Pablo, MT. 55 p.

*Werner, J.K. and T. Plummer. 1995. Amphibian monitoring program on the Flathead Indian Reservation 1995. Salish Kootenai College, Pablo, MT. 46 p.

*Werner, J.K., T. Plummer, and J. Weaselhead. 1998. Amphibians and reptiles of the Flathead Indian Reservation. Intermountain Journal of Sciences 4(1-2): 33-49.

*[WESTECH] Western Technology and Engineering Incorporated. 1991. Update on the wildlife resources of the Little Rocky Mountains environmental study area. Western Technology and Engineering, Inc., Helena, MT.

White, M. and J.A. Kolb. 1974. A preliminary study of Thamnophis near Sagehen Creek, California. Copeia 1974(1): 126-136.

Whittier, J.M. 1992. Effects of sex steroid implants on reproductive tissues of female garter snakes (Thamnophis sirtalis). Journal of Morphology 214(1): 43-48.

Whittier, J.M. and C.S. O'connor. 1991. Prostaglandin F-2alpha, sexual behavior and ovarian estrogen synthesis in garter snakes (Thamnophis sirtalis parietalis). Comparative Biochemistry and Physiology A 100(4): 881-886.

Whittier, J.M. and D. Crews. 1986. Effects of prostaglandin F-2alpha on sexual behavior and ovarian function in female garter snakes (Thamnophis sirtalis parietalis). Endocrinology 119(2): 787-792.

Whittier, J.M. and D. Crew. 1989. Mating increases plasma levels of prostaglandin F-2alpha in female garter snakes. Prostaglandins 37(3): 359-366.

Whittier, J.M. and D. Crews. 1990. Body mass and reproduction in female red-sided garter snakes (Thamnophis sirtalis parietalis). Herpetologica 46(2): 219-226.

Whittier, J.M. and R.T. Mason. 1996. Plasma triglyceride and beta-hydroxybutyric acid levels in red-sided garter snakes (Thamnophis sirtalis parietalis) at emergence from hibernation. Experientia 52(2): 145-148. 
Whittier, J.M., R.T. Mason, and D. Crews. 1985. Mating in the red-sided garter snake, Thamnophis sirtalis parietalis: Differential effects on male and female sexual behavior. Behavioral Ecology and Sociobiology 16(3): 257-262.

Whittier, J.M., R.T. Mason, and D. Crews. 1987. Plasma steroid hormone levels of female redsided garter snakes, Thamnophis sirtalis parietalis: relationship to mating and gestation. General and Comparative Endocrinology 67: 33-43.

Whittier, J.M., R.T. Mason, D. Crews, and P. Licht. 1987. Role of light and temperature in the regulation of reproduction in the red-sided garter snake, Thamnophis sirtalis parietalis. Canadian Journal of Zoology 65(8): 2090-2096.

Wilde, W.S. 1938. The role of Jacobson's organ in the feeding reaction of the common garter snake, Thamnophis sirtalis sirtalis (Linn.). Journal of Experimental Zoology 77: 445-464.

Wilkinson, R.S., P.M. Nemeth, B.W.C. Rosser, and H.L. Sweeney. 1991. Metabolic capacity and myosin expression in single muscle fibers of the garter snake. Journal of Physiology (Cambridge) 440: 113-130.

Williams, B.L., E.D. Brodie, Jr., and E.D. Brodie III. 2002. Comparisons between toxic effects of tetrodotoxin administered orally and by intraperitoneal injection to the garter snake Thamnophis sirtalis. Journal of Herpetology 36: 112-115.

Williams, B.L., E.D. Brodie, Jr., and E.D. Brodie III. 2003. Coevolution of deadly toxins and predator resistance: self-assessment of resistance by garter snakes leads to behavioral rejections of toxic newt prey. Herpetologica 59(2):155-163.

Williams, B.L., E.D. Brodie, Jr., and E.D. Brodie III. 2004. A resistant predator and its toxic prey: persistence of newt toxin leads to poisonous (not venomous) snakes. Journal of Chemical Ecology 30:1901-1919.

*Wilson, A.G., Jr. and E.M. Simon. 1987. Status of the Coeur d'Alene salamander (Plethodon vandykei idahoensis) in Montana. Report to the Montana Natural Heritage Program, Helena, MT. 134 p.

*Wilson, A.G., Jr. and E.M. Wilson. 1996. Caudata: Plethodon idahoensis (Coeur d'Alene salamander). Snake predation. Herpetological Review 27(3): 138.

Wirsing, A.J., J.D. Roth, and D.L. Murray. 2005. Can prey use dietary cues to distinguish predators? A test involving three terrestrial amphibians. Herpetologica 61(2):104-110.

Wood, J.T. 1945. Variation in length of newly-born garter snakes. Copeia 1945: 118.

Wood, W.F., J.M. Parker, and P.J. Weldon. 1995. Volatile components in scent gland secretions of garter snakes (Thamnophis spp.). Journal of Chemical Ecology 21(2): 213-219.

Wootton, J.T. 1994. The nature and consequences of indirect effects in ecological communities. Annual Review of Ecological Systematics 25:443-446.

*Wright, A.H. and A.A. Wright. 1957. Handbook of snakes of the United States and Canada, 2 Volumes. Cornell University Press, Comstock Publishing Associates, Ithaca, NY. 1105 p.

Wurst, G.Z., A.K. Pearson, and P. Licht. 1989. Pituitary gland of the garter snake (Thamnophis): morphology and immunocytochemistry. Journal of Morphology 200(2): 131140.

*[WWPC] Washington Water Power Company. 1995. 1994 wildlife report Noxon Rapids and Cabinet Gorge Reservoirs. Washington Water Power Company. Spokane, WA.

*Yarrow, H.C. 1882. Check list of North American reptilia and batrachia, with catalogue of specimens in the U.S. National Museum. United States National Museum Bulletin 24. 249 p. 
*Yeager, D.C. 1929. Reptiles of Yellowstone Park with notes on the Amphibia. Yellowstone Nature Notes. Yellowstone National Park Library, Mammoth, WY. 12 p.

Young, B.A. 1988. The arthrology of the head of the red-sided garter snake, Thamnophis sirtalis parietalis. Netherlands Journal of Zoology 38(2-4): 166-206.

Young, B.A. 1989. Ontogenetic changes in the feeding system of the red-sided garter snake, Thamnophis sirtalis parietalis: I. Allometric analysis. Journal of Zoology 218(3): 365-382.

Zehr, D.R. 1962. Stages in the development of the common garter snake, Thamnophis sirtalis. Copeia 1962(2): 322-329.

*Zisook, R., K. Almond, and B. Sharpe. 1996. Amphibian survey of the Birch Creek drainage, Beaverhead County. Wildland Studies Project. San Francisco State University, San Francisco, CA. 9 p.

Zwart, P., G.M. Dorrestein, F.C. Stades, and B.H. Broer. 1979. Vasectomy in the garter snake (Thamnophis sirtalis radix). Journal of Zoological Animal Medicine 10(1): 17-21. 


\section{Prairie Rattlesnake (Crotalus viridis)}

Up-to-date distribution and status information can be found on the Montana Natural Heritage Program's TRACKER website at http://mtnhp.org

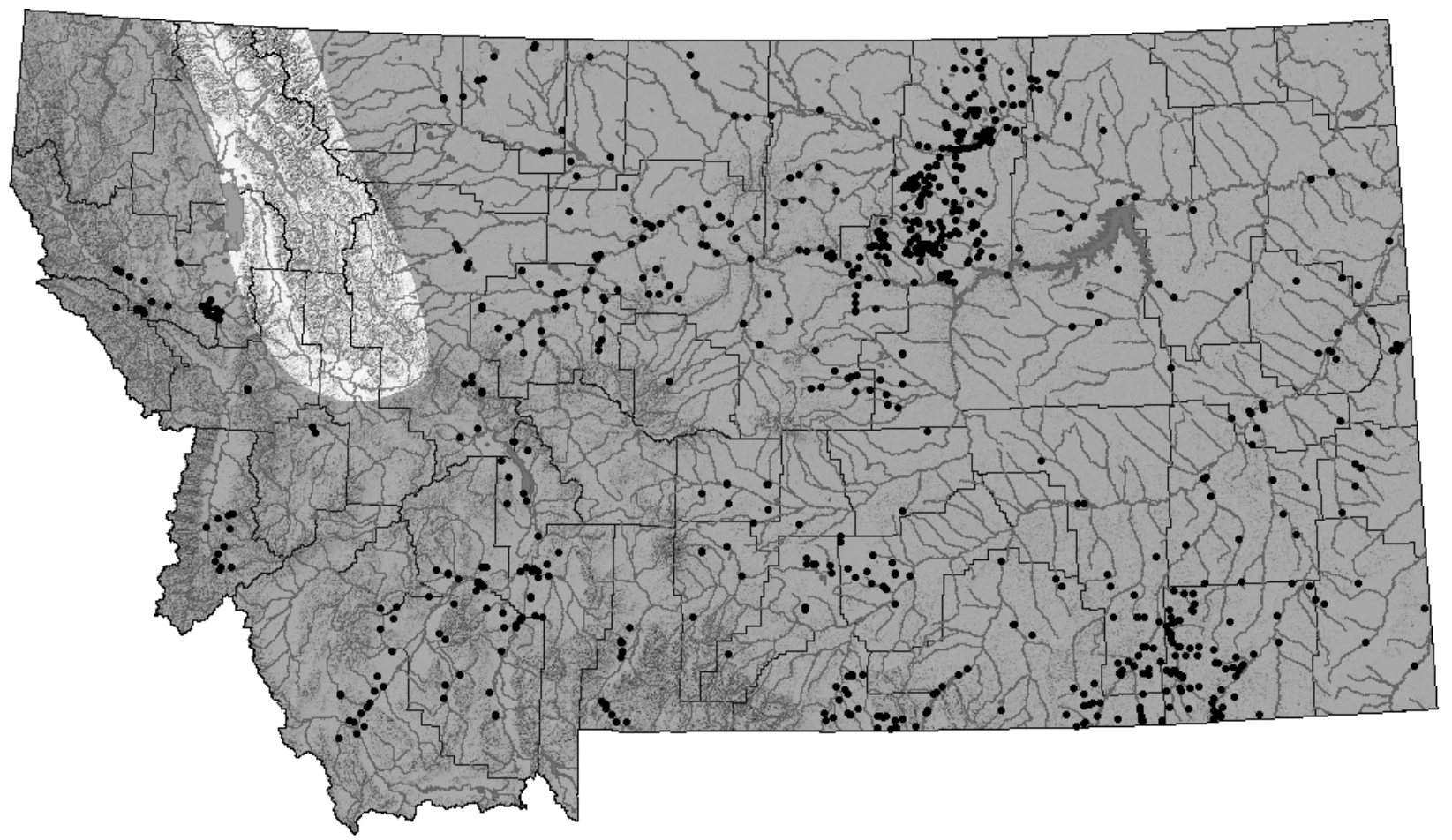

Distribution/Taxonomy

Prairie rattlesnakes range across western North America from Canada to Mexico. In Montana, the prairie rattlesnake (C. v. viridis), ranges throughout Montana and the Great Plains states south through Texas to northern Mexico (Stebbins 2003). Two subspecies, C. v. oreganus and C. v. lutosus, have been found near Montana's western border (Stebbins 2003), but have not been documented within the state. Prairie rattlesnakes have been documented in 44 counties in Montana.

Maximum Elevation

2,255 m (7,400 ft) in Park County (Tom Lemke, pers. com., MTNHP 2007).

\section{Identification}

\section{Young:}

Newborn coloration resembles adults with total length ranging 18-33 cm (7-13 in.) (Hammerson 1999, Werner et al. 2004). Average weight for newborns was $12 \mathrm{~g}$ in Saskatchewan (Gannon and Secoy 1985) and $17 \mathrm{~g}$ in British Columbia (Macartney and Gregory 1988).

Adults:

A key identifying feature of adult prairie rattlesnakes is the horny, lobed rattle at the tip of the tail. Newborn juveniles have no true rattle, only a silent nub referred to as a button. Prairie rattlesnakes have a triangular head and 35-55 brown/black blotches extending down the back on a tan or greenish background. There are heat-sensitive pits visible below each eye and eyes have vertical pupils. Most scales along the back are highly keeled (ridged) and there are 14-15 upper 
labial (lip) scales and 15-16 lower labial scales. Males are slightly larger than females with total length ranging 60-114 cm (approx. 2-4 ft) (Hammerson 1999, St. John 2002, Werner et al. 2004).

Similar species:

Juvenile racers (Coluber constrictor) and gophersnakes (Pituophis catenifer) also have blotched dorsal patterns but juvenile racers are much smaller and have smooth scales dorsally.

Gophersnakes may vibrate their tails when provoked, however, there is no morphological rattle present as in the rattlesnake.

Also, prairie rattlesnakes have vertical pupils while gophersnakes and racers do not.

Habitat use/Natural History

Prairie rattlesnakes occupy a broad range of habitats in Montana including grasslands, sagebrush, river bottoms, drier ponderosa pine forests, and rock outcroppings (Werner et al. 2004). Hammerson (1999) noted that rattlesnakes in Colorado only seemed to avoid permanently wet areas and high mountain regions. Diller and Wallace (1996) captured most rattlesnakes in rocky habitats, such as canyon rims and outcroppings even though rocky habitat comprised $<5 \%$ of their study area in Idaho. Diller and Wallace (1984) also noted that rattlesnakes captured in talus were typically near the top of the talus slope, where less large boulders accumulated. Rattlesnakes can be located under rocks and in brushy vegetation, woodpiles, and rodent burrows during the summer months (Watson and Russell 1997, Hammerson 1999). Largely diurnal during the summer, most activity occurs in the morning and late evening with individuals seeking some form of shelter at the hottest point of the day (Gannon and Secoy 1985, Diller and Wallace 1996). Prairie rattlesnakes breed in early to midsummer (Hammerson 1999), however, Macartney and Gregory (1988) noted that C. v. oreganus in British Columbia did not mate until late July/early August. Females will give birth to 4-21 live young in late summer/early September (Hammerson 1999). Diller and Wallace (1996) found clutch size averaged 8.3 and correlated positively with female body size for rattlesnakes in southwestern Idaho. Males reach sexual maturity at 2-3 years, whereas females typically do not breed until 4-6 years of age (Diller and Wallace 1984). Although there is great variation among studies, roughly $50 \%$ of females will reproduce annually (Aldridge 1979a). Pregnant females will reduce their foraging and food intake (Gannon and Secoy 1984, Macartney and Gregory 1988) and depend largely on fat reserves for successful reproduction (Diller and Wallace 1984). As a result, they are known to congregate at rookeries with other pregnant females during summer to facilitate thermoregulation and embryo development (Graves and Duvall 1987). Rookery sites have been found beneath large, flat rocks often over rodent burrows (Watson and Russell 1997). Pregnant females tend to use rookery sites relatively close to hibernacula (Gannon and Secoy 1985, Hammerson 1999) while non-pregnant females and male rattlesnakes can disperse quite far from hibernacula to summer range (King and Duvall 1990). Depending on food availability, summer range can be as near as $0.5 \mathrm{~km}(0.30 \mathrm{mi})$ or as far as $6 \mathrm{~km}(3.7 \mathrm{mi})$ from hibernacula (Hammerson 1999), although the average likely falls in the range of $1.5 \mathrm{~km}$ (0.93 mi) (Hirth et al. 1969). Dispersal from hibernacula usually occurs 3-4 weeks after emergence, is correlated with temperature and appears quite synchronous among individuals at a given site (Gannon and Secoy 1985, Diller and Wallace 1996). Prairie rattlesnakes return to hibernacula in late September/early October and will remain there until April or May of the following year (Parker and Brown 1974, Hammerson 1999). Hibernation is communal and can even occur with other species (Hirth 1966, Jacob and Painter 1980, Gannon and Secoy 1985). Rattlesnakes will 
overwinter in talus, rock outcroppings, rodent burrows, and even open cellars (Diller and Wallace 1984, Macartney et al. 1990, Hammerson 1999). Despite being able to undergo a shallow torpor (Jacob and Painter 1980) adult rattlesnakes can lose about 8\% and hatchlings 25\% of their body weight overwinter (Hirth 1966). In addition to weight loss, rattlesnakes can experience elevated mortality rates overwinter with up to one-third of adults perishing (Hirth 1966). However, Parker and Brown (1974) reported overwinter mortality less than $4 \%$ for adults and Hammerson (1999) reported that overwinter survival is quite high even for hatchlings which do not feed prior to hibernating. Charland (1989) estimated overwinter survival of rattlesnake neonates in British Columbia was 55\% and independent of initial weight prior to the onset of winter. Diet consists mainly of small rodents. Diller and Wallace (1996) found ground squirrels (Spermophilus sp.) and deer mice (Peromyscus maniculatus) comprised most of the diet for rattlesnakes in southwestern Idaho and Macartney (1989) found voles (Microtus sp.) were quite important for rattlesnakes in British Columbia. Prairie rattlesnakes are relatively sedentary predators who ambush their prey, injecting them with venom delivered through fangs (Hammerson 1999). Most prey will travel a short distance after being bitten (Hayes 1993) and the rattlesnake will use scent, odors from both venom and prey, to follow their trail and relocate prey (Lavin-Murcio et al. 1993). Because they are ambush predators, daily movements of prairie rattlesnakes may vary according to local prey abundance (Hammerson 1999). Estimates of total distance traveled in a season are variable and range from 2.7-3.5 km (1.7-2.2 mi) (King and Duvall 1990) to 0.65-0.87 km (0.40-0.54 mi) (Ashton 2003). Rattlesnakes are prey largely for raptors, but also badgers (Taxidea taxus) and coyotes (Canis latrans) (Hammerson 1999, Werner et al. 2004). Humans are the largest source of mortality for rattlesnakes (Hammerson 1999). Rattlesnakes have survived in captivity to nearly 30 years, however, maximum age in the wild is thought to be much younger (Hammerson 1999).

\section{$\underline{\text { Status and Conservation }}$}

Prairie rattlesnakes occur on both sides of the Continental Divide in Montana. Although most records are from the eastern portion of the state, rattlesnakes do inhabit drier sagebrush and ponderosa pine habitats in western Montana (Maxell et al. 2003). Highly urbanized areas and intensively farmed regions typically do not support high numbers of rattlesnakes (Hammerson 1999). Similar to other species of snakes, rattlesnakes can be impacted by disturbance to their hibernacula and rookery sites. Rattlesnakes show substantial site fidelity for overwintering sites year after year and even small disturbances to these sites may negatively impact the snake. Humans may disturb hibernacula incidentally or purposely for commercial collection or population control (Parker and Brown 1974, Hammerson 1999). Denning sites that are repeatedly disturbed will cease to support snakes (Parker and Brown 1974, Hammerson 1999). Although rattlesnakes may make limited movements within dens during winter (Marion and Sexton 1984), at body temperatures $<10^{\circ} \mathrm{C}\left(50^{\circ} \mathrm{F}\right)$ the rattlesnake's ability to move is impaired (Jacob and Painter 1980) and they may not respond to human disturbance as effectively at cooler temperatures (Prior and Weatherhead 1994). Roadways may also impact rattlesnakes near hibernacula. For example, more than 1,500 rattlesnakes were killed on a roadway in Colorado during migration to denning sites in the autumn (Hammerson 1999). In general, snake mortality on roadways has been documented widely with some drivers even purposely swerving to kill snakes (Langley et al. 1989, Krivda 1993, Rosen and Lowe 1994, Hammerson 1999). By far, humans are the foremost threat to the rattlesnake. Many rattlesnakes are killed out of fear, especially when found near homes. Sport hunting of rattlesnakes is also common and annual 
"rattlesnake roundups" result in thousands of individuals killed each year (Weir 1992, Arena et al. 1995). While rattlesnakes possess a highly effective rattle to deter intruders (Prior and Weatherhead 1994) their rattle may actually serve as a devise by which man detects and kills them (Parker and Brown 1974). Rattlesnakes are the only poisonous snake in Montana and are widely feared because of their venomous bite. Despite the snake's ability to avoid most confrontations through sounding its rattle, it will bite, particularly when provoked. Rattlesnake venom is highly toxic and can cause paralysis, cardiovascular and respiratory debilitations, and even death (Hammerson 1999). However, of 45 reported prairie rattlesnake bites in Montana from 1996-2004, none resulted in death (Timmerman 2004). Chemical contamination may adversely affect snakes (Werner et al. 2004), however changes in agricultural practices and federal laws can sometimes mitigate these impacts. For example, DDT levels in snakes have declined since the banning of the pesticide (Fleet and Plapp 1978). Snakes may harbor pollutants indicative of overall environmental health (Bauerle et al. 1975, Stafford et al. 1976, Anderson 1977), thereby adding to the value of their conservation and persistence. In addition, rattlesnakes consume deer mice and other rodents which may help control the spread of harmful viruses such as hantavirus (Degenhardt et al. 1996).

\section{Research and Management Suggestions}

1. The rapid growing human population in the valleys of western Montana, combined with human fears and the tendency to kill snakes, especially poisonous species, protection measures may be in order in this region.

2. If location is known, protect hibernation sites from disturbance or destruction.

3. Outreach programs that provide the public with scientifically accurate and lucid information about rattlesnakes should be encouraged and supported whenever possible.

4. Emphasis should be placed on rodent and disease control instead of elimination of snakes.

5. Roadways kill large numbers of snakes in some regions. Research that addresses these impacts at a population level and can examine the efficacy of various mitigation actions such as culvert crossings is needed.

Bibliography *indicates an article with information specific to Montana

Adame, B.L., J.G. Soto, D.J. Secraw, J.C. Perez, J.L. Glenn and R.C. Straight. 1990. Regional variation of biochemical characteristics and antigenicity in Great Basin rattlesnake (Crotalus viridis lutosus) venom. Comparative Biochemistry and Physiology B 97(1): 95-102.

Aird, S.D. 1984. Crotalus viridis viridis (prairie rattlesnake). Coloration. Herpetological Review 15(1): 18-19.

Aird, S.D. 1985. A quantitative assessment of variation in venom constituents within and between three nominal rattlesnake subspecies. Toxicon 23: 1000-1004.

Aird, S.D., C.S. Seebart, and I.I. Kaiser. 1988. Preliminary fractionation and characterization of the venom of the Great Basin rattlesnake (Crotalus viridis lutosus). Herpetologica 44(1): 7185.

Aird, S.D., G. William, G. Kruggel, and I.I. Kaiser. 1991. Multiple myotoxin sequences from the venom of a single prairie rattlesnake (Crotalus viridis viridis).

Aird, S.D. and I.I. Kaiser. 1985. Comparative studies on three rattlesnake toxins. Toxicon 23(3): 361-374. 
Aird, S.D., I.I. Kaiser, R.V. Lewis, and W.G. Kruggel. 1985. Rattlesnake presynaptic neurotoxins: primary structure and evolutionary origin of the acidic subunit. Biochemistry 24: 7054-7058.

Aird, S.D. and M.E. Aird. 1990. Rain collecting behavior in a Great Basin rattlesnake (Crotalus viridis lutosus). Bulletin of the Chicago Herpetological Society 25(12): 217.

Aird, S.D., W.G. Kruggel, and I.I. Kaiser. 1991. Multiple myotoxin sequences from the venom of a single prairie rattlesnake (Crotalus viridis viridis). Toxicon 29(2): 265-268.

Aldridge, R.D. 1975. Environmental control of spermatogenesis in the rattlesnake Crotalus viridis. Copeia 1975(3): 493-496.

Aldridge, R.D. 1979a. Female reproductive cycles of the snakes Arizona elegans and Crotalus viridis. Herpetologica 35(3): 256-261.

Aldridge, R.D. 1979b. Seasonal spermatogenesis in sympatric Crotalus viridis and Arizona elegans in New Mexico. Journal of Herpetology 13(2): 187-192.

Aldridge, R.D. 1981. Mobility, density, habitats and sex ratios in snakes. Transactions of the Missouri Academy of Science 15: 247.

Aldridge, R.D. 1993. Male reproductive anatomy and seasonal occurrence of mating and combat behavior of the rattlesnake Crotalus v. viridis. Journal of Herpetology 27: 481-484.

Aldridge, R.D. 2002. The link between mating season and male reproductive anatomy in the rattlesnakes Crotalus viridis oreganus and Crotalus viridis helleri. Journal of Herpetology 36(2):295-300.

*Allen, J.A. 1874. Notes on the natural history of portions of Dakota and Montana Territories, being the substance of a report to the Secretary of War on the collections made by the North Pacific Railroad Expedition of 1873, General D.S. Stanley, Commander. Proceedings of the Boston Society of Natural History 17: 33-85. Pages 68-70.

Alving, W.R. and K.V. Kardong. 1996. The role of the vomeronasal organ in rattlesnake (Crotalus viridis oreganus) predatory behavior. Brain Behavior and Evolution 48(3): 165172.

Anaya, M., E.D. Rael, C.S. Lieb, J.C. Perez, and R.J. Salo. 1992. Antibody detection of venom protein variation within a population of the rattlesnake Crotalus viridis viridis. Journal of Herpetology 26(4): 473-482.

Anderson, J.R. 1901. Rattlesnakes and scorpions. Ottawa Naturalist 15: 162-163.

Arena, P. C., C. Warwick, and D. Duvall. 1995. Rattlesnake round-ups. Pp. 313-324. In: R.L. Knight and K.J. Gutzwiller (eds). Wildlife and recreationists: coexistence through management and research. Washington, D.C.: Island Press

Armstrong, B. L., and J. B. Murphy. 1979. The natural history of Mexican rattlesnakes. University of Kansas Museum Natural History Special Publication. No. 5. vii + 88 pp.

Ashton, K.G. 1999. Shedding aggregations of Crotalus viridis concolor. Herpetological Review 30: 211-213.

Ashton, K.G. 2001. Body size variation among mainland populations of the western rattlesnake (Crotalis viridis). Evolution 55: 2523-2533.

Ashton, K.G. 2002. Headfirst ingestion of prey by rattlesnakes: Are tactile cues used? Journal of Herpetology 36(3):500-502.

Ashton, K.G. 2003. Movements and behavior of adult male midget faded rattlesnakes (Crotalus oreganos concolor) in Wyoming. Copeia. 1: 190-194. 
Ashton, K.G. and A. de Queiroz. 2001. Molecular systematics of the western rattlesnake, Crotalus viridis (Viperidae), with comments on the utility of the D-loop in phylogenetic studies of snakes. Molecular and Phylogenetic Evolution 21: 176-189.

Ashton, K.G. and T. M. Patton. 2001. Movement and reproductive biology of female midget faded rattlesnakes, Crotalus viridis concolor, in Wyoming. Copeia 2001:229-234.

*Audubon, M.R. (ed.). 1960. Audubon and his journals. Volume 2. Dover Publications Incorporated. New York, NY.

Bailey, V. and M.R. Terman. 1986. Noteworthy achievement in longevity in Crotalus viridis. Northern Ohio Association of Herpetological Notes 13(11): 18.

Bailey, V., M.R. Terman, and R. Wall. 1989. Noteworthy longevity in Crotalus viridus viridus (rafinesque). Transactions of the Kansaas Academy of Science 92(1-4): 116-117.

Bajwa, S.S., F.S. Markland, and F.E. Russell. 1981. Fibrinolytic and fibrinogen clotting enzymes present in the venoms of western diamondback rattlesnake, Crotalus atrox, eastern diamondback rattlesnake, Crotalus adamanteus, and southern pacific rattlesnake, Crotalus viridishelleri. Toxicon 19(1): 53-59.

Bar, O.D., J.B. Sullivan, E Black, and F.E. Russell. 1984. Neutralization of Crotalidae venom induced platelet aggregation by affinity chromatography isolated immunoglobulin $\mathrm{G}$ to Crotalus viridis helleri venom. Journal of Toxicology Clinical Toxicology 22(1): 1-10.

Bauerle, B., D.L. Spencer, and W. Wheeler. 1975. The use of snakes as pollution indicator species. Copeia 1975: 366-368.

*Benson, K.R. 1978. Herpetology of the Lewis and Clark expedition 1804-1806. Herpetological Review 9(3): 87-91.

*Bergeron, D.J. 1979. Terrestrial wildlife survey, Coal Creek Mine area, Montana 1977-1978. Western Technology and Engineering, Inc. Helena, MT.

Bieber, A.L., R.H. McParland, and R.R. Becker. 1987. Amino acid sequences of myotoxins from Crotalus viridis concolor venom. Toxicon 25(6): 677-680.

*BLM. 1982a. Bloomfield - North Fork baseline inventories - wildlife. Bureau of Land Management, Miles City District Office. Miles City, MT. 61 pp.

*BLM. 1982b. Moorhead baseline inventory - wildlife. Bureau of Land Management, Miles City District Office. Miles City, MT. 29 pp.

Blood, D.A. 1993. Western Rattlesnake. British Columbia Ministry of Environment, Lands and Parks, Victoria.

Bober, M.A. and C.L. Ownby. 1988. Rapid decline in blood antimyotoxin levels in the presence of myotoxin a from prairie rattlesnake (Crotalus viridis viridis venom). Journal of Toxicology Clinical Toxicology 26(5-6): 303-312.

Bogert, C.M. 1941. Sensory cues used by rattlesnakes in their recognition of ophidian enemies. Annals of the New York Academy of Sciences 41: 329-343.

*Books, D. 1994. A narrow fellow in the grass. Montana Outdoors 25(5): 7-11.

Boundy, J. 1992. Crotalus viridis viridis (prairie rattlesnake). Herpetological Review 23(4): 124.

*Boundy, J. 2001. Herpetofaunal surveys in the Clark Fork Valley region, Montana. Herpetological Natural History 8: 15-26.

Breidenbach, C.H. 1990. Thermal cues influence strikes in pitless vipers. Journal of Herpetology 24(4): 448-450. 
Brown, D.G. 1990. Observation of a prairie rattlesnake (Crotalus viridis viridis) consuming neonatal cottontail rabbits (Sylvilagus nuttalli), with defense of the young cottontails by adult conspecifics. Bulletin of the Chicago Herpetological Society 25(2): 24-26.

Brown, D.G. 1993. Habitat associations of prairie rattlesnakes (Crotalus viridis) in Wyoming. Herpetological Natural History 1: 5-12.

Brown, D.G. and D. Duvall. 1990. Movements of prairie rattlesnakes in Wyoming in two successive years. Journal of the Colorado-Wyoming Academy of Science 22(1): 5.

Brown, D.G. and D. Duvall. 1993. Habitat associations of prairie rattlesnakes (Crotalus viridis) in Wyoming. Herpetological Natural History 1(1): 5-12.

*Brown, E. 1950. Rattlesnake kills rabbit. Yellowstone Nature Notes 24(4): 47-48.

Brown, W.S. 1993. Biology, status and management of the timber rattlesnake (Crotalus horridus). Herpetological Circular 22: 1-78.

*Brunson, R.B. 1955. Check list of the amphibians and reptiles of Montana. Proceedings of the Montana Academy of Sciences 15: 27-29.

Bullock, R.E. 1971. Cannibalism in captive rattlesnakes. Great Basin Naturalist 31(2): 49-50.

Burger, L.W. 1971. Genera of pitvipers (Serpentes: Crotalidae). Ph.D. Dissertation, University of Kansas, Lawrence.

*Burroughs, R.D. 1961. The natural history of the Lewis and Clark expedition. Michigan State University Press. 340 pp.

*Butts, T.W. 1997. Mountain Inc. wildlife monitoring Bull Mountains Mine No. 1, 1996. Western Technology and Engineering. Helena, MT.

Cage, Y. 2004. Combat in the Prairie rattlesnake. Sonoran Herpetologist 17(11):107-108.

Campbell, J. A. and E. D. Brodie, Jr., (eds). 1992. Biology of the pit vipers. Selva, Tyler, Texas.

Chadwick, L.E. and H. Rahn. 1954. Temperature dependence of rattling frequency in the rattlesnake, Crotalus v. viridis. Science 119: 442-443.

Charland, M.B. 1987. An examination of factors influencing first-year recruitment in the northern Pacific rattlesnake, Crotalus viridis oreganus, in British Columbia. M.S. Thesis. Vancouver, British Columbia: University of Victoria.

Charland, M.B. 1989. Size and winter survivorship in neonatal western rattlesnakes (Crotalus viridis). Canadian Journal of Zoology 67(7): 1620-1625.

Charland, M.B. and P.T. Gregory. 1989. Feeding rate and weight gain in postpartum rattlesnakes: do animals that eat more always grow more? Copeia 1989(1): 211-214.

Charland, M.B. and P.T. Gregory. 1990. The influence of female reproductive status on thermoregulation in a viviparous snake, Crotalus viridis. Copeia 1990(4): 1089-1098.

Charland, M.B., K.J. Nelson, and P.T. Gregory. 1993. Status of the northern Pacific rattlesnake in British Columbia. B.C. Ministry of Environment, Wildlife Branch, Working Wildlife Report No. WR-54. 18 p.

Chiszar, D., D. Belcher, S.P. Mackessy, A. Petkus, and H.M. Smith. 1994. Stimulation of ingestion in solenoglyphous snakes. Herpetological Review 25(4): 158-159.

Chiszar, D., C. Byall, and H.M. Smith. 1996. Presence of cover influences response to prey by prairie rattlesnakes (Crotalus viridis). Psychological Record 46(4): 591-594.

Chiszar, D., J.D. Dickman, and J.S. Colton. 1986. Sensitivity to thermal stimulation in prairie rattlesnakes (Crotalus viridis) after bilateral anesthetization of facial pits. Behavioral and Neurological Biology 45: 143-149. 
Chiszar, D., D. Duvall, K. Scudder, and C.W. Radcliffe. 1980. Simultaneous and successive discriminations between envenomated and nonenvenomated mice by rattlesnakes (Crotalus durissus and C. viridis). Behavioral Neural Biology 29(4): 518-521.

Chiszar, D., C. Harvey, D. Dickman, and J. Colton. 1985. Thermal cues and striking behavior in viperid snakes. Journal of the Colorado-Wyoming Academy of Science 17(1): 35.

Chiszar, D., G. Hobika, and H.M. Smith. 1993. Prairie rattlesnakes (Crotalus viridis) respond to rodent blood with chemosensory searching. Brain Behavior and Evolution 41(3-5): 229-233.

Chiszar, D., G. Hobika, H.M. Smith, and J. Vidaurri. 1991. Envenomation and acquisition of chemical information by prairie rattlesnakes. Prairie Naturalist 23(2): 69-72.

Chiszar, D., R.K.K. Lee, C.W. Radcliffe, and H.M. Smith. 1992. Searching behaviors by rattlesnakes following predatory strikes. pp. 369-382. In: Campbell, J.A. \& Brodie, E.D., Jr. [Eds]. Biology of the pitvipers. Selva, Tyler, Texas.

Chiszar, D., L.J. Livo, R.R.J. Smith, and H.M. Smith. 1995. Crotalus viridis (western rattlesnake). Herpetological Review 26(3): 156.

Chiszar, D., T. Melcer, R. Lee, C.W. Radcliffe, and D. Duvall. 1990. Chemical cues used by prairie rattlesnakes (Crotalus viridis) to follow trails of rodent prey. Journal of Chemical Ecology 16: 79-86.

Chiszar, D., J. Perelman, H.M. Smith, and D. Duvall. 1992. "Shouldering" in prairie rattlesnakes: a new hypothesis. Bulletin of the Maryland Herpetological Society 28(3): 6976.

Chiszar, D. and C.W. Radcliffe. 1977. Absence of prey-chemical preferences in newborn rattlesnakes (Crotalus cerastes, C. enyo, and C. viridis). Behavioral Biology 21 (1): 146150.

Chiszar, D. and C.W. Radcliffe. 1980. Striking and the induction of chemosensory searching in rattlesnakes: effects of handling and transportation to test cages. Journal of the ColoradoWyoming Academy of Science 12(1): 5-6.

Chiszar, D., C.W. Radcliffe, T. Byers, and R. Stoops. 1986. Prey capture behavior in nine species of venomous snakes. Psychological Record 36(4): 433-438.

Chiszar, D., C.W. Radcliffe, and F. Feiler. 1986. Trailing behavior in banded rock rattlesnakes (Crotalus lepidus klauberi) and prairie rattlesnakes (C. viridis viridis). Journal of Comparative Psychology 100(4): 368-371.

Chiszar, D., C.W. Radcliffe, B. O'Connell, and H.M. Smith. 1981. Strike induced chemosensory searching in rattlesnakes (Crotalis viridis) as a function of disturbance prior to presentation of rodent prey. Psychological Record 31: 57-62.

Chiszar, D., C.W. Radcliffe, B. O'Connell, and H.M. Smith. 1982. Analysis of the behavioral sequence emitted by rattlesnakes during feeding episodes II. Duration of strike-induced chemosensory searching in rattlesnakes (Crotalus viridis, C. enyo). Behavioral and Neuralogical Biology 34(3): 261-270.

Chiszar, D., C.W. Radcliffe, and K.M. Scudder. 1977. Analysis of the behavioral sequence emitted by rattlesnakes during feeding episodes. Behavioral Biology 21: 418-425.

Chiszar, D., C.W. Radcliffe, and H.M. Smith. 1980. Ambushing and foraging behavior in rattlesnakes: a behavioral polymorphism. Journal of the Colorado-Wyoming Academy of Science 12(1): 5.

Chiszar, D., C.W. Radcliffe, H.M. Smith, and H. Bashinski. 1981. Effect of prolonged food deprivation on response to prey odors by rattlesnakes. Herpetologica 37(4): 237-243. 
Chiszar, D., C.W. Radcliffe, H.M. Smith, and P. Langer. 1991. Strike-induced chemosensory searching: do rattlesnakes make one decision or two? Bulletin of the Maryland Herpetological Society 27(2): 90-94.

Chiszar, D. and K.M. Scudder. 1980. Chemosensory searching by rattlesnakes during predatory episodes. In: Muller-Schwarze, D. and R.M. Silverstein (eds.), Chemical Signals: Vertebrates and Aquatic Invertebrates. Plenum Press, New York. Pp. 125-139.

Chiszar, D., K. Scudder, and L. Knight. 1976. Rate of tongue flicking by garter snakes (Thamnophis radix haydeni) and rattlesnakes (Crotalus v. viridis, Sistrurus catenatus tergeminus, and Sistrurus catenatus edwardsi) during prolonged exposure to food odors. Behavioral Biology 18(2): 273-283.

Chiszar, D., K. Scudder, L. Knight, and H.M. Smith. 1978. Exploratory behavior in prairie rattlesnakes (Crotalus viridis) and water moccasins (Agkistrodon piscivorus). Psychological Record 28: 363-368.

Chiszar, D. and H.M. Smith. 1993. Crotalus viridis viridis (prairie rattlesnake). Herpetological Review 24(4): 156.

Chiszar, D. and H.M. Smith. 1994. Serpentes: Crotalus viridis viridis (Prairie rattlesnake): Record rattle-string. Herpetological Review 25(3): 123.

Chiszar, D., H.M. Smith, C.M. Bogert, and J. Vidaurri. 1991. A chemical sense of self in timber and prairie rattlesnakes. Bulletin of the Psychonomic Society 29(2): 153-154.

Chiszar, D., H.M. Smith, and R. Defusco. 1993. Crotalus viridis viridis (Prairie Rattlesnake). Herpetological Review 24(3): 106.

Chiszar, D., H.M. Smith, J.L. Glenn, and R.C. Straight. 1991. Strike-induced chemosensory searching in venomoid pit vipers at Hogle Zoo. Zoo Biology 10(2): 111-117.

Chiszar, D., H.M. Smith, and A.R. Hoge. 1983. Post-strike trailig behavior in rattlesnakes. Memorial Institute Butantan 46: 195-206.

Chiszar, D., K.M. Scudder, and H.M. Smith. 1979. Chemosensory investigation of fish mucus odor by rattlesnakes. Bulletin of the Maryland Herpetological Society 15(2): 31-369.

Chopko, J.T. and J.Clarke. 1991. The influence of moonlight on the nocturnal activity of juvenile and adult prairie rattlesnakes (Crotalus viridis viridis). Journal of the ColoradoWyoming Academy of Science 23(1): 22.

Clarke, J.A., J.T. Chopko, and S.P. Mackessy. 1996. The effect of moonlight on activity patterns of adult and juvenile prairie rattlesnakes (Crotalus viridis viridis). Journal of Herpetology 30(2): 192-197.

Cobb, V.A. and C.R. Peterson. 1991a. Daily activity patterns of free-ranging, great basin rattlesnakes. Northwest Scientist 65(2): 70.

Cobb, V.A. and C.R. Peterson. 1991b. The effects of pregnancy on body temperature variation in free-ranging western rattlesnkaes. American Zoologist 31(5): 78A.

Consroe, P., N.B. Egen, F.E. Russel, K. Gerrish, D.C. Smith, A. Sidki, and J.T. Landon. 1995. Comparison of a new ovine antigen binding fragment (Fab) antivenin for United States crotalidae with the commercial antivenin for protection against venom-induced lethality in mice. American Journal of Tropical Medicine and Hygiene 53(5): 507-510.

*Cooper, J.G. 1860. Report upon the reptiles collected on the survey. In: Reports of explorations and surveys to ascertain the most practicable and economical route for a railroad from the Mississippi River to the Pacific Ocean. Volume 12, Book 2, Part 3, Number 4. pp. 292-306, +14 pls. 36th Congress, 1st session, House Executive Document Number 56.

Serial 1055. 
*Cooper, J.G. 1869a. The fauna of Montana territory. American Naturalist 3: 124-127.

*Cooper, J.G. 1869b. Notes on the fauna of the upper Missouri. American Naturalist 3: 294299.

*Cooper, S.V., C. Jean, and P. Hendricks. 2001. Biological survey of a prairie landscape in Montana's glaciated plains. Report to the Bureau of Land Management. Montana Natural Heritage Program, Helena, MT. 24 pp. plus appendices.

*Cope, E.D. 1875. Check-list of North American Batrachia and Reptilia; with a systematic list of the higher groups, and an essay on geographical distribution. U.S. National Museum Bulletin 1(1): 1-104.

*Cope, E.D. 1879. A contribution to the zoology of Montana. American Naturalist 13(7): 432441.

*Cope, E.D. 1900. The crocodilians, lizards and snakes of North America. Report of the U.S. National Museum 1898: 153-1270.

Coss, R.G. 1991. Context and animal behavior 3: the relationship between early development and -evolutionary persistence of ground squirrel antisnake behavior. Ecological Psychology 3(4): 277-315.

Coss, R.G. 1993. Evolutionary persistence of ground squirrel antisnake behavior: reflections on Burton's commentary. Ecological Psychology 5(2): 171-194.

Coss, R.G. and D.H. Owings. 1978. Snake-directed behavior of snake: naive and experienced California ground squirrels in a simulated burrow. Zeitschrift fuer Tierpsychologie 48(4): 421-435.

*Coues, E. and H.C. Yarrow. 1878. Notes on the herpetology of Dakota and Montana. Bulletin of the U.S. Geologic and Geographic Survey 4(1): 259-291.

Cowles, R.B. 1938. Unusual defense posture assumed by rattlesnakes. Copeia 1958: 13-16.

Cowles, R.B. and R.L. Phelan. 1958. Olfaction in rattlesnakes. Copeia 1958: 77-83.

Cox, M.K. and W.L. Franklin. 1989. Terrestrial vertebrates of Scotts Bluff National Monument, Nebraska (USA). Great Basin Naturalist 49(4): 597-613.

Crabtree, C.B., R.W. Murphy. 1984. Analysis of Maternal-Offspring Allozymes in Crotalus viridis. Journal of Herpetology 18(1): 75-80.

Cross, R.G., K.L. Guse, N.S. Poran, and D.G. Smith. 1993. Development of antisnake defenses in California ground squirrels (Spermophilus beecheyi): II. Microevolutionary effects of relaxed selection from rattlesnakes. Behaviour 124(1-2): 137-164.

Cruz, E., S. Gibson, K. Kandler, G. Sanchez, and D. Chiszar. 1987. Strike-induced chemosensory searching in rattlesnakes: a rodent specialist (Crotalus viridis) differs from a lizard specialist (Crotalus pricei). Bulletin of the Psychonomic Society 25(2): 136-138.

Cruz-Neto, A.P., D.V. Andrade, and A. S. Abe. 1999. Energetic cost of predation: aerobic metabolism during prey ingestion by juvenile rattlesnakes, Crotalus durissus. Journal of Herpetology 33(2): 229-234.

Cundall, D. 2002. Envenomation strategies, head form, and feeding ecology in vipers. Pp. 149161. In: G.W. Schuett, M. Hoggren, M.E. Douglas, and H.W. Greene. Biology of the vipers. Eagle Mountain Publishing.

Cunningham, G.R., S.M. Hickey, and C.M. Gowen. 1996. Serpentes: Crotalus viridis viridis (prairie rattlesnake): Behavior. Herpetological Review 27(1): 24.

*Curtis, S. 1994. The big sleep. Montana Outdoors 25(6): 2-7. 
*Day, D., P.J. Farmer, and C.E. Farmer. 1989. Montco terrestrial wildlife monitoring report December, 1987 - July, 1989. Montco, Billings, MT, and Western Technology and Engineering, Inc. Helena, MT.

*[DCC] Decker Coal Company. 1998. 1997 Consolidated annual progress report. Decker Coal Company West, North and East Pits. Decker, MT.

de Cock Buning, T. 1985. Localization of warm objects by heat sensitive snakes. Fortschritte Der Zoologie 30 1985: 719-721.

Dean, J.N., J.L. Glenn, and R.C. Straight. 1980. Bilateral cleft labial and palate in the progeny of a Crotalus viridis viridis rafinesque. Herpetological Review 11(4): 91-92.

Degenhardt, W.G., C.W. Painter, and A.H. Price. 1996. Amphibians and reptiles of New Mexico. Albuquerque, NM: University of New Mexico Press. 431 p.

Dickman, J.D., J.S. Colton, D. Chiszar, and C.A. Colton. 1987. Trigeminal responses to thermal stimulation of the oral cavity in rattlesnakes (Crotalus viridis) before and after bilateral anesthetization of the facial pit organs. Brain Research 400(2): 365-370.

Diemer Berish, J.E. 1998. Characterization of rattlesnake harvest in Florida. Journal of Herpetology 32: 551-557.

Diller, L.V. 1981. Comparative ecology of Great Basin rattlesnakes (Crotalus viridis lutosus) and Great Basin gopher snakes (Pituophis melanoleucus deserticola) and their impact on small mammal populations in the Snake River Birds of Prey Area. Ph.D. Dissertation. University of Idaho, Moscow.

Diller, L.V. 1990. A field observation on the feeding behavior of Crotalus viridis lutosus. Journal of Herpetolgoy 24(1): 95-97.

Diller, L.V. and R.L. Wallace. 1984. Reproductive biology of the northern pacific rattlesnake (Crotalus viridis oreganus) in northern Idaho. Herpetologica 40(2): 182-193.

Diller, L.V. and R.L. Wallace. 1996. Comparative ecology of two snake species (Crotalus viridis and Pituophis melanoleucus) in southwestern Idaho. Herpetologica 52(3): 343-360.

*Dood, A.R. 1980. Terry Badlands nongame survey and inventory final report. Montana Department of Fish, Wildlife, and Parks and Bureau of Land Management, Helena, MT. 70 p.

Douglas, M.E., M.R. Douglas, G.W. Schuett, L.W. Porras, and A.T. Holycross. 2002. Phylogeography of the western rattlesnake (Crotalus viridis) complex, with emphasis on the Colorado Plateau. Pp.11-50. In: G.W. Schuett, M. Hoggren, M.E. Douglas, and H.W. Greene. Biology of the vipers. Eagle Mountain Publishing.

Duvall, D. 1986. Snake, rattle and roll. Natural History 95(11): 66-73. mate searching in prairie rattlesnakes, Crotalus viridis viridis. Animal Behavior 54: 329334.

Duvall, D., S.J. Arnold, and G.W. Schuett. 1992. Pit-viper mating systems; ecological potential, sexual selection, and microevolution. Pp. 321-336. In: J.A. Campbell and E.D. Brodie, Jr. (eds). Biology of the Pitvipers. Tyler, TX: Selva.

Duvall, D. and S.J. Beaupre. 1998. Sexual strategy and size dimorphism in rattlesnakes: integrating proximate and ultimate causation. American Zoologist 38: 152-165.

Duvall, D. and D. Chiszar. 1990. Behavioural and chemical ecology of vernal migration and pre- and post-strike predatory activity in prairie rattlesnakes: field and laboratory experiments. Chemical Signals in Vertebrates 5: 539-554.

Duvall, D., K. Gutzwiller, and M. King. 1985. Reconstructing the rattlesnake. BBC Wildlife 3(2): 80-82. 
Duvall, D., M. B. King, and K. J. Gutzwiller. 1985. Behavioral ecology and ethology of the prairie rattlesnake. National Geographic Research 1: 80-111.

Duvall, D. and G.W. Schuett. 1997. Straight-line movements and competative Duvall, D., D. Chiszar, W.K. Hayes, J.K. Leonhardt, and M.J. Goode. 1990. Chemical and behavioral ecology of foraging in prairie rattlesnakes (Crotalus viridis viridis). Journal of Chemical Ecology 16(1): 87-101.

Duvall, D., K.M. Scudder, and D. Chiszar. 1980. Rattlesnake predatory behaviour: mediation of prey discrimination and release of swallowing by cues arising from envenomated mice. Animal Behaviour 28(3): 674-683.

Duvall, D., M. Goode, B. Graves, and M. King. 1988. Thermoregulatory and fitness consequences of social aggregation in pregnant female prairie rattlesnakes. International Conference on Behavioral Ecology: Program and Abstracts. No. 2. p. 49.

Duvall, D., M.J. Goode, W.K. Hayes, J.K. Leonhardt, and D.G. Brown. 1990. Prairie rattlesnake vernal migration: field experimental analyses and survival value. National Geographic Research 6(4): 457-469.

Engen, P.C. and E. A. Widmer. 1993. Asexually proliferous tetrathyridia of Mesocestoides sp. in the hepatic portal system of the prairie rattlesnake (Crotalus viridis viridis). Journal of Wildlife Diseases 29(1): 150-152.

*[EI] Econ Incorporated. 1984. Terrestrial wildlife inventory for the Lame Jones and Ismay coal lease tracts. Econ Incorporated. Helena, MT.

*Ernst, C.H. 1992. Venomous reptiles of North America. Smithsonian Institution Press, Washington, DC. 236 p.

*Ernst, C.H. and E.M. Ernst. 2003. Snakes of the United States and Canada. Washington D.C.: Smithsonian Books.

*Espelin, D.E. 1968. Tragedy and truth of snake bite treatment. Montana Outdoors 3(6) 5 p. Montana Fish and Game Department, Helena, MT.

*Espelin, D.E. and V. Craig. 1975. The truth abouth snakebite. Montana Outdoors 6(4): 46-49. Montana Department of Fish and Game.

*Farmer, P. 1980. Terrestrial wildlife monitoring study, Pearl area, Montana June, 1978 - May, 1980. Western Technology and Engineering, Inc. Helena, MT.

*Farmer, P. 1986. Chartam project baseline wildlife study. Western Technology and Engineering, Inc. Helena, MT.

*Farmer, P. and K. Burgess. 1983. Jardine area baseline terrestrial wildlife study May 15, 1981 - May 15, 1982. Western Technology and Engineering Inc. Helena, MT.

Fenton, M.B. and L.E. Licht. 1990. Why rattle snakes? Journal of Herpetology 24(3): 274-279.

Fiero, M.K., M.W. Siefert, T.J. Weaver, and C.A. Bonilla. 1972. Comparative study of juvenile and adult prairie rattlesnake (Crotalus viridis) venoms. Toxicon 10: 81-82.

Fitch, H.S. 1985. Observations on rattle size and demography of prairie rattlesnakes (Crotalus viridis) and timber rattlesnakes (Crotalus horridus) in Kansas. Occasional Papers of the Museum of Natural History at the University of Kansas No. 118. 11p.

Fitch, H.S. 2002. A comparison of growth and rattle strings in three species of rattlesnake. Scientific Papers Natural History Museum the University of Kansas 24:1-6.

Fitch, H.S. 2003. Reproduction in rattlesnakes of the Sharon Springs, Kansas, roundup. Journal of Kansas Herpetology 8:23-24.

Fitch, H.S. and H. Twining. 1946. Feeding habits of the Pacific rattlesnake. Copeia 1946: 6471. 
Fitch, H.S. and H.W. Shirer. 1971. A radiotelemetric study of spatial relationships in some common snakes. Copeia 1971(1): 118-128.

Fleet, R.R., and F.W. Plapp, Jr. 1978. DDT residues in snakes decline since DDT ban. Bulletin of Environmental Contaminants and Toxicology. 19: 383-388.

Foote, R. and J.A. MacMahon. 1977. Electrophoretic studies of rattlesnake (Crotalus \& Sistrurus) venom: taxonomic implications. Comparative Biochemistry and Physiology 57B: 235-241.

*Franz, R. 1971. Notes on the distribution and ecology of the herpetofauna of northwestern Montana. Bulletin of the Maryland Herpetological Society 7: 1-10.

Furry, K., T. Swain, and D. Chiszar. 1989. Rattlesnakes learn about idiosyncratic chemical features of rodents during the predatory strike. Journal of the Colorado-Wyoming Academy of Science 21(1): 23.

Furry, K., T. Swain, and D. Chiszar. 1991. Strike-induced chemosensory searching and trail following by prairie rattlesnakes (Crotalus viridis) preying upon deer mice (Peromyscus maniculatus): chemical discrimination among individual mice. Herpetologica 47(1): 69-78.

Gannon, V. 1978. Factors limiting the distribution of the prairie rattlesnake. Blue Jay 36(3): 142-144.

Gannon, V.P.J. 1980. Some aspects of the ecology of the prairie rattlesnake, Crotalus viridis, in Saskatchewan. Unpubl. M.S. Thesis, University of Regina.

Gannon, V.P.J. and D.M. Secoy. 1984. Growth and reproductive rates of a northern population of the prairie rattlesnake, Crotalus v. viridis. Journal of Herpetology 18(1): 13-19.

Gannon, V.P.J. and D.M. Secoy. 1985. Seasonal and daily activity patterns in a Canadian population of the prairie rattlesnake, Crotalus viridis viridis. Canadian Journal of Zoology 63(1): 86-91.

Garfin, S.R., R.R. Castilonia, S.J. Mubarak, A.R. Hargens, W.H. Akeson, and F.E. Russell. 1985. The effect of antivenin on intramuscular pressure elevations induced by rattlesnake (Crotalus viridis helleri) venom. Toxicon 23(4): 677-680.

*Gates, M.T. 2005. Amphibian and reptile baseline survey: CX field study area. Report to Billings and Miles City Field Offices of Bureau of Land Management. Maxim Technologies, Billings, MT. 28pp + Appendices.

*Genter, D.L. 1984. Crotalus viridis (prairie rattlesnake). Food. Herpetological Review 15(2): 49-50.

Gier, P.J., R.L. Wallace, and R.L. Ingermann. 1989. Influence of pregnancy on behavioral thermoregulation in the northern Pacific rattlesnake Crotalus viridis oreganus. Journal of Experimental Biology 145: 465-469.

*Gildart, R.C. and J. Wassink. 1982. Montana wildlife. Montana Geographic Series. Number three. Montana Magazine, Inc. Helena, MT. 128 p.

Giovanni, M.D., C.A. Taylor, and G. Perry. 2005. Crotalus viridis viridis (Prairie Rattlesnake). Diet. Herpetological Review 36(3):323.

Glenn, J.L. and R. Straight. 1977. The midget faded rattlesnake (Crotalus viridis concolor) venom: lethal toxicity and individual variability. Toxicon 15 (2): 129-133.

Glenn, J.L. and R.C. Straight. 1990. Venom characteristics as an indicator of hybridization between Crotalus viridis viridis and Crotalus scutulatus scutulatus in New Mexico (USA). Toxicon 28(7): 857-862.

Glenn, J.L. and R.C. Straight. 1985. Venom properties of the rattlesnakes (Crotalus) inhabiting the Baja California region of Mexico. Toxicon 23(5): 769-776. 
*Gloyd, H.K. 1933. An unusual feeding record for the prairie rattlesnake. Copeia 1933(2): 98.

Gloyd, H.K. 1940. The rattlesnakes, genera Sistrurus and Crotalus. Chicago Academy of Science, Special Publications 4: 1-266.

Golan, L., T. Miller, D. Chiszar, and C. Radcliffe. 1981. Prey trailing behavior in prairie rattlesnakes (Crotalus viridis). Journal of the Colorado-Wyoming Academy of Science 13(1): 52-53.

Golan, L., C. Radcliffe, T. Miller, B. O'Connell, and D. Chiszar. 1982. Trailing behavior in prairie rattlesnakes (Crotalus viridis). Journal of Herpetology 16(3): 287-293.

Goode, M.J. and D. Duvall. 1989. Body temperature and defensive behaviour of free-ranging prairie rattlesnakes, Crotalus viridis viridis. Animal Behaviour 38: 360-362.

Graves, B.M. 1988. Functions and causes of selected aspects of birthing rookery use by prairie rattlesnakes (Crotalus viridis viridis) in Wyoming. Ph.D. Dissertation. University of Wyoming, Laramie, Wyoming. 280 pp.

Graves, B.M. 1989a. Crotalus viridis viridis (prairie rattlesnake). Predation. Herpetological Review 20(3): 71-72.

Graves, B.M. 1989b. Defensive behavior of female prairie rattlesnakes (Crotalus viridis) changes after parturition. Copeia 1989: 791-794.

Graves, B.M. 1991. Consumption of an adult mouse by a free-ranging neonate prairie rattlesnake. Southwestern Naturalist 36(1): 143.

Graves, B.M., G.C. Carpenter, and D. Duvall. 1987. Chemosensory behaviors of neonate prairie rattlesnakes, Crotalus viridis. Southwestern Naturalist 32(4): 515-517.

Graves, B.M. and D. Duvall. 1983a. Occurrence and function of prairie rattlesnake mouth gaping in a non-feeding context. Journal of Experimental Zoology 227(3): 471-474.

Graves, B.M. and D. Duvall. 1983b. Pheromonal mediation of defensive behavior in prairie rattlesnakes. Journal of the Colorado-Wyoming Academy of Science 15(1): 48.

Graves, B.M. and D. Duvall. 1985a. Avomic prairie rattlesnakes (Crotalus viridis) fail to attack rodent prey. Zeitschrift Fuer Tierpsychologie 67(1-4): 161-166.

Graves, B.M. and D. Duvall. 1985b. Mouth gaping and head shaking by prairie rattlesnakes are associated with vomeronasal organ olfaction. Copeia 1985(2): 496-497.

Graves, B.M. and D. Duvall. 1987. An experimental study of aggregation and thermoregulation in prairie rattlesnakes (Crotalus viridis viridis). Herpetologica 43(2): 259-264.

Graves, B.M. and D. Duvall. 1988. Evidence of an alarm pheromone from the cloacal sacs of prairie rattlesnakes. Southwestern Naturalist 33(3): 339-345.

Graves, B.M. and D. Duvall. 1990. Spring emergence patterns of wandering garter snakes and prairie rattlesnakes in Wyoming. Journal of Herpetology 24(4): 351-356.

Graves, B.M. and D. Duvall. 1992. Reproduction, rookery use, and thermoregulation in freeranging, pregnant Crotalus viridis. Journal of Herpetology 26: 33-41.

Graves, B.M., D. Duvall, M.B. King, S.L. Lindstedt, and W.A. Gern. 1986. Initial den location by neonatal prairie rattlesnakes: functions, causes, and natural history in chemical ecology. Proceedings of the International Conference on Chemical Signals in Vertebrates 4: 285-304.

Graves, B.M., M.B. King, and D. Duvall. 1986. Natural history of prairie rattlesnakes (Crotalus viridis viridis) in Wyoming. Herptological Review 11(1): 5-10.

Gregory, P.T., G.J. Davies, and J.M. Macartney. 1989. A portable device for restraining rattlesnakes in the field. Herpetological Review 20: 43-44.

Grenard, S. 2000. Is rattlesnake venom evolving? Natural History 109(6): 44-49. 
Guyon, C. 1987. Prairie rattlesnake (Crotalus viridis) thermal sensitivity to paired rodent prey of differing temperatures. Journal of the Colorado-Wyoming Academy of Science 19(1): 16.

Hamilton, W.J., Jr. 1950. Food of the prairie rattlesnake (Crotalus v. viridus Rafinesque). Herpetologica 6: 34.

Hammerson, G.A. 1999. Amphibians and reptiles in Colorado. University Press of Colorado. Niwot, CO. 484 pp.

Hammerson, G.A., L. Valentine, and L.J. Livo. 1991. Crotalus viridis (western rattlesnake). Herpetological Review 22(2): 67.

Hanson, G.B. and E.A. Widmer. 1985. Asexual multiplication of tetrathyridia of Mesocestoides corti in Crotalus viridis viridis. Journal of Wildlife Diseases 21(1): 20-24.

*Hart, M.M., W.A. Williams, P.C. Thornton, K.P. McLaughlin, C.M. Tobalske, B.A. Maxell, D.P. Hendricks, C.R. Peterson, and R.L. Redmond. 1998. Montana atlas of terrestrial vertebrates. Montana Cooperative Wildlife Research Unit, The University of Montana. Missoula, Montana vii +1302 p.

Haverty, J.E. and K.V. Kardong. 1996. Sensory deprivation effects on the predatory behaviour of the rattlesnake, Crotalus viridis oreganus. Copeia 1996(2): 419-428.

*Hayden, F.V. 1858. Catalogue of the collections in geology and natural history, obtained by the expedition under command of Lieutenant G.K. Warren, Topographical Engineers. pp. 104-105. In: F.N. Shubert (1981) Explorer on the northern plains: Lieutenant Gouverneur K. Warren's preliminary report of explorations in Nebraska and Dakota, in the years 1855-'56'57. Engineer Historical Studies No. 2. Office of the Chief of Engineers, Washington, DC. $125 \mathrm{p}$.

*Hayden, F.V. 1863. On the geology and natural history of the upper Missouri. Transactions of the American Philosophical Society New Series 12(1): 1-218 (pages 177-178).

Hayes, W.K. 1986a. Factors influencing the release and aim of predatory strikes in the rattlesnake, Crotalus viridis oreganus. M.S. Thesis. College Place, WA: Walla Walla College.

Hayes, W.K. 1986b. Observations of courtship in the rattlesnake, Crotalus viridis oreganus. Journal of Herpetology 20(2): 246-249.

Hayes, W.K. 1989. Prey handling and envenomation strategies of prairie rattlesnakes. American Zoologist 29(4): 136A.

Hayes, W.K. 1990. Prey handling and envenomation behavior of prairie and midget-faded rattlesnakes. Journal of the Colorado-Wyoming Academy of Science 22(1): 6.

Hayes, W.K. 1991a. Envenomation strategies of prairie rattlesnakes. Unpubl. Ph.D. Dissertation, University of Wyoming, Laramie.

Hayes, W.K. 1991b. Ontogeny of striking, prey-handling and envenomation behavior of prairie rattlesnakes (Crotalus viridis). Toxicon 29(7): 867-876.

Hayes, W.K. 1992a. Factors associated with the mass of venom expended by prairie rattlesnakes (Crotalus viridis viridis) feeding on mice. Toxicon 30(4): 449-460.

Hayes, W.K. 1992b. Prey-handling and envenomation strategies of prairie rattlesnakes (Crotalus v. viridis) feeding on mice and sparrows. Journal of Herpetology 26(4): 496-499.

Hayes, W.K. 1993. Effects of hunger on striking, prey-handling, and venom expenditure of prairie rattlesnakes (Crotalus viridis viridis). Herpetologica 49(3): 305-310.

Hayes, W.K. 1995. Venom metering by juvenile prairie rattlesnakes, Crotalus v. viridis: Effects of prey size and experience. Animal Behaviour 50(1): 33-40. 
Hayes, W.K. and D. Duvall. 1991. A field study of prairie rattlesnake predatory strikes. Herpetologica 47(1): 78-81.

Hayes, W.K., D. Duvall, and G.W. Schuett. 1992. A preliminary report on the courtship behavior of free-ranging prairie rattlesnakes, Crotalus viridis viridis (Rafinesque), in southcentral Wyoming. pp. 45-48. In: Strimple, P.D. \& Strimple, J.L. [Eds]. Contributions in herpetology. Greater Cincinnati Herpetological Society, Cincinnati, OH.

Hayes, W.K. and D.M. Hayes. 1993. Stimuli influencing the release and aim of predatory strikes of the northern pacific rattlesnake (Crotalus viridis oreganus). Northwestern Naturalist 74(1): 1-9.

Hayes, W.K. and D.M. Hayes. 1994. Stimuli influencing the release and aim of predatory strikes of the northern Pacific rattlesnake (Crotalus viridis oreganus). Northwestern Naturalist 74(1): 1-9.

Hayes, W.K., I.I. Kaiser, and D. Duvall. 1992. The mass of venom expended by prairie rattlesnakes when feeding on rodent prey. pp. 383-388. In: Campbell, J.A. \& Brodie, E.D., Jr. (eds). Biology of the pitvipers.

Hayes, W.K., P. Lavin-Mucio, and K.V. Kardong. 1995. Northern Pacific rattlesnakes (Crotalus viridis oreganus) meter venom when feeding on prey of different sizes. Copeia 1995(2): 337-334.

Hayes, W.K., E.A. Verde, F.E. Hayes. 1994. Cardiac responses during courtship, male-male fighting, and other activities in rattlesnakes. Journal of the Tennessee Academy of Science 69(1): 7-9.

Henderson, J.T., R.A. Nieman, and A.L. Bieber. 1987. Assignment of the aromatic 1H-NMR resonances of myotoxin a isolated from the venom of Crotalus viridis viridis. Biochimica Et Biophysica Acta 914(2) 1987: 152-161.

*Hendricks, P. 1999. Amphibian and reptile survey of the Bureau of Land Management Miles City District, Montana. Montana Natural Heritage Program, Helena, MT. 80 p.

*Hendricks, P. and J.D. Reichel. 1996a. Amphibian and reptile survey of the Bitterroot National Forest: 1995. Montana Natural Heritage Program, Helena, MT. 95 p.

*Hendricks, P. and J.D. Reichel. 1996b. Preliminary amphibian and reptile survey of the Ashland District, Custer National Forest: 1995. Montana Natural Heritage Program, Helena, MT. $79 \mathrm{p}$.

*Hendricks, P. and J.D. Reichel. 1998. Amphibian and reptile survey on Montana refuges: 1996. Montana Natural Heritage Program, Helena, MT. 19 p.

Hennessy, D.F. 1983. Functional significance of variation in predator harassment. Ph.D. Dissertation. University of California Davis. 119p.

Hennessy, D.F. and D.H. Owings. 1988. Rattlesnakes create a context for localizing their search for potential prey. Ethology 77(4): 317-329.

Herbert, S.S. and W.K. Hayes. 1992. The role of facial pits in the thermoregulatory behavior of pit vipers. Journal of the Tennessee Academy of Science 67(1-2): 19.

Hersek, M.J. 1990. Behavior of predator and prey in a highly coevolved system: northern Pacific rattlesnakes and California ground squirrels. Ph.D. Dissertation, University of California, Davis, California 92p.

Hersek, M.J., D.H. Owings, and D.F. Hennessy. 1992. Combat between rattlesnakes (Crotalus viridis oreganus) in the field. Journal of Herpetology 26(1): 105-107.

Heyrend, F.L. and A. Call. 1951. Growth and age in western striped racer and Great Basin rattlesnake. Herpetologica 7: 28-40. 
Hirth, H.F. 1966. Weight changes and mortality of three species of snakes during hibernation. Herpetologica. 22: 8-12.

Hirth, H.F., R.C. Pendleton, A.C. King, and T.R. Downard. 1969. Dispersal of snakes from a hibernaculum in northwestern Utah. Ecology 50: 332-339.

Hoberg, T. and C. Gause. 1989. Reptiles \& amphibians of North Dakota. North Dakota Outdoors 55(1):7-18.

Holland, R.L., H.M. Smith, and D. Chiszar. 1995. Crotalus viridis viridis (prairie rattlesnake). Herpetological Review 26(4): 210.

Holycross, A.T. 1995. Crotalus viridis (western rattlesnake). Phenology. Herpetological Review 26(1): 37-38.

Holycross, A.T. and J.D. Fawcett. 2002. Observations on neonatoal aggregations and associated behaviors in the prairie rattlesnake, Crotalus viridis viridis. American Midland Naturalist 148(1):181-184.

Hossack, B.R., P.S. Corn, and D.S. Pilliod. 2005. Lack of significant changes in the herpetofauna of Theodore Roosevelt National Park, North Dakota, since the 1920s. American Midland Naturalist 154:423-432.

Iglehart, F. and D. Chiszar. 1977. Covariation among elements of rattlesnake posture: potential interspecific signals. Bulletin of the Psychonomic Society 9: 294-296.

Irwin, Kelly J. 1979. Two aberrant Crotalid snakes from Kansas. Herpetological Review 10(3): 85.

Ivanyi, C.S. and J. Johnson. 2004. Identifying individual rattlesnakes using pattern variation. Herpetological Review 35(2):154-156.

Ivanyi, C. and W. Altimari. 2003. Venomous reptile bites in academic research. Herpetological Review 35(1):49-50.

Jacob, J.S. and C.W. Painter. 1980. Overwinter thermal ecology of Crotalus viridis in the northcentral plains of New Mexico. Copeia 1980(4): 799-805.

Jesperson, D.M., W.M.M. Fowden, III, and G.T. Baxter. 1974. Observations on denning and reproductive behavior of the prairie rattlesnake. Journal of the Colorado-Wyoming Academy of Science 7(5): 80.

Johnson, E.K. 1987. Stability of venoms from the northern Pacific rattlesnake (Crotalus viridis oreganus). Northwest Science 61(2): 110-113.

Johnson, E.K., K.V. Kardong, and C.L. Ownby. 1987. Observations on white and yellow venoms from an individual southern Pacific rattlesnake (Crotalus viridis helleri). Toxicon 25(11): 1169-1180.

Kandler, K. and D. Chiszar. 1986. Spatial orientation by prairie rattlesnakes (Crotalus viridis) following the predatory strike. Bulletin of the Psychonomic Society 24(2): 169-170.

Kardong, K.V. 1980a. Evolutionary patterns in advanced snakes. American Zoologist 20: 269282.

Kardong, K.V. 1980b. Gopher snakes and rattlesnakes: presumptive batesian mimicry. Northwest Science 54(1): 1-4.

Kardong, K.V. 1986a. Predatory strike behavior of the rattlesnake, Crotalus viridis oreganus. Journal of Comparative Psychology 100(3): 304-324.

Kardong, K.V. 1986b. The predatory strike of the rattlesnake: when things go amiss. Copeia 1986(3): 916-820.

Kardong, K.V. 1992. Proximate factors affecting guidance of the rattlesnake strike. Zoologische Jahrbuecher Aabteilung Fuer Anatomie Und Ontogenie Tiere. 
Kardong, K.V. 1993. The predatory behavior of the northern Pacific rattlesnake (Crotalus viridis oreganus): laboratory versus wild mice as prey. Herpetologica 49(4): 457-463.

Kardong, K.V. 1996. Mechanical damage inflicted by fangs on prey during predatory strikes by rattlesnakes, Crotalus viridis oreganus. Bulletin of the Maryland Herpetological Society 32(4): 113-118.

Kardong, K.V. and S.P. Mackessy. 1991. The strike behavior of a congenitally blind rattlesnake. Journal of Herpetology 25(2): 208-211.

Keenlyne, K.D. 1978. Reproductive cycles in two species of rattlesnakes. American Midland Naturalist 100: 368-375.

Killebrew, F.C. and T.L. James. 1983. Crotalus viridis viridis (prairie rattlesnake). Coloration. Herpetological Review 14(3): 74.

King, M.B. 1987. Movements and natural history of prairie rattlesnakes, Crotalus viridus horridus, in Wyoming. M.S. Thesis. Laramie, WY: University of Wyoming. 94p.

King, M.B. and D. Duvall. 1983. Migration and predatory ecology of prairie rattlesnakes (Crotalus viridis viridis). Journal of the Colorado-Wyoming Academy of Science 15(1): 4748.

King, M.B. and D. Duvall. 1990. Prairie rattlesnake seasonal migrations: episodes of movement, vernal foraging and sex differences. Animal Behaviour 39(5): 924-935.

King, M.B., D. McCarron, D. Duvall, G. Baxter, and W. Gern. 1983. Group avoidance of conspecific but not interspecific chemical cues by prairie rattlesnakes (Crotalus viridis). Journal of Herpetology 17: 196-198.

Kissner, K.J., D.M. Secoy, and M.R. Forbes. 1996. Assessing population size and den use of prairie rattlesnakes Crotalus viridis viridis in southern Saskatchewan. Grasslands National Park Annual Report 1: 27-34.

Kisser, K.J. and J. Nicholson. 2003. Prairie rattlesnake (Crotalus viridis) hibernacula: monitoring history in Alberta 1987-2002. Alberta Species at Risk Report 76:1-14.

*Klauber, L.M. 1936a. A key to the rattlesnakes with summary of characteristics. Transactions of the San Diego Society of Natural History 8: 185-276.

Klauber, L.M. 1936b. A statistical study of the rattlesnakes. Occasional Papers of the San Diego Society of Natural History 1: 1-24.

Klauber, L.M. 1937. A statistical study of the rattlesnakes. IV. The Growth of the rattlesnakes. Occasional Papers of the San Diego Society of Natural History 3: 1-56.

Klauber, L.M. 1940. A statistical study of the rattlesnakes. VIII. The Rattle. San Diego Society of Natural History Occasional Papers 6: 1-62.

*Klauber, L.M. 1956. Rattlesnakes: their habits, life histories, and influences on mankind. University of California Press, Berkeley.

*Klauber, L.M. 1972. Rattlesnakes: their habits, life histories, and influence on mankind. 2 volumes. 2nd edition. Berkeley, CA: University of California Press.

Knight, A., D. Styer, S. Pelikan, J.A. Campbell, L.D. Densmore III, and D.P. Mindell. 1993. Choosing among hypotheses of rattlesnake phylogeny: a best-fit rate test for DNA sequence data. Systematic Biology 42: 356-367.

*Koch, E.D. and C.R. Peterson. 1989. A preliminary survey of the distribution of amphibians and reptiles in Yellowstone National Park. Pp. 47-49. In: T.W. Clark, A.H. Harvey, R.D. Dorn, D.C. Genter, and C. Groves (eds). Rare, sensitive and threatened species of the Greater Yellowstone Ecosystem. Northern Rockies Conservation Cooperative , Montana 
Natural Heritage Program, The Nature Conservancy, and Mountain West Environmental Services. 153 p.

Kocholaty, W.F., E.B. Ledford, J.G. Daly, and T.A. Billings. 1971. Toxicity and some enzymatic properties and activities in the venoms of Crotalidae, Elapidae, and Viperidae. Toxicon 9: 131-138.

Komori, Y., T. Nikai, and H. Sugihara. 1988. Biochemical and biophysiological studies on a kallikrein-like enzyme from the venom of Crotalus viridis viridis (prairie rattlesnake). Biochimica Et Biophysica Acta 967(1) 1988: 92-102.

Komori, Y., T. Nikai, C. Sekido, M. Fuwa, and H. Sugihara. 1994. Biochemical characterization of hemorrhagic toxin from Crotalus viridis viridis (prairie rattlesnake) venom. International Journal of Biochemistry 26(12): 1411-1418.

Komori, Y., T. Nikai, H. Sugihara. 1988. Biochemical and physiological studies on a kallikreinlike enzyme from the venom of Crotalus viridis viridis (prairie rattlesnake). Biochimica Et Biophysica Acta 967(1): 92-102.

Kraus, F., D.G. Mink, and W.B. Brown. 1996. Crotaline intergeneric relationships based on mitochondrial DNA sequence data. Copeia 1996: 763-773.

Krivda, W. 1993. Road kills of migrating garter snakes at The Pas, Manitoba. Blue Jay. 51(4): 197-198.

Kuhn, B.F., M.J. Rochelle, and K.V. Kardong. 1991. Effects of rattlesnake (Crotalus viridis oreganus) envenomation upon the mobility and death rate of laboratory mice (Mus musculus) and the wild mice (Peromyscus maniculatus). Bulletin of the Maryland Herpetological Society 27(4): 189-194.

Langley, W.M., H.W. Lipps, and J.F. Theis. 1989. Responses of Kansas motorists to snake models on a rural highway. Transactions of the Kansas Academy of Science. 92(1-2): 43-48.

Lavin-Murcio, P.A., and K.V. Kardong. 1995. Scents related to venom and prey as cues in the poststrike trailing behavior of rattlesnakes, Crotalus viridis oreganus. Herpetologica 51(1): 39-44.

Lavin-Murcio, P.A., B.G. Robinson, and K.V. Kardong. 1993. Cues involved in relocation of struck prey by rattlesnakes, Crotalus viridis oreganus. Herpetologica 49: 463-469.

Lee, R. and D. Chiszar. 1987. Poststrike behavior in rattlesnakes. Journal of the ColoradoWyoming Academy of Science 19(1): 19-20.

Lee, R.K.K., D.A. Chiszar, and H.M. Smith. 1988. Post-strike orientation of the prairie rattlesnake facilitates location of envenomated prey. Journal of Ethology 6(2): 129-134.

Lee, R.K.K., D.A. Chiszar, H.M. Smith, and K. Kandler. 1992. Chemical and orientational cues mediate selection of prey trails by prairie rattlesnakes (Crotalus viridis). Journal of Herpetology 26(1): 95-98.

Lemos-Espinal, J.A., D. Chiszar, and H.M. Smith. 1994. The distribution of the prairie rattlesnake (Crotalus v. viridis) in Mexico. Bulletin of the Maryland Herpetological Society 30(4): 143-148.

Leviton, A.E., G.S. Myers, and B.W. Grunbaum. 1964. An electrophoretic survey of rattlesnake venoms. In: Leone, C.E. (ed.), Taxonomic Biochemistry and Serology. Ronald Press, New York. Pp. 171-191.

Li, Q., T.R. Colberg, and C.L. Ownby. 1993. Purification and characterization of two high molecular weight hemorrhagic toxins from Crotalus viridis viridis venom using monoclonal antibodies. Toxicon 31(6): 711-722. 
Li, Q. and C.L. Ownby. 1994. Cross reactivities of monoclonal antibodies against hemorrhagic toxins of Prairie rattlesnake (Crotalus viridis viridis) venom. Comparative Biochemistry and Physiology B Comparative Biochemistry and Molecular Biology 107(1): 51-59.

Lillywhite, H.B. 1982. Cannibalistic carrion ingestion by the rattlesnake, Crotalus viridis. Journal of Herpetology 16(1): 95.

Liu, C.Z. and T.F. Huang. 1997. Crovidisin, a collagen-binding protein isolated from snake venom of Crotalus viridis, prevents platelet: Collagen interaction. Archives of Biochemistry and Biophysics 337(2): 291-299.

Liu, C.Z., H.C. Peng, and T.F. Huang. 1995. Crotavirin, a potent platelet aggregation inhibitor purified from the venom of the snake Crotalus viridis. Toxicon 33(10): 1289-1298.

Loughry, W.J. 1988. Population differences in how black-tailed prairie dogs deal with snakes. Behavioral Ecology and Sociobiology 22(1): 61-67.

Luchtel, D.L. and K.V. Kardong. 1981. Ultrastructure of the lung of the rattlesnake, Crotalus viridis oreganus. Journal of Morphology 169(1): 29-47.

Ludlow, M.E. 1981. Observations on Crotalus v. viridis (rafinesque) and the herpetofauna of the Ken-Caryl Ranch, Jefferson County, Colorado. Herpetological Review 12(2): 50-52.

Ludwig, M. and H. Rahn. 1943. Sperm storage and copulatory adjustment in the prairie rattlesnake. Copeia 1943: 15-18.

Lynch, J.D. 1976. Venomous snakes. Nebraskaland 54 (3): 10-13, 47-48.

Macartney, J.M. 1985. The ecology of the northern pacific rattlesnake, Crotalus viridis oreganus, in British Columbia. M.S. Thesis. Victoria, B.C.: University of Victoria.

Macartney, J.M. 1989. Diet of the northern Pacific rattlesnake, Crotalus viridis oreganus, in British Columbia. Herpetologica 45: 299-304.

Macartney, J.M. and P.T. Gregory. 1988. Reproductive biology of female rattlesnakes (Crotalus viridis) in British Columbia. Copeia 1988: 47-57.

Macartney, J.M., P.T. Gregory, and M.B. Charland. 1990. Growth and sexual maturity of the western rattlesnake, Crotalus viridis, in British Columbia, (Canada). Copeia 1990(1): 528542.

Macartney, J.M., P. T. Gregory, and K. W. Larsen. 1988. A tabular survey of data on movements and home ranges of snakes. Journal of Herpetology 22:61-73.

Macartney, J.M., K.W. Larsen, and P.T. Gregory. 1989. Body temperatures and movements of hibernating snakes (Crotalus and Thamnophis) and thermal gradients of natural hibernacula. Canadian Journal of Zoology 67(1): 108-114.

Macartney, J.M. and B. Weichel. 1989. Prairie rattlesnake survey and management plan. Blue Jay News 82: 7-8.

Macartney, J.M. and B. Weichel. 1993. Status of the prairie rattlesnake and the eastern yellowbellied racer in Saskatchewan. Provincial Museum of Alberta Natural History Occasional Paper 19: 291-299.

Mackessy, S.P. 1988. Venom ontogeny in the Pacific rattlesnakes Crotalus viridis helleri and Crotalus viridis oreganus. Copeia 1988(1): 92-101.

Mackessy, S.P. 1996. Characterization of the major metalloprotease isolated from the venom of the Northern Pacific rattlesnake, Crotalus viridis oreganus. Toxicon 34(11-12): 1277-1285.

Maeda, N., N. Tamiya, T.R. Pattabhiraman, and Russell, F. E. 1978. Some chemical properties of the venom of the rattlesnake, Crotalus viridis helleri. Toxicon 16(5): 431-441.

Marion, K.R. and O.J. Sexton. 1984. Body temperatures and behavioral activities of hibernating prairie rattlesnakes, Crotalus viridis, in artificial dens. Prairie Naturalist 16(3): 111-116. 
Marti, C.D., K. Steenhof, M.N. Kochert, and J.S. Marks. 1993. Community trophic structure: the roles of diet, body size, and activity time in vertebrate predators. Oikos 67(1): 6-18.

Martin, J.H. and R.M. Bagby. 1972. Temperature-frequency relationship of the rattlesnake rattle. Copeia 1972: 482-485.

*Martin, P.R. 1980a. Terrestrial wildlife habitat inventory in southeastern Montana. Montana Department of Fish, Wildlife and Parks and Bureau of Land Management, Helena MT. 114p.

*Martin, P.R. 1980b. Terrestrial wildlife inventory in selected coal areas of Montana. Montana Department of Fish, Wildlife and Parks and Bureau of Land Management, Helena, MT. 84 p.

*Martin, P.R., K. Dubois and H.B. Youmans. 1981. Terrestrial wildlife inventory in selected coal areas, Powder River resources area final report. Montana Department of Fish, Wildlife and Parks and Bureau of Land Management, Helena, MT. 288 p.

Martinez, R.A., S.Y. Huang, and J.C. Perez. 1989. Antigenic relationships of fractionated western diamondback rattlesnake (Crotalus atrox) hemorrhagic toxins and other rattlesnake venoms as indicated by monoclonal antibodies. Toxicon 27(2): 239-246.

*Matthews, W.L. 1979. Wibaux-Beach wildlife baseline study - nongame species. Bureau of Land Management, Miles City, MT. 93 p.

*Matthews, W.L. 1981. Broadus-Pumpkin Creek baseline inventory - wildlife. Bureau of Land Management, Miles City, MT. 83 p.

*Maxell, B.A. 2004a. Amphibian and aquatic reptile inventories conducted on and around the Bitterroot National Forest 2000-2003. Report to Region 1 Office of the U.S. Forest Service, Bitterroot National Forest, Montana Department of Fish, Wildlife, and Parks, and Biological Resources Division of the U.S. Geological Survey. Missoula, MT: Montana Cooperative Wildlife Research Unit and Wildlife Biology Program, University of Montana. 128 p.

*Maxell, B.A. 2004b. Amphibian and aquatic reptile inventories conducted on and around the Thompson River 2003-2004. Report to Region 1 Office of the U.S. Forest Service and Plum Creek Timber Company. Missoula, MT: Montana Cooperative Wildlife Research Unit and Wildlife Biology Program. 83 p.

*Maxell, B.A. 2004c. Preliminary report on amphibian and aquatic reptile inventories conducted in the West Boulder River area during summer 2003. Report to Region 1 Office of the U.S. Forest Service, and the Montana Department of Fish, Wildlife, and Parks. Missoula, MT: Montana Cooperative Wildlife Research Unit and Wildlife Biology Program, University of Montana. $27 \mathrm{p}$.

*Maxell, B.A. 2004d. Preliminary report on amphibian and aquatic reptile inventories conducted on and around the Ashland District of the Custer National Forest in 2002 and 2004. Report to Ashland District of Custer Forest, Region 1 Office of the U.S. Forest Service, and Montana Department of Fish, Wildlife, and Parks. Missoula, MT: Montana Cooperative Wildlife Research Unit and Wildlife Biology Program, University of Montana. 93 p.

*Maxell, B.A. 2004e. Report on amphibian and aquatic reptile inventories conducted on and around the Beaverhead-Deerlodge National Forest 2001-2003. Report to Region 1 Office of the U.S. Forest Service, Beaverhead-Deerlodge National Forest, Montana Department of Fish, Wildlife, and Parks, Montana State Office of the Bureau of Land Management, and Montana Department of Environmental Quality. Missoula, MT: Montana Cooperative Wildlife Research Unit and Wildlife Biology Program, University of Montana. 260 p.

*Maxell, B.A. 2005a. Amphibian and aquatic reptile inventories conducted on and around lands administered by the Missoula Field Office of the Bureau of Land Management. Report to 
Missoula Field Office of the Bureau of Land Management. Montana Natural Heritage Program, Helena, MT and Montana Cooperative Wildlife Research Unit and Wildlife Biology Program, University of Montana, Missoula, MT. 53 p.

*Maxell, B.A. 2009. State-wide assessment of status, predicted distribution, and landscapelevel habitat suitability of amphibians and reptiles in Montana. Ph.D. Dissertation. Missoula, MT: Wildlife Biology Program, University of Montana. 294 p.

*Maxell, B.A. and D.G. Hokit. 1999. Amphibians and reptiles. Pp. 2.1-2.30. In: G. Joslin and H. Youmans (committee chairs). Effects of recreation on Rocky Mountain wildlife: a compendium of the current state of understanding in Montana. Helena, MT: Committee on Effects of Recreation on Wildlife, Montana Chapter of the Wildlife Society. 307 p.

*Maxell, B.A., J.K. Werner, P. Hendricks, and D. Flath. 2003. Herpetology in Montana: a history, status summary, checklists, dichotomous keys, accounts for native, potentially native, and exotic species, and indexed bibliography. Olympia, WA: Society for Northwestern Vertebrate Biology. Northwest Fauna 5: 1-138.

McCartney, M.J. and P.T. Gregory. 1988. Reproductive biology of female rattlesnakes (Crotalus viridis) in British Columbia. Copeia 1988(1): 47-58.

McCartney, M.J., K.W. Larson, and P.T. Gregory. 1989. Body temperatures and movements of hibernating snakes (Crotalus and Thamnophis) and thermal gradients of natural hibernacula. Canadian Journal of Zoology 67: 108-114.

*McEneaney, T. and J. Jensen. 1974. The reptiles and amphibians of the Charles M. Russell National Wildlife Range - 1974. Charles M. Russell National Wildlife Refuge. Lewistown, MT. 3 p.

Melcer, T. and D. Chiszar. 1989a. Strike-induced chemical preferences in prairie rattlesnakes (Crotalus viridis). Animal Learning and Behavior 17(3): 368-372.

Melcer, T. and D. Chiszar. 1989b. Striking prey creates a specific chemical search image in rattlesnakes. Animal Behaviour 67(3): 477-486.

Melcer, T., D. Chiszar, and H.M. Smith. 1990. Strike-induced chemical preferences in rattlesnakes: role of chemical cues arising from the diet of prey. Bulletin of the Maryland Herpetological Society 26(1): 1-4.

Melo, P.A. and C.L. Ownby. 1996. Different sensitivity of fast- and slow-twitch muscles to some snake venoms and myotoxins. Toxicon 34(6): 653-669.

Mesquita, L.C., H.S. Selistre, and J.R. Giglio. 1991. The hypotensive activity of Crotalus atrox (western diamondback rattlesnake) venom: Identification of its origin. American Journal of Tropical Medicine and Hygiene 44(3): 345-353.

Milius, S. 1999. Hey snake - rattle this! Science News 156: 237-239.

Miller, M.W., M.W. Wild, B.J. Baker, and A.T. Tu. 1989. Snakebite in captive Rocky Mountain elk (Cervus elaphus nelsoni). Journal of Wildlife Diseases 25(3): 392-396.

Moon, B.R. 2001. Muscle physiology and the evolution of the rattling system in rattlesnakes. Journal of Herpetology 35(3):497-500.

Moon, B.R., W. Kemper, K.E. Conley, L. Hartzler, and J.H. Hicks. 2000. How rattlesnakes rattle. Northwestern Naturalist 81(2):83.

*Mosimann, J.E. and G.B. Rabb. 1952. The herpetology of Tiber Reservoir area, Montana. Copeia 1952: 23-27.

*Moulton, G. (ed.). 1983. The journals of the Lewis and Clark expedition. University of Nebraska Press. Lincoln, Nebraska. Volumes 4, 5, 8, 9 and 10. 
*[MTNHP] Montana Natural Heritage Program. 2006. Point Observation Database. Montana Natural Heritage Program, Helena, MT. Accessed April 24, 2006.

*Murphy, R.W. and C.B. Crabtree. 1985. Evolutionary aspects of isozyme patterns, number of loci, and tissue-specific gene expression in the prairie rattlesnake Crotalus viridis viridis. Herpetologica 41(4): 451-470.

Murphy, R.W. and C.B. Crabtree. 1988. Genetic identification of a natural hybrid rattlesnake: Crotalus scutulatus scutulatus x C. viridis viridis. Herpetologica 44(1): 119-123.

O'Connell, B., D. Chiszar, and H.M. Smith. 1981a. Chemosensory searching after predatory and defensive strikes in prairie rattlesnakes (Crotalus v. viridis). Journal of the ColoradoWyoming Academy of Science 13(1): 52.

O'Connell, B., D. Chiszar, and H.M. Smith. 1981b. Effect of poststrike disturbance on strikeinduced chemosensory searching in the prairie rattlesnake (Crotalus v. viridis). Behavioral Neural Biology 32(3): 343-349.

O'Connell, B., D. Chiszar, and H.M. Smith. 1982. Single vs. multiple predatory strikes by prairie rattlesnakes (Crotalus viridis). Bulletin of the Maryland Herpetological Society 18(1): 1-6.

O'Connell, B., T. Poole, P. Nelson, H.M. Smith, and D. Chiszar. 1982. Strike-induced chemosensory searching by prairie rattlesnakes (Crotalus v. viridis) after predatory and defensive strikes which made contact with mice (Mus musculus). Bulletin of the Maryland Herpetological Society 18(3): 152-160.

*[OEAR] Olson Elliot and Associates Research. 1985. 1983-1984 Wildlife monitoring report for the CX Ranch project. Olson Elliot and Associates Research. Helena, MT.

Owings, D.H. and R.G. Coss. 1977. Snake mobbing by California ground squirrels: adaptive variation and ontogeny. Behaviour 62(1-2): 50-69.

Owings, D.H., D.F. Hennessy, D.W. Leger, and A.B. Gladney. 1986. Different functions of "alarm" calling for different time scales: A preliminary report on ground squirrels. Behaviour 99(1-2): 101-116.

Ownby, C.L. and T.R Colberg. 1986. Ability of polyvalent (Crotalidae) antivenom to neutralize local myonecrosis induced by Crotalus atrox venom. Toxicon 24(2): 201-203.

Ownby, C.L. and T.R. Colberg. 1987. Characterization of the biological and immunological properties of fractions of prairie rattlesnake (Crotalus viridis viridis) venom. Toxicon 25(12): 1329-1342.

Ownby, C.L. and T.R. Colberg. 1990. Comparison of the immunogenicity and antigenic composition of several venoms of snakes in the family Crotalidae. Toxicon 28(2): 189-200.

Ownby, C.L., T.R. Colberg and G.V. Odell. 1986. In vivo ability of antimyotoxin a serum plus polyvalent (Crotalidae) antivenom to neutralize prairie rattlesnake (Crotalus viridis viridis) venom. Toxicon 24(2): 197-200.

Ownby, C.L., V.O. George, and R.D.G. Theakston. 1983. detection of antibodies to myotoxin a and prairie rattlesnake (Crotalus viridis viridis) venom in three antisera using enzyme-linked immunosorbent assay and immunodiffusion. Toxicon 21(6): 849-855.

Ownby, C.L., W.M. Woods, and G.V. Odell. 1979. Antiserum to myotoxin from prairie rattlesnake (Crotalus viridis viridis) venom. Toxicon 17(4): 373-380.

Parker, W.S. and W.S. Brown. 1974. Mortality and weight changes of Great Basin rattlesnakes (Crotalus viridis) at a hibernaculum in northern Utah. Herpetologica 30(3): 234-239.

Parkinson, C.L. 1999. Molecular systematics and biogeographical history of pitvipers as determined by mitochondrial ribosomal DNA sequences. Copeia 1999: 576-586. 
Pendlebury, G.B. 1972. Tagging and remote identification of rattlesnakes. Herpetologica 28(4): 349-350.

Pendlebury, G.B. 1976. Congenital defects in the brood of a prairie rattlesnake. Canadian Journal of Zoology 54(11): 2023-2025.

Pendlebury, G.B. 1977. Distribution and abundance of the prairie rattlesnake, Crotalus viridis viridis, in Canada. Canadian Field Naturalist 91(2): 122-129.

Perelman, J., G. Hobika, H.M. Smith, and D. Chiszar. 1991. Responses of several taxa of snakes to mammalian blood. Journal of the Colorado-Wyoming Academy of Science 23(1): 24.

Peterson, C.R. and V.A. Cobb. 1991. Thermal ecology of hibernation in great basin rattlesnakes. Northwest Scientist 65(2): 70.

Pfaffenberger, G.S., N.M. Jorgensen, and D.D. Woody. 1989. Parasites of prairie rattlesnakes (Crotalus viridis viridis) and gopher snakes (Pituophis melanoleucus sayi) from the eastern high plains of New Mexico (USA). Journal of Wildlife Diseases 25(2): 305-306.

Pierce, B.M., W.S. Longland, and S.H. Jenkins. 1992. Rattlesnake predation on desert rodents: microhabitat and species-specific effects on risk. Journal of Mammalogy 73(4): 859-865.

Place, A.J., and C.I. Abramson. 2004. A quantitative analysis of the ancestral area of rattlesnakes. Journal of Herpetology 38(1):151-156.

Pook, C. E., W. Wuster, and R. S. Thorpe. 2000. Historical biogeography of the western rattlesnake (Serpentes: Viperidae: Crotalus viridis), inferred from mitochondrial DNA sequence information. Molecular Phylogenetics and Evolution 15: 269-282.

Pool, W.R. and A.L. Bieber. 1981. Fractionation of midget faded rattlesnake (Crotalus viridis concolor) venom: lethal fractions and enzymatic activities. Toxicon 19(4): 517-527.

Poran, N.S., R.G. Coss, and E. Benjamini. 1987. Resistance of California ground squirrels (Spermophilus beecheyi) to the venom of the northern Pacific rattlesnake (Crotalus viridis oreganus): a study of adaptive radiation. Toxicon 25(7): 767-777.

Posson, M.C. 1979. Quantitative and qualitative characteristics of the rattle sound of three species of rattlesnakes. M.A. Thesis. California State University Fullerton. 88p.

Powers, A. 1972. An instance of cannibalism in captive Crotalus viridis helleri with a brief review of cannibalism in rattlesnakes. Bulletin of the Maryland Herpetological Society 8(3): 60-61.

Powers, A. 1973. A review of the purpose of the rattle in Crotalids as a defensive diversionary mechanism. Bulletin of the Maryland Herpetological Society 9(2): 30-32.

*[PRESI] Powder River Eagle Studies Incorporated. 1998a. Big Sky Mine 1997 wildlife monitoring studies. Powder River Eagle Studies Incorporated. Gillete, WY.

*[PRESI] Powder River Eagle Studies Incorporated. 1998b. Spring Creek Mine 1997 wildlife monitoring studies. Powder River Eagle Studies Incorporated. Gillete, WY.

Preston, W.B. 1964. The importance of the facial pit of the northern Pacific rattlesnake (Crotalis viridis oreganus) under natural conditions in southern British Columbia. M.S. Thesis, University of British Columbia.

Prior, K.A., and P.J. Weatherhead. 1994. Response of free-ranging eastern Massasauga rattlesnakes to human disturbance. Journal of Herpetology. 28(2): 255-257.

Promroy, C., P. Langer, and D. Chiszar. 1990. Strike-induced chemosensory searching in rattlesnakes: tests of several alternative explanations. Journal of the Colorado-Wyoming Academy of Science 22(1): 5. 
Radcliffe, C.W., D. Chizar, and B. O'Connell. 1980. Effects of prey size on post-strike behavior in rattlesnakes (Crotalis durissus, C. enyo, and C. viridis). Bulletin of the Psychonic Society 16: 449-450.

Radcliffe, C.W., K. Estep, T. Boyer, and D. Chiszar. 1986. Stimulus control of predatory behavior in red spitting cobras (Naja mossambica pallida) and prairie rattlesnakes (Crotalus viridis viridis). Animal Behaviour 34(3): 804-814.

Rafinesque, C.S. 1818. American Monthly Magazine Critical Review. Vol. 4, No. 1, Nov. p. 41.

Ragsdale, F.R. and R.L. Ingermann. 1991. Influence of pregnancy on the oxygen affinity of red cells from the northern Pacific rattlesnake Crotalus viridis oreganus. Journal of Experimental Biology 159: 501-505.

Rahn, H. 1942. The reproductive cycle of the prairie rattler, Crotalus viridis. Copeia 1942: 233-240.

*Rauscher, R.L. 1998. Amphibian and reptile survey on selected Montana Bureau of Reclamation impoundments. Montana Department of Fish, Wildlife and Parks, Nongame Program, Bozeman, MT. 24 p.

*Reading, R.P., S.R. Beissinger, J.J. Grenston, and T.W. Clark. 1989. Attributes of black-tailed prairie dog colonies in northcentral Montana, with management recommendations for the conservation of biodiversity. Pp. 13-28. In: T.W. Clark, D. Hinckley, and T. Rich (eds). The prairie dog ecosystem: managing for biodiversity. Montana Bureau of Land Management, Wildlife Technical Bulletin No. 2.

Reber, D.L. and A.S. Reber. 1994. Position paper regarding rattlesnake roundups. M.S. Thesis, Kansas Herpetological Society. 17 p.

Redder, A.J., D. Duvall, M. Goode, and B.M. Graves. 1986. Daily and seasonal activity patterns in the prairie rattlesnake Crotalus viridis viridis, in Wyoming. American Zoologist 26(4): 104A.

Reed, H. 1996. Review of rattlesnake exploitation needed. Traffic USA 15(2): 1-3.

Reed, R.N. 2003. Courtship and copulation in the Grand Canyon Rattlesnake (Crotalus viridis abyssus). Herpetological Review 35(1):111-112.

Reed, R. N. and M. E. Douglas. 2002. Ecology of the Grand Canyon rattlesnake (Crotalus viridis abyssus) in the Little Colorado River canyon, Arizona. Southwestern Naturalist 47: 30-39.

*Reichel, J.D. 1995a. Preliminary amphibian and reptile survey of the Lewis and Clark National Forest: 1994. Helena, MT: Montana Natural Heritage Program. 92 p.

*Reichel, J.D. 1995b. Preliminary amphibian and reptile survey of the Sioux District of the Custer National Forest: 1994. Montana Natural Heritage Program, Helena, MT. 75 p.

*Reichel, J.D. 1996. Preliminary amphibian and reptile survey of the Helena National Forest: 1995. Helena, MT: Montana Natural Heritage Program. 87 p.

*Reichel, J.D. 1997. Amphibian, reptile and northern bog lemming survey on the Rocky Mountain Front: 1996. Montana Natural Heritage Program, Helena, MT. 81 p.

Reinert, H.K. 1990. A profile and impact assessment of organized rattlesnake hunts in Pennsylvania, (USA). Journal of the Pennsylvania Academy of Sciences 64(3): 136-144.

Reinert, H.K. 1992. Radiotelemetric field studies of pitvipers: data acquisition. In: Campbell, J.A. and E.D. Brodie Jr. (eds.), Biology of the Pitvipers. Selva, Tyler, Texas. Pp. 185-197.

Reinert, H.K. and R.R. Rupert, Jr. 1999. Impacts of translocation on behavior and survival of timber rattlesnakes, Crotalus horridus. Journal of Herpetology 33(1): 45-61. 
Riedle, D. and P.K. Saunders. 1994. Comparison of rattling frequency at varying temperatures among different species of rattlesnakes. Journal of the Colorado-Wyoming Academy of Science 26(1): 29.

Robinson, B. and K.V. Kardong. 1989. Methods for relocation of prey for northwest rattlesnake, Crotalus viridis oreganus. Northwest Scientist 63(2): 71.

Robinson, B.G. and K.V. Kardong. 1991. Relocation of struck prey by venomoid (venom-less) rattlesnakes, Crotalus viridis oreganus. Bulletin of the Maryland Herpetological Society 27(1): 23-30.

Rockhill, A.W. and K.V. Kardong. 1994. Aging in snakes: results of long-term captivity on rattlesnake (Crotalus viridis oreganus) predatory behavior. Zoo Biology 13(6): 537-544.

*Rodgers, T.L., and W.L. Jellison. 1942. A collection of amphibians and reptiles from western Montana. Copeia 1942(1): 10-13.

*Roedel, M.D. and P. Hendricks. 1998a. Amphibian and reptile survey on the Bureau of Land Management Lewistown District: 1995-1998. Montana Natural Heritage Program, Helena, MT. $53 \mathrm{p}$.

*Roedel, M.D. and P. Hendricks. 1998b. Amphibian and reptile inventory on the Headwaters and Dillon Resource Areas in conjunction with Red Rocks Lakes National Wildlife Refuge: 1996-1998. Montana Natural Heritage Program, Helena, MT. 46 p.

Rosen, P.C., and C.H. Lowe. 1994. Highway mortality of snakes in the Sonoran desert of southern Arizona. Biological Conservation. 68: 143-148.

Rowe, M.P. 1985. California ground squirrels and their burrow coinhabitants: communicatory coevolution between predators and prey. Ph.D. Dissertation. University of California Davis. $110 \mathrm{p}$.

Rowe, M.P. and D.H. Owings. 1978. The meaning of the sound of rattling by rattlesnakes to California ground squirrels. Behaviour 66(3-4): 252-267.

Rowe, M.P. and D.H. Owings. 1990. Probing, assessment, and management during interactions between ground squirrels and rattlesnakes. Part 1: risks related to rattlesnake size and body temperature. Ethology 86(3): 237-249.

Rowe, M.P. and D.H. Owings. 1996. Probing, assessment and management during interactions between ground squirrels (Rodentia: Sciuridae) and rattlesnake (Squamata: Viperidae): 2: Cues afforded by rattlesnake rattling. Ethology 102(10): 856-874.

Ruben, J.A. 1979. Blood physiology during activity in the snakes /masticophis flagellum/ (colubridae) and /Crotalus viridis/ (crotalidae). Comparative Biochemistry and Physiology A 64(4): 577-580.

Rudolph, D.C., S.J. Burdorf, R.N. Conner, and J.G. Dickson. 1998. The impact of roads on the timber rattlesnake (Crotalus horridus), in eastern Texas. Pp. 236-240. In: G.L. Evink, P. Garrett, D. Zeigler and J. Berry (eds.) Proceedings of the international conference on wildlife ecology and transportation. February 10-12, 1998. Fort Meyers, Florida.

Russell, F.E., T.R. Pattabhiraman, and R.C. Schaeffer. 1978. Some properties of the venom of Crotalus viridis helleri. Toxicon 16(5): 425.

Russell, F.E., T.R. Pattabhiraman, R.C. Schaeffer, H. Gonzales, N. Tamiya, and N. Maeda. 1978. Some properties of the venom of Crotalus viridis helleri. Periodicals of Biology 80(suppl. 1): 51-53.

Samejima, Y., Y. Aoki, and D. Mebs. 1991. Amino acid sequence of a myotoxin from venom of the eastern diamondback rattlesnake (Crotalus adamanteus). Toxicon 29(4-5): 461-468. 
Schaeffer. R.C. Jr., C. Briston, S.M. Chilton, and R.W. Carlson. 1984. Hypotensive and hemostatic properties of rattlesnake (Crotalus viridis helleri) venom and venom fractions in dogs. Journal of Pharmacology and Experimental Therapeutics 230(2): 393-398.

Schaeffer, R.C. Jr., H. Randall, J. Resk, and R.W. Carlson. 1988. ELISA of size-selected crotalid venom antigens by Wyeth's polyvalent antivenom. Toxicon 36(1): 67-76.

Schmidt, D.F., W.K. Hayes, and F.E. Hayes. 1993. Influence of prey movement on the aim of predatory strikes of the western rattlesnake (Crotalus viridis). Great Basin Naturalist 53(2): 203-206.

Schroeder, D.M. 1981. Retinal afferents and efferents of an infrared sensitive snake, Crotalus viridus. Journal of Morphology 170(1): 29-42.

Schuett, G.W. 1992. Is long-term sperm storage an important component of the reproductive biology of temperate pitvipers? In: Campbell, J.A. and E.D. Brodie Jr. (eds.), Biology of the Pitvipers. Selva, Tyler, Texas. Pp. 169-184.

Schuett, G.W. and F. Kraus. 1982. Crotalus viridis concolor (midget faded rattlesnake). Coloration. Herpetological Review 13(1): 17-18.

Schuett, G.W., P.A. Buttenhoff, and D. Duvall. 1993. Corroborative evidence for the lack of spring-mating in certain populations of prairie rattlesnakes, Crotalus viridis. Herpetological Natural History 1(1): 101-106.

*Scow, K.L. 1980. Terrestrial wildlife survey American Colloid study area Phillips County, Montana. Western Technology and Engineering, Inc., Helena, MT.

Scudder, K.M. 1982. Mechanisms mediating the sequential aspects of rattlesnake predatory behavior. Unpubl. Ph.D. Dissertation, University of Colorado, Boulder.

Scudder, K.M. and D. Chiszar. 1977. Effects of six visual stimulus conditions on defensive and exploratory behavior in two species of rattlesnakes. Psychological Record 27(3): 519-526.

Scudder, K.M., D. Chiszar, and H.M. Smith. 1992. Strike-induced chemosensory searching and trailing behaviour in neonatal rattlesnakes. Animal Behaviour 44(3): 574-576.

Scudder, K.M., D. Chiszar, H.M. Smith, and T. Melcer. 1988. Response of neonatal prairie rattlesnakes (Crotalus viridis) to conspecific and heterospecific chemical cues. Psychological Record 38(4): 459-472.

Sehman, R.W. 1977. Hibernaculum dynamics of the great basin rattlesnake (Crotalus viridis lutosus). M.S. Thesis, Idaho State University 66p.

Seippel, A.J. 1988. Rattlesnake round-ups. Oklahoma Herpetological Society Newsletter 3: 16.

Sexton, O.J. and K.R. Marion. 1981. Experimental analysis of movements by prairie rattlesnakes, Cotalus viridis, during hibernation. Oecologia 51(1): 37-41.

Shaw, C.E. 1948. The male combat "dance" of some crotalid snakes. Herpetologica 4: 137145.

Sisk, N.R. and J.F. Jackson. 1997. Tests of two hypotheses for the origin of the crotaline rattle. Copeia 1997: 485-495.

Slowinski, J.B. and S.L. Rasmussen. 1985. Crotalus viridis viridis (prairie rattlesnake). Coloration. Herpetological Review 16(1): 29.

Smith, H.M., G.A. Hammerson, and C. Ramotnik. 1993. Crotalus viridis viridis (prairie rattlesnake). Herpetological Review 24(4): 156.

Smith, T.L. and K.V. Kardong. 2000. Absence of polarity perception by rattlesnakes of envenomated prey trails. Journal of Herpetology 34(4): 621-624. 
Smith, T.L., K.V. Kardong, and P.A. Lavin-Marcio. 2000. Persistence of trailing behavior: Cues involved in poststrike behavior by the rattlesnake (Crotalus viridis oreganos). Behaviour 137(6): 691.

Speake, D.W. and R.H. Mount. 1973. Some possible ecological effects of "rattlesnake roundups" in the southeastern coastal plain. Southeastern Association of Game and Fish Commissioners. 6 pp.

*St. John, A. 2002. Reptiles of the Northwest: California to Alaska; Rockies to the Coast. Renton, WA: Lone Pine Publishing. 272 p.

Stafford, D.P., F.W. Plapp, Jr., and R.R. Fleet. 1976. Snakes as indicators of environmental contamination: relation of detoxifying enzymes and pesticide residues to species occurrence in three aquatic ecosystems. Archives of Envirornmental Contamination and Toxicology. 5: $15-27$.

Stanford, L.R. 1979. The neuroanatomy and neurophysiology of the nucleus of the lateral descending trigeminal tract: a nucleus in the infrared system of the rattlesnake, Crotalus viridis. Ph.D. Dissertation, University of Illinois (Urbana-Champaign). 176 p.

Stark, M.A. 1984. Prairie rattlesnake drinking water. Blue Jay 42(4): 195-196.

Stark, M.A. 1985. A simple technique for trapping prairie rattlesnakes during spring emergence. Herpetological Review 16(3): 75,77.

Stark, M.A. 1986a. Implanting long-range transmitters in prairie rattlesnakes, Crotalus $v$. viridis. Herpetological Review 17(1): 17-18.

Stark, M.A. 1986b. Overwintering of an ambystomid salamander in a prairie rattlesnake hibernaculum. Herpetological Review 17(1): 7.

Stark, M.A. 1987. An active prairie rattlesnake den taken over by foxes. Blue Jay 45(1): 53-54.

Starrett, B.L. 1993. Crotalus viridis helleri (southern Pacific rattlesnake). Herpetological Review 24(3): 109.

*Stebbins, R.C. 2003. A field guide to western reptiles and amphibians. 3rd edition. New York, NY: Houghton Mifflin Co. 533 p.

Steehouder, T. 1991. Growth of the northern rattlesnakes. Litteratura Serpentium English Edition 11(4): 74-77.

Stejneger, L. and T. Barbour. 1943. A check list of North American amphibians and reptiles. 5th edition. Bulletin of the Museum of Comparative Zoology 93(1): 1-260.

Stille, B. 1987. Dorsal scale microdermatoglyphics and rattlesnake (Crotalus and Sistrurus) phylogeny (Reptilia: Viperidae: Crotalidae). Herpetologica 43: 98-104.

Straight, R.C., J.L.Glenn, T.B. Wolt, and M.C. Wolfe. 1991. Regional differences in content of small basic peptide toxins in the venoms of Crotalus adamanteus and Crotalus horridus. Comparative Biochemistry and Physiology B Comparative Biochemistry 100(1): 51-58.

Sweet, S.S. 1985. Geographic variation, convergent crypsis and mimicry in gopher snakes (Pituophis melanoleucus) and western rattlesnakes (Crotalus viridis). Journal of Herpetology 19(1): 55-67.

*Sweet, W.T. 1953. Rattlesnake roundup. Montana Wildlife 3(2): 27-28. Montana Fish and Game Department, Helena, MT.

Sweet, W.T. 1954. I've killed 5000 rattlers. Outdoor Life 113(2):54-55, 110-112.

Taggart, T.W. 1992. Crotalus viridis (western rattlesnake). Herpetological Review 23(3): 91. Taggart, T.W. and C.J. Schmidt. 2004. Crotalus viridis (Prairie rattlesnake). New maximum size for entire range. Journal of Kansas Herpetology 12:18. 
Tatano, P.M. 1970. Taxonomic electrophoresis of crotaline venom. M.S. Thesis, University of Dayton, Ohio.

Theodoratus, D.H. and D. Chiszar. 2000. Habitat selection and prey odor in the foraging behavior of western rattlesnakes (Crotalus viridis). Behaviour 137(1): 119-135.

Thomas, R.G. and F.H. Pough. 1979. The effects of rattlesnake venom on the digestion of prey. Toxicon 17: 221-228.

*Thompson, L.S. and P.S. Nichols. 1982. Circle West wildlife monitoring study; fourth annual report for period March 1, 1981 - May 31, 1982. Circle West Technical Report No. 10. Montana Department of Natural Resources and Conservation, Helena, MT.

Thornton, R.M. 1980. Comparison of oxygen storage capacity and tolerance of submergence of a non-aquatic reptile and an aquatic reptile. M.S. Thesis. University of Idaho. 17p.

*Timken, R. No Date. Amphibians and reptiles of the Beaverhead National Forest. Dillon, MT: Western Montana College. 16 p.

*Timmerman, W. 2004. Rattlesnake! Montana Outdoors. May/June 2004.

Towers, S.R. and R.G. Coss. 1990. Confronting snakes in the burrow: snake-species discrimination and antisnake tactics of two California ground squirrel populations. Ethology 84(3): 177-192.

Towers, S.R. and R.G. Coss. 1991. Antisnake behavior of Columbian ground squirrels (Spermophilus columbianus). Journal of Mammalogy 72(4): 776-783.

Tracy, M. and D. Chiszar. 1990. Strike-induced chemosensory searching in male and female rattlesnakes. Journal of the Colorado-Wyoming Academy of Science 22(1): 5.

Tu, A.T. 1982. Chemistry of rattlesnake venoms. In: Tu, A.T. (ed.), Rattlesnake Venoms: Their Action and Treatment. Marcel-Dekker, Inc., New York. Pp. 247-312.

*Turner, F.B. 1951. A checklist of the reptiles and amphibians of Yellowstone National Park with incidental notes. Yellowstone Nature Notes 25(3): 25-29.

*Turner, F.B. 1953. Rattlesnake near Stevens Creek. Yellowstone Nature Notes 27(6): 72.

*Turner, F.B. 1955. Reptiles and amphibians of Yellowstone National Park. Yellowstone Interpretive Series No. 5. Yellowstone Library and Museum Association. Yellowstone National Park, WY. 40 p.

Van Riper, W. 1955. How a rattlesnake strikes. Natural History 64: 308-311.

Vieler, E., W. Baumgartner, W. Herbst, and G. Kohler. 1994. Characterization of a reovirus isolate from a rattle snake, Crotalus viridis, with neurological dysfunction. Archives of Virology 138(3-4): 341-344.

*Vitt, L.J., J.P. Caldwell, and D.B. Shepard. 2005. Inventory of amphibians and reptiles in the Billings Field Office Region, Montana. Sam Noble Oklahoma Museum of Natural History and Department of Zoology, University of Oklahoma, Norman, OK. 33 p.

Vorhies, C.T. 1948. Food items of rattlesnakes. Copeia 1948: 303.

*[VTNWI] VTN Wyoming Incorporated. No Date. Second year's analysis of terrestrial wildlife on proposed mine access and railroad routes in southern Montana and northern Wyoming, March 1979 - February 1980. VTN Wyoming Incorporated. Sheridan, WY. 62 p.

*Waage, B.C. 1998. Western Energy Company Rosebud Mine 1997 annual wildlife monitoring report December 1, 1996 to November 30, 1997 survey period. Western Energy Company, Colstrip, MT.

*Walcheck, K. 1976. Montana Wildlife 170 years ago. Montana Outdoors 7(4): 15-30.

Wallace, R.L. and L.V. Diller. 1990. Feeding ecology of the rattlesnake, Crotalus viridis oreganus, in northern Idaho (USA). Journal of Herpetology 24(3): 246-253. 
Wallace, R.L. and L.V. Diller. 2001. Variation in emergence, egress, and ingress among lifehistory stages and sexes of Crotalus viridis oreganus in Northern Idaho. Journal of Herpetology 35(4): 583-589.

Warnock, N., R. Stoops, C. Radcliffe, D. Chiszar, and H.M. Smith. 1983. Prey-directed behavior in cobras and rattlesnakes. Journal of the Colorado-Wyoming Academy of Sciene 15(1): 47.

Warwick, C. 1990. Disturbance of natural habitats arising from rattlesnake round-ups. Environmental Conservation 17: 172-174.

Warwick, C., C. Steedman, and T. Halford. 1991. Rattlesnake collection drives - their implications for species and environmental conservation. Oryx 25: 39-44.

Watson, S.M. and A.P. Russell. 1997. Status of the Prairie Rattlesnake (Crotalus viridis viridis) in Alberta. Alberta Wildlife Status Report No. 6. 26 p.

*Watson, W.V. 1951. Rattlesnake. Yellowstone Nature Notes 25(4): 47.

Weaver, R.E. and M.E. Lahti. 2005. Diet of the Northern Pacific rattlesnake (Crotalus viridis oreganus) in the Yakima River canyon of Washington State. Abstract. Northwestern Naturalist 86:121.

Weinstein. S.A., S.A. Minton, and C.E. Wilde. 1985. The distribution among ophidian venoms of a toxin isolated from the venom of the Mojave rattlesnake (Crotalus scutulatus scutulatus). Toxicon 23(5): 825-844.

Weir, J. 1992. The Sweetwater rattlesnake round-up: A case study in environmental ethics. Conservation Biology 6: 116-127.

*Weisel, G.F. 1952. Animal names, anatomical terms, and some ethnozoology of the Flathead Indians. Journal of the Washington Academy of Sciences 42(11): 345-355.

Welch, S. 1990. A comparison of the structure and properties of serum transferrin from 17 animal species. Comparative Biochemistry and Physiology B 97(3): 417-427.

Wellborn, S.G. and C. David. 1979. Exploratory response by Crotalid snakes in the presence of novel and familiar odors. Journal of the Colorado-Wyoming Academy of Science 11 (1): 8182.

*Werner, J.K., B.A. Maxell, P. Hendricks, and D. Flath. 2004. Amphibians and reptiles of Montana. Missoula, MT: Mountain Press Publishing Company. 262p.

*Werner, J.K. and J.D. Reichel. 1994. Amphibian and reptile survey of the Kootenai National Forest: 1994. Montana Natural Heritage Program, Helena, MT. 104 p.

*Werner, J.K. and J.D. Reichel. 1996. Amphibian and reptile monitoring/survey of the Kootenai National Forest: 1995. Montana Natural Heritage Program, Helena, MT. 115 p.

*Werner, J.K. and T. Plummer. 1994. Amphibian and reptile survey of the Flathead Indian Reservation 1993-1994. Salish Kootenai College, Pablo, MT. 55 p.

*Werner, J.K. and T. Plummer. 1995. Amphibian monitoring program on the Flathead Indian Reservation 1995. Salish Kootenai College, Pablo, MT. 46 p.

*Werner, J.K., T. Plummer, and J. Weaselhead. 1998. Amphibians and reptiles of the Flathead Indian Reservation. Intermountain Journal of Sciences 4(1-2): 33-49.

*[WESCO] Western Ecological Services Company. 1983a. Wildlife inventory of the Knowlton known recoverable coal resource area, Montana. Western Ecological Services Company, Novato, CA. 107 p.

*[WESCO] Western Ecological Services Company. 1983b. Wildlife inventory of the Southwest Circle known recoverable coal resource area, Montana. Western Ecological Services Company, Novato, CA. 131 p. 
*[WESTECH] Western Technology and Engineering Incorporated. 1982. Wildlife reconnaissance, Cypress International Yellowstone Mine. Western Technology and Engineering, Inc., Helena, MT.

*[WESTECH] Western Technology and Engineering Incorporated. 1993. Diamond Hill project wildlife baseline survey. Western Technology and Engineering, Inc., Helena, MT.

*[WESTECH] Western Technology and Engineering Incorporated. 1998. Wildlife monitoring Absaloka Mine area 1997. Western Technology and Engineering, Inc., Helena, MT.

White, F.N. and R.C. Lasiewski. 1971. Rattlesnake denning: theoretical considerations on winter temperatures. Journal of Theoretical Biology 30: 553-557.

Widmer, E.A. and H.D. Specht. 1991. Asynchronous capsule formation in the gastrointestinal tract of the prairie rattlesnake (Crotalus viridis viridis) induced by Mesocestoides sp. tetrathyridia. Journal of Wildlife Diseases 27(1) 1991: 161-163.

Widmer, E.A. and H.D. Specht. 1992. Isolation of asexually proliferative tetrathyridia (Mesocestoides sp.) from the Southern Pacific rattlesnake (Crotalus viridis helleri) with additional data from two previous isolates from the Great Basin fence lizard (Sceloporus occidentalis longipes). Journal of Parasitology 87(5): 921-923.

*Wied, M.P. 1843. Travels in the interior of North America by Maximilian, Prince of Wied. With numerous engravings on wood, and a large map. Translated from the German by H. Evans Lloyd. To accompany the original series of eighty-one elaborately-coloured plates. Size, imperial folio. Ackerman and Co., London, England. 520 p.

*Wied, M.P. 1865. Verzeichniss der reptilien, welche auf einer reise in nordlichen America beobachtet wurden, von Maximilian, Prinzen zu Wied. Eigengangen bei der Akademie am 1, Juni 1865. Druck von E. Blochmann und Sohn, Dresden, Germany. 141 p.

Wingert, W.A., T.R. Pattabhiraman, D. Powers, and F.E. Russell. 1981. Effect of a rattlesnake venom (Crotalus viridis helleri) on bone marrow. Toxicon 19(1): 181-183.

Yancey, F.D., II. 1996. Crotalus viridis viridis (prairie rattlesnake). Herpetological Review 27(3): 154.

*Yarrow, H.C. 1882. Check list of North American reptilia and batrachia, with catalogue of specimens in the U.S. National Museum. United States National Museum Bulletin 24. 249 p. 


\title{
SPECIES ACCOUNTS FOR AMPHIBIAN AND REPTILE SPECIES POTENTIALLY PRESENT IN MONTANA
}

\author{
Great Basin Spadefoot (Spea intermontana)
}

\section{Status Overview}

The Great Basin spadefoot (Spea intermontana) has been reported as occurring in southwest Montana by Black (1970). In addition, in a review of amphibians and reptiles on the Beaverhead National Forest in the 1970's Timken (No Date) reported observation records for the plains spadefoot (Spea bombifrons) in the vicinity of Dillon, more than 100 miles southeast of the nearest reported locality for $S$. bombifrons. During the summer of 2000 spadefoot toads were heard calling on private lands at several sites immediately north of Dillon. Due to the brevity of the visit land owners were not contacted and individuals were unable to be collected. However, breeding calls were identical to those of $S$. bombifrons and were slower than those of $S$. intermontana (Bryce Maxell, pers. obs.). Thus, it is likely that the spadefoots in the Dillon area are the plains spadefoot. However, it is possible that the Great Basin spadefoot may be present in southwest Montana as well. Nussbaum et al. (1983) show records of the Great Basin spadefoot north of the Snake River Plain approximately 100 miles south of Dillon and seemingly suitable habitat occurs over much of the intervening area. More thorough surveys and collections of individuals throughout southwest Montana will allow the species present in the Dillon area to be identified with certainty and will provide more support for the presence or absence of the Great Basin spadefoot. One factor hindering the detection of either species is their cryptic nature. Spadefoots spend a majority of their life underground and are usually only active on the surface at night and after heavy rains. Their loud distinctive breeding calls after heavy rains in the summer and the presence of larvae in ephemeral water bodies offer the best chance of detection.

\section{Identification}

\section{Eggs:}

Laid in smaller clusters about 15 to $20 \mathrm{~mm}$ in diameter containing 20 to 40 eggs (Nussbaum et al. 1983). Egg morphology has not been described in detail (Hall 1998), but would be expected to be similar to those of the plains spadefoot. Corkran and Thoms (1996) describe each ovum as tan or gray above and cream below.

\section{Larvae:}

Dark gray, brown, or black dorsally and lighter irridescent gold with gold or brassy flecks ventrally (Hall 1998). Dorsal tail fin is clear with dendritic pigmentation and ventral tail fin is clear anteriorly and dendritically pigmented posteriorly (Hall 1998). Eyes are located dorsally. TL of 5-70 mm (Hall 1998).

Juveniles and Adults:

Pupil of the eye is vertical. A large and usually soft or glandular bump or boss is present between the eyes (Hall 1998). A single black digging "spade" is present on the soles of the hind feet. Dorsal color general matches the surroundings with a base color of gray, brown, or olive mottled with a darker color (Hall 1998). Four complete or broken lighter stripes are usually present laterally and dorsally and warts may be red or orange and located within dark brown or 
black spots or blotches (Hall 1998). Ventral color is light gray, cream, or white. SVL of 20-63 mm (Hall 1998).

Similar Species:

See account on the plains spadefoot. Adults of the plains spadefoot have a hard bony lump or "boss" present between the eyes (Hall 1998).

Habitat Use/Natural History

Found on or adjacent to sandy soils in sagebrush flats, shrublands, and pinon-juniper woodlands, and irrigated lands (Hall 1998, Hammerson 1999). Adults retreat to self excavated burrows in loose soils during periods when terrestrial conditions are not favorable (Nussbaum et al. 1983, Hammerson 1999). Adults are present on the surface on warm nights during damp and dry weather where they feed on a variety of insects (Nussbaum et al. 1983, Hammerson 1999). Breeding and egg deposition takes place in warm temporary (more rarely permanent) water bodies formed by extensive rains from May to July (Nussbaum et al. 1983, Hammerson 1999). Eggs hatch in about two days and larvae feed on both plant and animal matter until they metamorphose in 19 to 31 days (Hall 1998).

\section{Key References}

Baxter, G.T. and M.D. Stone. 1985. Amphibians and reptiles of Wyoming. Second Edition. Wyoming Game and Fish Department. 137 pp.

*Black, J.H. 1970. Amphibians of Montana. Montana Wildlife, Montana Fish and Game Commission. Animals of Montana Series 1970(1): 1-32.

*Brunson, R.B. 1955. Check list of the amphibians and reptiles of Montana. Proceedings of the Montana Academy of Sciences 15: 27-29.

Corkran, C.C. and C. Thoms. 2006. Amphibians of Oregon, Washington, and British Columbia. $2^{\text {nd }}$ Edition. Vancouver, B.C.: Lone Pine Publishing. 176 p.

Hall, J.A. 1998. Scaphiopus intermontanus. Catalogue of American Amphibians and Reptiles 650.1-650.17.

Hammerson, G.A. 1999. Amphibians and Reptiles in Colorado. Second Edition. University Press of Colorado and Colorado Division of Wildlife. $484 \mathrm{pp}$.

Leonard, W.P., H.A. Brown, L.L.C. Jones, K.R. McAllister and R.M. Storm. 1993. Amphibians of Washington and Oregon. Seattle Audubon Society: the trailside series. Seattle, Washington. $168 \mathrm{pp}$.

Matsuda, B.M., D.M. Green, and P.T. Gregory. 2006. Amphibians and reptiles of British Columbia. Victoria, B.C.: Royal British Columbia Museum. 266 p.

*Maxell, B.A. 2004. Report on amphibian and aquatic reptile inventories conducted on and around the Beaverhead-Deerlodge National Forest 2001-2003. Report to Region 1 Office of the U.S. Forest Service, Beaverhead-Deerlodge National Forest, Montana Department of Fish, Wildlife, and Parks, Montana State Office of the Bureau of Land Management, and Montana Department of Environmental Quality. Missoula, MT: Montana Cooperative Wildlife Research Unit and Wildlife Biology Program, University of Montana. 260 p.

*Maxell, B.A., J.K. Werner, P. Hendricks, and D. Flath. 2003. Herpetology in Montana: a history, status summary, checklists, dichotomous keys, accounts for native, potentially native, and exotic species, and indexed bibliography. Olympia, WA: Society for Northwestern Vertebrate Biology. Northwest Fauna 5: 1-138. 
Nussbaum, R.A., E.D. Brodie, and R.M. Storm. 1983. Amphibians and reptiles of the Pacific Northwest. University Press of Idaho, Moscow, Idaho. 332 pp.

*Peterson, C.R., C.J. Askey, and D.A. Patla. 1993. Amphibians and reptiles along the Grand Loop and Fountain Freight Roads between Madison Junction and Biscuit Basin in Yellowstone National Park. 26 July, 1993. Greater Yellowstone Ecosystem Amphibian Survey and Monitoring Program, Herpetology Laboratory, Department of Biological Sciences, Idaho State University, Pocatello, ID. 45 p.

Powell, R., J.T. Collins, and E.D. Hooper, Jr. 1998. A key to amphibians and reptiles of the Continental United States and Canada. University Press of Kansas, Lawrence, KS. 131 p. *Reichel, J.D. and D.L. Flath. 1995. Identification guide to the amphibians and reptiles of Montana. Montana Outdoors 26(3): 15-34.

Stebbins, R.C. 2003. A field guide to western reptiles and amphibians. 3rd edition. New York, NY: Houghton Mifflin Co. 533 p.

*Tanner, V.M. 1939. A study of the genus Scaphiopus. The spade-foot toads. Great Basin Naturalist 1: 3-23.

*Thompson, L.S. 1982. Distribution of Montana amphibians, reptiles, and mammals. Montana Audobon Council, Helena, MT. 25 p.

*Timken, R. No Date. Amphibians and reptiles of the Beaverhead National Forest. Western Montana College. Dillon, MT. 16 p.

*Werner, J.K., B.A. Maxell, P. Hendricks, and D. Flath. 2004. Amphibians and reptiles of Montana. Missoula, MT: Mountain Press Publishing Company. 262p. 


\section{Canadian Toad (Bufo hemiophrys)}

\section{Status Overview}

The presence of the Canadian Toad in Montana has not been positively confirmed, but they were reported to have been observed in 1966 at a single site in Daniels County at an elevation of approximately $790 \mathrm{M}$ (2,600 ft) (Black and Bragg 1968, Black 1970, 1971). Therefore, at the present time their presence in Montana must only be regarded as possible and their status must be regarded as unknown. Systematic surveys of the wetlands and streams in Sheridan, Daniels, Roosevelt, and Valley Counties should be undertaken in order to attempt to confirm the species presence in the state. Two subspecies are recognized. The Canadian toad, Bufo h. hemiophrys ranges across the prairies, aspen parkland, and boreal forest of Alberta, Saskatchewan, and southwestern Manitoba to northeastern South Dakota and central Minnesota at elvations up to 1,200 M (3,940 ft) (Stebbins 2003, Russell and Bauer 2000). The Wyoming toad, Bufo $h$. baxteri exists as an isolated and Federally endangered population in southeast Wyoming in the Laramie Basin (Baxter et al. 1982, Lewis et al. 1985, Jennings and Anderson 1997).

\section{Identification}

\section{Eggs:}

Eggs have apparently not been fully described in the scientific literature. Laid in single strings containing up to 6,660 eggs (Porter 1968, Russell and Bauer 2000). The egg string is scalloped with the jelly string being pinched between each egg (Russell and Bauer 2000). Each ovum is pigmented black above and lies within the outer jelly layer that composes the string. Ovum diameter has apparently not been reported.

\section{Larvae:}

Larvae have apparently not been fully described in the scientific literature. Blackish above and lighter below. Throat and chest are clear and tail fins are at least partly unpigmented (Stebbins 2003, Russell and Bauer 2000). The tail musculature is dark except for a narrow light ventral area (Stebbins 2003). TL has apparently not been reported.

Juveniles and Adults:

Parallel cranial crests are fused between the eyes to form a bump or boss which may or may not have a furrow between the ridges (Cope 1886, Russell and Bauer 2000). The hind feet each have two dark digging "spades" on their soles. Large parotid glands are present behind the eyes. Dorsal background color is usually grayish green to brown (more rarely reddish) with dark spots that are surrounded by white halos and are themselves spotted with red (Cope 1886, Cook 1964). A white stripe usually extends down the center of the back. The ventral surface is spotted with black or gray over a background of white which becomes more yellowish laterally (Cope 1886, Russell and Bauer 2000). SVL of 10-72 mm (Tester and Breckenridge 1964, Underhill 1961).

Similar Species:

If present, Canadian toads are likely to only be found in the extreme northeastern corner of the state. New metamorphs or juveniles may not have well developed cranial crests and may need to be compared by color patterns (see accounts). Both adult Woodhouse's toads and adult Great Plains toads are larger and have well developed cranial crests present behind the eyes and are larger in size (see accounts). Eggs and larvae of Woodhouse's toads, Great Plains toads, and 
Canadian toads are very similar and may not be differentiable by even thoroughly trained herpetologists. However eggs and larvae of Woodhouse's toads and Canadian toads are much more likely to be found in permanent or semi-permanent waters than those of Great Plains toads.

\section{Habitat Use/Natural History}

Found closely associated with permanent waters containing emergent vetation in short-grass prairies, forests, and on river floodplains (Underhill 1961, Roberts and Lewin 1979). Adults feed on a variety of invertebrates and smaller vertebrates and apparently shelter in the water or shallow self excavated burrows in the summer, and in burrows up to 1.3 meters deep in the winter (Moore and Strickland 1954, Underhill 1961, Tester and Breckenridge 1964, Roberts and Lewin 1979, Cook and Cook 1981, Kuyt 1991). Breeding probably occurs in May or early June and eggs are deposited around vegetation or loose on the bottom of the shallower waters of lakes, ponds, ditches, marshes, or slow moving streams (Black 1970, Roberts and Lewin 1979). Tadpole diet has apparently not been described. Tadpoles usually transform in 7 to 11 weeks (Tamsitt 1962, Porter 1968, Roberts and Lewin 1979). Adults appear to be more closely tied to water than other toad species, but are known to migrate at least 215 meters from overwintering to breeding sites and movements up to 390 meters have been reported (Breckenridge and Tester 1961, Tester and Breckenridge 1964).

\section{Key References}

Baxter, G.T. and M.D. Stone. 1985. Amphibians and reptiles of Wyoming. Second Edition. Wyoming Game and Fish Department. 137 pp.

Baxter, G.T., M.R. Stromberg and C.K. Dodd, Jr. 1982. The status of the Wyoming toad (Bufo hemiophyrs baxteri). Environmental Conservation 9(4): 338-348.

*Black, J.H. 1967. Toads of Montana. Montana Wildlife 1967(Spring): 22-28.

*Black, J.H. 1970. Some aspects of the distribution, natural history and zoogeography of the toad genus Bufo in Montana. M.S. Thesis. Missoula, MT: University of Montana. 70 p.

*Black, J.H. 1971. The toad genus Bufo in Montana. Northwest Science 45: 156-162.

*Black, J.H. and A.N. Bragg. 1968. New additions to the herpetofauna of Montana. Herpetologica 24: 247.

*Black, J.H. and R. Timken. 1976. Endangered and threatened amphibians and reptiles in Montana. p 36-37. In R.E. Ashton, Jr. (chair). Endangered and threatened amphibians and reptiles in the United States. Society for the Study of Amphibians and Reptiles Herpetological Circular 5: 1-65.

Breckenridge, W.J. and J.R. Tester. 1961. Growth, local movements and hibernation of the Manitoba toad, Bufo hemiophrys. Ecology 42(4): 636-646.

Carey, C., N. Cohen, and L. Rollins-Smith. 1999. Amphibian declines: an immunological perspective. Developmental and Comparative Immunology 23: 459-472.

*Cochran, D.M. 1961. Type specimens of reptiles and amphibians in the United States National Museum. United States National Museum Bulletin 220: 1-291.

Conant, R. and J.T. Collins. 1998. A field guide to reptiles and amphibians of eastern and central North America. $3^{\text {rd }}$ edition, expanded. New York, NY: Houghton Mifflin Co. 616 p.

Cook, F.R. 1964. The rusty colour phase of the Canadian toad, Bufo hemiophrys. Canadian Field Naturalist 78: 263-267.

Cook, F.R. and J.C. Cook. 1981. Attempted avian predation by a Canadian toad, Bufo americanus hemiophrys. Canadian Field Naturalist 95(3): 346-347. 
*Cope, E.D. 1886. Synonomic list of North American species of Bufo and Rana, with descriptions of some Batrachia, from specimens in the National Museum. Proceedings of the American Philosophical Society 23: 514-521.

*Cope, E.D. 1889. The Batrachia of North America. Bulletin of the U.S. National Museum 34: 1-525, figs. 1-119, pls. 1-86.

*Flath, D.L. 1998. Species of special interest or concern. Montana Department of Fish, Widlife and Parks, Helena, MT. March, 1998. 7 p.

*Hart, M.M., W.A. Williams, P.C. Thornton, K.P. McLaughlin, C.M. Tobalske, B.A. Maxell, D.P. Hendricks, C.R. Peterson, and R.L. Redmond. 1998. Montana atlas of terrestrial vertebrates. Montana Cooperative Wildlife Research Unit, University of Montana, Missoula, MT. 1302 p.

*Hendricks, P. 1999. Amphibian and reptile survey of the Bureau of Land Management Miles City District, Montana. Montana Natural Heritage Program, Helena, MT. 80 p.

Jennings, M. and A. Anderson. 1997. The Wyoming toad. Endangered Species Bulletin 22(4): 16-17.

Kuyt, E. 1991. A communal overwintering site for the Canadian toad, Bufo americanus hemiophrys, in the Northwest Territories (Canada). Canadian Field Naturalist 105(1): 119121.

Lewis, D.L., G.T. Baxter, K.M. Johnson and M.D. Stone. 1985. Possible extinction of the Wyoming toad, Bufo hemiophrys baxteri. Journal of Herpetology 19: 166-168.

*Maxell, B.A. and D.G. Hokit. 1999. Amphibians and reptiles. Pages 2.1- 2.30. In G. Joslin and H. Youmans, committee chairs. Effects of recreation on Rocky Mountain wildlife: a compendium of the current state of understanding in Montana. Helena, MT: Committee on Effects of Recreation on Wildlife, Montana Chapter of the Wildlife Society.

*Maxell, B.A., J.K. Werner, P. Hendricks, and D. Flath. 2003. Herpetology in Montana: a history, status summary, checklists, dichotomous keys, accounts for native, potentially native, and exotic species, and indexed bibliography. Olympia, WA: Society for Northwestern Vertebrate Biology. Northwest Fauna 5: 1-138.

Milius, S. 2000. New frog-killing disease may not be so new. Science News 157: 133.

Moore, J. E. and E. H. Strickland, 1954. Notes on the food of three species of Alberta amphibians. American Midland Naturalist 52(1): 221-224.

Morell, V. 1999. Are pathogens felling frogs? Science 284: 728-731.

Porter, K.R. 1968. Evolutionary status of a relict population of Bufo hemiophrys Cope. Evolution 22: 583-594.

*Powell, R., J.T. Collins, and E.D. Hooper, Jr. 1998. A key to amphibians and reptiles of the Continental United States and Canada. University Press of Kansas, Lawrence, KS. 131 p.

*Reichel, J.D. and D.L. Flath. 1995. Identification guide to the amphibians and reptiles of Montana. Montana Outdoors 26(3): 15-34.

Roberts, W. and V. Lewin. 1979. Habitat utilization and population densities of the amphibians of northeastern Alberta. Canadian Field Naturalist 93(2): 144-154.

*Roedel, M.D. and D.P. Hendricks. 1998. Amphibian and reptile survey on the Bureau of Land Management Lewistown District: 1995 - 1998. Montana Natural Heritage Program. Helena, MT. 53 pp.

Russell, A.P., and A.M. Bauer. 2000. The amphibians and reptiles of Alberta. Second Edition. Calgary, AB: University of Calgary Press. 279 p. 
Stebbins, R.C. 2003. A field guide to western reptiles and amphibians. 3rd edition. New York, NY: Houghton Mifflin Co. 533 p.

Tamsitt, J.R. 1962. Notes on a population of the Manitoba toad (Bufo hemiophrys) in the Delta Marsh Region of Lake Manitoba, Canada. Ecology 43(1): 147-150.

Taylor, S.K., E.S. Williams, E.T. Thorne, K.W. Mills, D.I. Withers, D.I., and A.C. Pier, $1999 a$. Causes of mortality of the Wyoming toad. Journal of Wildlife Diseases 35(1): 49-57.

Taylor, S.K., E.S. Williams, A.C. Pier, K.W. Mills, and M.D. Bock, M.D. 1999b. Mucormycotic dermatitis in captive adult Wyoming toads (Bufo baxteri). Journal of Wildlife Diseases 35(1): 70-74.

Taylor, S.K., E.S. Williams, and K.W. Mills. 1999c. Experimental exposure of Canadian toads to Basidiobolus ranarum. Journal of Wildlife Diseases 35(1): 58-63.

Taylor, S.K., E.S. Williams, K.W. Mills. 1999d. Mortality of captive Canadian toads from Basidiobolus ranarum mycotic dermatitis. Journal of Wildlife Diseases 35(1): 64-69.

Tester, J.R. and W.J. Breckenridge. 1964. Population dynamics of the Manitoba toad, Bufo hemiophrys, in northwestern Minnesota. Ecology 45: 592-601.

Underhill, J.C. 1963. Intraspecific variation in the Dakota toad, Bufo hemiophrys, from northeastern South Dakota. Herpetologica 17: 220-227.

*Werner, J.K., B.A. Maxell, P. Hendricks, and D. Flath. 2004. Amphibians and reptiles of Montana. Missoula, MT: Mountain Press Publishing Company. 262p.

Wheeler, G.C. and J. Wheeler. 1966. The amphibians and reptiles of North Dakota. Grand Forks, ND: University of North Dakota. 103 p.

Wright, A.H. and A.A. Wright. 1949. Handbook of frogs and toads of the United States and Canada. 3rd ed. Ithaca, NY: Comstock Publishing Company Inc. 640 p. 


\section{Wood Frog (Rana sylvatica)}

Status Overview

Reliable records for the wood frog (Rana sylvatica) have been reported 40 miles south of the Wyoming state line in the Big Horn Mountains (Dunlap 1977, Garber 1992), just north of the Canadian border near Waterton Park in Alberta (Russell and Bauer 2000), and just west of the Idaho state line in northeast Idaho (Nussbaum et al. 1983). Similar, and seemingly suitable, habitat exists adjacent to these localities in the Big Horn Mountains on the Crow Indian Reservation in south-central Montana and along the state border in northwest Montana (Hart et al. 1998). To date no surveys have been conducted in the Big Horn Mountains in south-central Montana and it is possible that surveys in suitable habitat above 2,400 meters elevation may reveal the presence of isolated populations. Their presence in northwest Montana may be less likely because extensive surveys recently conducted in that area failed to detect them (Werner and Reichel 1994, Werner and Reichel 1996).

\section{Identification}

\section{Eggs:}

Eggs are laid in a single orange to grapefruit sized globular mass and are laid individually or communally in groups of up to or more than 60 egg masses (Nussbaum et al. 1983, Corn and Livo 1989). Egg masses contain from 711 to 1,248 eggs $(X=876, N=15$, for estimates at two sites in the mountains of Wyoming) (Corn and Livo 1989). Each ovum is black above, white below, and surrounded by two jelly layers (Livezey and Wright 1947). Ovum diameters are approximately $1.7 \mathrm{~mm}$, but total egg diameters, including the two jelly layers, are approximately $5.0 \mathrm{~mm}$ (Livezey and Wright 1947).

\section{Larvae:}

Base color is blackish to olive-gray with darker speckles above, shiny bronze or pinkish laterally, and silvery pink below (Hammerson 1999). A white line occurs along the edge of the mouth (Russell and Bauer 2000). The dorsal and ventral tail fin are mostly clear, but some dark spots and blotches are present (Corkran and Thoms 2006, Hammerson 1999). TL of 7-60 mm (Nussbaum et al. 1983).

Juveniles and Adults:

A wide dark black mask extends from the tip of the snout through the eye and tympanum to just above the front leg. A white stripe may or may not extend down the center of the back (Corkran and Thoms 2006). The skin is smooth with a gray, light brown, or bronze base color with or without dark spots. Ventrally white with dark markings laterally, on the throat, and occasionally on the chest. SVL of 13-83 mm (Martof 1970).

Similar Species:

Adult Columbia spotted frogs do not have a white stripe down the center of the back, have salmon color on the thighs ventrally, and have a much thinner and fainter stripe from the snout through the eye and tympanum. In addition Columbia spotted frog adults have numerous black spots with light centers dorsally. 


\section{Habitat Use/Natural History}

Found along temporary ponds, lakes and stream shores, but adults also move into shaded portions of adjacent forests or brush where there is damp ground litter. Adults are largely terrestrial during the non-breeding season, but are usually not found far from water (Nussbaum et al. 1983). In Wyoming they were found only in shallow glacial kettle ponds without fish and most frogs were found in areas with extensive shallows and dense emergent sedges on the north side of the ponds (Garber 1992). Adults are freeze tolerant and overwinter terrestrially in burrows, root channels and crevices (Nussbaum et al. 1983). Adults may migrate up to one half kilometer to small pools, backwaters and beaver ponds which are used for breeding (Hammerson 1999). Breeding takes place from March to June and eggs are often deposited communally on emergent or submerged vegetation. Eggs hatch at different times depending on water temperatures and tadpoles metamorphose in 40-90 days (Martof 1970, Nussbaum et al. 1983). Low pH in breeding ponds causes low egg and larval survival (Gascon and Planas 1986).

\section{Key References}

Baxter, G.T. and M.D. Stone. 1985. Amphibians and reptiles of Wyoming. Second Edition. Wyoming Game and Fish Department. 137 p.

*Black, J.H. 1970a. Amphibians of Montana. Montana Wildlife, Montana Fish and Game Commission. Animals of Montana Series 1970(1): 1-32.

*Black, J.H. and R. Timken. 1976. Endangered and threatened amphibians and reptiles in Montana. Pp. 36-37. In: R.E. Ashton, Jr. (chair). Endangered and threatened amphibians and reptiles in the United States. Society for the Study of Amphibians and Reptiles Herpetological Circular 5: 1-65.

*Brunson, R.B. 1955. Check list of the amphibians and reptiles of Montana. Proceedings of the Montana Academy of Sciences 15: 27-29.

*Conant, R. and J.T. Collins. 1998. A field guide to reptiles and amphibians of eastern and central North America. $3^{\text {rd }}$ edition, expanded. New York, NY: Houghton Mifflin Co. 616 p.

Corkran, C.C. and C. Thoms. 2006. Amphibians of Oregon, Washington, and British Columbia. $2^{\text {nd }}$ Edition. Vancouver, B.C.: Lone Pine Publishing. 176 p.

Corn, P.S. and L.J. Livo. 1989. Leopard frog and wood frog reproduction in Colorado and Wyoming. Northwestern Naturalist 70: 1-9.

*Curtis, S. 1994. The big sleep. Montana Outdoors 25(6): 2-7.

Dumas, P.C. 1957. Rana sylvatica Le Conte in Idaho. Copeia 1957(2): 150-151.

Dunlap, D.G. 1977. Wood and western spotted frogs (Amphibia, Anura, Ranidae) in the Big Horn Mountains of Wyoming. Journal of Herpetology 11: 85-87.

*Flath, D.L. 1998. Species of special interest or concern. Montana Department of Fish, Widlife and Parks, Helena, MT. March, 1998. 7 p.

Garber, C. S. 1992. A survey for spotted frogs (Rana pretiosa), wood frogs (Rana sylvatica), and boreal toads (Bufo boreas) in Wyoming. Wyoming Natural Diversity Database, Laramie. 15 pp. + appendix.

Gascon, C. and D. Planas. 1986. Spring pond water chemistry and the reproduction of the wood frog, Rana sylvatica. Canadian Journal of Zoology 64:543-550.

Hammerson, G.A. 1999. Amphibians and Reptiles in Colorado. Second Edition. University Press of Colorado and Colorado Division of Wildlife. $484 \mathrm{pp}$.

*Hendricks, P. 1999. Amphibian and reptile survey of the Bureau of Land Management Miles City District, Montana. Montana Natural Heritage Program, Helena, MT. 80 p. 
*Marnell, L.F. 1997. Herpetofauna of Glacier National Park. Northwestern Naturalist 78: 1733.

*Martof, B.S. 1970. Rana sylvatica. Catalogue of American Amphibians and Reptiles 86.186.4.

*Martof, B.S. and R.L. Humphries. 1959. Geographic variation in the wood frog, Rana sylvatica. American Midland Naturalist 61: 350-389.

Matsuda, B.M., D.M. Green, and P.T. Gregory. 2006. Amphibians and reptiles of British Columbia. Victoria, B.C.: Royal British Columbia Museum. 266 p.

*Maxell, B.A. 2002. Amphibian and aquatic reptile inventories in watersheds in the South and Middle Forks of the Flathead River drainage that contain lakes being considered for application of piscicides and subsequent stocking of west slope cutthroat trout. Report to the Region 1 Office of the U.S. Forest Service and the Montana Department of Fish, Wildlife, and Parks. Montana Cooperative Wildlife Research Unit and Wildlife Biology Program, University of Montana, Missoula, MT. 62 p.

*Nussbaum, R.A., E.D. Brodie, and R.M. Storm. 1983. Amphibians and reptiles of the Pacific Northwest. University Press of Idaho, Moscow, Idaho. 332 p.

*Porter, K.R. 1968. Evolutionary status of the Rocky Mountain population of wood frogs. Evolution 23(1): 163-180.*Reichel, J.D. and D.L. Flath. 1995. Identification guide to the amphibians and reptiles of Montana. Montana Outdoors 26(3): 15-34.

Powell, R., J.T. Collins, and E.D. Hooper, Jr. 1998. A key to amphibians and reptiles of the Continental United States and Canada. University Press of Kansas, Lawrence, KS. 131 p.

Russell, A.P., and A.M. Bauer. 2000. The amphibians and reptiles of Alberta. Second Edition. Calgary, AB: University of Calgary Press. 279 p.

Stebbins, R.C. 2003. A field guide to western reptiles and amphibians. 3rd edition. New York, NY: Houghton Mifflin Co. 533 p.

*Thompson, L.S. 1982. Distribution of Montana amphibians, reptiles, and mammals. Montana Audobon Council, Helena, MT. 25 p.

*Werner, J.K., B.A. Maxell, P. Hendricks, and D. Flath. 2004. Amphibians and reptiles of Montana. Missoula, MT: Mountain Press Publishing Company. 262p.

*Werner, J.K. and J.D. Reichel. 1994. Amphibian and reptile survey of the Kootenai National Forest: 1994. Montana Natural Heritage Program, Helena, Montana. 104 pp.

*Werner, J.K. and J.D. Reichel. 1996. Amphibian and reptile monitoring/survey of the the Kootenai National Forest: 1995. Montana Natural Heritage Program. Helena, MT. 115 pp.

Wheeler, G.C. and J. Wheeler. 1966. The amphibians and reptiles of North Dakota. University of North Dakota, Grand Forks. 103 p. 


\section{Pigmy Short-horned Lizard (Phrynosoma douglassii)}

Status Overview

The short-horned lizard was recently split into the Pigmy Short-horned Lizard (Phrynosoma douglasii), the northwestern short-horned lizard subspecies prior to the split, and the Greater Short-horned Lizard (Zamudio et al. 1997, Hammerson 1999, Stebbins 2003), encompassing the other five subspecies prior to the reclassification (Reeve 1952). Cope (1872) described a $P$. douglasii specimen from “Carrington’s Lake Montana”, an unknown locality apparently in present day Gallatin, Madison or Beaverhead Counties near Yellowstone National Park. Cope's (1872) description clearly identifies the specimen as $P$. douglasii by modern Taxonomy (Zamudio et al. 1997, Crother et al. 2008). Although the current status of this specimen is unknown, another specimen collected in "Centennial Valley, Montana” by George Kennedy in August 1936 has been identified as P. douglasii (St. John 2002, Al St. John, Bend, OR, pers. comm.). Nussbaum et al. (1983) show reliable records for $P$. douglasii only a few $\mathrm{km}$ south of the Idaho State line near Monida Pass and seemingly suitable habitat exists in the valleys of southwest Montana. Given the cryptic nature of the species and lack of surveys suitable for detection, the presence of $P$. douglasii in southwestern Montana is possible.

\section{Identification}

Juveniles and Adults:

The body of the Pigmy Short-horned Lizard is small and oval with a large head and short tail that is very thick at its base. Adults rarely exceed $6 \mathrm{~cm}$ in snout-to-vent length and the maximum total length for a large animal is only about $9 \mathrm{~cm}$ (St. John 2002). The surface of the back has many small pointed scales and there is a fringe of small spines at the interface of the dorsal and ventral surfaces. The "horns" on the back of the head are merely small nubbins which usually project at a nearly vertical angle. The ventral surface is white or pale yellow and the dorsal surface has two paired rows of dark brown to black blotches on a gray or grayish brown background (St. John 2002). Young resemble the adults in coloration and morphology

\section{Similar Species:}

With the exception of the Greater Short-horned Lizard ( $P$. hernandesi), the broad flattened body separates the Pigmy Short-horned Lizard from the other lizard species regularly documented in Montana. Adults of the Pigmy Short-horned Lizard are much smaller than the greater shorthorned lizard, they lack the wide notch between the horns on the back of the head that gives the head of the greater short-horned lizard a "heart-shape" appearance when viewed from above, and the small horns on the back of the head project almost vertically, rather than horizontally as in the greater short-horned lizard (St. John 2002, Werner et al. 2004).

\section{Habitat Use/Natural History}

Pigmy Short-horned Lizards ( $P$. douglasii) have a much greater tolerance to cold climates than other short-horned lizards and are distributed up to elevations of at least 6,000 ft $(1,830 \mathrm{~m})$ in some Pacific Northwest mountain ranges (St. John 2002). The species in found in open sagebrush rangelands, bunchgrass plains, and sunny clearings in juniper and pine woodlands. In the Cascade Mountains of Oregon and northern California, the species occurs in volcanic pumice sand openings in pine forests and their distribution in general is limited to areas with sandy soils that they can burrow into (St. John 2002). They are often found in areas with ant hills since ants 
are the preferred prey and scattered bushes are often used for cover (St. John 2002). Mating takes place immediately after emergence from hibernation sites and females give birth to 3-15 young in mid to late summer depending on elevation (St. John 2002).

Bibliography *indicates an article with information specific to Montana

*Cope, E.D. 1872. Report on the recent reptiles and fishes of the survey, collected by Campbell Carrington and C.M. Dawes. pp. 467-469. In: F.V. Hayden, Preliminary report of the United States geological survey of Montana and portions of adjacent territories; being a fifth annual report of progress. 538 pp. 42nd Congress, 2nd Session, House Executive Document Number 326. Serial 1520.

*Maxell, B.A. 1999. Distribution and status of amphibians and reptiles in Montana. Abstract. Montana Chapter of the American Fisheries Society Meeting. Big Sky, MT. February 2-5, 1999.

*Maxell, B.A., J.K. Werner, P. Hendricks, and D. Flath. 2003. Herpetology in Montana: a history, status summary, checklists, dichotomous keys, accounts for native, potentially native, and exotic species, and indexed bibliography. Olympia, WA: Society for Northwestern Vertebrate Biology. Northwest Fauna 5: 1-138.

Nussbaum, R. A., E. D. Brodie, Jr., and R. M. Storm. 1983. Amphibians and reptiles of the Pacific Northwest. University of Idaho Press. Moscow, Idaho. 332 p.

*St. John, A. 2002. Reptiles of the Northwest: California to Alaska; Rockies to the Coast. Renton, WA: Lone Pine Publishing. 272 p.

*Werner, J.K., B.A. Maxell, P. Hendricks, and D. Flath. 2004. Amphibians and reptiles of Montana. Missoula, MT: Mountain Press Publishing Company. 262p.

Zamudio, K.R. 1996. Ecological, evolutionary, and applied aspects of lizard life histories. Ph.D. Dissertation. University of Washington, Seattle, WA. 167 p.

Zamudio, K.R., K.B. Jones and R.H. Ward. 1997. Molecular systematics of short-horned lizards: biogeography and taxonomy of a widespread species complex. Systematic Biology 46(2): 284-305. 


\section{Contact Information for Montana’s Amphibian and Reptile Working Group}

Last Name First Name

Aderhold Mike

Amish Stephen

Begley Allison

Bell Matt

Bergeron Dwight

Bertellotti Gary

Bowey Chuck

Campbell Shawna

Canfield Jodie

Carlson Ann

Carlson John

Claar Jim

Clancy Pat

Corn Steve

Curtis Sam

Daenzer Angela

Davis Windy

Dittmann Rebecca

Dood Arnold

DuBois Kristi

Dullum Jo Ann

Eby Lisa

Farmer Patrick

Feigley Rachel

Flath Dennis

Frazer Ken

Garcia Barbara

Gibbons Greg

Gniadek Steve

Gower Claire

Greene Erick

Gude Justin

Hadley Wayne

Hahn Beth

Hanauska-Brown Lauri

Hanebury Lou

Hansen Jim

Hazlewood Rob

Hendricks Paul

Hokit Gant

Holifield Jenny

Holland Tiffany

Horn Kirk

Hossack Blake

Husby Peter

Jakes Andrew

Joslin Gayle

Juris Margie

Kelly Lynn

Kitchen Kenda

Knotek Ladd

Lenard Susan

Lichtenberg Janene
Affiliation

MTFWP

UM

MTFWP

DNRC

MTFWP

MTFWP

Ranch Resources

USFS

USFS

USFS

BLM

USFS

MTFWP

USGS

MTFWP

UM/USFS

MTFWP

US FWS

MTFWP

MTFWP

US FWS

UM

Westech

USFS

APEX Environmental (406) 388-2810

MTFWP

USFS - B-D (406) 683-3944

MTFWP

NPS-Glacier NP

MTFWP

UM

MTFWP

MTFWP

USFS

MTFWP

US FWS

MTFWP

Private

NHP

Carroll College

USFS-Kootenai NF

Western Transportation Institute (406) 570-1496

Retired USFS

USGS

NRCS

MTFWP

Retired MTFWP

Redtail Resource

MT Loon Society

Redtail Resource

MTFWP

MT NHP

Confederated Salish \& Ko6ß日ai Tribes
Email Address

maderhold@mt.gov

Stephen.Amish@mso.umt.edu

abegley@mt.gov

mbell@mt.gov

dbergeron@mt.gov

gbertellotti@mt.gov

jacksonb@3rivers.net

slcampbell@fs.fed.us

jecanfield@fs.fed.us

adcarlson@fs.fed.us

john_carlson@blm.gov

jclaar@fs.fed.us

pcensfwp@3rivers.net

scorn@usgs.gov

sgcurtis@mcn.net

adaenzer@fs.fed.us

widavis@mt.gov

rebecca_dittmann@fws.gov

adood@montana.edu

kdubois@mt.gov

joanndullum@fws.gov

lisa.eby@umontana.edu

pfarmer@mt.net

rfeigley@fs.fed.us

denndlf@cs.com

kfrazer@state.mt.us

bagarcia@fs.fed.us

ggibbons@mt.gov

steve_gniadek@nps.gov

cgower@mt.gov

erick.greene@mso.umt.edu

jgude@mt.gov

whadley@mt.gov

bhahn@fs.fed.us

lhanauska-brown@mt.gov

lou_hanebury@fws.gov

jihansen@mt.gov

tierra1@theglobal.net

phendricks@mt.gov

ghokit@carroll.edu

jholifield@fs.fed.us

tiffany.holland@yahoo.com

KHCritters@aol.com

blake_hossack@usgs.gov

peter.husby@mt.usda.gov

ajakes@mt.gov

gjoslin@mt.gov

mjuris@hotmail.com

loonmont@hotmail.com

kitch@blackfoot.net

lknotek@mt.gov

slenard@mt.gov

janenel@cskt.org 
Lohrenz Travis

Lott Ryan

Lowe Winsor

Lynch Cat

Maples Wendy

Maxell Bryce

McClelland Pat

McDonald Ken

McFadzen Mary

McGrath Mike

Messer Adam

Moffat Tori

Moore Dave

Moser David

Nelson Lee

Olsen Jim

Oswald Dick

Patrick Angela

Parks Tawni

Pauli Dave

Pengeroth Denise

Peters Jody

Peterson Chuck

Pilliod David

Pitman Barb

Piwowar Aly

Rauscher Ryan

Rich Bruce

Riley Chris

Roberts Bruce

Roberts Wendy

Rogers Ralph

Romero David

Ryce Eileen

Sartorius Shawn

Sasse Don

Saul Lynda

Shepard Brad

Shirley Erinn

Shovlain Amie

Sitter Gayle

Snyder Bob

Sojda Rick

Sparks Jim

Stabins Henning

Stagliano David

Sterling Bruce

Story Scott

Swanekamp Leah

Tews Anne

Timmerman Walt

Vaughn Mike

Waltee Dean

Warren Jeff

Werner J. Kirwin

Wrobleski David
MTFWP

Maxim Tech, Inc.

UM

Mad Science of MT

USFS

NHP

Private

MTFWP

DNRC

MTFWP

USBOR

MTFWP

MTFWP

MTFWP

MTFWP

UM

USFS

HSUS

USFS

BLM

Idaho State University

USGS

USFS

BLM

MTFWP

MTFWP

USFS

USFS

Garcia \& Associates

USFS

MTFWP

US FWS

USFS

DEQ

MTFWP

BLM

USFS - B-D

BLM

MTFWP

USGS

BLM

Plum Creek

NHP

MTFWP

MTFWP

MSU

MTFWP

MTFWP

MTFWP

MTFWP

USFWS

Salish Kootenai College

USFS
(406) 329-3827

(406) 652-8100

(406) 444-3655

(406) 382-4253

(406) 784-2344

(406) 533-7603

(406) 892-6313

(406) 570-5275

(406) 276-3536

(406) 676-8988 tlohrenz@mt.gov

huckinbugs@yahoo.com

winsor.lowe@mso.umt.edu

bufo@nemontel.net

wmaples@fs.fed.us

bmaxell@mt.gov

brisley@bigsky.net

kmcdonald@mt.gov

mmcfadzen@montana.edu

mtmcgrath@mt.gov

amesser@mt.gov

vmoffat13@hotmail.com

dmoore@do.usbr.gov

dmoser@fs.fed.us

leenelson@fs.fed.us

jimolsen@mt.gov

fishfwpdillon@7pks.com

apatri4@lsu.edu

tparks@fs.fed.us

wildquests@aol.com

dpengeroth@fs.fed.us

jpeters@blm.gov

petechar@isu.edu

dpilliod@usgs.gov

bpitman@fs.fed.us

aly_piwowar@blm.gov

rrauscher@mt.gov

brucer@montana.edu

criley01@fs.fed.us

broberts@fs.fed.us

wroberts@garciaandassociates.com

nafanew@ttc-cmc.net

dtromero@fs.fed.us

eileenryce@yahoo.com

shawn_sartorius@fws.gov

dsasse@fs.fed.us

lsaul@mt.gov

bshepard@montana.edu

erinn_shirley@blm.gov

ashovlain@fs.fed.us

gsitter@blm.gov

bsnyder@mt.gov

sojda@montana.edu

jrsparks@blm.gov

henning.stabins@plumcreek.com

dstagliano@mt.gov

bsterling@blackfoot.net

sstory@mt.gov

gls6496@montana.edu

antews@mt.gov

wtimmerman@mt.gov

mvaughn@mt.gov

dwaltee@mt.gov

jeffrey_warren@fws.gov

jkw@ronan.net

dwrobleski@fs.fed.us 


\section{Site Data Form for Lentic Breeding Amphibian and Aquatic Reptile Surveys}

\section{Locality Information}

\begin{tabular}{|c|c|c|c|c|c|c|c|c|c|c|}
\hline Date & Obse & ver(s) & & Owner & & & Site Det & ection: & & GPS \\
\hline & & & & & & Aerial Photo & Tоро Мар & NWI Map & Incidenta & EPE \\
\hline $\begin{array}{l}\text { DM Region } \\
\text { SE MONTANA }\end{array}$ & QQUA & & $\begin{array}{l}\text { Site } \\
\text { Number }\end{array}$ & & State & County & & & $\begin{array}{l}\text { Map } \\
\text { Name }\end{array}$ & \\
\hline Locality & & & & & & $\mathrm{T}$ & $\mathrm{R}$ & $\mathrm{S}$ & & $\begin{array}{l}\text { Section } \\
\text { Description }\end{array}$ \\
\hline $\begin{array}{l}\text { Map } \\
\text { Elevation }\end{array}$ & FT & Datum & Latitude (D & & & de (DD) & & 0 & ${ }_{2}^{\mathrm{Su}}$ & \begin{tabular}{llll} 
& \multicolumn{4}{c}{ Type } \\
4 & 5 & 7
\end{tabular} \\
\hline
\end{tabular}

\section{Habitat Information}

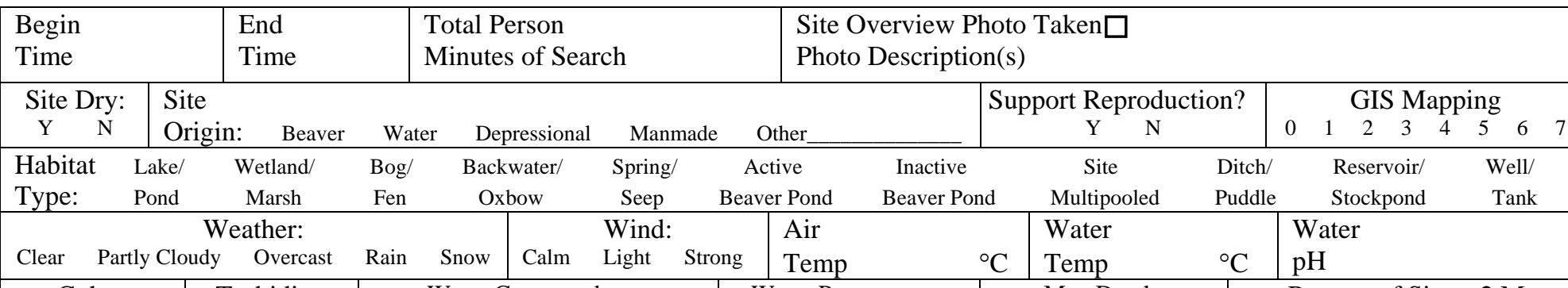

\begin{tabular}{l|l|l|l|l|l}
\hline Color: & Turbidity: & Water Connectedness: & Water Permanence: & Max Depth: & Percent of Site $>2 \mathrm{M}$ \\
\hline
\end{tabular}

\begin{tabular}{llllll|lll|lllllllll} 
Clear Stained & Clear & Cloudy & Permanent & Temporary & Isolated & Permanent & Temporary & $<1 \mathrm{M}$ & $1-2 \mathrm{M}$ & $>2 \mathrm{M}$ & 0 & $1-25$ & $26-50$ & $51-75$ & $76-100$ \\
\hline
\end{tabular}

\begin{tabular}{|l|l|l|l|l|l}
\hline Site & Site & Percentage of Site Searched: & Percent of Site at $\leq 50 \mathrm{~cm}$ Depth: & $\sim$ Emergent Veg Area (M⿻丷 ${ }^{2}$ ) \\
\hline
\end{tabular}

\begin{tabular}{l|l} 
Length: & Width: \\
\hline
\end{tabular}

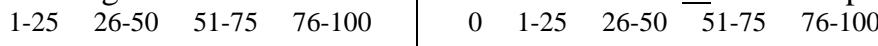

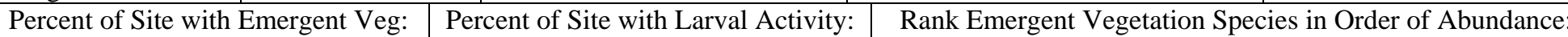

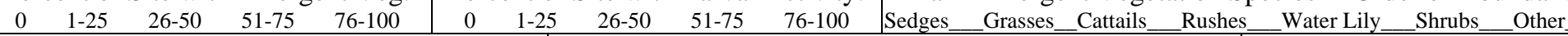
Primary Substrate of Shallows:

Silt/Mud Sand Gravel Cobble Boulder/Bedrock

North Shoreline Characteristics:

Distance (M) to

Shallows Present: $\mathrm{Y}$ N Emergent Veg Present: $\mathrm{Y} \quad \mathrm{N}$ Forest Edge:

\begin{tabular}{|l|l|l|l}
\hline Grazing Impact & Water Dammed/Diverted & Timber Harvest in Area & Mining Activity
\end{tabular} $\begin{array}{lllllr}\text { None Light } & \text { Heavy Structure Heavy Structure and Water } & \text { Heavy Water } & \text { Y N }\end{array}$

Other Human Impacts

Or Modifications:

Fish Spawning Habitat Present? Inlet Fish Detected? Time at First $\mathrm{Y} \quad \mathrm{N}$

Fish Species If Identified: \begin{tabular}{ll|l}
$\mathrm{Y}$ & $\mathrm{N} \quad \mathrm{U}$ & Width:
\end{tabular}

\begin{tabular}{l|l|l|l}
\hline Inlet & Inlet & Outlet & Outlet \\
Depth: & Substrate & Width & Depth
\end{tabular}

Outlet Substrate

\section{Species Information}

\begin{tabular}{|c|c|c|c|c|c|c|c|c|c|c|}
\hline $\begin{array}{c}\text { Amphibian } \\
\text { Species }\end{array}$ & & & $\begin{array}{c}\text { Time at first } \\
\text { detection }\end{array}$ & $\begin{array}{lllll}\text { E } & \text { L } & \text { M } & \text { J } & \text { A }\end{array}$ & $\begin{array}{l}\text { No. Egg } \\
\text { Masses }\end{array}$ & & & 5-20mm larvae & $\begin{array}{c}\leq 10 \quad \leq 10 \\
\leq 10 \mathrm{~K}\end{array}$ & $\begin{array}{c}\quad \leq 1000 \\
>10 \mathrm{~K}\end{array}$ \\
\hline $\begin{array}{c}20-50 \mathrm{~mm} \\
\text { larvae }\end{array}$ & $\begin{array}{c}\leq 10 \quad \leq 100 \\
\leq 10 \mathrm{~K}\end{array}$ & $\begin{array}{l}\leq 1000 \\
>10 \mathrm{~K}\end{array}$ & $\begin{array}{c}>50 \mathrm{~mm} \\
\text { larvae }\end{array}$ & $\begin{array}{c}\leq 10 \quad \leq 100 \quad \leq 1000 \\
\leq 10 \mathrm{~K} \quad>10 \mathrm{~K}\end{array}$ & $\begin{array}{l}\text { Number } \\
\text { Juveniles }\end{array}$ & & & $\begin{array}{c}\text { Number } \\
\text { Adults } \\
\end{array}$ & & \\
\hline $\begin{array}{c}\text { Tissue } \\
\text { Number } \\
\end{array}$ & & & $\begin{array}{l}\text { Voucher } \\
\text { Number } \\
\end{array}$ & & $\begin{array}{c}\text { Breeding } \\
\text { with Fish? }\end{array}$ & $\mathrm{Y}$ & $\mathrm{N}$ & $\begin{array}{l}\text { If breeding with fisl } \\
\text { is cover present? }\end{array}$ & $\mathrm{Y}$ & $\mathrm{N}$ \\
\hline $\begin{array}{c}\text { Amphibian } \\
\text { Species }\end{array}$ & & & $\begin{array}{c}\text { Time at first } \\
\text { detection }\end{array}$ & \begin{tabular}{llllll|} 
E & L & M & J & A \\
\end{tabular} & $\begin{array}{l}\text { No. Egg } \\
\text { Masses }\end{array}$ & & & 5-20mm larvae & $\begin{array}{c}\leq 10 \quad \leq 10 \\
\leq 10 \mathrm{~K}\end{array}$ & $\begin{array}{c}01000 \\
>10 \mathrm{~K}\end{array}$ \\
\hline $\begin{array}{c}20-50 \mathrm{~mm} \\
\text { larvae }\end{array}$ & $\begin{array}{c}\leq 10 \quad \leq 100 \\
\leq 10 \mathrm{~K}\end{array}$ & $\begin{array}{l}\leq 1000 \\
>10 \mathrm{~K}\end{array}$ & $\begin{array}{c}>50 \mathrm{~mm} \\
\text { larvae }\end{array}$ & $\begin{array}{c}\leq 10 \quad \leq 100 \leq 1000 \\
\leq 10 \mathrm{~K} \quad>10 \mathrm{~K}\end{array}$ & $\begin{array}{c}\text { Number } \\
\text { Juveniles }\end{array}$ & & & $\begin{array}{c}\text { Number } \\
\text { Adults }\end{array}$ & & \\
\hline $\begin{array}{c}\text { Tissue } \\
\text { Number }\end{array}$ & & & $\begin{array}{l}\text { Voucher } \\
\text { Number }\end{array}$ & & $\begin{array}{l}\text { Breeding } \\
\text { with Fish? }\end{array}$ & $\mathrm{Y}$ & $\mathrm{N}$ & $\begin{array}{l}\text { If breeding with fisl } \\
\text { is cover present? }\end{array}$ & $\mathrm{Y}$ & $\mathrm{N}$ \\
\hline $\begin{array}{c}\text { Amphibian } \\
\text { Species }\end{array}$ & & & $\begin{array}{c}\text { Time at first } \\
\text { detection }\end{array}$ & 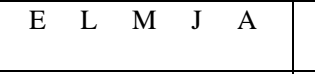 & $\begin{array}{l}\text { No. Egg } \\
\text { Masses }\end{array}$ & & & 5-20mm larvae & $\begin{array}{c}\leq 10 \leq 10 \\
\leq 10 \mathrm{~K}\end{array}$ & $\begin{aligned} & \leq 1000 \\
> & 10 \mathrm{~K}\end{aligned}$ \\
\hline $\begin{array}{c}20-50 \mathrm{~mm} \\
\text { larvae }\end{array}$ & $\begin{array}{c}\leq 10 \quad \leq 100 \\
\leq 10 \mathrm{~K}\end{array}$ & $\begin{array}{c}\leq 1000 \\
>10 \mathrm{~K}\end{array}$ & $\begin{array}{l}>50 \mathrm{~mm} \\
\text { larvae }\end{array}$ & $\begin{array}{c}\leq 10 \quad \leq 100 \quad \leq 1000 \\
\leq 10 \mathrm{~K} \quad>10 \mathrm{~K}\end{array}$ & $\begin{array}{l}\text { Number } \\
\text { Juveniles }\end{array}$ & & & $\begin{array}{c}\text { Number } \\
\text { Adults } \\
\end{array}$ & & \\
\hline $\begin{array}{l}\text { Tissue } \\
\text { Number }\end{array}$ & & & $\begin{array}{l}\text { Voucher } \\
\text { Number }\end{array}$ & & $\begin{array}{l}\text { Breeding } \\
\text { with Fish? }\end{array}$ & $\mathrm{Y}$ & $\mathrm{N}$ & $\begin{array}{l}\text { If breeding with fisl } \\
\text { is cover present? }\end{array}$ & $\mathrm{Y}$ & $\mathrm{N}$ \\
\hline $\begin{array}{c}\text { Amphibian } \\
\text { Species }\end{array}$ & & & $\begin{array}{c}\text { Time at first } \\
\text { detection }\end{array}$ & $\begin{array}{lllll}\text { E } & \text { L } & \text { M } & \text { J } & \text { A }\end{array}$ & $\begin{array}{l}\text { No. Egg } \\
\text { Masses }\end{array}$ & & & 5-20mm larvae & $\begin{array}{c}\leq 10 \leq 10 \\
\leq 10 \mathrm{~K}\end{array}$ & $\begin{array}{l}01000 \\
>10 \mathrm{~K}\end{array}$ \\
\hline $\begin{array}{l}20-50 \mathrm{~mm} \\
\text { larvae }\end{array}$ & $\begin{array}{c}\leq 10 \quad \leq 100 \\
\leq 10 \mathrm{~K}\end{array}$ & $\begin{array}{l}\leq 1000 \\
>10 \mathrm{~K} \\
\end{array}$ & $\begin{array}{c}>50 \mathrm{~mm} \\
\text { larvae }\end{array}$ & $\begin{array}{c}\leq 10 \quad \leq 100 \quad \leq 1000 \\
\leq 10 \mathrm{~K} \quad>10 \mathrm{~K}\end{array}$ & $\begin{array}{c}\text { Number } \\
\text { Juveniles }\end{array}$ & & & $\begin{array}{c}\text { Number } \\
\text { Adults } \\
\end{array}$ & & \\
\hline $\begin{array}{l}\text { Tissue } \\
\text { Number }\end{array}$ & & & $\begin{array}{l}\text { Voucher } \\
\text { Number }\end{array}$ & & $\begin{array}{l}\text { Breeding } \\
\text { with Fish? }\end{array}$ & $\mathrm{Y}$ & $\mathrm{N}$ & $\begin{array}{l}\text { If breeding with fisl } \\
\text { is cover present? }\end{array}$ & $\mathrm{Y}$ & $\mathrm{N}$ \\
\hline $\begin{array}{l}\text { Reptile } \\
\text { Species } \\
\end{array}$ & & $\begin{array}{c}\text { Time at first } \\
\text { detection }\end{array}$ & E $\quad J \quad A$ & $\begin{array}{c}\text { Number } \\
\text { Individuals }\end{array}$ & \begin{tabular}{c|c} 
SVL \\
in CM
\end{tabular} & & $\begin{array}{c}\text { Tissue } \\
\text { Number } \\
\end{array}$ & & $\begin{array}{l}\text { Voucher } \\
\text { Number } \\
\end{array}$ & \\
\hline $\begin{array}{l}\text { Reptile } \\
\text { Species } \\
\end{array}$ & & $\begin{array}{c}\text { Time at first } \\
\text { detection }\end{array}$ & $\begin{array}{lll}\mathrm{E} & \mathrm{J} & \mathrm{A}\end{array}$ & $\begin{array}{c}\text { Number } \\
\text { Individuals }\end{array}$ & $\begin{array}{c}\text { SVL } \\
\text { in CM }\end{array}$ & & $\begin{array}{c}\text { Tissue } \\
\text { Number } \\
\end{array}$ & & $\begin{array}{l}\text { Voucher } \\
\text { Number } \\
\end{array}$ & \\
\hline $\begin{array}{l}\text { Reptile } \\
\text { Species }\end{array}$ & & $\begin{array}{c}\text { Time at first } \\
\text { detection }\end{array}$ & $\begin{array}{lll}\mathrm{E} & \mathrm{J} & \mathrm{A}\end{array}$ & $\begin{array}{c}\text { Number } \\
\text { Individuals }\end{array}$ & $\begin{array}{c}\text { SVL } \\
\text { in CM }\end{array}$ & & $\begin{array}{l}\text { Tissue } \\
\text { Number }\end{array}$ & & $\begin{array}{l}\text { Voucher } \\
\text { Number }\end{array}$ & \\
\hline $\begin{array}{l}\text { Reptile } \\
\text { Species } \\
\end{array}$ & & $\begin{array}{c}\text { Time at first } \\
\text { detection }\end{array}$ & $\begin{array}{lll}\mathrm{E} & \mathrm{J} & \mathrm{A}\end{array}$ & $\begin{array}{c}\text { Number } \\
\text { Individuals }\end{array}$ & $\begin{array}{c}\text { SVL } \\
\text { in CM }\end{array}$ & & $\begin{array}{c}\text { Tissue } \\
\text { Number } \\
\end{array}$ & & $\begin{array}{l}\text { Voucher } \\
\text { Number } \\
\end{array}$ & \\
\hline
\end{tabular}


Grid Scale:

Site Map For Lentic Breeding Amphibian and Aquatic Reptile Surveys

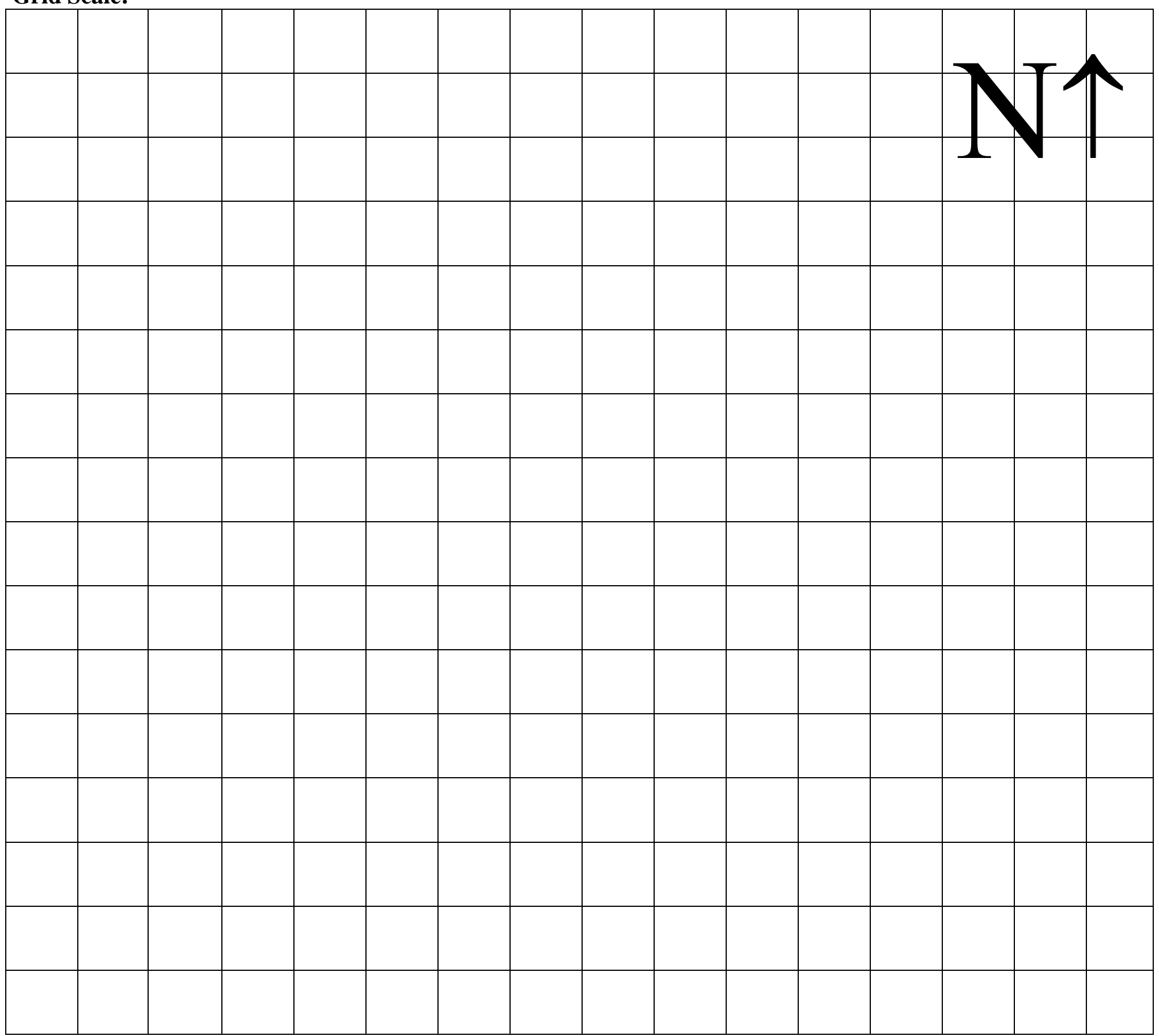

* Indicate the following locations on the map: $\mathbf{T}=$ temperature, $\mathbf{G}=$ GPS reading, $\mathbf{C}=$ clinometer reading, and $\mathbf{P} \rightarrow=$ photo locations and directions of photos. Indicate area with emergent vegetation with cross-hatching and indicate a 2-meter depth contour with a dashed line.

Other Notes:

Detection Summary(list surveyors in left column \& species detections in others (e.g., 1 @ 5 min) - list adults \& breeding separately)

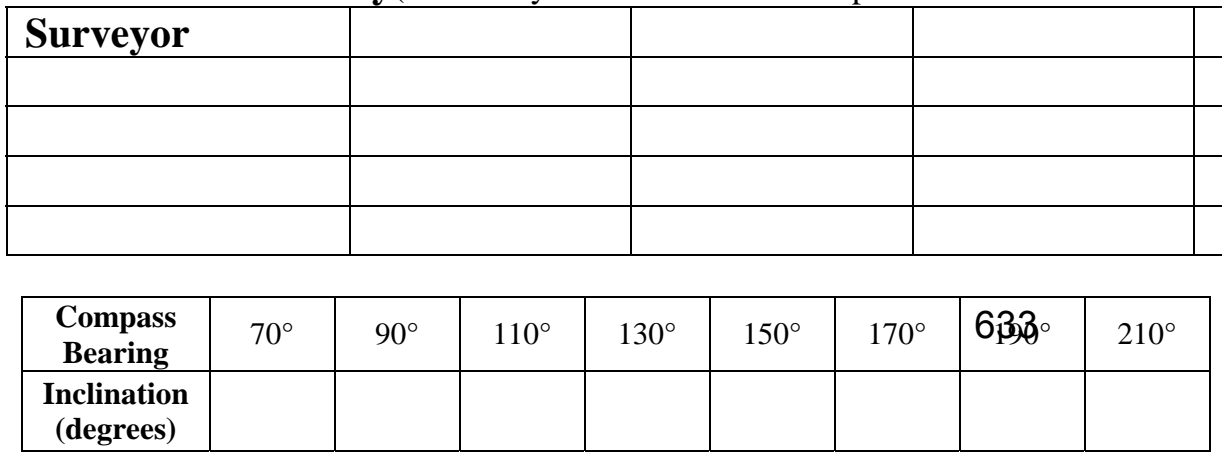




\section{Definitions of Variables on Lentic Breeding Amphibian Survey Data Sheet}

\section{Locality Information}

Date: Use MM-DD-YY format (e.g. 5/12/00 for May 12 of 2000).

Observers: List names or initials of individuals involved with survey of this site and circle the name of the recorder.

Owner: Use abbreviation of the government agency responsible for managing the land you surveyed. (e.g. USFS, BLM). If private land was surveyed list the owner's full name to indicate that you did not trespass.

Site Detection: Was site detected on aerial photo, topographic map, NWI map, or was it observed incidentally while in the field.

GPS EPE: The estimated positional error reported by the GPS receiver in meters.

Strata Number: The sample strata in which the $6^{\text {th }}$ level HUC watershed lies (one of nine defined in western Montana).

HUC Number: The sample number of the $6^{\text {th }}$ level HUC in one of the nine sample strata defined for western Montana.

Site Number: The number pre-assigned to the water body within each $6^{\text {th }}$ level HUC. If the water body was not pre-assigned a number because it was not on topographic maps or aerial photos then assign it a sequential number and draw it on the topo map.

State: Use the two-letter abbreviation.

County: Use the full county name.

Map Name: List the name of the USGS 7.5-minute (1:24,000 scale) topographic quadrangle map.

Locality: Describe the specific geographic location of the site so that the type of site is described and the straight-line air distance from one or more permanent features on a 7.5-minute (1:24,000 scale) topographic map records the position of the site (e.g., Beaver pond, 1.5 miles south of Elephant Peak and 1.3 miles east of Engle Peak).

T: Record the Township number and whether it is north or south.

R: Record the Range number and whether it is east or west.

S: Record the Section number.

Section Description: Describe the location of the site at the $1 / 4$ of $1 / 4$ section level (e.g., SENE indicates SE corner of NE corner).

Map Elevation: The elevation of the site as indicated by the topographic map in feet (avoid using elevations from a GPS)

UTM Zone: Universal Transverse Mercator zone recorded on the topographic map. Use NAD 27 as the map and GPS datum.

UTM North: Universal Transverse Mercator northing coordinate in meters as recorded on the topographic map or GPS receiver. Be sure to note any major differences between UTM coordinates on the map and those on the GPS receiver.

UTM East: Universal Transverse Mercator easting coordinate in meters as recorded on the topographic map or GPS receiver. Be sure to note any major differences between UTM coordinates on the map and those on the GPS receiver.

Survey Type: Circle the appropriate number defined as follows: $0=$ private land so site was not surveyed; $1=$ site not surveyed due to logistics; 2 = site is a lotic spring/seep not worth future survey; 3 = lentic site that is worth future survey; 4 = misidentified as a potential lentic site on the aerial photograph or on the topographic map (e.g., a shadow from a tree or a talus slope) and not worth future survey; $5=$ inactive beaver dam that now only has lotic habitat and is not worth future survey; $6=$ only lotic habitat is present and the site is not worth future survey, but it appears possible that the meadow was an historic beaver dam complex; $7=$ a lentic site because it would hold water for at least a short time period during wetter conditions, but it is not worth future survey because it would never hold enough water long enough to support amphibian reproduction; 8 = site is not worth future survey for some reason other than those listed above.

\section{Habitat Information}

Begin Time: List the time the survey began in 24-hour format.

End Time: List the time the survey ended in 24-hour format.

Total Person Minutes of Search: Record the total person minutes the site was searched (e.g. if one person surveys for 15 minutes and another surveys for 30 minutes, but takes 5 minutes to measure a specimen the total person minutes is 40 minutes).

Camera and Photo Number(s) / Description (s): Identify the camera and the number of the photo as viewed on the camera's view screen and a description of the contents of the photograph (e.g., $13=1 \mathrm{x}$ ASMO larvae and $14=1 \mathrm{x}$ habitat). Take photos of all portions of the site and anything else that may be of interest (e.g., areas with fish versus areas with amphibians).

Site Dry: Circle whether the site was dry or not at the time of the survey.

Site Origin: Circle whether the site origin is glacial, beaver, water (i.e., flooding or spring), depressional, manmade, or describe other origin. Support Reproduction: Is site capable of supporting reproduction so it is worth resurveying (e.g. in wetter years if now dry)?

GIS Mapping: Circle the appropriate number defined as follows: $0=$ site not surveyed; 1 = a 4 in the survey type and site is not worth future survey; 2 = a 2, 5, 6, or 8 in survey type and site is not worth future survey; $3=7$ in survey type and site is not worth future survey; $4=\mathrm{a} 3$ in the survey type and site is dry, but is worth future survey; 5 = a 3 in the survey type and site has ephemeral water and is worth future survey (including high elevation sites that freeze solid); 6 = a 3 in the survey type, site is worth future survey, has emergent vegetation, and has permanent water that lasts all summer long and does not freeze solid in the winter so that it is likely to support aquatic overwintering; $7=a$ in the survey type, site is worth future survey, does not have functional amounts of emergent vegetation, and has permanent water that lasts all summer long and does not freeze solid in the winter so that it is likely to support aquatic overwintering.

Habitat Type: Circle the appropriate habitat type of the site being surveyed. If site is multi-pooled water information does not need to be gathered for every pool, but you may wish to record this information on the map. If breeding activity is limited to one pool at a multi-pooled site water information should be recorded for this pool and this should be noted in the comments.

Weather: Circle weather condition during survey.

Wind: Circle wind condition during survey (> $20 \mathrm{mph}$ winds should be classified as strong).

Air Temp: Record air temperature at chest height in the shade. Record temperature in Celsius. ${ }^{\circ} \mathrm{C}=\left({ }^{\circ} \mathrm{F}-32\right) / 1.8$

Water Temp: Record water temperature where larvae or egg masses are observed or at $2 \mathrm{~cm}$ depth 1 meter from the margin of the water body. Record temperature in Celsius. ${ }^{\circ} \mathrm{C}=\left({ }^{\circ} \mathrm{F}-32\right) / 1.8$

Water $\mathbf{p H}$ : Record water $\mathrm{pH}$ at the same location water temperature was recorded.

Color: Circle whether the water is clear or stained a tea or rust color from organic acids. 
Turbidity: Circle whether water is clear or cloudy.

Water Connectedness: Circle if water body has permanent connection to flowing water (Permanent), is connected to flowing water for a temporary period each year (Temporary), or is never connected to flowing waters or other water bodies (Isolated).

Water Permanence: Circle whether the site contains water throughout the entire year (Permanent), or contains water for only a portion of the year (Temporary).

Max Depth: Circle the category corresponding to the maximum depth of the water body.

Percent of Site $>\mathbf{2}$ M: Circle the percentage of the site with water depth greater than 2 meters deep.

Site Length: The length of the longest dimension of the standing water body.

Site Width: The width of the second longest dimension of the standing water body.

Percentage of Site Searched: Circle the percentage of the site surveyed.

Percentage of the Site at $\leq \mathbf{5 0} \mathbf{~ c m}$ Depth: Circle the appropriate percentage.

Approximate Area with Emergent Veg $\left(\mathbf{M}^{2}\right)$ : The approximate area of the site that contains emergent vegetation.

Percentage of Site with Emergent Veg: Circle the percentage of the entire site with emergent vegetation.

Percentage of Site with Larval Activity: Circle the percentage of the site where amphibian larvae were observed.

Rank Emergent Veg Species in Order of Abundance: Record the rank order of abundance in front of the 3 most prevalent emergent

vegetation species. If the vegetation present is "other" indicate what it is.

Primary Substrate: Circle the substrate that covers the majority of the bottom of the site.

North Shoreline Characteristics: Circle whether shallows and emergent vegetation are present or absent on the north shoreline.

Distance (M) to Forest Edge: Record the closest distance between the water's edge and the forest margin in meters.

Grazing Impact: Circle the appropriate grazing category defined as follows: no grazing in vicinity of the site; grazing noted in the vicinity of the site, but no major impacts to wetland structure or water quality; heavy structural impacts to site (e.g.,vegetation destroyed creating bare ground, hummocks, pugging, or altered hydroregime); heavy structural impacts and water quality impacted due to animal waste; and water quality impacted due to animal waste.

Water Dammed/Diverted: Circle whether or not water has been dammed or diverted at the site (including blow outs or pits).

Timber Harvest: Circle whether or not timber has been harvested within 200 meters of the site.

Mining Activity: Circle whether or not there is evidence of mining activity within 200 meters of the site.

Other Human Impacts or Modifications: Briefly describe if, how, and when the site has been altered by human activities. If the site has not been altered record none for not altered. If multiple anthropogenic impacts exist document all of these using the back of the data sheet if

necessary and qualify approximate timing of impact (e.g., recent versus historic).

Fish Detected?: Circle whether or not fish were detected.

Time at First Detection: If fish were detected, indicate the time in total person minutes of survey when they were first detected.

Fish Species if Identified: List the fish species identified.

Fish Spawning Habitat Present?: Are shallow waters with adequate gravels/cobbles present that would allow salmonid fishes to spawn? An active search for fry is also a good idea.

Inlet Width: What is the average width of the inlet stream in meters?

Inlet Depth: What is the average depth of the inlet stream in centimeters?

Inlet Substrate: What is the primary substrate at the inlet stream (Silt/Mud, Sand, Gravel, Cobble, or Boulder/Bedrock)?

Outlet Width: What is the average width of the outlet stream in meters?

Outlet Depth: What is the average depth of the outlet stream in centimeters?

Outlet Substrate: What is the primary substrate at the outlet stream (Silt/Mud, Sand, Gravel, Cobble, or Boulder/Bedrock)?

\section{Species Information}

For each species record the first two letters of the scientific genus and species names for all amphibian and reptile species found at the site (e.g., BUBO for Bufo boreas). Record the total number of person minutes of survey required before each life history stage of each species was encountered beside the E (egg), L (larvae), M (metamorph), J (juvenile), or A (adult). Record the number or category of number of each of the specified life history and/or size classes. For amphibians indicate whether they have bred in the same water body where fish are present, and if they have, indicate whether there is protective cover (e.g., extensive shallows with emergent vegetation, a log barrier, talus). Record the tissue number or range of tissue numbers for tissue samples collected (see tissue collection protocols). If the animal was swabbed in preparation for testing the animal for chytrid infection indicate the chytrid sample number in the Tissue Number field. Record the preliminary museum voucher specimen number for voucher specimens collected (see voucher specimen collection protocols).

\section{Site Map for Lentic Breeding Amphibian and Aquatic Reptile Surveys}

General: Include a rough sketch of the site including the shape of the site and the shape and spatial relations of surrounding biotic and abiotic features. Indicate the area covered with emergent vegetation with cross-hatching. Indicate a 2-meter depth contour for the water body with a dashed line. Indicate the location where the water temperature was taken, the location where the GPS position was taken, the location where clinometer readings for southern exposure were taken, and the location of any photographs with an arrow indicating the direction in which the photo(s) were taken. Make sure that the orientation of the sketch (i.e. the north arrow) corresponds to the orientation of the site.

Grid Scale: Indicate the approximate scale of the grid lines relative to the site sketched in meters.

Other Notes: Include any other notes of interest in this space. Examples: (1) areas of highest larval density; (2) thoughts on why a species may not have been detected at a site; (3) problems associated with the survey of the site (e.g., dangerous boggy conditions); (4) If a site was dry would it support reproduction during wetter years.

Southern Exposure: From a site on along the northern shoreline that would most likely to be used as an oviposition or larval rearing area (e.g., shallow waters with emergent vegetation in the NW corner of the water body) record the degree inclination from your position to the

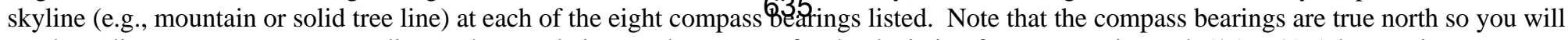
need to adjust your compass according to the map being used to correct for the deviation from magnetic north (15 to 19.5 degrees in western Montana). 
Page _of

Observer(s)

Summary Comments on Survey Route
Roadside Amphibian Calling Survey Datasheet

Start Lat/Long (DD)

\begin{tabular}{|c|c|c|c|c|c|}
\hline Date & Time & Weather & Latitude (DD) & Detection & Species Number, Bearing, \& Distance to Chorus (e.g., 5 x BUWO at 230 degrees and $100 \mathrm{~m}$ ) \\
\hline & & & Longitude (DD) & $\mathrm{Y} / \mathrm{N}$ & \\
\hline \multirow[t]{2}{*}{ Date } & Time & Weather & Latitude (DD) & Detection & Species Number, Bearing, \& Distance to Chorus (e.g., 5 x BUWO at 230 degrees and $100 \mathrm{~m}$ ) \\
\hline & & & Longitude (DD) & $\mathrm{Y} / \mathrm{N}$ & \\
\hline \multirow[t]{2}{*}{ Date } & Time & Weather & Latitude (DD) & Detection & Species Number, Bearing, \& Distance to Chorus (e.g., 5 x BUWO at 230 degrees and $100 \mathrm{~m}$ ) \\
\hline & & & Longitude (DD) & $\mathrm{Y} / \mathrm{N}$ & \\
\hline \multirow[t]{2}{*}{ Date } & Time & Weather & Latitude (DD) & Detection & Species Number, Bearing, \& Distance to Chorus (e.g., 5 x BUWO at 230 degrees and $100 \mathrm{~m}$ ) \\
\hline & & & Longitude (DD) & $\mathrm{Y} / \mathrm{N}$ & \\
\hline \multirow[t]{2}{*}{ Date } & Time & Weather & Latitude (DD) & Detection & Species Number, Bearing, \& Distance to Chorus (e.g., $5 \times$ BUWO at 230 degrees and $100 \mathrm{~m}$ ) \\
\hline & & & Longitude (DD) & $\mathrm{Y} / \mathrm{N}$ & \\
\hline \multirow[t]{2}{*}{ Date } & Time & Weather & Latitude (DD) & Detection & Species Number, Bearing, \& Distance to Chorus (e.g., 5 x BUWO at 230 degrees and $100 \mathrm{~m}$ ) \\
\hline & & & Longitude (DD) & $\mathrm{Y} / \mathrm{N}$ & \\
\hline \multirow[t]{2}{*}{ Date } & Time & Weather & Latitude (DD) & Detection & Species Number, Bearing, \& Distance to Chorus (e.g., 5 x BUWO at 230 degrees and $100 \mathrm{~m}$ ) \\
\hline & & & Longitude (DD) & $\mathrm{Y} / \mathrm{N}$ & \\
\hline \multirow[t]{2}{*}{ Date } & Time & Weather & Latitude (DD) & Detection & Species Number, Bearing, \& Distance to Chorus (e.g., 5 x BUWO at 230 degrees and $100 \mathrm{~m}$ ) \\
\hline & & & Longitude (DD) & $\mathrm{Y} / \mathrm{N}$ & \\
\hline \multirow[t]{2}{*}{ Date } & Time & Weather & Latitude (DD) & Detection & Species Number, Bearing, \& Distance to Chorus (e.g., 5 x BUWO at 230 degrees and $100 \mathrm{~m}$ ) \\
\hline & & & Longitude (DD) & $\mathrm{Y} / \mathrm{N}$ & \\
\hline \multirow[t]{2}{*}{ Date } & Time & Weather & Latitude (DD) & Detection & Species Number, Bearing, \& Distance to Chorus (e.g., 5 x BUWO at 230 degrees and $100 \mathrm{~m}$ ) \\
\hline & & & Longitude (DD) & $\mathrm{Y} / \mathrm{N}$ & \\
\hline \multirow[t]{2}{*}{ Date } & Time & Weather & Latitude (DD) & Detection & Species Number, Bearing, \& Distance to Chorus (e.g., 5 x BUWO at 230 degrees and $100 \mathrm{~m}$ ) \\
\hline & & & Longitude (DD) & $\mathrm{Y} / \mathrm{N}$ & \\
\hline \multirow[t]{2}{*}{ Date } & Time & Weather & Latitude (DD) & Detection & Species Number, Bearing, \& Distance to Chorus (e.g., 5 x BUWO at 230 degrees and $100 \mathrm{~m}$ ) \\
\hline & & & Longitude (DD) & $\mathrm{Y} / \mathrm{N}$ & \\
\hline \multirow[t]{2}{*}{ Date } & Time & Weather & Latitude (DD) & Detection & Species Number, Bearing, \& Distance to Chorus (e.g., 5 x BUWO at 230 degrees and $100 \mathrm{~m}$ ) \\
\hline & & & Longitude (DD) & $\mathrm{Y} / \mathrm{N}$ & \\
\hline \multirow[t]{2}{*}{ Date } & Time & Weather & Latitude (DD) & Detection & Species Number, Bearing, \& Distance to Chorus (e.g., 5 x BUWO at 230 degrees and $100 \mathrm{~m}$ ) \\
\hline & & & Longitude (DD) & $\mathrm{Y} / \mathrm{N}$ & \\
\hline \multirow[t]{2}{*}{ Date } & Time & Weather & Latitude (DD) & Detection & Species Number, Bearing, \& Distance to Chorus (e.g., 5 x BUWO at 230 degrees and $100 \mathrm{~m}$ ) \\
\hline & & & Longitude (DD) & $\mathrm{Y} / \mathrm{N}$ & \\
\hline \multirow[t]{2}{*}{ Date } & Time & Weather & Latitude (DD) & Detection & Speciés'Number, Bearing, \& Distance to Chorus (e.g., 5 x BUWO at 230 degrees and $100 \mathrm{~m}$ ) \\
\hline & & & Longitude (DD) & $\mathrm{Y} / \mathrm{N}$ & \\
\hline
\end{tabular}




\begin{tabular}{|c|c|c|c|c|c|}
\hline \multicolumn{4}{|c|}{ Page ___ of___ } & \multicolumn{2}{|c|}{ Roadside Amphibian Calling Survey Datasheet } \\
\hline Date & Time & Weather & Latitude (DD) & Detection & Species Number, Bearing, \& Distance to Chorus (e.g., $5 \times$ BUWO at 230 degrees and $100 \mathrm{~m}$ ) \\
\hline & & & Longitude (DD) & $\mathrm{Y} / \mathrm{N}$ & \\
\hline \multirow[t]{2}{*}{ Date } & Time & Weather & Latitude (DD) & Detection & Species Number, Bearing, \& Distance to Chorus (e.g., 5 x BUWO at 230 degrees and $100 \mathrm{~m}$ ) \\
\hline & & & Longitude (DD) & $\mathrm{Y} / \mathrm{N}$ & \\
\hline \multirow[t]{2}{*}{ Date } & Time & Weather & Latitude (DD) & Detection & Species Number, Bearing, \& Distance to Chorus (e.g., 5 x BUWO at 230 degrees and $100 \mathrm{~m}$ ) \\
\hline & & & Longitude (DD) & $\mathrm{Y} / \mathrm{N}$ & \\
\hline \multirow[t]{2}{*}{ Date } & Time & Weather & Latitude (DD) & Detection & Species Number, Bearing, \& Distance to Chorus (e.g., 5 x BUWO at 230 degrees and $100 \mathrm{~m}$ ) \\
\hline & & & Longitude (DD) & $\mathrm{Y} / \mathrm{N}$ & \\
\hline \multirow[t]{2}{*}{ Date } & Time & Weather & Latitude (DD) & Detection & Species Number, Bearing, \& Distance to Chorus (e.g., 5 x BUWO at 230 degrees and $100 \mathrm{~m}$ ) \\
\hline & & & Longitude (DD) & $\mathrm{Y} / \mathrm{N}$ & \\
\hline \multirow[t]{2}{*}{ Date } & Time & Weather & Latitude (DD) & Detection & Species Number, Bearing, \& Distance to Chorus (e.g., 5 x BUWO at 230 degrees and $100 \mathrm{~m}$ ) \\
\hline & & & Longitude (DD) & $\mathrm{Y} / \mathrm{N}$ & \\
\hline \multirow[t]{2}{*}{ Date } & Time & Weather & Latitude (DD) & Detection & Species Number, Bearing, \& Distance to Chorus (e.g., 5 x BUWO at 230 degrees and $100 \mathrm{~m}$ ) \\
\hline & & & Longitude (DD) & $\mathrm{Y} / \mathrm{N}$ & \\
\hline \multirow[t]{2}{*}{ Date } & Time & Weather & Latitude (DD) & Detection & Species Number, Bearing, \& Distance to Chorus (e.g., 5 x BUWO at 230 degrees and $100 \mathrm{~m}$ ) \\
\hline & & & Longitude (DD) & $\mathrm{Y} / \mathrm{N}$ & \\
\hline \multirow[t]{2}{*}{ Date } & Time & Weather & Latitude (DD) & Detection & Species Number, Bearing, \& Distance to Chorus (e.g., 5 x BUWO at 230 degrees and $100 \mathrm{~m}$ ) \\
\hline & & & Longitude (DD) & $\mathrm{Y} / \mathrm{N}$ & \\
\hline \multirow[t]{2}{*}{ Date } & Time & Weather & Latitude (DD) & Detection & Species Number, Bearing, \& Distance to Chorus (e.g., 5 x BUWO at 230 degrees and $100 \mathrm{~m}$ ) \\
\hline & & & Longitude (DD) & $\mathrm{Y} / \mathrm{N}$ & \\
\hline \multirow[t]{2}{*}{ Date } & Time & Weather & Latitude (DD) & Detection & Species Number, Bearing, \& Distance to Chorus (e.g., 5 x BUWO at 230 degrees and $100 \mathrm{~m}$ ) \\
\hline & & & Longitude (DD) & $\mathrm{Y} / \mathrm{N}$ & \\
\hline \multirow[t]{2}{*}{ Date } & Time & Weather & Latitude (DD) & Detection & Species Number, Bearing, \& Distance to Chorus (e.g., 5 x BUWO at 230 degrees and $100 \mathrm{~m}$ ) \\
\hline & & & Longitude (DD) & $\mathrm{Y} / \mathrm{N}$ & \\
\hline \multirow[t]{2}{*}{ Date } & Time & Weather & Latitude (DD) & Detection & Species Number, Bearing, \& Distance to Chorus (e.g., 5 x BUWO at 230 degrees and $100 \mathrm{~m}$ ) \\
\hline & & & Longitude (DD) & $\mathrm{Y} / \mathrm{N}$ & \\
\hline \multirow[t]{2}{*}{ Date } & Time & Weather & Latitude (DD) & Detection & Species Number, Bearing, \& Distance to Chorus (e.g., 5 x BUWO at 230 degrees and $100 \mathrm{~m}$ ) \\
\hline & & & Longitude (DD) & $\mathrm{Y} / \mathrm{N}$ & \\
\hline \multirow[t]{2}{*}{ Date } & Time & Weather & Latitude (DD) & Detection & Species Number, Bearing, \& Distance to Chorus (e.g., 5 x BUWO at 230 degrees and $100 \mathrm{~m}$ ) \\
\hline & & & Longitude (DD) & $\mathrm{Y} / \mathrm{N}$ & \\
\hline \multirow[t]{2}{*}{ Date } & Time & Weather & Latitude (DD) & Detection & Species Number, Bearing, \& Distance to Chorus (e.g., 5 x BUWO at 230 degrees and $100 \mathrm{~m}$ ) \\
\hline & & & Longitude (DD) & $\mathrm{Y} / \mathrm{N}$ & \\
\hline \multirow[t]{2}{*}{ Date } & Time & Weather & Latitude (DD) & Detection & Species Number, Bearing, \& Distance to Chorus (e.g., 5 x BUWO at 230 degrees and $100 \mathrm{~m}$ ) \\
\hline & & & Longitude (DD) & $\mathrm{Y} / \mathrm{N}$ & \\
\hline \multirow[t]{2}{*}{ Date } & Time & Weather & Latitude (DD) & Detection & Species Number, Bearing, \& Distance to Chorus (e.g., 5 x BUWO at 230 degrees and $100 \mathrm{~m}$ ) \\
\hline & & & Longitude (DD) & $\mathrm{Y} / \mathrm{N}$ & 637 \\
\hline \multirow[t]{2}{*}{ Date } & Time & Weather & Latitude (DD) & Detection & Species Number, Bearing, \& Distance to Chorus (e.g., $5 \times$ BUWO at 230 degrees and $100 \mathrm{~m}$ ) \\
\hline & & & Longitude (DD) & $\mathrm{Y} / \mathrm{N}$ & \\
\hline
\end{tabular}




\section{Data Form for Reptile Site Surveys}

\section{Locality Information}

\begin{tabular}{|l|l|l|l|l|l|l|l|}
\hline $\begin{array}{l}\text { DM Region } \\
\text { SE MONTANA }\end{array}$ & QQUAD & \multicolumn{4}{l|}{ Site No: } & Locality: \\
\hline State: & County: & \multicolumn{1}{l|}{$\begin{array}{l}\text { Map } \\
\text { Name: }\end{array}$} & T & R & S & $\begin{array}{l}\text { Section } \\
\text { Description: }\end{array}$ \\
\hline & $\begin{array}{l}\text { Map } \\
\text { Owner: }\end{array}$ & Elevation: & FT & Datum & Latitude (DD) & Longitude (DD) \\
\hline
\end{tabular}

\section{Habitat Information}

\begin{tabular}{|l|l|l|l|l|l|}
\hline Date: & Observer(s): & $\begin{array}{l}\text { Begin } \\
\text { Time: }\end{array}$ & $\begin{array}{l}\text { End } \\
\text { Time: }\end{array}$ & $\begin{array}{l}\text { Total Person } \\
\text { Minutes of Search: }\end{array}$ & $\begin{array}{l}\text { Area }\left(\mathrm{M}^{2}\right) \\
\text { Searched: }\end{array}$ \\
\hline
\end{tabular}

\begin{tabular}{l|l|lllllllll} 
Percentage of Site Searched: & Percent & Aspect: N & NE & NW & S & SE & SW & E & W & Flat
\end{tabular}

1-25 26-50 51-75 76-100 $\quad$ Slope:

Habitat Cover Type As Percent of Site Surveyed:

Cliff/Outcrop Bluff/Coulee Rim Talus Open Conifer Forest Open Mixed Forest Shrub/Steppe Grassland Other

$\frac{\%}{\text { Site Overview Photo Taken } \square}$

Photo Description(s)

\begin{tabular}{|llll|lll|c} 
Weather: Clear & Partly Cloudy Overcast Rain Snow & Wind: Calm Light Strong & $\begin{array}{c}\text { Potential Hibernaculum } \\
\text { N }\end{array}$ \\
\hline
\end{tabular}

\section{Soil Moisture:}

Dry Damp Wet Standing Water Snow Habitat Description/Threats:

Dominant Substrate Type:
Bedrock $\begin{gathered}\text { Compressed Soil } \\ \text { Cobble ( 4-30cm diameter) }\end{gathered} \quad \begin{gathered}\text { Detritus } \\ \text { Boulder }(>30 \mathrm{~cm} \text { diameter })\end{gathered}$

\section{Dominant Substrate Type:}

Cobble ( 4-30cm diameter)

\section{Reptile Species Information}

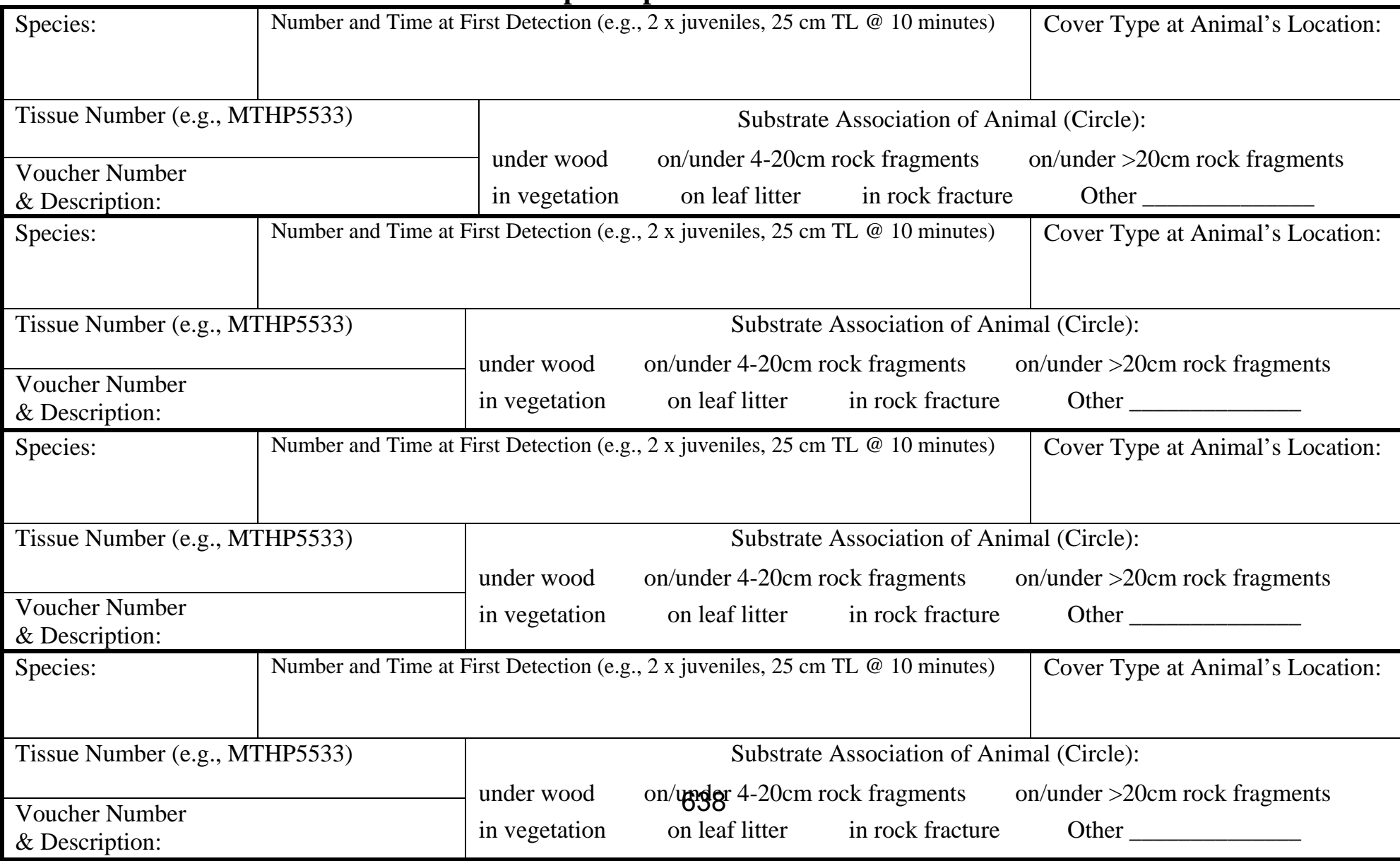


Grid Scale:

Site Map for Reptile Site Surveys

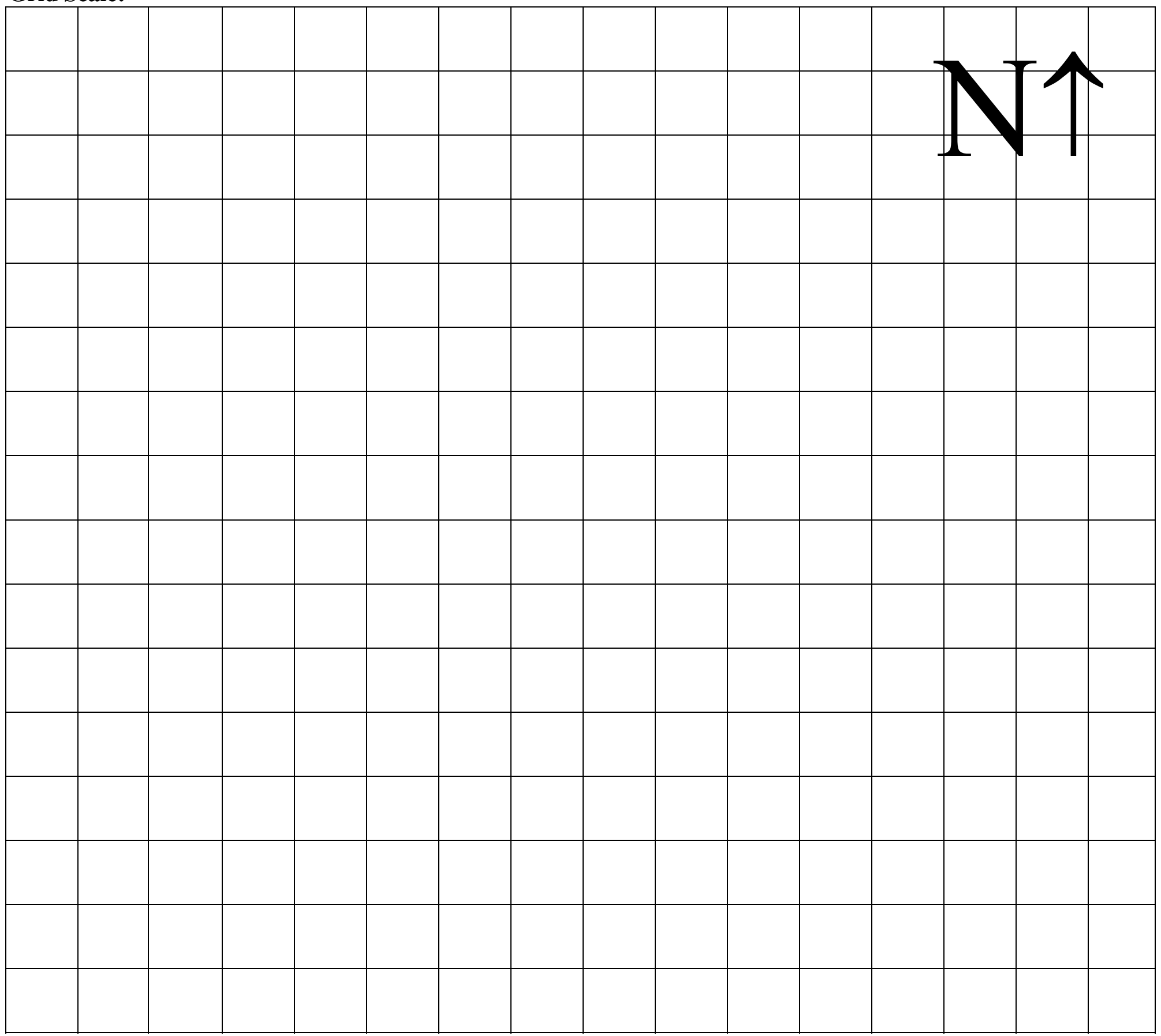

* Draw a rough sketch of the site labeling major features such as cliffs, talus slopes, and all habitat cover types. Be sure to indicate where animals were detected and label the following locations on the map: G = GPS reading, - - - - - $=$ area surveyed, and $\mathbf{P} \rightarrow=$ photo locations and directions of photos.

Other Notes:

Detection Summary (list surveyors in left column and species detections in others (e.g., 1 @ 5 min)

\begin{tabular}{|l|l|l|l|l|l|l|}
\hline Surveyor & & & & & & \\
\hline & & & & & & \\
\hline & & & 639 & & & \\
\hline & & & & & & \\
\hline
\end{tabular}




\section{Definitions of Variables on Reptile Site Survey Form}

\section{Site Information}

Strata Number: The sample strata in which the $6^{\text {th }}$ level HUC watershed lies.

HUC Number: The sample number of the $6^{\text {th }}$ level HUC.

Site No: Identify three digit number of the site being surveyed within each sampling block (range 001-999).

Locality: Describe the specific geographic location of the site so that the type of site is described and the straight-line air distance from one or more permanent features on a 7.5-minute (1:24,000 scale) topographic map records the position of the site (e.g., Large talus slope 1.5 miles north of Engle Peak, N side of FS Road 225).

State: Use the two-letter abbreviation.

County: Use the full county name.

Map Name: List the name of the USGS 7.5-minute (1:24,000 scale) topographic quadrangle map.

T: Record the Township number and whether it is north or south.

R: Record the Range number and whether it is east or west.

S: Record the Section number

Section Description: Describe location of the site at the $1 / 4$ of $1 / 4$ section level (e.g., SENE indicates SE corner of NE corner). Owner: Use abbreviation of the government agency responsible for managing the land you surveyed. (e.g. USFS, BLM). If private land was surveyed list the owner's full name to indicate that you did not trespass.

Map Elevation: The elevation of the site as indicated by the topographic map in feet (avoid using elevations from a GPS)

Datum: The map datum used (typically NAD 27 if off topographic map or WGS84 if off GPS unit on standard setting).

UTM Zone: Universal Transverse Mercator zone recorded on the topographic map.

UTM East: Universal Transverse Mercator easting coordinate in meters as recorded on the topographic map or GPS receiver.

Be sure to note any major differences between UTM coordinates on the map and those on the GPS receiver.

UTM North: Universal Transverse Mercator northing coordinate in meters as recorded on the topographic map or GPS receiver. Be sure to note any major differences between UTM coordinates on the map and those on the GPS receiver.

\section{Survey Information}

Date: Use MM-DD-YY format (e.g. 05/12/00 for May 12 of 2000).

Observers: List names or initials of individuals involved with survey of this site and circle the name of the recorder.

Begin Time: List the time the survey began in 24-hour format.

End Time: List the time the survey ended in 24-hour format.

Total Person Minutes of Search: Record the total person minutes the site was searched (e.g. if one person surveys for 15 minutes and another surveys for 30 minutes, but takes 5 minutes to measure a specimen the total person minutes is 40 minutes). Area $\left(\mathbf{M}^{2}\right)$ Searched: Area in square meters that was surveyed.

Percent of Site Searched: Circle the appropriate category.

Percent Slope: Percent slope of site. Enter range if variable.

Aspect: Circle primary aspect of the site.

Habitat Cover Type as Percent of Site Surveyed: Identify percent composition of each habitat type within site surveyed. Photo Frame Number(s) / Descriptions: The number of the photo as viewed on the camera's view screen and a description of the contents of the photograph (e.g., \#13 = 1 x Milksnake and \#14-18 = 5 x habitat). Take photos of all portions of the site and anything else that may be of interest (e.g., reptile species, potential site threats).

Air Temp: Record air temperature in ${ }^{\circ} \mathrm{C}$ at chest height in the shade. ${ }^{\circ} \mathrm{C}=\left({ }^{\circ} \mathrm{F}-32\right) / 1.8$

Soil Temp: Record soil temperature in ${ }^{\circ} \mathrm{C}$ at $10 \mathrm{~cm}$ depth. ${ }^{\circ} \mathrm{C}=\left({ }^{\circ} \mathrm{F}-32\right) / 1.8$

Weather: Circle weather condition during survey.

Wind: Circle wind condition during survey (> $20 \mathrm{mph}$ winds should be classified as strong).

Potential Hibernacula: Does the site contain suitable underground refugia (e.g., talus, caves) to support overwintering.

Soil Moisture: Circle the appropriate category.

Dominant Substrate Type: Circle the appropriate category.

Habitat Description/Threats: Note the most prominent characteristics of the site with relation to reptiles (e.g., could the site support overwintering). Also note habitat threats from grazing, logging, mining, flooding, road building, weeds, fire, etc.

\section{Species Information}

For each species record the first two letters of the scientific genus and species names for all amphibian and reptile species found at the site (e.g., COCO for Coluber constrictor). Record the total number of person minutes of survey required before each life history stage of each species was encountered and the size or size range of the animals encountered. Record the tissue number or range of tissue numbers for tissue samples collected (see tissue collection protocols. Record the preliminary museum voucher specimen number for voucher specimens collected (see voucher specimen collection protocols). Circle the substrate the animal was associated with at time of detection. Record the presence of other species detected at the site (e.g., millipedes), the time at

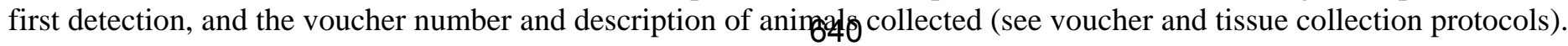




\begin{tabular}{|c|c|c|c|c|}
\hline \multirow{2}{*}{\multicolumn{3}{|c|}{ Page _of }} & \multirow{2}{*}{\multicolumn{2}{|c|}{$\begin{array}{l}\text { Incidental Observation Datasheet } \\
\text { Comments on Region }\end{array}$}} \\
\hline & & & & \\
\hline Date & Time & Latitude (DD) 45.44344 & Longitude (DD) -105.40885 & Location Next to Powder River Road, $11.5 \mathrm{~km}$ SW of Broadus \\
\hline $5 / 20 / 2009$ & $16: 30$ & \multicolumn{3}{|c|}{ Comments: 1 x WEME nest with 6 eggs (B) under clump of grasses in short grass prairie. Female flushed from nest. } \\
\hline Date & Time & Latitude (DD) & Longitude (DD) & Location \\
\hline & & \multicolumn{3}{|l|}{ Comments: } \\
\hline Date & Time & Latitude (DD) & Longitude (DD) & Location \\
\hline & & \multicolumn{3}{|l|}{ Comments: } \\
\hline Date & Time & Latitude (DD) & Longitude (DD) & Location \\
\hline & & \multicolumn{3}{|l|}{ Comments: } \\
\hline Date & Time & Latitude (DD) & Longitude (DD) & Location \\
\hline & & \multicolumn{3}{|l|}{ Comments: } \\
\hline Date & Time & Latitude (DD) & Longitude (DD) & Location \\
\hline & & \multicolumn{3}{|l|}{ Comments: } \\
\hline Date & Time & Latitude (DD) & Longitude (DD) & Location \\
\hline & & \multicolumn{3}{|l|}{ Comments: } \\
\hline Date & Time & Latitude (DD) & Longitude (DD) & Location \\
\hline & & \multicolumn{3}{|l|}{ Comments: } \\
\hline Date & Time & Latitude (DD) & Longitude (DD) & Location \\
\hline & & \multicolumn{3}{|l|}{ Comments: } \\
\hline Date & Time & Latitude (DD) & Longitude (DD) & Location \\
\hline & & \multicolumn{3}{|l|}{ Comments: } \\
\hline Date & Time & Latitude (DD) & Longitude (DD) & Location \\
\hline & & \multicolumn{3}{|l|}{ Comments: } \\
\hline Date & Time & Latitude (DD) & Longitude (DD) & Location \\
\hline & & \multicolumn{3}{|l|}{ Comments: } \\
\hline Date & Time & Latitude (DD) & Longitude (DD) & Location \\
\hline & & \multicolumn{3}{|l|}{ Comments: } \\
\hline Date & Time & Latitude (DD) & Longitude (DD) & Location \\
\hline & & \multicolumn{3}{|l|}{ Comments: } \\
\hline Date & Time & Latitude (DD) & Longitude (DD) & Location \\
\hline & & \multicolumn{3}{|l|}{ Comments: } \\
\hline Date & Time & Latitude (DD) & Longitude (DD) & Location \\
\hline & & \multicolumn{3}{|l|}{ Comments: } \\
\hline Date & Time & Latitude (DD) & Longitude (DD) & Location \\
\hline & & \multicolumn{3}{|l|}{ Comments: } \\
\hline Date & Time & Latitude (DD) & Longitude (DD) & Location \\
\hline & & \multicolumn{3}{|l|}{ Comments: } \\
\hline
\end{tabular}




\begin{tabular}{|c|c|c|c|c|c|c|c|c|c|}
\hline \multicolumn{4}{|c|}{ Page _of } & & & & & & \\
\hline & & & & & Time & Latitude (DD) & Longitude (DD) & Location \\
\hline & & & & & & & Comments: & & \\
\hline \multirow{2}{*}{\multicolumn{2}{|c|}{ Date }} & & & & & Time & Latitude (DD) & Longitude (DD) & Location \\
\hline & & & & & & & Comments: & & \\
\hline \multirow{2}{*}{\multicolumn{2}{|c|}{ Date }} & & & & & Time & Latitude (DD) & Longitude (DD) & Location \\
\hline & & & & & & & Comments: & & \\
\hline \multirow{2}{*}{\multicolumn{2}{|c|}{ Date }} & & & & & Time & Latitude (DD) & Longitude (DD) & Location \\
\hline & & & & & & & Comments: & & \\
\hline \multirow{2}{*}{\multicolumn{2}{|c|}{ Date }} & & & & & Time & Latitude (DD) & Longitude (DD) & Location \\
\hline & & & & & & & Comments: & & \\
\hline \multirow{2}{*}{\multicolumn{2}{|c|}{ Date }} & & & & & Time & Latitude (DD) & Longitude (DD) & Location \\
\hline & & & & & & & Comments: & & \\
\hline \multirow{2}{*}{\multicolumn{2}{|c|}{ Date }} & & & & & Time & Latitude (DD) & Longitude (DD) & Location \\
\hline & & & & & & & Comments: & & \\
\hline \multirow{2}{*}{\multicolumn{2}{|c|}{ Date }} & & & & & Time & Latitude (DD) & Longitude (DD) & Location \\
\hline & & & & & & & Comments: & & \\
\hline \multirow{2}{*}{\multicolumn{2}{|c|}{ Date }} & & & & & Time & Latitude (DD) & Longitude (DD) & Location \\
\hline & & & & & & & Comments: & & \\
\hline \multirow{2}{*}{\multicolumn{2}{|c|}{ Date }} & & & & & Time & Latitude (DD) & Longitude (DD) & Location \\
\hline & & & & & & & Comments: & & \\
\hline \multirow{2}{*}{\multicolumn{2}{|c|}{ Date }} & & & & & Time & Latitude (DD) & Longitude (DD) & Location \\
\hline & & & & & & & Comments: & & \\
\hline \multirow{2}{*}{\multicolumn{2}{|c|}{ Date }} & & & & & Time & Latitude (DD) & Longitude (DD) & Location \\
\hline & & & & & & & Comments: & & \\
\hline \multirow{2}{*}{\multicolumn{2}{|c|}{ Date }} & & & & & Time & Latitude (DD) & Longitude (DD) & Location \\
\hline & & & & & & & Comments: & & \\
\hline \multirow{2}{*}{\multicolumn{2}{|c|}{ Date }} & & & & & Time & Latitude (DD) & Longitude (DD) & Location \\
\hline & & & & & & & Comments: & & \\
\hline \multirow{2}{*}{\multicolumn{2}{|c|}{ Date }} & & & & & Time & Latitude (DD) & Longitude (DD) & Location \\
\hline & & & & & & & Comments: & & \\
\hline \multirow{2}{*}{\multicolumn{2}{|c|}{ Date }} & & & & & Time & Latitude (DD) & Longitude (DD) & Location \\
\hline & & & & & & & Comments: & & \\
\hline \multirow{2}{*}{\multicolumn{2}{|c|}{ Date }} & & & & & Time & Latitude (DD) & Longitude (DD) & Location \\
\hline & & & & & & & Comments: & & \\
\hline \multirow{2}{*}{\multicolumn{2}{|c|}{ Date }} & & & & & Time & Latitude (DD) & Longitude (DD) & Location \\
\hline & & & & & & & Comments: & & \\
\hline \multirow{2}{*}{\multicolumn{2}{|c|}{ Date }} & & & & & Time & Latitude (DD) & Longitude (DD) & Location \\
\hline & & & & & & & Comments: & & \\
\hline
\end{tabular}

